GÉNERO, PODER Y MUJERES

\title{
durante el nacionalsocialismo. Análisis de la prensa protestante, católica y no confesional en conflicto con la dictadura
}

\section{Tesis doctoral}

Dña. Begoña Prieto Peral

Director:

D. Manuel Redero San Román

Universidad de Salamanca 


\section{Índice}

Introducción, Metodología y Objetivos........................................................................ 8

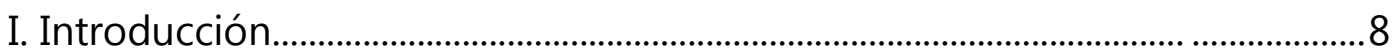

II. Objetivos y planteamiento metodológico …………………………………...... 10

III. Género como categoría de análisis histórico ..................................................... 12

IV. Mujeres y clases medias. El discurso de clase ................................................... 15

V. Resistencia, colaboración o exilio interior........................................................... 18

VI. La prensa como expresión del discurso de grupo ............................................ 20

VII. Género, historia de las mujeres y nacionalsocialismo …………………….... 22

VIII. Bibliografía sobre el tema. Estado de la cuestión ........................................... 30

IX. Conclusiones .......................................................................................................... 37

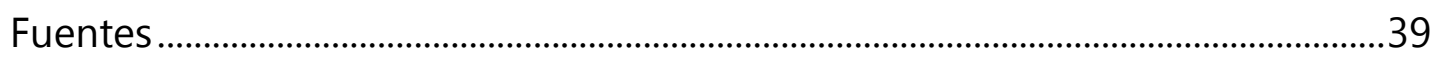

Primera PARTE

\section{Entre el primer feminismo de la República de Weimar y el Tercer Reich: Los grupos de mujeres confesionales}

1. La República de Weimar y su importancia en el cambio de la situación social de las mujeres ...................................................43

1.1. Introducción ..................................................................................................... 43

1.2. Aspectos políticos de la República de Weimar.............................................. 43

1.2.1. Formación y consolidación y crisis de la república de Weimar (1918/19-1923) .......................................................44

1.2.2. La lucha por la supervivencia (1924-1929) .............................................46

1.2.3. Los años de crisis y destrucción (1930-1933) .......................................46

1.2.4. El cambio en las relaciones de género .....................................................4 48

1.2.5. El periodo de emancipación (1914-1918) ............................................50 
1.2.6. Los años de posguerra (1918-1923).....................................................50

1.2.7. Los años de prosperidad económica (1924-1928)..............................51

1.2.8. Los años de decadencia (1929-1933) .....................................................53

1.3. La participación política de las mujeres durante la República de Weimar54

2. Movimiento de la mujer y construcción de modelos

de identidad femenina en Alemania (1900-1933) ........................................................60

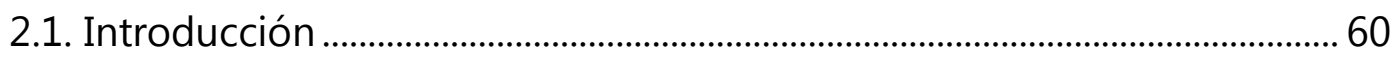

2.2. Los inicios del movimiento de la mujer alemán (1890-1918) ................... 62

2.3. Del asociacionismo a la radicalización de posturas (1919-1933) ............ 69

2.4. El feminismo conservador-liberal ................................................................. 70

2.4.1. La Federación de asociaciones de mujeres alemanas

(Bund Deutscher Frauenvereine). Organización y objetivos .........................70

2.4.2. La asociación de académicas alemenas

(Der Deutsche Akademikerinnenbund)...............................................................77

2.4.4. Contexto ideológico y social de la cúpula dirigente del BDF .........78

2.4.5. La herencia liberal-protestante. Friedrich Naumann ...........................87

2.4.6. El movimiento de la mujer y el discurso sobre la feminidad ...........88

2.4.6.1. La polaridad de los géneros. Die Polarität der Geschlechter ...89

2.4.6.2. El concepto de Geistliche Mütterlichkeit (maternidad espiritual)

2.4.7. El internacionalismo y movimiento de la mujer...................................96

2.4.8. Antisemitismo y movimiento de la mujer .................................................96

2.5. El movimiento confesional de la mujer ............................................................ 98

2.5.1. Las organizaciones de mujeres protestantes .....................................98

2.5.1.1. La Federación de mujeres protestantes alemanas........................99

2.5.1.2. Die Frauenhilfe. El Auxilio Femenino protestante..................... 105

2.5.1.3. Feminidad, protestantismo y movimiento de la mujer.

Construcción de género en el movimiento protestante de la mujer 107

2.5.1.4. La teoría de la diferencia de los géneros

como símbolo del orden divino. Magdalene von Tiling

2.5.1.5. La república de Weimar. Primeros pasos para

una organización supranacional de mujeres protestantes.

El nacimiento de la Vereinigung Evangelischer

Frauenverbände Deutschlands (VEFD)

2.5.2. Catolicismo y el movimiento de la mujer.

Asociaciones de mujeres católicas en la República de Weimar.

2.5.2.1. El milieu católico

2.5.2.2. El movimiento de la mujer de las mujeres católicas 
2.5.2.3 La Federación de mujeres católicas alemanas.

El Katholischer Deutscher Frauenbund (KDF) ..........................................116

2.5.2.4. La prensa de la Federación de mujeres católicas....................... 121

2.5.2.5. La influencia de Gertrud von Le Fort

en el entendimiento de la feminidad por las mujeres católicas ..........122

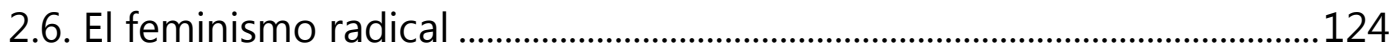

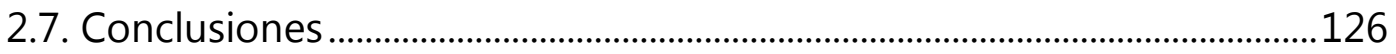

3. La decadencia del feminismo conservador.

Primeras reacciones de los grupos

de mujeres confesionales ante el nacionalsocialismo............................................. 130

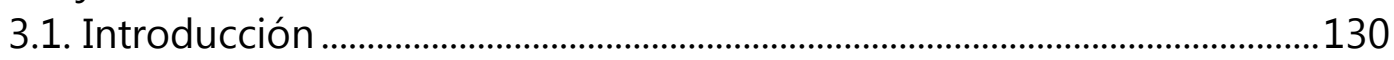

3.2. La decadencia del feminismo conservador (1930-1933) ..........................138

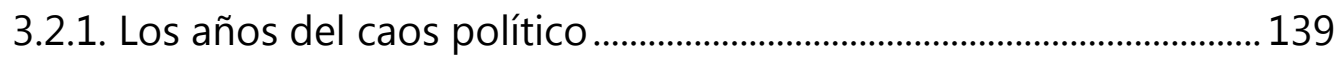

3.2.2. Die Gleichschaltung.............................................................................. 146

3.2.3 La fundación Helene Lange.......................................................................... 150

3.3. Primeras reacciones de los movimientos confesionales

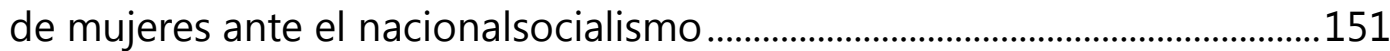

3.3.1. Las organizaciones de mujeres protestantes .................................. 155

3.3.2. Reacciones de la Liga de mujeres católicas alemanas.....................160

3.4. Conclusiones .................................................................................................... 168

SEGUNDA PARTE

\section{El discurso femenino en la prensa de las organizaciones de mujeres confesionales no integradas en la estructura nacionalsocialista}

4. Antifeminismo, mujeres y lenguaje durante el fascismo alemán.

Análisis de los modelos de feminidad propuestos por el nacionalsocialismo

4.1. El lenguaje del nacionalsocialismo: Características del discurso político173

4.2. Propaganda y la prensa nacionalsocialista para mujeres 175

4.3. Modelos de feminidad y la ideología nacionalsocialista 177

4.4. Las organizaciones nacionalsocialistas de mujeres 180 
5. Discurso en la prensa de mujeres protestante. Tres ejemplos:

Aufgaben und Ziele, Mutter und Volk y Die EVAngelische FraUenZeitung.......... 188

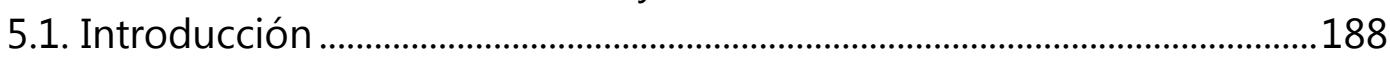

5.2. Contexto histórico-religioso de la integración de las asociaciones de mujeres protestantes en las estructuras nacionalsocialistas. La situación de la iglesia protestante durante el nacionalsocialismo. Repercusiones en el trabajo de las asociaciones de mujeres..........................190

5.2.1. La iglesia oficial del Reich y los cristianos alemanes........................ 190

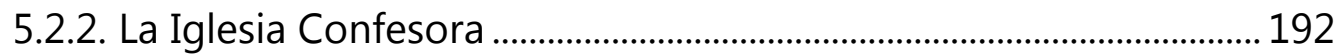

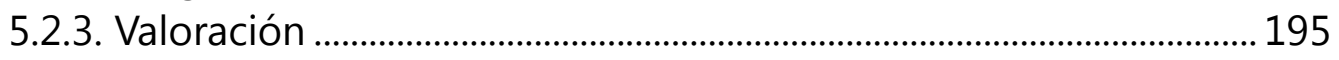

5.3. El desarrollo de las relaciones entre las organizaciones de mujeres protestantes y el nacionalsocialismo 196

5.3.1. Los primeros meses de la dictadura y las mujeres protestantes. La creación del Evangelisches Frauenwerk (EvFW) ...................................... 196

5.3.2. Estructura y organización interna del EvFW ........................................ 201

5.3.2.1. El Auxilio Femenino protestante. Evangelische Frauenhilfe.. 203

5.3.2.2. La Federación de mujeres protestantes

(Deutsch-Evangelischer Frauenbund DEF)............................................... 205

5.3.3. El conflicto entre el EvFW y Gertrud Scholtz-Klink (1934-1937) 209

5.3.4. El conflicto con la Iglesia del Reich (1934-1935) ............................. 213

5.3.5. El comité de las iglesias del Reich (1936-1937) ..................................220

5.3.6. El proceso contra Agnes von Grone...................................................225

5.3.7. El trabajo del "Evangelisches Frauenwerk" a partir de 1937......... 231

5.4. La prensa de mujeres protestante ....................................................................23

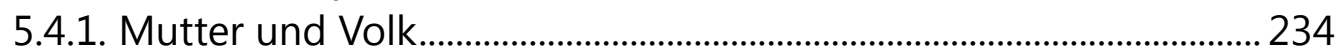

5.4.2. Discurso y realidad en la EvangelisChe Frauenzeitung ................... 239

5.4.2.1. Introducción ...................................................................................... 239

5.4.2.2. Las editoras del EF: Paula Müller-Ortfried y Meta Eyl.............. 241

5.4.2.3. Los años de crisis (1932-1933)....................................................... 242

5.4.2.4. Los años de la dictadura (1934-1941).

Entre colaboración, adaptación y defensa de los valores protestantes 248

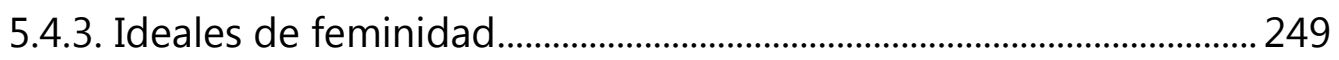

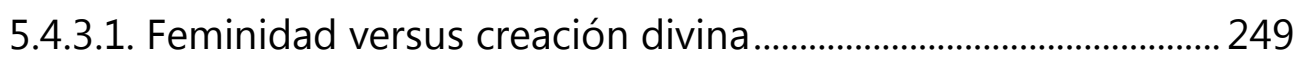

5.4.3.2. María y Eva entre el ejemplo y la tentación ................................. 252

5.4.3.3. La mujer como madre. La maternidad espiritual ....................... 253

5.4.3.4. Kirchenkampf, estado y mujeres ................................................. 255

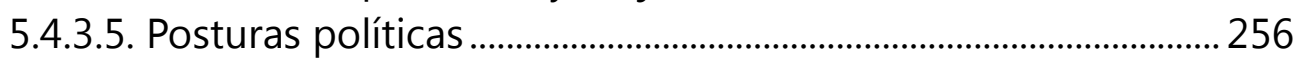

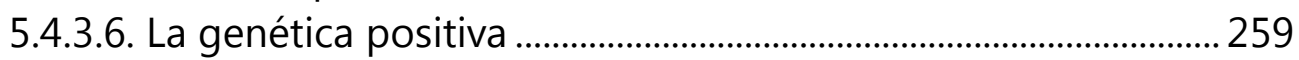




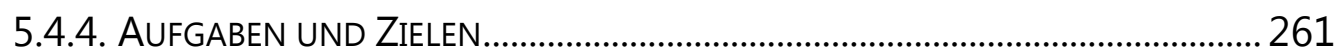

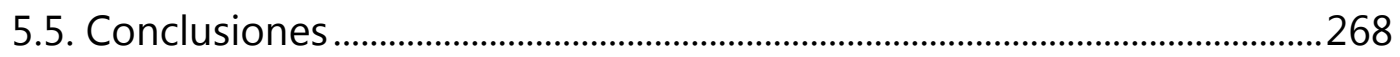

6. La Federación de mujeres católicas y el nacionalsocialismo.

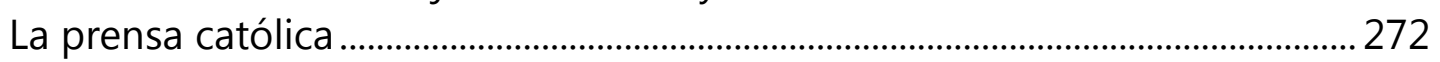

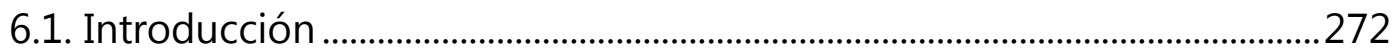

6.2. La Federación de mujeres católicas y el Nacionalsocialismo ...................2275

6.3. Die ChRISTLICHE FRAU. La visión católica de la mujer .......................................2.278

6.3.1. El discurso sobre la naturaleza de la mujer ......................................... 279

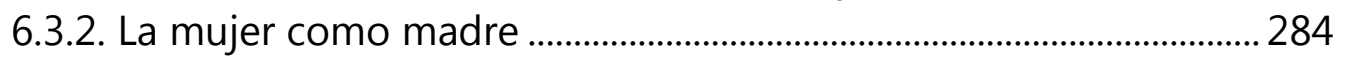

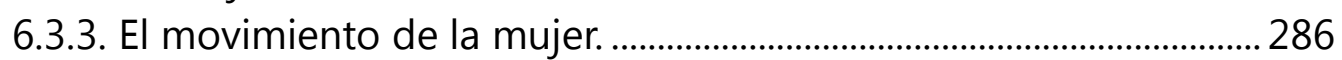

6.3.4. El mundo del trabajo ................................................................................. 290

6.3.5. Posturas políticas........................................................................................... 292

6.3.6. La guerra o la tentación de la unión nacional. El amor a la patria

293

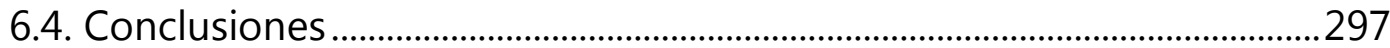

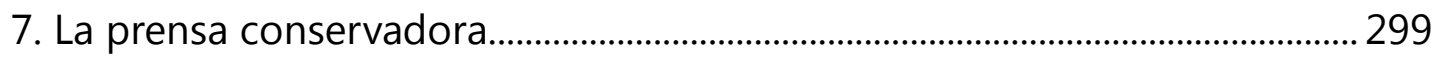

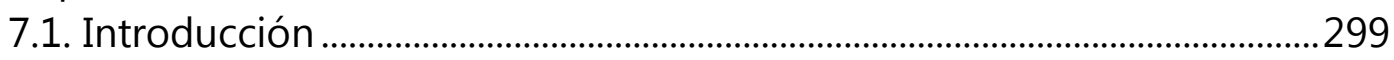

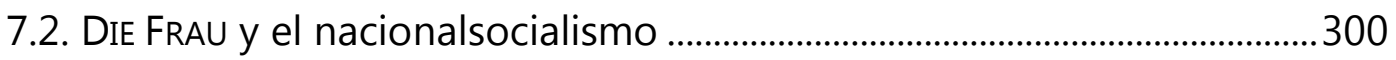

7.3. Las mujeres de DiE FRAU. Entre la crítica y la colaboración.

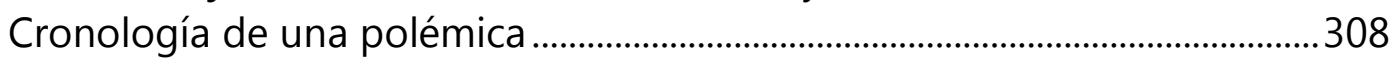

7.4. El círculo de Marianne Weber (Der Köngener Kreis) ....................................314

7.5. Discurso y construcción de género en DIE FRAU ..............................................317

7.5.1. Identidad femenina ¿Cultura o biología? ............................................. 317

7.5.1.1. La mujer como madre .......................................................................... 317

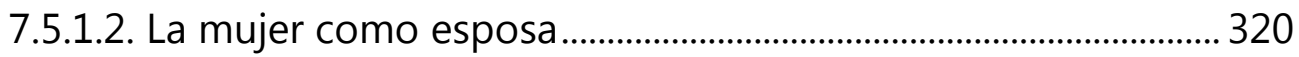

7.5.2. Entrega, servicio y sacrificio. Cualidades inherentes a lo femenino

7.5.3. El movimiento de la mujer. Pasado y presente.................................... 322

7.5.4. Sobre la naturaleza de lo femenino y el estado.

El papel de la mujer en la vida política .......................................................... 325

7.5.5. Mujer, Familia, Pueblo y Nación .......................................................... 326

7.5.6. La crítica „a lo burgués”.

Intelectualización de la ideología nacionalsocialista .................................. 329

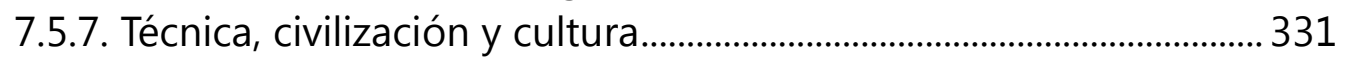

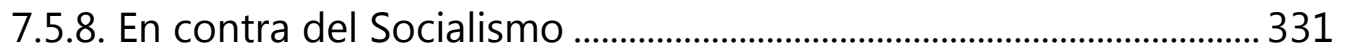

7.5.8. El discurso religioso y la emigración interior ....................................... 333

7.5.8.1. La mujer germana y el cristianismo ................................................ 337 
7.5.8.2. Reacciones ante la ley de esterilización........................................... 339

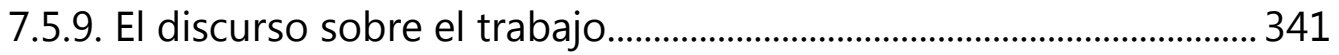

7.5.9.1. Política laboral femenina durante el nacionalsocialismo ....... 342

7.5.9.2. Significado y relevancia del trabajo femenino en Die FraU ... 344

7.5.9.3. Reivindicación de la necesidad del trabajo femenino.

El argumento de utilidad a la comunidad del pueblo.............................. 349

7.5.10. La guerra. Entre el descontento ante las desigualdades

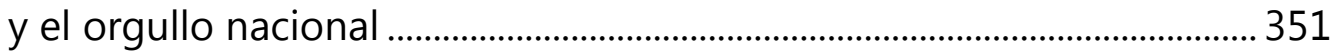

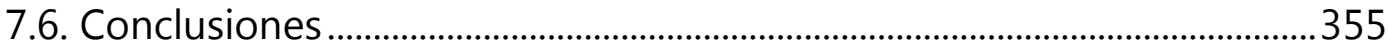

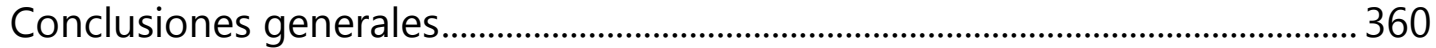

Apéndice

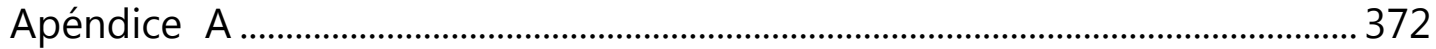

Apéndice B

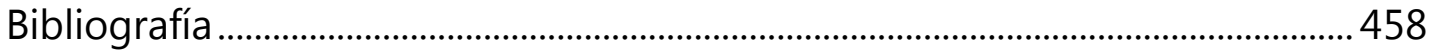

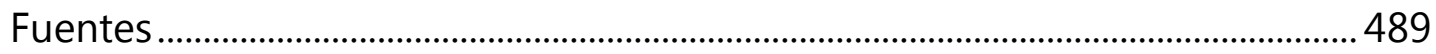

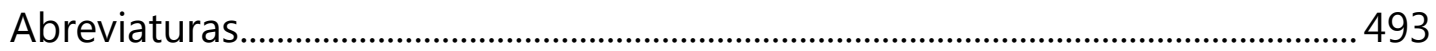




\section{Introducción, Metodología y Objetivos}

"Warum fesseln uns die Geschichten? Darauf gibt es nur die 'hermeneutische' Antwort: Weil wir uns im Andern, im Andern der Menschen, im Andern des Geschehens wiedererkennen."1

"Nosotras desfilamos dóciles en filas de cinco, acompañadas de mujeres con uniforme de las SS y dirigidas por un superior de las SS. El camino no es largo. De repente vemos una alambrada de espino, una alambrada de espino por todas partes y nos encontramos delante de un gran portón, flanqueado por hombres de las SS acompañados por perros que ladran y se acercan peligrosamente a nosotras, mientras atravesamos el portón. Estamos muy nerviosas pero no sabemos que en estos momentos entramos en el campo de concentración y exterminio de Auschwitz. Es el 20 de abril de 1943.”2

En estos momentos, Anneliese Borinski tiene 27 años. La causa de su internamiento en el campo de concentración de Auschwitz es su ascendencia judía. Diez años antes, en 1933, Anneliese Borinski había terminado su bachillerato. Sus compañeras de clase, sin intuir lo que se avecindaba empiezan a preparar los preparativos de su boda, Borinski decide estudiar magisterio. Cuando las acciones contra los judíos se incrementan se incorpora al movimiento de jóvenes judío, Makkabi Hazair, donde trabaja intensivamente en la posibilidad de emigrar a Palestina. Sin embargo el deseado permiso no llega, sino la orden de transporte al campo de concentración de Auschwitz. A pesar de las vejaciones sufridas consigue sobrevivir. En 1946 emigra a Palestina.

No era éste el futuro que había imaginado Mathilde Jacob, fiel secretaria de Rosa Luxemburg unos años atrás, protagonista directa de los excitantes años de la vida política de la república de Weimar. Durante el nacionalsocialismo es encarcelaba por su doble condición de judía y comunista, en 1943 acaba su vida en el campo de concentración checo de Theresienstadt, o Alice Salomon, feminista de origen judío, conocida por sus aportaciones a la mejora de la educación de las mujeres, y por su compromiso feminista con mujeres de otras confesiones. Su conversión al cristianismo no evita la emigración forzosa a los Estados Unidos y el olvido de años de trabajo y esfuerzo. El sentimiento de estar viviendo sobre un volcán, estaba presente durante los años de la república de Weimar, pero nadie, comenta Borinksi, parecía intuir lo que se avecinaba.

Existe también otra historia. La historia de las mujeres que permanecieron en Alemania, de las mujeres que no sufrieron bajo las consecuencias de la persecución nazi. No se trata de mujeres desconocidas, su huella se puede seguir en la Asamblea Nacional de Weimar, en los acalorados debates de las reuniones del parlamento alemán. Su recuerdo se encuentra en los

$1 \quad$ Koselleck,R.; Gadamer,H.G.: Hermenentik und Historik, Sitzungsberichte der Heidelberger Akademie der Wissenschaften, Heidelberg, Carl Winter, 1987.

2 Lixl-Purcell,A. (ed.): Erinnerungen deutsch-jüdischer Frauen. 1900-1990, Leipzig, Reclam, 1992, p.353. 
consejos directivos de organizaciones de mujeres que luchan por los derechos de la mujer, en calles, colegios e institutos de la Alemania actual. Cualquier referencia al nacimiento del movimiento de la mujer tropieza con sus nombres. Unas son católicas, otras son protestantes, otras se definen como liberales. Weimar está llena de sus huellas: escuelas para trabajadoras sociales, bolsas de empleo, conferencias, seminarios, revistas y periódicos. ¿Y el nacionalsocialismo? ¿Qué ocurrió con estas mujeres en 1933? ¿Qué pasó por sus cabezas cuando tuvieron que dejar sus puestos de responsabilidad en ministerios, escuelas y otros puestos de responsabilidad en manos de colegas masculinos cuya ideología definía a la mujer como madre y sostenedora de la familia? ¿Qué pensaron entonces, estas mujeres en su mayoría académicas, solteras, a veces viudas, cuando veían como sus compañeras de trabajo que no podían llamarse "alemanas" desaparecían gradualmente de las calles?

En mis primeras lecturas sobre el movimiento de la mujer alemán encontré a menudo sus nombres. Eran descritas como pioneras, como mujeres de una gran personalidad, como luchadoras. El nuevo movimiento de la mujer en Alemania podía estar orgulloso de sus predecesoras. La ausencia de información sobre sus actividades tras la desaparición de Weimar no despertó en un principio ninguna reacción. Al inicio de mi trabajo la fascinación de Weimar era más fuerte que los años oscuros de la dictadura nacionalsocialista.

Sin embargo, cuando se ha visitado Dachau, Flossenbürg o Theresienstadt, tres de los innumerables campos de concentración repartidos por Europa, es casi imposible no mirar detrás de las alambradas y de los muros. Es casi imposible no pensar en "los otros", en aquellos hombres y mujeres que vivieron los años de la dictadura nacionalsocialista, conviviendo consciente o inconscientemente con el terror. Es imposible, por otra parte eludir en las exposiciones que se encuentran en estos campos de concentración, las fotografías de una masa enloquecida que grita, bulle y suspira por su Fübrer y no deja de sorprender el gran número de mujeres que aparecen en estas fotografías. Y a la búsqueda de respuestas en las caras de las fotografias retornan las preguntas sobre las pioneras del movimiento de la mujer, sobre las grandes luchadoras. ¿Sucumbieron también al hechizo de Hitler?

El movimiento de la mujer alemán de principios de siglo es uno de los movimientos mejor organizado dentro del contexto europeo y con un gran número de miembros. Si tenemos en cuenta las organizaciones de mujeres laicas y confesionales, se pueden contabilizar casi cuatro millones de mujeres. La república de Weimar significa para las organizaciones del movimiento de la mujer la posibilidad de acceder a la vida pública y la participación consciente en el cambio de la realidad política.

La llegada del nacionalsocialismo trae consigo la desaparición de las libertades conquistadas. El nuevo régimen cuestiona en sí la razón de ser del movimiento. Las organizaciones laicas son obligadas a disolverse, las organizaciones confesionales católicas y protestantes continúan sus actividades protegidas por sus respectivas iglesias. Sin embargo la vOz de la crítica al nacionalsocialismo es casi un susurro. Y entonces entiendo por qué en mis lecturas sobre el movimiento de la mujer, éste termina en 1933.

El objetivo de este trabajo es analizar los procesos de adaptación, crítica o resistencia del movimiento moderado de la mujer y de sus paralelos confesionales, durante el nacionalsocialismo. Estas tres ramas del movimiento de la mujer aparecen representadas por tres organizaciones: el BDF (Bund deutscher Franenvereine), el DEF (Deutsch-evangelischer Frauenbund) y por último el KFB (Katholischer Frauenbund). De las tres organizaciones, sólo las confesionales consiguen trabajar activamente durante los años de la dictadura, el BDF se autodisuelve el 15 de mayo de 1933. A pesar de su desaparición, el espíritu de la organización se mantiene vivo en la continuación de la edición de su órgano de prensa. Éste continua funcionando durante el nacionalsocialismo, al igual que sus paralelos católico y protestante. Se trata de publicaciones escritas por y para mujeres. En la mayor parte de las veces dirigidas por las responsables de las organizaciones. El núcleo de colaboradoras pertenece también al círculo de dirigentes. El análisis del discurso elaborado durante 
los años del nacionalsocialismo en las publicaciones de las tres organizaciones, la reflexión que éstas hacen de la realidad social, el silencio sobre ésta y el trabajo en la construcción de modelos de feminidad al margen del discurso oficial, es el objeto de nuestro trabajo.

\section{Objetivos y planteamiento metodológico}

En los primeros estudios sobre el papel de las mujeres en el nacionalsocialismo, éstas aparecen como los "elementos" de la masa, más proclives a sufrir la histérica fascinación por Hitler, por las grandes marchas militares, y a secundar los nuevos roles de feminidad impuestos por los ideólogos del nacionalsocialismo. En estos trabajos se nos presentaba a la masa, entendida casi siempre como un ente femenino, enloquecida de placer ante la vista del Führer. Son imágenes que a menudo son utilizadas por historiadores y historiadoras para demostrar la "enfermiza" atención que dispensaron las mujeres al nacionalsocialismo. En muchos casos las mujeres son presentadas como un grupo de histéricas fanáticas, influidas por los efectos narcotizantes de la dictadura. ${ }^{3}$

Bajo esta interpretación se esconde un entendimiento del nacionalsocialismo que nosotros no compartimos. Éste se ve reducido a la figura de Hitler y al carácter demoniaco de éste que como un hipnotizador seduce a la masa, sin que ésta pueda hacer nada para evitar tal influencia. El nacionalsocialismo, sin embargo, no fue ninguna "pasión", ninguna demencia, o un "lapsus" en la historia alemana. Erich Fromm define Leidenschaft como una actividad que es "pasividad" en realidad porque el que "sufre" una pasión, sufre pero no actúa y no puede hacer nada para evitar los efectos de esta "oscura pasión". "Seducidos" por el nacionalsocialismo rehuyen instituciones, colectivos profesionales y al fin ciudadanos normales la propia responsabilidad en los acontecimientos. La "histeria colectiva" que reinó durante el nacionalsocialismo fue, a nuestro entender, un apoyo consciente, activo, a veces forzado, pero también resignado o indiferente al régimen de Hitler.

Esto también vale para el papel de las mujeres. Como señala Evans: "Hitler no habría triunfado si su mensaje, incluida su exigencia de jefatura política fuerte e individual, no hubiera respondido a las ideas y aspiraciones de una parte importante del electorado alemán." 4

El objetivo de este trabajo es analizar el discurso y las reacciones de las mujeres que vivieron el nacionalsocialismo desde el lado de los vencedores, desde el otro lado de las barracas de los campos de concentración. Entendiendo por discurso el concepto que utiliza Roland Barthes:

'Dis-cursus' significa originariamente "el movimiento producido por el vaivén al correr, es ir y venir, el discurso son pasos, enredos, complicaciones". 5

Desde esta perspectiva del movimiento, del cambio, y por qué no, de la contradicción en lo expresado públicamente comenzamos hace cuatro años y medio nuestra tesis doctoral sobre el discurso femenino durante el nacionalsocialismo, partiendo de las publicaciones de grupos de

3 Joachim Fest y Jürgen Kuczynski contribuyeron a finales de los años setenta a extender esta imagen de las mujeres como “fieles devotas de Hitler". Fest,J.: Das Gesicht des Dritten Reiches, München, Piper, 1963, p.359; Kuczynski,J.: Studien zur Gescbichte der Lage der Arbeiterin von 1700 bis zur Gegenwart, Berlin, Akademie Verlag, 1963, p.255.

4 Evans,R.J.: "Ascenso y triunfo del nazismo en Alemania”, en: Cabrera,M./Juliá,S./Martín Aceña,P. (eds.): Europa en Crisis 1919-1939, Madrid, Editorial Pablo Iglesias, 1991, p.102.

5 Barthes,R.: Fragmente einer Sprache der Liebe, Frankfurt am Main, Suhrkamp, 1989, p.15 (1 ${ }^{\mathrm{a} e d}$. París, 1977). 
mujeres protestantes y católicas, así como de grupos de mujeres no confesionales. Nuestro interés estaba centrado fundamentalmente en la utilización del lenguaje como estrategia de adaptación al régimen, pero también como estrategia de supervivencia en el mantenimiento de la identidad grupal. A diferencia de otros estudios sobre prensa que se ocupan de analizar los procesos de creación de opinión de las publicaciones en cuestión, nuestro estudio trata esta influencia como elemento de descripción interna de los grupos de mujeres que sostienen las publicaciones.

En la primera etapa de nuestro trabajo, tropezamos para nuestra sorpresa con una serie de publicaciones pertenecientes a tres de las más influyentes organizaciones para mujeres durante la República de Weimar, que curiosamente siguieron publicándose durante la dictadura. Las revistas en cuestión, Evangelische Frauenzeitung, Aufgabe und Ziele, dentro del espectro protestante, DIE CHRISTLICHE FRAU, como representante de la organización católica y DIE FRAU, órgano del ala moderada del movimiento de la mujer, reflejan la evolución durante el nacionalsocialismo de los grupos de mujeres de los que eran portavoces. En ellas encontramos discursos diferentes sobre lo femenino, sobre el trabajo, sobre la religión y sobre la guerra. El análisis del discurso, su origen, su parentesco con las ideas nacionalsocialistas y la aclaración de las actitudes políticas de sus principales colaboradoras, constituye el centro de nuestro trabajo.

Los objetivos que nos planteamos en esta investigación son los siguientes: en primer lugar desentrañar los móviles o motivos que llevaron al grupo de mujeres que dirigían y escribían en las mencionadas revistas a hacer un cambio en sus planteamientos ideológicos, desde sus posturas feministas y políticas; en segundo lugar seguir de cerca este cambio ideológico y explicar cómo se articula; y en tercer lugar analizar el discurso ideológico que producen estas mujeres una vez asimiladas por la dictadura. Finalmente tratamos de establecer modelos de actuación durante el nacionalsocialismo que nos pueden ser útiles para entender a otros colectivos sociales durante ésta época. Para conseguir estos objetivos hemos realizado los siguientes pasos:

> Análisis de las estructuras sociales donde actúan las mujeres entendiendo a éstas como sujetos activos en la realidad histórica.

$>$ Estudio de la motivaciones que mueven a las mujeres a actuar en una u otra manera.

$>$ Análisis del discurso de "grupo" de mujeres durante el nacionalsocialismo: dentro de este discurso de grupo pretendemos deconstruir los aspectos que predominan en el discurso; discurso de género, discurso político, discurso religioso, cultural etc.

$>$ Establecimiento de modelos de actuación. Definición del concepto de resistencia.

Nuestro trabajo pretende analizar las razones y las causas de el apoyo de estos grupos de mujeres al nacionalsocialismo, y sobre todo el proceso de adaptación y las estrategias de supervivencia que desarrolla cada grupo de uno. No queremos, sin embargo, reducir la discusión únicamente al aspecto de considerar a las mujeres como "víctimas o culpables" y unirnos a trabajos que demonizan a la mujer alemana o idealizan su papel de víctima del sistema patriarcal nazi. Tampoco queremos contribuir a las nuevas tendencias históricas, ${ }^{6}$ que desde un punto de vista revisionista pretenden restar importancia al nacionalsocialismo, comparándolo con los regímenes comunistas.

Sólo el análisis racional de los procesos sociales de adaptación durante el nacionalsocialismo puede ayudarnos a entenderlo, a que pierda su carácter de demonio, de destino inevitable, de pasión oscura que amenaza con volver y sentar su bota de hierro sobre todos nosotros.

$6 \quad$ Nipperdey, T./Doering-Manteuffel,A./Thamer,H.-U.: Weltbürgekrieg der Ideologien. Antworten an Ernst Nolte, Frankfurt am Main, Propyläen, 1993. 
El planteamiento metodológico de nuestro trabajo puede establecerse en función de varias perspectivas dentro de la investigación feminista. La primera posibilidad está relacionada con la propuesta de la investigación feminista de los años 70, donde se mantenía que la causa de la dominación femenina era el patriarcado, definido como sistema explotador o la relación estructural entre la esfera privada y pública con la adscripción respectiva de género. Este planteamiento metodológico caracteriza, como veremos más adelante, a una gran parte de la investigación que ha venido siendo realizada sobre mujeres y nacionalsocialismo. Dependiendo del entendimiento del sistema político y social nos encontramos con una investigación feminista liberal, una corriente materialista y una tendencia de investigación cultural. Sin embargo este planteamiento de la sociedad patriarcal, como dogma de la investigación feminista, empieza a presentar sus fracturas ya que presenta una perspectiva de la realidad social donde hombres y mujeres aparecen descritos en función de su papel como opresores o víctimas. Punto de partida para este cambio "paradigmático" son los estudios e investigaciones centrados en el análisis de la realidad femenina dónde se registran, especialmente en sociedades multiculturales, la variedad y multiplicidad de la experiencia femenina, así como la imposibilidad de ver a las mujeres como un colectivo neutro y homogéneo. Los primeros trabajos realizados en el campo de la historia, señala Michelle Perrot se concentraban en estos primeros años de investigación sobre las mujeres, fundamentalmente en los "roles naturales" de la mujer: maternidad, natalidad, prostitución. Un segundo paso conduce al mundo del trabajo: amas de casa, trabajadoras etc. ${ }^{7}$ En el terrero de la literatura y la historia encuentran gran aceptación los trabajos sobre la representación de la identidad femenina. Más tarde sucede la historia del cuerpo como lugar de la diferencia de género.

Sin negar la importancia de los trabajos realizados en esta temprana etapa de la investigación sobre las mujeres y su papel en la historia, nos alejamos sin embargo del planteamiento donde las mujeres son entendidas como víctimas de la historia. En este sentido nuestro trabajo se enmarca dentro de la perspectiva de los llamados Gender Studies, donde el género es entendido como una construcción social que no tiene porqué estar necesariamente relacionada directamente con la diferencia sexual. No se trata de hacer historia de la mujer, donde ésta aparece como elemento aislado del cambio social, por el contrario se intenta desde una perspectiva de género analizar discurso y actuación de las mujeres, entendidas éstas como actores del cambio e interrelación social, con el género masculino, con las instituciones como el estado o la iglesia pero también con otras mujeres. El género entendido como atributo, como entidad cultural que cambia de forma en el transcurrir de las épocas históricas. Género como factor de cambio social, como el de clase, raza o confesión. Las relaciones de género como representaciones de sistemas de reglas culturales. ${ }^{8}$

La tematización discursiva del concepto de género presenta múltiples facetas. Ute Frevert apunta en su último trabajo sobre las diferencias de género en la modernidad, lo maltratado que se encuentra éste término en los círculos feministas. Éste señala Frevert "es construido, deconstruido, reconstruido según las ganas del discurso feminista." ${ }^{\prime 9}$ Frevert distingue tres

7 Corbin,A./Farge,A./Perrot,M.: Geschlecht und Geschichte. Ist eine weibliche Geschichtsschreibung möglich?, Frankfurt am Main, Fischer, 1989, p.23.

8 Hof,R.: "Die Entwicklung der Gender Studies", en: Bußmann,H./Hof,R.: Genus. Zur Geschlechterdifferenz in den Kulturwissenschaften, Stuttgart, Alfred Kröner Verlag, 1995, p.16.

$9 \quad$ Frevert, U.: Mann und Weib, und Weib und Mann. Geschlechter-Differenzen in der Moderne, München, Beck, 1995, p.13. 
tendencias entre las investigadoras feministas. Una primera corriente ${ }^{10}$ acentúa la materialidad de la categoría de género donde éste aparece definido en función de la corporalidad, una segunda tendencia define el género como producto lingüístico discursivo, que en todo momento cambia de forma y expresión. ${ }^{11}$ Una tercera línea de investigación, en la que se incluye Frevert, concentra su atención en el hecho de que la construcción de género no se tiene lugar en la experiencia individual, sino que tanto hombres como mujeres participan activamente en ella. Los discursos continúa Frevert se traducen en acciones concretas, en actos "performativos" que construyen la pertenencia de género y a la largo plazo la estabilizan. ${ }^{12}$ Las tres corrientes coinciden en que el género no es una categoría ontológica sino una construcción. Como construcción no sólo se entienden los atributos socioculturales, políticos y económicos del género sino el sustrato biológico, lo que se ha venido definiendo como "el género" del cuerpo, es decir el sexo. ${ }^{13}$

En este punto creemos interesante utilizar el esquema que utiliza la teóloga e investigadora Leonore Siegele-Wenschkewitz partiendo del análisis que hace de las teorías de Sandra Harding sobre el género. ${ }^{14}$ Ésta última, hace referencia a tres procesos que intervienen en la determinación de género:

1. Este es resultado de la atribución dualista de metáforas de género a la percepción dicotonómica de la realidad: este procedimiento recibe el nombre de simbolismo del género social.

2. En la organización de la actuación social se utiliza únicamente este dualismo como elemento diferenciador que se manifiesta primero en el reparto de procesos de actuación social en determinados grupos de individuos, y segundo en la división de las tareas de trabajo en función del género.

3. Como último proceso y no por ello menos importante, señala Harding la construcción de la identidad genérica individual. Si partimos entonces que el género y la diferencia genérica son construcciones discursivas que no aparecen dadas para siempre, sino que son construidas una y otra vez en función de los diferentes contextos históricos se puede establecer como objetivo de las ciencias históricas:

“(...) la tarea de situar este proceso de producción (de la identidad genérica) espacial y temporalmente, denominar sus fuerzas motrices, analizar sus modos de proceder, reflexionar sobre sus alternativas y comprobar sus consecuencias."'15

Desde este punto de vista, no sólo los hombres aparecen como creadores de la identidad genérica como a veces parece deducirse de algunos trabajos, ${ }^{16}$ sino que las mujeres también participan en este proceso de creación o de destrucción a través de su acción (política, expresión

10 Duden,B.: "Die Frau ohne Unterleib", Feministische Studien, 1993 (Cuardeno n²), pp.24-33; Landweer,H.: "Kritik und Verteidigung der Kategorie Geschlecht", Ibídem, pp.34-43; Lindemann,G.:

"Wider Verdrängung des Leibes aus der Geschlechtskonstruktion", Ibídem, p.44-54.

11 Buttler,J.: Das Unbehagen der Geschlechter, Frankfurt am Main, Fischer, 1991

12 West,C./Zimmermann,D.H.: "Doing Gender", GENDER AND SOCIETY, 1987 (año 1), pp.125-151.

13 Frevert, U.: op.cit., p.14.

14 Siegele-Wenschkewitz,L.: "Die Rezeption und Diskussion der Genus-Kategorie in der theologischen Wissenschaft", en: Bußmann,H./Hof,R.: Genus. Zur Geschlechterdifferenz in den Kulturwissenschaften, Stuttgart, Alfred Kröner Verlag, 1995, p.67.

15 Frevert,U.: op.cit., p.14.

16 Válcarcel,A.: Sexo y Filosofía. Sobre "mujer" y "poder", Barcelona, Anthropos, 1991; Puleo,A.: Dialéctica de la sexualidad. Género y sexo en la filosofía contemporánea, Valencia, Cátedra, 1992. 
escrita etc.) lo que no significa que siempre padezcan las consecuencias de la opresión patriarcal, sino como una rueda más del engranaje social participan en el establecimiento del simbolismo del género como factor social a través de su actuación:

"Se demostró que la complejidad de la realidad social no podía ser entendida con las tradicionales oposiciones binarias como hombre versus mujer, o naturaleza versus cultura sino que (está explicación) tenía que ser sustituida por un pensamiento de la diferencia. En esta nueva concepción de las realidades sociales la polémica entre feminismo y postestructuralismo adquirió una gran importancia."'17

La utilización del concepto de género como categoría de análisis científico puede utilizarse, como señala Renate Hof, en función de cuatro argumentos:

1. como delimitación frente a una conexión causal preconcebida naturalmente entre el cuerpo (femenino y masculino) y la creación de determinados roles sociales;

2. con el objetivo de relacionar la estructura de las relaciones entre los géneros con otros contextos culturales y otras formas de organización sociales;

3. desde la perspectiva de que la organización social en la que hombres y mujeres actúan no se puede entender sin el análisis de los mecanismos de poder en la que ésta tiene lugar;

4. en el marco o el contexto del convencimiento de que el proceso de diferenciación que conduce a determinados papeles, tiene que ser tenido en cuenta. ${ }^{18}$

Para el historiador y la historiadora esta perspectiva, de la construcción discursiva del género, adquiere una gran importancia desde el punto de la articulación lingüística y sistemas de interpretación de las relaciones sociales. Así en nuestro trabajo analizamos en los capítulos dedicados a la prensa femenina confesional y del antiguo movimiento de la mujer, la valoración e interpretación de términos como Volkesgemeinschaft, Vaterland, Frauentum etc. ${ }^{19}$

La utilización del factor género como categoría de análisis social está estrechamente relacionada con los estudios de Foucault sobre la sexualidad donde en analogía a Nietzsche utiliza la llamada crítica genealógica. ${ }^{20}$ La critica genealógica rechaza la búsqueda de los orígenes de la identidad genérica, de la verdadera interioridad de la feminidad o de una genuina o auténtica sexualidad. El alma femenina no existe sino que se construye. Esta crítica investiga sobre las posturas políticas que entran en juego cuando las categorías de identidad son definidas como causa y origen, aunque en el fondo son efectos y producto de las instituciones, modos de discurrir y discursos que se producen en la realidad social. ${ }^{21}$

La utilización de la categoría de género ofrece la posibilidad de deconstruir la sospechosa oposición entre hombres y mujeres, y sin embargo paralelamente entender a ambos en el contexto de su realidad social, cultural y política, así como determinar estrategias de poder entre ambos géneros.

17 Hof,R.: op.cit., p.10.

18 Ibídem, p.20.

19 Esta perspectiva de trabajo ha sido utilizada por Reinhart Koselleck en su intento de realizar una "historia de los conceptos", Begriffsgeschichte. Koselleck,R.: "Sozialgeschichte und Begriffsgeschichte", en: Schieder,W./Sellin,V. (ed.): Sozialgeschichte in Deutschland, Göttingen, Vandehoeck \& Ruprecht, 1986.

20 García del Pozo,R.: Michel Foucault: Un Arqueólogo del Humanismo. Estructuralismo, Genealogía y Apuesta estética, Sevilla, Universidad de Sevilla, 1988.

21 Butler,J: Das Unbehagen der Geschlechter, Frankfurt am Main, Suhrkamp, 1991 (Gender Trouble, 1990), p.9. 
Con ayuda de esa categoría de análisis se intenta entender el fenómeno de las relaciones de poder entre los géneros sin utilizar como argumento el problemático postulado de la experiencia colectiva femenina de la represión.

Por otra parte el análisis de género permite reconstruir la multiplicidad de la experiencia femenina y no como señalan Cándida Martínez y Mary Nash: "El análisis de género permite detectar la especificidad de la experiencia femenina y a la vez, establecer las pautas de su integración en los procesos históricos." Inconscientemente Nash y Martínez recurren a la separación tradicional entre masculinidad y feminidad y la experiencia especifica y diferenciada de ambos. Aunque más tarde incide en la necesidad de "estudiar mujeres y hombres, y la relación entre ambos, como sujetos históricos pero sin asignarles a priori espacios, valores, expectativas, comportamientos y objetivos." Especialmente en el caso del nacionalsocialismo se presenta un problema de coherencia y también moral cuando se habla de la "especificidad" de la experiencia femenina. ${ }^{22}$

Consideramos que el factor género es decisivo a la hora de analizar determinados procesos históricos; su utilización no solo revela a la mujer como protagonista y actriz del acontecimiento histórico, sino que ofrece un nuevo aspecto de complicación en el análisis de la realidad. Sin embargo creemos que la utilización de este factor requiere, en la actualidad, una metodología que evite la carencia de rigor científico de muchos trabajos y el abuso de teorías a priori que limitan la exactitud y la seriedad de las investigaciones.

En primer lugar es necesario hablar de mujeres, no de mujer; la historia de la mujer es una entelequia: el hecho de ser mujer es mucho más complejo que los estereotipados análisis de los definidores y definidoras de lo femenino; las mujeres, como los hombres están expuestos a factores que delimitan su actitud política y su discurso; factores de clase, religiosos y educativos deberían ser conjuntamente analizados al lado del factor de género. Nuestro trabajo pretende ser una síntesis de todos ellos.

IV. Mijeres y clases medias. El discurso de clase

En nuestro análisis del discurso femenino durante el nacionalsocialismo, intervienen otro tipo de factores, además del de género que hacen de éste discurso característico y diferente. Es lo que denominaríamos el discurso de clase.

A la hora de determinar la importancia de la influencia del factor de clase en cuanto a la actitud política de los grupos de mujeres que estudiamos, creemos importante aludir al milieu del que provienen estos grupos de mujeres. En el caso de las mujeres protestantes y católicas hemos analizado las reacciones de sus respectivas iglesias respecto al nacionalsocialismo y los efectos que estas reacciones tuvieron en las dos organizaciones objeto de nuestro estudio. En el caso de la organización no confesional de mujeres alemanas es difícil hacer aclaraciones generales porque no existen demasiados estudios sobre las clases medias en especial sobre cómo "la población en su organización social y regional enjuiciaba el sistema nacionalsocialista y cómo se comportaba en situaciones concretas". ${ }^{23}$ De una manera general Norbert Elias resalta como característica principal de las clases medias de finales del siglo XIX y principios del XX, la tendencia progresiva a la idea nacional y el abandono de las grandes ideas de igualdad, fraternidad y libertad, que perdieron con el tiempo su capacidad integradora en la configuración de identidades colectivas:

22 Aguado,A./Capel,R./Calbet,T./Martinez

López,C./Nash,M./Nielfa,G./Ortega,M./Pastor,

R./Ramos,D./Rodriguez Galdo,M./Tavera,S./Ugalde,M.: Textos para la historia de las mujeres en España, Madrid, Cátedra, 1994, p.21.

23 Hüttenberg,P.: "La policracia nacionalsocialista", REVISTA AYER, 1992 (nº5), p.182. 
"En la mayoría de los individuos (pertenecientes a las clases medias) aparece una imagen idealizada de la propia nación como su propia imagen, su ideario político y su código de valores."24

La nación se convierte según Elias en un elemento legitimador de las clases medias. Elias define el etos nacionalista como un sentimiento de solidaridad y de obligación que no orienta a determinadas personas o a un individuos particulares sino a un colectivo soberano. Es entonces cuando términos como Volksgemeinschaft (comunidad del pueblo), Vaterland (patria), Heimat (patria, tierra) o Volk (pueblo), se convierten en señas de identidad de las clases medias, en especial del protestantismo alemán. Lo colectivo, en el sentido de agrupación, de unión, de anulación de lo individual, se disfraza de un aura sentimental y aparece como algo sagrado que requiere su veneración y adoración. Este tipo de explicación coincide con la que algunos historiadores marxistas 25 dedican al análisis de las mentalidades de la clase media: "La tendencia de la clase media de contemplar su mundo como un microcosmos normativo, le hizo el lugar idóneo de todas las consignas de la Volksgemeinschaft." Otro aspecto en el que tanto Elias como los otros autores inciden es en la utilización de razones y argumentos idealistas a la hora de justificar este "cosmos normativo" que en el fondo esconde un instinto de preservación y legitimación. ${ }^{26}$

Interesante es la relación de este sentimiento "colectividad" con la personalidad individualidad. El individuo no sólo tiene una imagen del yo, Ich-Bild y un yo ideal, Ich-Ideal, sino una imagen del nosotros, Wir-Bild, y un nosotros ideal, Wir-Ideal. Elias habla de una determinada "estructura de la personalidad" típica de los sociedades industrializadas de finales del siglo XIX y principios del XX, definida por la "nacionalización del ethos individual."27 La tematización del concepto nación es un fenómeno prolifera en el discurso filosófico, político y religioso de Weimar. El movimiento de la mujer (confesional y no confesional) interpreta este discurso desde la tradición de pensamiento de sus respectivos contextos: el protestantismo cultural (Kulturprotestantismus), el milieu católico y el liberalismo conservador.

Ute Frevert en sus análisis sobre el voto femenino en torno a los años 1930-1932 trata la variante género como un factor más en el conjunto del “acontecimiento mental”. Según Frevert las mujeres alemanas no votaron como mujeres sino "como participantes de las clases sociales, grupos religiosos, como trabajadoras, o como mujeres casadas con maridos sin trabajo". ${ }^{28}$ La decisión política de éstas no dependería únicamente de su condición femenina; otros factores como la crisis económica y el desempleo influirían en su decisión de voto.

24 Elias,N.: Studien über die Deutschen. Machtkämfe und Habitusentwicklung im 19. und 20. Jabrbundert, Franfurt am Main, Suhrkamp, 1992, p.197.

25 Winkler,M.A.: Mittelstand, Demokratie und Nationalsozialismus, Köln, 1972; Fricke,D.: „Zur Erforschung konservativer Politik und Ideologie in der Geschichte bürgerlicher Parteien", ZEITSCHRIFT FÜR GESCHICHTE, 1979 (año 27), pp.1139-1155; Fricke,D.: „Zur Geschichte der politischen Organisationen der bürgerlichen Gesellschaft. Methodologische Probleme", ZEITSCHRIFT FÜR GESCHICHTE, 1985 (año 33), p.68; Haupt,G.H.: „Mittelstand und Kleinbürgertum in der Weimarer Republik. Zu Problemen und Perspektiven ihrer Erforschung", ARCHIV FÜR SOZIALGESCHICHTE, 1986 (n 26), pp.217-238.

26 „El ethos nacionalista se basa en un sentimiento de solidaridad y de deber, que no se refiere a personas concretas o a una sola persona, (...) sino a un colectivo soberano, que los individuos afectados constituyen como Estado (...). Lo colectivo se vive como algo más sagrado y más valor que los propios individuos. El amor a la propia nación no es un amor al individuo, o a grupos de individuos. Este amor es una forma de amor a si mismo.", en: Elias,N.: op.cit., p.196.

27 Elias,N.: op.cit., p.197.

28 Frevert,U.: Frauen-Geschichte. Zwischen bürgerlicher Verbesserung und neuer Weiblichkeit, Frankfurt am Main, Suhrkamp, 1986, p.207. 
Otro de los aspectos que nos gustaría dejar claro es la utilización del término "burgués" con el que en los próximos capítulos aparece definido en algunas ocasiones el movimiento de la mujer. Nuestro entendimiento de este termino coincide con la definición que Barbara GrevenAschoff hace de éste:

"El adjetivo 'burgués' describe a grosso modo el origen social de aquellas mujeres, que desde la mitad del siglo XIX empezaron a organizarse. Éstas procedían principalmente de los círculos de la burguesía cultivada; desde el punto de vista político se encontraban unidas a los partidos liberales. Desde el punto de vista organizativo sus organizaciones representaban el tipo de un movimiento de la mujer autónomo e independiente, que no fue como en el caso de las socialistas absorbido por un partido."29

El hecho de que hubiera dos feminismos uno liberal y otro socialista manifiesta que el proceso de emancipación se desarrollaba en tendencias dependientes de las corrientes ideológicas de la sociedad. El movimiento de la mujer busca la igualdad de la mujer, pero no el cambio del sistema. La emancipación de la mujer se entiende como un proceso individual, de ahí la importancia que esta rama concede a la educación. El feminismo socialista se caracteriza por la doble emancipación: la de la mujer y la del individuo.

Los dos movimientos emancipadores tienen, sin embargo su origen en los principios de igualdad que se derivan de la filosofía de la ilustración. Theodor Gottlieb von Hippel al final del siglo XIX crítica los prejuicios contra el sexo femenino.

El proceso de emancipación no puede ser interpretada únicamente en función de su efectividad objetiva en la integración (Einbequehung) de las mujeres en subsistemas sociales no dependientes de la unidad familiar. El feminismo burgués exige la Selbstbestimmung, autodeterminación y la libertad individual. Por lo tanto su interés se orienta no sólo a la consecución del principio de igualdad en el trabajo y en la política, sino que aspiraba a un cambio de la moral social imperante.

Para poder evaluar correctamente la actuación de las mujeres del movimiento moderado durante el nacionalsocialismo, hay que tener en cuenta el carácter liberal de éste. El movimiento de la mujer se halla estrechamente ligado a los principios emancipadores de las revoluciones del 48 y a los esquemas liberales de concepción del individuo como elemento que decide libremente sobre su propia realidad. Sin embargo no podemos olvidar la peculiaridad del movimiento de la mujer alemán:

"El movimiento burgués de la mujer en Alemania se desvía de la argumentación del derecho natural. Aunque entre sus reivindicaciones se encontraba la igualdad ante la ley, (el movimiento alemán) parte del supuesto de la teoría dualista de los géneros. Hombre y mujer son por naturaleza diferentes pero sus funciones tienen el mismo valor en relación a la reproducción de la sociedad."30

La maternidad se convierte para las mujeres del movimiento de la mujer en el centro de su discurso. No se trata únicamente de la maternidad biológica sino que desarrollan una cultura de la feminidad cuyas raíces se encuentran en la "maternidad espiritual". En este concepto de la maternidad espiritual que se refiere fundamentalmente al carácter positivo de la naturaleza

29 Greven-Aschoff,B.: Die bürgerliche Frauenbewegung in Deutschland 1894-1933, Göttingen, Vandenhoeck und Ruprecht, 1981, p.13.

$30 \quad$ Ibídem, p.39. 
femenina para la comunidad, se basa la teoría de la diferencia del movimiento de la mujer alemán y constituye el armazón de su antropología dualista.

Esta "desviación" del movimiento de la mujer alemán conduce a historiadores como Evans a fundamentar la diferencia del caso alemán, Sonderweg alemán como una de las causas del desarrollo del nacionalsocialismo. Evans toma como modelo el feminismo inglés y americano del siglo XIX, y a partir de ahí juzga el caso continental europeo. En su estudio sobre el movimiento de emancipación estudia el liberalismo de la época guillermina y de sus "desviaciones" de la imagen clásica. La tesis del Sonderweg alemán se confirma. El interés del autor no reside en analizar los problemas de la emancipación femenina sino que su interés se dirige a utilizar el movimiento de emancipación como campo de investigación de la naturaleza para el Nacionalsocialismo. Greven-Aschoff intenta desde la perspectiva de la historia social combinar la historia política de las personalidades con determinados momentos del cambio social tomando como ejemplo el feminismo burgués intenta analizar la estructura del proceso de emancipación.

La teoría de las dos morales (femenina y masculina) se consolida con filósofos como Nietzsche o Schopenhauer que califican la capacidad de amor como atributo femenino y la capacidad de juzgar como masculina. Razón, sentimientos. De esta "doble moral" no se ha visto, desgraciadamente, relegada algunas de las alas del feminismo o de la investigación de las mujeres. Lo femenino como algo exótico, diferente y superior a la agarrotada y mediocre ratio masculina, no son sólo banderas de acción de filósofos misóginos.

\section{$V$. Resistencia, colaboración o exilio interior}

Finalmente nos gustaría hacer una pequeña alusión al concepto de resistencia que utilizaremos en nuestro trabajo. Junto a los intentos de buscar aclaraciones definitivas a la naturaleza del nacionalsocialismo, se encuentra unido, estrechamente la búsqueda de una definición del modelos de resistencia. ${ }^{31}$

Hüttenberger define el concepto de resistencia en Alemania como un termino impregnado por el 20 de Julio de 1944 y la legitimación política que el parlamentarismo de la República federal hace de este término, en especial los sectores conservadores y liberales. A este grupo de resistentes pertenecen figuras, integradas en la estructura nacionalsocialista que a finales de la dictadura se deciden por la solución violenta. Todavía en la actualidad esta fecha se convierte todos los veranos en motivo de crítica y de polémica. Marion Gräfin Dönhoff, una de los personajes más representativos de la vida política e intelectual de Alemania, responde a las críticas de antisemitismo, nacionalismo y diletantismo de los hombres del 20 de julio con una versión contraria y define a éstos como "hombres que se decidieron ejercer resistencia a raíz de los crímenes cometidos contra los judios" y "convecidos antinacionalistas". 32

La resistencia comunista o socialista, no goza por el contrario de un acto conmemorativo como ocurre con los hombres y mujeres del 20 de julio.

La dificultad de establecer que se puede considerar como resistencia ha llevado a historiadores a intentar presentar modelos que intentan hacer más fácil la valoración de este concepto.

31 Hüttenberger,P.: „Vorüberlegungen zum Widerstandsbegriff“, en: Kocha,J.: Theorien in der Praxis des Historikers, GESCHICHTE UND GESELLSCHAFT. ZEITSCHRIFT FÜR HISTORISCHE SOZIALWISSENSCHAFT, Göttingen 1977 (Sonderheft 3), pp.117-139.

32 Gräfin Dönhoff,M.: "Vorurteil statt Fakten", SÜDDEUTSCHE ZEITUNG, 5.8.1997 (n¹78), p.9. 
Uno de los autores que presenta un modelo de interpretación del concepto de resistencia es Hüttenberg. Este critica las llamadas Repräsentationstheorie des Widerstandes. Este tipo de teorías tienen la mayoría de las veces la siguiente estructura: ya que el régimen nacionalsocialista no permitió que un grupo social se pudiera articular políticamente, se manifiesta la oposición contra el Tercer Reich en pequeños grupos que originariamente estaban unidos personalmente a un determinado grupo social: Pastor/Sacerdote-Iglesia, Priester-Kirche, Trabajador-clases trabajadoras, Arbeiter-Arbeiterbewegung, etc. Estas modelo de identificación tiene la siguientes consecuencia: la tendencia a enjuiciar las actitudes de los grupos de oposición en relación a su rechazo de la ideología nacionalsocialista y a dejar de lado otras realidades sociales que no eran nacionalsocialistas. Los motivos de la actuación se explican en función de la moralidad del grupo de oposición y de la inmoralidad del régimen. Causas de tipo material, social-psicológico son infravaloradas.

Otro experimento, que utiliza elementos teóricos pero que no construye una teoría de la resistencia: determinación de las dimensiones de actuación de la dictadura, la investigación de las relaciones entre las unidades sociales y su disolución y el análisis del contenido de la dictadura.

En función de las relaciones entre grupo social y dictadura Hüttenberger distingue entre cuatro tipos de resistencia:

1. Resistencia de unidades políticas: las actividades de organizaciones prohibidas y sus seguidores. Partidos políticos (Socialdemocracia y Partido Comunista).

2. Seguidores y organizaciones que debido a la vigilancia policial tienen problemas para reunirse: protesta social, no conformidad, Abkapselung.

3. Unidades sociales que son toleradas por la dictadura y que influencia dentro del grupo de la población tiene, que están fueran del marco de la dictadura: iglesias, grupos políticos etc.

4. Resistencia dentro de la dictadura.

La división que hace Hüttenberg presenta a nuestro entender un déficit ya que se centra exclusivamente en los movimientos organizados y no incluye en su modelo a los grupos y círculos de personas que sin compartir los fines del nacionalsocialismo no se integran en las estructuras de éste y se caracterizan por su disidencia política no organizada.

Richard Löwenthal, por otra propone tres formas de oposición antitotalitaria: la oposición política, la desobediencia social y la disidencia ideológica. ${ }^{33}$ La primera forma de resistencia abarca todo tipo de actividad que en la ilegalidad se dirige contra la dictadura del partido. Se encuentra en las filas de los partidos de izquierda. La desobediencia social es un tipo de resistencia que se encuentra fundamentalmente en las iglesias, en el ejército y en la administración. Normalmente no se aducen motivos políticos. La última forma de resistencia esta formada por aquellos colectivos intelectuales y sociales que no comparten la ideología nacionalsocialista. Entre ellos se encuentran artistas e intelectuales, conocidos como los integrantes de la "emigración interior". Löwenthal nombra entre ellos a Ernst Wiechert, Ernst Jünger, Werner Bergengruen, Reinhold Schneider o Oskar Loerke, representantes de una tradición humanista conservadora que fue tolerada por los nacionalsocialistas.

Dentro de los historiadores que analizan el papel de las iglesias se proponen también modelos de resistencia que pretenden definir las actividades de las iglesias a favor o en contra del nacionalsocialismo. Klaus Gotto, Hans Günter Hockerts y Konrad Repgen ${ }^{34}$ proponen cuatro niveles de resistencia:

33 Löwenthal,R.: "Deutsche Opposition gegen das NS-Regime", en: Bracher,K.D./Funke, M./Jacobsen,H.A. (eds.): Nationalsozialistische Diktatur 1933-1945. Eine Bilanz, Bonn, Schriftenreihe der Bundeszentrale für politische Bildung, 1986, p.621.

34 Gotto,K./Hockerts,H.G./Repgen,K.: "Nationalsozialistische Herausforderung und kirchliche Antwort. Eine Bilanz", en: Bracher,K.D./Funke,M./Jacobsen,H.A.: (eds.): Nationalsozialistische Diktatur 1933-1945. Eine Bilanz, Bonn, Schriftenreihe der Bundeszentrale für politische Bildung, 1986, p.656. 
1. Descontento puntual: quejas de agricultores o trabajadores sobre bajadas de precios, y salarios bajos.

2. Defensa de intereses de grupo: Iglesia Católica, Iglesia Protestante

3. Protestas públicas.

4. Resistencia activa.

Finalmente nos gustaría aludir a un último esquema de resistencia elaborado exclusivamente para las organizaciones religiosas, que es el que utilizaremos en el análisis del discurso producido por las organizaciones de mujeres confesionales. Para las organizaciones protestantes utilizaremos el modelo definido por Ernst Wolf:

1. Resistencia contra los atentados de la autoridad estatal contra los intereses de grupo.

2. Defensa del derecho a predicar el evangelio.

3. Resistencia que se fundamenta en la vieja tradición que entiende a la iglesia como institución que tiene el derecho de a criticar la realidad exterior (Wächteramt der Kirche).

4. Oposición politica.

\section{La prensa como expresión del discurso de grupo}

El estudio del movimiento de la mujer en la Alemania de Weimar y su posterior evolución durante el nacionalsocialismo, quedaría incompleto sin no se hiciera alusión a la importancia a los órganos de prensa que sustentaban el movimiento. Las publicaciones de las organizaciones constituían la ventana hacia el mundo exterior y ofrecía a las mujeres más activas del movimiento la posibilidad de expresar sus ideas y proyectos del movimiento de la mujer. Las redacciones de estas publicaciones que a veces no pasaban los 2.000 ejemplares estaba formada principalmente por aquellas mujeres que ocupaban puestos de dirección en la organización. En la mayoría de los casos no se trataba de periodistas profesionales sino de maestras y universitarias que dedicaban una gran parte de su tiempo al trabajo de redacción. Estas publicaciones además de ser un foro de la actividad social, investigadora y artística de las mujeres de la época, se convierten en señas de identificación de los diferentes grupos del movimiento de la mujer. Durante el nacionalsocialismo este carácter de saberse perteneciente a un grupo se acentúa. Con la disolución de la mayoría de las asociaciones de mujeres protestantes, desaparecen lógicamente sus órganos de prensa, a excepción como ya hemos comentado con anterioridad, las publicaciones de las organizaciones de mujeres confesionales y el órgano de prensa del ala moderada del movimiento no confesional de la mujer. En nuestro trabajo no tratamos de hacer un análisis sobre la recepción de estas publicaciones en la opinión pública, empresa muy interesante pero que debido a la falta de estadísticas y testimonios orales es muy difícil de valorar. Así por ejemplo señala Almut Todorov en su trabajo sobre mujeres y periodismo durante la república de Weimar, los problemas de método que se plantean en la investigación de procesos comunicativos en el pasado:

"Ésta tiene como recurso, el producto en si, es decir la publicación, informaciones directas o indirectas sobre la redacción y sobre los periodistas. A veces las publicaciones son fragmentarias y no han sido conservadas en su totalidad. Los archivos de las redacciones se encuentran raramente a la disposición del investigador. Por lo tanto otros materiales como correspondencia privada, autobiografías, informes coetáneos y testimonios literarios y artísticos, no sólo 
ganan importancia sino que determinan el tratamiento socio-histórico de la investigación comunicativa."35

Partiendo del handicap que representa la escasez de fuentes, nuestro interés se centra en las mujeres que formaban parte de la redacción y de las colaboradoras más cercanas. ¿Defienden los órganos de prensa un discurso conjunto e uniforme? ¿Cuál es la postura que toman las publicaciones durante el nacionalsocialismo y como se desarrolla su trabajo entre 1933 y 1945 ? ¿Cómo se desarrollan las relaciones entre las mujeres de la redacción, existen diferencias de opinión respecto a tratar, especialmente aquellos que podrían demostrar una crítica al nacionalsocialismo?

Este análisis se refiere al comportamiento "discursivo" respecto a la familia, la profesión de la mujer, la identidad femenina, la guerra, la religión y la postura política respecto al nacionalsocialismo. Sobre el efecto de socialización es difícil establecer medidas, ya que carecemos de estadísticas que midieran la cuota de aceptación. Existen algunos estudios que se ocupan del control que sufren autores y autoras individualmente durante el nacionalsocialismo. ${ }^{36}$ Gertrud Bäumer, una de las redactoras jefe de DIE FrAU, es la única, de las mujeres de las que nos ocupamos en nuestro análisis, que aparece en las listas departamento sobre escritores/as y publicistas que el departamento de Rosenberg, Amt für Schrifttumspflege beim Beauftragten des Fübrers, elaboraba anualmente sobre los productos de la creación literaria que no eran bienvenidos dentro de las consignas nacionalsocialistas. ${ }^{37}$

Mientras que el papel de la prensa durante el nacionalsocialismo, y el análisis de las grandes publicaciones y periódicos, se encuentra medianamente investigado, ${ }^{38}$ no ocurre lo mismo con las aportaciones de las mujeres a este campo. Entre los pocos trabajos existentes sobre prensa femenina durante el nacionalsocialismo, destacan las aportaciones de Eva Maria Unger sobre las revistas ilustradas y el tratamiento de la guerra en éstas. ${ }^{39}$ Unger parte de la tesis de que uno de los fines del régimen nacionalsocialista era la guerra. En función de este interés se crea un complejo aparato de propaganda que ayuda a concienciar a la población femenina de la necesidad de ésta. A través de la prensa se crean modelos de identificación, imágenes, estereotipos etc. formando parte de la estrategia de propaganda, la Verberrlichung, la glorificación de la violencia y del Soldatentum, comunidad de soldados que aparece como la forma más elevada

35 Todorow,A.: "Frauen im Journalismus der Weimarer Republik", INTERNATIONALE SozIALGESCHICHTE, 1991 (n¹6), p.87.

36 Strothmann,D.: Nationalsozialistische Literaturpolitik. Ein Beitrag zur Publizistik im Dritten Reich, Bonn, Bouvier Verlag, 1985.

37 Ibídem, p.249 y 449.

38 Bender,O.: Der gerade Weg und der Nationalsozialismus. Ein Beitrag zur katholischen Widerstandspresse vor 1933, München, Tesis Doctoral, 1959; Frind,S.: Die Sprache als Propagandainstrument in der Publizistik des Dritten Reiches, untersucht an Hitlers "Mein Kampf" und den Kriegsjahrgängen des "Völkischen Beobachter", Berlin, Ernst Reuter Gesellschaft, 1964; Günsche,K.L.: Phasen der Gleichschaltung. Stichtagsanalysen deutscher Zeitungen 1933-1938, Osnabrück, Fromm, 1979; Dovirat,E.: "Die Presse der Weimarer Zeit", ZEITUNGSVERLAG UND ZeitschriftenVERLAG, 1982 (año 60, n¹3); Frei,N./Schmitz,J.: Journalismus im Dritten Reich, München, Beck, 1989.

39 Unger,E.M.: Illustrierten als Mittel zur Kriegsvorbereitung 1933 bis 1939, Köln, Pahl-Rugestein Verlag, 1984. Sobre la república de Weimar: Wischermann,U.: "Die Presse der deutschen Frauenbewegung 1848-1918. Anregungen zur Erforschung einer fast vergessenen Öffentlichkeit", Presse und Geschichte II, München 1987; Gerhard,U.: "Über die Anfänge der deutschen Frauenbewegung um 1848. Frauenpresse, Frauenpolitik und Frauenvereine", en: Hausen,K. (ed.): Frauen suchen ibre Geschichte. Historische Studien zum 19. Und 20 Jabrbundert, München, Beck, 1987; Wilhelms,K.: "Frauenzeitschriften in der Weimarer Republik", en: Hart und Zart. Frauenleben 1920-1970, Berlin, Elefanten Press, 1990, pp.53-60. 
de realización personal. Unger divide cronológicamente el análisis de las publicaciones en tres períodos, que puede ser útil para nuestro estudio. La primera fase (1933-1935/36), fase caracterizada por la "demagogia de paz" y que tiene como fin la consecución de la libertad de armamento. Una segunda fase (1936-1938) se caracterizaría por la movilización de la política de expansión, lucha contra el desempleo y prosperidad económica y finalmente la tercera fase( 1939-1945), fase de la guerra total.

Respecto al análisis de los textos de la prensa objeto de nuestro estudio hemos seguido una serie de pasos propuestos por Utz Mass ${ }^{40}$ para el análisis del lenguaje durante el nacionalsocialismo:

1. Datos sobre el contenido del texto.

2. Escenificación del contenido, es decir análisis de la "superficialidad" del texto a través del tipo de palabras que se utilizan, terminología específica, formas de la "decoración lingüística", elementos dominantes etc.

3. Análisis del sentido de la escenificación, y mensaje del texto teniendo en cuenta el contexto espacio-temporal.

\section{Género, bistoria de las mujeres y nacionalsocialismo}

Desde los años sesenta el debate tanto científico, como político sobre el nacionalsocialismo en la República Federal Alemana, se centró fundamentalmente en la intención de descubrir hasta donde llegaba la implicación de la sociedad alemana en el "estado del terror". Desde esta perspectiva surgieron trabajos sobre el papel en la dictadura de la gran industria, de las elites burocráticas, de la justicia, y del ejército, así como sobre la clase trabajadora. La situación de las mujeres durante el nacionalsocialismo comenzó a suscitar un gran interés durante los años setenta. El nuevo movimiento de la mujer marca los primeros impulsos en la investigación histórica sobre las mujeres.

El análisis del discurso de la prensa para mujeres durante el nacionalsocialismo no se puede entender sino hacemos referencia a tres problemas que atañen al tratamiento del tema mujeres y nacionalsocialismo y que se discutirá más tarde en el apartado dedicado a la bibliografía sobre el tema. Nos referimos en primer lugar a la controversia sobre el problema de la victimización y de la culpabilidad, que no se trata de otra cosa que del aspecto moral y del principio de responsabilidad de la valoración histórica del nacionalsocialismo. Unido a éste aparece como consecuencia lógica el tratamiento del problema de la resistencia y oposición al régimen. Sobre este tema hemos citado con anterioridad un par de estudios que intentan establecer "una metodología" de la resistencia que nos va a resultar muy útil a la hora de definir modelos de actuación de grupo durante el nacionalsocialismo. Como tercer problema se plantea la inclusión del factor de género. ¿Actúan las mujeres de una manera diferente? ¿Desarrollan durante el nacionalsocialismo un discurso diferente al masculino?

Creemos interesante llamar la atención sobre las investigaciones de la psicóloga americana, Caroll Gilligan, que se ocupa de estudiar la existencia de una moral femenina diferente a la masculina. ${ }^{41}$ Gilligan parte de la evaluación crítica de la tipología de conducta moral de Kohlberg, y registra que las respuestas de los grupos de mujeres investigadas se inclúa dentro del llamado nivel

40 Mass,U.: Als der Geist der Gemeinschaft eine Sprache fand. Sprache im Nationalsozialismus. Versuch einer historischen Argumentationsanalyse, Opladen, Westdeutscher Verlag, 1984, p.18.

41 Nummer-Winkler,G. (ed): Weibliche Moral. Die Kontroverse um eine geschlechtsperifische Ethik, München, DTV, 1995, p.11. 
tres, donde las preferencias morales del individuo analizado son las del grupo que pertenece. Los hombres aparecían por el contrario en el nivel cuatro donde la conducta moral se rige en función de las pautas establecidas por la sociedad.

Las investigaciones de Gilligan no pasaron por alto en los Estados Unidos sino que dieron lugar a una serie de reacciones que también tuvieron eco en Alemania: Gilligan señala dos orientaciones morales a través de las diferencias en el contenido de las situaciones morales de conflicto. Esta teoría habla de dominios de influencia morales: el interpersonal y el público, ambos son necesarios para el funcionamiento de la sociedad. En el caso de que las mujeres prefirieran el primero no sería un motivo discualificador.

La historia de la investigación sobre la actuación de las mujeres durante el nacionalsocialismo está extremadamente marcada por el análisis de las relaciones entre género y moral. La pregunta ¿piensan las mujeres de una manera diferente? la búsqueda de una literatura femenina, o la búsqueda de un modo de actuar especial en la historia son esquemas de todos conocidos. El tratamiento del ser en función de la diferencia se agudiza cuando se tratan temas relacionados con el ejercicio de la violencia por parte del estado en un estado de guerra o en una dictadura. Esta pregunta se acentúa con gran intensidad en un tema como el nacionalsocialismo, donde los primeros intentos de investigación sobre el papel de las mujeres en este periodo comenzaban con la supuesta tesis de que las mujeres eran las responsables de la llegada de Hitler al poder. La pregunta es, ¿puede sostenerse la teoría de género como factor de investigación si sólo trabaja en función de la diferencia moral de las mujeres ya sea positiva o negativamente? Nuestra respuesta es negativa. No queremos negar la importancia del principio de responsabilidad moral en el tratamiento del nacionalsocialismo, sin embargo la investigación respecto a la culpabilidad o la situación de víctimas de las mujeres en el patriarcado, conduce si no se utilizan otros puntos de vista a un callejón sin salida. Creemos que son necesarios otro tipo de factores o restricciones que ayuden a hacer más clara la foto de las mujeres durante el nacionalsocialismo. Grupos de edad, diferencias de educación, socialización política etc. Esta es la propuesta que hemos seguido en nuestro trabajo con la elección de tres grupos concretos de mujeres que se definen por la pertenencia al mismo partido, círculo ideológico, la misma formación intelectual y la misma generación.

El problema de la moral femenina es centro principal de los estudios sobre la actuación de las mujeres durante el nacionalsocialismo que rechazan la valoración del papel de la mujer desde el punto de vista masculino.

En 1976 aparece el primer trabajo que critica la versión de aquellos historiadores que consideraban que las mujeres habían contribuido con su voto, y con su culto a la figura de Hitler al ascenso del nacionalsocialismo. ${ }^{42}$ Tröger relativiza la importancia de la contribución femenina resaltando el carácter masculino del nacionalsocialismo, así como hace referencia a las esperanzas que las mujeres (especialmente las pertenecientes a las clases medias bajas) habían puesto en el nacionalsocialismo como un medio para mejorar la situación financiera de las familias.

Los años ochenta se caracterizan por un gran número de trabajos relacionados con el papel de las mujeres y el nacionalsocialismo. La variedad de éstos permite distinguir tres tendencias de investigación: (a) trabajos que presentan a las mujeres como oprimidas, en oposición o adaptadas al régimen; (b) tendencia que pretende introducir la categoría víctima/culpable a mediados de los años ochenta, y (c) a finales de los ochenta la caracterización de las mujeres como participantes y cómplices de la dictadura.

A finales de los años setenta y ochenta los trabajos se concentran en el tratamiento de la ideología y política nacionalsocialista sobre las mujeres. Centro de esta tendencia de investigación es la asunción del carácter de sociedad patriarcal que representa el nacionalsocialismo y la

42 Tröger,A.: "Die Dolchstoßlegende der Linken: 'Frauen haben Hitler an die Macht gebracht'. Thesen zur Geschichte der Frauen am Vorabend des Dritten Reichs", en: Frauen und Wissenschaft, Beiträge zur Berliner Sommeruniversität für Frauen, Berlin, 1977, pp.324-355. 
diferenciación en este período entre esfera pública (hombres) y privada (mujeres). ${ }^{43}$ Los estudios se centran en la valoración que hace la ideología nazi de la mujer como madre, y resaltar el carácter biológico de la maternidad para la procreación de la raza. ${ }^{44}$

En esta línea discurre el trabajo de Christine Wittrock ${ }^{45}$ en que el distingue discursos no sexistas en algunos de los planteamientos de mujeres nacionalsocialistas. Esta autora olvida sin embargo, que estos textos fueron escritos en los primeros años de la dictadura y así mismo que las mujeres que los escribieron fueron relevadas de sus cargos en el año 1933.

Un segundo tipo de trabajos publicados en la primera mitad de los años ochenta parte de la tesis de la opresión de las mujeres durante el nacionalsocialismo. Todas las mujeres, sin hacer ningún tipo de diferenciación son víctimas de la opresión patriarcal de la dictadura. Esta se define como Führerstaat o estado totalitario donde las mujeres sufren a condición de su sexo las vejaciones de un estado orientado al engrandecimiento del sexo masculino.

En esta línea se inscribe Irene Stoehr que considera que los conceptos de resistencia para definir grados de oposición en el nacionalsocialismo han sido elaborados desde el punto de vista masculino. Un artículo de esta autora publicado en 1983 pone el dedo en la llaga sobre la actuación del movimiento de la mujer, durante el nacionalsocialismo. En éste califica de resistente la actitud de Gertrud Bäumer, dirigente del movimiento de la mujer que continúa, a pesar de la disolución de su organización, con la publicación del órgano de prensa de ésta hasta 1944, y con ella incluye al movimiento de la mujer en su totalidad, durante el nacionalsocialismo, al poner ante todo su defensa del movimiento de la mujer sobre cualquier régimen democrático, dictatorial o parlamentario. ${ }^{46}$

En primer lugar habría que resaltar la estrecha unión que este tipo de literatura tenía en sus comienzos con el movimiento feminista y la historiografía en torno a éste. Se trataba por consiguiente de una construcción de la historia de carácter combativo cuyo principio fundamental era la lucha contra una situación de opresión que las mujeres habían sufrido a lo largo de la historia .${ }^{47}$ Era pues una literatura que atribuía a lo masculino los valores de la guerra, de la injusticia y de la opresión, que distinguía entre una moral femenina y una masculina. Los hombres serían por tanto los culpables del nacionalsocialismo y las mujeres, en general, víctimas de sus horrores. ${ }^{48}$

A mediados de los ochenta levanta el trabajo de Gisela Bock una gran polémica. ${ }^{49}$ El tema principal de sus trabajos es la teoría y aplicación de la ley del 14 de Julio de 1933 para la supresión

43 Kuhn,A./Rothe,V.: Franen im deutschen Faschismus. Eine Quellensammlung mit fachwissenschaftlichen und fachdidaktischen Kommentaren (Band 1: Frauenpolitik im NS-Staat, Band 2: Frauenarbeit und Frauenwiderstand), Düsseldorf, Schwann, 1982-1983; Winker,D.: Frauenarbeit im Dritten Reich, Hamburg, 1977.

44 Frauengruppe Faschismusforschung (ed.): Mutterkreuz, und Arbeitsbuch. Zur Geschichte der Frauen in der Weimarer Republik und im Nationalsozialismus, Frankfurt am Main, Fischer, 1981.

45 Wittrock,C.: Das Frauenbild in faschistischen Texten und seine Vorläufer in der bürgerlichen Franenbewegung der zwanziger Jahre, Disertación, Franfurt am Main, 1981.

46 Wigerhaus,R.: "Frauen unterm Nationalsozialismus“, Wuppertal, Peter Hammer Verlag, 1984, p.6.

47 En esta época aparecen un gran número de obras literarias en las que las alusiones a los tiempos de la dictadura son muy frecuentes. Autoras como Christa Wolf y Luise Rinser narran el proceso de socialización de las jóvenes en la dictadura nazi, la limitación de sus valores éticos, la importancia de la figura del padre como elemento desencadenador de una violencia familiar que posteriormente se traslada al Estado donde las mujeres son tan solo víctimas inconscientes.

48 Szepansky,G.: "Blitzmädel", "Heldenmütter", "Kriegerwitwe". Franenleben im Zweiten Weltkrieg, Frankfurt am Main, 1986; Lück,M.: Die Fran im Männerstaat. Die gesellschaftliche Stellung der Fran im Nationalsozialismus, Frankfurt am Main, Peter Lang, 1979.

49 Bock,G.: Zwangsterilisation im Nationalsozialismus. Studien zur Rassenpolitik und Frauenpolitik, Schriften des Zentralinstituts für Sozialwissenschaftliche Forschung der Freien Universität Berlin, Vol.48, Opladen, Westdeutscher Verlag, 1986. 
de enfermedades de transmisión hereditaria. Bock utiliza las obras publicadas durante 1933-1945 sobre la citada ley, y de igual manera se apoya en un número substancioso de documentos localizados en los archivos regionales alemanes. Se trata de un estudio realizado desde varias perspectivas: el desarrollo legislativo e institucional y la aplicación de la ley. Incluye también el contexto histórico, resultado de la política de esterilización y de las consecuencias para las personas afectadas. La aplicación de la ley no fue, según la autora, neutral en lo relativo al género. Por el contrario ésta fue aplicada a los diferentes sexos en diferentes grados de intensidad y rigidez. A diferencia de las víctimas masculinas, las mujeres que sufrieron las consecuencias de la ley fueron también objeto de la dominación sexual masculina..$^{50}$ Bock establece que la política de esterilización constituyó una parte más de la política de genocidio caracterizada por su contenido antisemita y antinatalista.

Las mujeres aparecen por consiguiente en la obra de Bock, definidas por su doble condición de víctimas: sufren por un lado por su condición de mujeres, y por otro por su raza o su salud mental o física.

Sin embargo en una etapa de la historia como el nacionalsocialismo, no era difícil encontrar mujeres que colaboraran con el régimen, y que incluso llegaran a protagonizar la ejecución de perversidades con más saña que algunos hombres. Los trabajos sobre los horrores cometidos en los campos de concentración por mujeres, el análisis de los procesos electorales (en los que supuestamente el electorado femenino había votado al partido nacionalsocialista), y la capacidad de sugestión de Hitler respecto al público femenino, revelaban, según autores como Jürgen Kuczynski y Joachim Fest ${ }^{51}$ que las mujeres fueron no sólo las responsables de que Hitler hubiera conseguido hacerse con el poder, sino que habrían sido uno de los pilares sobre los que se mantenía el régimen nacionalsocialista. Se deducía de estas conclusiones que las mujeres se caracterizaban precisamente por una actitud conservadora.

Algunas autoras, también feministas, aunque de una generación más joven que las anteriores, retoman este punto de vista y centran sus trabajos en ejemplos concretos de participación y colaboración en los que los protagonistas no aparecen definidos por su sexo, sino por su condición humana (en todos los casos despreciable) y su personalidad. Critican por encima de todo la investigación sociológica e histórica en la que las mujeres eran sólo vistas como víctimas. En 1987 publicaba Angelika Ebbinghaus una obra titulada, Opfer und Täterinnen, "Víctimas y verdugos"52, en la que se estudian las relaciones entre las mujeres que participaron en la política social de carácter sexista y racista del nacionalsocialismo y sus víctimas. Consideramos que este cambio de argumentación tiene bastante importancia ya que abandona posiciones simplistas y nucleares de una cierta inconsistencia científica, que explicaban la historia de las mujeres más desde el lamento

50 Esta afirmación no es del todo descabellada. Gracias a los documentos de archivo podemos probar como la esterilización femenina era practicaba en algunos caso a mujeres que mostraban una "sexualidad precoz", cosa que sin embargo no les ocurre a los hombres. En los caso que hemos tratado, una joven de 17 años fue internada en un campo de protección de menores y esterilizada, por la única razón de haber mantenido relaciones sexuales con individuos de nacionalidad polaca, por su necesidad de llamar la atención en la escuela, y por emplear palabras soeces. (Unterbringung von weiblichen Minderjährigen im Jugendschutzlager Uckermark, Stadtarchiv Heidelberg, n¹921).

51 Fest,J.: Eine Biographie, Frankfurt am Main, Propyläen, 1973. Esta afirmación ha sido posteriormente matizada por autoras como Ute Frevert. Según sus averiguaciones, fueron en un principio los hombres los que más votaron al NSDAP. En 1930 un 15,5\% de mujeres votaron al partido nazi frente al 19,8\% de los hombres; en 1932 los votos de las mujeres suponían un 19,2\% frente a un 21,8\% de los hombres. En: Frevert,U.: Frauen-Geschichte. Zwischen bürgerlicher Verbesserung und neuer Weiblichkeit, Frankfurt am Main, Suhrkamp, 1986, p.207.

52 Ebbinghaus,A.: Opfer und Täterinnen. Frauenbiographien des Nationalsozialismus, Nördlingen, Delphi, 1987. 
reivindicativo que desde el relato histórico y de investigación. Sobre este tema hay que citar trabajos importantes como el de Helga Schubert, Judasfrauen, o "Las mujeres Judas" (1990) ${ }^{53}$, publicado poco después de la caída del muro de Berlin, y que participa de la línea histórica "desenmascaradora" en la que se encuentran inmersos un gran número de historiadores que analizan los procesos de colaboración en la antigua República Democrática Alemana. Esta obra hace alusión a la traición y colaboración femeninas durante el nacionalsocialismo y participa de una literatura historiográfica en la que la dicotomía hombre-culpable, mujer-víctima no tiene ninguna validez. No obstante, se observa tanto en esta autora como en otras que trabajan en la misma dirección, ciertos matices de enjuiciamiento moral de la actuación de las mujeres, proveniente sin duda alguna de restos de idealización de lo femenino. Prueba de ello es el calificativo con el que se define la colaboración femenina como "demonización de la feminidad", o rebajación del instinto maternal. 54

Hasta ahora la mayoría de los trabajos partían de la perspectiva del carácter sexista del nacionalsocialismo. A partir de mediados de los años ochenta se encuentran los primeros intentos de alejarse de categoría de análisis que veía a las mujeres como víctimas del patriarcado. ${ }^{55}$

Este cambio de perspectiva refleja una necesidad de superar la dualidad teórica en que había caído la investigación sobre las mujeres en el nacionalsocialismo y pone de manifiesto uno de los puntos débiles de la Historia de las Mujeres, su limitación exclusiva al problema de género; el esquema víctima-culpable debía ser superado para dar paso a estudios en los que los factores de clase, confesión religiosa y actitud política comenzaran a ser analizados.

Partiendo de este punto de vista Christina Thürmer-Rohr profundiza en la categoría de la complicidad de las mujeres. Esta autora defiende como tesis de su argumentación que "en las sociedades patriarcales civilizadas una confusión diferenciada genéricamente de intereses produce la complicidad de las mujeres para que éstas no traicionen, luchen o impidan los actos de sus compañeros masculinos." ${ }^{56}$ No obstante la deducción de la pasividad femenina permanece en la interpretación de Thürmer-Rohr.

Claudia Koonz ${ }^{57}$ intenta finalmente salir del esquema de la pasividad femenina. Su trabajo en el estudio de las organizaciones y grupos de mujeres protestantes y católicas que perviven durante el Tercer Reich, así como en los grupos de mujeres nacionalsocialistas y mujeres judías. La religión, no solamente el factor género, se consolida como un determinante más de la actitud política de las mujeres respecto al nacionalsocialismo. Según Koonz las mujeres protestantes se caracterizarían por una actitud mucho más colaboracionista con el régimen; y las católicas, que dependían en su mayoría de las consignas de la Iglesia Católica, se mostrarían reacias a apoyar la ley de esterilización y la política de esterilización. La tesis central de Koonz señala que la actuación de las mujeres durante el nacionalsocialismo sólo se puede entender desde la perspectiva del espacio vital femenino. Las mujeres se agruparían en torno a determinados ámbitos de actuación: el trabajo, una organización nazi, una revista, una asociación de amas de casa etc., donde logran crear "su espacio vital" de influencia, autónomo de otros sectores de la sociedad, y no demasiado peligroso debido al calificativo de apolítico del que gozaban estas asociaciones en las mentes de los dirigentes del Tercer

53 Schubert,H.: Judasfrauen. Zehn Fallgeschichten weiblicher Denunziation im Dritten Reich, Freiburg, Kore, 1990.

54 Gravenhorst,L./Tatschmurat,C.: Töchter-Fragen zur NS-Frauen-Geschichte, Freiburg, Kore, 1990.

55 Schaeffer-Hegel,B. (ed.): Frauen und Macht. Der alltägliche Beitrag der Frauen zur Politik des Patriarchats, Pfaffenweiler, Centaurus-Verlagsgesellschaft, 1988 (1ª ed. Berlín 1984).

56 Thürmer-Rohr,C.: Vagabundinnen. Feministische Essays, Berlin, Orlanda Frauenverlag, 1987, $3^{\mathrm{a}} \mathrm{ed}$.

57 Sus trabajos han levantado por otra parte bastante polémica entre las historiadoras alemanas que recriminan a Koonz su mala utilización de las fuentes, y desconocimiento de situaciones en los cuales las mújeres no sólo actuaron como colaboradoras del régimen. 
Reich. Este "espacio vital" sería la única forma de salir adelante. Sin embargo la conclusión a la que llega Koonz vuelve a repetir el esquema simplista de considerar a todas las mujeres culpables de la llegada del nacionalsocialismo, el factor de género se convierte así en un calificativo moral de la actuación histórica en vez de llegar al razonamiento de que quizá el "asociacionismo" de mujeres estaría ligado más a factores de autodefensa y de preservación, que de "colaboración" con el régimen. Por otra parte creemos que es demasiado general hablar de actitudes de mujeres protestantes y católicas sin establecer diferencias de edad, de formación, de clase.

En su trabajo, Koonz, intenta distanciarse de la corriente historiográfica que consideraba a las mujeres como objetos pasivos del delirio nacionalsocialista. En relación a los paralelos que otras historiadoras hacían entre el carácter antisemita y antifeminista del nacionalsocialismo matiza Koonz:

"Los paralelos entre antifeminismo y antisemitismo no convierte en idénticas las experiencias de las mujeres y de los judíos como objetos de la propaganda nazi, ni siquiera políticamente. No puede existir una comparación entre los judíos que se vieron sometidos a la arbitrariedad de la dictadura y las mujeres nazis que conscientemente se decidieron a aceptar su posición inferior a cambio de una sólida gratificación." 58

Koonz llega a la conclusión que el carácter antifeminista del nacionalsocialismo proporciona a éstas la posibilidad de crear sus propias soluciones, enseñanzas, es decir su propio discurso al margen de las estructuras oficiales masculinas:

"Debido a que las mujeres nazis utilizaban el término Lebensraum en un sentido femenino, creaban su propio 'espacio' en tanto que cuidaban y conservaban una, por ellas mismas denominada, armonía que superaba las fronteras de clase, más allá de la vigilancia masculina." 59

Koonz saca a la luz el convencimiento de las mujeres nacionalsocialistas tan brillantemente que destierra la teoría de la entrega pasiva de las mujeres al nacionalsocialismo y las presenta como actrices deseosas de actuar en el teatro nacionalsocialista. Lo que en un principio parece como una teoría interesante, se convierte en una generalización absoluta: todas las mujeres, sin excepción apoyaron al nacionalsocialismo. Koonz, haciendo todo lo contrario a su propósito inicial, deja de lado motivos, diferencias de clase social, socialización y religión y embarca a todas las mujeres en el mismo bote. Para Koonz no existe una moral masculina o femenina, hombres y mujeres se adaptaron a las estructuras que el nacionalsocialismo les ofrecía, participando activamente en ellas.

El trabajo de Koonz crea una gran polémica, dirigida por la historiadora de Bielefeld, Gisela Bock. ${ }^{60}$ Mientras Koonz define el papel de las mujeres durante el nacionalsocialismo como la asimilación activa de las aspiraciones que estas tenían de la dictadura en determinados espacios vitales separados del espacio vital de los hombres, analiza Bock los aspectos patriarcales de la dictadura y llega a la conclusión del fracaso de los nacionalsocialistas con respecto a las mujeres, ya que éstas no tomaban los presupuestos nacionalsocialistas demasiado en serio:

58 Koonz,C.: "Das 'zweite’ Geschlecht im Dritten Reich", Feministische STUDiEn, 1986 (n²), p.15.

59 Ibídem, p.16.

60 Koonz,C.: "Erwiderung auf Gisela Bocks Rezension von 'Mothers in the Fatherland"', GESCHICHTE UND GESELLSCHAFT. ZEITSCHRIFT FÜr HISTORISCHE SOZIALWISSENSCHAFT, 1992 (año 18), pp.394399; Bock, G.: "Ein Historikerinnenstreit?", GeSCHICHTE UND GESELLSCHAFT. ZEITSCHRIFT FÜR HistorisCHE SOZIALWISSENSCHAFT, 1992 (año 18), pp.400-404. 
"Pero la mayoría de los millones de mujeres que tomaron cursos de cuidado maternal en nivel local, no parecen haber percibido en ellos un fondo de 'cuidado racial y hereditario’. Incluso en el nivel superior de la formación de maestras de las NSF, el interés por la raza, la herencia y la eugenesia era limitado. Menos de una décima parte de las dirigentes de las NSF se sintieron atraídas por el ofrecimiento especial de los cursos de 'política racial', mientras que el resto prefirió los cursos 'ordinarios' sobre gestión doméstica, enfermería, bienestar social, ayuda caritativa y vecinal; análoga proporción se registró entre el curso de participación a nivel local. Aun cuando las referencias a la 'política racial y de población' se repiten con harta frecuencia en la propaganda impresa y material de enseñanza de la NSF/DFW, raramente hacía abierta mención a la esterilización y al antisemitismo, y en esto se diferenciaba, por ejemplo, de los textos escolares para niñas, dependientes directamente del Estado."'61

Bock retoma la postura de la psicóloga Margarete Mitscherlich que defiende la tesis que el antisemitismo en las mujeres en menor que en los hombres debido a un débil desarrollo del super yo de éstas. ${ }^{62}$ Ambas se mueven en el esquema de las generalizaciones, aunque Koonz intenta en algunos momentos huir de este esquema, pero su teoría de la separación de las esferas queda en algunos momentos desdibujada, y como comenta Bock con contradicciones. De igual manera se echa de menos el estudio exhaustivo de las organizaciones de mujeres nacionalsocialistas, protestantes y católicas, así como la no diferenciación de grados de aceptación del nacionalsocialismo.

Algunas autoras han visto la confrontación entre Bock y Koonz como la lucha entre dos conceptos opuestos de femenidad que definen al movimiento de la mujer durante años:

“(...) por una parte se encuentra Bock que recurre a la teoría de la diferencia de la identidad femenina, que incluye la utopía de una forma de vida que no está influida por la lógica masculina sino por valores como la capacidad de amar, la sensibilidad, el comportamiento social, etc., que permanecen limitados a la esfera privada. Por otra parte, Koonz definida por Bock como una defensora del feminismo de la igualdad, postula los mismos derechos y el mismo trabajo para hombres y mujeres."63

En nuestra opinión la crítica que se le puede hacer a Koonz no tiene nada que ver con su pertenencia al grupo de historiadoras que tematiza el feminismo de la igualdad en sus investigaciones. Nuestra crítica parte desde otra perspectiva. El trabajo de Koonz está relacionada con otros estudios de tipo general sobre la naturaleza del nacionalsocialismo. Nos referimos a aquellos en los que el concepto de policracia es empleado para definir la compleja naturaleza y trama de relaciones de poder e influencias por las que se caracteriza el nacional-socialismo. ${ }^{64}$ Policracia aparece definida como "una pluralidad de portadores de poder en gran parte autónomos, que en determinadas condiciones pueden entrar mutuamente en conflicto". Esta definición teórica

61 Bock,G.: "Políticas sexuales nacionalsocialistas e historia de las mujeres", en: Duby,G./ Perrot,M.: Historia de las mujeres en Occidente, Madrid, Taurus, 1993, p.196.

62 Schomburg,P.: "Frauen im Nationalsozialismus. Ein Überblick über die historische Frauenforschung und die feministische Diskussion um Verantwortung und Beteiligung von Frauen am Nationalsozialismus", en: Niethammer,O. (ed.): Frauen und Nationalsozialismus. Historische und kulturgeschichtliche Positionen, Osnabrück, Universitäts-Verlag Rasch, 1996, p.48.

63 Ibídem, p.53.

64 Hüttenberg,P.: "Policracía nacionalsocialista", REVISTA AYER, 1992 (nº 5), p.182. 
suscita, en nuestra opinión, un serie de interrogantes a la hora de analizar el caso de las mujeres miembros de diversas organizaciones religiosas, culturales, o mujeres encargadas de la redacción de revistas o periódicos; o incluso el caso de las organizaciones de mujeres dependientes del régimen, donde según nuestras investigaciones la independencia era prácticamente inexistente. ${ }^{65} \mathrm{El}$ concepto de policracia es utilizado por el ala revisionista de la conocida Historikerstreit que tiene lugar en Alemania durante 1986 entre Jürgen Habermas y un grupo de historiadores, entre ellos Hüttenberg, a la cabeza de Ernst Nolte. Objeto de la disputa es la "revaloración" que este grupo hace del nacionalsocialismo en función de sus paralelos con otros regímenes autoritarios. Habermas, por el contrario, enfatiza el carácter único del nacionalsocialismo en la historia mundial. Esta discusión se enmarca dentro de la problemática de la historización de la propia historia del nacionalsocialismo a la búsqueda de un contexto europeo que, como en el caso de Nolte, acaba con la manipulación ideológica de los hechos históricos.

La teoría de Koonz de los diferentes campos de acción vital dónde las mujeres desarrollan sus intereses, apartadas de la esfera de actuación masculina relativiza todo tipo de crítica al nacionalsocialismo que proviene por parte de los diferentes grupos y presenta inconsciente al nacionalsocialismo como un sistema donde la crítica es posible siempre que no afecte a éste.

La última etapa en la investigación sobre el papel de la mujer durante el nacionalsocialismo se caracteriza sobre la reflexión crítica de los trabajos de investigación que se han ocupado del tema. La principal crítica que recibe la investigación feminista es que ésta practica una reconstrucción de la historia de las mujeres basada en la identificación. Con lo cual se rechaza cualquier tipo de culpa de las mujeres respecto al nacionalsocialismo para evitar tener que enfrentarse al hecho de que la generación de madres y abuelas hubieran tenido algo que ver con los crímenes cometidos durante el nacionalsocialismo. ${ }^{66}$ Muchas investigadoras temen que se haya escrito una historia positiva de las mujeres cercana a los planteamientos de los círculos conservadores de historiadores donde la tendencia a la relativismo es una constante. ${ }^{67}$

En el último trabajo representativo sobre el tema desaparece la constante del patriarcado método de explicación de la situación de las mujeres durante la dictadura, sino que se concentra en el problema de la culpa visto por las mujeres de la nueva generación. ${ }^{68}$ Gravenhorst utiliza como categoría de análisis el término Handlungskollektiv donde se intenta huir de un planteamiento del problema que englobe únicamente la perspectiva de género. Otros factores como socialización política, cultura y religiosa, situación económica son tenidos en cuenta.

La explicación de la investigación de identificación podría ser una de las causas por las que apenas existen estudios que se ocupen de la participación de las mujeres durante el nacionalsocialismo no sólo en los casos extremos como los de las enfermeras y guardianas de los campos de concentración, sino mujeres normales procedentes de lo espectro de la derecha, liberalismo y el centro de Weimar.

La polémica que ha levantado en el mundo académico e intelectual alemán, el trabajo sobre el antisemitismo durante el nacionalsocialismo realizado por el investigador de Harvard, Daniel

65 Existe un problema en los estudios teóricos sobre el nacionalsocialismo. Estos suenan muy bien, ofrecen un esquema abstracto de interpretación muy elaborado que no tiene apenas validez cuando se aplica a casos concretos. Durante nuestra consulta sobre la documentación de las Frauenschaften, asociaciones femeninas nacionalsocialistas pudimos comprobar que apenas tenían una independencia propia, y que tenían que consultar constantemente al NSDAP sobre los temas más inverosímiles.

66 Windaus-Walser,K.: "Gnade der weiblichen Geburt? Zum Umgang der Frauenforschung mit Nationalsozialismus und Antisemitismus", FEMINISTISCHE STUDIEN, 1988 (n¹), pp.102-115.

67 Frauen gegen Antisemitismus: Der Nationalsozialismus als Extremform des Patriarchats. Zur Leugnung der Täterschaft von Frauen und zur Tabuisierung des Antisemitismus in der Auseinandersetzung mit dem NS, BEITRÄGE ZUR FEMINISTISCHEN THEORIE UND PRAXIS 1983 (n³5), pp.77-89.

68 Gravenhorst,L../Tatschmurat,C. (eds.): Töchter-Fragen zur NS-Frauen-Geschichte, Freiburg, Kore, 1990. 
Goldhagen, pone de manifiesto las dificultades que todavía tienen la mayoría de los investigadores en tratar el tema de la culpa y de la responsabilidad de los alemanes durante la dictadura. ${ }^{69}$ Sin tratar específicamente el tema de género, Goldhagen se pregunta sobre el porqué de estos años de terror de la historia alemana. Al parecer las grandes teorías sobre la naturaleza del fascismo: teoría marxista de la victoria del capital sobre el proletariado, la teoría del oeste, que acentuaba el carácter nacional, antiliberal y democrático del nacionalsocialismo. Línea que centra sus estudios bien en la figura de Hitler, o la de sus colaboradores. Los interrogantes permanecen abiertos: es cierto que Hitler contó con ayuda de la industria, y que ésta contribuyó al ascenso del nacionalsocialismo, Siemens (apoyo) y Bosch (en contra) como también es cierto que la resistencia de la clase trabajadora, en comparación con Austria, y a pesar de los héroes no lograron crear una resistencia efectiva. Las teorías sobre el Totalitarismo y el Fascismo, presentaban otro tipo de problemas que todavía no se han solucionado. La pregunta es: ¿se pueden comparar dos regímenes tan distintos como la Unión Soviética y la Alemania nazi; una sociedad fundamentalmente agraria, y una sociedad en Umbruch, en cambio; una clase trabajadora, la más preparada y organizada de Europa? Y respecto a la teoría del fascismo, como sustrato del nacionalsocialismo, ¿se pueden establecer paralelos entre la Alemania de los años treinta y la situación de países Hungría, Rumania o España? Goldhagen pone de manifiesto como amplios sectores de la población alemana se encontraban infectados del virus del antisemitismo, un antisemitismo latente que encontró su cenit durante el nacionalsocialismo, y del que no se libraron los sectores liberales de la sociedad, las iglesias o los intelectuales.

\section{Bibliografía sobre el tema. Estado de la cuestión}

El análisis del aporte de las mujeres al nacionalsocialismo es un tema conflictivo, sujeto a numerosas especulaciones, por eso creemos necesario hacer una breve reseña sobre "el entendimiento" y la comprensión de esta participación. Nuestra intención es la de mostrar la utilización y la limitación a la que se ha visto sometido el factor de género, al ser utilizado únicamente como calificativo moral en el que se enjuiciaban las actitudes de las mujeres durante el Tercer Reich. Trataremos de mostrar como otros factores como el de clase, edad, educación y cultura son también decisivos a la hora de entender determinadas actitudes personales y de grupo.

Los trabajos tratan este tema son bastante reducidos. A pesar de la gran cantidad de investigaciones sobre el tema mujeres y nacionalsocialismo, el interés por los grupos de mujeres de organizaciones confesionales y no confesionales burguesas no despertaba la atención de las investigadoras. Hasta 1933 su existencia está bien documentada. A partir de la disolución de las organizaciones o de la integración de éstas en el aparato nacionalsocialista la investigación cesa. Por una parte debido a los prejuicios existentes dentro de las investigadoras feministas que analizaban la religión como uno de los últimos dominios del patriarcado y considerando a los grupos de mujeres confesionales como no dignos de investigar dado su carácter conservador. En el caso del ala moderada del movimiento de la mujer es quizá el carácter ambiguo de sus principales representantes respecto al nacionalsocialismo y por otra parte el gran peso histórico de éstas como pioneras del movimiento de la mujer hasta 1933, una de las causas de la ausencia de trabajos que se ocupen del tema.

69 Goldhagen,D.: Hitlers willige Vollstrecker. Ganz gewöhnliche Deutsche und der Holocaust, Berlin, Siedler, 1996. 
En el caso del ala moderada del movimiento de la mujer, la poca bibliografía existente se puede dividir en las siguientes categorías: memorias o relatos autobiográficos de las implicadas, y una serie de trabajos que abarcan fundamentalmente el período de fundación de las organizaciones hasta 1933, así como algunas valoraciones de los procesos de disolución a finales de Weimar. En el caso de las organizaciones confesionales existen algunos trabajos que documentan el papel de las organizaciones durante el nacionalsocialismo.

Con la llegada de los aliados comienza una nueva etapa en la vida de las mujeres alemanas. La élite política de Weimar que no había emigrado o perecido en los campos de concentración comienza a organizarse. El grupo de mujeres de Die Frau comienza a organizarse de nuevo. En 1945 Agnes von Zahn-Harnack, la última presidente del BDF funda el Berliner Frauenbund. Gertrud Bäumer, ideológa del movimiento de la mujer y redactora jefe de DIE FRAU participa en la fundación del futuro CSU en Bamberg etc.

A este trabajo de tipo práctico se une una intensiva publicación de memorias y trabajos autobiográficos de las mujeres en cuestión. Se trata de obras donde las autoras intentan resaltar sus años de lucha a favor de la democracia durante Weimar y de sus experiencias como pioneras del movimiento de la mujer. Infancia, juventud, participación política en Weimar son aspectos que aparecen descritos con detalle y profusidad. El nacionalsocialismo recibe curiosamente un trato seco y un proporción con los temas anteriores corto. Se intenta destacar el apoyo a personas judías (Marianne Weber) o la postura crítica de DIE FRAU (Gertrud Bäumer), o la actitud resignada de Dorothee von Velsen. Una valoración de la actuación personal no se lleva a cabo. La lectura de las biografía dan cuenta del parentesco que unía a estas mujeres; de la correspondencia entre ellas durante el nacionalsocialismo, de sus encuentros. Testimonia una unidad de grupo que se mantiene después de la desaparición del trabajo al frente del movimiento de la mujer. Por otra parte se pone de relieve el problema de la culpa. Muchas de ellas habían sido agredidas tras la guerra en función de su colaboración con el nacionalsocialismo. Memorias, diarios y confesiones aparecen como un ejercicio de justificación. 70

Los trabajos que con posterioridad hacen referencia a estos grupos de mujeres, son escasos. Y los únicos que aparecen se mueven en una línea de reconstrucción biográfica y de rehabilitación. ${ }^{71}$ Muchos de ellos están escritos por antiguas compañeras o alumnas de éstas que resaltan su trabajo por los derechos de la mujer y se esfuerzan en demostrar su rechazo del nacionalsocialismo. Es en estos trabajos cuando aparece por primera vez, el término mujeres de la segunda generación.72 Así como se resalta la relación especial existente entre ellas y el papel de DIE FRAU como centro de apoyo para aquellos que no estaban de acuerdo con el

70 Baum,M.: Rückblick auf mein Leben, Heidelberg, Kerle Verlag, 1950; Bäumer,G.: Der neue Weg der deutschen Frau, Stuttgart, Deutsche Verlags-Anstalt, 1946; Bäumer,G.: Im Licht der Erinnerung, Tübingen, Rainer Wunderlich Verlag, 1953; Beckmann,E.: Des Leben wie der Liebe Band, Tübingen, Rainer Wunderlich Verlag, 1956; Beckmann,E.: Was ich bier geliebt, Tübingen, Rainer Wunderlich Verlag, 1957; HeussKnapp,E.: Bürger zweier Welten. Ein Leben in Briefen und Aufżeichnungen, Tübingen, Marg-Vater, 1961; Lüders, M.-E.: Fürchte dich nicht. Persönliches und Politisches aus mehr als 80 Jahren, Köln/Opladen, Westdeutscher Verlag, 1963; Ulich-Beil,E.: Ich ging meinen Weg. Lebenserinnerungen, Berlin, Herbig Verlag, 1961; von Velsen,D.: Im Alter die Fülle. Erinnerungen, Tübingen, Rainer Wunderlich Verlag, 1956; Weber,M.: Lebenserinnerungen, Bremen, Johannes Storm Verlag, 1948.

71 Bach, M.L.: Gertrud Bäumer. Biographische Daten und Texte zu einem Persönlichkeitsbild, Weinheim, Deutscher Studien Verlag, 1989; Baum,G.: Der Lebensweg Gertrud Bäumers, Hohenlimburg, 1973; Huber,W.: Gertrud Bäumer. Eine politische Geographie, Inaugural-Dissertation, Augsburg, 1970; Gräfin Yorck von Wartenburg, B.D.: Gertrud Bäumer. Eine Bibliographie, 1957; Beckmann,E.: „Sonderheft Gertrud Bäumer", MÄDCHENBILDUNG UND FrAUENSCHAFTEN, September 1953 ( $n^{\circ} 9$, año 3).

72 Hansen-Blancke,D.: „Als Schülerinnen Gertrud Bäumers“, en: Beckmann,E.: op.cit., p.19. 
nacionalsocialismo. En la mayoría de los trabajos se resalta la figura de Gertrud Bäumer como dirigente "espiritual" del movimiento durante los años de la dictadura. Aparte de algunas excepciones 73 la figura de Bäumer es idealizada, destacando la falta de crítica respecto a su actuación durante el nacionalsocialismo.

El tratamiento de otras mujeres pertenecientes al movimiento de la mujer transcurre igualmente. Un ejemplo es la bibliografía publicada sobre Elly Knapp-Heuss, la esposa de Theodor Heuss, que aunque no ocupa ningún puesto de responsabilidad en el movimiento de la mujer, tiene relaciones con éste, debido al trabajo político en común de su marido con Gertrud Bäumer. En la mayor de los casos no existe una valoración extensa sobre la época del nacionalsocialismo, la palabra que se utiliza con más frecuencia para definir esta época es Zurückhaltung (recogimiento). ${ }^{74}$ Una biografía de Anna Paulsen (dirigente católica del movimiento de la mujer) hace una recopilación de narraciones de Knapp sin aludir a sus actividades durante el nacionalsocialismo. ${ }^{75}$ Durante esta época escribe dos artículos en DIE FRAU. ${ }^{76}$

Entre los años sesenta y setenta aparece un número de trabajos realizados por alumnas de Getrud Bäumer y Marie Baum, o por el grupo de las mujeres de la segunda generación. ${ }^{77}$ Estos trabajos son interesantes por la cantidad de datos que aportan, aunque no dejan de revelar una visión poco crítica de la vida de éstas mujeres. En el peor de los casos, se trata de publicaciones de cartas y escritos sin el menor comentario.

A estos hay que añadir dos trabajos realizados sobre el movimiento de la mujer, desde el punto de vista jurídico y desde el punto de vista social, concentrados en la obra de Gertrud Bäumer. ${ }^{78}$ Este último trabajo aporta interesante detalles sobre la personalidad de Bäumer.

La armonía que caracterizaba a los trabajos se rompe en los años setenta con la obra Evans 79 que analiza el feminismo alemán en oposición al movimiento de la mujer anglosajón y americano. En su estudio trata en general sobre el liberalismo de la época guillermina y sus desviaciones del liberalismo clásico. Evans cree encontrar en el movimiento de emancipación de la mujer elementos protofascistas que explicarían la rápida aceptación del nacionalsocialismo en 1933.

En esta misma línea destaca el trabajo de Christine Wittrock sobre los inicios de la imagen del fascismo en el primer momento de la mujer. Es un trabajo basado en el análisis de la obra de mujeres procedentes de diferentes espectros políticos en la república de Weimar. En su análisis

73 Lüders,E.: Fürchte dich nicht. Persönliches und Politisches aus mehr als 80 Jahren, Köln/Opladen, Westdeutscher Verlag, 1963.

74 Teusch,C.: Im Dienst der Stunde. Aus Lebensweg und Lebenswerk von Elly Heuss-Knapp, Nürnberg, Deutsches Mütter-Genesungswerk,1953, p.9; Heuss-Knapp,E.: Ausblick vom Münsterturm. Erinnerungen, Tübingen, Wunderlich Verlag, 1954 (4a ed.).

75 Paulsen,A.: Elly Heuss-Knapp. Zeugnisse ibres Wirkens, Stuttgart, Calwer Verlag, 1959.

76 Heuss-Knapp,E.: „Rheinüberwärts“, DIE FrAU, 1940/1941 (n48), pp.45-47; "Vom Werben und vom Waschen“, DIE FraU, 1940/1941 (n48), pp.148-149.

77 Anders,M./Reicke,I. (eds.): Zahn-Harnack, Agnes. Schriften und Reden 1914-1950, 1964; Boedeker,E.: Marksteine der deutschen Frauenbewegung von ibren Anfängen im 19. J.H. bis zum Neuanfang 1945, Hannover, Selbstverlag, 1968; Frandsen,D.: Helene Lange, Hannover, Niedersächsiche Landeszentrale für Politische Bildung, 1974.

78 Fels,O.M.: Die deutsche bürgerliche Frauenbewegung als juristisches Phänomen dargestellt a. d. Erscheinung Gertrud Bäumers, Dissertation, 1960; Zottmann,B.: Zum Helfen, Pflegen und Lebren verurteilt? Der Beitrag Gertrud Bäumers zum Berufsbild der Frau in der sozialen Arbeit, Frankfurt, Dissertation, 1986.

79 Evans,R.: The Feminist Movement in Germany 1894-1933, London, Croom Helm, 1976; "German Women and the Triumph of Hitler", JOURnAL OF MODERn History, Marzo $1976 .$. 
intenta demostrar la hipótesis de Evans. ${ }^{80}$ Wittrock argumenta que el BDF nunca defendió intereses emancipadores, sino que sirvió a los intereses del patriarcado.

Los trabajos de Evans y Wittrock levantaron una gran polémica dentro de los círculos de investigadoras e historiadoras feministas que veían en el primer movimiento de la mujer las bases del feminismo de los años setenta. La simple suposición de que la historia del nuevo movimiento de la mujer pudiera tener sus raíces en un grupo de mujeres de tendencias nacionalistas que se plegaron a los intereses del nacionalsocialismo, ocasionó una interesante discusión que pone de relieve la necesidad que tenía el nuevo movimiento de la mujer de buscar modelos y prototipos a imitar, pero que sin embargo desvirtúa la realidad.

En 1983 la revista COURAGE edita un artículo de Irene Stoehr que enciende la llama de la polémica en el campo de las investigaciones feministas. ${ }^{81}$ En oposición a Evans, argumenta Stoehr que la apoliticización del movimiento de la mujer en 1933 puede interpretarse como el rechazo del movimiento hacia el nacionalsocialismo. Analizar la postura de el movimiento de la mujer bajo el mismo modelo que el resto de la política masculina es un error, argumenta Stoehr. El silencio, su apoliticismo es la prueba de su rechazo de la política masculina y por consiguiente de la política nacionalsocialista. Esta autora, como veremos en capítulos posteriores, pasa por alto las declaraciones de aceptación de las dirigentes del BDF en 1933, las negociaciones que tienen lugar entre la organización y los responsables de las organizaciones de las mujeres nacionalsocialistas. Esta línea de estudio es defendida por investigadoras del círculo feminista, que ven en el movimiento de la mujer de los años veinte una serie de paralelos con sus propias reivindicaciones, en especial en lo relativo a la identidad femenina: el feminismo de la diferencia. Las mujeres del BDF defendían la diferencia de la naturaleza femenina respecto al hombre, su diferencia y su especialidad respecto a la práctica política masculina. A partir de 1983 la publicación feminista COURAGE comienza una serie de intentos para matizar la postura de Evans. La palabra clave de la argumentación es Männerpolitik, política de hombres o política masculina. En función de este término surgen una serie de trabajos que inciden en el carácter "masculino" del nacionalsocialismo, aspecto que nosotros también compartimos, pero que no descarta la posibilidad de la aceptación e incluso del apoyo de la población femenina a este sistema. ${ }^{82}$

En 1987 Hiltraud Schmidt-Waldherr ${ }^{83}$ lanza la teoría a la luz de la perversión de los ideales emancipadores del movimiento de la mujer por la dictadura nacionalsocialista. La perversión no parte según la autora del movimiento de la mujer. Los autores, los actores de la historia son en todo caso los hombres. El movimiento de la mujer encarna todo contra lo que estaban en contra los nacionalsocialistas: el internacionalismo, pacifismo y el liberalismo. El incremento de posturas nacionales dentro del ala moderada del movimiento de la mujer y la progresiva pérdida de influencia de la fracción que defendía el diálogo y la política de desarme son pasados por alto.

Hiltraud Schmidt-Waldherr intenta establecer diferencias entre el grupo de mujeres ideólogas como Bäumer, Weber o Alice Salomon y el nacionalsocialismo. Las primeras defienden el principio ético de responsabilidad de la emancipación, la tarea cultural femenina en el cambio social van en contra de las tendencias burguesas patriarcales (como el instinto maternal o la

80 Wittrock,C.: Das Frauenbild in faschistischen Texten und seine Vorläufer in der bürgerlichen Franenbewegung der zwanziger Jahre, Frankfurt am Main, Dissertation, 1981.

81 Stoehr,I.: „Macht ergriffen? Deutsche Frauenbewegung 1933“, COURAGE, 1983 (n8), pp.24-32.

82 Thalmann,R.: Frausein im Dritten Reich, München, Carl Hanser Verlag, 1984; Lück,M.: Die Frau im Männerstaat. Die gesellschaftliche Stellung der Fran im Nationalsozialismus, Frankfurt am Main, Peter Lang, 1979.

83 Schmidt-Waldherr,H.: Emanzipation durch Professionalisierung? Politische Strategien innerbalb der bürgerlichen Frauenbewegung während der Weimarer Republik und die Reaktion des bürgerlichen Antifeminismus und des Nationalsozialismus, Frankfurt am Main, Materialis Verlag, 1987. 
importancia de la madre en la vida familiar). Schmidt-Waldherr incide en la diferencia entre este discurso de la feminidad y la concepción biológica de la feminidad nacionalsocialista. ${ }^{84}$ La lucha de la segunda generación del movimiento de las mujeres es entendida como una lucha contra las estructuras del patriarcado burgués. Afirmación con la que no estamos de acuerdo, ya que como veremos a lo largo de este trabajo, se trata en realidad de una minoría dentro del movimiento de la mujer, las que realmente presentan una crítica de las estructuras de poder masculinas. La autora olvida que el movimiento emancipador no se rebela contra el "supuesto" mundo masculino sino que se ofrece a trabajar conjuntamente con él. En primer lugar no se critica el sistema, ni tampoco las "estructuras de patriarcado" en las que éste yace. El movimiento emancipador de la segunda generación, no tiene un "enemigo", no se opone a un sistema, es dualista, defiende la separación de las tareas de los géneros, y busca un lugar para la mujer dentro de éste. Sus aspiraciones no son de lucha, sino de adaptación. De ahí el carácter "educador" del movimiento: a través de la formación, de la educación recibe la mujer la posibilidad de descubrir su verdadera identidad. Se trata de una racionalización de lo femenino. Si la mujer es madre (tiene que hacer cursos), si es ama de casa también, lo mismo ocurre si quiere participar en la política.

Producto de la polémica surgida en torno a las investigaciones de Evans, Wittrock y Stoehr surgen trabajos que pretenden estudiar la situación general de las mujeres durante el nacionalsocialismo y abarcan en algunos capítulos la actitud de las mujeres del primer movimiento de la mujer..$^{85}$

Entre ellos cabe destacar el estudio de Barbara Greven-Aschoff sobre el movimiento de la mujer, con un capítulo sobre los últimos años del movimiento de la mujer. Este trabajo analiza exhaustivamente el movimiento de la mujer burgués en Alemania desde 1894 hasta 1933. Interesante es el análisis del desarrollo de este movimiento desde el punto de vista sociológico: Greven-Aschoff incluye al movimiento de la mujer dentro de los procesos de emancipación que tienen lugar en el siglo XIX. La autora pretende analizar el sistema de valores que desarrolla el feminismo burgués durante el siglo diecinueve y la creación de construcciones de feminidad que éste elabora. Una perspectiva desde la historia social que se diferenciaba de los trabajos de tipo positivista de la escuela anglosajona. ${ }^{86}$ En esta línea trabaja Jill Stephenson. ${ }^{87}$

Evans llega a la conclusión de que a pesar de los rasgos conservadores del movimiento de la mujer, especialmente durante los últimos años de Weimar, no se puede hablar de un apoyo de éste al nacionalsocialismo. El resto de los trabajos que aparecen en esta época tienden a idealizar el feminismo de Bäumer y de las mujeres del $B D F{ }^{88}$ resaltando su trabajo de resistencia respecto al nacionalsocialismo, o en todo caso su situación de "exilio interior".

En 1990 tiene lugar en Würzburg un congreso donde se intenta reflexionar teóricamente sobre las experiencias de las mujeres durante el nacionalsocialismo. La línea general del congreso se opone a la hasta ahora tendencia del feminismo alemán a considerar a las mujeres

84 Schmidt-Waldherr,H.: "Konflikte um die 'Neue Frau' zwischen liberal-bürgelichen Frauen und den Nationalsozialisten“, en: Gravenhorst,L./Taschmurat,C.: Töchter-Fragen. NS- Frauen-Geschichte, Freiburg, Kore, 1990, pp.167-181.

85 Greven-Aschoff,B.: Die bürgerliche Frauenbewegung in Deutschland 1894-1933, Göttingen, Vandenhoeck \& Ruprecht, 1981; Koepcke,C.: Geschichte der deutschen Franenbewegung. Von den Anfängen bis 1945, Freiburg, Herder, 1979.

86 Evans,R.J.

87 Stephenson,J.: Women in Nazi Society, London, Croom Helm, 1975; "Nationalsozialistischer Dienstgedanke, bürgerliche Frauen und Frauenorganisationen im Dritten Reich“, GESCHICHTE UND GESELLSCHAFT, 1981 (año 7), pp.555-571.

88 Koepke, op.cit., p.105. 
como simples víctimas de la dictadura, o de los procesos de una sociedad patriarcal. Es un paso importante en la teoría feminista. ${ }^{89}$

En dicho congreso se llega a la conclusión de que el análisis de la situación de las mujeres sobre el nacionalsocialismo, no se puede explicar únicamente con datos empíricos, sino que precisa del análisis de la experiencia subjetiva de estos datos, del tratamiento de la interpretación subjetiva de la realidad exterior e interior. Gravenhorst y Tatschmurat intentan y consiguen desentrañar las contradicciones del movimiento de la mujer de principios de siglo. En esta línea trabaja también Ulrike Prokop. ${ }^{90}$ Tomando como punto de partida la tesis de Evans analiza el conservadurismo del movimiento de la mujer y su progreso hacia ideas nacionalsocialistas.

El origen burgués del movimiento de la mujer aparece tratado en las investigaciones de Hans Jürgen Arends sobre el proceso de la disolución política de las organizaciones de mujeres en los años 1933/1934, donde se aportan datos interesantes sobre la decadencia de los grupos de mujeres burguesas en los últimos años de la república de Weimar. Arends considera que el movimiento de la mujer se caracteriza desde sus inicios por su carácter imperialista y como tal defiende la ideología vigente. Para Arends Weimar constituye un paso más en el avance imparable del imperialismo y capitalismo. Cabe decir sin embargo que éste proceso de disolución es analizado sin tener en cuenta la relación de los grupos con sus partidos políticos afines. ${ }^{91}$

La bibliografía existente sobre el tema es tan dispar como diversa. Es interesante observar como diferentes autores llegan a conclusiones totalmente opuestas, aún cuando utilizan los diferentes textos. Tal variedad de juicios de valor muestra hasta que punto el tema mujeres y nacionalsocialismo se encuentra ideologizado. A este tema nos dedicaremos en la parte donde tratamos los temas de método. ${ }^{92}$

Aunque la bibliografía sobre las organizaciones de mujeres protestantes no presenta esta cantidad de obras y trabajos, se observa en los últimos años un aumento del interés por este tema. Jochen-Christoph Kaiser ha publicado algunos artículos sobre la historia de la Evangelische Franenbilfe y del Evangelisches Frauenwerk así como un volumen comentado de fuentes sobre ambas organizaciones. ${ }^{93}$ En el marco de los trabajos históricos cabe destacar las investigaciones de Richard J. Evans, Amy Hacett, Barbara Greven-Aschoff y Herrad-Ulrike Bussemer ${ }^{94}$ sobre

89 Gravenhorst,L../Taschmurat,C.: Töchter-Fragen. NS-Frauen-Geschichte, Freiburg, Kore, 1990

90 Prokop,U: "Die Sehnsucht nach der Volkseinheit. Zum Konservativismus der bürgerlichen Frauenbewegung vor 1933“, en :Dietze,G. (ed.): Die Überwindung der Sprachlosigkeit. Texte aus der neuen Frauenbewegung, Darmstadt, Luchterhand, $2^{\mathrm{a} e d .}$ 1981, pp.176-202.

91 Arendt,H.-J.: "Die 'Gleichschaltung' der bürgerlichen Frauenorganisationen in Deutschland 1933/34, ZEITSCHRIFT FÜR GESCHICHTSWISSENSCHAFT, 1979 (año 27), pp.615-627.

92 Wittrock y Stoehr. Una orientación sobre el amplio espectro del tema se encuentra sobre el movimiento de la mujer, feminismo e historia de la mujer en Alemania desde 1930-1960 existe un trabajo bibliográfico excepcional publicado como compendio en 1993.

93 Kaiser,J.-C.: "Kirchliche Frauenarbeit in Westfalen. Ein Beitrag zur Geschichte des Provinzialverbandes der Westfälischen Frauenhilfe 1906-1945“, en: Jahrbuch für westfälische Kirchengeschicbte, 1981 (n 74), p.159-190; "Das Frauenwerk der deutschen evangelischen Kirche. Zum Problem des Verbandsprotestantismus im Dritten Reich", en: Dollinger, H. (ed): Weltpolitik - Europagedanke - Regionalismus. Festschrift für Heinz Gollwitzer, Münster, 1982; Frauen in der Kirche. Evangelische Frauenverbände im Spannungsfeld von Kirche und Gesellschaft 1890-1945, Quellen und Materialien, Düsseldorf, Schwann, 1985; "Das Frauenwerk der Deutschen Evangelischen Kirche. Zum Problem des Verbandsprotestantismus im Dritten Reich", en: Götz von Olenhusen,I.: Frauen unter dem Patriarchat der Kirchen. Katholikinnen und Protestantinnen im 19. und 20. Jahrhundert, Stuttgart-Berlin- Köln, Kohlhammer, 1995.

94 Evans,R.J..: The Feminist Movement in Germany 1893-1933, London, Croom Helm, 1976; "German Women and the Triumph of Hitler", JOURnAL OF MODERN HistorY, Marzo 1976; "Ascenso y triunfo 
el movimiento de la mujer en los siglos XIX y XX que se ocupan también de las organizaciones de mujeres protestantes. Por último Doris Kaufmann 95 seguidora de la línea feminista de la teóloga Elisabeth Moltmann-Wendel reflexiona sobre el movimiento de la mujer protestante durante los siglos XIX y XX, desde su carácter emancipador, de éste, aspecto hasta entonces no tenido en cuenta por las historiadoras del movimiento de la mujer que veían a las organizaciones de mujeres protestantes desde su aspecto conservador y represor. ${ }^{96}$ Esta búsqueda de modelos a imitar entre las mujeres protestantes lleva a Moltmann-Wendel a tratar las figuras de Gertrud Bäumer y a Gertrud von le Fort como iniciadoras de la emancipación del protestantismo femenino olvidando resaltar sus posiciones nacionalistas y conservadoras. ${ }^{97}$

La bibliografía que analiza las actitudes y políticas de las mujeres protestantes durante el nacionalsocialismo es bastante limitada y representa una línea apologética característica de algunos sectores de la iglesia protestante.

En la actualidad una nueva de generación de historiadoras más jóvenes empiezan a tratar con profundidad el tema en forma de tesinas y tesis doctorales. Es interesante observar la importancia del tratamiento "filológico" de los textos y el abandono de grandes teorías a priori que contribuye a desvirtuar en muchos casos el verdadero significado de éstos.

Desde el punto de vista teológico existe una análisis de la revista EvANGELISCHE FRAUENZEITUNG, donde a pesar del estupendo trabajo de análisis de textos, se observa una cierta falta de crítica respecto a la actuación de las mujeres miembros del DEF.98

Sobre la figura de Meta Eyl, la dirigente de la organización protestante, Kohler trabaja en estos momentos en una biografía sobre ésta. Una pequeña introducción a se encuentra en el trabajo sobre teólogas protestantes alemanas, Lamentablemente se vuelve a cometer el mismo error que en el caso del movimiento de la muerte, donde la búsqueda de modelos de legitimación de la propia historia, conlleva a ofrecer una visión incompleta de la realidad. En estos estudios se observa por ejemplo la falta de temas relacionados con el antisemitismo y las mujeres protestantes. En el marco de un coloquio para doctorantes, organizado por la teóloga Leonore Siegele-Wenschkewitz, tuvimos la oportunidad de escuchar los resultados de la investigación de Guy Schneider-Lüdorff sobre la figura de Magdalene von Tiling. Desde una

del nazismo en Alemania”, en: Cabrera,M./Juliá,S./Martín Aceña,P. (eds.): Europa en Crisis 1919-1939, Madrid, Editorial Pablo Iglesias, 1991; "Modernization Theory and Women's History. Literaturbericht", ARCHIV FÜR SOZIALGESCHICHTE, 1980 (año 20), pp.492-514; Greven-Aschoff,B.: Die bürgerliche Frauenbewegung in Deutschland 1894-1933, Göttingen, Vandenhoeck \& Ruprecht, 1981.

95 Kaufmann,D.: "Vom Vaterland zum Mutterland. Frauen im katholischen Milieu der Weimarer Republik“, en: Hausen,K. (ed.): Frauen suchen ibre Geschichte. Historische Studien zum 19. und 20. Jabrbundert, München, Beck, 1983, pp.250-275; "Die Begründung und Politik einer evangelischen Frauenbewegung in der Weimarer Republik", en: Dalhoff,J./ Frey,U./Schöll,I. (eds.): Franenmacht in der Geschichte. Beiträge des Historikerinnentreffens 1985 zur Franengeschichtsforschung, Düsseldorf, Schwann, 1986, pp.380-389; Frauen zwischen Aufbruch und Reaktion. Protestantische Frauenbewegung in der ersten Hälfte des 20. Jahrbunderts, München-Zürich, Piper, 1988; "Religion und Emanzipation: Konfessionelle Frauenbewegung in Deutschland 1900-1936", en: Götz von Olenhusen,I.: Frauen unter dem Patriarchat der Kirchen. Katholikinnen und Protestantinnen im 19. und 20. Jabrbundert, Stuttgart-Berlin-Köln, Kohlhammer, 1995.

96 En la actualidad surge una nueva tendencia de estudios que critican la línea de Moltmann-Wendel, ya que en su intento de poner de relieve la historia de las mujeres en la iglesia protestante, olvida la visión crítica de las actuaciones de éstas.

97 Moltmann-Wendel,E. (ed.): Frau und Religion. Gotteserfabrungen im Patriarchat, Frankfurt am Main, Fischer, 1984.

98 Kellner,H.: Die Evangelische Frauenzeitung 1930-1941, Arbeit zum Ersten Staatsexamen, Göttingen, 1993; Hilpert,C.: Die Geschichte des Deutsch-Evangelischen Frauenbundes 1899-1914, Magisterarbeit, RuhrUniversität Bochum, 1982. 
perspectiva de las relaciones de género, Schneider-Lüdorf analiza la aportación de la teología de Tiling al discurso de género de la república de Weimar, adentrándose en un pequeño capítulo en la postura de Tilling respecto al nacionalsocialismo. ${ }^{99}$

Si los trabajos en el caso de las mujeres protestantes son limitados, las investigaciones sobre las asociaciones de mujeres católicas, son menos numerosas. Como en el caso del movimiento de la mujer, las primeras publicaciones sobre las organizaciones católicas parten de las mujeres del movimiento. En los años cincuenta y sesenta aparecen una serie de trabajos que se ocupan de la historia de la Federación de mujeres católicas. La época del nacionalsocialismo aparece desgraciadamente tratada de una manera muy somera. ${ }^{100}$ Por esta misma época comienzan a aparecer una serie de trabajos que tratan fundamentalmente los inicios de la organización del movimiento de la mujer católico aunque no ofrecen una valoración política y sociológica de las asociaciones. ${ }^{101}$ Son interesantes los trabajos de Doris Kaufmann sobre el milieu católico de la región de Münster donde trata intensivamente la socialización de la población católica femenina. Kaufmann intenta rechazar la tendencia general que señalaba el conservativismo de las mujeres católicas como una de las causas de su posible apoyo al nacionalsocialismo. Kaufmann señala por el contrario los esfuerzos de las mujeres católicas por organizar sus intereses, su campo de acción vital y la creación de redes sociales de actuación que les permiten mejorar la situación de la mujer, logrando desde el punto de vista de la autora una independencia de acción hasta entonces desconocida en el milieu católico. ${ }^{102}$

Al hablar del discurso femenino de los grupos de mujeres pertenecientes al feminismo liberalconservador durante el nacionalsocialismo, nos enfrentamos a un tema con el que se relacionan estrechamente dos problemas: el factor género como un condicionante más del devenir histórico y la relación existente entre clases medias y nacionalsocialismo. El factor de género determina la exclusividad del discurso y el factor de clase la actitud política de los grupos en cuestión.

IX. Conclusiones

99 Esta investigación se presenta el año que viene como tesis doctoral en la Universidad de Frankfurt. Como introducción al tema Guy Schneider-Lüdorff ha publicado en una obra sobre pedagogas protestantes una introducción a la figura de Tilling. Schneider-Lüdorff,G. dagoginnen des 20. Jahrhunderts, Göttingen-Zürich, Vandehoeck \& Ruprecht, 1997.

100 Cosack,E.: 25 Jahre Katholischer Deutscher Frauenbund, Köln, Katholischer Frauenbund, 1938; Ehrle,G.: Jahrbundertwende, Jahrbundertmitte. Der Katholische deutsche Frauenbund auf dem Wege. 1903-1953, Köln, Zentrale des Katholischen Deutschen Frauenbundes, 1953; Krabbel,G.: Aus der Arbeit des Katholischen Deutschen Frauenbundes, Köln, Katholischer Deutsche Frauenbund, 1959.

101 Sobre los orígenes de las organizaciones de mujeres católicas: Pauls,M.: Die deutschen Frauenorganisationen. Eine Übersicht über den Bestand, die Ursprünge und die kulturellen Aufgaben, Dissertation, Aachen, 1966; Schaub,R.: Die Geschichte der Katholischen Frauenbewegung in Deutschland bis 1914, Freiburg, Zulassungsarbeit, 1970; Lion, H.: Zur Soziologie der Frauenbewegung. Die sozialistische und die katholische Frauenbewegung, Berlín, Schriftenreihe der Akademie für soziale und pädagogische Frauenarbeit in Berlin, Herbig, 1926. Sobre las mujeres católicas y sus experiencias durante el Nacionalsocialismo contamos con el trabajo de: Ehrle,G.: Licht über dem Abgrund. Aufzeichnungen und Erlebnisse christlicher Frauen 19331945, Freiburg, Katholische Reihe, 1951 (Heft 10); Kall,A.: Katholische Frauenbewegung in Deutschland. Eine Untersuchung zur Gründung katholischer Frauenvereine im 19. Jahrhundert, Paderborn, 1983. Sobre la vida de Gerta Krabbel: Schiffler,L.: Die Antwort der Frau in der sich ändernden Welt, Müster, Regensberg, 1969.

102 Kaufmann,D.: Katholisches Milieu in Müster 1928-1933, Düsseldorf, Schwann, 1984; "Vom Vaterland zum Mutterland. Frauen im katholischen Milieu der Weimarer Republik“, en: Hausen,K. (ed.): Frauen suchen ibre Geschichte. Historische Studien zum 19. und 20. Jahrbundert, München, Beck, 1983, pp.250-275. 
El discurso que analizamos esta elaborado desde la perspectiva de grupo. Las mujeres que estudiamos constituyen un grupo social, diferenciado por su condición de mujeres en el caso del ala moderada del movimiento de la mujer, por su condición de mujeres protestantes y católicas en el caso de las organizaciones confesionales. Cada grupo teje un discurso propio y particular realizado al amparo del propio grupo u organización a la que pertenece.

Desde esta perspectiva se plantea el problema de la actuación política, ¿dependieron las actitudes políticas de las mujeres respecto al nacionalsocialismo de su género, o entraron en juego otro tipo de factores como el de clase o confesión? En torno a esta pregunta gira la mayor parte de la historiografía existente sobre el tema "mujeres y nacionalsocialismo". Nuestro trabajo es heredero de este debate por una parte, pero por otra, pretende ir más allá de ciertos dualismos moralizantes que únicamente se ocupan del papel de las mujeres como víctimas del aparato patriarcal nacionalsocialista, no haciendo en este caso una gran diferencia entre las mujeres que vivieron en los campos de concentración y las mujeres alemanas, o en el caso opuesto los que resaltan la actuación de las mujeres como colaboradoras del régimen. 
Sobre las fuentes que utilizamos es necesario precisar un par de aspectos. En las citas de los diferentes documentos, nos encontramos con algunos problemas. En los archivos eclesiásticos, más pequeños se encuentran los documentos numerados, con lo cual su identificación es bastante fácil. En la cita de estos documentos nos hemos limitado a citar el archivo con el nombre en abreviatura, el número del documento y la signatura. En otros archivos, como es el caso del Bundesarchiv, por el contrario, aparecen numeraciones antiguas alternando con nuevas. Ésta alternancia tiene que ver con la unificación con los archivos de la antigua República Demócratica Alemana y el Document Center, hasta 1994 en manos americanas. En el caso del Document Center mi visita coincidió con el traspaso de manos americanas a manos alemanas; este "acontecimiento histórico" se tradujo en una serie de dificultades relacionadas con las signaturas. Finalmente nos decidimos por la nueva numeración, siempre que ésta estaba a la disposición para los documentos del Document Center, el cual aparece en la cita de los documentos como Bundesarchiv Zeblendorf y del Bundesarchiv Potsdam, y la numeración ya existente para los documentos consultados en Koblenz. Para garantizar la identificación de los documentos, nos hemos decido a incluir la fecha de éstos, así como una pequeña aclaración: título en el caso de circulares e informes o remitente y dirección en el caso de correspondencia privada o escritos particulares.

Dada la cantidad de textos utilizados en lengua alemana, no hemos decidido a hacer un apartado especial con la traducción del alemán al español, que se encuentra al final de este trabajo. Los textos llevan el número correspondiente al pie de página en el que son citados. Por otra parte, hemos creído necesario hacer un pequeño apartado para algunos documentos que ilustran determinados aspectos relevantes para nuestro estudio, en ellos hemos realizado una transcripción exacta, ello quiere decir que hemos respetado errores gramaticales o tipografías como ss en vez $\beta$ por tratarse en muchos casos textos escritos a máquina, y siguiendo el mismo esquema hemos dejado los fallos gramaticales existentes en el texto.

$\mathrm{Al}$ final del trabajo hemos incluido una selección de las fuentes de archivo utilizadas, así como una lista de los archivos y bibliotecas visitados. Respecto a la bibliografía hemos realizado una división entre los trabajos publicados hasta 1945, considerados como fuentes secundarias, en la que incluimos los artículos publicados en las revistas objeto de nuestro estudio, y los trabajos publicados a partir de 1945. La prensa representa para el movimiento de la mujer su principal forma de expresar sus aspiraciones e ideas. A finales del siglo XIX y principios del XX la prensa femenina prolifera, donde se ofrece la posibilidad de crear un marco de reflexión sobre la naturaleza femenina así como favorece la expresión y la creación para las mujeres. ${ }^{103}$ Por otra parte son testigos de los cambios políticos del país y juegan un gran papel en la formación dentro de las lectoras. El análisis de estas publicaciones nos muestra en primer una mirada en las organizaciones de mujeres, ya que como órganos de las organizaciones encontramos un gran número de noticias sobre encuentros, mítines, acciones etc. Interesante es el efecto que tienen las publicaciones en sus lectoras, cómo tienen lugar los procesos de comunicación, temas fundamentales en la historia social, en tercer lugar es importante la creación del discurso feministas, sus contradicciones, sus vericuetos intelectuales en la búsqueda de una reflexión sobre lo femenino.

103 Wischermann,U.: "Die Presse der deutschen Frauenbewegung 1848-1918. Anregungen zur Erforschung einer fast vergessenen Öffentlichkeit", en: Blühm,E./Gebhardt,H.: Presse und Geschicbte II. Neue Beiträge zur historischen Kommunikationsforschung, München-London-New York-Oxford-Paris, K.G.Saur, 1987 pp.349-363. 
La variedad de la prensa del movimiento de la mujer corresponde con el resto. A finales de Weimar existían 4.700 periódicos diarios y 7.300 revistas que aparecían regularmente. ${ }^{104}$ En 1933 sufre la prensa alemana una reestructuración. ${ }^{105}$ Como método de investigación se han utilizado fuentes primarias: correspondencia privada, memorias etc. y se ha seleccionado la literatura existente hasta la fecha, ofreciendo una visión crítica de ésta. Entrevistas con miembros de las revistas nos han sido imposible dado que según nuestras informaciones no viven ya.

Nuestro trabajo tiene como objetivo analizar reacciones, discurso, posturas políticas de tres grupos de mujeres desde una perspectiva de género relacionada con otros factores como de tipo religioso o de clase. Para ello hemos creído necesario hacer una referencia histórica de las organizaciones de mujeres, confesionales y no confesionales, durante la República de Weimar hasta su disolución en 1933. En segundo lugar tratamos las reacciones de las diferentes organizaciones durante la Machtergreifung y su posterior evolución durante el nacionalsocialismo. En tercer lugar realizamos análisis del discurso ideológico de las publicaciones de mujeres de las diferentes organizaciones que no fueron prohibidas y que continúan editándose durante el nacionalsocialismo. Con éstos pretendemos demostrar la continuidad ideológica de algunos sectores de la burguesía de Weimar con dicho movimiento, así como la progresiva adaptación de éstos a los modelos e imágenes en torno a lo femenino propuestos por el Tercer Reich.

La primera parte de nuestro trabajo se iniciará con un análisis de los antecedentes históricos de la Liga de mujeres protestantes (Evangelischer Frauenbund), la Liga de mujeres católicas (Katholischer Frauenbund) y la Liga de mujeres alemanas (Deutscher Frauenbund); para ello hemos creído necesario aludir a tres condicionantes previos: la importancia de la República de Weimar en el cambio de la situación social de las mujeres, las diferentes organizaciones de mujeres y sus referentes políticos e ideológicos, y las primeras reacciones de los grupos de mujeres confesionales y no confesionales ante el nacionalsocialismo, así como las respectivas actitudes de los órganos de prensa de ambas

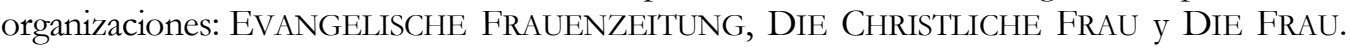

La segunda parte está formada por un análisis de tipo temático, de los diferentes discursos que se articulan en las revistas mencionadas. Este análisis no se realizará de manera diferenciada sino que estará estrechamente vinculado a determinados aspectos de la política e ideología nacionalsocialista: política de trabajo, política religiosa e ideario ideológico sobre lo femenino. A través del comentario detallado de los textos encontrados en la prensa de las tres organizaciones estableceremos las similitudes o discrepancias con la política del momento.

La constatación de nuestras hipótesis no se verá únicamente argumentada a través de textos periodísticos sino que para ello aportamos fuentes de archivo en los que documentarán "objetivamente" las hipótesis planteadas. Nos referimos a fuentes de archivo en las que se documentan temas como el Kirchenkampf, procesos de partido contra las dirigentes protestantes como Agnes von Grone o Klara von Lönnies, actas oficiales sobre Gertrud Bäumer y el resto de mujeres que ocupaban cargos de responsabilidad en la liga de mujeres alemanas, así como una innumerable selección de correspondencia privada, especialmente útil a la hora de analizar opiniones personales, valoraciones de la situación durante la dictadura, etc. juicios sobre la persecución de los judíos etc.

La mayoría de las investigaciones realizadas por no historiadoras/es se ocupan fundamentalmente de dos sistemas: mujeres, patriarcado y dictaduras. El análisis teórico de éstas parte de la siguiente norma lógica: si las mujeres viven en una sociedad patriarcal, está claro que

104 Seiterich,B.: Demokratische Publizistik gegen den deutschen Faschismus: Die DEUTSCHE REPUBLIK, eine politische Wochenschrift der späten Weimarer Republik. Ein Beitrag zur Geschichte der demokratischen Presse, Frankfurt am Main, Peter Lang, 1988, p.13.

105 Sobre la presa ilegal: Stroech,J.: Die illegale Presse. Eine Waffe im Kampf gegen den deutschen Faschismus. Ein Beitrag zur Geschichte und Bibliographie der illegalen antifaschistischen Presse 1933-1939, Frankfurt am Main, Röderberg-Verlag, 1979. 
viven en un situación de sometimiento. En una sociedad totalitaria como la nacionalsocialista, por sus características patriarcal por excelencia son las mujeres víctimas en función de su género, y también víctimas en función de su raza. Este argumento tiene sus puntos flacos. En primer lugar, no está probado que en sociedades patriarcales, en el caso de que existan, no existan mujeres que se aprovechen de la situación, y que conscientemente apoyen los objetivos de reproducción del supuesto patriarcado. Este mismo argumento puede aplicarse al nacionalsocialismo. Por otra parte ¿es una trabajadora en un campo de concentración, víctima del patriarcado? ¿O una dirigente feminista que se retira en el silencio a la creación literaria? Quizá sería necesario replantear el concepto patriarcado. El considerar a todas las mujeres como víctimas de un sistema patriarcal deja las puertas abiertas para la relativización de actitudes, de colaboración y apoyo o aceptación del nacionalsocialismo, y por otra manera de colocar en su punto justo cualquier tipo de oposición. Las mujeres no podían ejercer resistencia por que ya eran víctimas. 
Entre el primer feminismo de la República de Weimary el Tercer Reich: Los grupos de mujeres confesionales

y el feminismo liberal-conservador 


\section{La República de Weimary su importancia en el cambio de la situación social de las mujeres}

\subsection{Introducción}

Las calles de Berlín en los primeros años de la República de Weimar rebosan de vida. La ciudad ha crecido en los últimos tiempos, en los cafés se escucha jazz, se habla y se discute hasta la saciedad. Éstos están llenos de artistas, trabajadores, padres de familia y, joh sorpresa!, mujeres. Estas fuman, bailan en público y llevan el pelo corto, lo que entonces se conocía como Bubikopf. En el Kurfürstendamm se celebraba públicamente el corte de las trenzas como muestra de emancipación. Mientras que en el siglo XXI el símbolo de la mujer emancipada era la Blaustrumpf, la académica que rechazaba todo tipo de coquetería, soltera, en la República de Weimar es la Garconne. Con ropas masculinas, frack o smoking, fumadora de puros y bebedora de whisky. Con rasgos parecidos retrata Otto Dix (1891-1969), pintor alemán representante de la tendencia de la Neue Sacblichkeit a una "periodista": en ésta "la feminidad", el género ha desaparecido, es delgada, el cuerpo enjuto como el de un hombre, en la mesa de un bar, toma notas sola con un cigarro en la mano y un vaso de whisky en la otra, un puro ejemplo de la ambigüedad, de la "deconstrucción" del género, , fenómeno que no sólo encontramos en Alemania sino que alcanza su mayor repercusión en la creación literaria de escritoras como Djuna Barnes (Nichtwood), Virginia Woolf (Orlando) y Gertrud Stein (The Well of Loneliness).

La Garconne trabaja, como secretaria, enfermera o maestra, vendedora, peluquera. En la publicidad aparece retratada como una mujer independiente que consume con asiduidad moda, productos cosméticos y se preocupa de su salud y apariencia personal. Su imagen está unida a la silueta de las grandes ciudades. El Berlin de los años 20 y 30 es conocido entonces como "la ciudad de las mujeres" y constituye un ejemplo plástico del cambio de la situación de la situación social de la mujer a principios de siglo.106 1919 constituye el hito que marca este cambio, a partir de esta fecha, las mujeres alemanas acceden al voto femenino y dejan de ser, desde el punto de vista lega, ciudadanas de segunda categoría.

\subsection{Aspectos politicos de la República de Weimar}

El conjunto de cambios en el desarrollo político-socio-cultural de Weimar se enmarcan dentro de la época de crisis de la modernidad clásica. La sociedad industrial que surge en el mundo europeo durante el siglo XIX va acompañada de cambios en las estructuras socioculturales de ésta: cómo si de una caja de Pandora se tratara se desarrollan una multitud de tendencias y contracorrientes que ponen de relieve una serie de cambios: el valor del trabajo, la

106 Grossmann, A.: "Girlkultur or Thoroughly Rationalized Female. A New Woman in Weimar Germany?“،, en: Friedlander,J./Wiesen-Cook,B./Kessler-Harris,A./Smith-Rosenberg, C. (eds.): Women Culture and Politics. A Century of Change, Bloomington, 1986, pp.62-80. 
progresiva tecnificación de la sociedad, el cambio en la concepción del individuo, etc. y cambios de las relaciones entre los géneros. ${ }^{107}$

Sin embargo esta aparente armonía es irreal. Los cimientos de la República no son estables. Sus padres son una guerra perdida en una sociedad fuertemente militarizada, la disolución de la monarquía, la desilusión de los hombres y por otra parte, la nueva independencia de las mujeres. El 9 de noviembre de 1918, fecha del nombramiento de la república en Berlin, marca la ruptura con el sistema imperial, así como la importancia del movimiento de las masas. La república nace sin un consenso como en los Estados Unidos en su declaración de principios. El sentimiento republicano no gozaba de muchos defensores en la Alemania de principios de siglo. El liberalismo burgués de izquierdas se había decidido en 1848 por la monarquía e incluso los socialdemócratas no consideraban la disolución de la monarquía como uno de los objetivos más importantes de su política. ${ }^{108}$

Podemos diferenciar tres etapas en la evolución de Weimar. 1918/19-1923 - etapa de formación y consolidación, 1924-1929 - período de relativa estabilidad, también conocido como los años dorados de la república y por último los tres últimos años hasta 1933 que se caracterizan por la aparición del nacionalsocialismo, la crisis económica y la desintegración del sistema republicano parlamentario.

\subsubsection{Formación y consolidación y crisis de la república de Weimar 1918/19-1923}

La república carece de un mito de fundación que le diera una legitimación política. Esta falta de compromiso colectivo hace de la república un sistema con falta de apoyo en la gran mayoría. La aceptación y los intereses en ésta no era homogénea entre los diferentes grupos políticos.

Los espartaquistas en torno a Karl Liebknecht y Rosa Luxemburg, se oponían a ésta, ya que la consideraban como una forma incompleta de gobierno que no satisfacía sus ideales revolucionarios. La socialdemocracia se encontraba dividida entre simpatizantes de la fracción espartaquista, que aunque desaprobaban los métodos de actuación de éstos, se diferenciaban del ala moderada del partido, partidaria del sistema parlamentario republicano. La llegada de la república significa un gran schock para los partidos liberal y conservadores. La pérdida de la guerra, la disolución de la monarquía y el peligro de "bolschevización" habían causado una especie de actitud letárgica en éstos. La derecha conservadora se organiza en el DNVP, Deuschnationale Volkspartei. En este confluyen representantes de las clases medias conocidos por su antisemitismo, parte de la clase trabajadora organizada en asociaciones protestantes y representantes de la industria pesada del antiguo Partido Liberal Nacional. El DNVP no acepta el sistema republicano sino que se muestra partidario de la monarquía no parlamentaria. El partido de centro, Zentrumspartei representa los intereses de un heterogéneo electorado católico. El carácter republicano de éste fluctúa entre partidarios y detractores de ésta. El partido liberal democrático, DDP (Deutsche Demokratische Partei), representa a la burguesía liberal católica interesada en una política de estabilidad y de reformas moderadas. Grupo al que se puede denominar como los Vermunftrepublikaner, los “republicanos de razón” que aceptaban Weimar como un compromiso intelectual, históricamente inevitable. El ala nacional del partido liberal se reorganiza en torno a la figura de Gustav Stresemann en el DVP (Deutsche Volkspartei). ${ }^{109}$

107 Este período de cambio aparece analizado por R.Pannwitz (1917) como "La crisis de la cultura europea“, obra en la que por primera vez se utiliza el término postmodernidad como superación de la modernidad, aspecto que ya había sugerido Nietzsche.

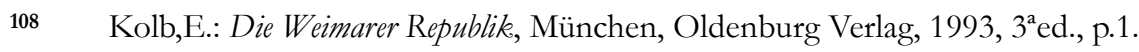

109 Ibídem, p.12. 
Tras las elecciones para la formación de la Asamblea Nacional el 19 de enero de 1919,110 se trabaja en la preparación de una constitución que se revela como un compromiso entre la socialdemocracia, el partido de centro y el DDP. Con la elección de Friedrich Ebert, el 11 de febrero, como presidente de la república y el nombramiento del gabinete de gobierno formado por miembros de la socialdemocracia, del centro y de la democracia liberal se consolida oficialmente la coalición de Weimar.

El 31 de julio la constitución de Weimar es aprobada por la asamblea general y el 11 de agosto es firmada por Ebert. Como órgano central de poder de la nueva república parlamentaria aparece el Reichstag, centro del poder legislativo y la vez control del ejecutivo. Como compromiso con la derecha conservadora, que temía un "absolutismo parlamentario", se dota a la figura del presidente de la república de ciertos poderes especiales. Por ejemplo éste es elegido directamente por el pueblo, con lo cual no depende de la mayoría parlamentaria. Así mismo el presidente posee el derecho de disolver el Reichstag; convoca y despide al gobierno, y puede decretar el estado de excepción.111

El futuro de la república se encontraba abierto. No obstante la pesada herencia del pasado limita su desarrollo. El 28 de julio de 1919 se firma el acuerdo de Versalles entre Alemania y las potencias aliadas, entrando éste en vigor el 10 de enero de 1920. Versalles se convertirá en el punto débil de Weimar. Los acuerdos que se toman atacan el orgullo nacional de los alemanes: Los territorios de Westpreußen y Posen y una parte del centro industrial de la región de Oberschlesien pasan a formar parte de Polonia. La parte norte de Nordschleswig entra bajo la soberanía danesas. En la parte oriental, los pequeños estados de Hultschin, y el territorio del Melmet dependen de Checoslovaquia y Lituania respectivamente. En la parte occidental Francia recibe la región de Elsaß-Lothringen y Bélgica el distrito de Eupe-Malmedy. A la concesión territorial se une las reparaciones de guerra que Alemania tiene que pagar a los aliados. La "segunda" derrota de Versalles constituirá la base para el desarrollo de un nacionalismo exagerado y violenta que finalmente acabará destruyendo a la república.

Los frentes políticos se radicalizan durante estos años, especialmente las fracciones de izquierda y derecha cuyo principal objetivo es destruir la coalición, y en el caso de los sectores más conservadores, instaurar una dictadura nacionalista. En este contexto hay que observa el Kapp-Lüttwitz. Putsch en marzo de 1920. En junio se convocan elecciones al parlamento, perdiendo la coalición la mayoría absoluta. El SPD se retira del gobierno, y el DVP ocupa su puesto en éste.

Los diferentes gobiernos que se suceden a lo largo de estos años tienen que hacer frente a nuevos desafíos. Millones de soldados regresan del frente, los acuerdos de Versalles entran en vigor, las reparaciones han de ser pagadas. Un clima de amargura y descontento reina en Alemania. Las fuerzas de la derecha radical se organizan. Rathenau, ministro de asuntos exteriores, y responsable de la firma del acuerdo de Rapallo resulta asesinado el 24 de junio de 1922. Un año más tarde en noviembre tiene lugar el golpe de estado de Hitler en el Bürgerbränkeller en la capital bávara.

Para resumir, los años entre 1920 y 1923 se caracterizaron por dos procesos esenciales. El aislamiento de la izquierda, acompañada por intentos revolucionarios organizados por los comunistas, y la expansión de un movimiento antirevolucionario de derechas, que utilizaba métodos terroristas y de conspiración. 112

\footnotetext{
110 SPD: 37,9\%, USPD: 7,6\%, Zentrumspartei: 19,7\%, DDP: 18,5\%, DNVP: 10.3\%, DVP: 4.4\%.

111 Kolb,E.: op.cit., p.19.

112 Peukert,D.: Die Weimarer Republik. Krisenjabre der Klassischen Moderne, Frankfurt am Main, Suhrkamp, 1987, p.81.
} 


\subsubsection{La lucha por la supervivencia (1924-1929)}

La república consigue sobrevivir esta fase de inestabilidad política. No obstante la nueva etapa no puede definirse como estable. De ahí que la mayoría de los autores hablen de una etapa de estabilización relativa. El panorama político se caracteriza por la constante fluctuación de coaliciones y partidos en la política parlamentaria, observándose un lento pero seguro crecimiento de los partidos de derechas, con pequeños momentos de éxito para la socialdemocracia, el centro y la democracia liberal, como por ejemplo las elecciones del 7 de diciembre de 1924 donde el SPD vuelve a convertirse en la fracción más fuerte, o en 1928 en las elecciones de mayo de 1928. La estabilidad política y económica va acompañada de una impresionante variedad de movimientos en la literatura, el arte, la música, la arquitectura y el cine que hacen de Berlín, la verdadera protagonista de este fenómeno cultura, una ciudad internacional, cosmopolita y liberal. Sin embargo este bienestar era aparente, según describe una mujer joven en sus memorias:

"Después de haber terminado nuestros estudios y debido a las listas de espera para poder acceder a un puesto de trabajo, teníamos mucho tiempo y ganas para interesarnos en el arte, la cultura, la ciencia y la política. (...) Los jóvenes que durante su niñez había vivido guerra y hambre, se hallaban sometidos durante los años veinte a una doble contradicción: a medida que íbamos madurando éramos testigos de la discrepancia entre la desastrosa situación política y económica y por otra parte la creciente oferta de diversiones que se refleja en el término de los 'dorados años veinte'. Los conciertos y los bailes en la asociación cultural, en el Herkulessaal y en el Deutscher Hof, los deliciosos conciertos al aire libre en la plaza del mercado, en el Stadtpark, los desfiles de carnaval (...)."'113

Este proceso de internacionalización permanece sin embargo reducido al marco de las grandes ciudades. En el resto de Alemania, la tendencia es el crecimiento de un acendrado nacionalismo, un rechazo del proceso de modernización, con todos los cambios que éste trae consigo, y el aumento de posturas antisemitas. ${ }^{114}$

\subsubsection{Los años de crisis y destrucción 1930-1933}

La crisis económica refuerza el descontento en la población, situación que es utiliza el NSDAP como instrumento de su propaganda política. Una mujer describe en sus memorias la situación de desorientación y de contradicción que la generación más joven vive en esta época:

"Después de que Hitler cumpliera su condena comentó el periodo de lucha, paralelamente al crecimiento del desempleo. Las fábricas estaban desmontadas, la economía no florecía, y la moneda estaba devaluada." 115

Desde 1925, fecha en el que partido se reorganiza tras la puesta en libertad de Hitler, se trabaja en la adquisición de una clientela electoral. En 1926 surgen dos organizaciones juveniles

\footnotetext{
113 Institut für Zeitgeschichte, MS 493, Diarios de Luise Sebing.

114 Goldhagen,D.: Hitlers willige Vollstrecker. Ganz gewöhnliche Deutsche und der Holocaust, Berlin, Siedler, 1996, p.109-112.

115 Institut für Zeitgeschichte, MS 493, Diarios de Luise Sebign
} 
dependientes del partido, la Federación nacionalsocialista de estudiantes alemanes, Nationalsozialistischer Deutscher Studentenbund, y las juventudes hitlerianas. En 1929 se funda la Federación de alumnos nacionalsocialista, Nationalsozialistischer Schülerbund, que ejercía su influencia en escuelas superiores e institutos de bachillerato. Kolb llama la atención sobre las tendencias antidemocráticas de una gran parte de la población estudiantil durante los años treinta. ${ }^{116}$ Esta política de adscripción de adeptos se extiende también a las organizaciones profesionales. En 1928 aparece la Federación de juristas nacionalsocialistas, Bund Nationalsozialistischer Juristen. Un año más tarde aparecen las federaciones de médicos y maestros nacionalsocialistas, Nationalsozialistischer Deutscher Ärztebund y Nationalsozialistischer Lebrerbund. A partir de 1930 tienen lugar los primeros intentos de socavar la influencia de los partidos de izquierda en la clase trabajadora. A ello se une la fundación de una organización para pequeños comerciantes, Kampfbund für den gewerblichen Mittelstand. A preparación consciente del electorado se une dos hechos que contribuyen a dar el último empujón a la carrera del partido nacionalsocialista: el plan Young y la crisis económica.

La oposición al plan Young pone en contacto a Hitler con los líderes del DNVP y la Federación de soldados alemanes, Bund Deutscher Frontsoldaten, grupo formado por antiguos veteranos de la primera guerra mundial. Estos contactos posibilitan a Hitler el "reconocimiento oficial" en la escena de la derecha política de Weimar. Aunque las acciones contra el plan no tuvieron los efectos deseados, los nacionalsocialistas se beneficiaron en todos los sentidos. A costa del DNVP mejora el NSDAP sus resultados electorales en las elecciones en Baden y Lübeck en 1929.

La crisis económica afecta intensamente a Alemania. De 1,3 millones de personas sin empleo en septiembre de 1929 se asciende a 3 millones en el mismo mes de 1930. A principios de 1933 el número de parados llega a los 6 millones de personas. ${ }^{117}$ Sobre el país se extiende un sentimiento de inseguridad, haciendo al sistema parlamentario culpable del desastre:

"A diferencia de la mayoría de los países europeos afectados por la crisis económica mundial, está provocó en Alemania una crisis de estado. Aunque la crisis económica afectó de igual manera a éstos el resto de los países pudieron asimilarla mejor debido a la solidez de los fundamentos del orden político y social." 118

A partir de 1930 el ascenso de los nacionalsocialistas era imparable. Hasta ahora no se ha llegado a un consenso sobre el origen de los grupos de votantes. En la discusión se tratan dos teorías: el éxito de los nacionalsocialistas se debió a la movilización de grupos de no votantes, la segunda teoría argumenta por el contrario que este éxito ha de buscarse en la radicalización del electorado procedente de las clases medias, antiguos votantes de los partidos burgueses. Las nuevas investigaciones sobre el tema no dan la razón a ninguna de las interpretaciones. Ambos factores, el aumento en la participación electoral y la "emigración" de los votantes del DNVP, $D D P$ y $D V P .{ }^{119}$ Lo que si es cierto es que para las clases medias, la república era la culpable de la situación de caos y de desorden en la que se encontraba Alemania:

"Las clases medias que deseaban la vuelta de una modesta y tranquila existencia llegaron a la conclusión de que la República era culpable del caos: ésta era la causa

\footnotetext{
116 Kolb,E.: op.cit., p.113.

117 Ibídem, p.119.

118 Ibídem, p.120.

119 Ibídem, p.123.
} 
de la pobreza, de la corrupción, del estraperlo y la discordia. Con añoranza se pensaba en los viejos tiempos de la monarquía, en la que, a pesar de sus fallos, se podía bajo la protección de la ley dedicarse sin problemas al ejercicio de las actividades profesionales." 120

\subsubsection{El cambio en las relaciones de género}

En el llamado Heimatfront las mujeres habían accedido a puestos de trabajo hasta ahora cerrados para ellas, pero que desde que la mano de obra masculina se encontraba en el frente habían quedado vacantes. ${ }^{121}$ Las costumbres morales cambian. Se habla del ocaso de la familia; la articulación del deseo sexual no se limita a un grupo de la bohemia femenina, sino que era un deseo general. Se discutía públicamente sobre sexualidad y medios anticonceptivos.

La "nueva mujer" con su independencia, sus modales masculinos y su cierta promiscuidad, es sólo una cara de la moneda. El proceso de industrialización no perdona y las mujeres trabajadoras son las que sufren las consecuencias. Largas jornadas de trabajo, cuidado y mantenimiento de la familia, despido en caso de enfermedad o maternidad etc. A ello se une el paro de sus compañeros masculinos, con lo que la actividad femenina se hace necesaria, no para mejorar el presupuesto familiar, sino como elemento de sostén de la familia. ${ }^{122} \mathrm{Al}$ mismo tiempo la autoridad del padre disminuye, cuya disposición para alimentar a la familia se ve deteriorada.

A esto se unen las luchas entre los partidos, la inestabilidad política; muchos empiezan a sentirse inseguros. Valores como la patria, el pueblo, la tierra, o la familia se utilizan como talismanes contra el vacío, "contra la pérdida" de los valores morales. Hombres y mujeres empiezan a desear otra imagen de sí mismos. La modernidad con sus aspiraciones de individualidad, privacidad, realización personal y liberación convive contradictoriamente con tendencias conservadoras dirigidas a "conservar" a "preservar" lo antiguo. ${ }^{123}$

Entre las mujeres se producen también trastornos en la búsqueda de los ideales de la nueva mujer. La vivencia de la propia sexualidad, el lento descubrimiento del propio cuerpo, la nueva estabilidad en la inestabilidad, son procesos que no se solucionan de la noche a la mañana y que requieren de las mujeres una lenta asimilación.

La historia de la República de Weimar ha sido hasta la saciedad analizada, en el intento de buscar posibles causas y razones sobre la aparición del nacionalsocialismo. Unos intentan demostrar la especialidad de la historia alemana en su Sonderveg otros pretender buscar puntos de comparación con otras sociedades europeas. Esto se traduce en la interpretación de la República como un tiempo de crisis de la modernidad. ${ }^{224}$ Esta época se caracteriza por cambios en la estructura demográfica, económica y social.

Para entender la evolución de los grupos de mujeres confesionales y conservadores y su reacción ante la dictadura nacionalsocialista es necesario, en nuestra opinión, incidir en el

120 Rosenberg,A: Geschichte der Weimarer Republik, Hamburg, Europäische Verlagsanstalt, 1991 (1ªed. 1946), p.91.

121 Reese-Nübel: "Kontinuitäten und Brüche in den Weiblichkeitskonstruktionen im Übergang von der Weimarer Republik zum Nationalsozialismus“, op.cit., p.111.

122 Ibídem, p.113.

123 Haß,U.: "Zum Verhältnis von Konservatismus, Mütterlichkeit und dem Modell der Neuen Frau", en: Schaeffer-Hegel,B. (ed.).: Frauen und Macht. Der alltägliche Beitrag der Frauen zur Politik des Patriarchats, Pfaffenweiler, Centaurus, 1988, pp.81-87.

124 Peukert,D.J.K.: op.cit., p.11. 
cambio de actitudes, modos de conducta y reparto de los roles masculino y femenino que se produce durante los años de la República de Weimar. Las mujeres que pertenecen a la llamada Gründerzeitgeneration, ${ }^{125}$ nacidas en los años de la fundación del Reich, constituyen la generación que tendrá una gran importancia política en la República de Weimar: Friedrich Ebert, Gustav Stresemann, Rosa Luxemburg, Konrad Adenauer, Albert Einstein, Thomas Mann. Interesante es la falta de nombres dentro del movimiento de la mujer en generaciones posteriores.

Con la llegada de la república comienza una nueva época para las organizaciones de mujeres. Los años de euforia y de trabajo quedan atrás. La concesión del voto a las mujeres las incita a replantear las reivindicaciones del movimiento de la mujer. La guerra y el tratado de Versalles pone en duda el internacionalismo del movimiento, al tiempo que la postura nacionalista se intensifica en casi todas las organizaciones. Por otra parte el fin de la guerra, y la consiguiente vuelta de la mano de obra masculina, ocasiona la pérdida de empleo de un gran número de mujeres, y su empobrecimiento paulatino, especialmente en el caso de las mujeres solteras, sin apoyo familiar, madres solteras y viudas. A la caída de la monarquía en 1918 se unen los problemas de la posguerra: una "generación perdida" de soldados vuelve a casa, refugiados nobles del este, liquidación de millones de créditos de guerra que fueron financiados por los ahorros de la clase media, una gran desproporción entre la población femenina y la masculina. A todo ello se unían las consecuencias económicas de la guerra: las reparaciones, la pérdida de los mercados de exportación, la extenuación de la industria y la inflación. Los problemas latentes de la preguerra adquirían una mayor dificultad, debido a la crisis de legitimación en el orden político que iba unido a la decadencia económica. ${ }^{126}$

La República de Weimar es un momento decisivo en la articulación del discurso feminista de principios del siglo XX. La incorporación de la mujer al mundo del trabajo en los años posteriores a la Primera Guerra Mundial era un hecho inevitable: a pesar de la vuelta del frente de grandes contingentes de mano de obra masculina, muchas mujeres conservaron sus puestos de trabajo al hacerse su contribución económica imprescindible para el sostenimiento del hogar familiar, así como su fuerza de trabajo en los sectores secundario y terciario.

En Weimar se juntan dos discursos, el viejo discurso del movimiento de la mujer, y la nueva mujer, considerada por ésta cómo algo superficial. La nueva causa, de la emancipación de la mujer, y del descubrimiento de la industria del mercado femenino: cosméticos, moda etc. Junto a estos dos discursos sobre lo femenino se articula una nueva tendencia que se opone a las dos anteriores que busca un tipo de mujer lejos de la esterilidad de la nueva mujer y de las aspiraciones intelectuales de las primeras fundadoras del movimiento de la mujer. Mientras tanto el movimiento conservador y los grupos confesionales sufren un proceso de radicalización conservadora. Se puede hablar dentro de los grupos de mujeres de una ruptura generacional. Las únicas que supieron aceptar este cambio de costumbres fueron los grupos de mujeres radicales, que sin embargo no pudieron encontraron una gran aceptación. La nueva generación de mujeres estaba profundamente despolitizada, lo que hace entender la facilidad con que las mujeres aceptaron el nacionalsocialismo. Por otra parte los grupos más conservadores de mujeres desarrollan un discurso que apoya los fines de la dictadura conscientemente.

Esta incorporación al mundo laboral se produce gradualmente, y no siempre con la misma intensidad, y su significado en el cambio social no se puede evaluar de la misma manera.

125 Este mismo autor señala cuatro generaciones durante que juegan un papel esencial durante la república de Weimar: la generación guillermina, Wilhelminische Generation, (1850-1940), la generación la fundación del Reich, Gründerzeitgeneration, nacida en los años 70, la generación del frente, Frontgeneration, nacida en los 80 y la generación pérdida, Überflüssige Generation, nacida en 1890, jóvenes que viven la guerra, el desempleo, etc.

126 Schoenbaum,D.: Die Braune Revolution. Eine Sozialgeschichte des Dritten Reiches, Köln, Kiepenheuer \& Witsch, 1980, (1ª ed. 1968), p.31. 
Podemos así hablar de cuatro etapas: período de emancipación (1914-1918), los años de posguerra (1918-1923), el periodo de prosperidad económica (1924-1928) y finalmente los años de la depresión (1929-1933). ${ }^{127}$

\subsubsection{El periodo de emancipación (1914-1918)}

Durante el primer período se produce una incorporación de la mujer al mundo del trabajo, sin demasiados estrangulamientos sociales: los hombres se encuentran en la guerra y las mujeres son incitadas a cumplir su deber con la patria ocupando los puestos de trabajo abandonados por los hombres:

"Work was no longer merely a mean of escaping economic want and therefore, confined to working-class women, but it became, by way of propaganda, a women's patriotic duty to replace the men. who were at the front in their jobs."'128

Socialmente las mujeres aprendieron a valorarse en actividades que tradicionalmente habían sido efectuadas por los hombres. Sin embargo una emancipación política y legal no se dio en absoluto. El acceso a la vida política y al voto permanecía cerrado. Las mujeres ganaban $1 / 30$ $1 / 4$ menos que sus colegas masculinos. ${ }^{129} \mathrm{El}$ final de la guerra pone de manifiesto la debilidad de la emancipación femenina y apoya la teoría de aquellos que señalan que las mujeres empezaron a trabajar más por necesidad que influidas por los principios emancipadores. Así los empresarios son obligados a despedir a todos aquellos que habían obtenido trabajo desde el 1 de Agosto de 1914. Esta medida afectaba fundamentalmente a la fuerza de trabajo femenina. ${ }^{130}$ El trabajo como empleada, vendedora, u oficinista permitía a las mujeres jóvenes de las clases trabajadoras un pequeño ascenso en la clase social. En Berlín el 33,6 \% de las vendedoras provenían de familias de trabajadores, en München entre 1909 y 1911 eran un 66,9\%, en Köln en 1932 eran un $51,5 \%$. Respecto a las cifras de las aprendices del sindicatos de empleados de oficina se encontraba un $42,9 \%$ de mujeres procedentes de familias de la clase trabajadora. ${ }^{131} \mathrm{El}$ ascenso del número de mujeres entre la población activa es digno de resaltar, entre 1913 y 1921 pertenecientes a organizaciones de empleadas sube de un $7,7 \%$ a un $23,8 \%$, lo que hace a algunos autores hablar de "lucha entre los géneros". ${ }^{132}$

\subsubsection{Los años de posguerra (1918-1923)}

El segundo período engloba años de gran actividad. Al terminar la guerra seis millones de hombres regresan del frente. a pesar de los numerosos despidos de mano de obra femenino, la ocupación de las mujeres se mantiene más alta que en los años posteriores a 1914. La

127 Esta clasificación la hemos tomado de la Tesis Doctoral, todavía sin publicar, de la historiadora americana Dagmar Klimmer: The Social Position of Women in Weimar and Nazi Germany. Retention of the Status Quo?, University of Adelaide, 1989.

128 Ibídem, p.2.

129 Klinsiek, D.: op.cit., p.15.

$130 \quad$ Ibídem, p.15.

131 Schoenbaum,D.: Die braune Revolution, op.cit., p.36.

132 Ibìdem, p.37. 
proclamación de la República de Weimar, establece el derecho al voto femenino. Es un momento de tensión social en el que los dos sexos luchan por determinar sus ámbitos de acción y de trabajo. A pesar de la igualdad política, no se reconoce la igualdad en materia de trabajo. Las mujeres reciben salarios más bajos, y sus condiciones laborales son lamentables. Dentro de un ambiente de relativa libertad política, se comienza a limitar a las mujeres casadas el acceso al trabajo. Es lo que se conoce como la campaña contra los Doppelverdiener, o matrimonio con dos sueldos. En el aspecto político, no existe ningún partido que se interese por la situación de las mujeres, ni el SPD (Sozialdemokratische Partei Deutschlands) o el KPD (Kommunistische Partei Deutschlands) o incluso el DDP (Deutsche Demokratische Partei), con el que la liga de mujeres alemanas tenía unas relaciones optimas, critican la situación de las mujeres trabajadoras. ${ }^{133} \mathrm{~A}$ pesar de ello se produce un gran cambio en las costumbres, en la apariencia física de las mujeres, y en sus actitudes sociales. Hablamos de la "nueva mujer", una mujer independiente, liberada, vestida a la moda, laboralmente activa, consciente y segura de sí misma. A este nuevo prototipo de mujer se oponía el antiguo modelo de mujer, la mujer vieja, la mujer en continua necesidad, la cansada ama de casa, la mujer eternamente embarazada y sufriente que trabaja por necesidad y no por gusto. La nueva mujer gozaba de cualidades masculinas pero no renunciaba sin embargo a su feminidad y sexualidad. Era la Garçonne, la Bubikopf, la mujer con el pelo cortado "a lo chico", vestida con ropas masculinas, fuma, bebe. En una palabra se adueña de los prototipos masculinos, cuestionando su la imagen de la feminidad hasta entonces existente:134

"Era la primera vez que las mujeres podían disponer de su cuerpo y de sus ganancias económicas: Las mujeres tenían por primera vez, su propio dinero y podían decidir si se compraban o no un par de medias de seda. Las viudas de guerra recibían una renta pequeña, las mujeres sin trabajo un pequeño subsidio de desempleo. Esto no lo había antes. Muchas mujeres estaban orgullosas de no ser nunca más, dependientes de sus maridos."'135

Estas circunstancias provocan un cambio en las relaciones entre los géneros y un gran golpe para una parte de la sociedad todavía muy arraigada a esquemas conservadores: El número de divorcios se incrementa, asciende el número de mujeres que conviven con hombres sin estar casadas y el de hijos desciende. Este cambio en la conducta social no es general y provocará en una etapa posterior el surgimiento de tendencias profundamente conservadoras en relación al papel de la mujer en la sociedad.

Sin embargo la participación femenina en el mundo laboral resultaba insuficiente; después de los primeros años de formación se produce el asalto de las mujeres a la vida política. Se organizan en partidos políticos, en organizaciones propias y empiezan a reivindicar mejoras en la situación social de la mujer. Son los años de auge de las asociaciones de mujeres.

1.2.7. Los años de prosperidad económica (1924-1928)

133 Jaschke,H.-G.: "Zur politischen Orientierung von Frauen und Frauenverbänden in der Weimarer Republik“, en: Lehnert,D./Mergele,K. (eds.): Teilkulturen zwischen Integration und Polarisierung, Frankfurt am Main, Westdeutscher Verlag, 1990, p.148.

134 Reese-Nübel,D.: "Kontinuitäten und Brüche in den Weiblickeitskonstruktionen im Übergang von der Weimarer Republik zum Nationalsozialismus", en: Otto,H.U./Sünker,H. (eds.): Soziale Arbeit und Faschismus, Frankfurt am Main, Suhrkamp, 1989, p.321.

135 Frauen unterm Hakenkreuz, ed. por Elefanten-Press, Berlin, Elefanten-Press, 1983, p.44. 
A la participación política de las mujeres va unido también un interés creciente del Estado por los asuntos de éstas. Se procede en primer lugar a la introducción de un conjunto de reformas que afectaban a las conductas sexuales de hombres y mujeres. Uno de los principales objetivos de la „reforma sexual“ era la seguridad de la reproducción de la población a través del patrón de la familia de tipo medio. La reforma sexual se basaba fundamentalmente en un control de la natalidad. ${ }^{136} \mathrm{El}$ exceso de hijos, unido a las malas condiciones de las viviendas y la falta de higiene de éstas, ocasionaba según los reformadores la degeneración y decadencia de la unidad familiar. El único modo de controlar la natalidad era informar a las mujeres sobre sus propios cuerpos y su propia sexualidad para que pudieran decidir por ellas mismas si deseaban evitar embarazos no deseados, saber cuando era el mejor momento en el que debían quedar embarazadas, las posibilidades que tenían de abortar, etc. Surgieron de esta manera, un gran número de organismos estatales, clínicas, publicaciones especializadas, investigaciones sociológicas, a fin de controlar la capacidad reproductora de la mujer. La reforma sexual reconoce la sexualidad femenina pero sólo en términos netamente masculinos, es decir, siempre en defensa de la familia y de la procreación. Cualquier extralimitación que supusiera el abandono de la idea de la regeneración de la familia suponía una amenaza al ideal tradicional de feminidad y con ello de la política de control sexual de la población. En los manuales de "vida sexual" y proyectos de reforma se apela a una "erotización del matrimonio". Conducta que supone una ideología sobre el sexo que define a éste como instrumento de trabajo, que merece controlarse y racionalizarse para adquirir los resultados deseados.

Desde el punto de vista de las nuevas investigaciones sobre la sexualidad, el caso particular de la República de Weimar es heredero de las corrientes ideológicas que sobre el discurso del sexo tuvieron lugar a finales del siglo XIX. Según Foucault se observa un proceso de "especificación, solidificación regional de cada una de las sexualidades" así como el control de éstas por parte del poder:

"El poder que así toma a su cargo a la sexualidad, se impone al deber de rozar los cuerpos; los acaricia con la mirada; intensifica sus regiones; electriza superficies; dramatiza momentos turbados. Abraza con fuerza el cuerpo sexual."137

Las ciencias médicas toman el relevo de la religión en la tarea de la definición, control y administración de la sexualidad. Se produce en palabras de Alicia Puleo "una histerización" del cuerpo de la mujer, ${ }^{138}$ proceso por el que se pasa a considerar al cuerpo femenino como totalmente saturado de sexualidad y objeto de estudio y de curiosidad científica. De ahí los controles y las investigaciones sobre aquél, con objeto de desentrañar sus secretos. Se procede así a la creación de un determinado tipo de sexualidad controlada de la que las mujeres también son partícipes.

La incorporación de las mujeres al trabajo evolucionaba paulatinamente. En los años veinte un $35,8 \%$ de la población activa eran mujeres, alrededor de unos 11,5 millones.

A ello hay que añadir el progresivo rechazo de la población masculina de esta "feminización" de la sociedad. Las primeras señales aparecen en las organizaciones juveniles, de gran tradición

136 En el proceso de racionalización de la sexualidad confluyen dos tendencias que tienen sus orígenes en el siglo XIX: el movimiento higienista que propagaba un sexualidad natural y razonable; y la política de población en la que se encontraban los primeros indicios de tendencias xenófobas, ya que uno de sus principales objetivos eran la salud de la raza. en: Peukert,D.: op.cit., pp.106-108.

137 Foucault,M.: Historia de la sexualidad. La voluntad de saber, Madrid, Siglo XXI, 1989, p.58.

138 Puleo,A.: Dialéctica de la sexualidad. Género y sexo en la filosofía contemporánea, Madrid, Cátedra, 1992, p.8. 
en la Alemania de principios de siglo. En ellas se recrea el culto a la masculinidad unido a la militarización de las organizaciones que no aceptan miembros femeninos. 139

\subsubsection{Los años de decadencia (1929-1933)}

Durante los años 1929 y 1933 observamos un fuerte rechazo de la imagen de la "nueva mujer", y de la política de reformas de los gobiernos de la República de Weimar.

Conviene hacer un balance del significado de esta época de profundos cambios sociales y sociológicos. El acceso legitimado a un puesto de trabajo, la racionalización de la economía contribuyeron a la reestructuración del mercado laboral y la institucionalización de la división sexual del trabajo, aspecto que utilizaría años más tarde la propaganda nacionalsocialista. Nuevos y modernos ámbitos de empleo se configuran para las mujeres: en la industria, en el comercio, en el servicio público. Así como empleos que se consolidan como típicamente femeninos: dependienta, secretaria de oficina, trabajadora de banda mecánica, maestra etc. Este tipo de trabajos eran ejecutados por mujeres procedentes de clase media-baja y clase media como un modo de ascender en la escala social. ${ }^{140}$ La mayoría de las mujeres que ejercitaban algún tipo de trabajo consideraban su actividad como una fase transitoria y provisional. Esta actitud era también compartida por las generaciones más jóvenes a través de la socialización familiar y escolar. Las escuelas primarias, así como las escuelas de formación profesional para jóvenes, preparaban a la totalidad de sus asistentes para trabajar pero sin olvidar su condición de mujeres, de futuras madres. ${ }^{141}$

Hay que tener en cuenta además que la reforma sexual era un movimiento dirigido fundamentalmente a mujeres trabajadoras. Partiendo de las condiciones en que vivían, se pasó a racionalizar su actividad reproductora. Sin embargo no se realizó ninguna medida de cara a aliviar su doble condición de madres y trabajadoras. La modernización, la racionalización del trabajo afectaron con matices positivos a las mujeres que trabajaban en el sector terciario: secretarias, oficinistas, maestras. Sin embargo para las mujeres proletarias estos procesos se manifestaron como "una fuerza retroactiva que dirige a un estado de idiotización de la mujer en relación a los hombres, al menos durante la primera fase de desarrollo"142:

"Mi día de trabajo comienza a las cinco de la mañana con la preparación del fuego. Hasta que el agua del café comienza a hervir, preparo los bocadillos necesarios para tres personas y unto el pan con mantequilla y un poco de fiambre. Entre tanto, tengo que despertar a la familia. Después tengo que preparar la sopa y el café para que no estén calientes cuando los señores de la creación estén listos para desayunar (se refiere a sus hijos). Cuando todo está listo preparo mi fiambrera y mi termo con café y me dispongo a salir para ir a trabajar; tardo tres cuartos de hora en llegar, el camino lo hago a pie, a través del campo. En verano es un placer, en invierno, cuando la nieve me llega a las rodillas no es nada divertido. Mi trabajo es tejer. Durante ocho horas y media permanezco sentada, sólo me levanto para comer, y tejo hilo por hilo, 800 cada hora. Hasta 6.000 veces mis manos y brazos

\footnotetext{
139 Reese-Nübel,D.: op.cit., p.116.

140 Hagemann,K.: Frauenalltag und Männerpolitik. Alltagsleben und gesellschaftliches Handeln von Arbeiterfrauen in der Weimarer Republik, Bonn, Dietz, 1990, p.457.

141 Ibídem, p.640.

142 Bridenthal,R.: "Beyond Kinder, Kirche, Küche. Weimar Women at Work", CENTRAL EUROPEAN HISTORY, $1973\left(\mathrm{n}^{\circ}\right.$ 6), p.149.
} 
hacen el mismo movimiento. A veces me quedo dormida. ¿Porqué no habrán inventado una máquina para este trabajo tan monótono? El camino a casa lo hago con alegría, aunque tengo que hacer la compra para el día siguiente, como vivimos un poco apartados, no hay tiendas en las vecindad. Llego a casa de nuevo, me esperan dos bocas hambrientas, tengo que poner el fuego, y preparar la merienda y la cena para el próximo día. Después lavo los platos, voy a buscar agua, regar el huerto. Después leo un poco el periódico, y me duermo. Así pasan los días. “143

La emancipación de la mujer en la República de Weimar no fue tan gloriosa como a veces se presenta en los libros. La reforma sexual no fue un movimiento que partiera de las mismas mujeres, y en segundo lugar, no estaba dirigido a crear un clima más libre, en el que la mujer dejara de seguir siendo el "otro sexo", sino que fue sometido a un control por parte del estado, el cual permitía "ciertos márgenes de libertad impuesta". Las mujeres, en especial las mujeres trabajadoras, se vieron forzadas a cargar con más obligaciones, y a pesar de las reformas su situación no cambió considerablemente. Como señala la historiadora Renate Bridenthal la mujer alemana sufría por un lado, la condena por su abandono de la familia, se sentía fracasada en el trabajo debido a que éste estaba considerado social y financieramente como inferior al de cualquier trabajador no cualificado. ${ }^{144}$ Este sentimiento de frustración contribuye, según la autora, a que muchas mujeres apoyaran más tarde al nacionalsocialismo, el cual prometía un nuevo y atrayente paraíso a las mujeres.

Entre las feministas moderadas y las partidarias del movimiento confesional se desarrollan cada vez más posturas que rechazan los ideales de la nueva mujer. Así, como contrapartida a la obra de Alexandra Kollontai, Wege der Liebe, publica Marianne Weber, Die Liebe, donde se ensalzan los valores de la familia y el papel de la mujer como madre. No en un sentido biológico como lo harán los nacionalsocialistas después sino intelectual y espiritual. En la misma línea se entienden los trabajos de Gertrud von Le Fort y Magdalene von Tiling.

Para concluir: en la República de Weimar aparecen varios modelos de construcción de género. Por una parte se encuentra el modelo de la Neue Frau, que mostraba un ideal de mujer moderna, independiente apolítica, y consumidora. Un segundo modelo estaba representado la añoranza del estatus seguro de la madre en el círculo familiar. Un tercer modelo, defendido por el ala moderada del movimiento de la mujer, preconizaba la "maternidad espiritual" como el objetivo a conseguir en la mujer, convirtiéndose la educación en un medio importante para llegar a ésta. Un cuarto modelo estaba representado por las mujeres implicadas en la lucha política para las que la actividad política era más importante que las reivindicaciones de los grupos de mujeres. La construcción de género durante el nacionalsocialismo se sirve de estos tres modelos.

\subsection{La participación política de las mujeres durante la República de Weimar}

La república significa para las principales dirigentes de las organizaciones de mujeres, la entrada en la política de partidos, la presentación de candidaturas, y en algunos casos el trabajo

143 Flemming,J./Saul,K./Witt,P.-C. (eds.): Familienleben im Schatten der Krise. Dokumente und Analysen zur Sozialgeschichte der Weimarer Republik, Düsseldorf, Droste, 1988, p.143.

144 Bridenthal,R.: op.cit., pp.148-166. 
parlamentario. ${ }^{145}$ Para las elecciones de la Asamblea Nacional se presentaron como candidatas 310 mujeres, de las cuales sólo fueron 37 elegidas. Durante el período de reunión de la Asamblea Nacional cuatro mujeres avanzaron en la lista de candidatos, con lo que la cifra de mujeres sube a 41 frente a los 423 representantes masculinos. ${ }^{146}$

La presencia de las mujeres en la Asamblea se deja notar. Una de las primeras acciones de éstas fue la redacción de una interpelación en la que todas las mujeres de las fracciones políticas exigían la retirada del boycott sobre Alemania y la vuelta de los prisioneros alemanes. La influencia de éstas se extiende a los artículos de la constitución relacionados con el matrimonio, la maternidad y la situación de la descendencia ilegítima. Así por ejemplo Marie Baum perteneciente al DDP defiende la propuesta de su fracción de remodelar el artículo 119 sobre el matrimonio, donde se pasa a definir a éste como "definido en función de la igualdad de ambos géneros". 147

De las 23 mujeres que formaron parte del parlamento alemán entre 1919 hasta 1933 representando al DDP, DVP y al DNVP, ocupan cargos en los consejos ejecutivos de las organizaciones del movimiento de la mujer y en la Federación de mujeres protestantes alemanas, $D E F$; lo mismo se puede decir de las representantes del partido de centro, ligadas a las organizaciones de mujeres católicas.

El trabajo de éstas en el parlamento se ocupa fundamentalmente de aspectos relacionados con la situación de la mujer en la sociedad. Margarete Behm representante del DNV presenta una propuesta en la que se daba la posibilidad a las mujeres que ejercían una profesión: costureras, modistas, mujeres de la limpieza, etc., de fundar corporaciones o gremios, y como consecuencia la dirección de éstos, derecho del que sólo disfrutaban los miembros masculinos de los gremios. El 26 de enero de 1921 Elisabeth Lüders, DDP, en nombre de las mujeres de todas las fracciones presenta una propuesta para redactar un proyecto de ley que permitiera a las mujeres realizar los mismos exámenes en el estudio de derecho. Esta unidad se vuelve a manifestar con motivo de la preparación de la ley para el bienestar de la juventud, Reichsgesetz für Jugendwoblfahrt, donde son exclusivamente mujeres las que participan en la discusión sobre ésta en el parlamento. ${ }^{148}$

145 Bäumer ingresa en el Deutsche Demokratische Partei (DDP) en 1918, junto a ella sus compañeras de organización: Agnes von Zahn-Harnack, Marie Elisabeth Lüders, Else Ulich-Beil, Martha Dönhoff, Rosa Kempf, Camila Jellinek, Frances Magnus von Hausen, Dorothee von Velsen, Marianne Weber, Marie Baum, Elisabeth Altmann-Gottheiner etc. Al Deutschnationale Volkspartei (DNVP) pertenecen mujeres que tienen una estrecha relación con las organizaciones de mujeres protestantes y de amas de casa: Paula Müller (dirigente del Evangelische Frauenbund), Anna Gierke, Margarete Keyserlingk-Cammerau, presidente de la Reichsverband landwirtschaftlicher Hausfrauenverein, Annagrete Lehmann, Käthe von Herwarth, Maria Jecker, Magdalene von Tiling (presidente de la Vereininigung evangelischer Frauenverbände), Margarete Behm, Margarete Wolf y Bertha von Kröcher. La socialdemocracia contaba con Adele Schreiber y Helene Stöcker. El Deutsche Volkspartei (DVP) contaba entre sus filas a Katharina von Kardorff, Emma Ender y Leonore Kühn. Helene Weber y Hedwig Dransfeld representaban al partido de centro Zentrumspartei.

146 Beckmann, E.; Kardel, E.: Quellen zur Geschichte der Frauenbewegung, Frankfurt am Main, Berlin, Bonn, Moritz Diesterweg, 1955, p.39

147 Ibídem, p. 40. Número de mujeres en la Asamblea Nacional: Socialdemocracia: 13,3\%, Partido demócrata alemán: 8,0\%. Partido del pueblo alemán: 4.5\%. Centro: 6,3\%. Partido nacional alemán: $7,0 \%$.

148 Ibídem, p. 41 . El 7 de abril de 1922 Margarete Behm informa sobre la ley sobre la aseguración de trabajadores/as del hogar, ley que afectaba a un gran número de mujeres que ejercían su profesión en el hogar, conocida más tarde por Lex Behm. Elisabeth Lüders y Gertrud Bäumer se ocupan de la ley que trataba el tema de la nacionalidad de mujeres que contraían matrimonio con un extranjero, donde se exige que la mujer pudiera decidir entre la nacionalidad alemana y la nacionalidad del esposo. Junto a la actividad de las mujeres conservadoras cabe destacar el trabajo de las mujeres de la socialdemocracia, 
La situación de las organizaciones de mujeres se puede clasificar en estos momentos de esquizofrénica. Por una parte todas las organizaciones sin excepción acentúan su apoliticismo y su neutralidad, por otra parte es de todos conocido, la afiliación política de sus principales dirigentes. Sin quererlo, el trabajo del movimiento de la mujer se politiza. Junto a los temas propios de la mujer, se abordan temas no específicamente femeninos, relativos a la política internacional. Otro aspecto que se observa es un proceso de radicalización en las organizaciones; no el sentido político como señala Evans, sino en relación a la naturaleza de las organizaciones. Las organizaciones confesionales se cierran en si mismas y centran sus objetivos en el papel religioso y confesional; las organizaciones no confesionales defienden patrimonio cultural e ideológico nacional.

El partido que sin duda se benefició de la concesión del voto a las mujeres fue el Zentrumspartei. En las áreas protestantes las mujeres votaron al DNVP y al DVP, mientras que el resto de los partidos apenas notan un incremento. ${ }^{149}$

Los años de la República de Weimar representan para el movimiento de la mujer una época de dificultades, de cambios en la situación de la mujer que la organización tarda en asimilar, de ahí sus dudas en lo relativo a la interrupción del embarazo, la moral sexual, al matrimonio etc. Ulrike Prokop define con gran exactitud, tomando como referencia los escritos de Gertrud Bäumer y Marianne Weber, el hastío que experimentan las mujeres en esta época, "su deseo experimentar, de vivir con pasión, con intensidad, de hacer cosas nuevas". ${ }^{150}$ Se tiene miedo de caer en una existencia rutinaria, insignificante y aburrida; se aspira a un experiencia global que proporcione un sentimiento de unidad con los otros, con la nación; un sentimiento que normalmente lo proporciona una tragedia, o una guerra. De la guerra nació el servicio femenino organizado por Bäumer, de ésta nació un sentimiento de utilidad y de unidad que las dos mujeres unos años después echaban de menos. Este miedo al vacío de la anarquía y el desorden no conlleva una retirada del mundo político. Al contrario el BDF colabora activamente con el gobierno en los programas de reintegración de las mujeres que habían perdido su trabajo con la llegada del contingente de soldados.

En 1920 la tendencias dentro del movimiento de la mujer se han homogeneizado predominando un claro contingente liberal y de derecha. Con la muerte de Minna Cauer en 1922, representante del ala radical del movimiento y la desaparición del órgano portavoz de éstas, Die Frauenbewegung, la influencia de éstas desaparece. El comité ejecutivo de la Federación aparece dominado por mujeres del DDP.

El movimiento confesional continúa trabajando en sus organizaciones, y se distancian claramente del movimiento de la mujer laico.

Una gran importancia cobran las organizaciones profesionales de maestras, profesoras, y empleadas de correos y telégrafos. La influencia sobre organizaciones de mujeres trabajadoras es mínima. Mientras que los grupos de mujeres confesionales intenta por todos los medios entrar en contacto con las organizaciones de mujeres trabajadoras, no se puede decir lo mismo del movimiento de la mujer, que defiende en estos momentos los intereses de las mujeres de la clase media. Con la pérdida de influencia de las feministas radicales sobre el movimiento, se observa la creciente importancia de las asociaciones de amas, las cuales además de defender posturas nacionalistas, se muestran contrarias a todo tipo de reformas en relación con las mujeres del

como por ejemplo Louise Schroeder, Marie Juchacz, Clara Bohm-Schuch y Toni Pfülf en el área de los permisos de maternidad, protección de menores y defensa de los derechos de las mujeres trabajadoras. Schroeder, L.: Ein Frauenleben unser Zeit, Berlin, Arami, 1956, p. 12

149 Boak,H.L.: Women in Weimar Germany. The 'Frauenfrage' and the Female Vote, op.cit., p.157.

150 Prokop,U.: "Die Sehnsucht nach der Volkseinheit. Zum Konservatismus der bürgerlichen Frauenbewegung vor 1933”, en: Dietze,G. (ed.): Die Überwindung der Sprachlosigkeit. Texte aus der neuen Frauenbewegung, Darmstadt, Luchterhand, 1981, p.180. 
servicio doméstico, que pusieran en duda sus privilegios. En 1930 el conflicto entre demócratas liberales y nacionales se intensifica. La ocasión se presenta con un escrito elaborado por el BDF y la liga de mujeres católicas (Katholischer Frauenbund) sobre la crisis económica. En el escrito se recomendaba el apoyo a la política de Brüning y la necesidad de buscar compromisos con el extranjero para llegar a una solución del problema económico. En un principio la mujeres protestantes (Vereinigung evangelischer Frauenverbände) y su presidente, a Magdalene von Tiling estaban dispuestas a firmar la declaración. Sin embargo unos días más tarde en un escrito a Gertrud Bäumer expresa su desacuerdo con la necesidad de pactar con el extranjero. Esta negativa se une posteriormente la declaración negativa del RLHV, la organización de amas de casa, donde defienden los valores nacionales, cristianos y patrióticos. ${ }^{151}$ Esta organización, junto al $R D H$ proclama su retirada de la Liga en 1932, con ocasión de la conferencia de Ginebra y las resoluciones sobre desarme en las que Bäumer y Lüders habían participado.

El trabajo de las mujeres del movimiento de la mujer en la política activa se caracteriza por la implicación de éstas en temas que atañían a los intereses de las mujeres. Gertrud Bäumer, quizá la más conocida por su trabajo político, es definida entonces por uno de sus compañeros como una de las mejores oradoras del parlamento. ${ }^{152}$ En 1919 presenta su candidatura para la Nationalversammlung y mantiene su escaño para el DDP hasta 1932. Desde el principio tiene tareas de responsabilidad en el partido, y goza del respeto de sus colegas. Pertenece al "grupo de los cuatro", y se encarga de las tareas programáticas de partido, junto con Erik Koch-Weser, Anton Erkelenz y Hermann Fischer. Este protagonismo se extiende a DIE HILFE donde Gertrud Bäumer trabaja como cronista, junto a Theodor Heuss. ${ }^{153}$ Marta Dönhoff y Frieda Wunderlich eran candidatas en el estado de Prusia, Else Ulich-Beil en Sajonia, Marie Schulz en Turingia, Emmy Beckmann en Hamburg, Agnes Heineken (no escribe para DIE FrAU) en Bremen y Luise Kiesselbach en München. ${ }^{154}$ Esta presencia en el DDP no significaba que las mujeres ocuparan cargos de responsabilidad, aun en el caso de Bäumer o Weber respetadas por su profesionalidad, se vieron relegadas a cargos subalternos. Los puestos importantes quedaban reservados a los hombres:

"Sólo Gertrud Bäumer alcanzaba la precisión de pensamiento y actuación, la rápida inteligencia y la seguridad de expresión de Koch-Weser. Pero en los primeros años de la república era impensable, que una mujer ocupara la jefatura de un partido. Finalmente Bäumer levantaba un gran máximo de admiración y adhesión. Su persona emanaba una gran autoridad pero no el atrayente calor humano." 155

La labor de estas mujeres se caracteriza por su defensa de los principios democráticos. Un entendimiento de la democracia que merece la pena analizar. Como señala Greven-Aschoff el concepto era muy variado. En primer lugar la democracia estaba determinada por la Gemeinschaft,

151 Greven-Aschoff,B.: op.cit., p.184. Las organizaciones de amas de casa son conocidas desde principios de siglo por su clara conciencia de clase, su rechazo del movimiento de la mujer, y de cualquier tipo de aspiración de las mujeres trabajadoras.

152 Stephan,W.: Aufstieg und Verfall des Linksliberalismus 1918-1933. Geschichte der Deutschen Demokratischen Partei, Göttingen, Vandenhoeck \& Ruprecht, 1973, p.59.

153 Ibídem, p.493.

154 Es interesante señalar la representación femenina de los parlamentos de los diferentes estados. En el parlamento bávaro son elegidas tres mujeres: Rosa Kempf, Aloisia Eberle y Emilie Maurer.

155 Ibídem, p.500. 
unida a una concepción liberal de la personalidad, la selección y el progreso de aquellos a los que se les había concedido los dones de la aplicación e inteligencia.

El trabajo de las mujeres en el partido se limita fundamentalmente a temas relacionados con la mujer. La influencia en este sentido era muy limitada. Aunque, como en el caso de Bäumer y Lüders se ganaron el respeto y la admiración de sus colegas, estos fueron casos excepcionales.

La fundación de un nuevo partido y la disolución del DDP, da sin embargo la oportunidad a criticar a Bäumer y al grupo responsable de la nueva fundación, como representantes de un Faschismus der Mitte, así como se critica la nueva actitud de la cabeza de partido y su negativa a entablar no negociaciones con la izquierda. ${ }^{156}$

En los primeros años de la República, todos los partidos hicieron un gran esfuerzo por incluir al menos unas pocas mujeres en sus escalones más altos y colocaron regularmente nombres de mujeres en sus listas de candidatos. En las posiciones más visibles, las mujeres ocupaban entre un 5 y un 10 por ciento de los cargos electos o del partido pero en los niveles locales, el porcentaje de mujeres descendía hasta situarse entre el 1 y el 2 por ciento. Aunque los partidos burgueses subrayaban el role de la mujer en una posible revolución espiritual y los partidos socialistas pidieron a las mujeres que se considerasen como trabajadoras para el decrecimiento del capitalismo, ningún partido integró con éxito su apoyo retórico a los derechos de la mujer con su teoría o práctica. Persistía el resentimiento hacia las mujeres que trabajaban, e incluso se vio reforzado por las dudas de los socialistas en luchar por salarios iguales para trabajos iguales. También en los partidos liberal y conservador, la participación de las mujeres en la economía fue alentado tan sólo en tanto que las mujeres no sobrepasasen los límites de sus intereses tradicionales.

$\mathrm{Al}$ aspecto de género se añade el grupo social al que pertenecen los tres grupos de mujeres de los que vamos a hablar. Como grupo organizado son de interés a la hora de entender el funcionamiento del nacionalsocialismo.

A pesar de las ventajas que traía la modernidad: la independencia de las mujeres, la libertad de la juventud, la sociedad experimentaba una distanciamiento de la naturaleza, la vida familiar se dispersaba, la sumisión a los dictados de la moda etc. ${ }^{157}$ Marianne Weber describe este sentimiento de inseguridad de la república de Weimar: la perdida de la monarquía, la perdida de la guerra, el desconcierto político. Es en este ambiente donde se desarrolla el movimiento de la mujer. ${ }^{158}$

Dentro del espectro confesional, las mujeres pertenecientes a la Federación de mujeres protestantes, Deutsch-evangelischer Frauenbund pertenecían al DNVP, a diferencia de las mujeres que pertenecían al $D D P$, no se encontraban integradas dentro del movimiento de la mujer. Como veremos en el capítulo siguiente, la Federación de mujeres protestantes abandona la organización no confesional en 1918, y desde esta fecha se distancia de los principios del movimiento de la mujer, y pretende convertirse en la respuesta protestante a éste.

Las mujeres católicas que participan en las tareas políticas del partido de centro, Zentrumspartei, se encuentra organizadas en la Federación de mujeres católicas, Katholischer Frauenbund. A diferencia de sus compañeras protestantes nunca estuvieron organizadas en el movimiento de la mujer. No obstante existe un movimiento católico de la mujer que lucha por cambios en las instituciones eclesiásticas y cuyas principales dirigentes se encuentran integradas en el proceso político de Weimar. Esta participación no es sin embargo, la norma general entre las mujeres católicas como muestra una polémica que tiene lugar entre Helene Weber (1881-

\footnotetext{
156 Ibídem, p.480.

157 Kaufmann,F.: Rat und Tat. Elly Heuss-Knapp. Nachklang eines Lebens, Tübingen, Rainer Wunderlich Verlag, 1964, p.22.

158 Weber,M.: Lebenserinnerungen, Bremen, Johannes Storm Verlag, 1948, p.81.
} 
1962), Gerta Krabbel (1881-1961) y Maria Grollmuß (1896-1944). ${ }^{159}$ Grollmuß, miembro de la organización juvenil Windhorstbund, ligada al partido de centro, publica un artículo sobre la "forma femenina en la política", 160 donde rechazaba la tesis de que la mujer, debido a su carácter marginal en la sociedad burguesa, no podía participar en la construcción del estado. Grollmuß alude al carácter proletario de la mujer, dado su rechazo de la sociedad actual. El ideal católico de la virginidad de la mujer, no es interpretado desde el punto de vista físico, sino como metáfora de la independencia y emancipación de la mujer, haciendo culpable al modelo protestante, de la mujer casada que trabaja al lado del marido, de la falta de independencia de las mujeres protestantes. Ejemplos a imitar son para ella Catarina de Siena y Rosa Luxemburg. Su crítica se extiende al movimiento de la mujer, y a la práctica política de sus representantes que justifican la participación política de la mujer en la llamada, "maternidad espiritual", convirtiendo su actuación en mera copia de la política masculina. Esta línea de aproximación a los principios socialdemócratas es defendida también por representantes femeninas del movimiento juvenil católico, como por ejemplo Helene Wesel y Klara Marie Faßbinder. ${ }^{161}$

Weber, presidente del consejo de mujeres del partido de centro y parlamentaria y Krabbel, desde 1926 dirigente de la Federación de mujeres católicas, defienden por el contrario la especificidad de la naturaleza femenina, así como la separación de esferas de actuación entre hombres y mujeres. En el campo de la política la mujer es definida como la madre del pueblo, y se resalta el carácter de "renovación" de su trabajo político.162 Mientras que para el grupo de jóvenes católicas la democracia se presenta como la única forma del estado, Weber y Krabbel es importante la restauración de un estado nacional poderoso que de forma a la naturaleza del pueblo.

159 Sack,B.: "Katholische Frauenbewegung, Katholische Jugendbewegung und Politik in der Weimarer Republik: Standorte, Handlungspielräume und Grenzen im Kontext des Generationskonflikts", en: Götz von Olenhusen,I.: Frauen unter dem Patriarchat der Kirchen. Katholikinnen und Protestantinnen im 19. und 20. Jahrbundert, Stuttgart-Berlin-Köln, Kohlhammer, 1995, pp.120-138.

160 Grollmuß, M.: "Über die weibliche Form in der Politik", DIE SCHILDGENOSSEN, 1926 (nº), pp.6267.

161 Ibídem, p.128.

162 Ibídem, p.130. 


\title{
Movimiento de la mujer y construcción de modelos de identidad femenina en Alemania 1900-1933
}

\author{
"Women's emancipation was one of the \\ great social issues of the day; the women's \\ movement was bracketed with the youth \\ movement and the labour movement as one \\ of the major emancipatory trends of the era." 163
}

Lejos quedan los tiempos en los que los investigadores y las investigadoras de la historia de la mujer tenían que soportar la mirada irónica de otros historiadores que consideraban el empeño un pasatiempo ideológico y no una disciplina científica. Lamentablemente no fue la historia quién ofreció la garantía de legitimación académica a la historia de la mujer, sino las llamadas ciencias afines. En el caso del movimiento de la mujer de finales del XIX y principios del XX, y del feminismo de los años sesenta y setenta fueron sociólogos y politólogos del área anglosajona y alemana, los primeros que incluyeron al movimiento de la mujer dentro de los grandes procesos de emancipación que se producen en las sociedades europea entre los siglos XXI y XX, y con ello uno de los eslabones del proceso de transición de la modernidad a la posmodernidad. Movimiento de la mujer y feminismo eran analizados a la misma altura que el movimiento proletario, el resurgimiento de los nacionalismos o el movimiento ecológico. ${ }^{164}$

Junto al carácter político y social del movimiento de la mujer existe otro aspecto que llama la atención de los investigadores. El movimiento de la mujer ofrece un marco de expresión y de creación para las mujeres que les ofrece la posibilidad de reflexionar sobre su propia feminidad y de crear sus propias construcciones de ésta. En otras palabras ofrece a las mujeres la posibilidad de considerarse sujetos de su propia reflexión a través de la creación de diferentes modelos de identidad femenina.

En la actualidad esta rama de investigación se encuentra tan consolidada que se puede permitir el lujo de criticar la teoría de los géneros en la construcción de la realidad social y de buscar una tercera vía entre la necesidad de construir una identidad femenina y los intentos de demoler la categoría "mujer". 165

El análisis del movimiento de la mujer alemán de finales del siglo XIX y principios del XX difiere del tratamiento que sus homólogos europeos y americanos en la historiografía sobre el

163 Evans, Richard J.: „Liberalism and Society“ en: Evans, Richard J. (ed.): Society and Politics in Wilbelmine Germany, London, Croom Helm, 1980, p.188.

$164 \quad$ von Beyme, Klaus: Theorie der Politik im 20. Jabrbundert. Von der Moderne zur Postmoderne, Frankfurt am Main, Suhrkamp, 1991.

165 Eifert, C.; Epple, A. (Ed.): Was sind Frauen? Was sind Männer? Gescblecbterkonstruktionen im bistorischen Wandel, Frankfurt, Suhrkamp, 1996; Scheich, Elvira, (ed.): Vermittelte Weiblichkeit. Feministische Wissenschafts- und Gesellschaftstheorie, Hamburg, Edition, 1996. 
tema. No existe ninguna investigadora o investigador, especialmente aquellos que tratan el movimiento de la mujer durante la república de Weimar, que no relacione la interpretación de éste con el nacionalsocialismo. Los intentos de analizar la construcción de modelos de identidad femenina durante los primeros años del siglo XX en Alemania, se definen en función de la concepción que los autores o autoras en cuestión, hacen de este movimiento autoritario, teniendo como punto de partida la teoría del Sonderveg alemán. Esta teoría intenta analizar las relaciones entre el nacionalsocialismo y el pasado alemán, donde se niega o se hace hincapié en las peculiaridades de la historia contemporánea alemana en relación con sus homónimos europeos:

"Esta palabra se encuentra ya en los años veinte, con ella se quería significar, en un sentido positivo, afirmativo, que Alemania, no seguía el camino democrático de la Europa occidental hacia la época moderna, sino su propia vía con su específico idealismo estatal, más de Estado de derecho autoritario que parlamentario. Ahora, después de 1960, con ese término se quiere decir, de modo negativo, su dramática modernización parcial: que Alemania realizó la industrialización sin una revolución burguesa triunfante, es decir bajo elites preindustriales, burocrático-autoritaria. En esta combinación de que las viejas elites se fortalecieron con la modernización reside la explicación para el imperialismo alemán, el desencadenamiento de la primera guerra mundial, el fracaso de la democracia de Weimar y el fascismo."166

Para la historiografía sobre el movimiento de la mujer, y el papel de las mujeres durante el nacionalsocialismo tiene esta concepción de la historia importantes consecuencias metodólogicas e interpretativas. Para aquellos que definen, a grosso modo, al nacionalsocialismo como producto del fracaso de los principios democráticos de las elites burguesas, ven en algunas tendencias de la construcción del discurso sobre lo femenino del movimiento de la mujer, señales tempranas que conducirían más tarde a la aceptación y a la adaptación de la ideología nacionalsocialista. ${ }^{167} \mathrm{El}$ movimiento de la mujer es entendido como una manifestación más del discurso liberal burgués. El análisis del nacionalsocialismo partía en el primer caso de las condiciones políticas y económicas del "fascismo", entendido como instrumento terrorista de la crisis capitalista, y que entra en acción cuando el sistema parlamentario no tiene posibilidades de sobrevivir. Elementos como racismo, antisemitismo o antifeminismo, no se consideran características definidoras del régimen autoritario, sino que son entendidos como elementos ya existentes en la sociedad de Weimar. Para estos autores existe una continuidad entre Weimar y la Alemania de Hitler. Este análisis relativiza la importancia del movimiento de la mujer, de sus logros y del enorme potencial creativo y de expresión que despertó en las mujeres alemanas.

Por otro lado para las autoras y autores que establecen claras líneas divisorias entre Weimar y el nacionalsocialismo, entre liberalismo democrático y movimiento totalitario, la historia del movimiento de la mujer se rompe en 1933 y continúa curiosamente en 1945. Esta tendencia es habitual dentro de algunos sectores del feminismo que a partir de una concepción del nacionalsocialismo como un sistema patriarcal de opresión, rechazan todo tipo de implicación del movimiento de la mujer a la ascensión del nacionalsocialismo.

Sin embargo el proceso es más complicado de lo que parece: es cierto que en las líneas de actuación del movimiento de la mujer liberal-conservador y de las organizaciones confesionales

\footnotetext{
166 Schulin, E.: "El desarrollo de la historia social en la historiografía alemana posterior a 1945", La historia social de España. Actualidad y perspectivas. Actas del I Congreso de la Asociación de Historia Social, Zaragoza, septiembre 1990, Madrid, Siglo XXI, 1991, pp.40.

167 Wittrock, C.: Das Frauenbild in Faschistischen Texten und seine Vorläufer in der bürgerlichen Frauenbewegung der zwanziger Jahre, Dissertation, Frankfurt am Main, 1981.
} 
de mujeres, se encuentra un nacionalismo excesivo 168 y una imagen de la mujer que a veces coincide con los ideales propuestos por el nacionalsocialismo; por otra parte, especialmente en los periodos de entreguerras, encontramos rasgos nacionalistas entre las feministas francesas, tendencias que se encuentran también durante la segunda guerra mundial entre las mujeres de la socialdemocracia alemana, lo que convierte a este nacionalismo no en un elemento que haga diferentes a las dirigentes alemanas, o que predestine su apoyo al nacionalsocialismo. ${ }^{169}$

Para entender mejor este proceso creemos necesario analizar la evolución de las asociaciones de mujeres pertenecientes al movimiento de la mujer durante los primeros años del siglo XX así como el milieu al que pertenecían y los modelos de feminidad que elaboran. Las conclusiones a las que llegan las investigadoras son profundamente polémicas, debido a su alto grado de ideologización proveniente de los círculos feministas, donde, la búsqueda de modelos y la escritura de la propia historia del movimiento conduce en muchos casos a una idealización del pasado del movimiento, especialmente durante los años oscuros de la dictadura nacionalsocialista. ${ }^{170}$

\subsection{Los inicios del movimiento de la mujer alemán (1890-1918)}

El proceso de formación de las asociaciones, grupos y organizaciones de mujeres en la Alemania del siglo XX se remonta a la mitad del siglo XIX. Reconocidas personalidades en los inicios del movimiento de la mujer son Luise Otto-Peters ${ }^{171}$ (1819-1895), Auguste Schmidt (1833-1902) ${ }^{172}$ y Henriette Goldschmidt (1825-1920) ${ }^{173}$. Intimamente unido a los acontecimientos políticos de 1848, el nuevo movimiento de emancipación no levanta la resistencia que se podía suponer de una

168 Marion Kaplan y Marlis Dürkop han llamado la atención en sus investigaciones sobre la existencia de rasgos antisemitas en la organización de mujeres que representaba los intereses del feminismo más moderado. Kaplan, M.: "Schwesterlichkeit auf dem Prüfstand. Feminismus und Antisemitismus in Deutschland, 1904-1938”, Feministische STUdiEN 1984 (n³), pp.128-139; Dürkop, M.: "Erscheinungsformen des Antisemitismus im Bund Deutscher Frauenvereine”, FEMINISTISCHE STUDIEN, 1985 (n¹), pp.140-149.

169 Stoehr, Irene; Aurand, Detel: „Opfer oder Täter“, COURAGE, 1982 (11/12, año 7), pp.43-50.

170 En esta línea transcurren las investigaciones de Irene Stoehr. Stoehr, I.: "Macht ergriffen? Deutsche Frauenbewegung 1933“, Courage, 1983 (n8), pp. 24-32. Polémica Bock-Koonz: Bock, G.:,Literaturbericht: 'Die Frauen und der Nationalsozialismus'. Bemerkungen zu einem Buch von Claudia Koonz“, Geschichte Und GeSELlsChaft, 1989 (año 15), pp.563-579; Koonz, C.: „Das 'zweite' Geschlecht im Dritten Reich“, Feministische STUDIEN, 1986 (n²), pp.14-33.

171 Luise Otto-Peters, fundadora por excelencia del movimiento de la mujer alemán, conocida en su época por su obra como escritora y poeta. Desde su puesto como redactora jefe en una revista que trataba temas femeninos, FRAUENZEITSCHRIFT, lucha por mejora en la naturaleza del sistema de educación femenino, así como el derecho laboral de las mujeres y su participación en la vida política. Boedeker, E.: Die Frau. Gesamtverzeichnis der Aufsätze, Hannover, Editado por Elisabeth Boedeker, 1968. Otto-Peters,: L.: Das erste Vierteljahrbundert des Allgemeinen Deutschen Frauenvereins, Leipzig 1890.

172 Auguste Schmidt, maestra, desde 1862 dirige la escuela privada para hijas en Leipzig. Cofundadora del Allgemeiner Deutscher Franenverein (1865) y del Allgemeiner Deutscher Lehrerinnenverein (1890). Sus objetivos como en el caso de Otto-Peters la mejora de la educación femenina, así como la elección libre por parte de las mujeres de la profesión que estuviera de acuerdo con sus aptitudes. En 1893 y 1894 organiza cursos para mujeres con objeto de su preparación para la entrada en la Universidad.

173 Henriette Goldschmidt, pedagoga, seguidora de las ideas de Fröbel, funda en 1872 un seminario para educadoras de guardería que en 1911 se convierte en la Escuela superior para mujeres en Leipzig. 
sociedad acostumbrada a la no participación de la mujer en la esfera pública. Es realmente en los años sesenta, a raíz de la traducción del libro de John Stuart Mill, Subjection of Women, cuando surge la polémica en torno a los deberes, principios y derechos de la mujer. Es en esta época cuando el término de Blaustrumpf, se utiliza de forma peyorativa contra las mujeres que se implican en el movimiento de la mujer, y que representaba a la solterona sin edad fija, delgada, con gafas, con una extremada afición por la lectura, frígida y con escaso atractivo sexual. ${ }^{174}$ En la realidad se trataba de mujeres bastante enérgicas, en mucho de los casos casadas con un gran potencial intelectual. Las primeras reformas a las que estas mujeres aspiraban se logran paradójicamente gracias al apoyo de los compañeros masculinos. Así por ejemplo, en los estados de Baviera y Prusia la pertenencia de mujeres a organizaciones y asociaciones de tipo político estaba prohibida, lo que hacía todo tipo de reforma dependiente de la benevolencia masculina.

El movimiento de la mujer se desarrolla desde sus inicios en tres direcciones: Frauenbildungsbewegung, movimiento de la mujer que aspiraba a la igualdad en la educación y en el trabajo; Soziale Franenbewegung, movimiento social de la mujer dirigido al trabajo social en círculos de mujeres menos favorecidas en la sociedad y que tenía como principal objetivo la regulación del horario de trabajo de las trabajadoras y su protección laboral. Y por último se encuentra el movimiento de la mujer, de tipo político, conocido también como movimiento de emancipación de la mujer, cuyas aspiraciones estaban dirigidas a la consecución de la igualdad legal y política de la mujer.

La historia del movimiento de la mujer en Alemania puede determinarse cronológicamente en varios períodos.

- Desde 1865 fecha de la fundación del Allgemeiner Deutscher Franenverein (ADV), Asociación general de mujeres alemanas, hasta la reorganización de todas las asociaciones de mujeres existentes en una organización de carácter nacional en 1894, Bund deutscher Fravenvereine (BDF), Federación de asociaciones de mujeres alemanas.

- Un segundo período puede establecerse desde 1894 hasta 1918. Etapa donde las organizaciones de mujeres definen sus objetivos, ejercen labores de asistencia social durante la primera guerra mundial y preparan el camino para la introducción del voto femenino.

- La tercera etapa va desde 1918 a 1933 y se reduce al trabajo político de las organizaciones durante la república de Weimar.

En el programa de la $A D V$ de 1905 se definen los intereses y objetivos del movimiento de la mujer como independientes de todo tipo de influencia política o religiosa. ${ }^{175} \mathrm{El}$ movimiento de la mujer está abierto a las mujeres de todas las clases y de todos los partidos. El movimiento reconoce la diferencia física y psíquica de los géneros y defiende la influencia cultural, Kultureinflu $\beta$, de la mujer como medio de desarrollo personal interior y cambio social. El programa consta de cuatro puntos principales que se refieren a los campos de educación, actividad profesional, matrimonio y familia, vida pública, y estado. En el terreno de la formación la $A D F$ denuncia el estado de la educación para mujeres y exige por parte del estado la creación de escuelas obligatorias de formación, Fortbildungscbulen para las niñas que terminan con la escuela primaria, la reorganización de las escuelas superiores femeninas que haga posible que las mujeres puedan acceder a una educación superior, y la matriculación libre de mujeres en la universidad. Para las mujeres casadas se señala la maternidad y el matrimonio como la profesión por excelencia, y se acepta que la mujer casada

$174 \quad$ Nave-Herz, R.: Die Geschichte der Frauenbewegung in Deutschland, Bonn, Bundeszentrale für politische Bildung, 1993, p. 17.

175 Beckmann, E., Kardel, E.: Quellen zur Geschichte der Frauenbewegung, Frankfurt am Main, Berlin, Bonn, Moritz Diesterweg, p. 28-29 
trabaje sólo en caso de necesidad económica. En todo caso se apoya especialmente el trabajo de las mujeres solteras y se acentúa la importancia de éste para el bien común, dada la influencia positiva de las cualidades femeninas en trabajos que se adecuan con su naturaleza. Familia y matrimonio son considerados como la célula de la salud social. Desde el punto de vista político se considera beneficioso para la comunidad la intervención de la mujer en la vida cultural y política, siempre que ésta tenga la preparación adecuada.

El trabajo de la $A D V$, la organización general de mujeres alemanas se limita en un principio a la reivindicación de una mejora en la calidad de la enseñanza para mujeres y en el derecho de éstas a un puesto digno de trabajo. Otros temas que también ocupaban a las mujeres de la asociación eran la fundación de escuelas industriales y de comercio para mujeres que se preocuparan de la formación de éstas, la protección laboral de la trabajadora, y el permiso de maternidad, la igualdad de oportunidades, el mismo salario para hombres y mujeres y por último el derecho electoral. Junto a ello la organización desarrolla un intenso trabajo de formación entre los grupos de mujeres trabajadoras, en forma de discusiones, seminarios, conferencias sobre temas históricos y literarios. La idea de una mejor formación para las mujeres es el Leitmotiv del movimiento desde su formación. Para las pioneras del movimiento, Bildung, constituye un medio de elevación intelectual y moral, de ahí el carácter intelectual del movimiento. Una vez conseguida la igualdad intelectual se podía reivindicar la igualdad política.

A principios del siglo veinte comienza a aparecer la distinción entre dos tendencias principales entre las organizaciones para mujeres: la rama burguesa o liberal-bürgerlich ${ }^{176}$. Bäumer, una de las principales dirigentes del movimiento de la mujer, señala la diferencia entre "radicales" y "moderadas".177 Para el movimiento de la mujer moderado constituían la educación y el rendimiento en el trabajo el camino para el desarrollo de la personalidad de la mujer, para el descubrimiento de su verdadero ser. Helene Lange (1848-1930) ${ }^{178}$, una de las ideólogas más importantes del movimiento acentúa la importancia del reparto de las esferas de trabajo e influencia entre los dos sexos, así como la diferente responsabilidad de los géneros en la renovación de la ética sexual. Las moderadas, aunque no estaban en contra del voto femenino, consideraban que, antes de la consecución de éste, era necesaria una etapa de preparación donde las mujeres nivelaban sus deficiencias en el terreno intelectual, donde la formación jugaba un papel fundamental. Las radicales por el contrario consideraban este periodo de formación como innecesario y reivindicaban el voto femenino como el primer paso para la emancipación de la mujer.

En segundo lugar se encontraba el movimiento de la mujer ligado a la socialdemocracia y a los grupos de izquierda. La práctica política de ambos movimientos pone de manifiesto la heterogeneidad de los inicios. No obstante los dos movimientos defendían cuatro principios fundamentales: la igualdad de derechos para los dos géneros, la protección de la mujer en aspectos

176 La traducción del adjetivo bürgelich aparece en todos los diccionarios como burgués. Sin embargo, dado que burgués tiene en español connotaciones un tanto negativas, nos decidimos por la traducción movimiento de la mujer liberal. La aparición de los partidos de ideología liberal se remonta en Alemania a 1848, divididos entre los gemäßigte Liberale, liberales moderados defensores del parlamentarismo monárquico y radikale Liberale, liberales radicales, defensores del sistema de gobierno republicano. Esta acepción aparece también para el movimiento de la mujer.

177 Bäumer, G.: Im Licht der Erinnerung, Tübingen, Rainer Wunderlich Verlag, 1953, p.155.

178 Helene Lange, maestra, seguidora de las ideas de Otto-Peters y Schmidt se convierte a la muerte de éstas en la figura más representativa del movimiento de la mujer. En 1893 pasa a formar parte del consejo del Allgemeiner Deutscher Frauenverein en el que permanecería hasta 19 y en el mismo año funda la revista DIE FRAU, un año más tarde órgano de prensa de la Federación de organizaciones de mujeres alemanas, Bund deutscher Frannereine, BDF. Partidaria de la introducción de año de servicio social femenino. Desde 1908 miembro del partido democrático alemán, Deutsche Demokratische Partei, DDP. Lange, H.: Lebenserinnerungen, Berlin, Herbig, 1930. 
que "atacaban" a su personalidad: cuestión sexual, control de la natalidad, el aborto (a favor o en contra), el principio social (en este terreno las posturas difieren con el tiempo), el trabajo de la mujer, y por último la formulación teórica de un concepto de emancipación para las mujeres, basado en la diferencia de éstas respecto al género masculino.

Los principios de emancipación provenían a grosso modo de las doctrinas socialistas o liberales. Con la ilustración se había abierto un campo libre a las teorías de emancipación del individuo que también afectaban al género femenino. ${ }^{179}$

Nuestro interés se centra fundamentalmente en los modelos de feminidad elaborados por el movimiento moderado y confesional de la mujer a partir de este concepto de emancipación. Lo que en un principio eran grupos creados a raíz de iniciativas personal de mujeres pertenecientes a la clase media, pertenecientes al llamado Bildungsbïrgertum, la burguesía cultivada, entendido, como estamento y no como clase social dada su heterogeneidad interna. ${ }^{180} \mathrm{El}$ movimiento liberal de la mujer nace en una estructura social conservadora y autoritaria y se diferencia en sus inicios del movimiento de la mujer anglosajón. El feminismo anglosajón parte de las teorías de John Stuart Mill en la que el feminismo se define como la teoría de los mismo derechos para las mujeres, es igual a la igualdad de los géneros, se trata de un feminismo humanista, cuyos objetivos se dirigen a la igualdad política, social, económica del sexo femenino.

El movimiento de la mujer alemán se desvía de la argumentación del derecho natural, y aunque reivindica la igualdad de los géneros, parte de una teoría dualista de éstos. El hombre y la mujer son por naturaleza diferentes pero legalmente iguale. En este momento el movimiento liberal de la mujer, asume una tradición discursiva que ve a la mujer como la representante de la naturaleza, del pacifismo y la garante de la armonía entre los dos géneros, tradición discursiva de la que curiosamente se nutrió una gran parte del feminismo alemán de los años setenta. Y en función de la diferente naturaleza del sexo femenino se deduce la conclusión moral de la influencia bienhechora de éste para la sociedad. En este nuevo proyecto moral se incluye un concepto de renovación general de la sociedad en la que vive la mujer. El programa no tiene a la mujer como sujeto, como en el caso de las sufragistas anglosajonas, sino que pretende utilizar las cualidades femeninas en el cambio social.

La evolución del ala socialdemócrata del movimiento de la mujer toma un giro diferente: mientras que el movimiento liberal consigue establecerse en la sociedad, dado su carácter neutral en cuestiones políticas, las organizaciones creadas en el seno del partido socialdemócrata a finales de los años 80 y que entre 1875-1890 sufren los efectos de la lucha contra la socialdemocracia y son disueltas por la policía. En Baviera, por ejemplo, existían entre 1875 y 1890 diez organizaciones de mujeres trabajadoras y ninguna de ellas sobrevivió a la prohibición. A ello hay que añadir la disolución de los principios de emancipación de las mujeres de la socialdemocracia en la práctica política: a partir de 1892 el partido socialdemócrata abre sus sindicatos a las mujeres, con lo que "teóricamente" la igualdad parece haber sido conseguida. En 191236.640 mujeres se encuentran integradas en las estructuras del partido sin formar organizaciones específicas de mujeres.181 Sin embargo la lucha de las "feministas proletarias" se extiende a las propias filas del partido donde la

179 Theodor Gottlieb von Hippel formula a finales del siglo XVIII su critica contra los prejuicios contra el género femenino. Para Hippel igualdad política corría paralela a formación y educación. El acceso de las mujeres a la igualdad se convertía en un problema moral, donde los hombres tenían la última palabra.

180 Haupt, H.G.: „Tendencias de la historia social alemana cinco años después de la reunificación“, Ayer, 18, 1995, pp. 35-37.

181 Kraft, S. (Cod.): Frauenleben in Bayern: Vor der Jabrbundertwende bis zur Trümmerzeit, München, Bayerische Landeszentrale für politische Bildungsarbeit, 1993, p.55. 
revolución del proletariado conlleva la disolución de todo tipo de desigualdad de clase y de género, y las reivindicaciones feministas eran consideradas como de segunda clase. ${ }^{182}$

Dentro del movimiento de la mujer liberal puede señalarse una diferenciación de las organizaciones en función de sus intereses y campos de acción. En primer lugar existen organizaciones de mujeres trabajadoras que funcionan como sindicatos específicos profesionales aunque sin el contenido político de sus homónimos masculinos, organizaciones de beneficencia, y finalmente grupos de mujeres confesionales y asociaciones dedicadas al trabajo social. ${ }^{183}$

Entre los primeros grupos que se organizan se encuentran las maestras de la escuela primaria que se agrupan en torno a la Asociación General de Maestras Alemanas ADLV (Allgemeiner Deutscher Lehrerinnen-Verband) fundada en 1890 por Helene Lange y Auguste Schmidt que defienden los derechos de las maestras de la primera enseñanza. Esta organización llega a tener en 1917 casi 40.000 afiliadas.

Las empleadas de pequeñas y grandes superficies se organizan en 1919 en $V W A$ (Verband der weiblichen Handels- und Büroangestellten). Sus objetivos se acercan a los de los sindicatos masculinos, aunque sin el matiz político de éstos. Entre las reivindicaciones más importantes se exige el fin de la jornada laboral a las ocho de la tarde, la prohibición del trabajo en domingo, la regulación de las horas de trabajo en las grandes superficies, pensiones estatales para las empleadas y la formación profesional obligatoria de éstas. La última gran organización la formaban las trabajadoras de correos y telégrafos (Reichsverband der Post- und Telegraphenbeamtinnen), fundada en 1912 con un número de 7.474 miembros.

Las organizaciones con fines reformadores o de beneficencia estaban divididas entre grupos de mujeres que trabajaban voluntariamente en diferentes campos de la beneficencia, especialmente en el cuidado de los enfermos. Estos grupos son conocidos como organizaciones de mujeres patrióticas, Vaterländische Frauenvereine, fundadas en 1867. A ellas se unen las organizaciones confesionales de mujeres que se dedicaban profesionalmente al cuidado de necesitados, niños y huérfanos. Al lado de éstas comienzan a surgir grupos de mujeres no confesionales que dedican sus esfuerzos al cuidado profesional y no voluntario de enfermos, al trabajo social, etc. Entre ellos cabe destacar los grupos de mujeres para la ayuda social, Mädchen- und Franengruppen für die soziale Hilfstätigkeit, fundados en 1893 por Minna Cauer (1842-1922) ${ }^{184}$ y Jeanette Schwenn.

Otro tipo de organizaciones de mujeres se dedican a los problemas de la moralidad pública, la mayoría de ellas son organizaciones de tipo confesional. En 1885 en el seno de la iglesia protestante el pastor Ludwig Weber funda un grupo de mujeres para la lucha contra la reglamentación estatal de la prostitución. En la misma línea trabaja el grupo de mujeres fundado por Hanna Bieber-Böhm en 1889, Jugendscbutr. La prostitución es para ambas organizaciones un delito que se tiene que castigar con la dureza. La corriente abolicionista anglosajona de Josephin

182 Losseff-Tillmann, G.: Frauenemanzipation und Gewerkschaften (1800-1975), Diss., Bochum 1975, p. 81. En este trabajo se señala el alto grado de antifeminismo entre los compañeros de partido, que creían amenazadas, su posición de poder y superioridad respecto a las mujeres trabajadoras.

183 Este proceso de radicalización ha sido interpretado por los especialistas de diferentes maneras. Por una parte Evans y Greven-Aschoff se alejan de las teorías de los sociólogos e historiadores de la Escuela de Bielefeld que interpretan el periodo 1871-1933 como una preparación para la dictadura. Evans y Greven-Aschoff señalan por el contrario el carácter „revolucionario“ y subversivo del movimiento de la mujer como una prueba más de la multiplicidad de éste periodo de la historia alemana. Matices sobre el carácter subversivo.

184 Minna Cauer, al igual que Otto-Peters, Schmidt y Lange maestra. Lucha sin embargo por la consecución del voto femenino. Pertenece al ala radical del movimiento de la mujer. En 1888 funda la organización Frauenwobly a partir de 1895 edita la revista FRAUENBEWEGUNG. 
Buttler está representada en Alemania por Gertrud Guillaume-Schak y Lyda Gustava Heymann (1868-1943). ${ }^{185}$

Existen también junto a las asociaciones con fines específicos, organizaciones de tipo general que acumulaban objetivos sociales, reformadores y emancipadores sin centrarse en un determinado grupo o clase de mujeres. Estas intentan aglutinar al movimiento de la mujer en una organización general para poder luchar más efectivamente por los derechos femeninos. La más importante de éstas es el $A D F$ (Allgemeiner Deutscher Franenverein) fundada en 1865 y dirigida por Auguste Schmidt hasta 1902, fecha en la que Helene Lange accede a la dirección de ésta.

El surgimiento de numerosos grupos de mujeres hace necesaria la coordinación de los esfuerzos de las organizaciones, lo que lleva en 1894 a la fundación de la Federación de asociaciones de mujeres alemanas BDF (Bund Deutscher Franenvereine). Bajo su tutela se organizan unas 77 asociaciones de mujeres confesionales y llega a tener cerca de un millón de miembros.

La segunda etapa del movimiento de la mujer se caracteriza fundamentalmente por la controversia respecto a la "nueva ética", que tenía como objetivo una nueva interpretación de la sexualidad femenina, y la actitud del movimiento ante los preparativos de la primera guerra mundial. Esta polémica provoca la división del movimimiento entre "burguesas" y "radicales" y el abandono de la organización de la Federación de mujeres protestantes alemanas DEF (Deutsch-evangelischer Frauenbund), con lo que se puede hablar de la división definitiva entre movimiento laico y confesional de la mujer.

El concepto de "nueva ética" es formulado por primera vez por Helene Stöcker, ${ }^{186}$ que plantea el derecho al matrimonio "libre", la despenalización de la interrupción del embarazo, así como el derecho de la mujer a gozar de su propia sexualidad y a decidir sobre su cuerpo. La discusión entre los dos grupos dentro del movimiento de la mujer alcanza sus cotas más altas durante la república de Weimar.

Antes de 1918, existían ya diferencias de actuación entre los dos grupos respecto a la concesión del voto femenino. Mientras que el grupo radical del movimiento de la mujer se muestra partidario de éste, Helene Lange y Gertrud Bäumer defienden una postura conservadora. No obstante el grupo de las radicales consigue que el BDF en 1917 firme una resolución donde se declara oficialmente la reivindicación de la organización del voto femenino. ${ }^{187}$

El canal de contacto de la mayoría de las organizaciones lo constituían los órganos de prensa publicados por éstas. ${ }^{188}$ Su importancia como elemento de educación y de formación ideológica no ha de ser minusvalorada. Para muchas de las mujeres trabajadoras que no vivían en las grandes ciudades y donde no existían grupos locales eran las únicas publicaciones existentes donde las mujeres veían reflejados sus problemas y sus expectativas. Gertrud Bäumer, una de las principales dirigentes del movimiento moderado de la mujer, comenta en sus años de maestra en la pequeña ciudad de Magdeburg la importancia que para ella tuvo una de estas publicaciones:

185 Lida Gustava Heymann, junto con Anita Augspurg (1857-1943) defensora del derecho al voto femenino. Ambas inician las conferencia de mujeres para la paz que se celebra en Haag en 1915, y editan desde 1919 hasta 1933 la revista feminista y pacifista, DIE FRAU IM STAAT. En 1933 abandonan Alemania, fijando su residencia en Suiza. Krafft, Sybille (Cord.): Franenleben in Bayern von der Jahrhundertwende bis zur Trümmerzeit, München, Bayerische Landeszentrale für politische Bildungsarbeit, 1993, pp.114-115.

186 Helene Stöcker (1869-1943), reformadora sexual y pacifista. Funda la asociación Bund für Mutterschutz. und Sexualreform en 1905.

187 Nave-Herz, R.: op.cit., p.45.

188 En 1921 se contabilizan 51 publicaciones de las organizaciones de mujeres, dependientes de la organización general: Deutscher Frauenbund De ellas unas 22 aparece una vez al mes, 8 son publicados dos veces al mes, 4 una vez a la semana, y el resto entre y una vez cada dos veces. 
"Y en este momento tuvo lugar realmente el primer contacto con el movimiento de la mujer. El lugar de encuentro tenía lugar el la revista, DIE LEHRERIN. En Magdeburg no había ninguna organización de mujeres ni tampoco ninguna asociación profesional que pertenecieran al movimiento de la mujer. (...) En la revista encontré, respuestas a mis preguntas y soluciones a mis dificultades, que otras mujeres, a consecuencia de su sexo también tenían. Y esto ocurría de una forma cálida, entusiástica y sin complicaciones motivada secretamente por la conciencia de saber estar ante una tarea extremamente importante y ante el comienzo de una vocación."189

El contacto con las aspiraciones del movimiento de la mujer es una de las causas que condujeron a Bäumer a completar su formación académica con un estudio en la Universidad. En el caso de otras mujeres, los pequeños órganos de prensa, estimulaban el deseo de saber de muchas mujeres que se había decido por una vida de estudio y de trabajo y contribuían a expandir sus horizontes, sus ambiciones y sobre todo ayudaron a crear una conciencia de pertenencia de grupo, quizá de clase, que se mantiene hasta el final de la república de Weimar. Junto a ello y no menos importante cabe destacar el carácter de foro de expresión que poco a poco van tomando estas publicaciones, para un determinado grupo de mujeres: maestras, historiadoras, germanistas, juristas, trabajadoras sociales, escritoras, encuentran un medio donde pueden escribir libremente sobre sus investigaciones, sus proyectos, etc. Esta agrupación de intereses pone de manifiesto los límites que el movimiento de la mujer encontraba para encontrar reconocimiento, por otra parte, de la clase intelectual masculina. Esta consciente separación de las esferas de actuación, facilitó en un principio el reforzamiento de la conciencia femenina respecto a sus capacidades y posibilitó la liberación del potencial intelectual de las mujeres. Sin embargo más tarde en Weimar, esta potencialidad de actuación femenina nacido al calor del la llamada ambiente de la "reserva", mostrará sus dificultades a la hora de articular los principios del movimiento de la mujer con la nueva realidad política.

Teóricamente Weimar significa el triunfo de las aspiraciones del movimiento de la mujer, la consecución del voto femenino conlleva la participación de la mujer en la vida política y por consiguiente la defensa de sus intereses en el parlamento. La nueva libertad viene, sin embargo acompañada de contradicciones. El movimiento liberal moderado tiene que aceptar con Weimar la disolución de la monarquía y el nacimiento de la república. En segundo lugar el carácter neutral del movimiento liberal no permite dentro de las organizaciones la adscripción a una u otra tendencia o partido político. La toma de decisiones se hace siempre buscando la independencia del movimiento respecto a las tendencias y partidos políticos. La política de neutralidad acompañará siempre sus actuaciones, siempre que los temas no tengan que ver con asuntos que tuvieran que ver con los intereses de la mujer.

No obstante casi todas las mujeres que participan en la vida política y que ocupan un escaño parlamentario, sin excepción, ocupan cargos de responsabilidad en las asociaciones de mujeres. La aspiración de neutralidad del movimiento liberal de la mujer será una tendencia constante en Weimar que culminará con la indecisión con que el nacionalsocialismo es aceptado entre los grupos de mujeres.

En tercer lugar el movimiento de la mujer se tiene que enfrentar a los efectos de la industrialización de la vida de las mujeres: por una parte el crecimiento de la pobreza, miseria y marginación entre la clase trabajadora que traen consigo la disolución de la entidad familiar. La situación de las mujeres trabajadoras se enfoca desde los efectos que ésta produce en la familia: desatención de los hijos, desintegración de la unidad familiar, pérdida de los valores de la feminidad. Como contrapartida el movimiento de la mujer no ofrece una visión política de 
"liberación" como ocurrían en los partidos de izquierda, sino que defendían valores propios de las clases medias. La maternidad espiritual, como forma de "encuentro" personal sirve de poco a las trabajadoras de las fábricas.

Por otra parte la nueva generación de mujeres que conquista puestos hasta entonces vedados a las mujeres, se desvían de los objetivos de las viejas luchadoras del movimiento: para la nueva generación son las reivindicaciones de igualdad agua pasada. La nueva generación quiere decidir sobre su cuerpo, empieza a descubrir activamente su sexualidad y los placeres del consumo. Planificación familiar, divorcio, aborto, consultas sexuales, anticonceptivos y amor libre es el lenguaje que conocen. El movimiento de la mujer intenta en esta época sin éxito dar respuesta a las preguntas de la nueva época.

\subsection{Del asociacionismo a la radicalización de posturas}

(1919-1933)

1918 significa también el comienzo del movimiento organizado de la mujer, Franenbewegung. ${ }^{190}$ Ante la multiplicidad de asociaciones, grupúsculos y grupos de mujeres comienza a verse necesaria la integración de éstas en organizaciones generales o organizaciones madres, en función de sus objetivos, ideología y origen. Por otra, aunque en líneas generales el movimiento de la mujer en general proclama su imparcialidad política como ya hemos señalado antes, se observa la lenta adscripción de las diferentes organizaciones a los partidos del espectro político de Weimar.

A pesar de los intentos de Greven-Aschoff de negar el carácter político de las diferentes organizaciones, se observan desde el principio claras tendencias que se cristalizarán en 1918. A partir de 1919 el número de organizaciones de mujeres se multiplica, y se observa una clara división política e ideológica entre ellas. Por ello hemos creído conveniente hacer una división entre los diferentes grupos en función de sus intereses y línea ideológica.

En Weimar el espectro de organizaciones de mujeres aparece claramente configurado en tres grupos de organizaciones pertenecientes al movimiento de la mujer: organizaciones moderadas con tendencias liberal-conservadoras, los grupos de mujeres confesionales, ligados a los partidos de centro y nacionales, y las organizaciones de carácter radical con inclinaciones a la izquierda. Nuestro estudio se centra fundamentalmente en los dos primeros grupos ya que en los dos casos se observa una continuidad de actuación (en forma de publicaciones) durante el nacionalsocialismo.

El asociacionismo femenino durante Weimar es un factor a tener en cuenta en el espectro político de la República. En 1932 existían en Alemania 230 organizaciones de mujeres. La mayoría de ellas centraban sus aspiraciones en una igualdad de la mujer dentro de los límites del orden liberal-conservador. La idea central de este movimiento burgués era "la participación de la mujer en una tarea conjunta cultural, que ella, como personalidad libre, ejercitaba para la comunidad del

190 Greven-Aschoff, Barbara: Die bürgerliche Frauenbewegung in Deutschland 1894-1933,Göttingen, Vandenhoeck \& Ruprecht, 1981, p.71. 
pueblo". 191 Se trata de un movimiento urbano que centra en torno a las ciudades de Berlin, Hamburg y München. ${ }^{192}$

Se pueden diferenciar dos grupos en función de su carácter más o menos conservador; organizaciones que se agrupaban alrededor de las dos confesiones religiosas y de los partidos conservadores: el partido de centro (Zentrumspartei), el partido popular bávaro (Bayerische Volkspartei), el partido popular nacional alemán (Deutsch-Nationale Volkspartei) y el partido popular alemán (Deutsche Volkspartei). Sus representantes se agrupaban en el Königin-Luise-Bund (Federación de la Reina Luisa). No defendían ningún tipo de reivindicación feminista, ni consideraban que la mujer estuviera discriminada en la sociedad. Su ámbito de actuación se limitaba a la organización de tres espacios fundamentales: la iglesia, la cocina y el cuidado de los hijos. Las organizaciones confesionales más importantes eran el DEF (1899), Deutsch-Evangelischer Frauenbund (Federación de mujeres protestantes alemanas) y el KDF (1903), Katholischer Deutscher Frauenbund (Federación de mujeres alemanas católicas). Ambas organizaciones se encontraban bajo la dirección de sus respectivas iglesias. Desde una fundamentación teológica defendían una imagen tradicional de la mujer contra la política de reformas, y las ambiciones de igualdad de las mujeres burguesas. Su ámbito de influencia se extendía a los votantes del partido católico de centro y del partido popular alemán, y sobre todo tenían gran influencia sobre ciertos grupos de mujeres trabajadoras. La cúpula de dirigentes del movimiento moderado pertenecía al Deutsche Demokeratische Partei, que integraba un gran número de la burguesía cultivada alemana.

\subsection{El feminismo conservador-liberal}

2.4.1. La Federación de asociaciones de mujeres alemanas (Bund Deutscher Frauenvereine). Organización y objetivos

A finales de siglo el número de organizaciones, grupos e iniciativas personales ha crecido de tal manera que motiva a imitación de los Estados Unidos, la fundación de una supraorganización que coordine nacionalmente los esfuerzos de las organizaciones existentes. Por otro lado existían también organizaciones no convencionales de amas de casa burguesas y pequeño burguesas, así como representantes femeninas de determinadas profesiones: funcionarias, empleadas y académicas. Este grupo de mujeres se organizaba en un grupo general que llevaba por nombre: la Federación de asociaciones de mujeres alemanas BDF (Bund Deutscher Frauenvereine), fundada en 1894 e integrada según sus detractores por "solteronas, viudas, judías, mujeres estériles o sin intención de tener hijos". ${ }^{193}$ La fundación del BDF esta unida al deseo de crear una organización madre que coordinara los esfuerzos y objetivos de los diferentes grupos de mujeres. Idea exportada de los Estados Unidos, donde el National Council of Women, había creado ejemplo. Los grupos que participan en la fundación son el Lette-Verein, el ADF, el ADLV, Frauenwohl, el Kaufmännischegewerblicher Hilfsverein für weibliche Angestellte y el Jugendschut:i ${ }^{194}$ La organización se caracterizaba por su

191 Wittrock, C.: Das Frauenbild in faschistischen Texten und seine Vorlänfer in der bürgerlichen Franenbewegung der zwanziger Jahre, Frankfurt am Main, Dissertation, 1981, p.35.

192 El círculo de la Federación se centra en Berlin. Anita Augspurg y Lida Gustava Heymann viven en München.

193 Weber, M.: Ein Lebensbild, München-Zürich, Piper, 1989 (1ªed. 1926), pp.434ss. Recogido en: Sáez Arance, A.: „El honor del burgués. A propósito de la historia social del duelo en Alemania", HiSTORIA CONTEMPORÁNEA, 1991 (nº 6), p.251.

194 Greven-Aschoff, Barbara: op.cit., p.88. 
heterogeneidad. Por una parte se encontraban los grupos de amas casas conocidos por su posturas conservadoras, las mujeres radicales que reivindicaban el derecho al aborto y la abolición de la penalización de la prostitución y el grupo de mujeres intelectuales dispuestas a establecer compromisos en todos los sentidos, con la organización, la política y la sociedad. Aunque la organización no tiene un carácter confesional pertenecían a ella también la organización de mujeres judías, Bund jüdischer Frauen (BJF), y hasta 1919 la organización de mujeres protestantes. Los conflictos que se producen la diversidad de los grupos, así como el principio de parcialidad política conducen a la ambigüedad con la que la Federación acogió los principios del nacionalsocialismo así como la contradicción en sus actuaciones.

La Federación de asociaciones de mujeres alemanas, $B D F$ no era como objetaban sus críticos un nido de viudas, solteronas o mujeres estériles, sino que gozaba de gran aceptación entre las mujeres. Su falta de radicalidad le posibilitada acercarse y conectar con amplios sectores de la población. De hecho aglutinaba asociaciones de mujeres judías, mujeres trabajadoras, profesoras, maestras, trabajadoras del sector textil etc. Las mujeres de la social democracia no son aceptadas, así como las mujeres católicas que no hicieron nunca un intento de pertenecer a la asociación.

Siete años después de su fundación la Federación cuenta con 137 asociaciones, y 70.000 miembros. ${ }^{195}$ En 1928 el BDF la cifra ha subido a un millón de miembros en total y algunas de sus dirigentes ocupaban escaños en el Reichstag. ${ }^{196}$

La estructura del BDF estaba organizada desde el principio asambleario. Aunque en la práctica las decisiones más importantes se tomaban en el consejo directivo y el consejo directivo general. El primero estaba formado por miembros elegidos en pleno asambleario, normalmente se trataba de las dirigentes de las organizaciones que formaban parte de la asamblea general. Entre 1919 y 1921 forman parte del congreso mujeres pertenecientes al grupo moderado del movimiento y ligadas políticamente al partido liberal $D D P$, algunas de las integrantes pertenecen a la comunidad judía.

A principios de los años treinta la situación ha cambiado. El sector conservador-nacionalista del $B D F$ ocupa la mayoría de los puestos del consejo. El segundo estaba formado por los miembros del primero y el resto de las dirigentes de las organizaciones de mujeres que integraban el BDF. El órgano de prensa del $B D F$, dependía estaba ligado a los integrantes del consejo ejecutivo, aunque con los años estará unido a la personalidad de Gertrud Bäumer, confundadora de éste. Esta dependencia garantizará que la publicación no caiga en manos de los sectores conservadores y nacionales de la organización. El consejo directivo general coordinaba las comisiones de trabajo del BDF. La Asamblea general, un pequeño parlamento de mujeres, constituía el foro donde se reunían los miembros de las organizaciones y se discutían las propuestas preparadas por las comisiones de trabajo.

195 Lange, H.; Bäumer, G. (eds.): Handbuch der Frauenbewegung. Die Geschichte der Franenbewegung in de Kulturländern, Berlin, W. Moeser Buchhandlung 1901, p.147.

196 Arendt, H.J.: „Die Gleichschaltung der bürgerlichen Frauenorganisationen in Deutschland 19331934", ZEITSCHRIFT FÜR GESCHICHTSWISSENSCHAFT, 1979 (año 27), p.619. 
Estructura y organización del BDF

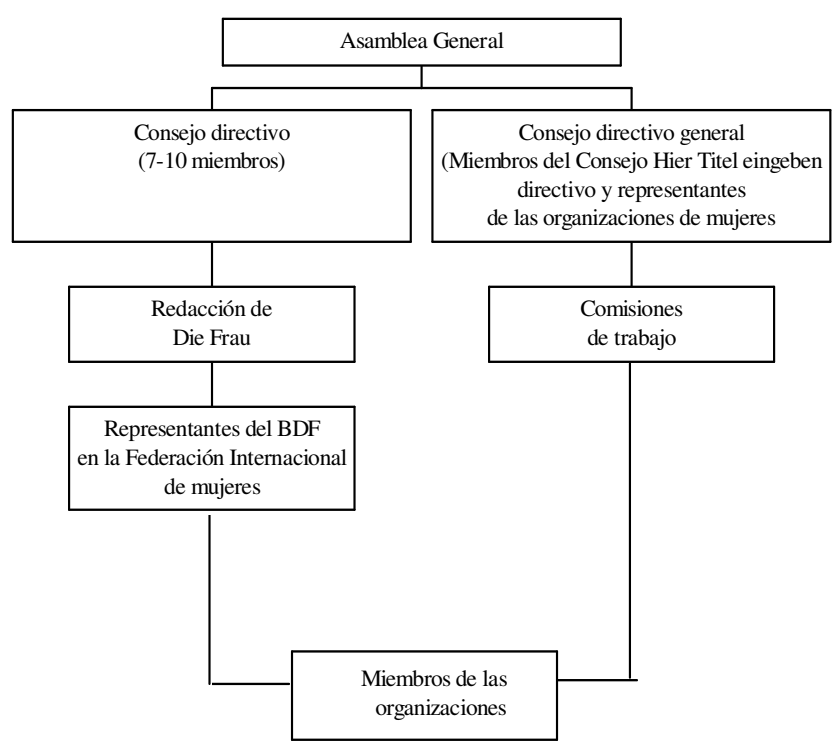

A parte de la labor de coordinación entre las diferentes organizaciones que integraban la Federación, esta desarrolló un programa de actuación propio. Los campos de actuación de la Federación eran los siguientes: la creación de jardines de infancia y guarderías en todas las escuelas primarias, la introducción de clases de hogar en los planes estudios, la protección de las trabajadoras, el cambio del código civil, así como la prohibición de la prostitución, junto a ello se reivindicaba el derecho de las mujeres a ejercer la profesión médica y a poder enseñar en las escuelas superiores. Por último se exigía la profesionalización del trabajo social femenino.197

El objetivo principal de la Federación era desarrollar las estructuras necesarias para que la mujer pudiera desarrollar su personalidad y poder participar posteriormente en la "vida cultural", Kulturleben:

"El movimiento de la mujer quiere que la mujer desarrollo todas su fuerzas y quiere asegurar la plena participación de esta en la vida cultural.“"198

El Bund Deutscher Franenvereine reivindicaba teóricamente la igualdad de la mujer, la igualdad de salarios para las mujeres trabajadoras, el derecho a una educación cívica y a una formación intelectual. No siempre, sin embargo, correspondían estas reivindicaciones con la realidad: su postura respecto a las primeras campañas en 1931 contra el empleo de la mujer casada trabajadora, Doppelverdiener, fue de gran ambigüedad. Defendían la igualdad de oportunidades pero "aceptaban que la fuerza física de las mujeres, su función biológica y sus inclinaciones naturales determinaban su desventaja respecto a los hombres" ${ }^{199}$ En cierto modo el trabajo femenino resultaba superfluo y

197 Lange, H.; Bäumer, G. (eds..): op.cit., p.134.

198 Weber, M.: Frauenfragen und Frauengedanken. Gesammelte Aufsätæe, Tübingen, Paul Siebeck, 1919, p.137.

199 Stephenson, J.: Women in Nazi Society, London, Croom Helm, 1975, p.25. 
en tiempos de crisis compartían la idea general de que las mujeres debían sacrificarse por el bien de la comunidad. En el fondo lo femenino seguía siendo definido por la tarea de ser madre:

"El movimiento de la mujer debe ser entendido como un movimiento hacia la maternidad. Para que el movimiento de la mujer se convierta en un movimiento hacia la maternidad, no basta sólo con ser madre. Esta tiene que ser purificada para convertirse en una maternidad espiritual que no se realiza únicamente en el cuidado de los hijos sino en los Ministerios y en los Parlamentos." 200

Algunos autores explican esta ambigüedad ideológica sobre las funciones de lo femenino debido al estrecho parentesco entre las organizaciones de mujeres burguesas y sus partidos políticos paralelos:

"Las organizaciones de mujeres burguesas eran en gran medida las sostenedoras, parcialmente las iniciadoras de la política que la burguesía imperialista alemana de la República de Weimar tenía sobre las mujeres. La función principal que tenían las organizaciones de mujeres burguesas era, por una parte influir a las mujeres de otras clases y grupos sociales en los valores e ideas burguesas, por otra, integrarlas en el sistema político que los grupos de poder representaban."201

La Federación era la principal organización del movimiento de la mujer en Alemania. Ideológicamente se identificaba con los partidos demócratas liberales, un gran número de las mujeres que pertenecían al BDF representaban en el parlamento al DDP. Así por ejemplo, Gertrud Bäumer fue diputada de éste y consejera para asuntos culturales en el Ministerio del Interior durante los años 1919 y 1933. El resto de las mujeres pertenecientes a la junta directiva de la Federación eran miembros de algunos de los partidos de tendencia liberal conservadora de la escena política de Weimar. ${ }^{202}$

Entre las asociaciones que dependían del BDF cabe destacar por su importancia la Comunidad de trabajo de las asociaciones profesionales alemanas, la Arbeitsgemeinschaft Deutscher Frauenberufsverbände (1924), y la Federación de mujeres académicas, el Deutscher Akademikerinnenbund (1926). ${ }^{203}$

200 von Zahn-Harnack, A.: Die Frauenbewegung, Berlin, 1928, p.78.

201 Arendt, H.J.: „Die bürgerlichen Frauenorganisationen in der Weimarer Republik. Ein Überblick", JAHRBUCH FÜR GESCHICHTE, 1989 (año 38), p.168.

202 Miembros de la Junta directiva 1919-1921 pertenecientes a partidos políticos: Marianne Weber (DDP), Gertrud Bäumer (DDP), Marie Baum (DDP), Elisabeth Altmann-Gottheiner (DDP), Luise Kiesselbach (DDP), Marie-Elisabeth Lüders (DDP), Emma Ender (DVP).

203 La Federación de mujeres académicas fue fundada en Berlin por M. E. Lüders. Agrupaba a filólogas, médicas, juristas, profesoras de universidad, estudiantes, y economistas. En 1933 se unen estudiantes católicas, dentistas, ingenieras, químicas y teólogas protestantes. Junto a una labor de investigación, defiende el derecho de las mujeres casadas a seguir ejerciendo su profesión, ofrece ayuda a estudiantes con becas, fundación de residencias. Mantienen contactos internacionales con el IFUW. En 1927 la organización cuenta con 3815 miembros. Con la llegada del nacionalsocialismo la organización entra a formar parte de la organización nacionalsocialista de mujeres. El número se reduce a 200 en 1934, y posteriormente 40 con la posterior retirada del IFUW. Una de las mujeres más importantes que trabajan en la organización como miembro del consejo es Agnes von Zahn-Harnack. Anders, Marga / Reicke, Ilse (Eds.): Agnes v. Zahn-Harnack. Schriften und Reden 1914 bis 1950, Tübingen, Hopfer Verlag, 1964, pp.1-8. 
En cuestiones de política exterior el BDF se declara en un principio pacifista. Sin embargo durante la primera guerra mundial se apoyan los intereses alemanes y moviliza, junto con las mujeres de la socialdemocracia „un segundo frente“, el de las mujeres.

El pensamiento de igualdad para todos los individuos, y el reconocimiento de la igualdad entre los dos sexos se reducían a una constelación teórica y abstracta que encontraba grandes dificultades en la práctica. La Federación ya había expresado su "lealtad" en 1914 al apoyar la entrada de Alemania en la guerra. ${ }^{204} \mathrm{El}$ caso no es único en la historia europea, como señala Françoise Thébaud las feministas francesas participan igualmente en esa fiebre de servicio y suspenden sus reivindicaciones. ${ }^{205}$ Unicamente en 1932, durante las conferencias que sobre desarme tienen lugar en Ginebra se muestra partidario de una política de desarme total.

La creación del servicio femenino nacional, Nationaler Frauendienst (NFD) supone la unión, momentánea de las fuerzas del movimiento moderado de la mujer y las mujeres de la socialdemocracia para organizar a las mujeres alemanas para apoyar a los soldados que se encontraban en el frente:

"Ya antes de la declaración del estado de sitio tuvieron lugar una serie de conversaciones, y antes de la declaración de guerra el plan se encontraba listo en líneas generales y había sido repartido por toda Alemania. Éste fue organizado por las mujeres integradas en el $B D F$ y recurrió a todas las fuerzas disponibles por encima de cualquier ideología y diferencias personales con la voluntad conjunta de hacer todo lo que estuviera en sus manos para aliviar el innumerable sacrificio que una guerra en todo caso significaba (para Alemania), y apelaba a todas las mujeres en su deber nacional que está unidad creaba. Y así el recién surgido servicio nacional tenía a su disposición a las preparadas fuerzas de las organizaciones confesionales, de bienestar y asistencia social, incluidas las asociaciones profesionales de trabajadoras. Esta unidad se mantuvo hasta el final de la guerra." 206

Para organizar el trabajo se crearon 23 comisiones, en cada uno dos mujeres a la cabeza, una perteneciente a los partidos "burgueses", la otra a la socialdemocracia. Una de las primeras tareas del NFD es, colaboración con la comisión para pobres de los ayuntamientos, la elaboración de un sistema de ayudas para aquellas familias en las que el marido había sido llamado al frente y todo tipo de financiación económica había desaparecido. Junto a ello se crean puestos de trabajo en el ramo de la confección, en los llamados Strickstuben donde las mujeres tejían todo tipo de prendas de vestir para los soldados que se encontraban en el frente. 207

Durante la segunda mitad de la guerra se crean los llamados Franenreferate que tenían tarea la movilización de la mano de obra femenina para las fábricas de munición.

"La primera guerra mundial, aunque con certeza todavía no podía considerarse como guerra total, influyó en gran medida en la vida del pueblo en su totalidad, especialmente en el año 1916, fecha en la que un gran número de mujeres fueron

204 Jaschke, H.G.: "Zur politischen Orientierung von Frauen und Frauenverbänden in der Weimarer Republik", op.cit., p.151.

205 Thébaud, Françoise: „La nacionalización de las mujeres. La primera guerra mundial“, en: Thébaud, Françoise: Historia de las mujeres. El siglo XX, Madrid, Taurus, 1993, p. 36.

206 BAK, NL. 151, Die deutsche Frauenbewegung im Kriege.

207 Anders, M.; Reicke, I.: Agnes v. Zahn-Harnack. Schriften und Reden 1914-1950, op. cit., p. 12 
llamadas a integrarse en la producción de munición. A propuesta de la Federación de organizaciones de mujeres alemanas, los departamentos de guerra, crearon los llamados Frauenreferate. Éstos trabajaban directamente con las trabajadoras y se encargaban de buscar alojamiento para éstas y de la manutención de su descendencia que, a causa de la actividad laboral femenina corrían el riesgo de sufrir una falta de desatención por parte de la madre."208

La dirección de estos departamentos cae en manos de las dirigentes del movimiento de la mujer. El NFD es fundado para paliar las penurias que ocasionaba el estado de guerra. Este se preocupa de organizar víveres para las familias necesitadas, asistencia social para mujeres cuyos maridos se encontraban en el frente y para aquellas familias en las que el hombre o la mujer se habían quedado sin trabajo a consecuencia de la guerra. El servicio se encarga de organizar una bolsa de trabajo para mujeres cuyos maridos se encontraban en el frente, mujeres preparadas que retomaran los puestos de trabajo que habían quedado vacíos. Por otra parte se ofrecen cursos de costura, improvisadas guarderías y se organiza al resto de las organizaciones de beneficencia y bienestar social. ${ }^{209} \mathrm{La}$ participación de las mujeres como defensoras de la retaguardia es interpretada por las mujeres del movimiento de la mujer como "politización" de éstas, como participación en la construcción de la patria, y sobre todo como superación de las diferencias ideológicas entre mujeres de la socialdemocracia y mujeres pertenecientes a las clases medias. Como señala Agnes v. Zahn-Harnack el NFD hace realidad la máxima del emperador: "yo no conozco ningún partido, sólo conozco a alemanes". 210

El $B D F$ se encarga de los trabajos de información, propaganda, reparto de panfletos y de la coordinación de todas las actividades.

Con la experiencia ganada en el Frauendienst, el trabajo del BDF se centra cada vez más en las tareas de trabajo y beneficencia social, convirtiéndose la organización en una fuerte aliada del estado. Ésta se profesionaliza, empezando las mujeres a trabajar en instituciones estatales de bienestar, hospitales, etc. Marie Baum resalta el sentimiento de solidaridad y de unidad entre las organizaciones de mujeres, así como lo valioso de la experiencia en la posterior organización del trabajo social femenino. ${ }^{211}$

La guerra al igual que quebró la internacional pone en duda también la internacionalidad del movimiento de la mujer. Aunque tras ésta las dirigentes feministas de los países implicados se esfuerzan en apoyar la política de desarme, el sentimiento nacionalista se ha introducido en amplios sectores del movimiento de la mujer alemán.

Uno de los objetivos del BDF es su Überparteilicbkeit, su neutralidad política y su independencia de cualquier influencia confesional. No obstante forman parte de ésta la Federación de mujeres judías, JFB y la Federación de mujeres protestantes, DEF. En los Estatutos de 1910 definen su carácter apartidista y aconfesional y el esfuerzo de la Federación en la unión de todas las organizaciones de mujeres alemanas para luchar por los objetivos del movimiento de la mujer. ${ }^{212}$ Esta es la razón por la que La Federación no permitió la integración de las mujeres de la socialdemocracia, ya que defendían, según las feministas moderadas, principios de clase y no universales. Este argumento no deja de ser, hasta cierto punto, irónico,

208 Baum, M.: Anna von Gierke. Ein Lebensbild, Weinheim, Berlin, Julius Beltz, 1954, pp. 69 y 70. Entre las mujeres del movimiento de la mujer que participaron activamente en los Frauenreferate destacan Dorothee v. Velsen, Elisabeth Lüders, Anna v. Gierke, Else Ulich Beil, Gertrud Bäumer, Elly Coler etc.

209 Aurand, D.; Stoehr, I..: “Opfer oder Täter?”, COURAGE, 1982 (n¹1), p.48.

210 Anders, M.; Reicke, I.: op. cit., p. 14

211 Baum, M.: op.cit., p. 68.

212 Schmidt-Waldherr, Hiltraud: Emanzipation durch Professionalisierung?, op. cit., p.21. 
si se tiene en cuenta que la organización de amas de casa alemanas, perteneciente al ala moderada, defienden desde el comienzo sus derechos, con lo que discriminan por ejemplo a las mujeres que trabajaban para ellas.

Desde su fundación aparecen en la Federación dos corrientes, una de tipo moderado, representada por Gertrud Bäumer y Helena Lange y una orientada al espectro de izquierdas y dirigida por Minna Cauer. En esta primera corriente se observa la tendencia de limitar el trabajo de la organización a temas exclusivamente femeninos y a apartarse de la realidad política, mientras que la línea dirigida por Cauer, combina el compromiso de los intereses de la mujer y la acción política y propagandista. Una colaboradora de Bäumer y buena conocedora de ésta señala los problemas de Bäumer con las exigencias del movimiento sufragista anglosajón conocido por su radicalidad en cuestiones relativas a la prostitución, familia y pareja. ${ }^{213}$

Greven-Aschoff habla de una falta de programa en los intereses de la Federación como la expresión de los problemas de articulación teórica de las ideas emancipadoras y su utilización en la práctica. Esta punto débil se muestra en las diferencias estrategias que las diferentes corrientes de actuación de la Federación desarrollan para poner en práctica sus intereses. El ala de Minna Cauer perteneciente a la organización fundada por ésta, Franenwobl, presenta sus objetivos de emancipación dirigidos a la consecución del voto femenino, como puerta para las demás posibles reformas (derecho al voto femenino, participación de las mujeres en la vida política, rechazo del sistema tradicional de educación femenina, prostitución etc.), mientras que el ala moderada centra sus objetivos en la mejora de la educación de las mujeres para una posterior participación en la vida política. Esta preparación conllevaba la consecución automática del voto femenino. Aspiración un tanto contradictoria ya que las líderes del ala moderada de la organización participan activamente en el DDP.

Las diferencias no obstante no pueden observarse desde un punto de vista político. Ambos grupos definían una visión liberal de la sociedad, y el mayor miedo del ala progresista era el ser identificadas con las mujeres de la socialdemocracia. ${ }^{214}$ Tanto Evans como Greven-Aschoff definen las aspiraciones de los grupos "de izquierda" como liberal-individualista. La heterogeneidad de la Federación es paralela a las diferentes tendencias dentro del liberalismo alemán. Sin embargo Evans señala la paradoja del movimiento de la mujer claramente. Por una parte tenemos un movimiento liberal de emancipación que empieza a desarrollar tendencias antiliberales a partir de 1908. La causa de este retroceso quieren verla algunos autores en la falta de raíces liberales dentro de las clases liberales explicada por la teoría del "imperalismo social". $215 \mathrm{El}$ proyecto emancipador quedaba sustituido por los valores nacionales.

Evans define 1908 como el fin del periodo liberal de la Federación y la introducción del darwinismo social en la formulación de los objetivos del movimiento moderado de la mujer. Punto de partida de esta argumentación es el tratamiento del $\$ 218$ StGB de la ley fundamental. Este tratamiento de la cuestión del aborto se enmarca en la línea general de actuación respecto a la política de población y natalidad cuyos objetivos están dirigidos a mejorar la situación de la mujer en la vida familiar, a incrementar el nivel de vida y a mejorar las cualidades de la raza.216 Por otra parte, señala por el contrario Greven-Aschoff los débiles intentos de las mujeres de la Federación de contraatacar las ideas de los teóricos Rassehygieniker contra el movimiento de la mujer. A diferencia de Evans creemos que 1908 pone por primera vez de manifiesto uno de los puntos débiles del movimiento de la mujer en relación a las teorías de raza e higiene y la falta de

213 von Velsen, Dorothee: „Gertrud Bäumer in der Frauenbewegung“, MÄDCHENBILDUNG UND FRAUENSCHAFFEN, Septiembre 1953 (nº 9, año 3), p. 33.

214 Greven-Aschoff, Barbara: op. cit., pp. 94-95.

215 Evans, op. cit. p. 192.

216 Ibídem, p.103. 
argumentos de éste para contrarrestarlas. Contradicción que posteriormente se revelará como una de las causas de la rendición de las organizaciones de mujeres respectos al nacionalsocialismo. Y aunque como señala Greven-Aschoff no todos los higenistas eran racistas, no dejar de sacar a la luz la falta de alternativas por parte del movimiento de la mujer al discurso higiénico.

Esta controversia entre las dos corrientes de la Federación se cierra con la entrada en ésta del DEF (Deutsch-Evangelischer Frauenbund), la organización de mujeres protestantes alemanas. La politización hacía la derecha había empezado. Tendencia que se intensifica con ocasión de la primera guerra mundial y que se manifiesta en la colaboración estatal a través del servicio femenino de guerra fundado por Gertrud Bäumer. Tras la guerra los sentimientos nacionales se acentúan. El principio de poder de Estado, representado por la corriente weberiana y del que las mujeres del $B D F$ hacen uso, parece olvidado. ${ }^{217}$ La reacción de los grupos de mujeres moderadas estaba determinada por el miedo de éstas a las capas sociales de la clase media perdieran su influencia y poder. Miedo a una revolución socialista.

En 1920 la crisis del BDF se acentúa con las presiones del ala más conservadora de la Federación, conocida como la Nationale Opposition, en la que propagaban ideas a favor de los partidos de derecha y la oposición a la socialdemocracia. ${ }^{218}$

El debilitamiento del BDF concluye en la fundación en 1931 de las Nationalsozialistische Frauenschaft que pretenderán después de la toma de poder en 1933 la absorción del resto, o la disolución de las organizaciones de mujeres.

\subsubsection{La asociación de académicas alemenas (Der Deutsche Akademikerinnenbund)}

Una de las organizaciones de más influencia del BDF era la Federación de académicas alemanas. Una reproducción minúscula de la organización madre, pero mucho más cultivada y liberal que ésta; características que tienen que ver con la homogeneidad de la organización.

Ésta fue fundada en 1926 en Berlín. Los estatutos fueron esbozados por Marie Elisabeth Lüders, perteneciente al DDP y representante de la corriente liberal dentro del BDF. Los objetivos de la asociación eran el aumento de la influencia de las académicas en la vida cultural, política y económica de Alemania. ${ }^{219}$ Como grupos más importantes que pertenecía a la asociación hay que citar a las organizaciones de filólogas, médicos, juristas, profesoras de universidad, estudiantes y economistas nacionales. Las tareas prácticas de la Federación estaban divididas en cuatro campos: el trabajo científico y de investigación, el apoyo financiero a académicas en necesidad, formación y financiación de estudiantes y el trabajo conjunto con organizaciones internacionales.

Aunque la Federación es una organización minoritaria: el número de miembros en 1927 es de 3815 miembros, en 1933 son 37.267220 en sus filas se encuentra la élite de las mujeres del movimiento de la mujer, que más tarde a la llegada del nacionalsocialismo, a pesar de no pertenecer a la oposición, mantienen una postura crítica respecto a éste. Con la llegada de los

217 Ibídem. p.156.

218 Este grupo se centra en torno a Lenore Kühn y Sophie Rogge-Börner. La primera es elegida en 1932 como miembro del consejo de la Federación y pertenece al partido de derecha Deutsche Nationale Volkspartei.

219 Miembros del Consejo directivo de la Federación de mujeres académicas son: Agnes von ZahnHarnack, presidente de la organización, Ilse Szagunn, Margarete Schlüter-Hermkes, Marie Elisabeth Lüders, Professor von Wrangell, Rosa Kempf y Gabriele Humbert, Schönborn, Lührßen. Anders,M; Reicke, I.(eds): Agnes v. Zahn-Harnack.Schriften und Reden 1914-1950, Tübinge, Hopfer Verlag, 1964, p. 1

220 NACHrichtenblatT DES Bundes Deutscher FrauenVEREInE, Septiembre 1931(nº9), p. 69. 
nacionalsocialistas al poder el consejo directivo dirigido por Elisabeth Lüders desde 1930 dimite de su cargo, Lüders no obstante permanece como dirigente de la organización, a la espera de poder establecer una política de cooperación con el nuevo régimen. ${ }^{221}$ Unos meses más tarde deja su puesto y la organización pasa a depender del $D F W$. En 1933, una parte de la organización, espera poder seguir trabajando con los nacionalsocialistas, aunque según el número de miembros que abandonan la organización, puede deducirse que un gran número de mujeres rechazaba la política de cooperación: tras la integración en el DFW son 200 los miembros con los que cuenta la organización. ${ }^{222}$ El número de miembros continúan descendiendo hasta cuarenta, y en este momento, la organización deja de existir por escasez de miembros y falta de contactos internacionales. El 19 de junio de 1949 fue refundada de nuevo por Agnes von Zahn-Harnack en Berlin.

\subsubsection{Contexto ideológico y social de la cúpula dirigente del BDF}

Sobre la estructura social de los grupos de mujeres objeto de nuestro estudio, cabe destacar la heterogeneidad. Mientras el feminismo liberal-conservador, se nutre de mujeres con un nivel de educación superior, el espectro de las organizaciones confesionales es más difícil de estimar. En el caso protestante existían la diferencia de clase aparece definida en el origen de los miembros de las organizaciones más importante. El espectro de mujeres católicas se encuentra representado en todos los sectores de la sociedad, en especial en el sector agrario.

La homogeneidad de los grupos, que integran el movimiento de la mujer, se encuentra, si nos atenemos a los escritos, artículos de las principales dirigentes de los grupos en cuestión, en el legado "cultural" de éstas. Por eso creemos necesario resaltar entre otros, aspectos como el origen ideológico de cada una de las mujeres, en cuestión, su afiliación política y por último el discurso de la feminidad que estas autoras producen. La totalidad de éste discurso se formula durante los años veinte, época de madurez intelectual de nuestras protagonistas.

Estos aspectos nos permitirán posteriormente entender mejor sus actitudes en 1933 que motivaron a una gran mayoría a permanecer en Alemania. Unas en el idealizado exilio interior, otras, como en el caso de las mujeres pertenecientes a grupos confesionales, a participar activamente bajo la protección de sus respectivas iglesias, en la política nacionalsocialista.

Las mujeres pertenecientes a la cúpula del BDF y que más adelante durante el nacionalsocialismo continúan publicando en DIE FRAU pertenecen a la élite de mujeres alemanas que reciben una educación superior, en muchos casos universitaria, durante los primeros años del siglo XX. El trayecto es siempre muy parecido: escuela primaria, examen como maestra de escuela, preparación del bachillerato con un profesor privado y posteriormente examen de acceso a la Universidad, y estudio universitario que se cierra con la tesis doctoral. En la mayoría de los casos estas mujeres permanecen solteras. Otra trayectoria está unida a un camino más convencional: escuela primera, clases privadas para señoritas, matrimonio y trabajo en organizaciones sociales. Esta implicación en el trabajo social conduce a los dos tipo de mujer a los primeros contactos con el movimiento de la mujer y a partir de 1918 ingreso en los partidos políticos.

\section{9-1921}

Presidencia: Vicepresidencia:

Marianne Weber (DDP)

Alice Salomon

221 Anders,M; Reicke, I.(eds): Agnes v. Zabn-Harnack.Schriften und Reden 1914-1950, Tübinge, Hopfer Verlag, 1964, p. 6

222 Von Zahn-Harnack, Agnes: Schriften und Reden. 1914 bis 1950, Tübingen, Hopfer Verlag, 1964 p. 7. 


\begin{tabular}{ll} 
& Gertrud Bäumer (DDP) \\
Secretaría: & Alice Bensheimer \\
& Marie Baum (DDP) \\
Tesorería: & Elisabeth Altmann-Gotheiner (DDP) \\
\hline Vocales: & Luise Kiesselbach (DDP) \\
& Marie-Elisabeth Lüders (DDP) \\
& Emma Ender (DVP)
\end{tabular}

1931-1932

Presidencia:

Vicepresidencia:

Agnes von Zahn-Harnack (Deutsche Staatspartei)

Vocales:

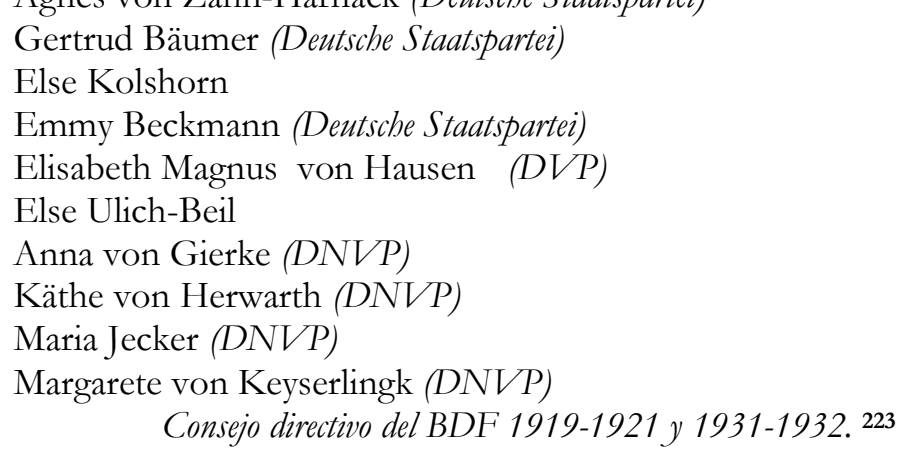

En el aspecto biográfico, la mayoría de las mujeres proceden de familias acomodadas donde la infancia transcurre feliz en hogares cultos y refinados que favorecen el desarrollo intelectual de los miembros femeninos de la familia:

"Aquel que vino al mundo a finales del siglo pasado en una familia burguesa, conoce todavía el valor del tranquilo recogimiento y del desarrollo ininterrumpido. De que en realidad este recogimiento no era real, no éramos entonces conscientes. Nuestra vida estaba asegurada, el entorno era cálido y bueno, reinaba orden, autoridad, amor y dureza. La creciente riqueza del pueblo alemán beneficiaba a las clases burguesas, aún cuando ésta no era responsable de ésta. La creación intelectual podía desarrollarse en tranquilidad y las influencias intelectuales formaban parte de la experiencia vital de las jóvenes criaturas.’’224

A la estabilidad económica y social de la familia se une el nivel intelectual de éstas. En el caso de Agnes von Zahn-Harnack y Agnes von Gierke, Elisabeth Lüders, la infancia de éstas está unida a los nombres más importantes de la intelectualidad liberal alemana. Marie Baum 225 describe la casa de los Gierke como un lugar de encuentro y reunión:

\footnotetext{
223 Greven-Aschoff, B.: op. cit., p. 298s.

224 Baum, M.: op. cit., p. 9.

225 Marie Baum: Nació el 23 de marzo de 1874 en el seno de una familia liberal. Al no estar autorizados los estudios de mujeres en las universidades alemanas estudia en Zürich Ciencias naturales, doctorándose posteriormente. Allí conoce a la estudiante de química Ricarda Huch, que con el tiempo se convertiría en una de las poetas más celebradas por el Movimiento de la Mujer. En 1902 deja su actividad como profesora de ciencias y comienza a interesarse por el trabajo social. En Baden trabaja como inspectora de trabajo y en Düssedorf dirige la Asociación para la protección de la madre y el niño. En 1917 comienza a trabajar junto Gertrud Bäumer en el Instituto de Pedagogía Social en Hamburg. En 1919 se presenta a las elecciones comunales de Schleswig-Holstein por el Partido Demócrata Alemán. En 1926 se le concede el cargo de portavoz en el Ministerio de Bienestarsocial. Entre 1929 y 1933 trabaja como profesora de ciencias naturales
} 
“Todas las tardes tenía lugar una exposición o se leía conjuntamente con una vital tertulia después, también había obras teatro con música. A menudo los padres se reunían en casas de otros amigos y ni el profesor von Harnack ni el alcalde Kirschner rehusaban de participar con una conferencia. (...) De la época de Breslau viene la relación con los profesores Brentano, Dilthey y Cohnheim. (...). En Berlin forman parte del círculo de la familia Gierke las familias de los profesores Harnack, Mommsen, Adolph Wagner, Gustav Schomoller, el concejal Weber y el poeta Ernst von Wildenbruch y muchos otros."226

La fuerte influencia del padre juega un papel muy importante en el desarrollo posterior de las mujeres en cuestión. El padre es el primero que despierta los intereses “intelectuales" de éstas. La madre por el contrario es admirada por su capacidad de sacrificio y por su fuerza interior. Marianne Weber en sus memorias comienza con una alabanza a su madre, cuya muerte temprana (Weber tenía dos años y medio) hace que la abuela se encargue de la educación de ésta. Weber define a su madre como: Sie war so gut und klug, so lebensvoll und liebenswürdig gewesen.227 La abuela que con el tiempo adquiere las funciones de madre es descrita como una mujer de un intenso sentimiento religiosos. Para la joven un modelo que la acompañara durante toda su vida, primero como esposa de Max Weber, más tarde como su viuda:

"Ella aspiraba a la perfección, se juzgaba a sí misma con extremada severidad, era devota y anclada en el cristianismo con la ininterrumpida naturalidad de la que también disfrutan los niños. Leía mucho, también con los niños crecidos; podía

en la Universidad de Heidelberg. A la llegada del nacionalsocialismo fue relevada de su puesto. Sigue colaborando en DIE FRAU.

Anna von Gierke: Nace el 14 de marzo de 1874. Dedicó toda su vida al trabajo social: trabaja continuamente en albergues femeninos para menores. Privadamente, sin apoyo ministerial se encargó de organizar centros de acogida para mujeres menores de edad en el campo, en las ciudades fuertemente industrializadas. Junto a trabajo práctico Edita una pequeña hoja informativa, SOZIALE ARBEIT, encargada de informar sobre todas las actividades, trabajos y proyectos relacionados con el trabajo social. Se mantiene unida al asociacionismo femenino a través de la organización de amas de casa, Reichsverband deutscher Hausfrauenvereine, donde es miembro del consejo directivo. Una de las primeras organizaciones que se desvincula del BDF y se alía a la causa nacionalsocialista, dándose más tarde cuenta de su error. A la llegada del nacionalsocialismo se dedica a publicar en DIE FRAU, y continúa trabajando en el campo de la asistencia social.

Marie Elisabeth Lüders: nace en Berlin el 25 de Junio de 1878. Estudia humanidades en la misma ciudad, y se doctora en 1912. Dos años más tarde se encarga de la dirección del departamento de la administración civil belga en Bruselas. Durante la Primera Guerra Mundial ocupa el cargo de directora de departamento de la mujer en el Ministerio de la Guerra. Posteriormente se dedica a la actividad académica como directora de la Academia de Mujeres en Düsseldorf. Como representante del Partido Demócrata Alemán viaja a Ginebra para participar en la cumbre económica mundial. Desde 1919 hasta 1932 es miembro de la Unión Nacional de Weimar y del Parlamento, donde obtiene un escaño representando al DDP. Junto a Gertrud Bäumer colabora en DIE HiLfE y en DIE FrAU. Su relación con el movimiento de la mujer proviene de su pertenencia a la organización de mujeres académicas, de la cual fue durante los años 1930-1933. A la llegada del nacionalsocialismo fueron suspendidas sus funciones como parlamentaria. Al terminar la guerra reanuda junto a Theodor Heuss su actividad política ingresando en el recién creado FDP.

226 Baum, M.: op. cit. , p. 16. El llamado profesor Harnack es nada menos que Adolf von Harnack (1851-1930), profesor de historia de la iglesia, y padre de Agnes von Zahn- Harnack.

227 Weber, Marianne: Lebenserinnerungen, Bremen, Johs. Storm Verlag, 1948, p. 5. 
leer incluso latín. La poca gente cultivada, el maestro, el párroco y el médico buscaban su cercanía y se dejaban inspirar por ella."228

En el mundo de Weber las mujeres apoyan, forman y se convierten en la columna imprescindible para la actividad masculina: ya sea intelectual como académico, o económica como hombres de negocios. Esta constante en la que el padre ejerce las tareas de educador y consejero intelectual y la madre permanece en un segundo plano como representante de los valores de la feminidad se repite en los relatos de las mujeres del movimiento y determina decisivamente su visión de la mujer y de si mismas. Así por ejemplo Marie Baum describe la relación de Anna von Gierke y una amiga:

"De esta temprana época procede también la relación con Else Wolff, que después se casaría con el abogado Arnold Reimer. (Wolff) procedía de una conocida familia berlinesa y encarnaba muchas de las cualidades que también caracterizaban a Anna von Gieke: calor humano, era maternal y poseía una compresión del mundo sin prejuicios. Mientras que Anna destacaba a través de su fuerza intelectual al servicio de tareas que trascendían lo personal, Else Reimer permaneció en el mundo de lo personal. Justamente estas mujeres poseían una gran fuerza de atracción sobre Anna von Gierke.“ 229

El respeto a la madre y a la "feminidad" está unido en las mujeres del movimiento de la mujer en un deseo de emular la figura del padre, en un deseo ardiente de participar en los procesos de creación intelectual que hasta entonces estaban vedados a la mujer. Estos impulsos se concentran en la teoría de género que esta rama del movimiento de la mujer desarrolla como código de conducta, la geistige Mütterlichkeit, la maternidad espiritual.

Otra circunstancia común que se repite en la biografía de estas mujeres es la pérdida temprana del padre, que ocasiona la desaparición de la idílica y segura vida de la infancia y la adolescencia y conduce a la obligación de trabajar. El camino utilizado sin excepción es la profesión de maestra, adecuada para señoritas procedentes de la clase media alta en dificultades..$^{230}$

En la mayoría de los casos permanecen solteras. Una de las razones era el celibato de las funcionarias: Hasta 1945 funcionarias, maestras tenían que abandonar su profesión en el caso de que contrajeran matrimonio, viviendo en el llamado celibato profesional. Otra de las razones es el origen social de éstas. En su gran mayoría pertenecen a familias de clase media alta, donde la perdida del padre significaba un descenso social, las mujeres de la familia tenía que trabajar y la mayoría de ellas no tenían la dote suficiente para encontrar marido en el mercado de matrimonios. Las que no estudian, como es el caso de Marianne Weber o Maria Jellinek,231 se

\footnotetext{
228 Ibídem, p.6.

229 Baum, M.: op. cit., p. 16.

230 El estudio de Otrun Niethammer sobre escritoras de ideología nacionalsocialista revela la importancia de la relación padre-hija caracterizaba por la autoridad y la admiración hacia lo masculino. Niethammer, O.: "Holocaust und Gedächtnis: Autobiographien von nationalsozialistischen Autorinnen" en : Niethammer, O.: Frauen und Nationalsozialismus. Historische und kulturgeschichtliche Positionen, Osnabrück, Universitätsverlag Rasch, 1996, p. 100-112.

231 Camilla Jellinek: nacida en Viena el 24 de Septiembre de 1860. Es una de las pocas mujeres citadas que no recibe una educación universitaria. Su contacto con el mundo académico se remonta a su matrimonio con el profesor de derecho, Georg Jellinek. En su residencia definitiva, Heidelberg, consigue con mucho esfuerzo seguir los pasos, seguir los pasos de su esposo e introducirse en el derecho, donde se especializa en caso que afectan a mujeres. En Heidelberg dirige durante treintitrés años el centro de asistencia legal para
} 
benefician del ambiente cultivado de sus familias y apoyan a sus maridos Max Weber, Walter Jellinek en su trabajo, consiguiendo posteriormente el título honorífico de doctoras por sus méritos en la investigación.

Su pertenencia al movimiento de la mujer está unida fundamentalmente a las primeras reivindicaciones de las mujeres para recibir una educación superior. En este sentido defienden los derechos de las mujeres pertenecientes a una clase superior. Los problemas de las mujeres trabajadoras, si bien aparecen recogidos en los trabajos de éstas, no son en realidad los suyos. Se trata de un feminismo cultivado y un poco ajeno a la realidad. A excepción de algunos casos (Marie Elisabeth Lüders, Alice Salomon, Marie Baum), durante la república de Weimar se observa el progresivo apoyo al ideario nacional-conservador.

Desde el punto de vista intelectual el grupo dirigente de la Federación pertenece a la llamada burguesía cultivada, Bildungsbürgertum. ${ }^{232}$ Según Fischer, en su análisis de la sociedad alemana a principios de siglo, es un grupo social integrado por profesores de Universidad y de instituto, pastores, periodistas e intelectuales y que se asimila a la élite industrial dirigente así como apoya sus objetivos en oposición de las clases sociales menos privilegiadas. ${ }^{233}$

El concepto de Bildung está profundamente relacionado con la ética protestante del individuo. En este sentido significa cambio, desarrollo, creación. La cultura es un acto de cambio vital. Esta existe y hay que descubrirla en las profundidades del acto creativo. Como un árbol que se desarrolla y la tierra que le nutre generación tras generación. Concepto influido por Ernst Troeltsch, teólogo protestante (1865-1923). Junto a estas cualidades se añadía la virtuosidad retórica, el conocimiento profundo de obras literarias y filosóficas y el trabajo científico.

Una de las características del Bildungsbürgertum protestante es el papel de la mujer como figura central de la educación familiar. La mayoría de estas mujeres, madres de familia, tenían una educación amplia, adquirida en las Töchterschule, escuelas privadas para hijas de familias acomodadas que con el tiempo, en 1908 adquieren categorías de escuelas superiores.

Estas mujeres se encargan de los rudimentos de la educación de los hijos, tienen conocimientos de música, y participan en las discusiones intelectuales del círculo hogareño. La investigación, la participación política o la actividad empresarial corre a cargo del cónyuge.

Hasta principios del siglo XIX el concepto de Bildungsbürgertum era un monopolio de la intelectualidad masculina. En el proceso de emancipación femenina las mujeres empiezan a reclamar su derecho a participar de éste. A diferencia del feminismo actual donde se observa el análisis crítico de la producción masculina, las mujeres del movimiento de la mujer admiran el milieu intelectual masculino y quieren formar parte de él. En el grupo de las mujeres de DIE FRAU está muy claro esta reivindicación. La mayoría de ellas acceden a la Universidad y desarrollan labores relacionadas con la enseñanza posteriormente. El contacto con el círculo masculino las hace introducirse en la política. En el grupo de mujeres que ocupa posiciones de importancia dentro del movimiento de la mujer, podemos establecer con claridad una serie de personas y círculos que influyeron en su universo ideológico.

mujeres y adolescentes. Es miembro de la dirección general del B.D.F. Y en DIE FRAU se encarga de escribir la mayoría de los artículos dedicados a la situación legal de la mujer. Su centro pasa en 1933 a manos nacionalsocialistas.

232 Koselleck, R. (Ed.): Bildungsbürgertum im 19. Jahrbundert, Stuttgart, Klett-Cotta, 1990.

233 Fischer, F.: „Zum Problem der Kontinuität in der deutschen Geschichte von Bismarck zu Hitler“ en: Bracher, K.D., Funke, M., Jacobsen, H.A. (Ed.): Nationalistische Diktatur 1933-1945. Eine Bilanz, Bonn, Schriftenreihe der Bundeszentrale für politische Bildung, Band 192, 1986, p.772. 
Gertrud Bäumer 234 por ejemplo, estudia en Berlín teología con Adolf von Harnack, 235 Hermann Gunkel y Hans von Soden. Con Erick Schmidt, Lessing y Goethe se convierten en sus autores favoritos y con Wilhelm Dilthey se adentra en las corrientes de la filosofía alemana. ${ }^{236} \mathrm{~A}$ través de von Harnack, Bäumer conoce a Friedrich Naumann, que admirado por las capacidades publicistas de Bäumer le ofrece la posibilidad de trabajar en la revista que éste editaba DIE HiLFE. Este contacto no se limita al terreno periodístico sino que pronto se extiende al campo político. Bäumer ingresa en el Partido del Progreso (Deutsche Fortschrittspartei) fundado por Naumann y más tarde se convierte en una de las confundadoras del DDP. ${ }^{237}$

La influencia de Goethe, Schiller y Lessing con sus creaciones femeninas (Ifigenia, Elonora), se traduce en novelas, trabajos y artículos de las mujeres de la Federación. Gertrud Bäumer dedica una gran parte de sus obras a la obra de estos autores. ${ }^{238}$ Junto a ello destaca una gran admiración por el idealismo alemán que trae como consecuencia una actitud vital donde la primacía del Geist 239 está por encima de cualquier instancia y se convierte en garantía moral, religión y ética:

“ (...) con Goethe y Fichte como la perfección de la reencarnación de la religión en el espíritu alemán. (Nosotros necesitamos) una religión que contenga la vida en

234 Gertrud Bäumer: nació el 12 de septiembre de 1873 en Hohenlimburg (norte de Alemania). Crece en una casa parroquial hasta la muerte de su padre. A los dieciocho años trabaja como maestra de educación primaria. En Berlin concluye sus estudios universitarios y comienza a enseñar en el Instituto de Pedagogía Social de Berlin. Durante sus años universitarios conoce a Helene Lange, una de las fundadoras del Movimiento de la Mujer alemán; a través de ella se pone en contacto con el círculo político de Friedrich Naumann, político social protestante, fundador del Partido Demócrata Alemán, con el que colaborará en la dirección de la revista liberal DIE HiLfE (a la muerte de Naumman, Gertrud Bäumer trabajará conjuntamente con Theodor Heuss). Al mismo tiempo Helene Lange le ofrece trabajar como codirectora en DIE FRAU, órgano de prensa de la organización de mujeres alemanas más influyente a principios del siglo XX. En 1919 participó en la reunión general de Weimar. Hasta el año 1932 ocupó un puesto en el Parlamento como diputada por el Partido Demócrata Alemán, y desde 1920 trabajaba el el Ministerio del Interior como consejera ministerial para asuntos sociales y escolares. En 1933 fue despedida, aunque continúa publicando y dirigiendo DIE FRAU hasta 1944.

235 Adolf von Harnack (1851-1930): teólogo protestante conocido por sus intentos de aunar el cristianismo y la ciencia. Historiza el dogma como unión de la tradición helenística y gnóstica y lo valora como decadencia y desviación de las primeras comunidades. Uno de los principales representantes del Kulturprotestantismus.

236 Hermann Gunkel (1862-1932): teólogo protestante, uno de los padres de la tendencia históricacrítica de la exegesis.

Hans Freiherr von Soden (1881-1945): teólogo protestante alumno de Adolf von Harnack, profesor de historia de la iglesia. Fundador de la iglesia confesora en Kurhessen.

Erich Schmidt (1853-1913): historiador de la literatura, especialista en Goethe y Lessing.

Wilhelm Dilthey (1833-1911): filósofo, fundador de la teoría del conocimiento en las humanidades y defensor del método hermeneutico en éstas.

237 Kaufmann, Friedrich: Rat und Tat. Elly Heuss-Knapp. Nachkang eines Lebens, Tübingen, Rainer Wunderlich Verlag, 1964.

238 Bäumer, Gertrud: Eine Woche im May, Tübingen/Stuttgart, Rainer Wunderlich Verlag, 1942; Goethe überzeitlich, Berlín, F.A. Herbig, 1932; Goethes Freundinnen, Leipzig, Teubner, 3.ed., 1921.

239 El término Geist se traduce como intelecto, pensamiento, razón que está por encima de las partes sensuales y materiales del individuo. Realidad inmaterial. Dentro del movimiento de la mujer se utiliza la terminología hegeliana del absoluter Geist, „el intelecto absoluto“. 
comunidad con sus formas sociales y estatales, y que cree y satisfaga el sentido y el alma."240

La separación del Geist de la política está profundamente arraigada en la historia moderna alemana. La aspiración a convertirse en una nación no se encontraba dentro del programa de escritores como Goethe y Schiller. La cultura se convertiría así en substitutivo de la política y se oponía a la práctica social real.

La entrada en el movimiento de la mujer permite a muchas mujeres el acceso a los principales representantes del liberalismo intelectual protestante. Bäumer describe esta "intelectualización” de la vida cotidiana durante la guerra ,en un retrato que hace sobre Frieda Duensig, una jurista íntima amiga de ésta que trabaja en la central de protección de menores en Berlin:

“Era época de guerra, en el invierno de 1915. Por entonces nos encontrábamos en Berlín por las tardes para leer a Platón. Las que se unían a nuestra actividad, no estaban unidas a la guerra, a través de parientes o por la lectura de los periódicos. Ellas traían cada día consigo un pedazo de servicio de guerra."241

Otros de los círculos de intelectuales unidos a la tradición protestante liberal, es el de la familia de Agnes von Zahn-Harnack, ${ }^{242}$ última presidente del BDF. Von Zahn-Harnack pertenece a una de las más prestigiosas familias del Berlín de primeros de siglo. Hija del teólogo protestante Adolf von Harnack. El historiador Hans Delbrück está casado con la hermana de la madre de Agnes. El círculo de Agnes von Zahn-Harnack se encuentra claramente influido por la figura de su hermano, Ernst von Harnack, una de los implicados en el atentado contra Hitler, del 20 de Julio de 1920. Este círculo se hallaba relacionado con los llamados socialistas religiosos, a los que también pertenecía el esposo de Elke Ulich Beil. ${ }^{243}$ Harnack pertenecía al Bund religiöser Sozialisten, dentro del partido socialdemócrata alemán, relacionados con la persona del teólogo protestante Paul Tillich (1886-1965). Esta actitud se intensifica durante los años de la dictadura, donde los nacionalistas utilizan símbolos religiosos para legitimar su poder. Poco a poco las diferencias entre estos se hacen más claras.

Junto al círculo de Agnes von Zahn-Harnack hay que señalar la figura de Marianne Weber. En los años 1920-1930, después de la muerte de Max Weber, se crea en la casa de Marianne Weber, en Heidelberg un círculo generacional de intelectuales en los que forman parte

240 Bäumer, Gertrud en : DiE HILFE, 1923 (n¹, año 29), p.3.

241 Bäumer, G.: Gestalt und Wandel. Frauenbildnisse, Berlin, Herbig, 1950, p.633.

242 Agnes von Zahn-Harnack: nace en Gießen el 19 de Junio de 1884. Hija del famoso historiador y teólogo Adolf von Harnack. Al igual que Gertrud Bäumer crece en una familia donde la religión jugaba un papel importante. En Berlin estudia Alemán, Inglés y Teología. Se doctora y en un principio trabaja en centro privado para "señoritas" de familias de clase alta. En Berlin contacta personalmente con Gertrud Bäumer y en 1926 llevada por su interés en el movimiento de la mujer preside la asociación de mujeres académicas. Es miembro también del Partido Demócrata Alemán. Desde 1931 preside la dirección general del B.D.F. y fue la mujer que se encargó de llevar las negociaciones para la disolución de la organización con Gertrud Scholtz-Klink, dirigente de las mujeres nacionalsocialistas. Durante los años de la dictadura la familia Harnack demuestra en contadas su rechazo al régimen nacionalsocialista.

243 Else Ulich-Beil: nace en 1883 en una familia de pocas posibilidades económicas. Se gradúa como maestra, y con dificultades consigue terminar el bachillerato. Desde muy temprano se le encomiendan tareas de responsabilidad. Tras la guerra conoce, a través de Helene Lange, a Dorothee von Velsen con la que trabaja conjuntamente en la Asociación general de mujeres alemanas, Allgemeiner Deutscher Franenverein. Miembro del DDP, participa activamente en la vida política. Durante el nacionalsocialismo trabaja como maestra y sigue colaborando en DIE FRAU. 
arqueólogos, juristas y filósofos como Jaspers y Jellinek, como mujeres procedentes del movimiento de la mujer, como Marie Baum, Dorothee von Velsen ${ }^{244}$, Gertrud Bäumer y Elisabeth Baumgarten.

El círculo se reunía todos los domingos por la tarde, donde se preparaban discursos y conferencias. Esta tertulia encuentra su fin en 1933 con objeto de la llegada al poder del los nacionalsocialistas. ${ }^{245} \mathrm{El}$ grupo sin embargo no tiene carácter político, todo tipo de tema que pudiera aludir a la situación política era evitado minuciosamente, según uno de los integrantes del círculo. ${ }^{246}$

Sin embargo las figuras más importantes del movimiento de la mujer de ésta son Helene Lange y Gertrud Bäumer. Helene Lange, sucesora de Auguste Schmidt a la cabeza del $A D E F$ y después dirigente del BDF es la gran dama del movimiento de la mujer. A ella la sigue Gertrud Bäumer que en sus tiempos de estudiante en Berlín empieza a trabajar como secretaria personal de Lange, que debido a una enfermedad ocular relega con el tiempo sus tareas a la recién llegada. Lange y von Harnack ponen a Bäumer en contacto con Friedrich Naumann y Theodor Heuss con los que empezará a trabajar en el periódico nacional-liberal DIE HILFE. Conjuntamente publican DiE FRAU. Durante los años de la primera guerra mundial Bäumer funda el Nationaler Frauendienst, un servicio de trabajo femenino que moviliza un gran número de mujeres al servicio de la Alemania en guerra. Sin embargo es durante la república de Weimar cuando se pone de relieve las facultades políticas de Bäumer. Una estudiante señala su impresión ante la personalidad de Bäumer en un discurso de ésta:

"Tuve la posibilidad de escuchar uno de esos discursos en los años veinte cuando era estudiante en Berlín y me acuerdo de su espontánea y fresca vitalidad, su ingenio, su clara lógica y la entrega que ponía a lo que estaba haciendo." 247

La personalidad de Bäumer la convierte en el verdadero centro del movimiento de la mujer. Este centro se mantendrá a pesar de la disolución de las organizaciones de mujeres en 1933 y marcará una forma concreta de enfrentarse a los años de la dictadura.

Otra de las mujeres más importantes del círculo del ala moderada del movimiento de la mujer Dorothee von Velsen ${ }^{248}$ :

244 Dorothee von Velsen: nace en 1883 Ella junto a Else Ulich-Beil pertenecen a la llamada tercera generación del movimiento de la mujer. Mientras que Helene Lange y Alice Salomon habían sido las pioneras del movimiento, Gertrud Bäumer, Agnes von Zahn-Harnack y Marianne Weber consolidaron la fuerza de éste a través de su actuación política durante los años de Weimar, Velsen y Ulich-Beil se encargarán de disolverlo. Más jóvenes, más críticas especialmente Dorothee von Velsen, cuestiona la actuación de Bäumer cuando los nacionalsocialistas llegan al poder. Fue alumna de Alice Salomon en la Escuela Social para mujeres en Berlin. No visita la Universidad hasta los cuarenta años, pero dada su facilidad para los idiomas trabaja continuamente en Bruselas como colaboradora de Elisabeth Lüders durante la primera guerra mundial. Su trabajo como portavoz en varios puestos de asistencia a la mujer, le valió su elección como presidenta de la Asociación general de mujeres alemanas, Deutscher Allgemeiner Frauenverein, donde permanecerá hasta su disolución en 1933. A pesar de su disputa con Gertrud Bäumer continua colaborando en DIE FRAU. Durante el nacionalismo se dedica a escribir novelas históricas

244 von Velsen, Dorothee: Im Alter die Fülle. Erinnerungen, Tübingen, Rainer Wunderlich Verlag, 1958, p.121.

245 Weber, Marianne: op. cit. p. 212.

246 Schadt, Jörg; Caroli, Michael (De.): Heidelberg unter dem Nationalsozialismus. Studien zu Verfolgung, Widerstand und Anpassung, Heidelberg, C.F. Müller Juristischer Verlag, p.283.

247 Scherer, A. (ed.): Frauen im Umbruch der Zeit, Freising, Kyrios Verlag, 1976, p.58. 
"La doctora Dorothee von Velsen: una figura que no llamaba aparentemente la atención, no muy alta, vestida con esmero, cada vez que hablaba, tomaba la palabra con una voz tranquila y oscura. Ella representaba para nosotras la idea del movimiento de la mujer en su pureza más abstracta."249

Von Velsen, junto con Else Ulich-Beil son elegidas por Helene Lange para la dirección de la asociación general de mujeres alemanas, $A D F$, más tarde conocida como StaatsbürgerinnenVerband.

Herederas del espíritu del movimiento de la mujer liberal-conservador son las alumnas de las escuelas sociales que estaban unidas desde su fundación con la historia de éste. Las escuelas de trabajo social se constituyen como formación profesional de las adolescentes tras el abandono de la enseñanza primaria. Dependiendo del BDF se fundan dos escuelas, una en Berlin con Alice Salomon a la cabeza y una segunda en Hannover.

Estas dos escuelas generan la tercera generación del movimiento de la mujer. Especial influencia en la escuela social de Hannover ejercen Gertrud Bäumer y Marie Baum debido a su labor de enseñanza. ${ }^{250}$ Los valores que se inculcan en ésta representaban la idea neumaniana nacional-social: la unidad del pueblo en el Estado, la democracia y el cristianismo, además del compromiso social con las clases más desfavorecidas. ${ }^{251}$ En la escuela viven las dos mujeres desde 1917 hasta 1919 fecha en la que las dos fueron elegidas en la Nationalversammlung de Weimar. La influencia en las alumnas fue grande. Margarethe Treuger, también miembro del $B D F$, permanece como directora de la escuela. Bäumer mantiene contacto posteriormente con sus alumnas, durante los años de la dictadura.

En un escrito de 1923 con motivo del 50 cumpleaños de Bäumer se definen a si mismas como "la tercera generación" del movimiento de la mujer, el futuro de éste. Como modelo y figuras a imitar citan a Helene Lange y a Gertrud Bäumer:

"Así crecía esta alianza de juventud ya que en otras ciudades surgían organizaciones hermanas, mujeres que ejercían su trabajo en la familia o en el trabajo con más apertura, responsabilidad y cariño, la primera preparada, entusiástica joven guardia del movimiento de la mujer."252

Estas escuelas constituyen el centro de formación de las futuras trabajadoras sociales: asistente social, inspectora de fabricación, ayudante en el tribunas de menores, orientadora profesional etc.

En un informe realizado por Dora Hansen-Blancke en 1942 sobre los primeros diez años de existencia de la Escuela (1927-1927), analiza la autora el camino laboral de las alumnas de éste

248 Dorothee von Velsen pertenece a una familia conservadora acomodada. Desde edad temprana pasa estancias en Inglaterra y Francia. Junto a su trabajo como Leiterin der Geschäftstelle de la BDF, hay que destacar su actividad en la Deutscher Staatsbürgerinnenverband, de la que es presidenta desde 1919 hasta 1933. El camino de v. Velsen no la lleva a la universidad como en el caso de sus compañeras, sino que ingresa en la escuela de trabajo social de Alice Salomon. Durante la guerra trabaja en el servicio de trabajo femenino fundado por Gertrud Bäumer, y tiene como compañera de trabajo a Elisabeth Lüders en Bruselas. Terminada la guerra ingresa en la Universidad donde estudia Historia y Literatura.

249 Reicke, I.: Die großen Franen der Weimarer Republik, Erlebnisse im "Berliner Frübling”, Frankfurt a. M., Suhrkamp 1989, p.60

250 Sobre la escuela véase obra de Bäumer Lebensweg durch eine Zeitwende.

251 Hansen-Blancke, D.: „Als Schülerinnen Gertruds Bäumers“, Mädchenbildung und Frauenschaffen, Septiembre 1953 ( $\mathrm{n}^{\circ}$ 9, año 3), p.20

252 Bach, Marie Luise: op. cit., p. 17 
período. En las entrevistas que ésta realizó se deduce que en los años de la crisis muchas de las tituladas se vieron afectadas por el desempleo, y todas señalan el cambio de la situación en 1934. Sobre su postura respecto al nacionalsocialismo, y biografía durante esta época, no hemos encontrando, desgraciadamente, ningún tipo material que nos pueda ofrecer informaciones al respecto. 253

\subsubsection{La herencia liberal-protestante. Friedrich Naumann}

A pesar de los intentos de las organizaciones de mujeres de preservar su independencia respecto a asuntos relacionados con la vida política, la cúpula de sus representantes se compromete con los principios democráticos. Helena Lange, la principal representante del movimiento moderado de la mujer, ingresó en el Deutsche Demokratische Partei pasando por alto las actitudes negativas de sus compañeros de partido que se mostraban reacios a aceptar la introducción del voto femenino. ${ }^{254}$ Sin embargo esta temprana aversión desaparece rápidamente. Bäumer escribe en 1924 sobre el movimiento de la mujer:

"El movimiento de la mujer no ha sido nada más que la utilización de los fundamentos democráticos a la posición de mujer en el estado y en la sociedad. El papel de la mujer y las relaciones entre los géneros han sido los últimos bastiones en el difícil asalto del castillo de las viejas ideas. (...) Como el movimiento de la mujer ha surgido del doble pensamiento de libertad e igualdad, ha dado testimonio en cada paso adelante, en todo refuerzo de la creencia en sus principios, de que sólo la forma democrática del estado permite a la mujer desarrollar su reino en libertad." 255

Democracia, paz y la defensa de la vida son los objetivos, según Bäumer del movimiento de la mujer, así como la superación del conflicto de clases, ya que las mujeres no entienden la política como "los trabajadores, los artesanos, los agricultores, empleados y patronos" y el sistema donde es posible alcanzar el paraíso de la mujer es la democracia.

Este entusiasmo por las ideas democráticas se extiende al resto de los miembros del consejo directivo del $B D F$ y de su órgano portavoz, DIE FRAU, que se reconocen públicamente como liberales. En este sentido podemos utilizar la definición de Theodor Heuss que define como liberal al:

$$
\begin{aligned}
& \text { “(...) el individuo que siente socialmente y que quiere hacer política nacional y } \\
& \text { cultural.”256 }
\end{aligned}
$$

Social, nacional y cultural. Estos liberales no eran revolucionarios, creían en la solución de los problemas del sistema dentro de éste y se proclamaban defensores de las clases menos

253 Hansen-Blancke, D.: „25Jahre Sozialer Beruf-gelebt und bezeugt“, DIE FrAU, Junio-Julio 1942, nº $9-$ 10, pp. 142-149

254 Andrae, Friedrich (ed.): Deutsche Demokratie von Bebel bis Heuss. Geschichte in Lebensbildern, Hamburg, Baken, 1964, p.53

255 Reichsfrauenauschuß der DDP: Gertrud Bäumer aus ibren Schriften, Aufsätzen und Reden, Berlin, Neuer Staat, pp.17-18

256 Heuss, Theodor: Politiker und Publizist. Aufsätze und Reden, Tübingen, Rainer Wunderlich Verlag, 1984, p. 14 
favorecidas. Esta preocupación por "los otros", y por la mejora de las condiciones sociales de la clase trabajadora es una constante del ala moderada del movimiento de la mujer.

El ideólogo del liberalismo alemán por excelencia es Friedrich Naumann, y representa una tendencia del liberalismo, calificado como "social liberal". Naumann de profesión teólogo y pastor protestante procede de los círculos del protestantismo que se motivados a dar respuestas, desde el punto de vista religioso, a los intensos cambios que se producen en la realidad social en la Alemania de finales del siglo XIX. Tras conocer a Max Weber funda en 1896 el Nationalsozialer Verein, y se distancia de los planteamientos cristianos sociales. Su ideal de democracia está ligado a los principios de la monarquía, defiendo un estado democrático con rasgos autoritarios y elitistas. Base del espíritu reformador lo constituye una política imperialista y de expansión que garantizara la fuerza de Alemania en la arena europea. Tras la disolución del el Nationalsozialer Verein, forma parte en 1903 de la Freisinniger Vereinigung y más tarde del Fortschrittliche Volkspartei hasta 1918 fecha en la que funda el partido demócrata liberal, Deutsche Demokratische Partei (DDP).

Respeto por el estado, defensa de los intereses nacionales, y politisches Gestalten vollizieht sich in der Spannung zwischen Idee und Wircklichkeit, acción política en contraposición de mundo ideal y la realidad, ${ }^{257}$ eran los contenidos del pensamiento de Naumann.

La integración de un gran números de mujeres en las filas del nuevo partido que representa los intereses de los liberales en Weimar, acentúa el carácter social de éste. Su papel no se reduce a un mero objeto de decoración sino que estas se imbuyen en la vida política con intensidad y abnegación. Marianne Weber señala en sus memorias lo intenso del compromiso político de sus compañeras de partido. La vida privada desaparece, los viajes de campaña electoral se suceden semanas y semanas, algunas mujeres, como Gertrud Bäumer participan en tres discursos electorales diarios. Y reaccionan con naturalidad ante el rechazo del electorado ante las mujeres, especialmente ante el lenguaje obsceno y tosco de los radicales de izquierdas. Weber es la única mujer en la fracción de Baden y es protagonista de las suspicacias y los escrúpulos, o de la excesiva caballerosidad de sus compañeros de trabajo. ${ }^{258}$

El modo de hacer política masculino es observado con curiosidad, aunque en muchos casos no escapa a las críticas de éstas. Durante los años de trabajo se manifiesta las diferencias en el partido entre el grupo de seguidores de Naumann, y nacional-liberales y los representantes de la gran industria, que luchan por conseguir el control del partido y de los puestos ministeriales. ${ }^{259}$ Esta lucha por puestos y ministerios es calificada por Weber como de "gran interés para las mujeres" y la compara con los conflictos en las organizaciones de mujeres dónde las ambiciones personales era uno de los principales obstáculos para el trabajo en conjunto.

\subsubsection{El movimiento de la mujer y el discurso sobre la feminidad}

La aportación más interesante de las mujeres de la Federación, aparte de sus logros en el campo judicial y legislativo, que mejoraron indudablemente la situación de las mujeres, es la construcción de modelos de feminidad que intentan descifrar la naturaleza de lo femenino. En la mayoría de los casos son intentos de definir el papel de la mujer en la sociedad, a partir de sus capacidades, de su especificidad.

El movimiento de la mujer alemán define un discurso de género basado en la polaridad de los géneros, en la influencia de la mujer a través de la geistige Mütterschaft, maternidad cultural y crea un ideal de mujer que pretende superar las limitaciones intelectuales a las que se veía

\footnotetext{
257 Ibídem, p. 18

258 Weber, Marianne: Lebenserinnerungen, op. cit., pp. 83-84

259 Ibídem, p. 88
} 
expuesta la mujer alemana. Marianne Weber critica el ideal de la "mujer burguesa" alemana con los versos de Goethe sobre la mujer: "Su vida es siempre ida eterna, es llegada, es apoyo, es sostén, es hacer y crear para los otros" y propone la participación de la mujer en el legado cultural alemán como parte de la liberación personal de ésta. ${ }^{260}$

\subsubsection{La polaridad de los géneros. Die Polarität der Geschlechter}

Se acepta la división de los géneros, la diferencia de comportamientos y estructura psicológica. El tema de la diferencia de los géneros es tratado profusamente en la república de Weimar. Fundamentalmente Helene Lange, Gertrud Bäumer, Agnes von Zahn-Harnack y Marianne Weber. La división de los géneros no es entendida como una consecuencia de las condiciones de socialización, sino como una realidad. La mujer es diferente. Su naturaleza es diferente. Para Gertrud Bäumer la naturaleza femenina no está preparada para las etapas de crisis, es callada, sutil de manipulación, su fuerza radica no en la conquista de nuevos ámbitos sino en mantener lo que ha conquistado. Tiene un sentido más débil para el orden que el hombre. ${ }^{261}$ La causa es su complexión (según la teoría de los humores). En la sexualidad también es diferente. La sexualidad de la mujer, es salvaje y descontrolada. La otra cara de esta sexualidad es el "instinto cósmico" de ésta, su relación con lo sobrenatural y lo religioso, a partir de su condición de "creadora de la vida". La mujer adquiere su plena identidad en su función de madre. A través de la maternidad se libera la mujer de la "naturaleza inferior" que se le adjudica debido a su sexualidad, que únicamente tiene una legitimación en caso de maternidad. ${ }^{262}$

Hombre y mujer son vistos como dos entidades opuestas y complementarias. Esta separación está fundamentada en el carácter cósmico de la diferencia sexual, carácter que se aplica a la maternidad femenina y que justifica la existencia de sociedades matriarcales en el pasado:

"Como culto sagrado la maternidad era una de las realidades originarias cósmicas como el sol, la luna, la tierra, el mar, como día y noche, cuya influencia sobre los destinos humanos se demostraba en la veneración religiosa." 263

Esta teoría de la diferencia complementaria de los géneros tiene una gran tradición en la historia del discurso de los géneros. Según Greven-Aschoff la feminidad se convierte en mitología, se idealiza y se considera "superior" al hombre. Esta superioridad constituía el modelo de legitimación de las reivindicaciones de igualdad. La consecuencia de la emancipación sería la creación de una cultura femenina paralela al hacer masculino.

\subsubsection{El concepto de Geistliche Mütterlichkeit (maternidad espiritual)}

\footnotetext{
260 Beckmann, E., Kardel, E.: Quellen zur Geschichte der Frauenbewegung, op. cit., p.45

261 Bäumer, Gertrud: Die Fran in der Krisis der Kultur, Berlin, Herbig, 1927, p. 12

262 Wittrock, Christine: op. cit., p.24

263 Bäumer, G.: Die Frau im neuen Lebensraum, Berlin, Herbig, 1931, p.9
} 
Las teorías de Fröbel y Pestalozzi 264 sobre el valor de la educación en armonía con la naturaleza y el universo cómo manifestación de la revelación divina influyen en la creación del concepto geistliche Mütterlicheit.265 En el proceso educador adquiere la mujer un papel fundamental en la familia. Ya que éste proceso requiere una formación adecuada, motiva a las mujeres a una formación personal. En las asociaciones de mujeres de finales del siglo XIX alcanzan estas teorías un eco extraordinario. La mujer no es vista únicamente como madre en el sentido biológico, sino que la maternidad es analizada desde múltiples perspectivas de identificación. Por una parte, ofrecía a las mujeres la posibilidad de ver reflejadas sus experiencias en la vida cotidiana como guardianas de la familia, así como la responsabilidad de éstas de ir más allá en el terreno socialpedagógico. El esquema masculino-femenino de racionalidad-amor permanecía, sin embargo, intocable.

Aunque el sistema de valores en la mujer quedaba cambiado: a su capacidad de amor, se unía el principio de responsabilidad en una sociedad impregnada de la política femenina. El nuevo concepto abría a la mujer "liberal" de la clase media nuevos campos de actuación social como educadora social, maestra y pedagoga. Desde el punto de vista político no cuestionaba el orden social, sino que pretendía suavizar las condiciones de desigualdad de éste. Las fronteras de actuación entre los dos feminismo empiezan a diferenciarse, participando éstos de la diferencia entre proletarios y trabajadores.

El concepto de geistige Mütterlichkeit continua siendo utilizado por la segunda generación de feministas liberales como Helena Lange ${ }^{266}$. La mujer no es definida por sus atributos biológicos sino por su condición moral, la cual la dota de características especiales que no se reducen exclusivamente al mundo de la familia. El objetivo del movimiento de la mujer era el sacar a la luz die Kulturkraft, la fuerza cultural de la mujer y su posterior influencia social, así como la utilización de esta fuerza en la vida familiar. ${ }^{267}$

El término Kulturkraft no hace referencia a la mera vida cultural. Marianne Weber, miembro activo del BDF define como Kultur.

“(...) cada transformación y formación racional, determinada por el intelecto de un material procedente de la naturaleza y depende de, si pensamos en la creación de objetos, órdenes o asociaciones de ideas o bien nos referimos a la formación del

264 Johann Heinrich Pestalozzi (1746-1827) entiende la educación como el desarrollo de las fuerzas positivas que se encuentran en la naturaleza humana. El fundamento de la educación no se encuentra en el mero conocimiento de los libros sino en la búsqueda del sentido interno de los individuos de valores como el orden del universo, el amor y la fe. P. reclama el desarrollo de las fuerzas mentales, moralesreligiosas y corporales (Cabeza, corazón y mano). Estas se encuentra en el círculo familiar, especialmente en la relación madre-hijo/a y finalmente en el lazo con lo divino. Fue a finales del siglo XIX cuando las teorías de Pestalozzi comenzaron a aplicarse.

Friedrich Wilhelm August Fröbel (1782-1746) influido por Pestalozzi formula una teoría de la educación basada en una concepción mística y religiosa del universo. El descubrimiento de la naturaleza, el amor a los animales y a las plantas, el deporte, los trabajos artesanales. El individuo es una parte de la obra de Dios y una parte del proceso educador está dirigido a la sensibilización de éste como parte de la obra divina. Brockhaus Enzyklopädie in vierundzwanzig Bänden. 19 ed., F.A. Brockhaus, Mannheim, 1988.

265 Bussemer, Herrad-Ulrike: Frauenemanzipation und Bildungsbürgertum. Sozialgeschichte der Frauenbewegung in der Reichsgründungszeit, Weinheim-Basel, Beltz Verlag, 1985, p.245

266 Beckmann, Emmy (ed): Was ich hier geliebt. Briefe von Helene Lange, Tübingen, Wunderlich Verlag, 1957, p. 83

267 Ulich-Beil, Else: „Aus persönlichen Erinnerungen“, MÄDCHENBILDUNG UND FRAUENSCHAFFEN, Septiembre 1953 ( $n^{\circ}$ 9, año 3), p.11 
individuo vital en un proceso constante del ser, acostumbramos a diferenciar entre cultura objetiva y subjetiva, cultura personal."’268

Desde el punto de vista filosófico Kultur significa la plena realización del alma través del desdoblamiento de las potencialidades que yacen en ésta a las posibilidades en las "ciencias objetivas del intelecto", Objektive Geisteswerke, de la humanidad: arte, técnica, derecho y religión. Marianne Weber diferencia como ya lo había hecho Kant entre Kultur y Zivilitation, donde Kultur aparece unido al arte y la ciencia y Civilización a la cortesía y humanidad ("Nosotros somos cultivados por el arte y la ciencia sin embargo hemos sido civilizados a través de todo tipo de cortesía y urbanidad"). De igual manera comparte el valor educador moral que Kant y Herder en otros conceden a la cultura. Más tarde Hegel pondrá al mismo nivel Kultur y Geist. El Geist absoluto, síntesis del Geist objetivo y subjetivo, y la razón dominan la naturaleza interior y exterior, dando a ésta forma a través de la cultura. ${ }^{269}$

El movimiento de la mujer, en palabras de Marianne Weber se considera heredero de la tradición filosófica del idealismo alemán que defiende la libertad ética del individuo y el derecho de éste a desarrollar su personalidad:

"La lucha de la mujer moderna por la libertad y el bien se plantea como un camino doble que tiene como objetivo el descubrimiento de la naturaleza de la mujer. Primero como un camino hacia la autonomía ética que tienen como consecuencia la obtención del derecho moral y del deber como individuo femenino de ejercer la autodeterminación y autoresponsabilidad en todos los aspectos vitales. Con esta aspiración a una determinada actitud interior, (la mujer moderna) se reconoce como heredera del concepto ético de libertad del idealismo alemán, y de las ideas sobre la personalidad de Kant y Fichte y busca a partir del regalo adquirido algo nuevo." 270

El reino del Geist absoluto hegeliano no está cerrado a las potencialidades de la mujer:

"No hay ningún campo de actuación, ya sea en la técnica, en el derecho, en la moral o en el arte, en la ciencia, en la filosofía o en la religión, del que con razón se pueda excluir a la mujer."'271

Sin embargo este principio de autonomía, sittliche Autonomie aunque entendido como el último objetivo en la evolución de todo individuo, es sólo privilegio de unos pocos: no todos los individuos, hombres o mujeres no están capacitados para ello. Weber parte del principio de la existencia de seres menos o más preparados para poder desarrollar libremente el derecho de libertad, llegando a formular un principio de selección entre la élite y aquellos que obedecen las decisiones que toma ésta:

"Mientras que los grandes precursores de la autonomía moral sancionaban la tutela del individuo femenino a través del masculino, nosotros consideramos la obediencia a la ley que nace en nuestro propio pecho como el objetivo más elevado del desarrollo ético a la vez que está por encima de las relaciones

\footnotetext{
268 Weber, M.: Frauenfragen und Frauengedanken. Gesammelte Auffsätæe, op. cit., p. 238

269 Störig, H.J.: Kleine Weltgeschichte der Philosophie, Frankfurt am Main, Fischer, 1989 pp. 454-465. $4^{\text {a }}$ ed.

270 Weber, M.: Frauenfragen und Frauengedanken, op. cit., p. 137

271 Ibídem, p. 239
} 
personales y de la naturaleza moral de la mujer. Hombre o mujer, aquel que está preparado para la autoresponsabilidad es llamado a ésta. Aquellos a los que no se le concede poder disfrutar de esta libertad moral, y es posiblemente a la mayoría de la humanidad, tienen la obligación moral de la subordinarse activamente y de obedecer voluntariamente al liderazgo de autoridades electas."'272

Para la mujer existe algo más ,por encima de cualquier derecho de autonomía y desarrollo personal, que está estrechamente relacionada con la diferencia entre hombre y mujer:

"Sin embargo en la elección de su vida tiene una gran importancia que (la mujer) está determinada como ser biológico a ser madre, y esta diferenciación desde el punto de vista físico y psicológico se traduce de manera diferente que la paternidad en el hombre."273

Partiendo del concepto hegeliano sobre cultura y naturaleza, Weber se niega aceptar un entendimiento de la maternidad como simple proceso natural, sino que utiliza el concepto de geistig geformte Natur, para definir la esencia del género femenino. La mujer como ser "cultural", el género como construcción "cultural" diferencia a Weber de las tendencias conservadoras que pretendía devolver a la mujer a su lugar natural. Lo que Hegel entiende como el principio absoluto del Geist, es para Weber, die Gestaltung der geitigen und seelischen Atmosphäre, es la función, la tarea cultural de la mujer, que depende de su determinación especial, que la diferencia del hombre:

"Su alma llena de sentimiento, su cálida apariencia que se transforma en amor, bondad y pura convicción, pero también su forma espiritual, su influencia en la cultura, que revaloriza la sencillez y la ausencia de hechos notables de la vida cotidiana. Estas son las tareas de creación que le corresponden a la mujer."’274

La tarea de la mujer en la familia, en la educación de los hijos es una función "cultural" que pertenece a las elevadas alturas de la expresión del Geist. Como modelos a imitar aparece una lista completa de las representantes de la burguesía internacional: la lady inglesa y americana, la mujer de las clases medias francesas, mujeres cultivadas, columna de la renovación moral de la familia.

De igual manera critica la concepción antropocéntrica de la filosofía que establecía paralelos entre individuo y hombre y la definición que hace el hombre de su propia identidad a partir de la diferenciación consciente respecto al género femenino:

"Donde quiera que el hombre sienta una deficiencia, una necesidad, un cambio de su ser específico masculino, vuelve entonces a la mujer y exige de ella la realización de lo que a él le es difícil de conseguir. (La mujer) tiene como obligación de destruir la intranquilidad de su ser (del hombre) en su reposada naturaleza, (ésta tiene que contrarrestar) la especialización, la totalidad de la existencia masculina con su sacrificio, la objetividad con su entrega a lo personal, la perfección de las obras con la perfección del ser, para que a través de este reparto de tareas, el ser individual logre su totalidad."'275

$\begin{array}{ll}272 & \text { Ibídem, p. } 138 \\ 273 & \text { Ibídem, p. } 138 \\ 274 & \text { Ibídem, p. } 240 \\ 275 & \text { Ibídem, p. } 141\end{array}$ 
El hombre construye la identidad femenina en función de las carencias que éste observa en su personalidad y crea en la "otra" una segunda identidad de si mismo, un segundo yo lleno de deseo y anhelo.

La tarea de la mujer es intentar unir en una "forma sintética" el principio de la sittliche Autonomie, llamada por Weber la allgemeinmenschliche Bestimmung, destino o determinación general, y un segundo principio denominado, Sonderbestimmung, la determinación extraordinaria, como madre y mujer. La armonía de los principios conduce al desarrollo perfecto y absoluto de la personalidad femenina. El marco donde tiene lugar la unión armónica de los principios es para Weber el matrimonio.

Weber señala también el carácter temporal del movimiento. Este desaparecerá una vez que las condiciones para el desarrollo completo de la personalidad de la mujer se cumplan.

El concepto de geistige Mütterlichkeit es utilizado por Gertrud Bäumer, Marianne Weber, Alice Salomon contra el mito del instinto maternal defendido por las antifeministas burguesas y contra el mito de la maternidad puramente biológica, y sobre todo como ideal de emancipación. La utilización de este concepto durante el nacionalsocialismo es interpretado por algunos autores como un símbolo de resistencia. ${ }^{276}$

Sin embargo esta interpretación no deja de estar influida por la polémica surgida durante los primeros años de la discusión feminista donde la maternidad se presentaba como forma específica de protesta femenina contra la masculinización de la sociedad. No creemos, sin embargo que las mujeres protestantes, o Gertrud Bäumer observaran la maternidad como medio contra la "masculinización de la vida política". Por el contrario la diferenciación genérica era la base de su pensamiento. Se puede hablar de motivos morales o religiosos que les impedían aceptar la biologización de la maternidad, o simplemente de la concepción de individuo o persona que ellas tenían que no tenía nada que ver con la imagen organicista y funcionalista de los nacionalsocialistas.

En cierto modo, el concepto de geistige Mütterlichkeit no era aplicable a todas las mujeres, sino una "gracia" que no toda mujer recibía y que al estar unido a la educación Bildung, dependía de las facultades intelectuales de cada mujer, y de la utilización de éstas en el desarrollo individual de cada una. Se deja entrever en este planteamiento una cierta superioridad social y conciencia de clase respecto a „la masa“ y un rechazo de las ideas socialistas.

Helene Lange se define por ejemplo como demócrata, pero no cree en la inteligencia de las masas, sino que piensa que estas deben están dirigidas por personas competentes y más capaces que ellas. ${ }^{277}$

Agnes von Zahn-Harnack, dirigente del movimiento de mujer, es entre las mujeres de la segunda generación, la que más contribuye a diferenciar este término. Como Bäumer pertenece al consejo del BDF. Tiene una educación universitaria: teología, filología inglesa y alemana, con tesis doctoral, y pertenece al DDP. En 1926 participa en la fundación del Deutsche Akademikerinnenbund y es hasta 1933 su primera consejera. En su obra Die Franenbewegung. Geschichte, Probleme, Ziele 278 publicada en 1928 es un compendio de las ideas sobre la mujer del movimiento liberal-conservador de la mujer. Para Zahn-Harnack la maternidad es el centro de la vida de la mujer: El movimiento de la mujer aparece definido como un movimiento de la maternidad. La maternidad no se refiere a la mera producción biológica, sino al trabajo cultural, social y político, cuyo principio es la humanización de todos los sectores de trabajo donde la mujer es activa. ${ }^{279}$

276 Schmidt-Waldherr, Hiltraud: „Pervertierte Emanzipation der Frau und die Organisation von weiblicher Öffentlichkeit im Nationalsozialismus“, en: Schaeffer-Hegel, Barbara: Frauen und Macht. Der alltägliche Beitrag der Franen zur Politik des Patriarchats, Centaurus, Pfaffenweiler, 1988, p.10.

277 Beckmann, Emmy (ed): op. cit., p. 84

278 von Zahn-Harnack, Agnes: Die Frauenbewegung. Geschichte, Probleme, Ziele, Berlin, 1928

279 Ibídem, p.18. 
La maternidad es una cualidad donde la mujer encuentra el sentido de su verdadera feminidad. Por lo tanto el aborto es von Zahn-Harnack un atentado contra la naturaleza esencial de la mujer. Significa la esclavitud para la mujer y la libertad para el hombre. La mujer se convierte en un mero objeto de deseo expuesto a la arbitrariedad del éste:

"La maternidad se encuentra en el centro de la vida de la mujer; debido a ella se aguantan desde hace siglos voluntaria y pacientemente pequeños y grandes dolores, y limitaciones, si al lado de la maternidad aparecen éstos sin importancia y pasajeros." 280

La relación entre madre e hijo pierde su carácter material y adquiere un carácter espiritual. Esta relación perdura por encima de cambios políticos, de épocas. La madre vela por la tradición, por la historia de la familia, el mantenimiento de las costumbres en el seno de la familia: Darum ist sie die Hüterin der Tradition; darum bängt sie am Überlieferten, darum begegnet sie allem Neuen, was in die Familie einzudringen droht, mit Mißtrauen. En función de su estado especial justifica von Zahn-Harnack la postura conservadora desde el punto de vista político de las mujeres y su inclinación por partidos de derecha. Conservar la tradición no es, sin embargo, a lo que aspira von Zahn-Harnack. La madre debe estar en un proceso de cambio, de descubrimiento personal, de autoeducación. Esta educación tiene su paralelo en la educación del pueblo en los principios democráticos. Una educación en la libertad, en la igualdad del individuo y en la selección de los mejores.

Durante los años veinte esta imagen de la mujer entra en conflicto con los nuevos ideales de feminidad que la revolución de la introducción de las mujeres en la vida laboral había ocasionado. El conflicto tiene lugar en relación a la moral sexual: aborto, prostitución, amor libre. Una actitud que entre las mujeres liberal-conservadoras es criticada como materialista., en relación con la Unión Soviética, el comunismo o el socialismo. A finales de los años veinte trata Marianne Weber las obras de Romano Guardini sobre ética sexual, donde el matrimonio católico y la virginidad se presentan como los mayores objetivos de la mujer. También von Zahn-Harnack critica la "nueva ética" que rechazaba el matrimonio como institución social y ética. ${ }^{281}$

La influencia de la actividad de la mujer expresada en su "maternidad espiritual" contrarresta el sentimiento de crisis, Kultupessimismus, que se apodera de esta generación de mujeres. La discusión sobre los conceptos cultura y civilización se traduce en una visión negativa de los cambios estructurales que estaba viviendo la sociedad alemana: tecnificación, alejamiento del individuo de la naturaleza. Estos cambios se unen a la valoración de la derrota de Alemania en la segunda guerra mundial, como decadencia del Geist alemán:

"La catástrofe mundial de la guerra se nos aparece hoy en día como el juicio final de la época de la civilización técnica. Naturalmente no en el sentido de que nosotros nos sintamos juzgados, porque somos los vencidos, sino en el sentido de un desmoronamiento de las circunstancias materiales de una época." 282

Bäumer señala como centro del problema la contradicción entre alma y civilización, los anhelos del individuo y el progresivo distanciamiento de éste de sus orígenes naturales y la aparición del microcosmos de la sociedad de consumo:

\footnotetext{
280 Anders, Marga; Reicke, Ilse: op. cit., p. 20

281 von Zahn-Harnack, Agnes: op. cit., p. 35

282 Bäumer, G.: Die Frau in der Krisis der Kultur, Berlin, Herbig, 1927, p. 5
} 
"A lado de la técnica aparece el segundo enemigo de la espiritualidad que convierte a los individuos en siervos: el capitalismo y la economía mercantil. Ambos crean una curiosa combinación de supuesta libertad y auténtica dependencia: una total insegura existencia en un orden perfectamente organizado." 283

El individuo se siente sólo en la nueva realidad, dónde sólo cuenta lo físico y lo sexual. Citando a Spengler se llora la muerte del Geist, la decadencia de la cultura europea:

"Sería también imaginable (Spengler), que la cultura misma, la capacidad creadora occidental, hubiera agotado todas sus energías. Que el espíritu universal (abendländischer Geist), como por ejemplo aparece en Goethe, se hubiera extenuado, no pudiera crear nada más ni se hiciera con las almas y las llenara de él, es como si hubiera perdido su fuerza engendradora. Esto es algo diferente. Es la verdadera muerte. Y aquel que piensa o siente esto, dirige la vista hacia el este y espera el renacimiento de Europa a través de los campesinos rusos." 284

Sin embargo en esta soledad existe, continúa Bäumer, la esperanza, el sueño, el anhelo de una existencia armónica que se manifiesta en el humanismo de Herder, Goethe y Hölderlin: una relación religiosa con el cosmos. Según Bäumer las mujeres sufren de una manera especial esta crisis de la civilización:

“(...) esta civilización con sistema de reparto de trabajo y especialización, con la retirada del poder vital de la familia, la extensión de la vida pública, ha estrechado y reprimido el círculo de influencia de las mujeres, sin crear otros ventiles dónde éstas pudieran desplegar su influencia espiritual." 285

Junto a las consecuencias del proceso de industrialización como elemento de opresión de la mujer, Bäumer añade también el abandono del verdadero sentido de la sexualidad: la maternidad. La mujer pierde su dignidad y su integridad cuando deja correr libremente su instinto y pierden su independencia respecto a la sexualidad masculina.

La dificultad de la mujer en aceptar esta nueva época radica en su naturaleza. Según Bäumer ésta no está tan preparada para las etapas de crisis como el hombre ya que ésta se encuentra arraigada a lo eterno. Su punto fuerte no es la conquista de nuevos terrenos, sino en la construcción silenciosa de lo que ya ha sido conquistado:

"Su naturaleza es más fuerte en una "época conservadora", ya que sus fuerzas espirituales no están orientadas a la estructuración, a la construcción de sistemas, en una palabra, no son arquitectónicas."286

La salida de este círculo viciosos de inactividad y destrucción es un camino de emancipación. Sin embargo Bäumer no se refiere al movimiento de la mujer, en su concepción anterior de reivindicación pública de los derechos de la mujer, sino que la emancipación aparece definida

\footnotetext{
283 Ibídem, p.6

284 Ibídem, p. 9

285 Ibídem, p. 11

286 Ibídem, p. 12. El término architektonisch aparece también en la obra de Rosenberg para definir la naturaleza masculina.
} 
como un camino hacia la interioridad de la mujer, un camino hacia la búsqueda de la verdadera fuente de su identidad y existencia: el amor. Bäumer propone un camino a través de la mística donde las mujeres redescubran el sentido de la vida:

"La sensibilidad respecto al vacío de la vida personal, en el trabajo, en el placer, en el arte, en el periodismo en la vida pública, no había hecho mella todavía en la generación de los últimos años del siglo XIX, crece continuamente entre nosotros. En una relación nueva, vital y metafísica con la naturaleza el sentimiento para lo verdadero se refuerza y se aclara; , el alma mutilada y sin aire, gana en placer y bien en la fuerza de la liberación de lo inútil, de las necesidades mundanas; en la voluntad de la simplificación de la vida exterior, ésta vuelve a revivir, a mostrar movimiento y crece en una tierra sana con un instinto para lo auténtico (...).”287

\subsubsection{El internacionalismo y movimiento de la mujer.}

1920 es una fecha clave para el desarrollo del carácter internacionalista del movimiento conservador. En 1920 abandona Alice Salomón la Federación, con motivo de un encuentro del Internationaler Frauenbund al que se oponen las otras miembros de la fracción alemana. No obstante Salomon sigue trabajando para la organización internacional e incluso colabora con el ministro de asuntos exteriores alemán, Ulrich Graf, donde trabaja para él con conferencias en el extranjero sobre Alemania con objeto de mejorar la imagen de ésta en el exterior. En sus memorias comenta Salomon sobre las mujeres del BDF:

"No debería ser juzgadas por sus actos después de la derrota alemana, cuando todavía la amargura de la pérdida estaba presente. Más tarde lamenté que se convirtieran en víctimas de Hitler: Aunque desde el punto de vista nazi eran arias, y no fueron expulsadas del país tienen una parte en la culpa colectiva del país y deben ser castigadas por ello." 288

En 1930 tienen lugar elecciones a la presidencia del ICW. Lady Aberdeen propone a Salomon como su posible sucesora. Sin embargo el BDF se opone debido al origen judío de ésta, lo que comprometería al Bund en Alemania debido al clima de intolerancia. ${ }^{289}$

\subsubsection{Antisemitismo y movimiento de la mujer}

Las relaciones del $B D F$ con el $J F B{ }^{290}$ son importantes a la hora de definir rasgos antisemitas en la Federación. El JFB pertenecía al BDF desde su fundación. La línea que defendía se

\footnotetext{
287 Ibídem, p. 8

288 Salomon, Alice: Charakter ist Schicksal. Lebenserinnerungen, Weinheim/Basel 1983, p.189

289 Ibídem, p. 203

290 La organización de mujeres judías fue fundada en 1904 por Bertha Pappenheim. Contaba con unos 50.000 miembros y desde un principio se integró en el movimiento burgués de la mujer, hasta 1933. Sus miembros eran en su mayoría amas de casa pertenecientes a la clase media.
} 
identificaba en su mayoría con el BDF. A partir de la primera guerra mundial, participa el JFB en el servicio femenino pero después de la guerra trabaja estrechamente con las organizaciones internacionales de mujeres para la paz, y se alía a la línea pacifista de Salomón, Lüders. En 1927 la organización ingresa en el WILPF (Women's International League for Peace and Freedom), una actitud no vista con buenos ojos por el BDF dónde las posturas nacionalistas eran mayoría.291

A finales de los años 20 la organización cuenta con el apoyo de Agnes von Zahn-Harnack que trabaja activamente contra prejuicios antisemitas y declara su apoyo incondicional al Bund. Sin embargo la política del Bund estaba dirigida fundamentalmente a defender los derechos de la organización, los derechos de las mujeres alemanas, sin hacer hincapié en la amenaza que los nazis suponían para las mujeres. ${ }^{292}$ La organización de mujeres judías se queja del "antisemitismo latente" que existía en el BDF. Kaplan señala que la situación de aislamiento de las mujeres judías en el $B D F$, donde tenían la impresión de ser aceptadas como mujeres pero no como miembros de una comunidad religiosa, a diferencia de las protestantes y las católicas que no pertenecían a la organización pero que tenían mejores relaciones. ${ }^{293}$ Un caso de clara actitud antisemita lo representa Alice Salomon una de la mujeres más preparadas del movimiento y teóricamente la sucesora de Gertrud Bäumer al mando del BDF. En 1919 Sin embargo a pesar de su conversión al cristianismo sigue siendo vista como judía, causa por la que el $B D F$ no la acepta como dirigente de la organización. Greven-Aschoff explica este suceso como una concesión al DEFB (Deutsche Evangelischer Frauenbund), que se oponía a la elección de Salomón. Sin embargo en enero de 1914 Paula Müller y Gräfin Göben comunican a Bäumer que han cambiado su opinión y estarían dispuestas a apoyar a Salomón. Pero Bäumer ya había tomado una decisión y convencido a Marianne Weber para que se hiciera cargo de la organización. Bäumer argumentaba que no sería malo tener a una mujer casada al frente de la organización y sería una ventaja táctica que no fuera ninguna judía. ${ }^{294}$

Marion Kaplan señala las contradicciones del BDF al defender por una parte la igualdad de las mujeres y por otra establecer claras diferencias respecto a las miembros de religión judía:

"Como mujeres compartían experiencias similares que iban más allá de las fronteras étnicas y religiosas, y sin embargo sufrían la separación que parecía haber sido superada a través de la identidad como mujeres y que sin embargo tomaban forma a través del racismo." 295

Otro de los casos donde las dos organizaciones entran en conflicto se refiere a la polémica iniciada por Alice Bensheimer, secretaria del $B D F$ y también miembro del $J B F$, con ocasión de una recención bibliográfica en el periódico de la organización de mujeres protestantes. En ésta se apelaba a la superación del verjudeter Liberalismus, liberalismo filosemita, como prerrogativa de la superación de crisis que sufría el pueblo alemán. A partir de 1920 el proceso de radicalización de la Federación se une a un aumento de tendencias antisemitas representadas fundamentalmente por los grupos de mujeres de amas de casa y mujeres trabajadoras del

291 Kaplan, Marion: „Schwesterlichkeit auf dem Prüfstand. Feminismus und Antisemitismus in Deutschland 1904-1938“ en: FeministisCHE STUDIEN, 1984 (n³), p.132

292 Ibídem, p. 133

293 La historiadora Marlis Dürkop cita y documenta en un artículo de gran interés siete casos ejemplares donde se manifiestan tendencias antisemitas en el BDF. Dürkop, Marlis: „Erscheinunsformen des Antisemitismus im Bund Deutscher Frauenvereine“, en: FEMINISTISCHE STUDIEN, 1985 (n²1), p. 140-149

294 Ibídem, p. 145

295 Kaplan, Marion: „Deutsche und Jüdische Frauenbewegung 1933“, COURAGE, Febrero 1984 (año 9), pp.43-44 
campo. ${ }^{296}$ Elisabeth Boehm una colaboradora de DIE FRAU perteneciente al ala conservadora de las amas de casa alemanas señala que el interés de su organización al ingresar en el BDF era liberar a ésta de la tiranía de las mujeres judías. ${ }^{297}$

Esta situación se refleja en la hoja informativa que publica mensualmente el BDF, donde en el número de noviembre de 1931 se hace eco de la creciente inseguridad del JBF. La organización de mujeres judías convoca una reunión del consejo general del BDF para tratar el tema del creciente antisemitismo, donde se invita a mujeres pertenecientes a las organizaciones confesionales. En la reunión se proponen trabajar con mujeres de otras confesiones para luchar contra los prejuicios existentes. ${ }^{298}$

Con la toma de poder de los nacionalistas en 1933 empieza la etapa más difícil de las relaciones entre ambas organizaciones. Unos días antes de la disolución del BDF, abandona el $J F B$ la organización ante la imposibilidad de trabajar conjuntamente. ${ }^{299}$ Kaplan describe la decepción que sufrieron de las mujeres judías en relación con las mujeres del BDF: se interrumpen contactos, el $B D F$ se aferra a su carácter nacional, a su intervención en la primera guerra mundial etc. La última dirigente del JFB comenta sobre esta situación:

“¿Dónde estaban las mujeres alemanas entonces? Si ellas poco después del 9 de noviembre de 1938 hubieran encontrado para mi las mismas palabras que encuentro en sus cartas de ahora (1955), hubieran sido para mí tan importantes. Ninguna de las supuestas amigas alemanas (...) encontró su camino hacia nosotras. Esto no tenía, desgraciadamente, que ver con un fenómeno personal. Empleadas, (...) trabajadoras, la gente de mi sector electoral, las personas que recibía asistencia social, no escondía su amistad, ellos sabían dónde nos podían encontrar, y a plena luz del día. Y creo que ninguno de ellos sufrió ningún tipo de problema."300

La organización sigue existiendo en la clandestinidad y se organiza para la supervivencia. Curiosamente aparece después la leyenda de que el BDF se diluyó por que se negó a expulsar a los miembros judíos de la organización, tal y como lo pedían los nacionalsocialistas. La verdad es que cuando sucede esto la organización era ya judenfrei. ${ }^{301}$

\subsection{El movimiento confesional de la mujer}

\subsubsection{Las organizaciones de mujeres protestantes}

La literatura sobre los grupos confesionales de mujeres durante la República de Weimar y durante el nacionalsocialismo es bastante escasa. La mayoría de los trabajos existentes sobre mujeres se centran, como hemos visto con anterioridad, en los grupos de mujeres de tendencia socialista o liberal, las asociaciones de mujeres confesionales permanecen, sin embargo,

\footnotetext{
296 Schwarz, Christina: Die Landesfrauenbewegung in Deutschland. Zur Gescbicbte einer Frauenorganisation unter besonderer Berücksichtigung der Jahre 1898 bis 1933, Mainz, Gesellschaft für Volkskunde in Rheinland-Pfalz, 1990, p. 254

297 Ibídem, p. 254

298 Nachrichtenblatt des Bundes Deutscher Frauenvereine, Noviembre, 1931, n ${ }^{\circ} 11$, p. 94

299 Kaplan, Marion: „, Schwesterlichekeit...“, op. cit., p. 136

$300 \quad$ Ibídem p. 136

301 Ibídem p. 148
} 
ignoradas. Resulta no obstante, extraño la falta de estudios sobre este tema, teniendo en cuenta el gran número de mujeres afiliadas a los grupos de mujeres protestantes. A finales de la República eran casi dos millones de mujeres las que pertenecían a los diferentes grupos de las organizaciones protestantes. ${ }^{302}$

La aparición de los primeros grupos de mujeres protestantes que se organizan dentro del contexto del movimiento de la mujer está estrechamente relacionada con las discusiones que se producen dentro del protestantismo finales del siglo XIX. A. Stoecker, L. Weber, A. von Harnack y A. Wagner fundan en 1890 el Congreso social protestante donde se discute la posición del protestantismo ante la cuestión social y el problema proletario. ${ }^{303}$ Dentro de este clima de renovación dentro del protestantismo alemán nace un grupo de mujeres, motivadas por la situación social de las trabajadoras. Elisabeth Gnauck-Kühne representa por primera vez al grupo en 1895 en sexto congreso social protestante. Hasta entonces en manos de teólogos y pastores protestantes, la intervención Gnauck-Kühne en el congreso levanta una gran convulsión:

„En un vestido negro, con un sombrero negro y velo retirado hacia atrás, llegó al podio. Los que estaban presentes en la sala no olvidaran el fuerte efecto, como esta pálida mujer con una voz melódica pero enérgica empezó a hablar, no olvidarán como la asamblea, formada en su mayoría por pastores, la observaba. Ya en el primer cuarto de hora, la oradora dominaba el congreso y el aplauso que ya durante su discurso se escuchó más de una vez en la sala no tocaba a su fin al terminar ésta con su exposición."’304

En este contexto nace la idea de crear una organización de mujeres protestantes que se preocupara temáticamente del problema social femenino. La influencia de Gnauck-Kühne dentro de las organizaciones de mujeres protestantes se ve interrumpida en 1900 con la conversión de ésta al catolicismo y su posterior dedicación a la Federación de mujeres católicas alemanas.

\subsubsection{La Federación de mujeres protestantes alemanas}

La historia de los grupos de mujeres protestantes está estrechamente unida al DeutschEvangelischer Frauenbund, o Federación de mujeres protestantes alemanas. Esta organización fue fundada en 1899 por Paula Müller-Ortfried. Su intención era crear un nuevo marco ideológico donde la mujer protestante, por medio de sus atributos naturales, encontrara un ámbito donde expresarse y encontrar su verdadera identidad. Agrupa a mujeres provenientes de círculos conservadores protestantes y nace desde principios benefactores y sociales:

"Para muchas mujeres cristiano-conservadoras resulta cada vez más clara, teniendo en cuenta las actuales circunstancias sociales, la necesidad de crear un

302 Mybes, F.: Geschichte der Evangelischen Frauenhilfe in Quellen, Gladbeck, Schriftenmissions-Verlag, 1975; Kaiser, J.-C.: Frauen in der Kirche. Evangelische Frauenverbände im Spannungsfeld von Kirche und Gesellschaft 18901945. Quellen und Materialien, Düsseldorf, Schwann, 1985

303 Galling, K. (Ed.): Die Religion in Geschichte und Gegenwart. Handwörterbuch für Theologie und Religionswissenschaft, Tübingen, J.C.B. Mohr, 1958, $3^{\text {a }}$ ed., Volumen n² 2, p.794

304 Se trata de un pequeño folleto editado por la Federación de mujeres católicas alemanas. Desgraciadamente no consta ningún tipo de información sobre las fuentes o material de archivo utilizados para la elaboración de la biografía de Gnauck-Kühne. 
régimen organizado de previsión social y la unión de las mujeres para la mejora de la situación económica actual." 305

Las miembros del DEF pertenecían en su mayoría a la clase media alta de las grandes ciudades. En su programa de 1907306 aparece definida la naturaleza de la organización. En primer lugar se trata de una organización de base religiosa en el sentido de la interpretación de la revelación de Dios, sin embargo rechaza todo tipo de dirección eclesial así como la adscripción a todo tipo de partido. Sus objetivos son fundamentalmente dos: la solución de la cuestión de la mujer que se traduce en la creación de las circunstancias ambientales que logren la madurez social y política de la mujer y su independencia de pensamiento; la mejora de las condiciones de trabajo y segundo el derecho a un trabajo digno. Un segundo aspecto de los objetivos de la Federación es la renovación religiosa y moral de las costumbres y contribuir a la mejora de la vida social y económica de la sociedad.

Desde su fundación hasta 1933 la Federación de mujeres protestantes atraviesa por una serie de etapas que van desde un feminismo moderado confesional, muy parecido a la línea del ala moderada del $B D F$, hasta la defensa de valores tradicionales y conservadores para las mujeres. ${ }^{307}$

Hasta la primera guerra mundial el movimiento de la mujer protestante trata casi los mismos temas del feminismo laico: el problema de las costumbres morales, la cuestión social que trataba fundamentalmente de la lucha contra la pobreza y la mejora de la situación de las mujeres trabajadoras y el campo de las reivindicaciones de tipo político, jurídico y social. En el primer caso el $D E F$ se muestra contrario a una reglamentación de la prostitución y de la abolición de la penalización del aborto. Conjuntamente con la línea moderada del BDF se oponen al programa de las feministas radicales, con sus reivindicaciones al amor libre, el reconocimiento de las madres solteras, sus acciones de reparto de anticonceptivos, etc.

Al mismo tiempo se lucha por la mejora de oportunidades de formación de la mujer, su introducción en el mundo del trabajo.

Aunque la Federación utiliza el término Frauenbewegung, movimiento de la mujer, para definir sus intereses y objetivos, no lo utiliza de la misma manera. Mientras que el movimiento laico centra sus actividades en el terreno de la educación y la formación, así como en la lucha por la igualdad de la mujer. Las mujeres protestantes entienden el "Movimiento de la mujer" como un servicio "al prójimo" que no tiene nada que ver con las reivindicaciones de igualdad de las organizaciones laicas.

El trabajo de la organización está organizado en cinco campos de actuación: ideológicamente se muestra partidario de la posibilidad de formación educativa y profesional de la mujer, de escuelas de ampliación o perfeccionamiento de conocimientos, de una reforma de las escuelas superiores femeninas, la apertura del acceso a la Universidad para las mujeres, y la admisión de ésas en escuelas superiores y academias del arte. En el aspecto judicial reivindica la desaparición de disposiciones legales que iban contra los intereses de las mujeres, la ampliación de los derechos y deberes de la mujer, ampliación de la legislación sobre seguros para las mujeres, apertura de los tribunales en casos relacionados con los intereses de éstas y de la infancia, derecho del voto femenino en representación de los intereses profesionales: cámaras de comercio, etc. En el campo de la economía y de la sociedad se muestran a favor de la apertura

\footnotetext{
305 Programa del Deutsch-Evangelischer Frauenbund, 1903, EZA, 7/3989

306 Kuhn, Annette; Kaiser, Jochen-Christoph: Frauen in der Kirche. Evangelische Frauenverbände im Spannungsfeld von Kirche und Gesellschaft 1890-1945. Quellen und Materialien, Düsseldorf, Schwann, 1985 pp. 50-51. Programa del Deutsch-Evangelischer Frauenbund, en: Handbuch zur Frauenfrage, 1907, p. 46 y s.

307 Ursula Baumann señala el contenido emancipador del movimiento protestante de las mujeres, especialmente en sus inicios: Protestantismus und moderne Gesellschaft. „Frauenfrage“ und Frauenbewegung in der evangelischen Kirche Deutschlands 1850-1920, Berlin, Dissertation, 1990
} 
del mercado laboral para la mujer, la organización de las mujeres para defender sus intereses profesionales y económicos, derecho a un salario justo y condiciones de trabajo justas. En el terreno moral el matrimonio es sagrado, así como la familia es considerada como la piedra angular de la moral social, la misma moral para ambos géneros basada en las enseñanzas cristianas y lucha contra reglamentación y la confinación de la prostitución.

En el terreno práctico se crean Escuelas Sociales, a imitación de las escuelas fundadas por las mujeres del movimiento de la mujer, para mujeres donde éstas pueden conseguir un título reconocido como trabajadoras sociales. Estas son formadas como enfermeras, comadronas, maestras, consultoras, y especialistas en alimentación etc. La primera escuela tiene su sede en Hannover (1905), a esta le siguen las fundaciones de las escuelas de Köln (1916) y Berlin (1917). Para facilitar la búsqueda de trabajo se crea centros de contratación de empleo con bolsas de trabajo.

Existen comisiones de educación donde se ofrecen cursos y seminarios donde las mujeres pueden profundizar sus conocimientos sobre temas económicos, industriales, científicos y sociales. A ello hay que añadir un grupo de auxilio cristiano, donde se plantean estrategias para cristianizar la sociedad, un grupo para la mejora de la moral pública y otro para la lucha contra el consumo de alcohol, así como una asesoría jurídica.

En la teoría el movimiento protestante es partidario del voto pasivo femenino, aunque en la práctica renuncia por respeto a los intereses de la patria, debido a la inmadurez política de las mujeres. Dentro de los principios protestantes la mujer debería ser educada para que pudiera decidir en libertad y en relación a su conciencia. Su función en la sociedad se entiende como una lucha contra el instinto y la degradación de las costumbres morales, convirtiéndose la mujer en factor de espiritualización de la sociedad.

Otro de los puntos más importantes de la acción de la Federación es la organización del trabajo social femenino. La imagen de la mujer como benefactora e instrumento de renovación espiritual y social, tiene la consecuencia lógica de que ésta manifieste sus cualidades en ámbitos de trabajo donde „el amor al prójimo“ este presente. El surgimiento del trabajo social se revela a primeros de siglo en Alemania como un fenómeno exclusivamente femenino. Este trabajo social abarcaba el mantenimiento de hospitales, guarderías, residencias de ancianos, etc. en manos de la iglesia y con mano de obra femenina. No se trata sin embargo de un „trabajo social" en el sentido de caridad, sino de un trabajo remunerado:

„La actividad caritativa disminuye el dolor, cura la herida, practica la asistencia social preventiva. La actividad social, por el contrario, intenta tapar las fuentes de la necesidad. Intenta apoyar a toda una clase, a todo un estado. Intenta luchar, a través de instituciones sociales, contra la miseria y la necesidad. Por eso es el trabajo social para nuestro moderno mundo actual, al lado de la caridad, tan imprescindible, tan eminentemente importante." 308

Otro campo social donde la Federación se muestra extraordinariamente activa es el grupo de los sindicatos de mujeres, donde apoyan las reivindicaciones para una reducción de la jornada laboral a diez horas (las asociaciones de mujeres socialistas pedían ocho), y la igualdad de salarios. La afinidad de principios de la Federación protestante con las organizaciones liberalconservadoras es todavía notoria en 1913 En la declaración de principios que la organización saca a la luz en este mismo se constata la similitud de las peticiones con el movimiento laico:

- Formación de la mujer, educativa y profesional

- Reforma de las escuelas superiores femeninas 
- Apertura de las universidades para las mujeres

- Desaparición de leyes que vayan contra los derechos de la mujer

- Ampliación de los derechos y deberes de las mujeres en las comunidades politicas y religiosas.

- Ampliación de los seguros para mujeres

- Ampliación de las posibilidades de trabajo para la mujer

- Organización de la mujer en organizaciones que defiendan sus intereses

- Mejores salarios, igual salario que los bombres

- Apoyo al matrimonio y a la familia como pilar de las buenas costumbres y del bienestar

- Igualdad moral para ambos géneros

- Lucha contra la reglamentación y control de la prostitución.

No obstante, por esta misma fecha se empiezan a agudizar las diferencias entre las partidarias de un protestantismo cultural, Kulturprotestantismus, que buscaba el contacto con las mujeres del BDF y las defensoras de una línea conservadora confesional, defendida por Paula Müller-Ortfried donde los aspectos nacionales y religiosos tienen gran relevancia.

Estas posturas conservadoras encuentran su legitimación con el estallido de la primera guerra mundial. Hombres y mujeres son integrados en diferentes esferas en la lucha, y las mujeres se sienten partícipes de ésta. Lo mismo ocurre con la derrota. No sólo atenta contra su sentimiento nacional sino que tienen de nuevo los privilegios recibidos en ausencia de la población masculina. A todo ello se une la ruptura con la tradición que trae consigo la llegada de la república de Weimar. La tradición monárquica, la unión de la iglesia protestante con la monarquía. Todo ello trae un rechazo de los valores democráticos y desarrollo de una conciencia nacional, unida a los valores protestantes y al movimiento de la mujer. Se utilizan metáforas corporales, como la violación, en relación con las tropas francesas para describir la situación tras la guerra, y se buscan símbolos conocidos, como el de la maternidad unido a la vida, y a la esperanza. Esto es según Carrol Smith-Rosenberg típico en fases de cambio social Umbruch, en las que las relaciones de clase y de género cambian y ponen en duda el control social. Especialmente grupos que debido a la transformación social y económica se sienten olvidados, impotentes e intentan con ayuda de sistemas simbólicos superar la situación. Metáforas sexuales son utilizadas para discutir los cambios sociales y políticos, el cuerpo se asimila al cuerpo de la nación. ${ }^{309}$

Las mujeres se identifican con la nación porque ésta representa los valores espirituales que definían a éstas. Se empieza a utilizar el término de salvación nacional, Nationale Rettungsaufgabe o Nationale Wiedergeburt. Esta postura conservadora llevará el peso de la organización y conseguirá dejar su influencia en los temas más brisantes de los años de la república. En primer lugar el tema relativo a las costumbres morales, la Sittlichkeitsfrage. Este problema aparece unido inevitablemente al tema de la prostitución. La Federación se opone a todo tipo de reglamentación o liberación propuesta por los grupos más liberales de mujeres. La lucha contra la prostitución se entiende dentro de la campaña por la lucha contra la nueva moral o la nueva ética propagada por los grupos más radicales. Las mujeres protestantes ven en esta avanzada un peligro para los valores de la mujer. Temas como el apoyo a madres solteras, reparto de anticonceptivos o la interrupción del embarazo levantaron fuertes críticas en la organización protestante. „Anarquía de las costumbres“, „individualismo desmesurado“ eran términos que utilizaban las mujeres protestantes para afrontar los nuevos tiempos. ${ }^{310}$

309 Smith-Rosenberg, C.: Disorderly Conduct. Visions of Gender in Victorian America, New York, Alfred A. Knopf, 1985, p. 44

310 Baumann, U.: „Religion und Emanzipation. Konfessionelle Frauenbewegung in Deutschland 19001933“, Tel AVIVER JAHrbuCH FÜR DEUTSCHE GESCHICHTE, 1992 (año 21), p.180 
La polémica en torno a estos temas había llevado ya en 1918 a la ruptura con el BDF. La causa de la separación es una memoria publicada por el $B D F$ que requería el tratamiento de la cuestión del voto femenino en la reforma de la constitución. El catorce de marzo de 1918 tiene lugar el abandono del $D E F$ de la organización laica de mujeres alemanas. ${ }^{311}$

A la ruptura sigue en 1919 una nueva declaración de principios donde aparecen enumerados los objetivos e intereses de la organización. Mientras que en el programa de 1903 las líneas de actuación se centraban en el reconocimiento de pertenecer al movimiento de la mujer, en 1909 se incide en el aspecto religioso de la organización y en su carácter de renovación moral. Así se reivindica la familia como célula sagrada de la sociedad, la limpieza moral del hombre y la mujer, el cuidado del carácter nacional en la escuela, el sentido de responsabilidad en el trabajo femenino, la formación de la madre, la elección por parte de las mujeres un puesto de trabajo que este de acuerdo con su sexo; el mismo sueldo para el mismo trabajo, el mantenimiento de la propiedad privada, la asistencia a los más necesitados, la lucha contra la inmoralidad, el alcohol, etc.

A todo ello se une el deseo de la Federación de ser financiada por la Iglesia Protestante. Hasta entonces se había logrado el mantenimiento de la asociación gracias a las cuotas que pagaban los miembros y a iniciativas de carácter privado. Las razones de esta renuncia a la independencia de la jerarquía eclesiástica tienen que ver con los nuevos objetivos de la organización. La llegada de la república, y con ella la decadencia de las costumbres, el miedo ante el comunismo y al caos social, hacen más que nunca necesario la ampliación del trabajo social en manos de las organizaciones de mujeres protestantes. Esto requiere seguir con la política de profesionalización del trabajo femenino, lo que conlleva la inversión de capital que supera los medios de la Federación. Por otra parte la iglesia protestante contaba de una infraestructura que superaba con creces los medios de la Federación. ${ }^{312}$

Aunque su orientación es confesional, se definen como una organización apolítica de tendencias „nacionales“. Sus miembros se encuentran entre la alta burguesía. Los padres, maridos y hermanos de las mujeres de la Federación eran en su mayoría funcionarios de alto rango, en el aparato judicial, la administración o la iglesia.

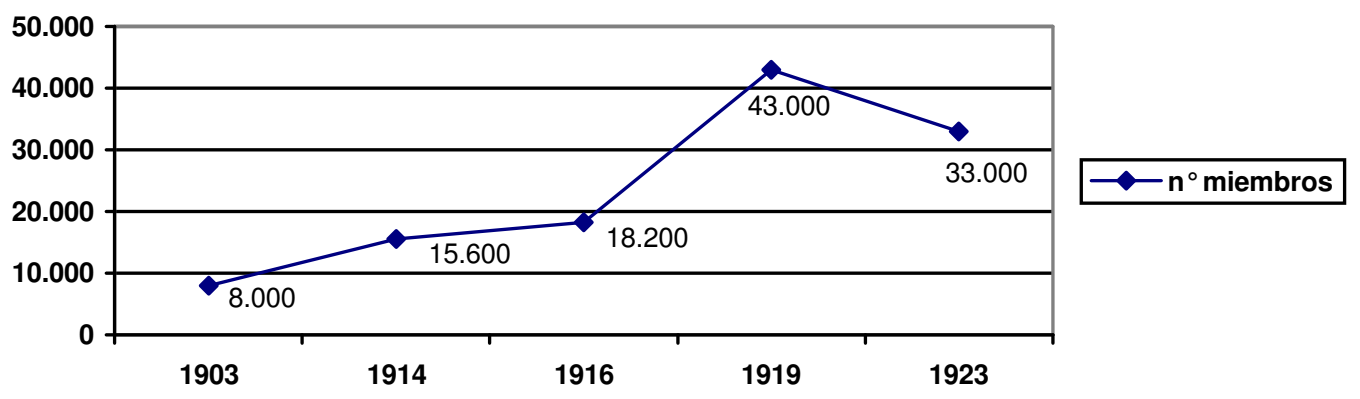

Fuentes: Programa del Deutsch-Evangelischer Frauenbund, 1903, EZA, 7/3989. Richtlinien für die Arbeit des Deutsch-Evangelischen Frauenbundes, Hannover, Mai 1919, EZA 3989313

311 Baumann, U.: Protestantismus und Frauebewegung, p. 252. Esta autora describe detalladadamente los detalles de la ruptura entre $D E F$ y $B D F$ que no obedece únicamente a divergencias relacionadas con el voto femenino sino con la posición del $B D F$ respecto a la política internacional.

312 Carta del Bund des Deutsch-Evangelischen Frauenbundes al Evangelischen Oberkircherat, Hannover, 28. Mai 1919, EZA/3989

313 Baumann, Ursula: „Religion und Emanzipation:Konfessionelle Frauenbewegung in Deutschland, 1900-1933, TAJB. Esta autora da para 1919 la cifra de 17.600. Interesante es que en los calendarios de la organización a partir de 1933 se da una cifra de 229.5000 de miembros. Cambio al que no han aludido 
La reconstrucción biográfica de la vida de estas mujeres se hace difícil, debido a la inexistencia de fuentes primarias. Existen sin embargo un intento por parte del DEF actual de investigar sobre las miembros de la organización en el pasado de ésta. En el archivo de la organización se encuentran un inventario, no publicado, en el que se encuentran algunos datos biográficos sobre miembros "ilustres" de la Federación. Entre las miembros se encuentran mujeres pertenecientes a la aristocracia, y a las clases medias altas. En primer lugar destacan Selma Gräfin von der Groeben, (1856-1938), Paula Müller-Ortfried (1865-1946), Adelheid Bennigsen (1861-1938), Auguste Jorns (1877-1966), Anna Moslof (1895-1974), que pertenecen a la rama del protestantismo social. Müller, Jorns y Moslof se dedican paralelamente a la política. Müller como miembro del Deutschnationale Volkspartei, Jorns en el Deutsche Volkspartei y Moslof como canditata al parlamento prusiano por el Deutsche Demokratische Partei. Su interés por los asuntos sociales está estrechamente relacionado con su socialización religiosa en la familia. Junto a las "activistas" se encuentra también un gran número de mujeres que se dedican a las bellas artes: Minna Barnay, actriz de teatro, la escultora Ellen Bernkopf y la pintora Tilla Jährig-Löhr. 314

La Federación permanece sin embargo una organización minoritaria, si nos atenemos al número de miembros que forman parte de la organización hasta 1933. La razón del carácter elitista de la Federación hay que buscarla en la existencia de una segunda organización protestante, donde se encontraba integrada la mayor parte de la población protestante femenina: el auxilio femenino, Evangelische Franenbilfe.

ninguno de los autores que se ocupan del tema. Lo más posible es que tenga que ver con la reorganización de las asociaciones a partir de 1933, así como la "emigración” del resto de las organizaciones que se habían diluido.

314 Selma von Groeben pertenece a una familia de la aristocracia prusiana. Su formación puede considerarse como autodidacta. En su familia recibe clases privadas y más tarde realiza estudios de música en Weimar. A la muerte de su padre en 1894 se traslada a Hannover donde trabaja en el DeutschEvangelischer Frauenbund. Su campo de actuación es el trabajo como mujeres y adolescentes desvalidas. En 1903 abre en el solar de una fábrica abandonada un centro de acogida para madres solteras embarazadas. En 1904 lucha por la introducción de asistentes sociales para prostitutas en las estaciones de policía.

La vida de Paula Müller transcurre hasta 1901, fecha en la que accede a la presidencia del DEF, como la de cualquier hija de familia acomodada. Desgraciadamente no existe ningún tipo de información sobre esta etapa de su vida. Durante su etapa como dirigente del DEF participa Müller activamente en la organización del trabajo social para mujeres desvalidas y apoya la creación de escuelas sociales superiores para la formación de asistentes y trabajadoras sociales. Durante la primera guerra mundial participa con las mujeres del movimiento moderado de la mujer en el servicio nacional femenino de guerra. Durante la república de Weimar es miembro del DNVP, desde 1920 hasta 1932 representa a éste en el parlamento.

Adelheid Bennigsen trabaja desde 1901 hasta 1910 como vicepresidenta del DEF. Dsde 1923 hasta 1932 edita junto a Müller el órgano portavoz de la organización, EVANGELISCHE FrAUENZEITUNG. En 1905 recibe la tarea de dirigir la escuela social cristiana para mujeres. En 1917 es relevada por Auguste Jorns, perteneciente a la nueva generación de mujeres protestantes con estudios. Jorns trabaja en la política activa como miembro del DVP y como miembro del departamento para menores de la ciudad de Hannover. Su trayectoria durante el nacionalsocialismo no está documentada.

Anna Moslof pertenece al grupo de mujeres que se decide por la profesión de maestra, ocupando posiciones de alta responsabilidad. Miembro del DDP hasta 1933, está documentado que durante el nacionalsocialismo pertenece al profesorado de una escuela de orientación nacionalsocialista en Hannover. Después de 1945 hace carrera en el ministerio de educación en el estado de Niedersachsen. 


\subsubsection{Die Frauenhilfe. El Auxilio Femenino protestante.}

Una segunda forma de trabajo femenino realizado por las mujeres protestantes estaba representada por la Frauenbilfe, Auxilio femenino. ${ }^{315}$ Fue fundada en 1897 por la Emperatriz Augusta Victoria y abarcaba a aquellas mujeres que trabajaban voluntariamente en centros parroquiales, visitando a los enfermos, a los huérfanos o a los viudos de uno u otro sexo. El Auxilio femenino estaba dirigido por el párroco local. Es decir éste estaba ligado íntimamente a las estructuras de la iglesia protestante. No se trataba de una organización dependiente de una determinada iglesia protestante, sino que se encontraba distribuida en toda Alemania. La Federación de mujeres protestantes por el contrario, DEF, tenía su sede en Hannover y su extensión dependía del trabajo individual de las mujeres que lo integraban en la fundación de grupos locales, actividades de prensa etc.

En Auxilio Femenino predominaban miembros de la pequeña burguesía, o incluso en regiones altamente industrializadas como es el caso de Westfalia, pertenecían a la organización un gran número de mujeres trabajadoras. ${ }^{316}$ Dos años después de su fundación, la organización cuenta con 13.000 miembros. Al final de la primera década de siglo había sufrido un incremento de 187.000 mujeres. En 1905 constaba de 1000 grupos locales.317

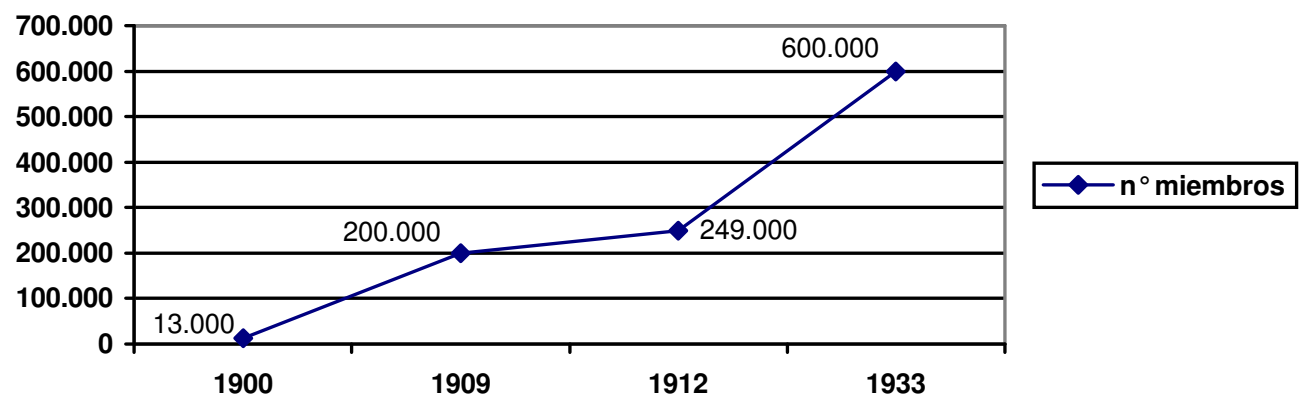

Fuente: Phayer, Michael: "Protestant and Catholic Women Confront Social Change", en: Dukes, J.R/Remak, J.: Another Germany. A Reconsideration of the imperial era., London, Boulder, 1988, p.89. 318

Al contrario que la Federación, el Auxilio se encuentra en manos masculinas y no goza de la relativa dependencia de la Federación, sino que se encuentra integrada en la institución

315 Kaufmann, D.: „Die Begründung und Politik einer evangelischen Frauenbewegung in der Weimarer Republik", en: Dalhoff, J. / Frey, U. / Schöll, I. (eds.): Frauenmacht in der Geschichte. Beiträge des Historikerinnentreffens 1985 zur Frauengeschichtsforschung, Düsseldorf, Schwann, 1986, p.381

316 Baumann, U.: op.cit., p.196

317 Phayer, M.: „Protestant and Catholic Women Confront Social Change“, en: Dukes, J. R. / Remak, J. (eds.): Another Germany. A Reconsideration of the Imperial Era, London, Boulder, 1988, p.98. En Westfalia contaba la Frauenhilfe con un $20 \%$ de mujeres trabajadoras, y en la zona del Rhin un $12 \%$. Un $20 \%$ pertenecían a la „nueva clase media“ y un $40 \%$ estaba integrado por mujeres provenientes del campo.

318 La cifra de 1912 aparece en Baumann, U.:’Religion und Emanzipation: Konfesionelle Frauenbewegung in Deutschland 1900-1933, p.176 
eclesiástica. Quizá esta sea la razón, aparte del origen ilustre, por la que el Auxilio supera con creces el número de miembros de la Federación y no tuvo nunca el carácter minoritario de ésta, es el carácter intelectual de ésta. Phayer señala también la importancia del apoyo de la corona y de la iglesia con el que cuenta la nueva organización. ${ }^{319}$ Otra de las razones del éxito del auxilio femenino se haya en la estructura organizativa de éste: el auxilio depende de las parroquias, lo que supone la preexistencia de una infraestructura, que el resto de las organizaciones de mujeres no disponen, por otra parte dependen directamente de la parroquia: en otras palabras, cuentan con la legitimación de la iglesia y en tercer lugar, en las zonas rurales, donde la influencia del movimiento de la mujer, y de la Federación es mínima, el auxilio constituye la única red social de comunicación para la población femenina.

Desde sus comienzos se distancian de las reivinciaciones e ideales del movimiento de la mujer y acentúan su función de administración del trabajo de las mujeres protestantes:

„El Auxilio femenino no es movimiento de la mujer sino servicio de la mujer en la comunidad protestante. El movimiento de la mujer busca en primera línea los derechos de la mujer: el Auxilio femenino pregunta en primer lugar sobre el deber de la mujer.“ 320

El punto central en la vida del Auxilio es la parroquia, la vida religiosa y no los derechos de la mujer, sino sus deberes y su responsabilidad en relación a la comunidad de creyentes.. La embajada de emancipación del movimiento de la mujer no tiene que ver con los principios de la Frauenhilfe que se cimenta el servicio y el sacrificio a la comunidad cristiana. Con el argumento: Die Fran ist zu schade für die Politik, mostraban su desprecio por la participación política, y la pérdida de la identidad femenina:

„Una mujer que llega a escuchar las maldades de una campaña electoral en salas llenas de olor a cerveza, humo de tabaco y exhalaciones humanas o que incluso participan en estas reuniones, tal mujer pierde el derecho a ser vista por el hombre como hembra y a ser tratada con caballerosidad y ternura. ${ }^{\text {“3232 }}$

También los intentos de la Federación de democratizar la vida interna protestante, son entendidos y aceptados pero no acogidos como objetivo de la organización. Y la actitud ambigua de éste respecto al derecho de voto femenino es criticada como falta de principios y de decisión. La posición de la Frauenbilfe reconoce su apoyo a organizaciones conservadoras como

319 Phayer, Michael: "Protestant and Catholic Women Confront Social Change", en: Dukes, J.R., Remak, J.: Another Germany. A Reconsideration of the imperial era., London, Boulder, 1988, p.89. Según este autor un $20 \%$ de los miembros del Auxilio pertenecía a las clases bajas. Otro $20 \%$ pertenecía a las llamadas clases medias. La población rural constituía un 40\%, tratándose de mujeres de propietarios rurales en su mayoría. Baumann considera errónea la alta cifra de la población perteneciente a las clases trabajadoras, y diferencia el concepto de clase media, entre clase media baja, al que pertenecían las mujeres del Auxilio, y clase media alta representada en la Federación de mujeres representantes. Si nos atenemos a las actas de archivo en la diferenciación de grupos se observa un predominio de grupos locales en las zonas rurales, así como en la procedencia de las dirigentes del Auxilio, en su mayoría mujeres de grandes propietarios.

320 Hein, A.: „Frauenhülfe und Frauenbewegung“, FrAUENHÜLFE, 1912 (n¹2), p.311-320; buscar, en : Kuhn Annette; Kaiser, Jochen-Christoph: op. cit., p. 61

321 Hein, A.: op. cit., p.62 
el Deutscher Bund zur Bekämpfung der Franenemanzipation, dónde se lucha organizadamente contra el movimiento de la mujer. ${ }^{322}$

Junto a esto reclaman el reconocimiento de la profesión de ama de casa, así como la plena dedicación a esta profesión, si las condiciones económicas lo permiten, y proponen la retirada progresiva de las mujeres casadas del trabajo fuera del hogar, aceptando únicamente trabajos de media jornada o tareas honoríficas no retribuidas. ${ }^{323}$ Las mujeres solteras, por otra parte, deberían trabajar en ocupaciones exclusivamente femeninas para evitar la competencia entre los dos géneros. El trabajo femenino en campos hasta entonces reservados para los hombres, es calificado de competencia desleal.

La organización es apoyada por la iglesia y el estado y nace orientada para paliar los problemas que sufren las mujeres en los inicios de la segunda revolución industrial. A diferencia de la Federación su interés se centra en las mujeres proletarias, realiza labores de tipo voluntario, como recogida de ropas, de alimentos etc., y le falta „la intelectualidad“ que tenía la Federación, versión protestante de los movimientos seculares de la mujer. En 1918 pasa a ser dirigida por Hermenau, posteriormente encargado de dirigir el trabajo de las mujeres protestantes bajo control de las autoridades nacionalsocialistas. En 1933 la organización cuenta con 600.000 miembros.

Entre 1912 y 1913 comienza una seria polémica entre la Frauenbilfe y la Federación, en torno a la postura de esta última respecto al movimiento de la mujer. ${ }^{324}$ La relación entre ambas organizaciones se ve dañada, y fundamenta la separación de ambas hasta 1933, fecha en la que el Auxilio femenino retoma el liderazgo de las mujeres protestantes, bajo control nacionalsocialista. No obstante a pesar de las diferencias de tipo "organizativo" ambas defienden el mismo ideal de mujer

Durante los años de la Primera Guerra Mundial la organización experimenta un incrementa un aumento de sus actividades y campos de acción. Se cosen uniformes para los soldados, se organizan viviendas para los refugiados, se trabaja en los hospitales, se hacen cursos para enseñar a las mujeres a tejer, a coser o hacer punto, o se introduce a las mujeres en el trabajo de las fábricas.

\subsubsection{Feminidad, protestantismo y movimiento de la mujer. Construcción de género en el movimiento protestante de la mujer}

La base ideológica del movimiento de la mujer protestante se encontraba no en los ideales del movimiento sino en la propia religiosidad evangélica: la religión ayuda a ambos géneros a reconocerse, a encontrar su propia y específica identidad. Paula Müller, dirigente de la Federación hasta 1934 define claramente como se produce este „reconocimiento“:

322 Esta organización se caracteriza por sus ataques al movimiento de la mujer. Estaba integrada por miembros masculinos y femeninos, algunos de ellos pertenecientes a los gremios universitarios y académicos. En 1905 tiene lugar una polémica entre el profesor de la Universidad de Heidelberg, Arnold Runge y Marianne Weber, debido a un comentario de éste sobre el movimiento de la mujer: "El movimiento de la mujer en la actualidad, es un movimiento formado por viejas mozas viejas, mujeres esterilizadas, viudas y judías. Las que son madres y las que cumplen con sus deberes como madres no se encuentran en este movimiento". En: Nave-Herz, R.: op. cit., p. 43.

323 Hein, A.: op. cit., p. 65

324 Müller, P.: „Was will die Frauenbewegung? Ein Wort zur Verständigung“, FraUENHILFE, 1913 (n¹3), pp.300-305, en : Kuhn, Annette; Kaiser, Jochen-Christoph: op. cit., pp. 65-66 
"Dirección y maternidad son, según el ideal cristiano las principales funciones de los géneros para la maternidad gobierno, mando y maternidad son para los individuos según la fe cristiana la función fundamental de los géneros. ${ }^{325}$

Algunas autoras ven en esta delimitación de esferas un distanciamiento consciente de los valores masculinos como nacionalismo y guerra, y la construcción de una identidad femenina basada en los principios del pacifismo. ${ }^{326}$ Sin embargo como veremos con posterioridad, las mujeres protestantes se dejan contagiar muy rápidamente por los valores nacionalistas.

El marco que canalizará esta búsqueda hacia „esta nueva identidad femenina“ no es, sin embargo, nuevo: a través de la tradición bíblica transcurre el nuevo discurso sobre lo femenino. La Biblia fundamenta la „diferencia“ de la mujer y por lo tanto su esfera de actuación. Las relaciones entre los géneros son vistas desde una perspectiva dualista: la feminidad sería el reflejo del bien, la ayuda y el sacrificio mientras que lo masculino aparece como sinónimo de destrucción y de muerte aunque también de creación. Por otra parte con la reforma protestante aparece un nuevo ideal de mujer representado por la mujer de Lutero. Katharina von Bora representa el ideal de abnegación, pragmatismo y compromiso con el mundo real, donde la maternidad real es interpretada como una parte de la creación y definida como un valor positivo, hasta entonces monopolio de la maternidad espiritual mariana:

"Comida, bebida, vestido, calzado, hogar etc. Aquí se consuma su trabajo diario. (La mujer) ayuda a sustentar a la familia en nombre de dios a través de la alimentación, del cuidado del vestido y del trabajo en el hogar. Ella se interesa más por este ámbito que el hombre. (...)La mujer está destinada por naturaleza para servir con amor. Como mujer cristiana realizará este servicio en el nombre de Cristo." 327

Desde el punto de vista práctico la Federación pretende, al igual que el feminismo moderado formar a la mujer para lograr su igualdad respecto al hombre así como la aceptación del trabajo de la mujer en el terreno social y la mejora de la situación social, económica y educativa de ésta. Un trabajo paralelo de las organizaciones protestantes es también una renovación moral y religiosa, un cambio de las costumbres, y solución de los problemas sociales y económicos ${ }^{328}$, objetivos en los que la mujer juega un papel, como pieza clave de la familia.

Las mujeres de la Federación entienden el cristianismo como un parámetro con el que definir la identidad de los dos géneros. Esta identidad está basada en la diferencia que, a su vez, está determinada por Dios y las escrituras. El hombre por naturaleza es „el que dirige“, la mujer por el contrario se caracteriza por su „capacidad de entrega“, cualidad que encuentra su punto culminante en la maternidad. ${ }^{329}$

Esta interpretación de las diferentes identidades y funciones de los sexos revela una idealización de lo femenino que es identificado con la paz y la cultura, y un punto de vista sobre lo masculino como representante del nacionalismo, de la guerra, de la destrucción. Este tipo de interpretaciones de las relaciones entre los sexos no se encuentran únicamente en los grupos de mujeres protestantes sino que son defendidas también por las asociaciones de mujeres radicales,

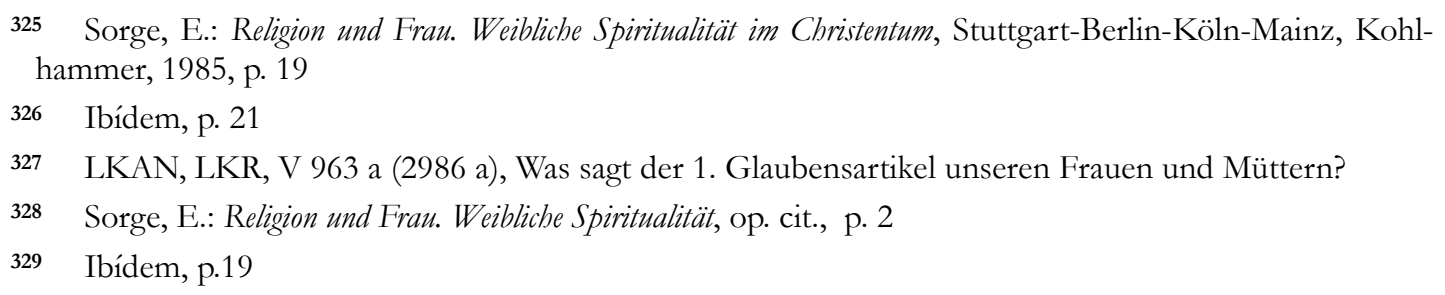


entre ellas Lida Gustava Heymann quien llega a definir al hombre como „el principio destructor de la humanidad“ y a la mujer como „el principio constructor de la ayuda, el bien, el entendimiento y la apertura“. 330

\subsubsection{La teoría de la diferencia de los géneros como simbolo del orden divino. Magdalene von Tiling}

Mientras que el movimiento laico de la mujer cuenta con un grupo de mujeres que forman y modelan las bases teóricas del movimiento, el asociacionismo protestante cuenta con la figura de Magdalene von Tiling ${ }^{331}$. Al igual que sus compañeras Tiling representa con exactitud el tipo de mujer alemana de principios de siglo integrada en el movimiento de la mujer: formación universitaria, soltera y funcionaria dedicada a la enseñanza.332 Aparte de su importancia en el campo de la pedagogía relacionada con las clases de religión, von Tiling desarrolla una teoría que une la ideas protestantes con las aspiraciones del movimiento de la mujer. El contexto teológico de Magdalene von Tiling se encuentra en la teología del orden creador, tendencia conservadora de la teología protestante de los años veinte, en la que todo individuo independientemente de su confesión se encuentra en un determinado orden o estamento. Estos órdenes o estamentos están creados por Dios y entre ellos se encuentran la familia, la iglesia, la raza, el pueblo, el matrimonio y la profesión. A diferencia del protestantismo liberal representado por Harnack y Troeltsch en el que el individio adquiere un papel fundamental en su relación con Dios, en la teología del orden, individuo y contexto social y político en el que éste actúa son considerados como una entidad dependiente del orden divino. Este orden se refleja socialmente en la Gemeinschaft cultural es decir en la Volksgemeinschaft donde se integran los valores del orden divino de una manera específica, en el pueblo alemán, de la que se excluye a la población judía como parte de identidad nacional y popular. ${ }^{333}$

En el marco de esa base teológico-política analiza el problema de la mujer y sistematiza un orden de las relaciones entre los géneros replanteando el reparto de tareas y los campos de actuación de la mujer.

Más allá de la cuestión femenina Tiling trata las relaciones entre principios sociales y orden social. Tiling llama la atención sobre la responsabilidad de la mujer en el „pueblo“, Volk y en el Estado. Esta responsabilidad no tiene lugar de una manera evidente, sino que se logra a través de la formación, y de la asimilación de principios religiosos, rechazando, la fundamentación ética de la socialdemocracia que se reducía a los derechos humanos. Tiling apela a una interiorización de los principios políticos. Este proceso se traduce en un cambio de la naturaleza de la mujer, donde tiene lugar la unidad del mundo exterior, y el mundo interior. Una tarea que llama a redefinir la naturaleza de la mujer protestante y que la libera de la esclavitud que produce la

330 Ibídem, p.21

331 Magdalene von Tiling: nacido 19.5.1877 en Riga. Hija de pastor protestante. Ejerce como profesora de educación secundaria en las áreas de Historia y Religión. Políticamente activa, es miembro del Deutschnationale Volkspartei, por el que se presenta como candidata a las elecciones del ayuntamiento en la ciudad donde vive. Desde 1923 preside la Vereinigung Evangelischer Frauenverbände Deutscblands, hasta su disolución en 1933. Junto con Paula Müller, trabaja activamente en la organización del asociacionismo femenino protestante. LKAH, Nachlaß Magdalene von Tiling, N 127, Nr. 2 y Nr. 4

332 Magdalene von Tiling comienza a dar clases en Liceo superior de Eberfeld en 1909, una institución de formación profesional para mujeres, donde después de la escuela primaria se podía acceder en dos años a una formación en economía del hogar y pedagogía social, y en tres años se preparaban las futuras maestras. LKAH, N 127, Nr 2

333 Principales representantes de esta corriente son Paul Althaus (1888-1966), Wener Elert (1885-1954), Friedrich Gogarten y Emanuel Hirsch (1888-1972). 
ignorancia y un incorrecto entendimiento de la verdadera función de la mujer. La correcta interrelación entre los sexos es entendida como una aportación al funcionamiento del orden establecido entre los géneros.

Tiling parte de la diferencia de los géneros. Al hombre le es concedido su papel dirigido hacia el mundo exterior, y la mujer hacia el mundo interior en la maternidad, maternidad no sólo física, sino intelectual que permite a las mujeres adentrarse en el mundo exterior.

La idea de la división de la identidad femenina en dos campos de acción, interno y externo, esta unida al modelo teórico de sociedad propuesto por el teólogo Friedrich Gogarten a principios de siglo. Según Gogarten Dios se muestra en creación, el orden terrenal es creación de Dios. La ley de Dios se muestra en la división „estamental“ de la sociedad. Así mismo la relación entre los individuos, que reflejan la relación Dios-Individuo definida por los valores de la autoridad y la obediencia. La garantía de este orden social es el estado.

Desde esta influencia se puede entender el pensamiento de Tiling. La feminidad y las funciones propias de ésta son para ella un estamento en el orden social, como la ama de casa, la esposa, el juez o el trabajador, que es a su vez producto del orden divino.

\subsubsection{La república de Weimar. Primeros pasos para una organización supranacional de mujeres protestantes. El nacimiento de la Vereinigung Evangelischer Frauenverbände Deutschlands (VEFD)}

Como ya hemos señalado antes la Federación de mujeres protestantes abandona la gran organización laica del movimiento de la BDF. La causa es una declaración de principios de 1917, lograda a partir de la presión del ala radical del $B D F$ en contra del ala moderada, donde se exige no sólo el derecho activo y pasivo de voto de las mujeres, sino la democratización del proceso electoral. En la asociación protestante se vota con 1310 votos a favor, 82 en contra y 49 abstenciones a favor de la separación.

Como consecuencia de la ruptura se crea en julio de 1918 la Vereinigung Evangelischer Frauenverbände Deutschlands (VEFD), una organización que abarcaba a todas las organizaciones de mujeres protestantes que se presentaba como alternativa ideológica al BDF. Unión de asociaciones de mujeres protestantes de Alemania, creada para defender los intereses protestantes en el mundo político y dirigida por Magdalene von Tiling. Aunque la Unión hace hincapié en teoría en la neutralidad de ésta en el campo político, en la realidad se acerca cada vez más a partidos de derecha, como el Deutsch-Nationale Volkspartei, Partido nacional del pueblo alemán, defendiendo la política de expansión y de control político de éste ${ }^{334}$, así como realiza campañas contra el aborto y para la renovación de las costumbres morales.

La nueva organización pretende representar los intereses del mundo femenino dentro del mundo protestante. A ello se une el trabajo político que pretende orientar a las mujeres protestantes a la hora de votar. La nueva organización recomendaba votar a aquellos partidos que representaran la identidad de la iglesia protestante, y defendieran las ideas de una Alemania unida.

Dentro de la $V E F D$ se reúnen organizaciones protestantes de distinta procedencia: junto al DEF: Die Evangelische Frauenhilfe, el Kaiserswerther Verband der Diakonissenmutterbäuser y el Evangelischer Verband zur Pflege der weiblichen Jugend. La Evangelische Frauenhilfe, con sus 500.000

334 Kaufmann, D.: op.cit., p.388 
miembros tenía gran influencia en el campo entre la clase media baja y campesina, mostraba claramente sus diferencias respecto al movimiento de la mujer y su carácter puramente confesional. Esta etapa significa para la Federación la renuncia a las reivindicaciones relacionadas con el movimiento de la mujer, y se centra en temas fundamentalmente religiosos y de tipo político. Tras las elecciones de 1918 en la que el partido sólo consiguió un 10,3 de los votos los esfuerzos se centran en el trabajo de formación política.

La organización se presenta sin duda alguna como contrapunto al movimiento laico de la mujer. Según Baumann a finales de los años veinte 27 asociaciones protestantes se había adscrito a la Vereinigung. En 1933 el número había ascendido a 29 y contaba con número de miembros en torno al 1.800.000. ${ }^{335}$ Aunque esta misma autora señala que a pesar del creciente antisemitismo de la línea política a la que pertenecía organización, esta se mantiene distante ante tales posturas. Esta opinión sin embargo aparece refutada en un estudio sobre las tendencias antisemitas en el movimiento de la mujer, donde se da a conocer en los grupos protestantes el aumento del nacionalismo y las posturas antisemitas dentro de la Federación protestante. ${ }^{336}$

Así por ejemplo en 1915 con motivo de una invitación del Congreso Internacional de Mujeres en Haag, que es rechazada por Paula Müller, con la argumentación de que mientras Alemania estuviera en guerra con Inglaterra y Francia no veía motivo de reunirse con mujeres de estos países.

La llegada de la República de Weimar es aceptada por las mujeres protestantes como „una pesadilla“.337 Este cambio político tiene una gran transcendencia en la evolución de la Iglesia Protestante y deja también huérfana a la Federación que se identificaba desde sus inicios con el régimen imperial. El cambio deja entrever un giro en la organización así como en las demás organizaciones protestantes. Por una parte la Federación se centra cada vez más en temas religiosos, aunque por otra parte vive un proceso de politización, mejorando y profundizando su relación con el partido conservador DNVP (Deutsch-Nationale Volkspartei). Fundado el 24 de noviembre de 1918. Se trata de una amalgama de diferentes partidos conservadores del Kaiserreich. Su ideario es nacionalista, antisemita, antiparlamentario, reivindica la restauración de la monarquía y la política colonial. Sus principales enemigos son el Liberalismo y el Socialismo. En la Asamblea Nacional de Weimar (42 representantes) rechaza el acuerdo de Versalles y la Constitución de Weimar. En 1931 bajo la dirección de A. Hugenberg se une con el NSDAP en lucha contra el gobierno de Brünning en el llamado Har乏burger Front.

Este fenómeno de politización no es característico de las mujeres protestantes, sino que va unido a la concesión del voto a las mujeres. Las católicas cierran filas en torno al partido de centro, Zentrumspartei, y las liberales ingresan en el DDP (Deutsche Demokratische Partei). Sin embargo, mientras las liberales concentran sus energías en luchar en el parlamento por los derechos de la mujer, las protestantes abandonan su origen feminista y se abandonan a posiciones conservadoras y nacionales, influidas por la línea del partido.

El 20 de Febrero de 1919 la organización se decide de manera oficial por el compromiso político:

335 Baumann, U.: Protestantismus und Frauenbewegung, op. cit., p. 254

336 Dürkop, M.: „Erscheinungsformen des Antisemitismus im Bund Deutscher Frauenvereine“, FEMINISTISCHE STUDIEN, 1985 ( $\left.{ }^{\circ} 1\right)$, p.147. La autora se refiere a la crítica de un libro que aparece en la EVANGELISCHE FRAUENZEITUNG en 1914 donde comenta que la situación de Alemania mejorará cuando se libere del liberalismo judío. La presidente de la Federación de mujeres judías, JBF, se hace eco del antisemitismo existente en la Federación de mujeres protestantes y llama la atención a Paula Müller para que exprese su opinión sobre el tema.

337 Baumann, U.: op.cit., p.199 
“en el futuro estarán todas nuestras preguntas relacionadas con la política”.338

Este apoyo público al compromiso público difiere de la evolución de la Federación de asociaciones de mujeres alemanas, BDF, dirigida por Bäumer, que insistían en su postura apolítica y neutral.

La organización pierde el último carácter secular que la había caracterizado en sus orígenes. Este juicio se confirma por el acercamiento al Auxilio Femenino, conocido por la orientación nacional-conservadora de alguno de sus miembros.

En 1919 el programa ha abandonado el contenido social de años anteriores y se centra en la preservación de las costumbres morales y de los valores religiosos.

„Los subversivos cambios de los últimos tiempos, la gran pobreza moral y religiosa de nuestro pueblo hacen necesario un mayor y más extenso trabajo de la Federación de mujeres protestantes alemanas. El fortalecimiento de las convicciones protestantes en el mundo femenino, la influencia religiosa y moral de mayores sectores de la población son en la actualidad una necesidad prioritaria." 339

Problemas económicos hacen que la Federación intente un acercamiento a la jerarquía eclesiástica para acceder a ayudas de tipo económico. El párrafo reservado a la „,santidad“ de la familia y del matrimonio que en el programa de 1903 aparecía al final de la declaración de principios, aparece en 1919 al principio, a éste le siguen la necesidad de las clases de religión en el plan de estudios de las escuelas de enseñanza básica, la formación de sentimientos favorables a la patria en la escuela, y la responsabilidad de la mujer en su tarea de educadora en la familia y en la vida pública, influencia de la mujer en el estado, comunidad, iglesia y escuela, formación de la mujer para las tareas del hogar y en último lugar siguen las peticiones de igualdad profesional de la mujer respecto al hombre. Las últimas peticiones abarcan una serie de medidas donde se observa la especialización de la Federación en la formación de trabajadoras sociales de confesión protestante y su profundización en tareas benefactoras. La organización es por encima de todo activa en el norte de Alemania, en Preußen.

Los años de la República con su libertad, sus cafés, su arte atrevido y descarado, su crítica de las instituciones políticas y religiosas, se enfrenta con el puritanismo cada vez más exacerbado de la Federación. En una época en la que el pintor George Grosz pintaba a un cristo crucificado con una máscara de aire, protestando contra la guerra, las mujeres protestantes echaban de menos la armonía, y el buen orden de épocas anteriores. Mientras Otto Dix se dedicaba a pintar a prostitutas, lesbianas, y demás „desechos“ de la sociedad, las mujeres protestantes volvían sus ojos a Dios, la patria, y el pueblo:

„Máquinas en vez de personalidad, mecanicismo en vez de alma, fuerza mental e inteligencia en lugar de espíritu, aquel principio que es la configuración vital, la forma orgánica (...). Esta es nuestra época en lo que tiene y en lo que le falta.“ 340

Las posturas de la organización se radicalizan con los años y el carácter nacional se acentúa. En una reunión general de la Federación en 1933 los tonos nacionales son bastantes claros:

„Como Federación de mujeres buscamos la comprensión para la manifestación de la voluntad alemana y la profundización en la nacionalidad alemana. La

\footnotetext{
338 Baumann, U.: Protestantismus und moderne Gesellschaft..., op. cit., p.261

339 EZA, 7/3989, 28. Mai 1919, Carta de la Federación a la Iglesia Protestante

340 Baumann, U.: „Religion und Emanzipation...“, p.199
} 
Federación continuará la lucha y tomará partido por una iglesia popular, por una verdadera comunidad del pueblo y por la disposición a sacrificarse por el genio alemán y el espíritu protestante.“ 341

2.5.2. Catolicismo y el movimiento de la mujer. Asociaciones de mujeres católicas en la República de Weimar

\subsubsection{El milieu católico}

En el caso del feminismo burgués y de las organizaciones protestantes de mujeres hemos establecido la pertenencia a un milieu académico que se relaciona con el protestantismo liberal de finales del siglo XIX y principios del XX. La esencia del protestantismo permitía su apertura a tendencias liberales de la sociedad. En el caso católico el espíritu ilustrado no motivó como en el caso protestante una revolución en la teología y en el pensamiento católico y en el siglo XIX encontramos un milieu, que se caracteriza por el rechazo de todo tipo de actividad intelectual que fuera en contra de las enseñanzas de la iglesia. Este fenómeno también es conocido en otros países como ultramontanismo, con la diferencia que en Alemania, el grupo católico constituye una minoría respecto a los protestantes. El milieu del que se integra el catolicismo esta lejos del mundo de funcionarios „ilustrados“ protestantes. Según los nuevos estudios se encuentran fundamentalmente entre pequeños campesinos, pequeños burgueses y artesanos. Como en el caso de las protestantes son las mujeres las encargadas de la educación de los hijos, especialmente la educación religiosa. Las tendencias antimodernistas contra la ciencia, cultura, y arte son más extremas en este milieu que en el de las protestantes.

La población católica se organiza a partir del siglo XIX con los comienzos del proceso de secularización en una estructura social con una red social y comunicativa propia, juicios de valores y prejuicios que permitían la supervivencia y la cohesión del grupo respecto al mundo exterior. ${ }^{342}$ Tareas importantes a la hora de preservar la identidad del grupo eran: la lucha por la supervivencia de la familia católica con su división de trabajo y poder entre los géneros, la preservación del carácter cristiano de las instituciones educadoras y por último el control de la moral pública. Tras la primera guerra mundial la organización social católica se organiza contra el incremento del individualismo, el materialismo, el espíritu de los tiempos modernos y el culto al capital, que contribuían a acelerar la decadencia del pueblo alemán. Todos factores que amenazaban el orden social. Por lo tanto la familia se consolida como la única formación social que puede crear una alternativa segura y estable al caos y la decadencia del orden social. Este papel de la familia como célula social de renovación moral trae como consecuencia la revalorización del papel de la mujer como instrumento de cambio dado su capacidad de entrega y amor desinteresado. Como contrapunto a la civilización determinada por rasgos masculinos se impone el orden femenino como bastión contra la decadencia del materialismo.

Sin embargo este modelo idílico del orden social se ve puesto en duda por las crecientes incursiones de las mujeres en el mundo masculino: el mundo del trabajo y la revolución en las costumbres familiares y las relaciones entre los géneros. Como ya hemos señalado en el capítulo anterior, la república de Weimar trae consigo una nueva imagen de la mujer, segura, independiente, que contradice no sólo los ideales conservadores de feminidad sino las aspiraciones del movimiento de la mujer. La iglesia católica reacciona impotente ante tales

341 van Norden, G. / Mybes, F.: Evangelische Frauen im Dritten Reich, Düsseldorf, Presseverband der Evangelischen Kirche im Rheinland, 1979, p.14

342 Kaufmann, Doris: Katholisches Milieu in Müster 1928-1933, Düsseldorf, Schwann, 1984 
cambios. Políticamente no pueden esperar gran cosa del régimen democrático. Una peligrosa mezcla de desprecio del régimen liberal-demócrata y de nostalgia monárquica se adentran dentro del milieu católico, que desde la llegada de Weimar se siente un tanto huérfano. A esto se une la derrota electoral en 1928 con uno de los peores resultados en la historia electoral en el partido de centro, Zentrumspartei. Como consecuencia los católicos comienzan a organizarse en la llamada Katholische Aktion que consiste en una movilización del milieu católico para influir en la vida política, económica y cultural que intenta preservar la estructura social de la degradación y el desorden. En esta llamada jugaba la mujer su papel como desinteresada ciudadana, dispuesta a imitar el ejemplo mariano como salvadoras de la decadencia de Europa. ${ }^{343}$

El proceso de feminización de la iglesia se acentúa: las mujeres toman un campo de actuación del que los hombres se distancian. Es un mundo en si cerrado, con un denso filtro respecto a nuevas tendencias e ideologías que a pesar de su carácter conservador se muestra como veremos posteriormente relativamente inmune a la ideología nacionalsocialista.

\subsubsection{El movimiento de la mujer de las mujeres católicas}

Las organizaciones de mujeres católicas tienen sus precedentes en 1892 cuando los dirigentes masculinos de los trabajadores católicos proponen la creación de organizaciones de mujeres que defiendan sus intereses en las fábricas. Aunque esta propuesta no tiene eco, aparecen unos años después, en 1900 residencias o asilos para trabajadoras solteras. Se trata de un modelo parecido al patronato español donde mujeres de la aristocracia o de la clase media alta dedican su tiempo a mitigar los sufrimientos de las pobres trabajadoras. Sin embargo ante la aceptación de las mujeres trabajadoras de la socialdemocracia, surgen las primeras agrupaciones de mujeres trabajadoras católicas. Dirigidas por sacerdotes se caracterizan por su alto contenido religioso y predican la convivencia armónica entre las clases sociales. Desde el punto de vista social las primeras organizaciones católicas fundan las cajas de ahorro que permiten a muchas mujeres disponer de una pequeña ayuda en caso de enfermedad o muerte. Existían también patronatos donde las mujeres podían acceder a alimentos, y a la tan preciada madera o el carbón para calentar las húmedas viviendas. A ello se unen bibliotecas cursos de costura y cocina etc. Respecto a la participación de la mujer en la vida política se oponen al voto femenino y al trabajo de la mujer en este campo. ${ }^{344}$

Este conjunto de organizaciones puede considerarse como una red de relación no familiar, donde las mujeres, a pesar del control por parte de la jerarquía eclesiástica o del sacerdote de la parroquia, aprenden lentamente a articular sus deseos e intereses desde el punto de vista social político y económico. 345

Junto al carácter "social y caritativo" de las primeras organizaciones es importante resaltar la función educadora de éstas. En las organizaciones se impartían cursos de economía doméstica, servicios de asesoramiento conyugal y de formación, servicios de protección de menores, conferencias sobre temas políticos y seminarios de lectura y comentario de la prensa diaria.

343 Kaufmann, Doris: „Vom Vaterland zum Mutterland. Frauen im katholischen Milieu der Weimarer Republik“, op. cit., p. 255

344 Krafft, Sybille (Coord.): op. cit., p. 56

345 Las primeras organizaciones de mujeres católicas se fundan en el siglo XIX. Eran una forma de asistencia espiritual y se encontraban bajo la autoridad eclesiástica. En el siglo XX presentan la alternativa católica al movimiento de la mujer con el que apenas compartían intereses comunes. Entre las más importantes destacan la Zentralverband der katholischen Jungfrauenvereinigungen Deutschlands que contaba durante la República de Weimar con unos 760.000 miembros y de gran importancia la Verband der katholischen Frauen- und Müttervereine con 900.000 miembros. 
Junto a ello existían cursos de deporte, senderismo, baile etc. Actividades que contribuyen a la elevación del nivel cultural y la intromisión de las mujeres católicas en la vida pública.

El contraste entre la dura realidad de las mujeres trabajadoras y la cómoda vida de esposa y madre de familia, y lleva a algunas mujeres a crear iniciativas para mejorar las condiciones de vida de aquellas. Agnes Neuhaus (1854-1944) es un ejemplo de mujer católica que motivada por causas religiosas crea una organización para la ayuda y protección de mujeres con hijos ilegítimos. Una conversación con una amiga próxima sobre una conocida que se había atrevido a alojar en su hogar a una madre con hijos ilegítimos, fue el impulso decisivo que la hace consciente de la necesidad de actuar:

„No puedo de repente explicar el efecto que estas palabras me causaron. Hasta aquel momento me ha había alejado de tales cosas con todas mis fuerzas. El nacimiento de un hijo ilegítimo me parecía como una vergüenza imborrable. $\mathrm{Y}$ en aquellos momentos llegaba a mis oídos que una mujer por motivos religiosos ofrecía su casa a una muchacha con hijo nacido de esta manera. (...) Lentamente se desarrolló en mi interior la convicción de que Dios me colocaría en el lugar donde yo pudiera ayudar a estas mujeres. “346

Los motivos son de índole religiosa y social pero no política. A diferencia del movimiento de la mujer laico y sus intentos organizados de mejorar la situación de la mujer, en el caso católico la iniciativa parte de la recepción de la desigualdad social existente y de la contradicción con los valores cristianos.

El conjunto de las organizaciones de mujeres católicas contaba a principios de la república de Weimar con un total de 1.560.000 ${ }^{347}$ miembros, siendo una de las más grandes organizaciones de mujeres en Weimar. ${ }^{348}$

Junto a las organizaciones que se ocupaban de temas sociales existían también organizaciones católicas de mujeres trabajadoras, cuyo fin era la situación laboral de las mujeres y la decadencia moral a la que estaban expuestas. ${ }^{349}$ Los primeros grupos que se organizan son las maestras de primaria y secundaria. En 1885 se funda el Verein katholischer deutscher Lebrerinnen ( $V k d L$ ), organización desde la que nace el movimiento católico de la mujer.

A diferencia de los grupos protestantes de mujeres, el asociacionismo femenino católico no se caracteriza por su naturaleza emancipadora. Por el contrario los grupos católicos de mujeres se centran en temas exclusivamente religiosos y defienden un ideal femenino, dependiente de la teología católica. Esta diferencia radica en la naturaleza del catolicismo y su rechazo de cualquier movimiento ilustrado o de tipo emancipatorio.

La nueva concepción del mundo y del individuo, que desde Kant se extiende entre los círculos protestantes, donde se establece una „teología de la razón“, es ignorada en los círculos católicos, y genera un movimiento „antiracionalista“ en el catolicismo alemán. Esta corriente tiene el nombre de antimodernista y cristaliza en el Edicto del Papa Pío X en el que se rechaza todo tipo de teoría científica o filosófica que vaya en contra de las enseñanzas de la iglesia. Esta mentalidad anticientífica tiene lugar también en círculos pietistas protestantes y se traduce en

346 Krabbel, G.: Selig sind des Friedens Wächter. Katholische Deutsche Frauen aus den letəten bundert Jabren, Münster, Regensberg, 1949, p. 160

347 Kirchliches Handbuch für das katholische Deutschland, editado por:Zentralstelle für kirchliche Statistik der katholischen Kirche Deutschlands, Köln, 1933

348 Kaufmann, Doris: „Vom Vaterland zum Mutterland“, op. cit., p. 264

349 Una de las más importantes era la Verband katholisch-kaufmännischer Gehilfinnen und Beamtinnen, (Asociación de funcionarias y ayudantes comerciales católicas) que contaba en 1930 con 12.500 miembros. 
líneas generales en una feminización de la iglesia, ya que la población femenina era más propia a rechazar los "adelantos" de la técnica y las nuevas teorías en los campos de la ciencia y de las humanidades. 350

Dentro de esta línea de renovación moral surge entre algunas mujeres católicas la idea de crear una organización independiente del clero que intente coordinar los intentos de las mujeres católicas: el Katholischer Deutscher Frauenbund (KDF), y que sirviera como contrapunto al movimiento de la mujer laico.

\subsubsection{La Federación de mujeres católicas alemanas. El Katholischer Deutscher Frauenbund (KDF)}

La Federación de mujeres católicas nace en un principio ante la situación de decadencia social, causada por la industrialización y por la incorporación de la mujer al mundo del trabajo. A diferencia del resto de las organizaciones de mujeres, pioneras de la profesionalización del trabajo social femenino, actúan motivadas por causas religiosas y de amor al prójimo. De ahí que denominen a su trabajo una ,actividad caritativa“, 351 destinada a luchar contra el „materialismo“ y la „cerrazón mental de la nueva época industrial. Y a pesar de la progresiva profesionalización de sus actividades, como la creación de escuelas de trabajo social para mujeres católicas o su importancia en el campo de los cursos de maternidad centran el objetivo de su trabajo en el servicio al otro, a las mujeres necesitadas:

„Fue el descubrimiento de un mundo en el que vivían otras mujeres, cuyas condiciones vitales eran totalmente diferentes a las de ellas, un mundo donde vivían también madres, que no podía alegrarse de su maternidad, un mundo donde todo era tan extraño y a la vez tan conocido por que tenía que ver con lo propio, con lo conocido. $\mathrm{Y}$ entonces los objetos de uso corriente adquiría un significado completamente diferente ya que se era consciente de que las telas que vestían y las misas cosas que se necesitaban, eran tejidas y fabricadas por mujeres empobrecidas que trabajaban diez y más horas en fábricas mal ventiladas y ganaban un salario miserable." 352

Respecto al movimiento de la mujer pretenden resolver la cuestión de la mujer desde el punto de vista religioso:

„Queremos asegurar la influencia de la mujer en el poderoso movimiento cultural de la cuestión de la mujer, sobre el que ella tiene el derecho de participar. La cuestión de la mujer desde el punto de vista cristiano. Nosotras estamos al

350 Götz, v. Olenhusen, I., (ed.): Wuderbare Erscheinungen. Frauen und Kabtolische Frömmigkeit im 19. Und 20. Jahrbundert, Paderborn-München-Wien-Zürich, Ferdinad Schöningh, 1995, p. 10

351 Cosack, E.: 25 Jahre Katholischer Deutscher Frauenbund, Köln, p.10. La historia de los inicios de la organización se encuentra excelentemente documentada. Por parte de la Federación existía desde un principio el deseo de dejar por escrito los comienzos de la historia del movimiento. La primera secretaria general de la Federación, Isabella von Carnap, nos ha dejado una relación de los protocolos del consejo directivo desde 1903 hasta 1907, donde se puede reconstruir detalle a detalle la historia de la fundación.

352 Ibídem, p. 58 
servicio de la iglesia y suponemos que la solución de esta procede de la ayuda de una mujer: (la cuestión de la mujer) deber ser salvada por el espíritu de María. ‘353

El primer llamamiento a ingresar en la Federación muestra con claridad cómo ésta pretendía solucionar la cuestión de la mujer. En primer lugar se señalaba que la principal tarea de la mujer era el desarrollo de su profesión natural, es decir como madre y esposa. La influencia en la familia se traduce en una renovación de las costumbres morales en la vida pública. La célula de control y garantía de la salud social se encuentra no obstante en peligro porque las mujeres, se dedican „forzosamente“ a otras tareas fuera del hogar. Estas mujeres necesitan ayuda y profesión. El problema del dualismo trabajo o familia se soluciona con la renuncia al matrimonio de la mujer que trabaja y se propone para las mujeres que trabajan la vida ascética y en abstinencia sexual. ${ }^{354}$

Una de las figuras decisivas en la fundación de la Federación es Elisabeth Gnauck-Kühne ${ }^{355}$, de profesión maestra y perteneciente a una familia protestante, se decide tras un matrimonio frustrado a los 44 años a iniciar un estudio universitario en sociología. Su interés por la situación de las mujeres trabajadoras la lleva a trabajar en una fábrica de papel, donde realiza un estudio sobre las condiciones de trabajo de la mano de obra femenina. Este estudio, Die deutsche Frau um die Jabrhundertwende, se convierte posteriormente en lectura obligatoria entre los círculos de mujeres católicas.

Junto a Gnauck-Kühne hay que destacar los esfuerzos de Pauline Herber y Albertine Badenberg, ${ }^{356}$ dirigentes de la ya existente organización de maestras católicas, Verein katholischer deutscher Lehrerinnen ( $V k d L$ ), fundada en 1885. Como presidente de la Federación se elige a Emilie Hopmann, ${ }^{357}$ una enérgica madre de familia, a la que sigue en 1912, Hedwig Dransfeld, ${ }^{358}$ conocida por su trabajo como redactora en DIE CHRISTLICHE FRAU. A su lado trabajará como secretaria general Antonie Hopmann, ${ }^{359}$ En 1925 ésta es revelada por Gerta Krabbel que dirigirá la organización hasta 1945. A pesar de la existencia de un consejo ejecutivo, formado por mujeres, y una presidenta, en la Federación se daba en los principios de su fundación una gran importancia a la presencia de prelados, obispos y sacerdotes. Hilde Lion perteneciente al movimiento laico de la mujer describe una de las reuniones de la Federación:

353 Ibídem, p. 15

354 Lion, H.: Zur Soziologie der Frauenbewegung. Die sozialistische und die katholische Frauenbewegung, Berlin, F.A. Herbig, p. 113

355 Elisabeth Gnauck-Kühne, 1850-1917, fundadora de la liga de mujeres protestantes (1894). Tras su conversión al catolicismo (1900) colabora intensamente en la fundación de la Federación de mujeres católicas.

356 Albertine Badenberg (1865-1859): fundadora de DiE CHRISTLICHE FRAU (1902) que más tarde se convertirá en el órgano de propaganda de la Federación de mujeres católicas. En el período 1917-1920 secretaria general del KDFB y representante del Zentrumspartei en el parlamento prusiano desde 1924 a1932.

357 Emilie Hopmann y Minna Bachem-Sieger pertenecientes a las clases acomodadas de Colonia impulsan el crecimiento de la Fundación. Las primeras reuniones de ésta tienen lugar en el hogar de Hopmann.

358 Hedwig, Dransfeld (1871-1925): maestra de la escuela secundaria. Desde 1915 hasta 1925 directora de Die CHRISTLICHE FRAU y presidenta de la Federación desde 1912 hasta 1925 y parlamentaria desde 1918 hasta 1924.

359 Antonie Hopmann (1882-1941) al igual que Dransfeld maestra de secundaria. Trabaja como secretaria de la Federación desde 1923. Es conocida su aversión hacia el Nacionalsocialismo. 
„La señora Dr. Amann abre la sesión con unas palabras de saludo a los presentes, el sacerdote Hecker habla sobre el tema ¿Qué le tiene que agradecer la mujer al cristianismo? El padre Benno Auracher habla sobre 'Movimiento de la mujer en general y la fundación de mujeres católicas', el señor Dr. Amann sobre la fundación de la Federación en Munich. La señora Dr. Amann cierra la reunión.“360

La Federación pretende desde el primer momento agrupar los intereses del resto de las organizaciones de mujeres católicas, en segundo lugar tiene como objetivo ofrecer formación social y de educación ciudadana y en tercer lugar la agrupación del trabajo social y la representación pública de los intereses de la mujer.

Las primeras actividades del KFB se centran en diferentes comisiones de estudio. Cada una se especializa en diferentes temas: investigación y actividad laboral de la mujer, actividades caritativas y temas sociales. Una vez que las comisiones han tratado los temas en cuestión, estos son puestos a disposición de los grupos y asociaciones de la Federación. ${ }^{361}$ Junto a las comisiones de trabajo cabe destacar la fundación de los Franenbildungsheime, y de las escuelas sociales, centros de estudio y de formación que pertenecían a la Federación donde mujeres provenientes de toda Alemania se reunían para participar durante los fines de semana en cursos de formación y seminarios. La fundación de la primera escuela social del KFB tiene lugar en Colonia en 1916, ${ }^{362}$ al frente de ella Helene Weber. ${ }^{363}$ Los planes de estudios estaban orientados para la formación de trabajadoras sociales. Entre las alumnas se encontraban mujeres de diferentes clases sociales y grupos de edades: religiosas, viudas de guerra, mujeres jóvenes activas en el trabajo social, hijas de familias acomodadas que tras sus experiencias en el servicio femenino en la primera guerra mundial se habían decidido por el trabajo social. ${ }^{364}$

$\mathrm{Al}$ igual que el resto de las asociaciones de mujeres la llegada de la primera guerra mundial, acentúa el carácter nacional de la Federación de mujeres católicas, que consideran normal prestar ayuda a la nación en tiempos de crisis. Más tarde con la llegada de la república el trabajo de información y educación se intensifica en forma de cursos sobre trabajo femenino en los municipios, sobre problemas económicos y políticos, lucha contra las enfermedades venéreas, protección de menores, lucha contra prácticas amorales etc., así como en la presión política a través de sus representantes en el parlamento, las cuales pertenecen en su totalidad al Zentrumspartei. Fundado en 1870 se caracteriza por su apoyo a la Constitución de Weimar y la defensa de los derechos de la Iglesia Católica. 365

El 6 de febrero de 1919 en la asamblea nacional de Weimar nos encontramos por primera vez mujeres en el parlamento alemán. De los 423 parlamentarios elegidos 36 eran mujeres. Seis mujeres representan al partido de centro en la Nationalversammlung, Agnes Neuhaus, Hedwig Dransfeld, Maria Schmitz, Helene Weber, Maria Zettler y Christine Teusch. ${ }^{366}$ Constitución del

360 Lion, H.: op. cit., p. 122

361 Ehrle, G.: Jabrbundertwende, Jahrbundertmitte. Der Katholische deutsche Frauenbund auf dem Wege. 1903-1953, Köln, Zentrale des Katholischen Deutschen Frauenbundes, 1953, p.8

362 La Federación de mujeres católicas alemanas contaba con centros de este tipo en Bendorf, Essen, Köln, Beuron, Berlin y München.

363 Helene Weber (1881-1962): maestra de enseñanza superior, miembro del KFB y parlamentaria del partido de centro durante la república de Weimar.

364 Hartmann, S; Dietlein-Rust, H.: "Beginn der Sozialarbeit", en: Prégadier, E., Mohr, A.: Helene Weber (1881-1962), Ernte eines Lebens. Weg einer Politikerin, Essen, Plöger, 1991, pp. 29 y 30

365 Ibídem, p. 125

366 Teusch, C.: “Die Parlamentarierin", en: Prégadier, E., Mohr, A.: Helene Weber (1881-1962), Ernte eines Lebens. Weg einer Politikerin, Essen, Plöger, 1991, p. 71 
gobierno consiguen un escaño en el Reichstag siete mujeres católicas miembros de la Federación. Hedwig Dransfeld (Düsseldorf), Agnes Neuhaus (Dortmund), Marie Zettler (München), Maria Schmitz (Aachen), Christine Teusch (Köln), Helene Pieper (Berlín) y más tarde Elisabeth Zillken (Dortmund). ${ }^{367}$ Sin embargo la influencia de las mujeres en el partido se limita únicamente a aspectos de la política social o cultural.

El apoyo al partido de centro se manifiesta públicamente en un artículo en DIE CHRISTLICHE FRAU donde se reconoce a este partido como el único que representa correctamente los intereses de la Federación. Como señala Hilde Lion, la organización católica pasa, a partir de 1918, de una política de neutralidad a la reserva política de partido. ${ }^{368}$

La valoración de la actividad de las mujeres en el partido es, salvo con algunas excepciones, positiva. Josef Joos, político de centro relata sus experiencias con las nuevas parlamentarias:

„A lo largo de los años he visto mujeres en distintos partidos y en el trabajo parlamentario. Por ejemplo las parlamentarias de centro en Weimar y Berlin, Hedwig Dransfeld, Helene Weber, Christine Teuch, Maria Schmitz, Agnes Neuhaus; todas mujeres que procedían de las profesiones de educadora o asistente social. Encontré que todas realizaron su tarea correctamente y que fueron capaces de dar a las cosas públicas una nota diferente a través de su positiva participación. Lo mismo puedo decir de las otras mujeres, ya fueran de derechas o de izquierdas, del centro o comunistas. La dirigente de las trabajadoras domésticas, Margarete Behm, o Anna von Gierke, Gertrud Bäumer, Antonie Pfülf, Louise Schröder, deseaban la participación de las mujeres como mujeres y no sólo como parlamentarias (...). De la mayoría de las mujeres con las que tuve contacto en la arena política puede decirse que poseían la capacidad tanto de cuidar el mundo en pequeño, como de participar en la creación de grandes ordenaciones políticas partiendo de sus principios ideológicos. “"369

El crecimiento de la Federación es digno de destacar, especialmente si tenemos en cuenta las cifras de su homónimo protestante y que no todas las organizaciones de mujeres católicas con un contingente de dos millones de miembros habían entrado en la organización, como un conjunto de organizaciones de mujeres católicas. A diferencia de la Federación de mujeres protestantes alemanas, $D E F$ las mujeres de la organización católica provenían de todas las clases

Hedwig Dransfeld (1871 -1925): maestra de la escuela secundaria. Desde 1915 hasta 1925 directora de Die Christliche FrAU y presidenta de la Federación desde 1912 hasta 1925 y parlamentaria desde 1918 hasta 1924. Maria Schmitz (1875), Maria Zettler (1885), Christine Teusch (1888-1968) parlamentaria del partido de centro, desde 1925 secretaria del parlamento, presidente de la asociación de protección de menores, Mädchenschutzverein desde 1926 hasta 1966, representante de centro en el parlamento de Nordhein-Westfalen, ministra de cultura en este estado, 1947-1957. Elisabeth Zillken (1888-1980), parlamentaria de centro, secretaria general de la asociación católica de trabajo social, Katholischer Fürsorgeverein, 1916-1958 y desde 1940 hasta 1971 presidente de ésta.

367 Pankoke-Schenk, Monika: „Katholizismus und Frauenfrage“, en: Rauscher, Anton (De.): Der soziale und politische Katholizismus. Entwicklunslinien in Deutschland 1803-1963, München/Wien, Günter Olzog Verlag, 1982, p.297

368 Lion, H.: op.cit., p. 131.Las primeras mujeres católicas que consiguen un escaño en la Asamblea Nacional y posteriormente en el parlamento de Weimar son: Hedwig Dransfeld, Agnes Neuhaus, Marie Zettler, Maria Schmitz, Christine Teusch, Helene Weber, Elisabeth Zilken, Else Peerenboom, Hedwig Fuchs y Klara Philipp.

369 Prégadier, E.: Der Beitrag der christlichen Frauenbewegung zur politischen Kultur in Deutschland, Schriften des KDFB, n², 1994, p. 9 
de la sociedad. La Federación estaba articulada en pequeñas organizaciones que reunían a estudiantes, trabajadoras, profesoras, amas de casa y trabajadoras del campo, aunque predominaban las amas de casa, las mujeres campesinas, estando las mujeres que ejercían una actividad laboral infrarrepresentadas. La existencia de mujeres con estudios superiores en la cúpula de dirigentes era menor que en el caso de la organización protestante.

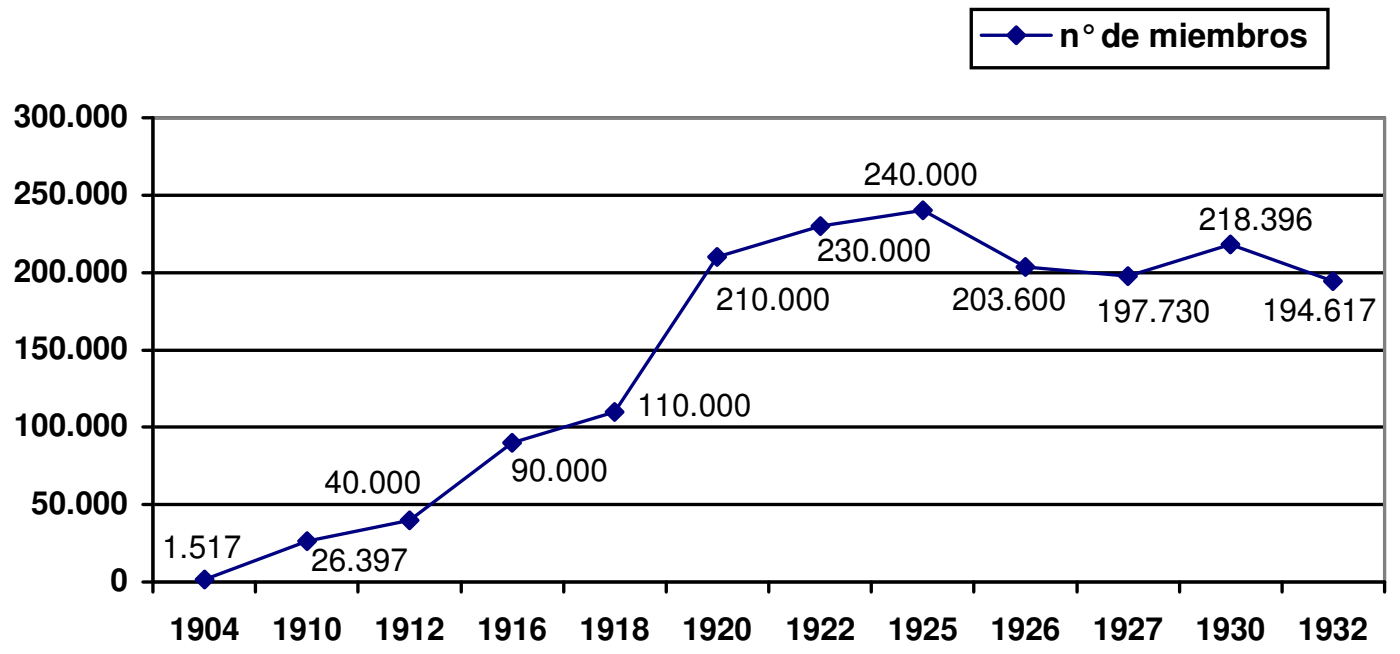

Fuente: Frauenland, Enero 1933, n¹

Los campos en los que el KFB es activo se pueden reducir a cuatro: el mantenimiento de la familia y el matrimonio como primeras células del orden social, el trabajo caritativo, el problema de las mujeres trabajadoras y la educación en el compromiso político a través de cursos, conferencias y seminarios. Su actitud respecto al movimiento de la mujer, es ambigua. En general se oponen a la igualdad legal a la que aspiraban las organizaciones no confesionales, sin embargo hablan de una sittliche Gleichberechtigung, de una igualdad moral. Esto quería decir que hombre y mujer eran moralmente iguales, y ninguno de los dos géneros tenía el derecho de creerse superior al otro. ${ }^{370}$

Al igual que el $B D F,{ }^{371}$ la Federación de mujeres católicas se relaciona internacionalmente. Los objetivos de este trabajo internacional se centran en la renovación moral de la familia y la lucha contra el neo-malthusianismo. ${ }^{372}$ A principios de los años treinta el trabajo se orienta hacia posiciones pacifistas, y se tienen en cuenta problemas como el de la igualdad de los géneros, cultura nacional, economía y entendimiento entre los pueblos. ${ }^{373}$ Destaca también su implicación en la política de desarme. La hoja informativa del KDF da a conocer en enero de 1932 una iniciativa de recogida de firmas a favor del desarme. En la petición se alejan de las

\footnotetext{
$370 \quad$ Ibídem, p.288 pp. 278-311

371 Hausmann, Christian: Leitbilder in der katholischen Frauenbewegung der Bundesrepublik, Freiburg, Diss, 1973 , p.22

372 BAP, 69468, VII. Kongress der Internationalen Katholischen Frauen Bund, 1928, Internationale Katholische Frauenkongresse.

373 BAP, 69468, Tagung der Studienkommissionen der Union Internationale des Ligues Féminines Catholiques in Luzern vom 26. September bis 2. Oktober 1932; Internationale Katholische Frauenkongresse.
} 
reivindicaciones en contra de la política de desarme de las mujeres del ala conservadora y también de la propuesta de la "Liga de mujeres para la paz internacional", es decir del grupo radical del movimiento de la mujer. Esta acción tiene lugar conjuntamente con la Unión Internacional de asociaciones de mujeres católicas, Union Internationale des Ligues Féminines catholiques. ${ }^{374}$

Estos esfuerzos se consolidan en una serie de Internationale Tagungen, congresos internacionales, donde se comprometen a luchar a favor de la moral y la familia y especialmente contra el neomaltusianismo. ${ }^{375}$ Los contactos se prolongan hasta el año 1932, prueba de ello es un congreso celebrado en Lucerna donde se tratan un gran número de temas que afectan a la mujer. ${ }^{376}$

El programa de la Federación de mujeres católicas, Katholischer Deutscher Frauenbund, en 1933 tiene como ideal la consecución del ideal de la mujer en la familia, en el trabajo y en la vida pública. La Federación advierte de varios peligros que afectan a la mujer, la masculinización de ésta, la sobreestimación biológica de la maternidad y la poca valoración de la mujer no casada. Para ello la Federación propone una serie de alternativas para luchar contra esta situación: el reforzamiento de la elevada apreciación del catolicismo por la naturaleza de la mujer, la renovación de los valores morales, el apoyo para el desarrollo de la libre personalidad, el significado del recogimiento, el deber de la responsabilidad, el reforzamiento de la conciencia, en fin la aplicación de los valores católicos a todas las esferas de la vida.

La Federación se dirige a mujeres de todas las clases y edades. En la práctica ofrecen, al igual que el Evangelisches Frauenwerk organizan una consulta matrimonial, ofrecen cursos de formación a comadronas y madres, y desarrollan actividades de información para amas de casa y trabajadoras del campo. ${ }^{377} \mathrm{El}$ apoyo a las mujeres trabajadoras, así como la preparación de éstas en su futura trabajo como madres. De igual modo se apoya la presencia católica en la prensa, literatura y demás medios de comunicación.

\subsubsection{La prensa de la Federación de mujeres católicas}

A diferencia del resto de las asociaciones que cuenta con un único órgano de prensa, la Federación de mujeres católicas se caracteriza por tener varios. En 1902 aparece la ya existente DIE CHRISTLICHE FRAU como órgano oficial de la Federación, dirigido hasta 1923 por Hedwig Dransfeld, fecha en la que Gerta Krabbel se hace cargo de la publicación. Como información suplementaria publica una hoja informativa sobre las actividades de la Federación, MiTTEILUNGEN AUS DEM KFB. En 1907 aparece Der Katholische Frauenbund más tarde conocido como FraUENLAND, dirigido por Elisabeth Cosack y Regine Broel donde se tratan temas relacionados con la mujer de una manera fácil y sencilla, con rúbricas dedicadas a la moda y a la cocina. Para las mujeres que trabajaban en el campo y para las católicas más jóvenes se publican

374 Nachrichtenblatt für die Zweigvereine es Katholischen Deutschen Frauenbundes, Enero 1932, n 1 , p.1

375 BAZ 69468, Schmitz, M.: „Der VII. Kongress der Internationalen Katholischen FrauenFederación 1928 “

376 El Congreso se organiza en en diferentes comisiones: cuestiones religiosas, familia, educación y formación, trabajo intelectual, trabajo de la mujer en la industria, agricultura, Fürsorge und Gefährdetenarbeit, protección de la infancia, Körperkultur y vida pública. BAZ 69468, Hilbach, K.: „Tagung der Studienkommissionen der 'Union Internationale des Ligues Féminines Catholiques' in Luzern vom 26. September bis 2. Oktober 1932“"

377 Archiv des Bistums Augsburg, Fen 57: „Aufgaben des Katholischen Deutschen Frauenbundes in der Zeit“, Köln, August 1933 
revistas especiales, Die KATHOLISCHE LANDFRAu y JugENDZIELE y finalmente también dependiente de la Federación se edita una publicación dedicada exclusivamente a la moda y a la decoración del hogar, BLÄTTER FÜR KLEID- UND HEIMKULTUR. Gertrud Ehrle se encargaba de la publicación de una serie monográfica de estudios que se ocupaban de temas relacionados con el movimiento de la mujer, la historia de la Federación y problemas sociales y económicos.

Entre ellas la más importante es DIE CHRISTLICHE FRAU. Dado su contenido, problemas teológicos, temas relacionados con la formación femenina, artículos sobre arte y literatura, se convertía en la réplica católica de revistas como DIE FrAU o DIE EVANGELISCHE FRAUENZEITUNG.

\subsubsection{La influencia de Gertrud von Le Fort en el entendimiento de la feminidad por las mujeres católicas}

Una de las mujeres que contribuye a modelar la imagen de las mujeres católicas es Gertrud von Le Fort. (1876-1971). Nacida en 1876 en el seno una familia protestante-hugonota perteneciente a la aristocracia prusiana de Westfalia donde recibe una educación humanística, aunque no recibe ningún tipo de educación secundaria. A los 32 años viaja a Heidelberg y se inscribe como oyente ya que no se puede matricular como estudiante oficial. En Heidelberg tiene una relación especial con el teólogo, filósofo e historiador cultural, Ernst Troeltsch 378. Producto de este entendimiento es la edición de una de las obras más importantes de Troeltsch que hace Le Fort a la muerte de éste. ${ }^{379}$ En Heidelberg se produce su conversión al catolicismo y comienza su carrera literaria. Tras Heidelberg estudia en Berlin de nuevo bajo Troeltsch que en aquellos momentos había recibido una plaza de profesor en la Facultad de Teología. En 1924 se convierte al catolicismo.

Gertrud von Le Fort no pertenece a ningún grupo de mujeres, ni a ningún partido político, pero marca la imagen de las mujeres católicas, su trabajo es comentado en los círculos protestantes y es criticada por los nacionalsocialistas. Sin ser nacionalsocialista, algunos autores han encontrado paralelos en sus ideas con la imagen de la mujer que proponían los nacionalsocialistas.

La visión católica del mundo determina su imagen de la mujer. Esta tiene como tarea redescubrir su papel originario de servidora, así como influir en un mundo que descristianizaba paulatinamente. ${ }^{380} \mathrm{Su}$ obra es fundamentalmente narrativa y poética y a diferencia del resto de las mujeres hasta ahora tratadas, no pertenece a ningún tipo de organización. Sin embargo su obra, en especial el ensayo, Die ewrige Frau publicado en 1934381 tuvo una gran resonancia 382 en los círculos de las mujeres protestantes, católicas, así como en el grupo del antiguo movimiento no confesional de la mujer.

378 Ernst Troelsch (1865-1923): teólogo, filósofo e historiador. Cofundador del partido demócrata alemán, DDP. Su teología se caracteriza por el análisis histórico-crítico de las fuentes. Representante del llamado "nuevo protestantismo".

379 Se trata de la obra Glaubenslebre, una selección de los seminarios de Troeltsch.

380 Moltmann-Wendel, Elisabeth (De.): Frau und Religion. Gotteserfahrungen im Patriarchat, Frankfurt am Main, Fischer, 1983, p.259

381 von Le Fort, Gertrud: Die ewige Frau, München, Kösel \& Pustet, 1934

382 Los ensayos que recogen las ideas de Le Fort sobre la mujer y la feminidad aparecen en 1934: Die ewige Frau, Die Fran in der Zeit, Die Zeitlose Frau, München, Kösel und Pustet Verlag, 1934. Otras obras sobre Gertrud von le Fort: Meyerhofer, Nicolas J.: Gertrud von le Fort, Berlín, Morgenbuch Verlag, 1993; La Chevallerie, Elonore von: Gertrud von le Fort. Wirken und Wirkung, Heidelberg, Heidelberger Bibliotheksschriften, 1983 
Le Fort defiende un ideal femenino común a las mujeres protestantes: la especialidad de la naturaleza femenina, debido a la relación especial que esta tiene con lo religioso. La maternidad predispone a las mujeres a defender el pacifismo y a luchar contra todas las guerras. Interesante en la figura de Le Fort es su falta de implicación en los asuntos políticos, aún durante la época nacionalsocialista.

La mujer es para Le Fort es la Trägerin y Beschützerin, protectora y piedra angular de la vida, y su naturaleza la dota de un carácter carismático que tiene como consecuencia la salvación del mundo. ${ }^{383} \mathrm{La}$ feminidad representa la interioridad, los valores intrínsecos y desconocidos del ser. El ejemplo a seguir lo constituye María, como expresión absoluta del contacto especial que la mujer tiene con la maternidad y representante de los dos caminos que puede elegir la mujer en la tierra: el camino de la virginidad, o el de la maternidad. Si para Tiling la feminidad es una parte más del orden divino, Le Fort defiende una "teología de la maternidad", es decir la experiencia de Dios a través de la maternidad. Le Fort no se refiere a la maternidad espiritual a la que hacían referencia las mujeres del movimiento de la mujer, sino a la pura y biológica maternidad, como representación de la voluntad divina en el mundo.

Le Fort utiliza una metáfora para explicar esta relación metafísica entre mujer y Dios. Se trata del velo, símbolo de la diferencia de la mujer, pero también de su función como protectora y defensora del amor.

Le Fort analiza las cuestiones que preocupaban a las mujeres católicas durante los primeros años de la dictadura: indaga sobre la naturaleza de la maternidad y sus relaciones con el mundo. La maternidad no es un proceso evidente, es una etapa de la vida de la mujer que se debe vivir con plena consciencia y responsabilidad. Esta responsabilidad además de atañer a la relación hijo-madre, se caracteriza por la responsabilidad social. Le Fort utiliza una metáfora en la que resalta esta responsabilidad. El mundo necesita como un niño pequeño y desvalido a la madre, como administradora de las pequeñas cosas de la vida y mediadora entre la vida y la muerte. La madre es como la tierra "que calladamente da, sostiene y apoya”.

El hombre por el contrario es responsable del mundo de las ideas, tarea que únicamente puede realizar gracias al apoyo de la madre, de su capacidad de solucionar „los problemas materiales". La supuesta insignificancia de este trabajo de la madre, su permanencia en el olvido es el éxito de ésta. Como los soldados desconocidos en la guerra. La maternidad dota a la mujer de un instinto especial para los pobres, desprotegidos, los perseguidos y necesitados.

La mujer es un símbolo, una imagen en la que la realidad metafísica se hace evidente en forma de metáfora. La mujer es un símbolo de lo religioso. María es la mejor representante de la entrega de la mujer a lo divino.

Como metáfora de separación de la mujer en dos mundos se utiliza el velo, para expresar la separación entre el mundo de la mujer (interior) y la realidad (exterior). El velo representa también la actitud de espera de la mujer; activa, atenta cuando es necesitada, y en silencio y discreta, cuando su presencia no es requerida. ${ }^{384}$

Como ya hemos comentado con anterioridad, el ensayo de Le Fort sobre la naturaleza de la maternidad tuvo gran resonancia en el mundo de las mujeres. ${ }^{385}$ Bäumer realiza una crítica positiva del libro y se muestra de acuerdo con las ideas de Le Fort, cercanas a los ideales del movimiento de la mujer. Sin embargo no acepta el símbolo del velo como representativo de la

383 Burggraf, Jutta: „Maria als Vorbild für die Frau“, en: Bossle, Lothar; Pottier Joël (De.): Christliche Literatur im Aufbruch. Im Zeichen Gertrud von le Forts, Würzburg, Creator, 1988, pp. 63-64

384 Moltmann-Wendel, Elisabeth, (ed.): op. cit., pp. 195-197

385 En DiE FraU, se publican cuatro críticas sobre el libro. Graefe, Johanna: „Gertrud von Le Fort’s Werk „Die ewige Frau“, gesehen von einer Protestantin. Zum 60. Geburtstag der Dichterin“, Die Frau, n 44 , año 1936/1937, pp. 10-15. Bäumer, Gertrud: „Fiat“. Gertrud von Le Fort zur Frauenfrage, DiE FRAU, nº41, año 1934/1935, pp. 168-171 
identidad de la mujer, así como la actitud recatada de la mujer, en los momentos en que ésta no es necesitada. 386

\subsection{El feminismo radical}

„En la actualidad tiene mucho más interés ser una mujer que un hombre. Para nosotras ha tenido lugar una gran revolución en el terreno ideológico, una nueva era de renacimiento ha nacido en la que no sólo la mujer aspira a la realización personal sino a algo más grande que se traduce en la nueva generación de mujeres jóvenes cuya aspiración es conseguir la perfección como individuos en el conocimiento, el placer y la actuación política. “387

Como ya hemos señalado al comienzo de este capítulo el movimiento de la mujer no se caracterizaba por su homogeneidad. Junto al grupo moderado, el más numeroso por cierto, se encontraba el llamado movimiento de la mujer radical. Los temas objeto de discusión estaban relacionados con la cuestión de las costumbres morales (legalización de la prostitución y reconocimiento de la madre soltera), la valoración de la sexualidad femenina y el derecho a elegir el momento adecuado para ser madre, con la consiguiente utilización de métodos anticonceptivos y la interrupción voluntaria del embarazo. ${ }^{388}$ En el caso de la prostitución femenina las mujeres más conservadoras apoyaban posturas de tipo "reglamentista“ o proteccionista, el grupo radical por el contrario era partidario de la liberación y defendían la concepción liberal en la que toda intervención estatal debía evitarse a fin de garantizar la libertad de los individuos y su propia responsabilidad. ${ }^{389}$ Figuras más importante de esta tendencia del movimiento de la mujer son Hedwig Dohm, Helene Stöcker, Lida Gustava Heymann, Minna Cauer ${ }^{390}$ y Anita Augspurg.

\footnotetext{
386 Bäumer, Gertrud: op. cit., p. 170

387 von Soden, op.cit., p.46
}

388 Las tensiones entre las dos tendencias del movimiento se acentúa con la fundación de la asociación de Helene Stöcker, Bund für Mutterschutz und Sexualreform en 1905 y la promulgación de la llamada neue Ethik. La organización no fue admitida en el BDF debido a la defensa que ésta hacía de la madre soltera, ya que su reconocimiento ponía en entredicho la legitimación de matrimonio y familia. Helene Stöcker, 1869-1943 basa su concepto de la nueva ética en un nuevo entendimiento del amor y el erotismo. Reivindica el reconocimiento social de la maternidad, siempre que esté en manos de la mujer el decidir sobre ella, así como la información en forma de consultas de planificación familiar. Reconocida pacifista participa en la fundación del Bund der Kriegsdienstgegner en 1919 y en 1921 funda la Internationale der Kriegdienstgegner. En 1933 emigra a través de Suiza y Suecia a los Estados Unidos.

389 Thalmann, R.: Frausein im Dritten Reich, München, Carl Hanser Verlag, 1984, pp.83ss.

390 Hedwig Dohm, 1831-1919, teórica del feminismo radical. Fue una de las primeras defensoras de los derechos de la mujer que exige la concesión del voto femenino, así como la admisión de las mujeres en los estudios universitarios.

Minna Cauer, 1842-1922, casi como el resto de sus compañeras maestra de profesión. En 1888 funda la organización Frauenwobl, y trabaja como redactora jefe en el órgano de prensa de la organización, Franenwobl. En 1895 pasa a editar la publicación DIE FRAUENBEWEGUNG. 
Los grupos de organizaciones de mujeres radicales se relacionan con el movimiento de la mujer europeo de carácter pacifista que se extiende por casi toda Europa central y del norte. ${ }^{391}$ Otra de las diferencias respecto al movimiento de la mujer moderado, se refieren al tratamiento del tema de la guerra así como la valoración del Tratado de Versalles. Lida Gustava Heymann y Anita Augspurg, entre otras, defensoras de un internacionalismo a ultranza, condenaron en sucesivas ocasiones la postura del $B D F$ por apoyar con su trabajo la primera guerra mundial. Como respuesta ambas fundaron la „Federación Internacional de la Mujer para la Paz y la Libertad“, asociación internacional que pretende despertar el espíritu pacifista entre mujeres a nivel supranacional:

„Nosotras no apoyaríamos ningún trabajo que estuviera relacionado con los fines de la guerra; servicio en hospitales, cuidado de enfermos. ¿Curar a hombres medio muertos y devolverles la salud para que vuelvan a sufrir de nuevo los mismos o peores horrores? No, para tales tareas demenciales no estamos dispuestas a trabajar.“"392

Esta actitud pacifista no solamente choca contra los ideales del movimiento de la mujer moderado que participa activamente en la defensa de la nación alemana con la fundación de un servicio femenino de guerra, sino también contra las autoridades ministeriales. El ministerio de guerra bávaro prohibe a Lida Gustava Heymann, Anita Augspurg y Margarete Quidde todo tipo de manifestación pública, sus correspondencia es censurada, sus viajes controlados y algunos de sus escritos son confiscados.

La labor del grupo de mujeres radicales se consolida en organizaciones que si bien pertenecen al BDF se distancian cada vez más de la política oficial de éste. ${ }^{393}$

Para ello se practica una intensa actividad periodística en revistas y publicaciones editadas por las organizaciones de mujeres radicales. ${ }^{394}$ Este tipo de publicaciones no sólo constituyen un foro de expresión para el grupo radical, sino que despliegan una intensa labor cultural en

391 En 1929 el Fondo Internacional para la emancipación económica de la mujer trabajadora, integrado por mujeres de ideología radical, consiguió que en Alemania se revocaran las medidas de proteccionismo económico que afectaban negativamente a las mujeres.

392 Krafft, S. (Coord.): Frauenleben in Bayern vor der Jahrbundertwende bis zur Trümmerzeit, München, Bayerische Landeszentrale für politische Bildungsarbeit, 1993, p. 168

393 Las principales organizaciones del feminismo radical son: Verein für Franenstimmrecht

394 En primer lugar hay que destacar Die Franenbewegung dirigido por Minna Cauer, conocido como, la hoja de izquierdas, p.40. Fundada en 1985. Aparece dos veces al mes y cuesta 1 marco, más tarde 1.50 con la editorial, Ferdinand Dümmler en Berlin, más tarde en la editorial Lowenthal. No es conocida la tirada. Los temas de la publicación hacen referencia a la polémica que se mantiene con el movimiento de la mujer moderado sobre los derechos de la mujer, la prostitución, la educación femenina y el derecho al voto. Defiende fundamentalmente la formación política de la mujer y su implicación en temas que fueran más allá de los puros intereses femeninos. La revista aparece por última vez en diciembre de 1919, ya que se considera que los objetivos de emancipación política que se perseguían aparecen logrados con la concesión del voto femenino.

Otra revista que tiene gran importancia en el espectro radical es, DIE ZEITSCHRIFT FÜR FRAUENSTIMMENRECHT fundada el 15 de enero de 1907, y dirigida desde München por Anita Augspurg. Aparece una vez al mes bajo la editorial Löwenthal en Berlin. Su tirada llega a 2.500 ejemplares. La publicación está dedicada a defender el derecho al voto femenino.

Representante de la tendencia pacifista era FRAU IM STAAT a cuya cabeza estaban Heymann y Augspurg. La revista se publica desde 1919 hasta 1933, fecha en que sus editoras emigran a Suiza. 
forma de mesas redondas, tertulias, exposiciones etc., que ofrecen a un gran número de mujeres la posibilidad de expresar sus intereses artísticos, literarios y políticos. 395

El grupo radical representa el verdadero feminismo de los años veinte. En su discurso, el género se convierte por primera vez en la categoría central de análisis. A diferencia del feminismo moderado donde el punto central de la emancipación femenina estaba unido al bien que ésta podía hacer a la sociedad, para las el grupo radical, el proceso de emancipación parte de la propia mujer y termina en ésta. Sin embargo a pesar de su "radicalidad", caen también en la diferenciación de esferas de actuación entre lo femenino y lo masculino. No se trata como en el caso confesional del reparto de tareas en la sociedad, lo que conllevaba a la consideración de que existían trabajos masculinos y trabajos femeninos. Las autoras practicaban un feminismo de la diferencia, donde ambos géneros se enfrentan en una relación de conflicto. Los hombres son responsables de la guerra y la violencia., mientras que las mujeres se convierten en las defensoras de la paz, y objeto de la violencia masculina. Al igual que el resto del movimiento de la mujer se declaran por encima de cualquier tendencia política. La identidad femenina se define en función de la oposición y resistencia contra lo masculino. El feminismo radical permanece sin embargo un lujo minoritario para académicas, artistas y literatas, que no consigue ofrecer un proyecto político de cambio como los partidos de izquierda.

Finalmente, sin pertenecer a una organización determinada, existían también grupos de mujeres que se caracterizaban por su desprecio por el resto de las organizaciones de mujeres burguesas y reivindicaban la vuelta a las viejas tradiciones germánicas donde se predicaba que las mujeres reencontrarían su verdadera identidad. Estos grupúsculos eran minoritarios, y crecen a la sombra del Partido Nacionalsocialista (NSDAP). Las mujeres miembros de organizaciones como el Deutscher Frauenorden (Orden de mujeres alemanas), o el Neulandbewegung (Movimiento del nuevo país), se convertirían con el tiempo en las bases de las organizaciones femeninas nacionalsocialistas: la NS-Frauenschaft y el Deutsches Frauenwerk.

Estos grupos se caracterizaban por su desprecio por el liberalismo y el materialismo, y aspiraban a una regeneración moral del pueblo alemán, así como un reencuentro de las raíces de éste en el pasado idílico de las sagas germánicas, junto a la maternidad, el amor a la patria, la regeneración de los valores morales encarnados en el ideal nórdico germánico y la pureza de la raza.

\subsection{Conclusiones}

„¿Qué fue el movimiento de la mujer? Simplemente todo, nueva vida para las mujeres, que un Dios desconocido esculpió de la piedra de los tiempos actuales. Fuerzas artísticas e intelectuales despertaron de su sueño o sólo la voluntad de rellenar el viejo ciclo vital más conscientemente, con más fuerza y valor. “396

Para explicar el porqué de la "supervivencia" del feminismo liberal-conservador durante el nacionalsocialismo, hay que tener en cuenta la naturaleza de este movimiento. El feminismo se

395 Wischermann, Ulla: „Die Presse der radikalen Frauenbewegung“, Feministische Studien 3, 1984, p. 3962

396 Bäumer, G.: Im Licht der Erinnerung, Tübingen, Wunderlich Verlag, 1935, p.160 
trata de un movimiento social de emancipación. ${ }^{397}$ Sin embargo a diferencia de otros movimientos de emancipación no se deja describir fácilmente su identidad. En primer lugar el movimiento de la mujer es „mayoritario“, los miembros no pueden configurarse „territorialmente“ como grupo como en movimientos étnicos, proletarios, religiosos o de raza. Dentro del movimiento existe una pluralidad dentro de la concepción de la propia identidad, lo que hace que la articulación política sea más complicada. Esta pluralidad está determinada por la raza, la confesión, la orientación política y la clase. Otra diferencia es respecto a sus relaciones con el poder, mientras que en los demás movimientos emancipatorios la consecución del poder, y la reforma o revolución de la sociedad, aparecen como objetivos a conseguir, el movimiento feminista, en sus origines, reivindica formar parte del poder a largo plazo, lo que un principio se revela como una esquizofrenia ideológica cuando entre los grupos de mujeres se propagaban posturas apolíticas, y las principales miembros del partido son miembros de partidos políticos y participan en la vida parlamentaria.

Los miembros de los grupos potenciales de mujeres no pueden ser organizados como los otros movimientos aislados, sin influencias. La imagen de un enemigo virtual con la que trabajan todos los movimientos de emancipación es difícil de reproducir.

Los grupos de mujeres evolucionan durante la república de Weimar de un feminismo humanista, a un feminismo ginocentrista, ${ }^{398}$ donde se fundamenta la identidad de la mujer, su alteridad basada bien en la maternidad o en la sexualidad de la mujer se convierten en las señas de identidad de lo femenino. Esta tendencia se radicaliza durante los años de la dictadura, y reaparece en los años 60 y 70, donde el feminismo de la igualdad, (feminismo humanista) pierde influencia, y posiciones ligadas a la espiritualidad de la mujer, la componente ética de la feminidad, el rechazo de la guerra, y la masculinización de la violencia.

Hasta ahora el modelo a comparar con la evolución del movimiento de la mujer en otros países europeos, en especial Inglaterra, propuesto por Evans, muestra sus divergencias del modelo alemán. Lo que hace algunos autores hablar de un Sonderweg en el caso alemán, teoría que es asumida por algunas de las especialistas en el movimiento de la mujer. ${ }^{399}$

En 1933 las tres organizaciones sobre las que tratamos están disueltas. La aparente resistencia con la que han sido definidas en la mayoría de la bibliografía es una leyenda a la que el feminismo de la Bundesrepublik ha contribuido. Es cierto que no asumen desde un principio la ideología nacionalsocialista y que defendieron sus intereses como organización. Rasgos antisemitas caracterizan fundamentalmente al grupo de mujeres liberal-conservadoras y a las mujeres protestantes. El grupo de mujeres católicas constituye un caso especial. Aunque parte de principios religiosos, su carácter en el campo de la educación, formación y asistencia social, así como su especial dedicación a la situación de la mujer trabajadora, permite dentro de unos límites sacar a un gran número de mujeres católicas de su situación de ignorancia. No obstante no se puede hablar de un movimiento absolutamente dependiente de la jerarquía católica, lo mismo ocurre con su orientación política que depende de la inclinación que el milieu católico masculino tenía en la época: Die Zentrumspartei. De ahí que las reacciones ante el nacionalsocialismo de la Federación y el resto de mujeres católicas está unida estrechamente a las actitudes de la iglesia católica y el partido de centro.

La segunda parte de este trabajo ofrece una visión en la evolución de las tres organizaciones. A través de las publicaciones que consiguieron salvar de la quema nacionalsocialista conseguimos una imagen de las reacciones de adaptación de las mujeres durante el

397 Beyme von, Klaus: op. cit., 296. Dentro de la investigación sobre movimientos sociales, se distinguen cinco movimientos clásicos de emancipación en torno a la raza, el género, la clase social, confesión religiosa y la identidad linguística.

398 Ibídem, p. 310

399 Greven-Aschoff, Barbara: op. cit., p.13 
nacionalsocialismo. Estos procesos no son homogéneos sino que difieren, como veremos, en función de la religión, de la clase social y de la antigua afiliación política.

Los grupos de mujeres confesionales demuestran su cohesión en el control de las actividades de asistencia social y caritativas que se revelan como un Lebensraum que sirve a las mujeres para tomar los primeros contactos con las estructuras de poder. Su actitud era conservadora: no estaban interesadas en cuestionar las relaciones de clase y poder existentes, aunque tampoco son partidarias de una caridad benevolente donde las clases altas limpian sus conciencias, sino que se convierten en las pioneras de la profesionalización del trabajo social de la mujer en hospitales, hospicios, centros psiquiátricos, escuelas de formación y crean, apoyadas por sus iglesias, la infraestructura para la posterior asistencia social alemana.

Las organizaciones confesionales especialmente la Federación de mujeres protestantes presentan una clara línea nacional y conservadora que se articula en un excesivo nacionalismo, así como en un distanciamiento de los presupuestos del movimiento de la mujer. Esta afirmación la hemos podido constatar en el análisis de los programas de la liga a partir de 1918, el apoyo oficial de ésta a los partidos de derecha, y el creciente antisemitismo. Estudios locales sobre el DEF confirman esta opinión, como es el caso del trabajo de la historiadora americana Nancy R. Reagin en su investigación sobre clase y género en la ciudad de Hannover desde 1880 hasta 1933. Esta autora da como explicación al acentuado nacionalismo de las mujeres protestantes la ruptura de esferas entre los géneros, entre el "frente exterior" (el frente militar) e interior:

"Nationalism was a way of clinging to the remnants of Germany's honour, to the God-given German values and culture with which Protestant bourgeois women identified. Thus, nationalist women tried to mount what they perceived as a last line of defence against foreign enemies by struggling to preserve German culture, or Deutschtum." 400

En el caso del $B D F$ esta inseguridad se manifiesta en algunos de los grupos pertenecientes a la organización que posteriormente tras la disolución de la Federación en 1933 pasaron a formar parte de las organizaciones nacionalsocialistas, como por ejemplo: la organizaciones de mujeres patrióticas de la Cruz Roja, la Federación de académicas alemanas, aunque se vio diezmada a lo largo de los años de la dictadura, la organización de funcionarias, Organisationen der Beamtinnen, el Willkommenclub, la Frauengruppe der Deutschen Christen, el Fachlehrerinnenverband, el Verband Deutsche Franenkultur y la Organisation weiblicher Angestellter. ${ }^{401}$

$\mathrm{El}$ ala radical del $B D F$ demostró su rechazo al régimen con el exilio voluntario, y la cúpula de la organización, aunque disuelta la Federación, continúo organizada a través de la publicación del órgano portavoz de ésta, DiE FrAU.

Los sueños de una Alemania grande que Gertrud Bäumer había expuesto en un artículo en esta revista se veían por fin cumplidos en el Tercer Reich. En éste se pone de manifiesto la creciente población en Alemania, y sugiere la necesidad de adquirir colonias para incrementar la fuerza económica de la nación. 402 Una opinión que también compartían sus compañeras de trabajo en el movimiento de la mujer, como por ejemplo Agnes v. Zahn-Harnack. ${ }^{403}$

400 Reagin, N.R.: Class and Gender in Hanover, 1880-1933, Chapel Hill \& London, University of North Carolina Press, 1995, p.223

401 En: Die FraU, año 41, no 1, Octubre 1933, p. 54

402 Bäumer, Gertrud: „Zwischen zwei Gesetzen? - Nachwort von Gertrud Bäumer“, DIE FrAU, n 4 , año 1916, p. 223

403 Bäumer, Gertrud: „Zwischen zwei Gesetzen? - Nachwort von Gertrud Bäumer“, DIE FrAU, n 4, año 1916, p. 223 
Como hemos visto con anterioridad los movimientos confesionales de la mujer se definen, especialmente a partir de la instauración de la República de Weimar, como movimientos espirituales de regeneración que intentan preservar a Alemania de la degradación moral. Este movimiento de renovación tiene sus raíces en la práctica y teoría política del sector conservador alemán, y que es conocido en la literatura histórica como „Revolución conservadora“.

El término revolución conservadora aparece por primera vez en un discurso de Hugo von Hofmannsthal, Das Schrifttum als geistiger Raum der Nation, „La escritura como dominio espiritual de la nación“" (1927). El ideólogo de la Revolución conservadora fue A. Moeller van den Bruck. Los revolucionarios conservadores se alejan de las ideas de la democracia liberal heredera de la Revolución Francesa y de las revoluciones del 1848. Thomas Mann define en Russische Anthologie el movimiento como una „síntesis (...) de ilustración y fe, de libertad y dotado, de espíritu y cuerpo, dios y mundo, de sensualidad y atención crítica...de conservadurismo y revolución “. Se trataba de una alternativa política al liberalismo y al socialismo, según el lema de Moeller, Dinge zu schaffen, die zu erbalten sich lohnt, „crear cosas que merece la pena mantener“. ${ }^{404}$ Rasgos conservador-revolucionarios se encuentran también en los filósofos del decisionismo como Martin Heidegger, Ernst Jünger y Carl Schmitt. La revolución es entendida más en términos intelectuales que políticos; como en el caso del movimiento de la mujer, se habla de una revolución de los valores, un cambio de la vida „espiritual“.

Sin embargo esto no significa que existiera un apoyo concreto a la ideología nacionalsocialista. En el próximo capítulo veremos como se articulan los diferentes grupos y sus publicaciones en los últimos meses de la república de Weimar.

404 Brockhaus Enzyklopädie, Mannheim, 1990, p.286 


\section{La decadencia del feminismo conservador. Primeras reacciones de los grupos de mujeres confesionales ante el nacionalsocialismo}

der glanze heldenplatz zirka versaggerte in maschenhaftem männchenmeere drunter auch frauen die ans maskelknie zu heften heftig sich versuchten, hoffensdick.

Und brüllzten wesentlich.

Pirsch!

Döppelte der gottelbock von Sa-Atz zu Sa-Atz mit hünig sprenkenkem stimmstummel. Balzerig würmelte es im männechensee und den weibern ward so pfingstig ums heil zumahn: wenn ein knie-ender sie hirschelte.

\subsection{Introducción}

El poema de Ernst Jandl sobre la adoración que las mujeres alemanas rindieron a Hitler no es una excepción. La apelación de éste Gottelbock, una palabra inexistente en el vocabulario alemán, hace referencia al carácter de Dios, Gott, y macho cabrío, Bock. Esta mezcla entre el carácter de religión y la atracción casi demoniaca que el nacionalsocialismo ejercía sobre la población, ha sido tratada con profusión en la historiografía sobre la época. ${ }^{405}$ En especial se comenta la atracción que ejercía Hitler sobre el género femenino dónde los límites de la sexualidad y el culto religioso eran difíciles de separar. ¿Son ciertas estas afirmaciones? El objetivo de este capítulo es señalar detalladamente las reacciones de los tres grupos de asociaciones de mujeres y sus correspondientes órganos de prensa durante los años anteriores a la llegada al poder del nacionalsocialismo.

En el periodo entre 1923, año del fracasado „putsch de la cervecería” en Munich, y el 30 de enero de 1933, fecha del nombramiento de Hitler como canciller alemán, se gesta lentamente la decadencia del movimiento laico y confesional de la mujer. En ambos bandos las posturas conservadoras se acentúan en forma de sentimientos antisemitas y de un fuerte nacionalismo que afecta a todas las organizaciones de mujeres, con excepción de las católicas, las mujeres radicales y algunas excepciones dentro de las organizaciones liberal-conservadoras. De esta manera, cuando en los primeros meses de 1933 se produce el llamado proceso de Gleichschaltung

405 Block, Ernst: Vom Hasard zur Katastrophe. Politische Aufsätze aus den Jabren 1934-1939, Frankfurt, 1972, p. 129 y s. 
406 las organizaciones del movimiento liberal-conservador se deciden por la disolución (el único órgano que consigue sobrevivir es la revista portavoz de la Federación, DIE FRAU) y las organizaciones confesionales continúan existiendo integradas en sus respectivas iglesias que se dota a Hitler de plenos poderes. Un año más tarde, el 8 de septiembre de 1934 pronunciará en Nürnberg, delante de miles de enardecidas alemanas, un discurso que marcará en adelante el papel de la mujer en el nacionalsocialismo:

„Cuando se dice que el mundo del hombre es el Estado, el mundo del hombre es su lucha (Ringen), la Einsatžbereitschaft, „disposición de combate“, para la comunidad, así se podría decir que el mundo de la mujer es uno más pequeño. Ya que su mundo es su marido, su familia, sus hijos, su casa. ¿Dónde estaría sin embargo el gran mundo si nadie se preocupara del pequeño mundo? ‘ 407

En este discurso se encuentran las líneas fundamentales del pensamiento nacionalsocialista sobre la naturaleza de la mujer: la feminidad se define por su Empfinden, „el sentir" y das Gemüt, „facultades sensitivas“ y, como en la naturaleza, si cada género realiza la tarea para la que está dispuesto, pueden vivir ambos armónicamente. El mundo femenino es la columna del masculino, es su sostén, su apoyo, su garantía para la supervivencia. Lo que el hombre consigue como soldado en el campo de batalla, lo recibe la mujer en el mantenimiento de la vida, en su actividad como madre. Ambos luchan como camaradas por la misma idea. El movimiento de la mujer nacionalsocialista no es una lucha contra el hombre, sino es una lucha conjunta de los géneros, y el programa del nuevo movimiento, a diferencia del movimiento „intelectualista y liberal" tiene un solo y único punto: el hijo.

La valoración que hace Hitler de la mujer como madre está estrechamente relacionado con las posturas antisemitas de éste:

„A través de miles de años de incesto que tenía a menudo lugar en estrechos círculos, el judío ha conservado en mayor medida en general su raza y las peculiaridades de ésta, que muchos pueblos entre los que éste vive. Y por lo tanto se da la situación de que entre nosotros vive una raza extranjera no alemana, no deseada, y que no quiere sacrificar las peculiaridades de su raza, ni está dispuesta a negar su propio sentir, pensar y desear y sin embargo posee todos los derechos políticos que nosotros también tenemos. “408

En este mismo informe escrito a las autoridades militares en 1919 señala que el carácter de movimiento político del antisemitismo. Parte de la „organización“ del movimiento es la participación de la mujer en éste como principal garantía de la concepción de una raza sana y pura.

406 Proceso de declaración de lealtad al nuevo régimen que se caracteriza por la introducción del Führerprinzip, „principio de liderazgo“ que fue aplicado por primera vez a la organización del partido y después de 1933 al gobierno del Estado, la no aceptación de miembros que no cumplieran con las leyes arias, la integración de todo tipo de asociación en las organizaciones nacionalsocialistas y la prohibición y disolución de aquellas que no estuvieran dispuestas a asimilarse al nuevo régimen.

407 Domarus, H (ed.): Hitler - Reden und Proklamationen 1932-1945 (Vol. 1), Würzburg, 1962, p.450

408 Informe escrito por Hitler durante su estancia en München como soldado para las autoridades militares, 16, septiembre 1919, en: Maser, W:: Hitlers Briefe und Notizen. Sein Weltbild in handschriftlichen Dokumenten, Düsseldorf/Wien, Econ Verlag, 1973, p.224 
Sin embargo Hitler no llega a articular en sus escritos una ideología sobre el papel de la mujer en el nuevo estado. Es Alfred Rosenberg quién ofrece en su obra Der Mythus des 20. Jahrbunderts una teoría sistemática sobre lo masculino y lo femenino que se complementa más tarde con las ideas de Hitler, Blut, Boden und Rasse.

La concepción que hace Rosenberg sobre los dos géneros parte de diferentes tradiciones poéticas y filosóficas. Desde influencias románticas: „para los filósofos románticos, las oposiciones son complementarias y en distintos niveles de la realidad se encuentra el mismo principio de división en pares opuestos. De esta manera, el día y la noche, el hombre y la mujer, son algunos aspectos de la polaridad universal.“409 hasta lo más destacados representantes del llamado Kulturpessimismus, como por ejemplo Schopenhauer, Wagner, Nietzsche, Houston, Chamberlain etc. ${ }^{410}$

Para Rosebenger el mundo está dividido entre dos principios: el masculino y el femenino. Esta diferencia parte de la naturaleza y es un factor decisivo para el funcionamiento armónico de las sociedades y de los pueblos:

„Dentro de esta oposición universal de las razas y de las almas la vida oscila también entre dos polos: el masculino y el femenino. Si las características físicas, raciales y psicológicas y las direcciones y estructuras de valores de macho y hembra de una especie determinada de un pueblo, son iguales, entonces puede decirse que la naturaleza al lado de la polaridad física e ideológica también ha creado la polaridad genérica como fuente de tensiones orgánicas, procreación espontánea y descargas eléctricas como garantía de la creación continúa.“411

El intento de borrar las diferencias entre los géneros, de eliminar la tensión entre estos, y la mezcla racial de éstos, lo que éste denomina como Geschlecbtskollektivismus, conduce a la disolución de las características genéricas y raciales. El hombre feminista y la mujer emancipada son los síntomas que aparecen en épocas de catástrofe, en tiempos de decadencia cultural y ocaso del estado. La Medea que recrimina a Euripides es comparada con las reivindicaciones de Helene Stöcker de libertad sexual. Rosenberg hace gala de conocer extremadamente bien la filosofía griega, especialmente las citas destinadas a poner de relieve la inferioridad o diferencia cualitativa del sexo femenino. Citando a Aristóteles, Das Weibchen ist Weibkraft einer gewissen Fäbigkeitslosigkeit intenta argumentar la naturaleza subjetiva y vegetal de la mujer y la falta de intuición y espiritualidad en su naturaleza:

„La falta de talento natural es la causa de la orientación de su naturaleza hacia lo vegetal y lo subjetivo. A las mujeres de todas las razas y todas las épocas les falta la violencia de un visión tanto intuitiva como intelectual. Siempre que aparece una obra épica o de un drama, o de una hipótesis para la investigación científica del cosmos, se encuentra detrás un hombre como creador." ${ }^{412}$

El estado y el matrimonio son invenciones del hombre. Una época de matriarcado no puede por lo tanto haber existido. Incluso la época dorada de los germanos donde las mujeres gozaban de grandes libertades, tiene que ver con la generosidad, y el reconocimiento general del derecho

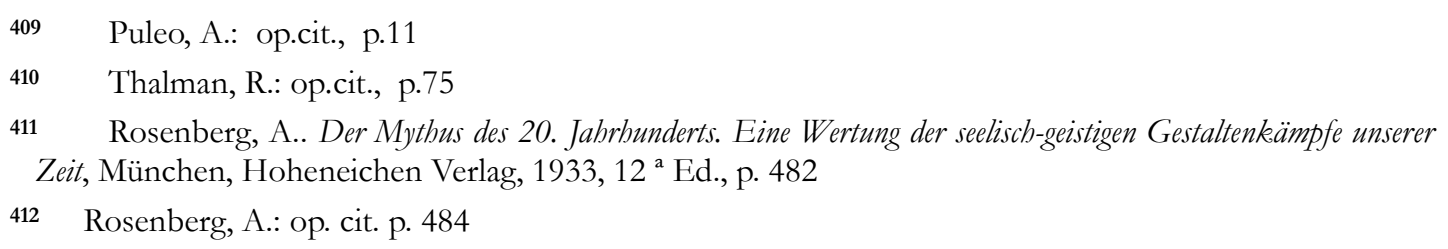


de paternal. En épocas de crisis se revela tal libertad como peligrosa. Y en un salto prodigioso de racionamiento pone en relación el proceso de emancipación de los judíos con el movimiento emancipador de la mujer. El esfuerzo del movimiento de la mujer por feminizar la sociedad se considera como un intento absurdo que rompe con todas las leyes naturales existentes y amenaza la armonía entre los géneros, y pone en duda el hecho probado históricamente de la supremacía masculina:

„Las enseñanzas del liberalismo eran: libertad, libertad de movimiento y de comercio, parlamentarismo, emancipación de la mujer, igualdad etc., esto significa que este movimiento iba en contra de una ley natural: la creación sólo nace de la explosión de tensiones determinadas polarmente, e iba en contra de lo necesario que es la falta de energía para ejercer cualquier tipo de trabajo y para crear cultura. El pensamiento alemán exige en estos momentos, en medio de la decadencia del feminizado viejo mundo, autoridad, fuerza que forme tipos, limitación, disciplina, autarquía, protección del carácter de la raza, reconocimiento de la eterna polaridad entre los géneros. “413

La polaridad de los géneros aparece en la obra de Rosenberg como división de cualidades y tareas entre los géneros. El hombre aparece como creador, inventor del mundo y de la vida, architektonisch, el principio femenino es definido como zusammenfassend y sintético, como la sostenedora del inconsciente. El principio masculino no se manifiesta en todos los hombres, sino en los dirigentes políticos, los militares, sacerdotes, artistas y creadores.

El mundo femenino estaría representado por el mundo ultraterrenal de Dionisio, Apolo y la cultura griega, encarnarían el mundo de lo masculino, el padre. Estos dos mundos están en lucha eterna, únicamente interrumpida por la institución del matrimonio que „llevaría“ a las mujeres por el buen camino y que significaría la domesticación de las fuerzas oscuras y malignas de la naturaleza, y la seguridad de la procreación de la raza. La mujer recibe el encargo de procrear y de servir al hombre en todas sus necesidades.

Fenómenos como el movimiento de la mujer, Rosenberg cita siempre al feminismo radical, Helene Stöcker y Anita Augspurg y no a la rama conservadora de éste, son considerados como un regreso del mundo de Dionisio, de un mundo regido con mano femenina. Este culto a la mujer como madre revela prácticas antifeministas y a su vez va acompañado de un alto grado de racismo. Es la mujer emancipada, la que con su generosa vida sexual contribuye a la decadencia de la raza:

„La mujer „emancipada“ se toma el derecho el derecho a tener relaciones sexuales con negros, judíos, chinos y la mujer que es llamada a ser la conservadora de la raza se convierte, gracias a la emancipación en la destructora de las bases de la esencia del pueblo alemán. “414

La mujer emancipada se convierte en la destructora de la pureza del pueblo alemán. El conflicto entre género, sexualidad y raza se convierte en una de las bases fundamentales de la naturaleza del nacionalsocialismo. Este conflicto determina la política antisemita y da forma a la ideología nazi sobre la feminidad.

El nuevo movimiento de renovación, como denomina Rosenberg al nacionalsocialismo, no se revela únicamente como una lucha contra el liberalismo, la democracia y la influencia judía. Es un movimiento de renovación de los principios de poder masculinos que incluye la

\footnotetext{
413 Rosenberg, A.: op. cit., p. 503

414 Rosenberg, A. op. cit., p. 506
} 
reducción de la mujer a la mera participación biológica. Esta afirmación aparece confirmada en los estudios de Gisela Bock sobre la política de esterilización y exterminio nazi. La mitad de las víctimas del terror nazi y de la política antinatalista nacionalsocialista eran mujeres, mujeres judías o mujeres que no correspondían al ideal de mujer que pudiera procrear nuevas generaciones sanas y superiores.

La perversión de la maternidad convierte a la mujer en una máquina de parir. El culto a la maternidad se revela como una táctica más de propaganda, en la que se busca el apoyo de las mujeres alemanas a la política nazi en su totalidad.

Este „culto“ a la maternidad revela una concepción de la mujer como un elemento más en la cadena del sistema, que debido a su disposición biológica recibe la función de preservar y mejorar la raza. A esto se une la existencia de un discurso ya existente en la mentalidad judeocristiana que apoya y exalta el papel de la madre, lo que hace difícil para la mayoría de las mujeres alemanas, el distinguir entre degradación de la maternidad y verdadera valoración de ésta. Junto a mujeres madres, se desean mujeres fuertes, adiós a los tiempos de Biedermeier y a la vida tranquila y sin problemas de las mujeres burguesas, señala Rosenberg. Junto a sus deberes como madre, tiene la obligación de servir a la comunidad del pueblo. Únicamente las funciones de juez, dirigente y soldado son exclusivas del hombre.

La mujer representa por otra parte el mundo oscuro, la sífilis, y aunque esta sea una „pura“, convencida alemana, siempre existe un oscuro deseo de su caída, de su degradación. Joachim Fest nos muestra un sueño de Hitler que ilustra plásticamente las complicadas relaciones con el sexo femenino: Hitler sueña con una mujer alemana, rubia atada a un mástil, a la que por detrás se acerca un negro judío con intenciones de violarla. Hitler tiene la posibilidad de salvarla, pero no lo hace, y asiste implacable a la violación de ésta. ${ }^{415}$

Podemos decir que la política nacionalsocialista respecto a las mujeres tiene dos vertientes, que se caracterizan en todo caso por su falta de respeto hacia la mujer, y por la convivencia de los factores de género y raza. Esta nueva construcción del género no es sin embargo nueva, sino que se puede incluir en un discurso conservador de género que tiene lugar en los últimos años de la república de Weimar, donde en oposición al discurso de género de la nueva mujer, se pretende elaborar una alternativa al modelo de igualdad entre los géneros.

En este contexto se enmarca la obra de Ernst Bergmann sobre la maternidad, Erkenntnisgeist und Muttergeist. Eine Soziosophie der Geschlechter. Una obra que encontró un gran eco en círculos nacionalsocialistas. Partiendo de la observación de la naturaleza, el autor establece en primer lugar la importancia de la maternidad en la constitución del estado, la lucha entre los géneros por la supervivencia. El matrimonio se establece como una construcción antinatural que va en contra de los instintos sexuales:

„Así aparece el matrimonio en la situación correcta. Éste se construye por lo general a raíz del amor entre los géneros y su duración no depende de ese amor. En realidad existe verdaderamente un matrimonio como alianza natural y unión entre la madre y los hijos de ésta." 416

La maternidad no aparece valorada dentro del matrimonio, sino en cualquier mujer, independientemente de su estado civil. La maternidad de la mujer es la verdadera emancipación de ésta y no la pseudo libertad que ofrece la participación de las mujeres en la vida política o la admisión en las universidades:

415 Fest, J.C.: Das Gesicht des Dritten Reiches. Profile einer totalitären Herrschaft, München-Zürich, Piper, 1963

416 Bergmann, E.: Erkenntnisgeist und Muttergeist. Eine Soziosophie der Geschlechter, Breslau, Ferdinand Hirt, 1933, p. 378 
„(Este entendimiento de la maternidad) floreció también dentro del movimiento de la mujer, que por encima de todo es un movimiento contra la maternidad. Las mujeres conquistaron durante la primera guerra mundial el derecho electoral. (...) Éstas no tenían ideas políticas propias sino que apoyaron slogans y programas de partido que habían nacido en la cabeza de los hombres. Se cae en un error cuando del trabajo que las mujeres han realizado en los parlamentos se espera la mejora y la salvación de la humanidad de su desesperada situación cultural.(...) En realidad la mujer sólo ha conquistado durante la primera guerra mundial el voto pasivo y activo masculino, igual que en los institutos de educación secundaria y en las universidades se ha hecho con la formación masculina, en vez de fundar y construir su propia educación."“417

La personalidad de la mujer aparece reducida a la mera reproducción. La mujer es madre y nada más. Trabajo, formación, participación política todo es secundario ante la principal tarea de la mujer y aquellas que no participan con su cuerpo en la construcción del estado no merecen formar parte de éste:

„Y las mujeres que quieren ser iguales que los hombres y que oprimen en contra de las leyes naturales sus sentimientos maternales son en un estado dedicado a las madres las parias y las proscritas y deberían ser tratadas pero que el hombre (que se comporta de la igual manera). Estas mujeres son hermafroditas antinaturales en las que la sana fuerza vital necesaria para la fundación del tercer Reich de la humanidad se ha apagado. Ellas son como los homosexuales masculinos degeneradas y enfermas, peor incluso que éstos ya que su caos instintivo es voluntario y querido.“418

Mientras que Rosenberg se centra en la división de tareas y en la diferencia natural de los géneros, Bergmann eleva la función de la maternidad a una tarea sagrada. Este aspecto de la maternidad como parte fundamental en la construcción del nuevo estado, convence a un gran número de mujeres. Mujeres que al igual que los hombres se sentían inseguros y perdidos, con el nuevo reparto de papeles. La maternidad, con las ventajas que esta parece traer, ofrece a las mujeres trabajadoras la posibilidad de salir de sus oscuras vidas de trabajo mal pagado, desempleo del compañero, a las amas de casa la revalorización de su trabajo, al hombre la autoridad perdida.

El discurso sobre el nuevo papel de la mujer en el nuevo régimen es tan variado como dispar. Dentro del grupo de mujeres nacionalsocialistas se encuentran partidarias de una participación activa en el nuevo estado. Así por ejemplo Guida Diehl, dirigente del llamado Neulandbewegung, agrupación de mujeres de derechas y cofundadora de la Frauenschaft nacionalsocialista. Diehl rechaza el carácter de adorno del movimiento masculino que algunos querían ver en las mujeres nacionalsocialistas, sino que exige la igualdad de oportunidades para las mujeres en el movimiento nacionalsocialista:

„Esta no es simplemente una ayuda caritativa secundaria, sino que se trata de una lucha de las mujeres espiritual e intelectual con la misma transcendencia que la de los hombres. (...) Nosotras mujeres debemos encontrar en las contracciones de este cambio de época nuestra tarea especial junto al trabajo en el movimiento: ésta 
es por encima de todo la verdadera y nueva solución de la cuestión de la mujer y un profundo trabajo de renovación femenino. “419

El nuevo estado nacionalsocialista ofrece la posibilidad de superar los errores del movimiento de la mujer. La crítica de Diehl se extiende a la totalidad de éste. El movimiento de la mujer había fracasado en su intento de ofrecer a la mujer el descubrimiento de su propia identidad. Este fracaso radica en las masculinización de los objetivos primarios del movimiento. En este fracaso incluye a las asociaciones de mujeres confesionales que, según Diehl, se limitan a imitar al movimiento laico de la mujer:

„El movimiento de la mujer tiene un objetivo propio: la influencia cultural de la mujer, sin embargo no consiguió que la mujer se desarrollara su totalidad interior y ni la libre influencia social de ésta, porque para éste movimiento la vida no se encontraba entre sus principios fundamentales y por que nunca entendió las leyes vitales que afectan a la feminidad."420

Otras de las razones con las que Diehl argumenta el fracaso del movimiento de la mujer, es su parentesco con los principios de las doctrinas individualistas que tienen origen en el renacimiento, la ilustración y el romanticismo, y por último con el liberalismo. Unicamente la superación del individualismo y el materialismo existente puede conducir al descubrimiento de la verdadera identidad de la mujer que no tiene nada que ver con la participación política parlamentaria y el trabajo intelectual, así como la traición de los valores nacionales que se traduce en la cooperación del movimiento de la mujer con otras naciones en la política de desarme:

„En verano de 1919 las defensoras del voto femenino visitaron una reunión de pacifistas en Zürich y Lida Gustava Heymann, presidente de la organización, saludó a la representante de la delegación francesa con un ramo de rosas. Si se piensa en la brutal violación que sufrió el Rheinland, a manos de la misma nación a la que esta defensora de los derechos de la mujer hacía honores con el ramo del amor, ganamos la deprimente impresión del fracaso de tales personalidades que pertenencen a als pioneras del movimiento de la mujer." 421

Diehl exige la constitución de una cámara parlamentaria de mujeres dónde estas pudieran decidir sobre asuntos y materias relacionados con sus intereses. A pesar del apoyo de Gregor Strasser, la posición de Diehl no encuentra, sin embargo, el eco deseado en los círculos nacionalsocialistas lo que provoca su retirada de la organización de mujeres nacionalsocialistas.

La reivindicación de la maternidad es interpretada como la creación de un estado nacionalsocialista que supera los principios del matriarcado y del patriarcado. también mujeres que apoyan estas nuevas ideas sobre la feminidad. Elisabeth Zander, por ejemplo, quién apoya la idea de crear una organización general de mujeres, o Lydia Gottschewski pertenecientes a grupos de mujeres radical-conservadoras. Estas mujeres rechazan la idea de la sumisión de la mujer, y reclaman la participación de las mujeres más capacitadas para dirigir al pueblo. Entre

419 Beyer, H.: Die Frau in der politischen Entscheidung. Eine Untersuchung über das Frauenwablrecht in Deutsch-

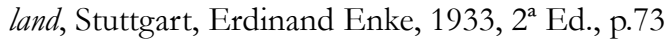

420 Diehl, G.: Deutscher Frauenwille, Gotha, Leopold Klotz Verlag, 1928, p. 17

421 Ibídem, p. 27. Gertrud Bäumer es igualmente criticada por su apoyo a las reivindicaciones al voto femenino de las activistas francesas y de sus buenas relaciones con éstas. 
esta primera generación de mujeres destaca Paula Siber quien se encarga de „coordinar“ a todos los grupos y organizaciones de mujeres existentes hasta entonces.

En 1931 se funda la organización nacionalsocialista de mujeres NSF (Nationalsozialistische Frauenschaft), como consecuencia de la fusión de grupos de mujeres de tendencias ultraconservadoras. En 1935 recibe la categoría de partido afiliado, y pasó de 110.000 miembros en 1932 a casi dos millones en 1935.

Gertrud Scholtz-Klink, una viuda joven, miembro del partido y alejada de las aspiraciones de independencia de la primera generación de mujeres nacionalsocialistas, pasa a dirigir la organización como „Dirigente de las mujeres del Reich“ (Reichsfrauenfübrerin). A la organización pertenecía la „élite“ de las mujeres del Reich. Funcionarias, maestras, mujeres con cierta responsabilidad. El resto de las mujeres se agrupaba en la Organización de mujeres alemanas DFW (Deutsches Frauenwerk), creada a raíz de la incorporación de los grupos y organizaciones de mujeres existentes en la República de Weimar en el aparato nazi, después de la „coordinación“ (Gleichschaltung). Scholttz-Klink defiende la política de separación de las esferas de actuación entre los sexos, aunque exige la participación de las mujeres en la construcción del nuevo estado. Su principal argumentación se basa en la crítica del movimiento radical de la mujer y el rechazo del sistema parlamentario:

„A las directivas generales y dirección del movimiento de la mujer tras la guerra le faltó el requisito indispensable para un desarrollo prospero, (le faltó) el suelo sano sobre el que hubiera tenido que estar de pie, para poder tener éxito entre las mujeres; la correcta construcción de sangre y de especie (...). La mujer fue enviada al parlamento con lo que empezó la primera traición a si misma; el primer pecado contra el espíritu.“422

La participación política de la mujer significa, al igual que para Rosenberg, Bergmann y Diehl un paso más hacia el alejamiento de la mujer de su propia identidad. La influencia de ésta en el estado se logra desde el descubrimiento de su interioridad, en la reconstrucción de su verdadera naturaleza. Este camino casi místico hacia la fuente de la personalidad femenina se traduce en la iniciación de actividades tan prosaicas como la economía del hogar, la educación de los hijos y la indoctrinación en la teoría política del estado nacionalsocialista. El desarrollo de la personalidad individual no cuenta sino el espíritu de sacrificio y la sumisión a los valores del nuevo estado:

„Donde quiera que estéis en el hogar, en la oficina, en el taller, en la escuela, a los pies del enfermo como médico o enfermera, un día tenéis que aprender: en primera línea tenemos que volver a lo más profundo de nuestra naturaleza: el servicio voluntario. En función de vuestro servicio se nos y os juzgará posteriormente." 423

Aunque Scholtz-Klink incide en que no todas las mujeres están destinadas a ser amas de casa y madres, se observa en esta concesión una valoración tendenciosa de la maternidad. Las madres son en realidad la élite del nuevo estado, las mujeres que trabajan, aunque necesarias, son consideradas como ciudadanas de segunda fila. El trabajo de la mujer no es considerado como un medio de desarrollo individual para ésta, sino en una necesidad:

422 Scholtz-Klink, G.: Die Frau im Dritten Reich. Eine Dokumentation, Tübingen, Grabert Verlag, 1978, p.488. Discurso ante las delegadas de las organizaciones de mujeres del estado de Baden, 21.06.1933

423 Ibídem, p. 491 
„Nosotras mujeres nacionalsocialistas somos conscientes que no todas las mujeres pueden ser amas de casa y madres, cuando una muchacha tiene la inclinación y la disposición para una determinada profesión, se le debe dar la posibilidad de poder convertir esta inclinación en realidad, (...). La maternidad es la vocación más profunda que se nos puede ser concedida. Esta profesión se ha convertido en la actualidad en algo superficial y ha caído en el desprestigio. “424

Lo importante de la maternidad no es tampoco la mujer, sino el hijo, no como individuo o ser, sino como unidad genética. De ahí que las mujeres tengan que aprender la profesión de ser madre. De ahí la importancia de los cursos de maternidad donde se aleccionaban a las jóvenes madres en el perfecto cuidado de su descendencia. El hijo tiene que nacer sano y fuerte para garantizar más tarde la pervivencia de la raza.

Para la indoctrinación de las mujeres en la procreación de unidades genéticas perfectas, se crea un complejo aparato de formación. La organización de Scholtz-Klink estaba organizada en numerosas secciones de las cuales las más imporantes (Volkswirtschaft / Hauswirtschaft y Reichsmütterdienst RMD) se ocupaban de la educación de la mujer para el trabajo doméstico y en la futura maternidad, así como organizaba un servicio de ayuda en el hogar para estudiantes universitarias. Los cursos de maternidad organizados por la $R M D$, hasta 1936 dirigidos las iglesias católica y protestante, tenían como fin la instrucción de las mujeres en problemas de salud, en la administración doméstica, labor y costura, educación de los hijos y folklore alemán. Junto a ello existían una formación especial sobre política racial, aunque ésta no tuvo tanto éxito como los contenidos más prácticos. ${ }^{425}$ En el capítulo cinco de nuestro trabajo se encuentra una descripción detallada de la estructura y trabajo de las organizaciones de mujeres nacionalsocialistas.

Las expectativas de las mujeres del movimiento de la mujer, y de las organizaciones confesionales, de poder mantener su independencia y de adquirir responsabilidad en la construcción del nuevo estado, no son más que una quimera, un fajo de ilusiones.

En un principio las mujeres no son admitidas en el consejo del partido. Las mujeres que ocupaban puestos de responsabilidad son despedidas de sus cargos y son sustituidas por colegas masculinos. A las estudiantes universitarias se les niega la posibilidad de acceder a diversas carreras, así como se impone ,numerus clausus” para mujeres, no pudiendo superar el número de estudiantes femeninas el diez por ciento de los estudiantes universitarios. ${ }^{426}$ No pueden ejercitar determinadas profesiones, como por ejemplo la carrera médica y se las van encaminando a puestos donde pueden desempeñar tareas apropiadas a su sexo. Las organizaciones de mujeres de izquierda son prohibidas, sus órganos de prensa y sus bienes son confiscados, sus dirigentes eligen el camino del exilio.

3.2. La decadencia del feminismo conservador 1930-1933

\footnotetext{
424 Ibídem, p. 492

425 Bock, G.: op.cit., p.196

426 Tidl, G.: Die Frau im Nationalsozialismus, Wien, 1984, p.21
} 


\subsubsection{Los años del caos político}

La historia del movimiento laico de la mujer encuentra su final el 15 de mayo de 1933, fecha en la que la $B D F$ se autodisuelve. Unas semanas antes la asociación de maestras alemanas, la $A D L V$ había llegado en una reunión del pleno de la organización a la misma conclusión. El 24 de septiembre, tras la resistencia inicial de algunos grupos locales, la organización general de mujeres alemanas, Allgemeiner Deutscher Franenverein se decide por el camino de la autodisolución, 70 años después de su fundación por Auguste Schmidt.

Durante los meses anteriores a mayo habían tenido lugar encuentros entre las dirigentes de las diferentes organizaciones y el Deutsche Arbeitsfront para tratar de evitar la autodisolución. Ante la falta de un acuerdo entre las dos partes, se opta por la no integración en el aparato nacionalsocialista. Esta decisión ha sido vista por la mayoría de las historiadoras como la prueba del claro rechazo de las mujeres del ala moderada del movimiento de la mujer, y concretamente del $B D F$ ante el nacionalsocialismo. ${ }^{427}$ En este capítulo intentaremos por una parte, señalar las causas que llevaron a la $B D F$ a llegar a esta decisión y por otra valorar los verdaderos motivos de la autodisolución.

Como hemos visto en el capítulo anterior el movimiento de la mujer experimenta durante la república de Weimar una etapa de contradicciones en sus objetivos y un alto grado de descontento entre sus miembros. Las posturas se radicalizan, lo que conduce a divisiones entre las filas del movimiento. Por una parte el movimiento confesional, representado por las organizaciones protestantes con su alto grado de posturas nacionalistas rechazan los principios del movimiento de la mujer, por otro lado, el movimiento radical que con sus reivindicaciones en el terreno de la sexualidad femenina refuerzan las conservadoras y debilitan al sector más moderado.

Ruptura y división caracterizan también al ala moderada del movimiento de la mujer representada por la $B D F$ en la que se encuentran posturas cada vez más conservadoras, representadas en su mayoría por las asociaciones de amas de casa y mujeres del campo. Otro factor a señalar era el envejecimiento de la organización. Esta perdía con los años partidarias, su ideal de mujer cultivada, participante en el juego político e implicada en el trabajo social, había dejado de ser atractivo para las generaciones más jóvenes. Gertrud Bäumer describe el rechazo que experimentaba la nueva generación por el movimiento de la mujer. Curiosamente se trataba de mujeres que habían accedido a una educación superior y se encontraban en puestos de responsabilidad. ${ }^{428}$

La política de la organización caía en descrédito en todos los frentes: para las radicales, las mujeres del movimiento de la mujer el ala moderada seguían una política de concesiones al orden burgués, las conservadoras por otro lado echaban de menos una política firme y coherente con los principios de las separación de las esferas entre los géneros y sobre todo en cuestiones relativas a la política internacional. El ala moderada había perdido a finales de la república su carácter mediador y modélico que hasta entonces había tenido en el movimiento de la mujer.

Durante los años 30 esta situación de debilidad se acentúa. Se trata de una etapa teñida de polémicas, divisiones en las filas del movimiento. A ello se une la presión de las mujeres nacionalsocialistas, cada vez más organizadas que comienzan a minar la base, ya frágil, del movimiento.

427 Schmidt-Waldherr, H.: Emanzipation durch Professionalisierung? Politische Strategien und Konflikte innerhalb der bürgerlichen Frauenbewegung während der Weimarer Republik und die Reaktion des bürgerlichen Antifeminismus und des Nationalsozialismus, Frankfurt am Main, Falta Verlag, 1987; Stoehr, I.: „Macht ergriffen?. Deutsche Frauenbewegung 1933“", COURAGE, 1983 (n8), pp. 24-32

428 Bäumer, G.: DieFrau im neuen Lebensraum, Berlín, Herbig, 1931, pp.100-108 
La postura respecto a la posición de Alemania en la política exterior de desarme, así como la contribución del movimiento de la mujer a la pérdida de las virtudes femeninas y por consiguiente al empobrecimiento de la capacidad genética de la nación alemana, sirve de justificación a las nacionalsocialistas para calificar a sus contrincantes de traidoras, desertoras y defensoras del sentimiento antialemán, propio de círculos judíos.

Estas críticas no son desoídas en la organización, donde ya en la cúpula de las dirigentes podía palparse desde el punto de vista político el abandono de los principios sociales que caracterizaban el compromiso político de éstas:

„La división de los partidos políticos, su incapacidad de construir mayorías para el bien del pueblo, el crecimiento de la radicalización y el embrutecimiento de la cultura política hacía la idea del „estado” muy atractiva para muchos hombres y mujeres pertenecientes al partido liberal. Así no es accidental que el partido demócrata alemán, la patria política de las mujeres dirigentes del $A D E F$ y del $B D F$, pasara a llamarse desde 1930 „partido del estado alemán”." ${ }^{29}$

Tras la frustrada coalición entre la SPD, el Zentrum, DDP y el DVP (28.6 1928), y el nombramiento de Brünnig como canciller (27.3.1930) crece en el partido liberal la incertidumbre. En verano del mismo año comienzas las primeras dimisiones del partido. Anton Erkelenz, hasta entonces editor con Gertrud Bäumer en DIE HILFE, ingresa en el partido socialdemócrata. La cúpula del $B D F$, perteneciente en su mayoría al partido liberal permanece sin embargo en el partido. Gertrud Bäumer hace una valoración de la situación:

„La utilización de las palabras „derecha” e „izquierda” como denominación de la actual situación política es totalmente falsa, porque los nuevos frentes se construyen en otras líneas. La coalición de las fuerzas políticas unida en el partido del estado alemán significa la ruptura del pensamiento republicano democrático en dos círculos populares hasta ahora sólo latentes: el cristiano social y el de los jóvenes nacionales. „,30

Aunque Bäumer reconoce los puntos en común con los ideales socialdemócratas, rechaza „su actitud anticapitalista y antiburguesa“, y critica su concepción materialista de la realidad en la que los valores ideológicos y religiosos son meros atributos de la materia. También pone por encima la fuerza de la nación y de los principios ideológicos de la solidaridad económica de la clase trabajadora. Con esta declaración Bäumer deja clara su rechazo a la coalición del centro con la socialdemocracia y declara su apoyo a la revolución conservadora.

Este planteamiento del conflicto entre las fuerzas conservadoras políticas muestra la desacertada valoración que Bäumer hacía del panorama político y demuestra la rapidez del cambio de las opiniones en el círculo del partido demócrata.

Dos años antes, durante el congreso de la comisión de mujeres del partido demuestran todavía las ponentes su espíritu democrático. Entre ellas se encuentra Else Ulich-Beil, perteneciente al BDF y estrecha colaboradora de Bäumer que como ella en 1930 apoya la conversión del DDP en el Staatspartei y que curiosamente en 1928 defiende ardientemente el sistema parlamentario y la república de Weimar:

429 Stoehr, I.: Emanzipation zum Staat? Der Allgemeine Deutsche Frauenverein. Deutscher Staatsbürgerinnenverband (1893-1933), Pfaffenweiler 1990, Centaurus-Verlagsgesellschaft, p. 132

430 Bäumer, Gertrud: „Und nun das sachliche Pröblem, das der Parteiweichsel von Erkelenz aufwirft: Unsere Stellung zur Sozialdemokratie“, DiE HiLFE 1930, (n³3, año 36), p. 817 y s. 
„Aquel que cree que puede hablar de una crisis del sistema parlamentario, tiene que ser consciente de que se puede demostrar que desde el punto de vista histórico no se plantea una crisis de la democracia y que la constitución de Weimar todavía no ha agotado todas sus fuerzas. Si se ve que el peor enemigo que la democracia puede tener es el fondo la dictadura. No deberíamos abandonar tan rápidamente el emblema del parlamentarismo por el que tantas generaciones han luchado en el pasado." 431

Sin embargo tres años después, en marzo de 1933 encontramos de nuevo la línea argumental de Bäumer en un artículo que escribe para DIE HILFE Bäumer trata de hacer una comparación entre el movimiento nacional de Friedrich Naumann, padre ideológico del partido demócrata alemán y el nacionalsocialismo. La idea central del pensamiento de Naumann, es según Bäumer, la superación de la lucha de clases marxista a través de la idea nacional. Bäumer saluda la llegada del nacionalsocialismo con una cita de Naumann, donde en el contexto de principios de siglo es descrito como una época nueva que necesita de nuevos conceptos y formas como un nuevo cuerpo que nace de la vieja nación alemana:

„Nos encontramos al principio de nuevas formas vitales, en el mediodía de una nueva era, cuyo placer todavía no se nos ha revelado. Después de nosotros, primeros después de nosotros, así sentimos lo verdaderamente nuevo, el periodo del perfecto capitalismo y quizá la aurora del socialismo." ${ }^{3} 2$

Tras la disolución del Reichstag el 18 de junio se convocan elecciones el 14 de septiembre donde los nazis con 107 escaños se convierten en el segundo partido del Reichstag tras el SPD con 143 escaños. Sin embargo a pesar de la victoria electoral del SPD, éste tiene cada vez más dificultades para hacerse cargo de la situación política y económica: un mes después de las elecciones, comienzan las primeras huelgas de los obreros de la metalurgia en Berlín contra las reducciones salariales, por otra parte, los propietarios de las minas del Ruhr piden reducciones de salarios del $12 \%$. El 31 de mayo de 1931 el congreso del SPD concluye que es preferible tolerar a Brüning que una dictadura. La situación económica ha empeorado; crisis económica, desempleo, caos político. A consecuencia del rechazo del programa de medidas de ahorro propuestas por el gobierno el 16 de julio se convocan nuevas elecciones.

El BDF llama a defender la democracia. ${ }^{43}$ Sin embargo las esperanzas y el apoyo a la república empiezan a flaquear. Los resultados de las elecciones son fundamentales para entender la progresiva orientación nacionalsocialista de los círculos de las clase media. La república se presenta como un sistema incompleto que nunca ha calado en las almas de los alemanes, y el nacionalsocialismo se acepta en su vertiente más moderada. 434

Desde el $B D F$ se hace una declaración pública de principios donde se apoyan los intentos del gobierno Brünnig en su política de entendimiento y cooperación internacional contra la política de obstrucción. ${ }^{435}$ En los primeros encuentros donde se redacta la declaración participa también

431 HLA, E/b/3 cc 1, Bericht über die Verhandlungen der Reichsfrauentagung der Deutschen Demokratischen Partei, Dresden, 21. 23.09.1928

432 Bäumer, G.: „Unsere nationalsoziale Bewegung und der Nationalsozialismus”, DIE HiLfE, Marzo 1933, (nº, año 33), p.163

433 Ibídem, p. 89

434 Bäumer, Gertrud: „Was nun?. Erneurerung der polistischen Fundamente“, KÖNIGSBERGER HART. ZEITUNG, n 366, v. 6, Agosto 1932

435 El documento está firmado por Arbeitsgemeischaft Deutscher Frauenverbände, Bund Deutscher Frauenvereine, Deutscher Akademikerinnen Bund, Katholischer Deutscher Frauenbund, Katholische 
el Vereinigung Evangelischer Frauenverbände, la asociación de mujeres protestantes dirigida entonces por Magdalene von Tiling, perteneciente también al DNVP. Sin embargo posteriormente, influida por la política de su partido cuyas relaciones con el frente nacional eran inmejorables. En octubre de 1930, DNVP, NSDAP y los Stablhelm, organización que agrupaba a los veteranos de la primera guerra mundial, se habían unido en el llamado frente de Harzburg.

Otro punto de fricción en la política interna del BDF es el relacionado con la política de desarme, tema que es tratado en el Consejo General de octubre de 1931. Durante las sesiones se pone de manifiesto la actitud negativa de las delegadas del DNVP respecto a las posturas del $B D F$ respecto a la política internacional. Entre ellas destaca Altgelt, dirigente de la comisión para asuntos femeninos del DNVP y delegada de la Reifensteiner Verband, una organización perteneciente al BDF Altgelt protagoniza una polémica con Gertrud Bäumer durante el consejo general, donde critica la política del $B D F$ respecto al tema del desarme como un atentado contra los principios de apartidismo y neutralidad de la Liga. ${ }^{436}$ En este aspecto hay que destaca los esfuerzos de Elisabeth Lüders a nivel internacional y nacional en el trabajo de información sobre la necesidad del trabajo para la paz. En una conferencia que tiene lugar en Berlín en 1931 apela a la unión de las mujeres europeas para apoyar los objetivos de la política de desarme:

„We appeal to the women because we know their faith and their will for peace are much stronger, moral and political power than all the cleverness, the stubbornness with which the old word tries to maintain itself, which cannot find the faith that yet will remove mountains!" 437

Tras la polémica en las preparación de la conferencia de desarme en Ginebra, el conflicto entre las organizaciones de amas de casa se acentúa en 1932 cuando una delegación del BDF viaja a Ginebra a exponer sus esperanzas de paz. La delegación es acusada de no defender correctamente los intereses alemanes. Esto provoca que dos de las organizaciones más importantes de las amas de casa alemanas el RLHV, Reichsverband Landwirtschaftliche Hausfrauenvereine y el RDH, Reichsverband Deutscher Hausfrauenvereine tras una polémica discusión deciden abandonar la organización. Otra de las razones se muestra en su vinculación ideológica con el NSDAP y la existencia desde 1931 de la organización nacionalsocialista de mujeres, Nationalsozialistische Frauenschaft, que con sus pretensiones de convertirse en el Nuevo Movimiento de la Mujer ejercía una gran atención en los círculos de las mujeres más conservadoras. ${ }^{438}$

Por otra parte el crecimiento de las tendencias antisemitas en la organización, lleva a la dirigente de ésta, Agnes von Zahn-Harnack a movilizar a las mujeres de la Federación para luchar contra los resentimientos existentes entre los grupos de la gran organización. Entre 1930 y 1932 von Zahn-Harnack organiza campañas de información conjuntamente con el Jüdischer Frauenbund (JFB) para luchar contra el antisemitismo. Sin embargo a pesar de los esfuerzos de ésta, las campañas no deben tener el éxito deseado ya que la Federación de mujeres judías abandona la organización en 1932, expresando su desagrado por la falta de apoyo a su causa entre las mujeres del movimiento de la mujer.

Berufsverbände, Katholische Mütter und Jungfrauenvereine, Jüdischer Frauenbund, Valterländischer Frauenverein vom Roten Kreuz.

436 Schmidt-Waldherr, Hiltraud: op.cit., p. 127

437 BAK, NL 151, n 7, Lüders, E.: „Women demand peace”. Lecture given by Frau Dr. Lüders, fBerlín, through the wireless, 30.06.1931.

438 Gehard, Ute: Unerbört. Die Geschichte der deutschen Franenbewegung, Hamburg, Rowohlt, 1990, p.374 
Un mes después se producen nuevas reducciones de los salarios de los funcionarios públicos, de las pensiones y de las prestaciones sociales En septiembre la cifra de parados llega a 4.350.000.

Tras las elecciones presidenciales el 10 de abril de 1932, donde Hindenburg es reelegido, se vuelven a convocar elecciones al Reichstag. La llamada del 31 de Julio de 1932 del BDF a la votación es el último intento de defender los intereses del movimiento de la mujer en la arena política:

„La Unión de Asociaciones de Mujeres Alemanas espera de los partidos políticos, que ellos reconozcan el derecho ciudadano de las mujeres (derecho a votar y a ser elegidas). Este derecho comprende la actividad política en todos los campos de trabajo y exige la participación de la mujer en las funciones de estado y en el parlamento. La mujer que es elegida, y que esté capacitada para cargar sobre sus hombros la responsabilidad total del destino de su patria, tiene derecho a no ser marginada del más elevado de los derechos de los ciudadanos y la obligación más sagrada." 439

Sin embargo el entusiasmo, lo elevado del derecho a participar en los asuntos de estado, y la obligación sagrada de representar democráticamente a los partidos políticos, se desvanecen ante la victoria electoral de los nacionalsocialistas que consiguen 230 escaños, convirtiéndose en el mayor partido del Reichstag.

Conscientes de su fuerza, la presión sobre los representantes del parlamentarismo de Weimar se acentúa. El movimiento de la mujer es también objeto de sus ataques.

En julio de 1932 sale a la luz un panfleto editado por el departamento de propaganda del partido nacionalsocialista en el que se plantean una serie de tesis dónde se pone en entredicho los fines del movimiento de la mujer. Esta acción forma parte de la campaña propagandista dirigida por la NS-Frauenschaft, la organización de mujeres nacionalsocialistas que tiene por objeto dividir y ganar para sus filas a los miembros de las asociaciones de mujeres burguesas. El documento, mitad apelación, mitad provocación define al movimiento de la mujer como una amante indecisa entre el bolchevismo y el espíritu judeo-marxista, y llama a éste a incorporarse al „verdadero movimiento“ de la mujer, basado en la polaridad de los géneros y el servicio a la comunidad del pueblo. Pacifismo e internacionalismo son características que traicionan a los miembros de la V aterland.

Aunque la Federación se encontraba dividida entre los intereses de las diferentes organizaciones de mujeres, era en estos momentos la única amenaza para las mujeres nacionalsocialistas.

Las dirigentes del BDF se defienden de las acusaciones mostrando su patriotismo, resaltando su servicio a la patria con su participación en la primera guerra mundial, mientras que reivindicaban su papel en el movimiento de la mujer. Marie Elisabeth Lüders (DDP) en una carta abierta a la líder de la NS-Frauenschaft, Elsbeth Zander, comenta la necesidad de llegar conjuntamente a una solución en el tema de la mujer. ${ }^{440}$

A pesar de las declaraciones negativas de Hitler, Rosenberg y Goebbels respecto a la participación de la mujer en la vida política, las mujeres burguesas todavía pensaban que llegando a un acuerdo, podrían conseguir sus limitadas aspiraciones de participar en la vida pública. Pensaban que podrían llegar a ocupar un papel en la distribución de las tareas de estado.

439 „Entschließung des Bundes Deutscher Frauenvereine zur Reichtagswahl am 31. Juli 1932“, en: BAK, N.L. 151, n 253

$440 \quad$ Vossische Zeitung, 1.11.1932. 
Else Ulich-Beil en una sesión del consejo de la Federación el 13 de junio de 1932 señala la necesidad de respetar al partido „fascista“ como otro cualquiera, y limitarse a hacer política para la mujer. ${ }^{441}$ Esta táctica defensiva se refleja también en la campaña electoral para las elecciones de noviembre de 1932. ${ }^{442}$

Un clima de desorientación reina en la BDF. Un ejemplo de esta inseguridad respecto a los verdaderos objetivos del nacionalsocialismo aparece en la hoja informativa de la organización a finales de 1932 y principios de 1933. En el número de diciembre de 1932 aparece publicado una conferencia de Margarete Kurlbaum-Siebert ante la asamblea general de la Staatsbürgerinnen$V$ erband. En la ponencia se critica especialmente la reducción, que hacía el nacionalsocialismo de las mujeres. Aunque se comparte el deseo de participar en la Volksgemeischaft se critica el camino que han elegido los nacionalsocialistas. La creación de un estado racial puro es imposible ya que las razas se hayan mezcladas durante siglos, aduce la autora. El camino ha de ser espiritual, interior y no biológico y corporal, y sobre todo no ha de tener que renunciar a la participación de la mujer. Curiosamente no se defiende el estado de democrático ni el sistema parlamentario, sino que se hace referencia únicamente a los intereses de la comunidad del pueblo. ${ }^{443}$ En el número de marzo de 1933 aparece la respuesta al artículo de Kurlbaum-Siebert, por parte de Elfriede Schmidt-Meyer, médico de profesión y nacionalsocialista. Esta niega la actitud negativa del nacionalsocialismo hacia las mujeres que no eligen el camino de la maternidad. Por el contrario, señala Schmidt-Meyer el nuevo movimiento ofrece a las mujeres la posibilidad de luchar como compañeras al lado del hombre en la construcción de la patria alemana:

„Yo misma vivo en mi carne como en el nuevo movimiento libertario alemán bajo la dirección de los hombres de Adolf Hitler de ninguna manera se piensa en las mujeres como objetos de caridad y de pena, al contrario también en este movimiento existe el ideal de la luchadora, (...) donde la mujer ejecuta su tarea biológica para la conservar la raza, como algo natural." 444

Las diferentes posturas que aparecen en el Allgemeiner Deutscher Frauenverein y el Deutscher Staatsbürgerinnenverband son un ejemplo de la situación de desorientación del ala moderada de movimiento de la mujer. Dorothee von Velsen después de un viaje a los diferentes grupos de la organización por toda Alemania refleja acertadamente la situación:

„(...) podrían entonces diferenciarse dos concepciones contrarias, por una parte si era correcto, a través del trabajo conjunto una influencia en la ideas políticas del nacionalsocialismo y la conservación de nuestra esfera de actuación, también en relación a las instituciones locales de beneficencia social, por otra parte se argumentaba el rechazo de todo tipo de compromiso con el consiguiente

441 Evans, Richard J.: The feminist movement in Germany 1984-1933, London, Bloom Helm,1976, p.255

442 Ulich-Beil, Else: DIE FraU, 1932 (n²), pp.65 y s.

443 Kurlbaum-Sibert, M.: „Grundlagen zur Mitarbeit der Frau am Staat”, NACHRICHTENBLATT DES Bundes Deutsche FrauenVEREINE, Diciembre 1932 (n²12), pp. 114-115

444 Schmidt-Meyer, H.: „Entgegnung auf Grundlagen zur Mitarbeit der Frau am Staat”, NACHRICHTEnblatt des Bundes Deutscher Frauenvereine, Marzo 1933 (n³), p. 28. La actitud positiva ante el nacionalsocialismo parece haberse extendido a la organización de las ciudadanas alemanas, Staatsbürgerinnenverband donde el interés por trabajar conjuntamente con las nacionalsocialistas crece cada vez. Voces como las de Kurlbaum-Siebert, apoyada por Dorothee v. Velsen, presidente de la organización, se encontraban en la minoría. 
abandono de una tarea que nos había ocupado toda nuestra vida pero que nos posibilitaba conservarla pura e intacta." 445

Esta política de conciliación y apoyo permanece todavía en 1933 cuando empiezan a entrar en vigor las primeras leyes que limitaban el trabajo de las mujeres casadas, así como de aquellas mujeres que ocupaban puestos de responsabilidad.

La política del BDF durante este período fluctúa entre la defensa de los intereses democráticas y la colaboración con el nacionalsocialismo. Por ejemplo Agnes von ZahnHarnack, que con motivo de las últimas elecciones del 13 de febrero de 1933 redacta un escrito, en nombre de la Liga en el cual se dirige a todos los partidos, dónde exige la igualdad de las mujeres en todos los campos de la sociedad y la incorporación de candidaturas femeninas a las listas electorales, así como las garantías de un estado de derecho y libre. La firmante exige una respuesta ante de cinco días con el fin de poder orientar a las mujeres antes de las elecciones. ${ }^{446}$

Por otra parte en DIE FRAU Gertrud Bäumer escribe en este mismo mes un artículo sobre la indiferencia sobre un gobierno democrático, fascista o parlamentario. ${ }^{447} \mathrm{Y}$ la misma Agnes von Zahn-Harnack, en tonos conciliadores a Leonore Kühn, miembro del partido DNVP y posteriormente conocida nacionalsocialista:

„todas nosotras (...) podemos sólo votar por un gobierno nacionalsocialista y que el $B D F$ hará todo lo posible por trabajar conjuntamente con las mujeres nacionalsocialistas. "448

Otra prueba de la disposición de los círculos de mujeres nacionalsocialistas para colaborar con la $B D F$ es un artículo que aparece el 23 de marzo de 1933, donde se apela a la organización a mostrar su apoyo al nuevo régimen. La autora del artículo, Freiin von Schmidtfeld, „Zeitwende in der deutschen Frauenbewegung” que aparece en la DEUTSCHE ALLGEMEINE ZEITUNG, trata el tema que define las relaciones entre movimiento de la mujer y nacionalsocialismo: ¿Debe pronunciarse éste políticamente?:

„Naturalmente debe el movimiento de la mujer trabajar desde un punto de vista objetivo y no desde posturas políticas. No se puede exigir de éste que se decida por un partido determinado, por el contrario una petición de este tipo ha de ser rechazada. Pero ¿no se encuentra el pensamiento patriótico en algunas, o por lo menos en una organización del movimiento de la mujer, lo suficientemente arraigado para que por parte de este no se escuche un saludo a la nueva Alemania que ha vencido al marxismo.? Un manifestación por ejemplo que al mismo tiempo que mostrara el programa del movimiento y para que la nueva Alemania vea: aquí se encuentran las fuerzas de las que no se puede prescindir en la reconstrucción de la patria ya que el movimiento de la mujer quiere servir al pueblo con su valoración de la mujer, su responsabilidad y su rendimiento. En la lucha contra problemas de

445 Stoehr, I.: Emanzipation zum Staat?. Der Allgemeine Deutsche Franenverein- deutscher Staatsbürgerinnenverband (1893-1933), Pfaffenweiler, Centaurus-Verlagsgesellschaft, 1990, p.135

446 Helene-Lange-Archiv, BDF 22-97, 13. Februar 1933, Informe de la Liga de mujeres alemanas

447 Bäumer, Gertrud: Lage und Aufgaben der Frauenbewegung in der deutschen Umwälzung, DIE FRAU, 1933 (n), p.380

448 Evans, Richard J:: op. cit., p. 256 
tipo social y moral no se puede prescindir de la experiencia que las mujeres tienen en estos terrenos. “449

La autora apela a las dirigentes de la organización a organizar una manifestación donde se manifieste públicamente el apoyo del movimiento de la mujer a la causa nacionalsocialista:

„Cuantas mujeres participaría hoy en día en una proclamación del movimiento de la mujer, que tomara una postura clara. Ellas esperan con todo su corazón que su movimiento muestre lo importante de los valores de la patria y de la comunidad del pueblo. Ellas quieren tener la seguridad de que las preparada representantes de éste en asuntos relacionados con la familia y la juventud en la vida pública está al servicio de la patria. “450

Las críticas contra la BDF están dirigidas a romper la política de neutralidad política de la Federación. Política que sin embargo ya había sido abandonada con el apoyo a Brüning y el rechazo de la política socialdemócrata.

Junto a las organizaciones confesionales, la BDF era la organización más importante dentro del espectro de la mujer. A ella pertenecía el milieu de mujeres más interesante para el triunfo nacionalsocialista: el predominio de posturas conservadoras en la organización había crecido durante la república de Weimar. Es interesante señalar que las críticas de Berta Braun, la firmante del escrito, están dirigidas fundamentalmente al ala más radical del movimiento cuya política era criticada por la mayoría de las integrantes de la $B D F$.

\subsubsection{Die Gleichschaltung}

El 30 de enero de 1933 Hitler es nombrado canciller. Entre febrero y el verano de este año tiene lugar el proceso de Gleichschaltung, proceso que consiste en la integración de todo tipo de organizaciones existentes, culturales, políticas y sociales en las estructuras organizativas del nacionalsocialismo. Las condiciones de la Gleichschaltung consistían en el reconocimiento oficial de la autoridad de Hitler, la expulsión de las organizaciones los miembros no arios, y la ocupación de los puestos de representación por nacionalsocialistas o miembros del partido. Una de las primeras medidas que se toman es el despido de los antiguos representantes parlamentarios que ocupaban cargos ministeriales. ${ }^{451}$ Víctima de esta política de depuración es también Gertrud Bäumer, la cual se ve desposeída de su cargo como referente de asuntos relacionados con la política juvenil en el Ministerio de Interior, debido a politische Unzuverlässigkeit, a ello se une su no inclusión en la Schrifttumkammer con lo cual se limitaban sus posibilidades de publicar. Una de las razones que se argumenta para su expulsión es la acusación de que DIE HILFE, el periódico en el que trabajaba Bäumer junto con Theodor Heuss y Anton Erkelenz había recibido 20.000 Reichsmark procedentes del erario público, fondos a los que Bäumer tenía acceso. En una carta a Emmy Beckmann, Bäumer se defiende de la acusación y aduce que ella únicamente se ocupaba de la parte cultural y literaria del periódico. A los asuntos relacionados con la situación

449 HLA, BDF, 22-97, 23. März 1933, Reproducción del artículo de Freiin von Schmidtfeld, publicado en: Deutsche ALlgemeine ZeITUNG

450 Ibídem.

451 En los meses de marzo a julio de 1933 desciende la cifra de la población activa femenina de una $36,1 \%$ a un 34,9\%. Arendt, H.J.: „Die „Gleichschaltung” der bürgerlichen Frauenorganisationen in Deutschland 1933/34”, ZEITSCHRIFT FÜR GESCHICHTSWISSENSCHAFT, 1979 (n²9), p. 619 
financiera del periódico, continúa, no tenía acceso. ${ }^{452}$ Puede ser que la historia no fuera más que una maniobra de las autoridades nacionalsocialistas para minar la autoridad de la figura de Bäumer.

En una carta posterior a Beckmann, Bäumer demuestra su decepción por la pérdida de su trabajo. Piensa que podrá seguir escribiendo libremente dónde se refugia en una actitud que es común al grupo de escritores y poetas del exilio interior:

„Ahora llega el momento en el que tenemos que trabajar desde el punto de vista espiritual y desde la unión personal, lo exterior se convierte en superfluo, porque en este terreno no podemos hacer nada. “453

El despido de Bäumer trae consigo una oleada de protestas por parte de las organizaciones pertenecientes al $B D F$, aunque si nos atenemos a las actas de la organización existen también grupos que consideran la medida adecuada y que utilizan la ocasión para demostrar su lealtad al nuevo gobierno. ${ }^{454}$

La oleada de despidos se extiende entre las mujeres del movimiento de la mujer. Elisabeth Blochmann, otra de las representantes del movimiento de la mujer, es despedida sin derecho a pensión debido a la ascendencia judía de su madre. Las organizaciones de mujeres de tendencias pacifistas fueron prohibidas, en virtud de la „ley de protección del pueblo y del estado“, Notverordnung zum Schutze von Volk und Staat. Sus dirigentes Anita Augspurg, Lida Gustava Heymann, Gertrud Baer y Helene Stöcker eligen el camino del exilio.

La política del BDF durante estas semanas llenas de cambios es de aproximación a las autoridades nacionalsocialistas. Este acercamiento consiste en una serie de propuestas que tienen por objetivo preservar la independencia de la Federación y la consecución del trabajo de ésta. Interesante es el comentario que se hace respecto al cambio que sufren los consejos directivos de las asociaciones, de lo que se deduce que la medida de prescindir de miembros no arios en las organizaciones podía estar llevándose a cabo:

„El conjunto de las organizaciones asociadas a la Federación de asociaciones de mujeres alemanas y sus asociaciones provinciales y estatales se encuentran en estos momentos en un proceso de cambio. Estas da nueva forma a sus consejos directivos y a sus métodos de trabajo en el convencimiento de que este nuevo periodo requiere nuevos puestos, nuevas personas y nuevos objetivos. Nosotras estaríamos profundamente agradecidas, cuando este desarrollo no fuera interrumpido desde fuera sino que se nos diera libertad de actuación durante unos meses. Una constitución orgánica de las asociaciones de mujeres posibilitaría la prosecución orgánica del trabajo de la beneficencia pública, que es el principal sostenedor de nuestra organización." 455

Dos días después, el 7 de mayo de 1933 la Asociación general de maestras alemanas, Allgemeiner Deutscher Lebrerinnenverein con 40.000 miembros, se disuelve en Erfurt. La comisión de representantes de la organización redacta un escrito donde quedan claras las líneas del futuro de

452 HLA, ADLV, L.000406, 17. März 1933, Carta de Gertrud Bäumer a Beckmann

453 Gertrud Bäumer a Emmy Beckmann, 13.04.1933 en: Bach, Marie Luise: Gertrud Bäumer. Biographische Daten und Texte ž einem Persönlichkeitsbild, Weinheim, Deutscher Studien Verlag, 1989, p. 88

454 HLA, ADLV, 135/ 1-91, Lista de los grupos que apoyan el despido de Bäumer

455 HLA, BDF 22-97, 5.05.1933, Correspondencia entre Agnes Zahn v. Harnack, presidenta del BDF al ministro del interior W. Frick. 
la organización: en primer lugar se recomienda a las miembros de la organización a integrarse en la Organización general de educadores alemanes, Allgemeine Deutsche Erzieber-Organisation. Junto a ello declaran su carácter nacional y social, así como apoyan los objetivos e intereses del nuevo gobierno:

„Las tareas de las maestras alemanas son grandes y múltiples en el movimiento de renovación nacional." 456

En el protocolo de la sesión celebrado un día antes se cita una reunión mantenida con el comisario de la organización de maestros alemanes, Becker, donde se discute sobre el futuro inmediato de la organización. Aunque se acepta la integración en el aparato nacionalsocialista, se intenta evitar la afiliación al NSDAP. Sin embargo se asume la exigencia de no poder pertenecer a otro partido. Como camino de integración se plantea la integración en la organización de maestros alemanes, no obstante a petición por parte de la $A D L V$ una comisión especial donde sólo estuvieran representadas las maestras es rechazada por éste. ${ }^{457}$

El protocolo de la sesión del consejo general de la organización es una muestra excepcional de la situación de la ignorancia del consejo respecto a las intenciones de los nacionalsocialistas. La fecha para la integración en el aparato nacionalsocialista es el 15 de mayo. Importante para las mujeres de la organización es evitar la pertenencia corporativa al NSDAP y proponen que cada mujer libremente decida sobre su afiliación. Otro de los temas se refiere a las condiciones de la integración:

„Se tendría que exigir del gobierno una declaración sobre en qué forma tienen que continuar organizándose las asociaciones. La disolución sólo puede ser llevada a cabo por las autoridades oficiales o por las propias organizaciones." $" 458$

El 10 de mayo de 1933 se crea el Deutsche Franenfront (Frente de mujeres alemanas) en el que todas las organizaciones de mujeres no abolidas hasta la fecha tenía la obligación de integrarse.459 Tenemos noticias de un encuentro que tiene lugar el 12 de Mayo de 1933, entre el Deutsche Frauenfront y Agnes von Zahn-Harnack como representante del BDF en la que se recomienda la disolución inmediata de éste:

„(...) La señora Gottschewski señala que el Frente alemán se ha decidido a no dejar que subsista ninguna isla de cualquier organización de mujeres. Debido a que no pensamos realizar ningún tipo de acción contra el BDF, se le recomienda que ingrese en el 'Frente de mujeres alemanas'. Se exige que el BDF se ponga sin ninguna condición a disposición de Adolf Hitler, y entregue una declaración

456 Beckmann, Emmy: „Die Auflösung des Allgemeinen Deutschen Lehrerinnen-Vereins“, DIE FrAU, Junio 1933, ( $\mathrm{n}^{\circ}$ 9), p. 550. Véase documento en el Apéndice A.

457 HLA, L.000403, 134/20, Vorstand des Allgemeinen Deutschen Lehrerinnen-Vereins, 6.05.1933, p. 1

458 Ibídem, p. 4

459 Entre las organizaciones que se integran al Frauenfront se encuentran las organizaciones de amas de casa, la asociación de mujeres patrióticas (Vaterländische Frauenverein), la liga de académicas alemanas (Deutsche Akademikerinnenbund), el Frauenhilfswerk, la asociación de Handlungsgehilfen, el Willkommenklub, el grupo de mujeres de los cristianos alemanes, las organizaciones de funcionarias, maestras, la organización para la cultura de la mujer (Deutsche Frauenkultur), las asociaciones de empleadas y la liga de la Reina Luise, (Bund Königin Luise). Fuente: DIEFraU, buscar el número donde está el artículo de Marie Baum sobre Das Opfer der Mutter. 
escrita. Los miembros no arios deben ser sustituidos y los puestos de dirección deben ser ocupados por mujeres nacionalsocialistas. “ 460

Tres días después se reúne el consejo de la Federación, a las diez de la mañana, se discuten las condiciones propuestas por Gottschewski. Agnes von Zahn-Harnack participa en la conversación y es consciente de la parodia a la que está siendo sometida. Si no acepta lo propuesto por los nacionalsocialistas, la organización está amenazada por la disolución. Después de algunas horas donde se discute apasionadamente sobre el futuro de la Federación se decide la disolución de ésta. Únicamente dos instituciones no se ven afectados por la media, DIE FRAU y la fundación Helene Lange. El 15 de Mayo se reúne el consejo general bajo la dirección de von Zahn-Harnack, donde se decide la autodisolución como una consecuencia de la „reorganización“ del sistema de asociación. Se aceptan que las organizaciones no pueden trabajar con los métodos democráticos utilizados hasta ahora, aunque se espera una posibilidad de actuación en el nuevo estado. 461

El 15 de mayo del mismo año el $B D F$ se disuelve, con él 114 grupos y organizaciones de mujeres que englobaban $3 / 4$ millón de mujeres. El 7 de Mayo en Erfurt se disuelve el $A D L V$. El 28 de junio corre el mismo camino el Deutsche Staatspartei, heredero del Deutsche Demokratische Partei . El 24 de septiembre del mismo año con la disolución de la organización de mujeres más antigua de la historia del movimiento de la mujer, la Allgemeiner Dentscher Franenverein, el proceso de autodisolución puede considerarse como terminado.

A partir de estos momentos comienza una nueva etapa en la vida de las dirigentes de las organizaciones del movimiento de la mujer. Esta se caracteriza por la retirada interior y la dedicación a las actividades literarias y de investigación histórica. Gertrud Bäumer, por ejemplo celebraba interiormente los inicios de esta etapa, en la idílica isla de Sylt donde comienza a escribir su biografía, y trabajar en un libro sobre Naumann.

¿Adaptación, colaboracionismo, o resistencia? Si nos atenemos a la lógica de los hechos podemos constatar el carácter democrático de las organizaciones de mujeres y el apoyo personal a la democracia. La llegada de la dictadura sin embargo, no se vive como una defensa de los principios democráticos, sino que se intenta preservar la obra de las asociaciones, y por encima de todo se intenta evitar una disolución violenta de éstas. Dada la imposibilidad de poder preservar el carácter y la independencia de las organizaciones se decide por la solución de la disolución. No creemos como algunas autoras que la imposición por parte de los nacionalsocialistas de expulsar a las personas de raza no aria de las organizaciones juzgara un papel importante. Como señala Marion Kaplan en su estudio estas ya habían abandonado las organizaciones. La autodisolución fue una acción de defensa de los propios intereses. A diferencia de las asociaciones confesionales que contaban con el apoyo de sus respectivas iglesias, las mujeres del ala moderada del movimiento de la mujer, son conscientes de la desaparición del loby político que las apoyaba. Su independencia de acción no podía continuar durante el nacionalsocialismo. El trabajo de la mujer ha de ser continuado en una ropaje diferente. Canalizador de este trabajo será la revista DIE FRAU que se convertirá en el órgano de expresión de las antiguas dirigentes del movimiento de la mujer durante los años del nacionalsocialismo. Esta nueva estrategia de trabajo no es sin embargo compartida por todas las dirigentes, sino que como veremos en el capítulo dedicado al análisis de la publicación, existen diferentes versiones entre el círculo de las viejas luchadoras sobre el papel de éstas durante los años de la dictadura. Otro punto de continuidad con el trabajo del movimiento de la mujer lo

460 Conversación en el Deutsche Frauenfront entre Frau Gottschewski, Frau Diers y Frau Agnes von Zahn-Harnack, 12. Mai 1933, en: BAK, NL 151, n 265

461 Evans, Richard J.: op. cit., p. 257 y Die Frau 1933 (nº9), pp. 513-514 
constituye la fundación Helene Lange, que a partir de 1933 pasará a administrar, legalmente, los bienes materiales e ideológicos de la trabajo de las asociaciones de mujeres pertenecientes al $B D F$.

\subsubsection{La fundación Helene Lange}

Con objeto de preservar los intereses de las diferentes organizaciones de la Federación de mujeres alemanas, sus dirigentes se dedican a elaborar estrategias de supervivencia. DIE FRAU mantenía vivo el espíritu de la Federación, la fundación Helene Lange, se encargaba de administrar el legado intelectual y económico del movimiento. Esta medida respondía al deseo de evitar a toda costa que los nacionalsocialistas pasaran a administrar los bienes de las organizaciones.

La fundación se constituye como una iniciativa para el fomento de la educación de la mujer, con la principal función de repartir becas a estudiantes alemanas y extranjeras. Ésta había sido creada en 1910 por Helene Lange, con capital propio y constaba de un consejo de siete miembros, donde la mayoría y la presidencia tenía que estar ocupadas por miembros femeninos. ${ }^{462}$ La fundación se encontraba estrechamente unida con la Organización general de profesoras alemanas, Allgemeiner Deutscher Lehrerinnen-Verein. Por ello cuando la citada organización es disuelta el 7 de mayo de 1933, los fondos de ésta pasan formar parte de la fundación:

„Después de que la asamblea general de la „asociación general de maestras alemanas", que tiene lugar en Erfurt el 7 de mayo de 1933 se ha decidido la disolución del ADLV, se ha encargado a las liquidadoras firmamentes con el encargo de preservar el patrimonio de la asociación. Por ello se han estimado los siguientes pasos: se retira una cantidad para la continuación de las tareas de apoyo que hasta ahora venía haciendo la asociación y otra cantidad para la promoción de las ideas y de los objetivos por los que luchó la fundadora de la organización." 463

El traspaso de bienes y fondos es autorizado en diciembre del mismo año. La fundación Helene Lange recibe una cantidad de $48.000 \mathrm{RM}$ y se compromete a cuidar la tumba de Helene Lange, a publicar la historia de la organización, y finalmente a apoyar a miembros de ésta en caso de necesidad. El motivo de esta rápida y no problemática autorización tiene que ver con la escasez de fondos de la fundación, la cual había visto su capital progresivamente devaluado durante la República de Weimar. Esperando que la fundación no sobreviviera más de unos meses, el permiso fue concedido. ${ }^{464}$

El 23 de noviembre de 1933 se elige un nuevo congreso cuyas representantes son: Gertrud Bäumer, Elisabeth Meyn-von Westenholz, Emmy Beckmann, Agnes von Zahn-Harnack y Anne von Kullesza, esta última muere un año después.

En 1938 el consejo esta formado por, Gertrud Bäumer, Elisabeth Meyn-von Westenholz, Emmy Beckmann, Agnes von Zahn-Harnack, Gertrud Schubart y Käthe Lohmann, además de Anna Encke, representante del nacionalsocialista y de la Reichsfrauenführerin, Gertrud ScholzKlink:

\footnotetext{
462 HLA, Rep. 105, no 4459, 23. Oktober 1938

463 HLA, ADLV, 134/15-27, 15. September 1933

464 HLA, ADLV, 135-1-91, 15.12.1933
} 
„Una correcta orientación del consejo de la Fundación Helene Lange debería estar asegurada con la presencia en el mismo de una persona de confianza de la Reichsfrauenfübrerin." 465

Unos meses más tarde la Reichsfrauenfübrerin nombra a Erika Semmler, dirigente del departamento de prensa y propaganda de la NS-Frauenscbaft como segunda persona de confianza en el consejo directivo de la fundación. ${ }^{466}$

La presencia de miembros pertenecientes al DDP levantan suspicacias en el NSDAP, donde se observa desde cerca las actividades de la fundación. Sin embargo las investigaciones realizadas por la Staatspolizei revelan la „respetabilidad“ de las afectadas, a pesar del pasado "democrático" de Bäumer, Beckmann y Lohmann, como miembros del DDP. Sobre Beckmann no aparece ningún tipo de comentario y sobre Lohmann se duda sobre su preparación como profesora de instituto. La persona de Bäumer sale por el contrario, bien parada. Tras años de control de DIE FRAU por parte de la Gestapo y de la policía militar se ha decidido conceder a la publicación un importante papel de cara a la política internacional. ${ }^{467}$

En el informe se resaltan, además, „las buenas intenciones“ de Bäumer, la importancia de su periódico frente a la prensa internacional, y los servicios al nuevo movimiento de la mujer alemana. Respecto al resto de los miembros de consejo se responde, a pesar de su pasado democrático de forma positiva. 468

Las esperanzas de las autoridades nacionalsocialistas sobre la corta vida de la organización no se cumplen. La fundación continuó trabajando, y a pesar de la guerra, los bombardeos pudo sobrevivir a la guerra. El material conservado se encuentra en la actualidad en el Helene-LangeArchiv, dependiente del archivo de la ciudad de Berlín.

\subsection{Primeras reacciones de los movimientos confesionales de mujeres ante el nacionalsocialismo}

La postura del partido nacionalsocialista respecto a la cuestión religiosa se reflejaba tempranamente en el punto 24 del programa de dicho partido de 1920:

„Nosotros exigímos la libertad de todas las confesiones religiosas en el Estado, siempre y que estas no amenacen la moralidad y las costumbres de la raza germana. El partido como tal defiende el criterio del cristianismo positivo, sin ligarse a un determinada confesión. El partido lucha contra el espíritu judeo-materialista en nosotros y fuera de nosotros y está convencido de que la curación definitiva de nuestro sólo puede tener lugar desde dentro hacia fuera a partir de la premisa: el interés colectivo prevalece sobre el individual." ${ }^{469}$

Las dos religiones católica y protestante serán toleradas siempre que no atentaran contra la raza germana. Utilizando la tradición antisemita de ambas confesiones Hitler pretendía organizar un frente común contra el judaísmo. Aunque en lo privado, éste manifestaba su

\footnotetext{
465 HLA, Rep. 105, n 4459, 22.08.1938

466 HLA, Rep. 105, $\mathrm{n}^{\circ} 4459,15.10 .1938$

467 HLA, Rep. 105, n 4459, 22 August 1938

468 HLA, Rep. 105, n 4459, 22 August 1938

469 Denzler, G. / Fabricius, V.: Die Kirchen im Dritten Reich. Christen und Nazis Hand in Hand?, Frankfurt am Main, Fischer, 1984, p.12
} 
desprecio tanto por el protestantismo como por el catolicismo cuya moral y piedad consideraba propio de actitudes débiles y sin personalidad:

„Con las confesiones, una o la otra: todas son iguales. Esto no tiene ningún futuro. Para los alemanes seguro que no. El fascismo puede hacer la paz con la iglesia en nombre de Dios. Yo también lo haré. ¿Porqué no? Eso no me detendrá de exterminar por completo al cristianismo en Alemania con todas sus raíces y filamentos. Para nuestro pueblo es definitivo decidir si mantienen su débil moral compasiva de raíz judeocristiana o una fuerte, heroica fe en la naturaleza, en el pueblo, en el destino, en la sangre (...).“ “470

A pesar del desprecio de Hitler por la religión, esta claro desde el principio la estrategia de aceptación de las dos confesiones y los intentos de conseguir el apoyo de ambas para los fines del nacionalsocialismo.

Unos años después de la publicación de Mein Kampf, Alfred Rosenberg, convencido de que la adaptación era mejor que la negación absoluta, intentó con su libro Der Mythus des 20. Jabrbunderts dar forma filosófica a las ideas nacionalsocialistas sobre el cristianismo:

„La religión de Cristo era sin duda la predicación del amor... Nadie podrá despreciar este sentimiento; conforma el fluido espiritual de individuo a individuo. Pero un movimiento religioso alemán que podría configurarse en una iglesia popular, debe aclarar que el ideal del amor al prójimo es necesario para apoyar la idea del aprendizaje nacional, que ningún acto de cualquier iglesia alemana debe ser consentido si éste no sirve a la seguridad de la nación. (...) Las confesiones religiosas no son un medio en si mismas sino un medio al servicio de los sentimientos nacionalsocialistas y de los valores germánicos. (...) El rechazo de los ideales germanos esta próximo a la traición." 471

La reacción ante la obra de Rosenberg es dispar. Mientras que la iglesia católica reacciona indignada ante la falsa interpretación del ideal cristiano, en el caso protestante da pié a una crisis de la unidad de esta iglesia y su división en diferentes grupos. La interpretación personal de la Biblia, punto central de la religión protestante, y base de la falta de dogmatismo, y de autoridad, conduce a la interpretación nacional del protestantismo como fenómeno puramente alemán y a la aceptación de los principios nacionalsocialistas en sus formas más degradadas, en una parte de la iglesia protestante.

Las primeras reacciones de las asociaciones de mujeres pertenecientes al movimiento confesional de la mujer están estrechamente relacionadas con las relaciones de sus respectivas iglesias con el nacionalsocialismo. De esta manera creemos importante para la comprensión del análisis del la prensa de las asociaciones de mujeres católicas y una breve alusión a la reacción de las iglesias oficiales ante la intromisión del estado en los asuntos religiosos.

Como ya hemos insinuado en un principio, las reacciones de la iglesia católica y la iglesia protestante fueron diferentes en función de las normas, los mandatos religiosos y de la naturaleza organizativa y jerárquica de ambas. Hay que decir sin embargo, que el advenimiento de la República de Weimar supuso para ambas un duro golpe. Dado que los vínculos iglesiaestado, o mejor dicho, iglesia-monarquía, se rompieron definitivamente ambas confesiones

470 Ibídem, p.14

471 Rosenberg, A.: Der Mythus des 20. Jahrhunderts. Eine Wertung der seelisch-geistigen Gestaltenkämpfe unserer Zeit, München, Hoheneichen Verlag, 1933, p.467 
perdieron gran parte de sus privilegios. De las dos confesiones es la protestante la que sufre más intensamente los efectos de la desaparición de la monarquía. En las diferentes iglesias estatales el príncipe o el rey era el primer dirigente de la iglesia, como actualmente ocurre con el sistema anglicano. La desaparición de la monarquía termina con una larga tradición que se remonta a los tiempos de la reforma:

„La magnificencia del imperio alemán, el sueño de nuestros padres, el orgullo de todo alemán ha desaparecido. Con ella el soporte del poder alemán, el gobernador y la casa regente que nosotros amábamos y admirábamos intensamente como abanderados de la grandeza alemana." 472

La derrota de Alemania y el tratado de Versalles contribuyen a crear una actitud antirepublicana en los círculos protestantes:

„(...) entre la iglesia (protestante) y la república de Weimar no hubo nunca una relación positiva., Tras la nueva constitución de la naturaleza de los partidos, y el fracaso de fundar un partido con un programa protestante, las simpatías de los representantes del protestantismo se dirigían al recien fundado 'partido popular nacional-alemán"”. 473

Otros partidos que eran votados por los círculos protestantes era el DVP, Deutsche Volkspartei, de carácter antidemócrata y el partido liberal, Deutsche Demokratische Partei, DDP que engloba al protestantismo liberal y cultivado.

El catolicismo, por el contrario, se organiza rápidamente en el llamado partido de centro, Zentrumspartei, y se consolida durante Weimar como una reconocida fuerza política respetuosa y defensora de los principios de la república. No encontramos, por el contrario tal unidad dentro de la población protestante, donde se encuentra un variado espectro de posturas liberal-democráticas hasta posiciones antirrepublicanas conocidas por su antisemitismo y su tendencias nacionalistas.

De las dos confesiones fue la protestante la que reaccionó más favorablemente a la llegada del nacionalsocialismo. Prueba de ello fue el silencio y la falta de protesta oficial ante las primeras medidas llevadas a cabo por los nacionalsocialistas: el decreto de eliminación de los derechos democráticos del 28 de Febrero de 1933 (Verordnung zum Schutz von Volk und Staat), la ley de plenos poderes (Ermächtigungsgesetz) del 23 de marzo de 1933 y la construcción de los primeros campos de concentración, no suscitaron ninguna protesta oficial. Tras el silencio llegó la aprobación, y la justificación del nacionalsocialismo, tarea no del todo difícil: la religión protestante, en su versión más conservadora, compartía con el nacionalsocialismo la aversión de éste al judaísmo, el marxismo y el liberalismo. Todo ello gozaba según la mayoría de los teólogos protestantes del beneplácito de Lutero. Estas aseveraciones partían de ciertas aseveraciones de éste en las que la Reforma iba unida al destino de la patria alemana: „Yo, 'profeta alemán', no busco mi salvación ni mi felicidad, sino la de los alemanes." Estas afirmaciones son según los estudiosos de la obra de Lutero, esporádicas, y están sacadas de contexto. Ėste también afirmó en ocasiones: „Todo alemán deberá, sin duda, lamentar el haber nacido alemán y ser tenido por tal.“ 474

La historia del protestantismo ortodoxo es corta. Durante el siglo XVIII bajo la influencia de los cambios producidos en las ciencias naturales y en la filosofía, crece entre los teólogos

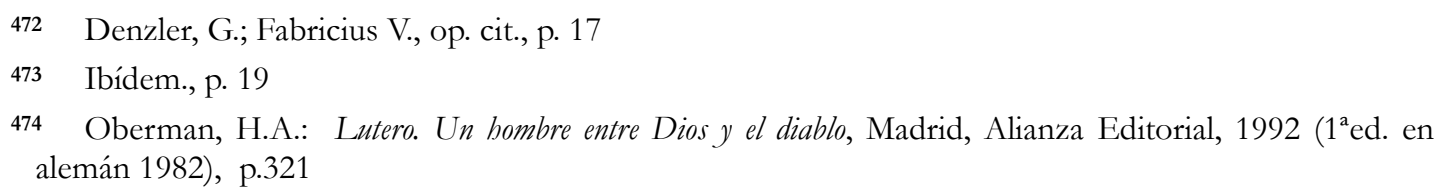


protestantes la práctica de una teología fundamentada en el estudio histórico y filológico de las fuentes. Como contrapunto aparece un movimiento de renovación, conocido por su oposición a los principios de la ilustración, y su interpretación literal de la Biblia. Se trata del llamado pietismo. Durante el siglo XIX se han establecido corrientes en la historia de la teología protestante: la corriente liberal representada por David Friedrich Strauss y Ferdinand Christian Baur influida por el historicismo y el positivismo. Junto a Strauss y Baur es importante destacar a los teólogos Albrecht Ritschl, Adolf von Harnack y Ernst Troeltsch que consolidan la interpretación desde puntos de vistas históricos de la religión, también conocidos como los representantes del llamado Kulturprotestantismus. Un hito fundamental para el desarrollo de la teología protestante lo constituye la primera guerra mundial. De las experiencias de la guerra se niega la concepción cultural de lo divino que caracterizaba al Kulturprotestantismus. Rudolf Bultmann plantea una interpretación existencialista, Paul Tillich defiende la teología sistemática y Karl Barth es conocido por la su teología dialéctica.

Desde la llegada del nacionalsocialismo a la arena política de Weimar, se desarrolla una controvertida sobre la naturaleza del movimiento entre los teólogos protestantes. En primer lugar existe una actitud de apoyo por parte de los jóvenes teólogos de los círculos nacionalsocialistas, representados por Wilhelm Stapel, Emanuel Hirsch y Paul Althaus, una postura de neutralidad en los círculos de teólogos y laicos del centro y por último, una reacción de rechazo entre los teólogos socialistas, con Barth y Tillich a la cabeza. 475

La postura de la iglesia oficial adopta la segunda vía, es decir la neutralidad. Postura que como veremos en los capítulos posteriores, aparece también en las asociaciones de mujeres protestantes.

En este contexto teológico extremadamente conservador y en oposición a las corrientes liberales y dialécticas del protestantismo surgen pequeños grupos religiosos que intentaban fundamentar teológicamente la síntesis entre el nacionalsocialismo y el cristianismo. Entre ellos cabe destacar al Movimiento de los cristianos alemanes, el Glaubensbewegung Deutscher Christen, fundado el 29 de Julio de 1933, que se convirtió en el brazo político-religioso del NSDAP cuya finalidad era la captar nuevos correligionarios. Las líneas ideológicas de este grupo quedan definidas el 26 de Mayo de 1932. Según su ideología su grupo no se define por una confesión religiosa, sino por una confesión vital, en segundo lugar proponen una reorganización de la iglesia, en la que ésta se constituiría en una institución estatal y centralizada; en tercer lugar proclamaban su rechazo al parlamentarismo, a los partidos políticos, a todo el sistema liberal.

La teología de estos grupúsculos se caracterizaba por una vuelta a las creencias de las tribus germanas y un desprecio generalizado por el cristianismo. Cristo era visto como la víctima necesario que todas las grandes religiones necesitan para recuperar de nuevo su fuerza:

„(...) en todas las religiones auténticas, el hijo de Dios debe morir siempre, de esta manera el Mesías judío tuvo que morir para hacer renacer de nuevo al occidente germano." 476

A esta idea de predominio de la religión cristiana sobre las demás estaba estrechamente unida a un sentido del deber hacia la nación y hacia los mismos alemanes:

„Yo intenté atraer a los hombres, darles apoyo en la religión cristiana y predicarles la verdad cristiana, también intenté ayudarles en su necesidad. Me

475 Dezler, G., Volker, F.: Die Kirchen im Dritten Reich, Frankfurt a. Main, Fischer, 19 p.20.

476 Dobroschke-Taeschner, M.: „Mutterkirche“, DIE FrAU, Octubre, 1933 (nº1), p.11. El comentario procede de Ernst Bergmann recogido de su libro Die Deutsche Nationalkirche. 
alegro de haber podido servir a mi patria como cristiano, soldado y nacionalista." 477

La fácil aceptación que tuvo el nacionalsocialismo por parte de la iglesia protestante está ligada a un conservativismo nacional y protestante que comienza a configurarse en las últimas décadas del siglo XVIII, en el que la historia se entiende desde un punto de vista religioso, y el principio de autoridad divina se traduce al concepto de nación. ${ }^{478}$

La exaltación de la cultura germánica no sólo conduce al desprecio del cristianismo, sino a los demás movimientos y actitudes del mundo occidental: la escolástica, la teología y el humanismo se consideran como los verdaderos enemigos que atentaron contra la ,inocencia“ $\mathrm{y}$ la „pureza“ de los pueblos germanos. El razonamiento, la lógica, el pensamiento científico eran juzgados como erróneos y limitados.

No obstante dentro de la iglesia protestante existen grupos de teólogos y laicos que se oponen a las teorías de los cristianos alemanes. En 1932 se funda la Alianza de pastores, el Pfarrernotbund, un grupo de pastores protestantes que crítica públicamente los artículos sobre las leyes arias, Arierparagraphen, o las disposiciones que evitaban los matrimonios entre alemanes de raza aria, y „alemanes de razas inferiores“, la única autoridad que puede decidir sobre la naturaleza de los hombres son los textos sagrados y las ideas de la reformación.

Desde la iglesia católica se vive la conquista del poder por los nacionalsocialistas desde el silencio de las autoridades eclesiásticas. Amparándose en las teorías paulinas sobre la autoridad del estado y tomando en la figura del papa como único transmisor de la voluntad divina, no aceptan la ideología nacionalsocialista pero tampoco la contradicen:

Si bien los protestantes estaban sujetos a las reflexiones éticas que su propia conciencia planteaba, para los católicos las cosas eran un poco diferentes: por un lado su iglesia no podía de ninguna manera ser asimilada como hizo Hitler con la iglesia protestante; por otro, los católicos alemanes se consideraban dependientes de Roma, de ahí que para los nazis fuera de vital importancia tratar directamente con el Vaticano.

El 20 de Junio de 1933 Hitler firmó un concordato con la Iglesia Católica. El Vaticano esperaba asegurar la protección de la fe católica en Alemania. La encíclica „Con ardiente pesar“ de Marzo de 1937, acusó a los nazis de hostilidad fundamental al cristianismo pero, para entonces Hitler no necesitaba ya del prestigio temporal que el concordato había prestado al régimen nazi.

\subsubsection{Las organizaciones de mujeres protestantes}

La historia de las organizaciones de mujeres protestantes durante el nacionalsocialismo constituye un ejemplo claro de los intentos del nacionalsocialismo de ,neutralizar” el poder de las instituciones eclesiásticas. Estas siempre fueron un problema para Hitler, aunque en su obra Mein Kampf, el tema ,iglesia y estado“ aparece muy someramente tratado; es después de la Machtergreifung cuando se empiezan a tomar medidas para regular las relaciones entre iglesias y estado. Según Bracher las tácticas que se emplean en cada caso dependen de la naturaleza de las iglesias. En la iglesia protestante se intento una conquista desde adentro, infiltrándose entre los párrocos fundamentalmente, en el caso de la católica, luchando contra sus apoyo políticos y

477 Declaraciones de un párroco afiliado al NSDAP, en: Rohr, B.: Die allmähliche Schärfung des weiblichen Blicks. Eine Bildungsgeschichte zwischen Faschismus und Frauenbewegung, Berlín, Argument, 1992, p.27

478 Scholder, K.: Die Kirchen zwischen Republik und Gewaltherrschaft, Frankfurt am Main, Siedler, 1983, p. 85 
logrando llegar a un acuerdo con el Vaticano que a pesar de todo no libró a la iglesia católica de perder su autonomía y libertad. ${ }^{479}$

Mucho más complicada es la reacción y evolución de la iglesia protestante. Las causas tienen que ver con los problemas estructurales de tipo organizativo, como teológicos del protestantismo alemán. La iglesia protestante fue hasta la República de Weimar una iglesia ligada a lo nacional. Los pastores, como ocurre en la actualidad, tenían un rango de funcionarios. Al desaparecer este soporte, con la llegada de la república, está sufrió una conmoción que afectó a todas sus estructuras.

La llegada del nacionalsocialismo restauraba los deseos nacionales de muchos protestantes.

Según Bracher la iglesia protestante se caracterizaba por su orientación nacional-alemana con tintes conservadores. De esta manera se entiende la rapidez con que muchos protestantes se adaptaron a las teorías nacionalsocialistas, como una evolución más de la política conservadora alemana.

Consecuencia de este nacionalismo religioso es la fundación en 1921 del Bund Deutscher Kirchen posteriormente conocido como Deutsch-Christliche Arbeitsgemeinschaft, caracterizado por sus posturas radicales y racistas e influido por Lagarde, Langbehn y Houston Stewart Chamberlain. En 1932 se funda la Glaubensbewegung Deutscher Christen con una gran participación de miembros del partido entre sus integrantes. Su dirigente será desde 6. Junio 1932 el pastor protestante Joachim Hosselfelder, miembro del NSDAP desde 1929.

El nombramiento de Müller como obispo del Reich es uno de los pasos a conseguir la Gleichschaltung de la estructuras de la iglesia protestante. Sin embargo este proceso se va a revelar como extraordinariamente difícil. Una de las causas radica en la misma estructura de la iglesia protestante. La división en diferentes iglesias ,estatales“, no era puramente administrativa. Las iglesias estaban acostumbradas desde la época de la reformación a una independencia de criterios y actuación.

La evolución de las relaciones entre los Deutsche Christen y la iglesia protestante iba a estropear los planes de asimiliación del protestantismo alemán. La escisión amenazaba a los protestantes que se oponían a los Deutsche Christen no por su orientación política sino por su peculiar interpretación de las escrituras. Esta disputa se centró en la elección del nuevo obispo. Mientras que el grupo de los cristianos alemanes reconoce el nombramiento de Müller, el resto de las iglesias observa como su propio candidato el pastor Friedrich von Bodelschwingh, en un principio obispo del Reich se ve obligado a dimitir por los cristianos alemanes. Esta intromisión directa del estado en los asuntos de la iglesia protestante será un golpe que muchos protestantes no olvidarán. Son los años de victoria para los DC, donde las iglesias se engalanan con símbolos nazis, esvásticas, donde los párrocos incómodos son despedidos de sus parroquias, donde se adoran estatuas de Cristo con rasgos arios.

En este grupo de pastores protestantes descontentos se define el nacimiento de la Bekennende Kirche. Iniciada por el teológo Berlínés Dietrich Bonhoeffer que ya en 1933 había llamada la atención sobre las verdaderas intenciones de Hitler. Por otra parte en el mismo año pronuncia un discurso sobre la iglesia y la cuestión judía donde defiende la misma situación de igualdad de los judíos convertidos al cristianismo. En septiembre del mismo año da a conocer, junto con Niemöller en una declaración pública, su oposición a las leyes arias. El nuevo movimiento de renovación se extiende por toda Alemania. Un grupo de jóvenes pastores y teológos en Rheinland y Westfalia empiezan a ejercer oposición al poder de los cristianos alemanes. Se trata

479 Bracher, K.D. / Schulz, G: / Sauer, W.: Die nationalsozialistische Machtergreifung. Studien zur Errichtung des totalitären Herrschaftssystems in Deutschland 1933/34, Bonn, Bundeszentrale für politische Bildung, 1974, p.442 
de los llamados Pfarrerbruderschaften, hermandades de párrocos. En 21 de septiembre se crea un Notbund integrado por 2000 párrocos para luchar contra los DC.

La primera iniciativa de este grupo fue la de luchar contra las leyes arias, elaborándose un documento donde que fue clavado en los árboles cercanos a la iglesia donde los DC celebraban con gran ornato el nombramiento de Müller como obispo del Reich, al lado de un Hossenfelder triunfante, recién nombrado ministro para los asuntos de la iglesia protestante. Este fue el primer acto de resistencia pública de los hombres de la Bekennende Kirche (iglesia confesora).

Una medida va definir el carácter de resistencia de la BK, el 20 de diciembre de 1933 los 1,2 millones de miembros de las juventudes protestantes son integrados por decreto en las juventudes nacionalsocialistas. Este golpe decisivo afirma la voluntad resistente de los miembros de la BK y incita a muchos a integrarse en la organización.

La oposición es clara pero la represión también. Por estas fechas se suceden procesos disciplinares, despidos, interrogatorios etc. La „,iglesia confesora“ se organiza en un „sínodo de oposición“ constituido por las hermandades de pastores, donde se crítica públicamente a la línea del obispo del Reich, Müller y los DC.

La progresiva fuerza de la BK y los torpes intentos de Müller de hacer valer su autoridad sobre la iglesia protestante hacen que Hitler le retire su confianza. El 16 de julio de 1935 se crea un ministerio para asuntos eclesiásticos cuyo dirigente Kerl pasará a dirigir las negociaciones con la Vorläufige Leitung der Deutschen Evangelischen Kirche, un órgano que representa los intereses de las iglesias protestantes que no se encontraban en manos de los cristianos alemanes. Müller permanece como obispo del Reich sin cargo, olvidado de todos. ${ }^{480}$

Una de las primeras acciones del nuevo órgano de representación de la iglesia protestante (VKL) fue un escrito a Hitler en junio de 1936. Este escrito engloba siete puntos en los que se expresaban las preocupaciones de los protestantes alemanes. Estos siete puntos no trataban únicamente de cuestiones religiosas sino que abordaban temas como el antisemitismo, los campos de concentración, las actuaciones de la policía secreta etc., y exigían la libertad para poder practicar su religión. El escrito fue entregado personalmente en la cancillería de Hitler, y se evitó a toda costa su publicación. Unos meses más tarde dos discípulos de Bonhoeffer lo enviaron a un periódico suizo donde fue publicado. ${ }^{481}$ Esta acción dio lugar a un trágico suceso ya que la VKL II, órgano representante de la iglesia confesora en la ilegalidad, que por entonces se había separado de la corriente moderada de las iglesias que habían permanecido libres de la influencia de los cristianos alemanes, no estaba informada y colaboró posteriormente con la Gestapo para incriminar a los dos estudiantes.

El seno de la BK se encontraba también dividido. Entre los partidarios de una oposición pasiva y la generación más joven deseosa de tomar posturas más comprometidas. Este ala más politizada de la BK se manifiesta en la figura de Dietrich Bonhoeffer, que organiza con altos mandos del ejército un atentado contra Hitler.

¿Porqué no continuaron apoyando los nacionalsocialistas a los DC, como en los primeros meses del 33? En este mismo año hay declaraciones de Rosenberg en el VÖLKISCHER BEOBACHTER donde el partido se desentiende de la lucha por los problemas de confesión, y no quiere convertirse en el apoyo político de uno o de otros. Esta maniobra puede calificarse de inteligente ya que pretendía eliminar el contenido político de la lucha entre las dos iglesias, y reducir el conflicto a u mero problema religioso. En opinión de Bracher este cambio obedece también al deseo de crear una iglesia alemana que tuviera como principal ideología el nacionalsocialismo; esta aspiración entraba en conflicto con las ideas exaltadas de Hossenfelder

$480 \quad$ Ibídem, p.459

481 Boyens, A.: „Widerstand der Evangelischen Kirche im Dritten Reich“, en: Bracher, K.D. / Funke, M. / Jacobsen, H.A. (eds.): Nationalsozialistische Diktatur 1933-1945. Eine Bilan₹, Bonn, Bundeszentrale für politische Bildung, 1986, p.672 
y la falta de carácter de Müller. ${ }^{482}$ Romper la afinidad entre los DC y el partido era socavar el grado de resistencia política que la BK tenía. Si el partido dejaba de apoyar a los DC, la BK no podía indirectamente criticar a los nacionalsocialistas, con lo cual disminuía su poder de convencimiento. El nuevo cambio de táctica aparece claramente reflejado en una de las circulares de Martin Bormann, íntimo colaborador de Hess y Hitler; en esta circular enviada en junio de 1941 a todos los jefes de distrito se incita a mantener esta controversia como una de las posibilidades de vencer el poder de influencia de la iglesia. 483

Exito de esta política de no implicación „aparente“ es el status quo al que llegan las llamadas iglesias intactas, que un principio habían apoyado los principios de la iglesia confesora, pero que sin embargo con el objetivo de preservar su independencia de acción se muestran a partir de 1938 dispuestas a colaborar con las autoridades nacionalsocialistas. Los miembros de la iglesia confesora, en la ilegalidad, sufre la política represora de la dictadura.

La guerra trae también cambios para la evolución de la BK, y en la situación en general de las relaciones entre la iglesia protestante y el régimen nacionalsocialisa. Al contrario de sus colegas católicos que en repetidas ocasiones muestras sus ideas pacifistas; un gran número de miembros de la BK es despertado por un sentimiento de defensa nacional:

„La guerra cambió la situación en totalidad. Todos amábamos Alemania, como nuestra tierra, nuestra patria. Esto era para nosotros algo diferente del Tercer Reich. Sólo que después del comienzo de la guerra ambas cosas no podían ya separarse. De esta manera algunos de nuestros jóvenes hermanos marcharon al frente, al principio con dudas, pero finalmente con lealtad al pueblo y a la patria. “484

La guerra trae como consecuencia la radicalización de las posturas dentro de la iglesia confesora. Se advierte una tendencia en algunos miembros más jóvenes de la BK a la resistencia activa. Estamos hablando del caso de Dietrich Bonhoeffer. Desde 1940 trabajaba por encargo del general Canaris para la resistencia alemana. Esta colaboración llega a su punto más alto en la preparación del atentado contra Hitler por que el Bonhoeffer pagará con su vida. En el capítulo dedicado al análisis de la prensa de las asociaciones de mujeres protestantes, nos ocuparemos más detalladamente de la valoración de las actividades de resistencia dentro de la iglesia protestante.

El entendimiento de la actuación de los grupos de mujeres protestantes va estrechamente unido a la reacción de las diferentes iglesias protestantes respecto al nacionalsocialismo. La interpretación de esta reacción de las asociaciones de mujeres ante el nacionalsocialismo ha dado lugar a interpretaciones de todo tipo a las que ya hemos aludido al comienzo de este trabajo. El apoyo incondicional de la mayoría ha sido interpretado por algunos autores como producto de la atracción „demoníaca“ que Hitler poseía. La consecuencia lógica de esta argumentación es que las mujeres eran más susceptibles de caer sobre el influjo hechizador de Hitler. Esta solución del problema es, a nuestro parecer, demasiado simplista. Como ya hemos aludido en otras ocasiones, el análisis de estas reacciones debe observarse no sólo desde una perspectiva de género. En el caso de las asociaciones confesionales de mujeres católicas y

\footnotetext{
482 Ibídem., p.459

483 Ibídem.' p.461

484 See, W. / Weckerling, R.: Frauen im Kirchenkampf. Beispiele aus der Bekennenden Kirche Berlin-Brandenburg 1933-1945, Berlín, Wichern-Verlag, 1984, p.31
} 
protestantes, juegan las peculiaridades de su confesión, características de la organización y la postura de sus respectivas iglesias un papel muy importante.

1933 no significa para las asociaciones de mujeres el final de sus actividades. A diferencia de las asociaciones laicas tienen la posibilidad de continuar con su trabajo bajo la dirección de sus respectivas iglesias. Sin ejercer resistencia comienza en 1933 el largo proceso de integración en las estructuras nacionalsocialistas. Este proceso sin embargo no transcurre armoniosamente. Podemos diferenciar cuatro etapas:

- 1933-1934. Etapa de reorganización del trabajo de las asociaciones de mujeres protestantes, caracterizada por la política de neutralidad.

- 1934-1935. Período de integración. Primeras limitaciones del trabajo de las asociaciones.

- 1936-1937. Conflicto y abandono de la iglesia de Müller. Participación en el Kirchenkampf

- 1937-1945. Etapa de continuidad de elevado sentimiento nacional, a causa de la entrada de Alemania en guerra.

$\mathrm{Al}$ igual que las dirigentes del movimiento moderado de la mujer, las mujeres protestantes esperaban del nuevo régimen una renovación y revolución de las costumbres en Alemania. Sin embargo la obligación de inscribirse en el partido a la que fueron sometidas las miembros de las organizaciones protestantes suscita las primeras críticas. Paula Müller-Ortfried, la anciana dirigente del Evangelischer Frauenbund, expone su negativa. No por ello deja de ser una ferviente admiradora de Hitler y de sus planes. ${ }^{485}$ Unos meses después abandona la redacción del EVANGELISCHE FRAUENZEITUNG y no vuelve a hacer ninguna declaración pública.

Un artículo aparecido en este periódico escrito por la joven jurista Elisabeth Schwarzhaupt pone el dedo en la llaga. Esta joven protestante de 31 años elabora tres tesis con las que intenta argumentar su rechazo al nazionalsocialismo desde su condición de creyente. En primer lugar critica la postura del régimen respecto a la política de población. Las mujeres, tiene según ella, tieferen Eimblick, un sentido más profundo, para entender los procesos de reproducción. Las mujeres no engendran a sus hijos como los animales, por lo tanto es para ella inaceptable el programa nazi de selección de la raza aria. Scwarzhaupt califica este ideal de materialista, porque entiende al individuo apartado de su condición humana y divina. La segunda tesis hace referencia a las ideas de Rosenberg sobre el amor al prójimo y sobre la humanidad, según herencia del pensamiento débil judío. La respuesta de Schwarzhaupt es tajante:

„Yo creo, que el amor, la humanidad, la aspiración a la satisfacción y la moral pertenecen a las características del ser femenino. (...) Además creo también que la mujer nace como la protectora del crecimiento, del progreso, de la vida, del ser vivo, de la humanidad y debe oponerse a la lucha brutal que la muerte y la oposición al progreso traen consigo."486

De nuevo aparece el viejo discurso sobre la naturaleza pacífica y armoniosa de la mujer, sobre su capacidad de amar, sobre su lucha contra la muerte. El mundo femenino aparece en este caso, asociado al mundo judío, algo que los nacionalsocialistas utilizaran para eliminar a ese tipo de mujer y elaborar un nuevo discurso sobre lo femenino de grandes rasgos antifeministas. Por otra parte esta actitud contribuye al relegar a las mujeres a su papel de sumisas musas que aceptan sin resistencias las decisiones masculinas. 
La tercera tesis pone en entredicho el principio de mando, Führerprinzip que es calificado como una opresión de la libertad individual. Esta opresión va contra los principios del movimiento de la mujer. Esta crítica va acompañada de un elogio del liberalismo como la mejor fórmula política y el rechazo de todo tipo de movimiento autoritario que coharte la libertad del individuo y de las mujeres.

\subsubsection{Reacciones de la Liga de mujeres católicas alemanas}

A diferencia del caso protestante, el milieu católico no sufre una crisis de identidad con la desaparición de la monarquía. Al contrario, Weimar significa para la población católica el comienzo de un protagonismo político desconocido hasta entonces. El sentimiento monárquico no desaparece del todo, no obstante, encontrándose en los círculos católicos declarados detractores del sistema republicano. ${ }^{487}$

Las relaciones del nacionalsocialismo con la iglesia católica se pueden diferenciar en varias etapas:

- 1930-1933. Esta época se caracteriza por el abierto rechazo desde el punto de vista religiosos por parte de los católicos.

- 1933-1937. Tras la desaparición del partido de centro, y las primeras medidas del nuevo régimen, continua una situación de espera.

- La firma del concordato en 1933 significa la garantía oficial para los católicos de la continuidad de sus actividades. Primeras declaraciones oficiales de apoyo al régimen.

- 1934-1938. Politica de control y de limitación de campos de actuación. Represión. Los primeros años de esta fase no se caracterizan por un ataque frontal contra el catolicismo alemán, sino que tiene lugar de una manera sucesiva y controlada: en un principio se critica de una manera subversiva el poder del vaticano y la influencia del papa sobre los católicos alemanes, se amenazan los intereses de éstos.

- 1938-1945. Al igual que el caso protestante se observa una concentración en la defensa del país.

La respuesta de la jerarquía eclesiástica a los ataques nacionalsocialistas tiene también sus etapas. En la época del concordato se práctica la política de defensa de los intereses de los católicos en el nuevo régimen. En esta época todavía se cree en la posibilidad de una autonomía de trabajo y en la capacidad de autoadministración. Esta postura no es única. Las asociaciones de mujeres no confesionales también creyeron en los primeros meses de 1933 en la posibilidad de mantener su independencia y sus ámbitos de trabajo. ${ }^{488}$

Sin embargo la firma del concordato vaticinaba una relación ambigua entre católicos y nacionalsocialistas. Las declaraciones del nuncio papal Pacelli a finales de año a la prensa británica reflejan el carácter de obligación con el concordato había sido aceptado:

„El gobierno alemán le había ofrecido concesiones, concesiones con las que, tiene que ser admitido, ningún otro gobierno hubiera estado de acuerdo, y él tuvo que elegir entre un acuerdo en sus propias filas o la virtual eliminación de la Iglesia

487 Denzler, G.; Fabricius, V.: op. cit., p. 25

488 Zimmermann-Buhr, B.: Die katholische Kirche und der Nationalsozialismus in den Jahren 1930-1933, Frankfurt am Main-New York, Campus, 1982, p.92 
Católica en el Reich. No sólo eso, sino que además le fue concedida no más de una semana para que tomara una decisión." 489

En esta tercera fase se pretende aislar a la iglesia católica de la sociedad. Los elementos de comunicación entre ambos desaparecen: la prensa católica, las organizaciones, las escuelas confesionales etc. ${ }^{490}$

La cuarta fase, 1936-1940, alcanza su punto más amplio entre 1936/7. En esta fase se intenta reducir a la Iglesia Católica a un mero instrumento de estado. Siguiendo el ejemplo protestante se nombra un obispo del Reich, Berning de Osnabrück con lo cual se quiere dar la impresión de tener a los católicos bajo control.

Sin embargo la crítica crece entre obispos católicos y la población contra las medidas de Gleichschaltung del gobierno, y sobre todo contra la ley de esterilización. El obispo de Fulda ejercía cada domingo en sus homilías duros ataques contra los nacionalsocialistas.

La situación se endurece cada vez más, cuando el papa publica la encíclica „Con ardiente preocupación“ el 14 de marzo de 1937, en la que expresa sus dudas sobre el régimen nacionalsocialista. La publicación de la encíclica fue prohibida, pero no evitarse que fuera leída en los púlpitos de las iglesias. Después se producen denunciaciones, encarcelamientos, procesos y finalmente traslados a los campos de concentración.

En esta fase se producen las primeras reflexiones sobre tácticas a seguir para hacer frente al ataque nacionalsocialista. Surgen dos líneas a seguir. Una de ellas está representado por el cardenal Bertram, el cual defiende una línea diplomática de negociaciones con el régimen. La otra línea, defendida por el obispo Graf Preysing, proclamaba la necesidad de una manifestación pública general que mostrara el descontento de los católicos alemanes. Esta postura fue desde un principio rechazada por el peligro que suponía.

La cuarta fase engloba el tiempo de la guerra. En esta época la rabia de los ataques contra la identidad religiosa y social de los católicos alcanza las cuotas más altas, que corre paralela a la radicalización de las medidas contra los judíos y disminuidos físicos. En esta época se radicalizan también las posturas de los católicos respecto al régimen. En la iglesias se discute sobre la supervivencia de la iglesia, se apoyan las posturas pacifistas de Pio XII, se condenan las medidas contra judíos y disminuidos físicos.

Dentro del espectro de asociaciones de mujeres católicas, tomamos como modelo de actuación la Federación de mujeres católicas alemanas, organización que se salvará de la política de disolución y que al igual que sus compañeras protestantes dedica gran parte de su esfuerzo a la publicación de su órgano de prensa, Die Christliche Frau. Durante los años 30 la Federación presta su apoyo a acciones a favor de la política de desarme. ${ }^{491}$

La Federación se había convertido en los últimos años de Weimar en una organización integrada fundamentalmente por madres y amas de casa. Los contactos con mujeres que ejercían una labor profesional se incrementan durante los años treinta. Para ello se organizan conferencias, seminarios y convivencias donde madres y amas de casa, entran en diálogo con juristas, médicos, maestras, vendedoras, educadoras y trabajadoras sociales. Contactos con mujeres trabajadoras no son conocidos. Objetivo de estos encuentros es luchar contra los prejuicios existentes contra las mujeres que ejercer una profesión:

489 Ibídem, p.467

490 Gotto, K. / Hockerts, H.G. / Repgen, K.: „Nationalsozialistische Herausforderung und kirchliche Antwort. Eine Bilanz“, en: Bracher, K.D. etc. (eds.): Nationalsozialistische Diktatur 1933-1945. Eine Bilanz, Bonn, Bundeszentrale für politische Bildung, 1986, p.657

491 Huch, A.: „Berufstätige und Hausfrauenin gemeinsamer Arbeit”, NACHRICHTENBLATT FÜR DIE ZWEIGVEREINE DES KATHOLISCHEN DEUTSCHEN FRAUENBUNDES, Enero 1932 (n²1), p. 4. 
„Junto a la amenaza de la seguridad exterior en la que está fundamentada la crisis económica actual y el desempleo, es necesario llamar la atención sobre la amenaza interior. Está opinión es apoyada en círculos de mujeres jóvenes que rechazan el trabajo femenino porque piensan que la especialidad del ser femenino no se puede desplegar e incluso piensan que ésta sufre daños irreversibles. " 492

Este apoyo al trabajo de la mujer, no se traduce en la crítica a la polémica en torno a ley que disponía la libertad del estado para despedir a las funcionarias casadas, siempre que se pudiera probar que el cónyuge ganaba lo suficiente, para mantener a la unidad familiar, con el trabajo de la mujer se consideraba como superfluo. La Federación apoya la petición del partido de centro. Dada la gran tasa de desempleo se argumentaba que era necesario hacer un reparto justo de los puestos de trabajo.

Los grupos de mujeres católicas requieren la atención de los nacionalsocialistas, no por el carácter „revolucionario“ de éstos sino por la influencia que los párrocos tenían supuestamente sobre las mujeres:

„Es una vieja táctica del clero católico influir a los hombres a través de sus esposas u otros parientes, con la intención de apartarlos del nacionalsocialismo.“ 493

Estas por el contrario se rebelan contra la „acaparamiento“ de funciones de las mujeres nacionalsocialistas, las cuales a través de las organizaciones del partido se hacen paulatinamente cargo de los campos de acción de los grupos confesionales. Desde el primer momento reprochan a las organizaciones de mujeres nacionalsocialistas su interferencia en el trabajo de las organizaciones confesionales y registran rápidamente el carácter de la organización:

„(...) pido que nos cuenten que han hecho hasta ahora las mujeres nacionalsocialistas como organización, en servicio de la patria, en el trabajo social, $\mathrm{o}$ en el ámbito de la caridad. Que me nombren nombres de mujeres nacionalsocialistas, como yo lo se nombrar de mujeres provenientes de los círculos católicos de nuestro trabajo social.“494

Este rechazo no se manifiesta únicamente contra las organizaciones de mujeres nacionalsocialistas. Con ocasión de las elecciones del treinta de noviembre de 1931 las mujeres católicas aprovechan para expresar su apoyo al partido de centro y su rechazo a la dictadura:

„Nosotros creemos que en el país se encuentran suficientes personas con buenas intenciones y de buen juicio que se oponen a la arbitrariedad y a la dictadura y que apoyan a los que ahora se aferran con fuerza al lado de la justicia, de la ley, el orden, la unidad y la libertad.“495

\footnotetext{
$492 \quad$ Ibídem, p. 4

493 BAZ, R 58 3577, 16. November 1936, Carta de las SS a la policía secreta de Turingia

494 Bayerisches Hauptstaatsarchiv, 1366, AugsBurger PosT, Siebert, K.: „Der 'antinationale Damenverein'. Zentrumsfrauen und Nationalsozialisten“, 2. Juli 1930 (n¹49)

495 Bayerisches Hauptstaatsarchiv, 1366, BAYRISCHER KURIER: „Aus der Wahlbewegung. Die katholischen Frauen und die Wahlen“, 5. August 1931 (n²17). La censura no viene únicamente de la Liga de mujeres católicas sino de numerosos grupos de mujeres católicas: mujeres funcionarias,
} 
Como derecho fundamental a defender se cita la traición a las enseñanzas cristianas y el apoyo a los valores del matrimonio, de la familia y la libertad religiosa.

Entre 1931 y 1933 las críticas se suceden y se toma partido por la mujer trabajadora y se descarta como „una solución demasiado fácil“ la idea de despedir a las mujeres de sus puestos de trabajo para luchar contra el desempleo. Se reivindica el desarme militar y por consiguiente se desvinculan de las posturas nacionalistas que tenían gran eco no sólo entre los círculos nacionalsocialistas. ${ }^{496}$

Con motivo de las elecciones para el Reichstag en julio de 1932 Helene Weber escribe un artículo en Die CHRISTLICHE FrAU donde describe brillantemente la situación política y el papel de las mujeres ante ésta:

„Y ahora estamos en los aledaños de una revolución: delante de las masas y de los grupos que desean un estado teñido de masculinidad, que en la economía y en política social rechazan las fuerzas de as mujeres como „negativas“ o „sentimentales“. De nuevo nos se pone e en duda el destino del pueblo, un destino pesado y amenazado por el desempleo. Se llama a las mujeres para que formen parte del frente político de los hombres, los cuales no desean la participación positiva y activa de las mujeres. “497

Weber describe la creciente resignación que se extienden en todas las capas de la sociedad. La decepción que algunas mujeres sienten respecto a los fines conseguidos por el movimiento de la mujer. La fascinación que las clases trabajadoras experimentan por el nuevo Reich con sus promesas de trabajo para todos. Ante la intranquilidad que todos los sectores de la sociedad experimentan, se presenta a la mujer como factor de armonía y reflexión y se rechaza todo tipo de revolución violenta. Respecto a las elecciones define como partes fundamentales de todo gobierno la protección estatal de los bienes cristianos: la libertad de la personalidad en el matrimonio, en la escuela, en la familia, destacando la responsabilidad colectiva y las costumbres morales como el sustento de ésta. Otro punto importante para las mujeres católicas es el sentimiento de Volksgemeinschaft.

„Esta gran decisión social no puede ser pasada por alto por el movimiento católico de la mujer: la decisión de la comunidad del pueblo. No somos ningún grupo académico, ni ninguna organización profesional, ni ninguna organización de mujeres, no somos madres ni mujeres trabajadoras. Somos toda un cuerpo y una sangre, una pulsación en la gran unidad social. Nosotras nos tendremos que decidir políticamente para que permanezca la unidad de la comunidad de pueblo, para que en ella se pongan en movimiento todos los objetivos, los deseos y las reivindicaciones. . ${ }^{498}$

Este sentimiento de colectividad popular aparece definido en un artículo en el mismo número por Gerta Krabbel, la dirigente de la Federación de mujeres católicas, KFB. Lo religioso, los valores del cristianismo y no la raza o el pueblo son presentados como lo genuino

comerciantes, empleadas; los colectivos de madres católicas, la organización de filólogas, los grupos de estudiantes, las trabajadoras sociales, y las organizaciones de mujeres vírgenes.

496 Bayerisches Hauptstaatsarchiv, 1366, GERMAnIA, 20. Oktober 1931 (nº422); Germania, 3. November $1932\left(\mathrm{n}^{\circ} 435\right)$

497 Weber, H.: „Gedanken zum Wahlkampf“, DiE CHristLiCHE FrAU, Julio 1932 (nº 7), p. 202 pp.202203

498 Ibídem, p.203 
de la patria alemana. Krabbel expresa su miedo ante la barbarie, ante la violencia de un nuevo futuro. Contra ello sólo se puede luchar si Alemania conserva su identidad como pueblo:

„La tarea de la mujer será dar tranquilidad, confianza y la profunda sabiduría a aquellos que han sufrido como valientes en Alemania durante 20 años en el desoído movimiento y en la pasión de estos días, y mantener vivar la alegre y valerosa esperanza en el futuro de aquellos que son jóvenes y saben que encuentran ante un nuevo paso adelante. Por encima de todo la mujer procurará evitar el odio de los luchadores a través del amor. Nuestro amor a Alemania a nuestro pueblo es la garantía de la construcción de nuestro futuro.“499

Sin embargo no es el nacionalsocialismo lo que se teme, sino el bolchevismo y el miedo de una era sin religión y Dios:

„Nosotras no queremos que la maravillosa herencia del espíritu alemán no se y creemos que ésta florecerá en el nuevo futuro en una forma diferente. Pero sabemos que la barbarie nos amenaza. Existen diferentes barbaries, pero todas conducen al mismo camino que amenaza al nuestro. La barbarie conduce al bolchevismo." 500

La crítica contra los partidos radicales de izquierda forma parte de del rechazo general de las mujeres católicas ante cualquier tipo de tendencia política que defendiera posturas radicales y que amenazara los principios cristianos. Esta tendencia aparece definida como „catolicismo conservador y realista “. Conservador por que se opone a cualquier tipo de revolución violenta y defiende el camino lento hacia la paz y realista por que se encuentra entre los extremos del internacionalismo y del nacionalismo:

„Las mujeres católicas alemanas dan muestra en esta hora decisiva de que ellas no se dejan influir por el radicalismo. El buen juicio, la inteligencia y la medida deben ser mantenidos. Ni la violencia o la dictadura, ni el terror en la calle o la guerra entre hermanos pueden salvar a Alemania sino la perseverancia firme y valerosa de sus hombres, mujeres y familias.“"501

Este apoyo a posturas de centro aparece de nuevo respecto a la política de desarme. Desde el punto de vista teórico las mujeres católicas consideran que todo católico debe apoyar las iniciativas dirigidas a mantener la paz en Europa. Los católicos alemanes apoyaría la política de desarme si Alemania no hubiera sido obligada a renunciar a una parte de su potencial militar. $\mathrm{Paz}$ a condición de que la política de desarmen se impliquen el resto de las naciones europeas. 502

Una de las obligaciones de las mujeres católicas es trabajar en la política de desarmen con mujeres de otros países y a través del internacionalismo mantener los valores nacionales de la patria:

499 Krabbel, G.: „Um Deutschland Schicksal“, Die ChristLiche FraU, Julio 1932 (nº 7), p.205

$500 \quad$ Ibídem, p.204

501 Bayerisches Hauptstaatsarchiv, 1366, AugSBURGER POST: „Es geht um Deutschlands Zukunft. Aufruf der katholischen Frauen“, 8. Juli 1932 (n¹54)

502 Schlüter-Hermkes, M.: „Katholische Gedanken zu Nationalismus und Krieg“, Die CHRISTLICHE FraU, Julio $1932\left(n^{\circ} 7\right)$, p. 207 
„La voluntad de paz de la mujer es conservadora y realista. Así es la mujer la representante nata de la idea católica de la paz. Conservador no son las que se llaman conservadoras y al mismo tiempo quieren llevar a su nación a la cúpula a través de poder y violencia, tampoco no son conservadoras las para las que lo bueno sólo se encuentra en el pasado, sino que realmente conservadoras son aquellas que quieren que las fuerzas vivas del pasado y del presente entren en el futuro como fuerzas vitales." 503

Fuente del compromiso de las mujeres católicas con la política de desarme es la maternidad. Fuente y creadora de vida, símbolo del deseo de paz:

„Todo lo que procede de la maternidad de la mujer es fuerte y valiente como una nueva vida y va más allá de la mera vida. Ya que la experiencia fundamental de la mujer es que vida y muerte se encuentran siempre muy unidas, y que ambas son deseo y voluntad de Dios. Esta veneración maternal hacia la vida que al mismo tiempo es también desasirse de la mera vida, da a la mujer valor, a pesar de todos los malentendidos y a pesar de la creciente poca popularidad de la que goza su identidad, y más decidida que nunca lucha en estos momentos tan peligrosos por la paz, por los acuerdos y medidas que se toman al respecto, contra el armamento material y espiritual.“504

Este balance entre nacionalismo e internacionalismo no se encuentra sin embargo en el tema relacionado con el Volkstum. Término que incluye únicamente a alemanes de religión católica y protestante pero no a la población judía. Símbolos de este Volkstum son las tradiciones y literatura germánica, canciones católicas y protestantes, el arte religioso alemán, etc.:

„Existe una espiritualidad religiosa alemana que se coloca entre la mentalidad católica supranacional. Este bien singular alemán de lo religiosos es el orgullo de nuestra iglesia, y por lo tanto de las fronteras donde existe vida alemana y en aquellos que hablan nuestro idioma y tienen nuestras costumbres. (...) ¿Quién se atreve a quitarnos nuestro orgullo? ¿Quién quiere reducir nuestro optimismo? Como alemanes y a través de nuestra escritura somos conducidos hacia Dios a través de los valores religiosos de otras razas y otros idiomas." 505

El bolschevismo como en el caso de los grupos de mujeres tratados con anterioridad se utiliza como el ejemplo por excelencia de la decadencia moral y espiritual de la época:

„Con el poder de la verdad demoniaca recorre su camino el bolchevismo no sólo en Rusia sino en casi todos los países de la tierra. Nosotras mujeres católicas nos quejamos con la más profunda indignación que justo en nuestra patria este surgiendo un punto de apoyo de esta impía corriente de individuos sin Dios.“ 506

\footnotetext{
503 Ibídem, p. 210

504 Ibídem, p. 210

505 Pater Grösser: „Religion und Volkstum“, Die Christiliche FraU, Agosto 1932 (n8), p.242

506 Bayerisches Hauptstaatsarchiv, 1366, KÖNISCHEN VOLKSZEITUNG, „Gegen den Bolschewismus“, 21. November 1931 ( $\left.\mathrm{n}^{\circ} 550\right)$
} 
En 1931 la liga se compromete a ejercer una campaña de propaganda contra el bolchevismo, calificado como „un poder demoníaco“ que atentaba contra la fe. ${ }^{507}$

En nuestro trabajo de archivo hemos podido documentar las reticencias iniciales que las organizaciones de mujeres católicas tuvieron durante los primeros años de la dictadura. La noticia de estas dificultades proviene fundamentalmente de las mujeres nacionalsocialistas que se encargan de „denunciar“ públicamente el „antinacionalismo“ de las organizaciones católicas. Estas habían demostrado repetidamente su apoyo a la democracia y al parlamentarismo:

„Nosotros creemos que hay suficiente buen sentido en nuestro país, para luchar contra la arbitrariedad y la dictadura y para apoyar a los que ahora quieren prolongar la unidad y la libertad de nuestro pueblo sobre el suelo de la justicia, la ley y el orden." 508

Al mismo tiempo renegaban de todo radicalismo ya fuera de izquierdas como de derechas. Esta falta de radicalidad explica también el silencio de los años posteriores, únicamente interrumpido por acciones de tipo personal.

En el caso de las mujeres existen dos hechos dignos de destacar. En primer lugar la defensa de los periódicos de mujeres católicas del Partido de Centro, Zentrumspartei, y otra el eco del despido de Gertrud Bäumer del Ministerio de Interior. El partido de centro había sido siempre „generoso“ con las mujeres. Aunque en 1919 se había manifestado en contra del derecho a voto femenino, incluyó después un gran número de mujeres en sus listas electorales. La orientación era conservadora, aunque a veces se daban casos en los que las diputadas votaban las mismas decisiones que las socialistas en temas como el derecho de la mujer al trabajo o las leyes para la protección del trabajo femenino. El electorado del partido se mantiene fiel incluso en 1933 cuando el resto de los partidos, liberales y nacionales, perdían una gran parte del electorado en beneficio de los nacionalsocialistas. Sin embargo después del nombramiento de Hitler como canciller, se produce una oleada de acciones dirigidas a disminuir el poder del partido de centro. 3.000 católicos son encarcelados, las oficinas de los periódicos de orientación católica son cerradas etc. A pesar de ello no se producen reacciones enérgicas por parte de los dirigentes del partido de centro. El mismo partido después de las elecciones de marzo dónde adquieren 5,5\% de votos, es la clave para la aprobación de la ley de poderes, Ermächtigungsgesetz, que permite a Hitler de poderes dictatoriales.

Las mujeres católicas, según Koonz, esperan la reacción de la jerarquía eclesiástica. A pesar de los intentos de Paula Siber de llegar a un acuerdo parecido al de las organizaciones de mujeres protestantes, las mujeres católicas guardan silencio. Esta misma autora aclara este silencio desde una postura de género. Mientras los hombres de las organizaciones católicas unen las creencias religiosas con el amor a la patria, las mujeres se rebelan contra la actitud anticatólica del partido y contra sus ataques contra las mujeres. Los hombres por el contrario no ven un obstáculo en la vuelta de las mujeres al hogar. ${ }^{509}$

En especial la expulsión de Bäumer causa una oleada de quejas y de cartas al gobierno donde se expone la pérdida de una persona tan capacitada y formada sobre los asuntos de la mujer.

La llegada de los nacionalsocialistas al poder en enero de 1933 trae consigo el cambio de tono en la Federación de mujeres católicas. En febrero de 1933, Antonie Hopmann

507 Bayerisches Hauptstaatsarchiv, 1366, KÖLNISCHE VOLKSZEITUNG: „Gegen den Bolschewismus“, 21. November 1931 ( $\left.\mathrm{n}^{\circ} 550\right)$

508 „Die katholischen Frauen und die Wahlen“, BAYRISCHER KURIER, 5.8.1931 (n²17), Colección Rehse, Documentos sobre organizaciones de mujeres católicas (Bayerisches Hauptstaatsarchiv, München)

509 Koonz, C: Mütter im Vaterland..., 1991, p.331 
vicepresidente de la Federación, son comentadas las medidas que el nuevo gobierno empieza a tomar para luchar contra el problema del desempleo. Destaca en el artículo la ausencia del patos que se encuentran por la misma época en DIE FRAU o en DIE EVANGELISCHE FRAUENZEITUNG. La apelación de Hitler es utilizada para resaltar la importancia del trabajo de las organizaciones de mujeres católicas en este campo y se da a conocer la fundación de un grupo de trabajo, integrado por las asociaciones católicas más importantes para luchar en conjunto contra el problema. 510

Junto al tema de desempleo, aparece en el número de mayo una valoración del nacionalsocialismo como la alternativa a la creciente expansión del bolchevismo:

„Con alegría saludamos la fuerte voluntad para la reconstrucción, la elevada valoración de la familia y de la alemanidad, la preocupación por la renovación y reforzamiento de nuestras costumbres, el esfuerzo por la unidad en el amor fiel a nuestra patria. Es algo grande lo que podemos establecer victoriosamente en contra del creciente bolchevismo y la propaganda contra el cristianismo. “511

Por otra parte se anuncia la necesidad de profundizar en el trabajo religioso de la organización, y la importancia del papel de la mujer en la reconstrucción de Alemania, que enlaza con la tradición germana y su especial relación con la esencia del cristianismo:

„Cada vez con más profundidad tenemos que entender la especialidad de nuestra naturaleza y de nuestro pueblo, la unidad de elementos germánicos de nuestro pasado y cristianos que se constituyeron con el tiempo en una forma alemana especial, (y tenemos que entender) la la eternidad de la llama y la singularidad de esta unión para la historia de nuestro pueblo.“512

Si nos atenemos a los artículos de la hoja informativa de la Federación, no podemos confirmar la valoración que Claudia Koonz hace de la actuación de las mujeres católicas. Koonz señala que las mujeres católicas se mantuvieron a la espera del concordato para mostrar su apoyo al régimen. Este apoyo comienza como en el caso de las mujeres protestantes, antes de la firma del concordato, durante los primeros meses de 1933. Creemos importante señalar esta diferencia de matices, ya que es común en la bibliografía sobre el movimiento confesional de la mujer a relatividad el apoyo del mileu católico al nacionalsocialismo. En el caso de la Federación de mujeres católicas, $K D F$, se observa el apoyo al nuevo régimen desde la instalación de este en el poder.

Tras la firma del concordato en julio de 1933, como el resto de las asociaciones confesionales, tiene lugar el reconocimiento oficial del nuevo régimen:

„Nosotras demostramos nuestra fuerza de voluntad y nuestra disposición a trabajar conjuntamente con el nuevo estado. No presenciamos de lado los acontecimientos sino que nos encontramos en el centro de éstos. Nosotras queremos influir con la fuerza de la fe de la mujer católica en todos los campos culturales de la vida con la implacable convicción de que nuestro trabajo es valioso para la construcción del pueblo. A través del concordato el estado ha legitimado el

\footnotetext{
510 Hopmann, A.: „Mitarbeit der katholischen Frauen am Notwerk für die deutsche Jugend”, NACHRiCHTENBLATT DES KATHOLISCHEN DEUTSCHEN FrAUENBUnDES, Febrero 1933 (n²), p.1

511 Krabbel, G.: „Der KDF in der Zeit”, NACHRICHTENBLATT FÜR DIE ZWEIGVEREINE DES KATHOLISCHEN DEUTSCHEN FRAUENBUNDES, Mayo 1933 (n5), p.1

512 Ibídem
} 
reconocimiento del trabajo de las organizaciones de mujeres católicas, y de nuestra Federación."'513

Junto al apoyo al nuevo régimen se expresa el interés de trabajar conjuntamente con las organizaciones de mujeres nacionalsocialistas, y aplauden la decisión de Krummacher, el dirigente de las organizaciones de mujeres, de levantar la resolución que prohibía la doble pertenencia a más de una organización.

Tras el reconocimiento del nuevo estado, el trabajo con los grupos de mujeres nacionalsocialistas es inevitable. A partir de noviembre de 1933, las organizaciones de mujeres católicas pasan a formar del Deutsches Franenwerk, bajo la dirección de Paula Siber.

„La composición de la obra femenina no esta todavía cerrada. Nosotras pensamos en un trabajo conjunto en forma de una comunidad de trabajo que deja campo de actuación a las organizaciones integradas en ella." 514

En el mismo número de diciembre la presidenta de la organización, Gerta Krabbel señala la importancia de las mujeres católicas en la construcción cristiana de la patria. ${ }^{515}$

La disolución de las organizaciones de mujeres liberal-conservadoras, la integración de los grupos confesionales en la estructura nacionalsocialista pone de manifiesto el conflicto generacional entre mujeres. Por una parte muestra como las mujeres jóvenes no cuadran en los esquemas organizativos de las organizaciones de mujeres y su interés por la organización supranacionalsocialista que eliminaba por una vez las barreras entre los géneros, y por otra parte vemos como las antigua guardia continúa con su discurso, en la esperanza de poder colaborar con el nuevo gobierno. Alice-Erika Bieber, una estudiante de biología señala en la figura de su hermano las expectativas de la joven generación:

„(Mi hermano) no quería ninguna explicación lógica, el quería creer, y la fe era para él gracia. No se puede discutir sobre cuestiones de fe, no obstante yo habría esperado de un cristiano practicante más tolerancia, parte fundamental del ,ama a tu prójimo“." "516

\subsection{Conclusiones}

Los últimos años de Weimar y los primeros meses de la dictadura nacionalsocialista se revelan para el movimiento de la mujer como una época de cambios intensos. En la dinámica de

513 „Zur Frage der Doppelmitgliedschaft in Vereinen”, NACHRICHTENBLATT FÜR DIE ZWEIGVEREINE Des Katholischen Deutschen Frauenbundes, Noviembre 1933 (n¹1), p.1

514 „Mitteilungen”, NACHRICHTENBLATT FÜR DIE ZWEIGVEREINE DES KATHOLISCHEN DEUTSCHEN FRAUENBUNDES, Diciembre 1933 (n¹2), p.1.

515 Krabbel, G.: "Mütterschulung", NACHrichtenblatT FÜR DIE ZWEIGVEREINE DES KatholiSCHEN DEUTSCHEN FRAUENBUNDES, Diciembre 1933 (n²12), p.44

516 Alice Erika Bieber: „Die Geschichte des Karl Bieber. Ein Fall schlimmster Rechtswillkür im NSStaat, Institut für Zeitsgechichte, Archiv, MS 540. Esta actitud se encuentra abundantemente documentada en una serie de diarios escritos por mujeres que se encuentran en el Institut für Zeitsgechichte. MS 583: Barbara Schütz-Sevin; Nacht über Heidelberg; MS 493: Luise Sebign 
las tres organizaciones de mujeres objeto de nuestro estudio: la organización laica del movimiento del movimiento, $B D F$, la Federación de mujeres protestantes, $D E F$ y su paralela católica, la KFB observamos dos modelos de actuación.

1. La organización laica y el KFB muestran en los últimos años de Weimar su rechazo al nacionalsocialsocialismo en repetidas ocasiones. Los argumentos que se utilizan son diferentes: la BDF utiliza el argumento feminista: el nacionalsocialismo amenaza los logros del movimiento de la mujer. En el caso de la organización católica se alude a la discrepancia de las enseñanzas cristianas y la ideología nacionalsocialista.

2. Un segundo modelo lo ofrecen la Federación de mijeres nacionalsocialistas, DEF, donde se observa durante toda la república de Weimar el rechazo de ésta, el distanciamiento de los principios del movimiento de la mujer, y el crecimiento dentro de la organización de tendencias nacionalistas y antisemitas.

3. Las críticas que se hacen al nacionalsocialismo están dirigidas a defender los propios intereses de la organización. Aparte de algunas excepciones en el BDF, no se tratan temas relacionados con el antisemitismo o la violencia nacionalsocialista, ni si quiera se defienden el sistema parlamentario.

1933 significa caminos diferentes para las organizaciones. Mientras que el KFB y el DEF, gracias a su carácter confesional se libra del proceso de autodisolución, la BDF es víctima del proceso de disolución de organizaciones que no quieren integrarse en las estructuras nacionalsocialistas. El proceso de disolución no ocurrió de forma dramática. La rápida y limpia reorganización de la población femenina en una organización nacional se hizo a costa de las organizaciones de mujeres existentes durante la República de Weimar. La crítica por parte del ala moderada de la mujer se refiere fundamentalmente a la actitud negativa del nuevo régimen respecto a la participación de la mujer en la vida pública. Respecto al sistema, parlamentario, monárquico, o dictatorial no se dan propuestas. Las llamadas durante las elecciones a votar a partidos que defendieran la participación de la mujer en la vida política no significa una defensa de los principios democráticos de Weimar, sino una defensa de los intereses de grupo. Por otra parte la decisión de disolución es tomada por las dirigentes de las organizaciones y después tratada, en algunos casos impuesta, en la asamblea general a los miembros de la organización.

En el caso del $A D F$, estrechamente unida al $B D F$ la disolución es llevada a cabo el consejo ejecutivo de la organización. Sin embargo la resolución no fue aceptada por todas los grupos locales. El grupo de Berlín por ejemplo se resistió durante algún tiempo a aceptar la disolución. La disolución definitiva de la organización llega el 24 de septiembre.

Claro está que existen excepciones en el movimiento moderado que llaman a defender los principios democráticos.

En el grupo de las mujeres del feminismo conservador son las reacciones diferentes. Mientras que Gertrud Bäumer es partidaria de la disolución porque piensa que con la llegada del nacionalsocialismo el trabajo del movimiento de la mujer tiene que organizarse de forma diferente: como por ejemplo la continuación con la publicación de Die Frau, el órgano portavoz de la organización. Otras dirigentes se deciden claramente por la otra alternativa: como por ejemplo Marie Baum o Elisabeth Lüders que por sus actividades de protección de amigos judíos, son encarceladas por la Gestapo. ${ }^{517}$ Aunque no por ello dejan de publicar en Die Frau. Durante 1933 y 1940, Baum publica diez artículos en la revista. Los temas son fundamentalmente de tipo biográfico o literario donde analiza fundamentalmente las figuras de Ricarda Huch y Ernst Jünger. En el caso de Elisabeth Lüders que se distancia claramente de la actitud de Gertrud Bäumer encontramos seis artículos publicados entre los años 1933 y 1937. En su biografía dedica un capítulo especial a su ruptura con Gertrud Bäumer. Lüders se queja, tras 1945, de la aparición de artículos en Die Frau donde mujeres como Scholtz-Klink, Alice Rilke y otras mujeres cercanas al partido podían expresar sus ideas, aunque ella continúa

517 Baum, Marie: Rückblick auf Mein Leben, Heidelberg, Kerle Verlag, 1950, p.285 
utilizando la revista como medio para seguir expresándose. La publicación de notas de prensa del gobierno nazi, e incluso artículos de periódico como el Schwarzen Corps muy cercano al régimen, hace presumir, si nos atenemos a la información de Lüders a una colaboración de la revista con el nuevo régimen. Una de las explicaciones que Lüders da al comportamiento de Bäumer es la esperanza de ésta de que el nuevo movimiento trajera la tan deseada „gran Alemania“. Lüders analiza esta predisposición al nacionalsocialismo como paralela al antisemitismo y se encontraba representada en un ala del partido demócrata alemán al que ésta también pertenecía. Bäumer y un compañero de partido, Lemmers demostraban, desde un principio, su entusiasmo por los Jungdeutschen Orden conocida por sus tendencias antisemitas que consiguen unirse al DDP con apoyo de Bäumer y Lemmers. Este incremento de tendencias nacionales dentro del DDP culmina con la remodelación del partido en el Staatspartei, partido estatal, en el que los principios democráticos pasaron a un segundo plano. Esta actitud de primer apoyo al nacionalsocialismo se encuentra también en miembros reconocidos del DDP, como Koch-Weser, Höpker-Aschoff, Ehrlermann y Dietrich. 518

El resto de las dirigentes del movimiento de la mujer utilizan DIE FRAU, como foro de expresión. Por ejemplo Dorothee von Velsen, sobre la que hemos descrito su polémica con Bäumer publica también diez artículos en DIE FRAU en los años 1933-1941 y participa regularmente en las reuniones de la redacción.

Else Ulich-Beil publica catorce artículos entre los años 1933-1943. Mantiene una relación amistosa con Gertrud Bäumer durante toda la guerra. A la muerte de su hijo, soldado en el frente, Bäumer se encarga de hacer la oración fúnebre. ${ }^{519}$

Podemos aventurar que Bäumer y con ella un gran número de sus colaboradoras ven con la llegada del nacionalsocialismo la posibilidad de realización de la idea nacional de Friedrich Naumann y la superación de la lucha de clases. La disolución del movimiento laico de la mujer se presenta desde otra perspectiva. No aparece como acto de resistencia, sino como el tributo necesario que las mujeres tienen que pagar para el desarrollo de nuevas „formas orgánicas” de gobierno y de intervención política.

En el caso del movimiento confesional de la mujer se observa dos modelos de actuación: mientras que la organización protestante crece a la sombra de una tradición nacionalista y profundamente conservadora, la Federación de mujeres católicas apoya los principios democráticos desde una interpretación de la función de la mujer en la sociedad que no responde a los principios del movimiento de la mujer. Sin embargo en ambos casos la llegada del nacionalsocialismo es recibida positivamente. Siendo el apoyo de las mujeres protestantes quizá más enérgico que el de sus compañeras católicas.

El análisis de la prensa de las tres organizaciones en el capítulo a continuación, nos servirá para adentrarnos en la dinámica de los procesos de adaptación y percepción de la realidad nacionalsocialista que los tres grupos de mujeres elaboran durante los años de la dictadura.

518 Lüders, Marie-Elisabeth: Fürchte dich nicht. Persönliches und Politisches aus mehr als 80 Jahren. 1878-1962, Köln-Opladen, Westdeutscher Verlag, 1963, pp. 140-143

519 Ulich-Beil, Else: Ich ging mein Weg. Lebenserinnerungen, Berlín, Herbig, 1961, p. 144 
SEgunda PARTE

El discurso femenino en la prensa de las organizaciones de mujeres confesionales no integradas en la estructura nacionalsocialista 


\section{Antifeminismo, mujeres y lenguaje durante el fascismo alemán. Análisis de los modelos de feminidad propuestos por el nacionalsocialismo}

Una de las características de las sociedades democráticas es la existencia de una prensa libre e independiente, donde los mensajes emitidos se caracterizan, en primer lugar por su variedad y, en segundo lugar, por su disposición a ser criticados. El proceso comunicativo no se somete „teóricamente“ a ningún control, ni la variedad de discursos esta monopolizada por el estado. Los discursos se critican, se analizan y se racionalizan. Esto no significa que no existan procesos de manipulación o de control de la opinión pública.

$\mathrm{El}$ proceso de comunicación en movimientos fascistas y totalitarios funciona con medios distintos. Lenguaje e ideología sirven a éstos como domesticación de la conciencia política. La propaganda se convierte en la forma ideológica de la práctica política. ${ }^{520}$ El proceso de comunicación se controla en todo tipo de medio de expresión pública, y (muy relevante para nuestro trabajo) se elabora lentamente, un tipo de lenguaje que paulatinamente se convierte en el espejo reflector de la realidad. Esta creación de un nuevo lenguaje que define la realidad se revela como la práctica de propaganda más importante del nacionalsocialismo. Siguiendo el moto „las cosas existen porque se las nombra“, activa el nacionalsocialismo una uniformación y control de la vida pública, por un lado y de todos los procesos vitales e íntimos, por otro. El lenguaje es entendido en esta época, según Sigrid Frind, como un soziales objektives Gebilde, capaz de transformar la realidad. ${ }^{521}$ Como comentaba Umberto Eco en la New Yorker Columbia University el nacismo retoma una de las trece características nombradas por él para definir el fenómeno del Urfaschismus. Se trata del Nenspeak, que se trataría de la instrumentalización del lenguaje y la simplificación de éste para eliminar el proceso crítico y complejo del pensamiento. 522

Uno de los grupos que más sufrieron ante esta „tiranía“ del lenguaje es el de las mujeres. La literatura existente sobre temas femeninos durante la época es innumerable. Lo femenino se define, se tipifica, se „racionaliza“ y se controla. Y poco a poco surge un lenguaje, que se transforma en un discurso dirigido a las mujeres, que intentará „tomar cuerpo" no solamente sobre el papel, sino en las actitudes de éstas.

Esta creación de nuevos valores sobre lo femenino no tiene lugar de una manera accidental o irracional. Durante el nacionalsocialismo se planea la feminidad, se elabora estratégicamente, se juega con ella, se investiga y se experimenta. En nuestra comunicación pretendemos analizar los métodos propagandísticos que utiliza el fascismo alemán a la hora de transmitir el mensaje sobre lo femenino. Nuestro objetivo es hacer hincapié en la utilización del leguaje sobre la mujer, tanto en el discurso como en la prensa escrita, y resaltar su importancia en la determinación de las actitudes sociales de las mujeres.

$520 \quad$ Haug, W.F.: Die Faschierung des bürgerlichen Subjekts. Die Ideologie der gesunden Normalität und die Ausrottungspolitiken im deutschen Faschismus, Berlin, Argument, 1985

$521 \quad$ Frind, S.: Die Sprache als Propagandainstrument in der Publizistik des Dritten Reiches, untersucht an Hitlers „Mein Kampf“ und den Kriegsjabrgängen des „V̈̈lkischen Beobachter", Ernst Reuter Gesellschaft, Berlin, 1964, p.16

${ }_{522}$ Eco, U.: „Urfaschismus”, DIE ZEIT, 7.7 .1995 (nº28), p.48 
„(...) El nazismo penetra en la carne y la sangre de la masa, a través de las palabras, los refranes, las perífrasis verbales. (...) Las palabras pueden ser como diminutas píldoras de arsénico, que uno traga sin darse cuenta, al principio parecer que no surgen efecto, pero después de un tiempo el veneno aparece de forma irreversible." 523

Entre los muchos trabajos existentes sobre el lenguaje en el nacionalsocialismo, pueden advertirse dos tendencias investigadoras que defienden posiciones diferentes. Un gran número de autores defienden la absoluteidad del lenguaje en el fascismo alemán y niegan la inexistencia de discursos diferentes, o discursos que difieran de éste. ${ }^{524}$ Unos defienden la uniformidad del discurso, otros, siguiendo las teorías de Foucault, señalan la contradicción del éste, y por tanto la aparición de lagunas y huecos para discursos diferentes. No obstante, todos los investigadores coinciden en la existencia de rasgos indiscutibles y específicos del lenguaje nacionalsocialista.

La dictadura existía en función del principio del mandato, de la orden (Befebl). Mandato en lugar de discusión. El mandato sustituye a la actuación política y elimina la decisión o la conciencia del oyente. Este estilo se conoce entre los lingüísticas cómo phático: „Todo en ella (en la dictadura, B.P.P.) era discurso, apelación, expresión oral, flagelación. “525 El proceso comunicativo depende de la „apelación“ y el oyente se ve relevado de su función como emisor.

Se trata de un discurso dirigido a la masa. El oyente no existe dentro del proceso de comunicación. Por eso su lugar se encuentra preferente en las plazas, teatros, coliseos, o en la radio o el cine. El discurso se celebra. En grandes congregaciones de personas, desfiles, discursos etc., la palabra puede inspirar un magnetismo de grandes dimensiones sobre todo cuando el consenso de la masa se organiza artificialmente. El efecto psicológico tiene consecuencias de gran importancia para entender como funciona el proceso de socialización del nacionalsocialismo. ${ }^{526}$ En el lenguaje escrito, en la presa o en la literatura que se publica durante este periodo, se traduce esta Phaatisierung en la abundancia de interjecciones apelativas, puntos, comas, reproduciendo en muchas ocasiones el lenguaje oral. Los textos se escriben de manera asociativa, como discursos, la lógica no es importante. En ellos se cultiva el estilo nominal; en

523 Klemperer, V.: LTI. Lingua Tertii Imperii. Die Sprache des Dritten Reiches, Frankfurt am Main, Röderber, 1982, p.21

524 Sería muy largo exponer esta polémica en toda su extensión. No obstante es recomendable la lectura de los trabajos de Gerhard Bauer: Sprache und Sprachlosigkeit im „Dritten Reich“, Köln, Bund Verlag, 1988; Mass, U.: „Als der Geist der Gemeinschaft eine Sprache fand“. Sprache im Nationalsozialismus. Versuch einer historischen Argumentationsanalyse, Opladen, Westdeutscher Verlag, 1984; Klemperer, V.: op.cit.

525 Klemperer, V.: op.cit., p.28

526 Frind, S.: op.cit., p.2 
vez de utilizar adjetivos o describir, se utilizan composiciones nominales de gran fuerza sentimental: Volksgemeinschaft, Volksseele, Volksnähe, Volkskörper, Volkskrankheit, Volkszersetzung (comunidad del pueblo, alma popular, calor popular, cuerpo popular, enfermedad del pueblo, sustitución del pueblo). ${ }^{527}$

Otro segundo aspecto tiene que ver con una „dimensión proposicional“‘528 que aprehende el lenguaje durante el nacionalsocialismo como conjunto de expresión colectiva, con la consiguiente reducción de la realidad a una entidad lingüística simplificada donde todo tiene su lugar.

El lenguaje se convierte en una forma colectiva de expresión donde confluyen miedos, temores y sueños de grandeza. Este se transforma en conciencia colectiva, en yo popular que expresa el y el anhelo de una nueva época que superara el „síndrome apocalíptico“ de los alemanes:

„El Apocalipsis aparece en situaciones de crisis, es producido por individuos que se siente amenazados y humillados, oprimidos y perseguidos en la totalidad de su existencia: espiritual, política y socialmente, con razón o sin ella. Ellos interpretan sus experiencias vitales de tal manera que el mundo en el que viven aparece sin sentido, corrompido y perverso. Sueña con la salvación, pero piensan que ésta sólo se puede conseguir si el viejo y corrompido mundo desaparece y el „enemigo“, culpable del ocaso del viejo mundo, es destruido.” 529

El discurso pierde su relación con la realidad, y se organiza binariamente: se distingue entre bien-mal, verdadero y falso. La palabra Untergang (ocaso) nos habla de un mundo oscuro, situado en las tinieblas, lleno de enfermedades como: úlceras, peste, tuberculosis, enfermedades venéreas que contaminan y envenenan al pueblo alemán:

„Allí dominan el egoísmo, el odio, la pasión, la rabia, la indignación, el fanatismo, la impaciencia, la lucha (...).“ 530

La sífilis es presentada como el mal horrendo por excelencia, y la prostituta judía la causante de la contaminación de la sangre aria. La asociación mujer, sangre, enfermedad es casi automática.

La introducción de Feindbilder, es la consecuencia lógica de esta dualización de la realidad. El pueblo judío aparece como el objeto de los ataques de los nacionalsocialistas. Éste se convierte en el rasgo decisivo para determinar lo que no es „normal“, „humano“ y „alemán“. La mujer es, de nuevo, la que determina esa pertenencia. La que decide sobre la pureza de la raza alemana.

Este dualismo se refleja también en el desprecio del pensamiento, de la intelectualidad. Denken (pensar) aparece opuesto a Sehen (ver). El que piensa quiere ser convencido, quien piensa sistemáticamente es doblemente difícil de convencer:

\footnotetext{
$527 \quad$ Ibídem, p.102

528 Ehlich, K.: Sprache im Faschismus, Frankfurt am Main, Suhrkamp, 1989, p. 21

529 Vondung, Klaus: „Angts vor dem Untergang und Sehnsucht nach Erlösung-ein deutsches Syndrom?, en Bohleber, W.; Drews, J. (eds.): Gift, das du unbewußßt eintrinkst... Der Nationalsozialismus und die deutsche Sprache, Bielefeld, Aistheis Verlag, 1991, p. 101

530 Winckler, L.: Studie zur gesellschaftlichen Funktion faschistischer Sprache, Frankfurt am Main, Suhrkamp, 1971, p.29
} 
„La retórica nazi (...) encuentra en la palabra Weltanschauung, la visión del místico, la contemplación del ojo interno, así como la intuición y la revelación del éxtasis religioso. “531

Curiosamente estas capacidades de ver más allá, de intuir, de sentir son adjudicadas, como veremos más adelante, al hombre.

En último lugar se produce una simplificación del lenguaje. El objetivo de ésta es la efectividad ligada a la militarización del lenguaje, o mejor dicho a la masculinización de éste. Palabras que con anterioridad pertenecían al lenguaje del romanticismo alemán, o incluso al ámbito de los movimientos de mujeres, se masculinizan y se comienzan a utilizar en el lenguaje militar.

„La palabra Aktion y Sturm emigraron en los años veinte de los cafés femeninos a las cervecerías y garitos masculinos. Acción empezó a relacionarse con recuerdos de los héroes del pasado, con la imagen del guerrero, del luchador. Sturm se unió al grupo de palabras propias del lenguaje militar." $" 532$

La idea de la „lucha“ se va afianzando en la ideología nacionalsocialista como pilar fundamental de ésta. Esta idea determinaba las categorías, los modos de pensamiento, los sistemas de valores y la terminología del primer movimiento y posteriormente el lenguaje del nacionalsocialismo. ${ }^{533}$

¿Existía la posibilidad de evitar el „virus“ que había infectado a la totalidad de la vida alemana? Esta posibilidad se encuentra en el círculo de la vida privada, donde se desarrolla una Gemeinschaft individual en oposición a la comunidad popular prescrita por el estado.

\subsection{Propaganda y la prensa nacionalsocialista para mujeres}

La transmisión del discurso nacionalsocialista se realiza a través de medios propagandísticos. Los medios de propaganda, especialmente en la prensa, se convierten en un instrumento para controlar y dirigir los deseos de la masa. Los métodos son conocidos: ignorancia de acontecimientos internacionales, incidencia en temas como el bolschevismo, el judaísmo, la plutocracia, antisemitismo etc. A través de la propaganda se pretende primero, conseguir adeptos para la organización, y segundo, la destrucción de los anteriores códigos de interpretación de la realidad. Un nuevo código, una nueva simbología, son el objetivo.

El aparato de propaganda del Tercer Reich estaba controlado por el Ministerium für Volksaufklärung und Propaganda. Dentro de éste, el departamento n ${ }^{\circ} 4$ o el también llamado Referat für Kultur und Zeitschriftenpresse se encargaba de diseñar la política que debían llevar las publicaciones alemanas. Este departamento actuaba a instancias de la Reichspressekammer (Cámara de prensa) donde todos los redactores/as de periódicos y revistas alemanas debían registrarse. El ingreso a la cámara tenía únicamente lugar si el interesado o la interesada cumplía con los requisitos establecidos por la cámara. Estos eran ser ario, tener un pasado político aceptable, aceptar los principios nacionalsocialistas y estar dispuesto a defenderlos.

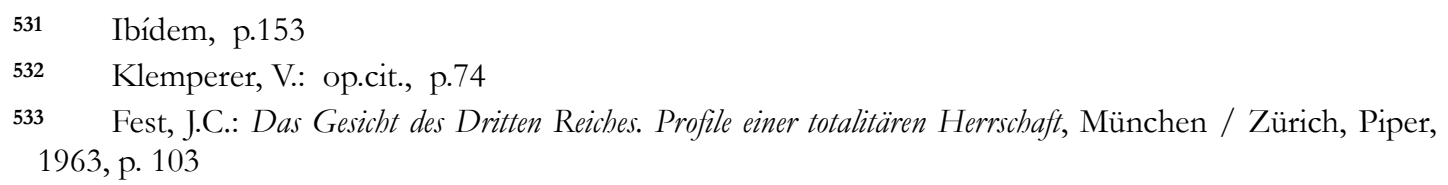




\section{Organización del sistema de control del Ministerio de Propaganda}

Esto mismo valía para los periódicos y revistas sobre mujeres. Éstas se habían especializado en varios temas: hogar, familia, moda, trabajos manuales, sociedad o ideología nacionalsocialista. Cuatro editoriales controlaban el mercado de la prensa para mujeres: Beyer, Ullstein, Vobach y la editorial del partido NS-Framenwarteverlag. ${ }^{534}$

El departamento $\mathrm{n}^{\circ} 4$ de la Reichspressekammer publicaba semanalmente un servicio de prensa para la mujer, que aparecía en todas las revistas nacionalsocialistas, y que recibían el resto de las demás publicaciones para mujeres. Esta colaboración se volverá más estrecha durante la guerra. Es en este momento cuando toda la prensa para mujeres fue movilizada al servicio de la propaganda.

La revista más representativa y de mayor difusión era la NS-FRAUENWARTE, aparece a partir del verano de 1932 dependiente del partido. Se define como la representante del único movimiento de la mujer. Su éxito fue muy rápido: de 289.092 ejemplares en 1934 ascendió a 1.461.357 en la segunda mitad de 1939, superando a todas las demás publicaciones del mercado. 535 Otro de los periódicos utilizados por la propaganda nacionalsocialista para expandir sus ideales sobre la mujer, era el VÖLKISCHER BEOBACHTER; órgano del partido desde 1920 hasta 1945 llegaba en 1944 a 1,7 millones de personas.536 En éste se publica una hoja para „la mujer alemana“".

Los objetivos de la prensa para mujeres eran, según Lott, distraer a las mujeres de la política. La palabra clave que se emplea para definir el control sobre la prensa para mujeres era die Franen fesseln (atar a las mujeres). El público femenino era considerado como „más conservador“,

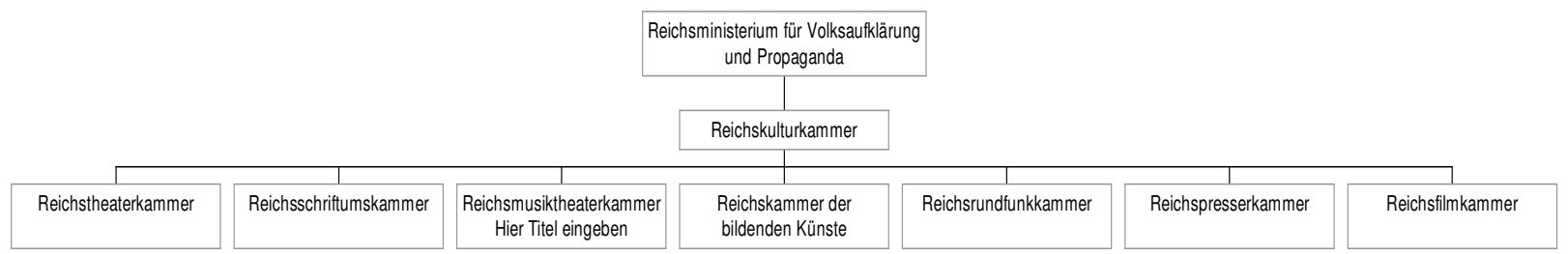

interesado en novelas y folletones más que en asuntos políticos, de ahí la inexistencia de temas políticos o económicos; por el contrario se centra la atención en motivos místicos, trabajo, propaganda antisemita y cuentos germánicos. Entre 1936 y 1937 abunda la presencia de temas históricos. Esta predilección por temas de la historia ha sido interpretada por algunos autores como señal de resistencia o „emigración pasiva““. 537

Entre estos temas se aludía siempre a la responsabilidad de la mujer en la vida de la nación. Esto afectaba incluso a las recetas de cocina donde se instaba a las mujeres a ser ahorrativas, ya que de su trabajo dependía el futuro de su patria. Esto mismo se puede aplicar al tema de la maternidad. Se ha hablado muchas veces de la importancia que el nacionalsocialismo centraba en la madre de familia. Sin embargo más que referirse a la mujer como madre, lo que se idealizaba era la función reproductora, vista como el único y legítimo atributo femenino. La

\footnotetext{
534 Lott, S.: Die Franenzeitschriften von Hans Hultrly und John Jahr. Zur Geschichte der deutschen Frauenzeitschriften zwischen 1933 und 1970, Berlin, Volker Spiess, 1985, p.186

535 Ibídem, p.171

536 Burghardt, C.: Die deutsche Frau: Küchenmagd, Zuchtsau, Leibeigene im III. Reich. Geschichte oder Gegenwart?, Münster, Verlag Frauenpolitik, 1978, p.7

537 Lethmair, T.: Die Frauenbeilage der „Frankfurter Zeitung“. Ihre Struktur - ihre geistigen Grundlagen, München, Dissertation, 1957
} 
maternidad era un servicio obligado al colectivo del pueblo. Servicio y sacrificio que todas las mujeres debían hacer.

\subsection{Modelos de feminidad y la ideología nacionalsocialista}

Existe una „anécdota“ sobre Ley, jefe del $D A F$ cambiar recogida por Peter Bleuel en la que se narra un suceso ocurrido en una cena organizada por la mujer de éste. A ésta estaban invitados un gran número de hombres. Después de la cena y con algunas copas en el estómago se hacen chistes se bromean, en un momento inesperado Ley toma a su mujer del brazo y le arranca el vestido, dejándola desnuda a la vista de todos los presentes. ${ }^{538}$

Este „acto simbólico“ revela de una manera plástica la actitud de las grandes cabezas del nacionalsocialismo hacia las mujeres. En los estudios sobre feminismo y fascismo alemán salta a veces la pregunta sobre los rasgos originales de los movimientos totalitarios y autoritarios hacia las mujeres. Autores y autoras se preguntan sobre la influencia de otro tipo de discursos sobre lo femenino: el discurso religioso, el filosófico, etc. Es cierto que el nuevo tipo femenino no se construye a partir de un ideario sobre la mujer, sino sobre imágenes ya existentes, tradicionales y conservadoras sobre ésta. En este sentido los nacionalsocialistas utilizaron en su propaganda la predisposición existente en las estructuras cognitivas de los oyentes, fenómeno conocido como "cognitive dissonance“. 539 A este respecto es necesario aclarar ciertos matices en relación con el fascismo alemán, ya que si bien en su ideología sobre la mujer existen elementos anteriores, éste movimiento revela una interpretación muy particular sobre lo femenino.

La realidad femenina se institucionaliza, el estado determina cuáles son sus valores, funciones y atributos en la sociedad. En su discurso del 8 de Septiembre de 1934 ante las mujeres nacionalsocialistas, tenido lugar en Nürnberg, Hitler establece claras líneas entre hombres y mujeres:

„(...) el mundo del hombre es el Estado, el mundo del hombre es la lucha, la capacidad de estar siempre al servicio de lo colectivo, así se podría decir que el mundo de la mujer es más pequeño que el del hombre. Por eso su mundo es su marido, su familia, sus hijos, su hogar." ${ }^{\text {"540 }}$

La programación ideológica de la diferencia entre los géneros tiene en la obra de Rosenberg, Der Mythus des 20. Jahrbunderts ${ }^{541}$ su mejor exponente.

A partir de 1934 será la prensa para mujeres, controlada por el aparato nacionalsocialista la que presente a las mujeres, modelos de feminidad y de conducta: ${ }^{542}$
Mujer
Hombre

538 Bleuel, H.P.: Das saubere Reich. Theorie und Praxis des sittlichen Lebens im Dritten Reich. Ein bisher ungeschriebenes Kapitel deutscher Vergangenheit, Bern / München / Wien, Scherz, 1972, p.55

539 Festinger, L.: A Theory of Cognitive Dissonance, Evanstown, 1957

540 Domarus, H. (ed.): Hitler. Reden und Proklamationen 1932-1945 (Vol.1), Würzburg, 1962, p.450

541 Rosenberg, A.: Der Mythus des 20. Jahrbunderts. Eine Wertung der seelisch-geistigen Gestaltenkämpfe unserer Zeit, München, Hoheneichen Verlag, 1933

542 Este grupo de asociaciones aparece en NS-FRAUENWARTE en los años anteriores a la guerra. 


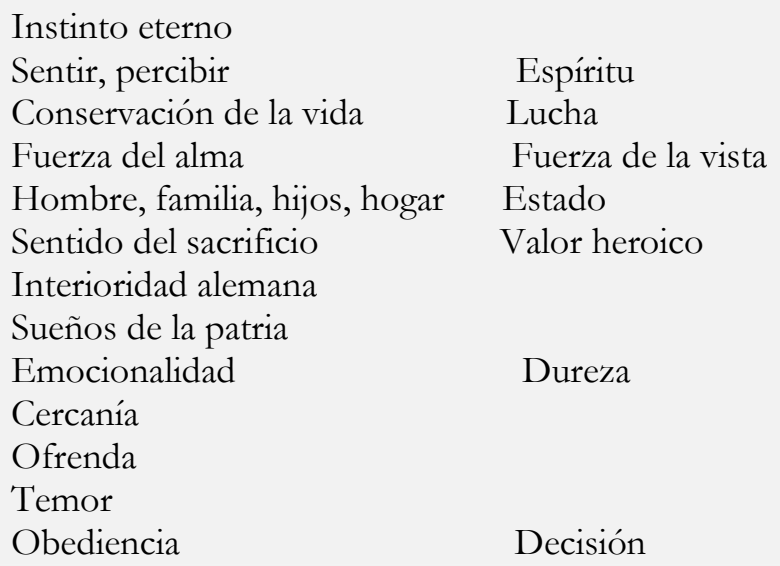

Los campos de acción de los géneros se encuentran separados. El lenguaje es binario. Dos mundos, dos realidades, y en ellos sólo un género tiene la propiedad de ,ver“; el hombre recibe la Kraft des Sehens, la capacidad de „entender“, de „intuir“". La mujer recibe la propiedad de lo desconocido, de lo que no tiene nombre: die Kraft der Seele.

De este campo semántico se revela una imagen de la mujer que se caracteriza por su sumisión, por su incapacidad de tomar decisión. Su naturaleza la coloca no a la altura de los niños, o de los ciudadanos de segunda clase, sino a la de los animales.

La mujer tiene que ser kräftig (fuerte), schön (bella) y fruchtbar (fértil). No es pecadora, no es débil, no encarna tampoco lo infernal a través de sus dotes seductoras. Su función radica en garantizar la procreación de la raza aria. La mujer no tiene sexualidad, si entendemos sexualidad como gozo, placer o incluso amor, no es amante. La prostitución no se prohibe por razones morales, sino por el miedo a la contaminación, el miedo a la sífilis, al mundo de lo oscuro, de las tinieblas. El acto sexual es entendido desde el punto de vista de la reproducción. En este lenguaje binario lo masculino se manifiesta como el motor que dirige la vida de la mujer. Lo masculino determina en su oposición lo que es femenino. El hombre representa todo lo que no es la mujer. En función de esta diferencia fundamental entre los mundos femenino-masculino se desarrolla una relación de poder, en la que el hombre ejerce una función de educador, de guía, una especie de Pigmalión:

„No hay nada más hermoso que educar a una cosa joven. Una chica de dieciocho o veinte años es manejable como la cera. Un hombre debe de ser capaz de dejar su huella en cada mujer joven. Ésta no quiere otra cosa." 543

Cualquier hombre es capaz de dejar su „marca, su sello“ sobre una mujer joven. El sello indica posesión, como un animal, se encuentra ésta a la disposición absoluta del hombre. Sin embargo los nacionalsocialistas se cuidan de hacer una referencia directa a la inferioridad de la mujer. Ésta, según ellos se encuentra en el mismo nivel que el hombre. Ella es su camarada y compañera en la vida. ${ }^{544}$ 
Esta sexualización de la sociedad afecta no solamente a las relaciones de poder entre hombre y mujer sino entre padres-hijos, adultos-jóvenes, educadores-alumnos, dirigentes-dirigidos, sacerdotes-creyentes, dirigente-masa.

Gertrud Scholtz-Klink 545 define en uno de los anuarios de la NS-Frauenschaftlas las principales funciones y obligaciones de la mujer alemana en la nueva Alemania:

1. El estado necesita mujeres que garanticen la conservación de la raza y participen en el proceso de socialización de la nueva generación.

2. Rechazo de las reinvindicaciones de igualdad. Los intereses de la Volksgemeinschaft están por encima de todo deseo personal. El yo individual es sustituido por la eternidad del pueblo.

3. El matrimonio y la maternidad constituyen la realización de la mujer por excelencia.

4. La maternidad significa: renuncia (entsagen), sacrificio (opfern), disponibilidady atención (wach und immer bereit sein).

5. La madre es la trabajora más importante del pueblo.

La parte más interesante de este capítulo es analizar las consecuencias del mensaje nacionalsocialista sobre las mujeres, y la evolución del proceso de socialización. Durante los primeros años del nacionalsocialismo, las mujeres no fueron precisamente inmunes a la ideología nacionalsocialista. La República de Weimar había cuestionado de manera radical el papel de la mujer en la sociedad. Un duro schock para muchas. Con este movimiento llegaba de nuevo una época de seguridad. Las cosas estaban claras.

Sin embargo, la aceptación de la imagen del nacionalsocialismo sobre lo femenino, empieza a sufrir algunas fracturas. Mientras los grupos de mujeres nacionalsocialistas defienden a ultranza el ideal de feminidad propuesto por el nacionalsocialismo, grupos de mujeres protestantes y católicas, comienzan a distanciarse de una visión de la mujer, donde lo individual no tiene ningún lugar. La maternidad empieza a ser vista como algo propio e único de la mujer, seña e identificación de ésta. La maternidad conecta a la mujer con lo divino. La mujer está salvada, de reproductora biológica asciende a salvadora de la humanidad. El círculo está cerrado. Alemania entra en guerra. La mujer encuentra de nuevo cómo servir y satisfacer a la patria. En la lucha contra la muerte, las mujeres son las esperanza, en ellas está de nuevo el futuro del país. Las mujeres tienen que hacer frente, ellas solas, a la economía de la nación. Trabajan en el campo, en la industria, en los hospitales, en la retaguardia, y de nuevo tienen que permanecer fuertes porque no pueden defraudar a su patria. El veneno había empezado a hacer efecto.

Un aspecto importante para poder estudiar en más profundidad este discurso sobre lo femenino, es el análisis de la figura femenina en otros países. La víctima predilecta es la mujer americana. Esta aparece caracterizada como vacía, artificial, histérica y mimada, una mujer que sólo vive para si misma y a expensas del marido, una mujer inútil y totalmente desprotegida para defenderse ante una vida difícil. Causa de esta falta de feminidad es la ausencia del sentimiento maternal en las mujeres americanas.

„Las devastadas caras de las viejas mujeres americanas son una prueba más de que algo fundamental les falta. Lo que nosotras denominaríamos corazón, alma o sentimientos. La totalidad del orden social americano está enfermo porque a la mujer americana le falta en general el instinto maternal.“" 546

\footnotetext{
545 Deutsches Frauenschaffen. Jahrbuch der Reichsfrauenführung, Dortmund, Westfalen Verlag, 1939, pp. 5 y 6

546 BDC, 62 Di. FC, Film 2379, Verkürzte Wiedergabe des im Dahlemer Schulungshaus gehaltenen Vortrages von Frau D. Hammer (sin fecha)
} 
Los hijos están malcriados, el hogar sin atender, el marido abandonado. La mujer americana es débil e insegura, ello la hace incapaz de llevar el control de la familia, de imponerse a los hijos o de tomar decisiones. En la casa de la americana se comen conservas y productos congelados. El hombre tiene que ayudar en las tareas del hogar. Los movimientos de emancipación son vistos como una marcha atrás, como una vuelta pasado, a costumbres no civilizadas.

A lo largo de este capítulo, hemos intentado exponer un análisis del lenguaje del nacionalsocialismo desde una perspectiva de género. Partíamos de la base que el lenguaje es un elemento fundamental e importante a la hora de crear actitudes, opiniones e ideologías. El estado nacionalsocialista, a través del control de los medios de difusión del lenguaje, tuvo en sus manos durante doce años, por una parte, las actitudes, deseos, y fantasías de hombres y mujeres, por otra reguló las relaciones entre ambos géneros de una manera tan brutal que, aún hoy las nuevas generaciones de alemanes sufren las consecuencias.

Nuestro objetivo era mostrar cómo se produce este control a través del lenguaje, y cómo tiene lugar la regulación de las relaciones hombre-mujer, desde el punto de vista del proceso de socialización de las mujeres.

Este proceso de socialización es iniciado y coordinado por hombres. Las mujeres no toman parte en la elaboración del discurso que las define, lo que hace que éste se pueble de innumerables fantasías masculinas, que tienen que ver de una manera muy estrecha con el cambio radical de las relaciones entre géneros que tuvieron lugar durante la República de Weimar. La masculinización de la sociedad durante el nacionalsocialismo puede considerarse como una respuesta al creciente aumento de la influencia de la mujer en la sociedad y en la vida política, una respuesta que se contiene grandes dosis de violencia contra lo femenino. Ejemplos de violencia contra lo femenino son sin duda alguna la variada lista de experimentos efectuados contra las mujeres en los campos de concentración o la esterilización de éstas; existe sin embargo también una violencia contra las mujeres alemanas, de la cual éstas no fueron conscientes, y que tristemente también tiene lugar en sociedades democráticas, se trata la violencia de la determinación de la feminidad, de las exigencias que tienen que cumplir las mujeres alemanas para ser ,verdaderas mujeres“. Esta violencia no se ejecuta abiertamente sino que tiene lugar en el difícil terreno de las actitudes, por eso es el lenguaje, y el discurso definitivo para registrarla.

La reacción de las mujeres alemanas ante esta violencia contra ellas no fue tristemente de resistencia. Aspectos como la cultura política no estaba muy extendida entre éstas, de igual manera la relación de las mujeres con su propia feminidad, a excepción de las mujeres pertenecientes al movimiento de la mujer, no rebasaba los ideales masculinos. Un gran número de mujeres asumieron la carga de ser kräftig, schön y fruchtbar, como una liberación como una nueva seña de identidad, perdiendo la posibilidad de descubrir una feminidad libre y sin fronteras.

\subsection{Las organizaciones nacionalsocialistas de mujeres}

A pesar de la inexistencia de una organización de mujeres dentro del Partido Nacionalsocialista, hasta 1931 fecha en la que se fundó la NS-Frauenschaft, existía una organización de mujeres, Deutscher Frauenorden, ${ }^{547}$ que apoyaba los objetivos de Adolf Hitler, y reivindicaba la retirada de las mujeres de la política para invertir sus esfuerzos en el terreno

547 Schmidt-Waldherr, Hiltraud: Emanzipation durch Professionaliesierung?, op. cit., p. 30 
social. En un principio la organización abarcaba unos 3.000, 548 en su mayoría mujeres que estaban relacionadas con los hombres de los círculos nacionalsocialistas:

„Éstas consideraban la activa lucha política, la tarea del partido nacionalsocialista antes de la toma de poder, como un asunto de los hombres. (...) Ellas permanecieron al lado de los hombres en los buenos y malos momentos y levantaban la fuerza moral de éstos con su indestructible fe en la victoria del movimiento. Su lealtad al Führer era incondicional.“ 549

La organización tenía como órgano portavoz la revista Opferdienst der deutschen Frau, dirigido por Elsbeth Zander. En 1926 durante el congreso del partido en Weimar, este reconoce al Deutscher Frauenorden como organización cercana a los objetivos del partido nacionalsocialista.

La orden se dedica también a tareas ligadas al trabajo social que eran dominio del movimiento de la mujer y de las organizaciones de mujeres confesionales: Formación profesional para el cuidado de enfermos, para la asistencia social de familias numerosas. Apoyo de presos políticos (nacionalsocialistas). Trabajo conjunto con las minorías alemanas en el extranjero. La educación racial forma también parte de las actividades de la orden, donde se impartían cursos para adolescentes. Miembros de la organización sólo podían ser „mujeres de sangre alemana" que pertenecieran al partido nacionalsocialista.

Dentro de la organización se crea una segunda rama para muchachas mayores de 14 años. Los grupos de muchachas estaban dirigidos por mujeres miembros de la orden. Importante era la educación en los valores alemanes: literatura y arte alemán, conferencias, senderismo, introducción en las tareas sociales: cuidado de enfermos y recién nacidos; asistencia social a las clases más pobres de la sociedad, así como se daba gran importancia a las tareas del hogar.

En 1931 se intenta coordinar el trabajo de las mujeres en una supraorganización, y la Orden es disuelta. El 1 de octubre de 1931 se funda la NS-Franenschaft, dependiente del Reichsorganisationsleiter Gregor Strasser. La base de la nueva organización estaba formada, por las mujeres del Deutscher Frauenorden, por la organización de Guida Diehl, Deutscher Frauenkampfbund y otros grupos de mujeres nacionalsocialistas. Elsbeth Zander se encarga de dirigir la organización.

La separación de los marcos de actuación entre los géneros durante la dictadura responde a las ideas de los ideólogos nacionalsocialistas tenía de la mujer. A partir de 1932 no se habla de la vuelta de las mujeres a la cocina o su retirada de la política, sino que la mujer aparece al lado del hombre nacionalsocialista como compañera dispuesta a regalar su ayuda en todo momento. Este cambio en las iniciales intenciones del partido está estrechamente unido a la derrota en las elecciones del 13 de marzo de 1932. A partir de esta fecha Hitler empieza a incluir a las mujeres como objeto de su campaña electoral. $\mathbf{5 5 0}$

Junto a la tarea al lado del hombre, es para Hitler la procreación y el mantenimiento de la raza, la principal tarea de la mujer. Y en el momento en que cada mujer alemana se esfuerce en regalar un hijo al Führer está actuando políticamente.

A partir del verano de 1932 comienzan las acciones de las mujeres nacionalsocialistas contra el movimiento de la mujer. Uno de las principales críticas es el espíritu internacionalista de éste y su abandono del carácter nacional. No es de extrañar el ataque. El BDF era la organización con el mayor número de miembros. Y de todos era sabido la división que el tema de cooperación

\footnotetext{
548 Deutsches Frauenschaffen. Jahrbuch der Reichsfrauenführung, Dortmund, Westfalen Verlag, 1939, p.10

549 Nationalistische Frauenschaft, Berlin, Junker \& Dünnhaupt, 1937, p.5

550 Ibídem, p. 37
} 
internacional una de las principales causas de la división. La crítica contra el BDF obedece a una estrategia que tiene como objeto ganar votos del ala más conservadora de la organización. Hiltraud Schmidt-Waldherr documenta esta controversia que comienza con un escrito redactado por Berta Braun, perteneciente a las NS-Frauenschaft. ${ }^{551}$ No sólo se critica el carácter internacionalista del movimiento de la mujer, sino la concepción del individuo que tenía éste, el concepto de feminidad y el carácter antialemán del movimiento.

Con motivo de la Gleichschaltung, se produce una reorganización en la NS-Frauenschaft. Zander es despedida de su puesto. Wilhelm Frick, (1877-1946), ministro de interior del Reich encarga a Paula Siber de la Gleichschaltung de las organizaciones de mujeres no nacionalsocialistas, creando para ello la Reichsarbeitsgemeischaft Dentscher Frauenverbände. Goebbels y Robert Ley, dirigente del Frente del trabajo, Deutsche Arbeitsfront tenían como candidata a Lydia Gottschewski y planeaban la creación de un frente femenino, Frauenfront. Finalmente se decide disolver las dos organizaciones, fundándose el Deutsches Frauenwerk. La dirección caía en manos de F. Krummacher y Paula Siber como segunda dirigente de la organización. ${ }^{552}$

El nombramiento de un dirigente masculino levanta numerosas críticas por parte de las mujeres nacionalsocialistas, quienes deseaban a una mujer al frente de la organización, así como mayor libertad de acción en las organizaciones de mujeres. A pesar del despido de Krummacher, su puesto no es ocupado por las nacionalsocialistas de la vieja guardia, sino por una mujer perteneciente a la nueva generación, Gertrud Scholtz-Klink ${ }^{553}$, sin experiencia política, joven, viuda y madre de familia. Como Reichsfranenfübrerin es responsable de la NS-Franenschaft, del Deutsches Frauenwerk, DFW, de la sección femenina del Deutsche Arbeitsfront, DAF, del servicio de trabajo femenino, Weiblicher Reichsarbeitsdienst, RAD, y finalmente del trabajo femenino de la cruz roja alemana.

551 Braun, Berta:Die Franenbewegung am Scheidewege, München, Propagandaabteilung der NS-Frauenschaft, 1932

552 Wiggerhaus, R.: Frauen unterm Nationalsozialismus, Wuppertal, Peter Hammer Verlag, 1984, p. 58

553 Gertrud Scholtz-Klink pertenece a una familia de la clase media. Su padre era landvermesser. A través de su primer marido entra en contacto con el partido nacionalsocialista. A la muerte de éste contrae de nuevo matrimonio con un miembro de las SS. Scholtz-Klink representaba el ideal de la mujer aria, rubia, robusta y madre de once hijos. 


\section{Estructura de las mujeres nacionalsocialistas}

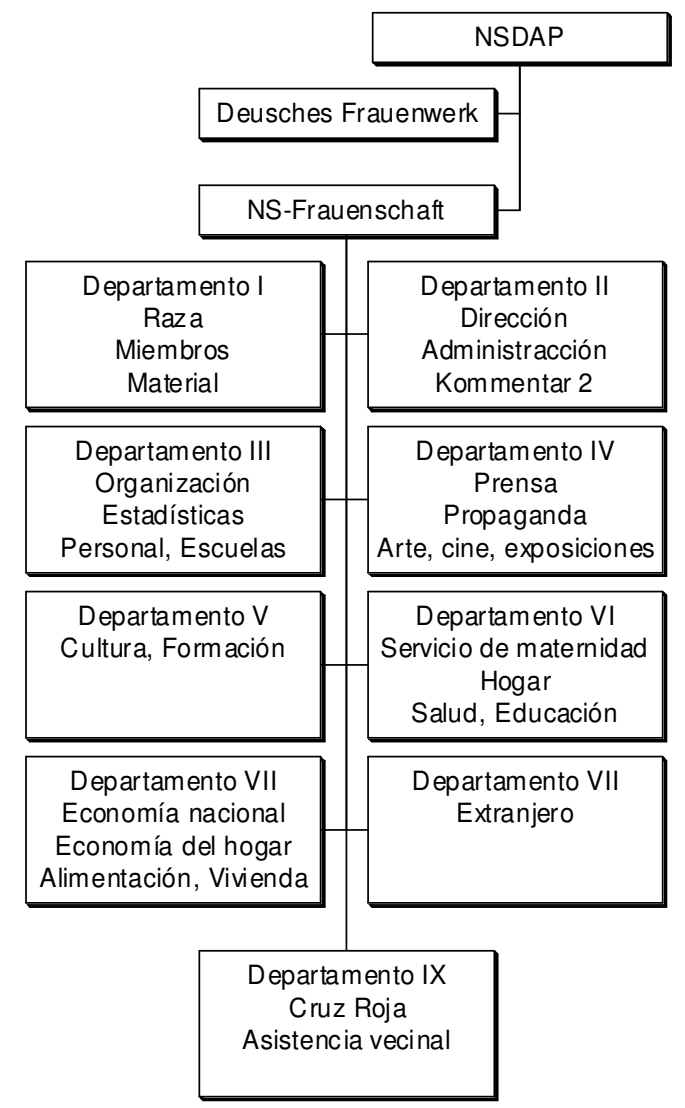

La NS-Franenschaft era la organización élite de las mujeres nacionalsocialistas. Desde el punto de vista organizativo se divide en nueve departamentos de trabajo.

Todo miembro de las NS-Frauenschaften trabaja en uno de los departamentos de la organización. El trabajo de los departamentos está repartido en función de la división administrativa del Reich. Los nuevo departamentos están representados en cada Gau (grupo regional), Kreis y grupos locales. Esta presencia se extiende a 32 Gaue, 780 Kreise y a 22.000 grupos locales, con un número de 587.118 mujeres que en los puestos de dirigentes, secretarias etc. Cada departamento está al cargo de una Fübrerin. Estas reciben una formación en escuelas especializadas.

El departamento más importante de la NS-Frauenschaft es el del servicio maternal. Estos cursos experimentan un desarrollo considerable. A finales de 1936 eran 1000 las mujeres que formaban parte del profesorado fijo y 2000 como profesorado contratado. Si nos atenemos a las estadísticas de la NS-Frauenschaft desde 1934 hasta 19371.140 .000 de mujeres participaron en 54.000 cursos de maternidad. 554 Los cursos contaban de tres bloques: el primero estaba dedicado a la economía del hogar (cocina y labores), el segundo se ocupaba de la formación de

554 Nationalistische Framenschaft, Berlin, Junker \& Dünnhaupt, 1937 
las mujeres en aspectos relacionados con la salud infantil y conocimientos generales de medicina y en el tercer bloque se trataban temas relacionados con la educación de los hijos, costumbres populares y decoración del hogar. Los cursos se impartían en las grandes ciudades en escuelas preparadas para este fin. La visita de estos cursos era obligatoria para las futuras mujeres de los miembros de las SS.

A partir de 1937 el trabajo del servicio de maternidad se organiza en función de las escuelas donde se imparte los cursos. En primer lugar se encuentra las llamadas Bräuteschulen, escuelas de novias, donde mujeres jóvenes se preparan para su futura maternidad. Se trata de mujeres entre los 18 y 35 años. La propaganda oficial retrata éstos centros como lugar de reunión de mujeres de todas las clases sociales:

„Aquí se encuentran empleadas con trabajadoras, la hija de familia acomodada y la dirigente del $B D M$, la estudiante de medicina con la vendedora, la estenotipista con la dirigente del servicio femenino, la modista con la estudiante de filología. Lo mismo se ocurre con los prometidos, los futuros esposos, donde encontramos una gran variedad de profesiones: al lado del SS, SA, dirigentes de las juventudes hitlerianas y miembros del ejército, se encuentran juristas, maestros, funcionarios, redactores, ingenieros, trabajadores manuales, trabajadores y comerciantes.“ 555

Los cursos duran seis semanas y en ellos las futuras madres de familia son aleccionadas en aquellos temas que serán necesarios en tal actividad. El trabajo se divide en grupos. El grupo $\mathrm{n}^{\circ} 1$ se encarga de las tareas de cocina, el grupo $\mathrm{n}^{\circ} 2$ realiza las tareas domésticas y el grupo $\mathrm{n}^{\circ} 3$ se ocupa del trabajo en el jardín y de las labores de costura. La segunda parte del día está reservada para cursillos de cuidado de bebes, salud, cuestiones educativas, decoración del hogar e informaciones sobre costumbres y cultura alemana.

En segundo lugar destacan las Werkmütterschulen, creadas en colaboración con el frente del trabajo, $D A F$. Estas están dedicadas para aquellas mujeres trabajadoras en grandes firmas que además son madres de familia. Estas escuelas se encuentran integradas en las mismas empresas.

Las Reichsschulen, escuelas del Reich donde las profesoras que se encargan de dar los cursillos en el resto de las escuelas reciben su educación.

Por último se encuentran las casas de maternidad de la asociación Lebensborn, en un principio reservadas para las mujeres de los dirigentes de las SS, con el objetivo de engendrar una élite aria.

El departamento de prensa y propaganda se ocupa de la formación de periodistas y redactoras, así como de la propia edición de prensa dedicada a la mujer. El órgano de prensa es la NS-FRAUENWARTE con una tirada en el cuartal de 1938 de un millón de ejemplares. Junto a éste destaca, DEUTSCHE HAUSWIRTSCHAFT, una publicación dedicada a temas del hogar, con 140.000 ejemplares al mes y una hoja informativa sobre las actividades de la organización, NACHRICHTENDIENST DER REICHSFRAUENFÜHRUNG con una tirada de 68.000 a 79.000. El departamento controla también la publicidad, y spots publicitarios para la prensa y la radio, así como exposiciones y todo tipo de acción propagandística sobre la organización. ${ }^{556}$

El departamento dedicado a la economía del hogar y a la economía nacional, se ocupa del trabajo elaboración de material sobre temas económicos que afectan al trabajo de la mujer en el hogar, a su papel como consumidora, aspectos relacionados con la dietética, costura etc. Es interesante resaltar que en este departamento se integran las asociaciones de amas de casa que

555 Deutsches Frauenschaffen. Jahrbuch der Reichsfrauenführung, Dortmund, Westfalen Verlag, 1939, pp. 21 y 22

556 Deutsches Frauenschaffen. Jahrbuch der Reichsfrauenführung, Dortmund, Westfalen Verlag, 1939, pp. 16 y 18 
durante la república de Weimar había pertenecido al ala más conservadora del movimiento de la mujer. Tras su definitiva disolución en 1935 éstas pasan a depender individualmente del Deutsches Frauenwerk. 557

El departamento ${ }^{\circ}$ VII se encarga de las tareas de propaganda en el extranjero:

„El departamento de fronteras y extranjero empezó su trabajo el 1 de julio de 1934, en una época en que la incitación al boycott contra Alemania se valía de la difusión de la mentira de la opresión de la mujer por parte del nacionalsocialismo, como una de sus medios de propaganda más influyentes." 558

Este departamento se encarga de velar por la buena imagen del régimen y se encarga de guiar a destacados miembros de delegaciones extranjeras por las instituciones y casas de la organización. La delegación española con representantes de los sindicatos verticales y el embajador español se encuentra por supuesto entre los invitados del departamento. ${ }^{559}$

Un segundo aspecto del trabajo del departamento $\mathrm{n}^{\circ} \mathrm{VII}$ era „la conservación de la sangre alemana en el extranjero". El trabajo con las minorías alemanas en territorios en Rumania, Rusia, Checoslovaquia etc, como medio de socialización política en los fines del nacionalsocialismo. A esto se unía el trabajo en las fronteras del Reich para fortalecer la presencia del cultura alemana, como luchar contra las influencias bolcheviques. 560

Sobre aspectos culturales, educación y formación se encarga el departamento $\mathrm{n}^{\circ} \mathrm{V}$. Los cursillos que se imparten en este departamento tienen un gran carga ideológica, especialmente los dedicados a la higiene racial, preparados en colaboración con el departamento de política racial.

El éxito de la NS-Frauenschaft entre las mujeres alemanas fue grande.

\footnotetext{
557 Nationalistische Franenschaft, Berlin, Junker \& Dünnhaupt, 1937, p. 26

558 Ibídem, p. 28

559 Deutsches Frauenschaffen im Kriege. Jahrbuch der Reichsfraueführug, Dortmund, Westfalen Verlag, 1941, p. 15

560 Nationalistische Franenschaft, Berlin, Junker \& Dünnhaupt, 1937, p. 29
} 


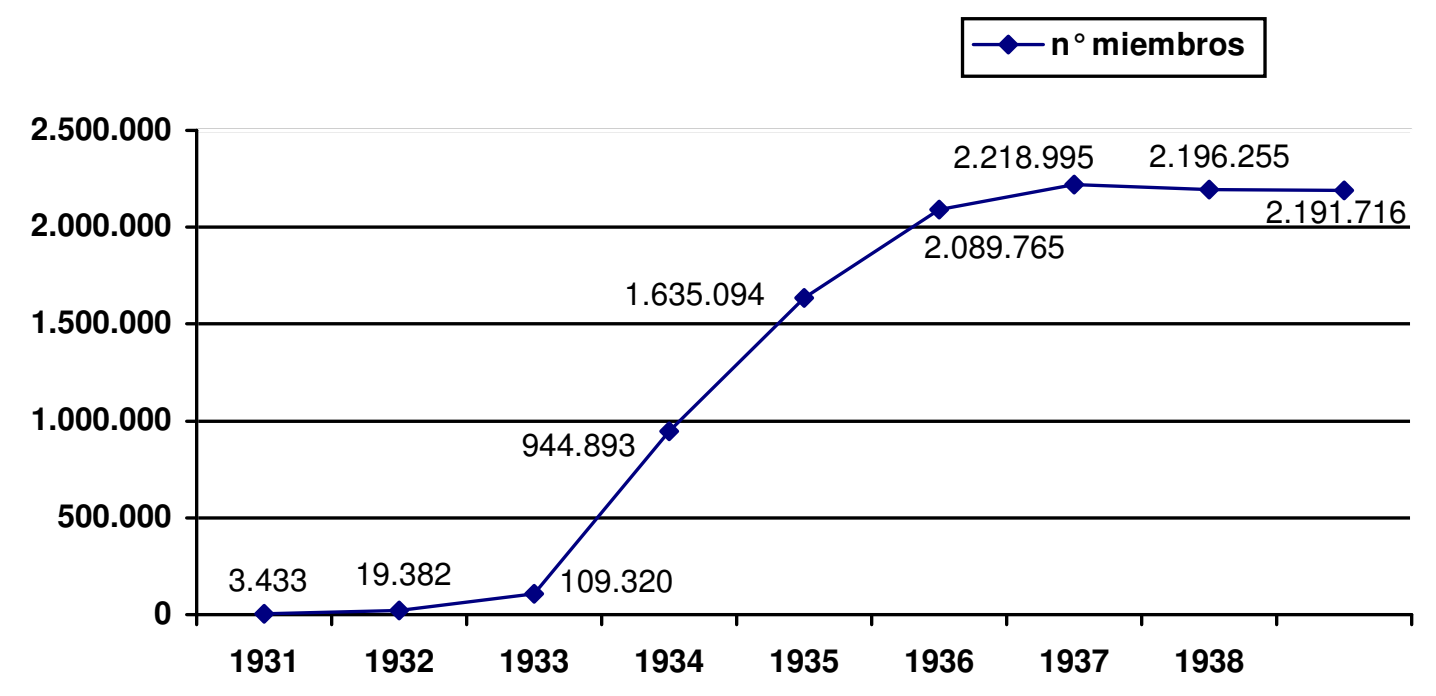

Durante la república de Weimar se observa ya una progresiva entrada de mujeres en la organización nacionalsocialista. En 1931 fecha de su fundación son 20.000 mujeres las que forman parte de ésta, lo que hace suponer que no se trata ya únicamente de las esposas, hijas y novias de los círculos nacionalistas. El número de miembros llega a las 900.000 mujeres y en 1935 son dos millones de miembros. Este rápido crecimiento está indudablemente relacionado con la disolución de las organizaciones de mujeres del movimiento de la mujer. ${ }^{561}$ En 1936, como ya hemos señalado con anterioridad se cierra la admisión de nuevos miembros en la organización, convirtiéndose el Deutsches Frauenwerk en la organización mayoritaria, mientras que la primera estaba formada por la élite de las mujeres nacionalsocialistas.

El resto de las mujeres que no estaban integradas en las estructuras del partido, se organizaban en el Deutsches Frauenwerk. En esta organización se encontraban las asociaciones de mujeres que se había librado de la disolución de 1933, como por ejemplo las organizaciones no confesionales. En los cuatro años siguientes se autodisuelven diecieocho asociaciones ya que sus estructuras estaban concebidas para un trabajo independiente que no coincidía con el centralismo de la organización nacionalsocialista.

En 193813 organizaciones forman parte de éste, estando la pertenencia individual también permitida. 562

Las organizaciones de mujeres nacionalsocialistas ponen de manifiesto la división genérica del nacionalsocialismo. La NS-Frauenschaft constituye un microcosmos que reproduce casi

561 Deutsches Frauenschaffen. Jahrbuch der Reichsfrauenführung, Dortmund, Westfalen Verlag, 1939, p. 12

562 Frauengruppe der Vereine gegen den Alkolismus im Deutschen Frauenwerk, Gruppe der Rechtswahrerinnen, Frauengruppe im Verband Deutscher Volksbibliothekare, Verband Deutscher Frauenkultur, Deutscher Reichsbund für Leibesübungen, Reichsverband Deutscher Turn-, Sport- und Gymnastiklehrer, Deutscher Lyzeum, Verband Alt-Katholischer Frauenvereine Deutschlands, Literarischer Bund, Reichsfachschaft deutscher Hebammen, Fachausschuß für Schwesternwesen in der Arbeitsgemeinschaft der freien Wohlfahrtspflege Deutschlands, Verein blinder Frauen, Altheimschenbund der Mathilde Zimmer-Stiftung. 
literalmente las estructuras nacionalsocialistas. Nuestra elección del término microcosmos no es accidental, queremos evitar la utilización de Lebensraum o esfera vital de actuación como hacen algunas investigadoras, levantando la impresión de una diferenciación genérica absoluta que observa el campo de acción femenino como inofensivo, sin embargo creemos que es necesario llamar la atención sobre un hecho fundamental. La NS-Frauenschaft es un lugar de indoctrinación política, dónde la mujer no sólo es vista como madre, sino como defensora de la raza alemana, frente al „enemigo apocalíptico“ de la raza judía. Esta adoctrinación se transmite de madres a hijas y a hijos, y se comparte con los hombres, que aunque de otro modo también se encuentran organizados en su propio microcosmos.

Esta maternidad esta sujeta a una fuerte reglamentación. De ahí que desde la NS-Frauenschaft se ofrezca un programa de educación en la maternidad. Esta tendencia no es un monopolio de la ideología nacionalsocialista, sino que tiene sus orígenes en Weimar. Las principales virtudes de una madre alemana en la educación de los hijos son Sauberkeit, Ordnung, Regelmäßikeit y Pünktlichkeit, limpieza, orden, regularidad y puntualidad. La relación personal con el hijo, o el desarrollo de sentimientos personales hacia éste no tenía lugar. ${ }^{563}$

La culminación del ideal de la madre como elemento fundamental en la mejora y conservación de la raza alemana, lo constituye la organización Lebensborn, fundada en 1936 por Heinrich Himmler. En esta organización se pretendía „generar“ especímenes puros de la raza alemana. 564

El proceso de socialización en la NS-Frauenschaft está fundamentado en la concepción de la mujer como madre, transmisora genética y cultural de los valores nacionalsocialistas. Desgraciadamente no existe material que nos ofrezca una visión de cómo asimilaron las participantes de estos cursos las teorías de higiene racial, o de la extensión de posturas antisemitas. ¿Participaron estas mujeres en las instituciones nacionalsocialistas sólo por motivos culturales, pedagógicos sociales? ${ }^{565}$ ¿Es cierto como señala Gisela Bock qué las teorías de higiene racial calaron en las conciencias de las mujeres alemanas que participaron en los cursos organizados por la Frauenschaft? Desgraciadamente sólo contamos con los informes oficiales y éstos, lógicamente, señalan el agradecimiento y la satisfacción de las mujeres.

563 Bez, Ute: „Deutsche Frau und deutsche Mutter- die langen Wirkungen der Ideologisierung im Nationalsozialismus", en Niethammer, O.: Frauen und Nationalsozialismus. Historische und Kulturgeschichtliche Position, Osnabrück, Rasch, 1996, p.144

564 Lück, M.: Die Fran im Männerstaat. Die gesellschaftliche Stellun der Fran im Nationalsozialismus. Eine Analyse aus pädagosicher Sicht, Frankfurt am Main, Peter Lang, p. 129

565 Wiggerhaus, R.: Frauen unterm Nationalsozialismus, Wuppertal, Peter Hammer Verlag, 1984, p. 78 


\title{
Discurso en la prensa de mujeres protestante. Tres ejemplos: AUFGABEN UND ZIELE, MUTTER UND VOLK Y DIE EVANGELISCHE FRAUENZEITUNG
}

\begin{abstract}
„(Die Kirche) war stumm, wo sie hätte schreien müssen, weil das Blut der Unschuldigen zum Himmel schrie. Die Kirche bekennt, die willkürliche Anwendung brutaler Gewalt, das leibliche und seelische Leiden unzähliger Unschuldiger, Unterdrückung, Haß und Mord gesehen zu haben, ohne Wege gefunden zu haben, ihnen zu Hilfe zu eilen.“
\end{abstract}

Dietrich Bonhoeffer 566

\subsection{Introducción}

A diferencia de las organizaciones no confesionales las asociaciones de mujeres protestantes y católicas no se ven afectadas por los efectos de la política de disolución que habían afectado al resto de las organizaciones de mujeres. Por el contrario, la desaparición de la estructura asociativa no confesional, provoca un flujo de mujeres a las organizaciones protestantes y católicas. En el caso protestante la reorganización que sufre las diferentes iglesias estatales tras 1933, con motivo de la interferencia de los cristianos alemanes, Deutsche Christen, aparecen nuevos grupos de mujeres protestantes. ${ }^{567} \mathrm{El}$ hecho de que las organizaciones confesionales no se vieran afectadas por la política de disolución nacionalsocialista, no significa que conservaran su independencia dentro del nuevo régimen. La manera más efectiva que tenían los nacionalsocialistas de controlar a las mujeres alemanas era hacerse con el control de las estructuras organizativas de la población femenina, existentes en la república de Weimar. En el caso de las asociaciones confesionales este control se traduce en el ingreso de éstas en una organización supranacional, „la obra de mujeres alemanas”, Deutsches Frauenwerk; en el caso de las organizaciones no confesionales en la autodisolución de la organización madre y la progresiva asimilación de las asociaciones profesionales.

Pese a los inocuos programas de las mujeres protestantes, sus inofensivas tardes de café y pasteles y sus círculos de Biblia, los nacionalsocialistas intentaron ampliar su control sobre los grupos de mujeres pertenecientes a las mujeres protestantes, a través de la introducción de éstas en el aparato de poder de las organizaciones nacionalsocialistas. El potencial de las mujeres

566 Bonhoeffer, Dietrich: Ethik, München, Kaiser Verlag, 1988, p. 120, $12^{\text {a }}$ Ed., (1 ${ }^{\text {a }}$ Ed. 1948, Kaiser Verlag, München)

$567 \quad$ Al respecto me gustaría citar las investigaciones de Mechthild Kraemer sobre el Auxilio Femenino, Frauenhilfe de la ciudad de Frankfurt, que tras 1933 queda bajo dominio de la iglesia estatal de los Cristianos Alemanes, Hesse-Nassau. En este caso el trabajo del Auxilio femenino se reorganiza a partir de 1933 bajo control de los cristianos alemanes. Detalles sobre la participación de las mujeres en la Kirchenkampf no son conocidos. 
protestantes era numeroso: unos dos millones de mujeres se podían contabilizar en el variado espectro de organizaciones. No hay que olvidar, las casas de reposo para madres, los programas de maternidad cursos de información para mujeres embarazadas y cursos de preparamiento para trabajadoras sociales, el trabajo en los hospitales. En otras palabras: el aparato de instituciones sociales estaba en gran parte en manos de las organizaciones de mujeres protestantes. Su disolución no se presentaba como la mejor alternativa, para controlar a la población femenina protestante ya que por otra parte gozaban de la protección de la iglesia protestante.

Pero el proceso de integración no puede considerarse fácil. A diferencia de las organizaciones de mujeres católicas, que mostraron un rechazo general hacia el régimen nazi, especialmente en los primeros años de la dictadura, la historia de las mujeres protestantes durante el nacionalsocialismo se revela tumultuosa, complicada y contradictoria. La organización y la misma naturaleza de la Iglesia, mejor dicho de las Iglesias Protestantes, así como su actitud respecto a la dictadura marcan de una manera especial el devenir de las organizaciones de mujeres. Mientras que la Iglesia protestante, debido a su heterogeneidad, presenta diferentes registros en relación a su actitud respecto al nacionalsocialismo, no se puede hablar de lo mismo en el catolicismo alemán, donde la unidad de la iglesia se manifiesta en la cohesión de las actitudes. La iglesia católica regula sus relaciones con el nuevo gobierno en un concordato, las iglesias protestantes, por el contrario se ven envueltas en una lucha interna donde diferentes posturas teológicas entran en contradicción. Por esta razón el análisis del discurso producido por los grupos de mujeres protestantes en sus órganos de prensa hace necesaria la referencia al contexto de las relaciones entre iglesia y estado, así como a la lucha que se crea en la iglesia protestante, conocida en la historiografía sobre el tema como Kirchenkampf. ¿Participan las mujeres en este momento de la historia del nacionalsocialismo o sólo son espectadoras, víctimas pasivas de la actuación masculina? ¿De qué manera se expresa su actuación y como se construyen modelos de actuación?

El control sobre las organizaciones de mujeres que ejerce el aparato nacionalsocialista comienza en las mismas filas de las mujeres nacionalsocialistas. Los grupos de mujeres nacionalsocialistas sufren desde 1933 una reorganización de sus estructuras, sus organizaciones son racionalizadas, estableciéndose la NS-Frauenschaft como organización cabeza del Deutsches Franenwerk, la obra de las mujeres alemana. La primera abarcaba a la élite de las mujeres del régimen y la segunda todo tipo de organizaciones, grupos integrados por mujeres, desde las organizaciones profesionales hasta las religiosas. En los primeros meses de reorganización se eliminan los elementos que defendían posturas „feministas” dentro del nacionalsocialismo. Se trataba de grupo de mujeres que rechazaban el régimen democrático, y apoyaban la idea de una Alemania fuerte y militarizada así como los valores propios y específicos de la cultura alemana.

El objetivo de los nacionalsocialistas era crear un organismo que controlara el servicio de la mujer para el Führer y su patria:

„Como mujeres a las que les ha sido concedida la alegría de poder trabajar en la obra de regeneración de nuestro Führer, tenemos que tener claro, que todo trabajo en general es más efectivo si en cada una de las partes que colaboran en éste rigen orden y disciplina, y que el Franenwerk alemán tiene que ser un organismo, que debe hacer presente la unidad de la mujer alemana al servicio del pueblo (...)“. 568

Una de las primeras medidas para acentuar el control de las mujeres protestantes fue el nombramiento en octubre de 1933 de un portavoz gubernamental, Friedrich Klein, para que regulara las relaciones entre las organizaciones de las mujeres protestantes y la iglesia oficial. A 
diferencia del caso católico en el que desde el primer momento estaba claro con quién tenía que negociar el nuevo gobierno, en el caso protestante el predominio de las iglesias protestantes sobre la dirección de la iglesia protestante, presentaba un serio problema de coordinación para los nacionalsocialistas. En el caso de las organizaciones protestantes nos encontramos con el mismo problema. Este se pretende resolver con la reorganización de las mujeres protestantes en una organización superior de mujeres, dirigida por Magdalene von Tiling, antigua miembro del $D N V P$. La organización se pone bajo la protección de la dirección de la iglesia protestante y por un tiempo se levanta la prohibición relativa a las nuevas fundaciones y admisiones. Paralelamente se produce por parte del gobierno los primeros intentos de acceder al control de la dirección de la iglesia protestante a través del grupo de los cristianos alemanes.

La relativa continuidad favorece que el trabajo de las publicaciones de las diferentes organizaciones no sufra sobresaltos. El objeto de este capítulo es analizar el discurso que produce la prensa de mujeres protestantes durante el período 1933-1945. Para ello hemos seleccionado las tres publicaciones más relevantes del mundo femenino protestante: AUFGABEN UND ZIELE, órgano portavoz del frente de trabajo de mujeres protestantes, Evangelisches Franenwerk, al que nos referiremos en adelante con la abreviatura con la que se le conocía entonces: $E v F W$, dependiente de la liga de mujeres protestantes alemanas que continúa sin problemas su labor, Deutsch-evangelischer Frauebund, conocido como DEF, y su publicación, y por último como ejemplo de la lucha de poder entre las mujeres nacionalsocialistas y protestantes por el control de las actividades relacionadas con el trabajo femenino nos referiremos al proceso que se lleva a cabo contra la publicación MUTTER UND VOLK, dependiente del Auxilio femenino, Evangelische Reichsfrauenhilfe.

Sin embargo, antes de empezar con el análisis temático creemos importante hacer referencia a la evolución de las organizaciones de mujeres protestantes durante el nacionalsocialismo y su postura durante el Kirchenkampf.

5.2. Contexto histórico-religioso de la integración de las asociaciones de mujeres protestantes en las estructuras nacionalsocialistas. La situación de la iglesia protestante durante el nacionalsocialismo. Repercusiones en el trabajo de las asociaciones de mujeres

\subsubsection{La iglesia oficial del Reich y los cristianos alemanes}

Antes de hacer referencia a las relaciones entre la organización de mujeres protestantes y el Kirchenkampf ${ }^{569}$ creemos que es necesario hacer una pequeña alusión a este movimiento de renovación que tiene lugar en la Iglesia Protestante durante el nacionalsocialismo, ya que las relaciones y „reacciones” de las asociaciones de mujeres protestantes dependen estrechamente de su postura ante el Kirchenkampf.

569 Literatura sobre el tema: Scholder, Klaus: Die Kirchen und das Dritte Reich, 2 V., Frankfurt/ Berlín, Wien, 1977; Maier, Kurt: Der evangelische Kirchenkampf, 3 V., Göttingen 1976-1984; Wolf, Ernst: „Zum Verständnis der politischen und moralischen Motive in der deutschen Widerstandsbewegung, en: Buchheim, Hans/ Schmitthenner, Walter: Der deutsche Widerstand, p. 215-255; Boberach, Heinz: Berichte des SD und der Gestapo über Kirchen und Kirchenvolk in Deutschland 1934-1944, Mainz 1984; Bracker, Karl- Dietrich; Funke, Manfred; Jacobsen Hans-Adolf: Nationalsozialistischen Diktatur 1933-1945. Eine Bilan₹, Düsseldorf, Schriftenreihe der Bundeszentrale für politische Bildung, 1983; Klessmann, Chr.: Widerstand und Exil 1933-1945, Bonn 1985; van Norden, Günther; Scholder, Klaus; Besier, Gerhard; Bethge, Eberhard, en: Schmädeke, J.; Steinbach, P.(Ed.): Der Widerstand gegen den Nationalsozialismus, München/Zürich, Akademie, 1984. 
La lucha de las iglesias se desencadenó a partir de la disolución del Deutscher Evangelischer Kirchenbund, institución de la que dependían las iglesias protestantes alemanas desde 1922. La estructura „federal” 570 de éstas hace sin embargo difícil la existencia de una verdadera unidad entre las iglesias estatales. En 1933 se crea un nuevo órgano central, la Deutsche Evangelische Kirche, la iglesia protestante alemana, que desde los inicios de su creación se ve sometida a los intentos de Hitler de integrarla dentro de las estructuras del nuevo estado. Ya en mayo de 1933 se producen indicios del futuro conflicto. Un grupo de pastores dentro de la iglesia protestante, que se autodenominan, los cristianos alemanes, reivindica la unión absoluto de los principios del cristianismo y nacionalsocialismo.

El movimiento de los cristianos alemanes fue fundado por los pastores protestantes Siegfried Leffler y Julius Leutheuser. Su primer campo de campo de acción tiene lugar en el estado de Turingia en el año 1927, desde donde se extienden a Prusia bajo de la dirección de Joachim Hossenfelder.

En una proclamación del 6 de julio de 1932 expresan públicamente su apoyo al programa político de Hitler. El escrito consta de diez tesis donde el nuevo movimiento da a conocer sus directivas de actuación. Objeto central del movimiento es conseguir la unidad de las 29 iglesias protestantes existentes en Alemania bajo una cúpula central. Desde el punto de vista teológico el nuevo movimiento defiende el llamado, cristianismo positivo que predica una visión de éste basado en la figura de Cristo y Lutero, con un alto contenido germánico. ${ }^{571}$

Los cristianos alemanes ponen en entredicho la postura de la iglesia protestante respecto a su falta de crítica constante al ateísmo marxista, así como su colaboración con los partidos de centro y de izquierdas. Raza, Volkstum y nación no son considerados como construcciones culturales sino como elementos establecidos por Dios. Por lo tanto se muestran contrarios, ya que se trata de un atentado contra la voluntad divina, a la mezcla de razas. La misión religiosa de un cristiano alemán se define como el mantenimiento de la pureza de la raza, que hay que defender de Untüchtigen und Minderwertigen. La religión judía aparece en la novena tesis como el peligro más relevante para el mantenimiento del Volkstum:

„(La religión judía) supone el acceso de sangre extranjera en el cuerpo de nuestro pueblo. Ella no tiene ningún derecho de existencia. Nosotros rechazamos la misión de los judíos en Alemania, en tanto que éstos poseen el derecho de ciudadanía y existe el peligro de que nuestro pueblo se llene de bastardos y que nuestra raza se enturbie con su presencia. La sagrada escritura sabe también de ira sagrada y amor fracasado. Especialmente es recomendable la prohibición de la unión en matrimonio entre alemanes y judíos. " 572

El 16 de mayo de 1933 vuelven a publicar un manifiesto con las directivas del movimiento, donde aplauden la llegada del régimen nacionalsocialista, y exigen la creación de una nueva constitución que regule los estatutos de la iglesia protestante, el nombramiento de un representante oficial del conjunto de la iglesia protestante. Y la unión de las iglesias estatales en iglesia protestante alemana.

El apoyo que posteriormente reciben de Hitler y del partido nacionalsocialista hace posible su victoria en las elecciones eclesiásticas que tienen lugar en todas las iglesias protestantes. Esta victoria les permite acceder a la cúpula de casi todas las iglesias estatales, con excepción de las

570 La división de la iglesia protestante en diferentes ,iglesias protestantes” se remonta a 1871, como consecuencia de los acuerdos tomados en los congresos de Viena.

571 Krumwiede, H.W., Greschat, M., Jachobs, M., Lindt, A.: Kirchen- und Theologiegeschichte in Quellen. Neuezeit 2. Teil: 1870-1975, Neukirchen, Neukirchener Verlag, 1989, (3ª Ed.), pp. 118-121

572

Ibídem, p. 119 
iglesia de Baviera, Hannover y Württemberg, que a partir de entonces se las conocerá por el nombre de las ,iglesias intactas”. Los cristianos alemanes reivindican una iglesia organizada en función del principio de autoridad y libre de pastores de procedencia no aria.

La reclamación de la unidad de la iglesia protestante se encuentra también en grupos de protestantes que no apoyaban las teorías de los cristianos alemanes. Así el 26 de abril de 1933 en la Liga de las iglesias protesantes, Deutscher Evangelischer Kirchenbund se negocia la unión de las iglesias estatales en una misma entidad. Cuestiones de culto, así como la línea teológica (reformada o luterana) dependen de éstas, la administración se centraliza. Junto a la creación de un sínodo nacional donde están representados los obispos de las iglesias estatales se decide elegir a un obispo del Reich que representara a la iglesia protestante en su conjunto. En un principio se presentan dos candidatos, Fritz von Bodelschwingh, perteneciente a la diaconía y Ludwig Müller, un pastor activo en el ejército. En un principio es elegido Bodelschwingh mientras que Müller se alía con los representantes de los cristianos alemanes, los cuales no aceptan a Bodelschwingh. Con objeto de estabilizar la situación se convocan elecciones en las iglesias estatales. Los cristianos alemanes con el apoyo Hitler ganan el $75 \%$ de los votos. De nuevo se reúne el sínodo del Reich y esta vez es elegido Müller como obispo. El 25 de abril de 1933 Hitler le concede por decreto plenos poderes para actuar en los asuntos eclesiásticos en las iglesias protestantes

\subsubsection{La Iglesia Confesora}

Tras la victoria de los cristianos alemanes en las elecciones eclesiásticas en julio de 1933 obtienen el control sobre la mayoría de las iglesias estatales. Es entonces cuando exigen la introducción de las leyes arias en la iglesia. Lo cual provoca las primeras reacciones en contra, como la de Ludwig Steil y Hans Ehrenberg, este último de origen judío y profesor de filosofía en la universidad de Heidelberg. Ambos publican 72 tesis respecto al problema judío en la iglesia, donde rechazan el aislamiento de los cristianos de ascendencia judía en ésta. ${ }^{573}$ En la misma línea se encuentra la obra que publica sobre el mismo tema el entonces joven pastor Dietrich Bonhoeffer „La iglesia y la cuestión judía“. Poco a poco empiezan a originarse grupos de oposición religiosa entre los círculos de los pastores protestantes.

En un principio se trata de una oposición desde el punto de vista teológico que poco a poco se convierte, en algunos casos aislados, en resistencia política. Ante la ocupación por las SA de algunos puestos eclesiásticos, Martin Niemöller, el cual en septiembre de 1933 convoca una alianza de pastores protestantes, Pfarrernotbund para oponerse a la iglesia de los cristianos alemanes. Los fundamentos de la nueva organización eran la Biblia y los escritos de la reformación. Junto a ello se llegaba a la conclusión de que en el credo protestante no se podía admitir la diferencia entre judíos y no judíos dentro de la iglesia. En cuestión de semanas 1300 pastores se apuntan a la declaración de Niemoller, y al final del año son 6.000. 574

Así en las iglesias donde los cristianos alemanes tienen el control se fundan „sínodos confesores" y forman un frente común contra la Reichskirche, la cual mientras tanto había nombrado a un obispo, Ludwig Müller para representarla, cuya elección curiosamente había sido también apoyada por las iglesias de Württemberg y Baviera, que a pesar de incidir en su distanciamiento de los cristianos alemanes, no se deciden a apoyar a los sínodos confesores, la cual a sus ojos pecaba de poco luterana. Pero a raíz de los intentos desde el estado de intervenir en los intereses de la iglesia de Württemberg provocan un acercamiento entre ésta, Baviera y los

573 Roon, Ger van: Widerstand im Dritten Reich. Ein Überblick, München, Beck Verlag, 1987, p. 82, (1 $\hat{E} d .1979)$

$574 \quad$ Ibídem, p. 84 
sínodos confesores. Este frente común de diferentes grupos de la oposición religiosa se organizan a principios de 1934575 en una iglesia común que recibe el nombre de Bekennende Kirche, la iglesia confesora, y que se define como la legítima representante de la iglesia protestante en Alemania. Uno de los principios de la declaración de Barmen, considera como uno de los primeros pasos de la oposición de la iglesia protestante al régimen nacionalsocialista, era la negación de uno de las ideas principales de los cristianos alemanes que veían en el Estado la manifestación del orden divino:

„El estado es una disposición (no orden) de Dios en la que el mundo que todavía no ha sido salvado por éste es una representación de la comunidad del reino de Dios." ${ }^{576}$

Centro fundamental de la declaración de Barmen es la separación final de la teología del orden que definía al estado como revelación del orden divino. Esta censura había sido marcada por el teólogo suizo, Karl Barth, fundador de la „teología dialéctica”: Dios es el otro absoluto, su conocimiento sólo se puede percibir a través de su revelación en Jesucristo. El punto de partida de su teología no es el individuo con su conciencia religiosa, opuesto a la teología antropocéntrica, sino la palabra de Dios. Todos los intentos por parte de la religión de intentar superar la separación entre Dios e individuo entran para Barth dentro del campo del „pecado”, poniendo en duda los principios del „protestantismo cultural” de los teólogos liberales, Friedrich Schleiermacher y Adolf von Harnack que habían construido una síntesis entre individuo, iglesia, mundo, cristianismo y cultura. Barth concluye que todo intento de la iglesia de asimilarse a las estructuras del mundo profano está en contra de las enseñanzas de la Biblia, en contra de la palabra de Dios. De ahí su clara rechazo de los cristianos alemanes. Importante también en Barth, el cuál a partir de 1935 es expulsado de Alemania, dada su condición de extranjero como ciudadano suizo, es su interpretación del mensaje de Cristo como embajada del „humanismo de Dios”, como fuente y norma de los derechos humanos y la dignidad humana. Desde esta concepción teológica Barth pasa más tarde a la oposición política, cuando con el estallido de la guerra incita a los pastores de la iglesia confesora a realizar objeción de conciencia. Esta medida es sin embargo para la mayoría de los miembros de la iglesia confesora , una implicación política en los asuntos del estado que no tiene nada que ver con la disputa teológica. 577

A finales de 1934 cada uno de los grupos que participaban en la Kirchenkampf había delimitado sus territorios de actuación. Así por ejemplo los cristianos alemanes se había establecido en las iglesias estatales de Renania, el Palatinado, Hessen-Nassau, Hessen, Oldenburg, Mecklenburg-Schwerin y Ostpreußen, las iglesias llamadas intactas donde se encuentran en Baviera, Silesia, Württemberg, Baden, Hannover, Westfalia y Schleswig-Holstein, y la iglesia confesora se encuentra en los territorios de Pomerania y Sajonia.

A partir del cinco de marzo de 1935 donde miembros de la iglesia confesora reaccionan oficialmente contra la ideología racista y popular del nacionalsocialismo, difieren los caminos de las iglesias intactas, que mantienen su postura de neutralidad respecto al régimen y los miembros de la iglesia confesora, cuya dirección, seminarios etc., entra en la ilegalidad. 700 pastores fueron encarcelados, a algunos de ellos se les prohibe hablar en público, otros son enviados a

575 El primer sínodo de la iglesia confesora tiene lugar en Barmen en enero de 1934, donde se fijan los principios de la nueva iglesia, tomando como fundamento un documento elaborado por Karl Barth. Barmen es un símbolo en la historia de la iglesia protestante, un símbolo de la unión de diferentes tendencias en la iglesia. Un símbolo de oposición contra los cristianos alemanes.

576 Frey, Christofer: Die Theologie Karl Barths. Eine Einfübrung, Frankfurt, Athenäum, 1988 p. 139

577 Barth, Karl: Der Römerbrief, Zürich, Theologischer Verlag, 1984, 13 Ed., (1Ed. 1922) 
campos de concentración, la mayoría se encuentra bajo el control de la Gestapo. Tras el sínodo de Dahlem es evidente la ruptura entre los diferentes frentes de la iglesia confesora. Por una parte se encontraban las llamadas iglesias intactas de Baviera, Hannover y Württemberg, por otra parte los llamados Bruderräte de las iglesias „destruídas”, llamadas así porque los cristianos alemanes habían conseguido ocupar los principales cargos de la administración eclesial. En noviembre de 1934 se consigue no obstante formar una dirección provisional de la iglesia (1.VKL, Vorläufige Kirchenleitung), que hasta mediados de 1935 se caracteriza por la unidad de decisiones.

Ante la división entre iglesia confesora y los cristianos alemanes ${ }^{578}$ Hitler decide nombrar en julio de 1935 a un ministro para asuntos religiosos Kerrl, cuya principal tárea era solucionar el conflicto entre los cristianos alemanes y el restos de las iglesias intactas. Las primera medida de Kerrl es nombrar un Reichskirchenausschuß, un comité eclesial, bajo la dirección de Zoellner, 579 para que negociara con las iglesias respectivas. Este comité representa a partir de 1935 a la iglesia protestante y formar parte de él miembros moderados en incluso partidarios de la iglesia confesora, medida que intentaba demostrar la buena voluntad del gobierno. A finales de 1935 los órganos de representación de la iglesia confesora son prohibidos, con lo que el nuevo comité aparece como la única dirección legítima de la iglesia protestante. Las iglesias intactas y algunos miembros de los Bruderräte participan en las negociaciones del comité, lo mismo ocurre con la dirección provisional de 1934 (1.VKL). No ocurre lo mismo con los Bruderräte prusianos quienes se niegan a todo tipo de negociación con el régimen nacionalsocialista.

En febrero de 1936 tiene lugar la última oportunidad para superar las divergencias entre los dos frentes de la iglesia confesora. En Bad Oeynhausen se celebra el último sínodo de ésta. Sin embargo las diferencias de opinión son tan grandes que a partir de ésta fecha se puede hablar una verdadera división entre el grupo moderado, constituido por las iglesias intactas y algunos Bruderräte luteranos y un grupo radical formado fundamentalmente por los grupos de pastores prusianos que en mayo de este mismo año eligen una nueva dirección (2.VKL) que desde entonces representa a la iglesia confesora. ${ }^{580}$

Sin embargo las negociaciones entre el comité se hacen tan difíciles, que éste termina desapareciendo en 1937. La situación permanece sin solucionar: por una parte continúa la división de la iglesia protestante entre los territorios dominados por los cristianos alemanes y las iglesias intactas las cuales defienden una postura moderada, por otra parte la iglesia confesora, que se considera la verdadera iglesia protestante y que actúa fundamentalmente en la ilegalidad. Por otra parte tras la dimisión de Kerrl como dirigente del comité de las iglesias protestantes, aparece una nueva iniciativa dirigida por Bormann ${ }^{581}$ que en contra de las directivas de Kerrl de querer formar una iglesia estrechamente unida al estado, es partidario de la estricta separación entre ambas instituciones, tomando las iglesias carácter de asociaciones privadas. Ejemplo de la „visión” de Bormann sobre el futuro de las iglesias tiene lugar tras la anexión de Austria al Reich alemán en marzo de 1938. Un año más tarde, 28.04 .1939 aparece una ley, Gesetz. über die Erhebung von Kirchenbeiträgen im Lande Österreichs. Esta ley organizaba las aportaciones financieras a la iglesia

578 Uno de los grandes problemas surge ante la posición de las asociaciones de mujeres protestantes, que por entonces se encontraban organizadas en una organización nacional y que aunque en un principio dependen de la iglesia del Reich, deciden finalmente separarse de ésta.

579 Teólogo protestante. (1860-1937) Líder de la derecha unida donde lucha por una iglesia luterana bajo una misma dirección.

580 Kottye R.; Moeller, B.: Ökumenische Kirchengeschichte 3, Mainz, Kaiser Verlag, 1989, p.306

581 Bormann, Martin (1900-1945), político nacionalsocialista conocido por su antisemitismo. Desde 1941 pertenece a la plana mayor de Rudolf Hess. Con el encarcelamiento de éste en Escocia en 1941 se convierte en dirigente de la cancillería del partido y ejerce una gran influencia sobre Hitler. Desde 1943 lleva el título de secretario del Führer. 
católica, a las iglesias protestantes (calvinistas y luteranas), y a los católicos reformados. Únicamente los miembros mayores de edad tenían la obligación de pagar las contribuciones y el estado se encargaba de establecer la cuantía de éstas, así la cantidad que cada iglesia recibía. Más tarde en marzo de 1938 se aplica a toda Alemania la obligación de juramento de lealtad a Hitler para todo pastor protestante.

Con la llegada de la guerra, la situación se estabiliza entre las iglesias del Reich y las llamadas iglesias intactas. Prueba de esta disposición es la figura del el obispo Marahrens en Hannover se muestra cada vez más abierto a llegar a un compromiso con tal de llegar a la unidad.

El endurecimiento de la postura nacionalsocialista puede tener que ver con este intento de colaborar. Dentro del grupo de colaboradores de Hitler se había impuesto la postura de Bormann. Himmler decide desde el cuartel general para la seguridad del Reich iniciar una ofensiva contra los líderes eclesiásticos más incómodos:

„El dirigente de grupo ha decidido definitivamente que en el futuro una persecución cerrada contra los adversarios más peligrosos tiene que tener lugar en todas los puntos policales del estados. La iglesia política toma en la actualidad el papel de los espartaquistas y los marxistas de 1918. Debido a esta actitud la iglesia política tiene que atenerse a las consecuencias. Nosotros tenemos con todos los medios que tenemos a nuestra disposición a contribuir a solucionar este problema." 582

Objetivo de la política de represión de Himmler y Bormann es la iglesia confesora. Ésta sufre con la entrada en guerra una crisis de ,identidad nacional”. Por una parte apoyar la empresa de la guerra significaba reconocer por fin al régimen anticristiano, una postura pacifista sin embargo atentaba contra los valores patriotas y nacionales de éstos. Esta contradicción aparece claramente cuando en 1938 Karl Barth en una carta al profesor de teología de la Universidad de Praga, Hromadka, instiga a los soldados checos a ejercer resistencia contra la invasión alemana. ${ }^{583}$ Esta carta sale a la luz pública en Alemania y es aceptada por los miembros de la iglesia confesora con rechazo e incomprensión. Contra Hitler si, pero no contra la patria.

Tras la muerte de Kerrl en diciembre de 1941 no se nombra ningún sucesor en su puesto en el ministerio para asuntos religiosos.

Las iglesias intactas consiguen llegar a 1945 centradas en su postura de neutralidad, y los cristianos alemanes continúan en sus puestos hasta 1945. Con la fundación de la República Federal Alemana los miembros de la iglesia confesoras son rehabilitados.

\subsubsection{Valoración}

Lo que empezó como un movimiento puramente religioso de resistencia contra las medidas religiosas nacionalsocialistas, se convirtió a lo largo de la dictadura para algunos de sus integrantes, Barth, Bonhoeffer, entre los más conocidos de resistencia política. Sin embargo la lucha entre las iglesias se puede considerar como un acto de oposición grupal que pretende defender los intereses del propio grupo. Para algunos se convierte individualmente en una oposición al régimen nacionalsocialista. Los miembros de esta iglesia actuaban en la clandestinidad, tenían sus propios centros de estudio donde teólogos y teólogas realizaban exámenes ilegales en sótanos de escuelas privadas. Muchos de ellos fueron encarcelados, otros

582 Kottye R.; Moeller, B.: op. cit., p. 314

583 Busch, E.: Karl Barths Lebenslauf. Nach seinen Briefen und autobiographischen Texten, München, Kaiser Ver-

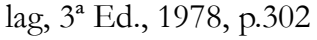


pagaron con su vida, un gran número de ellos vivieron el horror nazi en los campos de concentración. Pastores y pastoras ilegales se movían por toda Alemania para predicar contra la doctrina de los Deutsche Christen, para luchar contra el nombre de Hitler en el nombre de Dios.

El ascenso de Hitler al poder y su intromisión en los asuntos religiosos, así como el disfraz religioso de su aparato político y propaganda, radicalizó cada más los puntos de vista de los fundadores. Así lo que parecía ser únicamente una palabra más en el púlpito se convertía poco a poco en un pequeño acto de resistencia pasiva: el único señor es Cristo, proclamaban los párrocos de la Bekennende Kirche. Muchos de ellos no había demostrado en sus inicios grandes intereses políticos, pero poco a poco el compromiso con su iglesia se convertía en político, por su situación de ilegalidad.

Uno de los temas que normalmente aparece relegado a un segundo plano es el de papel de las mujeres en la Bekennende Kirche. La participación de éstas en el trabajo de bases de las comunidades no se debe sin embargo pasar por alto. Sin embargo, los puestos de decisión, los grupos de conspiración estaban integrados en su totalidad por hombres. Las mujeres de la BK en su mayoría esposas tenían un papel limitado. Ellas eran las que visitaban a sus maridos en la cárcel, las que escribían cartas a políticos para conseguir la liberación de los encarcelados, las que mantenían vivo el sentimiento de la BK en la ausencia de sus esposos. En sus casas se escondían judíos, se ayudaba a la salida del país. Incluso las pastoras o vicarias con la misma formación académica que sus compañeros se veían relegadas a funciones secundarias. Su posición de resistencia está motivada en la mayoría de los casos por razones religiosas y no políticas.

\subsection{El desarrollo de las relaciones entre las organizaciones de mujeres protestantes y el nacionalsocialismo}

5.3.1. Los primeros meses de la dictadura y las mujeres protestantes. La creación del Evangelisches Frauenwerk (EvFW)

Como en el caso de las organizaciones no confesionales, los primeros meses de la dictadura se caracterizan por una disposición para trabajar conjuntamente con las mujeres nacionalsocialista. Esta predisposición positiva estaba motivada por el deseo de preservar la existencia de las organizaciones y de su trabajo.

En capítulos posteriores hemos tenido la posibilidad de analizar el trabajo y organización de los diferentes grupos de mujeres protestantes. La llegada al poder de los nacionalsocialistas no trae consigo la disolución de las organizaciones, sino un cambio estructural de éstas.

Los primeros intentos de unificar el trabajo del innumerable número de organizaciones, grupos de trabajo, círculos de asistencia social a los que las mujeres protestantes pertenecía parte de una comisión con sede en Berlín, Arbeitsausschuß der Vereinigung Evangelischer Franenverbände in Deutschland, heredera de la organización madre, fundada en 1918 por Magdalene von Tilling. Las diferentes organizaciones se dividen en varios grupos de actuación: organizaciones dedicadas al trabajo parroquial, grupos cuyo trabajo se enmarca en lo social, o en lo caritativo, organizaciones dedicadas a la educación o a trabajos de formación, y el servicio maternal. Esta 
división afecta a todas las „iglesias provinciales”, que se encargan personalmente de elegir a las representantes de los diferentes grupos. 584

Hasta 1933 el trabajo de las mujeres protestantes estaba coordinado, organizativa y económicamente por las diferentes iglesias estatales. A partir del 4 de julio de 1933 pasan a depender directamente de la Iglesia Protestante Alemana (Deutsche Evangelische Kirche D.E.K.), es decir pasan a depender de Friedrich von Bodelschwingh y más tarde de Müller.

Unos meses después, en diciembre, se crea una organización específica para las mujeres protestantes: el Evangelisches Franenwerk (EvFW), del que pasan a depender todas las asociaciones.

El paso definitivo de integración en el aparato nacionalsocialista es la entrada en la Reichsarbeitsgemeinschaft Deutscher Franenverbände en la cual todas las organizaciones de mujeres que no han sido afectadas por la disolución tienen de obligación de inscribirse. Las firmantes del documento de ingreso, responsables de los diferentes grupos de mujeres protestantes, se comprometen a dirigir a las mujeres protestantes aceptando los principios nacionalsocialistas:

„Yo me comprometo en nombre de mi asociación a cumplir con estas obligaciones y me esforzaré conscientemente a dirigir y a educar a mi organización y a las mujeres que estan bajo mi mando según los principios del estado nacionalsocialista. Yo me obligo a la absoluta unidad con el resto de las asociaciones de mujeres alemanas que se han unido a la organización madre, así como reconozco el mando de nacionalsocialista de la Reichsarbeitsgemeinschaft Deutscher Frauenverbände. “585

A la cabeza del $E v F W$ se coloca una mujer hasta entonces desconocida en el grupo dirigente: Agnes von Grone.

„Al frente del Reichsfrauenwerk fue nombrada Frau von Grone Westerbrak. Ella y todas nosostras nos ponemos bajo la dirección del obispo del Reich nombrado por el Führer." ${ }^{586}$

Agnes von Grone procede de una familia de aristócratas en Schwerin. A diferencia del resto de las mujeres pertenecientes al movimiento de la mujer protestante no estudia teología o se dedica a la enseñanza. A los 18 años contrae matrimonio Siegfried von Grone, miembro de una conocida familia de militares Dentro del trabajo femenino en organizaciones protestantes no es una desconocida. Desde 1925 dirigía el Auxilio femenino protestante en Braunschweig

Con Agnes von Grone a la cabeza, la organización se supedita al obispo del Reich, Müller, nombrado por Hitler, rechaza cualquier tipo de afiliación política dentro de la iglesia y reconoce la unidad de la iglesia protestante, y la independencia de acción de la organización respecto a sus homogéneo laico de las mujeres nacionalsocialista.

Junto a von Grone participan también en la integración de las organizaciones protestantes en la estructura nacionalsocialista Paula Müller, como dirigente del Evangelischer Frauenbund y Magdalene von Tiling, como dirigente de la Vereinigung Evangelischer Frauenverbände Deutschlands.

584 Amtsblatt für die Evangelisch-Lutherische Kirche in Bayern rechts des Rheins., München $\mathrm{n}^{\circ} 25$, Septiembre 1933

585 LKAN, LKR V 963 a (2986b), Juli 1933. Las firmantes del documento son: Agnes von Agnes v. Grone (Frauenwerk der DEK), Frau von Oppen, Fräulein Brickenstein, Magdalene von Tiling, Klara Lönnies, (responsables de los cuatro grupos de trabajo del Frauenwerk) Marie von Harsdorf (responsable de la organización en Baden) y Martha Daumiller (responsable en Baviera).

586 BDC, Agnes von Agnes v. Grone, OPG, Band 1, Die geschichtliche Entwicklung des Frauenwerkes der Deutschen Ev. Kirche von seinen Anfängen bis heute. 
En la correspondencia entre Tiling y el EvFW muestra el importante papel de la antigua representante del DVNP en la construcción de la nueva organización. Parte de este trabajo es la búsqueda de una nueva dirigente. Todos los grupos y organizaciones de mujeres deben presentar a sus candidatas. ${ }^{587}$ La elección se hace rápidamente. No hemos encontrado ningún documento que explique el porqué de la elección de von Grone. Es interesante llamar la atención sobre los paralelos entre ésta y Scholtz-Klink la futura dirigente de las mujeres nacionalsocialistas. Sin formación académica, casada y con hijos, el típico ejemplo de mujer robusta y resoluta que la imaginería nacionalsocialista utilizaba como símbolo de la mujer alemana. En este sentido se puede habla para el caso de las principales organizaciones de mujeres protestantes, de un cambio generacional representado por mujeres jóvenes, la mayoría sin estudios, (la DEF, la Federación de mujeres protestantes alemanas constituye una excepción), y sobre todo limpias de todo pasado político parlamentario. ${ }^{588}$ Las antiguas luchadoras protestantes continúan trabajando en las organizaciones pero a la sombra de la nueva generación de mujeres. ${ }^{589}$

Agnes von Grone recibe en la primavera de 1933 el encargo del obispo Müller de „unificar“ las organizaciones protestantes de mujeres, y se pone al mando del $E v F W$ el 27 de julio de 1933. Aunque las organizaciones protestantes (ver apéndice documental) siguen existiendo la nueva organización controla sus actividades. Miembros de la Liga y de la Framenhilfe controlan los puestos de dirección en gran totalidad.

En los primeros acuerdos que regulan el ingreso de las asociaciones de mujeres protestantes en las organizaciones nacionalsocialistas von Grone trabaja en un principio con Paula Siber, dirigente del Deutsches Frauenwerk. Estos contactos tienen lugar desde mayo a septiembre de 1933 y se caracterizan por una atmósfera de cooperación entre ambas partes. ${ }^{590}$ En las negociaciones en las que también toma parte el obispo del Reich, Müller, se incide en la protección que recibe la nueva organización por parte del estado, así como se define el trabajo de ésta como dependiente de la iglesia protestante:

„Después de que el Frente de trabajo alemán femenino haya tomado posesión de la Reichsarbeitsgemeischaft y podemos remitirnos a las experiencias de un positivo trabajo en conjunto, le ruego que en el futuro el frente del trabajo de mujeres protestantes siga gozando de la protección de la iglesia protestante como se nos ha

\footnotetext{
587 LKAH, N10, $\mathrm{n}^{\circ}$ 6, 21.10.1933, Correspondencia entre Magdalene von Tiling y el EvFW

588 Frau von Bismarck (Evang. Reichsfrauenhilfe); Dr. A. Nopitsch (Bayer. Mütterdienst); Auguste Mohrmann (Müttedienst des Kaiserswerther Verbandes); Meta Eyl (Deutsch-Evang. Frauenbund); C. Brickenstein (Deutsch-Evang. Verband soz. Jugendgruppen); Eleonore grossherzogin von Hessen (Deutscher Verband der Freundinnen junger Mädchen); Fr.l Reineck (Reichsverband der Evang. Deutschen Bahnhofsmission); Wally Schick (Bund evang. Frauen im sozialen Dienst); Magdalene v. Tiling (Verband für evang. Religionsunterricht und Pädagogik); Frieda Cramer (Verein Deutscher Evang. Lehrerinnen); Frau Schleypen (Verband Evang. Theologinnen Deutschlands); Hanna Hoffmann (Bund Christlicher Akademikerinnen); Oberin K. Zarnack (Evang. Reichsverband Weibl. Jugend); Gertrud Zappka (Verband Evang. Frauengruppen „Wort und Werk”); Frau Nitzsche (Vereinigung der Evang. Sozialen Frauen-u. Wohlfahrtsschulen Deutschlands); B. Meyer (Christlicher Verein für Frauen u. Mädchen); Asta Rötger (Reichsgemeimschaft der Evang. Hausfrauen Deutschlands); Oberin von Scheven (Evang. Diakonieverein); J. von der Schulenburg (Marienburger Vereinigung für evang. Paramentik). $\mathrm{BAB}, 244$, Kirche Allgemein.

589 Prueba de este trabajo en segundo plano es la correspondencia entre von Tiling y von Grone donde la primera presenta propuestas sobre las futuras dirigentes de los diferentes grupos de la organización, consolida contactos con las mujeres nacionalsocialistas, envía información a von Grone sobre los temas a discutir. Etc.
}

590 LKAN, LKR V 963 a (2986 b), 7.12.1933, Carta de Paula Siber a Agnes v. Agnes v. Grone 
prometido hasta estos momentos. Hago constar que el trabajo del frente forma parte del servicio de la mujer a la comunidad y como tal es una actividad dependiente de la iglesia.“"591

En la correspondencia entre el obispo y Paula Siber, éste apela a la protección especial de que gozan las organizaciones confesionales e incide en la falta de definición política de estas, por lo tanto reclama el control de las organizaciones de mujeres, por tratarse de agrupaciones con intereses religiosos:

„Gracias al concordato firmado con la iglesia católica se ha concedido a las organizaciones católicas una protección especial - una protección que yo también deseo para las organizaciones de la iglesia protestante. Me gustaría también incidir en que el frente del trabajo de mujeres protestantes no es ninguna organización política, sino puramente religiosa y como tal se encuentra bajo la dirección de la iglesia protestante..$^{592}$

La organización protestante y su dirigente, von Grone, parece en un principio seguir la consignas del obispo Müller, y está dispuesta a trabajar conjuntamente con las organizaciones nacionalsocialistas, como lo demuestra una carta a Rudolf Hess:

„Mi admirado señor Hess, en nombre de dos millones de mujeres protestantes me gustaría rogarle que le trasmitiera al canciller del estado nuestros respetuosos saludos, especialmente en estos dias en los que toda Alemania en Nuremberg es objeto de un grandioso reconocimiento del nuevo Reich alemán. Estos dos millones de mujeres alemanes quieren dar las gracias, a él y al NSDAP por el apoyo a nuestro trabajo, por su protección y por la posibilidad que se nos ha concedido de participar en la reconstrucción de la patria, del estado y de la iglesia." $" 593$

Sin embargo en agosto de 1933, comienzan los primeros problemas para la joven dirigente. Wilhelm Frick, ministro del interior, prohibe la fundación de nuevos grupos locales dentro de la organización protestante, así como la admisión de nuevos miembros. Posiblemente se quería impedir un flujo de miembros procedentes de las asociaciones de mujeres que se había decidido por la autodisolución, hacia las organizaciones protestantes. En la mayoría de los casos, sin embargo, la prohibición no es respetada. No obstante esta medida crea una situación de pánico entre las mujeres protestantes que temen correr el mismo destino que las organizaciones no confesionales.

Paralelamente en septiembre de 1933 se produce una reorganización de las organizaciones de mujeres bajo el mando nacionalsocialista. El frente del trabajo femenino, Deutsche Frauenfront, y la Reichsgemeinschaft Deutscher Frauenverbände se fusionan en una organización común, Deutsches Franenwerk. Rudolf Hess nombra a G.A. Krummacher dirigente de la nueva organización y de las NSF. Paula Siber recibe el cargo de vicepresidente de la organización. Esta última había sida propuesto por Müller, el obispo protestante de la iglesia oficial, lo que hace suponer en un principio una política benévola para las organizaciones de mujeres.

591 LKAN, LKR V 963 a (2986 b), 10.02.1934, Carta de Ludwig Müller a Paula Siber.

592 LKAN, LKR V 963 a (2986 b), 09.09.1933, Carta de Ludwig Müller a Paular Siber

593 LKAH, N10, nº 6, Correspondencia entre Agnes v. Grone y Rudolf Hess, 30.08.1933 
La fuerza de las nuevas organizaciones de mujeres nacionalsocialistas crea un clima de inseguridad que empieza extenderse en las iglesias estatales, donde a su vez la autoridad de Müller comienza a poner se en duda. Un ejemplo de este desasosiego respecto al futuro de las organizaciones de mujeres es un escrito dónde el decanato de Aschaffenburg muestra sus temores a la dirección de la iglesia bávara, ante la posible disolución del DEF, la Federación de mujeres protestantes :

„Por aquí y por allá se expresa la opinión de que la Federación de las mujeres protestantes alemanas corre el peligro de ser disuelta como ha sido el caso de otras federaciones. Es necesario tener en cuenta que tal medida puede tener causar un daño irreparable a la vida de la comunidad“..594

El campo de acción de la Federación era tan amplio que su desaparición podría plantear serios problemas a las comunidades parroquiales. En caso de disolución, corrían su misma suerte, el programa de acción de jóvenes con problemas, el auxilio maternal, el auxilio de invierno, el taller de costura, e innumerables casas y centros administrados por la Federación dedicadas a la educación de adultos.

Esta situación de inseguridad provoca la reacción que los nacionalsocialistas habían esperado: unos meses después, concretamente el 6 de abril de 1934 la organización de mujeres protestantes, el $E v F W$, pasa a formar de la organización general de mujeres, Deutsches Franenwerk, $D F W$ dependiente del partido y bajo el control de las mujeres nacionalsocialistas que se comprometían, especialmente esta última a velar por la independencia y autonomía de la organización protestante:

„Para la conservación del trabajo femenino religioso es digno de atención la resolución del seis de abril de mil novecientes treinta y cuatro firmada en conjunto con el frente de trabajo de mujeres protestantes (dirigente Frau von Grone) y el frente del trabajo estatal (dirigente Frau Scholtz-Klink). La doble pertenencia a la NS-Frauenschaft y al Auxilio femenino femenino es permitida. Ya que toda comunidad parrroquial tiene especiales tareas al servicio de la comunidad del pueblo, necesita mujeres religiosas preparadas para este trabajo. En caso de nuevas fundaciones todo grupo tiene que ponerse en contacto con la dirección local de las NS-Frauenschaften para evitar controversias e intromisiones en los campos de trabajo. La inscripción de reuniones y celebraciones, mientras estas se circunscriban a aspectos religiosos no es necesaria.".595

594 LKAN, LKR V 963 a (2986), 8. März 1934. Carta del decanato de Aschaffenburg al Evang.-Luth. Landeskirchenrat, München.

595 LKAN, LKR V 963 a (2986), 28.4.1934.Comunicado del Bayerischer Mütterdienst, tambien en: Kaiser, J.C.: Das Franenwerk, der deutschen evangelischen Kirche. Zum Problem des Verbandsprotestantismus im Dritten Reich, en: Dollinger, H. / Gründer, H. / Hauschmidt, A. (eds.): Weltpolitik - Europagedanke - Regionalismus. Festschrift für Heinz Gollwitzer, Münster, 1982, p.488. Existe una carta de Agnes von Agnes v. Grone al obispo Müller en la que ésta le comunica su alegría por el ingreso en la organización estatal. EZA, 1/C4/21. Esta política de cooperación con las organizaciones nacionalsocialistas no es un ejemplo aislado sino que se incluye dentro del proceso de la Gleichschaltung, que afecta a todas las asociaciones existentes en Weimar que consiguieron librarse de la disolución o de la prohibición. Otro ejemplo de Gleichschaltung lo viven las organizaciones de bienestar social como Cáritas, la Cruz Roja, o la Innere Mission, Misión Interna, que se colocan en marzo de 1934 bajo la dirección de la organización libre de bienestar, dependiente a su vez del Instituto de bienestar. 
También entre los responsables de la iglesias protestantes desaparecen los últimos temores de una posible disolución, aunque desde Baviera, en nombre del obispo Daumiller, muestra su escepticismo respecto a la libertad de las mujeres protestantes en su trabajo conjunto con la organización nacionalsocialista:

„El peligro de disolución de nuestro Franenwerk protestante ha desaparecido. Es posible, naturalmente, que con el tiempo las organizaciones de mujeres nacionalsocialistas nos revelen en parte de nuestro trabajo. Aquí debemos de esperar el carácter que toman las cosas en el futuro. Lógicamente seguiremos realizando nuestro trabajo en servicio de nuestro pueblo con la responsabilidad que nos da nuestra fe cotidiana en el amor" ${ }^{\text {“. } 596}$

La historia del $E v F W$, no transcurre, sin embargo de una manera pacífica: la antigua estructural „federal“ de las iglesias protestantes permanece viva en alguna de las iglesias estatales, que no aceptan la dirección de Müller, ni la supeditación de éste a Hitler, produciendo una situación de tensión entre las diferentes iglesias protestantes que se traduce en la llamada Kirchenkampf en el que el $E v F W$ también participa, a pesar de sus intentos de permanecer neutral. A este aspecto se suma el progresivo empeoramiento de las relaciones con la organización nacionalsocialista de mujeres que desde 1934 tiene una nueva dirigente, Gertrud Scholtz-Klink, cuyas relaciones con Agnes von Grone no parecen ser las mejores, a esto se añade la progresiva política de restricción en los campos de acción de la organización protestante y el distanciamiento del obispo Müller.

En este contexto de lucha interna, de afirmación religiosa y organizativa respecto al nacionalsocialismo se centra el desarrollo de las organizaciones protestantes, así como la de la prensa que publican.

\subsubsection{Estructura y organización interna del EvFW}

Tras la agrupación de los diferentes grupos y asociaciones de mujeres protestantes en el $E v F W$ son 2.000 .000 de mujeres las que integran la nueva agrupación protestante. Se puede considerarla como la organización paraguas de todas los grupos de mujeres protestantes (ver apéndice documental). Desde el primer momento se concibe la organización como un órgano de la iglesia protestante que coordina el trabajo en y fuera de la comunidad:

"Las dos líneas de trabajo que hemos expuesto, trabajo parroquial y trabajo extra parroquial de las mujeres, provienen de una tradición que se ha impuesto desde hace años. Pero ambas tiene un objetivo único y principal: el frente del 
trabajo femenino de la iglesias quiere ser un miembro al servicio de ésta y como tal cumplir con sus funciones que toda mujer tiene para la patria y el estado." ${ }^{597}$

Su trabajo es fundamentalmente religioso, aunque se concibe también su labor como un servicio al pueblo y a la patria, por eso su integración en el grupo de organizaciones no religiosas dependientes del estado, Deutsches Frauenwerk, aunque independiente en cuestiones de organización y en cuestiones de fe:

„A pesar de la unidad del trabajo femenino de las mujeres alemaneas, se ha concedido en las negociaciones entre el frente femenino estatal y el de la iglesia protestante la plena libertad de trabajo religiosos de las organizaciones de mujeres protestantes. Ya que sólo a través del reconocimiento sin compromisos del trabajo protestante puede la iglesia, a través de las mujeres cumplir con su servicio al pueblo. La autoridad del mando de la organización se encuentra también en manos de la iglesia." "598

El EvFW fue creado con objeto de protegerse contra la poderosa organización de mujeres nacionalsocialistas, aunque desde un principio aparecen en sus estatutos el deseo de colaborar con la organización nacionalsocialista:

„En las iglesias regionales y provinciales colaboramos intensa y estrechamente con las autoridades eclesiásticas. Como el Franenwerk de la iglesia. Con el Frauenwerk alemán llegamos a un convenio, como mujeres protestantes, para ayudar a nuestro Führer en la reconstrucción de nuestra patria“. ${ }^{599}$

El trabajo de la organización tiene fundamentalmente una función pedagógica y social. Desde una perspectiva religiosa realizaba trabajo de formación en todos los terrenos que afectaban a la mujer, pero por otra parte tenía a sus espaldas un gran dispositivo de trabajo social, en hospitales, asilos, escuelas etc. No olvidemos que un gran número del trabajo social, e instituciones estaban en manos de las dos iglesias.

La presentación de von Grone ante sus compañeras de organización da cuenta de la orientación del trabajo de las mujeres protestantes. von Grone comienza con el moto, „madres de la iglesia son madres del estado". Entre iglesia y estado se encuentra la madre como pieza fundamental en la construcción de la nueva patria:

„Madres de la iglesia son madres del estado, estas palabras son una gran exigencia para nosotras. Nosotras queremos vivir en fe, queremos estar unidas a una iglesia viva, ya que así sólo podemos poner en práctica las palabras de nuestro Führer: „En mi estado será la madre la principal ciudadana!. Sólo podemos ser devotas madres de la iglesia si con la fuerza de la fe, y con la confianza en el evangelio podemos cumplir con nuestras obligaciones morales, sólo así podemos ser madres del estado, como representantes de éste."600

\footnotetext{
597 BDC, Agnes von Agnes v. Grone, OPG, Band 2, Richtlien für eine Einfügung des kirchlichen Frauenwerks in die Arbeit der Deutschen Evangelischen Kirche.

598 Ibídem

$599 \quad$ LKAN, LKR V 963 a (2986 b), Das Frauenwerk der Evangelischen Kirche

600 LKAH, N $10 n^{\circ}$ 6, 19.12.1933, Agnes von Grone a sus compañeras de organización
} 
La central de la organización se encuentra en Berlín. Su trabajo se divide en cinco grupos de trabajo: trabajo parroquial (realizado por la Evangelische Frauenhilfe), trabajo social, trabajo de formación y educación, y finalmente el grupo que integraba las asociaciones dedicadas al servicio maternal y la diaconía profesional. ${ }^{601}$

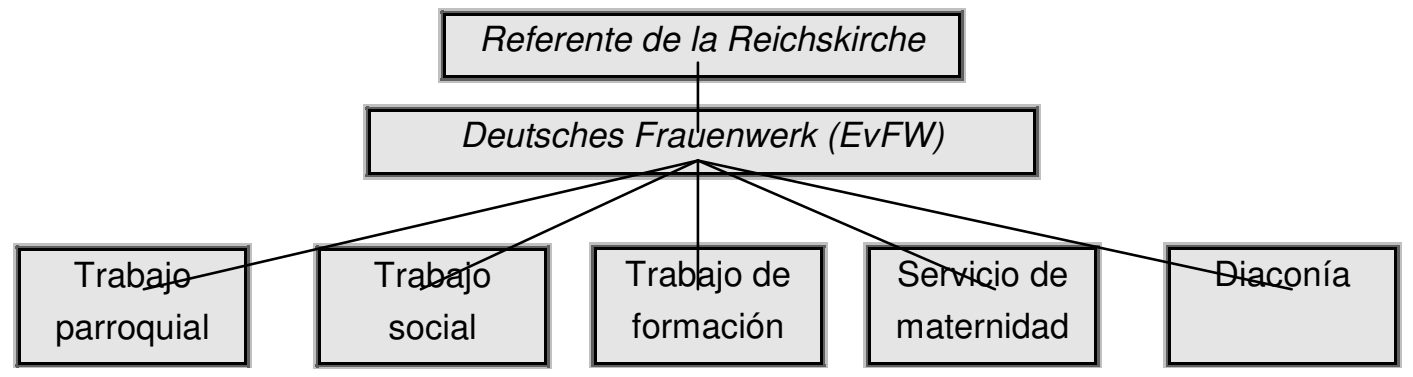

La línea de contacto entre EvFW y la Reichskirche la establece el pastor Klein que desde enero de 1934 actúa como referente del la Reichskirche.

$\mathrm{El}$ peso de la organización del $E v F W$ lo llevan las dos organizaciones más importantes del espectro protestante: la Federación de mujeres protestantes, DEF y el Auxilio Femenino, Evangeliche Frauenbilfe. La primera como canalizadora del trabajo teológico y la segunda, responsable del trabajo práctico en las parroquias.

\subsubsection{El Auxilio Femenino protestante. Evangelische Frauenbilfe}

Las organizaciones de más importancia en el EvFW siguen siendo el Deutscher Evangelischer Frauebund, DEF a partir de 1934 dirigido por Meta Eyl, el Auxilio femenino, Evangelische Reichsfrauenbilfe con Dagmar von Bismarck al frente y el servicio de maternidad dirigido por Clara Lönnies.

El Auxilio femenino era la organización protestante con el más elevado número de miembros. El carácter práctico, toda mujer protestante que trabajaba en las actividades de su parroquia pertenecía a éste, favorece el crecimiento de número de miembros durante la república de Weimar. En 1933 cuenta con grupos locales en toda Alemania, aunque se encuentra numéricamente más representada en el norte, es decir en las zonas protestantes ${ }^{602}$. En 1935 la cifra de miembros ${ }^{603}$ alcanza un millón de mujeres, cifra que al parecer se mantiene constante, si nos atenemos a los datos que aparecen en las actas, hasta $1939 .{ }^{604}$ El Auxilio centra sus trabajo en la actividad parroquial y sus campos de trabajo abarca los grupos de Biblia, trabajo de formación para madres, trabajo en hospitales y guarderías, que estaban en manos de la diaconía.

601 Frau von Oppen: trabajo parroquial, Fräulein Brickenstein: trabajo social, Magdalene von Tiling: trabajo de formación, Klara Lönnies: servicio para la madre. Las cuatro mujeres provienen de la Frauenbilfe.

602 Anhalt, Baden, Bayern, Berlín, Brandenburg, Braunschweig, Bremen, Danzig, Frankfurt, Grenzmark, Hamburg, Hannover, Hessen, Kurhessen, Mecklenburg, Oldenburg, Ostpreußen, Pfalz, Pommern, Rheinland, Sachsen, Schlesien, Schleswig-Holstein, Thüringen, Westfalen, Wiesbaden, Württemberg.

603 LKAH, N10 n²16, Documento sobre funciones y tareas del Auxilio femenino. Diciembre 1935

604 EZA, 7/ 4159, Correspondencia entre el Auxilio Femenino y la direción de la iglesia protesante, 24.6.39 
El trabajo de la organización se ve dificultado con la división que provoca Hermenau en 1935 al fundar un auxilio alternativo dependiente de la iglesia de los cristianos alemanes, donde se rechaza el principio de asociación y el trabajo asambleario que caracterizaba a las organizaciones protestantes y se pretende substituirlo por el principio de autoridad, Führerprinzip. Hermenau intenta poner a la totalidad del Auxilio bajo el control de la iglesia de Müller:

„Como la declaración del 24 de abril del obispo del Reich nos muestra, la única causa de la fundación de un nuevo servicio femenino tiene que ver con el intento de lograr que el Auxilio Femenino apoye a la iglesia de éste.“"605

La organización queda divida entre los grupos que apoyan a Hermenau, y los que se ponen de parte de Dagmar von Bismarck, la cual considera que su organización depende de Agnes von Grone. En 1935 tenemos noticias de las dificultades que tienen los grupos del Auxilio femenino en Berlín que apoyan al Agnes von Grone, cuyo trabajo se ve impedido por las mujeres de la parroquia que apoyan a los cristianos alemanes. ${ }^{606}$

Los grupos del Auxilio femenino de Brandenburg dan cuenta de las dificultades a las que se veían sometidas las mujeres, a costa de las luchas entre los cristianos alemanes y la iglesia confesora, y sobre todo lo importante que era para los dos grupos el trabajo femenino:

„Podemos entender perfectamente cuando las comunidades parroquiales y círculos religiosos, como por ejemplo en Crossen, ingresan en la iglesia confesora y naturalmente que los auxilios femeninos de las comunidades, como organizaciones éstas pasan a depender de la citada iglesia. Sin embargo nos oponemos al procedimiento de los Bruderräte que en el momento en que los círculos religiosos y las comunidades se encuentran bajo la dirección de los cristianos alemanes, utilizan al Auxilio Femenino como instrumento político y religioso para poder influir en estas comunidades." ${ }^{607}$

Desde Brandenburg se aconseja seguir una política de neutralidad y evitar por encima de todo los enfrentamientos entre las dos iglesias:

„Hasta ahora podemos observar en las filas de nuestras organizaciones una disciplina admirable, sin embargo no podemos esperar más tiempo a la declaración de la dirección provincial del Auxilio Femenino. Por lo tanto hemos dado a conocer con la circular del 1 de noviembre que a través de la integración del Auxilio Femenino en la Reichsarbeitsgemeischaft der missionarischen und diakonischen Verbände la posición del Auxilio se ha aclarado. En la circular hemos insistido que todo tipo de trabajo que se haga en dirección a la iglesia confesora, unión de tipo organizativo a ésta o supeditación a los fines de ésta no entra en nuestros planes.“"608

605 LKAH, N10 n 16 , Documento sobre funciones y tareas del Auxilio femenino. Diciembre 1935

606 En Mecklenburg por ejemplo los grupos del Auxilio Femenino se separan de la iglesia oficial y se integran en la iglesia confesora. LKAH, N10, $\mathrm{n}^{\circ} 2$, Sesión del cómite del Auxilio femenino, Potsdam, 1.02.1935

607 LKAH, N 10, n²8, Correspondencia entre el Auxilio Femenino de Brandenburg y Agnes v. Grone, 10.11.1934

608 Ibídem 
En otros casos se encuentra, por el contrario, un apoyo directo, desde el punto de vista personal, a la iglesia confesora:

„El mando y dirección de las asociaciones se encuentra personalmente cercano a la iglesia confesora, aunque esto no significa el apoyo oficial de las organizaciones a ésta." 609

Al igual que el resto de las organizaciones confesionales, entre 1934 y 1935, el Auxilio Femenino va perdiendo sus competencias en el campo práctico: servicios de asistencia social, los patronatos de asistencia a la maternidad, cursos de formación para comadronas, etc., pasan a ser controlados por las NS-Frauenschaften. Desde 1936 a 1941 se puede observar su influencia en acciones puramente religiosas: cursos de Biblia, convivencias para mujeres con temas religiosos, etc. En 1941 para evitar la desaparición total pasa el Auxilio Femenino a ser parte integral de la iglesia protestante. Durante la guerra mundial, retoma el Auxilio Femenino, en muchos casos dirigidos por las esposas de los pastores de las comunidades, la labor que hasta entonces realizaban sus compañeros masculinos.

\subsubsection{La Federación de mujeres protestantes (Deutsch-Evangelischer Frauenbund DEF)}

El DEF, la Liga de mujeres protestantes alemanas se centra en el tratamiento de temas religiosos y teológicos que difunde a través de su órgano de prensa, EvANGELISCHE FRAUENZEITUNG, organiza conferencias de sus representantes; además administra casas de reposo para madres y un seminario „cristiano-social” con sede en Hannover para muchachas. La reacción del $D E F$ respecto al nacionalsocialismo puede calificarse de positiva, aunque evitan por todos los medios definirse políticamente: el movimiento es aceptado, en cuestiones de política declaran su neutralidad. Esta línea de trabajo se fija en un congreso celebrado en Naumburg el 20 de junio de 1933 donde se apoya oficialmente al nuevo régimen, aunque se insiste en el carácter apolítico de la organización y su independencia respecto a cualquier tendencia política:

„La Federación de mujeres protestantes alemanas reconoce a Dios como el señor de los tiempos. Éste toma de la mano al levantamiento nacional que afortunadamente podemos vivir. La Federación se coloca a disposición de la iglesia y se coloca con alegría detrás del gobierno nacional.“ 610

Durante el congreso tiene lugar una conferencia pronunciada por Annerose Fröhlich, Der Ruf an die evangelische Frau im nationalen Staat, „La llamada a la mujer protestante en el estado nacional", donde apela a la mujer protestante a superar su Ichsucht y a trabajar conjuntamente para la patria y el nuevo estado en la familia, en el trabajo y fundamentalmente como madre.

Las actas de las reuniones internas del consejo ejecutivo reflejan el doble juego entre aceptación de la ideología nacionalsocialista, del principio de autoridad, de la política racial, la preservación del pueblo alemán y por otra parte la negación a definirse políticamente, con lo cual se utiliza el aspecto de género como escudo contra todo tipo de definición política:

, El nuevo movimiento nacional que ha conmovido a nuestro pueblo, debe ser objeto de discusión en la Federación. Respondemos a él positivamente pero no

609 LKAH, N10, n², Sesión del comité del Auxilio femenino, Potsdam, 1.02.1935

610 ADEF, A 6, n.o., Circular.20.06.1933 
podemos valorarlo desde el punto de vista político sino nuestra postura ante él es la de la mujer que siente lo alemán." ${ }^{611}$

Junto a otros problemas relativos a la futura organización de la Liga se discute sobre la cuestión racial. Un día después se decide que la liga apoye la idea de que familias alemanas intenten evitar la mezcla de sangre con miembros de otras razas y con extranjeros, que los alemanes compren en tiendas y productos alemanes:

„(...) otro aspecto es el que está relacionado con el papel de la mujer como consumidora. A este respecto tenemos que actuar conscientemente como alemanes, no pensar „popularmente“ desde el punto de vista teórico sino actuar prácticamente. Esto significa no comprar productos alemanes en negocios no alemanes. Para nosotras en la Federación de mujeres protestantes tiene esta cuestión dos partes: por una parte que nuestra decisión depende de nuestra convicción cristiana Pero no obstante mostramos nuestra compresión respecto a las medidas del gobierno por que nosotras apoyamos la naturaleza alemana. La sangre alemana tiene que conservarse en las familias, esto no sólo vale para la mezcla con la sangre judía sino con todo tipo de extranjeros. ${ }^{612}$

De igual manera se intentará que los dirigentes del consejo directivo tengan origen ario, y que aquellos que no lo sean no ocupen puestos de responsabilidad. No obstante, predomina la política de neutralidad como estrategia de supervivencia:

„Tenemos que mostrar alto y claro nuestro apoyo al gobierno. Nuestra posición no tiene que ser insulsa, sino política. En el fondo la Federación de mujeres protestantes es nacional y tiene los mismos objetivos. Sin embargo si nos decidieramos por una postura de partido, la Federación desaparecería en poco tiempo. Nosotras no pertenecemos a un ningún tipo de partido político o económico, al partido nacional alemán o a otros grupos políticos."613

En junio el apoyo al nacionalsocialismo se ha generalizado. No se trata de opiniones personales, sino que las autoras da su confirmación en nombre de la Liga protestante de mujeres alemanas. ${ }^{614}$ El DEF declara su apoyo al nuevo gobierno y se compromete a luchar por el pueblo alemán y la unidad de la iglesia de pueblo. En julio ingresa la Liga en la organización de mujeres protestantes, Evangelisches Framenwerk, EvFW y queda bajo control de Agnes von Grone. El control de la Liga por parte de los nacionalsocialistas se hace más agudo al entre la organización general de mujeres protestantes en la Reichsgemeinschaft Deutscher Frauenverbände, dependiente a su vez del ministerio del interior. La Liga queda incluía en el grupo dedicado al trabajo social y de caridad. Los intentos de Müller-Ortfried de preservar la independencia de la Liga, o las fuertes críticas de Schwarzhaupt quedan en el olvido.

El miedo a definirse políticamente acompaña a la Federación en todas sus actitudes, como por ejemplo la decisión del gobierno de expulsar a mujeres con cargos ministeriales como Gertrud Bäumer levanta entre las organizaciones de mujeres una gran polémica y una oleada de

611 ADEF, A 6, n. o. Actas de las reuniones del consejo directivo, 20. 06.1933 y 21.06.1933

612 Ibídem, p. 5

613 Ibídem, p. 7

614 Klamroth, K.: „Die Neugestaltung der evangelischen Kirche Deutschlands“, EVANGELISCHE FrAUENZEITUNG, Junio 1933 (año 34), pp.133-135; Schwarz, M.: „Unsere Tagung in Hamburg“, EvaNGELISCHE FrAUENZEITUNG, Julio-Agosto 1933 (año 34), pp.145-147 
protestas en forma de cartas al gobierno, donde demuestran su descontento. El DEF, por el contrario decide no tomar partido en el tema por tratarse de una cuestión política. ${ }^{615}$ Mientras que en la misma época en la EVANGELISCHE FRAUENZEITUNG se critica continuamente la decisión del gobierno prescindir de mano de obra femenina en puestos de responsabilidad.

A finales de 1933 la Federación presenta un boceto que define el nuevo programa de la ésta: la reconstrucción del matrimonio, la protección de la madre y del hijo, y el afianzamiento de la familia. La ama de casa tiene una responsabilidad en la higiene social, Volksgesundheit y en su economía. La Federación muestra su disposición para luchar contra la „recesión de la natalidad que destruye al pueblo alemán" y la Aufartung del pueblo.

Las funciones de la mujer aparecen claramente definidas: como Hüterin, protectora y educadora de la próxima generación, como defensora de su feminidad:

„La mujer tiene por lo demás como tarea la construcción de su propio género en una comunidad de las mujeres consciente (Frauentum) y despertar y fortalecer la voluntad femenina para poder estar a la altura de su compañero en la reconstrucción nacional. La mujer tiene derecho al trabajo siempre que su naturaleza se lo permita; y sobre todo es importante el trabajo no es un medio para ganar dinero sino una vocación, que nace a partir de la idea del servicio. Otro de los ámbitos de la mujer es el de las costumbres morales en el arte, la literatura y radio, donde las mujeres protestantes tienen que velar contra las malas influencias, así como en contra de todo tipo de instituciones, burdeles etc., que representan un peligro para la juventud." 616

A partir de febrero de 1934 Meta Eyl substituye a Paula Müller al frente de la organización. Eyl tiene 40 años, es teóloga y representa a la nueva generación de mujeres con estudios que no participa en el proceso democrático de Weimar, su mejor amiga y compañera de trabajo, Grete Gillet la define como:

„Una persona de una gran amplitud intelectual y vitalidad, de grandiosa fidelidad e incondicionalidad se ha ido con ella. Una naturaleza de mando. Una persona soberana que se caracterizaba por su nobleza y limpieza en su pensamiento y en su expresión. A mismo tiempo era también una mujer con un gran atractivo y gracia intelectual, alegría y calor humano. Su figura delgada y alta con la cabeza pequeña y fina, rubia y con ojos azules era la encarnación de la naturaleza nórdica.“"617

El pensamiento teológico de Eyl abandona los planteamientos del protestantismo cultural de von Harnack y se adentra en los primeros años de estudio dentro de los problemas planteados por la teología dialéctica, o también llamada teología de la crisis. Pecado, juicio divino, gracia y su relación con el individuo son los temas sobre los que escribe Eyl durante los años treinta. ${ }^{618}$ Sin embargo poco a poco se distancia de las ideas de Karl Barth.

Sobre las inclinaciones políticas de Meta Eyl no existen testimonios suficientes que nos den información sobre su afiliación ideológica durante la república de Weimar. Más tarde como

615 ADEF, A 2b, Informe sobre la reunión del consejo directivo del DEF, 27.03.1933

616 ADEF, A6, n.o. Boceto de trabajo, 9/10.1933

617 ADEF, Discurso de Grete Gillet en el entierro de Meta Eyl, 2.7.1952

618 Kellner, Hanna: Die Evangelische Frauenzeitung 1930-1941, Arbeit zum Ersten Staatsexamen, Göttingen, 1993 , p. 26 
presidente de la Liga de mujeres alemanas y como directora de la EF aparece como nacionalsocialista convencida, aunque nunca llegó a ingresar dentro del partido.

La nueva presidenta se encargará de dirigir los destinos de ambas durante los años de la dictadura ${ }^{619}$. Su carácter nacional-conservador la hace la persona adecuada para dirigir la organización. El abandono de Müller de la Liga y de la dirección de su órgano de prensa, supone la desaparición de la última baza de las mujeres protestantes provenientes del movimiento de la mujer. No hay pruebas para demostrar que existiera una intervención del partido en el abandono de Müller. La Liga continúa su labor anterior pero cada vez más centrada en temas religiosos, y en una visión de la mujer como madre y educadora de sus hijos, y abandona las posturas que la relacionaban con el movimiento de la mujer. ${ }^{\mathbf{6 2 0}}$

Respecto al número de miembros de la liga se puede observar un incremento en 1933 producto sin duda alguna de la disolución de las organizaciones de mujeres. Sin embargo este aumento no se mantiene a lo largo de los años sino que lentamente la liga va perdiendo miembros. Una de las razones es el elevado número de mujeres en edad anciana, y la falta de mujeres jóvenes dispuestas a ingresar en la organización. Otra de las razones es el abandono de algunas organizaciones, la pertenencia al DEF era corporativa e individual, que un principio se encontraban bajo la dirección de la liga, como por ejemplo la asociación Wort und Werk. ${ }^{621}$

Las tareas de la Federación comprenden la formación de trabajadoras sociales en las parroquias protestantes, la administración de casas de reposos para madres, residencias de ancianos, y hogares de asistencia para adolescentes y mujeres. Estas actividades se mantienen durante la guerra, aunque cada vez más amenazabas por dificultades económicas. ${ }^{622}$

Fuente: Calendarios del DEF desde 1933 hasta 1941

Una de las mujeres que no abandona rápidamente el escenario protestante es Margarete von Tiling. Esta pasa a dirigir uno de los grupos de trabajo del EvFW, y desarrolla una intensa labor

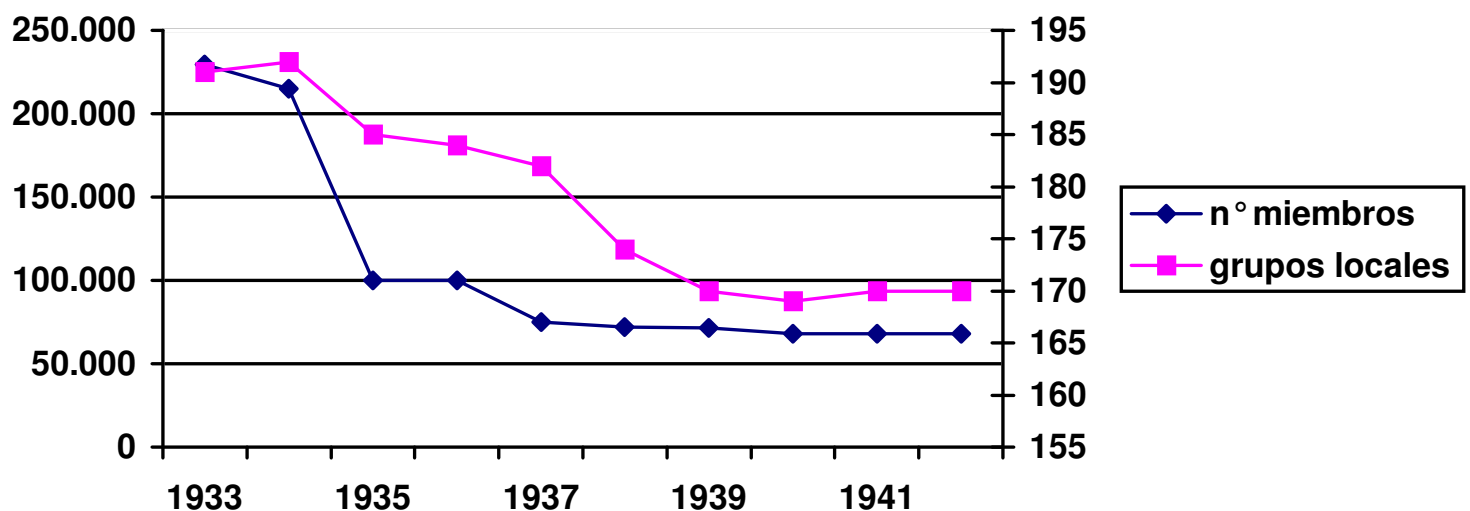

como conferenciante sobre temas de educación, donde se pone de manifiesto su color nacionalsocialista. No obstante sobre ella se escuchan críticas sobre su modo de entender la

\footnotetext{
619 LKAN, LKR V 963 a (2986), 7. Februar 1934

620 Eyl, M.: „Was ist der Deutsch-Evangelische Frauenbund?”, EvANGELISCHE FraUENZEITUNG, Octubre 1935 (año 37), p.2

621 ADEF, A 6p, Informe sobre el DEF, 10.02.1937

622 EZA, 7/3990, Correspondencia entre el DEF y la dirección de la iglesia protestante de Altpreußen, 15.10 .1936
} 
nueva ideología, y en algunas de sus charlas levanta las suspicacias de las autoridades nacionalsocialistas. ${ }^{623}$

\subsubsection{El conflicto entre el EvFW y Gertrud Scholtz-Klink (1934-1937)}

Como ya hemos señalado con anterioridad el 27 de Julio de 1933, Agnes von Grone, miembro del partido y procedente del Auxilio Femenino toma la dirección del EvFW. Es elegida para cuatro años, su puesto depende directamente del Reichsbischof, obispo del Reich, el cual puede en todo momento relevarla de su cargo. ${ }^{624}$ Desde el primer momento von Grone ${ }^{625}$ declara su deseo de participación en la construcción del nuevo estado y su acatamiento de los ideales nacionalsocialistas:

„Conozco los estatutos de la comunidad. Personalmente me obligo a cumplir con estos estatutos en el nombre de mi organización y me esforzaré conscientemente en dirigir y educar a mi organización y a las mujeres que se encuentra bajo mi dirección en el sentido de la ideología nacionalsocialista. Me obligo a la absoluta comunidad y unión con las organizaciones dependientes de la Reichsgemeinschaft deutscher Frauenverbände y reconozco sus estatutos. “ 626

En el primer boceto sobre las directivas de funcionamiento de la organización la dirigente tiene plena libertad de actuación y de negociación. Su actividad esta coordinada por un consejo directivo (Reichsführerrat) compuesto por ella misma, su sustituta, un representante de la iglesia protestante, las dirigentes de los cinco grupos de actuación en los que se divide la organización y un tesorero. Este consejo se reúne tres veces al año. La organización regional del Frauenwerk en las iglesias regionales es exactamente la misma. Esta permanecen en contacto con el consejo central y elaboran conjuntamente las líneas de actuación.

La organización toma carácter oficial al ser reconocida por Frick. Desde entonces von Grone goza de la protección oficial y espera trabajar conjuntamente con las mujeres nacionalsocialistas:

„Su idea era que las mujeres protestantes y las nacionalsocialistas trabajaran juntas en la movilización de bienhechores, fundar nuevas organizaciones, conseguir nuevos miembros o en la creación de actividades que apoyaran el sentir del Führer. Al mismo tiempo las mujeres protestantes deberían tener la posibilidad de decidir cuando y en qué querían participar. Ella (la Liga de mujeres protestantes

623 LKAH, N10, n³2, Correspondencia entre Agnes v. Grone y el DFW, 9.08.1934

624 BDC, OP 6 Band 2, Satzungen des Frauenwerkes der Deutschen Evangelischen Kirche, 1933. Esta disposición es, como veremos más adelante, no será aceptada por las mujeres protestantes, quienes paulatinamente se desligan de la iglesia oficial de los Deutsche Christen.

625 Agnes v. Grone es miembro del partido desde 1933 hasta 1938, fecha en la que será expulsada de éste a causa de su actividad en la organización protestante. Mybes, F.: Agnes von Agnes v. Grone und das Frauenwerk der Deutschen Evangelischen Kirche, Düsseldorf, Presseverband der Evangelischen Kirche im Rheinland, 1981, p.24

626 LKAN, LKR V, 963 a (2986b), Abschrift, Juli 1933. Acta de la declaración de principios en la toma de posesión de Agnes v. Agnes v. Grone como dirigente del Evangelisches Frauenwerk 
alemanas) esperaban mantener una cierta posición de poder respecto al régimen político." 627

Sin embargo un cambio en la dirección de en las estructuras de la organización de las mujeres nacionalsocialistas comienza a minar la unidad del Evangeliches Franenwerk. Las mujeres nacionalsocialistas de la vieja guardia como Siber y Gottschewski pierden control sobre las organizaciones de mujeres nacionalsocialistas que pasarán a ser dirigidas por Gertrud ScholtzKlink y Hilgenfeldt.

El nombramiento de Scholtz-Klink en febrero de 1934 como líder de la organización de mujeres nacionalsocialistas va a dar un giro nuevo a las relaciones entre el $E v F W$ y el $D F W$. Aunque en un principio ésta se atiene al acuerdo establecido con Paula Siber en el se garantizaba a la organización protestante la plena libertad de trabajo, esta etapa se va a caracterizar por los intentos del Deutsches Franenwerk, de ejercer su influencia sobre la organización protestante lo que causará el progresivo deteoramiento de las relaciones entre las dos dirigentes, con la consecuencia de la expulsión del partido de von Grone y su posterior dimisión como dirigente de las mujeres protestantes. Mientras que en la postura de Siber se muestra un cierto respeto por los principios del trabajo confesional de las mujeres protestantes, Scholtz-Klink representa la línea dura nacionalsocialista que se caracteriza por su actitud irrespetuosa respecto a las confesiones católica y protestante. Para Scholtz-Klink no existe un Dios católico o protestante sino una espiritualidad única y especial del pueblo alemán:

„(...) allí donde él está vivo para vosotras, donde vosotras sentís. No en las inútiles y estúpidas discusiones dogmáticas entre teólogos obsesos, no en Biblias viejas llenas de polvo, sino donde estáis vosotras, en vuestras familias, en vuestros hijos. Rezad a vuestro dios, al dios que vive allá arriba, pero no llaméis al dios católico o al padre protestante, al dios confesor o al dios de los cristianos alemanes, ya que sólo hay un dios y un señor que reina por encima de nosotros, y ese es nuestro Dios.“ 628

Con la llegada de Scholtz-Klink a la cúpula de la organización nacionalsocialista pretende extender su influencia a las organizaciones confesionales, que son considerados como miembros más el Frente del trabajo femenino. En este sentido podemos hablar de dos sistemas organizativos que entran en colisión. Por una parte la primera que está dirigida en función del principio de autoridad, por otra parte las organizaciones protestantes conservaban todavía sus „antiguos" métodos asambleario. Aunque durante los años es en realidad el consejo directivo el que se encarga de tomar las decisiones más importantes. Por otra parte las organizaciones protestantes dependen de la dirección de la iglesia protestante lo que les concede una cierta libertad y protección a la hora de exponer sus reivindicaciones ante las mujeres nacionalsocialistas. Sin embargo para Scholtz-Klink esta protección cuenta poco.

En febrero de 1934 von Grone intenta en una carta al Frente del trabajo femenino acentuar la necesidad de limitar los campos de acción entre las organizaciones nacionalsocialistas. Grone intenta fundamentar la necesidad del trabajo de las organizaciones confesionales como pieza fundamental en la „despolitización” de las mujeres y el recobramiento de éstas de los valores de la feminidad en el ámbito familiar cristiano que la república de Weimar había casi eliminado. Si nos atenemos al escrito de von Grone la transición se realizaba de una manera dramática: disoluciones, ataques a los grupos de mujeres protestantes, especialmente en Sajonia, Turingia,

627 Koonz, C.: Mütter im Vaterland..., cit. op., p.284

628 LKAH, N10, n 35, Discurso de G. Scholtz-Klink en Braunschweig, 4.11.1935 
Braunschweig, Pomerania, Hessen, Holstein, Hannover y Württemberg. El trabajo común se establece como medida fundamental para la convivencia de ambos grupos:

„Por esta razón tenemos que evitar los ataques procedentes del partido. Todo tipo de discrepancia personal tiene que ser impedidos. Esto ocurre en un trabajo paralelo sancionando (por el nuevo régimen) estrechamente ligado al espíritu de la verdadera comunidad popular y que necesita la base del cristianismo. Ruego explícitamente una declaración publica que claramente exprese la necesidad del trabajo de las mujeres protestantes y la protección de éste. Este es llevado a cabo por $2 \frac{1}{2}$ millones de mujeres alemanas, de las cuales el $90 \%$ son nacionalsocialistas. Yo garantizo con mi persona el mando nacionalsocialista del Frente de trabajo de mujeres protestantes.“629

En una circular de 1934, Schotz-Klink regula por escrito las relaciones entre las organizaciones religiosas y el Frauenwerk, donde se establecía que sólo las mujeres de funcionarios que no ejercieran funciones directivas en la Frauenschaft o en el partido podían desempeñar cargos de importancia en las organizaciones religiosas, con lo cual impedía que las mujeres preparadas de las organizaciones religiosas hicieran carrera en la organización nacionalsocialista. De éstas se esperaba su preparación en la materia. En un principio se permitía la doble pertenencia a organizaciones del gobierno y religiosas, y en el caso de nuevas fundaciones, éstas tienen que registrarse en la dirección local de la NS- Frauenschaft. 630

Von Grone se queja de la falta de perfil que reciben las organizaciones de mujeres protestantes en el marco general del trabajo femenino, de la poca capacidad de actuación que les queda. ${ }^{631}$ En la misma carta reitera sin embargo su lealtad a la causa nacionalsocialista y su deseo por la continuación del trabajo en conjunto de ambas organizaciones.

La nueva organización da lugar a un cambio entre las relaciones de mujeres protestantes y nacionalsocialistas que alcanzan su punto culminante en una serie de encuentros y comunicados por carta entre von Grone y Scholtz-Klink. Este intercambio de opiniones tiene que ver con la prohibición de Scholtz-Klink el 28 de junio de 1934 de la fundación de nuevos grupos regionales y la aceptación de nuevos ingresos en las organizaciones de mujeres hasta enero de 1935, medida que los grupos religiosos tiene que obedecer:

„Para poder garantizar el crecimiento y la evolución orgánica del Deutsches Frauenwerk, considero en estos momentos necesario que las fundaciones de nuevos grupos locales, así como la admisión de nuevos miembros en las organizaciones asociadas al Deutsches Frauenwerk se paralicen hasta el 1 de enero de 1935. Durante este tiempo se establece como tarea de todas las organizaciones la depuración fundamental de su organización en relación al orden y la disciplina, así como examinar la aptitud y la autenticidad de las dirigentes. En relación a la gran función que nos espera, nos proponemos mejorar el trabajo en conjunto en plena camaradería con la NS-Frauenschaft. (...) Esta prohibición no es válida para la NSFrauenschaft así como para las ramas del partido donde se encuentran organizadas las mujeres. “632 
Una de las primeras reacciones de von Grone y del resto de las mujeres responsables del $E v F W$ fue buscar apoyo en el obispo Müller, sin embargo la Reichskirche no toma ningún tipo de postura sobre el conflicto, lo que motiva que el $E v F W$ se desligue de la dirección de la iglesia del Reich y busque la cooperación con las iglesias provinciales que no aceptan la iglesia de Müller La organización de von Grone se va distanciando poco a poco de la iglesia oficial que no reacciona ante las intromisiones de Scholtz-Klink:

„El 19 de octbre hemos comunicado por escrito al obispo del Reich nuestras preocupaciones y necesidades más serias. No obstante no hemos recibido una contestación al respecto. Desde entonces no se puede hablar de una relación positiva con el obispo.“ ${ }^{633}$

En un escrito del 2 de noviembre de 1934 se opone oficialmente a la decisión Scholtz-Klink de levantar la prohibición en enero de 1935. Con esta actuación von Grone cuestiona el principio de autoridad de la dirigente de las mujeres nacionalsocialistas. ${ }^{634}$

La situación no mejora tras el levantamiento de la prohibición en enero de 1935: las organizaciones confesionales se ven obligadas a presentar listas de miembros al partido, a registrar en ésta todo tipo de encuentro, reunión o celebración.635 Esta es permitida, sin embargo los puestos directivos de la organización protestante sólo pueden estar ocupados por mujeres que no ocupen altos cargos en el partido o en la organización de mujeres. ${ }^{636}$

Ambas organizaciones trabajaran conjuntamente durante unos meses, en especial en los grupos de asistencia social para madre e hijo, en el trabajo para jóvenes y en los programas eugenésicos. Y hasta 1936 controla la organización de mujeres protestantes el servicio social femenino.

Este trabajo conjunto tiene causas de origen táctico. El gobierno nacionalsocialista sabía que no podía prescindir del trabajo de las organizaciones confesionales debido al múltiple trabajo social que estas ejecutaban. El fructífero trabajo entre las dos organizaciones tiene una corta vida. Von Grone no ve con buenos ojos la falta de independencia a las que la organización nacionalsocialista la somete. Esta intromisión en los asuntos de la organización protestante aparece claramente reflejada en el llamado caso Lönnies, encargada de coordinar el grupo número cinco del $\mathrm{E} v \mathrm{FW}$. La organización que presidía Klara Lönnies el Evangelischer Mütterdienst, se desvincula del $E v F W$, y se inscribe directamente bajo jurisdicción de la organización nacionalsocialista. Interesante en el episodio es que, debido al matrimonio de Lönnies con un alemán de ascendencia judía, el $E v F W$ comienza a recibir presiones por parte del $D F W$ para que la organización cese de trabajar con ella. Al parecer las presiones tienen éxito, con la consecuencia que Lönnies pone a disposición su organización y su periódico de la iglesia oficial de Müller, que era como hemos visto con anterioridad una marioneta del régimen nacionalsocialista. La jugada culmina con la expulsión de Lönnies del partido y la permanencia de su periódico en manos nacionalsocialistas. Esto es visto por von Grone como un atentado contra sus propios intereses y una pérdida de influencia y control en su organización. Además de la pérdida de las ganancias que la publicación de la organización suministraba con sus 70.000 ejemplares de edición. El control de la organización de Clara Lönnies por parte de los

633 LKAN, LKR V 963 a (2986 b), Correspondencia entre Meta Eyl y Dagmar v. Bismarck y ScholtzKlink, 10.08.1935

634 Mybes, F.: Agnes von Grone und das Franenwerk der Deutschen Evangelischen Kirche, Düsseldorf, Presseverband der Evangelischen Kirche im Rheinland, 1981, p. 33

635 LKAN, LKR V 963 a (2986 b), 6. April 1934

636 LKAN, LKR V 963 a (2986 b), 10. Februar 1934 
nacionalsocialistas ocasiona las críticas de la iglesia bávara, con lo cual el conflicto supera los límites de las organizaciones de mujeres. ${ }^{637}$

Las tensiones entre Agnes von Grone y Gertrud Scholtz-Klink alcanzan su punto culminante y definitivo cuando a principios del año $1935{ }^{638}$ algunas organizaciones protestantes son obligadas a dar las listas de miembros, en abril la medida se generaliza a nivel nacional. En estas listas se tenía que añadir además si las mujeres miembros de las organizaciones protestantes pertenecían o no al partido o a la organización de mujeres nacionalsocialistas. Tras un acuerdo con Scholtz-Klink está se muestra conforme con que se entreguen únicamente las cifras generales del número de miembros del $E v \mathrm{~F} W$ en los diferentes estados. Una exposición más detallada sobre la pertenencia al NSDAP a las Frauenschaften se deja en manos de los grupos. ${ }_{639}$ Por otra von Grone garantiza con su persona la plena lealtad de su organización a las organizaciones nacionalsocialistas:

„Nuestras federaciones están obligadas a asumir mis instrucciones como dirigente del Franenwerk protestante. Como tal represento a nuestras asociaciones en el Frauenwerk alemán y garantizo la tendencia nacionalsocialista de nuestra obra a través de mi pertenencia al partido“. ${ }^{640}$

En la misma circular en la que se recoge esta negativa, aparece reflejado su desagrado por otra de las medidas tomadas por Scholtz-Klink. Según von Grone es imposible tener informadas a las autoridades locales de cada una de las actividades que cada organización protestante realiza. Esta imposibilidad se debe a que las organizaciones de mujeres dependen del párroco de lugar, de modo oficial, lo que hace imposible que éstas dependan directamente de las NS-Frauenschaften locales. Con este truco se preservaba la independencia de las organizaciones de mujeres protestantes.

\subsubsection{El conflicto con la Iglesia del Reich. 1934-1935}

Paralelo al conflicto con Scholtz-Klink se desarrollan el enfrentamiento de Müller y von Grone. Uno de los motivos de enfrentamiento se debe, como hemos visto antes a la inactividad del obispo ante los intentos de la dirigente nacionalsocialista de limitar la capacidad de acción de la organización protestante. Otro de los motivos está relacionado con las estrechas relaciones que Müller mantenía con los cristianos alemanes.

En 1933 nada dejaba entrever conflictos entre von Grone y Müller, por el contrario ambos trabajaban conjuntamente, hasta que los $D C$ muestran sus aspiraciones a dirigir en conjunto el trabajo protestante femenino.641 En algunas iglesias regionales, Thüringen y Braunschweig dependientes de los $D C$ se intenta eliminar la totalidad del trabajo de las mujeres protestantes en integrar éste en la organización nacionalsocialista. La medida parte de los DC. La no prolongación del plazo sobre la fundación de nuevos grupos el 1 de julio de 1934 marca definitivamente el enfrentamiento entre von Grone, el obispo del Reich Müller y Scholtz-Klink.

Sin embargo no estamos seguros si los motivos de resistencia de von Grone y sus colaboradoras se debe a un rechazo teológico de la doctrina de los cristianos alemanes. En un

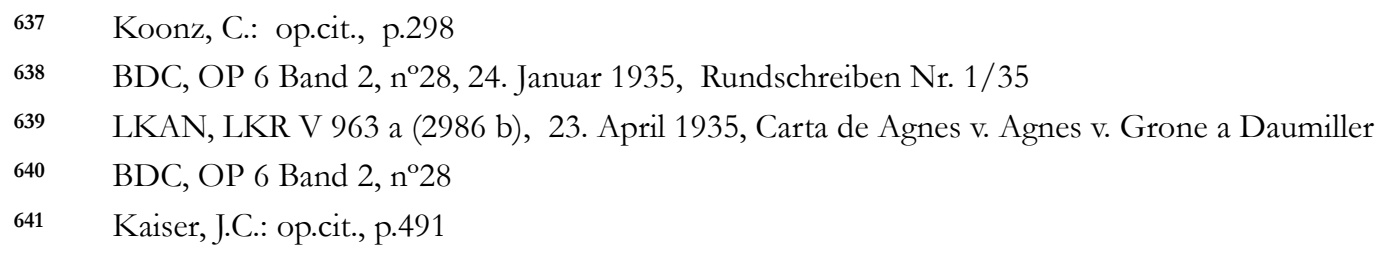


escrito redactado por Meta Eyl, presidente del Deutsch-Evang. Frauenbund y Dagmar von Bismarck, responsable de la Evang. Reichsfrauenhilfe, donde en nombre del EvFW, expresan ante Gertrud Scholtz-Klein su apoyo a von Grone, su independencia respecto a Müller y la Iglesia Confesora, y el daño que la fundación del Frauendienst der Deutschen Evangelischen Kirche, la organización de Hermenau, había causado al trabajo del EvFW. ${ }^{642}$

Esta estrategia de neutralidad no puede considerase exclusiva de las organizaciones de mujeres. Las mismas afirmaciones de neutralidad las encontramos en von Bodelschwingh, director del que el EvFW dependía como organización. Por encima de toda lucha se encuentra una iglesia fuerte, dependiente únicamente de las enseñanzas del evangelio pero por otra garantía del servicio a la Volksgemeinschaft:

„Por otra parte la comunidad de trabajo ha rechazado claramente la inclusión en los órganos de la iglesia confesora, los consejos de hermanos, Bruderäte o a la dirección de la iglesia provincial (VKL 1). Lo mismo se puede decir del frente de trabajo de las mujeres protestantes, el cual no ha pertenecido nunca organizativamente de tal parte. Sin embargo no se puede negar la circunstancia que el trabajo religioso realizado desde esta parte tiene que ver en gran parte con las reivindicaciones de la iglesia confesora. Cuando se ha trabajado en la construcción de una iglesia verdadera que saca su fuerza únicamente del evangelio, se puede servir también a la comunidad del pueblo, Volksgemeinschaft, de una manera correcta. “643

El argumento de la neutralidad aparece también en las organizaciones que se deciden a apoyar a Hermenau. Así por ejemplo el Auxilio Femenino de Silesia justifica las causas de su apoyo a éste:

„El único referente del frente del trabajo dependiente de la iglesia protestante es el Pastor Lic. Hermenau, el cual desde hace 14 años trabaja profesionalmente en el Auxilio Femenino. (...) Por escrito y públicamente insiste una y otra vez en el carácter religiosos del Auxilio Femenino y que por lo tanto tiene que permanecer neutral desde el punto de vista político y religioso, es decir respecto a los cristianos alemanes, a la iglesia confesora, y a la comunidad de trabajo de las organizacines misioneras de la diaconía (la organización de von Bodelschwingh)."644

¿Se trata de una estrategia de supervivencia que ambas organizaciones desarrollan para poder conservar sus áreas de influencia?. ¿Es un método de señalizar reserva ante todo tipo de postura radical?

El deterioro de las relaciones entre Müller y von Grone deriva fundamentalmente de la inactividad de Müller respecto a la política de control de Scholtz-Klink sobre la organización protestante. Es en este momento cuando el Evangelisches Frauenwerk pasa a depender de la organización de la diaconía dirigida por Friedrich von Bodelschwingh (octubre 1934) manifestando de una manera oficial su deseo de distanciarse de la iglesia oficial de Müller. El ingreso elimina todo tipo de deseo de trabajo conjunto y revela la falta de control de los $D C$ sobre las organizaciones de mujeres protestantes. Tal acción se hace a costa de la unidad del

${ }^{642}$ LKAN, LKR V 963 a (2986 b), 10.08.1935, Carta de Meta Eyl y Dagmar v. Bismarck a Gertrud Scholtz-Klink

643 LKAN, LKR V 963 a (2986 b), Bodelschwingh, D. v.: Bermerkungen zur kirchlichen Haltung des Evangelsichen Frauenwerkes; Circular sobre las tendencias religiosas del EVFW

644 EZA, 1C3 191, Circular del Auxilio femenino de Silesia, 22.03.1935 
$E v F W$ ya que una de las organizaciones más importante de éste, la Evangelische Franenbilfe toma partido por la Reichskirche. ${ }^{645}$

La postura de Agnes von Grone se hace cada vez más difícil. Sin el apoyo de Scholtz-Klink y la ruptura con la iglesia de Müller la unidad del $E v F W$ se afianzaba bajo cimientos muy frágiles. Müller es el primero en organizar su ataque. Con objeto de afianzar su control nombra el 2 de marzo de 1935 al pastor Hermenau, conocido por su afiliación a los Deutsche Christen, referente del Frauenwerk der Deutschen Evangelischen Kirche. Es decir Hermenau se convierte en el sucesor de von Grone. Éste funda una nueva organización paralela Der Frauendienst publica una revista RUF AN DIE FRAU, como órgano de prensa de la nueva organización, que curiosamente se reparte como suplemento de la revista de los DC, DER WECKRUF.

En la primavera de 1935 Ludwig Müller proclama como única organización legítima de mujeres protestantes el Frauendienst der Deutschen Evangelischen Kirche. Este acusa directamente a von Grone de su pertenencia a la Bekennende Kirche, y proclama su lealtad al estado nacionalsocialista. ${ }^{646}$

Las relaciones con Gertrud Scholtz-Klink no son tampoco demasiados intensas:

„Que Frau Scholtz-Klink no trabaja con agrado conmigo me lo ha lo ha hecho sentir a menudo. Desde la aparición de Hermenau no me contesta más por escrito, de aquí en adelante telefónicamente a través de su delegada“. ${ }^{647}$

Acusaciones sobre su pertenencia a la Bekennende Kirche, las deterioración de las relaciones entre el consejo de las iglesias, y el rechazo de la organización de mujeres nacionalsocialistas va fraguando la caída de Agnes von Grone. Kaiser señala que este nombramiento se hizo con el asentimiento de la dirección de las mujeres nacionalsocialistas. ${ }^{648} \mathrm{El}$ nombramiento de Hermenau sin embargo no es aceptado por la totalidad del EvFW. Este rechazo provoca una situación ambigua y extremadamente complicada.

Una de las mujeres que desde un principio apoya la causa de Hermenau y Müller es Eleanor Liebe-Harkort, dirigente del Auxilio femenino, en Westfalia, expulsada de éste en 1934 debido a su apoyo público a Müller.649 A pesar de su salida de la organización, Liebe-Harkort sigue exponiendo públicamente un ideario de actuación para la mujer protestante. El verso 1 de la carta a los romanos $n^{\circ} 13$ le sirve como punto de partida para argumentar la no implicación de las mujeres en los asuntos políticos y religiosos. En segundo lugar establece como función fundamental de la mujer tiene la tarea de servir a la comunidad y al pueblo. El trabajo en conjunto con las organizaciones de mujeres nacionalsocialistas es bienvenido. Así como exige de las madres alemanes que envíen a sus hijos a las juventudes hitlerianas. ${ }^{\mathbf{6 5 0}}$

645 LKAN, LKR V 963 a (2986 b), Überblick über die Entwicklung des Frauenwerks der D.E.K., 19.9.1936

646 BDC, OP $6 n^{\circ}$ 9, Frauendienst der Deutschen Evangelischen Kirche

647 LKAN, LKR V 963 a (2986 b), 5. Juli 1935

648 Kaiser, J. C.: op. cit., p.493

649 EZAB, 1/C3/ 185, Circular de Eleanor Liebe-Harkort a sus compañeras de organización, 03.1935

650 EZAB, 1/C3/ 185, Liebe-Harkort, E.: „Was fordert die Studne von der deutschen-evangelischen Frau?, sin fecha 
El nombramiento de Hermenau es únicamente aceptado por las iglesias dependientes de los $D C$ y fieles al obispo Müller, ${ }^{651}$ mientras que la dirección provisional de la iglesia protestante alemana reconoce a von Grone como la representante legítima de la organización:

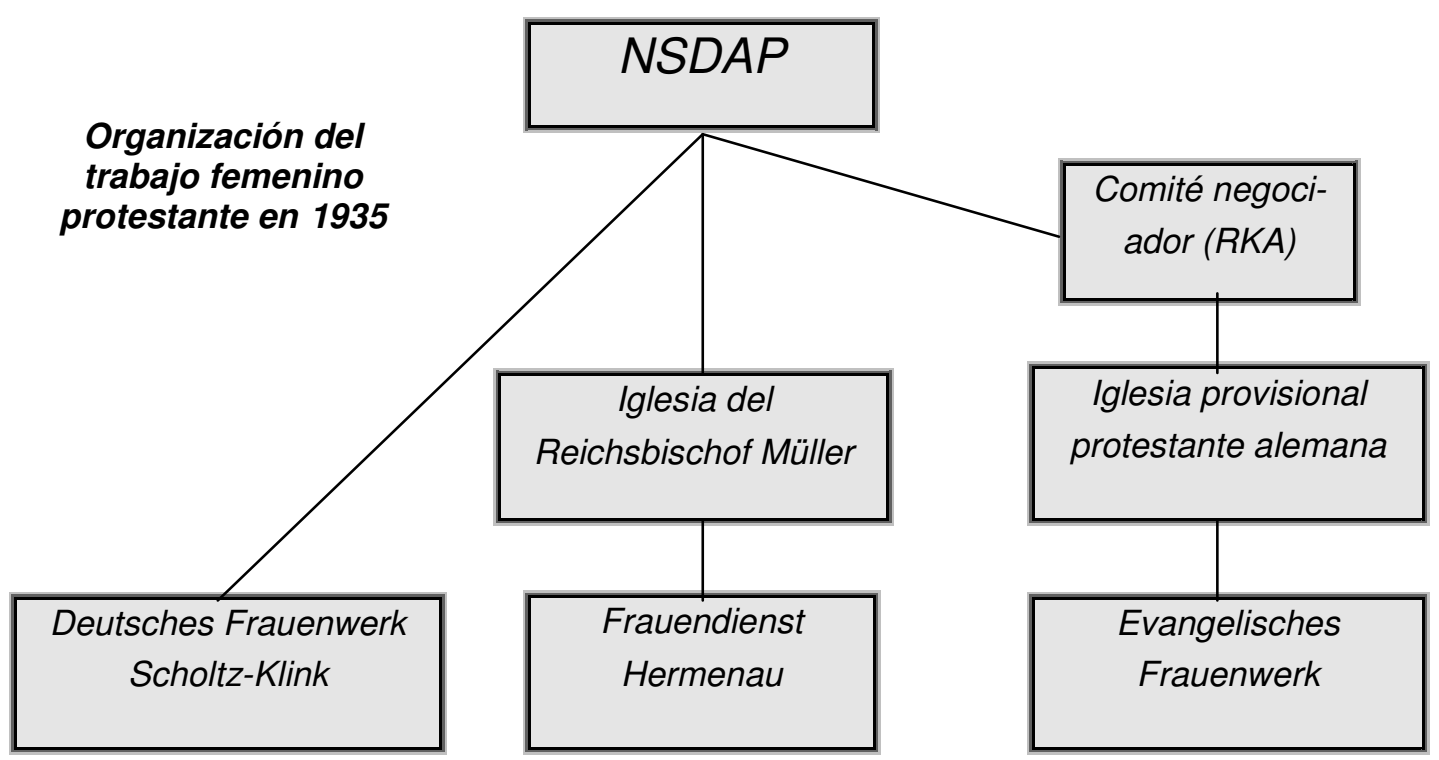

„El obispo provincial no se encuentra en la situación de poder aceptar al pastor Lic. Hermenau como referente de la iglesia protestante alemana para el frente de trabajo de las mujeres alemanes. El pastor Hermenau no ofrece ningún tipo de garantía de defender la libertad de acción y el trabajo de la organización y de la práctica del espíritu protestante y confesor dentro de la organización. Por lo tanto se sigue apoyando a la señora von Grone como la diregente legítima del frente de trabajo femenino protestante. Ella no sólo goza de la confianza de todas las organizaciones de mujeres que se han integrado en la comunidad de trabajo de la obra misionera y diacónica y de las organizaciones independientes de la iglesia, Arbeitsgemeinschaft der missionarischen und diakonischen Werke und freien Verbände der Kirche sino que ha demostrado su carácter como dirigente de la organización de mujeres mejor que cualquiera de los encargados para tal tárea por la Reichskirchenregierung. ${ }^{652}$

El trabajo de Hermenau (iglesia oficial) interfiere cada vez más en el trabajo de Agnes von Grone:

„Él significa la destrucción de la vida de la comunidad, la destrucción de nuestra unidad, y lo que es peor, él (está) en contra de la voluntad de nuestro

651 En 1935 se fundan grupos de la nueva organización paralela en Danzig,Bremen, Hannover, Oldenburg, Rehinland y Brandenburg. DER RUF AN DIE FRAU, Junio 1935,nº 1, p.2

652 LKAN, LKR V 963 a (2986 b), 12. 03. 1935. Carta del Evangelischer Obekirchenrat Wurm a la Deutsche Evang. Kirche 
Führer y canciller del Reich de introducir a la organización de mujeres nacionalsocialistas en la lucha eclesiástica“. ${ }^{653}$

Dos partidos presentan derechos sobre el $E v F W$, por una parte el obispo Müller, por otra parte von Grone que apela al principio de elección de las organizaciones del $E v F W$, las cuáles en su momento la eligieron a ella como dirigente legítima, y señala el aspecto „sancionador” del obispo en la elección. Aunque ni Scholtz-Klink, ni Müller reconocen a von Grone como dirigente del $E v F W$, ésta defiende su puesto ante Müller, sabiendo que con esta decisión cuestiona la autoridad de éste como obispo del Reich y de aquellos que lo había llevado al cargo:

„Yo continuaría mi trabajo imperturblamente, mientras yo pueda lograr algo que permita la permanencia del frente del trabajo de las mujeres protestantes y la consecueción de su trabajao al servicio de la iglesia y del pueblo. Yo continuo trabajando porque me siento apoyada por la confianza que las organizaciones protesntates, nuestras mujeres protestantes ha puesto sobre mi.“ 654

La dirección provisional de la iglesia protestante alemana, que no apoya a Müller, respalda, sin embargo, la candidatura de Agnes von von Grone.: 655

„La dirección provisional de las iglesias protestantes ha tratado en la reunión del 7 de marzo, en la que también participaron la señora von Grone y el director Kunze ámbos pertenecientes al Frente del trabajo de las mujeres protestantes, el tema sobre las consecuencias de las últimas declaraciones del obispo del Reich sobre sus intenciones de destruir la organización. Este se negado a negociar con la señora von Grone, en realidad la representante legal de la organización, y sólo acepta entrar en contacto con un representante nombrado por el mismo. El frente del trabajo para las mujeres protestantes de la iglesia de Baviera ha demostrado su confianza en la dirigente Frau von Grone y la reconoce como la única dirigente de esta organización. El pastor Hermenau, que sólo debe ser reconocido como referente del Franenwerk de la Iglesia Protestante, no ofrece las garantarís necesarias para un trabajo conjunto basado en la confianza mutua. Por lo tanto queda rechazado como referente y dirigente de nuestra organización“. 656

A pesar de la división de las iglesias y la ruptura de von Grone con Müller la mayoría de las organizaciones integradas en el $\mathrm{EvFW}$ apoyan a la dirigente protestante, como por ejemplo organizaciones de vital importancia para las nacionalsocialistas, Bayerischer Mütterdienst im Frauenwerk der Deutschen Evangelischen Kirche, el servicio para madres bávaros de la Liga de mujeres protestantes, cuya dirigente Antonia Nopitsch, estrecha colaboradora de von Grone, se opone claramente Müller. Por estas fechas declara en una carta al obispo de la iglesia regional bávara su apoyo incondicional a von Grone y la necesidad obligada de mantener el contacto con la iglesia oficial dada las dificultades de sobrevivir sin esta:

LKAN, LKR V 963 a (2986 b), 26.031935

654 LKAN, LKR V 963 a (2986), 4.03.1935, Carta de Agnes v. Agnes v. Grone al obispo del Reich Müller.

655 LKAN, LKR V 963 a (2986), 9. März 1935

656 LKAN, LKR V 963 a (2986), 9. März 1935. Carta de la Vorläufige Leitung der Deutschen Evangelischen Kirche al Landeskirchenamt der Evangelisch-Lutherischen Landeskirche in Bayern. 


\begin{abstract}
„Nosotras tenemos a nuestro lado, al lado de Frau von Grone afortunadamente la avasalladora mayoría de las mujeres protestantes. Pero debemos poder contar naturalmente en el último caso con la respuesta positiva de la dirección eclesiástica si el destino puede ser evitado como ha afectado a las organizaciones de jóvenes." 657
\end{abstract}

El apoyo de Nopitsch se ve respaldado por la Reichsframenhilfe que cuenta con casi 900.000 miembros, dirigida por Dagmar von Bismarck. ${ }^{658}$ Esta organización es la que prepara más inconvenientes a von Grone ya que los grupos de las diferentes iglesias, dado su dependencia de las comunidades parroquiales, dependían en algunos casos de la iglesia confesora y en otros de la iglesia de Müller.

Las relaciones en general de von Grone con la Iglesia Confesora se pueden calificar de positivas, lo que hace que se atribuya posteriormente el haber apoyado a la iglesia Confesora. Lo mismo puede decirse del resto de las organizaciones que integran el $E v F W$. Madalena von Waldthausen, dirigente del Auxilio Femenino de la iglesia renana es una de las primeras que apoya la decisión de von Grone de separarse de la iglesia de Müller. ${ }^{659}$ otro ejemplo de apoyo a von Grone lo constituye la asociación de maestras protestantes, Verband für evangelische Religionslehrerinnen, dirigidas por Magdalene von Tiling. ${ }^{660}$

El conflicto se agudiza cuando las representaciones de los diferentes estados del Franenwerk, se ponen bajo la dirección de los correspondientes obispos regionales, con lo que escapan a la dirección de la Reichskirche. Las iglesias de Bayern, Hannover, Altpreußen, Württemberg, Baden y Sachsen, demuestran su apoyo incondicional a von Grone en una acción donde muestran su rechazo a Hermenau: en la acción se manda un escrito al Ministerio del interior en Berlín, la dirección nacional del NSDAP, a la líder del Deutsches Frauenwerk, Gertrud Scholz-Klink y al Reichsleiter Hilgenfeld.

Desde este momento tanto Scholtz-Klink como el ministerio del interior interrumpen sus contactos con von Grone, y únicamente tratan con Hermenau sobre los asuntos del Frauenwerk. La situación llega a extremos paradójicos, pues von Grone es todavía la dirigente legítima de la organización.

A finales de 1935 la iglesia de Müller y sus aliados han perdido sin embargo el apoyo absoluto de los nacionalsocialistas, que por otra parte empiezan a negociar con el resto de las iglesias que se desligan de la iglesia confesora. Desde este contexto se puede entender como el obispo de la iglesia de Braunschweig, Johnsen se encarga personalmente de escribir a la policía política para interceder por von Grone. A todo esto hay que decir que la iglesia de Braunschweig apoya la causa nacionalsocialista:

„La iglesia de Braunschweig, cuya dirección eclesial ha abandonado la política religiosa y que reconoce públicamente a partir de la confesión luterana su apoyo al estado nacionalsocialista, no ve ninguna razón en aceptar las ejecución de medidas político-religiosas contra el Auxilio Femenino y contra la señora von Grone. No

\footnotetext{
657 LKAN, LKR V 963 a (2986 b), 8. März 1935, Nopitz a Daumiller

658 EZA, 7/4159, nº161

659 Cuando se habla de apoyo de la iglesia confesora nos referimos a las posturas moderadas que también defienden las iglesias intactas, que reconocen la declaración de Barmen y que sin embargo más tarde se desligan de la iglesia confesora al entablar negociaciones en 1936 con las autoridades nacionalsocialistas. Los grupos que no acceden al diálogo entran en la clandestinidad, cosa que no ocurre con los grupos de mujeres protestantes.
}

$660 \mathrm{LKAH}, \mathrm{N} 127, \mathrm{n}^{\circ} 35$, Protocolo de la reunión de la asociación, 07.04.1935 
existe ninguna razón en impedir a la legítima dirigente del Frente del trabajo para las mujeres protestantes continuar su trabajo al frente de la organización. “661

Este desinterés en la postura de los cristianos alemanes y el obispo Müller se demuestra en la creación del Reichskirchenausschuß, una comisión presidida por Zoellner, que a partir de 1935 representa a la iglesia protestante alemana y que por deseo del Ministro del Interior Kerrl se encarga desde mediados de 1935 de regular las relaciones entre los diferentes grupos y tendencias. Las iglesias intactas participan en las negociaciones como miembros legales y reconocidos, no ocurre así con el resto de la iglesia confesora cuya negativa a negociar con los nacionalsocialistas conduce a sus representantes a la ilegalidad y a la persecución.

Por otra parte en julio de 1935 sale a la luz la pérdida del juicio procesal contra von Grone, en el que se establecía su expulsión del partido. Èsta decide poner su puesto como dirigente del $E v F W$ a disposición del Reichskirchenausschuß, que a partir de este momento se encarga de debatir sobre el futuro de la organización. ${ }^{662}$

También el $E \nu F W$ se muestra dispuesto a entablar negociaciones con el nuevo comité para llegar a una conclusión respecto a sus relaciones con la iglesia de Müller. En noviembre 1935 se celebra una reunión del consejo de la Ev. Reichsfrauenhilfe y las representantes del Ev. Frauenwerk. En esta reunión se crea, a petición de la misma Agnes von Grone, una comisión de trabajo que se encargará coordinar las negociaciones de su organización con el Reichskirchenausschuß. En esta están presentes: Dagmar von Bismarck, (dirigente del Auxilio Femenino de la iglesia protestante, Frau Braem, Pastor Brandmeyer, Meta Eyl (redactora de la revista EVANGELISCHE FrauenzeITUNG y dirigente del DEF), Frau Kunze, Antonie Nopitsch, (dirigente del servicio de maternidad protestante) Frau. Bäcker y Magdalena von Waldthausen (dirigente del Auxilio femenino de la iglesia renana) ${ }^{663}$. Este consejo se compromete por encima de todo a luchar por la independencia de trabajo del Framenwerk y se declara partidario de la línea no oficial de trabajo en la iglesia:

„Para nadie es un secreto que actualmente tenemos que defender claramente la independencia del trabajo religioso. La pertenencia a la comunidad de trabajo de la obra misionera y diacónica es la línea que define nuestra afiliación religiosa „. ${ }^{664}$

El comité asume las funciones de dirección de la organización y representa al EvFW en todo tipo de negociación que este entable. Otra de las funciones de esta comisión es regular el trabajo de las mujeres protestantes. En un principio se propone crear una asociación general, con lo cual las organizaciones perdería su carácter asociativo. Esta medida levanta grandes protestas entre las diferentes asociaciones que no están dispuestas a perder su autonomía. Las reuniones de la comisión revelan la dificultad buscar una solución adecuada, que permita continuar con el trabajo de las organizaciones, dificultado, día a día por las organizaciones nacionalsocialistas. ${ }^{665}$

661 LKAH, N10, n 33, Correspondencia entre el obispo de la iglesia de Braunschweig y la policía política. 12. 06.1935

662 LKAN, LKR V 963 a (2986 b), 25.07.1935, Carta de

663 LKAN, LKR V 963 a (2986 b), 21.11.1935, Protocol de la sesión entre el consejo directivo del Auxilio femenino (Reichsfrauenbilfe) y la dirección del EvFW. En el comite resultan elegidos: Dagmar v. Bismark, Frau Braem, Pastor Brandmeyer, Meta Eyl, Agnes v. Agnes v. Grone, Direktor Kunze, Antonie Nopitsch, Frl. Bäcker y Frau von Waldthausen.

664 LKAN, LKR V 963 a (2986 b), 27. November 1935

665 LKAN, LKR V 963 a (2986 a), 15.02.1936, Carta de Antonie Nopitshc al Oberkirchenrat Daumiller. 
La oposición a la iglesia oficial no trae, como vemos, automáticamente la resistencia al nacionalsocialismo. No se trata de una cuestión de interpretación, sino en las actas, y demás escritos que tratan sobre el conflicto sobre el $E v F W$ se incide continuamente en el carácter interno y religioso de éste. La oposición a la iglesia oficial de Müller y a sus partidarios, los Cristianos Alemanes, parte de la interpretación, según el resto de las iglesias, incorrecta que éstos hacían de las escrituras, y de la perversión que estos hacían de la fe protestante. También se rechazaba la dependencia de éstos del aparato nacionalsocialista, y se hacía hincapié en la diferencia entre política, gobierno e instituciones religiosas. Por el contrario se afirma tajante la necesidad de continuar la colaboración y el trabajo conjunto con las organizaciones nacionalsocialistas:

„Nuestras relaciones con el Frauenwerk alemán permanecen las mismas. Nosotras realizamos el trabajo en conjunto si se respeta nuestra posición especial como organización confesional. Nosotras nos sacrificamos porque queremos participar en la construcción con alegría, como mujeres alemanas, en la comunidad dentro de nuestro estado nacionalsocialista, el cual protegió en su tiempo a los campos de trabajo confesionales“. ${ }^{666}$

Importante también el aspecto de la conciencia de grupo y de género que existe en las organizaciones como factor a tener en cuenta en el que rechazo que el $E v F W$ siente por la iglesia de Müller. Así señala von Grone en una carta al ministro de interior Frick:

„No queremos una iglesia de pastores que sólo puede reinar con violencia, queremos una iglesia del Reich fuerte y regida por la fuerza del espíritu, que nos una a todos los estados alemanes como bendición de nuestro pueblo y de nuestro estado, para la obra de renovación de nuestro Führer.“667

\subsubsection{El comité de las iglesias del Reich (1936-1937)}

Durante esta etapa el $E v F W$ se caracteriza en primer lugar por la defensa de sus intereses como organización de mujeres y por otra parte la necesidad de la protección de las instituciones eclesiásticas como garantía de su supervivencia frente al aparato nacionalsocialista.

La antigua organización de von Grone sigue manteniendo vivo el viejo espíritu del DeutschEvangelischer Frauenbund y del resto de las organizaciones de mujeres protestantes donde se entendía el trabajo femenino como la traducción de trabajo social, en hospitales, asilos, guarderías, hospicios etc. Actividades que aumentan desde la adscripción del Frauenwerk en la organización de Friedrich Bodelschwingh, desde donde el trabajo femenino se ve fundamentalmente desde la perspectiva del servicio al „otro”. Las expectativas que se tienen de la mujer protestante son fundamentalmente religiosas y tienen una imagen de la mujer muy conservadora. La mujer tiene que estar siempre a la escucha, a la espera de la llamada de Dios. Ejemplo de esa disposición y entrega es Maria, ,porque ella es capaz de oír lo que normalmente

666 LKAN, LKR V 963 a (2986 b), 26 .März 1935

667 LKAH, N 10, n³3, Correspondencia entre Agnes v. Grone y el Ministro de Interior Frick, 31.05 .1935 
es imposible de oír." Tiene que abrir sus ojos y hablar, toda para el servicio de Dios y de la comunidad. 668

Entre los últimos meses de 1935 y 1936 tienen lugar una serie de encuentros entre el Reichskirchenausschuß y las iglesias provinciales que pretenden reorganizar el trabajo de las mujeres protestantes. En marzo de 1936 se presenta una propuesta de acuerdo:

„El 16 de marzo, como consecuencia de negociaciones anteriores, se reunieron los referentes de las iglesias de los estados de Altpreussen, Hannover, Baviera, Würtemmberg, Baden y Sajonia con las representantes para el trabajo femenino en las respectivas iglesias, asó como dirigentes de las organizaciones de mujeres más importantes. Objetivo de esta reunión fue la preparación de las líneas de trabajo para la organización religiosas del Frente del trabajo para mujeres protestantes de la Iglesia protestante alemana." "669

En el acuerdo se establece que el trabajo femenino de la iglesia protestante pasará a estar controlado por las iglesias provinciales. Sin embargo será la Reichskirchenausschuss, la que toma la dirección general de la organización femenina. El presidente del consejo de las iglesias forma un comité consultivo para el trabajo femenino donde están presentes representantes de las iglesias provinciales. Este comité actúa en nombre de la organización central, que llevará el nombre de Reichsstelle der Deutschen Evangelischen Kirche für die Arbeit der evangelischen Frau in Gemeinde und Kirche. $\mathrm{El}$ antiguo Evangelisches Franenwerk pasa al olvido y con él su dirigente Agnes von Grone. Las relaciones entre el frente del trabajo femenino y la organización de Scholtz-Klink pasarán a estar coordinadas por la iglesia protestante y no por los diferentes grupos o las iglesias provinciales.

Durante las negociaciones entre Reichskirchenausschuß e iglesias provinciales se manifiesta desde un principio las intenciones de Zoellner de no incluir a von Grone en el futuro de la organización. En las actas de las numerosas reuniones no se encuentra en ningún momento que von Grone hubiera sido invitada a discutir sobre el futuro de su organización. Esta se encuentra en estos momentos ocupada por conseguir su rehabilitación como miembro del partido nacionalsocialista.

En una reunión mantenida el 14 de enero de 1936 con el Generalsuperintendent de la Iglesia Protestante, Zöllner, éste manifiesta el deseo de prescindir de los servicios de von Grone. En ella utiliza cinco puntos que definen el trabajo de ésta, en primer lugar se le atribuye un falso punto de partida respecto a la iglesia oficial, y al Frauenwerk, una falsa utilización del principio de dirección (Führerprinzip), incorrecciones de tipo jurídico en su atención, y la necesidad de hacer desaparecer el Ev. Frauenwerk si este no se integraba en la Frauenbilfe. 670

Durante la reunión donde tiene lugar el acuerdo definitivo el 16 de marzo de 1936, se deduce según la correspondencia entre el Kreisdekan, de München, Daumiller y el consejo general de las iglesias protestantes, parece darse entendido la no participación de von Grone en la dirección de la organización. Una compañera suya, Antonie Nopitsch, presidente del servicio de maternidad de Bayern, presenta la propuesta de un comité compuesto por tres personas para dirigir el Franenwerk. La propuestas no es aceptada ante el temor de que la cuestión se convirtiera en campo de batalla entre los Cristianos Alemanes y los representantes de la iglesia Confesora. ${ }^{671}$

668 Bodelschwingh: Der Dienst der Frau in der Kirche Jesu Christi. Impresión privada del discurso de Bodelschwingh en Nürnberg, 9. Mai 1935 (EZA, 611 Nr 16, 2-12)

669 LKAN, LKR V 963 a (2986), 23. März 1936. Acta de la reunión del Reichskirchenausschuss

670 LKAN, LKR V 963 a (2986 b), 17. September 1936

671 LKAN, LKR V 963 a (2986), 27.04.1936, Carta del Kreisdekan, Daumiller, en München al consejo de iglesias protestantes. 
Esta actitud contra von Grone despierta la disconformidad de algunas iglesias provinciales. Las iglesias de los estados de Bayern, Baden-Württemberg, Hannover, la diaconía en nombre de Friedrich von Bodelschwingh y el Reichskirchenausschuß (RKA) no aceptan la decisión de Zöllner y escriben expresan individual y conjuntamente su desagrado:

„Se trataba de tomar una doble postura en relación a las acusaciones que se levantaron en el juicio del partido contra Frau von Grone y contra la Iglesia Protestante, especialmente contra la Iglesia Confesora, además de aclarar los malentendidos que tienen lugar entre Frau von Grone y el Superintendente General Zöllner. Para este fin es necesario que a través de las actas existentes se refleje sin completamente la actividad de Frau von Grone como dirigente del Ev. Frauenwerk a lo largo de los últimos años“. ${ }^{672}$

El desagrado se extiende al modelo que Zöllner propone para el Franenwerk, que limita según la iglesia bávara la libertad de acción de cada una de las organizaciones de la organización, y las hace extremadamente dependientes del comité ejecutivo integrado por Zöllner y los representantes de las iglesias provinciales. ${ }^{673}$

Durante el mes de noviembre los miembros de las iglesias independientes mantienen correspondencia respecto al caso von Grone donde se plantean las diferencias entre ésta y el Reichskirchenausschuß, y cuestionan la credibilidad de una organización que trata tan dudosamente el tema von Grone. 674

El 23 de junio de 1936 tiene de nuevo una reunión del Reichskirchenaus-

schuß, donde se reúnen representantes de las iglesias del sur de Alemania, Sajonia, HessenNassau y Hannover. Thüringen, Mecklenburg y Bremen pretenden tomar parte de la reunión lo que levanta las protestas de la iglesia bávara. Finalmente tiene lugar la reunión donde Zöllner señala la necesidad de llegar a un acuerdo en el asunto del Franenwerk, ya que se corre el riesgo de que esta desaparezca si las iglesias provinciales continúan planteando resistencia. A pesar de los intentos de la iglesia bávara de evitar la limitación de la independencia de trabajo del Franenwerk y de incidir en la relación de ésta con las iglesias provinciales, se impone la postura de Zoellner:

„El Frente del trabajo femenino de la iglesia protestante alemana (DEK) es responsable de la generalidad del trabajo femenino religioso en nuestra iglesia. Este está en estrecho contacto con el comité de las iglesias del Reich (RKA), en estos momentos legítimo representante de la iglesia protestante en Alemania. El frente del trabajo femenino está obligado a realizar su trabajo en sus obras y organizaciones desde el punto de vista protestante y evangélico. El comité se encarga de conceder protección al frente dentro del iglesia protestante. El

672 LKAN, LKR V 963 a (2986 b), 11. September 1936, pp.1-2. Documento firmado por el dirigente de la Iglesia bávara Daumiller. Existe otro documento con fecha del 6 de octubre de 1936 que recoje la misma opinión y aparece firmado por: Bodelschwingh, Eger, Daumiller, Bender, Schaal, Niemann y Zänker, todos ellos miembros de la comisión para el trabajo de las mujeres (Ausschuß für kirchliche Frauenarbeit). Otras grupos de mujeres protestantes miembros de la Reichshilfe, no recogidas en el documento, como los grupos de mujeres de Silesia apoyan desde un principio la decisión de Agnes v. Grone.

LKAN, LKR V 963 a (2986 b), Das Frauenwerk der Evangelischen Kirche, pasan a depender de la diaconía. (EZA, 1/C 3/191, ZA 1619/94, nº1)

673 LKAN, LKR V 963 a (2986), 27.04.1936, op. cit.

674 LKAN, LKR V 963 a (2986 b), 3. November 1936, Niemann a Daumiller 
presidente del comité D.Zöllner asume la responsabilidad del cargo de curator dentro de la dirección del Frente.“"675

Mientras tanto desde el Franenwerk laico comienzan a verse las primeras manifestaciones respecto al conflicto en torno a la organización de mujeres protestantes. Gertrud Scholtz-Klink declara el 23 de noviembre de 1936 decisión de prescindir del frente de trabajo de mujeres protestantes. Esta decide dar por terminado el trabajo conjunto con las organizaciones de mujeres protestantes. Las mujeres protestantes tienen la posibilidad de pertenecer a la organización si se inscriben particularmente:

„Falta de claridad y ciertas medidas tomadas por las organizaciones de mujeres protestantes han creado un clima de intranquilidad en las filas de la NSFrauenschaft, por lo tanto me veo en la obligación de hacer la siguiente declaración: La pertenencia corporativa del Frente del trabajo de las mujeres protestantes dentro del frente femenino del trabajo estatal se puede dar por terminada a partir de hoy. Al mismo tiempo apelo a todas aquellas mujeres cuya pertenencia dependía de la pertenencia corporativa de la organización protestante a afiliarse individualmente al Frente femenino del trabajo. Para que entonces cada una de las mujeres alemanas le sea concedida la posibilidad poner a prueba su disposición para trabajar en la construcción del Tercer Reich a través de la incorporación como miembro individual, en vez de la hasta ahora existente afiliación corporativa“. ${ }^{676}$

Los dirigentes del Reichskirchenausschuß reaccionan sorprendidos ante la acción de ScholtzKlink y se esfuerzan en un documento en demostrar su actitud positiva hacia el nacionalsocialismo y los principios del movimiento:

„Nosotros lamentamos este paso extraordinariamente y expresamos nuestra sorpresa de que usted no se hubiera puesto en contacto con nosotros antes de esta decisión tan trascendente. (...) En la historia del trabajo nacional de la Iglesia Protestante alemana tiene el trabajo de las mujeres y de las madres desde hace tiempo una gran importancia“. 677

En el mismo documento se incide en los orígenes del movimiento confesional de las mujeres, donde se exalta su lucha contra las asociaciones liberales y proletarias. De igual manera se exalta el parentesco de las ideas de Lutero con las del nacionalsocialismo:

„El servicio para madres y mujeres fue creado mucho antes de la sublevación, a partir del ideario de la reforma luterana lo cual muestra de una manera muy clara el encuentro histórico, tan esperado por nosotras, entre el evangelio y el nacionalsocialismo“. ${ }^{678}$

Es interesante resaltar como las autoridades eclesiásticas rechazan todo tipo de responsabilidad en la actuación de las dirigentes protestantes y acaban condenando su actuación.

\footnotetext{
675 LKAN, LKR V 963 a (2986), 23.06.1936, Informe sobre la reunión del Reichskirchen-aussschuß

676 LKAN, LKR V 963 a (2986), 23. November 1936

677 LKAN, LKR V 963 a (2986), 7. Dezember 1936

678 Ibídem, p.2
} 
El documento muestra también la profunda tensión entre la jerarquía eclesiástica y las mujeres dirigentes de las organizaciones de mujeres, aludiendo la intromisión de éstas en el Kirchenkampf como una de las causas de la interrupción de las relaciones con las mujeres nacionalsocialistas, no obstante se incide en el deseo de seguir trabajando conjuntamente:

„No es culpa de las mujeres y madres protestantes que hayan sido implicadas en lucha entre las iglesias, no su culpa que las mujeres dirigentes de las organizaciones protestantes motivadas por una gran preocupación e intensa responsabilidad tomaran decisiones en nombre de estas mujeres y madres donde se echaba de menos la importancia de la reformación luterana para el nuevo estado. También tenemos que señalar que estos extravíos y desconciertes del trabajo femenino protestante tienen que ver en gran parte con algunas de las medidas del Frente estatal del trabajo femenino. Ya que nosotros no sólo tenemos una gran responsabilidad sobre la iglesia protestante alemana, sino sobre la totalidad del pueblo alemán, y tenemos interés en que este cambio en las relaciones no sea causa de desavenencias y discrepancias, estamos decididos a prestarle nuestro apoyo en su difícil tarea y estamos abiertos a nuevas negociaciones con usted."'679

No tenemos información sobre cuantas mujeres se afiliaron posteriormente al frente de trabajo nacionalsocialista, ni tampoco conocemos porqué la obra de mujeres alemanas, $D F W$, prescindió tan fácilmente de las mujeres protestantes. Una de las razones puede ser la nueva organización de mujeres de Hermenau, en un principio fundada para desbancar a la organización de von Grone, y según palabras de Hermenau el objetivo de liquidar a la actual dirección. ${ }^{680}$ De hecho Hermenau incita a las mujeres protestantes a que abandonen el $E v F W$ y se afilien a su propia organización. Otras de las razones puede estar relacionada con el cese de las actividades de tipo social que en esta fecha se encontraban ya en manos de las mujeres nacionalsocialistas, por lo que se puede entender que el interés de éstas en las rivales protestantes hubiera cesado.

El trabajo de las organizaciones de mujeres dependen más que nunca de las iglesias provinciales. Esto no significa la ruptura definitiva con el régimen de iglesias y trabajo femenino. El Reichskirchenausscbuß realiza una última apelación a las funciones de las mujeres en las comunidades y grupos de trabajo, y a su responsabilidad con el nacionalsocialismo:

„El comité de las iglesias del Reich ha reconocido oficialmente en una resolución del 25 de junio de 1936 al Frente del trabajo para las mujeres protestantes como órgano de la iglesia protestante alemana. Las secciones del Frente del trabajo se ordenan bajo el mando de las respectivas iglesias estatales. Para que el escrito de la dirigente de las mujeres nacionalsocialistas al Frente protestante no se cree una intranquilidad innecesaria, insistimos que no se puede privar a nuestro pueblo del servicio de las mujeres y de las madres de la iglesia. Las mujeres recogen su fuerza y sus preceptos de la palabra de Dios. Las mujeres quienes ayudar en la renovación de la iglesia. Las mujeres son las protectoras de las costumbres religiosas en las comunidades. Las madres cuidan y conservan las costumbres religiosas en el hogar y en la familia. Las madres se saben responsables de la curación de sus hijos. Las mujeres rezan por el Führer, por el pueblo y por la Iglesia. Convocamos a todas las mujeres protestantes a realizar a realizar esta tarea

679 LKAN, LKR V 963 a (2986 b), 7.12.1936, Carta del Reichskirchenausschuss a Gertrud Scholtz-Klink.

680 EZA, 50/222, 23. Dezember 1935, Richter a Seyferth 
diaria en el Frauenwerk der Deutschen Evangelischen Kirche. Nosotras aceptaremos siempre como una obligación hacer espacio al amor para el servicio de la fe"“. ${ }^{681}$

Una vez reguladas las relaciones entre las diferentes fracciones de la iglesia protestante, el comité de negociaciones deja de existir el 12 de febrero de 1937. La organización se adhiere a líneas nacionalsocialistas y se concentra el trabajo puramente confesional.

Como nueva dirigente del Framenwerk se elige a Frau von Bismarck. La nueva dirigente se enfrenta ya en los primeros días de su mandato a Scholtz-Klink. La diferencia que Bismarck hace entre religión y estado ya había entrado en conflicto en fechas anteriores con las ideas al respecto de Scholtz-Klink:

„Sobre el contenido de su carta (...) puedo solamente decirle que para los nacionalsocialistas no existe una separación entre intereses religiosos y nacionales y que para nosotros es una necesidad, hacer a la jerarquía eclesiástica compatible con las reivindicaciones totalitarias del nacionalsocialismo". 682

\subsubsection{El proceso contra Agnes von Grone}

„He recibido su carta del 10 de agosto, y tengo que refutar que mi rechazo hacia la señora von Grone está relacionado con su comportamiento, que para mí como miembro del partido con un puesto de dirección en una organización de mujeres es insostenible. Mi postura está fundamentada en pruebas objetivas. Pero antes de que el asunto no sea aclarado por la institución adecuada, rechazo entrar en detalles." 683

El conflicto en torno al $\mathrm{E} \nu \mathrm{FW}$ puede entenderse desde varios puntos de vista. En primer lugar sirve de excusa en la lucha de intereses de las diferentes posturas de las iglesias protestantes: los cristianos alemanes, la iglesia confesora y las llamadas iglesias intactas. Por otra parte se convierte en un escándalo político porque pone de manifiesto el interés de la organización de mantener su independencia de acción respecto al aparato nacionalsocialista. El caso von Grone revela como esta independencia no era más que una ilusión, un deseo casi pueril de las organizaciones protestantes. Mientras que las iglesias protestantes intentan llegar a un acuerdo en torno al EvFW, Scholtz-Klink demuestra el carácter político de la situación y pone en marcha la expulsión de von Grone del partido.

La postura de Agnes von von Grone respecto a su organización y al nacionalsocialismo permanece en algunas circunstancias de su actuación ambigua y un tanto complicada de entender. Por esta razón creemos importante hacer alusión a los detalles del proceso de partido que se abre contra ella en cuyas actas encontramos datos de gran interés para nuestro trabajo. Su deseo vehemente de evitar su expulsión del partido, su defensa, sus esfuerzos en demostrar su buen comportamiento nacionalsocialista la hacen una figura difícilmente adecuada para convertirla en un bastión de la resistencia protestante. Es cierto que luchó por preservar la

681 LKAN, LKR V 963 a (2986), 10.12.1936, Betreff: Evangelisches Frauenwerk, 10.12.1936

682 EZA, 7/3990, ZA 1619/94, nº54, 10.08.1935

683 LKAN, LKR V 963 a (2986), 16.10.1935, Carta de Gertrud Scholtz-Klink a Dagmar von Bismarck. 
independencia y neutralidad de su organización, pero no porque cuestionara la legitimidad del nacionalsocialismo, no porque se opusiera a sus ideas y objetivos.

Los orígenes del proceso tienen su origen, en un informe requerido por Martin Bormann (Reichsleiter), a instancias de Rudolf Hess. La encargada de realizar este informe es Gertrud Scholtz-Klink. En el informe se resume la actuación de von Grone y se llega a la conclusión que ésta abandone su puesto como dirigente de la organización protestante para encontrar una nueva mujer digna de este cargo donde se muestre a las mujeres alemanas que „religión y formas eclesiásticas son dos cosas diferentes“. En este se recomienda que von Grone abandone su puesto como dirigente de las mujeres protestantes. Del informe se deduce que Scholtz-Klink mantiene negociaciones con el representante de la iglesia protestante, Marahrens obispo de Hannover, donde decide buscar a una representante más adecuada para la tarea de dirigir al $E v F W$.

Según la dirigente nacionalsocialista von Grone no ha comprendido la diferencia entre el verdadero sentimiento religioso del que se caracteriza la ideología nacionalsocialista y las luchas eclesiásticas desprovistas de toda importancia y debido a su actuación ,antinacionalsocialista” se recomienda su expulsión del partido. ${ }^{684}$

Al final del informe Scholtz-Klink propone una reunión entre la interesada, Hess, Hilgenfeldt y ella misma. Sin embargo Hess no deja a la dirigente nacionalsocialista tomar la iniciativa, sino que a través de Martin Bormann organiza él mismo una reunión el 25 de Junio de 1935 entre Hilgenfeldt, Scholtz-Klink y von Grone. Hermann von Detten coordina el encuentro.

La principal crítica que se hace a von Grone es su rechazo a aceptar la autoridad del obispo del Reich, así como la de crear confusión entre las mujeres de su organización al abandonar la neutralidad en la controversia de las iglesias protestantes. ${ }^{655} \mathrm{~A}$ pesar de la fría objetividad del protocolo se observa claramente la discrepancia entre Scholtz-Klink y von Grone. La primera se niega a trabajar conjuntamente con la líder protestante ya que con su actuación atenta a la disciplina de partido. Otra de las acusaciones que se hacen en contra de von Grone es su apoyo a la iglesia confesora. A esto contesta von Grone que a pesar de que la dirección del EvFW apoya los puntos de vista de la iglesia confesora, se decidió seguir una política de la neutralidad para no poner en peligro la unidad del $E v F W$, ya que en éste se encontraban numerosos miembros que apoyaban a los cristianos alemanes. La disolución de la iglesia oficial se interpreta como un compromiso con el ala que apoyaba a la iglesia confesora.

El rechazo de la autoridad del obispo Müller significa para los nacionalsocialistas presentes en la reunión el abandono del partido:

„A todo miembro de partido se le ha quitado con anticipación todo tipo de facultad decisiva, ya que todo miembro de partido tiene la obligación de apoyar al hombre que el Führer ha designado personalmente. La señora von Grone está obligada como miembro de partido a apoyar en todo momento al obispo del Reich, en caso contrario tiene la obligación de abandonar el partido. Entonces tendría la libertad de decidir a qué parte pertenece.“686

El protocolo de esta reunión pone de manifiesto la contradicción de la política de von Grone y su organización. La lucha de las iglesias es interpretada como una pura disputa

684 LKA, n10, $\mathrm{n}^{\circ}$ 33, Correspondencia entre Getrud Scholtz Klink y Rudolf Hess, 20.05.1935

685 LKAH, N10, n 33. Reunión en el departamento para paz cultural entre v. Detten, G. Scholtz-Klink, Paul, Reichsleiter Hilgenfeldt, Agnes v. Grone y A.Nopitsch, 25.06.1935

686 LKAH, N10, $\mathrm{n}^{\circ}$ 33. Reunión en el departamento para paz cultural entre v. Detten, G. Scholtz-Klink, Paul, Reichsleiter Hilgenfeldt, Agnes von Grone y A.Nopitsch, 25.06.1935, p.2 
teológica, donde la organización de mujeres protestantes, a pesar de encontrarse en ésta partidarias de ambas fracciones, adopta como la neutralidad como la postura más adecuada para preservar la unidad de la organización. El apoyo a la iglesia confesora no es interpretado como crítica al régimen, ni pone en duda la naturaleza totalitaria de éste.

La discusión llega a cotas tan acaloradas que Scholtz-Klink llega a afirmar que si von Grone continúa como dirigente de la organización protestante hará todo lo posible para destruirla.

Ante la negativa de von Grone a abandonar su puesto como dirigente se presenta como única alternativa llevar el caso al tribunal del partido nacionalsocialista para que éste decida sobre el comportamiento de von Grone y si ésta merece seguir perteneciendo al partido. Finalmente se decide iniciar un juicio disciplinar que ponga de manifiesto la actitud antinacionasocialista de von Grone:

„Frau von Grone es miembro del partido pero le faltan las cualidades de una nacionalsocialista. En este punto se haya la causa de las desavenencias personales y de la imposibilidad de trabajo conjunto con Frau Scholtz-Klink en el Deutsches Framenwerk. Aunque hay que reconocer que a Frau von Grone se le ha asignado una difícil tarea y que ella ha actuado subjetivamente y sin culpa influida por el frente de la Iglesia Confesora. A pesar de todo permanece el reproche de que ella no se ha comportado ni ha actuado de ninguna manera como una nacionalsocialista. Por el contrario, ella ha introducido conscientemente en la lucha religiosa en el Evangelisches Frauenwerk y por consiguiente en el Deutsches Frauenwerk. A si mismo Frau von Grone ha inquirido contra una de las importantes fundamentales leyes del nacionalsocialismo ya que no ha contribuido a fomentar la verdadera comunidad del pueblo entre las mujeres alemanas, sino en gran medida a dañarla“". 687

El proceso comienza el 12 de Agosto de 1935 en el tribunal provincial (Gangericht) de Hannover-Süd / Braunschweig en la ciudad de Hannover y finaliza el 4.9.1935.

Se la acusa de haber contribuido a destruir las relaciones armónicas entre las organizaciones de mujeres y de haber creado un clima de división en las organizaciones protestantes de mujeres tras haber abandonado la política de neutralidad. Como último punto de la acusación se señala su falta de disciplina como miembro del partido nacionalsocialista.

Como pruebas se presenta la correspondencia entre Scholtz-Klink y los testimonios trece responsables de las organizaciones nacionalsocialistas. ${ }^{688}$

La primera negociación comienza el 26 del mismo mes. Agnes von von Grone interpone una nueva apelación para que el proceso sea revisado. Los resultados son, sin embargo negativos: la apelación es sobreseída y Agnes von Grone es expulsada del partido.

El juicio se basa en las declaraciones de trece dirigentes de las NS-Frauenschaften de la región de Süd-Hannover-Braunschweig que testimonian la actitud negativa de las mujeres protestantes de la zona respecto al nacionalsocialismo. En algunos lugares se impidió la creación de un grupo local de la Frauenschaft, en otros testifican la abierta oposición al nacionalsocialismo de una líder del Auxilio protestante femenino (Evangelische Frauenhilfe). ${ }^{699}$ En las actas se citan situaciones similares en Baden y Prusia del este, donde se observa la misma situación de enfrentamiento. De esta situación de enemistad respecto a las organizaciones nacionalsocialistas se hace responsable

687 Mybes, F.: „Widerstand wider Willen. Das Verfahren gegen Agnes von Grone vor den Gerichten der NSDAP”, MONATSHEFTE FÜR EVANGELISCHE KIRCHENGESCHICHTE DES RHEINLANDES, 1986 (año 35), p.227

688 LKAH, N 10, $\mathrm{n}^{\circ}$ 33, Acta del tribunal provincial Hannover-Braunschweig del NSDAP, 12.08.1935

689 LKAN, LKR V 963 a (2986 b), 20. 03. 1936, Actas del proceso contra Agnes v. Agnes v. Grone, p. 3 
a Agnes von Grone, que como dirigente de la organización tenía la obligación corregir esta actitud negativa hacia las organizaciones nacionalsocialistas.

En particular contra Agnes von Grone se destaca su falta de cooperación ante las medidas realizadas por Gertrud Scholtz-Klink y la incitación a la oposición en las filas de la organización protestante. Según las acusaciones von Grone impidió el trabajo armónico entre ambas organizaciones:

„A comienzos de 1935 la dirección de la organización del Reich mandó un informe a las organizaciones coordinadas por el Deutsches Franenwerk con la petición de referir sobre el número de miembros que pertenecen al partido. Estas demandas fueron también enviadas al Evangelisches Franenwerk y a las organizaciones dependientes de ésta. Como respuesta aconsejó la acusada a las organizaciones a las organizaciones dependientes de ésta contestar al NSFrauenschaft que el Evangelisches Franenwerk es una organización independiente y que depende únicamente de ésta (Frau von Grone)“. ${ }^{690}$

La afirmación de querer permanecer independiente es para las autoridades nacionalsocialistas un acto de oposición:

„De esto se deduce especialmente que en contra de una pura medida organizativa de recuento de miembros de las diferentes asociaciones con la interpretación tendenciosa de intromisión en los asuntos religiosos y en la independencia de la iglesia, (que la acusada) ejerció resistencia general“ “. ${ }^{691}$

Otra de las acusaciones es la de introducir la lucha existente en la Iglesia Protestante en el Franenwerk, al enfrentarse al obispo Müller y a Hermenau. De este enfrentamiento se suponía su apoyo a la Bekennende Kirche:

„A través de este paso, la acusada ha abandonado oficialmente el ámbito de la neutralidad político-religiosa y ha creado entre las mujeres alemanas dirigidas por ellas un desconcierto increible. La acusada ha contribuido ha extender con esta política una amplia intranquilidad, sino conflicto de conciencia, sino que lamentablemente ha inducido a error sobre la posición de la NS-Frauenschaft y sobre del partido sobre la cuestión religiosa para poder afirmar su posición de poder como dirigente de una organización de dos millones de miembros““. ${ }^{692}$

Esta postura divide, según la dirección del partido a las mujeres en dos frentes, partidarias del Ev. Franenwerk y las dependientes de la Reichskirche. División que atenta contra los intereses del partido y de la organización de mujeres, temerosos ante el nacimiento de focos de resistencia:

„Esta demanda demuestra que un gran número de las Frauenbilfe muy particularmente las que tienen una actitud de desconfianza, de incomprensión, cuando no de rechazo o de hostilidad respecto al nacionalsocialismo. Esta actitud

\footnotetext{
690 LKAN, LKR V 963 a (2986 b), 20. 03. 1936, Actas del proceso contra Agnes von Grone p.5

691 Ibídem, p.5

692 Ibídem, pp.6-7
} 
es más fuerte donde el clérigo, que tiene una influencia especial sobre la Frauenhilfe local, que rechaza el nacionalsocialismo o a menudo lo combate“. ${ }^{693}$

Según los testimonios de dirigentes regionales nacionalsocialistas eran muchos los casos donde los grupos de mujeres protestantes, dirigidos por el párroco del lugar, se mostraban reacias a trabajar con la organización nacionalsocialista.

Como conclusión se considera que la acusada ha trabajado en contra de las tareas de renovación del Führer. La última acusación se refiere a la disciplina de partido, y a la utilización de su pertenencia a éste para afianzar su puesto en la organización protestante. Su afiliación al partido está por encima de su confesión, por lo cual la desobediencia de las consignas de Scholtz-Klink, entran en contradicción con su ,apasionada defensa“ de los valores nacionalsocialistas.

Únicamente cuatro testigos testifican a favor de von Grone, el resto dirigentes locales nacionalsocialistas corroboran las acusaciones de Scholtz-Klink. La defensa de von Grone niega todas las acusaciones que se le imputan, resalta los servicios de von Grone como dirigente de la organización de mujeres protestantes e insiste en su apoyo a la ideología nacionalsocialista personalmente y al mando de la organización:

„Para nosotros la orden que el Führer dio a conocer el 21 de marzo de 1933 se ha convertido en pauta de nuestra actuación: las confesiones deben trabajar en la construcción de la iglesia teniendo como objetivo el fortalecimiento del estado cristiano. Esto se convirtió para nosotros en la tarea que el nacionalsocialismo esperaba de nuestro trabajo evangélico.“694

La resolución del juicio se hace muy rápidamente. Esta tiene lugar un mes después, concretamente el 4 de septiembre de 1935 donde se asumen las acusaciones y se decide la expulsión de von Grone del partido.

Unos meses después von Grone reclama la decisión del juicio disciplinar ante el Oberstes Parteigericht el 10 de Octubre de 1935. Unos meses después el 20 de marzo de 1936 la citada cámara sobresee las reclamaciones de von Grone y ratifica la decisión del tribunal popular dando por supuesto la expulsión del partido de la acusada. El 30 de Junio del mismo año el juicio es oficial. En diciembre del mismo año en una carta de Daumiller a von Grone todavía se piensa en una posible rehabilitación política. Aunque se es consciente del agravamiento de la situación religiosa y del empeoramiento de las relaciones entre los obispos de las iglesias independientes y el gobierno nacionalsocialista.

„A través del obispo regional Meiser he sabido que la sentencia actual no es definitiva y que la revisión del proceso es posible. Esto me alegra mucho porque su deseo de rehabilitación respecto al gobierno puede ser satisfecho, (aunque por otra parte) una reclamación de los obispos ante el partido en este momento le haría más daño que beneficio“. 695

Von Grone se encuentra fuera de la organización, sus intentos de continuar el trabajo con las nacionalsocialistas, por un lado y los ataques de éstas a las organizaciones protestantes, le retiraron su credibilidad para la jerarquía eclesiástica. En una carta se queja de la falta de apoyo

693 BDC, OP 6 Band 2, 4. September 1935, Beschluß

$694 \mathrm{LKAH}, \mathrm{N} 10, \mathrm{n}^{\circ} 33$, Correspondencia entre Agnes v. Grone y el presidente del tribunal provincial, 13.08.1935

695 LKAN, LKR V 963 a (2986 b), 2. Dezember 1936, Daumiller a Agnes v. Grone 
para su causa por parte de la iglesia, y de los malentendidos que su actuación creo en ambos lados:

„De esta manera me afectan las acusaciones personalmente no en mi cargo en la iglesia, sino como miembro del partido. El que yo entendiera las ofensas contra mí y no contra nuestra obra, fue entendido como una debilidad por mi parte ya que yo seguí luchando por un trabajo conjunto en el Deutsches Framenwerk.". ${ }^{696}$

El 15 de junio de 1937 von Grone reclama de nuevo la revisión del proceso, ya que la situación ha cambiado. Müller ha dejado su cargo como obispo de la iglesia oficial, con lo cual se puede hablar de nuevo de una unión de las diferentes organizaciones de mujeres protestantes. Además reclama la acusada un nuevo proceso dónde haya una mayor representación de testigos con relación a la iglesia protestante, mujeres y dirigentes eclesiásticos que puedan valorar su función como líder protestante. Esta petición era en el fondo justa ya que en el juicio anterior, esta representación era muy pequeña. Esta vez sin embargo tardé más tiempo en recibir respuesta hasta que se decide la reapertura del proceso, no será hasta el 18 de noviembre de 1938. Sin embargo aunque se decide no castigar a von Grone, se mantiene la decisión de expulsarla del partido.

A pesar del renovado fracaso von Grone escribe de nuevo al tribunal superior del partido para expresar su decepción como cristiana y nacionalsocialista:

„Mi actuación y sus resultados ha sido en todas partes entendida, yo he intentado cumplir siempre con mi deber, no sólo como cristiana en el trabajo protestante, sino como nacionalsocialista, y a través del trabajo positivo en conjunto, me he esforzado en superar la desconfianza existente contra la organización protestante“. ${ }^{697}$

El Ministerio del Interior, sin embargo no estima como sincera la actitud de von Grone. Por el contrario estima que ésta ha utilizado su pertenencia al NSDAP para favorecer a la iglesia protestante, concretamente al círculo de la Bekennende Kirche:

„Por lo tanto no tengo ninguna duda de que no sostengo a Frau Agnes von Grone como aceptable. Ella ha introducido a través de su posición políticoreligiosa la división en éste y ha impedido que un considerable número de mujeres alemanas se halla comprometido con el trabajo del Deutsches Franenwerk. Además de esto como miembro del partido no ha aceptado ninguna obligación de obediencia, mucho más ella ha utilizado su pertenencia al partido y la autoridad de éste para sus propios fines. Mientras que ella más de una vez juró seguimiento leal al DEF, ha hecho todo lo contrario en declaraciones y órdenes. Ella ha extendido por lo tanto desconcierto en los círculos de las mujeres protestantes y consciente o inconscientemente ha contribuido a hacer mayores las diferencias entre la Iglesia Protestante y el nacionalsocialismo“. ${ }^{698}$

Otras de las críticas que recibe von Grone es la de colaborar con las tendencias antinacionalsocialistas existentes en la iglesia protestante:

\footnotetext{
696 LKAN, LKR V 963 a (2986 b), 5. Juli 1935

697 BDC, OP 6 Band 2 n55, 28. Oktober 1936, Agnes v. Grone al Tribunal Superior del partido.

698 BDC, OP 6 Band 2 n40, 13. Mai 1936, El Ministerio del Interior al Partido Nacionalsocialista Alemán
} 
„Los clérigos protestantes pertenecen en su totalidad a los más fanáticos y a través de su influencia sobre las partes más valiosas de la población, especialmente sobre las mujeres son los adversarios más peligrosos del movimiento. Es difícil de creer que la valerosa e inteligente camarada de partido von Grone agraciada con todas las características exteriores e interiores de la raza nórdica no se de cuenta de que su postura respecto a la dirección del DFW apoya la causa de los adversarios del movimiento“. ${ }^{699}$

El asunto se ha convertido de vital importancia para las autoridades nacionalsocialistas. Ante la incertidumbre de los miembros del partidos, entre los que se encontraban un gran número de protestantes, y temiendo una posible intranquilidad entre la población ,recomienda la directiva del partido, a instancias de Scholtz-Klink y Rosenberg una aceleración del proceso de partido que se celebra contra von Grone. ${ }^{700}$

La lucha contra von Grone se extiende en 1937 contra su esposo, Siegfried von Grone, al igual que su mujer miembro del partido, ocupa una posición importante como dirigente local de los agricultores en Westerbrak, lugar donde reside la familia. El 16 de julio de 1937 se inicia una investigación preliminar de su caso. En ella se aconseja que se le revele de su cargo. Argumentando su mala salud, debido a una herida de guerra, y según los informantes, dependiente de la voluntad de su esposa, se aconseja que se retire de su cargo.

Por otra parte se critican sus tendencias monárquicas, debido a su parentesco con la línea de los Herzog, tendencias que ha tomado fundamentalmente de su esposa. ${ }^{701}$

\subsubsection{El trabajo del „Evangelisches Frauenwerk“ a partir de 1937}

Una vez finalizado el conflicto en torno a von Grone, el $E v F W$ entra en una nueva etapa que está caracterizada por problemas de reestructuración, la lucha contra el FD, el empeoramiento de las relaciones con el DFW y los ataques continuos de la policía política y el control de la Gestapo. A ello se une la desaparición del RKA con lo que se presentan de nuevo problemas en torno a la relación entre organizaciones religiosas y estatales..

En noviembre de 1937 es efectiva la destitución de von Grone, y son encargados de dirigir la organización Dagmar von Bismarck, Meta Eyl, Toni Nopitsch y el pastor Brandmeyer. ${ }^{702}$ Estas fundan el Neunerausschuß des Evangelischen Frauenwerks, un consejo formado por nueve miembros, donde intentan retomar el control de la organización.

Desde el punto de vista del conflicto entre la BK, la organización se muestra abierta a un compromiso y colabora activamente en los RKA. El nuevo órgano que representaba a la iglesia protestante. El control sobre los grupos de mujeres protestantes se había hecho durante los años 1935 y 1936 cada vez más intenso. La policía secreta informa periódicamente sobre reuniones religiosas celebradas en lugares públicos, ante una posible utilización de las tardes de

699 BDC, OP 6 Band 2 n¹2, 16. Oktober 1935, NSDAP al Tribunal Superior del Partido

700 BDC, OP 6 Band 2 n 41, 3. Januar 1936, NSDAP al Tribunal Superior del Partido

701 BDC, OP 6 Band 2, 16. Juli 1937, NDSAP al dirigente regional Knop

702 Schaeffer, S.: „Aus der evangelischen Frauenarbeit”, EVANGELISCHE FrAUENZEITUNG, 1938 (año 39), p.106 
mujeres para avivar las tensiones existentes entre iglesia y estado, se prohiben. ${ }^{703}$ Durante estos años casi todas las organizaciones de mujeres protestantes son paulatinamente disueltas, o son expuestas a un tremendo control.

A pesar de los problemas, discusiones el trabajo de la organización continúa, especialmente en la iglesia regional de Baden. Aunque muchas de las tareas dedicadas al trabajo social de las mujeres que un principio llevaba la iglesia regional, habían sido retomadas por la organización nacionalsocialista, se continúan organizando encuentros, charlas, conferencias donde las mujeres se reúnen por unos días. Los temas son en la mayoría de los casos de carácter religioso. En los encuentros participan mujeres de la vieja guardia, antiguas compañeras de von Grone, Meta Eyl y Toni Nopitsch. Existe pues una continuidad. Desde la tribuna se reflexiona sobre el papel de la mujer en la iglesia y en la sociedad, y se incita a ésta a ejecutar una labor de misión. Esta labor „misionera“ afecta fundamentalmente a la madre:

„En ningún momento de nuestra vida, así como en el hogar y la familia podemos apartarnos de la vitalidad de esta época. La madre cristiana, la hermana juegan un papel decisivo. Los hijos en edad escolar, los hijos e hijas mayores que vienen del trabajo, el marido. Todos vienen con preguntas a casa. Aun cuando a veces es difícil estar a disposición de todas en la estrecha vida familiar, la madre tiene la oportunidad de transmitir y dar su fe“. ${ }^{704}$

La madre, la mujer actúa sobre las cosas pequeñas, cuando los demás duermen, sin que los demás se den cuenta. A su manera pueden realizar „milagros increíbles“, y pueden sanar lo que esta enfermo. Las metáforas de la mujer como salvadora, como sabia escondida que reproduce el bien en sus semejantes se repiten en estas tardes, en estos congresos mientras que en la radio, en las plazas se apela únicamente a su condición biológica maternal.

En el informe de estos encuentros no se cita ningún acontecimiento político, ni si quiera se hace referencia al Führer, o a términos como pueblo, comunidad etc. A principios de 1937 tienen lugar en Halle encuentros de mujeres protestantes relacionadas con la Bekennende Kirche. ${ }^{705}$ En el frio Febrero se reúnen doscientas mujeres para reflexionar sobre la situación de la mujer en el mundo actual. Los temas que se tratan son exclusivamente religiosos: la mujer en la Biblia, la mujer en la familia y el matrimonio, la mujer y el mundo superfluo. En todos los discursos aparecen términos que nos son conocidos: Gehorsam y Opfer. Obediencia y sacrificio como cualidades esenciales de la mujer, que definen su papel y su modo de actuar y ser. Términos que van adornados de dienen y warten. Servir y esperar.

Sin embargo el control por parte de las autoridades nacionalsocialistas continúa. En Febrero del 38 se prohibe a instancias de la policía secreta el nombre de Evangelisches Franenwerk por que da lugar a confusiones entre las mujeres. El nombre se prohibe en los sellos, cabezas de carta, periódicos y hojas informativas, etc. ${ }^{706}$ A pesar de los intentos de von Grone por convencer a la jerarquía eclesiástica de ejercer un poco de presión, estos deciden que la protesta no tendrá ningún éxito. Finalmente se elige el nombre Frauenarbeit der DEK, trabajo femenino de la iglesia protestante. ${ }^{707}$

703 EZA 1/(3) 186, 25. März 1936, Carta de una dirigente local a la Policía Secreta

704 LKAN, LKR V 963 a (2986 b), 12. Juli 1937, Mitteilungsblatt des Frauenwerks der Evangelischen Landeskirche in Baden

705 EZA, 50/222, ZA 1620/94, n²22, 18 y 19

706 LKAN, LKR V 963 a (2986 b), 26. Februar 1938, Tagebuch Nr. A.1202

707 LKAN, LKR V 963 a (2986 b), 7. März 1938, Daumiller al Consejo de iglesias regionales protestantes 
El trabajo continúa de una manera desorganizada. Los pequeños grupos de mujeres continúan reuniéndose en un trabajo que es difícil de valorar dado la existencia de fuentes. Prueba del clima de enrarecimiento que sufren las organizaciones protestantes son las elecciones que tienen lugar en 1937 en la iglesia protestante. En una circular sobre el tema se incide en el peligro que todavía constituyen los cristianos alemanes para la unidad de la iglesia, así como la política de desprestigio que estos propagan. Entre las críticas que se aducen a ésta son el origen judío del $40 \%$ de los pastores, los contactos entre cardinales católicos y pastores protestantes como prueba de la futura dependencia de la iglesia protestante de Roma, la financiación americana de la iglesia protestante con capital judío y masónico, etc.

En los protocolos de trabajo de 1937 de algunas organizaciones como por ejemplo el servicio maternal bávaro, Bayerischer Mütterdienst, se caracterizan también por un tono reservado que no tiene nada que ver con las eufóricas demostraciones de 1933. Se es consciente las dificultades que el trabajo religioso conlleva, a pesar de la supuesta protección de la que gozan las instituciones religiosas:

„No es el camino de la madre especialmente importante en épocas en las que el cristianismo pasa por momentos de crisis? La madre determina el espíritu que reina en el hogar, ella refuerza al hombre en la fidelidad al evangelio a través de su propia perseverancia, de ella depende en último término si los hijos son educados como verdaderos cristianos." 708

\subsection{La prensa de mujeres protestante}

El estudio de la prensa de mujeres protestante se revela como una tarea de gran interés para un/a historiador/a. A diferencia de otras publicaciones para mujeres (revistas ilustradas, prensa del corazón) o la prensa de sucesos, donde la existencia de un discurso homogéneo es a veces difícil de establecer, presenta la prensa confesional una homogeneidad debido a su relación con las organizaciones de mujeres protestantes, y a su carácter en muchos casos de órgano de prensa de éstas. Esta homogeneidad permite reconstruir de una manera muy detallada las reacciones de los diferentes grupos de mujeres protestantes respecto al nacionalsocialismo y los procesos de adaptación en el nuevo régimen ${ }^{709}$. Al tratarse de una prensa para mujeres, el aspecto discursivo sobre los papeles de los géneros en la sociedad es uno de los temas que se tratan como exhaustividad. Para ello analizaremos en primer lugar los discursos sobre la naturaleza de lo femenino y sus parecidos y diferencias con el ideal nacionalsocialista. Y en segundo lugar nos ocuparemos de establecer la postura de la prensa de mujeres las mujeres protestantes en función de la relación de la iglesia protestante y el nacionalsocialismo. El análisis se centra también en las divergencias o paralelos del discurso desde un punto de vista cronológico. El período que nos ocupa transcurre desde 1933 hasta 1941, fecha en la que la mayoría de las publicaciones de la prensa confesional dejan de aparecer debido a la política de racionalización que ocasionaba la economía de guerra.

708 LKAN, LKR V 963 a (2986 a), 03.1937, Circular de Antonie Nopitsch, dirigente del servicio de maternidad bávaro a los pastores de las comunidades bávaras

709 La reacción en general de la prensa protestante en general se manifiesta favorable al nacionalsocialismo: Mehnert, G.: Evangelische Presse. Geschichte und Erscheinungsbild von der Reformation bis zur Gegenwart, Bielefeld, Luther-Verlag, 1983, p.235. La única excepción la constituye Die Christliche Welt. El resto de las publicaciones contrarias al régimen no sobreviven el año 1933 
Para ello nos valemos de tres revistas que representan tres grupos concretos de discurso dentro del ámbito protestante. AUfGABEN UND ZIELE que representa a la totalidad de las asociaciones protestantes, DiE EVANGELISCHE FraUENZEITUNG, homólogo protestante de DIE FRAU, reflejo del protestantismo intelectual y cultivado, y por último MUTTER UND VOLK, revista dedicada exclusivamente a temas de maternidad e iglesia.

El análisis comprende una primera parte donde se hace referencia a la historia de la publicación, tirada, y biografía de las editoras. Desgraciadamente, debido a falta de material hemos tenido que prescindir de un análisis sociológico del tipo de lectora que leía las publicaciones. La repercusión de los temas tratados se puede seguir fragmentariamente en alguno de los números donde aparecen publicados artículos o cartas del lectorado. Salvo contadísimas excepciones nos ha sido también difícil hacer una reconstrucción completa de la biografía de las colaboradoras de las publicaciones en cuestión, debido a la insuficiencia de material existente en los archivos de las organizaciones de mujeres, donde sólo pudimos acceder a materiales biográficos de las redactoras. La búsqueda individual en archivos provinciales, registros civiles y parroquiales es en Alemania una tarea que puede durar años. En primer se trata de mujeres tremendamente móviles, lo que no significa que el lugar donde trabajaban era el lugar donde habían nacido. Otro problema se planteaba con el estado civil de las mujeres en cuestión. En Alemania es costumbre que las mujeres, al casarse, pierdan su apellido de soltera. Costumbre que dificulta extremamente la labor del historiador/a. Por último hay que contar también con la desaparición de archivos de las diferentes organizaciones durante la guerra.

No obstante de la comparación de las listas de miembros de las organizaciones de mujeres y las colaboradoras de las diferentes publicaciones, se deduce que las colaboradoras no eran periodistas profesionales, sino que se trataban de miembros que expresaban sus opiniones, experiencias e ideas sobre sus campos de trabajo: educación, legislación, teología, literatura y arte. La mayoría de ellas ocupaba un cargo en el consejo directivo de la organización o era dirigente de un grupo local.

Después de esta introducción en la „vida” de las publicaciones, sigue un capítulo sobre las primeras reacciones respecto al nacionalsocialismo. Y posteriormente procedemos con el análisis temático. A partir de 1933 la totalidad de la prensa protestante se organiza bajo la Reichsverband der evangelischen Presse que a su vez depende de la Cámara de prensa del Reich. Esta sumisión garantiza la supervivencia de las publicaciones protestantes, y la hace dependiente de las prescripciones de la Cámara. Un golpe duro fue el decreto del 6 de Noviembre de 1934, también conocido como Decreto Frick en el que se prohibían en la prensa laica cualquier tipo de alusión a actividades de la iglesia protestante. El 1 de junio de 1941 debido a la economía de guerra la prensa protestante suspende sus publicaciones.

\subsubsection{Mutter und Volk}

Uno de los campos de acción donde se presenta grandes dificultades entre la iglesia protestante y las organizaciones nacionalsocialista, es el de los servicios de maternidad Mütterdienste. Servicios que no son nuevos en el paisaje de las asociaciones de mujeres desde sus orígenes hasta Weimar. En el caso de la iglesia protestante trabajaba el llamado Evangelischer Mütterdienst, cuyo trabajo consistía en consultas de orientación a la madre, servicios de relajamiento para las madres, en forma de curas y seminarios al aire libre. Servicios que los nacionalsocialistas pasará a ofrecer a partir de 1934 cuando se crea el Reichsmütterdienst. ${ }^{710}$ Los

710 LKAN, LKA V 963 a (2986 a), Declaración sobre la conferencia del Servicio maternal protestante. 
cursos de maternidad 711 que hasta entonces eran controlados por las dos iglesias pasar a ser impartidos por las organizaciones nacionalsocialistas de mujeres, aunque en los primeros años trabajan como profesoras, y tutoras, mujeres del ámbito protestante. No obstante la cooperación cesa cuando oficialmente se decreta la prohibición de que las iglesias impartan cursos de maternidad:

„La formación maternal formará parte del campo de funciones de la obra de las mujeres alemanas. Los cursos de maternidad no deben ser impartidos por el Auxilio Femenino. Los cursos que se dan en la actualidad tienen que tocar su fin, como máximo a finales de marzo, y no está permitido que se prolonguen más allá de esta fecha. Dentro de los cursos de maternidad conserva el Auxilio Femenino la influencia religiosa. "712

La distribución de los servicios de maternidad es bastante desigual. En el norte son organizados por la Evangelische Frauenhilfe. En febrero de 1933 el consejo directivo de la organización ratifica un nuevo nombre para la organización: Reichsverband der Evangelischen Frauenhilfe. La asociación es reconocida por la dirección de las 28 iglesias estatales, nombrándose como director al Pastor Hermenau. 713. El departamento dedicado a los servicios de maternidad, Mütterdienst der Evangelischen Reichsfrauenhilfe, pasará a ser dirigido por Clara Schlossmann-Lönnies. ${ }^{714}$ Lönnies es editora de una revista, Mutter und Volk que a partir de este momento se convertirá en el órgano de prensa del servicio maternal que aunque desde un principio es reconocida por el resto de las asociaciones de mujeres, forma parte en un principio de la Vereinigung Evangelischer Frauenverbände Deutschlands, Unión de asociaciones de mujeres protestantes alemanas, dirigidas por M. von Tiling y más tarde en 1933 del EvFW. Sin embargo los vínculos de la organización con el resto de las asociaciones no son estrechos:

„El principal impedimento para la participación de las iglesias estatales en el trabajo femenino tiene que ver con la postura de la „Unión de asociaciones de mujeres protestantes en Alemania“. Esta se convierte en 1933 como la organización madre de las asociaciones religiosas, con la señora Magdalene von Tiling a la cabeza. El gran bloque del Auxilio Femenino protestante de mujeres pertenecía también a la organización. Sin embargo no todas las iglesias estatales consideraban importante la actuación del Auxilio Femenino, oponiéndose algunas

711 Entre 1933 y 1936 los cursos de maternidad son impartidos por el Auxilio Femenino protestante, Ev. Reichsfrauehilfe. Un curso de maternidad abarcaba 80 horas aproximadamente, y estaba dividido en seis bloques temáticos: Mutter und Volk, Madre e hijo donde se trataban aspectos generales sobre el papel de la madre en el Estado nacionalsocialista, teorías sobre genética y ciencia de las razas, etc. Religiöse Vertiefung, Bloque de contenido religioso en el que se incidía en el papel de la mujer en la iglesia y en la comunidad parroquial, y por supuesto sus obligaciones y deberes. Die Frau in Haushalt und Volkswirtschaft, clases de planificación y economía del hogar. Heimgestaltung, decoración del hogar. Gesundheitspfege, higiene. Erziehungsfragen, bloque donde se trataban problemas relacionados con la educación en la familia. LKAH, N 10, n 30.

712 EZA, 1/(3) 183, 26.02.1934, Rundschreiben 34, Circular del Deutschen Frauenwerk

713 Mybes, Fritz: Geschichte der Evagangelischen Frauenbilfe in Quellen. Unter besonderer Berücksichtigung der Evangelischen Frauenhilfe im Rheiland, Wuppertal, Schriftenmissions-Verlag Gladbeck, pp. 62-63

714 Clara Lönnies, 1898-19 ,hija de del pastor protestante Eduard Lönnies. Formación como enfermera y asistenta social. Desde 1921 trabaja en el Auxilio Femenino en Breslau. En 1923 contrae matrimonio con Georg Schossmann del que se separa en 1933 debido a su procedencia judía. En 1933 es elegida directora del servicio maternal en el Frente de trabajo de la iglesia protestante. 
contra la extensión del Auxilio en toda Alemania. Lo mismo se puede decir con la también perteneciente asociación dedicada a la formación maternal que no encontró el suficiente entendimiento y apoyo en la organización madre."715

El 25.8.1934 firma la editorial de MUTTER UND VOLK un contrato con Gertrud ScholtzKlink en el que se establecen las directivas de trabajo, y en la que se declara la publicación como dependiente del $E \nu F W$. Este contrato es una obra maestra de la política de control y de propaganda que los nacionalsocialistas practicaba, donde se establece con extrema claridad como tenía que elaborarse la revista. Las dos primeras páginas debían dedicarse a artículos y fotos en relación a la formación nacionalsocialista de la mujer con el título „,Mujeres en el Tercer Reich“. La tercera página debía llevar el título, y en casos especiales también la cuarta página, de „Enseñanza de la Iglesia“ y debía dedicarse a cuestiones religiosas. Siete u ocho páginas deberían publicar artículos, informes y fotos sobre el círculo de intereses de la mujer, y llevaría el título „Sobre la vida de nuestra madre“. En la cobertura de la revista desaparece el órgano de edición donde aparecía el nombre de la Iglesia Protestante, y pasa a tener un nombre relacionado con la organización nacionalsocialista. Antes de cada edición la directora de la revista tenía que tomar contacto con el Deutsches Franenwerk el cual tenía que dar su aprobación para la edición. El material utilizado en las dos primeras páginas era proporcionado por la organización nacionalsocialista. El contrato se establece hasta el 1 de marzo de 1935, pudiéndose prolongar a largo plazo. En el contrato no toma parte Lönnies, sino Waldmann, director de la editorial. ${ }^{716}$ No ocurre lo mismo con la sección del servicio de maternidad, y el órgano portavoz, MUTTER UND VOLK donde se observa el apoyo de su editora, Clara Lönnies a Hermenau y presenta en su publicación un modelo de mujer que se acerca al concepto biológico nacionalsocialista:

„Nosotros hemos tenido noticias de una carta, que la señora Lönnies el 17 de octubre bajo el nombre de la empresa MUTTER UND VOLK ha mandado a las dirigentes del servicio maternal y las mujeres de confianza del Servicio maternal protestante en la central de Berlín, y en el que en nombre del Reichskirchenregierung se dedica a hacer notificaciones. De esta manera aparece ésta en la opinión pública como representante del gobierno de las iglesias del Reich y actúa pasando por alto nuestra dirección en asuntos que se encuentran bajo nuestra jurisdicción. La señora Lönnies sin embargo ha abandonado nuestra organización, y allí tiene que ser conocido, porque el partido rechazaba el trabajo conjunto con nosotros mientras que la señora Lönnies apareciera y actuara públicamente en nuestro nombre. Es una situación incomprensible que una persona que ha abandonado la organización de tal manera, actúe y que en estos momentos en nombre de la iglesia oficial del Reich pueda inmiscuirse en nuestros asuntos. “ 717

Por otra parte Lönnies pretendía crear una organización interconfesional para madres dependiente del estado, ideas con las que el $E v F W$ no estaba de acuerdo. ${ }^{718}$ Hermenau intenta

\footnotetext{
715 EZAB, 1/C3/185

716 EZA, 50/222, 25. Juni 1934, Condiciones del contrato de trabajo entre MUTTER UND VOLK y el Frauenwerk des Staates

717 Mybes, Fritz: 1976, op. cit., p.73;; Carta de Meta Eyl y Dagmar von Bismarck al obispo Ludwig Müller, 19.10.1934

718 EZA, 1 (3) 186, Protocolo del Ermittlungsverfahren ,23.05.1936
} 
centrar la totalidad del trabajo femenino protestante en la organización, y desde ésta controlar el recién creado Evangelisches Frauenfront. La cercanía de Hermenau a los cristianos alemanes levanta las suspicacias de las iglesias provinciales entre las cuales el Auxilio Femenino no tenía ninguna tradición. Por otra la fuerte personalidad de Agnes von Grone se opone al control del $E v F W$ por Hermenau. El Auxilio se encuentra dividido entre a lealtad a su dirigente y a von V. Grone del que dependen directamente. El $\mathrm{E} v \mathrm{FW}$ se considera integrado en las iglesias consideradas como íntegras, y el Auxilio está directamente unido a la iglesia del Reich. Mientras que el resto de las organizaciones protestantes, cuyo trabajo no estaba ligado exclusivamente a las parroquias, mantienen su lealtad a von Grone, no ocurre lo mismo con el Auxilio Femenino, que dependen de la actitud del pastor hacia los cristianos alemanes. Algunos ingresan en la recién creada organización de Hermenau, Evangelischer Franendienst, contrapunto de la organización de von. Grone. Mientras que otros, como por ejemplo los Auxilios Femeninos de la iglesias del Rhin ${ }^{719}$ y de Westfalia ${ }^{720}$ se colocan al frente del Reichsvervand der Evangelischen Frauenbilfe con D. von Bismarck a la cabeza.

El apoyo de Lönnies a Hermenau conduce a la ruptura con el Auxilio Femenino que decide dar por terminado el trabajo de Lönnies como directora de la revista, MUTTER UND VOLK:

„En las gracias que queremos transmitir a la señora Lönnies por su trabajo de años y su sacrificio para el Auxilio Femenino, se mezcla un sentimiento de doloroso desagrado por el camino que ésta ha elegido y que nos obliga dar por terminado el trabajo en conjunto entre ella, su editorial, y nuestra organización. Tomamos esta decisión motivados por nuestro sentido de responsabilidad respecto a nuestra iglesia y a nuestro pueblo.“721

La ruptura con el $E v F W$ traslada a Lönnies a las filas de la iglesia del Reich, y con ella el órgano de prensa de la organización, que con sus 70.000 constituía una fuente de ingresos considerable para las diferentes secciones de servicios de maternidad. Antonie Nopitsch, directora de éste en Baviera lamenta la pérdida de la revista y la editorial:

„En este contexto el asunto relacionado con la editorial MUTTER UND VOLK tiene un efecto negativo. Gracias a Dios que el Frente del trabajo femenino de la iglesia protestante no se encuentra implicado de ninguna manera, pero es naturalmente muy difícil en estos momentos negociar sobre la continuidad de la publicación con el Frente estatal para el trabajo femenino, por otra parte, como usted sabe, MUTTER UND VOLK es la única ganancia estable que tenemos.“'722

La historia de MUTTER UND VOLK empieza en 1931. Curiosamente Lönnies defiende una maternidad elegida, es decir la mujer tiene derecho a decidir si quiere tener hijos o no. Koonz compara la postura de Lönnies con los presupuestos de la feminista radical Helene Stöcker. ${ }^{723}$ Sin embargo la llegada del nacionalsocialismo significa un cambio radical en sus convicciones y en su ideología. El cambio fue tan radical que incluso llega a separarse de su marido de ascendencia judía. Durante los primeros años de la dictadura elabora un programa para solventar el problema iglesia-estado. Uno de los medios para luchar contra la secularización de

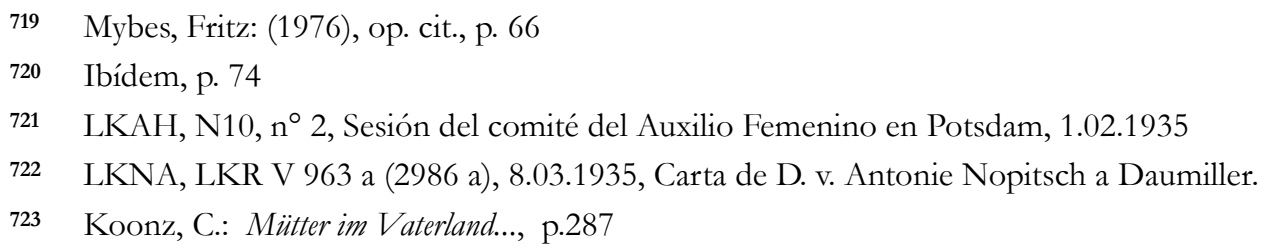


la sociedad era la integración de la mujer como piedra principal entre fe e iglesia, una organización religiosa de madres protestantes se hacía así imprescindible para lograr un servicio de madres en el estado (Mütterdienst). ${ }^{724}$

La actuación de Lönnies al frente de los servicios de maternidad de la iglesia protestante se ve amenazada desde un principio por el interés de las organizaciones nacionalsocialistas por controlar los servicios de consulta en manos de la iglesia protestante. Por otra parte, posiblemente debido a la gran tirada de la publicación, y por la independencia de pensamiento de Lönnies, respecto al resto de las organizaciones protestantes y su actitud irrespetuosa respecto a las mujeres nacionalsocialistas, hace difícil su trabajo con éstas. En enero de 1934 se observa claramente que desde la NS-Frauenschaften existe el deseo de prescindir del trabajo de ésta. ${ }^{725}$ Ruptura que conduce automáticamente a la interrupción de las relaciones con la iglesia de Müller. La rapidez de la destitución de Lönnies de su cargo da pie a algunas conjeturas. En unos meses había logrado la NS-Framenschaft, hacerse con el control de MUTTER UND VOLK que en un principio todo el mundo relacionaba con el servicio de maternidad protestante y separarlo de las organizaciones protestantes de mujeres que no apoyaban a la iglesia de Müller. Un mes después los cursos de maternidad empiezan a ser impartidos por el DEF, Dentsches Franenwerk y no por el Auxilio femenino. ${ }^{726}$

La revista permanece sin embargo en manos de la iglesia oficial. Una vez roto el contrato de la editorial de Lönnies y el Auxilio femenino, y el consiguiente abandono del $E v F W$, la revista había pasado a depender del DEF. Curiosamente las líneas de trabajo de la revista no aparecen fijadas por la iglesia de Müller, sino por la organización nacionalsocialista.

En 1935 encontramos una serie de directivas por parte de Scholtz-Klink a la redacción de la revista. En el informe se alude a la necesidad de la existencia de un plan de edición donde la principal característica es la claridad y la sencillez del mensaje. Se aconseja introducir, de temas históricos, de costumbres populares, temas en relación con la madre y las juventudes hitlerianas; investigaciones raciales etc. Los temas religiosos deben introducirse después de las materias relacionadas con los temas de Blut und Boden. Estos deben ser de carácter práctico y no teórico. Se aconseja „enriquecer“ la edición con aportaciones de mujeres católicas. Recomendables son canciones sobre el trabajo de la madre, y siempre debe publicarse una receta de cocina, casa, jardín. Por último se establece la existencia de una sección de retratos sobre las tareas y trabajos de mujeres: la trabajadora, la temporera, la pescadora, la quioskera o la maestra de pueblo. ${ }^{727}$

Sin embargo a principios del año 1935 la redacción de MUTTER UND VOLK se ve sometida a un proceso (Ermittlungsverfahren). Las causas tienen que ver con los fondos de financiación de la organización de las madres protestantes (Reichsmütterdienst des Frauenwerkes der Evangelischen Kirche), que teóricamente fueron desviados para financiar el periódico (total 10.000 Reichsmark). El empeoramiento de las relaciones entre organizaciones laicas y protestantes, produce la salida definitiva del EvFW del DEF en octubre de 1936, con lo cual la revista pasa a manos de la iglesia protestante:

724 EZA, 50/222, Informe sobre el proceso contra Klara Lönnies y Waldmann

725 EZA, 1 (3) 183. Correspondencia entre la NS-Frauenschaft y el obispo Ludwig Müller. 25.01.1934. Lönnies consideraba que el nacionalsocialismo de las dirigentes de las Franenschaften y el DEF, no era lo suficiente nacionalsocialista. Esta actitud negativa provoca que desde la cúpula nacionalsocialista existan presiones para que Müller no apoye a Lönnies: Wir werden den Eindruck nichtlos, daß hier eine Kraft am Werk ist, die in der Bewegung zerstörend wirkt und Verwirrung stiftet, wie oft jetzt von kirchlicher, bündischer oder politisch gleichgeschalteter seite versucht wird, im Namen irgendeines privaten „Nationalsozialismus" zu Einfluss zu gelangen.

726 EZA, 1 (3) 183, Informe del DEF, 26.02.1934

727 EZA, 1 (3) 184, 1935, Sobre el plan de redacción para MUTTER UND VOLK 
„Bajo estas circunstancias el DEK tiene la obligación de solucionar el asunto de la revista religiosa MUTTER UND VOLK y de su editorial. Estamos decididos a restablecer con todos los medios la legalidad e informaremos al Ministerio para asuntos religiosos sobre nuestra postura". ${ }^{728}$

El conflicto se reanuda un año después, no con los nacionalsocialistas sino con el $R K A$, el consejo encargado de suavizar las relaciones entre iglesia y estado. Los miembros de esta entidad reprochan en agosto del 36 a Lönnies el abandono de la línea original de la revista en el aspecto religioso, es decir la línea religiosa-popular (volkskirchliche Linie) con lo cual se aconseja que no se prolongue el contrato con las organizaciones de mujeres nacionalsocialistas. ${ }^{729}$

El Decreto del R.J.M. del 3 de Julio de 1935 prohibe la formación maternal confesional con lo cual obstaculiza y amenaza la existencia del Evangelischer Mütterdienst con un gran número de miembros y partidario de von Grone. Los subsidios y contribuciones financieras son recortados. A. Nopitsch pide más independencia de actuación y más protagonismo para las mujeres:

„Esta probado que especialmente en el sur de Alemania que nosotras estaríamos menos amenazadas - y lo digo aquí claramente - la Frauenhilfe del norte de Alemania estuviera dirigida por mujeres y no por religiosos. Los pastores no tienen la posibilidad de eligir un camino neutral, que hoy en día una organización del Reich tienen que seguir, debido a su vínculos con los Bruderräte o con los consejos eclesiásticos. Para las mujeres es mucho más fácil“. 730

Sin embargo los esfuerzos de neutralidad de las organizaciones de mujeres no impiden que la revista deje de publicarse al finales de 1936.

\subsubsection{Discurso y realidad en la EVANGELISCHE FRAUENZEITUNG}

\subsubsection{Introducción}

La agrupación de las asociaciones protestantes en el $E v F W$, fue la garantía de su supervivencia. La Federación de mujeres alemanas pertenece a las afortunadas, y con ella su órgano de prensa. Mientras las organizaciones protestantes veían disminuida su capacidad de acción y los periódicos y hojas informativas iban desapareciendo, ya por decreto o por razones económicas, la EVANGELISCHE FRAUENZEITUNG continúa publicándose hasta 1941, fecha en la que debido a las restricciones que imponía la economía de guerra, un gran número de publicaciones deja de editarse.

En esta parte del capítulo nos ocuparemos de cómo la EF percibe, trabaja y describe la situación política, social y religiosa durante el período 1933 y 1941. La revista se funda en 1899. Tiene su lugar de edición en Hannover y constituye desde el primer momento como el órgano de prensa de la Liga de mujeres protestantes alemanas. En un principio se trata de una modesta hoja de información sobre las actividades de la liga. Pero a partir de 1900 bajo la influencia de la fuerte personalidad de Paular Müller empieza a adquirir rango de revista. De cuatro veces al año empieza a publicarse cada dos meses, a partir de octubre de 1902 aparece la revista una vez al

728 EZA, 1 (3) 184, 1. Dezember 1936, El Reichskirchenausschuß (RKA) al Politischen Beauftragten der MUTTER UND VOLK

729 EZA, 1 (3) 184, 4. Juni 1936, El RKA a la dirección de MUTTER UND VOLK

730 LKAN, LKR V 963 a (2986 b), 5. Oktober 1936, Nopitsch a Daumiller 
mes, y a veces dos veces al mes. En 1903 la revista se podía adquirir en librerías. ${ }^{731} \mathrm{Su}$ configuración no difiere demasiado de la de DIE FRAU. La revista esta dividida en un gran número de secciones: la dedicada a artículos de carácter general que en su mayoría se refieren a temas literarios o artísticos; los temas religiosos tienen una gran representación en dos secciones llamadas „temas religiosos" e ,iglesia y misión interna“. Una gran sección se dedica a temas relacionados con la cuestión de la mujer y la política. Las tareas de la Liga, congresos, resoluciones y actividades varias tienen una sección especial. A esto hay que añadir una página dedicada a temas económicos, sociales, educativos, morales e internacionales. Este formato se mantiene durante un gran número de años durante el nacionalsocialismo. Llama la atención de la revista, la ausencia de fotos o ilustraciones, tan conocidas de las publicaciones dependientes de las organizaciones nacionalsocialistas. Como nota curiosa e interesante existe también publicidad especialmente dirigida a la mujer: medicamentos contra dolores de cabezas, neuralgias y depresiones, ofertas especiales en grandes almacenes, dietas milagrosas, etc. y productos alimenticios.

Durante la primera guerra mundial los temas cambian en función de la nueva problemática: los temas femeninos casi desaparecen, a excepción de aquellos que se refieren al trabajo femenino en la guerra. Después del conflicto se observa una abundancia de temas religiosos y de nuevo se empiezan a tratar temas sobre la cuestión de la mujer. Así mismo se tratan temas de política internacional que critican los acuerdos de Versalles y defienden la posición nacional alemana. En los años veinte los efectos de la inflación se hacen notar en la tirada. De 16.2000 ejemplares en 1914 decrece a 4.000. Hasta 1930 se nota una mejora con 11.600 ejemplares. A partir de 1933 comienza a observarse una descendencia en la tirada hasta 8.350 ejemplares en 1937. Esta bajada en la edición no se debe únicamente a razones de tipo financiero sino al alto nivel de la revista. Lo que hacía que muchas de los artículos no eran entendidos por las lectoras. Ante esta situación se hace un intento de „popularizar" la revista con recetas y narraciones, como era habitual en la prensa católica lo que levanta las críticas de numerosos miembros de la Federación. ${ }^{732}$

\section{$\multimap-$ Tirada del Evangelische Frauenzeitung}

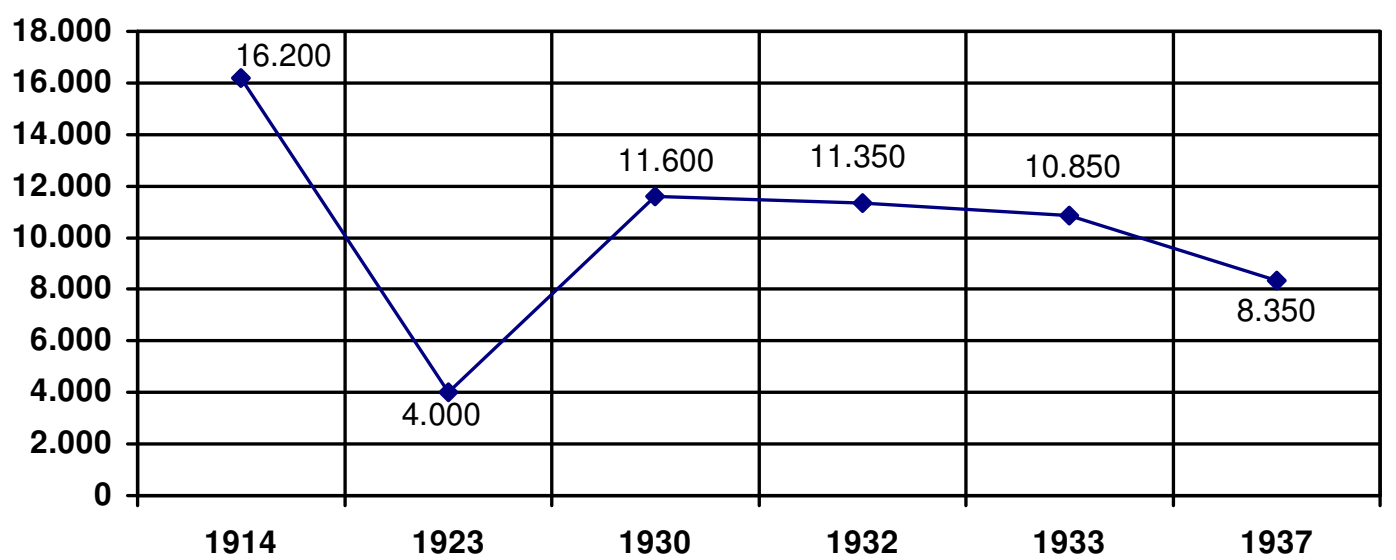

Fuente: Evangelische Framenzeitung, Octubre 1923, $n^{\circ} 14, p$ 1; Noviembre 1929, $n^{\circ}$ 31, p.6; Julio 1931, $n^{\circ}$ 32, p. 172 y ADEF, A6, p, 10.2.37, Informe anual; A6, n.0 20.06.1933 Informe anual

73130 Jahre Deutsch-Evangelischer Frauenbund, Hannover 1929, p. 37

732 ADEF, A 6 p, Informe anual, 10.2.37 
Con la llegada de Meta Eyl y Hedwig Winnecke a la redacción se observa un aumento de artículos con tema religioso. ${ }^{733}$ Este aumento no se debe únicamente a los gustos personales de las editoras, sino a las nuevas directivas de la cámara de prensa, Reichspressekammer, que a partir de 1936 exigen a las publicaciones confesionales el tratamiento de temas exclusivamente religiosos. Las ganancias que produce la revista son cada vez más importantes en la supervivencia del $D E F$, lo cual garantiza un cumplimiento absoluto de las directivas que vienen de la cámara de prensa.

\subsubsection{Las editoras del EF: Paula Müller-Ortfried y Meta Eyl}

Paula Müller-Ortfried 734 dirige los destinos de la revista desde 1900 hasta 1933, fecha en la que Meta Eyl su sucesora al frente de la Liga se hace igualmente cargo de la revista. Müller convierte la revista en el órgano del movimiento protestante de la mujer y juega un papel importante durante los meses de transición de Weimar a la dictadura nacionalsocialista. Mientras que los temas de Müller tenían una intensa relación con las reivindicaciones e ideología del movimiento de la mujer, bajo Eyl son los temas teológicos pasan a primer plano en la revista. ${ }^{735}$ Desde esta perspectiva, alemán, nacional, protestante pero neutral dirigirá Meta Eyl 736 organización y revista durante los años de la dictadura y de la lucha entre las iglesias protestantes. Durante este período no tenemos noticias de control por parte de la Gestapo o „,recomendaciones" por parte del ministerio de propaganda. Por el contrario Eyl se esfuerza en cumplir con las normas impuestas por la Reichspressekammer.

733 Kellner, Hanna: op. cit. p. 31. La autora corrobora esta afirmación con los datos de una estadística que analiza la cantidad de temas religiosos que aparece en la EF entre 1929 y 1941. En 1930 se observa un $14 \%$ de temas religiosos mientras que en 1940 la proporción ha ascendido a un 44,5 \%.

734 Nace el 7.06.1865 en el seno de una familia de altos funcionarios, donde recibe una educación refinada. Desde su juventud se dedica a tareas caritativas y en 1900 a los 35 años comienza a trabajar en la EF y un año más tarde ocupa el cargo de presidente del DEF, (Deutsch-evangelisch Frauenbud). En 1913 ingresa en el DNVP, (Deutschnationale Volkspartei), al que representa como diputada en el Reichstag desde 1920 hasta 1932. En 1933 saluda la llegada del nuevo gobierno aunque no ingresa en el NSDAP. Datos tomados del ADEF, Acta B7 III. Adelheid von Bennigsen (1861-1938), aparece desde 1923 hasta 1932 como editora. Cofundadora en 1899 del DEF, conocida por sus aportaciones en el campo de la formación y educación femenina.

735 El pensamiento teológico de Eyl se puede deducir, además de sus aportaciones en la EF, de una serie de artículos publicados en diferentes revistas. Acta ADEF T $1 \mathrm{~b}$

736 Las causas de su elección se deben a varias circunstancias, su formación, su independencia, su juventud, y sobre todo no pesaban sobre ella años de trabajo en las instituciones democráticas de Weimar. Es curioso resaltar la similitud con Agnes v. Grone y Magdalene v. Tiling, donde la primera retoma el trabajo de Tiling, que al igual que Paula Müller era conocida por su trabajo político en el Reichstag, donde ámbas habían sido diputadas del DNVP. 
„Lic. Meta Eyl y yo (Hedwig Winnecke) como redactoras jefes responsables del por Paula Müller Ortfried fundado y ampliado en largos años de trabajo, EVANGELISCHE FRAUENZEITUNG, nos esforzamos en darle forma según los intereses actuales de nuestra Federación y a la vez según los requisitos impuestos por la cámara de la prensa del Reich."737

Otras de las colaboradoras que trabajan constantemente en la publicación son Grete Gillet y Maria Hensius. Ambas estudian teología en la Universidad de Heidelberg, ambas se doctoran consiguiendo el título de Licenciadas en teología. A partir de este momento sus vidas adquieren caminos diferentes, Gillet realiza los exámenes estatales dedicándose posteriormente la enseñanza de la asignatura de religión en Mannheim y Karlsruhe en escuelas de formación profesional para mujeres. Hensius por el contrario contrae matrimonio y se dedica al trabajo social, publica artículos etc., y ayuda a su esposo en su trabajo como pastor protestante. ${ }^{738}$ Desgraciadamente no tenemos informaciones sobre su afiliación política y orientación teológica. Hensius asiste en Heidelberg a las clases del profesor Ernst Troelsch y más tarde junto con su marido en los años de Weimar se dedica intensamente a estudiar la obra de Karl Barth, no obstante no hemos podido constatar una relación con la iglesia confesora. Sobre el resto de las colaboradoras se trata de miembros del consejo de dirección de la Federación, una periodista Beda Prilipp conocida por su orientación nacional conservadora, y teólogas.

\subsubsection{Los años de crisis (1932-1933)}

Aunque la mayoría de los miembros del $D E F$ eran miembros del $D N V P$, la postura del EVANGELISCHE FRAUENZEITUNG respecto a las innumerables elecciones que tienen lugar entre 1930 y 1933, es de absoluta neutralidad. Con ocasión de las elecciones de septiembre de 1930 Müller 739 describe el clima de confusión e inseguridad que reina entre las mujeres. La causa es la cantidad de partidos, divisiones, la falta de programas políticos que luchen contra el paro, la corrupción. Müller, la antigua enemiga del voto femenino instiga a las mujeres a depositar su voto, a hacer uso de su derecho. Esta llamada a la neutralidad vuelve a repetirse con motivo de las elecciones presidenciales en marzo de 1932:

„La Federación de mujeres protestantes alemanas no puede tomar ninguna postura en función de los futuros resultados de las tan decisivas elecciones presidenciales para el pueblo alemán. Ésta, no obstante, ruega a sus miembros que piensen su decisión profundamente como mujeres responsables, y no se dejen influir por puntos de vistos objetivos sino por el deseo de ayudar a construir el futuro de Alemania“. ${ }^{740}$

Esta política de neutralidad no se restringe únicamente a las mujeres del $D E F$, sino que se encuentra de forma parecida en los números de DIE FRAU, de estos mismos años. Unos meses

\footnotetext{
737 ADEF, A 6p, Informe anual, 10.2.1937

738 Köhler, Heike; Herbrecht, Dagmar; Henze, Dagmar; Erhart, Hannelore: Dem Himmel so nah dem Pfarramt so fern. Erste evangelische Theologinnen im geistlichen Amt, Neukirchen, Neukirchener Verlag, 1996, pp. 35-39 у 63-67

739 Müller-Ortfried, P.: „Zum 14. September”, EvANGELISCHE FRAUENZEITUNG, Septiembre 1930, año 33, número especial

740 Müller-Ortfried, P.: „Reichspräsidentenwahl”, EvangELISCHE FraUEnZEITUNG, Marzo 1932 (año 33), p.85
} 
más tarde, sin embargo se rompe con la política de neutralidad, en mayo aparece un artículo de Elisabeth Schwarzhaupt sobre la posición de la mujer ante el nacionalsocialismo, donde la autora muestra su rechazo ante el movimiento. Schwarzhaupt analiza las causas de la decadencia del movimiento de la mujer como puramente económicas y culturales. El nacionalsocialismo contribuye a agudizar esta situación de crisis ya que atenta contra los fundamentos del movimiento de la mujer. La autora cita la obra de Rosenberg como un ejemplo de los ataques contra los derechos y los intereses de la mujeres, y critica la interpretación subjetiva que el nacionalsocialismo hace de la cultura literaria alemana para justificar la sumisión de la mujer. Esta degradación de la mujer a ciudadana de segunda categoría, se pone de manifiesto en la distinción que el programa del partido nazi hace entre Staatsangehöriger, súbdito y Staatsbürger, ciudadano. Mientras que el hombre recibe su Staatsbürgerrecht, derecho de ciudadanía cuando termina su formación escolar o su servicio militar, la mujer la recibe únicamente cuando ésta accede al matrimonio. Schwarzhaupt pone de relieve, sin ser consciente de ello, el carácter sexista y racista del nacionalsocialismo, cuando comenta que el nacionalsocialismo rebaja al mismo nivel a las mujeres solteras (alemanas), de los judíos y los extranjeros, o incluso de los criminales que pierden su ciudadanía. Esta distinción afecta principalmente a las funcionarias, ya que para poder acceder a este grado se exigía obligatoriamente el derecho de ciudadanía, únicamente en poder de las mujeres casadas. La autora define el mundo idílico nazi con mujeres casadas, y felices madres de familia como un atentado contra los derechos de la mujer, y una humillación de su personalidad que es reducida a un mero ser biológico:

„La mujer no debe valorarse en función de su personalidad, ni en función de sus cualidades psíquicas e intelectuales, dentro de las cuales la maternidad, según nuestra opinión se encuentra en primer lugar.' En esta argumentación se defiende la valoración de la mujer únicamente como madre, en función del aporte de ésta al crecimiento de la población. Este punto de vista denigra tanto a la madre como a la mujer intelectual y contradice nuestra concepción de la valoración del individuo en función de su valor personal“. ${ }^{741}$

La crítica de Schwarzhaupt no va en contra del nacionalsocialismo como ideología o régimen, sino que pone en duda la intromisión de éste en el mundo de la mujer y la reducción de su personalidad al aspecto biológico de la maternidad. El contenido del artículo causa una gran polémica entre las lectoras de la revista, algunas de ellas afiliadas al NSDAP. En el número posterior la dirección se hace eco de las críticas y propone una discusión en la que tomen parte el grupo contrario. La discusión es abierta por la Gräfin Selma von der Gröben ${ }^{742}$ quién discute sobre el significado de ser Gehilfin des Mannes, y fundamenta los argumentos de Schwarzhaupt teológicamente: „Wir glauben, von Gottes Handen, d.b. nach seinem Willen, Frauen zu sein - nicht von Mannes Gnaden." Von Gröben critica la concepción materialista de la maternidad, que ve a la mujer únicamente reducida a su condición de hembra y paridora de hijos. ${ }^{743}$ Esta polémica se encuentra también en Die Frau donde Marianne Weber y Gertrud Bäumer defienden la maternidad espiritual, que define la naturaleza femenina pero que no se reduce únicamente a la mera concepción biológica de ésta. Al artículo le sigue una colaboración de Marianne Müller-

741 Schwarzhaupt, E.: „Die Stellung des Nationalsozialismus zur Frau”, EvangELISCHE FraUENZEITUNG, Mayo 1932 (año 33), p.123

742 von der Groben,S.: „Die Frau und der Nationalsozialismus”, EvANGELISCHE FraUENZEITUNG, Junio 1932, (año 33), pp. 133-136. Selma v. Groeben: (1856-1938) presidenta de honor del DEF, conocida por su trabajo en el ámbito de la protección de menores, madres solteras y prostitutas. Pertenece al círculo de Gertrud Bäumer y Marianne Weber.

743 Ibídem, p.136 
Creskow que refleja las opiniones del círculo de mujeres nacionalsocialistas, donde contraargumenta la postura de Schwarzhaupt y defiende los principios liberadores e igualitarios del movimiento para los dos géneros:

„Nosotras nacionalsocialistas sabemos que somos valoradas en el Tercer Reich como personas, no sólo en función de nuestra tarea biológica. Las elevadas ambiciones y objetivos de nuestro movimiento nos indican de nuevo el camino y la dirección a seguir para la renovación y el renacimiento de la mujer alemana. Así el nacionalsocialismo se encuentra en las raíces de un movimiento de la mujer bien entendido que lucha por lo nacional y por el cristianismo. De ninguna manera contradice los objetivos de nuestra Liga."“.744

En el mismo número colabora, sin embargo, Lenore Kühn, conocida por su actitud favorable a los nacionalsocialistas. En verano la redacción se encuentra ante una fuerte presión. De nuevo tienen lugar elecciones. La redacción sigue sin decidirse políticamente, aunque por otra parte Paula Müller-Ortfried expresa su deseo de presentarse como candidata. Por otra parte la discusión sobre el movimiento de la mujer continúa. Selma von der Gröben se distancia de la postura de Müller-Creskow y argumenta que la crítica de Schwarzhaupt no tiene que ver con planteamientos políticos, no cuestiona al partido, sino con problemas específicos de la mujer, y defiende el derecho de la mujer a determinar su profesión, su futuro sin que el estado se inmiscuya en sus intereses. Un rechazo absoluto del nacionalsocialismo no se produce. En lo nacional von der Gröben da su conformidad:

„No me ha sido fácil escribir estas palabras. Lo mejor para mi es que las pudiera contradecir objetivamente. Estoy de acuerdo, sin embargo, en lo relativo al aspecto nacional con el nacionalsocialismo". ${ }^{745}$

Esta controversia sirve a algunos autores ${ }^{746}$ para argumentar una crítica al régimen que más allá de la defensa de los intereses de las mujeres. No corresponde tampoco con el análisis de otros autores como Claudia Koonz que ven en esta reducción una búsqueda de ámbitos propios de actuación. Sin embargo ellos olvidan los intentos por parte del movimiento de la mujer de legitimar su historia, por demostrar su carácter nacional y alemán. Esta crítica es una queja, un ruego a participar, a tener un papel en la nueva historia del pueblo alemán. Este grupo de mujeres intelectuales, con estudios, acostumbradas a tener responsabilidad, a dirigir y a tomar decisiones quieren seguir tomando decisiones en el nuevo régimen, a la misma altura que los hombres. von Groeben en un artículo posterior se participa en esta táctica de unión de las teorías del antiguo movimiento de la mujer, representado por Luise Otto-Peters, con el nuevo movimiento:

„La mujer que desea Dios está educada para las tareas maternales en el pueblo y en el estado. Luise Otto Peters, fundadora del movimiento de la mujer en la mitad del pasado siglo: Todo lo que nosotros exigimos del presente y esperamos del futuro, no lo hacemos con el estúpido objetivo de pensar que no existe ninguna diferencia entre el hombre y la mujer, no sólo físicamente, sino también

\footnotetext{
744 Müller-Creskow, M.: „Die Stellung des Nationalsozialismus zur Frau”, EvangELISCHE FraUENZEITUNG, Junio 1932 (año 33), p.140

745 von der Gröben, S.: „Zeitwende und Frauenbewegung. Gedanken zu unserem Verbandsthema”, EVANGELISCHE FraUENZEITUNG, Julio-Agosto 1932 (año 33), p.154

746 Kellner, Hanna: op. cit. 74;
} 
psicológicamente. De igual manera no exigimos ni esperamos que la mujer que se le concede a ésta se utilice para abandonar las obligaciones que la mujer tiene con la familia sino por el contrario para que ésta cumpla con sus deberes con más fidelidad y pureza. ${ }^{\text {"7 }}$ (47

Esta crítica caracteriza no sólo al movimiento protestante de la mujer sino también al movimiento no confesional. La defensa de sus intereses, en el caso protestante se une también la independencia de la actuación como grupo dependiente de la iglesia pone de relieve una de las características de la actuación de las mujeres del nacionalsocialismo, la defensa de sus principios por encima de todo sin llegar a criticar la base fundamental antidemocrática del nuevo régimen, lo que hace que su crítica, como también ocurre en las iglesias, no tiene la fuerza y la repercusión de un movimiento de resistencia organizado.

La discusión continua con cartas de mujeres líderes de grupos locales de la Federación donde se manifiesta la situación conflictiva en la que se encontraba el movimiento de la mujer protestante. Críticas contra la posición sexista del movimiento se mezclan con declaraciones de lealtad a los principios nacionales de éste.

El 31 de julio de 1932 tienen lugar nuevas elecciones y Paula Müller-Ortfried resulta elegida como representante del Partido Nacional Popular alemán (Deutsche Nationale Volkspartei). Sin embargo ésta renuncia a su escaño debido a problemas de salud. La retirada de ésta ocasiona un gran número de objeciones y críticas en las dirigentes de la Liga que ven en su dimisión una gran pérdida para los intereses de las mujeres protestantes. Unos días después el parlamento del Reich disuelto.

En los últimos meses de 1932 la EVANGELISCHE FRAUENZEITUNG se limita a publicar artículos de carácter religioso y se evaden todo tipo de comentarios sobre la situación política. En Enero de 1933 vuelve Paula Müller-Ortfried a pronunciarse sobre „los nuevos tiempos“ que se avecinan en la historia alemana. Paula Müller-Ortfried describe en un artículo del número de Enero la situación de pesimismo y desasosiego que reinaban en las filas protestantes:

„¿Qué podemos hacer? Nosotras no queremos enarbolar banderas o simplemente volar con éstas. Nada conduce con más seguridad a la continua duda que no hacer nada y esperar si un acontecimiento difícil tiene lugar o no“. ${ }^{748}$

Desempleo, la pérdida de los símbolos románticos, los nuevos valores de la edad moderna, todos ellos factores que ayudaban a aumentar el clima de inseguridad del año 1933 . Y sin embargo existe una esperanza, un deseo: la salvación del pueblo y de la patria que las mujeres protestantes están dispuestas apoyar, a través de su influencia en la familia y el hogar.

Esta situación de descontento e inseguridad está acompañada también de una búsqueda de un progresivo abandono de las ideas del primer movimiento de la mujer y de una búsqueda de nuevas imágenes de representación de la feminidad. ${ }^{79}$ La obra de Bachofen, sirve de pauta para buscar nuevos símbolos, ideales, un nuevo espejo donde las mujeres se pueden encontrar de nuevo a si mismas. Así la masculinidad aparecerá identificada con el nomadismo, el cambio, el día claro, y el entendimiento; la feminidad por otra parte con la agricultura, lo duradero, la casa, el regazo oscuro de la tierra, lo creador de eternidad y vida, lo que adora lo divino. La propuesta de Bachofen se actualiza en una búsqueda de una alimentación sana y equilibrada, deporte,

747 von der Gröben, S.: „Ein Neues?”, Evangelische FrauenZeitung, Mayo 1933, (año 34), p.114.

748 Müller-Ortfried, P.: „Rückblick und Ausblick“, EvANGELISCHE FrAUENZEITUNG, Enero 1933 (año 34), p.49

749 Biesig, A.: „Verborgene Frauenbewegung“, EVANGELISCHE FrAUENZEITUNG, Enero 1933 (año 34), pp.56-58 
restablecimiento de la familia y de la vida en común en grupos de canto, grupos de oración, etc. Una propuesta que tenía un nombre: regeneración. El matrimonio deja de ser el reducto romántico que muchas mujeres buscan sino „una tarea, un servicio en la vida con el fin de una gegenseitiger adaptación y capacidad de sacrificio“.750 El matrimonio es considerado como „la fuente de la vida“" y por consiguiente otro tipo de uniones como la homosexualidad o el lesbianismo no son aceptadas, así como las relaciones sexuales fuera del matrimonio.751 Otros temas como el aborto, la utilización de anticonceptivos son concebidos como pecados que atentan contra el orden natural de la creación.

El afán de renovación y de cambio de las costumbres morales se traduce en un trabajo político a nivel comunal. El 13 de Febrero de 1933 tiene lugar un encuentro de mujeres organizado por la Liga donde se discuten las estrategias a elegir para influir en la política comunal, en el encuentro se incita a las mujeres protestantes a trabajar en tres campos de acción: cuestiones de política educativa, Gefährdetenfürsorge, crítica a las leyes para lucha contra las enfermedades venéreas. ${ }^{752}$

Un problema encontrarán las mujeres protestantes en las críticas contra las mujeres casadas que trabajan, y contra la intención de relegar a las mujeres al hogar. En este aspecto coinciden con las mujeres de DIE FRAU en la defensa del derecho de la mujer a trabajar. ${ }^{753}$

Mientras tanto la llegada al poder de Hitler y los nacionalsocialistas se hace inevitable. Su nombramiento es celebrado con grandes esperanzas apoyadas por la ficción de las elecciones democráticas. El acontecimiento es celebrado como describe Paula Müller-Ortfried con gran júbilo:

„El 30 de Enero ha traído un cambio total. El júbilo de gozo que aquella tarde fue entonado para el presidente del Reich expresó lo que un gran parte del pueblo alemán siente y espera."’754

Sin embargo la directora de la revista de la Liga tiene puesta sus esperanzas en el 5 de marzo. Fecha donde tienen lugar nuevas elecciones generales. Desde su periódico Müller-Ortfried recomienda a las mujeres protestantes que sean fieles a los elevados objetivos de la tradición patriótica y que luchen por el renacimiento nacional del pueblo alemán. ${ }^{755}$

Su posición es no obstante, como en el caso de las católicas, de claro rechazo del nuevo régimen. En abril del mismo año Müller-Ortfried habla claramente del „,nuevo renacimiento nacional“ del pueblo alemán. El futuro se observa con esperanza e ilusión, un futuro donde los valores alemanes, nacionales y cristianos conjuntamente trabajan en la reconstrucción de los valores de la patria en contra de la „amenaza bolchevique“.756 En esta tarea tienen las mujeres un papel de gran importancia como las portavoces de los valores sociales y cristianos en la vida

750 Rötger, A.: „Gedanken über Frauenarbeit“, EVANGELISCHE FrAUENZEITUNG, Febrero 1933 (año 34), p.68

751 Müller-Ortfried, P.: „Die Fragen der geschlechtlichen Sittlichkeit, insbesondere das Eheproblem in der evangelischen Kirche“, Evangelische FrauENZEITUNG, Febrero 1933 (año 34), p.72

752 Artículo escrito por una participante en el congreso, en: EvANGELISCHE FraUENZEITUNG, Marzo 1933 (año 34), pp.84-85

753 Rötger, A.: op.cit., p.69

754 Müller-Ortfried, P.: „Deutschlands Entscheidung“, EvANGELISCHE FrAUENZEITUNG, Marzo 1933 (año 34), p.81

755 Ibídem.

756 Müller-Ortfried, P.: „Nationale Erhebung”, Evangelische FrauEnZEITUnG, Abril 1933 (año 34), p.97 
pública. Esta postura conservadora no apoya necesariamente la ideología nacionalsocialista, sino los partidos democráticos de ideología conservadora. Sin embargo esta postura no puede extenderse a todas las mujeres, ya que como comenta un artículo en el EVANGELISCHE FRAUENZEITUNG, la mayoría de las mujeres no hacen uso de su derecho al voto:

„A pesar de todo resulta relevante que el derecho al voto no se haya convertido en algo evidente entre las mujeres, de lo contrario no sería entendible el fuerte seguimiento que el nacionalsocialismo ha ganado“. ${ }^{757}$

Tal afirmación contradice la mayoría de los estudios sobre el voto de las mujeres en el nacionalsocialismo, en los que la mayoría se encuentran alusiones al apoyo incondicional de las mujeres al nuevo régimen. Otras colaboradoras de la revista expresan, por el contrario, su entusiasmo por el nuevo movimiento. Los apelativos que utiliza son dignos de resaltar: Wiedergeburt, renacimiento, regeneración, Emeurerung, renovación, y Erfüllung: realización personal. Una vez superados los miedos respecto a la postura del nacionalsocialismo sobre su actitud respecto a la maternidad y al trabajo de la mujer los primeros temores desaparecen:

„El cambio ha llegado. Un cambio que de debe de dar nuevas esperanzas a nuestro trabajo, así como un nuevo impulso. Nuestras almas vibraban cuando en Postdam las campanas de las iglesias saludaban la llegada del renacimiento nacional de nuestra amada patria y cuando la vieja bandera de nuevo ondeaba en el viento. Hoy competimos las organizaciones de mujeres por poder entrar a forma en las filas nacional-populares. Nosotras sentimos gratitud por poder formar parte de una gran corriente que nos trae la salvación del amenazador bolchevismo."“758

En los últimos meses de 1933 la parte dedicada a „Mujer y política“ aparece sustituida por temas religiosos, comentarios de libros, retratos sobre mujeres ilustres, noticias sobre el Franenwerk etc. Este predominio de temas religiosos se mantiene durante toda la dictadura. En algunos casos da lugar a „curiosas“ mezclas, donde Nietzsche, deporte y religión se amalgaman en un mismo artículo como con ocasión de los juegos olímpicos donde el tema „lucha“ sirvió de excusa para tratar la situación de crisis de la iglesia protestante.

La confrontación con el tema de los cristianos alemanes comienza a tratarse en la revista en números del año 1932. Estos son considerados como einen dem Wesen der Kirche grundsätzlich artfremden Einbruch weltlicher Parteipolitik in die Kirche. ${ }^{759}$ En esta misma línea de rechazo del nuevo movimiento se expresa Käthe Klamroth en un artículo en junio de 1933, donde insiste en la unidad de la iglesia. ${ }^{760}$ No obstante se trata de opiniones vagas que no se argumentan. Meta Eyl es la única que trata, sin embargo, temáticamente uno de los puntos sobre los que cristianos alemanes habían escandalizado el mundo protestante: el tema de la actualidad, y validez del antiguo testamento para la fe cristiana. Eyl enlaca la tradición gnóstica conocida por su no aceptación del viejo testamento, ya que se trataba el libro de la revelación de dios judío, con las teorías actuales. Eyl no considera sin embargo necesario la eliminación del viejo testamento para mantener la pureza de la conciencia colectiva nacional:

757 Reich, E.: „Über das Frauenwahlrecht“, EvANGELISCHE FraUenZeitung, Mayo 1933 (año 34), p.119

758 Rötger, A.: „Das Gebot der Stunde”, Evangelische frauenzeitung, Mayo 1933, (año 1933), p. 115

759 EVANGELISCHE FraUENZEITUNG, 1932, (año 1932) p. 185

760 Klamroth, Käthe: „Die Neugestaltung der Evangelischen Kirche Deutschlands”, EvangeLISCHE FRAUENZEITUNG, Junio 1933, (año 34), pp. 133-135 
„Los prejuicios contra los individuos de sangre judía nos hace adoptar una postura de falsa veracidad respecto al contenido objetivo del viejo testamento." ${ }^{\text {"761 }}$

En la misma línea de argumentación, Eyl critica los intentos de germanización que los cristianos alemanes, quieren hacer de la fe cristiana. Y critica el creciente rechazo por todo lo que es extraño a lo alemán:

„El medio hacia lo extranjero se convierte en manía. Nos encontramos en una situación donde corremos el peligro de empobrecernos. A causa del miedo que tenemos no arriesgamos nada porque tememos rodearnos de algo „extraño“ como nuestros padres hicieron, los cuales a raíz de su sangre germánica bajo algunos de los destinos espirituales se convirtieron a la variedad de la riqueza germánica." 762

\subsubsection{Los años de la dictadura (1934-1941). Entre colaboración, adaptación y defensa de los valores protestantes}

A pesar de la disolución de la mayoría de las organizaciones de mujeres, y de la integración de las organizaciones protestantes en una organización madre, la EVANGELISCHE FRAUENZEITUNG se mantiene como órgano de la Liga de mujeres protestantes. En el número de Febrero de 1935 Meta Eyl y Hedwig Winnecke sustituyen a Paula Müller-Ortfried en las tareas de dirección. El formato de la revista se mantiene casi en su totalidad, a excepción de la sección dedicada a mujer y política que desaparece para dar paso a una sección literaria. La parte religiosa se amplia. Tanto Eyl como Winnecke no son miembros del partido con lo cual la revista queda libre del control directo de las mujeres nacionalsocialistas. La retirada de MüllerOrtfried es vista como el final de una etapa, la propia Müller-Ortfried se lamenta de la dureza del nuevo comienzo:

„El año 1934 tiene una gran importancia para la Liga de mujeres protestantes alemanas. En este año se inició un nuevo capítulo en la historia de la Liga. La primera época de ésta está finalmente cerrada. Después de la revolución de Noviembre la situación de la mujer sufrió un gran cambio, lamentablemente como consecuencia del hacer del estado. Esto ha sido para las mujeres protestantes bastante difícil. Cuando en Febrero cedía a Eyl la dirección de la Liga tenía previsto un principio continuar en la redacción del EVANGELISCHE FRAUENZEITUNG (...). El número de enero será el último que éste dirigido por $\mathrm{mi}^{\mathrm{ic} .} .763$

El formato se mantiene, la línea no se modifica. Durante la guerra la supervivencia de las editoriales confesionales de hace cada vez más difícil. Al depender sus contingentes de papel de las asignaciones oficiales son las primeras en sufrir las restricciones. En 1943 un gran número (800 según cifras oficiales) de tales editoriales tienen que cerrar por falta de papel. ${ }^{764}$ Durante la

761 Eyl, Meta: „Zum Kampf um das Alte Testament”, EvangELisCHe FrauenZeITUNG, Mayo 1932, (año 33), p.121

762 Eyl, Meta: „Zum Kampf um das Alte Testament”, Evangelische FrauenZeitung, Mayo 1932, (año 33), p. 122

763 Müller-Ortfried, P.: „Abschied“, EvangElische FrauenZEITUnG, Enero 1935 (año 36), p.49

764 BAZ, 62 Di 1, Sign 26, n²6 
guerra es corriente la información de noticias oficiales relacionadas con decretos, o con la guerra misma. A partir de 1939, los números son más cortos, la propaganda desaparece y la información se limita progresivamente a temas religiosos.

Autoras como Gertrud Bäumer son citadas, o se comentan sus libros haciendo alusión a la importancia del acontecimiento (Gestalt und Wandel). Lo mismo ocurre con autoras católicas como Gertrud von le Fort. Curiosamente temas como el Kirchenkampf son evitados. Temas relacionados con el nacionalsocialismo no aparecen tan profusamente tratados como en la prensa propagandística.

\subsubsection{Ideales de feminidad}

\subsubsection{Feminidad versus creación divina}

Los ideales de feminidad se presentan como un apéndice de la teología protestante. La identidad de la mujer como individuo y su función en la sociedad se discuten desde una perspectiva confesional y religiosa. Confesional en su oposición y diferenciación de la ideología católica y religiosa entendido como su distanciamiento de la vida pública. De esta manera aparecen artículos que intentan exponer las expectativas que Dios tiene sobre la mujer, o se intentan legitimar desde puntos de vista teológicos y bíblicos la identidad y funciones de la mujer que hacía el nacionalsocialismo.

En sus intentos por definir la naturaleza de lo femenino se intenta buscar un tercer camino entre la consideración ,individualista“ y „biológica“ de la mujer:

„La mujer ni es un ser individual ni puramente biológico, según la Biblia ésta es la que es llamada por Dios, la que le ha respondido, la que recibe de él su papel y su tarea en el mundo". ${ }^{765}$

La mujer recibe el sentido de su existencia de Dios y por lo tanto su función está determinada por éste. Lo femenino „es“ porque Dios existe, por que él por medio de la palabra ha „nombrado“ al hombre y a la mujer. Hombre y mujer son iguales ante los ojos de Dios, ambos son personas:

„Ella tiene el mismo valor como persona que el hombre. Personalidad no entendida en el sentido moderno de la palabra. Persona no es quien se concibe a si mismo y como un yo individual y separado se presenta a los otros. La Biblia no ve al ser humano como individuo, que en la diferencia encuentra su identidad, sino como uno que es concebido por Dios y es llamado por éste por su nombre“".766

Sin embargo el concepto de persona no es utilizado en el sentido moderno de la palabra. ${ }^{767}$ Persona, individuo es de nuevo definido en relación a Dios; el individuo „es“ por medio de la gracia de Dios. La existencia de hombre y mujer se contempla como determinada por Dios. La determinación individual, el camino personal de cada individuo tiene lugar dentro del plan de Dios para los hombres. Hombres y mujeres no pueden hacer absolutamente nada para configurar su naturaleza, todo viene de Dios. Antropología: su función determina es por dios

\footnotetext{
765 Gillet, G.: „Von Beruf und Berufung der Frau”, EvangELISCHE FraUENZEiTung, Mayo 1938 (año 39), p.98

766 Ibídem, p. 98

767 El sentido kantiano de la palabra persona se refiere al control del individuo sobre sus actos.
} 
dada, Erfiullung von Gottes Willen. Específico de los protestantes es que nada determina la naturaleza de los hombres, sino Dios, ellos no pueden hacer nada, sino aceptar la voluntad de éste; esta tensión esta reflejada por las mujeres del EVANGELISCHE FRAUENZEITUNG por la lucha entre el „pequeño individuo“ y el „tu eterno“ que propone Søren Kierkegaard en su obra. ${ }^{768}$

La lucha del hombre por definir su identidad, se refleja bíblicamente en la lucha de Jacob contra Jahwe, la mujer tiene por el contrario otra manera de reconocer su naturaleza respeto a éste:

„Pero Dios llama a cada uno de una manera diferente. Éste ser revela a la mujer en la determinación de su género y justamente en los tiempos del nuevo testamento la llama a través de su maternidad pro la cual la mujer toma parte en la salvación de su pueblo. La lucha de Jacob en la vida de la mujer de entonces se manifiesta en su hijo y en el parto vive ésta la gracia y la providencia de Dios““.769

El fundamento, la clave para entender lo que es la feminidad y para delimitar por consiguiente el papel de la mujer, es para las mujeres protestantes el cristianismo. La Edad Media germánica es utilizada como el símbolo por excelencia de la mujer cristiana. ${ }^{770}$ Las raíces de la feminidad no se encuentran en el ideal de las tribus germánicas propuestos por los nacionalsocialistas o por los $D C$ que consideraban la influencia judeo-cristiana en la civilización, así como en la situación de la mujer, como funesta ya que contribuía a su exclavización y a la humillación de la identidad femenina.

„Un nuevo movimiento de la mujer con raíces germánicas afirma que el cristianismo proviene del universo semita-oriental que desprecia lo femenino y que ha traído a los pueblos germánicos la concepción de la mujer como un ser inferior. Sólo con la desaparición de las ideas bíblicas y con els espíritu y la sangre la mujer se puede liberar de si misma y encontrar su tarea como camarada del hombre y madre del pueblo“. .771

Por otra parte las mujeres del nuevo testamento son observadas como ejemplos para las mujeres alemanas ya que demostraron su fuerza de carácter y voluntad. De la misma manera se defiende a las mujeres judías por su compromiso como madres y por la defensa de su identidad nacional. ${ }^{772}$

La maternidad determina así la naturaleza de la mujer. Una condición que no viene establecida por „un poder terrenal“, el estado o por ella misma, sino por el mismo Dios. La mujer es mujer porque es madre, y es madre porque Dios así lo ha determinado en su orden sobre la existencia de ambos géneros. Por ello una de las principales características de la feminidad es la obediencia, la primera mujer que ejemplifica este rasgo es María:

768 Gillet, G.:'Von Beruf und Berufung der Frau", op.cit., p.99

769 Ibídem, p. 99.

770 Este símbolo también es utilizado por Gertrud Bäumer en contraposición a los Deutsche Christen que utilizaban como ejemplo a la mujer germana como símbolo de la femninidad alemana.

771 Gillet, G.: „Die Frau nach christlichem Glauben“, EvANGELISCHE FrAUENZEITUNG, Junio 1934 (año 35), p.126

772 Gillet, M.: „Das biblische Wort über die Frau“, EvANGELISCHE FraUENZEITUNG, Octubre 1936 (año 38), p.5 
"El camino de María, la primera mujer del nuevo testamento ejemplo de la madre de la tierra sagrada, es el camino de la obediencia y la disposición“. ${ }^{773}$

El otro ejemplo de mujer que se opone a la obediente María es Eva. Eva creada a imagen y semejanza de su compañero, con los mismo derechos y deberes que éste. Ella es concebida como la gran pecadora, la que instaura el mal en el mundo, la que rompe la armónica existencia en el paraíso, de ahí que la relación de igual a igual entre hombre y mujer no sea posible:

„(...) A través de la ruptura entre Dios y el mundo en pecado, el ser humano está roto. No existe una relación, como en la creación, entre el hombre y la mujer; por el contrario los demonios de la autoridad por un lado y por el otro la humillación y la seducción amenazan para siempre este campo“. 774

En esta consideración aparece un problema de argumentación lógico: la maternidad aparece en la Biblia como castigo al pecado original de Eva. Esta mancha en la dignidad de la mujer se argumenta tanto en el catolicismo como en el protestantismo, de ahí la necesidad de salvación por una parte, y por otra parte la necesidad de idealizar un proceso como el de la maternidad, no como castigo sino como don:

„Pero el destino de la hembra como dependiente de otros manifestado en su destino como esposas y como madres, no debe verse únicamente desde el punto de vista de la maldición. En el caso que la relación con el hombre conduzca a una indigna independencia y fijación en éste, debe entenderse no sólo desde el propio punto de vista sino positivamente como la forma que Dios ha dado a la mujer de existir y en la que ésta se reconoce“. .775

La mujer tiene el deber de realizar la voluntad de Dios en todos aquellos campos en los que está presente: matrimonio, familia, profesión y vida pública. Esta voluntad es estar al servicio de los demás, obediencia, capacidad de sacrificio y amor.

„En estas comunidades (de vida) a la mujer le es concedida una gran fuerza vinculante no conseguida por ella misma sino por encargo de Dios. A pesar de la ruptura entre Dios y el mundo, Dios acepta a la mujer en su forma especial de ser, donde el servicio de 'ver y cuidar para los otros' puede ser extremadamente difícil pero ratificante a la vez“. ${ }^{776}$

Esta argumentación tiene consecuencias éticas y políticas muy graves ya que predispone a los hombres y mujeres a no cuestionar los principios de la autoridad estatal o el orden social bajo el moto: todo viene de Dios, por lo tanto tiene que ser bueno. En el terreno de la ética revela un déficit de autodeterminación y crítica.

Este argumentación tiene sus raíces en el mismo Lutero y ocupa a los teólogos protestantes que viven bajo la dictadura nazi de una manera muy intensa. Un teólogo como Dietrich Bonhoeffer, adversario reconocido del nacionalsocialismo, argumenta en su escritos sobre ética la necesidad de un orden establecido por Dios:

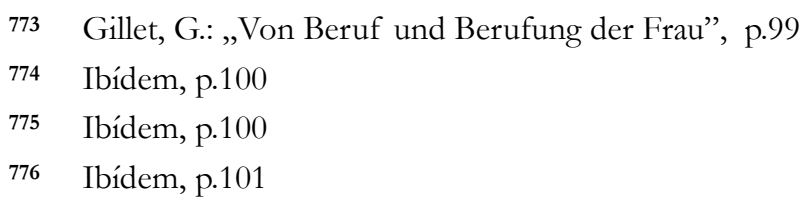


„El mundo existe en relación a Cristo. Si lo sabe o no. Esta relación se manifiesta en determinados mandatos. Las escrituras nombran cuatro de estos mandatos: trabajo, matrimonio, autoridad e iglesia“. 777

Hay que entender esta supeditación a lo nacional, al estado, a la idea de la autoridad no como un rasgo típicamente nacionalsocialista. Esta dependencia tiene sus raíces en las estructuras ideológicas del protestantismo alemán. Valores femeninos y masculinos existen pues en función de la creación divina. Las diferencias, funciones, deberes y derechos no deben establecerse desde una autoridad terrenal, sino desde el convencimiento de lo divino de la creación. Ni el estado, ni el individuo pueden determinar la existencia de lo femenino y lo masculino.

La fundamentación de esta actitud hacia lo femenino se encuentra en la Biblia. Este nuevo fundamentalismo se encuentra, como ya hemos comentado en otras ocasiones, en el contexto de las tendencias teológicas del nacionalsocialismo, donde la Biblia se convierte para muchos teólogos en la única arma contra el Tercer Reich:

„La Biblia en si misma es el credo del evangelio y los demás credos formulados a lo largo de la historia (...) son una compilación cristalizada de la embajada bíblica. Son guía en la comprensión de la Biblia. No son sin embargo nada sin ésta. Por esto no existe en la Iglesia Protestante un verdadero credo donde la Biblia no éste presente". ${ }^{778}$

Una vez más de igual manera que en Die FraU se alaba la cualidad de las mujeres como „intermediarias entre lo divino y lo profano“. Esta consideración de la mujer como „mediadora“ es comparada con la situación de las mujeres germanas, luchadoras, dadoras de la vida y compañeras en igualdad de sus maridos. DIE FRAU utiliza por el contrario ejemplos relacionados con el cristianismo primitivo o con la época medieval. Imágenes también acogidas por el nacionalsocialismo para definir los valores femeninos. Como por ejemplo la figura de Brunilda, Brunbild, que aparece en las leyendas nórdicas y germanas como una mujer de gran fuerza y poderes mágicos. Son mujeres conocidas por sus conocimientos de la medicina, por su capacidad de curar, por su lucha al lado de los hombres, por su valentía y por el reconocimiento del que gozaban en la comunidad. ${ }^{779}$ Los temas relacionados con la naturaleza de lo femenino se mantienen hasta 1938. Curiosamente en esta época se hace referencia al ala moderada de la mujer. El papel de la mujer en la sociedad es valorado todavía con optimismo y esperanza. ${ }^{780}$

\subsubsection{María y Eva entre el ejemplo y la tentación}

Siguiendo las teorías de Lutero al respecto, se mantienen las dudas sobre la virginidad de María. Se recogen también las teorías de Friedrich Schleiermacher. Las autoras son conscientes de dos cosas: según la tradición católica el acto sexual es considerado como pecado, si María no es virgen. En esta polémica sobre la virginidad de María se establecen una serie de pautas que afectan a la teoría de feminidad:

777 Bonhoeffer, D.: Ethik, München, Christian Kaiser Verlag, 1988 (12ªed., 1ª ed. 1949), p.220

778 Eyl, M.: „Die Bibel in der kirchlichen und geistigen Lage Deutschlands“, EVANGELISCHE FrAUENZEITUNG, Diciembre 1937 (año 39), p.35

779 Philipp, B.: „Zwiefältig Gewirk des nördlichen Geistes”, EvangeLISCHE FrauENZEITUNG, Mayo 1940 (año 41), p.59

780 Winnecke,H.: „Ein document”, EvangELISCHE FrauENZEITUNG, Enero 1937, pp. 62-63 
„El hombre está determinado en su naturaleza por el signo de la soberanía, mientras que la mujer por la tolerancia, la acogida y el sufrimiento". .781

Dios utiliza a la mujer como instrumento para hacer hombre a Cristo. Esta elección honra a la mujer ya que se trata de una gracia que Dios le concede. La mujer y el hombre tienen una naturaleza pecadora. María representada como el contrario de Eva, la pecadora, la amiga de la serpiente y gracias a su sacrificio redime tanto a hombres como mujeres de su pecado, no por su virginidad, sino por su entrega, sacrificio etc.:

„María no pude ser presentada como una nueva Eva y Cristo como el nuevo Adán. Como si a través de su desobediencia se hubiera olvidado la desobediencia de Eva. María no es salvadora, como Cristo, sino que ella misma es miembro de la comunidad de los redimidos. Ella es el polo opuesto a Eva a través del milagro que Dios ha hecho en ella. Ella es instrumento de salvación“. 782

María no es la madre de Dios en el sentido literal de la palabra, ella es la que permite que Cristo se haga hombre a través de su sacrificio y entrega. La mujer estaba desde el principio condenada, a causa de Eva, la acción de María la libera, le hace recuperar de nuevo su destino. Así la única manera de superar el pecado heredado por Eva es imitar el ejemplo de María:

„La primera mujer de la Biblia es hecha como compañera del hombre, a los ojos de Dios al mismo de nivel de igualdad y libertad que éste. En la huida después del pecado mortal su valor como persona depende del hombre hasta que éste desaparece, lo cual se refleja en la situación social de la mujer en las distintas épocas y culturas históricas“". ${ }^{783}$

Otros ejemplos que simbolizan a Eva son la hetárea y la amazona como mujeres libres que deciden su destino. ${ }^{784} \mathrm{El}$ matrimonio es considerado como parte del plan que dios tiene con los hombres y por lo tanto una institución eterna y duradera. Paralelamente se apoya las medidas que toma el nacionalsocialismo para proteger a la familia y al matrimonio en el nuevo derecho penal. ${ }^{785}$

\subsubsection{La mujer como madre. La maternidad espiritual}

La maternidad proviene de Dios y proporciona a la mujer cualidades especiales: entre ellas lo que algunas autoras de la EVANGELISCHE FrAUENZEITUNG llaman All-sein: el ser en su totalidad. ${ }^{786}$ Esta cualidad esencial de la mujer no define únicamente su actividad en la familia o

781 Paulsen, A.: „Geboren von der Jungfrau Maria”, EvangELISCHE FraUENZEITUNG, Diciembre 1938 (año 40), p.40

782 Ibídem, p. 40

783 Gillet, G.: „Von Beruf und Berufung der Frau”, op.cit., p.100

784 Heinsius, M.: „Die Macht der Frau“, Evangelische FraUENZEITUNG, Noviembre 1939 (año 41), p.11

785 Mayer, A.: „Deru Schutz von Ehe und Familie im neue deutschen Strafsrecht” EvANGELISCHE FRAUENZEITUNG, Febrero 1937, n² 2, p. 79

786 Witte, H.: „Die Verantwortung der evangelischen Frau für die heutige Volkspflege“, EVANGELISCHE FrAUENZEITUNG, Marzo 1936 (año 37), p.98 
como educadora de sus hijos sino que transciende al trabajo en conjunto con sus compañeros del género masculino en la vida laboral:

„La madre concede el ser en su totalidad. La madre se entrega a si misma a todo lo que necesita su amor, su dedicación, su ayuda. Ella ve en cada ser, sea éste insignificante, pequeño y débil como una representación de la existencia total. La mujer madre, sea casada o soltera, tiene en esta forma de ser la fuente de su sacrificio, de su abnegación en el trabajo“. ${ }^{787}$

Esta condición especial de la mujer garantiza su protagonismo en la historia de la humanidad. Su actuación no depende de una actividad material sino de su condición natural:

„A través de la actividad de la mujer es donde realmente se crea 'cultura', donde aparece la costumbre y la fuerza vital que une el caos con el cosmos, ahí aparece la 'historia'. Si, los hombres hacen la historia, ¿pero no son las mujeres los pilares de la vida?" 788

La maternidad no es únicamente una tarea biológica, sino que los objetivos de toda madre protestante es una geistig geschulte evangelische Mütterlich-keit, die innere Ertüchtigung der Frauen. 789

Las mujeres son el „rebaño desconocido“ que en silencio con su fuerza y valor defienden a su pueblo con la misma energía que sus compatriotas masculinos. Las mujeres son el rebaño que se sacrifica y se entrega para apoyar en toda ocasión a la patria. Este sacrificio es entendido al mismo nivel que la lucha del soldado en el frente, con la única diferencia que éste se realiza en el silencio y en el anonimato. ${ }^{790}$

La maternidad es presentada como el contrasentido de la guerra, ella es la paz y la fuerza del amor, valores que son imprescindibles en la creación de la vida. No obstante sería falso pensar en la existencia de ideas pacifistas en este entendimiento de la maternidad. La construcción fomenta la división dual entre lo masculino y lo femenino y no descarta o descalifica el ,instinto guerrero" del hombre, como complemento del alma femenina. El alma de la mujer es la fuente de la paz, cuando la sangre se derrama en la lucha del pueblo alemán. Ella defiende los valores de su pueblo: Rasse, Erbgut, Blut, Boden, Mutter, Kind y Volksgemeinschaft. ${ }^{791}$ Además de luchar y „sanar" las cualidades de su pueblo la mujer protestante permanece al lado de su marido cuando en todo momento. La mujer es la que garantiza con su presencia la fuerza del hombre, la que determina que el hombre pueda concluir su obra. ${ }^{792}$

Frente a esta admiración e idealización de la maternidad de la mujer, encontramos voces que defienden la tarea de aquellas mujeres solteras que dedican su vida al servicio de los demás.793 En su tarea para los otros se realiza el instinto maternal natural que tiene todas las mujeres:

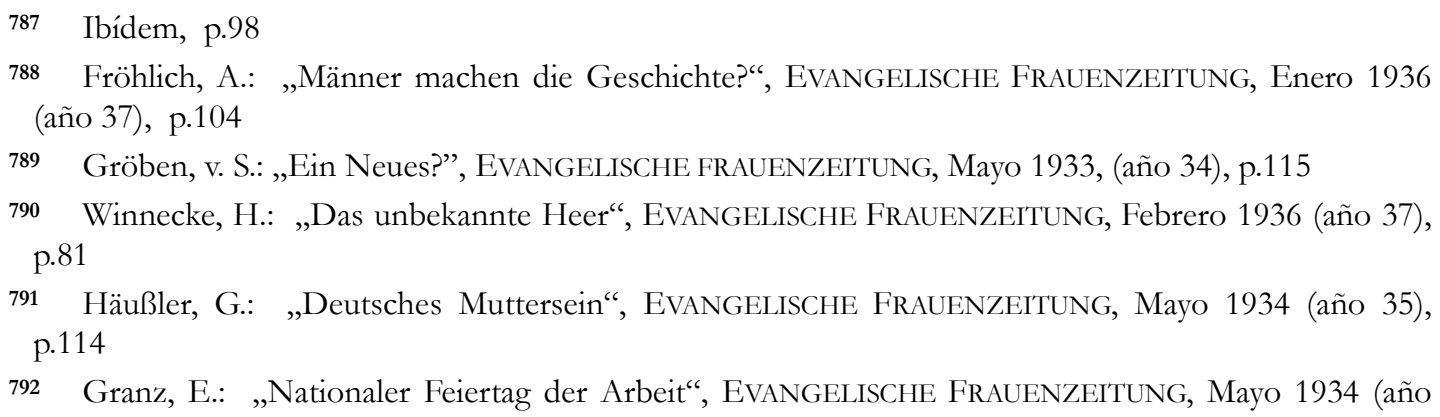
35), p.113

793 Eyl, M.: „Was ist der Deutsch-Evangelische Frauenbund?“, EvANGELISCHE FrAUENZEITUNG, Octubre 1935 (año 37), p.1 
„En toda mujer vive el deseo de tener sus propios hijos. El amor y el cuidado hacia la vida aún no nacida o hacia la vida potencial es tan profundo e indeleznable en su más intima naturaleza. Hay una parte en la naturaleza femenina que no se puede entender con la razón o la lógica sino siguiendo cuidadosamente las huellas con el sentido del alma“". ${ }^{794}$

\section{Campo semántico de las cualidades de lo femenino:}

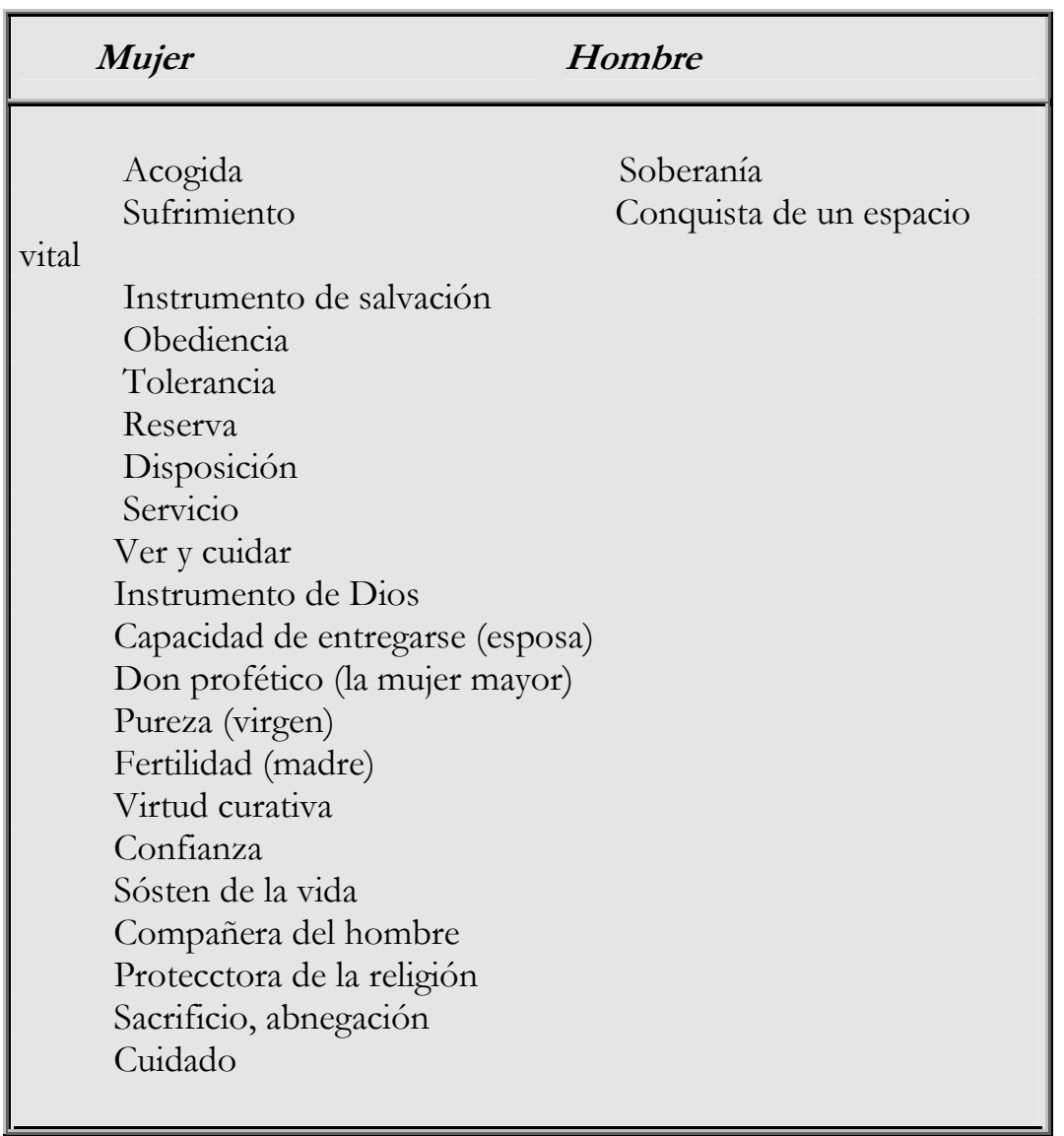

\subsubsection{Kirchenkampf, estado y mujeres}

794 Hueck-Dehio, E.: „Erziehung und Selbsterziehung der Frau zur Mutterschaft“, EvANGELISCHE FraUENZEITUNG, Mayo 1937 (año 38), p.129 
Entre 1934 y 1939 aparecen una serie de artículos que pretenden buscar una salida al papel de la mujer como protestante en el nacionalsocialista, punto central de las argumentaciones entre los diferentes bandos de Kirchenkampf. Sin mencionar el conflicto entre las iglesias protestantes, se intenta por una parte expresar la lealtad al sistema y por otra parte la obligación cristiana de „luchar contra los poderes de la oscuridad” y el apoyo a las víctimas de las leyes de esterilización. Como ya hemos comentado anteriormente, no se critican las leyes de esterilización, sino que se insiste en el deber de los cristianos de prestar su ayuda y apoyo a las personas afectadas, no haciéndolas sentir seres inferiores. ${ }^{795}$ Este carácter de servicio con los más necesitados aparece como una de las tareas de las iglesia. Es decir el carácter misionero en la comunidad y fuera de ésta es resaltado. Sin embargo no se hace mención a la lucha que las iglesias mantienen entre si. De nuevo prima el principio de la Federación de mantener neutralidad no sólo en cuestiones de política laica sino eclesial. Postura que concuerda con la del $E v F W$, la organización madre de la que dependía la Federación:

„La discusión sobre nuestra postura en el Frente del trabajo femenino protestante sobre las circunstancias en la iglesia ha alcanzado grandes cotas de interés. No obstante me gustaría resaltar de nuevo que la decisión sobre nuestra pertenencia en el espectro político religiosos, permanece como una discusión personal, si nos atenemos a la importancia de la construcción de la iglesia. Una decisión por parte de nuestra organización no debe ser tomada. El pasado año, especialmente durante los meses de verano nos encontramos en una situación parecida a la actual, y a pesar de la presión, por ejemplo de los cristianos alemanes, pudimos mantener nuestra postura apolítica de no implicarnos en asuntos que afectan a la política de nuestras iglesias. “"796

Los protocolos de las sesiones de la Federación con la organización madre, el EvFW muestran con mayor claridad el rechazo que existe en todas las organizaciones respecto a los cristianos alemanes, y en especial se expresa el miedo de la atracción que esta nueva iglesia tiene para las generaciones más jóvenes. Uno de los campos de „misión” son también las Frauenschaften, es decir las organizaciones nacionalsocialistas: se plantea necesario la entrada en la organizaciones de mujeres protestantes convencidas, la realización de proyectos en conjunto, e incluso la invitación de las mujeres nacionalsocialistas. ${ }^{797}$ Esta actitud anticristiano alemana se reproduce en los artículos que aparecen sobre el tema religioso hasta 1939, donde teológicamente se apoyan los principios de la declaración de Barmen. Sin embargo un apoyo a los principios de la iglesia confesora no llega a producirse. En la revista se cuida la línea de la neutralidad.

\subsubsection{Posturas politicas}

795 Eyl, M.: „Das Gebot der Stunden”, Evangelische Frauenzeitung, Abril 1934, (año 35), p. 102. La interpretación de este artículo por historiadores/as ha de lo más variada. Claudia Koonz cree ver un intento por parte de Meta Eyl de conseguir una posición privilegidada en el nuevo estado. Kaiser, por el contrario interpreta el artículo como una casi visión profética de Eyl sobre los excesos que quedaban por venir, y por lo tanto una clara protesta contra la política nazi. En nuestra opinión vuelve a repetirse una actitud positiva en general hacia el régimen, y la creencia de poder todavía influir desde la autoridad de la iglesia en los destinos del pueblo alemán.

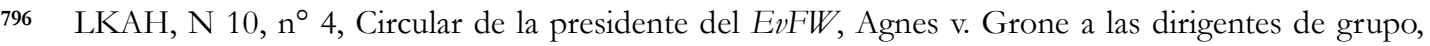
25.06.1934

797 LKAH, N10, n² 4, Reunión de las dirigentes de grupos del EvFW en Hannover, 2.02.1934 
A pesar de los primeras reacciones en contra de los nacionalsocialistas en los primeros años de la dictadura en los que éste se encuentra todavía bajo la dirección de Paula Müller-Ortfried. En 1935 Meta Eyl declara públicamente en un artículo su apoyo al nuevo régimen:

„La autoridad quiere servir al orden de nuestro pueblo, para nuestra fe es ésta un mandamiento establecido por Dios y por el orden establecido, dentro del que el individuo protestante tiene que cumplir la ley cristiana en la libertad creadora y constructora del amor". .798

Del nuevo régimen esperan las mujeres protestantes la superación del individualismo, una nueva era, el descubrimiento de la propia identidad, una personalidad estética y armoniosa, un individuo libre e independiente, la ciencia y el humanismo. Un mundo en orden, perfecto donde el parlamentarismo ha sido superado por la figura del Führer.

"El Führer no habla, él dirige, él muestra, él educa. Él guía únicamente a los que están dispuestos a seguirle, a los fuertes, a los que tienen buena voluntad." 799

En la creación del nuevo orden y del nuevo estado esperan las mujeres protestantes adquirir un papel relevante:

„La llamada del yo al nosotros apela a la mujer. Esta llamada apela a la mujer en el espacio vital de su pueblo, en la llamada del yo al nosotros. Alemán y protestante están en este aspecto relacionados estrechamente. Ya que nuestra confesión protestante es el credo de la reformación alemana, (...)“. 800

En el periódico se refleja de nuevo la situación política del EvFW. Por una parte su apoyo incondicional al nacionalsocialismo, por otra parte su deseo de mantener su independencia como protestantes y como grupo.

Otro tipo de artículo bastante común en la EVANGELISCHE FRAUENZEITUNG trataban temas sociales desde una perspectiva religiosa y filosófica. En ellos se reflexiona de manera abstracta sobre el papel del ,individuo" en la sociedad desde sus creencias religiosas. La perspectiva de género se abandona y los artículos se dirigen a todo tipo de lectores. De estos artículos se desprende una teoría de la sociedad en la que dios es el principal artificio de los destinos humanos. La historia es una parte del plan divino.

„El cristiano que conoce la historia dirá que ésta está designada por voluntad de Dios. (...) Es seguro que ésta influye en los más sutiles cambios de nuestra existencia general e individual“". 801

Esta influencia divina justifica también los tiempos de privaciones y dificultades que se han vivido desde 1933 y por supuesto la guerra:

\footnotetext{
798 Eyl, M.: „Was ist der Deutsch-Evangelische Frauenbund?“ op. cit., p.2

799 Fröhlich, A.: „Eröffnung der Aussprache am 20. Juni“, EvANGELISCHE FrAuENZEITUNG, JulioAgosto 1934 (año 35), p.148

800 Ibídem, p.149

801 Eyl, M.: „Zeiten der Bewährung”, Evangelische FrauenZEITUnG, Abril 1941 (año 42), p.59
} 
„Ya ha ocurrido de manera imperceptible en la actuación política desde 1933 y ocurre ahora en la guerra. En la dureza de la llamada humana se esconde la gracia de Dios. De nuevo se plantea la pregunta a la nación y a cada uno si quieren reconocer nuestra historia, si quieren aceptar las consecuencias, si quiere seguir viviendo". 802

Desde esta perspectiva teológica se argumenta la necesidad „natural“ de expansión „del pueblo de la mitad“, y por supuesto la defensa ante „invasores“ o pueblos que limitan el crecimiento:

„Al pueblo de la mitad europea ha sido al que menos se le ha permitido vivir en paz y en seguridad. Se ha encontrado siempre en la situación de un fuerte en movilización. Este pueblo no quiere ser el lugar de recreo de pueblos extraños, quiere ser lo que debe ser según está establecido por la providencia histórica. Está demostrado que si la naturaleza que el pueblo alemán está comprimida y limitada en su espacio vital, y si este espacio de acción es propio, (el pueblo alemán) levanta el temor entre sus vecinos“. 803

Junto a la asimilación de la propaganda nacionalsocialista aparecen argumentos que contradicen la teoría racista de la dictadura. El origen de un pueblo no está , según el periódico, en la raza o en la sangre alemana. La pertenencia esta determinada únicamente por Dios:

„El origen del pueblo radica sin embargo en Dios, porque la voluntad de éste es que éstos existan. Nuestro pueblo no lo podemos elegir. Está determinado por la voluntad de Dios que seamos alemanes, chinos o franceses“". 804

A diferencia de las revistas para mujeres católicas, se incita al „creyente“ a participar en la vida política, dada la especial importancia de éste en el devenir político:

„Los cristianos en Alemania, se encuentra en estos momentos entre el mantenimiento de su responsabilidad individual y la tensión entre evangelio e historia, tienen no obstante que esforzarse en una valoración objetiva de las conexiones política y religiosas. Porque allí donde la política entra en conflicto tiene el cristiano la obligación de luchar por aliviar la situación y llegar a una solución“. ${ }^{805}$

El creyente como mediador entre la vida pública y la religiosa y como garantía de la preservación de la iglesia. Este tema, como el de la secularización representan sin duda alguna, la ya antigua preocupación general de la iglesia protestante en sus relaciones con el poder. La solución a esta pregunta no encuentra alternativas directas sino que propone una nueva revalorización de la historia del protestantismo alemán, y el abandono de posturas que idealizan el pasado:

\footnotetext{
802 Ibídem

803 Ibídem

804 Widerholz, M.: „Volk“, EvANGELISCHE FrAUENZEITUNG, Octubre 1934 (año 36), p.2

805 Eyl, M.: „Zeiten der Bewährung“ op. cit., , p.60
} 
„La Iglesia Protestante está hoy en día amenazada; si ésta no acepta en serio los problemas de la historia y no trabaja en una verdadera concepción histórica del cristianismo. La mentalidad eclesiástica se balancea hoy entre una huida pequeñoburguesa de la historia o una contemplación de la historia como huida del presente“. 806

Sobre como afrontar la situación del presente no se da ninguna pauta. Casi de la misma manera que las mujeres de DIE FRAU reaccionan las mujeres protestantes, al estallar la guerra. Las últimas críticas y prejuicios contra los nacionalsocialistas quedaban enterrados por el „inmenso amor a Alemania“ que mostraban las mujeres. La guerra convencía a las últimas indecisas:

„Aquí radica para nosotras, mujeres alemanas, una gran tarea, de la que tenemos que ser conscientes. Es una tarea maravillosa, proveniente de Dios, precisamente ahora en tiempos de preocupación, de necesidad, de peligro para mostrar de donde sacamos la fuerza necesaria para seguir aguantando con alegría, para transmitir valor, para ayudar con amor, a todo aquel que lo necesite. Nosotras, mujeres alemanas protestantes, queremos ser en la patria, mujeres en el frente". 807

El amor a la patria, el acto de sacrificio, la actitud de espera son nada más que la condición natural de la mujer establecida según los deseos divinos. En casa configuraran su propio frente, contra aquellos que atentan contra la sagrada Alemania para no defraudar a novios, esposos e hijos.

\subsubsection{La genética positiva}

Durante los primeros años de la dictadura encontramos artículos en los que se llama la atención a los lectores sobre el tema eugenésico, o como aparece llamado en la revista, Volkespflege (cuidado del pueblo). La misma Meta Eyl toca el tema en Abril de 1934, donde se pregunta sobre la postura que deben tomar las mujeres protestantes sobre este tema. En el número de Septiembre del mismo año Mathilde Rüdel señala la imposibilidad de permanecer indiferentes sobre el tema y exige que las mujeres protestantes se pronuncien sobre éste.808 Los artículos que se suceden se muestran partidarios de una positive Eugenik (genética positiva) que consistía mayoritariamente en extender certificados de capacidad para el matrimonio, consultas para parejas en edad casadera, atención a la madre y al hijo, información para familias numerosas y préstamos a parejas casaderas. Lo que se entendía como genética negativa era la ley para evitar la fecundación de descendencia con enfermedades hereditarias, la prohibición del

806 Eyl, M.: „Zwischen Kirche und Reich. Ein Nachtrag“, EvANGELISCHE FraUENZEITUNG, Febrero 1941 (año 42), p.38

807 Anz, T.: „Stimmung”, EVANGELISCHE FrauENZEITUNG, Enero 1942 (año 43), p.31

808 Eyl, M.: „Das Gebot der Stunde“, EvangELISCHE FraUENZEiTUNG, Abril 1934 (año 35), pp.98102; Rüdel, M.: „Der Christ zu dem Problem der Eugenik“, Evangelische Frauenzeitung, Septiembre 1934 (año 35), pp.181-183 
matrimonio a personas incapacitadas (Entmündigte) y esterilizadas. ${ }^{809}$ Las mujeres protestantes se muestran partidarias de la primera posibilidad ya que apoya a la familia, facilita a la madre su trabajo en el hogar y contribuye a fomentar familias con sólidos principios éticos y morales. Sin embargo, motivadas por sus ideas cristianas las mujeres de EVANGELISCHE FRAUENZEITUNG critican la leyes de esterilización:

„Atenta fuertemente contra el destino del individuo, (la política ) lo ve como un miembro que no debe dañar al resto de la comunidad del pueblo a través de la enfermedad“. 810

La llamada genética negativa contradice las enseñanzas del evangelio, el cual no hace diferencia entre Vollwerte y Unwerte. 811 En contra de la ideología nacionalsocialista argumentan que un minusválido es un individuo y eso es lo que realmente importa. Por otra parte se rechaza la exigencia de definir la ascendencia aria. Para las mujeres protestantes lo que cuenta es la confesión a la que uno pertenece:

„La pregunta aria tiene además otra versión. Nosotras somos preguntadas con asiduidad si nuestros miembros son de procedencia aria pueden permanecer en nuestra organización. Para nosotros depende si nuestras condiciones son cumplidas. Estas establecen que toda mujer de confesión protestante puede ser miembro de la Liga. Esto quiere decir que para nosotros es el conocimiento del evangelio la medida que establece la pertenencia a nuestra organización“. ${ }^{812}$

El ideal nazi de hombres y mujeres sanos, perfectos, hermosos e inteligentes, es criticado desde las filas de EVANGELISCHE FRAUENZEITUNG:

„¿Por qué es la ideología de los superhombres tan popular y encuentra siempre resonancia? (...) nosotras sabemos de la Biblia que uno de esos (enfermo mental) no deja de ser nunca una persona creada por Dios a su imagen y semejanza“. ${ }^{813}$

Durante el período entre 1939 y 1941 los artículos de la revista se concentran en temas religiosos y relacionados con la guerra. En el número de octubre de 1939 se apela a las mujeres protestantes a mantener unidas las fuerzas y superar los intereses personales y privados. Mientras se llora la pérdida de Danzing se unen artículos sobre arte de la edad media donde se hace referencia a la influencia alemana en el arte polaco, en Praga y en Alsacia. En 1938 se celebra con júbilo la anexión de los sudetes checos al Reich alemán. ${ }^{814}$

La influencia de la guerra se extiende también al tratamiento de la mujer y su función en la sociedad. Uno de los pocos artículos dedicados a la naturaleza sobre lo femenino aparece en mayo de 1940. Beda Philipp escribe sobre el papel de la mujer en las tribus germánicas. La

809 Witte, H.: „Die Verantwortung der evangelischen Frau” op. cit., p, 100

810 Ibídem, p.101

811 Ibídem

812 Fröhlich, E.: „Eröffnung der Aussprache am 20. Juni“ op. cit., p.148

813 Voigt, E.: „Der evangelische Christ zur Frage der Erziehung und Pflege von Anormalen“, EvANGELISCHE FRAUENZEITUNG, Febrero 1935 (año 36), p.75

814 Drechsler,A.: „Die evangelsiche Kirche im Sudetenland und ihre Liebeswerke”, Febrero 1939, n 2 , p. 73 
mujer aparece definida como Kampfgefährtin, compañera de lucha del hombre y se resalta su función como curanderas, y cuidadoras de la vida en la tribu. ${ }^{815}$

Respecto a la situación religiosa es interesante destacar un artículo sobre la obra Hermann Sauer dedicada a los deberes del soldado. El tema de la prestación de juramento a Hitler de los soldados alemanes afectaba también a los pastores de la iglesia protestante que habían ingresado a filas. Entre ellos se encontraban también miembros de la iglesia confesora para los que la defensa de Alemania no entraba en contradicción con su oposición al régimen nacionalsocialista. El teólogo Karl Barth llama la atención sobre la contradicción de tal medida, y convoca a todos los pastores a oponerse al juramento. Esta exigencia no es aceptada positivamente entre los círculos de la iglesia confesora, donde tal medida hubiera significado la traición a la patria alemana. Meta Eyl se encarga en el artículo de definir el juramento del soldado como un símbolo de los principales valores alemanes: el valor de la vida comunitaria como ideal de entrega y sacrificio y libre de toda arbitrariedad y egoísmo personal. ${ }^{816}$

En el número de febrero de 1941, las principales representantes del trabajo de las mujeres protestantes, Meta Eyl, Dagmar von Bismarck y Antonie Nopitsch, publican un artículo donde se critican las consecuencias del tratado de Versalles y se reza por el Führer para que éste logre sus intereses. ${ }^{817}$

\subsubsection{AUfGABEN UND ZIELEN}

La revista existía como órgano de prensa de la Vereiningung Evangelischer Frauenverbände desde 1918 y con motivo de la reorganización de todas las asociaciones de mujeres protestantes en el EvFW, Evangelisches Franenwerk, aparece desde el 13 de diciembre de 1933 como órgano de prensa de la organización madre. Desde 1933 hasta finales de 1935 aparecen como editoras Magdalene von Tiling y Nora Hartwick, fecha en la que a raíz del conflicto entre las dos, von Tiling abandona la dirección. ${ }^{818}$ La revista aparece una vez al mes y pretende coordinar el trabajo de todos los grupos del EvFW a nivel nacional. Se trata por lo tanto, de DIE EVANGELISCHE FRAUENZEITUNG y AUFGABEN UND ZIELEN una publicación de carácter interno y fundamentalmente religiosa. No obstante aparecen esporádicamente artículos dedicados relacionados con el papel de la mujer protestante en el estado nacionalsocialista y la situación de lucha entre las iglesias protestantes.

La persona de Magdalene von Tiling marcará el carácter de la publicación. Nacida en una familia prusiana instalada en Riga, elige la profesión de magisterio donde trabaja como directora de un

815 Philipp, B.: „Zwiefältig Gewirk des nordischen Geistes”, Main 1940, n 5, pp. 58-59

816 Eyl, M.: „Das Reich als Eidgenossenschaft?, Mayo 1940, n 5, p. 61

817 Eyl, M., Bismarck, D., Nopitsch, A., Brandmeier, P.: „Neujahrgruß der Evangelischen Frauenarbeit für Kirche und Gemeinde”, EvangELISCHE FrauENZEITUNG, Febrero 1941, n² 2, p. 39

818 LKAH, N10, Nr 7, 23.09. 1935, Correspondencia entre Gerda Lucas y Agnes von Grone. Magdalene von Tiling continúa como miembro activo del EvFW al frente de grupo III de éste, dedicado al trabajo de educación y formación. Tras la reestructuración del EvFW el 15 de agosto de 1934, pierde su trabajo al frente de la comisión de educación y formación, y empieza a trabajar de nuevo en la enseñanza. Las causas de su despido no están claras, pero se establece una coincidencia entre su visita a Rumania dónde, según informes de la Gestapo se expresó despectivamente en relación al nacionalsocialismo LKAH, N 10, nr 32, 9.08.1934, Correspondencia entre el DFW y Agnes v.Grone. En la correspondencia que von Tiling entabla con von Grone y Scholtz-Klink, ésta se esfuerza en demostrar su apoyo al nacionalsocialismo. No obstante no creemos que von Tiling abandone el trabajo en el $E v F W$. En un comunicado de éste sobre la situación del Kirchenkampf firman junto a Agnes von Grone, Meta Eyl y Magdalene von Tiling como representantes de éste. LKHA, N 10, Nr 8 
liceo femenino en Elberfeld, gracias a su interés, ímpetu y personalidad es nombrada presidenta de la Asociación para la enseñanza de religión protestante, Verband für evangelischen Religionsunterricht und Pädagogik y de la Unión de las organizaciones de mujeres protestantes alemanas, Vereiningug evangelischer Frauenverbände Deutschlands. ${ }^{819} \mathrm{Su}$ tarea como educadora llega a su fin en 1921 al ser elegida diputada en el parlamento prusiano. Cinco meses en 1928 trabaja como referente en el ministerio del interior, tarea que se une a su actividad en el Reichstag (1930-1933) como diputada del Deutsch-Nationale Volkspartei:

„Como representante parlamentaria me ocupe de la construcción de nuestro pensamiento conservador en relación a cuestiones de educación, aspectos sexuales en el matrimonio y en la familia y en relación a temas relacionados con el estado." 820

Desde 1934 hasta 1938, fecha de su jubilación, trabaja de nuevo como maestra en Berlín. A partir de esta fecha se dedica a la organización de profesoras de religión de la cual es presidenta, y a la edición de las revistas AUFGABEN UND ZIELEN y SCHULE UND EVANGELIUM.

Durante Weimar, desde 1926, trabaja como editora con teológos y pedagógos de alto nivel en la revista, SCHULE UND EVANGELIUM, donde trabaja intensamente con Friedrich Gogarten, 821 trabajo que se prolonga hasta 1941 fecha en que la revista deja de publicarse.

La obra de Tiling se centra fundamentalmente en temas de carácter religioso. El papel de la mujer y la iglesia, el movimiento de la mujer protestante, la educación cristiana en las iglesias son temas que Tiling trata con frecuencia en su actividad como publicista. Sin su obra y sus artículos al respecto es difícil entender la evolución del protestantismo entre las mujeres alemanas. Tiling sienta las bases del movimiento de la mujer protestante y articula el pensamiento de las mujeres protestantes respecto a su propia identidad.

Su postura durante el nacionalsocialismo es como en el caso de las otras líderes protestantes ambigua. En 1933 pertenece al círculo conservador de su partido que esta dispuesto a crear gobierno con el NSDAP. Sin embargo se muestra en desacuerdo con el apoyo que Gorgarten y otros teólogos „,conservadores” otorgan a Hindenburg:

„ ¡Para la existencia de la iglesia sería un gran peligro si esta empieza a influir las elecciones políticas y si además lo hace en una dirección que contradice los sentimientos nacionales del pueblo! (...) Si se llega a descubrir que usted está implicado en una llamada „Instrucción“ para pastores, perdería usted definitivamente la confianza que ha depositado en usted la derecha conservadora, los Stablhelmer y los nazis." ${ }^{822}$

La actitud que recomienda Tiling es de neutralidad y espera. Reacción que después durante la dictadura se refleja en un apoyo al régimen teñido de cierto oportunismo: en uno de sus

819 LKAH, N127, n², Circular de la familia Tiling, marzo 1986

820 LKAH n127, $\mathrm{n}^{\circ}$ 3, Notas sobre la vida de Magdalene v. Tiling, Manuscrito

821 Gogarten, Friedrich, teólogo protestante, Dortmund 13.1.1887, Göttingen 16. 10. 1967. Junto con Karl Barth, Rudolf Bultmann y E. Brunner uno de los fundadores de la teología dialéctica. En un principio critica con Barth el historicismo y antropocentrismo de la teología del siglo XIX y resalta por el contrario la oposición absoluta entre Dios e individuo (influencia de S. Kierkegaard). La evolución de G. hacia una ética antropocéntrica basada en la relación entre el yo y el otro que progresivamente se rellena de ideología nacional-étnica y su posterior ingreso en la iglesia de los cristianos alemanes, Deutsche Christen conduce al fin de su colaboración y amistad con Barth.

822 LKAH, N 127, $\mathrm{n}^{\circ}$ 16, Correspondencia entre Madalene v. Tiling y Friedrich Gorgarten, 13.03.1932 
múltiples conferencias, concretamente en Rumania, en la comunidad alemana de Siebenbürgen, tras la charla sobre educación no ocultó su descontento en algunos asuntos del régimen. Ante la pregunta porqué entonces se dedicaba a hacer conferencias sobre temas nacionalsocialistas contestó:

„Si en Alemania se quiere conseguir algo, se debe actuar como si se fuera „nacionalsocialista“, y eso lo había hecho ella, contestó (Magdalene von Tiling) y así le pagaron el viaje para poder venir a Siebenbürgen. “823

En 1934 en un congreso del EvFW Tiling da por cerrado el período de Weimar y del sistema parlamentario:

„Todo pueblo que goza de salud y tiene un estado sano, trae consigo una clase dirigente, la cual carga con la responsabilidad de la totalidad del pueblo. En tiempos de individualismo esta clase dirigente entra en decadencia. El estado de Weimar ni vió esta caída de la clase dirigente ni reconoció la necesidad de sus existencia como elemento necesario para defender los intereses del estado, especialmente del Führer. En la actualidad nos enfrentamos con la pregunta si nuestro pueblo puede producir una clase dirigente y en este punto se encuentra la responsabilidad de las mujeres protestantes. “824

En su testamento „intelectual” escrito después de la guerra sólo hace referencia a su actividad como maestra durante el nacionalsocialismo, y silencia su trabajo en el EvFW, la edición de AUfGABEN UND ZiELEN y SCHULE UND EVANGELIUM, tampoco emite juicio de valor sobre los acontecimientos. Según nuestras actas, Tiling participó activamente en la integración de las organizaciones de mujeres protestantes en las estructuras del régimen. Durante los años de la dictadura desarrolla una intensa actividad como conferenciante al servicio del $E v F W$, y del Auxilio Femenino. 825

En la misma línea de Meta Eyl o Agnes von Grone que a pesar de su apoyo al régimen, proclama una política de neutralidad de las organizaciones protestantes respecto a la iglesia de Müller y de los cristianos alemanes, Tiling no muestra en ningún momento un claro rechazo a la política de la iglesia oficial, aunque personalmente no podemos demostrar que estuviera realmente en contra. Este juicio se ve afirmado por el trabajo de Tiling con Gogarten, miembro de la iglesia de los cristianos alemanes, que se prolonga durante toda la guerra. Si tenemos en cuenta la correspondencia que ésta mantiene con sus colaboradores de la revista SCHULE UND Evangelium, Tiling apoya la decisión de Gogarten de ingresar en la iglesia de los cristianos alemanes. Aunque el clima en el grupo de colaboradores se observan ciertas simpatías con la iglesia de Müller y se critican los métodos „liberales” del resto de las iglesias, no obstante se rechazan los métodos violentos de la nueva secta. ${ }^{826}$

No obstante la organización que preside se adquiere con su consentimiento a Agnes von Grone. ${ }^{827}$ Tiling defiende la diferencia de los géneros, la diferencia biológica de estos, y a partir

823 LKAH, N 10, n³2, Correspondencia entre el Deutsches Frauenwerk y Agnes v. Grone, 9.08.1934

824 LKAH, N 10, $\mathrm{n}^{\circ}$ 4, Besprechung der Gruppenführerinnen im Frauenwerk der Hannoverschen Landeskirche, 2.02.1934

825 LKAH, N 127, $\mathrm{n}^{\circ}$ 6, Correspondencia entre Magdalene v. Tiling y la VeRP Verband für evangelischen Religionsunterricht u. Pädagogik,, 28.05.1937

826 LKAH, N 127, n²16, Correspondencia entre Magdalene v. Tiling y K. Jarausch, 6.09.1933

827 LKAH, N 127, $\mathrm{n}^{\circ}$ 35, Protocolo de la sesión del VeRP, 7.04.1935 
de ésta llega a la conclusión de que la mujer está determinada por la naturaleza en mayor medida que el hombre, y esta íntima relación con lo natural se manifiesta tanto en su alma como en su intelecto (Geist). El género de la mujer determina su vida en mayor medida que el género del hombre: la relación de esta con su cuerpo y la percepción que tiene ésta en la realidad:

„La mujer es en función de su naturaleza más fuerte que el hombre. La mujer en función de su ley especial se encuentra en su corporalidad a la naturaleza. Esta cercanía con la naturaleza se expresa tanto en el alma de la mujer como en en su ser espiritual: ella no existe con su cuerpo sino en toda su totalidad, a raíz de la continua interacción entre cuerpo y alma como entre cuerpo e intelecto, la mujer se encuentra „encarcelada“ en su género más que el hombre en el suyo.“828

La característica principal que define al ser femenino es según Tiling la unión intrínseca entre cuerpo, alma e intelecto. Esta cualidad es desconocida para el hombre:

„En el hombre no se encuentra esa existencia de encarcelado producida por la influencia controlada de la naturaleza, y por lo tanto no puede vivir el cercano encadenamiento y la intíma compenetración de la totalidad de su ser, ni tampoco el ahnelo de la unidad de cuerpo, alma e intelecto. Por lo tanto la imagen que éste tiene de su propio yo es totalmente diferente a la de la mujer. Por lo tanto se puede deducir que la percepción que el hombre tiene de si mismo diferente es a la que tiene la mujer." ${ }^{\text {"829 }}$

La mujer se encuentra encarcelada en su propia naturaleza y como en una jaula de cristal disfruta de la perfección y armonía de la unidad entre cuerpo y alma, e intelecto. El hombre mira, observa, enjuicia y reflexiona. El hombre objetiva las relaciones personales, su relación consigo mismo requiere distancia, la mujer ve su identidad con un todo en el absoluto. La garantía esta diferencia la busca Tiling en las escrituras. En Adán y Eva y en su caída fundamenta Tiling el surgimiento del patriarcado y la causa de la sumisión de la mujer:

„A través del pecado original la relación entre los géneros imagen de la obra de Dios experimenta una transformación. El mando del hombre, creado para ser utilizado de otra manera se transforma en las cosas exteriores de la vida en un deseo de dominar a la mujer.“ ${ }^{\text {‘830 }}$

Unicamente la nueva religión del nuevo testamento ofrece a ambos géneros la posibilidad de descubrir su verdadera identidad, basada en la diferencia y en el respeto mútuo. ${ }^{831}$ La cultura judía y la cultura griega contribuyen a profundizar en la separación entre los dos géneros. Y sobre todo a romper la armónica relación entre ambos. Es la religión cristiana la que por fin ofrece a la mujer la posibilidad de redescubri su verdadera nauraleza libre y en paz.

Mientras que la mujer disfruta de la unión entre cuerpo, alma e intelecto, el hombre sufre bajo los efectos del dualismo entre cuerpo e intelecto. Por el contrario en la mujer lo intelectual

828 LKAH, N $127 \mathrm{n}^{\circ}$ 44, Magdalene v. Tiling: Die grundlegende Vereschiedenheit der Geschlechter, Manuscrito, 1966, p. 6

829 Ibídem, p. 9

830 LKAH, N127, $\mathrm{n}^{\circ}$ 44, Madalene von Tiling: Zur Verschiedenheit der Geschlechter, Manuscrito (sin fecha), p. 3

831 LKAH, N127, $n^{\circ}$ 44, Magdalene v. Tiling: Die Stellung der Frau in der Bibel, Manuscrito, (sin fecha). 
no logra vivir armónicamente con lo espiritual. El esfuerzo de Tiling de buscar una solución que fundamente la diferencia entre los géneros desde un nuevo punto de vista fracasa. La mujer queda reducida en su discurso al terreno de lo natural y el hombre al campo de lo activo, del movimiento hacia fuera:

„La unidad interior es para la mujer lo natural, lo que el hombre tiene que conseguir es la anulación de su desgarramiento interior. Por otra parte la gran seguridad del hombre es del hombre es la experiencia de su ser exterior natural, para la mujer por el contrario la motivación de acercarse a su centro interior." 832

Tilling ofrece una visión casi cósmica de los géneros: la mujer se orienta hacia la unidad y armonía de su ser, el hombre se mueve hacia fuera y lucha contra la desintegración de su propia personalidad. Esta división forma parte del orden divino y como tal no se puede hacer nada en contra de ella. Cuando los dos géneros hayan aceptado y descubierto la verdadera naturaleza de su ser, la diferencia, se habrán logrado las condiciones objetivas para la desaparición de la opresión del patriarcado:

„El hombre que vive en armonía interior a partir de la creciente sumisión a Dios, no necesita nunca más aspirar a la dominación de la mujer. El se convierte a través del desarrollo de su propia masculinidad por si mismo en el dirigente (no a través de la dominación de otro ser). La mujer que de repente ha adquirido una nueva fuerza, no se pierde en el hombre sino que conserva su propia personalidad sin perder el consciente y responsable vínculo que la une al hombre. Ya que ésta ha encontrado la paralización del punto esencial de su ser es finalmente libre para desarrollar su disposición natural: dar forma a las relaciones colectivas entre los individuos." 833

Tiling no pone en duda la existencia del patriarcado, o la legitimidad del movimiento de la mujer, sin embargo ha sido el cristianismo, y no las asociaciones de mujeres, o cualquier religión el que ha logrado que hombre y mujer superen la etapa de sumisión, lucha y enfrentamiento entre ambos sexos. El esfuerzo es personal no depende de estructuras políticas o de clase, no reclama la agrupación de intereses, depende únicamente del individuo. En este aspecto Tiling toma la concepción antropocéntrica que Gorgarten hace de la religión:

„Yo no soy responsable de mi propio yo, sino que soy responsable del otro para mi propio ser. En ambos casos se esconde un concepto totalmente diferente del ser. Para empezar se trata de dos palabras diferentes aquel ser es idiomáticamente un neutro, es objetivamente género, el otro ser es masculino o femenino. “834

El cristianismo ofrece la posibilidad de volver a alcanzar el estadio de perfección entre los dos sexos antes de la tentación de la serpiente y la expulsión del paraíso:

„Para ambos géneros es sólo posible regresar a la unidad de su ser que disfrutaban en los tiempos de la creación, en una vuelta a través de Dios, el

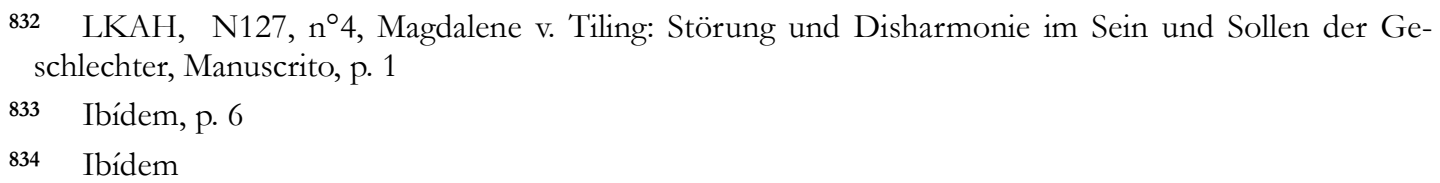


creador. Aunque el hombre puede tener alma sin vivir durante toda su vida la cercanía de Dios, no encuentra en este camino la unidad de su ser y por lo tanto no descubre su masculinidad. Lo mismo se puede decir de la mujer que sin Dios puede educar su vida intelectual pero no llegará nunca a la por Dios deseada armonía y tranquilidad ni a la realización de su feminidad. " 835

La evolución de AUFGABEN UND ZIELE entre 1933 y 1941

\section{Mujer, iglesia y nacionalsocialismo}

Según Meta Eyl la mujer protestante tiene un geistliche Amt, que incluye tres funciones fundamentales: Verkündigung, Seelsorge und das Ordnen des liebenden Tuns. ${ }^{836}$ La actitud de las líderes del $E v F W$ respecto al nacionalsocialismo era en líneas generales positiva. El nuevo movimiento traía orden, seguridad, dirección, viejos valores que se habían perdido, una nueva oportunidad tras el desastre de la primera guerra mundial y los años de posguerra:

„Nosotros nos dimos cuenta de que el idealismo se había roto en pedazos, que la realidad del individuo era su falta de libertad, sus ataduras. Entendimos entonces lo que significaba la autoridad del estado: el mando autoritario, la unión de la comunidad del pueblo. Estos son también los términos que utiliza el nacionalsocialismo." 837

Las mujeres protestantes se ponen a disposición de un estado que encarna los valores a los que ellas durante Weimar habían aspirado: orden, autoridad, unión de la comunidad del pueblo, rechazo de los valores individualistas y liberales, vuelta a los valores cristianos y la supremacía de las cualidades intrínsecas al pueblo alemán. El nuevo estado devuelve a las mujeres protestantes el sentimiento de pertenecer a un pueblo sin diferencia de pertenencia social o clase, en su papel de madres de la nueva generación. Las barreras de lo individual se diluyen:

„No necesitamos permanecer paradas y mirar sin hacer nada, podemos participar en la construcción del presente y del futuro, podemos como madres preocuparnos y crea una Alemania que tiene que permanecer y ser patria, para nuestros hijos, para las generaciones venideras; para una Alemania que cumple con su obligación histórica en el mundo. “638

La llamada a trabajar conjuntamente en el nuevo estado no pretende debe entenderse como una reminiscencia de los intereses del movimiento de emancipación de la mujer. Por el contrario éste es demonizado de la misma manera que lo habían hecho los nacionalsocialistas:

„Pensamos con horror en los días de la emancipación de la mujer como un movimiento, ajeno al pueblo, como un movimiento indisciplinado en su voluntad,

\footnotetext{
835 Ibídem, p. 7

836 Eyl, M.: „Der innermissionarische Auftrag der evangelischen Frau”, AUFGABEN UND ZIELE, Diciembre $1934, \mathrm{n}^{\circ} 12$, p.190

837 Teußner, I.: „Schule und Erziehung”, AUfGABEN Und ZIELE, Diciembre 1934, n 12, p. 196

838 Eyl, Meta: „Der Auftrag der evangelsichen Frau im Volke”, AUfGABEN UND ZIELE, Junio 1935, n 6, p. 84
} 
en su acción y en su ambición. Un movimiento que negaba todo lo específico de la mujer; un movimiento que reducía el instinto de la maternidad a una mera valoración intelectual y con la creación de un nuevo tipo de mujer trajo consigo una gran desgracia para Alemania ${ }^{839}$

Sin embargo se critica un nuevo nacionalsocialismo de carácter, „intelectual y académico”, que defiende principios individualistas y liberales que entran en contradicción con las raíces del verdadero nacionalsocialismo. La autora del artículo, Irmgard Teußner, ${ }^{840}$ se refiere a aquella vertiente del nacionalismo que defiende una concepción de un dios panteísta y mítico y que se desliga del aspectos fundamentales de la fe protestante como el carácter pecador del individuo. Objeto de esta crítica son los cristianos alemanes. La tarea de las mujeres protestantes radica en luchar contra esta tendencia antiprotestante y antinacionalsocialista en las parroquias, en la familia y en sus círculos de trabajo e influencia.

Otro de los aspectos donde se muestra diferencias de opinión con el nuevo régimen es en el tema de la esterilización de aquellas personas que engendran un riesgo para la armonía genética del pueblo. Desde AUfGABEN UND ZIELE se califica la creencia de liberar al pueblo alemán de taras para siempre, como de racionalismo optimista. El argumento en contra no se caracteriza por su fundamentación ética, sino que se basa en uno de los pilares del protestantismo clásico: muerte y enfermedad son consecuencias de la naturaleza pecadora del individuo, por lo tanto es imposible desterrar de su ser la imperfección, la enfermedad y el desorden para siempre. No obstante no se oponen a la ley de esterilización sino que se utiliza la famosa carta de Pablo a los Romanos 13,1-7, donde se exige del cristiano la obediencia a la autoridad con todas las consecuencias. El orden político refleja el orden divino. No obstante se critica la división que hace el nacionalsocialismo entre seres superiores e inferiores y se ofrece el apoyo de la iglesia protestante a las personas que sufren la esterilización. Estas en su desvalidez, su vulnerabilidad son los elegidos de Dios. ${ }^{841}$

La ideología subyacente a la ley no se comparte porque entra en conflicto con las enseñanzas protestantes, sin embargo la ley no es puesta en cuestión, el poder del estado se acepta como imagen del orden divino. Este es el punto de fricción en toda la política de las iglesias protestantes respecto al nacionalsocialismo, la incapacidad de oponerse a la autoridad del estado, que creen una imagen del orden divino.

\section{Educación protestante y mujer}

Los ideales de educación femenina que plantean las mujeres del $E v F W$ pretenden por una parte resaltar la igualdad entre mujeres y hombres, por lo tanto habría que plantear una educación para las mujeres que les permitiera acceder a esa igualdad, sin olvidar, sin embargo, su condición de mujeres. En esta línea proponen la introducción de un Frauenlehrjahr, donde todas las mujeres, especialmente aquellas que se deciden por un estudio universitario, tengan la posibilidad de ser seleccionadas en el trabajo doméstico y tareas de tipo práctico que serán de gran utilidad en su papel de madres. Otros valores importantes son la disciplina, la puntualidad, limpieza y exactitud.

839 Lucas, Gerda: „Kameradin”, Aufgaben und ZiELEN, Enero-Marzo 1936 n 1-3, p. 11 pp. $10-16$

840 Teußner, Irmgard: „Schule und Erziehung”, AUFGABEN UND ZIELE, Diciembre 1934, n 12, p. 196

841 Lukas, Gerda: „Die evangelische Frau und das Problem der Gefährdeten im neuen Staate”, AUFGABEN UND ZIELEN, Diciembre 1934, pp.198-203 


\section{Mujer, religión, estado}

El papel de la mujer como transmisora de la religión protestante es tratado en el número de septiembre de 1935, donde en unos de los capítulos se trata la influencia del nacionalsocialismo en la vida religiosa:

„La afirmación de que el cambio de 1933 ha afectado a la posición de la fe y las iglesias cristianas en nuestro pueblo se ha convertido en una cuestión fundamental que preocupa todavía a muchos cristianos, especialmente sobre la actitud positiva respecto a este cambio. Sin embargo no podemos dejar de preguntarnos qué efecto ha tenido este cambio en nosotros y la postura de la iglesia al respecto. Tenemos que confrontarnos con el hecho de que el „estado cristiano” alemán en el año 1933 encontró definitivamente su muerte." ${ }^{842}$

A pesar de esta sentencia lapidaria sobre el futuro se expresa más adelante, la obligación del estado nacionalsocialista de velar y defender los intereses de la iglesia:

„El tercer Reich de los alemanes es sin duda alguna un estado popular. Esto significa que el pueblo como unidad biológica e histórica constituye la base de éste. El estado tiene como tarea defender y proteger al pueblo y potenciar su crecimiento y desarrollo. Por lo tanto se concluye que el estado nacionalsocialista tiene que tener la misma postura respecto a la religión y a la iglesia cristiana." ${ }^{843}$

Un estado que se define como defensor del pueblo es un estado que señala también su actitud positiva hacia el cristianismo. La critica que se intuye en un principio desaparece por completo cuando la autora del artículo señala que el estado y los valores que éste defiende, forman parte del plan divino por lo tanto todo cristiano tiene la obligación de apoyar al nuevo movimiento:

„Lo que se pide hoy en estos momentos de nosotros es que pongamos nuestra decisión y todas nuestras fuerzas en el orden político que el estado nacionalsocialismo representa, y luchar para que este estado se constituya como la única autoridad y para funde de nuevo el orden destrozado de nuestro pueblo. Con la misma fuerza con la que aceptamos el nuevo orden político intentaremos en éste luchar por la libertad de la iglesia para realizar su misión religiosa." ${ }^{844}$

\subsection{Conclusiones}

La actitud de las mujeres protestantes que se encontraban al frente de las organizaciones de mujeres ligadas a la iglesia protestante, así como el discurso que se desprende de los órganos de prensa de ésta, aparece resumida en una carta que Meta Eyl, redactora de DIE EvANGELISCHE

\footnotetext{
842 Jarausch, R.: „Evangelischer Religionsunterricht heute”, AUFGABEN UND ZIELE, Septiembre 1935, $\mathrm{n}^{\circ} 9$, p. 130

843 Ibídem, p. 131

844 Ibídem, p. 134
} 
FraUenzeITUNG, y dirigente del DEF recibe de Dibelius y Niemöller, miembros de la iglesia confesora:

„La tarea de combinar corazón e intelecto, sentido común y sabiduría, maternidad y trabajo de la mujer en múltiple interacción recíproca, no se discute únicamente sino que se vive intensamente en sus organizaciones, especialmente en estos momentos. En sus comunidades religiosas ha encontrado la mujer lugares de reflexión, de educación y de aprovisionamiento que ayudan en esta difícil tarea." ${ }^{845}$

El sentimiento de comunidad, de pertenencia a un grupo ofrece a las mujeres objeto de nuestro estudio una sensación de independencia respecto a la situación política y religiosa de su país. Las organizaciones protestantes se convierte en casa y morada de estas emigrantes interiores. Independencia y neutralidad son las bases del trabajo de las organizaciones protestantes, sin tener en cuenta los compromisos que se hicieron con el estado nacionalsocialista.

El grupo, la comunidad se observa como un reducto cerrado, dirigido por la mano femenina, donde la mujer puede realizarse a si misma, donde, a través de la religión, encuentra su lugar en la tierra. Se trata de un reducto de santidad, donde la mujer preserva, crea y vive su religiosidad apartada de las dañinas influencias del mundo masculino.

En el tratamiento del papel de las organizaciones en cuestión sobre su actitud en el Kirchenkampf, es utilizado como excusa por la mayoría de los autores/as que se ocupan sobre el tema. La pertenencia a la iglesia confesora es inmediatamente interpretada como ejemplo de resistencia al nacionalsocialismo. Para poder llegar a una conclusión sobre los aspectos de la resistencia, adaptación o apoyo al régimen nacionalsocialista en los grupos de mujeres protestantes pude sernos útil la diferenciación que hace Ernst Wolf ${ }^{846}$ de los niveles de resistencia en la iglesia protestante:

1. Rechazo contra la intromisión estatal en la onganización edesial. La enseñanza de los dos reinos (el terreno/ y el divino) es el punto de partida para la oposición.

2. Defensa de la libertad de expresión del evangelio. En este contexto se valora la declaración teológica de Barmen en 1934 como base teológica.

3. Oposición en virtud del carácter de Wäcbteramt, institución guardiana de la iglesia. En este contexto se incluyen las declaraciones de la dirección provisional de la iglesia confesora en julio de 1936 (V KL II) y otras declaraciones de los sinodos confesores como por ejemplo e de la Union Prusiana en agosto de 1937 y en octubre de 1943.

4. Resistencia con motivos de responsabilidad cristiana que se extiende al ámbito politico y que abarca la cuestión del juramento de obediencia a Hitter, la objeción de conciencia, y el derecho de atentado. Esta resistencia es practicada individualmente y en pequeños grupos.

Según Wolf la iglesia confesora estaba integrada por un gran potencial de resistencia pero nunca llamó a ésta. Respecto a los grupos de mujeres y a las declaraciones que aparecen en su órganos de prensa que hemos tratado en este capítulo podemos establecer una gradación si nos atenemos al esquema de Wolf. En el caso de Agnes von Grone y su organización la oposición se limita al primer punto, la defensa de los intereses de la organización. El apoyo de ésta a la iglesia confesora, es puramente provisional, ya que Grone y el $E v F W$ se adhiere a la posición de las iglesias intactas. Lo mismo se puede decir sobre Magdalene von Tiling y su revista AUFGABEN UND ZIELE.

845 ADEF, T 1.b, 27.04.1937, Correspondencia entre Meta Eyl, Dibelius y Niemöller

846 Wolf, E.: Kirche zwischen Versuchung und Gnade, München, Chr. Kaiser, 1984, $3^{\text {a }}$ Ed. 
En el caso del DEF, y su dirigente Meta Eyl se puede integrar en el nivel número dos. El análisis en DiE EVANGELISCHE FrAUENZEITUNG demuestra que el análisis teológico de las doctrinas de la iglesia confesora tiene una gran importancia en la revista. El apoyo inicial no obstante desaparece con el tiempo en el que la Federación decide a seguir el camino de la iglesia de Hannover, una de las iglesias intactas que entra en la línea de la negociación con la dirección nacionalsocialista. Por lo tanto no podemos afirmar que la actividad de estas mujeres pueda definirse dentro de la línea de la iglesia confesora.

El análisis del caso von Grone lleva inevitablemente al interrogante sobre la existencia de oposición contra el nacionalsocialismo en su actitud. Especialistas sobre temas iglesia y nacionalsocialismo tematizan el tema con el nombre de "oposición contre cour "847. Autores como Jochen-Christoph Kaiser848 argumentan por el contrario que los textos documentan que el nacionalsocialismos consideraba a los miembros de la Bekennende Kirche como adversarios y enemigos políticos. Nowak habla de Teilwiderstand, resistencia parcial y Peter Hüttenberger utiliza el término de Widersetzlichkeit. ${ }^{849}$

Kaiser especialista en organizaciones de mujeres protestantes define la postura de von Grone como valerosa. Incluso su deseo de ser admitida en el partido es considerado por éste como actitud encaminada a ayudar a su propia organización dentro del partido, ayuda que respondía, en nuestra opinión a un conflicto de intereses entre las organizaciones laicas y religiosas, donde no se demuestra en ningún caso que von Grone ejerciera crítica del programa nacionalsocialista.

La valoración de la actuación de von Grone y Lönnies ha sido objeto de estudio en los trabajos de Fritz Mybes y Jochen-Christoph Kaiser ${ }^{850}$. Ambos investigadores afirma que la actitud de las dos dirigentes protestantes puede calificarse de „resistente“. E incluso definen su comportamiento como una prueba más de la incapacidad global de la iglesia a adaptarse a las consignas del partido. Tales conclusiones son comprensibles ya que provienen de personas con fuertes vínculos con la iglesia protestante, pero no pueden calificarse como objetivas. Lo cierto es según nuestras investigaciones es que no hubo una resistencia real organizada como tal contra el partido o contra el régimen. Existió una ,incompatibilidad“ de intereses, basada en diferentes actitudes respecto a las relaciones iglesia y estado. En ningún momento se registra una oposición o crítica al régimen como tal. Por el contrario tanto Eyl como von Grone se califican en todo momento como „fieles nacionalsocialistas“. Fritz argumenta por el contrario que a pesar de la pertenencia de von Grone al partido y de sus reiteradas afirmaciones de su fidelidad al partido y a la causa de Hitler, no puede hablarse de una „profunda relación hacia el nacionalsocialismo" ${ }^{851}$ El autor justifica su afinidad al movimiento debido a un falso entendimiento de éste, como liberador del ateismo bolchevique que ,amenazaba“ en aquellos tiempos, sin darse cuenta de que lo que realmente se propagaba, era, según el autor, „una nueva herejía (Neuheidentum)“. Esta visión de una von Grone ingenua que no reconoce la verdadera auténtica naturaleza del nacionalsocialismo, es difícil de creer, si tenemos en cuenta su enérgica

847 Gollwitzer, H.: Vorüberlegungen zu einer Geschichte des politischen Protestantismus nach dem konfessionellen Zeitalter, Düsseldorf, Rheinisch-Westfälische Akademie der Wissenschaften, 1981

848 Kaiser, J.C.: Frauen in der Kirche. Evangelische Frauenverbände im Spannungsfeld von Kirche und Gesellschaft 1890-1945. Quellen und Materialien, Düsseldorf, Schwann, 1985, p.248

849 Historikertag Hamburg 1979, 99

850 Mybes, F.: „Widerstand wider Willen..“., pp.221-250; Geschichte der Evangelischen Frauenbilfe in Quellen, Gladbeck, Schriftenmission-Verlag, 1975; „Die Arbeitsgemeinschaft der missionarischen und diakonischen Werke und Verbände der Deutschen Evangelischen Kirche“, en: van Norden, G. / Mybes, F. (eds.): Evangelische Frauen im Dritten Reich, Düsseldorf, Presseverband der Evangelischen Kirche im Rheinland, 1979, p.31s; Kaiser, J.C.: Frauen in der Kirche...

851 Mybes, F.: „Widerstand wider Willen..“., p.242 
correspondencia con Scholtz-Klink o sus intentos por ser readmitida en el partido, donde insiste en la pureza de su ideología nacionalsocialista. ${ }^{852}$

¿Podemos conformarnos con una aclaración que fundamenta sus argumentos en la „inocencia y buena voluntad“ de von Grone y Lönnies? Este argumento ha sido utilizado con demasiada facilidad para justificar la pasividad durante el Tercer Reich. ¿Es posible que mujeres como von Grone y Lönnies, cultivadas, con un grado de acceso a información mucho más grande que el resto de la población fueran tan ignorantes de las verdaderas intenciones de los nacionalsocialistas?

La postura de von Grone contiene un alto grado de oportunismo. Y revela la situación por un lado de la iglesia protestante, pero por otro las esperanzas que las mujeres de la clase media habían puesto en la dictadura. Su afán de independencia sobre la organización nacionalsocialista no debe ser confundido, como Mybes argumenta, con un acto de resistencia, sino con motivaciones religiosas y de conservación de esferas de poder.

En segundo aspecto está relacionado con el análisis del discurso que se produce en los órganos de prensa objetos de nuestro estudio, donde se corrobora los resultados relacionados con el análisis de la evolución del EvFW: aceptación del estado nacionalsocialista, apoyo a la línea moderada de las iglesias intactas que participan en el Kirchenkampf, defensa de un espacio vital donde la mujer protestante pueda ejercer las tareas prescritas por Dios y no por el estado.

852 Ibídem, p.245 


\section{La Federación de mujeres católicas y el nacionalsocialismo. La prensa católica}

\subsection{Introducción}

Los estudios sobre la resistencia en general de la iglesia católica coinciden en afirmar la oposición de ésta a la ideología nazi, pero no al estado nacionalsocialista. Sería no obstante, injusto argumentar que la iglesia católica no ejerció resistencia.853 Desde 1930 se observan indicios de rechazo por parte de la jerarquía católica hacia el NSDAP. Según una disposición del obispo de Mainz a los católicos les estaba prohibido ser miembros del partido, formaciones del NSDAP no podían participar en servicios religiosos y existía la posibilidad de negar los sacramentos a miembros del partido de religión católica. No obstante no todos los obispos eran de la misma opinión, el obispo de Berlín por ejemplo no acepta la prohibición de pertenecer al partido.

Los obispos bávaros, por el contrario en la declaración del 10 de febrero de 1931, Nationalsozialismus und Seelsorge, „Nacionalsocialismo y asistencia espiritual“, recomiendan a los párrocos católicos no formar parte del NSDAP; además no se aceptaba la visita de la misa católica por formaciones nacionalsocialistas. La pertenencia al partido sin embargo no era sancionada La declaración es apoyada posteriormente por los obispados de Colonia y Breslau.

En agosto del mismo año tiene lugar un encuentro de los obispos de la diócesis prusiana, con el resto de los obispos alemanes. En la sesión se decide luchar contra todo tipo de tendencia radical, pero únicamente desde el punto de vista religioso y no político.

Sin embargo esta resistencia inicial se debilita cada vez más en función del ascenso del NSDAP y la colaboración del catolicismo político con éste. En la victoria electoral del partido nazi en julio de 1932, donde el NSDAP un 37,2\% de los votos se especula que el voto católico contribuyó en gran medida a este ascenso. ${ }^{854} \mathrm{~A}$ los intentos del Zentrumspartei de negociar con el NSDAP, no hubo ningún tipo de protesta entre los obispos y milieu católico, con excepción de Konrad Adenauer, Max Pribilla, Fritz Gerlich y Ingbert Naab y ciertos sectores de la prensa católica donde se llama la atención sobre la „oposición diametral entre la ideología nacionalsocialista y el catolicismo“. 855

La política católica en los años que se suceden hasta los prolegómenos de la toma de poder de Hitler es de reserva y silencio, postura que se prolonga en las primeras semanas de 1933. Con el nombramiento de Hitler como jefe de estado, y canciller del Reich el 30 de enero de 1933 la situación toma un carácter diferente. Según las enseñanzas católicas, basadas en la epístola de Pablo a los Romanos la autoridad del estado es obra divina, y todo cristiano está sometido a ésta.

\footnotetext{
853 van Roon, G.: Widerstand im Dritten Reich. Ein Überblick, op.cit., pp. 101-121

854 Denzler, G., Fabricius, V.: Die Kirchen im Dritten Reich. Christen und Nazis Hand in Hand?, Frankfurt am Main, Fischer, 1884, p.28

855 Ibídem, p. 29
} 
Esta actitud de colaboración se intensifica a raíz de las acciones terroristas de hombres de las SA y SS, que a través de encarcelamientos y ejecuciones sin juicio previo contribuían a crear pánico entre la población. ${ }^{856}$

Los intereses del Vaticano para firmar un concordato tienen causas diferentes. En primer lugar el clima de agresividad del nuevo gobierno respecto a las confesiones, lo que convertiría al concordato en un intento de proteger los intereses de la iglesia católica en Alemania, y en segundo lugar, el miedo al comunismo que hacía del gobierno de Hitler un aliado adecuado para oponerse a la creciente influencia del peligro eslavo. Según Denzler y Fabricius a cambio Hitler había recibido el apoyo de los políticos de centro a la Ley de concesión de poderes, Ermächtigungsgesetz el 23 de marzo de 1933.857

Este mismo día Hitler se compromete a respetar los derechos de las confesiones cristianas y espera de éstas que se muestren abiertas a un trabajo conjunto en la reconstrucción nacional. El gobierno nacionalsocialista promete no recortar la influencia de las dos confesiones en la escuelas y en los ámbitos relacionados con la educación. En los círculos de la conferencia episcopal alemana, se comienza a reflexionar si no sería posible redimir la actitud negativa respecto al nacionalsocialismo. ${ }^{858}$ A partir del 28 de marzo de 1933, en un informe de los obispos, se levanta la prohibición de pertenencia al partido para los miembros de la confesión católica.

Desde el punto de vista de las asociaciones católicas la declaración de Hitler es entendida como una carta blanca a la participación voluntaria en las estructuras nacionalsocialistas. Así por ejemplo la asociación de uniones estudiantiles católicas, Cartellverband der Katholischen Deutschen Studentenvereinigungen levanta la prohición a sus miembros de pertenecer al NSDAP. El 4 de abril de 1933 el consejo de las asociaciones de solteros católicos, Katholischer Jungmänner Verein proclama su intención de apoyar con todas sus fuerzas al nuevo movimiento de renovación nacional. 859

En abril de 1933 comienzan las conversaciones para la firma del concordato entre Göring, von Papen y el prelado Ludwig Kaas, representante del Zentrumspartei y el Vaticano. No obstante van Roon señala la existencia de algunos obispos alemanes que se mostraban reticentes ante la firma del concordato. ${ }^{860}$ No obstante la firma del concordato tiene lugar el 20 de julio de 1933 en un ambiente festivo.

Con la firma del concordato del gobierno nazi con el Vaticano, Hitler se compromete a reconocer al cristianismo como la bases de la nueva Alemania y la iglesia católica sanciona la „legitimidad“ del nuevo régimen, y el reconocimiento oficial de éste. La inclusión en el concordato de una cláusula dónde, la iglesia católica se comprometía a no inmiscuirse en asuntos políticos, eliminaba la posibilidad de cualquier tipo de resistencia organizada, y se convertiría en años posteriores en objeto de control y vigilancia de todo tipo de manifestación pública de la iglesia. Por otra parte el concordato significa también, a partir de 1938 cuando Martin Bormann (1900-1945) como jefe de etat en la cancillería de estado, empieza a practicar

\footnotetext{
$856 \quad$ Ibídem, p. 49

$857 \quad$ Ibídem, p. 50

858 Con excepción del obispo de Eichstätt, Graf Preysing y el obispo de Regensburg Buchberger.

859 Dezler, G., Fabricius, V.: op. cit., p. 52

860 van Roon, G.: op. cit., p. 109. Entre los obispos y prelados que se oponían a la firma del concordato se encontraban el cardenal Schulte (Köln), el obispo de Regensburg, Buchberger,y el obispo de Eichstätt Graf Preysing. Para poder controlar el proceso de las negociaciones se exige que un obispo esté presente en éstas, eligiéndose al obispo de Friburgo, Gröber.
} 
una política religiosa dirigida a reducir a las dos iglesias, protestante y católica, a organizaciones de tipo privado. ${ }^{861}$

No obstante la firma del acuerdo entre la iglesia católica y Hitler encuentra también sus detractores. ${ }^{862}$ A pesar de la firma del concordato se suceden atentados contra la supuesta libertad de acción de los miembros de la iglesia católica. ${ }^{863}$ Ejecuciones, encarcelamientos, prohibición de publicaciones católicas, son las acciones paralelas de una política de difamación (acusaciones de homosexualidad, etc.) que pretendía diezmar el poder de la iglesia católica. Otros de los grupos católicos que se ve sometido a las presiones de las autoridades nacionalsocialistas son las organizaciones juveniles católicas que poco a poco son disueltas e integradas en las juventudes hitlerianas.

No obstante el silencio de las autoridades eclesiásticas y del Vaticano se mantiene hasta 1937, fecha en la que los obispos alemanes mandan un escrito al ministro para asuntos religiosos, Kerrl donde muestran su preocupación ante la inefectividad del concordato de 1933. A ello se une la encíclica papal, Mit brennender Sorge, donde se trata el tema de la libertad de la iglesia. La encíclica es transportada a Alemania en secreto, y una serie de imprentas se hizo cargo de su impresión, lo que provocó posteriormente una serie de represalias por parte de las autoridades nacionalsocialistas: las imprentas fueron incautadas y las personas que se habían encargado del reparto de la encíclica, en su mayoría sacerdotes y adolescentes, fueron encarcelados. 864

Estas dos acciones movilizan a los católicos alemanes en un gran número de acciones, en forma de peregrinaciones, donde expresan su descontento ante la política religiosa de Hitler.

Una prueba de la atmósfera de rechazo hacia el régimen de Hitler son los informes que realiza la policía secreta sobre la cantidad de panfletos que son repartidos por protestantes y católicos, donde se hace referencia al carácter anticristiano del nacionalsocialismo: el nacionalsocialismo rechaza la creación, la responsabilidad humana, la iglesia católica y se presenta como una religión racista en contra de las enseñanzas cristianas. ${ }^{865} \mathrm{La}$ policía secreta recomienda la prohibición de tales acciones, debido al clima de intranquilidad que reina en la población, a raíz de las actividades „propagandisticas“ de los cristianos. ${ }^{866}$

Sin embargo, ante la inminente entrada de Alemania en guerra los obispos llaman de nuevo, a la cautela y a la reserva. Heinz Hürten señala una reserva respecto al sentido de la guerra especialmente entre la población joven, una reserva que se caracteriza por una distancia respecto a la política, la aceptación de la realidad tal y como es, el servicio a la patria, y la fuerte unión a la iglesia. ${ }^{867}$ Hürten llama la atención también de la ausencia del argumento de lucha contra el bolchevismo por parte de la jerarquía eclesiástica como apoyo a la guerra, argumento que había

Kottye, R., Moeller, B.(ed.): Ökumenische Kirchengeschichte. Neureit, Band III, München, Chr.Kaiser, p. 293

862 Entre ellos se encuentra de nuevo el obispo de Eichstätt y el Capitular de la catedral de Berlín Lichtenberg.

863 En este contexto tienen lugar los sermones de adviento del Cardenal Faulhaber a finales de 1933 donde critica a aquellos que minimizan el papel del antiguo testamento, lo que provoca una reacción de agradecimiento en Alemania y en el extranjero por parte de católicos y judíos. La repercusión fue tal, que el mismo Faulhaber intenta más tarde relativizar su postura ante el nacionalsocialismo.

864 Van Ron, G.. op. cit., p. 117

865 BAZ, 243 Y, Katholische Kirche, „Nationalsozialistische Religion“, Panfleto de la iglesia católica.

866 BAZ, R 58-266, 30.031934, Correspondencia entre la central de la policía secreta en Berlín y las estaciones de la policía estatal.

867 Hürten, H.: „Katholische Kirche und nationalsozialistischer Krieg“ en: Broszat,M.; Schwabe, H. (eds.): Die deutschen Eliten und der Weg in den Zweiten Weltkrieg, München, Beck'sche Reihe, 1989, p. 171 
sido utilizado ya con ocasión de la guerra civil española por los obispos alemanes para definir la lucha contra el comunismo como, „guerra justa“. 868

Si nos atenemos al modelo de niveles de resistencia de Ernst Wolf, utilizado con anterioridad para el caso de la iglesia protestante, coincidimos con van Roon en que la dirección de la iglesia católica no pasa del primer nivel, el de resistencia a los atentados del nacionalsocialismo contra los propios intereses y entidad de la iglesia católica. En alguno de los sermones de los obispos y párrocos alemanes se pueden integrar en el segundo nivel donde se lucha por la libertad del evangelio. En el tercer nivel, se encuentran numerosos casos particulares, que partiendo de la ética cristiana critican la persecución en función de la raza y confesión. Oposición política se encuentra en casos particulares. ${ }^{869}$

\subsection{La Federación de mujeres católicas y el Nacionalsocialismo}

Siguiendo el ejemplo de las autoridades eclesiásticas las primeras reacciones de las dirigentes católicas se caracterizaron por su silencio. A diferencia de las organizaciones de mujeres protestantes, que desde un principio se ofrecieron a trabajar conjuntamente con el nuevo gobierno, las mujeres católicas esperaban la postura oficial de los obispos, y del Vaticano. ${ }^{870}$ Mientras que las protestantes, debido a los acuerdos entre organizaciones protestantes y nacionalsocialistas pudieron preservar sus campos de actuación, las mujeres católicas, a pesar de los acuerdos del concordato, que garantizaba teóricamente la libertad de la iglesia protestante se vieron privadas de sus funciones en el terreno de la caridad.

Así por ejemplo en 1936 los cursos impartidos en los seminarios de las organizaciones católicas, y en las escuelas de asistencia social y de higiene pública, así como los cursos de maternidad para educadoras y maestras católicas son prohibidos. La causa que se aduce es que la ideología católica sobre educación eugenésica, información pre o matrimonial e higiene racial difiere de los presupuestos nacionalsocialistas y por lo tanto únicamente las organizaciones nacionalsocialistas disfrutan del permiso para esta labor de formación. ${ }^{871}$

A esta medida siguen la prohibición en las escuelas católicas para maestras, de los cursos para madres, que caerán bajo control de la organización nacionalsocialista.

A esto se añadía la exigencia de la pertenencia al partido a todas las mujeres que impartan cursos relacionados con la Erbhygiene, Eheberatung, Rassenpflege. ${ }^{872}$ Esto ponía a las mujeres católicas en una situación difícil ya que la mayoría de los principios del nacionalsocialismo, respecto a la mujer, ponían en duda el ideal católico de la feminidad.

En el mismo año se acentúa el control de la prensa católica. El 1 de octubre de 1936 el Ministerio para asuntos religiosos da a conocer un decreto en el que se establece que sólo sermones y circulares de las autoridades eclesiásticas pueden publicarse. Bajo la protección del decreto no se incluyen, como hasta la fecha era normal, panfletos, publicaciones religiosas,

868 Ibídem, p. 175

869 Van Roon, G.: op. cit., p.121. Klausener, E: Frauen in Fesseln. Hoffnung in der Finsternis. Von Mut und Opfer katholischer Frauen im Dritten Reich, Berlín, Morus, 1982; Kleinwächter, J.: Frauen und Männer des christlichen Widerstands. 13 Profile, Regensburg, Friedrich Pustet, 1990.

870 Koonz, C.: Mütter im Vaterland, op. cit., p.325

871 BAZ, R 58-266, 7.05.1936, Correspondencia entre el Ministro para asuntos religiosos y la policía secreta.

872 BAP, R 58-266, 7.05.1936, Correspondencia entre el Ministro para asuntos religiosos y la policía secreta. 
periódicos y todo tipo de publicaciones de contenido religioso, que se donde se mostrara cualquier tipo de desacuerdo con el estado nacionalsocialista. ${ }^{873}$

Una notable manifestación de rechazo hacia el nuevo régimen es la organización de maestras católicas, que al contrario que sus compañeros, reconocen los peligros que el nacionalsocialismo significa para la enseñanza católica. ${ }^{874} \mathrm{Su}$ influencia se extiende fundamentalmente a grupos de amas de casas y trabajadoras del campo. 875

En este clima de inseguridad y de amenenza que experimentan las organizaciones católicas, se hacen las primeras declaraciones oficiales de la Federación de mujeres católicas, Katholischer Frauenbund, respecto al nuevo gobierno que se caracterizan por una gran cautela.

Gerta Krabbel presidente de la asociación saluda en 1933 la nueva etapa de la historia alemana con reserva donde la mujer adquiere un papel conciliador:

„Siempre en tiempos de cambio era tarea de la mujer sostener la antorcha de la espiritualidad para demostrar con todas sus fuerzas que el amor, y la bondad iluminan y reviven el mundo." 876

Sin embargo la cooperación que existe entre las mujeres protestantes y las mujeres nacionalsocialistas, y sobre todo la libertad de acción que las asociaciones protestantes disfrutan respecto a su iglesia, especialmente durante los primeros años de la dictadura no se manifiesta tan claramente en el KFB. La independencia de acción de las organizaciones de mujeres protestantes se muestra en la rápida organización de éstas bajo el mando de Agnes von Grone, a imitación, claro está del Führerprinzip de las organizaciones nacionalsocialistas.

Este proceso de organización no tiene lugar dentro de las organizaciones de mujeres católicas, lo cual limita su capacidad de actuación y su dependencia directa de la jerarquía eclesiástica. Así por ejemplo ante los intentos de las mujeres nacionalsocialistas para entablar relaciones con el KFB, Gerta Krabbel siempre pedía permiso al obispo de su diócesis. ${ }^{877}$

Otra de las causas de la reserva de la Federación ante los intentos de contacto con las organizaciones nacionalsocialistas está relacionada con el rechazo del concepto que el nacionalsocialismo tenía de la religión y con el ideal biológico de maternidad que atentaba contra los principios religiosos de las mujeres católicas, así como la superficialidad con que la ideología nazi trataba los temas del aborto y de la esterilización. Unos meses después de la firma del concordato, Krabbel se queja ante la jerarquía eclesiástica de la concepción biológica que los nazis hacía de la maternidad. 878

El programa que el KFB publica en 1933 nos permite reconstruir el trabajo de ésta durante el nacionalsocialismo. Como objetivo principal se proponen el apoyo a la importancia del ideal femenino católico en la familia, en la vida laboral y pública. Esta intervención de la mujer católica se considera de gran importancia debido al peligro existente de masculinización de la mujer, así como la consideración de la maternidad como un proceso exclusivamente biológico y la minusvaloración de la mujer soltera a causa de su falta de fecundidad.

873 BAP, 243 II, 13.11.1936, Correspondencia entre la policía secreta y el resto de las centrales de la policía estatal

874 Koonz, C.: op. cit., p. 331

875 „Was der katholische Bund ist und was er will. Eine ernsthafte Plauderei über unsere Organisation“, BAYRISCHES FraUENLAND, Marzo 1933 (año 15), pp.18-22

876 Krabbel, G.: ,„,Der KDF in der Zeit“", NACHRICHTENBLATT, Mayo 1933, n 5

877 Koonz, C.: op. cit., p. 340

878 Koonz, C.: op. cit. , p.343 
El $K F B$ se plantea como objetivos de actuación la revaloración y el redescubrimiento de la naturaleza femenina, el apoyo a la verdadera libertad individual, la importancia de la vida interior, el deber de la responsabilidad, etc.

El trabajo práctico está dividido en diferentes campos de acción: en primer lugar el trabajo en las consultas de información pre, o matrimonial. La formación de comadronas, y la organización de cursos de maternidad. Trabajo de formación para amas de casa y campesinas. A ello se une el trabajo de ilustración respecto a la actividad laboral femenina y los peligros que aparecen en la vida familiar, cuando la mujer se dedica exclusivamente a trabajar.

La Federación administra escuelas de asistencia social para mujeres en Aachen, Berlín y München. Este tipo de actividades cesan a partir de 1936 fecha en que el trabajo de las asociaciones de mujeres católicas es prohibido en los campos de la asistencia y trabajo social, así como en los cursos de maternidad y éstos empiezan a ser impartidos por mujeres formadas por las NS-Frauenschaft.

El trabajo de la Federación comienza a tener dificultades a partir de 1937, donde la vigilancia por parte de la policía secreta sobre las organizaciones católicas se intensifica. A veces son las organizaciones de mujeres nacionalsocialistas las que se encargan de elaborar informes sobre las actividades de la Federación sobre el número de asistentes, el contenido de éstas, etc.

Este tipo de organizaciones se encuentran fuertemente vigiladas por la policía secreta, o las Frauenschaften se encargan de elaboran informes sobre el número de asistentes, el contenido, etc. 879 Tres semanas antes de los encuentros o reuniones cada organización tenía que presentar un comunicado donde se aludía al carácter de la actividad.

De la misma manera que en las organizaciones de mujeres protestantes se prohibe la doble pertenencia entre las organizaciones nacionalsocialistas y las católicas. ${ }^{880}$ Durante esta época la Federación participa en ,actividades“ consideradas ilegales por los nacionalsocialistas: repartían sermones ilegales, creaban capillas en viviendas privadas, ${ }^{881}$ etc. Algunas de las mujeres más conocidas del KFB , como por ejemplo Helene Weber forman parte de los grupos que más tarde en el 41 se deciden eliminar a Hitler de una manera violenta. Hermann Josef Schmitt, sacerdote conocido de Weber describe la atmósfera de la vivienda de Weber durante los años de la dictadura:

"Su piso en Berlín-Schöneberg era para un círculo de personas de confianza que estaban en contra del régimen, un buscado lugar de refugio, donde todavía era posible conversar(...). En este círculo se encontraban hombres de la resistencia y aquellos que en secreto querían hacer algo contra la desgracia que nos rodeaba. La señora Weber no sólo era su confidente sino que transmitía noticias importantes." 882

El órgano portavoz de la Federación era la revista DiE Christliche FraU, fundada en 1902. Desde su fundación hasta 1933 depende de la editorial del KFB A partir de este año pasa a depender de la editorial Regensberg en Münster.

879 BOA, Fen-57, A.S. 126, 4. Juni 1935, Escrito del obispado de Augsburg al Ministerio del interior en München

880 BOA, ibid., 13. März 1935

881 Koonz, C.: op. cit., p. 371

882 Pregradier,E., Mohr, A.: Helene Weber (1881-1962). Ernte eines Lebens.Weg einer Politikerin, Essen, Plöger Verlag, 1991, p. 94 
Durante los años de dictadura es dirigida por Gerta Krabbel883 y Maria Offenberg. En Junio de 1941 por falta de papel, como en el caso del EVANGELISCHE FrAUENZEITUNG, la revista deja de editarse. El contenido de ésta es variado, aunque predominan temas culturales y filosóficos. Existe una profusidad de artículos sobre literatura, teatro y antropología. En cada número que aparecía mensualmente se comentaban los últimos libros salidos al mercado, el tema de la mujer estaba representado por retratos y biografías de mujeres ilustres. No hay apenas publicidad. DIE CHRISTLICHE FRAU estaba dirigida a mujeres de clases medias altas con estudios o con intereses ,intelectuales“. La contrapartida a ésta por su carácter popular era otra publicación, también dependiente del KFB, BAYRISCHES FRAUENLAND, con gran aceptación en Baviera. Esta es fundada en 1919 y se edita como la anterior hasta 1941. BAYRISCHES FRAUENLAND abarca fundamentalmente temas religiosos, da consejos sobre nuevas recetas, tiene un gran número de fotos que ilustras peregrinaciones, comuniones o simplemente Marias y otras figuras sagradas.

Otra importante publicación de la Federación es la revista FrauenLAND fundada en 1907. Esta publicación goza de gran aceptación entre las mujeres católicas, procedentes de regiones rurales. En 1902 tiene una tirada de 40.000 ejemplares, número que asciende a 110.000 en 1918. 884

Las colaboradoras de las revistas son las mismas que en DIE CHRISTLICHE FRAU, aunque los temas que se tratan en éstas difieren. Mientras que DIE CHRISTLICHE FrAU trata temas relacionados con una religiosidad intelectual, en las dos restantes se cultiva una religiosidad popular con fotos de iglesias barrocas, peregrinaciones y madonnas, junto a artículos sobre temas de tipo práctico como economía del hogar, decoración y cocina, etc. La Liga se concentra, según Rauscher, a partir de 1937 en actividades fundamentalmente religiosas. Sus dirigentes, son consideradas, como politisch unzwwerlässig, y no son rehabilitadas como ocurre con Bäumer. Su trabajo transcurre en la clandestinidad y en el anonimato, a través de discusiones de grupo en viviendas privadas. ${ }^{885} \mathrm{La}$ única actividad oficial es la publicación del órgano portavoz de la Federación. De ahí la importancia de nuestro análisis del discurso que se elabora en la revista entre 1933 y 1941.

\subsection{DIE CHRISTLICHE FRAU. La visión católica de la mujer}

La reserva con la que reacciona el KFB ante la llegada del nacionalsocialismo, no se manifiesta en las declaraciones que Gerta Krabbel hace en DIE ChristLICHE FrAU. Al contrario el nacionalsocialismo es analizado como un paso esencial en la historia alemana:

„Este año caracteriza por un gran acontecimiento de carácter histórico, de una forma como hasta ahora no hemos vivido nunca. Nosotras sentimos especialmente este acontecimiento que cambia la expresión de nuestro pueblo, la expresión de Alemania. Cuanto más profundo lleguen las ondas de este

883 Gerta Krabbel (1881-1961), estudio de Filosofía e Historia y doctorado. A partir de 1926 presidenta de la Federación de mujeres católicas alemanas. Pertenece al círculo de Romano Guardini, Heinrich Weiger y Pfarrer Weiger. En: Schiffler, Lotte: Die Antwort der Frau in der sich ändernden Welt, Münster, Regensberg, 1969, pp.124-128

884 Cosack, E.: „25 Jahre Frauenland“, FrauenLAnd, Enero 1933, n¹, p. 25 pp.23-26

885 Rauscher, A. (ed.): Geschichte und Staat. Der soziale und politische Katholizismus. Entwicklungslinien in Deutschland 1803-1963, München, Günter Ulzog, 1982, p.299 
acontecimiento en el sentir de nuestros corazones, más difícil será que éste desaparezca de nuestros corazones. " ${ }^{\text {"886 }}$

En el mismo artículo Krabbel saluda afirmativamente la firma del concordato entre la iglesia católica y el nuevo gobierno, así como confirma la protección de la Federación por parte de la iglesia y el estado:

„En el acuerdo festivo que el gobierno alemán y la iglesia católica han clausurado queda garantizada para el KFB la protección de la iglesia y del estado. Por lo tanto se da por entendido que tanto estado como iglesia esperan que cumplamos con las tareas que se esperan de nosotras. Esto exige de nosotras un gran responsabilidad que nosotras aceptamos con alegría y entrega en la seguridad de que a partir de la decisión interior, de nuestra conciencia y de nuestra fe, encontraremos el lugar correcto donde aplicar nuestro trabajo en el nuevo estado." 887

\subsubsection{El discurso sobre la naturaleza de la mujer}

En su artículo de diciembre de 1933 unos meses después de la firma del concordato que regulaba las relaciones entre la iglesia católica y el gobierno de Hitler, Gerta Krabbel, 888 presidente de la Federación de mujeres católicas, llamaba a concentrar la atención en la figura de la madre y del héroe como respuestas a la inseguridad que traía consigo la nueva etapa de la historia alemana. La madre aparece como lugar de seguridad y protección, significa también recogimiento de la realidad circundante:

„En los nuevos tiempos tan intranquilos y nuevos, añora el individuo el reino de la madre, allí donde se sabe de la vida y del ser, de nacer y del morir, allí donde el destino del hombre es impulsado de generación en generación en su sencillez y grandeza. ${ }^{\text {"8889 }}$

La imagen del „sumergimiento“ en el regazo de la madre es utilizada para expresar el deseo de refugiarse frente al creciente racionalismo y a la decadencia de los valores. Esa fuerza de la madre, es la fuerza del pueblo, es la victoria de los valores innatos de éste:

„Un gran anhelo se une en este resurgimiento en el pensamiento y en la esperanza de que se reconozca la grandeza, la autenticidad, la profundidad y la fortaleza de la maternidad; fuerte y pura en su naturaleza corporal, fuerte y grande en su fuerza espiritual. Ya que ésta no sólo ofrece al niño, sino también al adulto, patria, recogimiento, así como la profunda e indestructible confianza de un amor sin fronteras que le acompaña durante toda su vida que renace siempre de nuevo

\footnotetext{
${ }_{886}$ Krabbel, G.: „Ringen der Zeit“, DiE ChristliCHE FrAU, Septiembre 1933, n 9. p. 225 pp. $225-229$

887 Ibídem, p. 228

888 Krabbel, G.: „Ringen der Zeit“, Die ChristLiCHE Frau, Septiembre 1933, nº 9. p. 225

889 Ibídem, p. 227
} 
en la humanidad para hacer del individuo capaz y su vida llena, fuerte y dispuesta a ser vivida, en su fuerza y grandeza protectora." ${ }^{890}$

El héroe recibe la tarea de defender la fuerza vital, de la madre, del pueblo con fuerza, entereza, valor, bondad y nobleza. El mundo de la mujer, centrado en figura de Maria, como veremos más adelante, invita al recogimiento, al descanso de la realidad, es un mundo fuerte centrado en la fuerza espiritual y religiosa de aquellos que se atreven a entrar en él.

En el papel de creadora y protectora de la vida se invita a las mujeres al recogimiento espiritual a la búsqueda de la paz interior:

„Esto significa un recogimiento en nosotras mismas, una fuerte valoración de nuestra vida interior, un eterna alimentación de las fuentes religiosas, una nueva valoración de la contemplación procedente de las fuerzas que agitan en el silencio y significa al mismo tiempo un estar siempre dispuesto para el trabajo en alegría y heroísmo. Nuestra fuerza al servicio de nuestro pueblo se encuentra en viejos y nuevos caminos que preparen nuestra vida con y para el pueblo; compartimos su necesidad, su anhelo y sabemos para siempre, que se nos ha concedido a partir de la profundidad de la fe católica y del amor a los hombres, poder hacer nuestro, nuestro pueblo, nuestra patria, nuestro país, nuestro destino. “"891

Aunque en el KFB de las mujeres católicas el tema de la madre había sido desde su fundación una constante en su programa, desde 1933 los artículos sobre este tema se caracterizan por su abundancia, una línea que siguen la mayoría de publicaciones para mujeres. La especificidad del discurso católico sobre la feminidad radica en la introducción del carácter de virginidad, como el elemento de la naturaleza femenina que determinaba el carácter sagrado de ésta.

En un cuadernillo publicado por el KFB la mujer aparece caracterizada como virgen, y madre:

„Hay que destacar el doble significado de la mujer en la actualidad. Por un lado la importancia de la madre como transmisora de generación en generación de las capacidades constructivas del hombre y por otra parte la importancia de la virgen que representa el polo contrario de la conciencia histórica del hombre. Si se reconoce el carácter religioso de la virgen, se reconoce también su significado temporal para los individuos. La misma virgen que sacrifica la maternidad y el matrimonio en soledad, asegura al mismo tiempo con su sacrificio la existencia del matrimonio y la maternidad. “'892

La figura de la virgen aparece en reflejada en las figuras de la Ifigenia, Antígona, la Beatriz de Dante o la Juana de Arco de Schiller. Tan importante como la virginidad es la maternidad, como símbolo de la vida, y del fecundidad en la naturaleza, pero también como transmisora de la voluntad divina.

„(...) la educación religiosa de los hijos, el cuidado del hombre, la vida religiosa y por encima de todo la responsabilidad protectora y educativa, ejemplar, y religiosa que le han sido concedidas. “'893

\footnotetext{
$890 \quad$ Ibídem, p. 227

891 Ibídem, p. 228

892 v. Le Fort, G.:"Die Frau in der Zeit“, Die Christliche Frau, Abril 1934, (año 32), p.101 pp. 97-102

893 BOA, Fen-146, 1944, Frauenbund
} 
Constituyen las funciones de la mujer como instrumento de la voluntad divina. La maternidad es presentada como un estado que impregna a la mujer de valores divinos, valores que afirman la unión especial con la tierra, con su pueblo y con el destino de su patria:

„Ser madre expresa la plenitud de la vida en si misma; ser madre enraíza en la profunda terrenalidad de la sangre y es al mismo tiempo la configuración de la sangre derramada de las almas llamadas por Dios a la eternidad. En la pura maternidad se encuentra la fuerza del pueblo, y es además, algo más grande: el reino de Dios en la tierra." 894

Maternidad y virginidad toman un carácter sagrado, y constituyen el sentido de la feminidad. Lógicamente María se convierte en el ejemplo a imitar, en ella se concentran las dos cualidades que hacen a una mujer alcanzar la divinidad.

El ideal femenino visto desde estos dos estadios vitales dependientes de su sexualidad, aparece claramente sistematizado en la obra de Gertrud von Le Fort, escritora católica, de la que se hacen eco las dos revistas en cuestión. Para la Le Fort la mujer es un símbolo, una metáfora de la realidad metafísica en el marco de la creación divina, donde la naturaleza de las cosas sólo se puede entender en función de su carácter simbólico. Naturaleza y ser de la mujer ofrecen ayuda para entender una parte del orden y la verdad divinas.

\begin{tabular}{|c|c|}
\hline Fülle des Lebens \\
Heiliger Ehebund
\end{tabular}

Para ella el símbolo de la mujer es el velo como encubrimiento sutil del comportamiento de la mujer: actuar sin ser notada, con altruísmo; es el símbolo de la entrega y del sacrificio, motivos que según la germanista Godele von der Decken no son exclusivos del discurso católico, sino que se encuentran también en obras y escritos de mujeres de tendencias nacionalsocialistas ${ }^{895}$ como Guida Diehl, Emil Strauß o Josepha Berens-Totenohl.

Este camino en silencio aparece coronado por la mujer-virgen. La que, sin la sexualidad, se convierte en madre. Este aspecto en el que el hombre no tiene que decir, no aparece recogido por von der Decken, que no observa la separación de principios nacionalsocialistas donde el padre, es el que dirige la sexualidad y no la madre, además „la pieza central de la propaganda y la política nazi en materia de población, que impuso un límite a todo lo que divergía de los rasgos distintivos de la política nazi, o los contradecía, no fue precisamente el pronatalismo y el culto a la maternidad', sino el antinatalismo y el culto a la paternidad y a la masculinidad." 896

En la mujer es el contrapunto de la identidad masculina, ambas identidades se compenetran, se definen en su diferencia a si mismas, y se necesitan para existir armónicamente. La feminidad aparece definida como en el caso protestante como das Tragende y das Einigende, lo que sostiene y une; la masculinidad por el contrario como das Begreifen, das Strebende, lo que entiende, lo que aspira. ${ }^{897}$

\footnotetext{
894 „Gedanken zur Mütterschulung“, BAYRISCHES FrAUENLAND, Septiembre 1933 (año 15), p.65

895 von der Decken, G.: Emanzipation auf Abwegen. Frauenkultur und Frauenliteratur im Umkreis des Nationalsozialismus, Frankfurt am Main, Athenäum, 1988, p.174

896 Bock, G.: „Políticas sexuales nacionalsocialistas e historia de las mujeres“, en: Thebáud, F.: Historia de las mujeres. El siglo XX, Madrid, Taurus, 1993, p.194

897 Schumacher, M.: „Wende in der Frauenbewegung“, DiE Christliche FrAU, Enero 1933 (año 31), p.14
} 
Le Fort formula también el concepto de Geistige Mutterliebe, como característica del ideal femenino en su lugar en la familia y como oposición al género masculino. Le Fort busca en su ideal femenino nuevas imágenes que se aparten de la tradición burguesa de la mujer, reclama una vuelta a la naturaleza, y se revela contra la tradición ilustradora de la emancipación. Le Fort propone una emancipación mística.

La obra de Gertrud von Le Fort alcanza gran resonancia entre las mujeres protestantes, y en DIE FRAU se ocupa exhaustivamente de propagar su obra que levanta, si nos atenemos a la correspondencia privada de Bäumer un gran interés en los círculos del antiguo movimiento de la mujer. ${ }^{898}$

Como en la valoración que hacen las mujeres protestantes de la feminidad, „el amor“ aparece como la cualidad fundamental que da conturas a la identidad femenina. Amor como fuente de entereza, de aguante, disposición y atención. ${ }^{899}$ La mujer representa por otra parte los valores de la tierra, de la nación. Ésta encarna a la patria en la que los individuos nacen, ella ofrece calor, protección y seguridad: „la mujer, la maternidad y la nacionalidad se encuentran al mismo nivel" propagan y engendran vida. La madre es el símbolo de la naturaleza, de la vida, del calor humano: Heimat ist die Frau, la patria es la mujer. ${ }^{900}$ Sin la mujer no existe la patria, el pueblo, la nación. Otra de las imágenes que aparecen en DiE CHRISTLICHE FRAU para definir la naturaleza de la mujer es la del Volkstum, que se puede definir como el conjunto de cualidades que configuran el alma alemana:

„Sólo podemos sentir de una determinada manera, de una manera alemana, porque nuestra alma ha sido creada, según las leyes naturales, a imagen y semejanza de nuestra tierra y de nuestro paisaje. Y ésta es la gran alma de nuestro pueblo, que nos hace completos y llega a nuestro ser más profundo que determina también nuestra lengua“"901

El Volkstum como símbolo de la especificidad del alma alemana, marca la diferencia y la unicidad de Alemania respecto a otros pueblos, y se encuentra íntimamente relacionada con la naturaleza de la mujer:

„La mujer, la verdadera mujer, se encuentra muy cerca del Volkstum. Ella es su propio soporte. Cuando (la mujer) vive totalmente su feminidad es entonces un pedazo de Volkstum. El suelo maternal de todo Volkstum es su corazón. Ambos se pertenecen, en el fondo de su esencia son lo mismo: mujer, maternidad y Volkstum."902

La base maternal del pueblo es el Volkstum. En su regazo se encuentra la vida del pueblo, vida como en la naturaleza en silencio, tranquila y eterna. Esta fuerza de la naturaleza y del alma alemana de la que la mujer también forma parte se opone a cualquier tipo de explicación racional. Como el alma se trata de una fuerza invisible, de un aliento creador que se siente pero que no se puede explicar, y que se caracteriza por su naturaleza religiosa:

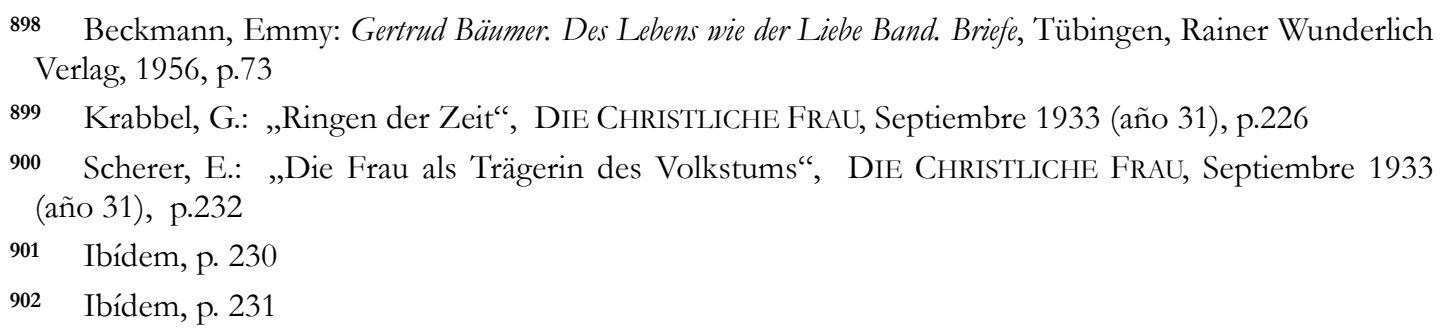


„Ya hemos señalado con anterioridad que es difícil explicar lo que significa Volkstum. Ya que éste es el espíritu invisible, el aliento puro y cálido que forma nuestro idioma, nuestra lengua, nuestra historia y nuestra vida religiosa. Es el alma y las formaciones culturales que proceden de ésta. Dios con su fuerza creadora se despliega en este alma. Esta es la causa por la que el Volkstum tiene raíces religiosas." ${ }^{903}$

El poder de la mujer es la religión, es su capacidad de contactar con lo extraterrenal, su íntima relación con el alma del pueblo:

"Junto a su maternidad corporal, la hermandad espiritual que tiene con los orígenes de la vida hace a la mujer objeto de veneración. Lo eterno del espíritu del pueblo se muestra en el alma de ésta. Y aquí encontramos los sentimientos más profundos del pueblo: su éxtasis religioso, su entrega al misterio, su obediencia a las leyes de la naturaleza, su esperanza en el más allá.“904

El reino de la madre, de la mujer se encuentra a medio camino entre la terrenalidad y la objetividad de la vida, y el mundo religioso. La naturaleza de la mujer se mitologiza, así como la diferencia entre ambos géneros, que esta legitimidada por la voluntad divina. Uno de los modelos de mujer que representa los valores de la feminidad alemana es la mujer germánica. Con los atributos de la fuerza, la seguridad y la dignidad se describe a las mujeres que aparecen en las sagas y leyendas germanas. ${ }^{905}$

Como ejemplo de las mujeres germanas, destaca la vidente, la mujer a la que los hombres acuden en busca de consejo y la sacerdotisa en contacto con lo religioso. Sin embargo a diferencia de la propaganda nacionalsocialista que también señalaba a la mujer germánica como modelo a imitar, sino que se incide en el protagonismo de las mujeres germánicas en la conversión de los guerreros arrianos al cristianismo. Esta época de preponderancia germánica y más tarde la Edad Media se consideran como hitos históricos en la armonía de las relaciones entre los dos géneros, donde ambos viven en armonía e igualdad.

Será más tarde cuando la aspiración del espíritu racional a explicar el mundo aparecen grietas en la relación. El culpable de la progresiva importancia del individuo frente a los intereses de la comunidad es, a los ojos de las mujeres católicas, la reforma protestante que trae consigo la época de decadencia del protagonismo de la mujer y su entrada en la vida silenciosa y anónima. La reforma elimina el carácter de virgen de la mujer, con lo cual su relación directa con Dios se pierde para siempre.

El movimiento de la mujer nace de la necesidad de devolver a la mujer su antigua fuerza, sin embargo fracasa al centrar sus esfuerzos en la mera reivindicación de derechos materiales. Éste no contribuye sin embargo a que la mujer descubra de nuevo su verdadera, identidad, la fuerza y entereza de las mujeres germánicas.

Campo semántico sobre la feminidad en DIE CHRISTLICHE FRAU
Mujer
Hombre

\footnotetext{
903 Ibídem, p. 234

904 Ibídem, p. 234

905 Schroeder, A.: „Erbe deutscher Frauen“, DiE CHRISTLICHE FrAU, Octubre 1933 (año 31), p. 272
} 


$\begin{array}{lc}\text { El regazo } & \text { Héroe } \\ \text { La acogida } & \\ \text { El país que espera } & \\ \begin{array}{l}\text { Defiende la generación } \\ \text { La tierra }\end{array} & \begin{array}{c}\text { Defiende el momento } \\ \text { La semilla }\end{array} \\ \text { La corriente } & \text { El acantilado } \\ \text { La patria } & \\ \text { La naturaleza } & \text { La cultura } \\ \text { El sostén } & \text { El entendimiento } \\ \text { La conservación } & \text { La ambición } \\ \text { La unión } & \\ \text { Protectora de la vida } & \text { Hecho } \\ \text { Amor } & \text { Voluntad } \\ \text { Fidelidad } & \\ \text { Sabiduría } & \text { Razón } \\ \text { Fuente del ser } & \\ \text { Conservadora de la vida eterna }\end{array}$

La mujer ha sido creada para recibir. Su naturaleza depende del otro, (el hijo, el marido, Dios). Como la tierra recibe la semilla y pone sus frutos a disposición de los seres humanos, la mujer ofrece su feminidad para que los otros se realicen en ella. El hombre por el contrario es el polo activo, activo de la relación:

„La mujer es la tierra a la espera. El hombre se mueve hacia ella. Ella no puede buscarle,. El se mueve hacia ella. Sin embargo ésta tiene la libertad de tomarle o rechazarle. Si la mujer se hace a la búsqueda del hombre, falsearía su naturaleza y corrompería la relación entre los dos géneros. Está en la naturaleza del hombre que éste se tenga que esforzar por la atención de la mujer." 906

La genialidad de la mujer radica en su capacidad de amar, en su dependencia del mundo de los sentimientos:

„A menudo se ha planteado la pregunta sobre las cualidades artísticas de la mujer. Por supuesto que ésta alcanza al hombre en muchos campos. Pero, creo que su verdadera genialidad, en el sentido originario de la palabra, se encuentra en el reino del amor."'907

\subsubsection{La mujer como madre}

En la maternidad encuentra la naturaleza de la mujer su realización absoluta: maternidad es espera, es regalo, es abandono y sacrificio, es vida:

906 Ibídem, p. 18

907 Scherer, Elsbeth: „Vom Zeitlosen Wesen der Frau“, DiE CHRistliche FraU, Febrero 1934, (año 34), p. 35 
„La mujer debe regalar vida, ella es la dadora de la nueva vida, pero no desde fuera sino en su propio ser. El principio de la nueva vida llega hacia ella desde fuera, pero su entrega no se produce para producir, sino que la vida que ella lleva dentro forma una identidad en si."“908

Como ejemplo de esta dependencia natural se presenta a Eva, la hembra que da luz a la descendencia, la hembra que trabaja al lado del hombre. El reconocimiento „divino“ de la diferencia de lo femenino se presenta en la figura de Maria. En ella la maternidad no es biológica o natural, sino que se convierte en un instrumento de Dios para ejercer su influencia en el mundo. Por lo tanto la maternidad es el regalo que recibe la mujer, que la hace diferente, única y especial. 909

Como prototipo de las cualidades de la mujer en la historia, se presenta a la mujer medieval que vive encerrada en los claustros, con un velo en el rostro, dedicada a la alabanza de Dios, la mujer que espera al guerrero, y que después de la batalla le ofrece como recompensa la sonrisa, la tranquilidad y la paz. ${ }^{910}$

La diferencia de los géneros está determinada en la naturaleza, y por lo tanto está por encima de toda aspiración individual, como en el caso de las aspiraciones del movimiento de la mujer, que pretenden, desde el punto de vista católico, poner en cuestión un orden dado por la naturaleza y por lo tanto intocable.

Interesante y nuevo respecto al resto de las publicaciones objeto de nuestro análisis es la crítica que se hace de la masculinización de la sociedad; el hombre aparece calificado como víctima del egoísmo sexual, de la neurosis económica, su histeria voluntarista y activista, cualidades que la mujer imita en su deseo de participar en los terrenos de la vida pública y laboral, hasta entonces reservados a sus compañeros masculinos. ${ }^{911}$

La división entre masculinidad y feminidad estarían en un principio unidos, a la caída en pecado de Adán y Eva, donde se rompe la unidad entre los dos principios cósmicos, por eso la razón de su continúa búsqueda y lucha con el otro. Matriarcado y patriarcado son las consecuencias de lucha entre los dos principios. Al igual, que entre las mujeres protestantes, el cristianismo aparece como la etapa donde la lucha entre los géneros llega a su fin, donde las mujeres pueden liberarse del período patriarcal que las había sometido.

Sin embargo, la reforma, el individualismo, y el espíritu burgués constituyen los prolegómenos de la sexualización de la sociedad en la democracia, con su excesiva libertad para hombres y mujeres. La proletarización de la sociedad industrial constituye una amenaza de la armonía entre los géneros donde:

„Ambos géneros enferman de masculinidad; neurosis, histeria en las dos partes son las consecuencias y lo individual de cada uno desaparece para dar paso al narcisismo, soledad, y el vacío del alma.“"912

En el matrimonio y no en el trabajo encuentra la mujer el lugar dónde desarrollar su verdadera existencia y establecer la vieja armonía entre los géneros:

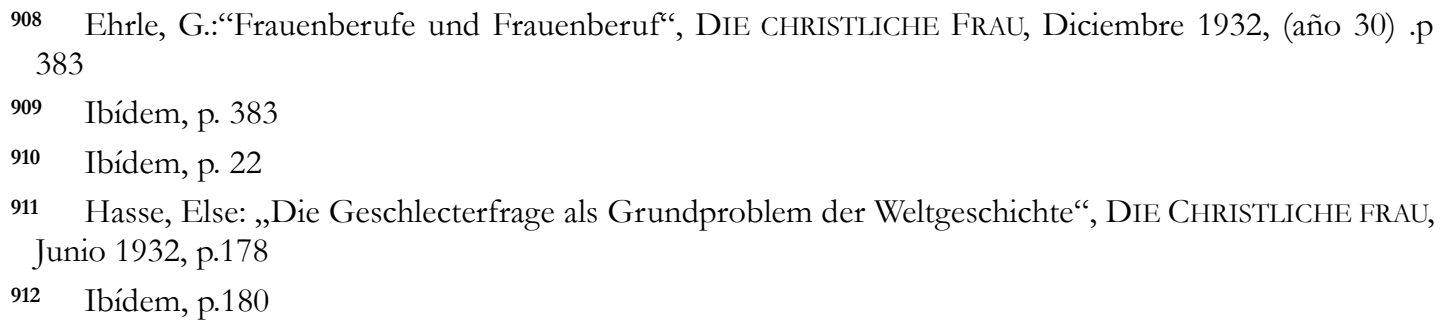


„Creando al hombre un lugar donde éste pueda aguantar su soledad, que a través de la sabiduría de la mujer se convierte en alegría. Creando un lugar donde el hombre pueda olvidarse de su intranquilidad con la que éste se encuentra día a día en su profesión en sus contactos con otros individuos, en la lucha por trabajo, posesión y éxito. “913

Esta actitud de ayuda para el hombre, se extiende fuera del hogar matrimonial, en forma de acciones y responsabilidades en el ámbito de la caridad, aspecto que las mujeres solteras debido a su trabajo no pueden desarrollar: el dar, el estar para los demás. ${ }^{914}$

\subsubsection{El movimiento de la mujer.}

Las relaciones entre el movimiento de la mujer y el asociacionismo católico habían sido distanciadas. La Federación de mujeres católicas, a diferencia del resto de las asociaciones de mujeres confesionales, Evangelischer Frauenbund, Jüdischer Frauenbund, no había pertenecido nunca al $B D F$, debido al carácter aconfesional de éste.

Esto no quiere decir que éstas no se ocupen de definir su posición como organización respecto al movimiento de la mujer. Durante 1932 se trata con asiduidad en DiE CHRISTLICHE FRAU el tema de la participación de la mujer en las tareas de estado. La discusión estaba relacionada con los puntos de vista de los partidarios del partido nacionalsocialista sobre el carácter masculino del estado. Bajo el moto, Der Staat ist Männersache, Das Volk ist Franensache, el estado es cosa de hombres, el pueblo de mujeres, se pretendía relegar a las mujeres de las tareas del estado. Helene Weber, miembro del BDF, y parlamentaria del partido de centro, se plantea el interrogante sobre la naturaleza del estado:

„¿Qué es el estado? ¿Es aquella organización impersonal hambrienta de poder de la que las mujeres no pueden formar parte?, ¿ es la fría abstracción sin sangre y vida?, ¿es la exigencia al hombre como juez y soldado?. No, no debería ser esto. Para nosotros el estado es más que la organización de poder, que todo país considera necesaria. El estado crea el derecho y protege la cultura. Éste no debería ser en su administración la red de organización de leyes y medidas, sino debería representar la realidad humana y que se encuentra en relación con el pueblo.“915

Weber, sin pertenecer durante Weimar al movimiento de la mujer, es partidaria de la unidad entre estado (hombre) y pueblo (mujer) en lo que ella llama una democracia orgánica, donde las mujeres tengan la posibilidad de expresar su deseo de participar en el devenir político de la nación. Weber llama a las mujeres a luchar por sus derechos políticos:

„La lucha por los derechos del pueblo esa es nuestra lucha. La lucha por la libertad personal e intelectual. Quizá no han sido las mujeres alemanas en nuestra historia tan fuertemente llamadas a influir en la historia del pensamiento alemán. Esto significa el trabajo intelectual en la constitución de Weimar. Esto exige de

913 Gemtges, M.: „Die Frau als Gattin“, Die Christliche FraU, Diciembre 1932, (añ0 30), p.388

914 Ibídem, p. 390

915 Weber, H.: „Volk und Staat. Eine Zeitgeschichtliche Betrachtung zur Frauenfrage“, DIE CHRISTLICHE FRAU, Octubre 1932, n¹0, p. 299 
nosotras una lucha política por el destino de la política exterior de Alemania y por su desarrollo interno en una lucha de intereses y clases. "'916

Es evidente que el artículo, escrito en octubre estaba dirigido a las elecciones que iban a tener lugar en noviembre del mismo año. Weber, por entonces representante del partido de centro, Zentrumspartei, intenta convencer al lectorado católico de que el voto al cualquier partido que represente tendencias moderadas es un voto a favor de la república de Weimar:

„La dictadura no es 'un estado de excepción' sino la desconfianza ante la influencia del pueblo y prepotencia ante la fuerza de éste. Dictadura es el dominio de la tiranía o de una clase de tiranos que quieren apoderarse del estado sin contar con el pueblo." 917

Angele Auburtin en el número de diciembre expresa la necesidad de una reorientación del movimiento de la mujer. Los objetivos no consisten en luchar por la igualdad de la mujer sino en resaltar la „alteridad“ de la mujer y las obligaciones que ésta tiene para la comunidad:

„La mujer tiene que demostrar ahora que ella puede cumplir con el verdadero sentido del movimiento de la mujer, esto quiere decir completar la visión femenina del mundo del a partir de la diferencia de su naturaleza, que hasta entonces venía siendo determinada por la forma masculina de ver las cosas y llegar a formar algo nuevo a partir de la totalidad de los valores posibles. “918

Esta valoración negativa contra el movimiento de la mujer, se mantiene también después de 1933, como ocurre entre las mujeres nacionalsocialistas, sino que se intenta una valoración objetiva de la actuación de éste y se plantea la cuestión si el movimiento de la mujer ha contribuido a abrir el camino a la crisis de los valores que ha contribuido a acelerar la decadencia en las relaciones de los géneros:

„Nosotras sentimos que una grave enfermedad se ha hecho con el cuerpo social de la humanidad, una enfermedad que fácilmente puede llevar a la muerte. La palabra „crisis“ se nos aparece constantemente. Es como si el termómetro hubiera alcanzado una temperatura de 40 grados. Crisis de la economía, crisis del estado, crisis de la cultura. Todo esto significa que en todas partes tenemos la impresión de vernos impulsados fuera del carril del sano desarrollo y reconocemos con horror que andamos por caminos falsos y buscamos una salida, un lugar donde podamos descansar, buscamos salvación. Sería raro que el movimiento de la mujer no se viera implicado en este caos. ¿Hasta que punto no es éste responsable de este caos?." 919

En los números de enero y agosto de 1934 aparecen una serie de artículos donde Helene Weber intenta definir y diferenciar el movimiento de la mujer católico del movimiento de la mujer, en una táctica que también aparece en las publicaciones protestantes, donde se intenta

916 Ibídem, p.299

917 Ibídem, p.299

918 Auburtin, A. : „Katholische Friedensidee und Frau“, DiE CHRISTLICHE FraU, Diciembre 1932, n²12, p. 396

919 Schumacher-Köhl, M.: „Wende in der Frauenbewegung“, DIE CHRISTLICHE FRAU, Enero 1933 (año 31), p.11 
fundamentar el parentesco de ideas de la propia organización con las expectativas que el nacionalsocialismo tenía sobre la mujer. ${ }^{920}$

En el primero de los artículos Weber se encarga de detallar la historia de la Federación de mujeres católicas, $K F B$, insistiendo en el carácter puramente social y religioso de la organización. En el segundo artículo compara a la organización con una betende Frauengemeinschaft, un colectivo femenino de oración. Objetivos y trabajo de la organización pasan a un segundo plano. Como ejemplo de la cohesión y la fuerza religiosa de la organización Weber hace alusión al viaje que miembros de la Federación hacen hasta Altötting, un conocido lugar de peregrinación en el sur de Alemania. En la idílica Baviera, en armonía con la naturaleza y el arte las mujeres católicas dan testimonio de su fe y como señala Weber aleja por un día las preocupaciones cotidianas:

„Una paz indescriptible reinaba sobre la naturaleza y el hombre y una belleza casi irreal nos rodeaba. La oración, „Maria siempre ayuda“ era repetida por todas las mujeres a la vez. Todos se encontraban en nuestras oraciones: nuestra familia, nuestros amigos y enemigos, nuestra patria y nuestra iglesia."921

La valoración de la mujer desde el punto de vista biológico es entendido como una reacción normal a los principios emancipadores, aunque se rechaza la valoración de la maternidad como un mero proceso biológico:

„La consumación de la emancipación, tras la primera guerra mundial era para algunos, lo mismo que la victoria de la mujer sobre el hombre. En estos momentos vivimos el caso contrario. La llamada a la determinación natural de la mujer es una entendible reacción contra un estado antinatural. Pero la naturaleza del individuo no se realiza únicamente en el campo biológico. Nosotros creemos que la naturaleza recibe su forma de un estadio superior, como la física de la metafísica." $" 922$

Sin embargo las mujeres católicas critican la visión antropocéntrica del movimiento de la mujer como egoísta. En especial se rechaza el derecho de las mujeres a disponer en todos los casos de su cuerpo, como por ejemplo en el caso del aborto. No obstante reconocen que este movimiento surge del derecho de legítimo de las mujeres a poner en duda el orden de los géneros. Desde el punto de vista católico se intenta dar una respuesta que devuelva la convivencia armónica de entre los dos géneros y de a la mujer la oportunidad de encontrar su „verdadera“ identidad. Para ello se cita la obra de una autora perteneciente a una comunidad religiosa, Thoma Angélica Walter, ${ }^{923}$ que había escrito un estudio sobre la metafísica de los géneros donde se presenta una solución a la naturaleza identidad de los géneros: hombre y mujer integran la totalidad de la naturaleza humana que en diferente forma se mueven en ritmos diferentes:

920 Weber, H.: „Der Katholische Deutsche Frauenbund. Sein Gesicht im Wandel der Zeit“, DIE CHRISTLICHE FraU, Enero 1939, n¹, pp.2-6; „Die betende Frauengemeinschaft“, DIE CHRISTLICHE FraU, Agosto/Septiembre 1934, n8/9, pp. 231-233

921 Weber, H.: „Die betende Frauengemeinschaft“, op. cit., p. 233

922 Sellmair, J.: „Die Frau in der christlich-humanen Ordnung“, DiE CHRISTLICHE FRAU, Enero 1936, $\mathrm{n}^{\circ} 1$, p. 4 pp. $2-5$

923 Walter, Angelica: Seinsrhythmik. Studie zu einer Metaphysik der Geschlechter, Freiburg, Herder, 1932 
„La mujer es dentro de la totalidad de la humanidad la causa del ser, el yo que reposa y que está unido a la realidad, aspirante a armonía y unidad. El hombre por el contrario aspira al ser en crecimiento en intranquilidad, a la realidad abstracta que analiza y entiende. Ambas son fuerzas vitales que deberían relacionarse en el ritmo armónico de la fecundidad.“924

La mujer apoya, sostiene, unifica. En su identidad y la aceptación de ésta se encuentra la solución para la armonía de los géneros. Un orden que no tiene nada que ver con los presupuestos de las democracia formales, o con las reivindicaciones del movimiento de la mujer, sino con el orden divino. Esto significa la revaloración del matrimonio y de la familia y el replanteamiento de un nuevo movimiento de la mujer que libere a la mujer de la esclavitud del liberalismo:

„La tragedia (del movimiento de la mujer) fue que se alimentó de un principio que era antimujer, antimaternal. El individualismo es su naturaleza poco femenino y antimaternal. “925

La educación, Bildung, punto central de las reivindicaciones del movimiento de la mujer, no obstante no se plantea como una tara para la mujer, como es común en las publicaciones nacionalsocialistas, donde las críticas de intelectualismo a las mujeres del movimiento de la mujer era una de las principales objeciones contra el movimiento. La educación de la mujer casada, es una de las garantías del buen funcionamiento de un matrimonio:

„Seguimos creyendo que la formación intelectual de la mujer no puede destruir su originaria feminidad, mientras que la mujer cultive ésta interiormente y a través de su capacidad de amor no sea destruida sino que se forme continuamente. ${ }^{\text {"926 }}$

Educación se presenta como una instancia moral que favorece el desarrollo personal. Sin embargo la llegada de la mujer al mundo de laboral, a posiciones de responsabilidad en la política y en la vida social, no son los verdaderos fines del movimiento de la mujer según las mujeres católicas:

„El verdadero movimiento de la mujer comienza ahora, como una „contrarevolución“. Las mujeres no han ganado nada, ni para ellas, ni para el hombre, al intentar conquistar el estado masculino, la ciencia masculina, la economía masculina, por las cuales son vencidas en estos momentos. Ya que junto al hombre-máquina apareció también la mujer-máquina que tenía que seguir a todas partes a su contrayente."'927

La tarea del nuevo movimiento de la mujer, basado en los principios del cristianismo es redescubrir las cualidades de la naturaleza femenina, y devolver al caos terrenal el orden divino y cósmico de la armonía de los géneros.928

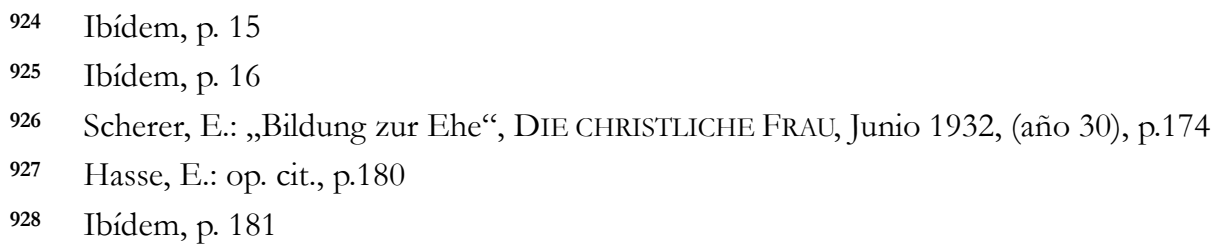


La solución de la cuestión de la mujer por el cristianismo no significa la disolución de las tensiones existentes entre los géneros, sin embargo se puede considerar como una separación de la primacía del patriarcado o del matriarcado:

„El cristianismo proclama la igualdad metafísica de los géneros, por lo tanto la mujer se define en primer lugar por su naturaleza genérica sino como persona con alma inmortal y creada a imagen y semejanza de dios. La Antigüedad nunca entendió a la mujer bajo este punto de vista y por lo tanto se distingue considerablemente el papel de las mujeres en culturas cristianas de las no cristianas. El cristianismo no levanta de ninguna manera la diferencia entre los géneros. El hombre no es creado como un género, sino que dios creo a éste como hombre y mujer. Por lo tanto sólo se puede concebir al hombre como „imago Dei“ en su doble unidad y este orden posibilita a la mujer la realización de su ser femenino. “929

\subsubsection{El mundo del trabajo}

Uno de los pilares del movimiento no confesional de la mujer era sus esfuerzos por mejorar las condiciones laborales de la mujer, así como mejorar la educación y formación de éstas, a través de la apertura de las universidades para las mujeres. Trabajo y formación aparecían como valores importantes en el desarrollo individual. Para las mujeres católicas esta aspiración se coloca en segundo plano:

„La profesión por excelencia de la mujer es ser mujer. Dejar fluir su naturaleza y su vida entera. Sobre la raíz de su feminidad crece su ser que se despliega en su hacer como esposa, madre, hermana, virgen y trabajadora. La mujer tiene que ser mujer. Esto abarca todo e influye todo su ser.“(930

El aspecto de realización personal a través del trabajo es rechazado por las mujeres católicas por su carácter individualista y liberal. La mujer no es, no existe_en función del trabajo que hace, sino que su existencia, su conocimiento de si misma proviene de su relación con Dios. ${ }^{931}$

Ya en 1932 con motivo de la reforma de los derechos de la funcionaria casada, expresan las mujeres católicas sus reservas ante la actividad laboral de mujeres casadas, cuyos deberes en la familia sufrirían bajo su dedicación a una actividad fuera de la casa. La familia es una identidad que no se puede separar y que necesita de una responsabilidad constante. Por lo tanto el trabajo fuera del hogar constituye una amenaza para ésta, y para el proceso de redescubrimiento que la mujer hace de su propia identidad. ${ }^{332}$ El término de Geistige Mütterlichkeit, maternidad espiritual que las dirigentes del movimiento de la mujer habían introducido para definir actuación de la mujer en la vida pública y cultural, es rechazado por las mujeres católicas por tratar el fenómeno de la maternidad como algo superficial y racionalizable.

929 Sellmair, J:: op. cit., p.4

930 Scherer, Elsbeth: „Vom Zeitlosen Wesen der Frau“, Die Christliche Frau, Enero, 1934 (año 34), p. 17

931 Ehrle, G.: op. cit., p. 387

932 Weber, H.: „Eine Entscheidung über die Rechtstellung der weiblichen Beamten“, DIE CHRISTLICHE FRAU, Junio 1932, (año 30), p. 182 
Una de las críticas que las mujeres católicas hacen al movimiento de la mujer es el carácter intelectual y elitista de éste. Helene Weber distingue irónicamente entre dos movimientos de la mujer: uno que veía en el trabajo la posibilidad de que la mujer desarrollará su carácter y se realizara a sí misma y un segundo formado por aquellas mujeres que tenían que trabajar obligatoriamente bajo condiciones infrahumanas. 933

El trabajo femenino, especialmente las mejoras de la educación femenina aparece valorado positivamente. No así los resultados del proceso de industrialización y las repercusiones en la vida familiar. El menor coste de la mano de obra femenina conduce al desempleo a sus colegas masculinos. Lo que provoca un círculo vicioso difícil de romper, el hombre pierde su trabajo, la mujer se ve obligada a aceptar cualquier tipo de trabajo para poder sacar adelante a la familia, que a su vez sufre ante la ausencia de la madre, que hasta ahora se había ocupado de la educación de los hijos. La imagen que se presenta es la de una mujer agotada, que poco a poco pierde su feminidad frente a la deshumanización de un mundo dominado por la técnica y el ansia de progreso. El matrimonio se convierte en una entidad de tipo económico donde la inseguridad del trabajo del hombre provoca que la mujer recién casada no se atreva a dejar su propia ocupación. Inconvenientes de esta situación es el trabajo adicional que la mujer tiene que hacer en el hogar, lo cual aumenta el número de horas que esta dedica a trabajar. En muchos de los casos el hombre pierde su trabajo con la mujer se convierte en la sustentadora de la familia. Esto no quiere decir que se apoye una política de empleo que utilice la prohibición del trabajo femenino como factor de estabilización del mercado de trabajo, sino que se reivindica una mejora en las condiciones y ofertas de la educación de los hijos y la nivelación de la oferta laboral. ${ }^{934}$

Las aspiraciones de una mejor educación, y el deseo de acceder al mundo laboral es analizado desde la perspectiva católica:

„Las mujeres católicas siempre han saludado la posibilidad de desarrollo y formación del ser. Sin embargo no hicieron depender el desarrollo de la personalidad de la formación, sino de la relación con la familia, con la economía del pueblo, del servicio a la comunidad popular. Por lo tanto nunca hemos estado en contra del trabajo profesional, al contrario, hemos destacado el valor positivo de éste, aunque también hemos llamado la atención sobre los peligros que este tipo de trabajo conlleva." "935

Esto no significa que se rechace por completo el trabajo femenino. Siempre que se traten de tareas propias de la mujer, y siempre que la mujer no este casada, o de su trabajo dependan económicamente otros miembros de la familia. ${ }^{936}$

Las medidas del nuevo gobierno para luchar contra la tasa de desempleo y su interés en disminuir la mano de obra femenina, son aceptadas siempre que éstas suponga regular el trabajo femenino que puede ser una amenaza para la salud de la mujer. Sin embargo la tendencia general de reducir la presencia de las mujeres en el mundo laboral es criticada como única medida para luchar contra el desempleo. El argumento se legitima con opiniones de las mujeres

933 Weber, H.: „Frauenberufsarbeit und Frauenpersönlichkeit“, DiE CHRISTLICHE FrAU, Abril 1932, (año 30), p. 97

934 Maresch, M.: „Beruf und Mutterschaft“, Die ChristliChe FraU, Marzo 1933, n³, pp.77-79

935 Hopmann, Antonie: „Fragen der Zeit an die Berufstätige Frau“, DiE CHRISTLICHE FrAU, Enero 1934,(año 32), p.11

936 Weber, H.: „Berufsarbeit und Frauenpersonlichkeit“, op. cit., p. 101 
nacionalsocialistas, Paula Siber, Lydia Gottschewski y Magda Goebbels. No obstante la actitud respecto al gobierno permanece benevolente:

„Allí, donde las mujeres, que deseaban fundar una familia y las posibilidades financieras eran limitadas siempre se ofreció por parte del gobierno ayuda positiva." 937

En especial se saludan las medidas de apoyo a la familia, la política de préstamos para parejas jóvenes que desean contraer matrimonio, y sobre todo la valoración de la maternidad como una de las fuerzas que van a hacer salir al pueblo alemán de la crisis, y de la „oscuridad“.

\subsubsection{Posturas políticas}

A pesar de su conservadurismo en cuestiones relacionadas con la mujer, la postura de la Liga respecto a la llegada del nacionalsocialismo no se celebra tan eufóricamente como en el resto de las organizaciones de mujeres. 938 En Marzo de 1933 unos días antes de las elecciones manifiestan su claro rechazo al nacionalsocialismo:

„Nosotras, alemanas, católicas de Baviera, no podemos, debemos olvidar nuestra responsabilidad, de defender nuestros bienes de la tierra. Todos los católicos que llevan todavía este nombre con dignidad, tienen la tarea de conseguir el 5 de marzo no sea un día de derrota para el catolicismo político, sino de victoria y confesión. “939

En el número de noviembre de 1933 en FraUenLAND Gerta Krabbel muestra en los mismos términos que en DIE CHrISTLICHE FraU el alivio que experimentan la Federación de mujeres protestantes ante la firma del concordato entre iglesia y estado. Y aún más se muestran dispuestas a colaborar con éste:

,(con la firma del concordato) se nos dice que el trabajo de las organizaciones católicas es importante para la vida de nuestra iglesia y nuestro pueblo. En este punto se realiza el trabajo conjunto y la influencia mutua entre iglesia y estado. En ello se encuentra una gran responsabilidad. Debemos hacer todo lo que se encuentre en nuestras manos para mantener vivo el trabajo de la Federación católica de mujeres alemanas." ${ }^{\text {"940 }}$

En la declaración de colaboración con el nuevo gobierno se expresa también el modo en el que tendrá lugar la influencia de las mujeres católicas:

937 Ibídem., p. 15

938 En julio de 1932 con motivo de la dimisión de Brüning el 30 de mayo de 1932 como canciller, aparece un artículo en DIE CHRISTLICHE FRAU donde se expresa la preocupación de los círculos de mujeres católicas ante las nuevas elecciones. El apoyo de la Federación de mujeres católicas al partido de centro, Zentrumspartei, queda patente en todas las declaraciones de la ésta. Nunca, a diferencia del resto de las organizaciones utilizaron el argumento de la neutralidad política. En: DiE CHRISTLICHE FrAU, Junio 1932, (año 32), pp.199-200.

939 Brumann, L.: „Es bleibt uns nichts erspart. Zum 5. März“, BAYRISCHES FrAUENLAND, Marzo 1933 (año 15), p.19

940 Krabbel, G.: „Wir katholische Frauen im Bund“, FraUENLAND, November 1933, n 11, p. 281 
„Como mujeres católicas tenemos que estar dispuestas a mantener vivo y a fortalecer nuestro sentir católico. Esto sólo es posible sin nos esforzamos en conseguir la correcta orientación, silencio, interioridad. (...) Especialmente en estos momentos tenemos que mantener viva la conciencia de renovación: la influencia de la mujer en el silencio, en lo invisible, en lo indecible.“ 941

Esta declaración se puede considerar como la primera imprecación a practicar la llamada „emigración interior“. Modelos a imitar no son figuras de la antiguedad clásica sino figuras importantes del pasado alemán, como Hildegard von Bingen, Hedwig, Elisabeth von Thüringen o Gertrud la grande, que representan el ideal de la mujer cristiana. Esta emigración interior, se refleja también en el resto de las publicaciones dependientes del KFB.

En 1935, las revistas dependientes de la Federación de mujeres católicas BAYERISCHES FRAUENLAND, FRAUENLAND, entre otras, han dejado de hacer declaraciones sobre la situación política, y se concentran en temas específicamente femeninos o religiosos. Los artículos sobre la cuestión de la mujer o la posición de la mujer en la sociedad, se hacen escasos. ${ }^{942}$

En el caso de DiE CHRISTLICHE FRAU se muestran combativas en los primeros años de la dictadura y muestran su apoyo al movimiento de la mujer, criticando la postura conservadora que culpaba a éste de haber contribuido a aumentar el clima de caos y confusión moral existente en la república de Weimar. En los primeros meses de 1933 aparecen una serie de artículos que argumentan las posturas de Guida Diehl, nacionalsocialista de la primera hornada, donde defienden los principios liberales y demócratas del movimiento de la mujer. No obstante la redacción expresa su inseguridad y su desconcierto ante la situación política y cultural, ante el poder de la técnica, de la industria, del dinero, y proclama una vuelta a la naturaleza, a las raíces del ser humano. Una vuelta a lo femenino, a lo irracional, a lo verdadero. ${ }^{943}$

A partir de 1935 el contenido de la revista se intelectualiza, se huye al pasado, a culturas antiguas, se hacen elogios de las grandes mujeres de la historia, se reza, se discute teológicamente, el presente deja de existir.

\subsubsection{La guerra o la tentación de la unión nacional. El amor a la patria}

La postura de las mujeres católicas respecto a la guerra se encuentra influida por su trabajo después de la primera guerra mundial en las conversaciones de paz. Desde el primer momento apoyan la política de desarme. Más que por un convencimiento político, defienden posturas pacifistas, guiadas por su imagen de la mujer como defensora de la vida:

„Las mujeres, como dadoras, guardianas y cuidadoras de la vida quieren estar seguras de que los horrores de la guerra moderna no se vuelvan a repetir. Por lo tanto exigimos que, en los países que todavía no practican la política de desarme,

\section{Ibídem, p. 281}

942 Si tenemos en cuenta las noticias sobre las actividades de las organizaciones nacionalsocialistas, se puede constatar la presencia de la Federación de mujeres católicas en diferentes campos. Así por ejemplo la Federación participa con las NS- Frauenschaften y las organizaciones de mujeres de amas de casa y de campesinas, en las conversaciones que el Instituto para desempleo inició para tratar el tema del año de servicio femenino en el hogar. Die CHRISTLICHE FrAU, Abril 1934, (año 32), p. 125. Otro de los compromisos que hacen las mujeres católicas está relacionado con los servicios de maternidad, Katholischer Mütterdienst, donde en el plan de formación para las mujeres que se encargaban de impartir los cursos se introducen materias relacionadas con el problema racial y eugenésico.

943 Krabbel, G.: „Wir katholische Frauen im Bund“, op. cit., p.225 
se empiece a reducir el número de armas, y que métodos de guerra como el uso de gases tóxicos se eviten en absoluto. “944

El trabajo por la paz se traduce en la recogida de firmas que apoyan las conversaciones de Ginebra. Interesante es la ausencia de tonos patrióticos o nacionales, sino el interés de salvaguardar la paz en el resto de Europa. Este interés tiene su símbolo para las mujeres católicas en la construcción de una iglesia, die Frauen-Friedenskirche en Frankfurt.

Sin embargo unos meses después, en octubre de 1932 se critican las resoluciones tomadas en la conferencia de Ginebra y las consecuencias negativas que estas medidas tenían para Alemania:

„La respuesta a este asunto nos lleva de nuevo a tener que señalar que Francia, parece decidida a negar a Alemania el derecho de poder defenderse no desde un interés de rearme nacional, sino desde el punto de vista internacional. “945

Sin embargo se incide en que la posición de la iglesia respecto a la guerra no puede definirse en función del internacionalismo o del nacionalismo. La idolización del estado es, desde el punto de vista católico, una herejía, pero por otra parte la función del estado en la doctrina católica como una „societas perfecta naturalis“ cuya última finalidad se encuentra en Dios impide la defensa del internacionalismo, ya que la características nacionales, völkisch, son también obra de la voluntad divina. En segundo lugar se acepta la ,guerra justa. ${ }^{946}$

Interesante es la responsabilidad que se da a las mujeres en las decisiones en torno a la guerra. Tal responsabilidad depende de la interpretación que se hace sobre la personalidad del hombre. Este construye su personalidad en función del ideal que la mujer se ha hecho de éste:

„De la mujer depende si el hombre acepta que el heroísmo guerrero es una característica especial de la verdadera masculinidad. De la mujer depende también si se construye un nuevo tipo de ideal masculino, cuyo heroísmo se aplique en la lucha por la paz, hombres cuyo valor sea mayor que el temor a ser reprochados por su falta de patriotismo. (...). ${ }^{947}$

En 1936 con motivo de la crítica de dos libros sobre la aportación de las mujeres a la guerra. ${ }^{948}$ Se vuelve a enlazar con la tradición de 1914 y la participación femenina en el evento nacional, así como se resalta la participación de las mujeres católicas en el servicio femenino para la guerra:

„Las mujeres católicas participaron en todo tipo de actividad al servicio del pueblo. Ellas participron en el servicio femenino naciona (...). En todas partes pusieron a disposición sus mejores fuerzas, z si en el aspecto exterior quizá no brillaron tanto como las mujeres de otros grupos, o quizá no llamaron la atención

944 Krabbel, G.: „Katholische Frauen zur Abrüstung“, DiE CHristliCHE FraU, Enero 1932, (año 1932), p. 2

945 Montgelas, P.: „Das Ergebnis der Abrüstungskonferenz“, DIE CHRISTLICHE FraU, Octubre 1932, $\mathrm{n}^{\circ} 10$, p. 313

946 Auburtin, A.: „Katholische Friedensidee und Frau“, DIE CHrISTLICHE FraU, Diciembre 1932, n 12, p.398

947 Ibídem p. 399

948 Lüders, E.: Das unbekannte Heer, Berlín, E.S. Mittler \& Sohn, 1936. Staewen-Ordemann,G.: Kameradin. Junge Frauen im deutschen Schicksal 1910-1930, Berlín, Hans Bott-Verlag, 1936 
en la organización, es importante su tarea en el reconfortamiento moral de la mujer y de la madre. “649

Otro de los temas que llama la atención en DIE CHRISTLICHE FRAU es el de los cristianos alemanes. En un artículo publicado en 1936 por Ingeborg Dieck se trata de señalar las diferencias y similitudes existentes entre el cristianismo y el nuevo movimiento de renovación. El artículo intenta de una manera racional adentrarse en los principios de la nueva religión. A pesar de establecer diferencias en temas teológicos se insiste en el acierto de los cristianos alemanes en lo relativo a „lo alemán“ en la religión:

„Si las condiciones de Hauer son verdaderas, Si la fe no es más que la conmoción del ser en el todo y eterna realidad que se revela en los hombres, y si el cristianismo no es más que la manifestación semítica de esta fe, entonces son las conclusiones de Hauer ciertas, y entonces es inconcebible porqué nosotros cristianos en Alemania, si somos alemanes tenemos que depender justamente de la forma semítica de la fe." 950

Si teóricamente se asume la suposición de Hauer, el dirigente de los cristianos alemanes, de que toda religión es en realidad una „religio naturalis“, como expresión de la revelación divina pero representación de la experiencia que hombre tiene de Dios, por lo tanto:

„Estas religiones naturales son producidas por los hombres, son la expresión de la interpretación que los individuos hacen de las huellas de Dios en el mundo, estas religiones por lo tanto están condicionadas por la raza de los que las producen. (...) En este punto Hauer tiene razón, en el caso de que exista una revelación, es una obligación natural para un individuo alemán que ésta tenga lugar de manera alemana y no de una forma semítica."951

No obstante continúa la autora del artículo Hauer olvida por completo la figura de Cristo que representa una segunda revelación de lo divino que no tiene nada que ver como los individuos representan, viven o interpretan la experiencia de lo divino, sino que en la figura de Cristo se encuentra la revelación en sí, independiente de razas, de lenguas o de culturas, con lo que la bases de los cristianos alemanes, concluye la autora, se revela como falsa:

„Desde este punto de vista todo se ve más claro, primero que la religión sobre la que se construye la nueva fe, no puede hacer depender su naturaleza de conceptos racionales y populares, esta religión no es la expresión de la experiencia del hombre, de la interpretación humana de las huellas de Dios en el mundo. Esta religión es obra de Dios, un regalo de éste y por lo tanto sobrenatural, en el sentido de que supera las condiciones de la vida humana."952

El resto de las religiones es considerado como naturalista, el cristianismo aparece como la religión perfecta por antonomasia. La religión judía se entiende como prolegómenos de la

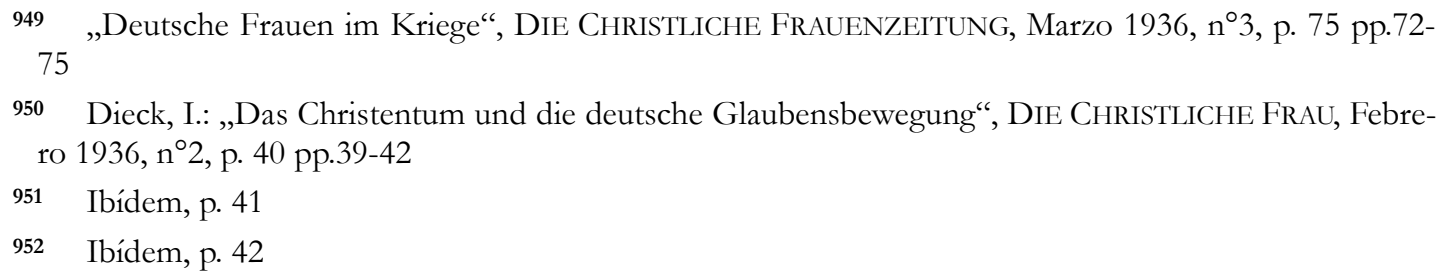


verdadera religión. Lo que se critica en la teología de los cristianos alemanes, no es el carácter antisemita de ésta, sino el carácter nacional. La religión cristiana tiene sus bases en el carácter universal de ésta. Pero mientras el nacionalsocialismo y los cristianos alemanes pretendían eliminar todo tipo de influencias „orientales“ de la religión cristiana por considerarlas ajenas a la naturaleza germana, las mujeres católicas reconocen la tradición helenística y judía de la religión cristiana:

„El viejo mundo se encuentra en decadencia. Pero sus valores fundamentales no desaparecen. La cultura helenística y romana, el principio judío de la tensión, de la disposición, todos ellos se encuentran como un estrato fundamental en la vida de la iglesia. Las fuerzas occidentales y orientales se incorporan conjuntamente en el cuerpo joven de la iglesia y aparece una religión universal." 953

Una de los primeros comentarios que aparecen en DIE CHRISTLICHE FraU sobre la Ley para la esterilización de disminuidos físicos (14.07.1933), se encuentra en el número de junio de 1934. El artículo no está escrito por las colaboradoras habituales de la revista sino por un profesor universitario procedente de Berlín. El autor parte de la necesidad de proteger a la raza alemana de influencias que pudieran debilitarla. Dentro de estas influencias se encuentran no sólo todo tipo de enfermedades de transmisión genética, sino también comportamientos asociales y amorales.

Desde el punto de vista „católico“ se propone que este grupo de asociales y amorales sean ingresados en determinadas instituciones para „mejorar" sus condiciones de vida:

„La exigencia de que esos individuos, aún cuando ellos mismos a consecuencia de un daño psíquico genético hayan sido esterilizados, sean aislados del entorno de individuos sanos física y psíquicamente, es considerada cómo positiva, no sólo porque ésta quiere sólo lo mejor para estos necesitados, sino desde el punto de vista genético, ya que esta exigencia está orientada a la mejora de las condiciones ambientales de los individuos en cuestión." 954

Esta misma medida se propone para aquellos individuos que muestras comportamientos de „inferioridad“ moral y asocial pero cuyo origen no radica en la herencia genética. Bajo este tipo de personas se incluía a vagabundos, pedigüeños y prostitutas. Para conseguir un cambio en sus actitudes se recomienda también el internamiento en organismos especializados.

Respecto a la esterilización se incide en la necesidad de que ésta se lleve a cabo dentro de los principios de la ética cristiana:

„Muchos de los individuos que sufren bajo taras genéticas, especialmente la imbecilidad, o los individuos que se dejan llevar por su instinto como los alcohólicos no son conscientes de que deben renunciar al matrimonio y a la descendencia. Les falta intención o control de la voluntad. Como única alternativa aparece únicamente la utilización de la fuerza física, lo que naturalmente tiene que ocurrir de una manera que no vaya en contra de las leyes cristianas de amor al prójimo." 955

953 Scherer, E.: „Ein christliches Geschichtsbild“, DIE CHrISTLICHE FrAU, Febrero 1937, n², p. 43

954 Muckermann, H.: „Zur Frage der Verhütung erbkranken Nachwuches“, DiE ChristLICHE FraU, Junio $1934, n^{\circ}$ 6, p. 177

955 Ibídem, p. 180 
Finalmente se señala la importancia de la educación de las generaciones más jóvenes en la „elección genética“ correcta:

„Debe estar claro que individuos sanos desde el punto de vista genético deben contraer matrimonio con individuos que se encuentren en la misma condición, con la misma decisión que la pertenencia al pueblo alemán exige el rechazo de otras razas. Es fundamental que la voluntad se acostumbre a poner el deseo por debajo de la conciencia genética. Aunque no aconsejamos prohibir los matrimonios de este tipo, se prefiere que éstos ocurran entre personas sanas. También consideramos importante la educación genética del pueblo y la formación de la opinión pública respecto a tales materias." 956

Como conclusión se alude a un tema conflictivo dentro de los círculos católicos. Si una de las mujeres, cuyo material genético o el de su compañero presentara anomalías, y accidentalmente quedara embarazada, se plantea la pregunta sobre una posible interrupción del embarazo:

„Respecto al asesinato de la vida en fecundación, no podemos dejar de insistir en que el individuo desde el primer momento de la unión de factores hereditarios es un individuo completo, cuya vida inocente intocable. El problema no se soluciona con la negación de la vida, sino con su afirmación de ésta (...)." 957

El control del nacionalsocialismo sobre las actividades de las mujeres católicas, no significa el cese de todas las actividades de éstas. La comisiones de trabajo del KFB siguen funcionando en temas religiosos y de educación. En Baden en el período de 1939 hasta 1941 tuvieron lugar 843 conferencias donde participaron unas 100.000 mujeres.958 También las escuelas sociales para mujeres católicas dependientes de la Federación, a excepción de las escuelas en München y Aachen continuaron con sus actividades.

\subsection{Conclusiones}

Para las mujeres del $B D F$ la firma del concordato con las autoridades nacionalsocialistas significa el apoyo al nacionalsocialismo, y la búsqueda, en los primeros años de la dictadura, de un ámbito de actuación donde poder seguir ejerciendo sus actividades. Como en el caso de las mujeres protestantes, en un principio, se muestran partidarias de un gobierno fuerte que se sepa hacer frente a la amenaza bolchevique y que ponga fin al desorden social y moral de la república de Weimar. ${ }^{959}$

Fundamental en el discurso de género que se deduce del análisis de DIE CHRISTLICHE FRAU, es la reivindicación de una feminidad que se despliegue en todos los aspectos de la realidad, una feminidad que se caracteriza por la diferencia respecto a la masculinidad, sin oponerse a ésta. Se trata de un discurso de la diferencia genérica, fundamentada en la voluntad divina como regla,

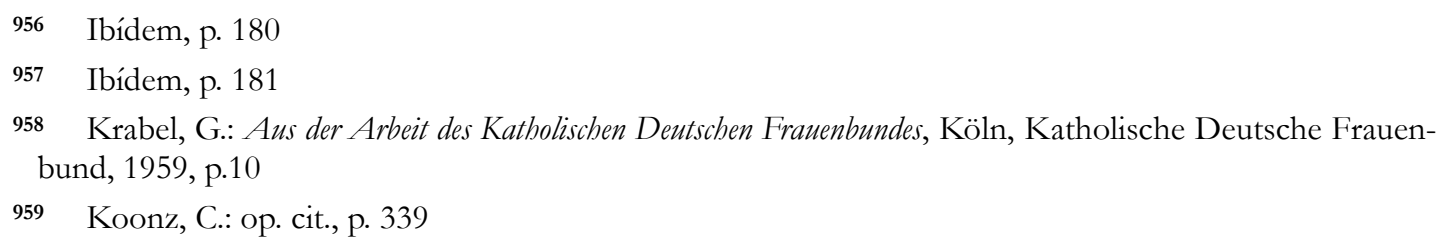


ley natural del universo. En función de este „orden cósmico” tanto mujer como hombre tienen determinadas funciones que cumplir para garantizar la pervivencia armónica del plan divino.

Otro aspecto de la feminidad es su íntima relación con la tierra, con el pueblo alemán. La glorificación de la madre se hace a través del amor y la confianza en la patria y en el pueblo alemán, y se convierte en expresión de lo que podríamos llamar como un nacionalismo maternalista de carácter cristiano, que intenta distanciarse en todo momento del concepto biologista de maternidad que planteaban los nacionalsocialistas. Esto no significa que exista un rechazo del régimen desde el punto de vista ideológico. En aspectos relacionados con la política de esterilización, encontramos con asombro una postura positiva hacia ésta, y al igual que ocurre con las mujeres protestantes, lo importante en esta complicada materia es el tratamiento cristiano de las personas que sufren la esterilización. La ley no se cuestiona, sino los efectos de ésta.

El discurso de género en DIE CHRISTLICHE FRAU ofrece a hombres y mujeres católicos un reducto de recogimiento, un exilio interno religioso donde ambos géneros pueden recoger fuerzas para seguir adelante en la realidad social. Hombre y mujer en armonía con el plan divino, encuentran las verdaderas raíces de su identidad en oposición al mundo terrenal. 


\section{La prensa conservadora}

\subsection{Introducción}

„Bajo estas circunstancias las representantes de las organizaciones asociadas a la Federación decidieron diluir con efecto inmediato la Federación de organizaciones de mujeres alemanas. (...) El boletín de la Federación continuará publicándose hasta la completa liquidación de las negociaciones. La revista DIE FRAU, la cual no pertenece a la Federación, sino que es utilizada por éste como órgano de prensa no se verá afectada por la disolución de la Federación. “960

A pesar de los intentos de lograr un acuerdo con las autoridades nacionalsocialistas, no fue posible entre las mujeres del BDF, Bund Deutscher Frauenvereine, llegar a una determinación común sobre el modo de cooperación con el nuevo régimen. El precio a pagar era demasiado alto. La única solución viable era la de la disolución.

La desaparición de las organizaciones de mujeres, la pérdida de puestos ministeriales de la élite dirigente de las asociaciones, no trae consigo sin embargo, una disolución completa de las estructuras de las organizaciones. Dos hechos contribuyen a mantener una sensación de continuidad: la publicación de DIE FRAU, el órgano de prensa del BDF, y el nombramiento oficial de la fundación Helene Lange como administradora de los bienes de algunas de las organizaciones del BDF. La fundación se encarga durante los años del nacionalsocialismo de publicar obras sobre el movimiento de la mujer, de conceder becas a estudiantes, de proteger en otras palabras el legado cultural del movimiento.

La pervivencia de ambos órganos crea entre las dirigentes del BDF, sabedoras de ser herederas de una tradición de pensamiento, la sensación de continuidad, y el mantenimiento de una colectiva de grupo ligada al ala moderada del movimiento de la mujer de principios de siglo así como la continuidad de éste, durante los años de la dictadura, bajo una forma diferente de organización.

Esta cohesión se traduce en la expresión pública a través de los artículos en DIE FRAU. Por eso podemos hablar de un discurso colectivo en la publicación que pone de manifiesto las contradicciones, la lucha interna del feminismo conservador por convivir con el nacionalsocialismo, sus intentos fallidos de distanciarse del régimen y sus esfuerzos tras 1945 a defender su carácter democrático opuesto a los principios de la dictadura. En este sentido es DIE FRAU una aportación de gran valor que nos muestra una de las partes desconocidas del nacionalsocialismo, el pensamiento ,intelectual-cotidiano“ de un grupo de mujeres que debido a sus contactos, quizá a su oportunismo, tienen la posibilidad de vivir el nacionalsocialismo desde dentro, con las contradicciones que ello conlleva dado el carácter democrático de éste en la república de Weimar. El análisis del discurso que se produce en este grupo de ,viejas luchadoras por los derechos de la mujer“ durante la dictadura es el objetivo de este capítulo.

960 HLA, BDF 22-97,/2, Montag 15.5.1933. Acta de la reunión del Consejo general Del BDF dónde se deciden las medidas en que la organización tiene que disolverse. 
Entre 1933 y 1945 colaboran en la revista unas 300 mujeres. Todas ellas provienen del movimiento de la mujer conservador. De este grupo hemos podido reconstruir la vida de unas 50 , las cuales pertenecen al círculo de dirigentes de las organizaciones integradas en el BDF. Del resto nos ha sido imposible reconstruir totalmente sus biografías y únicamente podemos deducir su origen por los temas sobre los que escriben.

Se trata de mujeres con formación académica, muchas de ellas firman con el título de doctoras, otras provienen de los círculos del trabajo social femenino o de las escuelas de formación para mujeres. Sobre la afiliación política encontramos un equilibrio entre miembros del DDP, Deutsche Demokratische Partei, a partir de 1928 conocido como Staatspartei, y el segundo grupo pertenecientes al partido de derechas, DNVP, Deutschnationale Volkspartei.

Esta conciencia de grupo no debe llevar a pensar que existe una unidad de pensamiento. Especialmente en los primeros años de dictadura se observan discrepancias sobre el papel de DIE FRAU respecto a la dictadura. Gracias a la conservación de la correspondencia entre las antiguas líderes del movimiento de la mujer y colaboradoras de DIE FRAU hemos podido reconstruir las discrepancias entre éstas sobre la actitud de la publicación respecto al nacionalsocialismo. Nos referimos a la controversia entre Dorothee von Velsen Gertrud Bäumer, (editora de la revista) y al desacuerdo entre la segunda y Elisabeth Lüders y Agnes von Zahn-Harnack, (última presidenta del BDF). En esta controversia se pone de manifiesto el conflicto entre un feminismo democrático que se muestra impotente frente a las expectativas que el nuevo régimen levantaba entre un sector del movimiento de la mujer cuyo nacionalismo y crítica de la sociedad democrática las hacía perfectas candidatas a apoyar los objetivos del nuevo régimen por encima de todo escrúpulo. ${ }^{961}$

\subsection{DIE FRAU y el nacionalsocialismo}

Antes de seguir adelante creemos que es conveniente hacer una pequeña relación a la evolución histórica de la publicación objeto de nuestro análisis. DIE FRAU se funda en 1893. Durante veinte años evita unirse a una determinada organización de mujeres. Será durante la República de Weimar cuando se convierta en el órgano de prensa del Bund Deutscher Frauenverein (BDF). Hasta 1916 fue dirigida por su fundadora Helene Lange, ${ }^{962}$ una de las iniciadoras del movimiento de la mujer en Alemania, una mujer según las palabras de su discípula y compañera de trabajo Gertrud Bäumer como una mujer que „ve, que intuye el desorden de la vida más agudamente que los demás, una mujer que consigue hacer del desorden orden“. La fundación de DIE FRAU debía hacer realidad la posibilidad de la difusión de los principios del movimiento de la mujer:

961 Son conocidos los esfuerzos de Agnes von Zahn-Harnack, Amalie von Harnack, Elisabeth Lüders, Marie von Mutius (directora de la Frauenhilfe de Berlín) Paula Herwig, Clara Mommsen y Louise ScheffenDöring, por llamar la atención respecto al creciente antisemitismo. Dirigida por Zahn v. Harnack, mandan un escrito a la DEKA en febrero de 1933 (órgano ejecutivo central del protestantismo alemán) dónde muestran su preocupación por las acciones contra el ambiente de la campaña electoral antijudío y sobre la responsabilidad de la iglesia para tomar cartas en el asunto .En: Smid, M.: Deutscher Protestantismus und Judentum, 1922-1933, München, 1990, p. 328

962 Helene Lange, 1848-1930. Maestra de profesión es una de las iniciadoras del movimiento de la mujer alemán. En un principio lucha por una nueva regulación de la organización escolar femenina, donde las maestras tienen mayor influencia, y en segundo lugar reivindica una mejor formación académica para éstas. En 1894 funda el BDF como Federación central de todas las asociaciones de mujeres. Frandsen, D.: Helene Lange. Ein Leben für das volle Bürgerrecht der Frau, Lugar, Editorial, 1980 
„Yo había fundado la revista DIE FRAU. Ella debía realizar algunos pensamientos que a menudo me tenía ocupada: nos faltaba un órgano que pudiera estar al servicio de nuestros ideales como una hoja informativa común que comprendiera al movimiento de la mujer en su significado cultural, en su trascendencia y su profundidad“. .963

Según Gertrud Bäumer, Helena Lange fundó DIE FRAU como un instrumento „para la construcción de los fundamentos ideológicos del movimiento de la mujer“. La importancia de este órgano de expresión del movimiento de la mujer es intensificada por Bäumer cuando afirma:

„Una cosa debe ser quizá dicha: ningún movimiento de la mujer de los países europeos, resumiendo en cualquier país tuvo una publicación que llevara a cabo la discusión ideológica de la manera como (lo hizó DIE FRAU), y que permaneciera durante años en el centro de atención." 964

En 1916, tras el empeoramiento de la salud de Lange, Gertrud Bäumer comienza a trabajar en la revista como codirectora y ambas dirigirán conjuntamente la publicación hasta 1930, fecha de la muerte de Helene Lange. Durante este período Bäumer, la enfermedad de Lange se intensifica con los años, se revela como el verdadero motor de la publicación. Sus contactos como representante del DDP, hacen posible que DIE FRAU brille no sólo como órgano del ala conservadora del movimiento de la mujer, sino como lugar de expresión de la intelectualidad liberal-bürguesa de ésta época. En 1933 entra a formar parte de la redacción Frances Magnusvon Hausen, la cual permanece en ésta, hasta la clausura de la revista en 1944.

A diferencia de otras revistas y periódicos ligados a las organizaciones de mujeres que fueron prohibidos al llegar el nacionalsocialismo, DIE FRAU sigue editándose. Sobre las causas de la no prohibición de la publicación no hemos encontrado ninguna explicación. Especulaciones hablan del interés de Goebels en la revista, debido a su buena fama en el extranjero.

Durante el período 1933-1944 la redacción permanece intacta. Unicamente durante los años 1934-1937, ante la pérdida de Bäumer de su permiso de la Reichspressekammer que permitía su trabajo como redactora, se encarga Ilse Reicke, antigua miembro del BDF, y con experiencia en el mundo del periodismo de dirigir la revista de manera oficial, aunque Bäumer sigue agitando como redactora jefe.

En 1945 existen intentos de que DIE FraU salga de nuevo a la luz pública, sin embargo la petición de apertura es denegada por el gobierno americano debido a la excesiva importancia de ésta durante el nacionalsocialismo. Tanto Ilse Reicke como Frances Magnus-von Hausen, resultaron absueltas de las acusaciones de colaboracionismo por parte de las autoridades americanas en los juicios de Nürnberg. ${ }^{965}$

La revista aparece mensualmente a un precio de $50 \mathrm{RD}$ y abarca 65 páginas. ${ }^{966} \mathrm{La}$ línea temática de DIE FRAU, varía a lo largo de los años; se pueden establecer a nuestro entender tres etapas hasta 1933:

\footnotetext{
963 BAK, NL 76, $\mathrm{n}^{\circ}$ 3, Manuscrito sobre Helene Lange, p.161

964 Bäumer, G.: Gestalt und Wandel. Frauenbildnisse, Berlin, Herbig, 1950, p.401

965 Reicke, I.: Die großen Frauen der Weimarer Republik. Erlebnisse im „Berliner Frübling, Frankfurt, Suhrkamp, 1989 , p. 28

966 Seggers, S.: DIE FRAU. Studien zu ibrer Entwicklung, München, Dissertation, 1959, p.17
} 
- La primera etapa 1893-1903, se caracteriza por la dedicación a la defensa de los derechos de la mujer a adquirir una buena educación, a elegir libremente un puesto de trabajo, y al control de su situación legal en la familia y en el estado.

- La segunda etapa 1903-1913, se define por la lucha de el derecho de la mujer a gozar de una educación superior, así como del derecho a controlar su sexualidad.

- En la tercera etapa 1913-1933, los años de guerra condicionan el mensaje de la revista a la defensa del servicio voluntario femenino, al trabajo de la mujer en la economía de guerra y a los logros de las mujeres en el parlamento. En estos momentos, su línea ideológica está próxima a las corrientes del Partido Demócrata Alemán (Deutsche Demokratische Partei). Tras la guerra y la llegada de la república de Weimar se intensifica la tensión existente entre las partidarias de un feminismo moderado y las defensoras de posturas radicales en relación a la sexualidad femenina, la interrupción voluntaria del embarazo o la liberación de la prostitución. DIE FRAU, en manos del primer grupo dedica un gran espacio a esta polémica.

El equipo de colaboradoras más intimas de la revista, estaba integrado por un gran número de mujeres que en los últimos años de la República de Weimar ocupaban cargos como diputadas en el Parlamento, o como funcionarias en diferentes ministerios nacionales y de los diferentes estados. Todas, sin excepción trabajaban en alguna de las organizaciones de mujeres burguesas, y en la mayoría de los casos pertenecían a los consejos de dirección de éstas. Otro grupo estaba constituido por artistas y académicas (historiadores del arte, germanistas, jurístas etc.) para las que DIE FRAU significaba un foro de expresión dónde poder exponer sus investigaciones o trabajos.

1933 significa el nacimiento de una nueva etapa para DIE FRAU. Un período que nace desde la ambigüedad ideológica y desde el compromiso con los nacionalsocialistas. La redacción de DIE FRAU se traslada, a partir de 1934 desde Berlin a Gießmannsdorf, un pequeño castillo del siglo XIII, en la provincia de Silesia, donde Bäumer vive con su amiga Gertrud von Sanden-Hamer y con la hija de ésta Kathleen von Kospoth. Según Marie Luise Bach el lugar se convirtió en hogar y refugio para el círculo de amigos y conocidos de las mujeres y para aquellos que se sentían amenazados por los nacionalsocialistas. Según la correspondencia privada de Gertrud Bäumer el lugar es frecuentemente visitado por antiguas dirigentes del movimiento de la mujer. En la idílica atmósfera del campo de Silesia se discute sobre literatura, arte, religión y filosofía. Para las dos mujeres Gießmannsdorf se convierte en un reino der Freibeit, des Geistes und der Kunst, de la libertad, del espíritu y del arte. En 1946 escribe Bäumer sobre el paisaje idílico del castillo, ideal para dedicarse a la creación y a la contemplación:

„Un segundo mundo de vida perfecta me rodeaba en el pueblo de Silesia. Ya que desde el punto de vista profesional no estaba ligada a ningún lugar, me decidí a tomar esta residencia como segundo hogar al lado de Berlin. La casa ofrecía espacio para muchos invitados. En los tilos florecientes de la alameda zumbaban los panales de abejas y en el bosque rezumaba la flor de mayo. Por la noche los corzos visitaban en la niebla el parque, y los caballos corrían por la pradera, (...) “967

El esposo de una de las hijas de Gertrud von Sanden es Hermann Leins, responsable de la editorial Wunderlich, que edita DIE FRAU y la obra de Gertrud Bäumer.

Poco a poco el centro de influencia de DIE FrAu se traslada a la „segunda residencia“ de Bäumer, desde dónde ésta coordina las actividades de redacción. Ilse Reicke, redactora de DIE FRAU, describe el carácter festivo de estas reuniones que con el tiempo se diezmaron a

967 BAZ, NL 076, Gertrud Bäumer, Selbsporträt, 1946 
consecuencia de las restricciones de papel, que hacía la publicación de la revista con continuidad cada vez más difícil. Bäumer, según Reicke, es el verdadero artífice de la revista:

„Lo más asombroso, una vez más causa de respeto y de admiración de los que la escuchaban, era la rapidez y claridad con la que la redactora Gertrud Bäumer, trabajaba, era su increíble memoria que en seguida la llevaba recordar informaciones completas y enteras. Digno de admiración era también su premura en la compresión y la rapidez de combinación cuando se trataba de algo nuevo. Era también su sentido de la ponderación para las cosas más o menos importantes, pero también la riqueza en la improvisación repentina para asuntos totalmente diferentes, y por último, aunque no por ello no menos importante, su humor cuando se trataba de buscar un camino intermedio para evitar los lazos corredizos del ministerio de Goebbels.“ 968

El trabajo de DIE FraU se ve dificultado por una serie de ataques contra la persona de Gertrud Bäumer. Según algunas colaboradoras de la responsable de la revista, Gertrud Bäumer se vio sometida a fuertes presiones e incluso su vida estuvo en peligro en determinadas ocasiones. ${ }^{969}$ Una de las primeras demostraciones de fuerza del nuevo gobierno fue el despido de Bäumer de su puesto como referente en el Ministerio del Interior. Si bien esta acción hay que verla desde la política de despidos de cargos ministeriales que no pertenecían al NSDAP:

„Tengo que contarte además más detalladamente algo sobre mi retiro y despido. El despido ha tenido lugar por que durante mi anterior postura política no apoyé al gobierno presente. Cobraré una pensión que cuenta únicamente mis años de trabajo como maestra. " 970

En una carta a Emmy Beckmann, una de sus íntimas conocidas, del 25 de marzo de 1936, Gertrud Bäumer informa sobre el creciente control de la Gestapo sobre DIE FRAU:

"Querida Emmy, quería decirte en todo caso que la Gestapo se encuentra en posesión de mis circulares para la publicidad de Die FraU. (...) Me llamaron primero por teléfono y me hicieron algunas preguntas. El funcionario trató el asunto de una manera muy tranquila y objetiva.“971

Huber Werner, ${ }^{972}$ biógrafo de Bäumer cita intentos de la Gestapo de controlar la publicación. Este control se manifestaba a través de las famosas cartas azules que todas las revistas y periódicos que tenían el permiso de publicación, recibían en relación a temas sobre los que no podían publicar. Werner cita tres casos de control, lo que es relativamente poco para una revista que se publica desde 1933 hasta 1944. En uno de los casos se prohibía citar el nombre de

968 Reicke, Jlse: „Geschichtsschreiberin, Publizistin, Poetin“, Mächenbildung und Frauenschaffen, Septiembre $1953, \mathrm{n}^{\circ}$ 9, año 3

969 „En la revista DIE FRAU (Gertrud Bäumer) tuvo que hacer concesiones para evitar su prohibición durante el tiempo que le fue posible“, en: BAK, NL 762, 12. September 1953, Marie Baum: „Zu Gertrud Bäumers 80.Geburstag“"

970 BAK, NL 76, n²2, 28. April 1933, Carta de Gertrud Bäumer a Werner Schede

971 Gertrud Bäumer a Emmy Beckmann, 25.03.1936, en: Beckmann, E.: Des Lebens wie der Liebe Band. Briefe, Tübingen, Rainer Wunderlich Verlag, 1956, p.87

972 Werner, Huber: „Die Zeitschrift „Die Frau“ während des Dritten Reiches“, Mitteilungsblatt des Deutschen Akademikerinnenbundes e. V.Bonn, n 60, 1981, pp. 31-34 
Hugo Eckener un aviador alemán, o la mención de un concierto de Johannes Brahms y el cumpleaños de Ricarda Huch 973 poeta conocida por su actitud antinacionalsocialista. Sin embargo parece un poco exagerado comentar que la revista se encontraba bajo el pleno control de la Gestapo, cuando en la época en que se suceden las cartas azules todo de publicación, revista o periódico estaba sometido a una gran censura.

Es difícil establecer una relación entre las visitas de la Gestapo y el nombramiento de una nueva redactora al frente de DIE FRAU. La nueva elegida es una alumna de Gertrud Bäumer, Ilse Reicke, ${ }^{974}$ hija del antiguo alcalde de Berlín, la cual procede, como Bäumer de las filas del movimiento de la mujer, en la República de Weimar y como Bäumer miembro del reconvertido DDP, el partido estatal alemán, Deutsche Staatspartei. En los informes confidenciales elaborados por la cámara de prensa del Reich, sobre Reicke se la define como „políticamente limpia“. A pesar de que Bäumer está teóricamente relevada de su puesto, su nombre continua apareciendo durante este periodo junto al de Frances Magnus-von Hausen en la portada de DIE FRAU como redactora.

Durante 1936 y 1937 Bäumer se esfuerza por reingresar en la cámara de escritores, Reichsschrifttumskammer, dónde no obstante se ponen serias dificultades a su petición. ${ }^{975}$ Según la documentación consultada la expulsión se debe a que Bäumer no entregó los documentos necesarios para permanecer en ésta. Unos meses después se inician investigaciones sobre su pasado político como miembro del partido demócrata alemán, y sobre sus actividades como consejera ministerial en el Ministerio del Interior. ${ }^{976}$

Parece que en marzo de 1937, como encontramos en su correspondencia privada, se le permite de nuevo volver a la dirección del periódico. Sin embargo no es admitida en la Cámara sino que se le concede un estatus intermedio como „redactora no profesional“, estatus que no exigía la pertenencia a la cámara de escritores:

„Debo comentarte algo sensacional: me han permitido volver de nuevo al equipo de redacción de DIE FRAU. Expresado técnicamente: colocada en la categoría $\mathrm{B}$, que permite un permiso restringido (en otras palabras no para periódicos o diarios políticos). Por DIE FRAU debo de estar muy contenta naturalmente, porque este ir y venir entre tres personas no podía haber funcionado a largo plazo".977

No obstante por parte de la cámara de escritores existen intentos de evitar que Bäumer continúe publicando. Estas medidas conducen a un informe completo sobre Bäumer elaborado durante el mismo año, donde se expresa la actitud negativa respecto a ésta:

„Gertrud Bäumer fue antes de la toma de poder una de las demócratas más salvajes y creo que en todas partes conocida. De lo contrario los informes de la

973 Ricarda Huch, 1864-1947, escritora alemana conocida por su actitud contra el Nacionalsocialismo. En 1933 dimite de su puesto en la Academia del Arte debido a la expulsión de miembros no arios.

974 BAZ, RKK/ 2100, 01173, Informe sobre Ilse Reicke. Ilse Reicke conocida por su afiliación al movimiento de la mujer. Su padre es íntimo amigo de Bäumer. En los informes que existen sobre elaborados por las autoridades nacionalsocialistas, se la considera como fiel y leal desde el punto de vista nacionalsocialista.

975 BAZ, RKK/ 21101, 25. Januar 1937, Correspondencia entre la cámara de escritores a Bäumer

976 BAZ, RKK/ 21101, 3. März 1937, Escrito de la cámara de escritores

977 BAK, Kl. Erw, n²67, 19. März 1937, Carta de Gertrud Bäumer a Emmy Beckmann 
policía secreta y del NSDAP dan más noticias sobre ella. Yo estoy por encima de todas las circunstancias a favor de su expulsión. “978

La discusión sobre la admisión de Bäumer se prolonga hasta el otoño de 1937 donde se vuelve a escribir un informe negativo sobre ésta:

„En función de su filiación política e intelectual parece totalmente imposible que se autorice su autoridad como escritora. Ella fue representante de un mundo y de una constelación pacifista y feminista (...). Su política juvenil fue tal que se puede imaginar una gran divergencia de los presupuestos nacionalsocialistas. “979

Sin embargo parece ser que la decisión no fue aceptada en los círculos nacionalsocialistas. En el mismo informe se señalan las consecuencias negativas para la imagen del régimen en el extranjero, en el caso de que Bäumer fuera cesara en su condición de responsable de DIE FRAU. Aunque desgraciadamente no hemos encontrado material por parte de las autoridades nacionalsocialistas que testifiquen oficialmente el apoyo a Bäumer, es de suponer que los intereses de la cámara de escritores chocaban con los del ministerio de propaganda. Uno de los compañeros de partido como Werner Stephan, ponen de relieve la admiración que Goebbels sentía por Gertrud Bäumer, con motivo de una cena en casa del ministro :

„Únicamente con muy pocas personas su arte fracasaba: una mujer como Gertrud Bäumer. Gertrud Bäumer permaneció fría hasta lo más profundo de su corazón y éste (Goebbels) expresó su desilusión por no poder disponer de la fuerza de defensa intelectual de „esa vieja demócrata“ que el hubiera querido ganar para su trabajo propagandístico." 980

Así en mayo de 1938 en un escrito de la cámara de escritores se muestra la imposibilidad de ésta de prohibir a Bäumer que siga dirigiendo DIE FRAU:

„Independiente de la parte legal la presentación de Gertrud Bäumer para la librería Gilde significativa. Pero mientras esa vieja demócrata pueda dirigir un periódico en Alemania, no podemos desde la cámara prohibirle que hable.“981

Si nos atenemos a la información que encontramos en las actas, podemos deducir que la actitud positiva hacia Bäumer proviene desde la dirigente de las mujeres nacionalsocialistas, Gertrud Scholtz-Klink. Una de sus mejores colaboradoras, Erika Semmler se encuentra en el consejo de la fundación Helene Lange, en el que Bäumer también es miembro. Semmler informa periódicamente a Scholtz-Klink sobre las actividades del consejo directivo, formado como ya hemos señalado con anterioridad, por conocidas dirigentes de las organizaciones del movimiento de la mujer. En un escrito del 3 de agosto de 1938 se incluye el trabajo de Bäumer durante la república de Weimar dentro de la ideología nacionalsocialista:

978 BAZ, RKK/ 21101, 20. Juli 1937

979 BAZ, RKK/ 21101, 26. Octubre 1937, Informe de la cámara de escritores

980 Stephan, Werner: Joseph Goebbels. Dämon einer Diktatur, Stuttgart, Union Deutsche Verlagsgesellschaft, 1949, p. 274

981 BAZ, RKK/ 21101, 31. Mai 1938, Informe de la cámara de escritores 
„La señorita Semmler continuó, para fundamentar su argumentación, que la dirección de las mujeres del Reich, había llegado a lo largo de los años a la conclusión que la señora Bäumer durante sus actividades en el Movimiento de la Mujer, por el contrario había ejercido a este respecto un estupendo trabajo de campo para el trabajo femenino actual, y que durante su actividad política como representante parlamentaria había tomado la postura correcta nacional respecto a todas las cuestiones decisivas para la nación alemana. "9882

Por lo tanto se recomienda su habilitación. Según palabras de Semmler, la autora del informe, Bäumer no es considerada en adelante como contraria a los intereses nacionalsocialistas, sino que se la considera „políticamente de confianza“.

Según nuestras averiguaciones, la mayoría de las mujeres que escribieron para DIE FrAU en el período comprendido entre 1933-1945, habían trabajado estrechamente o se encontraban cercanas al círculo político de las dirigentes del BDF y de las organizaciones de mujeres burguesas que dependían de él. Sin embargo debemos de igual forma constatar el hecho de la publicación de artículos de mujeres próximas a círculos nacionalsocialistas. ${ }^{983} \mathrm{De}$ hecho la misma Gertrud Bäumer habla en sus cartas de la llegada del „Nuevo Movimiento de la Mujer“, de sus contactos con numerosos grupos jóvenes académicas dispuestas a seguir luchando por este nuevo movimiento y de la importancia de DIE FRAU para mantener el nivel intelectual. ${ }^{984}$

La línea política de las mujeres es hetereogénea. Desde antiguas miembros del DDP como Marianne Weber, Dorothee von Velsen, Elisabeth Lüders, Agnes von Zahn-Harnack, hasta mujeres pertenecientes al DNVP y al DVP como Leonore Kuhn.

Otro aspecto interesante es la casi inexistencia de artículos de las principales colaboradoras de DIE FrAU en otros medios de prensa ligados a las organizaciones de mujeres dependientes del régimen. Aunque del escrito no puede deducirse que el apoyo de Scholtz-Klink fuera la causa de que Bäumer pudiera seguir al frente de DIE FRAU, sino que es precisamente la colaboración de ésta con el Ministerio de Propaganda, la garantía del apoyo de Bäumer a la causa nacionalsocialista. Según la acta la publicación de Bäumer es utilizada por el Ministerio para el trabajo de prensa en el extranjero.

La rehabilitación política de Bäumer parece tener éxito. Unos años más tarde, en un certificado del NSDAP sobre conducta política se cierra con un escueto comentario sobre la falta de información sobre una conducta extraordinaria, „desde el punto de vista político“. ${ }^{985}$

La postura de Bäumer ha sido objeto de múltiples interpretaciones. Para algunos autores constituye el último bastión del movimiento de la mujer frente al patriarcado nacionalsocialista; ${ }^{986}$ otros autores intentan demostrar en el análisis de su obra anterior a 1933 señales de una actitud nacionalsocialista. ${ }^{987}$

Si nos atenemos a la información que presentan las actas, se observa en primer lugar un control de Bäumer por parte de la Gestapo, lo que hace suponer, en primer lugar que su publicación era

982 BAZ, RKK/21201, 0037, Escrito del Ministerio del Interior, 3.08.1938

983 Las mujeres nacionalsocialistas no se caracterizaban precisamente por su unidad. Entre ellas existía un grupo de jóvenes militantes que curiosamente consideraban a Gertrud Bäumer, como la figura clave que debiera dirigir los destinos de las mujeres dentro del nacionalsocialismo.

984 BAK, NL 76, nº 4, 2. Mai 1934, Gertrud Bäumer a Helene König

985 BAZ, RKK/ 21101, 19. Januar 1940, Correspondencia entre el NSDAP y la oficina de control de escritos pedagógicos

986 Stoehr, Irene: „Macht ergriffen? Deutsche Frauenbewegung 1933“, COURAGE, 8, 1983, pp. 24-32

987 Wittrock, Christine: Das Frauenbild in faschistischen Texten und seine Vorläufer in der bürgerlichen Frauenbewegung der zwanziger Jahre, Frankfurt am Main (Dissertation), 1981 
importante para las autoridades nacionalsocialistas y en segundo lugar los intereses en contra, por parte de la cámara de escritores, de que Bäumer continuara publicando. El hecho de que a partir de 1937 Bäumer este rehabilitada a los ojos de los nacionalsocialistas, está posiblemente relacionado con las concesiones que Bäumer tuvo que hacer para seguir adelante. Sin embargo no podemos determinar lo profundo del apoyo del Bäumer al nacionalsocialismo.

Un hecho que se puede comprobar es el deseo de Bäumer de continuar, aunque con conceptos diferentes, el trabajo de las asociaciones de mujeres. Esto hace necesario la toma de contacto con las antiguas compañeras de trabajo. DIE FrAU se convierte así en órgano fundamental de cooperación. Bäumer expresa su interés de crear un círculo de conocidos como en el caso de Die Christliche Welt, el periódico protestante de gran influencia política. Tenemos noticias de la colaboración de Gertrud Bäumer con grupos cercanos al periódico en 1935. 988

La aportación de Bäumer no sólo se reduce a su trabajo en Die Frau, sino que en este año escribe en DIE HILFE 14 artículos de contenido político, colaboración que se mantienen hasta la desaparición del periódico. Los contactos se mantienen a todos los niveles especialmente con grupos de mujeres protestantes de Hessen y Rheinland. Gertrud Bäumer viaja incansablemente de ciudad a ciudad donde lee en grupos de mujeres sus nuevas obras, hasta que recibe la prohibición de reunirse en locales dependientes de organizaciones religiosas. Este trabajo en conjunto, se extiende a la apertura del Archivo de la fundación Helene Lange a teólogas protestantes.989 Lo que en un principio parece un contacto aislado se concreta en un Arbeitskreis, círculo de trabajo integrado por protestantes y católicas. ${ }^{990}$ Estos contactos se extienden durante toda la dictadura hasta 1945.

DIE FRAU, sobrevive, a diferencia de un gran número de publicaciones, (también de carácter nacionalsocialista) los altibajos de la política nacionalsocialista, lo que revela que ésta tenía que ser muy importante para el ministerio de propaganda. Por ejemplo cuando en 1939 el órgano de la organización nacionalsocialista para mujeres DIE FRAUENKULTUR deja de publicarse, el Ministerio de Propaganda propone un 80\% más de papel para DIE FRAU, lo que demuestra el interés en que la revista continuara publicándose. Esto permitió que el número de abonos a la revista ascendiera. ${ }^{991} \mathrm{El}$ contingente llega 3000 ejemplares. Número limitado en comparación con los 10.000 en 1933. Dos años más tarde, aunque un gran número de revistas y periódicos tuvieron que parar la publicación de éstas debido a la economía de racionalización como consecuencia de la entrada en guerra, DIE FRAU consigue sin embargo un contingente de papel que permite continuar con el trabajo de la revista hasta 1943, según Bäumer sin haber hecho concesiones. ${ }^{992}$ en la que el contingente de papel se reduce y DIE FRAU deja de aparecer una vez al mes, sino cuatro veces al año. En 1944 la revista se deja de publicar definitivamente Gertrud Bäumer cierra la última página de la historia de DIE FRAU con optimismo, y con cierta nostalgia:

„Lo que DIE FraU fue y siguió siendo, también en los difíciles y últimos años de su existencia 1933-1942, conduce en la belleza de una sucesión espiritual de las

\footnotetext{
988 Beckmann, Emmy: op. cit., p. 82

989 Bach, Marie Luise: op. cit., p.110

990 Beckmann, Emmy: op. cit., p. 96

991 Gertrud Bäumer a Emmy Beckmann, 18.6.1940, en: Des Lebens wie der Liebe Band, op. cit., p. 136. También en: Gertrud Bäumer a D.v. Velsen, 3.3.1941 (Kl. Erw. Nr. 296-1, p.94

992 Gertrud Bäumer a Emmy Beckmann, 15.03.1941, en: Des Lebens wie der Liebe Band, op. cit., pp. 146147
} 
generaciones en la que según las palabras de Platón 'una a la otra entrega la antorcha del sentido divino de la vida'." 993

\subsection{Las mujeres de DIE FRAU. Entre la crítica y la colaboración. Cronología de una polémica}

A pesar de la dependencia de DIE FRAU de la figura de Gertrud Bäumer, su publicación durante el nacionalsocialismo está estrechamente unida a la participación a la intensa participación de sus colaboradoras. El grupo más importante de éstas lo constituye mujeres que en los años anteriores de la República de Weimar habían ocupado puestos importantes en el gobierno, en el partido demócrata alemán y en el movimiento de la mujer. Entre ellas destacan Marianne Weber, Marie Baum, Elisabeth Lüders, Agnes von Zahn-Harnack, Dorothee von Velsen, y Else Ulich-Beil entre otras. A diferencia de Gertrud Bäumer, que debido a su trabajo como redactora en DIE FRAU, existen sobre ella informes oficiales del NSDAP, nos ha sido difícil reconstruir la trayectoria de éstas durante el nacionalsocialismo. En algunos casos contamos con memorias o biografías escritas después de 1945, que desgraciadamente se centran en la actividad de estas mujeres durante la república de Weimar, el período 1933-1945, aparece en la mayoría de los casos como un gran vacío donde no se menciona ningún tipo de actividad que las ataña. Este silencio tiene que ver en parte porque la mayoría se retira de la vida pública, y se dedican a actividades literarias o publicistas. Por eso son los artículos que publican en DIE FRAU su único contacto con la realidad. Gracias a la correspondencia que se ha conservado, se puede constatar la continuidad de los encuentros entre éstas.994

Durante los primeros años de la dictadura los encuentros tenían lugar en la casa de Elisabeth Meyn en Berlin o en la antigua sede de la $A D L V$. 995 Más tarde con motivo del traslado de Bäumer a Obergießmannsdorf las reuniones tienen lugar en el norte de Alemania, donde Gertrud Bäumer había fijado su residencia y en Heidelberg donde residían Marianne Weber y Camilla Jellinek.

Estos contactos no fueron pasado por alto por la Gestapo si nos atenemos a las informaciones que aparecen en una carta de Gertrud Bäumer a Emmy Beckmann, anterior representante de la organización de maestras alemanas, en la que se comenta una notificación de la Gestapo. Según la mencionada carta los encuentros en Gießmannsdorf, lugar donde residía Gertrud Bäumer eran observados por las autoridades nazis con suspicacias dado el pasado político de cada una de las participantes. Se alude incluso a la posible existencia de un grupo político. Finalmente se recomienda a Gertrud Bäumer que se abstenga de organizar tales encuentros. ${ }^{996}$

En esta correspondencia entre Bäumer y el resto de sus colaboradoras aparecen en numerosas ocasiones, su posiciones respecto al nacionalsocialismo. En una de las cartas Bäumer defiende la idea nacional como determinante del espíritu alemán, refiriéndose a Karl Barth, teólogo protestante, miembro de la iglesia confesora defiende el derecho de los alemanes a la

993 BAK, NL 76, n³, Manuscrito sobre Helene Lange, p.165

994 Gertrud Bäumer a Emmy Beckmann, 19.12.1933 en Bach, Marie Luise: op. cit., p. 98

995 Beckmann, Emmy: Des Lebens wie der Liebe Band, Wunderlich Verlag, Tübingen, 1956, p. 67

996 BAK, Kl. Erw, n²67, 17. Juli 1944. Entre las mujeres que mantienen correspondencia con Gertrud Bäumer y que además publican en DIE FraU podemos mencionar a Marianne Weber (viuda de Max Weber), Else Ulich-Beil, Emmy Beckmann, Dorothee von Velsen, Marie Baum. Todas ellas visitaron a Bäumer en su residencia de Gießmanndorf. 
seelische Kultur. Por otra parte critica el sistema de obediencia que proclama el nacionalsocialismo y el racismo de éste, así como la progresiva fuerza que adquieren las masas, fenómeno que ésta define como bolchevique:

„No nos damos cuenta en realidad de que ya estamos bolchevizados, ¿no es el bolchevismo lo mismo que la actitud nihilista ante la supremacia de lo espiritual y lo intelectual? La enemistad fanática contra lo intelectual (como describe Ortega y Gasset en la Revolución de las masas) y la falta de temor respecto a las cosas religiosas es el peligro central del bolchevismo y no el sistema económico.“997

Sin embargo la convicción de Bäumer de la existencia de un „alma cultural alemana“ la hace proclive a aceptar al nuevo régimen. Y los primeros recelos contra éste no llegan lo suficiente lejos como para ocasionar una oposición total al régimen:

„En primer lugar no es cierto que nos despedimos definitivamente de los sucesos actuales. Me imagino que te refieres a la actuación del gobierno. Pero la cuestión definitiva alemana ha sido por fin planteada, si los primeros indicios nos gustan o no, nos vemos obligados como alemanes a presenciarlos. El planteamiento moral y político de la cuestión nunca se defienden. Esto no lo ha visto tan claro como Max Weber. En estos momentos nos planteamos a la pregunta, right or wrong, my country. No quiero con ello embellecer lo incorrecto pero tampoco debo envolverme en el abrigo de las virtudes y librarme del destino de mi pueblo, sino que como su culpa (la del pueblo), al mismo tiempo la mía es, tengo que afrontarla cuando se trata de la propia existencia." “998

Los temas de la correspondencia entre Gertrud Bäumer y el resto de las mujeres citadas revelan datos de interés político. En la mayoría de las veces se remiten a comentar los libros, artículos y conferencias que cada una en su „exilio interior“ produce. Pequeños comentarios a viajes realizados a Italia, Austria; correspondencia con Lou Andrea-Salomé los primeros problemas de las restricciones de alimentos, el frío, los bombardeos, el miedo durante los años de guerra.

El círculo de mujeres permanece activo. Elisabeth Boedeker relata sobre una reunión tenida lugar en su casa de Berlín, en Enero de 1935 en la que Gertrud Bäumer lee algunos capítulos de su nuevo libro Adelheid.999 Junto a las antiguas compañeras del movimiento de la mujer, se incorporan al grupo de colaboradoras mujeres provenientes del ala nacionalsocialista como Irmgard Reichenau, Leonore Kühn, Yella Erdmann. Este grupo defendía la postura de que el nuevo estado sólo podía tener éxito si contaba con la ayuda de una élite de mujeres. ${ }^{1000}$

La progresiva participación de mujeres provenientes de círculos nacionalistas, es quizá una de las causas por las que aparecen algunas discrepancias entre el viejo grupo de luchadoras del movimiento de la mujer. A pesar de los contactos sucesivos del grupo podemos observar en la correspondencia con algunas de sus compañeras algunas diferencias de opinión respecto al papel de DIE FRAU en el contexto político del nacionalsocialismo.

Este intercambio de pareceres tiene lugar entre Dorothee von Velsen, antigua dirigente de la Unión general de mujeres alemanas (Allgemeiner Deutscher Franenverein) y Gertrud Bäumer.

Carta de Gertrud Bäumer, sin remitente 19.12.1933, en: Bach, Marie Luise: op. cit., p.98

Bach, Marie Luise: op. cit., p.159

Bach, Marie Luise: op. cit., p.104

Reichenau, I. (Ed.): Deutsche Frauen an Adolf Hitler, Leipzig, Adolf Klein Verlag, 1934, $2^{\mathrm{a}}$ Ed. 
Dorothee von Velsen muestra desde un principio su descontento por la decisión de Gertrud Bäumer de abolir la organización „paraguas“ de las mujeres burguesas, la Federación de las asociaciones de mujeres alemanas (Bund Deutscher Franenvereine), y la renuncia a defender los principios democráticos de la organización:

„Yo había esperado que encontraría en usted una justificación que defendiera y justificara aquellas ideas por las que nosotros habíamos luchado: la idea democrática, el parlamentarismo, las formas de las responsabilidad política individual."“1001

La polémica continua a raíz de la crítica internacional de la prohibición de viajar a la celebración del congreso de la asociación internacional de mujeres, International Women Comittee en París en 1934, a Alice Salomón, secretaria por entonces de la organización, dada su ascendencia judía. Ante las quejas de von Velsen sobre lo injusto de la acción contesta Bäumer:

„A pesar del rechazo del antisemitismo, salta a la luz que hemos sido en la representación alemana demasiado tolerantes a causa de las judías, teniendo en cuenta que los puestos en las organizaciones internacionales se convierten con el tiempo en puestos hereditarios. Yo siempre he tenido a lo largo de los años el sentimiento de que la presidente del I.C.W. (International Women Committee) siempre ha demostrado una cierta deslealtad respecto al Federación de asociaciones de mujeres alemanas. "“002

La crítica que von Velsen hace al nacionalsocialismo radica en la limitación que éste hace del individuo, mayor que la opresión del patriarcado. De una manera asombrosamente inteligente, cuestiona las opiniones de Bäumer dónde se observa al bolchevismo como el enemigo del espíritu religioso alemán, y señala sus objeciones a un movimiento conocido por su brutalidad, su antisemitismo y su oportunismo. 1003

La alternativa que propone von Velsen es una oposición silenciosa, Stiller Opposition, y la creación de un círculo de geistiger Besinnung, donde a través del cultivo en la intimidad de los valores de la cultura alemana se pudiera ,sobrevivir“":

„He mantenido a veces conversaciones con amigos conocidos que han vivido en la vida política las mismas experiencias. Ellos demuestran su más profunda decepción pero comentan que en estos momentos tenemos que callar. ¡Oh si usted supiera con que griterío de placer el engendro nazi se abalanza sobre sus sentencias, como de su propio arsenal toman las armas para la maldición y condena del todavía para mí sagrado nombre de la democracia! ¿Y que se puede decir después en su defensa?"1004

En esta última frase se encuentra definida la actitud de una generación ante la dictadura. Esta actitud de resignación aparece descrita con brillantez por Victor Klemperer, romanista, profesor de literatura, de origen judío que consigue sobrevivir la dictadura, gracias a su esposa. Klemperer se dedica durante los años de aislamiento y soledad a hacer un análisis de lenguaje

BAK, Kl. Erw, n²96, 2. März 1934, Carta de Dorothee von Velsen a Gertrud Bäumer

BAK, Kl. Erw., n 296, 15. 11. 1934, Carta de Gertrud Bäumer a Dorothee von Velsen

BAK, Kl. Erw., n²96, 21.11.1936, Carta de Dorothee von Velsen a Gertrud Bäumer

BAK, Kl., n 296, 2.3.1934, Carta de Dorothee von Velsen a Gertrud Bäumer 
del tercer Reich. En sus diarios retrata también a una parte de la sociedad alemana y su actitud respecto al nacionalsocialismo, como Die Müdigkeit einer Generation. Sie will vom Zwang zum Eigenleben frei sein, el cansancio de una generación. ${ }^{1005}$ Ella quiere ser liberada de la obligación de su propia responsabilidad. Cuando von Velsen se queja ante Bäumer sobre la imposibilidad de salvar a la democracia, refleja la actitud de una generación que no es capaz de reconocer su responsabilidad, su autonomía como individuos en el acontecer histórico, sus voces están cansadas y sólo pueden esperar a que llegue alguién que les libera de su propia autonomía.

La polémica se radicaliza cuando von Velsen critica un artículo publicado en Die Frau sobre los Schwarze Corps, dónde según von Velsen se traicionan por completo el espíritu del movimiento de la mujer. ${ }^{1006}$ Bäumer argumenta sobre las dificultades que tiene la revista para poder difundir su postura crítica:

„Yo creo que usted no se imagina, como muchos otros, de las dificultades que conlleva, en nuestra situación publicar una revista, y tiene quizá por lo tanto ninguna medida para imaginarse todo lo que una se arriesga como principal redactora jefe sobre el camino que yo voy. Usted no podría nombrarme ningún otro periódico o revista alemana que en su campo vaya tan lejos en franqueza y en crítica (directa e indirecta) como DIE FRAU“. ${ }^{1007}$

De la contestación de Bäumer a von Velsen se deduce que existe un grupo de colaboradoras de DIE FRAU, entre los que se encuentran Elisabeth Lüders que critican la falta de crítica en la revista. Dorothee von Velsen junto a Lüders es una de las única de las mujeres de la segunda generación que hace referencia a las concesiones de Bäumer durante el nacionalsocialismo, y argumenta que la postura de ésta de crear un movimiento de la mujer dentro del partido, se plantea como ilusoria e incoherente. ${ }^{1008}$ Esta opinión se confirma en la correspondencia privada entre Velsen y Bäumer donde la segunda señala la posibilidad de una cooperación con el gobierno, en el caso de que éste se lo pidiera. ${ }^{1009}$

Por otra parte Bäumer se rebela contra la crítica de von Velsen y considera injustas las atribuciones de cooperación con el régimen:

„Solamente unas palabras sobre la gente, según usted me ha descrito, que en su casa critican a DIE FRAU de esa manera. ¿Quién son realmente? La pregunta no significa naturalmente que yo quiera conocer los nombres de esas personas pero el pequeño ejemplo reconozco el carácter injusto y lo desconfiado de esta crítica. ¿Por qué entonces continúan leyendo DIE FRAU? Esta claro que desde la redacción estamos abiertos a todo tipo de objeción objetiva, especialmente sobre sugerencias positivas del círculo de lectores. Queremos añadir que nos esforzamos en mantener, de una manera diferente el contacto con las organizaciones de la Federación, como por ejemplo la presente circular que en estos momentos mandamos a mujeres en todas partes de Alemania. Lo característico es que de las partes de las que proviene la crítica nunca se reciben deseos o sugerencias op. cit. p. 37

1009 BAK, Kl. Erw, n 296, 15. 11. 1934, Carta de Gertrud Bäumer a Dorothee von Velsen

Klemperer, V.: Ich will Zeugnis ablegen bis zum letzten, Berlin, Aufbau Verlag, 1995, p.218

BAK, Kl. Erw, n²96, 31. März 1940, Carta de Dorothee von Velsen a Gertrud Bäumer

BAK, Kl. Erw., n²96, 4.4.1940, Carta de Gertrud Bäumer a Dorothee von Velsen

von Velsen, Dorothee: „Gertrud Bäumer in der Frauenbewegung“", Mädchenbildung und Frauenschaffen, 
positivas. Por lo tanto es esta crítica, a mi entender, una crítica meramente parasitaria." 1010

A pesa de la división sobre la pervivencia de la revista y del deseo de una actitud más crítica respecto a la situación política, el grupo discrepante sigue publicando en DIE FRAU y las relaciones personales continúan durante toda la dictadura. ${ }^{1011}$ Con el tiempo la situación de resignación se apodera del círculo, las desgracias personales: muerte de compañeras, de hijos y de familiares se ponen por delante de la política, incluso por encima del tema judío:

„Todos sabemos de la expulsión de 7000 judíos de Baden y el Palatinado hace cuatro semanas. También nos podemos imaginar como actúan las SS contra la población civil de Polonia. No podemos cambiar nada en estas cosas, en el caso de los judíos muy poco, en el de los polacos menos. “1012

Sin embargo, Bäumer tiene razón cuando habla de las dificultades que tiene para proseguir con su trabajo. Con motivo del cumpleaños de Gertrud Bäumer, el 12 de septiembre de 1943, donde un grupo de conocidos entre los que se encuentran: Emmy Beckmann, Walter Goetz, Dorothee von Velsen, Anna Encke, Else Ulich-Beil, Agnes von Zahn-Harnack, elaboran una carpeta donde se recogen pensamientos y recordatorios sobre Gertrud Bäumer. En la elaboración de la carpeta participan 168 personas, procedentes de los círculos del DDP y del movimiento de la mujer. No obstante el inofensivo regalo es requisado por la Gestapo para evitar que se forme una congregación política, con motivo de la entrega de éste. ${ }^{1013}$

La prohibición no es uno más de los muchos intentos por parte de las autoridades nacionalsocialistas, de limitar las actividades de Bäumer. En octubre de 1940 ésta, recibe oficialmente la prohibición de pronunciar discursos en locales de las organizaciones religiosas:

„Mis conferencias en la primavera y verano de este año en diferentes organizaciones confesionales de los estados de Renania y Hessen, que fueron visitadas por un gran número de oyentes y cuentan con una gran aceptación, han levantado, como ya me había imaginado, la atención de la Gestapo.” 1014

La prohibición no se debe al contenido de las conferencias, sino a la política de restricciones que sufre la iglesia protestante a partir de la entrada de Alemania en guerra. No obstante, Bäumer escribe al DEF en Bielefeld para organizar un encuentro de carácter privado. En una de estas reuniones, organizadas por el príncipe de Sajonia, conoce a los principales representantes del movimiento literario del exilio interior.

No sabemos si se debe a los contactos con la iglesia protestante, o la dificultades para seguir adelante con su trabajo como conferenciante o y quizá la muerte de su compañera, Gertrud von Sanden 1015 el interés de Bäumer por las obras de Reinhold Schneider, Jochen Klepper y Werner

1010 BAK, Kl. Erw. n² 296, 9.4. 1934, Carta de Gertrud Bäumer a Dorothee von Velsen

1011 BAK, Kl. Erw. n 296, 11.4.1934, Carta de Dorothee von Velsen a Gertrud Bäumer

1012 BAK, Kl. Erw, n²96, 30. November 1940, Carta de Dorothee von Velsen a Gertrud Bäumer

1013 Bach, M.L.: op. cit., p. 232

1014 Bach, M.L.: op. cit. p. 183

1015 Gertrud Bäumer no se libra del destino que sufren sus colegas de trabajo. El castillo esta vacío. La compañera de Bäumer, Gertrud von Sanden-Hamer, después de una larga lucha contra un cáncer de pecho 
Bergengruen, todos miembros de la llamada generación del exilio literario interior, crece en esta época. 1016

La polémica entre von Velsen y Bäumer ejemplifica en gran medida la postura de esta emigración interior respecto al nacionalsocialismo. ¿Se podía luchar contra el régimen dentro de éste?, o ¿era más conveniente exiliarse en la literatura y mostrar entre líneas el desacuerdo con el régimen?

Bäumer parece intentar integrar las dos posturas. Von Velsen expresa su cansancio y decepción, y sobre todo impotencia. En los círculos liberales burgueses se admitía el silencio como la mejor opción a la dictadura, y se esperaban „mejores tiempos“ en los que poder practicar de nuevo la política.

El problema judío acompaña a von Velsen durante todo los años de la dictadura, esta preocupación se documenta en numerosas cartas a Marianne Weber. En su correspondencia privada se encuentra también una copia de una carta escrita por el obispo de la iglesia protestante de Württemberg al ministro del interior Frick, en la que se expresa su desagrado por la política de selección de raza del régimen, en la que disminuidos físicos y psíquicos son eliminados, esterilizados o utilizados como conejillos de indias. ${ }^{1017}$

Enferma, adicta a la cocaína, con depresiones, celebra con alegría los primeros intentos de resistencia contra Hitler. No existen pruebas que confirmen su participación o conocimiento de los planes del atentado contra Hitler, únicamente existe una carta a Marianne Weber donde demuestra su alegría respecto al posible atentado:

„Me encuentro mucho, lo tengo que decir, mucho más feliz que en el 33. La horrible presión ha desaparecido, las otras fuerzas se encuentran en movimiento y no sólo dependientes de un solo poder. Los otros se han quedado ya pequeños y habrá más. El poder no es lo mismo que la dictadura- con lo que no quiero decir que quiere para nosotros una democracia ,a la Weimar“ “.1018

A pesar del control ejercitado por el Ministerio de Propaganda y la Gestapo, DIE FrAU, no estuvo nunca en peligro de ser prohibida, ni tampoco existe documentación en la que se puede probar un control más amplio, como en el caso del periódico „paralelo“ a DIE FRAU, DIE Hilfe, en manos de Theodor Heuss (antiguo dirigente del Partido Demócrata Alemán), que se vio sometido a continuas investigaciones por parte de las autoridades nazis hasta 1939, fecha en que fue prohibida su publicación. ${ }^{1019}$ En el caso de DIE HILFE, las advertencias son más

muere en Tübingen a finales de febrero de 1940. Gertrud Bäumer lucha contra el vacío que experimenta después de la muerte de alguien con el que ha convivido más de 20 años. Unos meses más tarde trabaja, sin embargo, en la organización de un círculo de lectoras que ponga en contacto a antiguas miembros de las organizaciones de mujeres

1016 Chu, Tea-Wha: Nationalsozialismus und Verantwortung der christlichen Literatur. Zur Poetologie des Zwischenden-Zeilen-Schreibens der christlichen Dichter in der Inneren Emigration 1933-1945, Peter Lang, Frankfurt, 1994.

1017 HLA, Dorothee von Velsen, 3-27/1, 19. Juli 1933, Wurm a Frick Las relaciones de Gertrud Bäumer con el problema judío es difícil. Su fiel secretaria, Isa Joschkowitz, de origen judío, trabaja con ella durante toda la dictadura. A finales de 1944 , con motivo de la deportación de su abuela en el campo de concentración Theresienstadt, en la antigua Checoslovaquia, comete un intento de suicidio. En la correspondencia donde relata el suceso, habla sobre su secretaria con el apelativo peyorativo de Mischling, con el que se conocían a los descendientes de matrimonios entre judíos y alemanes. En Bach, M. L.: op. cit., p.272

1018 HLA, Dorothee von Velsen, 2-20/3-21, 1. März 1940, von Velsen a Marianne Weber

1019 Creemos necesario hacer una mención de la ausencia de este material en las actas del Ministerio de Propaganda, en la que se encontraron sin embargo las citaciones de otro periódico, Die HiLfE, para el 
numerosas dado el carácter político de alguno de los artículos publicados no obstante se sigue publicando hasta 1939. La provocación política que se atribuía a DIE HILFE no tenía lugar sin embargo, según los archivos, en DIE FRAU. Es más, Gertrud Bäumer aparece como mediadora en las „conversaciones“ que tienen lugar en el Ministerio de Propaganda en las que se regulan las funciones de DIE HILFE. 1020 Incluso las advertencias que recibe DIE HILFE son leves en comparación con los procesos judiciales de personas particulares cuyas actividades no revestían la importancia pública que podía tener la edición de una revista y un periódico.

La polémica Bäumer-Velsen ejemplifica dos posturas comunes durante la dictadura, por una parte la de intento de colaborar con el régimen, defendiendo los derechos del grupo al que se pertenece o intentando corregir alguno de sus „excesos", y por otra parte la postura de emigración interior, que se traduce en la crítica a través de obras literarias, casi crípticas, que alcanzan un grupo limitado de lectores.

\subsection{El círculo de Marianne Weber (Der Köngener Kreis)}

Otro ejemplo de emigración interior dentro del círculo de las colaboradoras de DIE FRAU, está representado por Marianne Weber. La viuda de Max Weber, había logrado reunir en torno suyo a un grupo de intelectuales que se reunían en su casa de Heidelberg para discutir asuntos religiosos. En 1933 el grupo continua sus actividades, Gertrud Bäumer, Dorothee von Velsen participan también en éste, donde la tensión entre los principios liberales y nacionalsocialistas alcanza cotas elevadas. ${ }^{1021}$ Durante los primeros años el círculo está abierto todo tipo de tendencias, así por ejemplo participa en una de las tertulias el filósofo y teólogo de origen judío Martin Buber ${ }^{1022}$ sobre la identidad judía, y posteriormente Krannhals, Krieck y Hielscher (filósofos del nacionalsocialismo) dan a conocer sus primeras conclusiones sobre el organisches Weltbild, la visión orgánica del mundo como la expresión del espíritu alemán. Según estos la ciencia exacta se opone a lo instintivo, al pensamiento orgánico e intuitivo. En palabras de Goethe: Geist und Leib, Geist und Natur, Natur und Gott. La naturaleza, Dios y la cultura forman un organismo, una unidad. Dios sin cristianismo. En este clima participa Gertrud Bäumer con una ponencia sobre Fübreridee und Fübrerwirklichkeit, donde se pone de manifiesto la progresiva decadencia de los principios democráticos y el crecimiento de la fe en el Reich. En la ponencia discute la idea de una relación entre el reino de Dios y el imperio alemán (Reich). Lo nórdico germano es definido como consecuencia de la evolución de diferentes culturas en la antigüedad. Lo religioso es un aspecto que está por encima de lo político y del pueblo. El estado, el arte la

que Gertrud Bäumer continuaba trabajando, y del que era representante Theodor Heuss (líder del partido demócrata alemán), colaborador y amigo personal de la primera. En la correspondencia privada entre la editorial de DIE HILFE, Gertrud Bäumer y Theodor Heuss se registran también „las recomendaciones“ que el editor hace sobre temas de política internacional, religión y sociedad. El no cumplimiento de estas observaciones ponía a los responsables del períodico en peligro.

1020 BAK, NL 221, n²21, Notiz über die Besprechung im Propaganda-Ministerium am 13. September 1934

1021 Weber, Marianne: Lebenserinnerungen, Bremen, Johs. Storm Verlag, 1948,p. 286

1022 Martin Buber (1878-1965) filósofo y teólogo judío, profesor en la Universidad de Frankfurt a. M. Conocido por su traducción de la Biblia del hebreo al alemán, y por s sus estudios sobre la tradición casidística. Como centro de su pensamiento político y religioso destaca su formulación del principio del diálogo, expuesto en la teoría de la relación del yo al tu como principio de relación entre los individuos y también en la relación con Dios. En 1938 abandona Alemania y se traslada en Palestina donde trabaja como profesor de filosofía social en la Universidad de Jerusalén. 
ciencia, la religión no pueden estar determinadas por la dirección política, pero si por el Reich como expresión del sentimiento específico de la alemanidad.

La entidad total del reino no se fundamenta en un partido sino en todo el pueblo. ${ }^{1023}$ Sin embargo la atmósfera libre e intelectual del grupo, donde confesión, raza y nacionalidad no jugaban ningún papel empieza a cambiar tras la llegada del nacionalsocialismo. Marianne Weber es testigo en sus memorias de cómo algunos miembros del grupo comienzan a apoyar las ideas religiosas de los cristianos alemanes lo que provoca una división del grupo y su disolución durante unos años. Una vez desaparecidos los miembros más reaccionarios la tertulia comienza a reunirse de nuevo en enero de 1936. Debido a su carácter religioso los encuentros son permitidos por las autoridades nacionalsocialistas. No se tratan temas actuales sino preguntas relacionadas con la existencia personal, religiosa y ética. Christoph Schrempf, Edmund Mugler, Leo Weismantel, Carola Barth, Gertrud Spoerri, Anna Schieber, Wilhelm Stählin, Carl Gustav Jung, son algunos de los ponentes más conocidos que participan en las ponencias del grupo. En 1938 Gertrud Bäumer pronuncia una conferencia sobre el encuentro del alma alemana y el cristianismo, donde se discuten las tesis nacionalsocialistas sobre la religión cristiana como error del camino nórdico germánico. El grupo continúa reuniéndose, a pesar de las dificultades casi todos los años. La guerra, el aislamiento hacen los contactos más necesarios. ${ }^{1024}$. Los temas permanecen religiosos. Esta claro que se distancian del nacionalsocialismo, pero no elaboran ningún tipo de estrategia de resistencia.

El surgimiento de estos círculos privados parece haber sido una táctica normal de supervivencia y protección respecto al nacionalsocialismo. Marie Baum en su biografía sobre Anna Gierke, también miembro del movimiento de la mujer señala como el hogar de ésta en Berlín se convierte en un lugar de recogimiento y de encuentro para aquellos que rechazaban el nacionalsocialismo:

„Anna von Gierke fue influída por el movimiento de la iglesia confesora. Ella y su círculo visitaban, aún después del encarcelamiento de Niemöller, la iglesia de Dahlem y las horas de Biblia. El mismo grupo se encontraba cada segundo miércoles en su casa para la lectura de la Biblia. (...) Al comienzo de cada encuentro se discutía sobre la situación de la iglesia confesora. Y la intensidad con la que los miembros del círculo participaban en la lucha de ésta encontraba consuelo y fortaleza en la comunidad para la propia lucha persona, en la que todo el mundo, cada uno a su manera, se encontraba implicado." 1025

El mismo círculo organiza conferencias y tertulias por las tardes, donde según Baum llegan a participar 80 personas y llegan a participar personajes como Martin Niemöller, Romano Guardini, Helmut Gollwitzer y Hermann Mass, todos ellos miembros de la iglesia confesora. Hermann Mass dirigía una agencia para evacuación de cristianos no arios. Entre las mujeres que participaban en las tertulias se encontraban Agnes von Zahn-Harnack, Gertrud Bäumer y Elly Heuss-Knapp. ${ }^{1026}$

El círculo se encuentra periódicamente hasta finales del año 1942, fecha en la que las horas de Biblia y las tertulias fueron prohibidas por la Gestapo. La llegada del nacionalsocialismo significa una clara interrupción en la vida de las mujeres que colaboraban en DIE FRAU. Una vez disueltas las organizaciones, deben dirigir sus vidas en otro sentido. La mayoría eligen una vida

Weber, op. cit., p. 293

Weber, Marianne: op. cit., p. 327

Baum, M.: Anna von Gierke. Ein Lebensbild, Berlin, Julius Beltz, 1954, p.103.

Ibídem, p. 104 
retirada donde la literatura juega un papel importante. Pequeños artículos que después se publicaran en DIE FrAU, memorias, novela histórica o poesía. Para mujeres como Marianne Weber no resultó un trauma ya que como ella misma dice, la vuelta a la vida privada es bienvenida después de tantos años dedicados al trabajo en la vida pública. ${ }^{1027}$ La misma Gertrud Bäumer señala lo positivo de esta situación:

„Fue una transición en otra forma vital, que para mí era bella y fácil, en relación a lo personal no me fue difícil acostumbrarme a ésta; pero el destino alemán con su carga emocional se aguantaba y se vivía más fácilmente cuando cada día se era consciente de la comunidad todavía existente de las convicciones y objetivos ${ }^{\mathbf{1 0 2}}$

Círculo de las principales colaboradoras de DIE FRAU

\begin{tabular}{|c|c|}
\hline Baum, Marie: & $\begin{array}{l}1874 \text { estudio de química en Leipzig. Trabajo social como } \\
\text { inspectora de trabajo. Miembro del DDP. }\end{array}$ \\
\hline Beckmann, Emmy: & Presidente de la asociación de maestras alemanas. \\
\hline Beichler, Seegeritz & $\begin{array}{l}\text { Maestra en Leipzig, debido a una recesión del libro de } \\
\text { Meyn von Westelholz sobre el movimiento de la mujer } \\
\text { cae en desgracia ante el gobierno. }\end{array}$ \\
\hline Blochmann, Elisabeth: & Despedida de su cargo porque su madre es judía. \\
\hline Boedeker, Elisabeth: & Bibliotecaria en la Technische Hochschule en Hannover. \\
\hline Boerchers, Hilde: & $\begin{array}{l}\text { Alumna de Gertrud Bäumer en la Soziale Schule de } \\
\text { Hamburg. }\end{array}$ \\
\hline Encke, Anna: & Participa en la Sammlung para G.B. el 12 de sept. 1943. \\
\hline Gröning, Gisela: & $\begin{array}{l}\text { Estudiante de medizina, } 1933 \text { vive en Berlin en casa de } \\
\text { Else Bäumer, hermana de Gertrud. }\end{array}$ \\
\hline ansen-Blancke, Dora & $\begin{array}{l}\text { Alumna de Gertrud Bäumer en Hamburg. Escribe } \\
\text { también en DIE FRAU (tres artículos). }\end{array}$ \\
\hline Heuss-Knapp, Elly: & Esposa de Theodor Heuss. \\
\hline Hübner, Tilla: & Contacto con las organizaciones de mujeres protestantes. \\
\hline Kühn. Leonore: & Miembro del DNVP. \\
\hline Leins, Hermann: & $\begin{array}{l}\text { Editor de DIE FRAU. Editorial Rainer Wunderlich. } \\
\text { Miembro del Regierungsrat y del Reichswirtschaftsminis- } \\
\text { terium. }\end{array}$ \\
\hline Peters, Grete: & $\begin{array}{l}\text { Alumna de Gertrud Bäumer en la Soziale Schule de } \\
\text { Hamburg. }\end{array}$ \\
\hline uge, $\operatorname{Mar}_{\mathrm{z}}$ & $\begin{array}{l}\text { Profesora en la Soziale Schule de Hamburg, colabora en } \\
\text { DIE FRAU (dos artículos). }\end{array}$ \\
\hline
\end{tabular}
mann, E.: op. cit., p.65 


\begin{tabular}{|ll|}
\hline Ulich-Beil, Else: & $\begin{array}{l}\text { Miembro del DDP. Miembro del consejo directivo del } \\
\text { Allgemeiner deutscher Frauenverein. }\end{array}$ \\
von Velsen, Dorothee: & Historiadora. Miembro del consejo directivo del BDF. \\
Weber, Marianne: & Esposa de Max Weber. Miembro del consejo ejecutivo del \\
& BDF. \\
Weiberlen, Gertrud: & Alumna en la Soziale Schule en Hamburg. \\
v.Zahn-Harnack, Agnes: Germanista, última dirigente del BDF.
\end{tabular}

\subsection{Discurso y construcción de género en DIE FRAU}

Uno de los fines de este capítulo es analizar los nuevos modelos de feminidad que se proponen en DIE FrAU, así como su parentesco con los propuestos por el nacionalsocialismo. Nuestro análisis parte de una serie de artículos cuyo tema principal es el de descifrar y aclarar el papel de la mujer en relación a la sociedad, el Estado y la familia. De estas reflexiones se deduce una determinada naturaleza de lo femenino y una búsqueda de un nuevo imperativo ético y moral que defina los atributos de la feminidad.

No sólo nos interrogamos sobre las coincidencias o divergencias de los discursos sobre lo femenino sino que nos preguntamos también sobre la naturaleza de éste.

\subsubsection{Identidad femenina. ¿Cultura o biología?}

\subsubsection{La mujer como madre}

La mujer, lo femenino se hallaban según las ideas nacionalsocialistas muy próximos al terreno de lo biológico; la esencia de la feminidad encontraba su manifestación en la ocupación biológica de la maternidad. ${ }^{1029}$ En realidad en la imagen nacionalsocialista de la mujer el principal y único aspecto que caracterizaba a ésta era ser madre. El naturaleza femenina no fue nunca vista como mujer sino como madre. ${ }^{1030}$ Sin embargo en DIE FRAU se observa un ligero alejamiento de esta tesis principal, si bien no contradice, ni quiere las propuestas nacionalsocialistas:

1029 Klinsiek, D.: Die Fran im NS-Staat, Stuttgart, Deutsche Verlags-Anstalt, 1982, p.23

1030 En 1936 Hitler se dirige a las mujeres alemanas y comenta sobre el lugar de trabajo de la mujer: „Yo quiero proporcionarle la posibilidad de fundar su propia familia y tener hijos porque esta es la mejor manera de servir a su pueblo.“ en: Mosse, G.L.: Der nationalsozialistische Alltag, Frankfurt am Main, Athenäum, 1993, p.65 
„Las consecuencias que se deducen de la utilización del término „lugar orgánico de la mujer", utilizado por el nacionalsocialismo, se encuentran bastante cerca de las ideas del movimiento de la mujer." 1031

En un artículo en forma de carta publicado por Sybille Arnold en 1935 la maternidad aparece como experiencia fundamental en la existencia de una mujer. En su ser la mujer es Mädchen, Frau, Mutter. Y el camino hasta la maternidad se define como el cambio del ser individual al ser maternal. ${ }^{1032}$ La unión de la pasividad con la responsabilidad. Y se utiliza la cita de Rilke donde la mujer vive una liberación de la inseguridad y la extrañeza. La mujer, en su maternidad, es una artista que crea con su amor la existencia del hijo. Se trata de una seelische Mütterlichkeit, creativa y creadora. Su principal función es crear consciente armonía y un lugar donde el hijo crezca apropiadamente y en si una fuerza de renovación individual de la propia madre.

Autoras como Baumgart definen la naturaleza femenina en función de la especial relación de ésta con el mundo natural. Debido a la maternidad y a su papel en la familia su naturaleza está estrechamente relacionada con el cuidado de la vida moral: la idea del bien, de lo verdadero y de lo bello. La mujer tiene el don de entender la realidad no sólo con el conocimiento, con la razón sino con sus facultades afectivas. El hombre por el contrario tiene las cualidades necesarias para la creación intelectual, él es el soporte del progreso cultural. ${ }^{1033}$ La sociedad modelo donde se encarnan la lucha en común de ambos géneros aparece ejemplificada en las tribus germanas, donde la mujer tenían un alto grado de consideración como: Priesterin, sacerdotisa, Seherin, profetisa y ärztliche Helferin, ayudante en la curación de enfermos y era la compañera fiel, amada y respetada del hombre en la necesidad y en la muerte. ${ }^{1034}$

No se puede hablar de rechazo absoluto de las ideas nacionalsocialistas. En un principio se espera, se analizan lo que espera el nuevo estado sobre la madre:

„Por encima de todo es necesario que la posición de la mujer y de la madre en la construcción y en la nueva tarea del futuro estado se establezca a partir de líneas claras." 1035

En este momento se cree todavía en la posibilidad del trabajo conjunto con el nuevo régimen y se exponen claramente una especie de programa de intenciones por parte del movimiento de la mujer: la decisión de la madre de casarse tiene que hacerse libremente. Se rechaza el Versorgungsehe, el matrimonio de manutención, de la „época burguesa“, como una caricatura de la decisión responsable de la mujer, una humillación para ésta y un gran peligro para la dignidad moral y valor racista-político del matrimonio.

Junto a ello se resalta la importancia de la educación de la madre para la maternidad, formación de la seguridad interior de la madre y fomento de la autoridad maternal. Otro punto importante es la protección social de la mujer trabajadora en caso de maternidad. La madre es fundamental en el destino del pueblo, no sólo como columna y sostén sino como creadora, iniciadora, influyente responsabilidad, a la misma altura que la del hombre. ${ }^{1036}$

1031 Baumgart, G.: „Vom Bildungsziel der Frau im Lichte des Nationalsozialismus und der Frauenbewegung“, DIE FraU, Noviembre 1933 (n²), p.99

1032 Arnold, Sybille: „Der Weg der Mutter“, DiE FraU, Junio 1935, (nº 9), p.452 (452-456)

1033 Baumgart, G.: op. cit., p. 100

1034 Ibídem, p. 101

1035 Bäumer, G.: „Mutter, Kind und Staat“،, DiE FrAU, Mayo 1934, n 8, p.450 (pp. 449-451

1036 Ibídem., p.451 
El distanciamiento al que nos referimos se refiere al tratamiento de la maternidad.1037 En primer lugar ésta no se vive como un fenómeno colectivo, sino como un proceso de conocimiento personal. Ser madre no es una cualidad que este determinado por lo biológico y que por lo tanto se pueda domesticar, como pensaban las mujeres nacionalsocialistas, es una cualidad que va más allá de las fronteras de lo irracional, y que diferencia al individuo del animal. Es un don que proviene de la relación Dios-Individuo:

„Ser madre significa: ser una persona que ha lanzado tan profundamente su ancla que internamente vive en paz. Es posible que aparezcan dificultades y tormentas de sentimientos en el hogar, en lo más profundo rige por el contrario la paz, la armonía que no pueden ser despejadas por ninguna tormenta. (...) Este ser que goza raíces asentadas encuentra su significado y su esencia en la religión. “"1038

El fin de la maternidad no sería el tener hijos sanos, o sacrificarse por la patria sino la realización personal del individuo, la realización religiosa de la mujer. Al igual que en la ideología nacionalsocialista se presenta a la madre como ejecutora del mandato religioso, sin embargo la idealización religiosa de la maternidad que encontramos en los textos de DIE FRAU no se justifica con los principios de una religión neutra sino con los del protestantismo más apartado de las posturas oficiales de los teólogos nacionalsocialistas: 1039

La mujer no era por lo tanto, para las mujeres de DIE FRAU, únicamente una máquina de hacer hijos a la que se le colocaba un programa (el programa genético para la mejora y la selección de la raza) con el que estaba preparada para engendrar y educar. La maternidad se presentaba como „un hermoso camino“ en el que la mujer se descubre a si misma, se conoce en una actividad creadora que complementa una supuesta actividad en la vida pública, la aportación intelectual.

Este alejamiento de la tesis Mujer-Naturaleza proporciona la llave argumental adecuada para justificar la participación de la mujer en la vida pública.

El motivo que se utiliza justificar tal participación es precisamente la familia. Partiendo de la concepción que asimila el movimiento de la mujer a la política familiar se argumenta:

„La familia no funciona cuando el marido y el padre están sin trabajo. Cuando las mujeres y las madres son expulsadas de la vida laboral, cuando el destino de la juventud está amenazado por el sentimiento de la inseguridad. (...) Y si la familia no funciona no puede servir al Estado y al Pueblo. “"1040

La solución sería dar a las mujeres la posibilidad de expresar sus opiniones en campos en los que ellas eran más expertas que los hombres. Esta movilización femenina no afectaría a todas las mujeres sino a las más inteligentes y a las más experimentadas. Se propone por tanto un principio de selección que no estableciera diferencias entre los sexos y que posibilitara a las mujeres el control y la toma de decisiones en el funcionamiento del Estado. Un principio de

\footnotetext{
1037 La presentación de la mujer como madre no es un elemento propio del discurso nacionalsocialista sino que se empieza a articular a finales del siglo XVIII principios del XX en los que tanto filósofos, A.Schopenhauer y E.Hartmann, como médicos ven a la mujer como a un ser totalmente determinado por su destino natural de madre. Para profundizar en este tema vease la obra de Alicia H. Puleo: Dialéctica de la sexualidad. Género y sexo en la filosofía contemporánea, Madrid, Cátedra, 1992

1038 von Zahn-Harnack, A.: „Mütterschulung“, DIE FrAU, Diciembre 1933 (n³), p.149

1039 Obermaier-Schoch, H.: „Zur Frage der Auslese für das akademische Studium“, DIE FraU, Enero $1934\left(\mathrm{n}^{\circ} 4\right)$, p.232

1040 Urban, G.: „Zum Wirkensraum der Frau“, DIE FraU, Abril 1935 (n7), p.414
} 
selección que no entra en contradicción con las principales ideas del nacionalsocialismo, porque no cuestionaba temas conflictivos como el del parlamentarismo, el de la democracia o el de la cuestión judía.

\subsubsection{La mujer como esposa}

En su relación con el hombre la mujer se revela como la Tragende, la que sostiene y apoya al hombre. El hombre aparece como un el principio pasivo de la relación. Sin la mujer no es nada, con ella reconoce su propia masculinidad. El estatus de la mujer no significa la plena consecución de la feminidad. En la seguridad de la vida matrimonial pierde la mujer casada todo tipo de profundidad sobre su propia existencia. Aquí aparece la mujer soltera, que trabaja (no importa si se trata de una profesión adecuada a las características femeninas, y se pone como ejemplo a una trabajadora en una fábrica de munición) como la que realmente se confronta con su propia feminidad en su dedicación y entrega. Con la misma intensidad tiene que olvidar la mujer su propia existencia para dedicarse al hombre. ${ }^{1041}$ La consigna es la autoentrega y el sacrifico de la mujer. Esa es su verdadera identidad. Cualidades que pueden encontrarse también en la madre ilegítima.

\subsubsection{Entrega, servicio y sacrificio. Cualidades inherentes a lo femenino}

La mujer como víctima, o como individuo caracterizado por sus dotes de sacrificio, son constantes en el discurso masculino que encontramos desde comienzos de la Edad Media, sin embargo alcanzan su consolidación final en la mentalidad colectiva durante el siglo XIX en el que la sexualidad femenina se interpreta como objeto del deseo sexual masculino en su totalidad. Según este discurso la relación sexual es concebida sobre el modelo de la violación y el sacrificio ritual. En las manos del que la asalta, la mujer es desposeída de su ser. Junto con su poder, pierde esa firme barrera que la separa de las demás y la hacía impenetrable. ${ }^{1042}$ Durante el nacionalsocialismo estos valores fueron idealizados de manera perversa: la mujer en concreto se podía realizar únicamente desde su papel de madre y sirvienta de su esposo. La madre recibía el más alto reconocimiento gracias al gran sacrificio que ofrecía para la conservación de la raza y era vista como el pilar fundamental de la familia. ${ }^{1043}$

En la mayoría de los casos la entrega y el sacrificio se hace desde el punto de la individualidad femenina: entrega a la patria, a la nación. Esta abnegación no se plantea desde la insconsciencia de la mujer, sino que es articulada por esta misma como una forma de desarrollarse personalmente. De la misma manera que lo hace el hombre en sus obligaciones con el pueblo.

Desde DIE FrAU se aborda el tema con cierta cautela y ambigüedad. Se añoran los tiempos, no se precisa cuáles, en los que la mujer no se limitaba únicamente a ser la costilla de su esposo:

„Las mujeres de aquellos tiempos se esforzaban con una entrega admirable en aparecer como hechas de la costilla de sus maridos. Entre ellas y sus maridos reinaba una total unidad y entendimiento respecto a su vocación y capacidad. La

1041 Glaser, Martha: „Vom Auftrag der Frau in der Ehe“, DIE FrAU, marzo 1940, (nº 6), pp. 164-168

1042 Puleo, A.H.: op.cit., p.32

1043 Weyrather, I.: Muttertag und Mutterkreuz. Der Kult um die „deutsche Mutter“ im Nationalsozialismus, Frankfurt am Main, Fischer, 1993, p.85 
cuestión del movimiento de la mujer en el sentido de nuestra época no existía en aquellos tiempos maravillosos. “"1044

Por otra parte se evalúan los efectos que sobre la educación puede tener una excesiva dedicación de las mujeres a los otros: una mujer que se entrega demasiado crea también situaciones de dependencia en las personas que educa:

„Una madre ya se sacrifica lo suficiente también cuando conserva su propia identidad e intereses. (...) Cada madre que se sacrifica hasta la saciedad educa a personas que a su vez necesitarán víctimas (...).“1045

Sin embargo el valor del servicio y de la obediencia no se rechazan de forma absoluta, especialmente cuando se comparan los campos de acción de los dos géneros. El hombre está dedicado a ejecutar un servicio elevado, el servicio al Estado, con el que la mujer no se identifica totalmente. Esta encuentra su idealización en aquellos espacios donde puede cuidar, ayudar y amar. Se utiliza en resumen un lenguaje que pretende reivindicar la naturaleza especial de la mujer desde un discurso patriarcal que ve a la mujer diferente y dedicada a tareas diferentes del hombre.

Las mujeres de DIE FRAU se esfuerzan en ser las constructoras de su propia identidad, pretenden como señala Else Hueck-Dehio no verse en el espejo de la concepción masculina de la femineidad, sino ser su propia imagen:

„(...) desde que las mujeres han empezado a no orientarse nunca más en función de la imagen que el hombre desea de ellas, desde que sienten sus propias leyes, y dejan de hacerse daño a si mismas, ni siquiera para consguir el deseado precio del amor. En el día en que la mujer empezó a buscarse a sí misma, empezó también la gran transformación del tipo de mujer que se diferencia extremadamente de la imagen de mujer en los tiempos de nuestras abuelas. Nos sentimos como criaturas con capacidad para distinguir y sentir, sin depender del amor de un hombre o de la cantidad de hijos que traemos al mundo. Empezamos a liberar nuestras fuerzas mentales y físicas de las cárceles en las que estas se encontraban. Conseguimos records en todas las actividades deportivas: carrera, natación, disco, podemos conducir automóviles e incluso aviones. Podemos de repente calcular y pensar." ${ }^{1046}$

Sin embargo a pesar de sus esfuerzos la fuerza del espejo masculino es tan grande que resulta difícil resistirse a sus encantos.

Resumiendo podríamos decir que se trata de un discurso que desprecia lo natural, lo biológico, en el sentido puramente materialista e intenta elevar a categoría de racional todo aquello que liga a la feminidad a lo biológico: el sexo y la maternidad. Lo femenino en su dimensión biológica entra a formar parte de la esfera de lo ideal, de lo espiritual. Esta respuesta de las mujeres de DIE FRAU se incluye en un discurso ya utilizado con anterioridad en el que la mujer se convierte en la redentora de la humanidad por su especialidad. Por otro lado es un discurso que acepta también la polaridad entre géneros en la sociedad, necesaria para estabilidad de ésta. La mujer no alcanza únicamente su realización a través del cuidado de la

Hueck-Dehio, E.: „Die Frau und die geistige Schöpferkraft“, DiE FrAU, Febrero 1934 (nº 5), p.266

Reicke, I.: „Wandlung der Mutter durch das Kind“, DIE FraU, Diciembre 1933 (n³), p.153

Hueck-Dehio, E.: op. cit., p. 266 
familia y del hogar (presupuesto calificado de liberal e individualista que olvida los principios de lealtad al pueblo y a la patria), sino en el trabajo. Paradójicamente la maternidad se entiende como algo sagrado, donde la mujer puede encontrarse a si misma, y puede descubrir a través de la religión lo esencial de su naturaleza: amar, cuidar y ayudar.

\subsubsection{El movimiento de la mujer. Pasado y presente}

Tras 1933 no se puede hablar de un cambio fundamental en los contenidos de la revista. A pesar de la disolución de las organizaciones de mujeres, de la emigración forzosa de múltiples compañeras de trabajo, Hasta los primeros años de la guerra se hace alusión a las publicaciones de las colaboradoras más directas de la revista. DIE FRAU continúa informando sobre el movimiento de la mujer, aunque de una manera conciliatoria con el nuevo régimen. Se buscan puntos de contacto, se niegan las críticas de intelectualismo y pacifismo, se merodea en torno al poder. Entre 1933 y 1934 DIE FRAU desarrolla una „limpieza historiográfica“ del movimiento de la mujer alemán. De la mano de Magnus-von Hausen, coeditora de la revista, Gertrud Bäumer y Gertrud Baumgart, 1047 antigua miembro del DNVP, se procede a una explicación detallada del surgimiento del movimiento de la mujer, de sus intereses y objetivos, su postura ante la primera guerra mundial y sus expectativas ante el nuevo gobierno. La primera conclusión a la que se llega es que el movimiento de la mujer no tiene sus raíces en el Liberalismo, como en el caso anglosajón, sino en la orientación nacional de Louise Otto:

„Es importante, especialmente en la actualidad, donde debido a la asombrosa ignorancia de los hechos históricos, se cubre al movimiento de la mujer con los más curiosos reproches y críticas, dar a conocer y llenarse del pensamiento de Louise Otto para demostrar qué lejos se encuentra éste de la Frauenrechtelei, de su carácter alemán, su realismo y fuerza de sentimiento, origen y columna de nuestro movimiento de la mujer." 1048

Las influencias liberales fueron inevitables y se consideran un mal menor. El movimiento de la mujer tiene sus raíces en el espíritu alemán, es un movimiento social, por encima de partidos y tendencias políticas. ${ }^{1049} \mathrm{~A}$ las críticas de Gottschewski de no haberse opuesto a los acuerdos de Versalles se argumenta:

„Pero el reproche de que ésta no se hubiera opuesto a los acuerdos de Versalles, es verdaderamente injusto, si nos acordamos de la proclamación pública de la Federación en contra de la oferta de Wilson, así como la unidad de las mujeres del parlamento al rechazar conjuntamente las imposiciones que traía consigo los dictados de paz." ${ }^{1050}$

1047 Iniciaciadora del Movimiento de la Mujer.

1048 Magnus-von Hausen, F.: „Anfänge und Gegenwart der deutschen Frauenbewegung“, DIE FrAU, Setiembre 1933, $\mathrm{n}^{\circ}$ ?, p. 707

1049 Ulich-Beil, E.: „Naiv oder sentimentalisch?. Zur Wesensdeutung der geschichtlichen Frauenbewegung“", DIE FraU, Enero 1935, n4, pp. 218-226

1050 Groenig, G.: „Ausprache. Jugend und „alte Frauenbewegung“““, DIE FrAU, Julio 1934, n 10, p. 617 (pp.615-619). El acuerdo de Versalles divido en quince partes y 440 artículos afecta a los territorios de Nordschleswig, Eupen, Malmedy, Elsaß-Lothrigen, Posen, Westpreußen, algunas partes de Ostpreußen, Hinterpommern y Oberschlesien, Danzig, la región de Memel. Junto a la cesión, y desarme Alemania se 
Las diferencias entre el „nuevo movimiento de la mujer“ y el „antiguo“ sobre las que inciden las nacionalsocialistas no son tales y se reconoce el parentesco de ambos:

„(...) así yo no puedo descubrir ninguna diferencia en el origen de ambos movimientos. Ambos se fundamentan en el deber de poner a disposición de la comunidad las mejores fuerzas de ésta. Esto es lo más importante. Sería por lo tanto aconsejable buscar una manera de trabajar conjuntamente para escoger qué tipo de camino común es el más adecuado para este servicio. Hay muchos caminos y es posible que en algunos momentos haya diferencias de opinión, pero si continuamos hojeando el libro llegaremos a la conclusión de que no existen diferencias con las reivindicaciones del antiguo movimiento de la mujer, como se puede leer una y otra vez en el libro de Helene Lange, Kampfzeiten." 1051

Ya no se trata de Louise Otto Peters sino de la obra de Helene Lange la que presenta los fundamentos teóricos que establecen las igualdades de los dos movimientos.

En segundo lugar se esfuerzan en incidir en su carácter patriótico y nacional e intentan diferenciarse del movimiento de la mujer de izquierdas (el ala radical, de las mujeres de la socialdemocracia), negando la pretensión del movimiento de la mujer de haber querido integrar totalmente a las mujeres en la vida laboral:

„La opinión de que la mujer, a pesar de sus obligaciones familiares, puede realizar de igual manera la misma actividad profesional que el hombre, en realidad el doble que éste, no fue nunca apoyada por el ala moderada del movimiento de la mujer." 1052

Por el contrario, con sus esfuerzos y el movimiento de la mujer contribuyó desde su fundación al mantenimiento de la familia, así como a suavizar las tensas relaciones entre los géneros. Haciéndose eco de las ideas de Rilke sobre la lucha de los géneros:

"Quizá la gran renovación de mundo consiste en que hombre y mujer, liberados de sentimientos equivocados y aversiones, dejen de verse como contrarios en lucha sino como hermanos y vecinos y que unan sus fuerzas como individuos para cargar seriamente, pacientemente con el pesado género que a cada uno le ha sido concedido." 1053

No deja de ser curioso que bajo la rúbrica de noticias sobre el Movimiento de la Mujer, aparecieran todo de tipo de convocatorias, actividades relacionadas con el Franenwerk o las Franenschaften. No se puede hablar de la misma disposición por parte de las mujeres nacionalsocialistas. En 1935 Lydia Gottschewski, dirigente de la NS-Frauenschaft señala que:

ve obligada a pagar una cantidad de dinero (reparaciones). En el caso de incuplimiento del acuerdo, los aliados dsponían del poder de ejercer sanciones que se reflejan en el ultimatun de Londres en 1921 y en 1923 con la ocupación del Ruhr. Sobre el tema: Mischalka, W. Niedhart, G. (Ed.): Deutsche Geschichte 1918-1933. Dokumente zur Innen- und Außenpolitik, Frankfurt am Main, Fischer, 1992

1051 Groening, G.: op. cit., p. 617

1052 Magnus-von Hausen, F.: op, cit., p.710

1053 Weber-Colonius, E.: „Die Ehe und die geistige Bestimmung der Frau. Gedanken von Sören Kierkegaard“, DIE FRAU, Diciembre 1935, p. 299 
„,todos esos frentes parciales son manifestaciones de un tiempo pasado y hoy no tienen ningún sentido. Existe sólo un frente único: el frente de la mujer y el hombre, del hombre y la mujer en lucha por el derecho vital de su descendencia y de todo el pueblo.“ " 1054

En especial durante los primeros años de la dictadura se esfuerza DIE FRAU en pertenecer a este frente único esforzándose en hacer frente a las críticas de intelectualismo, superficialidad y antipacifismo del ala de las mujeres nacionalsocialistas sobre el „Movimiento de la Mujer“. Gertrud Bäumer es la encargada de defender el movimiento de la mujer, donde se incide en la autenticidad de éste, en su compromiso nacional, (en la primera guerra mundial). Ante la crítica de intelectualidad, Bäumer compara ambos movimientos: el nacionalsocialismo también se sirve de la divulgación „intelectual“ para expandir su teoría, lo mismo intentaban las mujeres del movimiento de la mujer. Es necesario la existencia de mujeres preparadas que puedan guiar a las demás, aludiendo claramente al principio de mando, Führerprinzip. ${ }^{1055} \mathrm{El}$ movimiento de las mujeres no quiere que todas las mujeres estudien, o que todas se conviertan en intelectuales, sino que todos los aspectos de la vida de una mujer se llenen del Geist. ${ }^{1056}$

Bäumer también rechaza el reproche de haber contribuido a la decadencia de la familia y acentúa el hecho de que la tasa de matrimonio continuó subiendo después de la guerra hasta 1932 dónde la tasa bajo a niveles parecidos al año 1913, producto de la crisis económica. De una manera inteligente Bäumer transforma los reproches en críticas, para ello cita a Goebbels, y ofrece la posibilidad de un trabajo en conjunto a las mujeres nacionalsocialistas, destacando que no se trata de un asunto individual sino del movimiento de la mujer por entero.

Gertrud Baumgart se expresa más claramente. Se muestra partidaria de la continuidad del Movimiento de la Mujer durante el Nacionalsocialismo, así como encuentra una gran afinidad con las ideas que éste propaga sobre la mujer y su papel en la sociedad.

En esta estrategia de „supervivencia“ se encuentra la inclinación positiva a trabajar conjuntamente en la construcción del nuevo Reich. En primer lugar se observa con admiración los logros de las Frauenschaften y su éxito en la movilización de las mujeres alemanas. Así mismo se analiza positivamente los esfuerzos del Frente femenino del trabajo que contribuye a la mejora de la situación y condiciones de la mano de obra femenina. ${ }^{1057}$

Las noticias sobre las organizaciones nacionalsocialistas se hacen a partir de 1939 cada vez más frecuentes. Comunicados de prensa, informes sobre las organizaciones, etc. Característico de estos artículos es el intento de justificar y aclarar el parentesco de las ideas del grupo de DIE FRAU, ya sea en relación al movimiento de la mujer, ya en relación a la política social-liberal.

En 1940 con motivo de una exposición con el título Frau und Mutter. Lebensquell des Volkes, Mujer y madre. Fuente de energía del pueblo, Bäumer, en la crítica que hace de la exposición, señala el aspecto „espiritual“ que se le da a la maternidad, con lo cual el único aspecto propio del grupo de mujeres de Die Frau aparece también asimilado por el ideal de la mujer nacionalsocialista.

En 1942 celebra la NS-Volkswohlfahrt, beneficencia popular nacionalsocialista, una década de existencia. DIE FRAU publica un artículo de Bäumer con motivo del aniversario, donde se hace una reflexión sobre la beneficencia anterior a 1933 y sobre los límites y fracasos de la política

\footnotetext{
1054 Baumgart, G.: „Vom Bildunsziel der Frau im Lichte des Nationalsozialismus und der Frauenbewegung“, DIE FRAU, Junio 1935, (nº 9), p. 98

1055 Bäumer, Gertrud: „Frauenbewegung und Mütterschaft“, DIE FrAU, Diciembre 193, (n`39 pp. 171 181

1056 Bäumer, Gertrud: „Spießbürgertum in der Frauenfrage“, DIE FrAU, Marzo 1934, (nº) p.324

1057 Bäumer, Gertrud: „Frauenschafffen 1938 und in Zukunft“, DIE FrAU, Enero 1939, (n^4), p.171
} 
social a este respecto. Según Bäumer la concepción nacionalsocialista de la beneficencia se presenta como la alternativa y solución a los problemas sociales de 1933. Mientras que la política social de los años veinte se revela como una operación de urgencia en un cuerpo enfermo, ofrece la versión nacionalsocialista la curación definitiva. ${ }^{1058}$

\subsubsection{Sobre la naturaleza de lo femenino y el estado. El papel de la mujer en la vida política}

Como hemos visto en el capítulo anterior las cualidades de la mujer que aparece reflejada en DIE FraU no quedan restringidas al espacio de la familia o del hogar. Por el contrario en la mayoría de los artículos de la revista se estimula el trabajo de la mujer, argumentado lo valioso de esta aportación para el buen funcionamiento del Estado. Aunque siempre diferenciando las esferas de actuación de los sexos. El Estado no aparece necesariamente definido, sino que se alude a él como la institución sin caracteres demarcados, que garantiza el bienestar de los ciudadanos y ciudadanas, a cambio del trabajo conjunto de éstos . ${ }^{1059}$

El concepto de Estado encuentra su definición a partir de términos como Pueblo y Reich. Se encuentra una diferencia de valores a la hora de diferenciar entre Estado, Pueblo y Reich. Mientras que para los nacionalsocialistas el Estado no es fin, sino instrumento, ${ }^{1060}$ en los textos de DIE FRAU que hablan sobre la naturaleza del Estado se observa que éste aún goza de sus atributos como aglutinador entre pueblo y nación, como el marco teórico que necesita la vida de la idea:

„El Estado es un concepto, un postulado, una exigencia que puede ser comparado con el efecto de una fórmula matemática. (...) El Pueblo (Das Volk), es lo que es, lo que vive, lo que fluctúa, lo que muere y vuelve a revivir. En tiempos de cambio, comparable con un ejemplo similar: el Reich.“"1061

La figura del Reich sirve para explicar la ausencia histórica de un Estado nacional en Alemania como en el resto de los países europeos, y se define al Tercer Reich como un estado „tribal, popular, racista y sin fronteras“. Sin embargo el comentario no pasa de ser explicativo, y como siempre la definición se pierde en la ambigüedad de las palabras abultadas. Aunque no sería justo no aludir a la ausencia continua a la raza aria o a la cultura aria como fundamentación de cada una de las instituciones, y valores de la realidad.

Esta colaboración estaba sujeta a varias interpretaciones, mientras las mujeres de DIE FRAU se manifestaron abiertamente por la participación de las mujeres en el mundo laboral, así como de una posible participación política. Los nacionalsocialistas por el contrario se mostraban por el contrario opuestos a todo tipo de responsabilidad política de la mujer.

De una manera limitada la conjunción madre-trabajadora posibilitaba el salto a la vida pública, y la expresión de determinadas opiniones políticas, dentro de la ideología nacionalsocialista. Sin embargo este deseo y reivindicación no pudo ser realizado en la práctica. Sin embargo desde ningún momento se muestra un rechazo abierto de las estructuras

1058 Bäumer, G.: „Zehn Jahre NS Volkswohlfahrt“, DIE FrAU, Junio-Julio 1942, (nº 9-10), pp. 157-159

1059 von Velsen, D.: „Frauen, Volk und Staat“, Die FraU, Marzo 1933 (nº 6), p.334

1060 Así comenta Hitler en Mein Kampf: „El (estado) es la condición para la formación de una elevada cultura humana, sin embargo no ese la única causa. De ello depende la existencia de una raza capacitada para ello. En la tierra podrían existir cientos de estados modelos, en el caso de muerte de lo herederos de la cultura aria no habría ninguna cultura que pudiera compararse con la grandeza espiritual de la cultura alemana.“ en: Mosse, G.: op.cit., p.27

1061 von Velsen, D.: „Frauen, Volk und Staat“, p.334 
nacionalsocialistas. Se critica que las plazas de la administración ocupadas por mujeres que habían sido relevadas de sus cargos por su pasado político, no hubieran sido ocupadas de nuevo por mujeres. Por el contrario se ve en la complicada estructura del aparato nacionalsocialista una gran oportunidad de nuevas ocupaciones para las mujeres. ${ }^{1062}$

\subsubsection{Mujer, Familia, Pueblo y Nación}

„Todo el mundo sabe que después de la Machtergreifung una ola de odio y de calumnias venenosas se extendió poderosamente contra el nuevo Reich. No se quería tolerar que el pueblo alemán restableciera su honor que recobrará su capacidad de defenderse y que estuviera dispuesto a partir de sus propias fuerzas a legitimar su lugar bajo el sol."“1063

De las ambiciones internacionalistas de la república de Weimar, los contactos con otras mujeres europeas, el trabajo conjunto con otras naciones en la conferencia para el desarme en Ginebra, dan paso en 1933 a posiciones claramente nacionalistas. Anteriormente la naturaleza internacional de los diferentes grupos de mujeres encuentra en la práctica ciertas dificultades para articular su discurso: la mayoría de las organizaciones apelaban al individuo, hombre o mujer, desde un punto de vista abstracto que evitaba pronunciarse en profundidad sobre el concepto de nacionalidad. Las grupos liberales-burgueses de mujeres optan por lo nacional como elemento de definición de lo individual y de lo auténtico:

„Nosotros hemos experimentado, más fuerte de lo que podíamos imaginar, más profundo de lo que podíamos saber, más allá de lo que llega nuestra experiencia, el valor de la nación, del Estado, para nuestra vida individual." 1064

Pero por encima de la individualidad y de la diferencia de género esta la unión de alemanes y alemanas en una misma patria, en un mismo pueblo, eine gemeinsame Heimat der deutschen Seele, una patria común del alma alemana. ${ }^{1065} \mathrm{El}$ papel de la mujer en esta alma alemana es la abnegada dedicación a la idea de la Volksgemeinschaft.

„Pero los fundamentos de nuestra naturaleza como mujeres en la Alemania que viene, la base para que podemos cumplir con nuestros deberes y responsabilidad con honor, alegría y orgullo, respecto a esta Alemania, es definitivo que no sintamos nuestro género como un instrumento, como medio y objeto sino que nos veamos en la figura de líderes responsables con la voluntad para la entrada en acción total que nuestras intrínsecas fuerzas nos conceden."’1066

1064 Meyn-von Westenholz, E.: „Nation als Bildungsidee der Frau“, DIE FrAU, Enero 1936 (número especial), p.43

1065 Hoffmann-Linke, E.: Frau, Volk und Nation“, DIE FraU, Septiembre 1933, nº 12, p. 712

1066

Bäumer, Gertrid: „Zum „Statu““ der deutschen Frau“, DIE FraU, Septiembre 1937, (n¹2), p.642

Baumgart, G.: „Nationalsozialismus und Auslandsdeutschtum“, DIE FraU, Marzo 1937, (nº 6), p. Ibídem, p. 713 
En su deseo de no verse relegadas a la mera observación pasiva de la nueva Alemania, se incide en la íntima relación de lo femenino con la nación:

„La gran dependencia de éstas de las condiciones naturales y de las realidades de la vida trae consigo que las mujeres entre ellas representan una masa más uniforme, mucho más undiferenciadamente que los hombres. Ellas son más pueblo (que los hombres) y conservan tambien su carácter de pueblo, sin ser simplemente masa."'1067

Esta relación especial y privilegiada de la mujer con el pueblo depende de su capacidad reproductora, de su servicio al pueblo como madre, de su sacrificio como madres de los soldados que se disponen a defender a la patria. Las mujeres con los hombres, sin diferencia de en la valoración cualitativa de su trabajo, juntos al servicio de la misma causa.

Mediadora entre la mujer y el pueblo aparece la familia. Desde DIE FrAU se apoya la idea general de la decadencia de la familia como consecuencia de la urbanización, industrialización, el individualismo liberal y el marxismo. ${ }^{1068}$ Sin embargo no se muestran tan partidarias a aceptar la vuelta al hogar y el abandono de la vida laboral que pedían los nacionalsocialistas, ni de que las mujeres se conviertan en meras ejecutoras de la política oficial masculina:

„No existe ninguna duda que la verdadera renovación de la familia está estrechamente relacionada con el cambio interior y exterior de la posición de la mujer, después que la cultura femenina casi destruyera la familia, como lo muestra el ejemplo bolchevique." ${ }^{1069}$

Prácticamente se argumenta con argumentos feministas, oposición femenino-masculino, sin embargo por otra parte este tipo de argumento se encuentra también en las posturas nacionalsocialistas. Las posturas pacifistas de los últimos años de Weimar han desaparecido por completo. Por el contrario, se utiliza de nuevo el servicio femenino durante la primera guerra mundial, como símbolo de la entrega y el servicio de las mujeres a la nación alemana y a la comunidad del pueblo:

„Todas hemos sentido, mas fuerte de lo que nunca hubiéramos creído como posible, más profundo de lo que en general sabíamos que estas experiencias nos pudieran enriquecer: el valor de la nación y del estado para nuestra vida en solitario. Lo que para nosotras eran tan querido, lo que ha enriquecido y ha hecho valiosa nuestra vida, lo que hemos experimentado, nada es tan valioso como esto, como lo único para lo que hoy en día se ofrece el precio de la vida: el movimiento hacia adelante, la cohesión de nuestro estado. Y así estamos preparadas interiormente para que en la pedagogía de la generación venidera, para muchachos y muchachas se superen los objetivos individualistas, las cuestiones sutiles sobre la perfección de la vida personal y se conceda la parte más importante a nuestro ideal de educación, a la nación, al estado, a la comunidad orgánica cultural, al trabajo y a

1067 Ibídem, p. 713

1068 Kühn, L.: „Frau, Familie und Staat“; Urban, G.: „Zum Wirkensraum der Frau“, DiE FraU, Abril 1935, nº 7 , pp. $414-416$

1069 Ibídem, p. 682 
las formas orgánicas cuyo significado para nuestra vida hemos sentido hasta lo más profundo."1070

El reconocimiento oficial de los servicios del movimiento moderado de la mujer llega en 1937 cuando en Nürnberg durante el Parteitag se inaugura una exposición sobre la participación de la mujer en la nación. En ella se podía ver una serie de fotos de las mujeres más importantes del movimiento bajo una cita de Gertrud Scholtz-Klink, la dirigente de las mujeres nacionalsocialistas:

„Estamos agradecidos a cada corriente auténtica que ha jugado un papel en el pasado, porque estas corresponden con los objetivos del nacionalsocialismo. "1071

A pesar de los intentos acentuar el aspecto positivo del movimiento de la mujer, se expresan también críticas respecto al estado nacionalsocialista. Una de las objecciones que encontramos es la incoherencia entre la teoría y la práctica del movimiento: mientras que en la teoría éste pretende devolver a la familia su papel originario, en la práctica pierde ésta cada vez más su importancia. La expansión del aparato nacionalsocialista en suborganizaciones, la obligatoriedad de participar en las reuniones y encuentros, tienen como consecuencia que cada uno de los miembros de la familia, dedica la mayor parte de su tiempo al Estado, pero no a su propia familia. ${ }^{1072}$

No obstante la individualidad como virtud de la feminidad y de la maternidad es sustituida por el valor de la pertenencia a la comunidad del pueblo: no se trata de una comunidad contemporánea, o pasajera; ésta existe en el pasado, en la historia de los alemanes. La comunidad popular es el lugar de encuentro donde el alma de cada individuo se encuentra desde tiempos remotos con el Geist del pueblo, en el gran alma de la Volksgemeinschaft:

„Como individuo alemán fui concebido intelectualmente (geistig) a través del genio creador (Schöpfergeist) de mi propia nación. (...) Como individuo alemán tengo una conciencia histórica especial, esto significa que me considero conscientemente herencia del extraordinario pasado de mi pueblo y soy consciente de mi responsabilidad al mismo tiempo en la configuración de su presente y futuro. Mi pertenencia al pueblo alemán es realidad vital, mi pueblo es una parte de mi propio cuerpo, cuando sufre, sufro yo con él, aún cuando no tiene que ver estrechamente conmigo. Cuando el líder, de mi pueblo comete fallos, yo también me siento responsable. ${ }^{1073}$

Por otra parte Weber, aunque acepta la entrega y la abnegación a la patria, Vaterland critica posturas radicales en intolerantes:

„Nos alegramos de la abnegación hacia los objetivos que están por encima de nuestros deseos personales, fe y esperanza en la nueva grandeza de nuestra patria. Sin embargo no aceptamos el odio fanático contra compatriotas de otra índole,

1070 Bäumer, G en: Meyn-v. Westenholz, E.: „Nation als Bildungsidee der Frau“, op. cit., pp.21 у 22

1071 En la exposición aparecen las fotografías de Luise Otto-Peters, fIda von Korzfleisch, Agnes Karrl, Franziska Tiburtius, Auguste Schmidt, Marga Belm, Henriette Schrader-Breymann, Frieda Duensing, Helene Lange y Hedwig Heyl. En: DiE FraU, Octubre 1938, $\mathrm{n}^{\circ} 1$

1072 Patzig, G.: „Familie, Volkstum und Volksgemeinschaft“, DIE FraU, 1933, pp. 539-543

1073 Weber, M.: „Persönliche Existenz und überpersonale Verantwortlichkeit“, DIE FrAU, Marzo 1933, p. 337 
contra la falta de entendimiento de otras convicciones contra la injusticia y la grosería salvaje. La medida de actuación en relación con los críticos es la humanidad y la tolerancia, ya que la humanidad es la exigencia más alta de todo individuo privado. La expansión de esta humanidad debiera ser el objetivo fundamental de todo poder colectivo." 1074

El nacionalismo de las mujeres de DIE FRAU no encontró ningún problema para adaptarse a las ideas nacionalsocialistas; cuestiones de política exterior, ensayos sobre la literatura alemana, el interés por la especialidad de las mujeres alemanas, ponen de relieve la coincidencia de intereses. ${ }^{1075}$

En otros puntos sin embargo diferencia DIE FRAU de otras publicaciones para mujeres dependientes de las Frauenschaften, como por ejemplo en lo relacionado a la figura del Führer. En los artículos que hemos analizado no aparece en ningún caso referencias directas a éste, mientras que en las revistas nacionalsocialistas es normal encontrar discursos, y artículos de tipo laudatorio. Otro tanto podría decirse de los discursos que Hitler pronunció ante las mujeres alemanas en Nürnberg. Estos, no encontraron eco en DIE FRAU.

\subsubsection{La crítica „a lo burgués“. Intelectualización de la ideología nacionalsocialista}

Aunque el movimiento de la mujer era heredero de la tradición burguesa-conservadora, observamos a partir de 1934 la intención reiterada en algunos artículos de olvidar tal tradición. Lo burgués, en especial lo pequeño burgués, aparece retratado como el gran enemigo de todo movimiento de creación, en especial se critica la falta de interés que demuestra por las aportaciones femeninas, y la lucha histórica del movimiento de la mujer contra esta actitud reaccionaria.

El peligro de la mentalidad pequeño burguesa, es según Gertrud Bäumer es que no tiene en consideración la capacidad creativa e intelectual de la mujer. Bäumer no considera que la crítica de los rasgos „exteriores“ de la emancipación de la mujer: el Bubikopf, la utilización de maquillaje, el tabaco como símbolos de la decadencia de la mujer fueran los peligros del Spießsürgertum tal y como criticaban las mujeres nacionalsocialistas, sino que el verdadero peligro era la falta de imaginación de lo burgués para todo lo que es femenino. ${ }^{1076} \mathrm{El}$ pequeño burgués, señala Bäumer, es el peor enemigo de la mujer. Se trata según un tipo internacional, lleno de convenciones e ideas fijas, prejuicios, intolerante hacia los que no son cómo él, especialmente hacia los que son mejores que él y su intolerancia se convierte en odio cuando esta se deja seducir por las redes del fanatismo. ¿Era realmente consciente Bäumer de lo que estaba escribiendo?, ¿se trata de una crítica entre líneas del nacionalsocialismo? Sin embargo la esperanza de encontrar un rastro de disentimiento desaparece rápidamente. En el mismo artículo señala Bäumer la posibilidad que ofrece el nacionalsocialismo para superar las discrepancias en las relaciones entre mujer, pueblo, Volk, y estado

\footnotetext{
1074 Ibídem, p. 338

1075 Sobre el desarrollo de la conciencia nacional en las clases burguesas en Alemania es de gran interés la obra de Norbert Elias, Studien über die Deutschen (Frankfurt am Main, Suhrkamp, 1992), en la que analiza la tendencia general entre las clases medias europeas a posiciones y valores nacionalistas. Una de las características de esta tendencia es una imagen idealizada de la propia nación constituída en el centro de la propia individualidad, del ideario político y de la escala de valores. De esta manera términos como Volksgemeinschaft, das Kollektive, comienzan a integrar el lenguaje político, y a configurar determinados modos de actuar en la clase media.
}

1076 Bäumer, G.: „Spießbürgertum in der Frauenfrage“, DIE FRAU, Marzo 1934 (nº), p.321 
La lucha contra lo burgués es utilizada en todo momento como factor de identificación ideológica. En algunos casos principios que podían atribuirse tanto al nacionalsocialismo como al parlamentarismo, reciben el calificativo de burgueses: „el moto: la mujer deben encontrar su profesión en la familia es un principio burgués". El nacionalsocialismo se presenta por el contrario como alternativa ideológica:

„Hay en la actualidad muchas mujeres que ven en la ideología nacionalsocialista una posibilidad para superar las discrepancias existentes en la relación MujerEstado y Mujer-Pueblo."“1077

La posibilidad de trabajar conjuntamente existe, sin embargo dentro del nacionalsocialismo se encuentran, según Bäumer una serie de tendencias que pueden considerarse como pequeño burguesas, en especial entre aquellos que proclaman la desaparición de las mujeres del mundo laboral, o los que critican las tendencias intelectualistas.

Otro de los intentos de Bäumer de diferenciar la terminología e ideología nazi con un carácter intelectual que la hace „socialmente“ aceptable es el concepto que ésta concede al término rassisch, donde se distancia de la línea biológica del concepto de raza y formula una concepción intelectual. El Geist alemán sería el contenido que rellena el alma alemana y no las características meramente físicas y biológicas de la raza:

„Parece realmente necesario, no sólo respecto a los temas relacionados con la cuestión de la mujer, colocar al lado de la Alemania racista la Alemania (das geistige Deutschland) del Geist. Y se debe finalmente quizá indicar que „racista“ no sólo se trata de un término relacionado con la especie: germánico, eslavo, nórdico sino un término relacionado con la cualidad.“"1078

El distanciamiento definitivo de Bäumer de los principios democráticos se muestra claramente en los artículos que ésta escribe sobre la revolución francesa, tradicionalmente considerada por el movimiento de la mujer como piedra angular de los comienzos de éste. No es extraño que a partir de este argumento central, se observe un rechazo del orden democrático incapaz de resolver los problemas que tiene la mujer. Hechos históricos como la Revolución Francesa son juzgados arbitrariamente desde el punto de vista „feminista“ y censurados. El destino de las mujeres durante la Revolución Francesa, señala Bäumer, es una tragedia con rasgos cómicos, como en el caso de Mme. Roland, amante de Condorcet, el cual mientras su amada subía al cadalso, conseguía huir de París.

La Revolución Francesa es vista como una recesión en la consecución de las libertades de la mujer, la legitimación escrita de la pérdida de su libertad política:

„Donde principalmente como en Francia o en Suiza debido a la estratificación sociológica del pueblo se atribuye la estabilidad política a la pequeña burguesía y a la población rural, se mostrará, como en el plebiscito suizo como un gran inconveniente para la ascensión de la mujer a la responsabilidad política." ${ }^{1079}$

En los mismos términos se critica la democracia inglesa como un sistema que varía entre „el parecer“ y lo que es realmente. El sistema social inglés con su aristocracia y su „insignificante

\footnotetext{
1077 Ibídem, p.322

1078 Ibídem, p.323

1079 Bäumer, G.: „Die Menschenrechte und die Frauen. A propos d' un Anniversaire“, DiE FraU, Julio 1939 (n'10), p.508
} 
middle class" refleja las desigualdad social del parlamentarismo inglés. El pueblo, das Volk, no tiene según Bäumer ningún acceso a los „privilegios“ democráticos. ${ }^{1080}$

La crítica a lo burgués es paralela al uso despectivo de términos como liberal, individualista, individuo único, materialista, egoísta, así como al rechazo del periodo de industrialización, origen de la destrucción de la familia. El cambio en las costumbres, la vida urbana, el desempleo, la delincuencia y la prostitución entre otros, son el precio que deben pagar los hombres por su desafío a la naturaleza. La naturaleza aparece como la gran vengadora, la máquina como el enemigo de la paz y la armonía de tiempos anteriores.

Este discurso no se diferencia apenas de la ideología nacionalista antiliberal. El discurso sobre lo burgués coincide significativamente con el del nacionalsocialismo tanto en el contenido como en la forma. Esta coincidencia se volverá a repetir en otros temas relacionados con la vida pública, la guerra, el socialismo o la democracia.

\subsubsection{Técnica, civilización y cultura}

La discusión en torno a los efectos negativos de la ciencia y el progreso durante los primeros años de la dictadura la progresiva adaptación de Die Frau a las ideas nacionalsocialistas. En 1935 aparecen dos artículos que tratan este tema y llegan a conclusiones diferentes.

Para Baumgart la técnica, la época de la industrialización es utilizada como una de las razones de la decadencia de la sociedad en los años veinte. La „naturaleza violada“ se venga del individuo en forma de decadencia social, desempleo, pérdida de las costumbres morales, etc. ${ }^{1081}$ La autora fundamenta la política familiar de Hitler, así como el papel de la renovación de la familia como paso principal en el cambio social y incide en el trabajo del Movimiento de la Mujer en sus esfuerzos por la conservación de la familia en las épocas de necesidad.

Ilse Acker-Wulf escribe por el contrario sobre el error de la tendencias actuales de convertir a la máquina, y la civilización en el moloch de las críticas de aquellos que consideraban que el progreso sólo traía degradación y decadencia y era responsable de las elevadas tasas de desempleo. La autora considera correcta la política de inversión financiera del gobierno como pieza fundamental en la renovación económica de Alemania.

Por otra parte señala que entre las mujeres se encontraban un gran número de partidarias de la vuelta a los valores de la naturaleza., y no se dan cuenta de los progresos que ha hecho la humanidad gracias a la ciencia y a la máquina. Un tiempo idílico donde las mujeres trabajaban en casa no ha existido nunca comenta la autora. Por el contrario inventos y adelantos de la técnica han servido para que la mujer tenga más tiempo libre. La palabra clave de la actitud ante la técnica es Vorwärts, hacia adelante.

\subsubsection{En contra del Socialismo}

„Socialismo y capitalismo se alzan sobre el mismo suelo. La formación de la concepción materialista de la historia fue decididamente combatida por el nacionalsocialismo. Ella era más un acto de fe que una teoría: La humanidad está condicionada por circunstancias e intereses materiales. El nacionalsocialismo 
quería realizar el socialismo en el marco de la nación. Lo que él bajo socialismo entendió, aparece definido por las claras formulaciones del marxismo." 1082

Así se expresaba Gertrud Bäumer en un manuscrito sin datar, aunque se puede deducir que éste fue escrito después de la guerra. A pesar de su falta de fecha, es interesante pues nos muestra un rasgo común que encontramos en los dos únicos artículos que sobre el socialismo se escriben en DIE FRAU. En ellos vuelve a repetirse el esquema de asimilación entre socialismo y capitalismo, entre materialismo e individualismo e incluso un miedo al „gran enemigo rojo“ que se prolonga hasta muy entrado el siglo XX. Estos términos son combativos con una gran dureza, especialmente el de marxismo:

„El marxismo más consecuente no es ningún socialismo sino una curiosa unión entre colectivismo e individualismo.“"1083

En 1936 con ocasión de la guerra civil española dedica un artículo, titulado Der Feind, „El enemigo", al bolchevismo sobre el significado de la amenaza que significa éste para la civilización occidental. El frío racionalismo ateo había causado, según Bäumer, la disolución de las estructuras familiares, la pérdida del sentido de Gemeinschaft. ${ }^{1084}$

La relación de éstos con el movimiento de la mujer, en épocas anteriores, desencadena una declaración de principios por parte de las escritoras de DIE FRAU, en la que se pretende dejar muy claro las diferencias de sus reivindicaciones, con las de las mujeres de otros países. El discurso que emplean a la hora de criticar las carencias del socialismo respecto a las mujeres comparte forma con las críticas que éste recibía en otros países de partidos conservadores de derecha. Concretamente, al hablar de las mujeres de la Unión Soviética, se define su proceso de liberación como un „falso proceso de emancipación“. Se critican las cifras de incorporación de mujeres a la vida laboral como insuficientes, y la inexistencia de mujeres en cargos de mayor responsabilidad. Se critica al marxismo como una entelequia que no funciona en los casos más cotidianos, como las mujeres musulmanas que no asisten a las reuniones del Komsomol por indicación de sus maridos. Por último se comenta la decadencia del núcleo familiar, crítica muy común de sectores conservadores de derecha en otros países europeos. Especialmente se hace hincapié en el individualismo de la ideología comunista donde las diferencias de género se diluyen en la colectividad, dónde la madre no trabaja para el padre, o para su familia sino para sí misma, en otras palabras la imposición de un egoísmo colectivo. ${ }^{1085}$

Finalmente la utilización del argumento religioso adorna un marco pintado con el lenguaje de la clase burguesa europea que mira con miedo al coloso ruso. El ateísmo produciría según las escritoras de DIE FRAU un sentimiento de soledad en las mujeres que conduciría a su aislamiento y la decadencia de las relaciones organizativas entre mujeres. ${ }^{1086}$

Junto a la crítica del socialismo ruso, existe paralelamente una valoración positiva de „otro tipo de socialismo“. Valoración que habría sorprendido en gran manera a Marx y a los demás teóricos del socialismo:

1082 BAK, NL 76, nº, Manuscrito sin datar de Gertrud Bäumer

1083 Bäumer, G.: „Die falsche Emanzipation. Zur Stellung der Frau in der Sowjet-Union“,

DIE FrAU, Octubre-Noviembre 1941 (nº1/2), p.1

1084 Bäumer, G: „Der Feind“, DIE FRAU, Octubre 1936, (n 1), pp. 3-7

1085 Bäumer, G.: „Die falsche Emanzipation. „, op. cit., p. 4

1086 Ibídem, p. 5 
„El socialismo sobre el que nosotros hablamos, no es el que es tan a menudo llamado socialismo. Este no es un sistema, una ideología, una máxima. No es un hecho doloroso producto de deberes sociales. El no viene desde arriba ni proviene del interés o de la razón. El socialismo del que hablamos aquí es más viejo que el socialismo primitivo, no tiene tiempo es eterno e incambiable como tal, aunque a veces cambia en su forma y estructura. En esta formación es el socialismo, dentro del espíritu dominante de la época, el movimiento más cercano a la naturaleza femenina. En su contenido es intemporal y ahistórico."1087

Este tipo de socialismo no es una ideología o un sistema político, ni un programa o un gobierno. Se trata exclusivamente de una cualidad femenina que define la naturaleza de ésta. Los cimientos de este socialismo femenino se encuentra en la Caridad, en la forma de la política, la reforma y la orientación social.

\subsubsection{El discurso religioso y la emigración interior}

El aspecto sociológico de la religión no ha pasado por alto a los investigadores. Desde la configuración de un tipo de moral económica, hasta la creación de una „ética“ política que legitima lo profano desde las altas cumbres de lo sagrado, la religión constituye desde el punto de vista ideológico una fuente para el individuo de justificaciones, legitimaciones de la realidad :

„El hombre vive inmenso en un mundo de creencias, aunque a menudo no sea consciente de ello, precisamente por la naturaleza interior de las mismas. Así se acepta y aprueba su casta, tribu y religión; considera justos los prejuicios de su grupo racial, el etnocentrismo de su país y la moral de su profesión." 1088

Al considerar „lo religioso“ como un elemento fundamental de regulación de las convicciones sobre la naturaleza de la realidad, creemos necesario abordar este tema con el fin de ahondar en la naturaleza del pensamiento y actitudes femeninas en cuestión. No estamos hablando de convicciones en un sentido espiritual, sino de la utilización que se hace del discurso religioso para legitimar, „sancionar“ una realidad, aun cuando ésta sea incompatible con los mandatos de cada una de las religiones. Por otra parte, como algunos historiadores del proceso civilizador, creemos que la confesión en el momento histórico que nos ocupa puede definirse también como un definidor social y político. Según estos autores, una de las características del proceso de modernización de finales y principios de los siglos XIX y XX, es el de la configuración de un modelo específico de cultura política en el que se configuran áreas regionales y confesionales con diferentes tendencias ideológicas y distintas tendencias políticas. 1089

DIE FRAU era una revista dirigida y escrita por mujeres de confesión protestante. Sin definirse como una publicación confesional, la revista trata en sus artículos temas de tipo religioso. Durante los primeros años de dictadura nacionalsocialista el discurso sobre lo religioso es una constante en las páginas de DIE FRAU. Cada Navidad, la revista dedicaba un número especial, ilustrado con imágenes de la sagrada familia, al estado de la cuestión. El discurso se articula en torno a varios temas: la sensación de crisis general que se agudiza cuando Alemania

Graefe, J.: „Liebe zum Lebendigen“, Die FraU, Agosto 1935, n 11, p. 686

Giner, S.: Sociología, Barcelona, Nexos, 1987, p.156

Peukert, D.: Die Weimarer Republik, Frankfurt am Main, Suhrkamp, 1987, p.149 
declara la guerra a Polonia, el descubrimiento de la interioridad religiosa, la situación de la mujer y sus vínculos con lo religioso, y las dudas ante una religión nacional (religión del pueblo) o una religión interior.

Durante los primeros años de la dictadura el discurso religioso documenta la sensación de caos y desorden de los últimos años de Weimar, la añoranza de tiempos pasados. La fe, protestante se presenta como una alternativa al mundo real. Una de los síntomas de esta crisis es la progresiva descristianización de amplios sectores de la población y de la pérdida de sus convicciones religiosas. El ejemplo más claro se encuentra en la Rusia Soviética. Las dos iglesias son llamadas a poner fin a la crisis de valores, aunque cada una de manera diferente; la católica en un sentido universal, la protestante debido a su unión especial con la nación alemana, en el ámbito germano. 1090

Uno de los temas que aparece con gran frecuencia en DIE FRAU es la crisis religiosa. La aparición de pequeños grupos religiosos, la pérdida de la fe de muchas personas, el descontento de los jóvenes respecto a la Iglesia protestante, es recogido de manera insistente. El relato sobre la crisis está descrito de manera sombría y dramática. La llegada de Hitler, y „su nueva Iglesia“, no se acepta con jubileo y alegría sino que se califica de „situación crítica“. Los hombres buscan a Dios pero no lo encuentran porque los hombres lo han asesinado. dios ha muerto. ${ }^{1091}$ Las palabras de Nietzsche son utilizadas para dar testimonio de una situación límite, una situación extrema en la cual la religión vive en sus momentos más grises. ${ }^{1092}$ Lo importante, es que „los hombres no reconocen que Dios ha muerto y esta actitud no puede definirse como atea sino como indiferencia y pasividad burguesa" ${ }^{1093}$. La crisis tiene por lo tanto sus raíces. Se critica un estado de la sociedad en la que lo religioso se ha convertido en una parcela más del alma. A ello ha ayudado en primer lugar la renovación que llevaron a cabo los filósofos de la Ilustración, Nietzsche y Kierkegaard. Esta independencia del hombre de lo religioso, es un peligro, por que desaparece por tanto todo tipo de coacción objetiva que limite a éste. No olvidemos que para la teología protestante, a diferencia de la católica, la naturaleza del hombre es por encima de todo pecadora. La iglesia ha perdido su fuerza como institución, su validez como garante del orden.

Junto al sentimiento de crisis se une el miedo a la pérdida de la identidad alemana. En las Navidades de 1934 Alemania ha tenido que cumplir uno de los últimos puntos del acuerdo de Versalles: la pérdida de la soberanía sobre el Saar. La situación es interpretada como algo apocalíptico, como una prueba más de Dios al pueblo alemán para finalmente demostrarle que Dios no ha olvidado a su pueblo (suplantación de los judíos). La crisis religiosa, el período de dificultad está inscrito en la historia de Alemania como un hierro de fuego que da a esta Nación su verdadera identidad. Es lo que se conoce como el sentido de la crisis:

„Ha sido más de una vez parte del destino alemán, incluso en la construcción del Reich ver como este perece entre las llamas en la Edad Media en lucha del imperio alemán con el papado, después en la reformación más tarde en la guerra de los treinta años- mientras que los (países) vecinos rápidamente al calor de las olas de aire que este fuego mandaba, protegidos por la paz de la civilización, vivían el noble florecimiento de sus culturas y podían recoger los frutos maduros de la

\footnotetext{
1090 Bäumer, G.: „Zum Schicksal des Christentums“, DIE FrAU, Abril 1934, (nº7), p. 387

1091 Paulsen, A.: „Glaube und Sein“, DIE FraU, Abril 1935 (nº ), p.385

1092 El filósofo alemán Alfred Baumler (1887) reinterpretó la filosofía de Nietzsche con objeto de que sirviera a los principios ideológicos del nacionalsocialismo. Baumler resaltó en la obra de Nietzsche la filosofía del heroísmo así como sus ideas sobre la capacidad de voluntad y la defensa de una elevada comunidad vital. Baumler relaciona la filosofía nietzscheana con los valores guerreros de los pueblos del norte.
}

1093 Paulsen, A.: „Glaube und Sein“..., p.385 
cultura occidental. Nosotros conocemos en la actualidad ese fuego que Dios ha encendido y que siempre bulle y quema la tierra alemana. Si no supiéramos esto pensaríamos que Dios ha muerto.“1094

La historia de Alemania es un producto de un plan creador de Dios. Cada guerra, cada crisis es producto de su intervención. También la próxima. La respuesta a la superación de esta situación tan problemática se encuentra en el pasado: la religiosidad de las tribus germanas es vista como modelo de consumación espiritual entre individuo y divinidades: „la religión no se sostiene en el ámbito estético. Tiene que ver con el conjunto de la existencia, principalmente con el problema del destino. Ella no es de ningún modo una cosa privada. Mito y culto están relacionados con el pueblo, con las costumbres." 1095 Las tribus germanas personifican ese ideal de sociedad en la que los hombres y las mujeres buscan por todos los medios reconciliarse con la divinidad a través del sacrificio y del esfuerzo (mirar lo referente al sacrificio de los seres humanos). La sociedad estaría organizada según el principio religioso, y la vida política dependería de éste también. El problema del hombre moderno es el „problema de la revelación“. En épocas anteriores las divinidades, los dioses eran inaccesibles a los hombres; en la actualidad el hombre conoce a Dios, éste se ha revelado, y el hombre quiere ser como Dios, y le olvida: „el Evangelio como promulgación de ésta revelación es la supresión y el fin de todas las religiones“.1096

Voces a favor de los Deutsche Christen se oyen también en DIE FRAU. La idealización del mundo germánico va unido a la consideración de que esa religiosidad proviene de la conjunción entre la patria, el origen y la raza; y puede ser un modelo a seguir para resolver la crisis religiosa y espiritual:

„La vida religiosa y su configuración en las formas de vida comunales está fundada sin duda alguna con los principios de la sangre y la tierra. (...) La sangre y la tierra configuran a los individuos del soleado sur de manera distinta que a los del norte frío y gris. En esto se basa la diferencia aunque no la inferioridad, como el pensamiento confesional afirma. Parece seguro que la procedencia y la patria ejercen una gran influencia sobre los individuos. Una lucha hacia la mirada interior, hacia el conocimiento verdadero, una seriedad y dificultad de las preguntas sobre la fe, están en relación con la naturaleza de los pueblos nórdicos. El hecho de que en los países del norte encontramos la religión protestante en mayor medida esta condicionado por la naturaleza. “ 1097

El protestantismo en particular, y el cristianismo en general es visto como una religión extraña al sentimiento religioso germánico. Este se encuentra influido por tendencias orientales que no se corresponden con el sentir del pueblo alemán. El protestantismo sería históricamente un intento, serio pero incompleto de adaptar la naturaleza religiosa del pueblo alemán a una reglamentación. 1098 Curiosamente se entiende el nuevo movimiento como específicamente religioso, sin implicaciones políticas. Aunque unas líneas después se presenta al nuevo movimiento como la unión entre religión y Weltanschauung; el fundamento de una ética, espiritualidad, una religión alemanas:

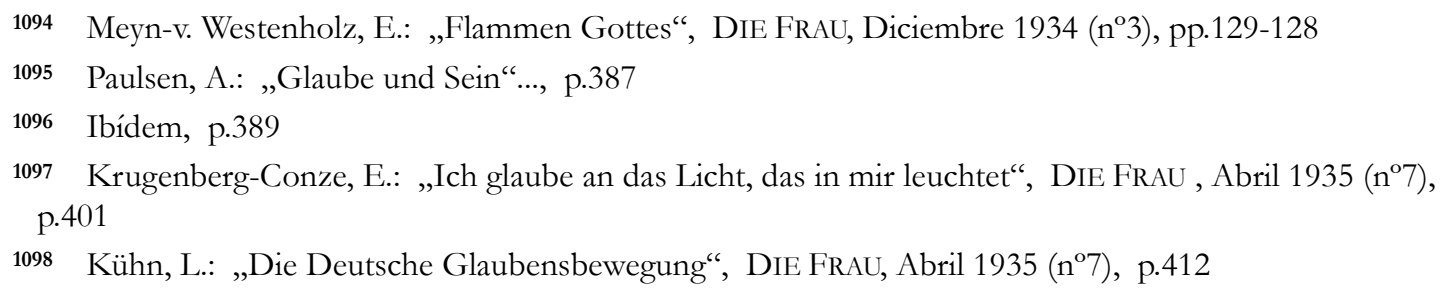


„Y se entenderá al movimiento de la fe alemán como lo que es: el único posible camino para la perfección de la propia contemplación, el autoencuentro perfecto de un pueblo. Ya que sin raíces no es posible el florecimiento vital y la verdadera renovación."'1099

Existen no obstante voces en DIE FRAU que difieren de esta valoración de los cristianos alemanes. Magnus-von Hausen crítica abiertamente la arrogancia del nuevo movimiento religioso que pretende sustituir al cristianismo por una versión alemana de éste. ${ }^{1100}$ Sin embargo aunque da la bienvenida a los intentos de renovación de la iglesia confesora, Bekenntniskirche, crítica la implicación política de la iglesia:

„En los servicios religiosos de la Iglesia Confesora se tiene la impresión de que una nueva Iglesia debe aparecer. Pero una cosa tiene que ser expresada explícitamente: Oposición política, da igual lo poco que la naturaleza del estado pueda sin daños a largo plazo prescindir de ésta, tiene que buscar sus propios caminos y no debe bajo ninguna circunstancia esconderse en las problemas de opinión de las iglesias. Justo porque por parte de la otra parte hemos sentido con horror como se mezcla en asuntos eclesiásticos, queremos mantener la objetividad del alma tan pura como nos sea posible. ${ }^{1101}$

En el fondo no se critica el contenido que propagaba la nueva religión. Lo que importa es que la independencia de la iglesia respecto al poder político sea lo que motivó al cambio de ésta. Postura que, como ya hemos visto con anterioridad, encontramos también entre las mujeres protestantes, para quienes la neutralidad más importante que el debate teológico.

En esta misma línea de crítica al movimiento de los cristianos alemanes se pueden considerar la interpretación del momento de crisis que hacen, Gertrud Bäumer y Marianne Weber. El problema de la crisis religiosa, según ellas, es que ésta no existe como tal, „(las crisis) provienen de la superficialidad y no de la profundidad de la vida religiosa" 1102 , sin embargo la crisis está ahí, y es más peligrosa de lo que parece y atenta contra la „naturaleza del individuo“. No importa si éste es alemán o chino, lo religioso afecta fundamentalmente al individuo y a Dios. Partiendo de aceptación de lo religioso como algo personal e individual, no es extraña pues la pregunta sobre la relación entre las obligaciones que tiene el individuo con Dios, y los deberes con el Estado:

„El cristianismo como religión universal, la que por encima de todo es religión en el más profundo sentido, no puede crearse, dada su naturaleza, para servir a un pueblo, o a un estado el apoyo ideológico necesario para sus fines populares o estatales. No es ninguna Lebenslebre para la autoafirmación en la esfera del poder. No es ningún sistema de valores y virtudes populares burguesas.“ " 1103

Desde DIE FRAU se recomienda la no politización de lo religioso, y se llama a los cristianos católicos a la cooperación para la renovación de la fe:

\footnotetext{
1099 Ibídem, p. 415

1100 Magnus-von Hausen, F.: „Hatten wir eine Kirche?, DIE FrAU, 1933, pp.428-432; „Zwangsweise Christianisierung“, DIE FRAU, Enero 1938, (n²), pp.169-176

1101 Ibídem, p. 432

1102 Bäumer, G.: „Zum Schicksal des Christentums“, DiE FraU, Abril 1934 (nº7), p.387

1103 Ibídem, p.388
} 
„La Iglesia debe ser reformada por aquellos que buscan la Iglesia. Una religión debe construirse desde su propia esencia, desde lo religioso, y debería por encima de todo hacer crecer el amor.“"1104

Son posturas que recuerdan el tono de la Iglesia Confesora. Sin embargo Frances Magnusvon Hausen advierte contra „la oposición política“ dentro de la iglesia, los caminos de ésta deben ser otros. La aparición de grupos religiosos como el Deutsche Glaubensbewegung o el Nationalkirchliche Glaubensbewegung der Deutschen Christen, de inspiración nacionalsocialista es analizado en DIE FRAU como una muestra del ímpetu religioso de la generación más joven que busca una crear una iglesia nacional alemana lejos de los dogmas y de las enseñanzas de las dos confesiones. Ante tal impetuosidad se reacciona desde Die Fran con soltura: en vez oponerse vehemente al nuevo movimiento se aconseja esperar a que éste se tranquilice para evitar la división de las iglesias., especialmente en el caso de la iglesia protestante. ${ }^{1105}$

Si la primera corriente que encontramos valora el mundo nórdico, y las tribus germánicas son las primeras cédulas de identidad nacional alemana, la otra versión, apoyada por Bäumer, Weber y Magnus-von Hausen vuelven sus ojos a la Edad Media, y ante las críticas de aquellos próximos a los movimientos de los cristianos alemanes, consideran al cristianismo como la seña de identidad de lo alemán: Esto significa no sólo la afiliación a un código religioso, sino a uno ético, de comunidad, libertad y tolerancia hacia otras confesiones y otros pueblos. Para estas autoras religión y política son campos bastantes diferenciados, y la religión, mejor dicho la Iglesia tiene el deber moral de constituirse en avanzada y vanguardia crítica de la sociedad. Según Christine Wittrock la actitud de Gertrud Bäumer hacia la historia tiene tintes fuertemente religiosos. De esta relación se entiende la predilección que esta autora tenía por épocas históricas como el imperio romano o la edad media, donde según ella se manifestaban la imagen del reino de Dios.

Habíamos comentado con anterioridad las referencias continuas que los Cristianos Alemanes hacían a los valores germanos, como encarnadores del espíritu de Alemania. Esta misma idea se puede encontrar en las mujeres nacionalsocialistas que reivindicaban el nacimiento de una nueva cristiandad, en la que la mujer recuperara los privilegios de esposa y madre que habían sido destruidos en la época moderna por el americanismo, el materialismo y el mammonismo, Fe, Amor y Esperanza; Verdad, Pureza y Amor 1106 eran los grandes valores de las grandes mujeres de raza nórdica que podían hacer frente a los peligros que amenazaban al Pueblo, a Dios y a la Patria. ${ }^{1107}$

\subsubsection{La mujer germana y el cristianismo}

En la ideología nacionalsocialista aparece la mujer germánica como modelo a imitar. La llegada del cristianismo es interpretada por los ideólogos del nacionalsocialismo como una pérdida de los valores del pueblo germánico que se repercutió de igual manera en la situación de la mujer en la sociedad. El cristianismo con sus influencias hebreas hizo que la mujer perdiera su soberanía en las tribus germánicas.

\footnotetext{
1104 Magnus-von Hausen, F.: „Hatten wir eine Kirche?“, DIE FraU, Abril 1934 (nº7), p.432

1105 Glaue, H.: „Aus dem Suchen der Zeit““, Die FraU, Abril 1934 (nº7), pp.391-394

1106 Nótese la alusión trinitaria.

1107 Koonz, C.: Mütter im Vaterland..., pp.28-29. Este argumento sobre las condiciones de las mujeres de las tribus germanas aparece también en Alfred Rosenberg, aunque.
} 
Gertrud Bäumer responde en DIE FRAU con un artículo publicado en 1934. De una manera bastante sutil critica la postura de las nacionalsocialistas desde dos puntos de vista: en primer lugar no considera que la mujer alemana haya sido sometida por el cristianismo:

„En la actual y apasionada discusión sobre el valor y el efecto del cristianismo sobre la naturaleza y el desarrollo de las tribus germanas se argumenta que la mujer germana ha sido oprimida por el cristianismo. Este argumento es desde un principio no del todo correcto. Donde quiera que la mujer haya sido considerada inferior, las cualidades biológicas han sido decisivas para que su naturaleza siempre haya sido comparada con la del hombre de modo que las cualidades de la mujer parecen siempre inferiores a las de éste.“"1108

La opresión según la autora obedece más que a causas estructurales y culturales, como por ejemplo la influencia oriental, concretamente a la griega, que a la influencia de una religión en concreto. Una religión, como la cristiana, que busca un sentido a la vida, y no la fundamentación de las diferencias biológicas, y que incluso niega tal diferencia: „Aquí no hay hombre, ni mujer“, debe por lo tanto olvidar las diferencias biológicas entre el hombre y la mujer. La naturaleza del cristianismo es para Gertrud Bäumer ayuda a superar las diferencias entre hombres y mujeres y argumenta con el caso de los inicios del cristianismo inglés e irlandés, del que se deriva el alemán, como una de las épocas de mayor libertad para la mujer. ${ }^{1109}$

Sin abandonar su entusiasmo por la época precristiana alemana, Bäumer señala la importancia de la edad media en la historia alemana y con ella el valor positivo del cristianismo para la mujer alemana. No el mundo germánico, sino la edad media serían las columnas del ser alemán. Con esta interpretación se aleja de los planteamientos nacionalsocialistas sobre la historia de Alemania. Esto mismo argumento caracteriza su obra sobre hombres y mujeres de la Edad Media que se publica en el mismo año. ${ }^{1110}$ De esta interpretación que Bäumer hace de la historia se deducen dos consecuencias, por un lado la autora legitima la posición de preponderancia de la mujer en una época a la que la mayoría de los alemanes miran iniciadora del espíritu alemán, y por otra parte revaloriza el cristianismo, como igualador entre los hombres y mujeres, frente a aquellos los valores germanos como las verdaderas referencias de Alemania.

A partir de la fundamentación histórica de la igualdad de la mujer en los primeros momentos de la cristianización en Alemania, Gertrud Bäumer va más allá. Haciendo suyas las palabras de Hieronymus: „Yo no hago ninguna diferencia entre los hombres y mujeres sagrados de la iglesia. Para los dos el trabajo religioso es el mismo." "1111 La intervención de las mujeres en los asuntos religiosos puede llevar a la Iglesia a perder su situación de rigidez, y a superar la crisis en la que está hundida; la solución se encuentra en el pasado. No sabemos si se trata de una argucia literaria o simplemente un gusto por el historicismo, sin embargo, el pasado recobra un elemento legitimador y moral en este caso, para justificar la participación de la mujer en la vida religiosa. Un ejemplo ilustrativo es un artículo sobre las mujeres de la antigüedad que dirigían cultos religiosos en el que se vuelve a repetir una visión de lo femenino que no nos es desconocida: la mujer como intermediaria entre la realidad y la naturaleza, entre lo cotidiano y lo desconocido:

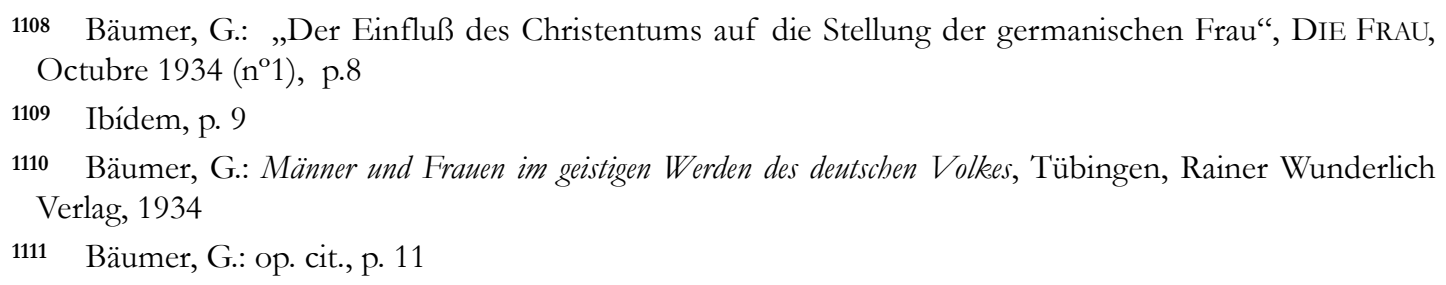


„Sabia, observa la sacerdotisa la vida y la muerte, el sueño y la realidad, el oscuro delirio y la claridad, la el sufrimiento y la redención." "1112

Y gracias a su naturaleza especial lo femenino tiene la facultad de sanar, de cuidar, de amar; de velar en el silencio por la tranquilidad de los otros:

„La mujer aparece como el soporte de las fuerzas sagradas como mediadora de la esencia del poder que supera a la muerte." ${ }^{\prime 1113}$

Esta facultad femenina ligada con la compresión de lo sagrado, no es histórica; no se remite únicamente a un suceso del pasado, sino constituye un seña ,premonitoria“ de la verdad de los valores del cristianismo, valores que se engendrarán posteriormente en personas como Hölderlin o Nietzsche „mediadores“ de lo oscuro, de lo dionisiaco, traductores de una verdad que se manifiesta a los demás a través de gestos y palabras incomprensibles.

Desde DIE FrAU se pide una mayor responsabilidad para las teólogas, se exige que estas puedan dirigir los cultos religiosos, puedan consagrar, puedan al igual que los hombres revelar la parte de su naturaleza que las une con lo sagrado:

„ (...) una mujer no necesita callar en la comunidad, no puede callar, cuando

Dios quiere que ella diga lo que tiene que contar a los hombres. “1114

La confesionalidad de estas mujeres determina en gran medida sus formas de actuar. Ellas no diferencian totalmente entre esfera religiosa y esfera pública, constantemente apelan a su condición de cristianas para subrayar la paradoja existente entre Estado y Religión, Estado e Individuo. La Religión se orienta hacia el cultivo de lo individual, la búsqueda del bien en un mismo , y la preparación del reino de Dios en la tierra. Lo religioso apela al amor a uno mismo, y sobre todo el amor al prójimo como la realización más elevada del individuo. De ahí la dificultad que tienen autoras como Dorothee van Velsen, Gertrud Bäumer y Marianne Weber en aceptar un término como „religión del pueblo“:

„¿Es posible hablar de religión del pueblo entendiendo que ésta consiga llegar a y representar a un pueblo entero? Si y no. El pueblo somos todos nosotros; si miramos al fondo de nosotros mismos la diferencia de la educación no impide que todos busquemos las mismas cosas (...).“"1115

En un lado opuesto se encuentra la ética del Estado, una ética que olvida al individuo y que se dirige fundamentalmente al pueblo. El individuo es limitado, su vida es corta, pero el pueblo como totalidad pervive para siempre.

\subsubsection{Reacciones ante la ley de esterilización}

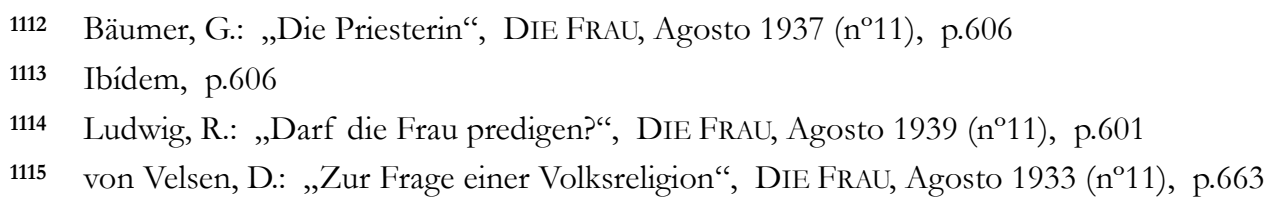


Una de las primeras medidas tomadas por el gobierno de Hitler, tras su nombramiento como canciller fue la promulgación de la ley de esterilización el cuatro de julio de 1933. Diez días después le sigue una nueva ley, Gesetz zur Verbütung erbkranken Nachwuchses, donde se establecen las medidas necesarias para evitar la concepción de descendencia con posibles taras genéticas. El número de personas esterilizadas entre 1934 y 1945, afectadas por la Ley, fueron unas 400.000. Ésta establecía que aquellos que sufrieran una enfermedad hereditaria, debían ser esterilizados con el objeto de no perpetuar la enfermedad. Como enfermedades hereditarias se entendían: debilidad mental, esquizofrenia, demencia, epilepsia hereditaria, síndrome de Huntington, ceguera y sordera hereditarias, malformaciones corporales, el alcoholismo en su grado más extremo. ${ }^{1116} \mathrm{Si}$ los implicados eran mujeres con una sexualidad precoz, o se observaba falta de progreso y aplicación en la escuela, pequeños detalles como el robar o el mentir, o incluso decir tacos, unido a la existencia de unos padres con ciertas deficiencias mentales, eran la garantía para su internamiento en campos de protección de menores donde se procedía a su esterilización. 1117 En el caso de que el afectado/a se niegue a efectuar la operación, la ley prevé la esterilización forzosa.

La primera reacción en DIE FRAU aparece en marzo de 1934 dónde se informa sumaria y objetivamente sobre la ley. ${ }^{1118}$ En 1942 se hace un comentario exhaustivo de ésta y se llega a la conclusión de la gran „utilidad“ para mantener al pueblo alemán inmune a enfermedades genéticas que pudieran manchar su pureza. Por otra parte, el mantenimiento de las personas que padecen las enfermedades mencionadas anteriormente, cuesta al Estado alemán un dinero que podía ser invertido con otros fines:

„(...) Tenemos en la actualidad tantos millones de individuos que padecen enfermedades de transmisión genética a los que se les puede aplicar la ley; ellos cuestan al año tantos millones de Reichsmark: gracias a la esterilización dentro de unos 30 o 40 años ellos habrán desaparecido de la población con lo cual esos millones estarán libres para otros fines.“ "1119

Resumiendo, podríamos hablar de la existencia de dos tipos de discurso: uno profundamente relacionado con la ideología nacionalsocialista, y otro nacionalista y protestante, representado en los textos de Gertrud Bäumer, Marianne Weber etc. En ambos discursos no existe una huella aparente de crítica, por el contrario, la impresión que se siente en todo momento es la del apoyo incondicional, y la del silencio.

Sin embargo sin quererlo, el segundo grupo de autoras son víctimas de una politización del discurso religioso: lo religioso aparece dotado de una función niveladora entre individuo y Estado. A diferencia del discurso nacionalsocialista que pretendía erosionar esa función, los discursos que aquí se presentan, buscan un lugar donde lo religioso puede acomodarse, intentan preservar a la religión protestante de sus características originarias. Se trata pues de evitar que la religión deje de tener un papel fundamental en la vida de los ciudadanos, se intentaba defender una ética que finalmente como todo el mundo conoce se traiciona a si misma, un modo de vida, una estabilidad y una tranquilidad, que ni siquiera la muerte de millones de personas podían trastocar.

1116 Bluhm, A.: „Das Gesetz zur Verhütung erbkranken Nachwuchses. Eine kritische Würdigung“, DIE FrAU, Junio $1934\left(\mathrm{n}^{\circ}\right.$ 9), p.532

1117 „Unterbringung von weiblichen Minderjährigen im Jungendschutzlager Uckermark“, Stadtarchiv Heidelberg, n¹921; Normalia-Generalia: Errichtung von Jugendwohlfahrt. Errichtung von Jugendschutzlagern, Fach 106, 1941-1944

1118 Lenz-von Borries, K.: „Zum Sterilisierungsgesetz“, DIE FrAU, Marzo 1934, nº 6, pp. 354-357

1119 Bluhm, A.: op.cit., p.536 
Este cierto alejamiento de la teoría biológica de los nacionalsocialistas se manifiesta también en los comentarios a la literatura sobre la ley de salud matrimonial de 1935, donde se comenta la importancia de la herencia „popular“ y de la tradición intelectual como elementos que junto a los puramente genéticos configuran la personalidad de un individuo. ${ }^{1120}$ Como anécdota es el rechazo que encontró una de las obras que incluía a enfermos, sufragistas y a mujeres poco femeninas entre los no recomendables para contraer matrimonio. ${ }^{1121}$

Respecto a la relación concreta mujeres-religión volvemos a encontrar una suave reivindicación de la actividad de la mujer en todos los campos, aunque en esta reivindicación la condición de „mujer“ está limitada a unas pocas. Reivindicación selectiva por tanto.

\subsubsection{El discurso sobre el trabajo}

„Por primera vez durante muchos años, la figura encorvada con manos abultadas y los ojos casi cerrados de coser en la oscuridad, (...), salió de su lavadero, dio un paseo al aire libre y fue a la fábrica. Este fue el primer y doloroso paso hacia el camino de la libertad.“ (Virginia Woolf, 1929) ${ }^{1122}$

A comienzos del siglo XX, y en especial durante la República de Weimar, 1919-1933, las mujeres alemanas comenzaban a recorrer este „doloroso camino hacia la libertad“, que Virginia Woolf menciona. Sin embargo en 1933 la llegada al poder del Partido Nacionalsocialista frustró en gran medida las posibilidades de emancipación de la mujer.

Como ya hemos señalado al comienzo de nuestra investigación, una de las primeras medidas que llevó a cabo Hitler fue la disolución de todas las organizaciones políticas. Esta medida afectó unos años más tarde a las Franenvereine, organizaciones de mujeres (literarias, religiosas, de ayuda asistencial), cuya proximidad a puntos de vista feministas las relacionaba sospechosamente con „lo judío“.1123 En total unas 230 asociaciones femeninas fueron abolidas. Se mantuvieron sin embargo diferentes publicaciones, revistas femeninas, que a pesar de un incierto pasado liberal, llegaron a un pacto con las estructuras de poder, comprometiéndose a reproducir en sus páginas la ideología nacionalsocialista. ${ }^{1124} \mathrm{El}$ aspecto antifeminista del nuevo régimen se registra por parte de la prensa confesional y no confesional como una vuelta de las mujeres al mundo del hogar, de la familia y de los hijos. Esto hace que durante los primeros

1120 Graefe, J.: „Gattenwahl zu ehelichem Glück und erblicher Ertüchtigung“, DIE FRAU, Febrero 1942, n $5-6$, p. 93

1121 Ibídem, p. 94

1122 Woolf, V.: A Room of One's Own, London, Grafton Books, 1988, p.41

1123 „La palabra, emancipación de las mujeres, es sólo una palabra inventada por el intelecto judío, y el contenido está impregnado por el mismo espíritu. La mujer alemana no necesito emanciparse en los momentos más importantes de la vida alemana.“ en: Domarus, M. (ed.): op.cit., p.450, Discurso de Hitler a las mujeres alemanas (Nürnberg, 8. September 1934)

1124 El punto 21 del programa del NSDAP mostraba lo importancia de la protección a la mujer y a la juventud en la consolidación del Estado nacionalsocialista: „Para el fomento de la salud del pueblo el Estado debe preocuparse del apoyo a la madre y al hijo a través, de la prohibición del trabajo juvenil, a través de la producción de medios de educación corporal, a través de una gran protección de todos con la institución de organizaciones juveniles de formación corporal.“ 
años de la dictadura el tema del trabajo femenino sea tratado con profusidad como una de las críticas que se hace hacia el nacionalsocialismo. Die Frau no constituye una excepción.

\subsubsection{Política laboral femenina durante el nacionalsocialismo}

„Nosotros no necesitamos mujeres que puedan producir, sino mujeres que con sentido y juicio puedan administrar lo que ha ganado el hombre.“ ( Joseph Goebbels) ${ }^{1125}$

Uno de los principales problemas de Alemania en 1933, fecha en la que Hitler toma el poder, es la tasa de desempleo. Cuatro millones, ochocientos mil hombres y un millón de mujeres. Una de las medidas que se lleva a cabo para luchar contra este problema es la limitación de las posibilidades de trabajo para las mujeres. Junto a ella se elabora una ideología antifeminista en la que se conminaba a las mujeres a volver al hogar. Su papel de madre era mistificado hasta la saciedad en los discursos oficiales, en el arte y en el cine. Preservando a la madre, se preservaba a la familia, la cual según Hitler y sus ideólogos era la célula de la vida del pueblo alemán. Sin la mujer dedicada a su papel de madre y esposa la dirección de la nación alemana no podía sobrevivir.

„Si nosotros afirmamos que el hombre es el estado, el mundo del hombre es su compromiso, su lucha en beneficio de la comunidad, podríamos entonces decir que el mundo de la mujer es un mundo más pequeño. Su mundo es su marido, su familia, sus hijos y su hogar. Pero, ¿donde estaría el gran mundo si nadie quisiera cuidar del pequeño mundo?, ¿cómo podría existir el gran mundo si no hubiera alguien que adquiera la responsabilidad de preocuparse por el mundo pequeño, el centro de su vida? No, jel gran mundo se apoya en el mundo pequeño! El gran mundo no podría sobrevivir si el pequeño mundo no esta seguro." 1126

La política de trabajo femenina puede dividirse en dos etapas. De 1933-1937 donde se muestra una constante disminución de la participación laboral femenina. Durante este período se promulga la ley para la disminución del paro, Das Gesetz, zur Verminderung der Arbeitslosigkeit, 1 de junio de 1933. Esta ley contemplaba una serie de medidas para alejar a la mujer de los puestos de trabajo, como la campaña contra la Doppelverdiener, dirigida a las mujeres trabajadoras cuyo marido, hermano o padre ocupaban un puesto de trabajo. Al mismo tiempo se ofrecían préstamos a aquellas parejas que contraían matrimonio, siempre y cuando la mujer hubiera dejado su puesto de trabajo un año antes de la fecha de la boda. A partir de agosto de 1934, los directores de fábricas y empresas fueron autorizados a sustituir mujeres solteras menores de 25 años por padres de familia sin trabajo. A las 130.000 mujeres despedidas se les procuró un puesto de trabajo en el servicio doméstico o en la agricultura. ${ }^{1127}$

Esta reducción del número de mujeres de la población activa se extiende también a la universidad. Las mujeres que quisieran acceder a ésta no podían rebasar la cuota de un $10 \%$ Este interés en que

1125 Bajohr, S.: Die Hälfte der Fabrik. Geschichte der Franenarbeit in Deutschland 1914-1945, Marburg, Verlag Arbeiterbewegung und Gesellschaftswissenschaft, 1979, p.219

1126 en: Domarus, M. (ed.): op.cit., p.451, Discurso de Hitler a la Organización de mujeres nacionalsocialistas (Nürnberg, 8. September 1934)

1127 Frevert, U.: Frauen-Geschichte. Zwischen bürgerlicher Verbesserung und neuer Weiblichkeit, Frankfurt am Main, Suhrkamp, 1986, p.210 
las mujeres permanecieran en el hogar, en especial las casadas, radica también en uno de los pilares principales de la política nacionalsocialista: el crecimiento de la población y la regeneración de la familia, factor central y determinante de la pureza de la raza, y sobre todo como parte la de la política de propaganda se pretendía crear una sensación de restauración del orden social donde las relaciones entre los géneros recobraban por fin el camino habitual. 1128

Una segunda etapa de la política laboral respecto a las mujeres comienza a finales de 1939. El 4 de septiembre de 1939, una semana después de la declaración de guerra de Francia e Inglaterra el servicio femenino se hace obligatorio. Todas las mujeres solteras entre 17 y 25 años que no trabajan, o que no se encuentran en su formación profesional, y no son necesarias en sus lugares de trabajo, (por ejemplo en la agricultura o en la ganadería) están obligadas a hacer el servicio femenino. ${ }^{1129}$

La medida estaba dirigida fundamentalmente a prestar ayuda a las mujeres que se había hecho cargo del trabajo masculino en la agricultura y en la ganadería. Con la llegada de la guerra, la mano de obra masculina se encuentra en el frente, y sin una ayuda adicional, hubiera sido imposible sacar adelante el trabajo en el campo. El éxito de la medida, a pesar de la propaganda, no fue considerable. En las memorias de una campesina de Baviera que tuvo que hacerse cuenta de la finca de su marido durante la guerra, cuenta lo difícil que era recibir una muchacha, y en segundo lugar, la ineptitud de éstas para adaptarse a la dura vida del campo. ${ }^{1130}$

Polonia había sido conquistada pero Francia e Inglaterra se encontraban en guerra con Alemania. Es en este momento cuando los líderes del Tercer Reich discuten la posibilidad de reclutar a mujeres para el trabajo en las fábricas. La decisión fue negativa, sin embargo no definitiva. Durante los años siguientes hasta 1945, se observa una política de vacilación en torno a este tema. En enero de 1943 se hace una llamada general a hombres y mujeres de edades comprendidas entre los 16 y 45 años (a las mujeres desde los 17), para que se presenten en las oficinas de trabajo y declaren sobre su situación laboral. ${ }^{1131}$ Esta medida afectaba a aquellas personas que trabajaban por lo menos 48 horas semanales, a aquellas en cuyas fábricas, empresas o talleres empleaban a más de 5 personas, a todo el mundo que trabajaba en el campo o en lugares de carácter asistencial. La medida afectaba también a los estudiantes, a mujeres embarazadas, y a mujeres con hijos únicos mayores de seis años y con dos hijos mayores de catorce años. El resultado de ésta llamada fue un fracaso. Las mujeres no se presentaron o evitaron por encima de todo presentarse.

1128 „La profesión esencial, que se nos puede asignar, es la maternidad. Esta profesión se ha convertido actualmente en una excepción y está por encima desacreditada. (...) A través del rechazo de la profesión de la maternidad, los hijos de estas madres no son individuos con gran fuerza moral sino individuos necesariamente tristes y no capacitados para la el éxito en la vida." en: Scholtz-Klink, G.: Die Frau im Dritten Reich. Eine Dokumentation, Tübingen, Grabert Verlag, 1978, p.492

1129 Bäumer, G.: „Arbeitsdienstpflicht im Rahmen der deutschen Frauenerziehung“, DIE FrAU, Octubre $1940, \mathrm{n}^{\circ} 1$, p. 5.

1130 Wimschneider, A.: Herbstmilch. Lebenserinnerungen einer Bäuerin, München-Zürich, Piper, 1987

1131 Stephenson, Jill: Women in Nazi Society, London, Croom Helm, 1975

Mason, Timothy: „Zur Frage der Frauen in Deutschland 1930-1940“, BEITRÄGE ZUR MARXSCHEN THEORIE, 1976 (año 6), pp.118-193

„Women in Germany 1925-1940. Family, Welfare and Work“ (part I and II), HiSTORY WORKSHOP. A JOURNAL OF SOCIALIST HiSTORIANS, part I: 1976 (primavera), pp.74-113 / part II: 1976 (otoño), pp.532

Sozialpolitik im Dritten Reich: Arbeiterklasse, Volksgemeinschaft, Opladen, Westdeutscher Verlag, 1977

Rupp, L.J.: „Klassenzugehörigkeit und Arbeitseinsatz der Frauen im Dritten Reich“, SOZIALE WELT. ZEITSCHRIFT FÜR SOZIALWISSENSCHAFTLICHE FORSCHUNG UND PRAXIS, 1981 (n²), p.192 
Las causas de esta negativa no están muy claras. Los trabajos de Tim Mason y Jill Stephenson aluden a una reacción pública de las mujeres que podría definirse como oposición al régimen. Otros como Winkler apoyan la tesis en la que se interpretaba esta negativa como el resultado de la política de trabajo nazi que no admitía la posibilidad de que la mujer trabajase. Finalmente Leila Rupp tiene en cuenta la clase social a la que pertenecen las mujeres, y observa que en las mujeres de clase media y alta son las que más se oponen a su „reclutamiento“, y las mujeres trabajadoras acceden a éste porque no tienen otra alternativa. Mi opinión se acerca a la de esta última autora: si bien la política de antifeminista de Hitler hizo mella en el ánimo de las mujeres, existía ya de por sí una mentalidad femenina antitrabajo en tiempos de guerra que volvía surgir de nuevo cuando el fracaso y la derrota se hacían evidentes. ${ }^{1132}$

\subsubsection{Significado y relevancia del trabajo femenino en DIE FRAU}

En el análisis que hemos realizado sobre los textos hemos descubierto una serie de constantes que aparecen en los artículos de opinión, informes y noticias breves sobre la situación laboral de la mujer. Especialmente en DIE FRAU se vivió intensamente la polémica en torno a la necesidad del trabajo femenino, la cual comenzó, al promulgarse la „Ley para la disminución del desempleo de 1933“, cuyas medidas limitaban el acceso de la mujer a determinados puestos de trabajo y en los que indirectamente, a través de ayudas estatales, se conminaba a la mujer trabajadora a volver al hogar. Más tarde esta discusión alcanzó su punto culminante, ya en época de guerra, cuando las mujeres fueron esta vez llamadas a trabajar, para sustituir a los hombres que luchaban en el frente.

La doble actividad Maternidad-Trabajo es defendida en un gran número de artículos. La mayoría de ellos fueron escritos entre los años 1933-1935, momento en el que la propaganda nacionalsocialista incidía en sus propósitos de retirar a las mujeres de la esfera laboral.

Trabajo en general significa para DIE FRAU servicio, Dienst, formación personal, persönliche Formkraft, y educación en la comunidad del pueblo, Erziehung zur Volksgemeinschaft. Desde estas premisas transcurre la línea principal del discurso sobre el trabajo que quiere fundamentar lógicamente la necesidad del trabajo femenino. No se trata de reivindicaciones entendidas como derecho, tal y como las conocemos en el antiguo movimiento de la mujer, el trabajo aparece como un deber, como una obligación de la mujer hacia si misma, y lo que es más importante, para su pueblo. 1133

La postura de la redacción es clara. En un principio se argumenta desde el punto de vista económico. Se critica la postura nacionalsocialista y se defiende la actividad laboral de las mujeres casadas como una ganancia para la comunidad, y como una manifestación del principio de rentabilidad. La contribución de las mujeres solteras y casadas a la economía familiar es tan importante que resultaría para las familias un gran sacrificio la desaparición de esta fuente de ingresos adicional:

„Hay que añadir que son a menudo justamente las personas que muestran una capacidad de mayor rendimiento, los que intentan mejorar su situación financiera y su modo de vida a través del Doppelverdienst. Algunas familias sin embargo no pueden ser fundadas ya que hombre y mujer tienen que seguir trabajando. (...) La lucha contra la doble ganancia es por lo tanto asocial, en tanto que castiga la voluntad de una persona o de una familia de mejorar la situación financiera. La

\footnotetext{
1132 Rüpp, L.: op. cit., p.191

1133 Bäumer, G.: „Arbeitsdienstpflicht im Rahmen der deutschen Frauenerziehung“, DIE FrAU, Octubre $1940, \mathrm{n}^{\circ} 1, \mathrm{p} .3-8$
} 
doble ganancia que se basa en la pura acumulación de capital permanece sin embargo sin castigar, porque existen intereses que fomentan la necesidad de la acumulación de capital."”1134

En segundo lugar se señalan las repercusiones negativas que estas medidas podrían traer para la familia, ya que la madre trabajadora contribuye con su trabajo desde el punto de vista económico y personal a mantener la salud de la institución familiar:

„Nosotros podríamos decir: también aquí y especialmente en todas partes, donde un individuo aprende a controlarse a si mismo, a rendir paulatina y continuamente en un trabajo y a vivir con otros individuos en paz y en comedida armonía. Esto se aprende en la vida profesional de ahí su importancia para la mujer y para la futura madre." 1135

El trabajo es utilizado como un concepto moral en el hombre y la mujer se realizan como individuos y cuya ejecución favorece el desarrollo de determinados valores: la realización personal, el control del hogar, el cuidado de los hijos, expectativas más realistas del matrimonio. 1136

Este principio de realización personal no se presenta como un mero „derecho individual“, sino en función del servicio que se presta a la comunidad. De nuevo se intenta fomentar la creación de una élite en función de la calidad de su trabajo: el rendimiento y no la realización personal es lo más importante:

„(...) el apoyo( a las medidas) que fomentan la opinión de que no debiera dar trabajo realmente a quién lo necesita económica sino a quien mejor pueda rendir en éste, no es individualista. También el florecimiento de la economía que carga con totalidad de un pueblo se esfuerza en la cualidad, especialmente en lo que se refiere a las capas dirigentes, todos aquellas fuerzas productivas, todos aquellos cuya fuerza de creación es decisiva para los pueblos. No es indiferente si la totalidad de rendimiento laboral de un pueblo depende de fuerzas más o menos preparadas." ${ }^{1137}$

La progresiva desaparición de las mujeres de puestos de responsabilidad levanta indignación y protesta. No se critica que el despido se produzca por causas políticas, sino por que se entiende una atmósfera general de rechazo de la participación de las mujeres en puestos de mayor responsabilidad:

„No puede dejar de llamar la atención que el número de mujeres en puestos de responsabilidad en las escuelas ha disminuido considerablemente, y esto no se debe únicamente a la expulsión de las mujeres que tenían antecedentes políticos (durante Weimar), sino a la predisposición negativa existente respecto a la ocupación de los puestos de responsabilidad en los centros educativos por mujeres. La administración de los centros que bloquea todo tipo de posibilidad de

1134 DiE FraU: „Zur Frauenbewegung. Berufliches“, Diciembre 1933, nº 3, p.181

1135 von Zahn-Harnack, A.: „Mütterschulung“, DIE FrAU, Diciembre 1933 (nº3), p.148

1136 Lenz-Borries, K.: „Frauenstudium und Frauenauslese“, DIE FraU, Enero 1934 (nº4), p.204

1137 Bäumer, G.: „Bilanz 1934“, DiE FraU, Enero 1935, n 4, p.195 
conceder a mujeres puestos donde sea posteriormente posible una ascensión en la escala profesional."'1138

Desde DIE FrAU se plantea la necesidad de un grupo de mujeres capaz de ocupar puestos de responsabilidad, donde éstas puedan dirigir al resto de las mujeres en la tarea de servir a la comunidad:

„Necesitamos en el complicado cuerpo social del presente una capa dirigente de mujeres, que puedan ,pensar“ sobre estas preguntas (en el sentido de participar). Gracias a la formación específica de éstas (mujeres), necesaria para el dominio de esta materia, gracias al pensar y sentir orgánico están capacitadas para mostrar a otras mujeres los caminos de realización (que existen a su disposición).“ 1139

Como modelos a imitar se presentan mujeres como Marie Curie donde se incide en su servicio a la ciencia. ${ }^{1140}$ En 1937 se analiza la causa de la inexistencia de mujeres en puestos de responsabilidad, los despidos de carácter político. Esta apreciación no se critica o se cuestiona sino que se acepta como uno de los gajes de la política. Bäumer señala que en este caso las mujeres corrieron el mismo destino que los hombres. No obstante en algunas instituciones de la administración se encuentran algunas excepciones, y se aplaude la nueva estrategia del estado respecto al trabajo femenino. ${ }^{1141}$

El prototipo de la mujer trabajadora sin hijos era sin embargo difícil de aceptar, éste representaba al ideal de mujer liberada e independiente de la república de Weimar, desde un comienzo inaceptable.

Otra de los aspectos del trabajo femenino que se tratan en DIE FRAU, es el relacionado con el crecimiento de las dificultades para el acceso a la Universidad para las mujeres y la consiguiente pérdida de aceptación y reconocimiento del mundo intelectual masculino. ${ }^{1142}$ En este caso concreto se muestra DIE FRAU especialmente sensible ya que la mayoría de sus colaboradoras, por una parte eran académicas, por otra parte había dedicado una gran parte de sus esfuerzos en Weimar para mejorar la situación de las mujeres en la Universidad. La reivindicación de esta figura pertenece a una de las preocupaciones del Movimiento de la Mujer, especialmente entre las mujeres conservadoras; preocupación que como ya hemos señalado se recoge también en DIE FRAU. La estudiante representaba el deseo de la participación de la mujer en la vida política, su no exclusión de la organicidad del mundo. La conciencia política que se exigía de las mujeres, no estaba en contradicción con las ideas de las mujeres nacionalsocialistas, siempre que esta no se desarrollara individualmente:

„(la mujer) debe ser de tal manera, que haga con agrado todo lo que se exige de ella, debe poder pensar políticamente, no en el sentido de una lucha con otras

1138 Ibídem, p. 198

1139 Ibídem, p. 201

1140 Bäumer, G.: „Der hohe Dienst“، Die FraU, Marzo 1938, nº, pp.286-293

1141 Bäumer, G.: „Zum „Status“ der deutschen Frau“, DiE FrAU, Septiembre 1937, n 12, p.644

1142 La figura de la estudiante es uno de los objetos de crítica de la propaganda nacionalsocialista: „Studentin? Ja, was wollt denn ihr noch im Dritten Reich? Ihr gehört doch an den Kochtopf! Es entspricht gar nicht dem Willen des Führers, daß ihr studiert. Geistige Arbeit schadet der Frau!“ en: VÖLKISCHER BEOBACHTER, 11.12.1935 
naciones, sino de tal forma que ella sienta, se entregue y se sacrifique con la totalidad de su pueblo en una actitud segura y orgullosa." 1143

Frente al prejuicio nacionalsocialista contra la educación las mujeres en la Universidad (no podrían tener hijos), se argumenta por el contrario la inexistencia de tal incompatibilidad:

„Desde la perspectiva nacionalsocialista se entiende, que la cuestión definitiva es la de lo biológico: ¿ es el estudio de las mujeres contraproducente para el mantenimiento y la conservación de la herencia de nuestro pueblo? La afirmación de la mujer podría estropear su capacidad de reproducción debido a los estudios, carece de un argumentación objetiva." ${ }^{1144}$

Posiblemente ante el temor de posibles represalias, se incide en la feminidad de las estudiantes y en sus buenas aptitudes para el matrimonio. No se trata de monstruos según las colaboradoras de DIE FRAU sino que a pesar de ser estudiantes son mujeres, son dóciles, aplicadas y femeninas y lo más importantes son dignas de casarse. ${ }^{1145}$

Desde DIE FRAU se intentaba también combatir el viejo prejuicio machista sobre la incapacidad de las mujeres de realizar tareas creativas. Una de las explicaciones que se da sobre la falta de mujeres filósofas, poetas, o escritoras es la subordinación de las propias mujeres a lo masculino, y su adaptación a la imagen que el hombre ha construido sobre ellas. En otras palabras las mujeres acabaron viéndose con los mismos ojos de los hombres: incapaces, inactivas, musas y vírgenes a la caza del amor como única forma de realización. La liberación de la mujer contribuye a luchar contra la dependencia de las mujeres de su necesidad de amor:

„Esta existe (la liberación de la mujer) desde que las mujeres han dejado de comportarse según las directrices de los deseos masculinos, desde que siente sus propias leyes, desde que han dejado de dañarse a si mismas para conseguir el preciado precio del amor!" 1146

Lo femenino no se caracteriza únicamente por su capacidad de entrega y sacrificio, o por su capacidad de amar, sino que puede aprender a crear si se libra de su sometimiento a lo masculino. A través de esta liberación la mujer deja de ser naturaleza para convertirse en individuo:

"La mujer no es sólo mujer, no es sólo un elemento de la naturaleza, no sólo la sirvienta incondicional de la vida. Ella es también un individuo. “1147

La situación en la que viven las mujeres trabajadoras es objeto de análisis en una serie de artículos en los que se nos habla de su forma de vida y de su rendimiento. En los informes no aparecen nombres, sólo iniciales, y es frecuente que la autora utilice la técnica de la fábula y del cuento con moraleja en los cuales aparece un personaje prototipo y modelo a seguir. El prototipo suele ser encarnado por una mujer trabajadora que no sucumbe a la

1143 Bäumer, G.: „Bilanz 1934“, DIE FrAU, Enero 1935 (nº4), p.200 (atribuído a la dirigente de las organizaciones de mujeres nacionalsocialistas, Gertrud Scholtz-Klink).

1144 Lenz-Borries, Klara: „Frauenstudium und Auslese“..., p.203

1145 Ibídem, p.204

1146 Hueck-Dehio, E.: „Die Frau und die geistige Schöpferkraft“, DIE FRAU, Febrero 1934 (n 5), p.267

1147 Ibídem, p.269 
„proletarización“.1148 Proletarización significa sucumbir a la pobreza, abandonar a los hijos, despreocuparse por su educación, aún cuando no hubiera dinero en casa, enamorarse de otro hombre, aun cuando el marido fuera alcohólico y la mujer cobrara en palos lo que él no podía cobrar en el trabajo. Es cierto que existe una cierta denuncia de las condiciones en las que vivían las mujeres trabajadoras, sin embargo esta queja no implica que en los informes se ofrezcan alternativas a la situación de pobreza y desamparo en la que vivían éstas :

„La señora Arends -prototipo a seguir- es un excepción, esto debe ser claramente reconocido. Es cierto que ella carga con un destino proletario en su modo de vida exterior -marido alcohólico, desempleo, falta de espacio en la vivienda-. Pero su resistencia a las circunstancias no estriba en su fuerza vital sino en la convicción de sus ideas religiosas, ella es miembro de una parroquia donde participa intensamente." 1149

De este comentario se deduce que lo que diferencia a esta mujer del resto de las mujeres cuya historia aparece también en el informe, es su fe religiosa, su ética, hasta diríamos su moral sexual. No es extraño pues, que en los ejemplos que se suceden a continuación se incida en la vida amorosa de las mujeres haciendo resaltar la cantidad de maridos, amantes o compañeros de éstas y el número de hijos que iba a parar a los orfelinatos porque la madre se desentendía de éstos. Estas mujeres sin recursos, sin educación son definidas por las mujeres educadas, virtuosas y cristianas en una categoría casi animal:

„Frau Danz se preocupa del lactante con el típico calor animal de madre, que muchas madres tienen cuando el hijo es pequeño y que desaparece tan pronto como éste ha crecido". 1150

Pasados unos años, el niño es mandado al hospicio, la mujer ha encontrado un nuevo compañero y vuelve a quedar embarazada. Esta crítica sumergida de los valores de la clase trabajadora no es nueva, ya en la república de Weimar, se encuentran en los escritos de las mujeres pertenecientes al movimiento burgués-liberal para la liberación de la mujer, comentarios sobre la decadencia de la familia de la mujer trabajadora, corrompida por el olvido, rechazo y abandono de las funciones maternales. ${ }^{1151}$ Sin embargo en nuestro caso, el trabajo de la mujer no es visto como causa de la corrupción de la familia sino más bien la falta de una ética, de unos valores que las mujeres que escriben el artículo consideran como justos y legítimos: fortaleza moral y sentido del deber hacia la nación.

\footnotetext{
1148 Staewen-Ordemann, G.: „Proletarische Mütter. Bilder ihrer Lebenslast und Leistung“, DIE FraU, Enero $1934\left(\mathrm{n}^{\circ} 4\right)$, p.141. La autora, trabajadora social pertenece al grupo de la iglesia confesora que apoya a Karl Barth.

1149 Ibídem

$1150 \quad$ Ibídem, p.142

1151 Geyer, A.: „Die Bedeutung der Erwerbsarbeit verheirateter Frauen für die wirtschaftliche Lage und den Zusammenhalt der Familie“, en: Flemming, J. / Saul, K. / Witt, P.-C. (eds.): Familienleben im Schatten der Krise. Dokumente und Analysen zur Sozialgeschichte der Weimarer Republik, Düsseldorf, Droste, 1988, p.138
} 


\subsubsection{Reivindicación de la necesidad del trabajo femenino. El argumento de utilidad a la comunidad del pueblo}

„El argumento, de que un puesto de trabajo no ha de ser dado al que lo necesita sino al que es más productivo, no es individualista." $" 1152$

El papel de la mujer en lo relativo al trabajo se concebía en función del argumento de utilidad. Si el trabajo de ésta era útil a la Nación entonces era legítimo reivindicar el derecho a éste. En segundo lugar el ejercicio de éste podría garantizar la existencia de mujeres seguras y contentas de si mismas que a su vez podían crear familias estables en cuyo „seno“ crecieran hijos fuertes y saludables. „Hay que tener en cuenta el doble significado de la profesión: primero como estructura existencial, como determinante para la fundación de una familia y por otro como factor vital para el general rendimiento de una nación“ “1153. Nos encontramos ante un cambio frente a la ideología antifeminista del nacionalsocialismo. Frente a la consigna „mujeres al hogar y a la cuna" se reivindica la presencia de las mujeres más preparadas en el mundo del trabajo. Se reivindica la presencia de un principio de selección en el mercado de trabajo que no discrimine en función del sexo, sino en función de la preparación y educación de éstos. Ahora bien, se trata tan solo de un cambio aparente ya que en el fondo reproduce concepción nazi del individuo, cuyo núcleo principal es la teoría de selección de los mejor preparados y más fuertes a la hora de dirigir el Estado y la Nación; selección que supone también el privilegio de la opresión y supresión de los menos aptos. La raza, la nación alemana, el estado adquieren una importancia inmensurable respecto al individuo, ya sea hombre o mujer, instrumentos del ejercicio del poder. Desde 1933 DIE FRAU pretende dar una solución intermedia que evite por un lado que las mujeres sean relegadas de la vida laboral, y por otro que no atente contra los intereses de los trabajadores masculinos:

„La formas mas sanas de trabajo y empleo son aquellas que puedan ser practicadas dentro de un ámbito familiar. Nadie definiría el trabajo de una mujer en la agricultura, en un taller $o$ en una empresa familiar como „Doppelverdienertum (...).“1154

Por lo tanto lo que aparece a primera vista una aspiración feminista, no es más que una premisa impuesta por el sistema, que las mujeres creen hacer suya. Dentro de su papel de instrumento al servicio del estado, las mujeres que se manifiestan en los textos que analizamos no buscan el conflicto con los hombres, „para nosotros es importante el trabajo de los géneros en lucha conjunta no en conflicto“ " 1155 . Esta opinión es apoyada por algunos ideólogos del régimen, precisamente aquellos que en 1939 votarán a favor de la incorporación de la mujer en la industria de guerra y en la retaguardia, ya en 1934 hacía alusión Ley a los efectos positivos del trabajo para las mujeres:

Bäumer, G.: „Bilanz 1934“, DIE FraU, Enero 1935 (nº4), p.195

Ibídem, p.194

Bäumer, G.: „Panik über den Frauenberufen“, Die FraU, Noviembre 1933 (n²), p.87

Doherr, A.: „Ersatz von Frauenarbeit in der Industrie“, DIE FraU, Marzo 1935 (nº), p.307 
„Por lo tanto hay algunos trabajos, que el hombre no ejecuta tan bien o tan rápido como la mujer, es falso decir que la mujer a través de su trabajo puede poner en peligro su salud.“ 1156

El criterio a elegir al determinar qué trabajos son adecuados para la mujer, sería el de la inclinación natural de ésta. La ideología oficial que en 1933 proclamaba el retorno de la mujer al hogar, entraba en contradicción: ciertas mujeres eran necesarias. Había por supuesto varias ventajas: eran más baratas y más eficientes. Y en el caso de que las cosas no fueran bien en el campo de batalla, no habría ningún impedimento que impidiera hacer uso de ellas.

Dentro de la política social nacionalsocialista, el ama de casa, la madre, tenía un lugar privilegiado. La imagen de la mujer de raza aria, de aspecto tranquilo y mirada cálida se explotó hasta la saciedad. Su trabajo en la casa determinaba según los hombres nacionalsocialistas, en gran medida el futuro del país; a la ama de casa se le mima, se le conceden grandes honores si desarrolla ininterrumpidamente su papel de madre, se la observa, se la vigila si no cumple con lo establecido. „Nunca las amas de casa habían recibido tantos honores y su trabajo había sido tan reconocido" comentan algunas mujeres que vivieron durante el Tercer Reich.

Esta valorización del trabajo del ama de casa, no es algo que define la política femenina nacionalsocialista, o encontramos en la República de Weimar como consecuencia de las políticas higienistas y de control de la población que lleva a cabo el Estado. Desde DIE FRAU reciben especial atención las mujeres que además de trabajar deben cumplir con sus deberes de ama de casa; esta situación se reconoce problemática ya que significa un doble esfuerzo que además no se cobra. Se plantean dos alternativas: el recortamiento de la jornada laboral a 40 horas semanales, así como el recortamiento de la jornada de trabajo doméstico gracias a la ayuda de los hijos y del marido: „la introducción de la semana de 40 horas produciría una mejor combinación entre la maternidad y el ejercicio de la actividad laboral"“1157.

La familia se entiende como un organismo en el que cada uno de los miembros debe contribuir al buen funcionamiento de éstos, a hacer olvidar las veleidades individualistas de éstos (como el caso de la familia burguesa), y aprender a que la madre, el padre y los hijos y hijas son responsables individualmente del resto de la familia:

„A través del trabajo en el hogar se deberían fomentar los sentimientos de compañerismo, el conocimiento de la propia responsabilidad hacia los otros. No sólo se vería fortalecida la situación económica de la familia, también su situación espiritual." "1158

La valoración de la nueva legislación relacionada con la mujer, es aceptada en general en términos positivos. Así por ejemplo se comenta la nueva ley sobre la herencia de propiedades agrícolas, Erbhofgesetr, de 1935 donde se establece quién de los hijos del campesino hereda las propiedades en su totalidad. ${ }^{1159}$ En este caso señala DIE FRAU, la aplicación de la ley como favorable para la mujer. Sobre la ley para el impedimento de descendencia con taras genéticas, Gesetz. zur Verbütung erbkranken Nachwuchses, se informa exhaustivamente sobre ésta sin hacer una valoración positiva o negativa.

1156 Cita del jefe del Frente de trabajo alemán, Dr. Ley, publicada en el VÖLKISCHER BEOBACHTER del 11.7.1934, y recogida en DIE FrAU, Marzo 1935 ( $\mathrm{n}^{\circ}$ 6), p.306, dentro de la sección „Servicio de noticias sobre el trabajo de las mujeres“ („Nachrichtendienst über Frauenberufe“).

1157 Urban, G.: „Die Vierzigstundenwoche und die Frau“, DIE FraU, Abril 1935 (nº7), p.362

1158 Ibídem

1159 Bäumer, G.: „Wie entwickelt sich die Rechtsstellung der deutschen Frau?”, DIE FraU, Junio 1935, $\mathrm{n}^{\circ} 9$ pp. $5565-566$ 
Sobre los derechos de la mujer como ciudadana, Staatsbürgerrechte, se considera que con la declaración del ministro del Reich, Frick sobre la posibilidad de votar y con la posible integración de las mujeres en el servicio militar, se muestra plena satisfacción. ${ }^{1160}$ Crítica se muestra por el contrario en relación a la situación jurídica de las funcionarias donde éstas a consecuencia de la Stadtgesetż del 19 de enero de 1934 podían perder su empleo si vivían en una unión de hecho.

7.5.10. La guerra. Entre el descontento ante las desigualdades y el orgullo nacional

„Al trabajo de la mujer alemana se añade un significado definitivo relacionado con la guerra. Miles de mujeres trabajan con un gran esfuerzo en la actualidad en nuestras fábricas, consiguen suministrar efectivamente al ejército armas y munición, se encargan y educan a sus hijos en su tiempo libre y se preocupan calladamente sobre el hombre que afuera se enfrenta al enemigo. Su actitud es modélica y algunas veces sin ejemplo." "1161

A partir de 1938 las cosas han cambiado, el régimen nazi ha comprendido que el sistema económico y el estado de guerra necesita a un mayor número de mujeres. En enero del mismo año el director del departamento para „responsabilidad social“ del Deutsche Arbeitsfront apela a las mujeres a incrementar su participación en el mundo laboral. El 1 de septiembre de 1939 se proclama una ley para la economía de guerra, en la que se exige de todo ciudadano o ciudadana que no se encuentre en el frente, su disposición para estar al servicio de la patria, en el momento en que se le necesite. ${ }^{1162}$

En el mismo mes en una circular del ministerio de trabajo se exige de las mujeres, su contribución en los sectores agrícola e industrial fundamentalmente. Esta participación de las mujeres en el trabajo sólo tendrá lugar cuando sea necesario y no exista otra fuerza de trabajo. La medida afecta a mujeres que trabajan en sectores no demasiado relevantes para la economía de guerra, mujeres solteras entre 16 y 50 años sobre las que no pesa la tarea de alimentar a hermanos o personas mayores, o que se encuentran en la escuela o periodo de formación educativa. La necesidad de mano de obra femenia y masculina es tan grande que el 29 de diciembre de 1940 se decreta la prohición de la entrada de hombres y mujeres en edad laboral y en plenas condiciones psíquicas y físicas en órdenes religiosas. ${ }^{1163}$

La entrada en guerra es vista desde DIE FRAU con tranquilidad, se compara con la situación de 1914 y se considera que la situación entonces era más complicada, las pérdidas son menores, se vive en una situación de seminormalidad. Las mujeres aparecen definidas como Franenreserven o Heimatheer.1164 Las medidas que toma el gobierno para introducir a las mujeres de nuevo en el mercado laboral encuentran la plena aceptación, e incluso se acepta la teoría oficial de que la

\footnotetext{
$1160 \quad$ Ibídem, p. 566

1161 VÖLKISCHER BEOBACHTER, 18.10.1942, Bayerisches Staatsarchiv, 133. Zeitungsausschnitte (Zeitungsarchiv Teil VI) über Tagungen, Propaganda, Kultur.

1162 Bäumer, Gertrud: Einsatz der Frau in der Nationalwirtschaft“", DIE FrAU, Febrero 1939 (nº5), p.17

1163 BAYRISCHES STAATSARCHIV, 5550/218

1164 Bäumer, G.: „Frauenreserven“, DIE FRAU, Abril 1941, nº 7, pp. 194-196
} 
integración de las mujeres en el mundo del trabajo no se lleva a cabo por motivos económicos, sino por el deseo de éstas de contribuir a la victoria de Alemania. 1165

Las quejas que aparecen en este momento en DIE FRAU están relacionadas con la baja remuneración de los trabajos y la ínfima calidad de éstos. La causa que se aduce a esta baja remuneración estriba en la deficiente formación intelectual de las mujeres que las hace incapaces para realizar determinados trabajos. ${ }^{1166} \mathrm{~A}$ pesar de su contribución a la economía nacional las mujeres seguían siendo consideradas como ciudadanos de segunda categoría. Así cuando en 1943 son llamadas a presentarse para hacer uso en un futuro de su capacidad de trabajo, evitaron por todos los medios no presentarse. Quienes lo lograron fueron las mujeres de clase media y alta. Las mujeres trabajadoras sin recursos no pudieron, por dos razones, rehusar la invitación: carecían de medios de subsistencia, y recibían penas de cárcel si no se presentaban. Esta negativa no se recoge en los textos que hemos analizado.

Es obvio que en este discurso femenino del trabajo se observan ciertas reivindicaciones a favor de las mujeres, que pueden ser confundidas con un discurso antipatriarcal o feminista. Yo no diría tanto; a mi modo de ver el discurso constituye en su totalidad una reivindicación de clase, de una clase opresora, en este caso las mujeres, oprimidas a su vez dentro de una dictadura en la que la mujer era utilizada en función del concepto de rendimiento a la Nación. Las opciones eran claras o formar parte de la resistencia y arriesgarse a morir en uno de los tres campos de concentración para mujeres, o seguir viviendo, seguir inventando una realidad en la que parecía que la mujer tenía una función, una realidad en la que aparentemente las mujeres creían influir, o simplemente servir de instrumento del terror nazi para atemorizar y matar a otros hombres, a otras mujeres.

Me gustaría también aludir a esa idea del discurso, como ,acontecimiento histórico que configura y regula el saber" del que Foucault habla en toda su obra. 1167 En lo que se refiere al discurso femenino sobre el trabajo es interesante señalar la continuidad existente de las imágenes que las mujeres tienen de si misma durante el siglo XX. Me refiero a esa alusión constante a la función de utilidad al Estado, a los hijos, al marido, a ellas mismas, a la necesidad constante de tener que justificar una posición pública no en nombre de las mujeres sino en nombre de instituciones, a la incapacidad de poder hablar de las mujeres como fin sino como instrumento, para el bien del Estado, la estabilidad de la familia, la seguridad del hombre, y el porvenir de los hijos.

En cuanto a la relación discurso-poder, creemos que la existencia de este discurso femenino propio, personal e incluso diferente, propicia el reforzamiento por un lado, del propio poder nacionalsocialista, y por otro, de la creencia (ficticia) por parte de las mujeres que elaboran este discurso, de su participación y capacidad de influencia en las estructuras de poder. Esta supuesta independencia de articulación y movilidad, proporciona a las mujeres que escribían en DIE FRAU una falsa conciencia de crítica hacia al régimen que destruye lógicamente cualquier posibilidad de acción contra el sistema. En realidad nos encontramos ante un discurso femenino de élite que pretende llegar a todas las mujeres desde la misma cara del poder.

Volviendo el texto de Virgina Woolf con el que comienza la este capítulo, y a la metáfora trabajo-libertad que esta autora utiliza, me gustaría señalar la diferencia existente entre este concepto de trabajo y el que tenían las mujeres que escribían en DIE FRAU. Trabajo, para ellas no era libertad, era un deber, una obligación que el Estado les exigía para el buen

1165 Bäumer, G.Fraueneinsatz in der Kriegswirtschaft 1940“, DIE FRAU, Diciembre 1940, n³, pp. $107-$ 112

1166 Bäumer, G.: „Einsatz..“ op. cit., p.18

1167 García del Pozo, R.: Michel Foucault. Un arqueólogo del bumanismo, estructuralismo, genealogía y apuesta estética, Sevilla, Universidad de Sevilla, 1988, p.10 
funcionamiento de la nación. La reivindicación del derecho al trabajo no puede considerarse en este caso como algo subversivo, revolucionario, que atente contra las estructuras del sistema, sino como la legitimación y el reconocimiento de éste.

Finalmente me gustaría dejar claro que el discurso femenino analizado no es representativo de todas las mujeres que vivieron los años de la dictadura nazi. Sería interesante analizar los informes que la Gestapo realizó en el año 1943, sobre las mujeres que no se presentaron a la llamada oficial para cuantificar la mano de obra femenina disponible, así como opiniones y noticias de mujeres trabajadoras que no se encuentren „contaminadas“ por las organizaciones de mujeres dependientes del régimen.

Un aspecto importante en el análisis del discurso que aparece en DIE FrAU son las repercusiones que sus artículos tenían entre el círculo de mujeres nacionalsocialistas. Tales repercusiones eran recogidas en DIE FRAU y se reconvertían en nuevos artículos que en su mayoría hablaban sobre la naturaleza del movimiento de la mujer. Ante la insistencia de las nacionalsocialistas de relacionar el movimiento de la mujer con los sistemas políticos de los países demócraticos y marxistas. Desde las filas nacionalsocialistas se renegaba del prototipo de mujer cultivada, decorativa e inútil representante de la sociedad burguesa. Se proclamaba como única y legítima organización de mujeres aquellas dependientes del organigrama nacionalsocialista. Las opiniones que vertía DIE FRAU no eran peligrosas por su contenido ya que en muchos casos, aunque con pequeñas diferencias, su discurso era casi idéntico al de las nacionalsocialistas, sino por la importancia histórica de las mujeres que escribían los artículos.

La declaración de guerra de Alemania contra los Aliados desencadena una feroz afirmación nacionalista de la que DIE FRAU no pudo escapar. Desde las trincheras se exigía a las mujeres que substituyeran a los hombres en sus puestos de trabajo. Se declaró una prestación obligatoria por la que todas las mujeres, solteras y casadas debían dedicar una parte de su tiempo a "ganar“ la guerra desde la retaguardia. Como ya hemos reseñado anteriormente DIE FRAU, y las organizaciones afines a su ideario, 1168 ya había mostrado con ambigüedad sus tendencias „nacionalistas“ antes de que Hitler llegara al poder. En un principio al igual que el resto de las organizaciones de mujeres, el Bund Deutscher Frauen y su órgano de prensa, se hacen eco de las reivindicaciones pacifistas de otras organizaciones internacionales de mujeres. En concreto Gertrud Bäumer y otras mujeres del partido demócrata alemán participan en las conferencias sobre desarme en Ginebra, donde se pretenden evaluar la exactitud de los acuerdos de Versalles, donde se proclamó una notificación alemana donde se opta por una postura de desarme para Alemania y para el resto de las naciones. Entre las firmantes de esta notificación encontramos a Gertrud Bäumer, Emmy Beckmann, Anna von Gierke, Else Giese, Elly Heuss-Knapp, Marie Elisabeth Lüders, Alice Salomon, Dorothee von Velsen y Agnes von Zahn-Harnack ${ }^{1169}$, organizativamente son la Staatsbürgerinnenverband (Unión de ciudadanas alemanas) y el Akademikerinnenbund (Federación de académicas) los que llevan la carga de la campaña. En 1931 la misma Gertrud Bäumer definía el movimiento de la mujer como un „fenómeno internacional de diferentes colores", y aunque reivindicaba lo nacional, lo internacional estaba por encima de éste.

1168 En 1914 Helene Lange, Redwig Heil, Helene Levy-Rathenau, Marie Elisabeth Lüders y Gertrud Bäumer fueron las artífices del Servicio Nacional Femenino. Una organización que en tiempos de guerra se encargaba de organizar a las mujeres para la ejecución de trabajos de interés nacional: reparto de víveres y alimentos, asistencia a las familias que habían sufrido la pérdida del padre, búsqueda de trabajo para mujeres cuyos maridos habían muerto, organización de un servicio de trabajo voluntario dedicado a los esfuerzos de la guerra.

1169 BAK, NL 151, Marie Elisabeth Lüders, „Deutsche Kundgebung an die Abrüstungkonferenz“, Genf 1932 
Esta iniciativa tomada por las organizaciones dependientes o ligadas al Bund Deutscher Frauenverein (Federación de asociaciones de mujeres alemanas), suscita suspicacias entre otra organización de carácter conservador, el Ring Nationale Frauen (Alianza nacional de mujeres) en la que expresan su preocupación ante las declaraciones de las asociaciones democráticas de mujeres que defienden el desarme total de Alemania. ${ }^{1170}$

Sin embargo la llegada de Hitler al poder frustra cualquier posibilidad de entendimiento. Unos meses antes de la toma de poder, Gertrud Bäumer se opone a que Alice Salomon, defensora judía de los derechos de la mujer, sea la única representante alemana en International Women Council (Comité Internacional de Mujeres), y recomienda a Dorothee von Velsen la presentación de su candidatura.

Durante los primeros años de andadura nacionalsocialista, son raras las ocasiones en que DIE FrAU publica artículos sobre temas belicistas. Estos comienzan en el 1939. No son textos sobre la ofensiva alemana, sobre las victorias, sino que se remiten a la reflexión sobre las experiencias de las mujeres alemanas en la guerra. En ningún caso se la condena, ni siquiera utilizando como pretexto las ideas religiosas, tan importantes en las otras partes del discurso femenino, como la naturaleza de la mujer, la educación de los hijos, el trabajo fuera del hogar etc.

Por el contrario la condición femenina es observada como un impedimento para participar en la guerra. Se reconoce con pesar la separación de las funciones de las mujeres y de los hombres. Sin embargo esta diferencia se acaba aceptando, dotando a las funciones de lo femenino de la especialidad. Y como en otras ocasiones lo femenino se revela como lo que da vida, lo que se opone a la muerte; el antónimo de la destrucción y de la muerte:

„La guerra (...) nos proporciona la posibilidad de una reconstrucción interna, la transformación de la muerte en vida, de lo destruido en construcción."

La guerra por otra parte no es vivida con horror. Desde un primer momento esta se justifica como consecuencia de la primera guerra mundial y de sus nefastos resultados para Alemania (son muchos los artículos que se encargan de describir organizaciones, mujeres que jugaron un papel importante en aquellos años). ${ }^{1172}$

Por otro lado la guerra se presenta como la consecuencia lógica de la falta de disponibilidad de los países vencedores para limitar las exigencias de los Tratados de Versalles y Locarno, y de impedir el rearme alemán. ${ }^{1173}$ Luchar se convierte en una afirmación nacional, en la demostración de la oportunidad alemana de demostrar su capacidad de entereza, su fuerza de voluntad, ante las privaciones, el hambre y la destrucción. En vez de hacer hincapié en lo perdido, en el desastre, en la derrota se incide en el poder de la animación espiritual que agita a los alemanes en tiempos difíciles. ${ }^{1174}$ Esta fuerza no encuentra su fuente en la raza, en la especialidad de la cultura alemana, sino en la oración.

Agnes von Zahn-Harnack hace un análisis diez años después del comienzo de la guerra que refleja extraordinariamente las reacciones de las mujeres de su generación:

1170 BAK, NL 151, Marie Elisabeth Lüders, Ring Nationaler Frauenbünde, 1933

1171 Gierke, A.: „Der 'Nationale Frauendienst’ im Weltkriege“, DIE FrAU, Enero 1944 (nº4), p.677

1172 Editorial: „Zwei Jahrzehnte nach Versailles“, DIE FrAU, Julio 1940 (nº10), p.289

1173 Ante las negativas de Francia e Inglaterra de limitar su política de rearme, se comenta en DIE FRAU la normalidad del rearme alemán. La fuerza de Alemania no sería ningún peligro para Europa sino su salvación.

1174 Bäumer, G.: „Frauenreserven“, DIE FrAU, Abril 1941 (nº7), p.197 
"Junto al miedo se encontraba la mala conciencia: ¿habíamos hecho algo para evitar la llegada de esta desgracia? Pecados de omisión- una larga cadena desde los años veinte hasta la actualidad que se levantaba delante de nuestra alma como una acusación a la vez silenciosa y estridente. Muchos nombres llevaba esta cadena: cobardía y estrechez de miras, apatía, egoísmo y rechazo del sufrimiento- mil pequeños y grandes descuidos y posibilidades perdidas. Todas las frases que empezaban así: "justo en el 33 tendríamos que haber...” o "en las primeros atentados contra los judíos tendríamos que..." o "ya entonces cuando el ejército negro se estaba formando se tuvo que...”. Pero no se hizo, se calló, el puño alzado en el bolsillo, pero salvándose con un buen chiste en las altas esferas- por todo esto llegaba la cuenta. Pero algo no debemos olvidar, el sentimiento general era de fatalismo que estaba teñido de una manera horrible de cinismo."1175

\subsection{Conclusiones}

En uno de los últimos de 1943 celebra DIE FRAU su cincuenta aniversario. En octubre de 1893 aparecía por primera vez, bajo la dirección de Helene Lange, con la atención de ofrecer al público femenino algo más que artículos sobre moda, hogar y cocina. Sus objetivos eran aportar a la mejora de la situación de la mujer, a través de la educación de las lectoras, a defender los derechos de la mujer. DIE FRAU es la historia del movimiento liberal-conservador de la mujer, es la crónica de sus éxitos y sus fracasos. Durante el nacionalsocialismo continúa su trabajo no al servicio del movimiento de la mujer, no al servicio de los intereses y derecho de sus lectoras, al de la Volksgemeinschaft, una nueva forma, según Bäumer, del geistiges Band que unía a las mujeres. 1176

DIE FRAU no se opone al nacionalsocialismo como estado, como dictadura, no crítica sus actuaciones; se opone únicamente cuando defiende los intereses de las mujeres en oposición a un estado masculino. Se puede hablar entonces, como en el caso de la prensa protestante y católica, de la defensa de un campo de actuación relacionado con los intereses del grupo en cuestión: para las mujeres protestantes era su independencia de actuación, para las católicas la areligiosidad del nacionalsocialismo, para las mujeres de DIE FRAU su universo femenino, sin ningún tipo de connotación política, donde la maternidad se utilizaba como escudo contra un estado masculinizado y violento.

La valoración de la diferencia sexual en función de la biología y la raza es aceptada en general, como una consecuencia más de la unión del pueblo en la gran comunidad. Hombres y mujeres sin excepción de género y clase luchan hombro a hombro por los mismos ideales, superando las diferencias de tiempos anteriores, y otros modelos políticos. DIE FRAU_reclama trabajo para las mujeres, educación universitaria y también la posibilidad de trabajar en el nuevo gobierno, al lado del hombre en plena igualdad. DIE FRAU no se cuestiona la legitimidad del régimen, no se cuestiona la situación de dictadura. Hasta que punto esto se puede considerar como dictadura es preguntable. Esta misma línea de argumentación se encuentra en el análisis que se hace de la situación religiosa. Se condena los intentos de los Deutsche Christen de eliminar los elementos cristianos de la religión. Y aunque se aceptan las ideas de la iglesia confesora, se

1175 Anders, Marga; Reicke Ilse (Ed.): Zahn-Harnack, Agnes. Schriften und Reden 1914-1950, Tübingen, Hopfer Verlag, 1964, p.80

1176 Bäumer, G.: „Fünzig Jahre DIE FrAU“, Octubre-Diciembre 1943, (n 1-2-3), pp. 1-5 
critica todo tipo de implicación política de ésta. Es decir se rechaza la crítica que ésta hace al régimen de Hitler.

Durante los primeros años, entre 1933-1934 se permanece a la expectativa. Todavía no se conocen las líneas de actuación del nacionalsocialismo respecto a la mujer. La disolución de las organizaciones de mujeres no se vive de manera traumática, sino como la consecuencia lógica de un cambio radical de gobierno. La actitud general es de apertura, a la espera de una posible colaboración. No obstante como ya hemos señalado a lo largo de este capítulo existen voces como la de Marianne Weber que condenan postura fanáticas y llaman al humanismo y a la tolerancia, o como por ejemplo Gerda Hebestreit, quién exige al nacionalsocialismo la lucha contra la literatura inmoral, pero por otra parte se muestra en contra de la quema de las obras de autores o autoras conocidos por sus posturas pacifistas, de izquierda o simplemente por no pertenecer a la raza aria.1177 En el número de noviembre de 1933 se trata la posición del nacionalsocialismo respecto a la cuestión de la mujer, en las que se dan la bienvenida a los intentos del nuevo gobierno de reducir la tasa de desempleo. Aunque sin hacerlo a costa de la población femenina trabajadora. En Diciembre se trata exhaustivamente el tema de la maternidad, imponiéndose las ideas de la geistige Mütterlichkeit, de Weber, Bäumer y von ZahnHarnack. Por otra parte se intenta demostrar las similitud de objetivos en los intereses de las organizaciones nacionalsocialistas de mujeres, también llamado neue Franenbewegung, nuevo movimiento de la mujer, y el alte Franenbewegung, y el movimiento de la mujer de Weimar. Así como de dejar claro el carácter nacional y alemán del antiguo movimiento de la mujer, junto con las intenciones de trabajar conjuntamente con el nuevo movimiento.

Las constantes que aparecen en los textos analizados son las siguientes: conciencia de clase respecto a la mujer proletaria, virtuosismo moral ligado a un sentimiento cristiano que provee una conciencia de superioridad respecto a otras mujeres, exaltación de la mujer fuerte que sabe afrontar las dificultades de la vida (en muchos casos se deduce un cierto tono de superioridad moral respecto al hombre), crítica a la retirada de la mujer del mundo del trabajo unido a una valoración de éste como una parte más de las cualidades integrales de la persona humana, en este caso de la mujer, aceptación de la maternidad y del trabajo de las amas de casa como profesión.

No existen referencias por el contrario a las otras mujeres, a las mujeres que ejercían la prostitución, a las mujeres judías, y no judías que morían en los campos de concentración, a las mujeres de los territorios ocupados que trabajaban involuntariamente, en condiciones infrahumanas en las fábricas alemanas. No, ser mujer en aquellos momentos no conllevaba una garantía de solidaridad. La solidaridad detrás de las alambradas y los barracones de Moringen, Lichtenburg y Ravensbrück no exístia. Las mujeres que allí morían eran sólo una realidad inexistente que todavía hoy responde con el consabido „yo no sabía nada“.

Los intentos de aceptación son finalmente reconocidos por las autoridades nacionalsocialistas cuando con motivo de la inauguración de una exposición sobre la participación de la mujer en la nación durante el día del partido en Nürnberg en 1937, las mujeres más importante del ,antiguo movimiento de la mujer" aparecen como las pioneras del „,nuevo movimiento“. Las críticas sobre la pérdida de influencia de la mujer sobre el mundo laboral desaparecen lentamente a partir de 1939, cuando el trabajo de las mujeres se hace necesario en víspera de la nueva guerra. Con la llegada de ésta podemos hablar de una nueva etapa en Die FraU. Ya no se trata de legitimar o no el movimiento de la mujer, de tratar de buscar apoyos en el nacionalsocialismo, el discurso se dirige a la patria, al sentimiento nacional de las alemanas, a su entrega para conseguir la victoria, y al sacrificio de las madres cuyos hijos, maridos y hermanos se encuentran en el frente. Temas históricos y literarios ganan en protagonismo.

1177 Hebestreit, G.: ,Jugend, Geist und Zeitgeist“, DIE FRAU, Julio 1934, nº p. 
Otro de los temas donde DIE FRAU parece diferir de la ideología nacionalsocialista es el religioso. Desde el principio se muestra una clara actitud de rechazo respecto a los cristianos alemanes, y a la iglesia del Reich, aunque se intenta evitar demostrar el apoyo a la iglesia confesora. En este aspecto adoptan una postura parecida a la de las mujeres protestantes que justifican su crítica con argumentos religiosos e inciden en la falta de connotaciones políticas de sus objeciones. En esta misma línea rechazan el ideal germánico que los nacionalsocialistas proponían ya que estos consideraban que la religión cristiana había contribuido a la decadencia de la mujer, a la pérdida de su independencia y poder en relación con la mujer germana.

En el aspecto religioso hemos podido constatar la pertenencia de las mujeres de DIE FRAU a grupos y círculos religiosos que se distanciaban de la postura de los cristianos alemanes. Gertrud Bäumer por ejemplo pertenece al círculo de renovación cristiana en torno a la figura del pastor Daur (Dauerscher Kreis) y no cree que la Iglesia Confesora sea la manera de solucionar la unión de la iglesia protestante. 1178

Marianne Weber organiza personalmente el llamado Kongener Kreis y Anna von Gierke tiene relaciones con la iglesia confesora en Berlín en un círculo de tertulias donde participan Agnes von Zahn-Harnack, Gertrud Bäumer, Elly Heuss-Knapp.

¿Pertenecen las mujeres de DIE FraU al grupo de escritores y poetas pertenecientes a la „emigración interior"? Esta generación ha sido muy discutida. Por una parte se defiende su componente de oposición política ${ }^{1179}$ o se la denomina como una „literatura de la resignación", 1180 dónde el ejercicio de la actividad literaria y publicista esta dirigido a la supervivencia personal y no como protesta contra la dictadura.

Esta literatura de la emigración interior son la creación literaria de una Alemania diferente a la real, ein anderes Deutschland donde los autores crean una realidad ajena a la realidad; como señala se produce un proceso de emigración interior donde no sólo creían encontrarse a si mismos sino a la verdadera Alemania. Proceso que a menudo va acompañado de una actitud religiosa y mística:

„La tendencia (de esta generación) a la interioridad renueva un tipo de actitud ante la vida que ha influido en la historia del pensamiento occidental. El resdescubrimiento de la interioridad por parte de la generación de emigración interior tiene sus bases en la imagen del mundo y pensamientos cristianos. “"1181

Esta constatación es también defendida por Walter Schutz, especialista en temas de emigración literaria. Schutz: La intención de infravalorar la unión con el mundo real, y la construcción del „verdadero“ mundo en el interior de un mismo tiene sus raíces en el mundo cristiano. ${ }^{1182}$ Cabe preguntarse si es válida la interpretación de Chu sobre la distancia crítica respecto al nacionalsocialismo que caracteriza a los integrantes de esta generación. Según Chu esta generación se esfuerza en la rehabilitación de figuras literarias y religiosas utilizadas por la iconografía nacionalsocialistas. Así por ejemplo en caso de Lutero, cuyos escritos sobre los judíos fueron utilizados por los nacionalsocialistas para fundamentar sus teorías desde el punto de vista religioso, intenta el poeta R.A. Schröder reivindicar la figura de éste, exclusivamente

\footnotetext{
1178 Beckmann, Emmy (De.): Gertrud Bäumer. Des Lebens wie der Liebe Band, Tübingen, Rainer Wunderlich Verlag, 1953, p. 74

1179 Chu, Tea-Wha: op.cit., p.19

1180 Ketelsen, U.K.: Völkisch-nationale und nationalsozialistische Literatur in Deutschland, Stuttgart 1976 , p. 100.

1181 Chu, Tea-Wha: op.cit., p.47

1182 Schulz, Walter: Philosophie in der veränderten Welt, Pfullingen 1984, p. 249
} 
desde el punto de vista protestante. ${ }^{1183}$ Lo mismo ocurre con Hölderlin uno de los poetas con mayor aceptación dentro de los círculos nacionalsocialistas. Sus visiones, su amor por la patria, le convierte a los ojos de los nacionalsocialistas en uno de los poetas de la renovación popular.

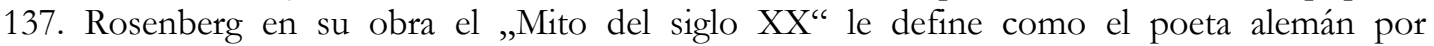
excelencia. R. Schneider, otro de los poetas de la emigración interior intenta resaltar los aspectos positivos de Hölderlin desde el punto de vista religioso. Lo mismo se puede hablar de Novalis, y el resto de las figuras literarias del romanticismo alemán.

En DIE FRAU se encuentra, especialmente en los artículos dedicados a la literatura una continúa alusión a la riqueza del pasado literario alemán, como prueba de la grandeza del Geist alemán, evitando conscientemente la alusión al nacionalsocialismo.

En 1946 continuando la costumbre de publicar obras de tipo biográfico, o una obra general, cada vez que se produce un cambio de gobierno intenta Bäumer analizar los efectos que el nacionalsocialismo tuvo para la situación de las mujeres y resaltar el carácter de emigración interior del movimiento de la mujer. El nacionalsocialismo no sólo contribuyó a retirar a las mujeres del trabajo en las instituciones políticas, sino que significó un cambio en todos los sentidos. Bäumer habla de una fuerza demoniaca, de una „pasión“ pasiva que impidió reaccionar ante el régimen del terror:

„En cuanto esa corriente pudo más que la consistencia de los diques, cayó nuestro pueblo en una depravación del alma, que en poco tiempo destruyó su gran humanidad. El pueblo se entregó a ella (a la degeneración) en una diabólica falta de voluntad, que no sólo anestesió su voluntad sino que obscureció más y más su capacidad de juicio moral.“ 1184

Especialmente en los hombres según las palabras de Goethe se cumple esta tragedia: „Un hombre, el mejor, acostumbra a su espíritu al horror y hace de si mismo una ley de lo que más le horroriza." Aunque las mujeres también participaron del horror, continúa Bäumer, sin embargo en el caso de que hubieran sabido que ocurría en los campos de concentración hubieran mostrado su resistencia. El horror, la muerte es cosa de hombres. Causa de esta falta de resistencia reside, según Bäumer en la falta de información sobre „la verdad“, ella la mujer que tenía los mejores contactos con la intelectualidad alemana, admirada por Goebbels, y responsable de una publicación, se queja de la censura, de las falsas esperanzas que levantaron los nacionalsocialistas en la población. Ella la mujer que luego se adorna con un discurso fúnebre que pronuncia en el entierro del marido de Elsa Maas, alumna suya en la Escuela Social de trabajo femenino en Hamburg. El conyuge pertenece a las víctimas del 20 de julio, aquel grupo de resistentes que decide acabar con la vida de Hitler. Bäumer argumenta como posteriormente lo harán muchas feministas e historiadoras que tratarán el tema de la participación de la mujer en el nacionalsocialismo: el género femenino sufrió la denigración nazi más profundamente que el masculino, política de empleo, política racista, la política de esterilización son atentados contra la naturaleza de la mujer, contra su dignidad como trabajadora y madre. Tal apreciación es cierta, pero parece fuera de lugar cuando proviene de alguien que participó, quizá sin darse cuenta, como instrumento en esta política contra lo femenino.

Esta suposición nuestra se confirma unas páginas más adelante cuando Bäumer alaba el „la seguridad instintiva" del movimiento a la hora de organizar el trabajo femenino: el nacionalsocialismo dio a las mujeres la posibilidad de organizarse, de ejercer una tarea

\footnotetext{
1183 Chu, Tea-Wha: op.cit., p.134

1184 Bäumer, G.: Der Neue Weg der Deutschen Frau, Stuttgart, Deutsche Verlags-Anstalt, 1946. P. 9
} 
importante en la reconstrucción de la patria, en la Asistencia maternal, en el servicio femenino del trabajo, en el frente del trabajo. Las mujeres desarrollaron un trabajo loable, señala Bäumer, un trabajo que no tenía nada que ver con la máquina de exterminación a la que servían los hombres:

„El estado nacionalsocialista era fundamentalmente un estado masculino: construido bajo el principio de la dureza, (...). La exclusión de las mujeres de las tareas de la administración, en las que hombres estuvieran de alguna manera bajo la dirección de éstas fue llevada caba de una manera exacta. (...) De hecho las mujeres que ocupaban cargos importantes en el partido no gozaron de ninguna influencia sobre la política nacionalsocialista." 1185

Y aunque la autora hace un intento de aceptar la culpa de las mujeres en el apoyo „inconsciente" a un régimen del horror, verdadero respresentante del anticristo, siempre incide en la ignorancia o en la falta de influencia de éstas.

Bäumer se ocupa también del futuro y es una de las primeras autoras que contribuye a idealizar el trabajo de las llamadas, Trümmerfrauen, las mujeres alemanas que después de la guerra, en muchos caso sin hijos, sin compañero se dedican a trabajar entre las ruinas que habían dejado los bombardeos de las fuerzas aliadas. Ese trabajo en las ruinas, la pérdida de los seres queridos, de los hogares, se convierte en un símbolo de un nuevo comienzo, donde las cenizas y las ruinas son el precio a pagar por el sueño, alejado de la razón, en el que los alemanes vivieron durante doce años. Y la gran admiradora de Goethe y Schelling acaba su obra con los siguientes versos:

\author{
Wir sind die Hüterinnen. \\ Wachen ist unser Auftrag. \\ Unserer Amt ist der Friede. \\ Die Tat ist des Mannes. \\ Doch wiegt sie \\ Gering vor dem großen Erbarmen. \\ 208000
}

1185 Bäumer, G.: Der Weg der deutschen Frau, op.cit., p. 24 


\section{Conclusiones generales}

El estudio sobre los grupos de mujeres conservadoras-liberales y confesionales, sobre sus actividades políticas sobre su discurso durante el nacionalsocialismo pone de relieve las contradicciones entre las aspiraciones de privacidad, realización personal, liberación e intimidad, y las tendencias conservadoras del movimiento de la mujer. Las mujeres objeto de nuestro estudio, provenientes de un millieu conservador-liberal, sufren esta contradicción de una manera doble. Por un lado, experimentan el mismo proceso de adaptación que sus colegas masculinos: en el caso de las mujeres que habían participado en el mundo de la política, estas se ven obligadas a abandonar su trabajo político como parlamentarias o como consejeras en los ministerios, sus organizaciones son disueltas, o tienen que afrontar como en el caso de las organizaciones confesionales una reestructuración de su organizaciones en función del nuevo régimen. En un principio sin embargo, este tipo de medidas que se imponen contra las mujeres son aceptadas como un mal menor que el nuevo régimen impone, por supuesto existen críticas contra los intentos de éste de „devolver” a las mujeres a su lugar „natural”, es decir el hogar.

No obstante las críticas se mueven en el terreno de una „aplicación cosmética” al régimen, una vez que parece claro que el electorado se ha puesto de parte de Hitler, y sobre todo una vez que los respectivos partidos políticos votan la ley de poderes el 23 de marzo de 1933, desde las tres publicaciones en cuestión se saluda al nuevo movimiento de renovación nacional y se pone a su disposición las fuerzas de las mujeres católicas, protestantes y del movimiento de la mujer. Por otra parte desde las organizaciones de mujeres nacionalsocialistas existían serios intentos de incidir en que el nuevo régimen no tenían interés en que todas las mujeres se dedicaran a ser madres de familia.

Desde el punto de vista de género, sin embargo, realizan una evolución especial. A diferencia de los hombres, permanecen en la vida pública al amparo de sus organizaciones religiosas, o en el caso de DIE FRAU protegidas por el nombre de Gertrud Bäumer. Su campo de acción se respeta en un principio, a costa de ciertos compromisos: las organizaciones confesionales reconocen públicamente su apoyo al nacionalsocialismo en los órganos de prensa y DIE FRAU legitima con su presencia la continuidad del movimiento de la mujer con los valores nacionalsocialistas. Todas ellas comparten un juego peligrosos con el sistema nacionalsocialista, un juego de poder por conservar sus campos de influencia, donde control y censura por parte de la Gestapo y el ministerio de propaganda también están presentes.

En los tres casos estudiados se elabora una estrategia de supervivencia, que consiste en la elaboración de un discurso de género propio y particular que pretende contrarrestar el discurso biológico de género del nacionalsocialismo y por otra parte, como ocurre en el caso de las organizaciones protestantes y católicas defienden sus intereses e independencia de acción, en función de su componente religiosa: las organizaciones protestantes en relación al Kirchenkampf, donde se oponen a ser manipuladas por la Reichskirche de Müller y los cristianos alemanes y en el caso de las mujeres católicas por la defensa de ideal católico femenino dentro de la protección que ofrecía el concordato.

Las características del discurso de género son similares en el análisis de los tres grupos, las reacciones de las diferentes organizaciones se articulan, sin embargo, de manera diferente.

En la elaboración del discurso de género hay dos aspectos que son tratados en los tres casos estudiados: la identidad femenina y la maternidad. Aspectos que se distancian del presupuesto biológico materialista con el que era concebida la mujer. 
Hasta ahora la mayoría de los trabajos que analizaban el discurso de la maternidad durante el nacionalsocialismo, partían del presupuesto de que el fin de la política femenina de los nacionalsocialistas estaba dirigida a fomentar exclusivamente el culto a la maternidad, esto motivaba que todas las obras de mujeres sobre el tema en ésta época fueran incluidas en el cajón de nacionalsocialistas, simplificando en gran medida las reacciones de las mujeres. Los trabajos de Gisela Bock han demostrado que realmente estos el discurso nacionalsocialista respecto a la feminidad, estaba dirigido fundamentalmente a apoyar el antinatalismo, el culto a la paternidad y a la masculinidad. Con lo cual se puede establecer en la diferencia de ambos discursos, diferencia que no sólo podemos establecer de la perspectiva investigadora, sino que aparece registrada también, especialmente dentro del $K B F$ y en círculo de colaboradoras de DIE FRAU.

Esto no quiere decir, ni mucho menos, que los grupos de mujeres estudiados sean considerados como grupos de resistencia al nacionalsocialismo. Y aquí entra la contradicción que quizá sea la clave del éxito del nacionalsocialismo. En la oposición a la política de género nacionalsocialista se encuentra por otra parte un apoyo a los fines de la dictadura: como defensora del peligro burgués y comunista, como restauradora de las costumbres morales, y sobre todo como reinstauradora del orgullo nacional, perdido en la primera guerra mundial.

Por eso creemos que se trata de un discurso que busca las raíces de la feminidad a veces en contra, a veces apoyando las ideas nacionalsocialistas, pero siempre contradiciendo la idea del nacionalsocialismo de querer sólo un estado de hombres. Esta estrategia de supervivencia, no tiene consecuencias políticas, no se traduce en un resistencia o en oposición. Es una estrategia tolerada.

Esta estrategia tolerada se convierte con el tiempo, a raíz de las actividades de control que se extienden en el país en una estrategia de supervivencia, donde lo femenino, la mujer, se utiliza en diferenciación de lo masculino, de lo brutal, del mundo de la guerra. El regazo de la madre, de la tierra, es la figura por excelencia que se utiliza en las tres publicaciones se convierte en el exilio de la feminidad.

DiE Frau, Die Christliche Frau y el Evangelische FraUENZEITUNG, entienden lo femenino en función de su carácter complementario de lo masculino. La mujer es la columna, la protectora, la sabia, el objeto de sacrificio; para católicas y protestantes la maternidad es una prueba más de la especialidad de la existencia femenina, en el caso de las protestantes una manera de pagar las deudas de Eva, en el caso de las católicas la revelación de Dios a la mujer tiene lugar a través de la maternidad, entre las mujeres no confesionales es la „maternidad espiritual“. En todo caso la mujer se muestra como salvadora, como elemento de paz, como garantía de vida.

La herencia de este discurso no tiene sus raíces en el nacionalsocialismo sino que se forma en el último tercio del siglo XVIII en las capas más educadas de la sociedad y encuentra su culminación en los salones burgueses del siglo XIX donde la mujer se consolida como la guardiana del hogar y el hombre como el cabeza de familia, y que después será „reutilizado“ por el ala conservadora del movimiento de la mujer, como un discurso de liberación de la „influencia cultural“ de la mujer, que tenía por objetivo la elevación del nivel intelectual de la mujer, la potenciación de sus facultades y la utilización de éstas para el servicio de la comunidad.

En el caso de DIE FraU: se trata de un discurso que cuando habla de la maternidad, desprecia lo natural - en algunos casos, Gertrud Bäumer llega a decir que „odia lo sexual“ -, lo biológico que hay en la función maternal, es un discurso que adora a la madre por su función espiritual, por su carácter sagrado, fortalecido por la creencia religiosa de estar realizando algo que se escapa de los límites de lo natural e irracional. En DIE FRAU lo religioso es sustituido por la fuerza del Geist.

En el análisis de los textos correspondientes al apartado religioso, de la prensa confesional hemos podido constatar de nuevo el papel de mediadora que recibe la mujer. Su naturaleza especial le concede la oportunidad de curar, de dar la vida, de trasladar a los muertos al mundo 
de los vivos. Esta proyección de si mismas se traduce, a través del análisis de sus actitudes políticas, en mera especulación intelectual, y se adapta por su carácter teórico fácilmente a las espectativas que el nacionalsocialismo tenía de las mujeres. La visión sobre lo femenino que las mujeres protestantes defendían es profundamente conservador. La mujer recibe su identidad de Dios, y su existencia, su género está determinado por su capacidad de ser madre, cualidad proveniente de Dios. El sacrificio de la mujer, su subordinación, su dependencia de los otros, son atributos divinos que la mujer tiene que aceptar. Desde una perspectiva exterior parecen los postulados nacionalsocialistas idénticos, sin embargo en los tiempos de la dictadura decir Dios o decir Hitler eran cosas bastante diferentes.

En esta concepción de la mujer como mediadora entre lo humano y lo divino, entre el bien y el mal, se acercan tanto las mujeres de DIE FRAU como las mujeres protestantes y católicas a los ideales de los filósofos del Kulturpessimismus, que en la búsqueda de un nuevo fundamento ontológico, valoran a la mujer positivamente. Como señala Alicia Puleo se rescatan antiguos mitos, la Mujer-Mesías sansimoniana, se crea la femme-enfant, se recurren a mitos orientales, que otorgan a la mujer el papel de guardiana entre mundos diferentes. ${ }^{1186} \mathrm{El}$ papel de mediadora exige una cierta neutralidad respecto al mundo terrenal, es decir respecto al mundo político. Esta tendencia neutral se corresponde perfectamente con los ideales de „universalidad” a los que aspiraba el movimiento de la mujer y se refleja interesantemente en la neutralidad que muestran las organizaciones protestantes de mujeres durante el Kirchenkampf. Esta característica no se encuentra dentro del discurso católico, donde la acción de la mujer en el mundo es considerada de por sí como reflejo de la obra de Dios. La universalidad de la mujer católica no necesita por lo tanto de adoptar posturas intermedias, sino que se define políticamente desde el primer momento: es interesante resaltar, que el movimiento de la mujer católica no se sintió nunca atraído por el „liberalismo” del movimiento laico de la mujer, donde ésta era sujeto central de las reivindicaciones del movimiento, en oposición al carácter de entrega social del movimiento de la mujer católico. Desde el punto de vista político era normal apoyar al partido de centro, como durante el nacionalsocialismo era normal defender la imagen católica de la mujer. ${ }^{1187}$

Otra de las características comunes que se observan en el discurso analizado es el amor a la madre, sin estridencias, sin sacrificios que se ve reforzado por una alusión constante a la individualidad, en los tres grupos de mujeres, a la actuación privada que se libra de las grandes palabras como pueblo o patria. Esta actuación privada remite constantemente a la religión, concretamente a la religión protestante, que se revela como fundamento de cualquier actuación política. Sin embargo este principio de individualidad, desaparece a partir de 1939 cuando los temas a tratar son los que defienden el derecho al trabajo, o a la actitud de las mujeres ante la guerra. Es entonces cuando el discurso retoma los rasgos inconfundibles de la propaganda nacionalsocialista, cuando el discurso de clase, y los primeros inicios de una conciencia nacional se alían fácilmente con las consignas de servicio a la patria, el sacrificio del pueblo, o la utilidad al estado. Discurso por otra parte también utilizado por regímenes democráticos durante el siglo $\mathrm{XX}$, cuando se reivindicaba el cuerpo de la mujer como propiedad del estado.

Existe pues una pervivencia de viejos y nuevos modelos de pensar sobre la mujer en el discurso que hemos analizado en nuestro trabajo. El maternalismo espiritual que preconizaban

1186 Puleo, A.H.: Dialéctica de la sexualidad. Sexo y género en la filosofía contemporánea, Madrid, Cátedra, 1992, p. 62

1187 Rauh-Kühne llama la atención sobre el hecho de que en zonas protestantes las mujeres votaron en mayor número por Hitler que en zonas católicas, donde éstas en su mayoría votaron al partido de centro. Rauh-Kühne, C.: „Katholikinnen zwischen Vereinnahmung und Resistenz“, en: Wickert, C.: Frauen gegen die Diktatur. Widerstand und Verfolgung im nationalsozialistischen Deutschland, Berlin, Hentrich, 1995 , p. 34 
las feministas burguesas de principios de siglo, asumido y continuado por las publicistas de las tres revistas estudiadas, (aunque las católicas siempre se intentaban diferenciar de una corriente demasiado sospechosa de descuidar el aspecto religioso) convive con la reproducción de las consignas propagandísticas impuestas por el régimen. Un discurso con el que las mujeres pretendían salvarse a si mismas.

No podemos olvidarnos sin embargo de que se trata, eso sí, de un discurso femenino propio, personal e incluso diferente, que propiciaba el reforzamiento por un lado, del propio poder nacionalsocialista, y por otro estimulaba una creencia -ficticia - por parte de las mujeres que elaboran este discurso, de su participación y capacidad de influencia en las estructuras de poder.

A pesar de la originalidad del discurso, y de la creencia de estar resistiendo al régimen, las reacciones de los grupos estudiados, a excepción de las mujeres católicas, condujeron a crasas contradicciones. Como en el caso de Agnes von Grone que lucha por su incorporación en el partido, Gertrud Bäumer que se compromete, inconscientemente con el ministerio de propaganda en tanto que pone al servicio de los nacionalsocialistas el buen nombre de DIE FRAU, como ejemplo de la „tolerancia“ del régimen. Como mujeres, reclaman su valor en una sociedad que las contempla como máquinas de hacer hijos, como mujeres reclaman en la tarea de „reconstruir“ su país, aceptando sin embargo , la división de esferas de actuación entre los dos géneros.

En el caso de las mujeres protestantes, por una parte son totalmente leales al aparato nacionalsocialista, piensan que son importantes para los objetivos de éste. Por otra parte la crítica a la uniformación del trabajo femenino y la pérdida de la independencia de las organizaciones nacionalsocialistas. ${ }^{1188}$

Respecto a las organizaciones de mujeres protestantes Phayer señala, en relación de un estudio realizado en Westfalia sobre la Frauenhilfe. ${ }^{1189}$ que las mujeres reaccionaron en función de su condición de mujeres. ¿Qué significa „en función de su condición de mujeres"? ¿Actúan las mujeres del $E v F W$ y del $D E F$ en función de una estrategia de género? A este respecto podemos afirmar que las relaciones del $\mathrm{EvFW}$ con las autoridades nacionalsocialistas están influidas por su postura respecto al Kirchenkampf, convirtiéndose las organizaciones protestantes en un juguete entre gobierno y autoridades eclesiásticas. Sin embargo la negativa del $E v F W$ a colocarse bajo la dirección de la Reichskirche, no significa que la organización estuviera con este acto mostrando su rechazo al nacionalsocialismo, sino que demostraba la independencia de su organización respecto al estado, sin cuestionar a éste.

Según los estudios de Baumann ambos movimientos confesionales de la mujer muestran posturas conservadoras que tienen que ver con la reacción conservadora de las dos iglesias en la República de Weimar. La relación de éstas con la moderna sociedad industrial levanta entre los grupos de mujeres grandes protestas. A pesar de los rasgos „modernos“ de la reforma protestante ya señalados por Hegel y Weber, permanecen en ésta, según Nipperdey, un gran número de vestigios medievales como la infabilidad de la Biblia, el trabajo conjunto entre iglesia y estado etc. Son estos rasgos los que se pone en duda en la República de Weimar y los que ponen en entredicho la cohesión de la confesión protestante. ${ }^{1190}$ Esta crisis no se manifiesta por primera en la República de Weimar. Durante el siglo XIX la teología protestante, influida por la filosofía, sufre una serie de cambios y divisiones que van a cuestionar su identidad en tiempos posteriores. Al contrario que en la teología católica, donde las cosas no han cambiado demasiado, podemos distinguir en el siglo XIX tres tendencias.

\footnotetext{
1188 Koonz, C.: Mütter im Vaterland..., op.cit., p.279

1189 Phayer, M.: Protestant and Catholic Women in Nazi Germany, Detroit, Wayne State University Press, 1990, p.42

1190 Baumann, U.: Protestantismus und moderne Gesellschaft..., op.cit., p.10
} 
Durante la República de Weimar conviven en „pluralismo protestante“ la teología dialéctica, la teología liberal y la teología del orden en la creación. La primera estaba íntimamente unida con la situación política y ideológica de la primera guerra mundial, se caracteriza por su conservativismo teológico, donde la Biblia, las escrituras como testimonio de la revelación están por encima de cualquier poder terrenal, pero políticamente puede calificarse de liberal.1191 Se trata de una teología que exige la desestalización y liberación de la iglesia, y llama al trabajo social y al compromiso político y democrático. La teología liberal representada por los discípulos de Harnack, defiende la concepción historicista de la religión. Finalmente la teología del orden en la creación, luterana por excelencia representa a un protestantismo nacional, donde se identifica la religión no sólo con el estado alemán, sino con un determinado tipo de cultura, de práctica política e identidad, donde frecuentemente se encuentran posturas antisemitas. ${ }^{1192}$ En el círculo de mujeres que publicaban en Die Evangelische FRAUENZEITUNG se encuentran representantes de estas tendencias como von Tiling y Eyl.

La colaboración de las mujeres de DIE FRAU con el régimen y su aceptación de éste refleja por una parte la inmadurez política del feminismo burgués alemán a principios del siglo XX, y su incapacidad, por otra, para comprender el significado del orden democrático. Su conciencia de clase y de raza, le lleva a posturas de ignorancia y silencio sobre la situación de las mujeres trabajadoras, de las mujeres judías, o de las mujeres implicadas en actividades de los partidos políticos en la clandestinidad. Es un feminismo replegado en actitudes literarias y artísticas que evita la implicación política de la mujer, y que sigue perpetuando la doble división de esferas de actuación entre los dos sexos.

Esta aceptación de la separación de esferas de actuación entre los dos géneros, constituye quizá la respuesta, a la pregunta sobre las actitudes políticas de las mujeres de DIE FrAU ante el nacionalsocialismo, ya que hablar de ámbitos distintos de actuación significa también hablar de la radical diferencia que estas mujeres hacían entre lo cultural y lo político. Al considerar que estos campos estaban separados, relegaron la actuación política a sus compañeros masculinos, que como Theodor Heuss comprendió la imposibilidad de editar un periódico de „carácter cultural" sin definirse políticamente, $\mathrm{y}$ ante las presiones del régimen decidió replegarse en el anonimato.

Por el contrario, Gertrud Bäumer y las demás publicistas de DIE FRAU retomaron el trabajo de ilustrar y motivar a las mujeres, pensando que únicamente realizaban ,una labor de tipo cultural", jugando a ser Diotimas sin Hiperión, sin entender las connotaciones políticas que derivaban de aquel acto.

A diferencia de otros miembros influyentes de la clase media que realizaban algún tipo de labor intelectual durante la República de Weimar, este grupo de mujeres no optó por la oposición, el exilio o quizá otras posturas menos heroicas, sino que continuaron ejerciendo, es difícil matizar si conscientemente o inconscientemente, una labor de influencia pública muy beneficiosa para el nacionalsocialismo, que veía así legitimada su actuación por los grandes santones del movimiento de la mujer, de tradición liberal y democrática. En las memorias de las mujeres relacionadas con el movimiento laico de la mujer, como por ejemplo Marie Baum, Agnes von Zahn-Harnack, Else Ulich-Beil y Elisabeth Lüders, se alude a una disconformidad constante respecto al nacionalsocialismo, a una desazón por no poder hacer nada, por una parte con el puño en posición de combate en el bolsillo, por otro lado la sonrisa en los labios cuando se trataba de hacer una crítica abierta. Agnes von Zahn-Harnack tiene palabras duras para las

1191 Krumwiede, H.W.: Evangelische Kirche und Theologie in der Weimarer Republik, Neukirchen-Vluyn, Neukirchener Verlag, 1990, pp.10-11

1192 Scholder, K.: Die Kirchen zwischen Republike und Gewaltherrschaft, Frankfurt am Main, Siedler, 1983, p.78. El principal representante de esta tendencia era Emanuel Hirsch que posteriormente apoyaría a los Deutsche Christen. 
representantes de su generación, una generación cobarde y apática dominada por un fanatismo teñido en muchos casos de cinismo, un cinismo que a pesar de todo hacía posible que esta generación se siguiera ocupando del movimiento de la mujer como si estuvieran viviendo todavía en Weimar.

Los años posteriores a la dictadura nacionalsocialista están llenos de actividades para las mujeres del movimiento de la mujer. Gertrud Bäumer se dedica a la actividad política con su participación en la fundación del CSU, y posteriormente pasa a formar parte del CDU. Agnes von Zahn-Harnack refunda la Federación de académicas alemanas.

A esta actividad en la nueva república va unida a la publicación de biografías, y escritos de homenaje. Como por ejemplo en 1953 con motivo del 80 cumpleaños del Gertrud Bäumer la revista MÄDCHENBILDUNG UND FRAUENSCHAFFEN publica un número especial con aportaciones de las colaboradoras más íntimas de Bäumer.

La valoración de la actuación de Bäumer es positiva. DIE FRAU es elogiada por su aportación a la causa del movimiento de la mujer, incluso durante el nacionalsocialismo. A Gertrud Bäumer se la presenta como un modelo a imitar por la generación futura de jóvenes. Interesante es la percepción del papel de este grupo durante el nacionalsocialismo: Gießmannsdorf es visto como un lugar de refugio de aquellos que estaban contra el régimen. Y DIE FRAU como el reflejo de la otra Alemania o como otros han llamado la cultura del exilio interior.

Es interesante observar como interpreta Bäumer los años de la dictadura. El primer punto que nombra es la pérdida de las mujeres de las posibilidades de desarrollarse en el mundo laboral. Esta observación no pasaría de ser una mera crítica al carácter antifeminista del nacionalsocialismo si no fuera por la segunda observación de Bäumer. Los hombres por el contrario vivieron einen nie gekannten Auftrieb ibres Selbsbewußtseins, ,un hasta ahora no conocido impulso de su conciencia individual". Por otra parte define al nacionalsocialismo como el anticristo, como un demonio que se apodera de las almas de los alemanes, que como drogados sucumben al poder de éste. Sin darse cuenta Bäumer formula la teoría del carácter de víctimas de las mujeres durante el nacionalsocialismo, su vida se simplificó contra la saciedad, la mayoría estaba mal informada, sobre los campos de concentración no tuvieron noticia, la reducción de la mujer a simplemente paridora de hijos es vista por esta como una humillación y la decadencia del verdadero sentido de la maternidad. Ya que el nacionalismo se trata de un estado masculino, las mujeres apenas forman parte de las decisiones que este toma, con lo cual quedan liberales de todo tipo de culpa colectiva., no obstante apoyaron con su ignorancia una dictadura del terror.

Esta falta de definición política del feminismo burgués, hace que su discurso quede limitado a posturas reivindicativas que excluyen a la mujer del mundo político, y debilita la capacidad de provocación que el movimiento de la mujer había tenido en otras épocas. Se trata de un feminismo mesiánico y domesticado que atribuye a la mujer funciones sobrenaturales y paradójicamente la destina a aceptar calladamente las decisiones de los hombres; esta situación no es contradictoria para las mujeres de DIE FRAU ya que, gracias a esta división, lograron construir su Lebensraum, un lugar de influencia y de actuación en el las diferencias de género aparecían levantadas: el reino del Geist. Es en esta diferencia donde radica la facilidad que tuvo el nacionalsocialismo de convencer, ya que al atribuirse el estado los valores masculinos, las mujeres alemanas quedaban libres de la responsabilidad moral de cuestionarse cualquier tipo de duda sobre la legitimidad del régimen.

El movimiento laico de la mujer no lo hace porque no se encuentra en sus funciones influir en aspectos políticos, en el caso católico y protestante se encuentra el apoyo ciego e incondicional a la política de sus respectivas fracciones esto hace casi imposible una alternativa individual y propia o la elaboración de un discurso político propio que pudiera presentar una alternativa política o de crítica. La supuesta neutralidad del movimiento de la mujer, se convierte en un apoyo a las diferentes fracciones y a su política de colaboración con los nacionalsocialistas. Existen excepciones en el caso católico, como Helene Weber, la cual votó en 
su fracción contra la aceptación de la ley de poderes, en marzo de 1933. Esta separación entre política y cultura se manifiesta en los últimos años de la República de Weimar, y se confirma en el trabajo posterior de las organizaciones durante el nacionalsocialismo.

El antifeminismo del régimen no impide no obstante, que las mujeres no lo acepten, son víctimas inconscientes de su situación de víctimas y a la vez son consentidoras silenciosas del régimen. Que un régimen sea patriarcal no es ninguna garantía para que no existan mujeres que no acepten las reglas del juego y que contribuyan a que este se reproduzca.

Uno de los problemas cuando analizamos la actuación de los grupos de mujeres estudiados es nuestra percepción del concepto de resistencia. En esta tarea se corre el peligro de extender el concepto hasta tal punto, que cualquier chiste o comentario jocosos podría considerarse como expresión de resistencia. Autores como Gotto, Hockerts y Repgen definen el concepto de resistencia como histórico, ${ }^{1193}$ que debe relacionarse con los condiciones del sistema a estudiar.

Según estos autores sin tener en cuenta las condiciones cotidianas de control, denunciación, etc., no puede elaborarse un concepto de resistencia o oposición durante el nacionalsocialismo. Hasta ahora el concepto iba unido a riesgo, peligro, sacrificio de la propia vida, valores hasta ahora atribuidos a los resistentes masculinos, con lo que actitudes de disidencia quedaban fuera del concepto. Según Gotto, Hockerts y Repgen se pueden diferenciar varios grados de resistencia: el primero podría abarcar el descontento puntual de la población expresado en insultos, chistes, quejas emitidas, en el bar, en la tienda de comestibles, o en una comida con conocidos. Gracias a las actas de denuncias en el tribunal de München hemos podidos comprobar los innumerables casos de condenas por injurias contra el régimen que se hacían todos los días contra ciudadanos normales. El segundo paso es la resistencia efectuada desde los valores de la autoconservación, resistencia efectuada por un grupo cuyos valores son amenazados. En este caso se encuentran las iglesias, que como grupo social veía amenazada su integridad, la resistencia en defensa de esta integridad es lo que se considera como la segunda escala de resistencia (grado defensivo). El tercer grado de resistencia afecta a la manifestación pública del descontento. (grado ofensivo) a través de manifestaciones, huelgas generales, etc. El cuarto grado de resistencia abarcaría a la resistencia activa y organizada.

$\mathrm{Si}$ nos atenemos a este esquema que específica los diferentes grados de „resistencia“ podríamos considerar que en el caso de DIE FRAU, no se observa una resistencia de tipo público, privadamente se puede considerar al grupo como de disidente, en el caso de las organizaciones de mujeres protestantes y católicas se muestra una disidencia en función de la defensa de los intereses del grupo confesional al que pertenecen. La disidencia respecto al discurso de género nos parece en todo caso una „estrategia de supervivencia” dirigida al conservar al grupo, dentro del proceso de atomización de la sociedad nacionalsocialista, pero no como una expresión de descontento hacia el régimen.

En el caso católico esta conciencia de grupo, el deseo de defender el ideal católico del mundo tiene tal éxito que se convierte, como en el caso de la iglesia confesora, en un potencial de resistencia, que en casos individuales conducirá a la oposición política, como el caso de Sophie Scholl, o la asociación de maestras católicas, o las mujeres que pertenecieron a la iglesia confesora, por poner un ejemplo. Bracher diferencia, entre la forma de disidencia que se encuentra entre las dos confesiones; mientras que la Iglesia Católica entendía la resistencia global de todos los católicos contra el régimen, transcurre el fenómeno de la resistencia entre los protestantes de una manera más individualizada. En este caso no se puede hablar de resistencia generalizada. Esta tuvo lugar en las filas de la Iglesia Protestante, fundamentalmente dentro de la iglesia confesora. Sin embargo, a excepción de Bonhoeffer muy pocos se atrevieron a ejercer una resistencia activa.

1193 Gotto, Kl.; Hockerts, G.; Repgen K.: „Nationalsozialistische Herausforderung und kirchliche Antwort. Eine Bilanz“..., op.cit., p.655 
¿Qué ocurre como mujeres como Gertrud Bäumer, Agnes von Grone o Meta Eyl, y los círculos de colaboradoras de sus organizaciones? ¿Dónde las incluimos? ¿Debemos considerarlas como brujas oportunistas, ávidas de poder y reconocimiento? y seguir. Digamos que como ocurre con los hombres, ellas constituyen también nuestro pasado negro, nuestras zonas oscuras, nuestros recovecos, la tentación del poder, la devuelta del orgullo nacional, etc.

Sin embargo sería injusto decir que el nacionalsocialismo fue un éxito a causa de las mujeres. Este juicio de valor suena a justificación, a lavado de conciencia del alma masculina. En las filas nacionalsocialistas se encontraban también, y ellos se beneficiaron en gran manera del estado de cosas que supuso el nacionalsocialismo. Como en todo régimen fundamentalista disfrutaron de las garantías de seguridad que este ofrece a los hombres en su entorno vital: la valoración de la masculinidad, el culto al héroe, la admiración y el apoyo femenino.

El nacionalsocialismo tocó las entrañas a las mujeres, les removió los corazones con sus premios a la natalidad, con sus himnos a la mujer fuerte, bella y fértil, el nacionalsocialismo les ofreció de si mismas una imagen que muchas estaban buscando.

Sería absurdo creer, por último, como concluyen algunos autores, en un determinado pluralismo dentro del régimen nacionalsocialista. Este "pluralismo“ tiene lugar fundamentalmente en grupos de mujeres que tienen una cobertura de tipo confesional o social, precisamente porque son mujeres, y por que no contradecían los fundamentos del sistema. Dentro de estas condiciones elaboran un discurso. Su actuación durante el nacionalsocialismo no esta únicamente determinada por su condición de mujeres, sino que es representativa de una determinada clase social, y pone de relieve la autoridad de un sistema que anula toda posibilidad de resistencia real por la capacidad que tenía de hacer creer a la mayoría de sus súbditos su omnipotencia sobre cada uno de ellos. Sería interesante un estudio relacionado con los hombres desde esta perspectiva de género.

Una pregunta que nos asalta durante nuestras investigaciones es sobre la naturaleza „feminista“ del las construcciones sobre lo femenino elaboradas por mujeres durante el nacionalsocialismo. Si nos atenemos a la definición de Luise F. Pusch, estas se integrarían en el llamado movimiento de la mujer Frauenbewegung. Según Pusch, el movimiento feminista es la teoría que afecta a todos los campos y pone en cuestión y critica la influencia de la sociedad patriarcal. El feminismo sería por lo tanto la teoría del movimiento de la mujer. Esta separación tiene para la autora sus límites históricos: 1848-1933, finales de los años sesenta. ${ }^{1194}$ Esta separación entre teoría y práctica se encuentra ampliamente difundida, por ejemplo en Janet Radcliffe Richards quien plantea el movimiento de la mujer como la posibilidad de mejorar las situación de la mujer; por el contrario ve el feminismo como el tratamiento social de la feminidad desde la reflexión teórica, como mujeres y no como trabajadoras, o como inválidas. ${ }^{1195}$ Esta definición coincide con todas las ramas del feminismo que surge en la Bundesrepublik después de la guerra. A esta definición radical se une la distancia de las nuevas feministas con respecto al feminismo de la primera generación. Desgraciadamente no existe una confrontación con este, especialmente con la figura de Gertrud Bäumer. Hasta 1933 aparece en muchos libros sobre la historia del movimiento de la mujer como la gran dama del movimiento. Sus actividades entre 1933-1945 pesan como una losa que las feministas no han querido remover.

La generación de mujeres de DIE FRAU, las mujeres católicas y protestantes, eligieron durante el nacionalsocialismo una alternativa complicada: no colaboraron activamente, no se

\footnotetext{
1194 Pusch, L.: “Feminismus und Frauenbewegung. Versuch einer Begriffsklärung”, en: Pusch, L. (ed.): Feminismus. Inspektion der Herrenkultur. Ein Handbuch, Frankfurt am Main, Surhkamp, 1983, p. 14.

1195 Radcliffe Richards, J.: "Welche Ziele der Frauenbewegung sind feministisch", en: Pusch, Luise (ed.): Feminismus..., op.cit., p. 20.
} 
replegaron en el silencio de la creación solitaria, sino intentaron dentro de las circunstancias influir a su manera en el régimen.

Desde esta perspectiva podemos concluir que los grupos de mujeres sobre los que trabajamos no se integran desde la perspectiva del feminismo, por una parte elaboran discursos que dependen de sus orígenes sociales, y desde esta punto de partida pretenden elaborar una imagen general de la mujer. No critican la sociedad patriarcal, sino que la aceptan dentro de las reglas del juego, aunque se opone una alternativa de género que se aleja de la mera división entre los géneros.

Así por ejemplo, el concepto de geistige Mütterlichkeit. Concepto utilizado por Gertrud Bäumer, Marianne Weber, Alice Salomon contra el mito del instinto maternal defendido por las antifeministas burguesas y contra el mito de la feminidad nacionalsocialista. Este concepto se sigue utilizando como instrumento de identificación, como seña de identidad del movimiento de la mujer. ${ }^{1196}$

La mayoría de las autoras que se ha ocupado con este período del ala moderada del movimiento de la mujer, hacen siempre referencia a la autodisolución del BDF, como prueba de rechazo de los principios del nacionalsocialismo. No obstante se obvian declaraciones de las principales dirigentes del movimiento de la mujer, donde se alude a la poca importancia que para el movimiento de la mujer, tenía un gobierno democrático o no. Esta interpretación olvida por completo la naturaleza especial del movimiento de la mujer alemán en el aspecto de la neutralidad política que llevan a la práctica hasta la exasperación, y que es interpretada en los años setenta y ochenta como prueba del rechazo al régimen.

Esta interpretación no deja de estar influida por la polémica surgida durante los primeros años de la discusión feminista donde la neutralidad política, se presentaba como forma específica de protesta femenina contra la masculinización de la política, y se defiende una forma exclusiva de política femenina.

¿Cual es la actitud de las mujeres estudiadas en relación al antisemitismo? Este aspecto es difícil de analizar, ya que en la prensa analizada no hemos encontrado ningún tipo de referencia en relación a este tema. Por el contrario en DIE EvangELISCHE FRAUENZEITUNG, encontramos en una ocasión como Eyl llama la atención sobre los prejuicios antisemitas como causa de la imposibilidad de poder discutir objetivamente sobre el valor del nuevo testamento. Si esta tendencia tiene que ver únicamente con motivos de discusión intelectual, no podemos comprobarla. Si tenemos noticias del apoyo al boycott contra las tiendas en posesión de ciudadanos judíos, en los protocolos de las reuniones del Evangelischer Frauenbund. Tanto en la prensa católica como en DIE FRAU aparece referencias al tema, ni en contra o a favor.

En el caso protestante existe, desde 1988, fecha del 50 aniversario del progrom contra los judíos el 9 y 10 de noviembre de 1938, un interés creciente en la confrontación con rasgos antisemitas en el protestantismo alemán. ${ }^{1197}$ Uno de los primeros estudios llama la atención sobre la polémica entre Leo Baeck y Adolf von Harnack, donde el primero establece rasgos antisemitas en la obra de Harnack. ${ }^{1198}$

1196 Schmidt-Waldherr, H.: "Pervertierte Emanzipation der Frau und die Organisation von weiblicher Öffentlichkeit im Nationalsozialismus”, en: Schaeffer-Hegel, B.: Frauen und Macht. Der alltägliche Beitrag der Frauen zur Politik des Patriarchats, Centaurus, Pfaffenweiler, 1988, p.10.

1197 Kaiser, J. C.; Greschat, M. (eds.): Der Holocaust und die Protestanten. Analysen einer Verstrickung, Frankfurt a. M., Athenäum, 1988

Smid, M.: Deutscher Protestantismus und Judentum, 1932-1933, München, Christian Kaiser, 1990

Nowak, Kurt; Raulet, Gérard (eds.): Protestantismus und Antisemitismus in der Weimarer Republik, FrankfurtNew York, Campus, 1994

1198 Ibídem, p. 38 
Otros trabajos se ocupan de las relaciones entre la idea nacional y los contenidos teológicos del protestantismo. Desde principios del siglo XIX los intelectuales alemanes empiezan poner los fundamentos de la identidad alemana como un conjunto cultural determinado por el idioma y la tradición.

Los teólogos protestantes no pasan por alto esta corriente e integran dentro de la teología el interés de construir la unidad alemana. Al mismo tiempo la relación Alemania-protestantismo comienza a ser uno de los signos de esta unidad nacional y de la naturaleza de la identidad alemana. ${ }^{1199}$ Este protestantismo que cultiva la tradición de la cultura alemana a través de la relación de los pastores con las familias más relevantes de la intelectualidad alemana, es lo que se llama como Kulturprotestantismus. Entre los principales representantes del Kulturprotestantismus, como ya hemos señalado con anterioridad, cabe destacar a Adolf von Harnack, Heinrich von Treitschke y Friedrich Naumann personaje que marcará a la generación intelectual y política que vive el ocaso de la república y el ascenso del nacionalsocialismo.

Junto a la idea nacional, el Kulturprotestantismus ofrece una visión de la religión desde un punto de vista cultural que se caracteriza por un alto grado de cristocentrismo, que le hace no aceptar a otras religiones, y en especial al judaísmo como origen de la religión cristiana. En este sentido algunos autores hablan de una tradición antijudaísta como un punto de cohesión y de la identidad protestante.1200 Esta tradición se acentúa, cuanto más fundamentalistas son las tendencias del protestantismo.

Interesante es el estudio sobre una organización formada por teólogos protestantes y otras personalidades del espectro liberal fundada en 1890 por Theodor Barth, Theodor Mommsen, Wilhelm Foerster y Rudolf von Gneist para luchar contra el antisemitismo. Se trata de la Verein zur Abwebr des Antisemitismus, a la que también pertenece Gertrud Bäumer. La organización logra sobrevivir hasta 1933. ${ }^{1201}$ Esta organización (en la que la mayoría de los integrantes eran protestantes o católicos) comienza en los años veinte a adoptar actitudes contrarias en relación al problema judío. Así por ejemplo apoya la decisión del DDP de retirar las candidaturas de miembros de partidos de confesión judía, o condena las muertes de Rosa Luxemburg, Kurt Eisner, Karl Lieb- knecht como bien ganadas debido a su actuación. En el DDP esta tendencia se acentúa ante el miedo de convertirse en un partido de judíos. Theodor Heuss recomienda a estos recogimiento y no la agitación que puede empeorar las cosas. ${ }^{1202}$

Estos estudios ofrecen la posibilidad de entender el porqué, especialmente la generación de mujeres perteneciente al mundo del Kuturprotestantismus, se pusieran en contra del antisemitismo, sin contar con la excepción que constituye Agnes von Zahn-Harnack. Incluso la actuación de la iglesia confesora ${ }^{1203}$, considerada tradicionalmente como un refugio para cristianos de ascendencia no aria, empieza a ser criticada por la investigación. ${ }^{1204}$

1199 Reymond, Bernard: „Die Konzepte einiger protestantischer deutscher Theologen zur „Judenfrage“, en: Nowak, Kurt; Raulet Gérard (eds.): op.cit., p.131

1200 Ibídem, p. 135

1201 Thalmann, Rita: „Die Schwäche des Kulturprotestantismus bei der Bekämpfung des Antisemitismus“, en: Nowak, K.; Raulet G. (eds): op. cit., p. 149

1202 Ibídem, p.156

1203 Graf, Friedrich Wilhelm: „Wir konnten dem Rad nicht in die Speichen fallen. Liberaler Protestantismus und „Judenfrage“ nach 1933“, en: Kaiser, J.C.; Greschat, M. (eds.): Der Holocaust und die Protestanten. Analysen einer Verstrickung, Frankfurt am Main, Athäneum, 1988

1204 Gerlach, Wolfgang: Als die Zeugen schwiegen. Bekennende Kirche und die Juden, Berlin, Institut für Kirche und Judentum, 1993. Este trabajo fue presentado como tesis doctoral en 1970 y a pesar de la positiva crítica que recibió, no logró ser publicado hasta 1993 
Esperamos que este estudio haya contribuido a aclarar los rasgos del feminismo conservador de principios del siglo XX, así como ofrecer una nueva perspectiva en el entendimiento de la perspectiva de género en el quehacer histórico, así como de las diferentes caras que un discurso que adula la maternidad y la feminidad.

Nuestra conclusión no pretende establecer un juicio de valor sobre la presunta o no culpabilidad de las mujeres. Nuestros objetivos van más allá de buscar una mistificación de las mujeres como víctimas o una demonización de éstas como opresoras. Nuestro estudio contribuye a profundizar en las diferentes reacciones de diferentes grupos de mujeres ante el nacionalsocialismo. Los grupos que tratamos no eran precisamente hadas de cuento, ejemplos de la feminidad que el. Haciendo nuestra la perspectiva de Foucault que ve analiza la sexualidad como el resultado de un complejo proceso de construcción social, pensamos que el discurso sobre la feminidad hecho por mujeres, nos da pautas muy valiosas, para entender sus posturas en casos tan complicados como una dictadura; como por ejemplo la división entre cultura y política, la percepción de si mismas en conceptos biológicos, su dependencia de las instituciones religiosas más que de las políticas. Sólo así podemos establecer un juicio de valor, sólo así podemos entender su apoyo al nacionalsocialismo, donde se utiliza la sexualidad como una estrategia de poder para perfeccionar el control sobre los individuos y sobre todo sobre las mujeres. 


\section{Apéndice $A$}

Documentos de interés

Asociaciones de mujeres

\section{Documentos de interés}

Comunicado del Bund Deutscher Frauenvereine a todos los partidos donde se recaba información sobre la postura de los partidos respecto al movimiento de la mujer.

Bund Deutscher Frauenvereine, Berlin W 30, den 13. Febr. 1933

An alle Parteien des Deutschen Reichstags

Sehr geehrter Herr Vorsitzender,

angesichts der dringenden Aufgaben im Leben von Staat und Volk und der wachsenden Beunruhigung weitester Frauenkreise um ihre Stellung und Mitarbeit in Volk und Staat erlauben wir uns, an die Leitung Ihrer Partei die nachfolgende Fragen zu richten:

1. Erkennt Thre Partei die volle, uneingeschränkte staatsbürgerliche Gleichberechtigung der Frauen als tragende Grundlage des politischen, kulturellen, sozialen und wirtschaftlichen Lebens an?

2. Ist Ihre Partei bereit, bei den bevorstehenden Wahlen diesem Grundsatz der Gleichberechtigung praktisch Ausdruck zu geben durch die Aufstellung von Frauenkandidaturen, die dem zahlenmäßigen und staatsbürgerlichen Gewicht der weiblichen deutschen Bevölkerung entsprechen?

Wir stellen diese Fragen in der Überzeugung, dass die Erfüllung der hohen Aufgaben der Frau im Familien- und Volksleben nur möglich ist unter der Anerkennung der Grundsätze von Recht und Freiheit.

Ihre Antwort erbitten wir innerhalb von 5 Tagen, da wir den Wunsch haben, unsere Mitglieder noch rechtzeitig vor der Wahl zu orientieren. Wir beabsichtigen, Ihre Antwort zu veröffentlichen; eine Nichtbeantwortung werden wir dabei als Verneinung bewerten.

In vorzüglicher Hochachtung

Der Vorstand des Bundes Deutscher Frauenvereine

Dr. Agnes von Zahn-Harnack

Vorsitzende

Fuente: HLA, BDF 22-97

\section{Reunión en el Deutschen Frauenfront}

Besprechung bei der „Deutschen Frauenfront“ am Freitag, den 12. Mai, 10,30 Uhr Anwesend: Frl Gottschewski, Fran Diers, Fran Dr. v. Zabn-Harnack. 
Frl. Gottschewski setzte auseinander, dass die Deutsche Frauen front entschlossen sei, keine „Inseln“, de.h. irgendwelche nicht zu ihr gehörigen Frauenorganisationen bestehen zu lassen. Da sie den Wunsch habe, gegen den Bund keine harten Massregeln ergreifen zu müssen, fordere sie ihn hierdurch auf, in die Deutsche Frauenfront einzutreten. Hierzu sei erforderlich, dass sich der Bund Deutscher Frauenvereine bedingungslos Adolf Hitler unterstelle und eine dementsprechende Erklärung abgebe. Die nichtarischen Mitglieder müssten aus den Vorständen entfernt werden, die prominenten Stellen müssten mit Nationalsozialistinnen besetzt werden. Die Führung der Frauenfront liege in ihren Händen. ueber die endgültige Formung, nach der ich fragte, sei noch nichts Endgültiges bestimmt, es se an die Bildung eines „Frauenkapitels“ gedacht, das in regelmässigen Zeitabstände zusammen kommen solle, und das seine Weisungen über die in Angriff zu nehmenden Aufgaben und die Art ihrer Bearbeitung von Frl. Gottschewski empfangen würde. Sie sagte ausdrücklich, dass hierbei Abstimmungen oder sonstige Meinungsäusserungen entsprechend der grundsätzlichen Ablehnung des parlamentarischen Systems durch die NSDAP nicht zugelassen sein würden, sondern dass die Entscheidungen einzig bei ihr als der Führerin lägen.

Auf meine Frage nach der Notiz, die in der gestrigen Voss über die bisherige Wohlfahrtsarbeit der Verbände gestanden hatte, zog sie ihre Behauptungen, dass wir „vom hohen Ross herab Wohltaten ausgeteilt" hätten, etwas zurück; im übrigen lenkte sie aber immer wieder in die bekannten nationalsozialistischen Gedankengänge der Bekämpfung des Liberalismus, Individualismus und Marxismus zurück. Ihr wurde hierbei durch Frau Diers sekundiert, Ich nahm dazwischen Gelegenheit, ihr einiges zu sagen über das, was wir als „national“ zwar weniger auf den Lippen, aber desto tiefer im Herzen tragen; ferner versuchte ich ihr zu erklären, dass der Bund Deutscher Frauenvereine ein Gedanken gut zu verwalten habe: nämlich die Überzeugung dass kein menschliches Werk gedeihen könne, andem Männer und Frauen nicht unter gleicher Verantwortung beteiligt seien und dass auch im geistigen Leben das Eingeschlechtige zur Unfruchtbarkeit verdammt sei. hierzu bemerkte sie, das alle diese Fragen zurücktreten hätten hinter der einfachen Frage nach der Existenz des deutschen Volkes.

Auf meine Frage, wie man sich die Organisation der weiblichen Beamten und Berufstätigen dächte, die ja sämtlich bereits in die nationalsozialistischen Organisationen eingegliedert seien, sagte sie mir, dass man für diese Frauen eine doppelte Organisation, nämlich sowohl nach der beruflichen wie nach der Frauenfront hin beabsichtige.

Endlich fragte ich sie, was geschehen würde, wenn der Bund sich nicht entschliessen könnte, in die deutsche Frauenfront einzutreten. Sie erwiderte, dass er dann Kraft des Rechts der Revolution aufgelöst werden würde. Unsere Entscheidung müsse sie spätestens bis Dienstag haben. Ich bat sie, mir zu unserer Besprechung, die ich auf Montag einberufen würde, ihre Hauptforderungen schriftlich zu geben. Sie machte hierbei erst einige Vorbehalte, sagte dann aber zu, uns eine kurze Aufzeichnung zu übersenden.

gez. Dr. A. von Zahn-Harnack

Fuente: BAK, NL.151, B.265

\footnotetext{
Reunión del Consejo directivo del Bund Deutscher Frauenvereine el lunes 15 de mayo de 1933
} 
Vertraulich!

Gesamtvorstandssitzung des Bundes Deutscher Frauenvereine am Montag, den 15. Mai 1933 vormittags $10 \mathrm{Uhr}$

Die Vorsitzende eröffnet die Sitzung und begrüsst die zum ersten Male in diesem Kreise Erschienenen, die sich durch Namensnennung der Versammlung vorstellten. Sie stellt fest, daß diese Gesamtvorstandssitzung die Befugnisse einer Mitgliederversammlung hat. Sie berichtet hierauf über ihre Besprechung mit Fr. Lydia Gottschewski, in der dieselbe die Aufforderung an den Bund Deutscher Frauenvereine gerichtet hat, der Deutschen Frauenfront beizutreten. Als Aufnahmebedingungen wurden genannt:

1. Bedingungslose Unterstellung unter den Führer der NSDAP.

2. Anerkennung der Aufgaben, die der nationalsozialistische Staat den Frauen stellt.

3. Entfernung nichtarischer Mitglieder aus den Vorständen.

4. Wahl von nationalsozialistischen Frauen in die prominenten Stellen.

Als Arbeitsmethode sei in Aussicht genommen: Zusammenkünfte eines sog. Frauenkapitels in regelmäßigen Zeitabstände zur Entgegennahme der Weisungen über Aufgaben und Arbeitsmethoden. Frl. Gottschewski betonte ausdrücklich, dass, da die NSDAP das parlamentarische System ablehne, eine Abweichung von den gegebenen Anweisungen nicht zulässig sein würde, sondern dass sie als die Führerin die alleinige Entscheidung habe.

Sie teilt ferner mit, dass die konfessionellen Verbände keine Aufforderung zum Eintritt in die Frauenfront erhalten würden.

Über die Organisation der berufstätigen Frauen wurde ausgesagt, dass dieselben nach zwei Seiten, nämlich in ihrer Berufstätigkeit durch die berufsständische Gliederung und in ihrem Frauendasein durch die Frauenfront erfasst werden sollten.

Auf die Bitte um Erläuterung von Punkt 2: Die Aufgaben, die der nationalsozialistische Staat den Frauen stellt, erwiderte sie, dass dies wohlfahrtspflegerische und fürsorgerische Aufgaben sein. Es wurde ihr entgegnet, dass der Bund Deutscher Frauenvereine keine Wohlfahrtsorganisation sei, sondern ein bestimmtes Gedankengut zu verwalten habe, nämlich die Überzeugung von der gemeinsamen Verantwortung von Mann und Frau auf allen Lebensgebieten einschließlich des politischen Lebens, also in Verwaltung, Gesetzgebung und Rechtsprechung. Frl. G. schob diese Frage beiseite, da sie bei der derzeitigen Lage Deutschlands nicht von wesentlicher Bedeutung sei.

Frl. G. Lehnte die Bitte, ihre Ausführungen auf der Sitzung am 15. Mai dem Gesamtvorstand persönlich zu machen, ab, da sie zu diesem Termin nicht in Berlin sein Könnte; sie sagte dagegen zu, uns eine kurze schriftliche Aufzeichnung der Hauptpunkte zu übersenden.

\section{Fuente:HLA, BDF 22-97}

\section{Carta del Ministerio para la Propaganda a Theodor Heuss}

Der Reichsminister für Volksaufklärung und Propaganda

Geschäftszeichen: IV 4001/18.7.

(In der Antwort anzugeben)

Berlin W 8, den 30. August 1934.

Wibelmplate 8-9 
An Herrn Schriftleiter Dr. Theodor Heuss, Bln.-Lichterfelde.

Die Art und Weise, in der die politischen Ereignisse in der Zeitschrift „Die Hilfe“ behandelt werden, entspricht nicht den Forderungen die der nationalsozialistische Staat stellen muss, und hat mehrfach zu Beanstandungen Anlass gegeben.

Ich habe meinen Referenten Dr. Brauweiler beauftragt, mit Ihnen im einzelnen zu besprechen, welche Anforderungen von Ihrer Zeitschrift zu erfüllen sind, damit Unzuträglichkeiten, wie sie sich in letzter Zeit gezeigt haben, vermieden werden.

Ich ersuche Sie, sich mit Herrn Dr. Brauweiler, der am \%. September aus seinem Urlaub zurückkehrt, in Verbindung zu setzen und mit ihm den Zeitpunkt einer mündlichen Rücksprache zu vereinbaren.

Im Auftrag gez. Dr. Jahncke

BAK, NL.221 


\section{Correspondencia entre Gertrud Bäumer y Dorothee von Velsen}

\section{D. von Velsen an G. Bäumer}

Dorothee von Velsen

Ried bei Benediktbeuern, Obb.

26.2.1934

Liebe Frau Dr. Bäumer.

Es war gut von Ihnen, mir so bald zu schreiben und noch dazu mit Hand, und ich bin Ihnen dankbar. Ich will jetzt nur einige Missverständnisse aufklären, die die Sache unnötig beschweren.

Zuerst aber besten Dank für die Papiere der Helene Lange Stiftung. Was das Wort Konkurrenz angeht, so hatte ich es ja gleich eingeschränkt, denn ich weiss natürlich ganz gut, dass Ihnen wie Frau Beckmann alle Absicht ferngelegen hat. Wenn Frau Fricke sich mit mir in Verbindung gesetzt hätte, anstatt mit der nicht mehr so orientierten Frau Dumstrey-Freytag, von der ich erst Absicht und Ergebnis erfahren habe, so hätte sich sofort feststellen lassen, dass der Rat der Stadt Leipzig nicht mehr eventueller Erbe der Lenzstiftung ist, diese vielmehr autonom, und L. nur die Rechnungsprüferinnen ernennt. Das ist in Erfurt und Leipzig genau dargelegt worden; Frau Fricke war bei beiden Tagungen, Frau Adam bei der zweiten. Da das Hamburger Legat m.W. Hamburger Studentinnen zugute kommen soll, werden wir also Bewerberinnen aus H. zunächst an die H.Lange Stiftung verweisen. Ich verstehe ohne Weiteres, dass Sie mich in der anderen Sache kleinlich finden. Vielleicht denken Sie auch, ich hätte aus persönlicher Eitelkeit gewünscht, selber mit Namen genannt zu werden. Hierzu kann ich natürlich garnichts sagen; die Befürchtung dieser Missdeutung hatte mich so lange zögern lassen, Ihnen zu schreiben. Ich habe es schliesslich getan, weil ich ja garnicht vermeiden kann, mit Anderen über Ihr Buch zu sprechen, und es mir unsympatisch war, da Kritik zu äussern (oder dieselbe anzuhören) ohne dass Sie es wissen. Denn ich bin keineswegs das einzige Mitglied des A.D.F., das so empfindet. Selbstverständlich haben Sie eine rein persönliche Schilderung Ihrer Eindrücke und Erlebnisse geben wollen. Sie betonen das ja mehrmals. Gelungen ist das aber nur für Teile des Buches. Sobald Sie über Zustände oder Tatsachen berichten, wird objektives Gebiet betreten, und die Dinge verlassen das Subjektiv-Psychologische. Jedes Werk ist doch aus beiden Elementen zusammengesetzt, und ganze Kapitel der zweiten Hälfte Ihrer Erinnerungen gehören vorwiegend in das allgemein Darstellende. Hierunter vieles aus der Frauenbewegung, und ganz gewiss das über die staatsbürgerliche Arbeit des Bundes etc, das unsere Mitglieder fragen lässt „was hat G.B. gegen den Staatsbürgerinnen-Verband?", (worauf ich stets erwidere „sie hat ihn nur vergessen."). Man muss wahrscheinlich in so enger Berührung mit der kleinen Plage in den Ortsgruppen, der Anfeindung unserer Mitglieder, zum Schluss der direkten Gefährdung der lokalen Vorsitzenden gewesen sein, wie ich es durch meine dauernden Reisen war, um zu wünschen, dass diese Tätigkeit eine Anerkennung bei der Erwähnung staatsbürgerlicher Arbeit deutscher Frauen in einem Buch von Ihnen gefunden hätte. Nennen Sie es meinetwegen kleinlich - ich fühle mich da meinen Mitgliedern näher verbunden.

Nun das Wort „feindlich“. Ich habe das nun allerdings in einem sehr missverständlichen Sinne gebraucht. Selbstverständlich sind Sie Niemandem feindlich gegenüber getreten (ausser in dem Sinn wie in der „Medusa“ usw., was hier nicht zur Frage steht.). Ich habe m.W. auch geschrieben „es ist mir feindlich“ und damit andeuten wollen, dass ich hier Mächte fühle, gegen 
die ich mich zur Wehr setze. Nicht so sehr gegen das, was Sie schreiben, als dass Sie schreiben, und jetzt. Mehr mag ich hierzu dem ungefügen schriftlichen Wort nicht anvertrauen.

Es wird mir nicht leicht, glauben Sie mir, Ihnen so zu schreiben. Ich tue es aber auch gerade auch um des Gemeinsamen willen, das die Belastung durch Unausgesprochenes in einer Zeit so ungeheuren Leidens schwerer erträgt also sonst. Im letzten Grunde wird das Gemeinsame ja nicht angetastet - und was wäre schliesslich eine Zusammengehörigkeit, die nicht Proben zu bestehen hätte!

In diesem Sinne grüsse ich Sie herzlich. Sollte ich mal wieder nach Norden kommen, werde ich anfragen. Zunächst bin ich durch mein Schatzmeisteramt beim Weltbund, das ich bis Konstantinopel (Frühjahr 1935) mit besonderer Sorgfalt zu Ende führen möchte, in andere Richtungen gebunden.

Ihre D.v.V.

\section{D. von Velsen an G. Bäumer}

\subsubsection{4}

Liebe Frau Dr. Bäumer.

Ich will nun doch einmal versuchen, Ihnen zu schreiben, damit nicht Thre ungeduldigen und sarkastischen Worte die letzten dieser Korrespondenz bleiben. Es tut mir unendlich leid, dass Sie betrübt worden sind; das sollte ja in solcher Zeit am wenigsten geschehen.

Es ist nun vielleicht am besten, ich sage auf alle Gefahr, was mich an Ihrem Buch derart umgeworfen hat, dass sich - da ich davon nicht sprechen wollte und doch in dauernder innerer Auseinandersetzung mit Ihnen stand - die ganz periphere und wirklich nicht belangreiche Verbandssache vordrängen konnte (und auch das nur, weil die Aktendurchsicht mir die Arbeit dieser Jahre wieder ganz lebendig gemacht hatte.).

Sehen Sie - ich hatte erwartet (und wie Viele es gebraucht), dass die demokratische Idee, der Parlamentarismus - kurz, die Formen der individuellen politischen Verantwortung, für die wir gekämpft haben, eine gedankliche Rechtfertigung bei Ihnen finden würden. Mir sind gestürzte Systeme wie unterlegene Menschen; niemals könnte ich an ihnen die Rolle der Freunde Hiobs übernehmen. Ich werde auch nie zugeben, dass die Dinge so waren, nur so waren, wie sie in Ihrem Buch erscheinen. Die grosse Nähe zu den Dingen, die Enttäuschung über Nichtzureichendes und natürlich die schreckliche Ernüchterung des Endes machen Sie hier wirklich (und das ist Ihr gutes Recht und das, was Sie in dem Buch wollen) ganz subjektiv. Sie zitieren sich selbst, ich weiss es; aber das Negative. In der Zeit haben wir doch einen Wiederaufstieg begonnen, grauenhafte Zeiten überwunden, das Reich zusammengehalten. Nun soll das Alles nichts mehr sein, weil nicht mehr erreicht wurde. Ich weiss, ich weiss, Sie führen entschuldigend die Erschöpfung an - aber verschlägt das gegen den Vorwurf der Würdelosigkeit, Schwäche, Selbstsucht! Ich habe über die Zustände gelegentlich mit befreundeten Männern gesprochen, die im politischen Leben ähnliche Erfahrungen gemacht haben; sie geben ihre tiefe Enttäuschung zu, sagen aber: „wir müssen jetzt schweigen“.

O wenn sie wüssten, mit welchem Wonnegeheul sich die Nazibrut auf Ihre Aussprüche stürzt, aus Ihrem Arsenal die Waffen zur Verdammung und Verhöhnung der - mir noch immer heiligen - Demokratie nimmt! Und was soll man danach noch zu ihrer Verteidigung sagen?

Aber andererseits - gewiss: Sie haben vor sich und öffentlich erklären und rechtfertigen wollen, warum es Ihnen nicht gelungen ist, das Programm, das Sie sich vorgesetzt hatten und das 
Sie mit Friedrich Naumann verband, zu erfüllen. Dass Sie das mussten, und jetzt mussten, ist freilich eine Sache, die nur Sie selbst angeht, und die man wie jede Äusserung einer Persönlichkeit hinnehmen und respektieren muss. Das habe ich jetzt besser verstanden, und so ist dieser unerfreuliche Briefwechsel doch vielleicht nicht vergeblich gewesen.

Mehr ist nun nicht zu sagen. Zu den ollen Kamellen nur möchte ich hinzufügen, dass Dinge, die die Frauen berühren, mit denen ich so lange auch in der kleinen Drecklinie gestanden habe, mir kein Vereinsklüngel sind. Aber all das ist ja individuell verschieden und wir wollen es ruhen lassen.

Ihre D.v.V.

\section{D. von Velsen an G. Bäumer}

\section{D.v.Velsen}

Ried bei Benediktbeuern, Obb.

14.7.1934

Liebe Frau Dr. Bäumer.

Hier schicke ich den bewussten Artikel. Ich hoffe, er entspricht dem, was Sie wollten, denn ohne Unterlagen und auf so knappem Raum ist eine systematische Darstellung eben einfach nicht möglich. Da Dr. Lüders an einer allgemeinen Darstellung arbeitet, sind diese mehr persönlichen Eindrücke für Ihren Zweck auch vielleicht überhaupt das Richtigere.

Ich habe mich gefreut, dass meine geliebten schlesischen Akten in der letzten „Frau“ figurieren.

Mein Pariser Aufenthalt gerade in jenen Tagen war natürlich denkbar spannend. Kein Mensch sprach von was Anderem, und Niemand sah klarer als wir, d.h. also garnicht. Aber das Irrationale des Vorgangs nahm die Phantasie auch der Anderen gefangen. Auch in der gestrigen Rede trat mir dies einer völlig anderen Kategorie Angehörige so stark entgegen, und nach den Einzelheiten, die hier durchsickern, fühlt man unabweisbar einen eben einfach vorhandenen charismatischen Zauber. Und das mit Flugzeugen etc. Die Welt ist des Wunderbaren doch nicht bar, ob man es bejaht oder nicht.

In Paris - ich hatte Vorstandssitzung des Weltbundes - war in unserem Kreis viel die Rede von der Ablehnung des I.C.W., deutsche N.S.D.A.P.Frauen zuzulassen, nachdem Alice Salomon etc die Ausreise verweigert worden war. Für den Weltbund wünsche ich nach wie vor einen neuen Zweig, wenn auch die Frauenschaften wohl bei uns weniger leicht anfragen werden als bei dem stimmrechtlich weniger belasteten I.C.W. Dessen Tagung war übrigens ziemlich kläglich, selbst beim Thema „Frauenarbeit“ der Saal der Sorbonne nicht einmal zur Hälfte voll, und die schlafende Lady Aberdeen. Es war aber hübsch, Frauen wie Gräfin Apponyi wiederzusehen. Da wir vom Weltbund ziemlich viel Zeit hatten, habe ich auch Paris recht genossen, das Musée Carnavalet, wo Sie und ich damals waren - und Vincennes, reines Mittelalter, Fontainebleau usw, immer in angenehmer Gesellschaft. Diese wird mir später direkt fehlen, aber in Istanbul kandidiere ich bestimmt nicht wieder, ohne Rückhalt in Deutschland fühle ich mich zu sehr in der Luft schweben.

In Heidelberg, wo wir drei sehr nette Lenz Stipendiatinnen haben, war ich 11/2 Tage, sehr hübsch; sprach Marianne Weber, Marie Baum (die jetzt wider (sic!) viel heiterer ist) und Ricarda Huch. Diese sah direkt wohl aus gegen früher; nachdem sie sich mit ihrem Missgeschick abge- 
funden hatte, fing die Ruhe an, ihr wohl zu tun; sie macht übrigens jetzt ganz schnelle Fortschritte. Ich find's schön, wie stark doch die deutsche Öffentlichkeit jetzt Teil nimmt, Radio etc.

$\mathrm{Ja}$, ich würde Sie sehr gern wiedersehen. Vielleicht ergäbe sich dann eine gute Stunde, ich der ich Ihnen sagen könnte, was sich bei mir angesammelt hatte - es ist natürlich immer besser, man reagiert gleich ab, aber dazu haben weder Sie noch ich viel Talent; aus diesem Gesichtspunkt war mir Ihre damalige Explosion ganz recht! Ich sehe nur nicht, wann ich mal östlich reise, d.h. nord-östlich; tue ich es aber, so frage ich beizeiten an.

Sylvia-Mo mit dem Knabenkopf ist ja goldig, und Frau v.S., die ich bestens grüssen lasse, doch ganz gut getroffen. Das Haus interessiert mich, es ist so unschlesisch. Hier in Ried ist z.Zt. Familie Fleischmann mit drei furchtbar netten Kindern und einem Spaniel. Sie waren auch in Wiessee und Peter-Paul hat sofort auf Röhms Stuhl Platz genommen. Dieser Morgen muss phantastisch gewesen sein; R's Leibwache hat nicht zu schiessen gewagt, und die verstörten Hotelgäste in den Korridoren. Aber nun Schluss.

Ihre D.v.V.

\section{G. Bäumer an D. von Velsen}

Oberschloß Gießmannsdorf

Landkreis Bunzlau

Berlin

W15., Emserstr. 22

den 15.11 .34

Frau Dr Dorothee von Velsen,

München

Maria Theresiastr. 6I

b/ Prof. Rothenbücher

\section{Liebe Frau Doktor!}

Also versparen wir das religions-philosophische Gespräch auf Stambul oder vielleicht sogar Delphi, obgleich ich für mich nicht so recht daran glaube. Ihre Frage geht nun allerdings sehr weit über mein Ziel hinaus. Ich muss natürlich die persönlichen Gründe, die Sie zu Ihrem Entschluss bestimmen, respektieren. Ich habe natürlich nur daran gedacht, dass Sie selbst doch besser nicht resignieren sollten. Die Situation, dass man zwei Deutsche nicht wieder wählen wird, dass es sich also dann um eine Entscheidung zwischen Ihnen und Adele Schreiber handelt, habe ich mir dabei nicht vergegenwärtigt. Wenn Sie nun aber ausscheiden, so entsteht ja wirklich die ganz unmögliche Situation, dass wir nur durch sie dort vertreten sind. Man sieht ja doch, bei aller Ablehnung des Antisemitismus, dass wir in der deutschen Repräsentation durch die Jüdinnen ein wenig zu tolerant gewesen sind angesichts der Tatsache, dass diese Plätze in den internationalen Organisationen ja immer zu Erbsitzen werden. Ich habe das Verkehrte daran im I.C.W. seit Jahrzehnten gefühlt, besonders eben durch eine gewisse Illoyalität der Inhaberin dieses Sitzes dem deutschen Bund gegenüber.

Ich selbst möchte lediglich, so weit es mir (...) möglich ist, vermitteln helfen. Meine Kandidatur kommt aus vielen Gründen nicht in Betracht, vor allen Dingen deshalb, weil ich als politisch abgebaute Beamtin ohne ein gewisses Einverständnis mit der Regierung einen solchen Posten gar nicht annehmen könnte, und weil ich persönlich nicht die geringste Lust habe, mich dieses 
Einverständnisses von mir aus zu versichern. Ich habe mir zum Grundsatz gemacht, von mir aus nicht einen Schritt des Entgegenkommens zu tun. Irgend eine positive Mitarbeit käme erst bei einer Wendung in Betracht, durch die man ganz generell etwa im Sinne des HindenburgTestamentes anders gesinnte Kreise, die gleichwohl „nationalsozial“ sind, einbezieht. Ich bin überzeugt, dass der Augenblick sehr schnell kommt und vielleicht schon da ist, wo nur in diesem Schritt noch die Möglichkeit läge, Katastrophen zu verhüten. Ob das gesehen und danach gehandelt wird - oder noch gehandelt werden kann - ist natürlich eine andere Frage.

In der Vertretung in den internationalen Organisationen sind sie ja jetzt an einen dead stop und im Akademikerinnenbund hat man sich ja schon zu jeder Konzession bereit erklärt, um nur überhaupt acceptiert zu werden. Auch darum würde ich es für ein Unglück halten, wenn man jetzt Adele Schreiber das Feld überliesse. Aber das könnte nur durch Ihr Dabeibleiben verhütet werden oder dadurch, dass man eine Deutsche fände, die so wenig mit der Regierung in Verbindung gebracht werden kann, dass sie draussen nicht dem Verdacht von Dr. Lüders ausgesetzt ist, im Auftrag der Regierung zu handeln, und die zugleich Aussicht hat, angenommen zu werden. Ich weiss aber allerdings niemanden.

Ich habe möglicherweise Gelegenheit, diese Fragen in den nächsten Tagen mit einem der massgeblichsten Herren des Auswärtigen Amtes zu besprechen. Schreiben Sie mir doch auf alle Fälle Ihre Londoner Adresse, damit ich Ihnen evtl. noch dorthin Nachricht geben kann.

(...)

\section{Herzliche Grüsse \\ Ihre Gertrud Bäumer}

\section{D. von Velsen an G. Bäumer}

D.v.Velsen

21.11.1936

Liebe Frau Dr. Bäumer.

Ich war sehr überrascht, zu hören und zu merken, dass Adelheid schon im Druck vorliegt. Ich komme nicht zum Lesen, weil ich - im Arbeitsdruck vor Wien - nicht richtig dafür frei bin und es doch sein möchte. Aber den Abschnitten in der Frau habe ich natürlich doch nicht widerstanden. Sicher ist das Buch sehr schön, und wie gut ist es, diese Zeit, die auch mir als die grösste deutsche erscheint und von der hohenstaufischen viel zu sehr überschattet worden ist, wieder heraufzuführen und lebendig zu machen. Dass sie lebendig geworden ist, merke ich schon an den Proben. Wie schön, zu wissen, dass Ihr ganzes eigenes Leben, alles was Sie selber getan und wofür sie gekämpft haben, nun diesen Menschen als Widerhall dient. Drücke ich mich verständlich aus? Ich meine so: viele Menschen schreiben Gutes und Vorzügliches, und es wirkt nur wenig, weil sie selber den Menschen oder den meisten unter diesen wenig bedeuten. Darin liegt scheinbar eine Ungerechtigkeit und in höherem Sinn doch eine Gerechtigkeit. Denn der Einsatz und die Fülle eines Lebens kommt so zu seinem Recht. Und darüber hinaus wird es für eine Idee oder eine Persönlichkeit, der man zum Dasein verhelfen will, in die Wagschale geworfen und drückt diese herunter. Das ist wunderbar, und dazu beglückwünsche ich Sie.

Ihr Brief, den ich nicht erwartet hatte, hat mich natürlich sehr beschäftigt. Ich verstehe Ihren Standpunkt, aber ich teile ihn nicht. Zugegeben, dass sehr viel verschiedene Elemente im Nat. Sozialismus zusammenkommen und selbstverständlich gutes Wollen dabei ist - das ich n.b. ganz scharf von dem verschwommenen Gefühl trennen möchte, das überwiegt - so bleibt der 
Grundsatz, die freie Selbstbestimmung des Menschen durch einen Zwang zu ersetzen, davon unberührt. Darum aber geht es mir. Eine Gemeinschaftsbildung auf solcher Basis scheint mir ein Rückfall schlimmster Art. Dann hätten wir die patriarchalische Gemeinschaft ostelbischer Observanz, für die sich wirklich auch allerhand sagen lässt, nicht erst zu bekämpfen brauchen. Und die offizielle deutsche Verfassung (auch die geistige) ist doch keine Spur mehr im Unbedingten verankert als die russische und mit weit weniger Entschuldigung. Wenn man die Popenwirtschaft gesehen hat - vermutlich ist sie mutatis mutandis in Spanien ebenso - so findet man die Reaktion begreiflich. Das russische Volk ist doch nach Allem was Augenzeugen berichten (allerdings nicht in unserer Presse!) nach wie vor tief religiös. Ist unsere Blut und Bodentheorie weniger diesseitig fundiert? Also warum soll nur der Bolschewismus der Feind sein? (bzw. der bestimmte Typ, wie Sie hervorheben, der aber bei uns doch in der uns entsprechenden Form genau so herrscht). Ich würde ja so gern das Bestehende als gut oder doch aussichtsreich anerkennen, denn die Negation ist etwas Furchtbares, Ertötendes - o wie klug rechnet das System damit! - aber wie kann ich das? Könnte ich wie Sie wahre, der Menschenwürde entsprechende Gemeinschaftsbildung irgendwo erblicken, in Kreisen, die denken und nicht nur ihren kleinen Spiess mit Gefühl umkleiden oder sich plötzlich als Mirmidonen/führer fühlen - ja, dann müsste ich ja mittun und mich Frau Scholz-Klink zur Verfügung stellen!! Einstweilen aber scheint mir, dass Deutschland besser gedient ist, wenn sich irgendwo noch Kreise geistiger Besinnung und stiller Opposition halten, und darin sind wir ja wohl einer Meinung. Wie schwer es ist, dabei nicht im Ressentiment stecken zu bleiben - o Gott, ich weiss es. Nichts fliehe ich so sehr, wie die Greuelatmosphäre. Vielleicht wird mir das Verständnis zum Nat.Soz. so erschwert, weil ich ihn nur in üblen Exemplaren erlebe, von der krassen Brutalität und dem Radauantisemitentum bis zum ordinären Opportunismus, soweit unsere geistigen Kreise in Frage kommen. Die vielen braven Handwerker (...) nehme ich aus; ich achte sie, sie haben in der Tat reinen Willen und es ist viel, dass wahrhaft erfasst worden sind, was wir nicht gekonnt haben, letzten Endes weil wir sie nicht genug liebten, um ihre Sprache sprechen zu können - aber sollten nun die Werte von ihnen geprägt werden, deren Blickfeld über das Nächste nicht hinausgehen kann? Ach, wie kompliziert ist es Alles! Lassen Sie bitte diesen Brief als Selbstgespräch gelten.

Dass die Nürnberger Hausfrauen Ihren (sic!) Aufsatz zustimmen, scheint mir selbstverständlich. Das ist ja gerade was ich bedenklich finde. Man liest „Feind“ und „Bolschewismus“, und damit ist der Fall abgetan.

Ich lege für die Frau eine Anzeige des neuen Buchs von Vera Brittain bei, dass (sic!) ich für Jus Suffragii zu besprechen bekommen hatte. Da ich auf meinen Aufsatz ziemlich viel Zuschriften erhalten habe, glaube ich, dass sie die Leserschaft interessieren wird. Sodann einen Times Ausschnitt zu gleichem Zweck. Es ist doch interessant, dass Mosley Frauen kandidieren lässt. Übrigens, die Richtlinien für Schulzeugnisse und die für körperliche Übungen in ihrer völligen Ignorierung der Existenz weiblicher Schüler ist doch sehr bezeichnend.

Die Sie jetzt in Berlin sind: wollen Sie einmal an meinen Vorschlag einer Sammlung von Erinnerungen aus der Frauenbewegung denken? Ich schlug damals vor, eine Reihe Frauen - A. Pappritz, Frau Jellinek z.B. - um solche persönlichen Aufzeichnungen zu bitten (...).

\section{D. von Velsen an M. Weber}

z.Zt. München. 1.3.1940

Kaulbachstr. 35, Pension (...)

Liebe Marianne. 
Die Maschine steht noch von langer Korrespondenz da, und so will ich den Abend mit einem Gruss an Dich beschliessen. Ich habe Dir seit langem schreiben wollen, denn ich wusste von Marie Baum, wie sorgenvoll Eure Tage waren. Aber nach dem Tempo der Arbeit vor Weihnachten war ich entschieden müde, auch musste ich gleich eine energische, zeitraubende und bis jetzt nicht sehr erfolgreiche Behandlung von Hals, Ohren und Nase beginnen; ich werde drei-viermal die Woche bestrahlt, was u.A. die Wirkung hat, dass die Kopfnerven noch weniger zum Schlafen zu bringen sind als sonst; auch das viele Kokain bekommt mir schlecht. Ich habe aber keine Depressionen!! und folglich garkeinen Grund zur Klage. Es bedeutet nur, dass ich mich auf meine Arbeit beschränken muss. Ohnehin kamen mir die schon viel zu zahlreichen Bekannten aufs Bett, und ich war ganz froh, mit meinem Kehlkopf als Begründung jede Unterhaltung absagen zu können.

Ich war nach vier Wochen Ried, in denen ich viel gelesen hatte, vierzehn Tage hier, als ich eines Nachts ein Telegramm erhielt, wonach Moni, unsere geliebte Moni, schwer erkrankt war. Als ich am Morgen anrief, war es schon vorbei. Eine ernste Krankheit, die sich G.s.D. gleich beim ersten Anhieb so ausgewirkt hatte. Operation, Herzschwäche. Dieser Verlust bedeutet mir nicht nur den endgültigen Abschluss meiner (...) Vergangenheit, sondern den eines des innerlich vornehmsten Menschen, die ich gekannt habe. Und es war so reizend, für sie zu sorgen. Sie war noch garnicht ,alt", noch keine 70, und i.W. ganz frisch. Wie hat sie doch meinen Wagen genossen! Ich fuhr dann gleich nach Berlin und ordnete alles, eine grässlich traurige Sache. Da ich schon mal auf der Achse war, rutschte ich nach Göttingen weiter, fand meine Schwester endlich viel wohler und genoss innigst, innigst ihre Enkelkinder. Es ist das erste Mal, Marianne, dass ich an Kindern solche Freude hatte - ach, Freude ist ein unzulänglicher Ausdruck - dass sie mir in ihrer Besonderheit aufgingen, und alle Möglichkeiten, die in ihnen ruhen, mich bewegten. Ich buche dies als neuen grossen Gewinn. Das zunehmende Alter bringt so manches. Die Reise war an sich phantastisch, chaotisch, wie die Kohlenlage, mit der die Reg. sich blamiert.

Und nun Frau von Sandens Tod! Mir blieb förmlich der Atem stehen, als ich die Anzeige bekam. Es ist mir auch jetzt noch unfasslich, nachdem Frau Ulich-Beil mir das Nähere, wahrhaft Versöhnende, geschrieben hat: ein Einschlafen, das sie den Schmerzen derselben Krankheit enthob, die Moni ergriffen hatte, nachdem die letzten Monate offenbar zwar Beschwerden, aber keine quälenden Schmerzen gebracht hatten. Ich kann sie mir so garnicht aus unserem Kreis fortdenken. Ohne eigentlich mit ihr befreundet gewesen zu sein, hatte ich doch in den Jahren seit 1920 so unendlich viel mit ihr erlebt - erst die allerletzten hatten den Verkehr gelockert, dass sie mir näher stand, als viele die ich weit länger kannte. Und für G.B. ist es natürlich eine schwer auszumalende Veränderung.

Und dann die allgemeine Ungewissheit - der Tod und die akute Gefährdung so manches Sohnes von Freunden - von Eckart garnicht zu reden. Wie ein Nachtmahr liegt das Frühjahr vor Einem.

Und doch überlässt man sich mit einer unerhörten Wonne dem Tage. Da die nächste Stunde unberechenbar ist, wird die gegenwärtige kostbar. Ich finde alles ungeheur (sic!) spannend. Ich bin viel - ja ich muss sagen: glücklicher, als ich es seit 33 je gewesen. Der furchtbare Druck hat sich gelöst, die anderen Kräfte sind auch mobil und man nicht nur der einen Gewalt ausgeliefert. Ganz klein werden schon die anderen und sollen es noch mehr werden. Macht ist nicht mehr dasselbe wie Diktatur - womit ich nicht sagen will, dass ich für uns eine Demokratie á la Weimar zurückwünsche.

Du meinst, ob ich überrascht sei über die Ausweitung meines Lebens durch das Lesen, Lernen und Produzieren? Aber nein, keineswegs! Es ist doch nur eine der Erfüllungen, die das Leben mir schuldete. Ich wäre ebenso wenig erstaunt, wenn ich sechsfache Mutter oder grosse Liebende geworden wäre - das alles ist ein Frage der Umstände; die Anlage ist gegeben und will heraus. 
Ich habe auch einen neuen Stoff. Er kam nach etwas mühsamem Warten - das muss man sich anerziehen, es lässt sich nicht erzwingen. Es wurde nicht Therisiana, obwohl ich seit über einem Jahr darin arbeite (Und G.Bs Aufsatz über M.Th. mich - unter uns gesagt - unangenehm journalistisch im Ausdruck berührt), sondern eine frühere, mehr barocke Periode: Türkenkriege, Banat, Serbien; also sehr viel Vorarbeit.

(...)

\section{D. von Velsen an G. Bäumer}

Ried, 31.3.1940

„... Lassen Sie mich nun, da ich Ihnen schon einmal schreibe, noch ein Wort zur letzten „Frau“ sagen. Ihren Aufsatz, den von Marianne Weber, und den kurzen „Ich habe Angst um Dich" finde ich (einen) würdigen und guten Ausdruck der Gegenwart. Und dann kommt - und zwar unter Volkswirtschaft - der Auszug aus dem Schwarzen Corps zur Kriegsväterfrage. Ich hatte, da eine Opposition gegen dieses Blatt sich verbietet, erwartet, die Frau würde diesen Artikel, dem sich nicht leicht etwas an die Seite setzen lässt (Wattenscheid allenfalls, aber das ist ja desavouiert) mit Stillschweigen übergehen. War das nicht möglich? Der kleine zahme Kommentar (aus Alice Rilkes Feder?) ist beinahe eine Zustimmung. Der springende Punkt, die Brandmarkung des Mädchens, das nicht bereit ist, sich (man muss schon sagen: irgendwie) zur Mutter machen zu lassen, als Fahnenflüchtige und quasi Vaterlandsverräterin, steht doch in schreiendem Gegensatz zu allem, was die Frauenbewegung vertritt. Dazu die S.S.Briefe, die Lebensbornhäuser - das ist doch ein geschlossenes System! Muss auch eine Zeitschrift wie die „Frau“ ihm dienen? Meine Frage ist nicht rhetorisch, sie ist ernsthaft. Ich übersehe das nicht und möchte es wissen. Ich hätte ja auch Frau Magnus fragen können, aber das widerstrebte mir. Bitte, denken Sie nicht, ich ginge herum und suchte, wo ich etwas zu meckern fände! Ich bin wirklich nur froh, wenn ich irgendwo zustimmen kann, denn Opposition mit verschlossenem Mund ist ein zu verfluchender Zustand, ein ertötender. Aber schliesslich, es giebt (sic!) Dinge - ! Nun, das wissen Sie ebenso gut. Sollte ich Sie mit diesen jetzt verschonen? Wenn ja, so bitte verzeihen Sie. Man verlernt es nachgerade, Privatmensch zu sein." ...

31.3.1940

D. v. Velsen

\section{G. Bäumer an D. von Velsen}

Schloss Ober-Giessmannsdorf

über Bunzlau, 4.April 1940

Frau Dr. Dorothee von Velsen, Ried bei Benediktbeuren / Oberb.

Liebe Frau von Velsen,

Ich möchte gleich zu der letzten Frage etwas sagen, die Sie in Ihrem Brief berühren und Ihnen für den ersten Teil vorläufig vielmals danken. Wenn ich Zeit habe, komme ich auf die Punkte, die Maria Theresia betreffen, noch einmal zurück. Von dem Buch wird jetzt das zweite 
Zehntausend gedruckt. Ich freue mich, dass Sie es in der „Hilfe“ besprechen. Ich bekam übrigens einen bezaubernden Brief von Ricarda Huch, er enthält für mein Gefühl die beste Formulierung über ihre „Form“, die man nur finden kann.

Aber nun zu der Frage der Notiz. Natürlich schreibe ich alle Notizen, die eine Stellungnahme enthalten, selbst. Auch für die übrigen bekomme ich von A.R. das Material, das meist in eine andere Form gebracht werden muss, schon wegen des Raumes.

Ich bin nun in Bezug auf die Behandlung solcher Dinge wie dieser Ausführungen im Schwarzen Korps absolut entgegengesetzter Ansicht wie Sie. Erstens müssen die Frauen solche Dinge wissen, und es lesen eben nicht alle das Schwarze Korps. Ich kann vielleicht zunächst einmal an einem anderen Beispiel diese Notwendigkeit erörtern: Es ist seit einiger Zeit der Presse verboten, Ehescheidungsurteile zu kommentieren. Das Verbot kam nach einer Erörterung über den jetzigen Zerrüttungsparagraphen und die sich daran anschliessende Rechtsprechung, bei der Bedenken gegen Gesetz und Rechtsprechung vom Interesse der Frau aus ausgesprochen wurden. Einige Zeit später wurde sogar verboten, die Urteile selbst abzudrucken, zweifellos um keine Beunruhigung unter den Frauen hervorzurufen. Wir haben nun in unserer bibliographischen Übersicht über die Rechtstellung der Frau diese Urteile zwar natürlich nicht im Wortlaut abgedruckt, aber doch so inhaltlich wiedergegeben, dass der Sinn erkennbar wird. Eben um die Frauen aufmerksam zu machen.

Die Erlasse, von denen der Aufsatz im S.K. ausgeht, müssen meines Erachtens mit dem dazu gegebenen Kommentar bekannt werden. Was nun die Stellungnahme dazu anlangt, so ist es selbstverständlich unmöglich, seiner moralischen Entrüstung hemmungslosen Ausdruck zu geben, wie wir das früher konnten. Es ist aber wohl möglich, den Punkt sachlich zu bezeichnen, an dem die Gefahr dieses Erlasses liegt: dass nämlich Erzeuger und Vater noch zwei sehr verschiedene Begriffe sind, und dass man den Begriff der Vaterschaft nicht anwenden darf auf solche Männer, die nicht daran denken, Vaterpflichten übernehmen zu wollen. Je sachlicher und ruhiger im Ton das geschieht, umso besser nach meiner Meinung. Ich kann nicht zugeben, dass unsere Stellungnahme in der Sache „zahm“ ist, und darauf kommt es doch schliesslich an. Im übrigen hat sich auch über diese Sache - genau wie damals über Wattenscheid - eine grosse Auseinandersetzung erhoben bei einer Tagung der Gau-Frauenschafts-Leiterinnen, an der auf deren Wunsch die für den Erlass verantwortlichen Männer teilgenommen haben. Es ist daraufhin ein zweiter Erlass vom Himmler an die SS. ergangen, der natürlich nicht öffentlich bekannt gemacht wird, etwa in dem Sinne: „wehe dem Schuft, der das Mädchen sitzen lässt.“ In Verbindung damit ist dann die Frage der Rechtsstellung des unehelichen Kindes wieder zur Diskussion gekommen, und es wird eine Gesetzgebung vorbereitet, die anscheinend durch die „List der Vernunft" genau zu denselben Vorschlägen führen wird, die wir immer gemacht haben.

Ich glaube, Sie machen sich - wie sehr viele andere - keine rechte Vorstellung von den Schwierigkeiten, von unserem Boden aus eine Zeitschrift herauszugeben, und haben vielleicht deshalb keinen rechten Massstab dafür, was auf dem Wege, den ich als Hauptschriftleiterin gehe, dauernd und mit jedem Heft riskiert wird. Sie werden mir keine Zeitschrift in Deutschland nennen können, die auf ihrem Gebiet in der Freimütigkeit und Kritik (direkt und indirekt) so weit geht, wie „Die Frau“ es tut, und darum muss ich allerdings sagen, dass ich mich - und nun lassen Sie mich den Ausdruck gebrauchen, den Gertrud von Sanden in einem solchen Falle gebrauchen würde - über solche Anmerkungen ganz einfach ärgere, besonders wenn sie aus dem Refugium gemacht werden, in dem einen der Wind überhaupt nicht trifft.

Ich wollte diese Sache erst gern loswerden, ich schreibe noch persönlich.

Mit herzlichen Grüssen

Ihre Gertrud Bäumer 


\section{D. von Velsen an G. Bäumer}

D.v.Velsen

7.4.1940

Liebe Frau Dr. Bäumer.

Ich bin Ihnen dankbar für Ihre Antwort, und dass Sie mir geantwortet haben. Ich kann Ihnen auch den „Ärger“ sehr gut nachfühlen - (ach, wie höre ich Frau von Sanden sprechen!) und glauben Sie mir, das Bewusstsein meines ungefährdeten backwaters verlässt mich bei solchen Anfragen nie und gibt mir das peinliche Gefühl, das Sie, mit Recht, zu verschärfen trachten. Es ist ganz richtig, dass man sich aus der Zurückgezogenheit, die ich nun einmal gewählt habe (denn meine innere Zustimmung zu der Nötigung lässt sich einer Wahl gleich setzen), schwer ein zutreffendes Bild macht. Und ich hätte, trotz meiner inneren Verbundenheit zur „Frau“ und ihrem Kreis wirklich nicht an diese Sache gerührt, wenn ich nicht glaubte, und dies auch nach Ihrem Brief, dass sich eine Schriftleitung über die Wirkung einer Formulierung häufig täuscht. Es ist wie mit behördlichen Erlassen. Sie enthalten Feinheiten und eine subtile Kritik , die der Eingeweihte versteht, die dem üblichen Leser aber ganz verloren gehen. Ich hatte mich auch schon gefragt, ob Sie vielleicht das Dokument festhalten wollten. Dafür schien mir der Ausschnitt zu fragmentarisch. Und wenn auch natürlich eine Kritik nicht „,hemmungslos“ sein kann, so war ich der Meinung, dass sie die Stellung des Blattes doch deutlicher hätte ausdrücken können.

(...)

\section{G. Bäumer an D. von Velsen}

Schloss Obergiessmannsdorf

über Bunzlau, 9.April 1940

Liebe Frau von Velsen,

Ich muss noch einmal auf Ihren Brief vom 7.4. antworten und zwar wegen des Satzes, vor dem ich einigermassen fassungslos stehe: „mir lag am meisten daran, zu erfahren, ob „Die Frau“ verpflichtet war, dem Schw.C. gewissermassen zu sekundieren, und das scheint ja nicht der Fall zu sein“. Was bedeutet eigentlich dies „scheint“, muss ich fragen, und zwar wirklich sehr ernsthaft fragen, denn, nicht wahr, Sie sind sich doch darüber klar, dass in der Wahl dieses Wortes ein Zweifel an meiner Darlegung der Angelegenheit enthalten ist? Aber darüber hinaus die Vermutung, die der Satz ausspricht, an sich: Glauben Sie wirklich, dass ich eine solche Verpflichtung eingehen würde? - Das einmal zum Prinzipiellen.

Zur Sache selbst: mit welchem Recht nennen Sie die Wiedergabe des Textes ein ,,sekundieren“, wenn sie erfolgt, um zu dem grundsätzlichen Punkt Stellung zu nehmen. Unter „,sekundieren“"versteht man ja, wie Sie wissen, im dritten Reich etwas sehr anderes! Darüber sind die Begriffe ja eindeutig!

Und noch ein Wort über die Leute, die bei Ihnen in dieser Weise, die Sie beschreiben, an der Frau Kritik üben. Wer ist das eigentlich? Die Frage soll nicht bedeuten, dass ich irgendwelche Namen wissen will natürlich, aber ich erkenne an diesem einen Beispiel schon, wie unfair und 
misstrauisch diese Kritik sein muss. Warum lesen die Leute dann eigentlich die Frau überhaupt noch?

Dass wir uns sachliche Einwände und vor allen Dingen irgendwelche positiven Anregungen aus dem Leserkreis direkt wünschen, dass wir den Kontakt, der ja nun nicht mehr durch die Vereine hergestellt wird, auf andere Weise herzustellen bemüht sind, mag Ihnen das beiliegende Anschreiben zeigen, das wir an Frauen in allen Teilen Deutschlands in diesen Tagen verschicken. Das Charakteristische ist nämlich, dass man von den Seiten, die Kritik üben, so gut wie niemals irgend einen positiven Wunsch oder eine positive Anregung bekommt, und so lange hat für mein Gefühl die Kritik allerdings etwas sehr Parasitäres.

Es liegt hier ein Buch von Else Hocks über den letzten deutschen Papst. Da ich eigentlich annehmen muss, dass Ihre Studien Sie mit Adrian von Utrecht zusammengeführt haben, wollte ich Sie bitten, für die „Frau“ dies Buch zu besprechen. Ausserdem bat schon vor längerer Zeit Dr. Fassbinder darum, dass Sie das Buch ihrer Schwester über Clara von Assisi besprechen möchten. Ich schicke deshalb beide mit.

(...)

Ihre Gertrud Bäumer

\section{D. von Velsen an G. Bäumer}

Dorothee von Velsen

Ried bei Benediktbeuern, Obb.

11.4.1940

Liebe Frau Dr. Bäumer.

Wenn Sie es nicht schrieben, würde ich erklären, den Ausdruck „scheint“ nicht gebraucht zu haben. Er ist in der Tat vollkommen unzulässig, aber auch unzutreffend. Was ich meinte, ist: „das ist nun offensichtlich nicht der Fall“, also „scheint“ im Sinne von „es ist klar" - ein Sinn, den der Ausdruck nicht hat, und der mir auch nicht - psychoanalytisch gesprochen - aus einem unterbewussten Zweifel verräterisch in die Feder geflossen ist, sondern aus einer stilistischen Nachlässigkeit , die ich nicht verstehe und wirklich sehr bedaure. Denn natürlich war für mich die Frage mit Ihrer Erklärung erledigt.

Das „Sekundieren“ jedoch bezieht sich auf die Möglichkeit, dass den Blättern Auflagen in dieser Beziehung gemacht werden. Das lesende Publikum weiss, dass alle Blätter Zuschriften bekommen über Dinge, die sie bringen müssen und andere, die sie nicht erwähnen dürfen. Wir schliessen, dass es oft unvermeidlich ist, um ein Blatt zu halten, entgegen zu kommen, oder dass man, um einem wirklich unerträglichen (,nicht tragbaren“) Beitrag zu entgehen, einem anderen zustimmen muss, wenigstens in den Punkten, in denen man nicht unbedingt anderer Ansicht ist. Wir haben uns manchen Aufsatz in der Frau gewissermassen als Abschlag erklärt. Es ist nicht möglich - niemandem, er versteinere denn - sich von den herrschenden Ideen frei zu halten (oder in eine ungemessene Oposition (sic!) zu treten), und so fragt man sich wirklich oft, welches die Stellung auch solcher Personen ist, deren Ansichten man einigermassen zu kennen glaubte.

Wenn Sie nun wissen wollen, wer „wir“ sind, so kennen Sie ja ungefähr meinen alten Arbeitskreis und wissen auch, dass ich in Österreich von früher her starke Beziehungen habe, die ich natürlich in den letzten Jahren noch vertieft habe. Es ist unvermeidlich, dass, wenn man über Frauenfragen spricht, auch die Stellung Ihres Blattes berührt wird. Der Aufsatz im Schwarzen Corps hatte in München sehr stark eingeschlagen, man wartete mit einer gewissen Span- 
nung, was die Frau sagen würde, ob sie nicht vorziehen würde, zu schweigen. Ich bitte Sie aber, nicht zu denken, dass wir die Köpfe zusammenstecken oder dass geklatscht und „gemeckert“ würde. Es ist eine Art Kopfzerbrechen, ob es so sein müsse etc, und manche ziehen die Haltung der „Kämpferin“ vor, die ungeniert Kritik übte, auf die Gefahr hin, verboten zu werden, was ja auch geschah, aber eine klare Sachlage schuf. Andere meinen, es sei besser, so viel Kompromisse zu schliessen, wie nötig, um nur das Blatt zu erhalten. Das finden namentlich die, die der NSDAP nahe stehen. Man solle ruhig sekundieren, das sei das geringere Übel. Ich war froh, als Frau M.v.H. mir einmal Beispiele gab, über die Dinge, die die Frau zu bringen abgelehnt hatte, weil ich dadurch die Schwierigkeit einer Schriftleitung bei solchen Gesprächen illustrieren konnte. Misstrauisch ist man geworden und hat nach all den Erfahrungen auf öffentlichem Gebiet ja auch allen Anlass dazu (ich denke jetzt nicht an die Frau), aber unfair scheint mir nicht der richtige Ausdruck. Wenn diese Frauen sich nicht an sie wenden - wie ich es tue - so aus einer Scheu und Unsicherheit (im Ausdruck, nicht in der Anschauung). Ich würde auch nicht von parasitär sprechen, denn viele Menschen, deren Kritik durchaus fundiert ist, und die wertvolle praktische Arbeit aufweisen können, aus der ihre Überzeugung hervorgeht, haben nicht die Gabe, zu formulieren oder theoretische Anregungen zu geben. Sollen sie sich deswegen einer Kritik enthalten? Das kann man doch kaum verlangen.

Ich hoffe, ich habe Ihre Fragen beantwortet, soweit das möglich ist. Wenn das Rundschreiben einen guten Erfolg hätte, wäre das sehr zu begrüssen.

Ich verstehe ganz gut, dass Sie scharf werden, und es tut mir leid, dass ich Sie - z.T. durch eine ungeschickte Ausdrucksweise - verletzt habe.

Die Bücher will ich gern besprechen.

Ihre D.v.V.

\section{G. Bäumer an D. von Velsen}

Schloss Obergiessmannsdorf über Bunzlau 16. April 1940

Frau Dr. Dorothee von Velsen,

Liebe Frau von Velsen,

Ich lege Ihnen auf alle Fälle Ihren Brief noch einmal ein - zu meiner Rechtfertigung, wenn Sie so wollen. Über die Art, in der den Zeitschriften „Auflagen“ gemacht werden, müsste ich Sie einmal mündlich orientieren können. Sie lässt auf alle Fälle immer noch sehr viel Spielraum für die Art, wie die Sache ausgeführt wird. Das ist bei den Zeitschriften anders, als bei der Tagespresse, es wird im allgemeinen nur die Sache benannt, die behandelt werden muss (wobei auch das „muss" kein ganz unbedingtes ist und sein kann, da ja die Zeitschriften durch ihre fachliche Spezialisation ihren Raum etc. garnicht in der Lage sind, alle diese geäusserten Wünsche zu berücksichtigen). Ich kann es Ihnen vielleicht am deutlichsten machen an dem Stichwort „England“. Sie werden auch aus der übrigen Presse gemerkt haben, dass diesem Stichwort das zweite: Plutokratie hinzugefügt war, und wenn Sie dann meinen Aufsatz im Aprilheft mit dieser Parole vergleichen, dann haben Sie ungefähr einen Eindruck von dem Spielraum, der einem zwar nicht ausdrücklich gegeben wird, den man sich aber nehmen kann.

Noch ein Wort zur „Kämpferin“. Sie berücksichtigen nicht, dass die Kämpferin eine nationalsozialistische Zeitschrift war. Sie hat an manchen Dingen Kritik geübt, aber nicht - und das 
ist der grosse Unterschied - an der grundsätzlichen politischen Einstellung. Sie ist, wie ich ja durch Herrn Bott und auch aus anderen Quellen weiß, nicht so sehr wegen ihrer Kritik an sich verboten worden, sondern weil sie diese Kritik vom Boden des Nationalsozialismus selbst geübt hat und insofern, um es mit dem offiziellen Ausdruck zu bezeichnen, „Verwirrung“ stiftete. Die Schwierigkeit lag darin, dass die Zeitschrift sich dem Nationalsozialismus zurechnete und ihn bekanntem, aber keine Partei-Disziplin übte. Und nun würde ich noch gerne wissen, welche Aufsätze im Sinne Ihres Briefes Sie als eine Art von „Abschlag“ für unerfüllbare Forderungen betrachtet haben. Ich habe buchstäblich niemals einen solchen Aufsatz gebracht und würde es niemals tun. Ich würde niemals in der „Frau“ ein Wort sagen, zu dem ich nicht aus voller sachlicher - nicht taktischer - Überzeugung stehe. Meine Absicht ist, in eine sachliche Auseinandersetzung zu kommen, dazu ist die rein journalistische Schneidigkeit, die wird uns früher leisten konnten, nicht nur unmöglich, sondern auch vom Ziel aus gesehen unzweckmäßig.

Aber den Ausdruck „unfair“ muss ich aufrecht erhalten angesichts einer Kritik, die selber nichts riskiert und das nicht wertet, was bei dieser Haltung riskiert wird. Das müsste schon der Vergleich mit der ganzen übrigen Presse, auch der Zeitschriften-Presse, gerade unseren Mitarbeiterinnen ohne weiteres einleuchtend sein.

Nun aber genug davon, ich merke, indem ich diktiere, doch immer mehr, dass es unmöglich ist, jemandem, der die Situation der Presse heute nicht kennt, ein Bild zu geben. Aber es ist ein wenig peinlich, zu empfinden, dass diese Lücke eben nicht durch das persönliche Vertrauen ausgefüllt wird, auf das man geglaubt hat einen gewissen Anspruch erworben zu haben.

Noch etwas anderes: Marie Baum schreibt mir, dass sie auch schon an den kommenden siebzigsten Geburtstag von Marianne Weber denken. Ich finde natürlich unbedingt, dass irgend etwas veranstaltet werden muss.

Mit herzlichen Grüssen

Gertrud Bäumer

\section{D. von Velsen an G. Bäumer}

Dorothee von Velsen

z.Zt. Gotha

21.4.1940

Liebe Frau Dr. Bäumer.

Ich war auf Ihre Frage natürlich ganz vorbereitet, und wenn ich erst heute antworte, so liegt es daran, dass Ihr Brief mir auf verschiedene Etappen gefolgt ist und ich die ersten Tage hier allerhand Dinge zu erledigen hatte, die ich nicht gern verschieben wollte. So bin ich erst jetzt an einer befreundeten Maschine.

$\mathrm{Zu}$ den mir unangenehmen Aufsätzen hat, wie Sie sich entsinnen werden, der über den Internationalen Frauenbund gehört. Nicht nur an sich und weil er in starkem Gegensatz zu dem stand, was Sie selber - ich glaube 1919 - unter dem Titel „Demokratie und Frauenbewegung“ (oder ähnlich) gebracht haben, sondern auch, weil ich der Meinung war, es handle sich um eine oben gewünschte Beurteilung dieses Fragenkomplexes. Als ausgesprochenen „Abschlag“ habe ich später einen Aufsatz betrachtet, der sich mit der Kritik durch die Presse befasste. Diesem Artikel stimmte ich inhaltlich zwar zu, er schien mir aber so wenig mit den Aufgaben der „Frau“ zu tun zu haben, und der Leiter der R. Propaganda aus nicht zwingenden Gründen genannt, d.h. lobend hervorgehoben zu werden, dass ich (und durchaus nicht ich allein) ihn als eine Art 
Loskauf aufgefasst habe. Diese Beispiele genügen gewiss. Ich kann hier nicht die letzten Jahrgänge durchsehen, möchte es auch nicht. Es ist ja nicht meine Absicht, mich über die Stücke zu verbreiten, in denen ich von Ihrer Auffassung abweiche, oder die ich nicht gern in diesem Blatt sehe. Ich wollte vielmehr Ihnen in akuten Fällen, in denen sich eine Diskussion notgedrungen entspinnt, dieses mitteilen, weil es mir richtiger schien.

Ich weiss nach Ihrem letzten Briefe nun nicht, glaube es aber beinahe, dass ich mich auch zu denen rechnen soll, die Sie als unfair und Schmarotzer bezeichnen. Ich hatte das bei den früheren Briefen nicht so aufgefasst. Sei dem nun, wie ihm sei: ich werde fortan nicht mehr der Schriftleitung in solchen Fällen schreiben.

Das soll mich aber nicht abhalten, im Sinne der Schriftleitung über die wirklichen Schwierigkeiten aufzuklären, die diese behindern. Ich fand hier eine gewisse Misstimmung über den Aufsatz über England vor, der sich zwar von dem Tenor „Plutokratie“ unterscheidet, aber doch wesentliche Merkmale des englischen sozialen Lebens, wie die Fabianer, die Quäker, die settlements etc, offensichtlich nicht erwähnen durfte. Ich nahm an, in Ihrem Sinne zu verfahren, wenn ich die Stellen unserer Korrespondenz, die sich mit dieser Frage i.e.S. befassen, vortrug. Der hiesige Kreis war lebhaft interessiert und ganz überwiegend, ich glaube einstimmig der Ansicht, die Frau müsse auch unter Opfern dieser Art gehalten werden. Auch wurde dankbar anderer Aufsätze Ihrer Feder gedacht, so dessen vom 20. April 1939 und seiner Würdigung der Arbeit unter der Weimarer Regierung (...). Wir haben auch einige praktische Vorschläge formuliert, die Ihnen in diesen Tagen zugehen werden. Persönlich möchte ich hinzufügen, dass mich seinerzeit ausserordentlich der Bericht der Vorsitzenden der Organisation der Hebammen über ihre Ausbildung interessiert hat, und dass ich solche Darstellungen für sehr wertvoll halte, auch in Hinblick auf die junge Generation. Vielleicht liesse sich mehr diser (sic!) Art gewinnen.

Ich bin in etwa 14 Tagen wieder in Ried, berühre vorher Jena, wo ich Ricarda Huch besuche, Gera und Leipzig.

Mit besten Grüssen

Ihre D.v.V.

\section{D. von Velsen an G. Bäumer}

D.v.Velsen

z.Zt. Wien I, Dotoheergasse 6, Pens. Aclon

30.11 .1940

Liebe Frau Dr. Bäumer.

Heute ist Samstag und alle Archive und Bibliotheken zu (...) uns (sic!) man kann mit dem besten Gewissen der Welt anderen Dingen nachgehen.

Die Frau kam programmgemäss an, und ich habe mit grossem Interesse Ihren einführenden Artikel wie den Aufsatz von Frau Ulich-Beil gelesen. An sich graust es mir immer, wenn diese alten Sachen hervorgeholt werden, die man so gern der Vergessenheit anheimgeben würde, aber es gehört mit zu dem Schicksal der Gegenwart, dies nicht zu können und zu dürfen. Gerade in seiner Ruhe finde ich die Rekapitulierung des Versailler Vertrags höchst eindrucksvoll. Bei Ihrem Aufsatz frage ich mich, ob die anderen auch Europa empfinden oder nur wir? Ich hoffe, auch die anderen. Und da ist der griechische Maaststab (sic!) sehr schön gedacht. Zum Problem 
Europa würde ich aber wünschen, auch den Osten in der Frau behandelt zu sehen. Was weiss man schon von Littauen, dem Balkan, der Türkei - die doch alle das Antlitz und die Zukunft unserer Welt mit bestimmt haben.

Der Osten ist einem hier besonders nahe. Schon in Wiener Vorstädten, die mit einiger Mühe schon der Ukraine angehören könnten. Ich gehe mit Genuss hindurch, mit noch grösserem allerdingd (sic!) durch Grinzing und die anderen Weindörfer. Kürzlich war ich einige Tage auf dem Jagdgut der Prinzessin von S.-Meiningen, habe die Stille, die langen Unterhaltungen, die z.T. von mir ganz fremd gewordenen Voraussetzungen ausgingen, und die wunderbaren tiefen, an Stifter gemahnenden Wälder sehr genossen. Ich sehe überhaupt viel Menschen, und, da Österreich mir über die Maassen (sic!) interessant ist, ohne Widerstreben. Es sind alle Stimmungen vertreten, und es ist schwer zu sagen, welche überwiegt. Denn die Kompliziertheit der Lage, der Fluss der Dinge und die Erziehung der Menschen, die sie ungern direkt widersprecehn (sic!) lässt (wie in England), bringt es mit sich, dass allzu leicht aus dem Walde nur widerschallt. Ich liebe Österreich, bewundere es, halte die Türkenkriege für eine ganz grosse Periode deutscher Geschichte, und habe es somit leicht, Verständnis zu finden. Natürlich sind viele sehr verbittert, von der Art der Übernahme (es ist überhaupt sehr, sehr viel wieder gut zu machen) und dem, was sie im Freundeskreis erleben, und der alte Minderwertigkeitskomplex macht sie schon an sich empfindlich. Es ist summa summarum die Situation wie nach 71 in Bayern. Es sind viel zu viel Preussen hier, und Niemand (sic!) soll mir einreden, dass, wenn es schon Altreichler sein sollen, nicht Süddeutsche es sachlich ebensogut - vielleicht etwas langsamer - und menschlich wesentlich besser machen würden. Ich liebe den hiesigen Schlendrian! Ich warte gern auf meine Akten, weil der Registrator sich mit dem Kollegen über die letzte Inszenierung der Zauberflöte unterhalten muss, und ich bummle selber mit Vergnügen in den alten herrlichen Räumen herum, wo ich selber stöbern darf.

Es ist mir hier viel leichter, über allerhand Unerfreuliches der Gegenwart hinwegzukommen, weil gerade Partei und dgl. ein Moment des Zusammenwachsens werden können, vielleicht es schon sind. Was unerfreulich wirkt, ist die Verärgerung, die nicht mehr im Stande ist, zu fühlen, dass wir in hohem Maasse (sic!) Geschichte erleben, und keinen Blick für geschichtliche Zusammenhänge besitzt. Aber uns fällt es ja auch nicht immer leicht, die Steine, an denen wir anstossen, zu übersehen, und es sind wirklich auch oft allzu grosse Klötze.

Dies erinnert mich an Ihre Bemerkung über das allgemeine Mitleiden, von dem Sie sagen, es sei Ihnen, im Sinne von Dostojeweskis Schuld aller an allem, fremd. Dies hatte ich auch nicht gemeint, und so will ich mich konkreter ausdrücken.

Wir alle wissen z.B. von der Ausweisung der ca 7000 Juden aus Baden und der Pfalz vor etwa vier Wochen. Wir machen uns wohl auch alle eine ziemliche Vorstellung von dem Vorgehen der SS gegen die polnische Zivilbevölkerung. An diesen Dingen können wir nichts ändern und, im Falle der Juden sehr wenig, in dem der Polen garnicht helfen. Vielleicht halten Sie es für müssig und für eine nutzlose Kraftvergeudung, diesen Dingen nachzuhängen. Ich aber glaube, dass innerhalb grösserer Zusammenhänge, die wir nicht übersehen und die sich dem Verstande entziehen, solches „Mitleiden“ nicht verloren ist, und dass wir es den Leidenden schuldig sind. Ich halte deswegen auch vielen Unterhaltungen still, weil die Aussprache oft die einzige Hilfe ist, die wir gewähren können, sei es den Betroffenen selber, sei es denen, die in besonderem Masse mitleiden. Dies hatte ich damals andeuten wollen.

Nun möchte ich Ihnen noch sagen, dass ich vor Kurzem Ihr Buch „Sinn und Formen“ gelesen habe. Sie hatten es mie (sic!) früher geschickt, damals aber war ich mit anderen Dingen zu sehr beschäftigt. Jetzt habe ich eine Fülle einleuchtender und aufschlussreicher Gedanken dort gefunden, für die ich aufnahmefähig war. Also danke ich Ihnen verspätet für die Gabe. Ich werde das Buch zu Weihnachten einigen jungen Freundinnen schenken, die sich mit der Gegenwart herumschlagen. 
Wo werden Sie das Fest verbringen? Hoffentlich in Giessmannsdorf. Ich hoffe bestimmt, bis dahin hier so weit zu sein, dass ich heimkehren kann. Ich habe hier viel gute Bekannte, möchte aber nicht bleiben. Melk oder Krems, an das ich dachte, oder ein anderer Ort mit schöner Kirche, ist unter den Kohlen- und Verpflegungsverhältnissen auch nicht eindeutig reizvoll.

Ich vermute Sie in Reutlingen, wo die Tage sicher wehmütig sind, aber doch sicher auch hübsch und erfreulich.

Mit besten Grüssen

Ihre D.v.V.

Fuente de correspondencia entre Gertrud Bäumer y Dorothee von Velsen: BAK, Kl. Erw. Nr.296

\section{Disolución de la Asociación general de maestras Alemanas Erfurt, 7 de mayo 1933}

„Die Vetreterinnen-Versammlung des Allgemeinen Deutschen Lehrerinnen Vereins empfiehlt den Reichsfachsverbänden, sich der Pfingsten 1933 zu begründenden Allgemeinen Deutschen Erzieher-Organisation anzuschließen.

1. Die im A.D.L.V. zusammengeschlossenen Lehrerinnen stehen mit Aufrichtigkeit und innerstem Verantwortungsgefühl in der Arbeit an der Erziehung der Jugend zu ihren Pflichten im Volk. Sie stellen sich bewußt in den Dienst der Volkwerdung und arbeiten daran mit begeisterter Hingabe in nationalem und sozialem Sinne. Mehr noch als von anderen Volksgenossen wird von Lehrern und Erziehern bewußtes Erfassen der großen nationalen Ziele der Regierung und letze Dienstbereitschaft für sie gefordert werden müssen.

Im Interesse der Volkwerdung und der Einheit des Erzieherstandes sind die Lehrerinnen bereit, ihre ihnen so wertvolle Gemeinschaft im A.D.L.V. aufzugeben. Die Verbände gliedern sich in die neue gemeinsame Erzieher-Gemeinschaft ein unter der Voraussetzung, daß die Zugehörigkeit zu ihr nicht abhängig gemacht wird von anderen Bindungen als denen, die die Reichsregierung für die Erziehertätigkeit im neuen Staat für notwendig erklärt.

2. Die Fachverbände behalten ihre geographische Gliederung nach Ländern, Provinzen und Gemeinden. Neben der in den „Anweisungen des Reichsbevollmächtigen für die Überführung der bestehenden Lehrerverbände in den Reichserzieherbund" enthaltenen Zusicherung, daß bis zur grundsätzlichen Neuregelung die rechtliche Struktur der Verbände nicht berührt wird, muß zugleich die Sicherheit gegeben werden, daß die sozialen Einrichtungen der übertretenden Verbände auch in der neuen Gemeinschaft erhalten werden.

Es erscheint erwünscht, durch Übernahme des Vereinsorgans auch in der neuen Erziehergemeinschaft ein Blatt weiter bestehen zu lassen, in dem grundsätzlich die Fragen des gesamten Mädchenbildungswesens sowie der weiblichen Lehrerschaft erörtert werden können.

3. Der Allgemeine Deutsche Lehrerinnen-Verein wird am 7. Mai 1933 aufgelöst.“

Fuente: Beckmann, Emmy: Die Auflösung des Allgemeinen Deutschen LehrerinnenVereins, DIE FRAU, Junio 1933, n9, p. 549 
Primeras críticas de Scholtz-Klink a Agnes von Grone

\author{
Abschrift \\ Deutsches Frauenwerk \\ Reichsstelle
}

Berlin 8.0.36, 16.Aug.1935

An das Frauenwerk der Deutschen Evangelischen Kirche,

z. Hd. Frau Dagmar von Bismarck, Potsdam, Mirbachstr. 1.

Die Reichsfrauenführerin

Sehr geehrte Frau von Bismarck!

Ihren Brief von 10. August habe ich erhalten, und ich muss Ihnen darauf erwidern, dass meine Ablehnung Frau von Grone darauf beruht, dass sie durch ihre Verhalten für mich als Parteigenossin in führender Stellung in einem Frauenverbände untragbar ist. Meine Einstellung hierin ist sachlich begründet. Ehe aber die Angelegenheit von massgebender Stelle aus geklärt ist, muss ich es ablehnen, auf Einzelheiten einzugeben.

Zu dem Satz Ihres Briefes:

"Für die Führung unseres Werkes müssen wir für uns in Anspruch nehmen, dass wir in voller Freiheit und Verantwortung Entscheidungen kirchlicher Art allein treffen" kann ich lediglich sagen, dass es für Nationalsozialisten eine Trennung von religiösen und völkischen Belangen nicht gibt, und dass es für uns eine Notwendigkeit ist, auch die kirchliche Führung mit dem Totalitätsanspruch des Nationalsozialismus in Einklang zu bringen.

Heil Hitler!

gez. Gertrud Scholtz-Klink

Fuente: LKAN V 163a (2986b)

Prohibición de la doble pertenencia a las organizaciones de mujeres nacionalsocialistas y organizaciones confesionales

Nationalsozialistische Deutsche Arbeiter Partei

Reichsleitung

Die Reichsführerin.

Berlin, den 23.11.1936

An das Evangelische Frauenwerk

über den Reichskirchenausschuss.

Unklarheiten und Massnahmen innerhalb der kirchlichen Frauenarbeit, die geeignet sind, Beunruhigung in die Reihen der N.S. Frauenschaft zu tragen, veranlassen mich, folgende Erklärung abzugeben: 
Die korporative Mitgliedschaft des Evangelischen Frauenwerks (Evangelische Frauenhilfe) im Deutschen Frauenwerk ist mit dem heutigen Tage erloschen.

Gleichzeitig stelle ich es jeder bisher nur korporativ durch das Evangelische Frauenwerk (Evangelische Frauenhilfe) erfassten Frauen anheim, die Einzelmitgliedschaft im Deutschen Frauenwerk zu erwerben.

Damit wird dann jeder deutschen Frau anstelle der bisherigen korporativen (d.h. mehr oder minder anonymen Mitgliedschaft) durch namentliche Eintragung als Einzelmitglied die Möglichkeit gegeben, im Deutschen Frauenwerk ihre Bereitschaft zur Mitarbeit am Aufbau des Dritten Reiches unter Beweis zu stellen.

Heil Hitler

gez. Gertrud Scholtz-Klink

Fuente: LKAN V 163a (2986b)

Medidas de control sobre las organizaciones de mujeres protestantes

Abschrift

N.S. Frauenschaft

Deutsches Frauenwerk

Berlin SW 11, den 6.4.1934

Prinz Albrechtstr. 5

Preussenhaus.

Rundschreiben Nr. 10.

An alle Gaufrauenschaftsleiterinnen

An die Vorsitzenden der im

Deutschen Frauenwerk zusammengefassten Verbände

Zwischen dem Frauenwerk der deutschen evangelischen Kirche und dem Deutschen Frauenwerk wurde folgendes vereinbart: Frauen von Amtswaltern, welche nicht in führenden Stellungen in Frauenschaft oder Partei sind, können führende Stellungen in kirchlichen Frauenverbänden einnehmen.

Doppelmitgliedschaft der NS Frauenschaft und der Evangelischen Frauenhilfe ist gestattet.

Da jede Kirchengemeinde zum Dienst an der Volksgemeinschaft besondere Aufgabe hat, bedarf sie kirchlich geschulter Frauen für diesen Dienst.

Bei Neugründungen soll mit der örtlichen Leitung der NS Frauenschaft Fühlung genommen werden, um von vornherein Gegensätze und Spannungen auszuschalten. Anmeldungen von Versammlungen, soweit sie sich lediglich mit religiös-kirchlichen Angelegenheiten beschäftigen, sind nicht notwendig.

F.d.R.

gez. Hildeg. Loeser. Heil Hitler!

gez. Gertrud Scholtz-Klink

Führerin der NS Fraueschaft

Führerin des Deutschen Frauenwerks 


\section{Fuente: LKAN V 163a (2986b)}

\section{Programa de la liga católicas de mujeres alemanas 1933}

Aufgaben des Katholischen Deutschen Frauenbundes in der Zeit.

Köln, im August 1933

Der Katholische Deutsche Frauenbund ist der Überzeugung: daß die in seinen Satzungen zuerst genannte Aufgabe, „die Herausarbeitung des katholischen Frauenideals in Familie, Beruf und öffentlichem Leben und seine wirksame Einstellung in die gesamte Kulturbewegung der Gegenwart" heute ihre besondere Bedeutung hat. Ja, die Vollziehung der Aufgabe tritt in ein neues, sehr wichtiges Stadium.

Es besteht die Gefahr:

einer Vermännlichung der Frau, wie sie sich bei den verschiedensten Veranstaltungen und Erziehungsmaßnahmen zeigt; ferner

einer nur biologischen Wertschätzung der Mutterschaft und

einer Geringschätzung der unverheirateten Frau.

Demgegenüber hat der Katholische Deutsche Frauenbund die Aufgabe:

die hohe Auffassung des Katholizismus vom Wesen der Frau wachzuhalten und zu stärken, für die Erhaltung einer rechten Rangordnung der Werte Sorge zu tragen

und in erster Bemühung für die wahre Freiheit der Persönlichkeit,

die Bedeutung der Stille und Verinnerlichung,

die Pflicht der Verantwortung,

die Kraft der Unterscheidung der Geister,

die Stärkung des Gewissens

und die große Aufgabe der Verwirklichung katholischer Auffassung im gesamten Bereich des Lebens wirksam einzutreten.

Es ist bedeutsam, daß im katholischen Deutschen Frauenbund die Frau zur Frau spricht,

daß Frauen aller Bildungsschichten und Stände

Verheiratete und Unverheiratete

Jüngere und Ältere

geeint an der Erziehung der katholischen Frau arbeiten und eine Atmosphäre geschaffen wird, die in das ganze Leben hineinwirken kann.

Es ist wichtig, daß es Laienbereiche gibt, die in engster Verbindung mit der Kirche stehen . Sie können das Laiengewissen stärken und haben die Möglichkeit zu wirken, wohin der im engeren Sinne kirchliche Verein nicht reicht. Das ist heute besonderes notwendig, da interkonfessionelle Vereine (Frauenschaften der N.S.D.A.P.) ständig an Ausdehnung und Bedeutung zunehmen.

Aus der geistigen Arbeit ist seit Bestehen des Bundes immer wieder seine praktische Tätigkeit erwachsen, die stets neue Gebiete in sich aufnahm.

(Wir erlauben uns nochmals auf den gesandten Tätigkeitsbericht „Aus der Arbeit des KDF“ 1931/32 hinzuweisen; dem heutigen Schreiben liegen noch besonders bei: Ausführungen der Haus und Landfrauenvereinigungen, ein Bericht de Bundesjugend über das große Reichstreffen in Eibingen, das das Wollen der Jugend zeigt, sowie eine Aufzeigung der Aufgaben der Mütterschulung.) 
als solche Arbeitsgebiete nennen wir besonders:

die Herausarbeitung des rechten Bildungsideals der katholischen Frau (Mutterschaft und Jungfräulichkeit);

die Bemühung um die Erhaltung und Stärkung der christlichen Auffassung der Ehe und Familie. In dieses Große Bereich gehört die seit einigen Jahren übernommene Eheberatung, die sich besonders darum bemüht, neben der gesundheitlichen und allgemeinen Beratung der geistigseelischen gebührende Raum zu sichern. In diesem Zusammenhang ist die Zusammenfassung und Schulung der Hebammen zu nennen, die in Einkehrtagen und Kursen auf die große Bedeutung ihrer Aufgabe hingewiesen werden;

die Mütterschulung, die vom katholischen Deutschen Frauenbund als eine umfassende Bildungsarbeit angesehen wird und die neben vielfältiger hauswirtschaftlicher und volkswirtschaftlicher Ausbildung vor allem die Stärkung der aus dem Religiösen aufsteigenden geistigen Kraft zur Gestaltung und Beseelung der Familie vermittelt. Die im großer Zahl eingerichteten Gemeinschaftsferien für Mütter bieten eine besonders gute Gelegenheit neben wahrer körperlicher Erholung auch die geistig-seelischen Kräfte zu stärken;

die Bildungs- und Schulungsarbeit an Haus- und Landfrauen. Die Berufsvereinigungen müssen in ihrem organisatorischen Aufbau erhalten bleiben. Auch wenn sie die wirtschaftliche Vertretung einstweilen nicht ausüben können, müssen sie doch als geschlossene Einheiten bestehen bleiben, um gegebenenfalls als Katholische Gruppen in den Neuaufbau der Berufsstände einzutreten. Außerdem haben sie gerade jetzt eine Fülle anderer Aufgaben;

die Bemühungen um die Umgestaltung der Frauenberufstätigkeit, die Erhaltung der Berufsarbeit in bestimmten Grenzen (u.a. Frauenstudium), die rechte Einordnung der berufstätigen Frau in die Familie. Hier ist insbesondere auch zu nennen; die Mitarbeit an der wesenseigenen Gestaltung des weiblichen Arbeitsdienstes und des Werkjahres für Abiturientinnen;

die Stärkung einer neuen christlichen Liebesgesinnung, die den Vielen, um die die Öffentlichkeit keine Sorge mehr tragen wird, treu Behütung zusichert. Die soziale Ausbildung, die zur Einrichtung von Sozialen Frauenschulen in Aachen, Berlin und München geführt hat, in denen eine große Zahl katholischer Fürsorgerinnen herangebildet wurde, muß vertieft und gefördert werden;

Mitarbeit an der Gestaltung der Massenbildungsmittel wie Buch, presse, Theater, Film Rundfunk, erschien beim heutigen Stand der Dinge besonders notwendig.

Die wichtigste Aufgabe ist die religiöse Vertiefung und Verinnerlichung, Nur von dieser Grundlage aus wird es möglich sein, die großen und mannigfaltigen, ständig wachsenden und ständig neuen Aufgaben mit innerer Sicherheit und wirklicher Zuversicht in Angriff zu nehmen.

Der Jugendbund ist ein Teil des Katholischen deutschen Frauenbundes. Er hat unter der gebildeten weiblichen Jugend der höheren Schulen, die heute von der neutralen Organisation des „Bundes deutscher Mädel“ erfaßt wird, einer starke Entwicklung genommen, und hat gerade wegen der weiblichen Führung einen besonderen Wert.

\section{Fuente: $A B A, F e n-57$}


Colaboradoras de DIE FRAU desde 1933 hast 1944

\begin{tabular}{|c|c|}
\hline Acker-Wulff & Ilse \\
\hline Agricola & Ellen \\
\hline Arnold & Sybille \\
\hline Auburtin & Angèle \\
\hline Aust & Johanna \\
\hline Baum & Marie \\
\hline Bäumer & Gertrud \\
\hline Baumgart & Gertrud \\
\hline Beckmann & Emmy \\
\hline Beheim-Schwarzba & ch Martin \\
\hline Bertrand & Karin \\
\hline Bettingen & Ilse \\
\hline Beyer-Katte & Wanda \\
\hline Bez-Mennicke & Trude \\
\hline Blochmann & Elisabeth \\
\hline Bode & Gertrud \\
\hline Boedecker & Elisabeth \\
\hline Boehm & Elisabeth \\
\hline Boettischer v. & Armgard \\
\hline Boje & Walter A. \\
\hline Bönig & Hedwig \\
\hline Bornstedt & Silvia \\
\hline Botsky & Katarina \\
\hline Boughaus & Gerta \\
\hline Breit & Maria \\
\hline Brökelschen-Kemp & er Else \\
\hline Bub & Gertraude \\
\hline Buch & Martha \\
\hline Bunsen v. & Marie \\
\hline Burchard-Lange & Franzi \\
\hline Burkhardt & Ilse \\
\hline Cauer & Marie \\
\hline Crailshaim v. & Carola \\
\hline Cron & Helmut \\
\hline Dehio & Adelheid \\
\hline Diepgen & Paul \\
\hline Dimel & Grete \\
\hline Dobroschke & Maria \\
\hline Dohna, Gräfin & Freda Maric \\
\hline
\end{tabular}

\begin{tabular}{|c|c|}
\hline Dönhoff & Martha \\
\hline Drechsler-Hohlt & Mathilde \\
\hline Droz-Rüeg & Gertrud \\
\hline Dubber-Marcks & Hilde \\
\hline Eckardt von & Eva \\
\hline Ehlers & Gusta \\
\hline Einem v. & Charlotte \\
\hline Encke & Anna \\
\hline Enckendorff & Marie Luise \\
\hline Engelhardt von & Julie \\
\hline Engler & A. \\
\hline Erdmann & Franz \\
\hline Erdmann & Yella \\
\hline Erdmann & Veronika \\
\hline Ernst & Johanna \\
\hline Ersch & Margarete \\
\hline Esser & Elisabeth \\
\hline Esser & Gisela \\
\hline Fabricius & Clara \\
\hline Fassbinder & Anna Klara \\
\hline Ferber & Elfriede \\
\hline Feuerbach & Henriette \\
\hline Fischer & Erika \\
\hline Fischer-Lamberg & Hanna \\
\hline Foster & Mafalda \\
\hline Frank & Erika \\
\hline Freiburg & Ursula \\
\hline Gaebel & Kathe \\
\hline Gallwitz & S.D. \\
\hline Geyer & Sophie \\
\hline Gierke & Anna \\
\hline Glasenapp v. & Elisabeth \\
\hline Glaser & Martha \\
\hline Glaue & Helene \\
\hline Godin, Freiin v. & Maria Amalie \\
\hline Gottlieb & E. \\
\hline Graefe & Johanna \\
\hline Gröning & Gisela \\
\hline Grüntzig & Christa \\
\hline Grüters-Kühn & Hanna \\
\hline Hahn & Erna \\
\hline Hansen-Blanke & Dora \\
\hline Happig-Natorp & Annemarie \\
\hline Harmsen & Elisabeth \\
\hline Hartog & Hans \\
\hline Hartong & M. Magd. \\
\hline Hass & Sibylle \\
\hline
\end{tabular}




\begin{tabular}{|c|c|c|c|}
\hline Heim & Erna & Kübler & Käthe \\
\hline Heine & Margarete & Kuhn & Leonore \\
\hline Heinrichs & Charlotte & Kühn & Editha \\
\hline Heister & Elisabeth & Kühn & Margarete \\
\hline Helms & Dorothea & Kurlbaum-Siebert & Margarete \\
\hline Henneberger & Ziska & Landgraf & Helene \\
\hline Henschke & Margarete & Lenz von Borries & Kara \\
\hline Herkommer & Agnes & Leschke & Hedwig \\
\hline Herzog & Edgar & Leupold & Charlotte \\
\hline Hetzer & Hildegard & Lindenau & Käthe \\
\hline Heuser & Hilde & Lippert & Elisabeth \\
\hline Heuss-Knapp & Elly & List-Ganser & Berta \\
\hline Hilger & Lina & Lorentzen & Lutz \\
\hline Hippke & Margarete & Lück & Conradine \\
\hline Hofer & Klara & Lüders & Marie- \\
\hline Hohly & Pauline & Elisabeth & \\
\hline Holtz & Erna & Ludwig & Renate \\
\hline Hübler & Meta & Ludwig & Robert \\
\hline Hueck-Dehio & Else & Lungershausen & Margarete \\
\hline Inönü & Ismet & Мacco & Ida \\
\hline Irmer & Martha & Magnus & Anneliese \\
\hline Iwanowa & Dimitrana & Magnus von Hausen & Frances \\
\hline Jaehner & Doris & Malsburg von der & Fides \\
\hline Jellinek & Camilla & Mankiewictz & Eva Marie \\
\hline Jung & Gertrud & Martens-Edelmann & Agnes \\
\hline Kapfer & Josephine & Matz & Rose \\
\hline Keller & Gertrud & Mayer & Anna \\
\hline Kempf & Rosa & Meinradus & Else \\
\hline Keyserlingk v. & Margarete & Meissner & Else \\
\hline Kirsch & E. & Merleker & Elisabeth \\
\hline Klante-Eger & Lydia & Messerschmidt & Ingeborg \\
\hline Klein & Johannes & Meyer-Frank & Heinrich \\
\hline Klewitz & Käthe & Meyer-Rottmannsdorf & f Marie \\
\hline Klingg & Thomas & Meyn von Westenholz & z Elisabeth \\
\hline Klipstein & Editha & Mittermaier & W. \\
\hline Köhler & Theodor- & Moers, von & E. \\
\hline Heinz & & Molzahn & Ilse \\
\hline König-Warthausen, v. & r. Gabriele & Mosolf & Anna \\
\hline Konrad & Johanna & Müller & Irmgard \\
\hline Körner & Klara & Müller & Jenny \\
\hline Korowin & Konstantin & Müller & Paula \\
\hline Köstlin & Therese & Multz & Erna \\
\hline Kottenhoff & Anna & Nadler & Käte \\
\hline Kretschmar & Freda & Nau-Roeser & Gertrud \\
\hline Krieger-Wimpf & J. & Neumeister & Heddy \\
\hline Krieser & Lotte & Neundörfer & Ina \\
\hline Krisch & Lieselotte & Niemann & Almuth \\
\hline Krog & Tora & Niemeyer & nnemarie \\
\hline Kroll & Edith & Nolte & Hilde \\
\hline Krukenberg-Conze & Elsbeth & Obermair-Schoch & Hilde \\
\hline
\end{tabular}




\begin{tabular}{|c|c|c|c|}
\hline Oehquist & Rita & Stahl-Meding & Hildegard \\
\hline Oertzen von & Etta & Steckner & Erika \\
\hline Oldenberg & Babette & Striecker & Käthe \\
\hline Patzig & Gabrielle & Suersen & Elisabeth \\
\hline Paulsen & Anna & Taxis-Bordogna & Olga \\
\hline Peters & Margarete & Thielen & H.S. \\
\hline Piper & Otto & Thomas & Anneliese \\
\hline Possart & Margarette & Thomson & Tusnelda \\
\hline Ranke & Leopold & Tidemann & Wera \\
\hline Rathgen & Imgard & Treuge & Margarete \\
\hline Rauchberg & Helene & Ulich-Beil & Else \\
\hline Reck & Gertrud & Urban & Gisela \\
\hline Reichenau & Irmgard & Usinger & Fritz \\
\hline Reicke & Ilse & Utz-Brüssov & Lotte \\
\hline Rhode & Käthe & Velsen, v & Dorothee \\
\hline Ribbentrop v. & Maria & Vitzthum, Gräfin & Anne-Lore \\
\hline Riezler & Paula & Wagner & Elisabeth \\
\hline Rilke & Alice & Wald & Annemarie \\
\hline Ripke & Ruth-Roberta & Walther & Henny \\
\hline Rogge-Börner & Sophie & Weber & Marianne \\
\hline Romberg & Irma & Weber-Colonius & Ellen \\
\hline Rüdiger & Gertrud & Wegener & Ilse \\
\hline Sachsen-Meiningen v & v. Prinzess Georg & Weinberg-Becker & Hermann \\
\hline Sanden von & Gertrud & Weiss-Reyschner & Elisabeth \\
\hline Sanden-Loeschke, v. & Katharina & Wellmann & Hilde \\
\hline Saring & Toni & Werfer & Fanny \\
\hline Satz & Anna & Wessel & Helene \\
\hline Schauer & Marie & Westerkamp & Alix \\
\hline Schemann & Bertha & Wex & Else \\
\hline Scheucher & Lydia & Wilbrandt & Ilse \\
\hline Schick & Philippine & Wilbrandt & Robert \\
\hline Schieber & Anna & Will & Ruth \\
\hline Schleicher & Berta & Willich & Lotte \\
\hline Schlözer von & L. & Willmer & Hermann \\
\hline Schlüter-Hermkes & Maria & Wirth-Stockhausen & Julia \\
\hline Schmitz & Chr. & Witting & Gabrielle \\
\hline Schmücker & Anna & Witzthum & Anne-Lore \\
\hline Schneider & Marie & Wölfel & Liddy \\
\hline Scholtz & Gertrud & Wunderlich & Friede \\
\hline Schubart & Wilhelm & Wünsche & Ilse \\
\hline Schubart & Gertrud & Wurmb & Agnes \\
\hline Schwarz & Maria & Wussow v. & Erna \\
\hline Schwiesau & Elli & Zahn-Harnack v. & Agnes \\
\hline Seggel & Sophie & Zarncke & Lily \\
\hline Siebels & Eva & Ziekursch & Else \\
\hline Siebold v. & Judith & Zilken & Elisabeth \\
\hline Sierstopfff & Bertha & Zypries & Johanna \\
\hline Silling & Marie & & \\
\hline Spörri & Gertrud & & \\
\hline
\end{tabular}


Organizaciones de mujeres conservadoras-liberales y confesionales en el año 1933

\begin{tabular}{|c|c|}
\hline $\begin{array}{l}\text { Bund Deutscher Frauenvereine (1894) (Federación de asociaciones } \\
\text { de mujeres alemanas). Número de miembros en } 1931\end{array}$ & \\
\hline - Deutscher Staatsbürgerinnen-Verband (Unidad de mujeres alemanas) & 4.000 \\
\hline $\begin{array}{llll}\text { - Allgemeiner deutscher Hausbeamtinnenverein } & \text { (Unión general de } \\
\text { funcionarias) } & & & \\
\end{array}$ & 2.350 \\
\hline $\begin{array}{l}\text { - Allgemeiner deutscher Hebammenverband (Unión general de } \\
\text { madronas) }\end{array}$ & 15.700 \\
\hline $\begin{array}{l}\text { - Berufsorganisation der Krankenplegerinnen Deutschlands (Organización } \\
\text { profesional de enfermeras de Alemania }\end{array}$ & 3.757 \\
\hline - Bund deutscher Künstlerinnnen (Federación de artistas alemanas) & 1.500 \\
\hline - Bund für angewandte und freie Bewegung (Federación artística libre) & \\
\hline $\begin{array}{l}\text { - Deutscher Frauenbund für alkoholfreie Kultur (Federación de mujeres } \\
\text { alemanas para la cultura sin alcohol) }\end{array}$ & 2.053 \\
\hline - Deutscher Fröbelverband & \\
\hline $\begin{array}{l}\text { - Deutscher Verband der Hauspflege (Unión de mujeres para el cuidado del } \\
\text { Hogar) }\end{array}$ & 3.811 \\
\hline $\begin{array}{l}\text { - Deutscher Verband der Sozialbeamtinnen ( Unión alemana de las } \\
\text { funcionarias sociales) }\end{array}$ & 4.000 \\
\hline $\begin{array}{l}\text { - Deutscher Verband gegen Alkoholismus (Unión alemana contra el } \\
\text { alcoholismo) }\end{array}$ & 1.903 \\
\hline - Sozialbeamtinnen & 4000 \\
\hline - Diplom und Handelslehrerinnen & 400 \\
\hline $\begin{array}{l}\text { - Frauengruppe des Gewerkschaftbundes der Angestellten (grupo de } \\
\text { mujeres de la federación sindical de trabajadoras) }\end{array}$ & 90.000 \\
\hline - Genossenschaft für Frauenheimstätten (Cooperativa de hogares de mujeres) & 129 \\
\hline - Jüdischer Frauenbund (Federación de mujeres judías) & 16.420 \\
\hline - Kartell deutscher Frauenklubs (Cártel de los clubs de mujeres alemanas) & 3.259 \\
\hline - Komba & 11.061 \\
\hline - Loheland & 400 \\
\hline $\begin{array}{l}\text { - Reichsfrauenausschuss des Reichsbundes der Beamten und } \\
\text { Angestellten Deutschlands ( Comité de mujeres de la federación de } \\
\text { funcionarias y trabajadoras) }\end{array}$ & 400 \\
\hline $\begin{array}{l}\text { - Reichsverband der Innungen für das Damenschneiderei-Gewerbe (Unión } \\
\text { de los gremios de las trabajadoras en la industria textil) }\end{array}$ & 35.000 \\
\hline $\begin{array}{l}\text { - Reichsverband deutscher Hausfrauenvereine (Unión de amas de casa } \\
\text { alemanas) }\end{array}$ & 130.000 \\
\hline $\begin{array}{l}\text { - Reifensteiner Verband für wirtschaftliche Frauenschulen auf dem Lande } \\
\text { (Unión de escuelas industriales para mujeres) }\end{array}$ & 2.250 \\
\hline 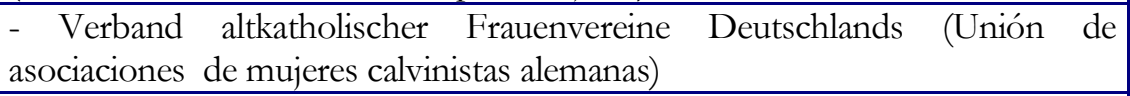 & 7.900 \\
\hline $\begin{array}{l}\text { - Verband der deutschen Reichs, Post und Telegraphenbeamtinnen (Unión } \\
\text { de trabajadoras de correos y telégrafos) }\end{array}$ & 36.895 \\
\hline $\begin{array}{llllll}\text { Verband der Reichsbahnbeamtinnen } & \text { (Unión de trabajadoras de } \\
\text { ferrocarriles) }\end{array}$ & 1.980 \\
\hline - Verband Deutsche Frauenkleidung und Frauenkultur (Unión para la moda & 10.000 \\
\hline
\end{tabular}




\begin{tabular}{|l|l|}
\hline y la culturas femeninas) & \\
\hline $\begin{array}{l}\text { - Verband Frauenbildung, Frauenstudium (Unión para el estudio y la } \\
\text { educación de las mujeres) }\end{array}$ & 1.120 \\
\hline $\begin{array}{l}\text { - Verband der Strafvollzugsbeamtinnen ( Unión de funcionarias de } \\
\text { prisiones) }\end{array}$ & 400 \\
\hline $\begin{array}{l}\text { - Reichsverband der Beammtinnen und Fachlehrerinnen in Haus, Garten } \\
\text { und landwirtschaft (Unión de funcionarias y profesoras de economía } \\
\text { doméstica, jardinería y agricultura) }\end{array}$ & 1.500 \\
\hline $\begin{array}{l}\text { - Allgemeiner deutscher Lehrerinnenverein (Asociación general de } \\
\text { profesoras alemanas) }\end{array}$ & 36.132 \\
\hline - Bund deutsche Ärztinnen (Federación de médicas alemanas) & 536 \\
\hline - Deutscher Juristinnenverein (Asociación de juristas alemanas) & 243 \\
\hline $\begin{array}{l}\text { - Hochschuldozentinnen-Verband (Unión de profesoras de educación } \\
\text { superior) }\end{array}$ & 46 \\
\hline $\begin{array}{l}\text { - Vereinigung der Nationalökonominnen Deutschlands (Unión de } \\
\text { economistas nacionales de alemania) }\end{array}$ & 240 \\
\hline $\begin{array}{l}\text { - Verband der Studentinnenvereine Deutschlands (Unión de las } \\
\text { asociciones de estudiantes alemanas) }\end{array}$ & 170 \\
\hline -Gymnastikbund & 175 \\
\hline -Reichsverband Landwirtschaftliche Frauenvereine & 54.000 \\
\hline
\end{tabular}

\begin{tabular}{|l|l|}
\hline $\begin{array}{l}\text { Deutscher Akademikerinnenbund (1926) (Federación de académicas } \\
\text { alemanas) }\end{array}$ & \\
\hline $\begin{array}{l}\text { - Allgemeiner deutscher Lehrerinnenverein ( Asociación general de } \\
\text { profesoras alemanas) }\end{array}$ & 36.132 \\
\hline - Bund deutscher Ärztinnen (Federación de medicas alemanas) & 536 \\
\hline - Deutscher Juristinnenverein (Unión de juristas alemanas) & 143 \\
\hline $\begin{array}{l}\text { - Hochschluldozentinnen-Verband (Unión de docentes de escuelas } \\
\text { superiores) }\end{array}$ & 46 \\
\hline $\begin{array}{l}\text { - Vereinigung der Nationalökonominnen Deutschlands (Unión de econo- } \\
\text { mistas nacionales alemanas) }\end{array}$ & 240 \\
\hline $\begin{array}{l}\text { - Verband der Studentinnenvereine Deutschlands (Unión de las asociaciones } \\
\text { de estudiantes alemanas) }\end{array}$ & 170 \\
\hline
\end{tabular}

Fuente: Nachrichtenblatt des Bundes Deutscher Frauenvereine, Septiembre 1931, no9, p. 69

\begin{tabular}{|ll|}
\hline $\begin{array}{l}\text { Arbeitsgemeinschaft deutscher Frauenberufs-Verbände (1924) } \\
\text { trabajo de las uniones de mujeres trabajadoras alemanas) }\end{array}$ & Gewisión derkschaften \\
\hline $\begin{array}{l}\text { Frauensekretariat des Gesamtverbandes der christlichen } \\
\text { (Secretariado femenino de la unión general de sindicatos cristianos) }\end{array}$ \\
\hline $\begin{array}{l}\text { Frauenausschuss des deutschen Gewerkschaftsbundes (Comité femenino de la federación } \\
\text { de sindicatos alemanes) }\end{array}$ \\
\hline $\begin{array}{l}\text { Gesamtverband evangelischer Arbeiterinnenvereine Deutschlands (Unión general de la } \\
\text { asoción de mujeres protestantes de Alemania) }\end{array}$ \\
\hline Gewerkverein der Heimarbeiterinnen (Asociación de empleadas de hogar) \\
\hline
\end{tabular}


Reichsverband weiblicher Hausangestellter Deutschlands (Unión general de empleadas de hogar)

Verband katholischer kaufmännishcer Gehilfinnen und Beamtinnen (Unión de asistentes comerciales católicas y funcionarias)

Verband der evangelischen Wohlfahrtspflegerinnen Deutschlands (Unión de asistentes sociales protestantes alemanas)

Verband der weiblichen Handels und Büroangestellte (Unión de oficinistas femeninas)

Verein deutscher evangelischer Lehrerinnen (Asociación de profesoras protestantes alemanas)

Verein katholischer Sozialbeamtinnen (Asociación de trabajadoras sociales)

\begin{tabular}{|c|c|}
\hline & $\begin{array}{l}\text { Zentralverband katholischer Frauen und Müttervereine (1928) (Unión central de } \\
\text { mujeres católicas y asociaciones de madres) }\end{array}$ \\
\hline & Katholischer Deutscher Frauenbund (Federación alemana de mujeres católicas) \\
\hline & $\begin{array}{l}\text { Verband süddeutscher katholischer Arbeiterinnen (Unión de mujeres católicas de Alemania } \\
\text { lel sur) }\end{array}$ \\
\hline & $\begin{array}{lccc}\text { Verband } & \text { katholischer } & \text { deutscher } & \text { Arbeiterinnen } \\
\text { Westdeutschlands (Unión de trabajadoras católicas de alemania occidental) } & \\
\end{array}$ \\
\hline & $\begin{array}{ll}\text { Verband katholischer Vereine erwerbstätiger Frauen Bund } & \text { Mädchen } \\
\text { Deutschlands (Unión católica de jóvenes y mujeres trabajadoras) } & \\
\end{array}$ \\
\hline & ischer deutscher Lehrerinnen (Asociación de profesoras católicas alem \\
\hline & $\begin{array}{l}\text { d katholischer deutscher Studentinnenvereine (Unión de las asociaciaciones de } \\
\text { ntes alemanas católicas) }\end{array}$ \\
\hline & $\begin{array}{l}\text { erein zur Unterstützung katholische studierender Frauen (Asociación "Hilder- } \\
\text { apoyo a estudiantes católicas) }\end{array}$ \\
\hline & Asociones de filólogas católicas alemanas) \\
\hline & $\begin{array}{l}\text { Verein katholischer deutscher Sozialbemtinnen (Asociación católica de funcionarias } \\
\text { ociales alemanas) }\end{array}$ \\
\hline & $\begin{array}{l}\text { katholischer Hausbeamtinnen Deutschlands (Asociación católica de funcionarias } \\
\text { nania) }\end{array}$ \\
\hline & $\begin{array}{l}\text { Verband der weiblichen kaufmännischen Angestellten und Beamtinnen (Uni- } \\
\text { e comerciantes y funcionarias) }\end{array}$ \\
\hline & $\begin{array}{l}\text { Berufsverband katholisher Fürsorgerinnen (Unión profesional de asistentes sociales } \\
\text { atólicas) }\end{array}$ \\
\hline & $\begin{array}{l}\text { er Fürsorgeverein für Mädchen, Frauen und Kinder (Asociación católica de } \\
\text { ocial a jóvenes, mujeres y niños) }\end{array}$ \\
\hline & $\begin{array}{llll}\text { Deutscher } & \text { nationalverband } & \text { der } & \text { katholischen } \\
\text { Mädchenschutzvereine (Unión alemana nacional de } \\
\text { orotección de menores) }\end{array}$ \\
\hline & $\begin{array}{l}\text { 3erufsverband der katholischen Hausgehilfinen Deutschlands (Unión profesional de } \\
\text { empleadas de hogar católicas de Alemania) }\end{array}$ \\
\hline & $\begin{array}{l}\text { Verein der katholischen weiblichen Pfarrhausangestellten (Asociación de } \\
\text { aatólicas de casas parroquiales) }\end{array}$ \\
\hline & Verband der katholischen Hausangestellte Diennstmädchen (Unión de \\
\hline
\end{tabular}




\begin{tabular}{|l|}
\hline Flottenbund Deutscher Frauen (Círculo de damas alemanas) \\
\hline Deutscher Frauenverein (Asociación de mujeres alemanas) \\
\hline Baltischer Frauenbund ( Federación de mujeres bálticas) \\
\hline Deutscher Jungmädchendienst (Servicio alemám de jóvenes) \\
\hline Mädchengruppen der Bismarckjugend (Grupo de jóvenes de las juventudes bismarckianas) \\
\hline $\begin{array}{l}\text { Reichsverband deutscher Hausfrauenvereine (Unión imperial de las asociaciones de amas } \\
\text { de casa alemanas) }\end{array}$ \\
\hline Verband der Postbeamtinnen (Unión de las funcionarias de correos) \\
\hline $\begin{array}{l}\text { Landes verband preussicher Volksschullehrerinnen (Unión prusiana de profesoras de } \\
\text { enseñanza primaria) }\end{array}$ \\
\hline
\end{tabular}

\section{Ring nationaler Frauen (1920) (Alianza de mujeres nacionales)}

Flottenbund Deutscher Frauen (Círculo de damas alemanas)

Hausbesitzerinnen-Verein zu Berlin (Asociación de propietarias)

Deutscher Frauenorden Darmstadt (Orden de las mujeres de Darmstadt)

Verein Deutscher Hausfrauen (Unión de amas de casa alemanas)

Organizaciones dependientes del Evangelischer Frauenwerk. 1934

Organizaciones dependientes del „Evangelisches Frauenwerk“

Gemeindliche Frauenarbeit. Trabajo parroquial

- Evangelische Reichsfrauenhilfe, D. v. Bismarck, Postdam

- Landesverband für christlichen Frauendienst in Sachsen

- Frauenabteilung des Evangelischen Volksbundes für Württemberg

- Verband evangelisch-kirchlicher Frauenvereine in Hessen 
- Ausschuß des Frauendienstes für Innere Mission in Oldenburg

- Landesverband der Evangelischen Frauendienste in Baden

- Kirchliche Gemeindehilfe in Bayern

Karitativ-soziale Arbeit. Trabajo social y de beneficencia

- Deutsch-Evangelischer Frauenbund, M. Eyl, Hannover 31.000

- Deutsch-Evangelischer Verband sozialer Jugendgruppen, C. Brickenstein, Bremen

- Deutscher Verband der Freundinnen junger Mädchen, Blanck, Heidelberg, 12.020

- Reichsverband der Evangelischen Deutschen Bahnhofsmission, Reineck, Berlin 200

- Bund evangelischer Frauen im sozialen Dienst,H. Bäcker, Berlin 3. 500

- Verband kirchlich-sozialer Frauengruppen, H. Seraphim, Steindamm 4000

- Verband d. ev. Kindergärtnerinne, Horterinnen und Jugendleiterinnen Deutschlands 2400

Erziehungs- und Bildungsarbeit. Trabajo de formación y educación

- Verein Deutscher Evangelischer Lehrerinnen, Frieda Cramer, Barmen

- Verband Evangelischer Theologinnen Deutschlands, Schleypen, Marburg

- Bund Christlicher Akademikerinnen, M. Cremer, Lichterfelde

- Evangelischer Reichsverband weibliche Jugend, H. Zarnack, Berlín

- „Wort und Werk“, Gertrud Zappka, Berlín

- Vereinigung der Evangelischen Sozialen Frauen- und Wohlfahrtsschulen, Gräfin D Bertha, Berlín

- Christlicher Verein für Frauen und Mädchen, B. Meyer, Berlín

- Gesamtverband Evangelischer Arbeiterinnenvereine Deutschlands

- Verband für evangelischen Religionsunterricht und Pädagogik. M. v. Tiling, Berlín

Mütterdienste. Servicios de maternidad

- Mütterdienstwerk der Evangelischen Reichsfrauenhilfe, C. Lonnies, Nürnberg

- Reichsgemeinschaft der Evangelischen Hausfrauen Deutschlands, Asta Rötger, Berlín

- Mütterdienst des Kaiserswerther Verbandes

Fuente: LKAH, N10, $n^{\circ}$ 2. Listas de organizaciones miembros del $E_{V F W}, 1934, N$ 10, $n^{\circ} 6$ 
Revistas de las asociaciones de mujeres en la República de Weimar en 1933

ADLV. Deutsche Lehrerinnenzeitung. Halbmonatlich. Organ des Allgemeinen Deutschen Lehrerinnen-Vereins. Schritleitung Irma Stoß, Verlag F. A. Herbig. Berlin.

An der Wende. Zeitschrift für weibliche Bildung und Kultur. Herausgegeben von Hedwig Michel. Schrifleitung Hedwig Brey. Verlag Rauch, Wiesbaden.

Aufgaben und Ziele. Monatsschrift. Nachrichtenblatt der Vereiningung evang. Frauenverbände Deutschlands. Schriftleitung D. von Tiling und Nora Hartwich. Berlin

Blätter des Jüdischen Frauenbundes für Frauenarbeit und Frauenbewegung. Offizielles Organ des Jüdischen Frauenbundes von Deutschland. Schriftleitung: Hannah Karminski und Martha Ollendorf. Berlin

Der Abolitionist. Organ des Bundes für Frauen und Jugendschutz. Schriftleitung Anna Pappritz,Verlag Kupky \& Dietze. Radebeul bei Dresden. 1902-1933

Der Kindergarten. Monatsschrift. Schriftleitung Elfriede Strnad, Verlag Quelle \& Meyer. Leipzig

Deutsche Frauenkultur. Herausgegeben vom Verband Deutsche Frauenkultur. Verlag Otto Beyer. Leipzig

Deutsche Frauen-zeitung. Schriftleitung Cornelia Kopp, Verlag Otto Beyer, Leipzig.

Deutsche Hausfrau. Monatszeitschrift des Reichsverbandes deutscher Hausfrauenvereine. Herausgegeben von der Verbandsleitung Aachen.

Deutsche Krankenpflege. Zeitschrift des Deutschen Verbandes für die berufliche Krankenund Wohlfahrtspflege. Hauptgeschäftsstelle Köln.

Deutsche Mädchenbildung. Monatsschrift. Zeitschrif fürdas gesammte höhere Mädchenschulwesen. Herausgegeben von Oberstudiendirektor Stracke, Verlag G. B. Teubner, Berlin.

Deutsche Werkmeister-Zeitung. Organ des Deutschen Werkmeister-Verbandes. Deutsche Werkmeister-Zeititung, Düsseldorf.

Die Ärztin. Monatsschrift des Bundes Deutscher Ärztinnen. Schriftleitung: Dr. K. Wassertrüdinger, Verlag F. A. Herbig, Berlin.

Die Christliche Frau. Monatszeitschrift im Dienste katholischen Frauenlebens. Herausgegeben vom Kath. Deutsche Frauenbund. Verlag Regernsbergsche, Münster.

Die Deutsche Frau. Schritleitung Ilse Hamel, Beda Prilipp, Katharina Herwig. Neutdeutsche Verlags und Treuhand-Ges. m.b.H., Berlin 
Die Frau. Organdes Bundes Deutscher Frauenvereine. Herausgegeben von Gertrud Bäumer. Verlag F A. Herbig, Berlin. 1893-1944

Die Frau und ihr Haus. Monatsschrift. Herausgegeben von der Werberstelle für Deutsche Frauenkultur, Köln.

Die Frau im Staat. Monatsschrift. Herausgegeben von Dr. Anita Augspurg und Lida G. Heymann. Verlag Kommissionverlag S. Kiefer, München. 1919-1933

Die Handels- und Büroangestellte. Monatsschrift. Herausgegeben vom Verband der weiblichen Handels- und Büroangestellten E.V., Schriftleitung Katharina Müller, Berlin.

Die Heimarbeiterin. Monatsschrift des Organs des Gewerkvereins der Heimarbeiterinnen. Herausgegeben vom Hauptverstande. Berlin.

Die schaffende Frau. Zeitschrift für modernes Frauentum. Monatsschrift. Herausgegeben von Margarete Kaiser. Majo-Verlag, Berlin.

Die Studentin. Monatsschrift. Schriftleitung Gabriele Humbert, Verlag „Hochschule und Ausland“,Berlin.

Evangelische Frauenzeitung. Monatszeitschrift für die evangelische Frauenwelt. Herausgegeben von Paula Muller-Ortfried und Adelheid von Hennigsen. Verlag Deutsch-Evangelischer Frauenbund, Hannover.

Frauenarbeit. Organ des Verbandes katholischer Vereine erwerbstätiger Frauen und Mädchen Deutschlands. Schriftleitung Amalie v. Schalscha-Ehrenfeld. Verlag Germania, Berlin.

Frauenblatt der christlichen Gewerkschaften. Herausgegeben vom Arbeiterinnen-Dezernat des Gesamtverbandes der christlichen Gewerkschaften. Schriftleitung Elisabeth Bürthmann (späte Mina Amann). Verlag Volksvereins- Druckerei, Müchen-Gladbach.

Frauendienst am Auslandsdeutschtum. Monatliches Nachrichtenblatt der Frauengruppen des Vereins für das Deutschtum im Auslande. Herausgegeben von Else Kunckel. Verlag Thormann \& Goetsch, Berlin.

Frauenland. Herausgegeben vom Katholischen Deutschen Frauenbund. Schriftleitung: Dr. Elisabeth Cosak, Köln.

Frauenwelt. Schriftleitung Tony Sender, Verlag J. H.W. Dietz, Berlin.

G.D.A. Zeitschrift des Gewerkschaftsbundes der Angestellten. Halbmonatsschrift. Leipzig. Sitz des Bundesvorstandes Zehlendorf-Berlin. 
Apéndice $B$

(1) "Und wir marschieren, begleitet von Frauen in SS-Uniform und geführt von einem höheren SS-Mann, folgsam in Fünferreihen. Der Weg ist nicht lang. Wir sehen auf einmal vor uns Stacheldraht, überall Stacheldraht. Wir sehen vor uns ein Riesentor, umlagert von SS-Posten mit zerrenden, schnaubenden, kläffenden Hunden, und durch dieses Tor ziehen wir ein. Sehr aufrecht, und ohne daß uns eigentlich bewußt wir, daß wir mit diesem Moment das Lager Auschwitz, das Konzentrations und Vernichtungslager, betreten haben. Es ist der 20. April 1943."

(15) "(...) die Aufgabe, diesen Produktionsprozeß räumlichzeitlich zu situieren, seine Triebkräfte zu benennen, seine Verfahrensweisen zu analysieren, seine Alternativen zu bedenken und seine Folgen zu ermitteln."

(17) "Es zeigte sich, daß die Komplexität der sozialen Realität nicht länger mit traditionell binären Oppositionen wie etwa Mann versus Frau oder Natura versus Kultur erfaßbar war und von einem Denken in Differenzen ersetzt werden mußte. Für dieses neue Denken sozialer Realitäten wurde die Auseinandersetzung zwischen Feminismus und Poststrukturalismus von besondere Bedeutung. "

(24) "Das Bild, das die individuellen Zugehörigen von ihrer Nation haben, ist darum zugleich ein Bestandteil ihres Selbstbildes. Die Vorzüge, der Wert und Sinn der Nation sind zugleich die eigenen."

(29) "Das Adjektiv "bürgerlich" umschreibt grob die soziale Herkunft jener Frauen, die sich seit der Mitte des vorigen Jahrhunderts zu organisieren begannen. Sie kamen vorwiegend aus dem Bildungsbürgertum; politisch standen sie den liberalen Parteien nahe. Organisatorisch repräsentieren ihre Vereinsbildungen den Typus einer autonomen Frauenbewegung. Sie wurden nicht wie die der Sozialistinnen von einer Partei absorbiert."

(30) "Die deutsche bürgerliche Frauenbewegung wich von der naturrechtlichen Argumentation ab. Sie forderte zwar auch die Gleichheit vor dem Gesetz, ging aber von einer dualistischen Theorie der Geschlechter aus. Mann und Frau sind wesensverschieden, aber funktional gleichwertig bezogen auf ein Ganzes, nämlich auf die Reproduktion der Gesellschaft."

"Sie hat zunächst den Ausweg, das Produkt selbst, die einzelne Zeitung, auf direkte und indirekte Auskünfte über Redaktion und Journalisten hin zu prüfen. Dem steht entgegen daß Zeitungen häufig nur unvollständig erhalten und bisher so gut wie nicht inhaltlich erschlossen sind. Die Redaktionsarchive stehen nur noch selten zur Verfügung. Damit gewinnen anderweitige Materialien Briefnachlässe, Autobiographien, zeitgenössische Berichte und literarische oder künstlerische Zeugnisse - nicht nur an Bedeutung, sie bestimmen auch eine stärker qualitativ und sozialhistorisch Umgang mit dem Gegenstand der Kommunikationsforschung."

(58) "Die Parallele zwischen Antifeminismus und Antisemitismus macht natürlich die Erfahrungen von Frauen und Juden als Objekten der Nazipropaganda oder -politik nicht gleich. Es kann keinen 
Vergleich geben zwischen Juden, die sich der Gewalt beugten, und Nazifrauen, die sich dafür entschieden, ihre unterlegene Position im Austausch für handfeste Belohnungen zu akzeptieren."

(59) "Dadurch daß die Nazifrauen den Begriff Lebensraum in einem speziell weibliche Sinne verwendeten, schufen sie sich ihren eigenen "Raum", in dem sie eine, wie sie behaupteten, "klassenüberschreitende" Harmonie der Frauen jenseits männlicher Überwachung hegten und pflegten."

(63) "(...) auf der einen Seite Bock, die auf das weibliche "Anders-sein" rekurriert, welches die Utopie einer Lebensform beinhaltet, die nicht geprägt ist von männlicher Logik, sondern von Werten wie Liebesfähigkeit, Sensibilität, Sozialverhalten u. a., wie sie zumeist auf den privaten Bereich beschränkt bleiben. Auf der anderen Seite Koonz, in der Bock eine Verfechterin des "equal rights feminism" sieht, die "gleiche Rechte" und "gleiche Arbeit" von Männern und Frauen postuliert."

(113) "(...) Wir jungen Leute hatten nach vollendetem Studium mit langen Wartezeiten auf Anstellung Zeit und Muse mit Kunst, Kultur, Wissenschaft und Politik zu interessieren. (...)Junge Menschen, die als Kind Krieg und Hungersnot erleben, mußten waren in den zwanziger Jahren einem doppelten Zwiespalt unterworfen: zu den natürlichen beim Heranreifen kam die Diskrepanz zwischen der schlechten politischen und wirtschaftlichen Lage und einem doch bereits wieder erwachten Angebot an Vergnügungen, die das Wort von den "goldenen Zwanziger Jahren mitprägten. Die vielen Konzerte und Bälle im Kulturverein, im Herkulesaal und Deutschen Hof, die ergötzlichen Freikonzerte am Hauptmark, im Stadtpark, die Faschingsumzüge (...).

(115) "Nach Hitlers Entlassung folgte die "Kampfzeit bis 1933, gleichzeitig die steigende Arbeitslosigkeit. Die Fabriken waren demontiert, die Wirtschaft lag darnieder, das Geld total abgewertet. "

(118) "Die Wirtschaftskrise (...) stürzte daher Deutschland unmittelbar in eine schwere Staatskrise- im Unterschied zu den meisten anderen Ländern, die von der Weltwirtschaftskrise kaum weniger hart getroffen wurden, die aber die Folgen der Krise aufgrund einer solideren Fundierung ihre politischen und gesellschaftlichen Ordnung besser verkrafteten."

(120) "So kamen die Mittelschichten, die wieder eine wenn auch beschiedene, so doch ruhige Existenz haben wollten, zur der Überzeugung, daß die Republik an der Verwirrung schuld sei: Die Republik erzeuge die Verarmung, das Schiebertum, die Korruption und die Zwietracht. Sehnsüchtig dachte man an die alten Zeiten der Monarchie zurück, die zwar auch ihre Mängel hatte, in denen man aber ungestört und unter dem Schutz der Gesetze seinem Beruf nachgehen durfte."

(135) "Die Frauen hatten häufig zum ersten Mal eigenes Geld und konnten selbst entscheiden, ob sie sich ein Paar Seidenstrümpfe kaufen wollten oder nicht. Kriegerwitwen bekamen eine kleine Rente, arbeitslose Frauen eine Erwerbslosenunterstützung. Das gab es vorher nicht. Viele Frauen waren stolz, von ihren Männern nicht mehr so abhängig zu sein". 
(143) "Mein Tagewerk beginnt früh um 5 Uhr mit anfeuern. Bis das Kaffewasser kocht, scheneide ich die nötigen Stullen für drei Persone und bestreiche sie mit Butter und Wurst. Zwischendurch muß ich des öfteren mal wecken gehen. nir schnell Suppe und Kaffe eingekocht und ausschütten, damit sie nicht zu heiß sind, wenn die Herren der Schöpfung essen wollen. Sin dann noch Eßeimer und Kaffeflaschen gefühlt, so kann auch ich mich fertig machen. Nun geht's zur Arbeitstätte. 3/4 Studen Wegs, immer durch Wiesen und Felder, ist es bei schönem Wetter ein köstlicher Genuß. Doch im Winter, wenn kniehoch der Schee liegt, ist's kein Vergnügen. Meine Arbeit ist Andrehen. So sitze ich nun täglich 8 1/2 Stunden, nur von der Mittagstunde unterbrochen und drehe Faden für Faden zusammen, 800 in der Stunde. Bis 6.000 mal jeden Tag müssen Arme und Hände dieselbe Bewegung machen. Oft schlafe ich dabei ein, besonders an schwülen Tagen. Warum hat man für diese eintönige Arbeit noch keine Maschine erfunden? Froh geht's dann abends heimwärts. Doch muß ich mir alles Nötige für die Küche auf dem Heimweg mit einkaufen, da wir abseits wohnen und kein Laden in der Nähe ist. Zu Hause warten dann schon weider zwei hungrige Magen auf mich. So wird schnell wieder angefeuert, Abendbrot und Mittagessen für den nächsten Tag zubereitet. Dann noch das Geschirr waschen, das nötige Wasser holen, was fünf minuten weit ist. Im Sommer noch den Garten gieBen und jäten. So lese ich noch die Zeitung und dabei kommt Freund Schlaf. So vergeht ein Tag wie der andere, mit wening Änderung.

(155) "Nur Gertrud Bäumer kam in der Präzision von Denken und Handeln, im raschen Erkennen und sicherem Formulieren Koch-Weser gleich. Aber in dieser Frühzeit der Republik war eine Frau an der Spitze einer Partei nicht denkbar. Und schließlich: sie erweckte wohl ein Höchstmaß an Bewunderung und Gefolgschaftswillen. Es ging respektgebietende Autorität von ihr aus, aber nicht anziehende Wärme."

(189) "Und an dieser Stelle geschah die eigentlich Begegnung mit der Frauenbewegung. Der Ort dieser Begegnung war zunächst nur die Zeitschrift, Die Lehrerin. Es gab in Magdeburg keinen Frauenverein, auch keinen weiblichen Berufsverein, der in irgendeinem Sinne zur Frauenbewegung gehörte. (..) Her fand ich Antworten auf meine Fragen und Lösungen für meine Schwierigkeiten, Die Frauen als Frauen gefunden hatte, auf eine warme, enthusiastische und unpedantische Art, heimlich beschwingt durch das Bewußtsein, an einer, neuen größeren Aufgabe und am Beginn einer Berufung zu stehen."

(198) "Die Frauenbewegung will der Frau frei Entfaltung aller ihre Kräfte und volle Beteiligung am Kulturleben sichern".

(201) "Die bürgerlichen Frauenorganisationen waren in hohem Maße Träger, partiell auch Initiatoren der Frauenpolitik der imperialistischen deutschen Bourgeoisie in der Weimarer Republik. Sie vermittelten in ihrem Wirkunsbereich in großem Umfange den Kontakt zwischen deren Herrschaftssystem und der weiblichen Bevölkerung als einem wichtigen, in der neuen Epoche an politischer Bedeutung gewinnenden Teil der werktätigen Massen. Die Hauptfunktion der bürgelichen Frauenorganisationen bestand darin, die Frauen breiter werktätiger Klassen und Schichten im Geiste bürgelicher "Volksgemeinschafts" Ideologie zu beeinflussen und in das Herrschaftssystem der Bourgeoisie zu integrieren." 
(206) "Schon vor der Erklärung des Belagerungszustandes fanden die Besprechungen statt und schon vor der Kriegserklärung war de Plan in seinen großen Zügen fertig und wurde der Plan durch ganz Deutschland bis in die kleinsten Orte hinein versandt. Er baute sich auf den in der deutschen Frauenbewegung in Bunde deutscher Frauenvereine zusammengefassten Menschen auf und griff dann schnell " über Personen und Weltanschauungen hinweg in de gemeinsamen Willen, alles zu tun, um die unermesslichen Opfer, die ein Krieg in jeden Fall fordern wird, zu erleichtern" und rief alle Frauen auf, " in der Klarheit über ihre nationale Pflicht, die diese Einheit schafft". Den so entstandenen Nationale Frauendienst stand die tatkräftigste Mitarbeit aller konfessionellen und paritätischen Organisationen zur Verfügung einschließlich der beruflichen und politischen Arbeiterinnenorganisationen zur Seite. So eist es bis zum Ende des Krieges geblieben."

(208) "Schon der erste Weltkrieg, obschon gewiß noch kein "'totaler", griff tief in das Leben des Volkes als Ganzem ein, besonders als im Jahr 1916 in erhöhtem Maße Frauen zu der aufs äußerte angespannten Munitionsherstelllung gerangezogen wurden. Auf Antrag des "Bundes deutscher Frauenvereine" errichteten die Kriegsamtstellen, deren es bei jedem Armeekorps eine gab, Frauenreferate, die sich der Arbeiterinnen innerhalb der Betriebe, der Unterbringung von Ledigen und der Versorgung solcher Kinder anzunehmen hatten, denen infolge der Arbeit ihrer Mütter Vernachlässigung drohte. "

(224) "Wer zu Ende des vorigen Jahrhunderts als Kind des Bürgertums zur Welt kam, weiß noch um den Wert ungestörter Geborgenheit und Entwicklung. Daß es nicht eine echte, das ganze Volk umfassende Geborgenheit war, wurde einem solchen Kinde nicht bewußt. Sein Leben war gesichert, die Umwelt warm und gut, es herrschte Ordnung, Autorität, Liebe, Strenge. Der wachsende Reichtum des deutschen Volkes kam der Bürgerschicht zugute, auch wo sie an seiner Hervorbringung nicht unmittelbar beteiligt war. Geistiges Schaffen konnte sich in Ruhe entfalten, und geistige Einflüsse strömten als selbstverständlicher Lebensstoff den Kindern zu."

(226) "Jeder Abend brachte einen Vortrag oder gemeinsame Lektüre mit nachfolgender lebhafter Aussprache oder auch Theaterauführungen mit Musik. Oft gesellte sich die Eltern, in deren Haus gerade getagt wurde, zu dem fröhlichen Kreis, und weder Prof. von Harnack noch Oberbürgermeister Kirschner verschmähten es, sich selber mit Vorträgen zu beteiligen. (...) Aus der Breslauer Zeit stammte die nahe Beziehung zu den Professoren Brentano, Dilthey, Cohhnheim. (...) In Berlin traten in de Gierkeschen Kreis die Familien der Professoren Harnack, Mommsen, Adolph Wagner, Gustav Schmoller, des Stadtrats Weber, des Dichters Ernst von Wildenbruch und macher anderer (...).

(228) "Sie strebte nach Vollkommenheit, maß sich an hohen Maßstäben, sie war fromm und mit ungebrochener Selbstverständlichkeit im Christentum verankert, in das auch die Kinderseelen eingepflanzt wurden. Sie las viel, auch mit den heranwachsenden Kindern; sie konnte sogar Latein. (...) Die wenigen gebildeten Leute, der Lehrer an der Rektorschule, der Pfarrer und der Arzt suchten ihre Nähe und ließen sich von ihr anregen.

(229) "Aus dieser frühen zeit leitet sich auch die Beziehung zu Else Wolff her, die später den Rechtsanwalt Arnold Reimer heirate. Sie entstammte einer angesehenen Berliner Familie und verkörperte in sich viele Eigenschaften, die auch Anna v. Gierke in sich trug: Wärme, Mütterlichkeit, unbefangenes Erfassen der Welt. Während Anna sich durch ihre starke Geistigkeit in den Dienst überpersönlicher Aufgaben gehoben hatte, blieb Else Reimer im Persönlichen verhaftet. Gerade solche Frauen aber übten auf Anna von Gierke stets eine große Anziehungskraft aus." 
(240) "...mit Goethe und Fichte als den Vollenden in der Wiedergeburt der Religion aus deutschem Geist. Eine Religion, die das diesseitige Gemeinschaftsleben mit seinen staatlichen und sozialen Formen mit umfaßt, mit Sinn und Seele erfüllt und gestaltet."

(241) "Es war Kriegswinter 1915. Und wir fanden uns in Berlin allwöchentlich abends zusammen, um -Plato zu lese. Die dazu kamen, waren nicht nur als einzelne Menschen - durch Angehörige, als Zeitungsleser und fernere Zeugen großer Dinge- mit dem Krieg verbunden. Sie hatten jeden Tag ein Stück sozialen Kriegsdienstes hinter sich zu bringen."

(249) "Die Doktor Dorothee v. Velsen: eine äußerlich unscheinbare Gestalt, nicht groß, erlesen gekleidet, die mit dunkler, leiser Stimme ruhig zu Worte kam. Sie verkörperte für uns die Idee der Frauenbewegung in abstrakter Reinheit."

(252) "So wuchsen durch diesen Jugendbund, dem bald Schwesterorganisationen in anderen Städten entstanden, Frauen heran, die in die Familie oder Beruf offener, liebevoller, verantwortungsbewußter standen, eine erste tiefer geschulte enthusiatische junge Garde der Frauenbewegung"

(255) "Die Franenbewegung ist nichts andres gewesen, als die Anwendung demokratischer Grundsätze auf die Stellung der Frau in Staat und Gesellschaft. Die Stellung der Frau und die Beziehungen der Geschlechter sind wohl allenthalben die am schwerste zu überwindenden Festung des alten Machtgedankes gewesen. (...) Wie Die Frauenbewegung aus dem Doppelgedanken der Freiheit und Gerechtigkeit herausgewachsen ist, so hat sie mit jedem Fortschritt, mit jeder Stärkung ihres Glaubens an sich selbst, Zeugnis dafür abgelegt, daß nur die demokratische Staatsform Reich und Freiheit der Frau in sich aufzunehmen und zu verwirklichen vermag."

(256) " der sozial empfindende Mensch, der nationale und kulturelle Politik treiben will"

(263) "Kultisch geheiligt, war Muttertum eine der kosmischen Grundtatsachen, wie Sonne und Mond, wie erde und Meer, wie Tag und Nacht, deren Herrschaft über das Menschenschicksal der religiöse Sinn ehrfürchtig anerkannte."

(268) " jede Geist-bestimmte zweckvolle Bearbeitung und Formung eines von der Natur gegebenen Materials, und je nachdem, ob wir dabei an außer uns liegendes, an das Schaffen von Gegenstände, Ordnungen und Ideenzusammenhängen denken oder aber an die Formung des lebendigen, im steten Werden begriffenen Menschen, pflegen wir zwischen objektiver und subjektiver, sachlicher und persönlicher Kultur zu unterscheiden."

(270) "So angesehen stellt sich das Ringen der modernen Frau um jene Freiheiten und Güter da als Weg zu einem doppelten, erst am Wesen der Frau mündenden Ziel. Nämlich einmal: als der Weg zur ethischen Autonomie, zum Gewinn eines sittlichen Rechts, einer Pflicht auch des weiblichen Menschen auf Selbstbestimmung, Selbstverantwortlichkeit in allen Lebensgebieten. Mit diesem auf eine bestimmte innere Haltung zielenden Streben bekennt sich die moderne Frau dankbar und stolz als Erbe der ethischen Freiheitslehre des deutschen Idealismus, der Persönlichkeitsideale eines Kant und Fichte; als ein Erbe , der mit dem hinterlassenen Schatze etwas Neues zu schaffen sucht. "

(271) "Es gibt gar kein Schaffensgebiet, sei es nun Technik, Recht und Sitte oder Kunst, Wissenschaft,Philosophie und Religion, von dem Sie mit Recht ausgeschlossen werden darf." 
"Denn während die großen Verkünder de sittlichen Autonomie die grundsätzliche Bevormundung des weiblichen Menschen durch den männlichen ruhig weiter sanktionierten, stellen wir "den Gehorsam gegen das Gesetz in der eigen Brust" als höchstes Ziel ethischer Entwicklung auch über die Lebensbeziehungen und das sittliche Wesen der Frau. Mann oder Wein- wer zur Selbstverantwortlichkeit befähigt ist, ist auch dazu berufen. Wem es aber nicht gegeben ist - und es mag die überwiegende Mehrheit der Menschen sein- moralisch auf eigenen Füßen zu stehen, für den ist aktive, autonome Unterordnung, freiwilliger Gehorsam gegen die Führerschaft selbstgewählter Autoritäten sittliche Pflicht."

(273) "Es muß für die Wahl ihrer Lebensinhalte immer von fundamentaler Bedeutung bleiben, daß sie als Naturwesen zur Mutterschaft, zur Mütterlichkeit veranlagt ist, und daß dieser Gattungszweck für sie physisch und seelisch etwas durchaus anderes, mehr als die Vaterschaft für den Man’bedeutet."

(274) "Ihre Gefühlsbeseelung, ihre Durchwärmung mit Liebe, Güte und reiner Gesinnung, aber auch ihre geistige Formung und Durchdringung mit Kultur derart, daß auch der schlichte ereignislose Alltag in sich selbst wert ist gelebt zu werden ist eine Gestaltungsaufgabe, die in erster Linie der Frau zufällt."

(275) "Wo immer der Mann einen Mangel, eine Not, einen Bruch seines spezifisch männlichen Seins fühlt, da verweist ihn jene Idee an die Frau, um von ihr die Verwirklichung dessen zu fordern, was ihm als Mann besonders schwer fällt. Der Unruhe seines Werdens soll sie das in sich beruhende Sein, seiner Spezialisiertheit die Ganzheit des Wesens, seiner Hingabe a das Objektive die Hingabe an das Persönliche, seiner Werkvollendung die Seinsvollendung gegenüberstellen, damit durch solche Arbeitsteilung die Idee des Menschseins erfüllt werde."

(280) "Die Mutterschaft steht im Mittelpunkt des Frauenlebens; um ihretwillen werden kleine und große Leiden, Schmerzen und Behinderung durch Lebensjahrzehnte willig und geduldig ertragen; ja, in ihrem Lichte erscheinen sie gering und vorübergehend. "

(282) "Zur Technik kommt die zweite seelenfeindliche Macht, die den Menschen knechtet: der Kapitalismus, die Warenwirtschaft. Sie schaffen eine merkwürdige Verbindung von scheinbarer Freiheit und tatsächlicher Abhängigkeit: in einem straff organisierten Dasein dennoch eine vollkommene Unsicherheit der Existenz."

(284) "Es wäre aber auch denkbar (Spengler), daß die Kultur selbst, die abendländische Gestaltungskraft, ausgelebt wäre. $\mathrm{Da}$ der abendländische Gestaltungskraft, ausgelebt wäre. Daß der abendländische Geist, wie er in Goethe z. B. erscheint, sich erschöpft hätte, nichts mehr hervorbrächte, die Seelen nicht mehr packte und ergriffe, seine Zeugungskraft verloren hätte. Und wer dies meint oder fühlt, der pflegt dann den Blick nach Osten zu richten und auf die Wiedergeburt Europas durch den russischen Bauern zu warten."

(285) "(...) diese Zivilisation mit ihrem System der Arbeitsteilung und Spezialisierung, mit der Zurückdrängen der Lebensmacht der Familie, mit der Verbreitung des öffentlichen Lebens, hat die Frauen in ihrem eigensten Wirkungskreis eingeengt und gehemmt, ohne ihnen dafür andere Ventile seelischen Wirkens zu öffnen"

(286) "Sie wird immer stärker sein in einer "konservativen Zeit", denn ihre geistigen Kräfte sind weniger die der Struktur, der Systembildung, sie sind weniger, um im Bilde zu bleibe, architektonischer Art." 
(287) "Die Empfindlichkeit für das Leere im persönlichen Leben, in Arbeit und Genuß, in Kunst und Journalismus, im öffentlichen Leben- die noch die Generation der letzten Jahrzehnte des 19. Jahrhunderts nicht hatte, ist da und wächst. In einem ganz neuen, lebendigen und geradezu metaphysischen Verhältnis zur Natura stärkt und klärt sich dieses Gefühl für das Wesenhafte; in der Kraft, sich von sinnlosen, nicht lebensteigernden Bedürfnissen zu befreien, dem Willen zur Vereinfachung des äußeren Lebenszuschnitts gewintt die vom Vielerlei der Güter und Genüsse erstickte und abgestumpfte Seele ihre Spannkraft wieder; und in diese Seele, die sozusagen wieder belebt und Bewegunsfroh geworden ist, wächst aus gesundem Boden der Instinkt für das Echte, (...). "

(288) "Sie sollten nicht nach ihren Handlungen unmittelbar nach der deutschen Niederlage beuerteilt werden, als die Bitterkeit dieser Wunde sie noch schmerzte. Ich habe sie später sehr bedauert, als sie Opfer Hitlers wurden. Obwohl sie nach den Begriffen der Nazis reine Arierinnen waren und nich aus dem Land hinausgeworfen wurden, haben sie Teil an der kollektiven Schuld des deutschen Volkes und müssen dafür büßen."

(300) "Wo waren die deutschen Frauen damals? Wenn sie kurz nach dem 9. November 1938 dieselben Worte für mich gefunden hätten wie in ihren Briefen heute (1955), sie hätten mir soviel bedeutet. Kaum eine unserer deutschen sogenannten Freundinnen (...) fand den Weg zu uns. Dies war unglücklicherweise nicht ein persönliches, nur hier und da auftretendes Phänomen. Ja, Angestellte (...) Arbeiter, die Leute in meinem Wahlkreis, die Armenunterstützung erhielten, scheuten sich nicht, ihre Zuneigung zu zeigen (...) sie wußten, wo sie uns finden konnten, und das am hellichten Tag. Und soweit ich weiß, hat keinem von ihnen geschadet."

(304) "In schwarzem Kleid, mit schwarzen Hut und zurückgeschlagenem Schleier betrat sie das Podium. Wer bei diesem Ereignis zugegen war, wird den mächtigen Eindruck nie vergessen, wie die blasse Frau mit fester melodischer Stimme begann, wie die Versammlung ihr lauschte, und zwar eine Versammlung, die zum größten Teil aus Pastoren bestand. Schon nach der ersten Viertelstunde beherrschte die Rednerin die Stimmung des Kongresses, und der Beifall, der bereits während des Vortrages fortwährend ausbrach wollte kein Ende nehmen."

(305) "Es war vielen christlich-konservativen Frauen klar geworden, daß den heutigen sozialen Verhältnissen gegenüber die Schaffung einer organisierten Wohlfahrtspflege und der Zusammenschluß von Frauen zur Besserung der wirtschaftlichen Verhältnisse nötig sei. "

(308) "Die charitative Tätigkeit lindert den Schmerz, heilt die Wunde, übt fürsorgende Arbeit, die soziale Tätigkeit hingegen sucht die Quelle der Not zu verstopfen; sucht eine ganze Klasse, einen ganzen Stand zu heben, sucht durcht pracktische Einrichtungen dem Elend, der Not vorzubeugen. Darum ist die soziale Arbeit für unsere heutige moderne Welt neben der Karitas so unentbehrlich, so eminent wichtig."

(331) "Eine Frau, die es fertig bringt, in Sälen voller Biergeruch, Tabaksqualm und Menschendunst die Gemeinheiten eines politischen Wahlkampfes anzuhören oder sich gar tätig daran zu beteiligen, verliert den Anspruch darauf, vom Manne als Weib angesehen und mit Ritterlichkeit und Zartheit behandelt zu werden."

(325) "Führung und Mütterlichkeit sind nach christlichem Ideal die Hauptfunktion der geschlechter für die Menscheit" 
(327) "Essen, Trinken, Kleider, Schuh, Haus" usw. hier vollzieht sich ihre tägliche Arbeit. Sie hilft in Namen und Auftrag Gottes die Familie erhalten durch Nahrung, Kleidung und Bestellung der Wohnung. Sie ist mehr angesprochen als der Mann in diesem Bereich, sowohl in froher, wie in sorgender Hinsicht. Sie ist auf den Glauben angewiesen, dass Gott hilft, (...). Die Frau ist von Natura auf geschaffen zum Dienst der Liebe, der miterhält. Als christliche Frau wird sie aber diesen Dienst im Geiste Jesu tun."

(338) "in Zukunft (werden) alle uns beschäftigenden Fragen mit der Politik verknüpft sein (...)"

(339) "Die Umwälzungen der letzten Zeit, die grosse sittliche und religiöse Not unseres Volkes machen nun aber eine vermehrte und ausgedehntere Arbeit des Deutsch-Evangelischen Frauenbundes unbedingt nötig. Die Kräftigung des evangelischen Bewusstseins in der Frauenwelt, die religiös-sittliche Beinflussung möglichst weiter Volkskreise ist heute eine dringenden Notwendigkeit geworden."

(340) "Machina statt Personlichkeit; Mechanismus statt Seele, Hirnkraft, Inteligenz statt Geist, welcher Prinzip der lebenden Gestalt, der organische Form (...) ist. (...) Das ist unsere Zeit in dem, was sie hat, was ihr fehlt".

(341) "Als Frauenbund sucht er Verständnis für den Durchbruch deutschen Wollens und die innere Vertiefung deutschen Volkstums. Er wird den Kampf weiterfüheren und sich einsetzen für eine deutsche Volkskirche, wahre Volksgemeinschaft und Opferbereitschaft im deutschtum und evangelischen Geist."

(346) "Ich kann die plötzliche Wirkung dieser Worte auf mich nicht beschreiben. Ich hatte mir bis jetzt alle solche Dinge mit ausgestreckten Händen fernhalten, sie mit aller Kraft abgewehrt. Die Geburt eines unehelichen Kindes schien mir auch als eine unauslöschliche Schande. Nun hörte ich auf einmal, daß eine Frau aus religiösen Motiven solche Mädchen in ihr Haus aufnähme. (...) Langsam entwickelte sich in mir die Überzeugung, daß Gott mich eines Tages an eine Stelle stellen würde, wo ich solchen Mädchen helfen könnte."

(352) "Es war die Entdeckung einer Welt, einer von anderen Frauen bevölkerten Welt, deren Daseinsbedingungen jedoch so gänzlich verschieden von den ihrigen waren, wo auch andere Mütter lebten, die indes ihres Mutterseins nicht wie sie froh werden konnten, wo alles so fremd und doch so bekannt erschien, weil es mit dem eigenen, gewohnten in ganz naher Berührung stand. Und es war, als ob die Gebrauchsgegenstände des täglichen Lebens plötzlich ein anderes Gesicht erhielten, da man nun wußte, daß die Stoffe, die man trug und die hundert- und tausenderlei Dinge, deren man benötigte, gewebt und angefertigt wurden von abgehärmten Frauen, die 10 Stunden, wenn nicht länger, in schlechtgelüfteten Fabrikräumen an diesen Stoffen und Dingen einen kümmerlichen Lohn verdienten."

(353) "Wir wollen der katholischen Frau in der mächtigen Kulturbewegung der Frauenfrage den Einfluß sichern, auf welchen sie ein wohlerworbenes Recht hat. Die Franenfrage wollen wir losen im christlichen Sinne. Wir stellen uns in den Dienst der Kirche, und gehen voran in der Lösung der Aufgabe, welche sie Beihilfe einer Frau; sie soll gerettet werden durch den Geist Mariens." 
(360) "Frau Dr. Amann eröffnet mit einigen Begrüßungsworten. Geistl. Rat, Hofprediger Hecker, spricht über das Thema "Was verdankt Die Frau dem Christentum?". Pater Benno Auracher spricht über "Frauenbewegung im allgemeinen und der katholische Frauenbund", Herr Dr. Amann über den in München zu gründenden Zweigverein des katholischen Frauenbundes. Frau Dr. Amann schließt die Versammlung."

(369) "Ich habe Jahre hindurch Frauen der verschiedensten Partien in der politischen und der parlamentarischen Arbeit gesehen. Ich sah sie als Zentrumsabgeordnete in Weimar und Berlin. Hedwig Dransfeld, Helene Weber, Christine Teuch, Maria Schmitz, Agnes Neuhaus u. a.m. alles Frauen, die vom Beruf der Erzieherin oder Fürsorgerin her kamen. Ich fand sie alle wohl am Platz und fähig, der positiven Mitgestaltung öffentlich Dinge eine bessere Note zu geben. Nichts anderes läßt sich sagen von den Frauen politischer Orientierung rechts und links vom Zentrum bis nahe an die Kommunisten heran. Die Führerin der Heimarbeiterinnen, Margarete Behm, Anna von Gierke, Gertrud Bäumer, Antonie Pfülf, Louise Schröder, wollten sicherlich den Einsatz der Frau als Frau und nicht bloß als Parlamentarierinnen gelegentlich auch edler Frauenhaltung herausfiel, hatte es nicht im Parlament gelernt. Von der Mehrzahl aber der Frauen, die mir auf dem politischen Felde begegneten läßt sich sagen, daß sie den Willen zur Sachen besaßen die Fähigkeit, die Welt sowohl im kleinen zu pflegen wie auch an der Formung der großen Ordnungen mitzuwirken aus einem weltanschaulichen Prinzip heraus."

(387) "Es bedeutet heute mehr fast einen Reiz mehr, zu sein als Mann. Für uns hat sich eine unendlich viel größere Umwandlung der Weltanschauung voll zogen- eine neue Renaissancezeit ist angebrochen, in der nicht nur die einzelne Frau nach Entwicklung der Persönlichkeit drängt, sondern in der ein großes, allgemeines, heißes Sehen durch die ganze junge Frauengeneration geht, daß sie Mensch sein will, ganzer, vollkommener Mensch im Erkennen, Genießen, Handeln! ."

(392) "Wir würden keine Arbeit für direkte Kriegszwecke leisten, wie Hospitaldienst, Verwundetenpflege. Halbtot geschundene Menschen wieder lebendig und gesund machen, um sie abermals den gleichen oder noch schlimmeren Qualen auszusetzen? Nein für einen solchen Wahnsinn würden wir uns nicht hergeben. "

(396) "Was war denn Frauenbewegung?. Doch einfach alles neue Leben unter den Frauen, das ein unbekannter Gott aus dem Stein des harten Zeitalters schlug. Erwachen künstlerischer und geistiger Gestaltungskräfte, oder auch nur der Wille, den alten Lebenskreis bewußter, kraftvoller und mutiger zu füllen."

(407) " Wenn man sagt, die Welt des Mannes ist der Staat, die Welt des Mannes ist sein Ringen, die Einsatzbereitschaft für die Gemeinschaft, so könnte man vielleicht sagen, daß die Welt der Frau eine kleinere sei. Denn ihre Welt ist ihr Mann, ihre Familie, ihre Kinder und ihr Haus. Wo wäre aber die größere Welt, wenn niemand die kleine Welt betreuen wollte?."

(408) "Durch tausendjährige Inzucht, häufig vorgenommen in engstem Kreise, hat der Jude im allgemein seine Rasse und ihre Eigenarten schärfer bewahrt, als zahlreiche der Völker, unter denen er lebt. Und damit ergibt sich die Tatsache, daß zwischen uns eine nichtdeutsche fremde Rasse lebt, nicht gewillt und auch nicht im Stande, ihre Rasseneigenarten zu opfern, ihr eigenes Fühlen, Denken und Streben zu verleugnen, und die dennoch politisch alle Rechte besitzt wie wir selber."

(411) "Innerhalb dieser weltumspannenden Gegensätze der Rassen und Seelen schwingt das Leben aber noch außerdem um zwei Pole: den männliche und weiblichen. Sind die äußeren ras- 
sischen und tiefsten seelischen Merkmale, Richtungen und Wertgefüge von Mann und Weib eines artbedingten Volkes auch gleich, so hat die Natur neben den Polaritäten physikalischweltanschaulicher Art auch die geschlechtliche Polarität geschaffen, um organische Spannungen, Zeugungen, Entladungen zu schaffen als Vorbedingung einer jeglichen Schöpfung."

(413) "Die Fähigkeitslosigkeit ist die Folge des rein auf das Pfanzenhafte und auf das Subjektive gerichteten Wesens. Es fehlt der Frau aller Rassen und Zeiten die Gewalt einer sowohl intuitiven als geistigen Zusammenschau: überall da, wo eine mythische Weltgestaltung, ein großes Epos oder Drama, eine dem Kosmos nachforschende wissenschaftliche Hypothese in der Weltgeschichte auftaucht, steht ein Mann als Schöpfer dahinter."

(413) "Der Liberalismus lehrte: Freiheit, Freizügigkeit, FreihandelParlamentarismus, Frauenemanzipation, Menschengleichheit usw., d. h. er kündigte gegen ein Naturgesetz, daß Schöpfung nur durch Auslösungen polarbedingter Spannungen entsteht, daß ein Energiegefälle nötig ist, um Arbeit irgendwelcher Art zu leisten, Kultur zu schaffen. Der deutsche Gedanke fordert heute, mitten im Zusammensturz der feminisierten alten Welt: Autorität, typenbildende Kraft, Beschränkung, Zucht, Autarkie (Selbstversorgung), Schutz des Rassencharakters, Anerkennung der ewigen Polarität der Geschlechter."

(414) "Die "Emanzipierte" darf für sich das Recht auf Verkehr mit Niggern, Juden, Chinesen in Anspruch nehmen, und aus der Frau, als der berufenen Erhalterin der Rasse, wäre dank der Emanzipation die Vernichterin aller Grundlagen des Volkstums geworden."

(417) "Sie blüht auch in der Frauenemanzipation, die eher als alles andere eine Bewegung gegen das Muttertum der Frau ist. Die Frauen haben im Weltkrieg das Stimmrecht erobert. (...) Sie haben keine eigenen politischen Ideen, sondern schwören auf die Parteiparole und das Parteiprogramm, das von männlichen Gehirnen ersonnen wurde. Man irrt sich sehr, wenn man von der bisherigen parlamentarische Arbeit der Frauen wie überhaupt von der gesamten bisherige Frauenbewegung eine Besserung und Rettung der Menschheit aus ihrer verzweifelten Kulturlage erhofft. (...) In Wirklichkeit aber hat die Frau im Weltkrieg nur das aktive und passive Männerstimmrecht erobert, so wie sich auch in de Gymnasien und Universitäten die herkömmliche Männerbildung aneignet, statt sich ihre eigen Bildung zu gründen und auszubauen."

(418) "Und Frauen gar, die den Männern gleich sein wollen und darum den Muttergeist wider alles Naturrecht in sich freiwillig unterdrücken, sind in einem Mutterrechtsstaat die wahren Ausgestoßenen und Verfemten und sollten schlechter gestellt sein las selbst der Mann. Sie sind unnatürlichen Zwitterwesen, in denen die gesunde Lebenskraft, deren wir zur Gründung des "dritte Reiches der Menschheit bedürfen, erloschen ist. Sie sind, was bei den Männern die Homosexuellen sind, Entartete und Kranke, ja schlimmer noch als diese, denn ihre Triebverirrung ist meist bewußt und gewollt."

(419) "Diese ist nicht nur die karitative Mithilfe, sondern ein seelisch-geistiger Frauenkampf von ebenso großer Tragweite wie der der Männer. (...) Wir Frauen müssen in den Wehen dieser Zeitwenden neben der Mitarbeit im Ganzen der Bewegung unsere besonderen Aufgaben finden: das ist vor allem eine wahre, neuartige Lösung der Frauenfrage und eine tiefgehende Frauenerneuerungsarbeit."

(420) "Die Frauenbewegung hat also ihr eigenes Ziel: den Kultureinfluß der Frau, zu voller innerer Entfaltung und freier sozialer Wirksamkeit zu bringen, überhaupt nicht beginnen können, weil ihr 
der Urgrund des Lebens nicht im Mittelpunkt stand und weil sie deshalb das Lebensgesetz des Frauenwerdens nicht begriff."

(421) "So besuchten die Vertreterinnen des Frauenstimmrechts eine Pazifistinnenversammlung in Zürich im Sommer 1919 und Lida Gustava Heymann, die Vorsitzende und Vorkämpferin, trat der französischen Vertreterin mit einem Rosenstrauß entgegen. Wenn man an die damals besonders furchtbare Vergewaltigung des Rheinlandes durch dieselbe Nation denkt, die diese Frauenrechtlerin mit dem Strauß der Liebe ehrte, so bekommt man auch hier wieder einen wahrhaft niederdrückenden Eindruck von dem Versagen solcher Persönlichkeiten, die zu den Vorkämpferinnen der Frauenbewegung gehören."

(422) "Der gesamten maßgebenden und Richtung bestimmenden Frauenbewegung der Nachkriegszeit fehlte die Voraussetzung zu einer gedeihlichen Entwicklung, der gesunde Boden, auf dem sie hätte stehen müssen, um erfolgreich für die Frauen sein zu können; der artgemäße, blutmäßig richtige Aufbau. (...) Die Frau wurde ins Parlament geschickt und damit beging man den ersten Verrat an sich selbst, die erste Sünde wider den Geist!."

(423) "Wo Ihr auch steht, ob im Haushalt, im Büro, an der Werkbank, in der Schule, am Krankenbett als Ärztin oder Schwester, eines werdet Ihr lernen müssen: In erster Linie wir zurück zu müssen zu Eurem innersten Wesen, und das schreibt und schieb Euch immer vor: zu dienen aus freiem Willen! Wie ihr dient, danach wird man euch danach wird man uns alle werten."

(424) "Wir Nationalsozialisten sind uns sehr wohl klar darüber, daß nicht alle Frauen Hausfrauen und Mütter werden können; wenn ein Mädel die Neigung und die Eignung zu einem besonderen Beruf hat, soll ihr die Möglichkeit geschaffen werden, dieser Neigung eine Verwirklichung zuteil werden zu lassen, (...). Die tiefste Berufung, die uns zuteil werden kann, ist die zum Muttertum. Dieser Beruf ist heute zu eine Äußerlichkeit geworden und ist überdies noch in Mißkredit geraten."

(429) "Die "Zersplitterung" der politischen Parteien, ihre Unfähigkeit "zum Wohle des Volkes" Mehrheiten zu bilden, die zunehmende Radikalisierung und "Verrohung" der politischen Kultur machten die Idee des "Staates" für viele bürgerlich-demokratischen Männer und Frauen immer attraktiver. Nicht zufällig nannte sich die "Deutsche Demokratische Partei"- die politische Heimat der führenden ADEF und BDF Frauen seit 1930 ,Deutsche Staatspartei. "

(430) "Die Worte "rechts" und "links" sind zur Bezeichnung der gegenwärtigen politischen Bewegung in Deutschland überhaupt falsch, weil sich die neuen Fronten auf anderen Linien bilden. Der Zusammenschluß der in der Deutschen Staatspartei verbundenen Kräfte bedeutet den Durchbruch des republikanisch-demokratischen Gedankens in zwei Volkskreisen, in denen er bisher zwar vorhanden, aber latent war: den christlich-sozialen und den Jungnationalen."

(431) "Wer der Überzeugung ist, mag von einer Krise des Parlamentarismus reden, es muß ihm gegenüber erlaubt sein, darauf hinzuweisen, daß geistesgeschichtlich - eine Krise der Demokratie nicht besteht, und die Verfassung von Weimar noch voller unausgeschöfpter Kräften ist. (...) Seiht man davon ab, daß der schlimmste Feind der Demokratie im Grunde nur einen bedrohlichen Gegner hat - das ist die Diktatur. Das Kennzeichen alles Parlamentarismus beim Zustandekommen der Gesetze und nicht so leichtfertig sollte man diese Gott preisgeben, um das Generationen so heiß gekämpft haben".

(432) "Wir befinden uns erst am Anfang neuer Lebensformen, am Vorabend einer Zeit, deren Wonnen sich uns noch kaum enthüllt hat. Nach uns, erst nach uns, so fühlen wir, kommt das wirk- 
lich Neue, die Periode das sich vollendendes Kapitalismus, und vielleicht die Morgenröte des Sozialismus. "

(439) "Der Bund Deutscher Frauenvereine erwartet von sämtlichen politischen Parteien, daß sie das staatsbürgerliche Recht der Frau in vollem Umfang anerkennen und aufrecht erhalten helfen. Dieses Recht schließt die Möglichkeit ungehinderter politischer Betätigung auf allen hier in Frage kommenden Arbeitfeldern ein und verlangt unabweislich eine der Bedeutung der Frau in Staat und Volk entsprechenden Beteiligung der Frauen an der politischen Vertretung in de Parlamenten. Die Frau, die gewillt und befähig ist, die volle Verantwortung für das Schicksal ihres Vaterlandes mit auf Bürgerrecht und dieser heiligen Pflicht nicht abgedrängt werden. Der Bund Deutscher Frauenvereine ruft insbesondere alle Frauen auf, bei der Ausübung ihres Wahlrechts diesen Gesichtspunkt fest im Auge zu behalten."

(444) "Ich selber erlebe schon mit, wie in der neuen deutschen Freiheitsbewegung unter Führung Adolf Hitlers vom Manne keinesfalls an die Frauen "als an die Objekte von Wohltat und Qual" gedacht wird, sondern es gilt hier als Ideal die Mitkämpferin, (...) wo die Frau einmal ihre biologische Aufgabe für die Rasse als Selbstverständlichkeit erfüllte."

(445) "es stünden sich überall zwei Auffassungen gegenüber, nämlich ob es richtiger sei, durch praktische Mitarbeit eine Beeinflussung der herrschenden Idee und eine Erhaltung unserer Wirkunssphäre, auch mit Bezug auf vorhandene örtliche Wohlfahrtseinrichtungen, anzustreben oder aber unter Verzicht auf allen Kompromiß und bei Aufgabe einer Lebensarbeit die Grundsätze unserer Gemeinschaft in ihrer Reinheit zu bewahren und zu überliefern."

(449) "wir alle ... einer nationalsozialistischen Regierung nur zustimmen können und daß der BDF alles tun werde um mit den besten Frauen der NSDAP zusammenzuarbeiten."

"Selbstverständlich soll Frauenbewegung nach sachlichen und nicht nach parteipolitischen Gesichtspunkten arbeiten. Eine Festlegung auf bestimmte Parteien kann nicht verlangt, muss vielmehr durchaus abgelehnt werden. Aber sollte der vaterländische Gedanke nicht in einigen, oder wenigstens in einer Organisation der deutschen Frauenbewegung so sehr zur weltanschaulichen Grundlage gehören, daß ein Gruß an das neue Deutschland, das den Marxismus besiegte, möglich ist? Eine Kundgebung etwa, die gleichzeitig die Hauptpunkte des eigenen Programms herausstellt, damit das neue Deutschland sieht: Hier sind Kräfte, deren es beim Wiederaufbau nicht entraten kann, denn die Frauenbewegung will mit ihrem Eintreten für Frauenwertung, Frauenverantwortung und Frauenleistung dem Volksganzen dienen. Bei Bekämpfung sozialer und sittlicher Mißstände läßt sich die Erfahrung und Sachkunde der Frau ebenfalls nicht mehr ausschalten."

(450) "Viele deutsche Frauen werden heute auf eine Kundgebung der organisierten Frauenbewegung warten, die in der angedeuteten Weise Stellung nimmt. Ja, sie werden von ganzem Herzen darauf hoffen, denn sie wollen zum Ausdruck gebracht sehen, wie sehr ihre Bewegung dem Vaterland und der Volksgemeinschaft verhaftet ist. Sie wollen daraus die Gewißheit schöpfen, daß eine im Hinblick auf das Volksganze geübte Vertretung der Frauen- und Jugendbelange in Familie und Beruf, in der Schule und im öffentlichen Leben Dienst am Vaterlande ist."

(453) "Jetzt kommt eine Zeit, in der man ganz einfach seelsorgerisch aus persönlicher Verbundenheit arbeiten muß, das Äußere wird unwichtiger, weil man da nicht viel wird machen können." 
(455) "Die Sämtlichen dem Bund Deutscher Frauenvereine und seinen Landes und Provinzialverbände angehörigen Organisationen sind z. Zeit in eienr Umbildung begriffen. Sie gestalten ihre Vorstände und Arbeitsmethoden um inder Überzeugung daß die neue Zeit an vielen Stellen neu Menschen und neue Zielsetzungen erfordert.Wir würden es mit grössten Dank begrüssen, wenn diese Entwicklung nicht durch Eingriffe von aussen unterbrochen werden würde, sondern wenn ihr einige Monate raum gelassen werden könnte. Eine organische Weiterbildung der Frauenvereine würde allein die organische Weiterführung der Wohlfahrtsarbeit ermöglichen, deren Träger unsere Vereine in grösstem Umfang sind".

(456) "Zahlreich und groß sind die Aufgaben, die der deutschen Lehrerin in der nationalen Erneuerungsbewegung gestellt sind."

(458) "Es müsste von der Regierung eine Erklärung verlangt werden, in welcher Form die Organisationen weiterbestehen sollen. Auflösungen können nur durch Behörden oder durch die Organisationen selbst geschehen."

(460) "Frl. Gottschewski setzte auseinander, dass die Deutsche Front" entschlossen sei, keine "Inseln", d.h. irgendwelche nicht zu ihr gehörigen Frauenorganisationen bestehen zu lassen. Da sie den Wunsch habe, gegen den Bund keine harten Massregeln ergreifen zu müssen, fordere sie ihn hierduch auf, in die Deutsche Frauenfront einzutreten."

(463) "Nachdem die Generalversammlung des Allgemeinen Deutschen Lehrerinnen-Vereins in Erfurt am 7. Mai 1933 die Auflösung des A.D.L.V. beschlossen hat, hat sie die unterzeichneten Liquidatoren mit der Bestimmung über das Vermögen des A.D.L.V. beauftragt. Sie hat dafür als Richtlinien aufgestellt, dass eine Summe bereitgestellt werde für die weitere Erfüllung der vom A.D.L.V. zuletzt geleisteten Unterstützungsaufgaben und dass ein betrag zur Verfügung gestellt werde zur Förderung der Ideen und Zwecke, denen das Leben und die Arbeit der Gründerin des A.D.L.V. dienten."

(469) "Wir fordern die Freiheit aller religiösen Bekenntnisse im Staat, soweit sie nicht dessen Bestand gefährden oder gegen das Sittlichkeits- und Moralgefühl der germanischen Rasse verstoßen. Die Partei als solche vertritt den Standpunkt eines positiven Christentums, ohne sich konfessionell an ein bestimmtes Bekenntnis zu binden. Sie bekämpft den jüdisch-materialischen Geist in und außer uns und ist überzeugt, daß eine dauernde Genesung unseres Volkes nur erfolgen kann von innen heraus auf der Grundlage: Gemeinnutz vor Eigennutz."

(470) "Mit den Konfessionen, ob nun diese oder jene: das ist alles gleich. Das hat keine Zukunft mehr. Für die Deutschen jedenfalls nicht. Der Faschismus mag in Gottes Namen seinen Frieden mit der Kirche machen. Ich werde das auch tun. Warum nicht? Das wird mich nicht abhalten, mit Stumpf und Stiel, mit allen seinen Wurzeln und Fasern das Christentum in Deutschland ausrotten. Für unser Volk aber ist es entscheidend, ob sie den jüdischen Christenglauben und seine weibliche Mitleidsmoral haben oder einen starken, heldenhaften Glauben an Gott in der Natur, in eigenen Volke, an Gott im eigenen Schicksal, im eigenen Blute." 
(471) "Die Religion Jesu war zweifellos die Predigt der Liebe...Niemand wird dieses Gefühl mißachten; es schafft das seelische Fluidum von Mensch zu Mensch. Aber eine deutsche religiöse Bewegung, die sich zu einer Volkskirche entwickeln möchte, wird erklären müssen, daß das Ideal der Nächstenliebe der Idee der Nationallehre unbedignt zu unterstellen ist; daß keine Tat von einer deutschen Kirche gutgeheißen werden darf, welche nicht in erster Linie der Sicherung des Volkstums dient. Damit ist der unlösliche Widerstreit zu einer Anschauung nochmals bloßgelegt, die offen erklärt, die kirchlichen Bindungen ständen höher als die Bindungen der Nation.(..) Konfessionen sind nicht Zweck an sich, sondern wandelbare Mittel im Dienste des nationalsozialistischen Lebensgefühls und der germanischen Charakterwerte. (...) Die Ablehnung des germanistischen Ideals in Deutschland ist nackter Volksverrat."

(472) "Die Herrlichkeit des deutschen Kaiserreiches, der Traum unsere Väter, der Stolz jedes Deutschen ist dahin. Mit ihr de hohe Träger der deutschen Macht, der Herrscher und das Herrscherhaus, das wir als Bannerträger deutscher Größe so innig liebten und verehrten. "

(473) "(...) die Kirche selbst fand zur Demokratie von Weimar kein positives Verhältnis. Die Sympathien der Vertreter des Protestantismus galten nach der neuerlichen Konstituierung des Parteienwesens und gescheiterten Versuchen, eine Partei mit ausdrücklinch protestantischer Programmatik ins Leben zu rufen, der Deutschnationalen Volkspartei, DNVP."

(476) "(...) in allen echten Religionen-in altgermanischen wie in steinzeitlichen-der göttliche Sohn immer wieder sterben muß, um neu zu erstehen."

(477) "Ich versuchte, den Menschen nahezukommen, ihnen Halt zu geben in der christlichen Religion und ihnen die christliche Wahrheit zu predigen, auch in sozialen Nöten zu helfen, so gut es ging."

(484) "Der Krieg veränderte die Situation total. Wir alle liebten Deutschland als unsere Heimat, unser Vaterland. Das war für uns aber etwas ganz anderes als dieses "Dritte Reich". Nur ließ sich das nach Kriegsbeginn nicht mehr voneinander trennen. So sind auch mache unserer "junger Brüder" ins Feld gezogen -zwar mt schweren Bedenken, aber letztlich aus, Treue zu Volk und Vaterland."

(486) "Ich glaube, daß die Liebe, die Humanität, das Streben nach Befriedigung und Gesittung zu den Daseinsbedingungen der Frau gehört. (...) Außerdem glaube ich, daß die Frau gerade als Hüterin des Wachstums, des Lebens, des lebenden Menschen für die Liebe, die Menschlichkeit entstehen und dem brutalen Kampf, der den Tod und die Hinderung ungestörten Wachstums bringt, widerstreben muß."

(492)"Neben der Bedrohung der äußeren Sicherung, die in der heutigen wirtschaftlichen Krisis, in der Arbeitslosigkeit begründet ist, wurde besonders auf die innere Gefährdung hingewiesen. Diese wird gefördert durch die Einstellung in Kreisen weiblicher Jugendlicher, die den Beruf für die Frau ablehnen, weil sie glauben, daß die weibliche Eigenart sich in der beruflichen Arbeit nicht voll entfalten kann, ja sogar geschädigt wird."

(493) "Es ist eine alte Taktik des katholischen Klerus, über de Frauen und sonstigen Angehörigen auf die betrefenden Männer einzuwirken, vor allem um diese vom Nationalsozialismus zu entfremden." 
(494) "(...) aber bitte ich, uns zu erzählen, was die nationalsozialistischen Damen als Organization bis jetzt geleistet haben in Dienst des Vaterlandes, in der sozialen Hilfsarbeit, im karitativen Wirken, un mir Namen zu nennen von Frauen, wie ich sie nennen kann aus den Kreisen unserer katholischen Frauenarbeit."

(497) "Und nun stehen wir heute vor einer neuen Revolution: vor der Massen und Gruppen, die nur den männlich geprägten Staat wünschen, die im Wirtschafts und Sozialpolitischen die "negativen" und "sentimentalen" Frauenkräfte ablehnen. Wiederum ist ein Volksschicksal in Frage gestellt, ein schwer bedrängtes, durch Arbeitslosigkeit unterwühltes Schicksal. Man ruft die Frauen auf, sich in jene politische Front der Männer zu stellen, die einen positiven, aktiven Anteil der Frau in der Politik nicht wünschen. "

(498) "Einer großen sozialen Entscheidung vor allem kann die katholische Frauenbewegung nicht ausweichen: der der Volksgemeinschaft. Wir sind nicht akademische Gruppe, nicht Kartell der Berufsverbände und Frauenverbände, nicht Mütter oder Berufsfrauen. Wir sind alle ein Fleisch und Blut, ein Pulsschlag in der großen sozialen Verbundenheit. Wir werden uns politisch so entscheiden müssen, daß diese Volksgemeinschaft ungebrochen bleibt, so daß in ihr alle Ziele, Wünsche und Forderung aufbrechen."

(499) "Aufgabe der Frau wird es sein, in die unerhörte Bewegung und Leidenschaftlichkeit dieser Tage, die Ruhe und Zuversicht, das tiefe Wissen derer hineinzugeben, die um Deutschland in 20 Jahren vieles starkmütig gelitten haben, und hineinzutragen die freudige, mutige Zukunftshoffnung derer, die jung sind und wissen, daß sie vor neuem Aufstieg stehen. Vor allem aber wird die Frau den Haß der Kämpfenden zu überwinden suchen durch die Liebe. Unsere Liebe zu Deutschland, zu unserem Volke soll bauen an seiner Zukunft."

(500) "Wir wollen das wunderbare Erbe deutschen Geistes nicht verkümmern lassen und glauben daran, daß es in neuen Forme in neuer Zukunft aufblühen wird. Aber wir wissen, daß Barbarei uns bedroht. Barbarei, die sich ganz verschieden gibt, aber sicher auf einen Weg führt, der unser verderben ist, denn sie führt zum Bolschewismus."

(501) "Die katholischen deutsche Frauen geben in dieser Stunde der Überzeugung Ausdruck, daß es darauf ankommt, sich nicht vom Radikalismus verleiten zu lassen. Besonnenheit, Klugkeit und Mäßigung müßen bewahrt werden. Nicht Gewalt und Diktatur, nicht Terror der Stasße und Bruderkrieg retten Deutschland, sondern das Stille, tapfere Durchalten seiner Männer und Frauen und Familien."

(503) "Der Friedenswille der Frau ist konservativ und realistisch. So ist die Frau die geborene Verkörperin der katholischen Friedensidee. Konservativ sind nicht die, die sich konservativ nennen und gleichzeitig ihre Nation durch Macht und Gewalt an die Spitze bringen wollen, auch nicht die, für die das Gute nur in der Vergangenheit liegt, sondern wahrhaft konservativ sind diejenigen, die wollen, daß alle lebendigen Kräfte der Vergangenheit und der Gegenwart als lebendige Kräfte in die Zukunft eingehen."

(504) "Alles was aus der Mutterschaft der Frau kommt, ist stark und mutig wie junges Leben und hinausgerichtet über das bloße Leben; denn die Grunderfahrung der Mutter ist, daß Leben und Sterben ganz nahe beieinander sind, und daß beide in Gottes Willen sind. Diese mütterliche Ehrfurcht vor dem Leben, die gleichzeitig Losgelöstheit vom bloßen Leben ist, gibt der Frau den Mut, trotz aller möglichen Mißverständnisse und trotz der wachsenden Unpopularität ihres 
Wollens, entschiedener denn je in diesem gefährlichen Augenblick für den Frieden zu kämpfen, für vertragliche und organisatorische Friedenssicherungen, gegen materielle und geistige Rüstung."

(505) "Es gibt eine religiöse deutsche Geistigkeit, die sich hineinstellt in die zwischen- und übernationale katholische Mentalität. Und dieses deutsche Sondergut des Religiösen ist en Stolz der Kirche und darum in deutschen Grenzen Leben, aber auch allen jenen, die von unser Sprache und Art sind. (...) Wer will uns den Stolz auf all dies verwehren. Wer unsern Optimismus verdammen, daß deutsche Menschen in aller Welt durch unser Schrifttum eher als durch die religiösen Sonderwerte anderer Rassen und fremder Sprachen zu Gott geführt werden!. "

(506) "Mit Wahrheit dämonischer Macht geht der Bolschewismus so seinem Weg nicht nur in Rußland, sondern fast allen Ländern der Erde. Wir katholischen Frauen beklagen in tiefster Empörung, daß gerade in unserem Vaterlande ein besondere Stützpunkt dieser unheilvollen Strömung, die Zentrale der Gottlosen, errichtet ist."

(508) "Wir glauben, daß sich noch genug Gutgessinnte und Besonnene im Lande finden, um Willkür und Diktatur abzuwehren und die zu stützen, die jetzt und uberreirt auf dem Boden von Recht, Gesetz und Ordnung, Einheit und Freiheit des deutschen Volkes erlangen wollen."

(511) "Freudig bejahen wir den starken Willen zum Aufbau, die hohe Wertschätzung von Familie und Volkstum, die Sorge um die Erneuerung und Stärkung guter Sitte, das beiße Bemühen um die Einigung aller in treuer Liebe zu unserm Volk. Es ist etwas Großes, dem herandrigenden Bolschewismus, der Propaganda der Gottlosigkeit das Bekenntnis zum Christentum sieghaft entgegenzustellen. "

(512) "Immer tiefer müssen wir das besondere Wesen unseres Volkes begreifen und erkennen, wie innig sich seit seinen Jugendtagen germanische und christliche Elemente zu deutscher Art geeint haben und wie unauslöschlich und unersetzlich diese Verbindung für eine zukünftige Geschichte unseres Volkes ist."

(513) "Wir stehen mit dem starken Willen zur Mitarbeit im neuen Staat. Wir stehen nicht abseits, sondern mitten im Gang der Ereignisse. Wir wollen aus den Glaubenskräften der katholischen Frau in alle Kulturbereiche des Lebens hineinwirken aus der unerschütterlichen Überzeugung, daß unsere Arbeit wertvolle Mitarbeit am Volksaufbau sei. Durch das Konkordat hat der Staat die Anerkennung der Arbeit der katholischen Verbände u. a. auch unseres Frauenbundes bestätigt."

"Die Zusammensetzung des Frauenwerkes ist zentral noch nicht abgeschlossen. Wir denken uns eine Zusammenarbeit wesentlich in der Form der Arbeitsgemeinschaft, die für die einzelnen Organisationen freie Betätigung zuläßt."

(516) "Er wollte keine logische Erklärung, er wollte glauben, und Glaube war für ihn Gnade. Man kann eben über Glauben nicht streiten, allerdings hätte ich von ihm als gläubigen Christen mehr Toleranz erwartet, was doch ein teil des "liebe Deinen Nächsten" ist." 
(89) "Ich will nur ganz kurz Ihre Anfrage bezüglich Gertrud Bäumer gleich beantworten. Gertrud Bäumer ist entlassen wegen ihrer politische Zugehörigkeit und ihrer Stellung in einer Frauenbewegung, die von der nationalsozialistischen Bewegung nicht gebilligt würde. Es muss dabei aber doch immer wieder von uns betont werden: wenn sie auch durch eine demokratische Regierung in ihr Amt gekommen ist, sie ganz bestimmt nicht in erster Linie als Demokratin in die Regierung berufen ist, sondern dass diese Berufung der repräsentativsten Frau Deutschlands der neuen Gleichberechtigung der Frauen Ausdruck geben wollte."

(94) "Eine einwandfrei Ausrichtung des Vorstandes der Helene Lange Stiftung dúrfte nach Entsendung einer Vertrauensperson der Reichsfrauenführerin auch insofern sichergestellt sein(...)".

(523) " (...), der Nazismus glitt in Fleisch und Blut der Menge über die Einzelworte, die Redewendungen, die Satzformen (...). Worte können sein wie winzige Arsendosen: sie werden unbemerkt verschluckt, sie scheinen keine Wirkung zu tun, und nach einiger Zeit ist die Giftwirkung doch da."

(525) "Alles in ihr war Rede, mußte Anrede, Anruf, Auspeitschung sein."

(529) "Die Apokalypse entsteht in Krisensituationen, produziert von Menschen, die sich in ihrer gesamten Existenz- spirituell, politisch, sozial- gefährdet und gedemütigt, unterdrückt und verfolgt empfinden, zu Reicht oder zu Unrecht. Sie legen ihre Leidenserfahrungen so aus, daß die Welt, in der sie leben, als sinnentleert erscheint, als zutiefst verdorben und böse. Sie sehnen sich nach Erlösung, aber sie glauben nicht, daß sich durch Veränderungen hier und da, durch Verbesserungen oder Reformen noch irgendetwas bewirken lasse. Erlösung, so glauben sie, lasse sich nur dadurch erreichen, daß die alte, verdorbene Welt untergeht und der "böse Feind", der das Verderben verschuldet hat, vernichtet werde."

(530) "Dort herrschen Egoismus, Haß, Leidenschaften, Wut und Empörung, Fanatismus und Unduldsamkeit, Kampf (...)."

(531) "Die nazistische Rhetorik (...) findet in dem Wort Weltanschauung das Schauen, die Schau des Mystikers, das Sehen des inneren Auges, also die Intuition und Offenbarung der religiösen Ekstase."

(532) "Die Worte Aktion und Sturm wanderten um 1920 aus dem weibischen Café in das männliche Brauhaus. (...) Aktion verband sich mit den Erinnerungen an die heroische Frühzeit, mit dem Bilde des Stuhlbeinkämpfers; Sturm wurde zur militärisch-hierarchischen Gruppenbezeichnung."

(540) "(...) die Welt des Mannes ist der Staat, die Welt des Mannes ist sein Ringen, die Einsatzbereitschaft für die Gemeinschaft, so könnte man vielleicht sagen, daß die Welt der Frau eine kleinere sei. Denn ihre Welt ist ihr Mann, ihre Familie, ihre Kinder, und ihre Haus."

Es wird da und dort die Anschauung geausert, daß wie andere Verbande so auch de deutsche evangelische Frauenbund der Auflosung von her verfallen konnte. Davon mußte eine ordentliche Schadigung des Gemeindelebens befurchtet werden."

(543) "Es gibt nichts Schöneres, als sich ein junges Ding zu erziehen: Ein Mädel mit achtzehn, zwanzig Jahren ist biegsam wie Wachs. Einem Mann muß es möglich sein, jedem Mädchen seinen Stempel aufzudrücken. Die Frau will auch nichts anderes." 
(546) "Die verwüsteten Gesichter alter Amerikanerinnen sind ein weiterer Beweis, daß irgendwas wesentliches fehlt, was wir mit Herz, Seele oder Gemüt bezeichnen würden.Die ganze amerikanische Gesellschaftsordnung krankt daran, daß der Amerikanerin im allgemeinen das Mütterliche fehlt."

(549) "Schon früh erkannten einzelne Frauen in Adolf Hitler den Führer zu einem einigen, starken und freien Neue Deutschland und schossen sich seiner Bewegung an. (...) Sie betrachteten den aktiven politischen Kampf, die vordringlichste Aufgabe der NSDAP vor der Machtübernahme, als Angelegenheit der Männer. (...) Sie standen in begeisterten und schweren Stunden an ihrer Seite und erhöhten ihre seelische Kraft durch ihren unzerstörbaren Glauben an den Sieg der Bewegung. Ihre Treue zum Führer war unbedingt."

(555) "Es treffe sich hier die kaufmännische Angestellte mit der Arbeiterin, die Haustochter mit der BDM-Führerin, die Medizinstudentin mit der Verkäuferin, die Stenotypistin mit der Arbeitsdienstführerin, die Modistin mit der Philologie Studentin. Ebenso zeigt sich bei den Verlobten, den zukünftigen Ehemännern, eine erfreuliche Vielseitigkeit der Berufe: Neben SS-, SAund HJ-Führern und den Angehörigen nahezu aller Gattungen der Wehrmacht stehen Juristen, Lehrer, Beamte, Schrifteiter, Ingenieure, Handwerker, Arbeiter und Kaufleute."

(558) "Die Grenz- und Auslandshauptabteilung begann ihre Arbeit zunächst am 1. Juli 1934, zu einer Zeit, in der die Boykotthetze gegen Deutschland sich der Lüge von der Unterdrückung der deutschen Frau durch den Nationalsozialismus als eins ihrer wirksamsten Propagandamittel bediente."

(153) "In den Landes- und Provinzialkirchen gingen wir eine engere Bindung mit den Kirchenbehörden ein. Als kirchliches Frauenwerk kamen wir zu Abmachung mit dem Deutschen Frauenwerk, um als evang. Frauen mitter unter allen deutschen Frauen von unserer konfessionellen Grundlage her mitzuhelfen am Neuaufbauwerk unseres Führers für unser Vaterland."

\section{La prensa protestante}

(572) "Sie ist das Eingangstor fremden Blutes in unsern Volkskörper. Sie hat neben der Äußeren Mission keine Daseinsberechtigung. Wir lehnen die Judenmission in Deutschland ab, solange die Juden das Staatsbürgerrecht besitzen und damit die Gefahr der Rassenverschleierung und bastardierung besteht. Die Heilige Schrift weiß auch etwas zu sagen von heiligen Zorn und sich versagender Liebe. Insbesondere ist die Eheschließung zwischen Deutschen und Juden zu verbieten."

(576) "Der Staat ist eine Anordnung (nicht Ordnung!) Gottes in der noch nicht erlösten Welt, in der die Gemeinde an Gottes Reich erinnert".

(582) "Der Gruppenführer hat daher endgültig entschieden, daß für die Zukunft eine geschlossene Bekämpfung des gefährlichsten aller gefährlichen Gegner durch die staatspolizeilichen Stellen erfolgen muß. Die politische Kirche übernimmt heute die Rolle, die die Spartakisten und Marxisten von 1918 spielten. Für diese Haltung ist den politischen Kirchen einst die Rechnung zu präsentieren. Wir haben daher mit allen uns zur Verfügung stehende Mitteln diese Material zusammengetragen..." 
(585) "Ich habe mich für meinen Verband diesen Satzungen verpflichtet und werde gewissenhaft darum bemüht sein, meinen Verband und die meiner Führung unterstellten Frauen im Sinne des nationalsozialistischen Staates zu führen und zu erziehen. Ich verpflichte mich zu absoluter Gemeinschaft Deutscher Frauenverbände zusammengeschlossenen Vereinen und anerkenne rückhaltlos die nationalsozialistische Führung der Reichsarbeitsgemeinschaft Deutscher Frauenverbände. "

(586) "An die Spitze des Reichsfrauenwerkes wurde Frau von V. Grone, Westerbrak, berufen. Sie und wir alle mit ihr unterstellten uns dem vom Führer bestimmten Reichsbischof, in der festen Zuschützen und jeden gewollte Dienst fördern würde".

(591) "Nachdem das Deutsche Frauenwerk die Reichsarbeitsgemeinschaft übernommen hat und Erfahrungen über gute Zusammenarbeit vorliegen, möchte ich nochmals dringend bitte,, dass weiterhin dem Frauenwerk der Deutschen evangelischen Kirche der bisherige Schutz gewährt bleibt, wie er zugesagt worden ist. Ich stelle ausdrücklich fest, dass die Arbeit des Frauenwerkes der Deutschen Evangelischen Kirche Dienst der evangelischen Frau an der Gemeinde und als solcher eine rein kirchliche Angelegenheit ist. "

(592) "Durch das Reichskonkordat mit der katholischen Kirche ist für die katholischen verbände ein besonderer Schutz geschaffen worden -ein Schutz, den ich für die Verbände der evangelischen Kirche in gleichem Masse in Anspruch nehme. Betonen möchte ich noch, dass das Frauenwerk der Evangelischen Kirche kein politischer Verband ist, sondern ein rein kirchlicher, der also nur der Kirchenführung als solcher untersteht."

(593) "Darf ich im Namen dieser 2 Millionen evangelischer Frauen die Bitte aussprechen, dass Sie, sehr verehrter Herr Hess., unsere Ehrerbietigen Grüße dem Herrn Reichskanzler übermitteln, gerade in den Tagen, die für ganz Deutschland dort in Nürnberg ein machtvolles Bekenntnis in sich schließen zu dem neue, geeinten deutschen Reich. (...) Wir 2 Millionen evangelischer Frauen möchten den Dank auch an die Deutsche Arbeiterpartei sagen, die unsere Arbeit gestürzt und gefördert hat und uns den Weg frei machte zu Lebendigem Mitschaffen an Volk, Staat und Kirche".

(594) "Es wird da und dort die Anschauung geausert, daß wie andere Verbande so auch de deutsche evangelische Frauenbund der Auflosung von her verfallen konnte. Davon mußte eine ordentliche Schadigung des Gemeindelebens befurchtet werden."

(595) "Für die Erhaltung der kirchlichen Frauenarbeit ist die Entschließung beachtenswert, die am 6.4.34 gemeinsam von dem Frauenwerk der Deutschen Evang. Kirche (Führerin Frau v. Grone) und dem Deutschen Frauenwerk (Führerin Frau Scholtz-Klink) erfolgte. "Doppeltmitgliedeschaft der NS-Frauenschaft u. der Evangelischen Frauenhilfe ist gestattet. Da jede Kirchengemeinde zum Dienst an der Volksgemeinschaft besondere Aufgaben hat, bedarf sie kirchlich geschulter Frauen für diesen Dienst. Bei Neugründungen soll mit der örtlichen Leitung der NS-Frauenschaft Fühlung genommen werden, um von vornherein Gegensätze u. Spannungen auszuschalten. Anmeldungen von Versammlungen, soweit sie sich lediglich mit religiöskirchlichen Angelegenheiten beschäftigen sind nicht notwendig. " 
() "Als Frauen, die die Freude haben dürfen, am Aufbauwerk unseres Führers mitzuarbeiten, müssen wir uns darüber klar sein, dass alle Arbeit umso wirkungsvoller ist, je besser die einzelnen Träger der Arbeit in ihren Reihen Ordnung und Disciplin haben und da das Deutsche Frauenwerk ein Organismus werden soll, der die geschlossene Einheit der deutschen Frau zum Ausdruck bringen soll im Dienst am Volke, (...)."

(596) "Die Gefahr der Auflosung unseres evangelischen Frauenwerks besteht zunachts nicht. Es ist naturlich moglich, daß im Laufe der Zeit das N.S. Frauenwerk und die N.S.-Volkswohlfahrt unsere Vereine aushohlen oder ihnen die Arbeit zum Teil abnehmen. Hier wird man abwarten mussen, wie die Zukunft sich gestalten wird. Selbstverstandlich tun wir unsere Arbeit zum Besten unseres Volkes und aus der Verpflichtung heraus, die uns der in der Liebe tatige Glaube gibt."

(597) "Die beiden aufgezeigten Arbeitslinien - gemeindliche und übergemeindliche Frauenarbeit - sind aus der Tradition vergangener Jahrzehnte geworden, haben aber nur ein gemeinsames Ziel: das Frauenwerk der Kirche will dienendes Glied der Kirche sein und als solches Frauenaufgaben in Volk und Staat erfüllen".

(598) "Bei aller Einheitlichkeit der deutschen Frauenarbeit ist in den Abmachungen zwischen dem Frauenwerk des Staates und dem Frauenwerk der Kirche die volle Selbständigkeit der Glaubensarbeit evangelischer Frauenarbeit gewahrt. Denn nur durch die kompromisslose Anerkennung evangelischer Aufgaben Erfüllung kann die Kirche durch die Frauen ihren Dienst dem Volke tun. - Die Autorität der Führung liegt auch darum für das kirchliche Frauenwerk bei der Kirche."

(165) "Ihre Vorstellung war, daß evangelische und nationalsozialistische Frauen gemeinsam Spenden mobilisieren, neue Organisationen gründen, neue Mitglieder werben und Aktivitäten im Sinne des Führers tragen würden. Dabei sollte den evangelischen Frauen die Entscheidung vorbehalten bleiben, wann und woran sie sich beteiligen wollten. Sie hoffte, sich dadurch eine gewisse Machtposition dem weltlichen Regime gegenüber zu bewahren."

(600) "Mutter der Kirche sind Mütter des Staates" dieses Wort ist eine grosse Forderung an uns. Wir wollen im Glauben leben, wir wollen gebunden sein an eine lebendige Kirche, denn nur so können wir das Wort unseres Führers Wahr machen: "In meinem Staat wird die Mutter die wichtigste Staatsbürgerin sein!." Nur wenn wir aus der Kraft des Glaubens, aus der Treue zum Evangelium Sitte bewahrend und Sitte lebend fromme Mütter der Kirche sind, können wir gutte Mütter des Staates, die für ihn bürgen sein."

(605) "Wie der Aufruf des Reichsbischofs vom 24. April 1935 erweist, ist de einzige Grund zur Gründung des Frauendienstes der Versuch, die Evangelische Reichsfrauenhilfe in die Kirche Gefolgschaft des Reichsbischofs zu bringen."

(607) "Wir können es wohl verstehen, wenn Kirchengemeinden und Kirchenkreise, z. B. Crossen, der Bekenntnissynode beitreten und dann selbstverständlich die Frauenhilfen als Gemeindeorganisation ebenfalls der Bekenntniskirche sich eingliedern. Wir verwehren uns aber gegen das Vorgehen des Bruderrates in dem Augenblick, in dem er in Kirchenkreisen und Gemeinden, die weithin unter deutsch-christlicher Leitung stehen, die evangelischen Frauenhilfen als krichenpolitisches Instrument benutzt, um in diesen Gemeinden Fuss zu fassen." 
(608) "Wir können bis zur Stunde auf eine bewundernswerte Disziplin in den Reihen unserer Organisation sehen, können aber mit einer Erklärung der Provinzialführung die Frauenhilfen nicht mehr warten lassen. Wir haben daher in einem Rundschreiben vom 1. November den Frauenhilfen die Zwischennachricht bekannt gegeben, dass durch Ihren Beitritt zur Reichsarbeitsgemeinschaft der missionarischen und diakonischen Verbände die Stellung der Frauenhilfe eindeutig geklärt ist. Wir haben in dem Rundschreiben betont, dass die Arbeit in Richtung zur Bekenntniskirche hingetan wird, ein organisatorischer Anschluss oder eine Unterstellung unter die Bekenntniskirche nicht in Frage kommt." 1205

(609) "Die Führung der Verbände steht persönlich positiv zur bekennenden Kirche, ohne für die Verbände diese Erklärung abzugeben."

(610) "Der Deutsch-Evangelische Frauenbund bekennt sich zu Gott als dem Herrn der Zeiten. Er nimmt die nationale Erhebung, die wir erleben durften, mit tiefem Dank aus seiner Hand. Der Kirche verantwortlich zugeordnet, stellt der deutsch-Evangelische Frauenbund sich mit ihr freudig hinter die nationale Regierung."

(611) "Die neue nationale Bewegung, die unser Volk ergriffen hat, muss uns im Bund beschäftigen. Wir bejahen sie, aber wir können sie parteipolitisch nicht werten, sondern unsere Einstellung zu ihr ist die der deutsch empfindenden Frau."

(612) "...die andere, die Frau als Konsumentin angeht. Hier bewußt deutsch handeln, nicht theoretisch völkisch denken und praktisch dazu im Gegensatz handeln. Deutsch waren kaufen, nicht in undeutschen Geschäften kaufen. Für uns im DEF hat die frage zwei Seiten: wir dürfen nicht vergessen, daß wir als Christen zu entscheiden haben. Aber trotzdem haben wir wohl Verständnis für die Maßnahmen der Regierung, weil wir für deutsches Wesen eintreten. Auf deutsches Blut in den Familien halten, das gilt nicht nur für Vermischung mit jüdischem Blut, sondern für alle Vermischung mit Ausländern."

(613) " Wir sollen uns laut und deutlich zur Regierung bekennen, unsere Stellung soll nicht farblos sein, politisch. DEF ist im Grunde nationalpolitisch und hat die gleichen großen Ziele. Würden wir aber parteipolitisch uns entscheiden, würde der DEF in kurzer Zeit zerfallen. Wir gehören keiner wirtschaftspolitischenpartei an, nicht der deutschnationalen Partei oder einer anderen politischen Gruppe. "

(616) "Die Frau hat außerdem ihr eigens Geschlecht zu bewußten Frauentum heranzubilden und Frauenwille zu wecken und zu stärken"

(617) "Ein Mensch von großer geistiger Weite und Lebendigkeit, von gr0ßartiger Wahrhaftigkeit und Unbedingtheit ist mit ihr dahingegangen. Eine Führernatur. Sie war ein völlig souveräner Mensch, von Vornehmheit und Sauberkeit auch im Denken und im Ausdruck. Zugleich war dieser Mensch eine Frau von Charme und geistiger Anmut, von Fröhlichkeit und Wärme. Ihre das Mittelmaß überragende hohe und früher so schlanke Gestalt mit dem schmalen feine Kopf, blond und blauäugig, war eine Verkörperung nordischen Wesens."

(628) "dort, wo er euch lebendig ist, wo ihr fühlt. Nicht in nutzlosem, törichtem Streit von Dogmatik besessener Theologen, nicht in verstaubten alten Bibeln, sondern dort, wo ihr selber seid, in euch, in eurer Familie, in euren Kindern, Betet zu eurem Gott, der da droben wohnt, 
aber ruft ihn nicht an als euren katholischen Vater, als euren evangelischen Herren, als euren Bekenntnistgott oder als euren deutschen Christenvater, denn es ist nur einen Herrn, der über euch tront, und das ist unser Gott".

(629) "Aus dem Grund müssen Eingriffe von Parteistellen vermieden werden, jede persönliche Unstimmigkeit muss unterbunden werden. Das geschieht in sanktionierter Nebeneinander- Arbeit, die verbunden ist durch den Geist rechter Volksgemeinschaft, die den Boden des Christentums braucht. Ich bitte ausdrücklich über eine Verlautbarung, die klarstellt, dass evangelische Arbeit gewollt und geschützt ist. Sie wird geleistet von $2 \frac{1}{2}$ Millionen deutschen Frauen, von denen $90 \%$ Nationalsozialisten sind. Ich garantiere für die nationalsozialistische Führung des evangelisches Frauenwerks mit meiner Person."

(632) "Um ein organisches Werden und Wachsen des Deutschen Frauenwerkes gewährleisten zu können, halte ich es im Augenblick für dringend notwendig, daß sämtliche Neugründungen von Ortsgruppen und Neuaufnahmen in die im "Deutschen Frauenwerk" zusammengeschlossenen Frauenverbände bis zum 1. Januar 1935 unterbleiben. Während dieser Zeit wird es die Aufgabe aller Verbände sein, eine gründliche Überprüfung ihrer Organisation in Bezug auf Ordnung und Disziplin, sowie Eignung und Zuverlässigkeit der Führerinnen, entsprechend den großen Aufgaben, die vor uns liegen, vorzunehmen, die Zusammenarbeit untereinander zu einer kameradschaftlichen und insbesondere mit der NS-Frauenschaft zu einer noch besseren auszubauen. (...) Dieses Verbot gilt nicht für die NS-Frauenschaft und für Parteigliederungen, in denen Frauen organisiert sind".

(633) "Am 19. Oktober haben wir einmütig dem Herrn Reichsbischof unsere ernsten Sorgen und Nöte brieflich mitgeteilt. Eine Antwort darauf haben wir nicht erhalten. Seitdem besteht eine positive Verbindung zum Hernn Reichsbischof nicht mehr."

(640) "Unsere Verbände sind an an meine Weisungen gebunden als Führerin des Evangelischen Frauenwerkes. Als solche vertrete ich unsere Verbände im deutschen Frauewerk und gewährleiste die nationalsozialistische Ausrichtung unseres Werkes durch meine Parteimitgliedschaft."

(643) "Auf der anderen Seite hat die Arbeitsgemeinschaft es ausdrücklich abgelehnt, sich den Organen der bekennenden Kirche, also den Bruderräten oder der vorläufigen Kirchenleitung, zu unterstellen. Es ist daher auch für das Evangelische Frauenwerk niemals eine organisatorische Bindung nach dieser Seite hin eingetreten. Dabei konnte die Tatsache freilich nicht verschwiegen werden, daß die gesamte frei kirchliche Arbeit sich mit dem inneren Anliegen der Bekenntnisbewegung eins wußte. Nur wenn an dem Neubau einer Kirche mitgearbeitet wurde, die wirklich Kirche ist, und ihre Kraft allein aus dem Evangelium schöpft, kann auch der Volksgemeinschaft in der rechten Weise gedient werden".

(644) "Der einzige Referent für das kirchlich Frauenwerk ist jetzt Pastor Lic. Hermenau, der seit 14 Jahren hauptamtlich in der Frauenhilfsarbeit steht. (...) Mündlich und schriftlich betont er immer wieder, daß die Frauenhilfe eine kirchliche Frauenorganisation sein soll die kirchenpolitisch wirklich neutral, weder zu den DC noch zur Bekenntnisfront gehört, auch nicht zur Arbeitsgemeisnchaft missionarisch-diakonischer Verbände."

(647) "Dass Frau Scholtz-Klink nicht gerne mit mir arbeitete, hat sie mich wohl öfters fühlen lassen, seit Hermenau Auftreten antwortete sie mir nicht mehr schriftlich, aber weiterhin telefonisch durch ihre Vertreterin." 
(652) "Der Oberkirchenrat ist nicht in der Lage, Pfarrer Lic. Hermenau als Referent der D.E.K. für das Frauenwerk der D.E.K. anzuerkennen. Pfarrer Hermenau bietet keinerlei Gewähr dafür, daß die Arbeit des Frauenwerks der D.E.K. in wahrhaft evangelisch-kirchlichem, bekenntnisgemässem Geist vertreten oder getrieben wird.

Nach wie vor erblicken wir in Frau von V. Grone die rechtmäßige Reichsführerin des Ev. Frauenwerks. Sie besitzt nicht nur das Vertrauen aller in der "Arbeitsgemeinschaft der missionarischen und Diakonissen Werke und freien Verbände der Kirche" zusammengefassten ev. Frauenorganisationen, sondern hat als charaktervolle Führerin des Frauenwerks der D.E:K. sich besser bewährt als jeder der bisherigen "Beauftragten" der Reichskirchenregierung. "

(178) "er bedeutet, das Zerstören des Gemeindelebens, das Zerstören unserer Einheit und, was noch viel schlimmer ist, gegen den Willen unseres Führers und Reichskanzlers das Hereinziehen der NS Frauenschaft in den kirchlichen Kampf."

(654) "Ich wurde unbeirrt weiterarbeiten, solange ich etwas daran tun kann, daß das evangelische Frauenwerk ungehindert erhalten bleibt zum Dienst an Kirche und Volk, ich arbeite weiter, wenn ich mich getragen weiß von dem Vertrauen unserer evangelischen Verbände, unserer evangelischen Frauen."

(656) "Die Vorläufige Kirchen Leitung hat in ihrer Sitzung vom 7. März d. Js., zu der Frau von V. Grone und Herr Direktor Kunze vom Frauenwerk der deutschen Evangelischen Kirche zugezogen waren, sich mit der Frage befasst, was angesichts der vom Reichsbischof offenbar beabsichtigten Zerstörung des Frauenwerks der Deutschen Evangelischen Kirche geschehen könne. Der Reichsinnenminister hat sich geweigert mit Frau von V. Grone, der allein rechtmäßigen Reichsführerin des Frauenwerks künftig zu verhandeln und will nur noch mit einer vom Reichsbischof anerkannten Führung des Frauenwerks in Verbindung treten. El Frauenwerk de la Iglesia Protestante en Bayern, que depende del obispo regional de Bayern, (...). Das Frauenwerk der D.E.K., in Bayern, das sich dem Landesbischof in Bayern unterstelltete hat durch die Reichsfuhrerin des Evangelischen Frauenwerkes Frau von Grone wertvolle Forderung erfahren, hat bisher im vollen Vertrauen zu ihr gestanden und erkennt auch fernerhin nur Frau von Grone als rechtsmaßige Reichsfuhrerin des Frauenwerkes der D.E.K. an. Herr Pfarrer Hermenau, der nur als Referent des Frauenwerkes in der D.E.K. bestellt werden soll, bietet nicht die Gewähr dafür, daß diese Arbeit auf der Grundlage eines uneingeschrankten Vertrauens und in wirklich evang. kirchl. bekenntnismaßigem Geist getrieben wird, er wird daher als Referent und Fuhrer dieses Werkes abgelehnt." "

(657) "Wir haben erfreulicherweise die überwältigende Mehrzahl der evangelischen Frauen hinter uns und Frau von Grone. Aber wir müssen natürlich im Ernstfall mit einem ganz positiven Einstehen der Kirchenleitung für uns rechnen können, wenn das Schicksal vermeiden werden soll wie es die evangelischen Jugendverbände getroffen hat."

(661) "Die braunschweigische Kirche, deren Kirchenregierung kirchenpolitisch nicht mehr gebunden ist, und sich offen und auf Grund des lutheischen Bekenntnisses zum nationalsozialistischen Staat bekennt, sieht keine Veranlassung, die rein kirchenpolitischen Maßnahmen gegen die Frauenhilfen und gegen Frau v. Grone gut zu heißen. Es liegt m. E. kein Grund vor, Frau v. Grone, die nach wie vor die rechtmäßige Leiterin des Deutschen Evangelischen Frauenwerkes in ihrer Tätigkeit zu hindern." 
(184) "So treffen mich die Anschuldingungen persönlich, nicht in meinem kirchlichen Amt, sondern als Parteigenossin. (...) Dass ich die Beleidigungen auf mich persönlich bezog und nicht auf unser Werk, indem ich weitere Zusammenarbeit im Deutschen Frauenwerk für uns bejahte, wurde mir als Schwäche ausgelegt.

(664) "Es is niemand verborgen, dass wir heute deutlicher denn je die Eigenständigkeit der kirchlichen Arbeit vertreten müssen. Unsere innerkirchliche Bindung liegt in der Zugehörigkeit zur Arbeitsgemeinschaft der missionrischen und diakonischen Werke und Verbände."

(666) "Unsere Beziehungen zum Deutschen Frauenwerk bleiben unverändert. Wir tun alle Mitund Zusammenarbeit dort gern, wenn unsere konfessionelle Sonderstellung geachtet wird. Wir brachten unsere Opfer, weil wir als deutsche Frauen in der großen Gemeinschaft freudig mitbauen wollen innerhalb unseres nationalsozialistischen Staates, der beide konfessionelle Arbeitsgebiete seinerzeit unter Schutz stellte."

(667) "Wir wollen keine Pastorenkirche, die nur mit Gewalt regieren kann, -wir wollen eine starke und in der Kraft des Geistes geführte Reichskirche, die uns alle in deutschen Landen kraftvoll zusammeschliesst zum Segen für unser Volk und unseren Staat, für das Erneuerungswerk unseres Führers."

(669) "Am 16. März waren auf Grund vorausgegangener Vorbesprechungen die Referenten der Landeskirchen von Altpreussen, Hannover, Bayern, Württemberg, Baden, Sachsen mit den Vertreterinnen ihrer landeskirchlichen Frauenarbeit, sowie Vertreter und Vertreterinnen der großen Frauenverbände unter dem Vorsitz des Unterzeichneten im Gebäude der Kirchenkanzlei versammelt. Zweck der Aussprache war die Erarbeitung von Richtlinien für die kirchliche Ordnung des Frauenwerks der Deutschen Evangelischen Kirche.

(672) "Es handelte sich um eine doppelte, Stellung zu nehmen zu den Anschuldigungen, die in dem Parteigerichtsurteil gegen Frau von Grone und gegen die Evang. Kirche vor allem die bekennende Kirche erhoben wurden, ferner Klarheit zu schaffen über die Mißverständnisse, die zwischen Herrn Generalsuperintendenten Zoellner und Frau von Grone offenbar bestehen. Zu desem Zweck ist notwendig, daß auf Grund der vorliegenden Akten die Tätigkeit der Frau von Grone als Leiterin des Evang. Frauenwerks im Laufe der letzten Jahre lückenlos dargestellt wird."

(675) "Das Frauenwerk der Deutsch-evang. Kirche (DEK) schließt die kirchliche Frauenarbeit zusammen. Es steht in enger Verbindung mit dem Reichskirchenausschuß (RKA) als der derzeitigen Leitung der DEK. Das Frauenwerk in seinen Werken und Verbänden hat die gesammte kirchliche Frauenarbeit im Sinne der evang. Gemeinde wahrzunehnen. Der RKA. Nimmt das Frauenwerk in die fördernde Obhut der DEK. Der Vorsitzende des RKA., Gen. Superintendet D. Zöllner, tritt als Kurator in die Leitung des Frauenwerks ein".

(676) " Unklarheiten und Maßnahmen innerhalb der kirchlichen Frauenarbeit, die geeignet sind, Beunruhigung in die Reihen der N.S. Frauenschaft zu tragen, veranlassen mich, folgende Erklärung abzugeben: 
Die korporative Mitgliedschaft des Evangelischen Frauenwerks im Deutschen Frauenwerk ist mit dem heutigen Tage erloschen. Gleichzeitig stelle ich es jeder bisher nur korporativ durch das Evangelische Frauenwerk erfassten Frauen anheim, Die Einzelmitgliedschaft im Deutschen Frauenwerk zu erwerben. Damit wird dann jeder deutschen Frau anstelle der bisherigen korporativen (d.h. mehr oder minder anonymen Mitgliedschaft) durch namentliche Eintragung als Einzelmitglied die Möglichkeit gegeben, im Deutschen Frauenwerk ihre Bereitschaft zur Mitarbeit am Aufbau des Dritten Reiches unter Beweis zu stellen."

(677) "Wir bedauern diesen Schritt außerordentlich und geben unserer grossen Verwunderung Ausdruck, dass Sie sich nicht selbst vor dieser weittragenden Entscheidung mit uns in Verbindung gesetzt haben. (...) In der Geschichte der volkskirchlichen Arbeit der Deutschen Evangelischen Kirche nimmt seit langem die Frauen-und Mutterarbeit einen grossen und wichtigen Raum ein."

(678) "Lange vor der Erhebung wurde aus dem Gedankengut der lutherischen Reformation der evangelischen Frauen- und Mütterarbeit ein Arbeitsmaterial geschaffen, das die von uns allen erhoffte geschichtliche Begegnung des Evangeliums mit der nationalsozialistischen Weltanschauung in klarer Form aufzeigte."

(679)"Es ist nicht Schuld der evangelischen Frauen und Mütter, wenn sie in den Kirchenstreit hineingezogen werden konnte, wenn führende Frauen der evangelischen Frauenarbeit aus groBer Sorge und in tiefster Verantwortung für das eigentliche Anliegen frommer Frauen und Mütter Entscheidungen trafen, die vielleicht eine letzte Klarheit über die Bedeutung der lutherischen Reformation für den neuen Staat vermissen ließen. Aber wir müssen heute mit allem Ernst sagen, daß diese Abwege und Umwege der evangelischen Frauenarbeit weithin veranlasst sind durch Maßnahmen des deutschen Frauenwerks, die schlechterdings missverständlich wirken mussten. (...)

Da wir aber nicht nur vor der ganzen Deutschen Evangelischen Kirche, sondern auch vor dem ganzen deutschen Volk dafür verantwortlich sind, daß aus dieser Wendung der Dinge nicht neuer Unfriede und neue Unklarheit entstehen, und da wir nach wie vor entschlossen sind, Sie in Ihrer schweren Aufgabe, soweit an uns liegt zu unterstützen, stehen wir zu einer neuen persönlichen Verhandlung zur Verfügung. "

(681) Damit durch das Schreiben der Reichsfrauenführerin a das Evang. Frauenwerk . 23.11.36 keine unnötige Beunruhigung entsteht, weisen wir mit Nachdruck darauf hin, dass unser Volk den Dienst der Frauen und Mütter in Kirche und Gemeinde nicht entbehren kann. ) "Frauen holen sich Kraft und Weisung aus Gottes Wort. Frauen wollen zur Erneuerung der Kirche mithelfen. Frauen sind die Hüterinnen kirchlicher Sitte in den Gemeinden. Mütter pflegen und bewahren kirchlicher Sitte in Haus und Familie. Mütter wissen sich verantwortlich für das Heil ihrer Kinder. Frauen beten für Führer, Volk und Kirche. Wir rufen alle evangelischen Frauen zu solcher tätigen Mitarbeit im Frauenwerk der Deutschen Evangelischen Kirche auf. Wir werden es allezeit als unsere Pflicht ansehen, für diesen Dienst des Glaubens und der Liebe Raum zu schaffen."

(682) "Zu dem Satz Ihres Briefes (...) kann ich lediglich sagen, dass es für Nationalsozialisten eine Trennung von religiösen und völkischen Belangen nicht gibt, und dass es für uns eine Notwendigkeit ist, auch die kirchliche Führung mit dem Totalitätsanspruch des Nationalsozialismus in Einklang zu bringen." 
(683) "Ihren Brief vom 10. August habe ich erhalten, und ich muß Ihnen darauf erwidern, dass meine Ablehnung Frau von v. Grones darauf beruht, daß sie durch ihr Verhalten für mich als Parteigenossin in führender Stellung in einem Frauenverbände untragbar ist. Meine Einstellung hierin ist sachlich begründet. Ehe aber die Angelegenheit von massgebender Stelle aus geklärt ist, muß ich es ablehnen, auf Einzelheiten einzugeben."

(686) "Als Parteigenossen sei ihm aber die Entscheidung schon vorweg genommen, denn ein Parteigenosse könne nur hinter dem Mann stehen, den der Führer eingesetzt habe. Frau von Grone könne als Parteigenosssin nur ninter dem Reichsbischof stehen oder sie müsse aus der Partei austretetn. Dann könne sie stehen, wo sie wollen."

(687) "Frau von Grone ist Mitlglied der Partei, aber es fehlt ihr jeder Begriff einer Nationalsozialistin. Hierin liegt hauptsächlich der Kern der persönlichen Zwistigkeiten und der Unmöglichkeit gemeinsamer sachlicher Arbeit mit der Frau Scholtz-Klink und dem Deutschen Frauenwerk. Wenn auch zuzugeben ist, daß Frau von Grone eine äußerst schwere Aufgabe in die Hand gegeben ist und daß sie vielleicht subjektiv schuldlos und gedrängt von der Bekenntnissfront gehandelt hat, so bleibt doch der Vorwurf bestehen..., daß sie in keiner Weise nationalsozialistisch eingestellt ist und gehandelt hat; im Gegenteil, sie hat in das Evangelische Frauenwerk selbst und in ihre Beziehungen zum Deutschen Frauenwerk den kirchenpolitischen Streit bewußt hineingetragen .Somit hat Frau von Grone gegen eines der obersten Grundgesetze des Nationalsozialismus verstoßen, indem sie nicht nur nicht dazu beigetragen hat, wahre Volksgemeinschaft unter den deutschen Frauen zu fördern, sondern sie in erheblichem Maße zu schädigen."

(690) "Anfang des Jahres 1935 schickte die Reichsorganisationsleitung ein Rundschreiben an sämtliche vom deutschen Frauewerk betreuten Verbände mit der Bitte um Angabe über die ungefähre Mitgliederzahl, Parteizugehörigkeit ihrer Mitglieder usw.. Diese Anfragen wurden auch an das evangelische Frauenwerk und die ihm angeschlossenen Verbände weitergeleitet. Als Antwort darauf wies die angeschuldigte ihre Untergliederungen an, der NS-Frauenschaft zu antworten, dass das Evangelische Frauenwerk eine selbstständige Organisation der Kirche sei und ihr unterstünde."

(691) "Aus diesen ergibt sich insbesondere, dass gegen die rein organisatorische Massnahme der Mitgliederzählung von den Verbände des ev. Frauenwerks mit der tendenziosen Auslegung einer unstatthaften Einmischung in innerkirchliche Angelegenheiten und religiöse Selbständigkeit allgemeiner Widerstand geleistet wurde."

(692) "Durch diesen Schritt hat die Angeschuldigte offiziell den Boden der kirchenpolitischen Neutralität verlassen und unter den bisher von ihr geleiteten deutschen Frauen ungeheure Verwirrung angerichtet. (...) Die Angeschuldigte hat durch diese Politik nicht nur vermehrte Unruhe und Gewissenskonflikte unter c.a 2 Millionen deutscher Frauen getragen, sondern sie hat diese auch in bedauerlicherweise über die Stellung der NS- Frauenschaft und inbesondere der Partei selbst zu Religions- und Glaubensfragen bewusst irregeführt, um selbst ihre Machtstellung als Leiterin eiens 2 Millionenverbandes behaupten zu können."

(693) "Diese Klagen gehen dahin, dass vielfach die der Frauenhilfe angehörigen Frauen dem Nationalsozialismus verständnislos, mißtraurisch, wenn nicht gar ablehnend oder feindselig gegenüberstehen. Diese Haltung ist dort am stärkesten ausgeprägt, wo der Geistliche, der auf die örtliche Frauenhilfe naturgemäss einen besonderen Einfluss hat, seinerseits den Nationalsozialismus ablehnt oder offen bekämpf." 
(694) "Für uns ist der Befehl des Führers vom 21. März 33 zur Richtschnur gegeben: das die Konfessionen an den Grundfesten bauen sollten zur Festigung des christlichen Staats. Das galt uns als Auftrag des Nationalsozialismus in unsere evangelischen Arbeit."

(695) "Durch Herrn Landesbischof D. Meiser habe ich erfahren, daß der bisherige Spruch nicht endgültig und das Wiederaufnahmeverfahren möglich ist. Das freut mich sehr, weil damit auch Ihr Wunsch zur Rehabilietierung gegenüber den politischenStellen erfüllt werden kann. (...) auch ein Einspruch der Bischöfe bei der Partei würde in diesem Augenblick Ihnen kaum nützen sondern eher schaden."

(697) "Mein Handeln und seine Auswirkung ist überall recht verstanden worden, ich habe stets nicht allein als Christin in der evangelischen Arbeit, sondern als bewusste Nationalsozialistin meine Plicht zu tun versucht und mich bemüht das Misstrauen gegen evangelisch-kirchliche Verantwortung zu überwinden durch positive Zusammenarbeit."

(698) "Daher habe ich des öfteren schon keinen Zweifel darüber gelassen, daß ich Frau v. Grone als Leiterin des Evangelischen Frauenwerkes nicht mehr für tragbar halte. Sie hat durch ihre kirchenpolitische Parteinahme die Zersplitterung in dasselbe hineingetragen und es verhindert, daß ein sehr erheblicher Teil deutscher Frauen sich geschlossen in eine gemeinsame Arbeit des Deutschen Frauenwerkes einfügte. Darüberhinaus aber hat sie als Parteigenossin keine Pflichten des Gehorsams und der Unterordnung anerkannt, vielmehr ihre Zugehörigkeit zur Partei in der Hauptsache benutz, für ihre eigenbrötlerischen Zwecke die Autorität der Partei zu benutzen. Während sie mehrfach der Leiterin des Deutschen Frauenwerkes loyale Gefolgschaft gelobte, hat sie gleichzeitig in offiziellen Äußerungen und Anordnungen das Gegenteil getan. Sie hat dadurch die Verwirrung in den Evangelischen Frauenkreisen vermehrt und-bewußt oder unbewußt- dazu beigetragen, die Gegensätze sowohl innerhalb der Deutschen Evangelischen Kirche wie dieser als Ganzes zum Nationalsozialismus zu vertiefen."

(699) "Die evangelischen Geistlichen gehören in ihrer Mehrzahl zu den erbittertsten und durch ihren Einfluss auf wertvollste Bevölkerungsteile, insbesondere unter den Frauen, zu den gefährlichsten Gegnern der Bewegung. Es fällt schwer, zu glauben, dass die tapfere und kluge, mit allen inneren und äusseren Vorzügen nordischer Rasse ausgestattene Pgn. von Grone es nicht empfindet, daß sie mit ihrer Einstellung zur nationalsozialistischen Führung des Deutschen Frauenwerks die Geschäfte der Gegner der Bewegung besorgt."

(704) "An keiner Stelle unseres Lebens, auch nicht in Haus und Familie, können wir Frauen uns absperren von dem flutenden Leben der Zeit. Die christliche Mutter, die christliche Schwester steht auf entscheidendem Posten. Die Schulkinder,die grossen Söhne und Töchter, die von der Arbeit kommen, der Gatte: sie alle tragen die grossen Fragen unmittelbar ins Haus. Wenn es oft auch sehr schwer ist, dort zu stehen, wo in der engen Gemeinschaft der Familie die Geister aufeinanderstossen, so ist der Mutter doch damit eine grosse Möglichkeit, ihren Glauben zu bezeugen, gegeben."

(708) "Ist nun nicht in einer Zeit, in der Christentum in schwerer Bedrängnis steht, gerade der Weg über die Mütter ganz besonders wichtig? Sie bestimmt den Geist des Hauses, sie bestärkt den Mann in der treue zum Evangelium durch ihre eigene Standhaftigkeit, von ihr hängt es letztlich ab, ob die Kinder zu rechten Christen erzogen werden." 
(712) "Die Mütterschulung wird als Aufgabengebiet dem "Deutschen Frauenwerk" zugeteilt. Mütterschulungskurse dürfen seitens der Evangelischen Frauenhilfe nicht mehr durchgeführt werden. Die laufenden Kurse sind spätestens bis Ende März zu beenden und auch nicht über die früher vorgesehene Zeit hinaus auszudehnen. Innerhalb der Mütterschulungskurse behält die Evangelische Frauenhilfe den religiösen Einfluss."

(715) "Das Haupthindernis, warum diese Landeskirchen noch in der Frauenhilfsarbeit fehlten, lag in der Stellungnahme der "Vereinigung Ev. Frauenverbände Deutschlands". Diese wurde als Dachorganisation kirchliche Frauenvereine 1933 gegründet und stand unter Führung von Frau M. von Tiling. Der große Block der Ev. Frauenhilfe gehörte wohl zu diesem Spitzen Verband. Man erkannte da die für die Kirche prinzipielle Bedeutung der Ev. Frauenhilfe nicht ausreichend. Man wehrte sich gegen die Ausbreitung auf weitere Landeskirchen. So ist es zu verstehen, dass diese ev. Dachorganisation der Frauenvereine auch nicht den an sie herangetretene Mütterdienstplan verstand, wertete und aufnahm."

(715) "Wir erhielten Kenntnis von einem Briefe, den Frau Lönnies am 17. Oktober unter der Firma "Mutter und Volk" Verlagsgesellschaft m.b.H. an die "Mütterdienstleiterinnen und Vertrauensfrauen des ev. Mütterdienstes im Berliner Frauenwerk der Deutschen Evangelischen Kirche" gerichtet hat und in dem sie im Auftrag der Reichskirchenregierung" Mitteilungen macht. Damit tritt sie in der Öffentlichkeit als Beauftragte der Reichskirchenregierung auf und handelt über unsere Führung hinweg in Arbeiten hinein die unserer Führung unterstehen. Frau Lönnies ist im Frühjahr d. Js. -wie dort bekannt sein muß - aus unserer Arbeit auf ihren Antrag ausgeschieden, weil Parteistellen die Zusammenarbeit mit uns ablehnten, so lange Fraue Lönnies in unserm Namen redend und handelnd auftrat. Es ist ein unmöglicher Zustand, daß eine Persönlichkeit, die aus diesen Gründen bei uns ausscheiden, mußte, jetzt im Auftrag der Reichskirchenregierung entscheidend in unsere Arbeit eingreifen kann."

(721) "In den Dank, dessen wir uns allezeit Frau Lönnies für ihre langjährige, opferwillige Arbeit in der Frauenhilfe schuldig wissen, mischt sich das Gefühl schmerzlichen Bedauerns, dass sie mit ihrer Arbeit Wege eingeschlagen hat, die eine endgültige Trennung zwischen ihr und ihrer Verlagsgesellschaft und uns aus der Verantwortung gegenüber Kirche und Volk notwendig machen."

(722) "In diesem Zusammenhang wirkt die Angelegenheit des Verlages "Mutter und Volk" besonders erschwerend. Gott sei Dank ist ja das Evangelische Frauenwerk in keiner Weise darin verwickelt, aber es ist natürlich sehr schwierig gerade jetzt über die Weiterführung eines gemeinsames Blattes mit dem deutschen Frauenwerk zu verhandeln, andrerseits ist wie Sie wissen "Mutter und Volk" die einzige laufende Einnahme, die wir überhaupt haben."

(728) "Unter diesen Umständen ist es die Aufgabe der Leitung der DEK., die Belange der kirchlichen Zeitschrift "Mutter und Volk" und ihres Verlages zu wahren. Wir sind entschlossen, mit allen Mitteln den Rechtszustand wieder zustellen und werden den Hern Reichs- und Preussischen Minister für die kirchlichen Angelegeheiten von unserer Stellungnahme unterrichten."

(730) "Dabei wurde insbesondere von Süddeutschland festgesttelt, daß wir bedeutend weniger gefährdert wären -ich darf dies hier doch ganz offen sagen- wenn, nachdem es sich doch um ein Frauenwerk handelt, auch die norddeutsche Frauenhilfe durch Frauen und nicht durch Herren Geistliche vertreten wäre. Die Pastoren sind nämlich durch ihre Bindung an die Bruderräte oder Kirchenausschüsse viel weniger in der Lage den mittleren Weg zu gehen, der eben heute von einer großen Reichsorganisation gefunden werden muß. Für Frauen ist es viel leichter." 
(737) "Lic. Meta Eyl und ich (Hewig Winnecke) als verantwortliche Schriftleiterin bemühen uns, die von Paula Müller Otfried begründete und in jahrzehntelanger Arbeit ausgebaute Evangelische Zeitung so zu gestalten daß sie den heutigen Aufgaben unseres Bundes entspricht und zugleich den die Gestaltung einer Zeitschrift heute genau regelnden Anforderungen der Reichspressekammer. "

(740) "'"Zu dem bevorstehenden, für die Zukunft des deutschen Volkes entscheidenden Ereignis der Reichspräsidentenwahl kann der Deutsch-Evangelische Frauenbund keine Stellung nehmen. Er bittet aber seiner Mitglieder, daß sie als verantwortungsbewußte Frauen ihre Entschließungen gründlich überprüfen, sich durch seine anderen als sachliche Gesichtspunkte beeinflussen und nur von dem Gedanken leiten lassen, an Deutschlands Zukunft mit bauen zu helfen."

(741) "Die Frau ist nicht nach ihrer Persönlichkeit zu werten, nicht nach ihren geistigen und seelichen Eigenschaften, unter denen auch nach unserer Meinung die Mütterlicheit an erster Stelle stehen kann; hier vertritt man die alleinige Bewertung der Frau wegen der Mutterschaft, wegen des Beitrages, den sie zu der Bevölkerungszahl geleistet hat. Diese Einstellung erniedrigt die mütterliche genau so wie die intellektuelle Frau; sie widerspricht schroff unserer Auffassung von der Wertung und sozialen Einordnung des Menschen nach seinem Persönlichkeitswert."

(744) "Wir Nationalsozialisten wissen, daß wir im dritten Reich als Frauen auch als Persönlichkeiten gewertet werden, nicht nur nach unserer biologischen Aufgabe. Die hohen Ziele und Bestrebungen der Bewegung weißen immer wieder Weg und Richtung auch für die Erneuerung und Widergeburt der deutschen Frau. So steht der Nationalsozialismus auf dem Boden einer recht verstandene Frauenbewegung, er kämpft für das Nationale und für das Christentum. In keiner Weise widerspricht er den Zielen unseres Bundes. "

(745) "Es is mir nicht leicht geworden, diese Zeilen zu schreiben. Am liebsten wäre mir, ich könnte sachlich widerlegt werden. Fühle ich mich doch, was die vaterländlische Gesinnung betrifft, mi de NS. verbunden."

(747) "Die Frau, wie Gott sie will, Ihr Erzogen sei für die mütterliche Aufgaben im Volk und Staat. Sagt doch L. Otto-Peters die Begründerin der deutschen Frauenbewegung, schon Mitte des vorigen Jahrhunderts: "Alles, was wir von der Gegenwart fordern und von der Zukunft hoffen, fordern wir nicht in der törichten Voraussetzung, es bestehe kein Unterschied zwischen Frauen und Männer, nicht allein physisch, sondern auch psychisch, noch viel weniger fordern wir und hoffen wir es, damit das Weib die ihm endlich gegeben Freiheit gebrauche, sich der Familie und ihren Pflichten zu entziehen, sondern vielmehr um dieselben um so reiner und treuer üben zu können."

(748) "Was können wir tun?. Wir wollen doch nicht nur flagen oder gar anflagen. Nichts führ sicherer zur Verzweiflung als untätiges Bussehen und Warten, ob ein schweres Geschid sich vollende oder noch einmal abgewendet werden könne."

(754) "Der 30. Januar hat einen volligen Umschwung gebracht. Der Jubel der Begeisterung, der an jenem Abend dem Reichspresidenten aus einer überwaltigend großen Volksmenge entgegentönte, brachte das zum Ausdruck, was ein großer Teil des deutschen Volkes fühlt und hofft".

(757) "Dennoch prägt sich darin die Tatsache aus, daß das Wahlrecht noch längst nicht allen Frauen zur Selbstverständlichkeit geworden ist, denn sonst wäre die starke Anhängerschaft, die der Nationalsozialismus gewonnen hat, nicht zu verstehen." 
(758) "Eine Wende ist da, die unserer Arbeit neue Hoffnung, aber auch neuen Antrieb geben muß. Unsere Seelen schwangen mit, als in Potsdam die Kirchenglocken die nationale Wiedergeburt des geliebten Vaterlandes einläuten, als die alte stolze Fahne wieder zu Ehren kam. Heute wetteifern die Frauenvereine, sich einzureihen in die Völkischen nationalen Reihen. Wir empfinden Dankbarkeit, daß wir eingeschlossen sind in eine große bejahende Strömung, die Rettung vor dem drohenden Bolschewismus brachte."

(761) "Die Voreingenommenheit gegen den jüdischen Menschen macht uns unwahrhaftig gegen den objektiven Sachverhalt des alten Testaments."

(762) "Die Furcht vor dem "fremden" wird zur Manie. Wir sind im Begriff zu verarmen. Wir riskieren vor Furcht nicht mehr, etwas "Fremdes" uns eigenständig anzueignen, wie es unsere Väter taten, die auf Grund ihres germanischen Blutes unter mancherlei geistigen Schicksalen zum vielfältigen Reichtum deutschen wurden. "

(763) "Das Jahr 1934 ist für den Deutsch Evangelischen Frauenbund von Bedeutung. Es leitete einen neuen Abschnitt in der Geschichte des Bundes ein. Die erste Epoche des DeutschEvangelischen Frauenbundes ist endgültig abgeschlossen. Erst nachdem durch die NovemberRevolution die Stellung der Frau verschoben wurde, leider erst infolge des stattlichen Vorgehens. Das ist evangelischen-kirchlichen Frauen oft recht schwer gewesen. Als ich im Februar den Vorsitz an Lic. Eyl gab hatte ich mir vorbehalten, einstweilen ncoh die Schriftleitung der Evangelsichen Frauenzeitung fortzuführen ... aber. Die Januar Nummer wird die letzte von mir verantwortlich gezeichnete Zeitung des Deutsch Evangelischen Frauenbundes sein."

(765) "Die Frau, die weder individualistisches Einzelwesen ist noch bloß biologisch zu bewertendes Gemeinschaftswesen, ist nach der Bibel die von Gott gerufene, die ihm Antwort zu geben hat, und die von ihm ihre Aufgabe in der Welt und in ihrem Stand empfängt."

(766) "Sie hat vollgültigen Personenwert wie der Mann, d. h. nicht Persönlichkeit sein im modernen Sinn, sondern Gott gegenübergestellt und ihm verantwortlich sein. !Person ist nicht, wer sich selbst erfaßt und als ein Ich sich selbst andern gegenüberstellt. Die Biblel sieht den Menschen nicht als einen, der sich so in der Abgrenzung selbst erfaßt und über sich verfügt, sondern als einen, der von Gott erfaßt und mit Namen gerufen wird!."

(769) "Aber Gott ruft jeden doch auf besondere Weise, er ruft die Frau in der Bestimmung durch ihr Geschlecht, und gerade in de Zeit des alten Bundes ruft er sie durch ihre Mutterschaft, durch die sie Anteil Bekommt an den Verheißungen ihres Volkes. Der Jacobskampf im Leben der Frau von damals wird zum Gebet um das Kind, in der Geburt erlebt sie vor allem die Gnade und hilfe ihres Gottes, wenn auch einzelne Frauen zu besonderen prophetischen Ämtern berufen werden."

(771) "Eine neue germanische Frauenbewegung behauptet, daß das Christentums aus orientalischen-semitischen Selentume stammend, die Frau herabgewürdigt und den nordgermanischen Völkern die orientalische Auffassung vom Untertan-Sein der Frau gebracht habe; nur aus nordlichen Geist und Blut unter loslösung von allen biblischen Gedanken könne die Frau zu sich selbst und zu ihrer Aufgabe als Kamaradin des Mannes und Mutter des Volkes zurückfinden."

(773) "Der Weg der Maria, der ersten Frau des neuen Bundes, die als Mutter des Heilands eine ganz besondere Berufung hat, ist der Weg des Gehorsams von dem Wor gläubiger Bereitschaft an." 
(774) "'"aber durch den Riß zwischen Gott un der gefallenen Welt ist das menschliche Wesen gebrochen, es gibt kein schöpfungsgemäßes Verhältnis zwischen Mann und Weib mehr, sondern die Dämonien der Herrschaft einerseits un der Verlockung und Erniedrigung andrerseits bedrohen für immer dies Gebiet."

(775) "aber das Weibesschicksal, die Abhängikkeit vom andern, die in ihrem Gefährtinnen und Mutterschicksal beschlossen ist, ist doch wohl nicht bloß von dem Geschtspunkt des Fluches aus zu sehen. Bei aller Gefahr, daß das Verlangentragen nach dem Mann zu einer unwürdigen Abhängigkeit und Einstellung auf ihn führt, ist das Existieren vom andern her, nicht aus dem eigenen Mittelpunkt doch auch positiv zu sehen als diebesondere Art, die Gott der Frau gegeben hat, und durch die er sie in seinen Dienst nimmt."

(776) "In diesen Gemeinschaften ist der Frau nicht durch ihr eigenes Verdienst, sondern als Auftrag Gottes in ihrer besonderen Geschlechtseigenart eine hohe bindende Kraft gegeben.(...) Trotz des Risses zwischen Gott und Welt nimmt Gott die Frau in ihrer besonderen Eigenart, dem "Sehen und Sorgen für andere" in einen Dienst, der schwer und beglückend zugleich ist, und in dem die Existenz vom andern her möglich."

(777) "Die Welt steht in Beziehung auf Christus, ob sie vweß oder nicht. Diese Beziehung der Wel auf Christus wird konkret in bestimmten Mandaten Gottes in der Welt. Die schrift nennt vier solcher Mandate: Die Arbeit, die Ehe, Die Obriegkeit, die Kirche."

(778) "Die Bibel selber ist das bekenntnis der Kirche des Evangeliums und alle in der Geschichte formulierten Bekenntnisse sind Umkehr und Heimkehr aus zeitlichen -------- in die Bibel selbst; sind kristallisierte Zusammenfssung der entscheidenden biblischen Botschaft, sind Leitfaden fur das Grundverstandis der Bibel; sind selber nichts ohne die dahinterstehende fulle der heiligen Schrift, aus der sie kommen und zu der sie hinfuhren wollen. Darum gibt es in der evangelischen Kirche kein wahres Bekennen, wo nicht die Bibel selbst erweckt wird."

(781) "Der Mann steht seinem Wesen nach im Zeichen der Selbstherrlichkeit, während das Zeichen der Frau das Hinnehmen und Empfangen, das Erleiden ist."

(782) "Maria darf nicht als neue Eva Christus als dem neuen Adam gleichgestellt werden, als wäre durch ihren Gehorsam der Ungehorsam Evas aufgewogen worden. Maria ist nicht Miterlöserin neben Christus, sondern ist selbst Glied der Gemeinde der Erlösten. Sie ist Gegenpol zu Eva durch die große Tat, die Gott an ihr geschehen läßt. So wird sie Werkzeug der Erlösung,"

(783) "Die erste Frau der Bibel, Eva, wird gezeigt in ihrem Urbild, Gefährtin des Mannes zu sein auf gleicher Stufe, ihm in Freiheit anzugehören vor Gottes Augen, und in dem Fluch nach dem Sündenfall, der geschlechtlichen Abhängigkeit vom Mann, durch die ihr Personenwert immer mehr verdeckt wird, was sich in der sozialen Lage der Frau in verschieden Zeiten und Kulturen widerspiegelt."

(787) "Die Mutter gibt das All-Sein, die Mutter gibt sich selbst an alles, was ihrer Liebe, ihrer Fürsorge, ihrer Hilfe bedarf. Sie sieht das einzelne, sei es auch unscheinbar, klein und schwach, immer als Zeit des All-Seins. Die mütterliche Frau -verheiratet oder ledig- hat in dieser Eigenart die Quelle für ihre Aufopferung an die Arbeit." 
(788) "Wo wirklich "Kultur" geschaffen wird, wo Sitte entsteht und die flütende Kräfte des Lebens vom Chaos zum Kosmos bindet, da geschieht "Geschichte" durch das Werk der Frau. Ja Männer machen die Geschichte- aber sind nicht Frauen die eigentlichen Trägerinnen des Lebens?."

(794) "In jeder unverbildenten Frau lebt der Wunsch nach eigenen Kinde; und die Liebe und Fürsorge zu jedem noch nicht geborenen oder auch nur möglichen Leben ist so tief und unlösbar in ihrem innersten Wesen verandert (...) Es ist eine Schicht im weiblichen Menschen, zu der sich niemals mit Verstand und Logik Zutritt verschaffen kann, sondern höchstens mit behutsamen Nachgehen, mit dem Taftsinn der Seele."

(796) "Die Fragen unsere Haltung im evangelischen Frauenwerke den kirchlichen Verhältnissen gegenüber sind brennend geworden. Uno doch möchte ich immer wieder betonen: Die Entscheidung, wo wir kirchenpolitisch hengehören, muss eine rein persönliche Entscheidung bleiben, wenn es im Aufbau der Kirche von wirklich Wert sei soll. Ein Verbandschluss darf nicht indieser Richtung gefasst werden. Wir haben im letzten Jahr, besonders im letzten Sommer vor einer ähnlichen Situation wie jetzt, rein formal gesehen, gestanden, und haben trotz dem Druck, der z.B. durch das Verlangen 75\% Deutscher Christen in der Führung zu haben, unseren Kurs gehalten, völlig kirchenunpolitisch zu bleiben."

(798) "Die Obrigkeit der Zucht unseres Volkes dienen will, ist für unserenn glauben eine durch Gottes Gebot gesetzte und begrentzte Ordnung, innerhalb dener der deutsche evangelische Mensch, das Gesetz Christi zu erfüllen hat in der ungebeugten Freiheit gestaltender und bauender Liebe."

(799) "Der Führer spricht nicht, er führt, er zeigt, er erzieht. Er führt nur den folgsamen, den Starken und Willigen."

(800) "Der Ruf vom Ich zum Wir ruft die Frau hinein in den Lebensraum ihres Volkes. Deutsch und evangelisch gehören hier eng zusammen. Denn unser evangelisches Bekenntnis ist das Bekenntnis der Deutschen Reformation, (...). "

(278) Der Christ, der um den Glauben an den Herrn aller Geschichte weiß, wird sagen. die wird als Fügung Gottes anzunehmen haben." (...) "Sicher ist, daß sie sich bis in die feinsten Verälterungen unseres gemeinsamen und unseres einzelnen Daseins verfolgen lassen, die Grundlage unserer täglichen Existenz bestimmen.."

(801) "'Das ist unüberhörbare Weise im politischen Handel seit 1933 geschehen und geschieht jetzt im Kriege. In der Härte dieses menschlichen Rufes verbigt sich eine Barmherzigkeit des Herrn der Geschichte. Es ergebt noch einmal die Frage an die Nation und jeden einzelnen, ob sie die Anerkennung der Voraussetzungen unserer Geschichte vollziehen wollen oder nicht, ob sie die Verantwortung dafür ergreifen und leben wollen oder nicht."

(803) "Es ist dem Volk der europäischen Mitte am wenigsten erlaubt, kampflos und sicher zu leben. Es befindet sich jederzeit in der Lage einer mobilierten Festung. Will es nicht Tummelplatz fremder Völker sein, will es das sein, was es nach geschichtlicher Fügung sein soll, so schützen allein Wehrgeist und Wehrkraft. Es ist naturgegeben, daß das Volk der Mitte, so zusammegedrängt, so an Lebensraum ungefästigt, so ohne eigenständigen Einsatzraum seiner gewaltigen inneren Kräfte die Furcht seiner Nachbarn ist, (...)." 
(804) "Der Ursprung von Volk aber liegt in Gott, weil es Gottes Wille ist daß Völker sind, denn sonst wären sie nicht. (...) Unser Volk können wir uns nicht wählen. Es ist durch Gottes unersfrohlichen Willen voraus bestimmt Deutscher zu sein, oder Chinese, oder Franzose."

(805) "Dem Christen in Deutschland, der in der gleichzeitigen Beiwährung von geschichtlicher Verantwortung und christlichem Glauben steht, dem die Spannung von Evangelium und Geschichte eindeutig wie selten auf die Schultern gelegt ist, ist eine Sachliche bemühung um die geschichtlichen und politischen Zusammehänge besonders nötig. " (...) Gerade wo Politik miteinander in Gegensatz zu geraten scheinen, hat der Christ beide mit seiner Liebe zu umspannen und um Lösung zu ringen."

(806) "Die evangelische Kirche ist heute gefährdet, wenn sie sich nicht Ernst des Problems der Geschichte wieder annimmt und nicht eine wirkliche innerweltliche christliche Gesichtsauffassung erarbeitet. Die kirchliche Mentalität schwankt heute heute zwischen einer kelinbürgelichen Flucht vor allem Geschichtlichen und einer rein endzeitlichen Schau der Geschichte als Flucht aus der Gegenwart."

(807) "Hier liegt gerade für uns deutsch-evangelischen Frauen eine ganz große Aufgabe, deren wir uns voll bewußt sein müssen. Es ist eine wunderschöne Aufgabe, ja eine uns von Gott gegebene Aufgabe, gerade jetzt in schwerster Zeit der Sorge, der Not, der Gefahr zu zeigen, woher wir die Kraft schöpfen zum freudigen Durchhalten, zum Mut machen, zur helfenden Liebe, zum -wenn es sein muß- getroften Leidtragen. (...) Wir deutsch-evangelischen Frauen wollen in der Heimat "Frauen an der Front sein".

(810) "Es greift am stärkesten in das Schiksal des Einzelmenschen ein, sieh ihn als Glied seiner Volksgemeinschaft die er nicht schädigen darf duch erbkranke."

(812) "Die arische Frage hat jedoch noch eine andere Seite. Wir werden häufig gefragt, ob die Mitglieder nicht arischer Abstammung bei uns bleiben können. Für uns kommt es darauf an, ob unsere Satzung erfüllt wird. Sie besatz daß jede Frau evangelischen Bekenntnisses Mitglied des Bundes werden kann. Hierauf kommt es für uns an; nur hiernach haben wir zu fragen. Das Kenntnis zum Evangelium ist für uns maßgebend."

(813) "Warum ist die Lehre vom Übermenschen so populär geworden und findet immer noch Widerhall? (...) so wissen wir aus dem biblischen Zusammenhang, daß auch ein solcher nie aufhört, ein Mensch in des Wortes Vollsinn zu sein, geschaffen von Gott zu seinem Ebenbilde."

(820) "Als Abgeordnete beschäftigte mich der konservative Neubau unseres Denkens in Bezug auf die Erziehungsfrage, die Sexualfragen (Ehe und Familie) und in Bezug auf die Fragen des Staates."

(822) "Es wäre höchste Gefahr für den Bestand der Kirche selbst, wenn sie anfinge, politische Wahlen zu beeinflussen und noch dazu, wenn sie es versuchen würde in einer Richtung, die dem nationalen Volksempfinden widerspricht!. (...) Sollte herauskommen das Sie beteiligt sind bei irgend solch einer "Instruktion" für die Pfarrer, so wäre alles Zutrauen der konservativen Reichten, der Stahlhelmer und Nazis zu Ihnen endgültig dahin."

(823) "Wenn man in Deutschland etwas erreichen will, muss man sich als "Nationalsozalistist" ausgeben, und das hatte sie eben auch getan, und so habe ma ihr die Reise bezahlt, und so sei sie nach Siebenbürge gekommen." 
(824) "Jedes Volk, welches gesund ist und einen gesunden Staat hat, bringt aus sich selbst eine führende Schicht hervor, die die Verantwortung für das ganze Volk trägt. In Zeiten des Individualismus zerbricht notwendig die führende Schicht. Der Weimarer Staat hat dies Zerbrechen der Schicht der Führenden weder gesehen, noch die Notwendigkeit einer führenden Schicht anerkannt. Heute steht die Neubildung einer führenden Schicht im Vordergrund des Interesses des Staates, vor allem des Führers. Es ist heute die Frage, ob unser Volk wieder eine führende Schicht hervorbringen kann; hier liegt die Verantwortung auch der evangelischen Frauen. "

(828) "Die Frau ist von ihrem Leibe her -stärker als der Mann - der nach ihrem besonderen Gesetz sich in ihrer Leiblichkeit auswirkenden Natur unterworfen. Diese Naturnahe und Naturverbundenheit wirkt sich aus in der Seele der Frau wie in ihrem geistigen Sein: Sie ist nicht nur mit ihrem Leibe, sondern mit ihrem Gesamtsein -auf Grund jener beständigen Wechselwirkung zwischen Leib und Seele wie zwischen Seele und Geist - ihrem "Geschlecht verhaftet" als der Mann dem seinen."

(829) "Bein dem Manne gibt es jenes Verhaftetsein an eine in ihm gesetzmäßig wirkende Natura so nicht, darum auch nicht jedes nahe Zusammegeschossen und Verbundensein seines ganzen Wesens nach Leib, Seele und Geist zur Einheit. Von da her ist auch sein Ich-bewußtsein von anderer Art als das der Frau. Nan kann darum voraussetzen, daß auch sein Wissen um sein Selbstsein sich von dem der Frau unterschiedet."

(830) "Durch den Sündenfall erfährt das schöpfungsmäßig gegeben Verhältnis der Geschlechter zu einander eine Veränderung. Die in der ganzen Art seiner Existenz angelegte "Führung" des Mannes in den äußeren Dingen des Lebens wandelt sich in ein Bestreben, die Frau zu "beherrschen".

(832) "Die innere Einheit ist für die Frau das Natürliche, die Aufhebung der Zerspaltenheit ist für den Mann etwas zu Erstrebendes. Dem Manne ist anderseits die größere Sicherheit des äuBeren Seins natürlich, während für die ihres Zentrums das zu Erstrebende."

(833) "Der in der Unterwerfung unter Gott seiner selbst mächtig gewordene, in innerer Harmonie lebende Mann braucht nun nicht mehr äußerlich nach Herrschaft über die Frau zu streben, er wird durch die Entfaltung seiner eigenen Männlichkeit von selbst der Führende. Die ihrer selbst mächtige Frau verliert sich nicht mehr an den Mann, sondern bleibt sich ihres Eigenwertes auch in der verantwortlichen Gebundenheit an den Mann bewusst. Weil sie die Stillegung des Schwerpunktes ihres Seins gefunden hat, ist sie frei in Entfaltung ihrer Anlagen, das Gemeinschaftsverhältnis zwischen den Menschen zu gestalten."

(834) "Hier bin ich nicht mir verantwortlich für mein Selbst. Sondern hier bin ich dem Andern verantwortlich für mich selbst. Das ist beide Male ein völlig anderer Begriff des Selbst. Es sind schon sprachlich zwei verschiedene Worte: jenes Selbst ist Neutrum, ist sachlich Geschlechts; das andere ist männlich oder weiblich."

(835) "Für beide Geschlechter ist eine Rückkehr zur schöpfungsmässigen Einheit ihres Seins nur möglich durch eine Rückkehr zu Gott, dem Schöpfer. Zwar kann der Mann auch ohne die Bezogenheit seines ganzen Lebens auf Gott Seele haben, aber kommt dann dadurch nicht zur Einheit seines Seins und gelangt nicht zu seiner Männlichkeit. Ebenso kann die Frau ohne Gott ihr geistiges Leben ausbilden, aber auch sie wird dadurch nicht zu gottgewollter Harmonie und Ruhe kommen und nicht zur Vollerfüllung ihres Frauentums. 
(837) "Wir begriffen: Der Idealismus ist zerbrochen, des Menschen Wirklichkeit ist, daß er grundsätzlich unfrei, gebunden ist. Wir verstanden was Autorität des Staates sein müßte, autoritäre Führung, Gebundenheit in der Volksgemeinschaft. Das alles aber sind Grundbegriffe des Nationalsozialismus."

(838) "Wir brauchen nicht beiseite zu stehen, wir dürfen selber an Gegenwart und Zukunft mitbauen, wir dürfen als Mütter und mütterliche Frauen mitsorgen, mitschaffen für ein Deutschland, das unseren Kindern, das der kommenden Reihe der Generationen, - die wir Frauen von Natur nun einmal immer im Auge haben -, Heimat sein und bleiben soll; für ein Deutschland, das seinen geschichtlichen Auftrag in der Welt erfüllt."'"

(839) " Man denkt mit Schrecken an die Tage der Frauenemanzipation als einer volksfremden, im Wollen, Ehrgeiz, und Handeln undisziplinierten Bewegung, die alles spezifisch Weibliche verleugnete, den Willen zur Mutterschaft um einer intellektuellen Wertschätzung willen über Bord warf, und mit der Schaffung eines unweiblichen Frauentypus ein großes Unheil über Deutschland heraufbeschwor."

(842) "Nun ist es aber nachgerade zur Binsenwahrheit geworden, daß die Wendung des Jahres 1933 die Stellung des christlichen Glaubens und er christlichen Kirchen in unserm Volk grundlegend verändert hat, und die Frage bewegt noch immer viele der ernstesten Christen, ob das Ja zu dieser Wendung so einfach gegeben werden kann. So bleibt es uns nicht erspart, immer von neuem nach dem Sinn dessen zu fragen, was an uns und um uns geschehen ist, soweit es die Stellung der Kirche berührt. Wir werden von der Tatsache ausgehen müssen, daß der "christliche Staat" in Deutschland mit dem Jahre 1933 endgültig zu Grabe getragen worden ist." (...)

(843) "Das Dritte Reich der deutschen jedenfalls ist eindeutig ein völkischer Staat. Das heißt, daß das Volk als biologische und geschichtliche Größe die Grundlage darstellt, auf der es sich erhebt. Von ihm leitet es seinem Auftrag her. Seinem Schutz, ja mehr, seinem Wachstum und seiner Entfaltung auf allen Lebensgebieten will es dienen. Von daher ergibt sich folgerichtig die Stellung, die der nationalsozialistische Staat zu der christlichen Religion und den christlichen Kirchen einnimmt."

(844) "Was heute von uns gefordert ist, ist vielmehr dies, daß wir entschlossen und mit dem ganzen Einsatz unserer Kraft in der politischen Ordnung, die der nationalsozialistischer Staat uns zuweist, darum kämpfen, daß dieser Staat sich nun auch wirklich als Herrschaft erfaßt und durchsetzt, damit er so die zerrüttete Ordnung unseres Volkslebens neubegründen imstande ist. Beugen wir uns dieser Forderung, dann werden wir uns allerdings innerhalb dieser politischen Ordnung mit derselben Entschiedenheit dafür einzusetzen haben, daß der Staat der Kirche nun auch ihrerseits die Freiheit gibt, ihren Auftrag am Volk dem Gebot gemäß auszurichten."

(845) "Die Aufgabe, wie sich Herz und Intellekt, Schlicht und Gelehrt, Mutterschaft und Arbeit der Frau in vielfacher Wechselwirkung aufeinander beziehen wird unter ihren nicht nur erörtert, sondern lebendig gelebt und in ihren "Vereinen", jetzt vor allem. Ich ihren kirchlichen Gemeinschaften hat die Frau Stätten der Besinnung, der Erziehung und Ausrüstung gefunden, die in der ungeheuer schweren Aufgabe helfen."

(196) "Es ist nicht die Schuld der evangelischen Frauen und Mütter, wenn sie in den Kirchenstreit hineingezogen werdenkonnten, wenn führenden Frauen der evangelischen Frauenarbeit aus grosser Sorge und in tiefster Verantwortung für das eigentliche Anliegen frommer Frauen und Mütter Entscheidungen trafen, die vielleicht eine letze Klarheit über die Bedeutung der lutherischen Reformation für den neuen Staat vermissen liessen." 
(199) "Unser jahrzehntelanger, stiller kirchlicher Dienst ist im ev. Frauenwerk heute verpflichtet hervor zu treten. -Gern wollen wir als Frauen in Haus und Beruf still dahin wirken. (...) Und persönlicher Einsatz wird von uns gefordert, -nicht gefühlsmässiges Frömmsein soll es sein, sondern ein Wissen um heiligste Verantwortung. Das gerade ist die Anforderung an uns Nationalsozialisten, uns Parteigenossen und Genossinen. Wir wissen, dass die starken Kräfte, die aus dem Glauben an Christus und sein Evangelium notwendig sind, wie's liebe Brot, notwendig sind zum Bau am Fundament des christlichen Staates im 3. Reich nach dem Willen unseres Führers und Volkskanzlers".

(186) "Unser jahrzehntelanger, stiller kirchlicher Dienst ist im ev. Frauenwerk heute verpflichtet hervor zu treten. -Gern wollen wir als Frauen in Haus und Beruf still dahin wirken. (...) Und persönlicher Einsatz wird von uns gefordert, -nicht gefühlsmässiges Frömmsein soll es sein, sondern ein Wissen um heiligste Verantwortung. Das gerade ist die Anforderung an uns Nationalsozialisten, uns Parteigenossen und Genossinen. Wir wissen, dass die starken Kräfte, die aus dem Glauben an Christus und sein Evangelium notwendig sind, wie's liebe Brot, notwendig sind zum Bau am Fundament des christlichen Staates im 3. Reich nach dem Willen unseres Führers und Volkskanzlers."

prensa católica

(876) "Immer in Zeiten der Umgestaltung war es Sache der Frau, die Fackel des Geistes zu halten und mit ihre ganzen Kraft dafür einzustehen, daß Liebe und Güte leben und die Welt durchleuchten."

(882) Ihre Wohnung in Berlin-Schöneberg war für einen Kreis von Vertrauten und Widerstandswilligne eine gern aufgesuchte. Zufluchtssstätte, wo noch ein Gespräch unabhängig vom überhörbarem Telephon, möglich war. Heir verkehrten Männer des Widerstandes, auch solche, die ganz im geheimen den Plänen diente, die, in Kreisen und Gruppe vereint, dem Unheil steuern wollte. Frau Dr. Weber war nicht nur ihre Vertrauten, sie übermittelte auch notwendige Nachrichten.

(886) "Dieses Jahr 1933 ist von großen geschichtlichen Werden in einem Maße erfüllt, wie wir es seit langem nicht erlebten. Wir fühlen irgendwie ein Geschehen, das, so scheint es, Jahrzehnte, vielleicht Jahrhunderte in sich zusammenfaßt und tatsächlich das Antlitz unseres Volkes, das Antlitz Deutschlands verändert. Je tiefer die Wellen dieses Geschehens das Fühlen und Sinnen des Herzens erreichen, um so weniger vermag sich wohl das klare Urteil herauszulösen."

(887) "In dem feierlichen Vertrag, den die deutsche Reichsregierung und die Kirche geschlossen haben, im Reichskonkordat, ist dem Katholischen Deutschen Frauenbund der Schutz der Kirche und des Staates zugesichert. Damit ist gesagt, daß Staat und Kirche von uns volle Erfüllung unserer uns einmal gesetzten Aufgaben erwarten. Darin liegt eine große Verantwortung, die wir mit ganzer Freude und Hingabe auf uns nehmen in der Zuversicht, daß wir aus der inneren Entscheidung unseres Gewissens und unseres Glaubens den rechten Arbeitsplatz im neuen Staat finden. "

(889) "In tief beunruhigten, neuwerdenden Zeiten verlangt der Mensch nach dem Reich der Mütter, nach dort wo man um Leben und Sein, um Geborenwerden und Sterben weiß, wo menschliches Schicksal in seiner Schlichtheit und Größe, Schicksal von Generationen zu Generationen getragen wird." 
(890) "Große Sehnsucht eint sich diesem Neuerstehen in dem Gedanken, in der Hoffnung, daß diese Mutterschaft nun groß, stark, echt und tief gesehen wird, sicher stark und rein in ihrer leiblichen Wesenheit, aber auch und vor allem stark und groß in ihrer geistig-seelischen Kraft. Denn diese ist es ja, dei dem Kinde nicht nur, sondern auch dem reifenden und erwachsenen Menschen Heimat, Geborgenheit gibt und das tiefe, unzerstörbare Vertrauen in eine ganz große, ganz selbstlose Liebe, die sein Leben begleitet, und die immer neu in der Menschheit erwachen muß, im in ihrer hütenden, freigebenden Größe und Kraft den Menschen fähig u machen, sein Leben voll, stark, erfüllt zu leben."

(891) "Das bedeutet eine Einkehr in uns selber, eine stärkere Wertung innerlichen Lebens, ein immer neues Sichnähren aus religiösen Quellen, eine neue Wertung der Kontemplation, der aus der Stille wirkenden Kräfte und es bedeutet gleichzeitig ein volles Bereitsein für freudiges, starkmütiges Schaffen. Auf alten und neuen Wegen müssen wir unsere kraft in de Dienst unseres Volkes stellen, in unserem Volke leben, mit leben; seine Not, sein Verlangen teilen und immer wissen, daß es uns zugewiesen ist, aus den tiefsten Gründen katholischen Glaubens und katholischer Liebe den Menschen, unser Volk, unsere Heimat, unser Land, unser Schicksal zu umfassen. "

(892) "Von hier aus tritt die doppelte Bedeutung der Frau zu Tage. Ist es die Bedeutung der Mutter, daß sie die geschichtsbildenden Fähigkeiten des Mannes weiter gibt in die Generation, so ist es die Bedeutung der Jungfrau, daß sie die Geschichtsfähigkeit des Mannes, die Person, erst verbürgt. Hat man die religiöse Bedeutung der Jungfrau anerkannt, so hat man aber sofort auch ihre zeitliche Bedeutung für den Menschen. Dieselbe Jungfrau, welche Mutterschaft und Ehe opfert, um den einsamen Wert der Person zu erbringen, sichert mit ihrem Opfer zugleich auch Ehe und Mutterschaft.

(893)"(...) das religiöse Schicksal der Kinder, die Glaubenstandhaftigkeit des Mannes, das religiöse Leben der Familie vor allem in ihre tragende, belehrende, beispielhalfte, bekennde Verantwortung gegeben sind".

(894) "Mutter-sein schließt ja die Fülle des Lebens in sich; Mutter-sein wurzelt in der tiefsten Erdhaftigkeit des Blutes und ist zugleich Gestaltung aller im hingeopferten Erlöserblut zu ewigen Gotteszielen berufenen Seelen. In reiner Mutterschaft ruht die Kraft eines jeden Volkes, in ist aber noch Größeres, das Gottesreich auf Erden, zu treuen Händen gegeben."

(901) "Nur wir können es gerade in dieser Weise empfinden, in unserer ganz eigenen deutschen Weise, weil unsere Seele nach den Gesetzen der großen Seele gebildet wurde, die mit dieser unserer Erde und Landschaft eines ist. Und sie ist es, die große Seele unseres Volkes, die uns ergreift und anrührt, wenn wir im Gleichklang der Tage plötzlich hinhorchen auf ein Wort unserer Sprache."

(902) " Die Frau, die echte Frau, ist dem Volkstum nahe. Sie trägt in sich. Wenn sie ihr Frauenwesen ganz lebt, ist sie ein Stück Volkstum. Der Mutterboden für alles Volkstum ist ihr Herz. Sie gehören zusammen, im letzten Grund sind sie dasselbe: nämlich, Frau, Muttertum und Volkstum."

(903) "Wir sagten, daß es schwer ist, darzustellen, was Volkstum ist. Denn es ist der große unsichtbare Geist, der warme reine Atem aus der Tiefe hinter den tausend Formen unserer Sprache, unserer Geschichte, unseres religiösen Lebens. Die Seele, die die von ihr gezeugten Gestalten alle nach einem einheitliche Bilde prägt. Gott mit seiner Schöpferkraft weht in dieser Seele. Darum ruht das Volkstum auf einer religiösen Wurzel." 
(904) "Neben ihrem leiblichen Muttertum macht diese seelische Verbundenheit mit den Ursitzen des Lebens sie verehrungswürdig. Das Ewige des Volksgeistes zeugt sich in ihrer Seele fort. Hier liegen die tieferen Gefühle des Volkes: seine religiöse Ergriffenheit, seine innige Hingabe an das Mysterium, seine Ergebenheit unter die Gesetze der Natur, seine ins Jenseits hinübergehende Hoffnung."

(906) "Die Frau ist das wartende Land. De Mann kommt zu ihr. Sie kann ihn nicht suchen. Er kommt zu ihr. Aber ihr ist der Freiheit gegeben, ihn anzunehmen oder abzulehnen Die Werbung der Frau um den Mann würde ihre Wesensart fälschen um den Kern der Beziehung verderben. Es liegt in der Natura des Mannes, daß er werben will."

(907) "Man hat manchmal die Frage gestellt, ob die Frau schöpferisch ist. Sie erreicht den Mann in vielen Leistungen, aber ich glaube, daß ihre wahre Genialität - nun wirklich Genialität im ursprünglichen großen Sinn als das Einzigartige, über alles Hinausgehende -, im Reich der Liebe liegt."

(908) "Die Frau soll Leben geben, Spenderin eines neuen Lebens sei, aber nicht aus sich sonder in sich. Das Prinzip des neue Lebens kommt ihr von außen. Doch empfängt sie es nicht zu bloBen Weitergeben, sondern sie trägt es in sich und nährt es von ihrer eigenen Substanz."

(912) "Beide Geschlechter kranken am männlichen Eingeschlechterwesen; Neurosen und Hysterie auf beiden Seiten sind die Folgen; an Selbstentwürdigung, Halbheit, Vereinsamung, Leere Erstarrung der Seele geht der Einzelne zugrunde."

(913) "Dem Manne eine Stätte schaffen, wohin er sein Einsamkeit tragen kann, auf daß sie durch dieses Wissen der Frau um sie nicht mehr quälend sei, sondern zu froher Kraft werde. Eine Stätte schaffen, wohin er die Unruhe tragt, die täglich aufs neue draußen aufflackert im Beruf, in seinem Weg durch die Menschen, feindlich im Ringen um Arbeit, Besitz und Erfolg."

(915) "Was ist der Staat. Ist er jenes unpersönliche, machthungrige, auf organisatorischer Basis ruhende Etwas, an dem wir Frauen keinen Anteil haben sollte?. Ist er jene kalte Abstraktion, die ohne Blut und Leben sein muß? Ist er nur die Forderung an Mann als Richter und Soldat? Er sollte es nicht sein. Er ist für uns heute viel mehr als die Organisation der Macht, die jeder Staat als sein Wesentliches notwendig hat. Er schafft auch Recht und schütz die Kultur. Er soll in seiner Verwaltung nicht nur das organisatorisch ausgespannte Netz der ausführenden Gesetze und Maßnahmen sein, sondern auch eine lebendige menschliche Wirklichkeit, die in Verbindung mit dem Volke steht."

(916) "Der Kampf um grundlegende Volksrechte ist unser Kampf. Das Ringen um persönliche geistige Freiheit ist unser Ringen. Vielleicht wurden wir Frauen niemals stärker aufgerufen, um die deutsche Geistesgeschichte und die deutsche Politik zu formen und zu beseelen. Das bedeutet allerdings eine geistige Mitarbeit an der Verfassung von Weimar. Das verlangt von uns einen politischen Kampf um das außenpolitische Schicksal Deutschlands und um seien innere Entwicklung in de großen Klassen- und Interessenkämpfer der Zeit."

(917) "Diktatur aber ist nicht nur "Ausnahmezustand" sondern auch Mißtrauen gegen Volkseinfluß, Ohnmacht gegenüber gestaltenden Volkskräften. Diktatur ist die Herrschaft der Herrenmenschen oder einer Herrenschicht, die das staatliche Ziel ohne das Volk erreichen wollen. " 
(919) "Die Frau hat jetzt zu beweisen, daß sie den wahren Sinn der Frauenbewegung erfüllen kann, nämlich gerade aus ihrem Anderssein, aus ihre Eigenart heraus, das bisher einseitig am und vom Manne orientierte Weltbild durch die weibliche Weltansicht zu ergänzen und so etwas qualitativ Neuem, zu einer Totalität von Wertmöglichkeiten zu gelangen. "

(919) "Wir spüren, daß eine schwere Krankheit den sozialen Körper der Menschheit durchwühlt, die sehr leicht zur Todeskrankheit werden kann. Das Wort "Krise" ist uns geläufig geworden. Es ist uns, als ob das Fieberthermometer schon über $40 \mathrm{Grad}$ gestiegen wäre. Krise der Wirtschaft, Krise des Staates, Krise der Kultur, alles das bedeutet, daß wir uns überall wie aus der Bahn einer gesunden Entwicklung geschleudert vorkommen, daß wir erschreckt erkennen: wir wandeln auf Irrwegen, und nun nach Ausweg, Umkehr, Rettung suchen. Es wäre seltsam, wenn nicht auch die Frauenbewegung in das allgemeine Chaos mit hineingezogen wäre. In wieweit ist sei mitverantwortlich dafür?."

(921) "Ein unsagbarer Frieden lag über Natura und Mensch und eine fast unwirkliche Schönheit hüllte uns ein. "O Maria, immer Hilft", war das inständige Bittgebet der Tausenden. Alle waren darin eingeschlossen: unsere Familie, unsere Freunde und Feinde, unser Vaterland, unsere Kirche."

(922) "Die Erfüllung der Emanzipation, namentlich aber die Entwicklung des Weltkrieges, schien manchen gleichbedeutend mit dem Sieg der Frau über den Mann. Wir erleben aber schon wieder den Umschlag. Der ruf nach Rückkehr zur natürlichen Bestimmung des Weibes ist wohl zunächst als Reaktion gegen einen allenthalben als unnatürlich empfundenen Zusand zu verstehen. Aber die Natur des Menschen erschöpft sich nicht im biologischen Naturbereich, der Mensch weist über sich hinaus. Wir glauben, daß die Natur ihre letzte Ausrichtung von der Übernatur erhält, die Physik von der Metaphysik."

(924) "Die Frau ist im Menschheitsganzen der breitgelagerte Daseinsgrund, ins ich ruhen, mehr der realen Wirklichkeit verbunden, zur Fülle und Einheit streben - der Mann der zur Daseinshöhe Strebende, Unruhvolle, die idealen Wirklichkeiten abstrakt Begreifende, einseitig, gliedernd, auserinanderteilend. Beide Wessenskräfte sollen im Rhythmus zusammenwirken und dadurch fruchtbar werden."

(925) "Es war ihre Tragik, daß sie bisher aus einem Prinzip gespeist wurde, das ins sich unfrauenhaft, unmütterlich, war; dem Individualismus ist wesentlich unweiblich und unmütterlich."

(926) "Wir glauben weiter, daß durch die geistige Bildung der Frau ihre weibliche Ursprünglichkeit nicht zerstört wird, sofern sie eine in sich hat; daß ihre Fähigkeit zur Liebe nicht getötet, sondern ausgestaltet wird."

(927) "Die wahre Frauenbewegung beginnt erst jetzt, als eine "Gegenrevolution". Frauen haben für sich selber und den Mann nichts ganz Wesentliches gewonnen, indem sie sich den Männerstaat, die Männerwissenschaft, die männliche Wirtschaftsordnung eroberten, von der sie bereits besiegt werden. Denn neben dem "homme machine" ist nun die "Femme machine" aufgetaucht, die dem gejagten männliche Pol und seinem manischen Fortrasen folgen muß." 
(929) "Erst das Christentum proklamiert die metaphysische Gleichheit den Geschlechter und von an ist die Frau nicht mehr nur oder primär Geschlechtswesen, sondern Person mit unsterblicher, gottebendildlicher Seele. Die Antike erreichte diese Auffassung vom Wesen der Frau nicht und dadurch unterscheidet sich wesentlich die Mitwirkung der Frau in christlichen und außerchristlichen Kulturen. Das Christentum bebt den Unterschied der Geschlechter keineswegs auf. Der Mensch ist nicht eingeschlechtlich erschaffen, "als Mann und Frau schuf Gott den Menschen". Deshalb kann auch den ganze Mensch als imago Dei nur in der Zweieinheit verwirklicht werden und deshalb ist in dieser Ordnung der Frau die volle Auswirkung ihres weibliche Seins ermöglicht."

(930) "Der erste Beruf der Frau ist es, durchaus Frau zu sein. Ihre Wesensart auf ihr ganzes Leben ausströmen zu lassen. Auf der Wurzel ihres Frauentums erhebt sich ihr dasein, das sie als Gattin, als Mutter, als Schwester, als Jungfrau, als Berufsfrau entfaltet. Im ersten Sinne hat sie Frau zu sein. Das umfaßt alles, das durchdringt alles."

(935) "Ausgestaltung und Formung ihres Seins begrüßt. Sie haben aber nicht nur den Wert der Ausbildung der Kräfte für die Gestaltung der Persönlichkeit, sondern sie immer an gesehen im Zusammenhang mit der Familie, der Volkswirtschaft, dem Dienst an der Volksgemeinschaft. So haben sie in der Berufsarbeit auf der einen Seite nicht ein notwendiges Übel, sondern einen positiven Wertfaktor gesehen, haben aber auch immer die Gefahrenpunkte erkannt, die in der Berufsarbeit liegen."

(937) "Da, wo Frauen, die zur Ehe- und Familiengründung kommen wollten, die Wege aus wirtschaftliche Gründen versperrt waren, hat man von Seiten der Reichsregierung positive Hilfen geboten".

(939) "Wir können, dürfen und werden uns deutsche, namentlich uns bayerische Katholiken, die wir noch besondere Heimatgüter zu verteidigen haben, nicht aus der Verantwortung hinausstoBen lassen. Lassen sie uns alle wachrütteln, die den Namen Katholiken noch zu Recht tragen, daß der 5. März nicht ein Tag des Erlöschens für die Bedeutung des politischen Katholizismus, sondern ein Tag des Bekenntnisses und des Sieges werde."

(940) " Es sit damit gesagt, daß die Arbeit der katholischen Verbände wichtig ist für das Leben der Kirche und unsere Volkes. Hier vollzieht sich ein Miteinander- und Ineinanderwirken von Kirche und Staat. Darin liegt für uns eine große Verantwortung. Wir müssen alles tun, was in unseren Kräften steht, um die Arbeit des Katholischen Deutschen Frauenbundes lebendig und fruchtbar zu gestalten."

(941) "Als katholische Frauen müssen wir von Herzen darauf bedacht sein, unser katholisches Empfinden lebendig zu halten und zu stärken. Das ist nur möglich, wenn wir uns vor allem bemühen um rechte Besinnung, Stille, Innerlichkeit. (...) Gerade heute müssen wir das Bewußtsein in uns lebendig halten und immerneu wecken: es gibt ein stilles, verborgenes Wirken der Frau, das Unsagbares vermag."

(944) "Die Frauen, die Spenderinnen, Hüterinnen und Pflegerinnen des Lebens sind, wollen wissen, daß die Schrecknisse des modernen Vernichtungskrieges nicht wieder aufleben können. Darum fordern sie, daß in den noch nicht abgerüsteten Länden gleicherweiser der Rüstungstand herabgesetzt und das bedrohlich aufgehäufte Kriegsmaterial vermindert wird und alle Mittel des Gaskrieges zerstört werden." 
(945) "Die Antwort darauf bringt erneut zum Ausdruck, daß Frankreich nach wie vor fest entschlossen scheint, Deutschland das Recht zu verweigern, daß es in eigener Sache nicht allein durch eine gigantische nationale Rüstung, sondern auch durch internationale Garantien geschützt sein will."

(947) "An der Frau liegt es, ob der Mann annimmt, daß kriegerisches Heldentum ein wesentliches Kennzeichen echter Männlichkeit sei. An der Frau aber liegt es auch, ob ein neuer männlicher Idealtyp geschaffen wird, dessen Heldentum im Kampfe für den Frieden, in dem Mut, auch einmal den Vorwurf mangelnden Patriotismus und der Weichlichkeit zu tragen, in dem bewußten freudigen Einsatz aller Kräfte als Potenzierung aller Kräfte zur Erlösung aus der Schalheit und Schlappeheit des Alltags nicht bedarf."

(949) "Die katholischen Frauen haben an allem mitgearbeitet. Sie haben in nationalen Frauendienste gestanden (...). Sie haben überall ihre besten Kräfte für die Tätigkeit auf allen Gebieten eingesetzt, mögen sie selbst an manchen Orten an dem äußeren Geschehen der Hilfeleistung vielleicht weniger getan haben als die Frauen aus anderen Gruppen, mögen sie in der Organisation weniger in Erscheinung getreten sein: zur inneren Stärkung der Frau und Mutter haben sie sicher Wesentliches beigetragen."

(950) "Wenn die Voraussetzungen Hauer's stimmen, wenn glaube nichts ist als das Ergriffenwerden von der sich im All und im Menschen "offenbarenden" ewigen Wirklichkeit und wenn das Christentum nichts ist als die semitische Ausgestaltung dieses Glaubens, dann ist auch die Schlußfolgerung Hauers richtig und es ist einfach unverständlich, weshalb wir Christen in Deutschland, obwohl wir Deutsche sind, so hartnäckig gerade an der semitischen Form des Glaubens festhalten."

(951) "Diese natürlichen Religionen sind also vom Menschen her gestaltet, sie sind der Ausdruck dessen, wie er (der Mensch) die Spuren Gottes in der Welt deutet und zu reden von Gott bringt, daraus folgt aber, daß diese Religionen stets rassisch bedingt sind.(...) Hier sieht Hauer ganz richtig, wir geben ihm zu, falls es nur diese eine Offenbarung gibt, ist es für einen deutschen Menschen naturgegebene Pflicht, auf deutsche und nicht auf semitische Art religiös zu sein."

(952) "Von da aus wird alles andere klar, zunächst das, daß die Religion, die auf diesem neuen Glauben aufbaut, ihrem Wesen nach nicht mehr rassegebunden und völkisch bedingt sein kann, sie ist ja nicht wie die natürlichen Religionen von Menschen geschaffen, ist nicht der Ausdruck menschlichen Erlebens, menschlichen Ausdeutens der Spuren Gottes in der Welt, sondern sie ist ganz und gar Gottes Tat, Geschenk von ihm, und deshalb wesentlich über die Bedingtheiten des Menschen hinausragend, "übernatürlich".

(953) "Die alte Welt geht unter. Aber ihre höchsten Werte gehen nicht unter. Die hellenische und römische Kultur, das Judaistische als Prinzip der Spannung, der Tatbereitschaft, sie ziehen als eine tiefe, wirkende Schicht in das Leben der Kirche ein. Östliche und westliche Kräfte bauen sich hinein in de jungen Leib. Es entsteht eine universale Religion."

(954) "Daß diese Menschen, selbst wenn sie wegen einer erblichen Geisteskrankheit sterilisiert worden sind, aus der Umwelt der erbgesunden, körperlich und geistig tüchtigen Menschen herausgenommen und gesondert bewahrt werden ist eine Forderung, die nicht nur zum Wohle der Hilfsbedürftigen aufgestellt wird, sondern die auch von erbbiologischer Seite begrüßt werden muß, da sie geeignet ist eine Verbesserung der Unweltbedingungen der Übrigen herbeizuführen." 
(955) "Viele erblich Belastete, zumal erblich Schwachsinnige und Triebmenschen wie Alkoholiker, kann man nicht von innen heraus bestimmen, auf Ehe und Nachwuchs zu verzichten. Es fehlt ihnen entweder an Einsicht oder an Willensbeherschung oder, wie zumeist, ab beiden. Es bleibt also nichts anderes übrig, als den physischen Zwang anzuwenden, was allerdings auf eine Art geschehen muß, die den großen Gesetzen der christlichen Ethik und der christlichen Nächstenliebe entspricht. "

(956) "Es muß jedem von ihnen klar und selbstverständlich sein, daß erbgesunde Menschen nur mit erbgesunden Menschen eine Ehe schließen -ebenso wie man mit alle Entschiedenheit die Zugehörigkeit zum deutschen Volk verlangt oder jedenfalls doch Fremdrassiges ablehnt. Hinzu kommt eine entsprechende Willensgewöhnung, die das Begehren dem eugenisch gebildeten Gewissen unterordnet. So wenig sich eugenische Eheverbote als solche empfehlen, so wird man doch durch Bevorzugung derer, die selbst erbgesund Erbgesunde heiraten, die eugenische Erziehung des ganzen Volkes fördern und durch Bildung einer öffentlichen Meinung das rechte Handeln erleichtern. "

(957) "Was die Tötung des keimenden Lebens angeht, so kann nicht genug betont werden, daß der Mensch vom ersten Augenblick der Zusammenfügung von Erbanlagen an ein echter Mensch ist, dessen unschuldiges Leben kein Mensch antasten darf. Nicht die Verneinung des Lebens löst die Probleme, sondern die Lebensbejahung, die allerdings sich immer erfolgreicher dem erbgesunden Leben zuwenden sollte."

(960) "Unter diesen Umständen beschlossen die Vertreterinnen der dem Bund angeschlossenen Verbände, den Bund Deutscher Frauenvereine mit sofortiger Wirkung aufzulösen. (...) Das Nachrichtenblatt des Bundes wird bis zur völligen Abwicklung der Geschäfte weiter geführt. Die Zeitschrift "Die Frau", die nicht dem Bund gehört, sondern von ihm nur als Publikationsorgan benutzt wird, wird von der Auflösung des Bundes nicht berührt."

(963) "Ich hatte die Monatszeitschrift "Die Frau" gegrundet. Sie sollte einen Gedanken verwirklichen, der mich schon häufig beschaftigt hatte. Uns fehlte ein Organ, das in anderer Weise in den Dienst unserer Sache gestellt werden konnte als ein Vereinsblatt, das die Frauenbewegung mehr in ihrer kulturellen Bedeutung, in ihrer ganzen Breite und Tiefe vertraft."

(964) "Eines darf vielleicht gesagt werden: die Frauenbewegung keines europäisches Landes überhaupt keines Landes- hat eine Zeitschrift gehabt, die in dieser Weise den Kampf als geistige Auseinanderseztung geführt hat und Mittelpunkt durch Jahrzehnte hindurch geblieben ist."

(967) "Eine zweite Welt des reinen Lebens erschloss sich mir in dem schlesischen Dorf, das ich nun, dienstlich nicht mehr gebunden, als zweite Heimat neben Berlin bewohnte: das Haus bot Raum für viele Gäste. Die blühenden Linden der Allee brausten von Bienenvölkern und den Wald durchduftete die Maiblume. Im Park standen nachts die Rehe im Nebel; die Pferde auf der Koppel liefen einem mähneschüttelnd nach, (...)"

(968) "Das Erstaunliche, immer wieder zu bewundernder Ehrfurcht, Hinreißende war die Schnelligkeit und Klarheit, mit der die Schriftleiterin Gertrud Bäumer arbeitete, war das verblüffende Gedächtnis, das die ganze vorliegende Fülle des Stoffes sofort gegenwärtig hatte und übersah, war die rasche Auffassung und sofortige Kombination, wenn es um Neues ging, war der Gewichtssin für Haupt- und Nebensachen, aber auch der plötzliche Einfallsreichtum für etwas völlig Anderes, - und nicht zuletzt der Humor, wenn es galt, einen Ausweg zu finden aus den Schlingen des GoebbelsMinisteriums!." 
(971) "Liebe Emmy, ich wollte Dir doch auf alle Fälle sagen, daß die Gestapo im Besitz meines Anschreibens zu der Werbung für die "Frau" ist. (...).Ich wurde angerufen und einiges darüber gefragt. Der Beamte behandelte die Sache sehr ruhig und sachlich."

(978) "Gertrud Bäumer war vor der Machtübernahme eine der wildesten Demokratinnen und, glaube ich, hinreichend bekannt. Sonst geben die Berichte der Geheimen Staatspolizei und der NSDAP. nähere Auskunft über sie. Ich bin unter allen Umstände für Ausschluss der Bäumer."

(979) "Nach ihrer politischen und geistigen Einstellungen scheint es aber völlig ausgeschlossen, dass sie als Schriftleiterin zugelassen wird. Sie war Vetreterin einer ausgesprochen pazifistischen und feministischen Welt- und Staatsanschauung...... Ihre Jugendpolitik war so, dass man sich einen schärferen Gegensatz gegenüber nationalsozialistischer Anschauung schwerlich vorstellen kann(...)."

(980) "Nur bei wenigen versagte seine Kunst: eine Frau wie Gertrud Bäumer. Gertrud Bäumer blieb kühl bis an Herz hinan, als er sie einst in ein langes Gespräch zog, und er äußerte sich tief enttäuscht über die intellektuellen Abwehrkräfte dieser alten Demokratin, die er gern für seine Propapangda gewonnen hätte."

(981) "Unabhängig von dieser rechtlichen Seite ist das Auftreten der Gertrud Bäumer für die Gilde-Buchhandlung bezeichnend. Aber solange diese alte Demokratin in Deutschland noch eine Zeitschrift redigieren darf, können wir von der Kammer aus nicht das Reden verbieten."

(982) "Fräulein Semmler führte zur Begründung, die Reichsfrauenführung, sei im Laufe der Jahre zur der Erkenntnis gelangt, dass Frau Bäumer während ihrer Tätigkeit in der Frauenbewegung doch in sehr vieler Hinsicht wertvolle Vorarbeit auch für die heutige Frauenarbeit geleistet habe und dass sie auch während ihrer politischer Tätigkeit als Abgeordnete in allen wichtigen nationalen Schicksalsfrage die nationale richtige Haltung eingenommen habe."

(993) "Was "Die Frau" wurde und blieb, auch und erst recht in den letzten schweren Jahren ihres Bestehens 1933-1942, da führt schon hinein in die Schönheit einer geistigen Generationsfolge, in der nach dem Worte Platos "die eine der anderen die Fackel des Lebens göttfürchtenden sinnes weiter reicht".

(997) "Wir spüren gar nicht, wie bolschewisiert wir tatsächlich schon sind, denn was ist Bolschewismus anderes als der Nihilismus gegenüber geistigen und seelischen Überlegenheiten? Die fanatische Geistfeindlichkeit (genau wie sie Ortega y Gasset im "Aufstand der Massen" beschreibt) und die Ehrfurchtslosigkeit in den religiösen Dingen ist der Gefahrenkern des Bolschewismus, nicht das wirtschaftliche System. "

(998) "Es ist doch erstens nicht so, daß wir nicht "endgültig Abstand nehmen vom gegenwärtigen Geschehen"- ich nehme an, daß Du die Haltung und die Handlung der Regierung meinst?- aber die deutsche Schicksalsfrage ist nun einmal gestellt, und ob die Vorzeichen uns passen oder nicht, wir haben sie als Deutsche anzusehen. Die politische und die moralische Fragestellung decken sich nie. Das hat niemand klarer gesehen als Max Weber.. Hier heißt es einmal wirklich: right or wrong, my country. Ich will damit nicht das wrong beschönigen, aber ich darf mich nicht im Mantel der Tugend dem Schicksal meines Landes entziehen, sondern, da seine Schuld in gewissen Sinne zugleich meine ist, habe ich sie mit auf mich zu nehmen, wenn es um die Existenz geht." 
(1001) "Sehen Sie - ich hatte erwartet (...) daß, die demokratische Idee, der Parlamentarismus- kurz, die Formen der individuellen politischen Verantwortung, für die wir gekämpft haben, eine gedankliche Rechtsfertigung bei Ihnen finden würden.

(1002) "Man sieht ja doch bei aller Ablehnung des Antisemitismus, daß wir in der deutschen Repräsentation durch die Jüdinnen ein wenig zu tolerant gewesen sind angesichts der Tatsache, daß diese Plätze in den internationalen Organisationen ja immer zu Erbsitzen werden. Ich habe das Verkehrte daran im I.C.W. seit Jahrzehnten gefühlt, besonders eben durch eine gewisse Illoyalität der Inhaberin dieses Sitzes dem deutschen Bund gegenüber."

(1007) "Ich glaube, Sie machen sich - wie sehr viele andere- keine rechte Vorstellung von den Schwierigkeiten, von unseren Boden aus eine Zeitschrift herauszugeben, und haben vielleicht deshalb keinen rechten Maßtab dafür, was auf dem Wege, den ich als Hauptschriftleiterin gehe, dauernd und mit jedem Heft riskiert wird. Sie werden mir keine Zeitschrift in Deutschland nennen können, die auf ihrem Gebiet in der Freimütigkeit und Kritik (direkt und indirekt), so weit geht, wie "Die Frau" es tut."

(1010)"Und nun noch ein Wort über die Leute, die bei Ihnen in dieser Weise, die Sie beschrieben, an der Frau Kritik üben?. Wer ist das eigentlich? Die Frage soll nicht bedeuten, daß ich irgendwelche Namen wissen will natürlich, aber ich erkenne an diesem einen Beispiel schon, wie unfair und misstrauisch diese Kritik sein Muß. Warum lesen die Leute dann eigentlich die Frau überhaupt noch? Daß wir uns sachliche Einwände und vor allen Dingen irgendwelche positiven Anregungen aus dem Leserkreis direkt wünschen, daß wir den Kontakt, der ja nun nicht mehr durch die Vereine hergestellt wird, auf andere Weise herzustellen bemüht sind, amg Ihnen das beiliegende Anschreiben zeigen, das wir an Frauen in allen Teilen Deutschlands in diesen Tagen verschicken. Das Charakteristische ist nämlich, daß man von de Seiten, die Kritik üben, so gut wie niemals irgend einen positiven Wunsch oder eine positive Anregung bekommt, und so lange hat für mein Gefühl die Kritik allerdings etwas sehr Parasitäres."

(313) "Ein zweites Sensationelles: Ich bin wieder zur verantwortlichen Schriftleitung der "Frau" zugelassen. Technisch ausgedrückt; auf die Liste B gesetzt, die eine begrenzte Zulassung (also nicht für politische Tageszeitungen) enthält. Der "Frau" wegen muß ich natürlich sehr froh darüber sein, weil dieses Hin und Her zwischen drei Leute auf die Dauer nicht gegangen wäre."

(1012) "Wir alle wissen von der Ausweisung der 7000 Juden aus Baden und der Pflalz vor etwa vier Wochen. Wir machen uns wohl auch alle eine ziemliche Vorstellung von dem Vorgehen der SS gegen die polnische zivilbevölkerung. An diesen Dingen können wir nicht ändern und, im Falle der Juden sehr wenig, in dem der Polen garnicht helfen.

(1014) "Meine Vorträge im Frühling und Frühsommer dieses Jahres in verschiedenen konfessionellen Vereinen des Rheinlandes und Hessens, die alle einen sensationell starken Besuch hatten, haben, wie ich mir schon vorher dachte, die Aufmerksamkeit der Gestapo auf sich gezogen." 
(1018) "Ich bin viel - ja ich muss es sagen: gLücklicher, als ich es seit 33 je gewesen. Der fuchtbare Druck hat sich gelöst, die anderen Kräfte sind auch mobil und man nicht nur der einen Gewalt ausgeliefert. Ganz klein werden schon die anderen und sollen es noch mehr werden. Macht ist nich mehr dasselbe wie Diktatur -womit ich nicht sagen will, dass ich für uns eine Demokratie a la Weimar zurück wünsche".

(327) "Politisch sei sie gewies noch wie vor demokratisch angestellt und in ihrem Alter sei eine Wandlung auch nicht mehr zu erwarten. Die von ihr herausgegebene Frauenzeitschrift aber gebe zu Beanstandungen keinerlei Anlass und werde auch im Ausland viel gelesen. Gerade in Auslande verstehe man nicht, dass Frau Bäumer bei ihren auch vom Nationalsozialismus anzuerkennenden Leistungen in der Frauenbewegung durch Anwendung des \& 4 ausgeschieden worden ist, un es sei dort die Legende aufgekommen, dass diese Frau wohl Jüdin sein müsse. (...) Seit einiger Zeit werde Frau Bäumer vom Reichspropagandaministerium in der Auslandsarbeit verwendet."

(320) no hemos encontrado el texto en alemán

(1025) " Anna von Gierke war durch den Schwung der Bekennende Kirche ergriffen und mitgerissen worden. Sie und ihr Kreis besuchten ständig, auch nach Pfarrer Niemöllers Inhaftierung, die Dahlemer Kirche und die dort abgehaltenen Bibelstunden. Der gleiche Kreis versammelte sich an jedem zweiten Mittwoch in ihrem Hause zur Lesung und Betrachtung von Bibelworten. (...) Zu Beginn jeder Versammlung wurde über die Lage der Bekennenden Kirche berichtet. Und wie die Mitglieder an deren tapferen Kampf innerlich teilnahmen, so fanden sie selber in der Gemeinschaft Trost und Stärkung für die eigenen Kämpfe, in die fast jeder von ihnen in der einen oder anderen Weise verwickelt war."

(1028) "Es war ein Übergang in eine andere Lebensform, der für mich denkbar schön und leicht war - mir ist ja das Persönliche an dieser Veränderung überhaupt nicht so schwer geworden; aber das deutsche Gesamtschicksal mit seiner seelischen Belastung erträgt und erlebt sich unendlich leichter, wenn an sich jeden Tag der Unverlierbarkeit einer schattenlosen Gemeinsamkeit der Überzeugungen und Ziele bewußt wird. "

(1031) "Die Folgerungen, die der Nationalsozialismus aus dem Grundbegriffe von dem "organischen Ort der Frau" zieht, stehen den Gedanken der Frauenbewegung durchaus nahe."

(1035) "'Notwendig ist aber darüber hinaus, daß für die Stellung der Frau und Mutter in Aufbau und Tätigkeit des künftigen Staates aus seinen neuen Wertungen heraus klare Richtlinien aufgestellt werden."

(1038) "Eine Mutter sein heißt: ein Mensch sein, der seine Anker so tief ausgeworfen hat, daß er innerlich ruht. Es mögen Wogen des häuslichen Lebens und Stürme des Gefühls über die Seele ziehen. im Tieftsten ist Ruhe, ist ein Unerschüterliches, dem kein Sturm beikommen kann. (...) Dieses Gegründetsein in der tiefsten Tiefe ist Religion; von hier gehen letztlich alle richtunggebenden, alle erziehenden Kräfte aus."

(1040) "Wenn Gatten und Vater erwerblos sind, wenn Frauen und Mütter aus dem Erwerb gedrängt werde, wenn das Schicksal der Jugend von der Tragik des Sichüberflüssigfühlens auf dieser Welt beschattet wird, dann leidet die Familie." 
(1044) " Die Frauen jener Zeiten bemühten sich mit opferfreudiger Hingabe wahrhaft als aus einer Rippe des Mannes geschaffen zu erscheinen. Zwischen ihnen und den Männern herrschte volle Einigkeit über weibliche Bestimmung und Befähigung. Eine Frauenfrage im heutigen Sinn gab es in jenen schönen Zeiten nicht."

(1045) "Eine Mutter bringt Opfer genug, auch wenn sie, eben wieder unter Opfern, ihr Selbst behauptet und ihr Selbst erhält. (...) Jene Mütter, die sich opfern, erziehen Menschen, die wiederum Menschenopfer brauchen."

(1046) "(...) seitdem die Frauen angefangen haben, sich nicht mehr allein nach dem Wunschbild männlichen Geistes zu richten, seitdem sie ihren eigenen Gesetzen nachspüren und ihrer eingeborenen Persönlichkeit nicht mehr Gewalt antun .- nicht einmal mehr um den geliebten Preis der Liebe! Mit dem Tag, an dem die Frau sich selbst zu suchen begann, begann auch die äußere große Veränderung des Frauentypus, die uns heute so stark von unsern Großmüttern unterscheidet. Wir fühlen uns als Geschöpfe mit einem völlig eigenen Sinn und Wert, der nicht nur von der Liebe eines Mannes oder von der Zahl unserer Kinder abhängt. Wir beginnen unsere körperlichen und geistigen Kräfte aus ihren Gefängnissen zu befreien. Wir stellen Rekorde im Laufen, schwimmen und Diskuswerfen auf, und wir lenken Autos und sogar Flugzeuge. Wir können auch auf einmal rechnen und folgerichtig denken. "

(1048) "Es ist wichtig, gerade heute, wo eine erstaunliche Unkenntnis der historischen Tatsachen die Frauenbewegung mit den seltsamste Vorwürfen überhäuft, sich mit diesem Eintauche in Louise Ottos Gedankenwelt vor Augen zu führen, wie fern von aller Frauen-Rechtelei, wie völlig deutsch, gefühlsbestimmt und lebensnah der Ursprung unserer deutschen Frauenbewegung ist."

(1050) "Aber der Vorwurf, sie hätte sich nie gegen den Versailler Vertrag Aufgebäumt, ist wahrlich ungerechtfertigt, wenn man sich an die ganz einzig dastehende Proklamation des Bundes gegen das Angebot Wilsons erinnert, sowie daran, daß die Frauen des Reichstags sich einheitlich für Ablehnung des Friedensdiktates eingesetzt haben."

(1051) "(...) so kann ich keinen Unterschied in diesem und jenem Ursprungserlebnis entdecken. Beide erkennen eben die Verpflichtung, die besten und letzen Kräfte für die Gemeinschaft einsetzen zu müssen. Das ist das Wesentlichen. Es wäre deshalb erfolgreicher und eben diesem Ziel dienlicher, wenn man nun gemeinsam beriete, welches die Wege zu diesem gereiften Einsatz sind. Es gibt da viele Wege, und über sie scheint mir überhaupt erst eine verschiedene Meinung möglich, aber, wenn wir das Buch weiter durchblättern, so finden wir, daß eben gerade hier keinerlei Differenzen mit den Forderungen der alten Frauenbewegung bestehen, daß wieder ganz dasselbe gefordert wird, was man in Helene Langes "Kampfzeiten" Wort für Wort lesen kann."

(1052) "Die Meinung, daß die Frau trotz ihrer Familienaufgaben genau dieselbe Berufsarbeit leisten könne wie der Mann, also eigentlich doppelt so viel wie er, ist von der maßgebenden Frauenbewegung nie gestützt worden."

(1053) "Vielleicht wird die große Erneuerung der Welt darin bestehen, daß Mann und Mädchen sich, befreit von allen Irrgefühlen und Unlüsten, nicht als Gegensätze suchen werden, sondern als Geschwister und Nachbarn und sich zusammentun werden als Menschen, um einfach, ernst und geduldig da schwere Geschlecht, das ihnen auferlegt ist, gemeinsam tragen."

(1061) "Staat ist ein Begriff, ein Postulat, eine Forderung, mit allem Unbedingten, Geformten, Abgezogenen begabt, das, in der Wirkung der einer mathematischen Formel vergleichbar, schon allein durch seine Vorstellung göttliche Ruhe zu verbreiten vermag." 
(1063) "Man weiß, wie nach der Machtergreifung eine neue Welle des Hasses und giftigster Verleumdung sich mächtiger denn je gegen das neue Reich auftürmte. Man wollte es nicht dulden, daß das deutsche Volk seine Ehre wiederherstellte, daß es sein Wehrhaftigkeit wiedergewann, daß es seinen Platzt an der Sonne aus eigener Kraft zu behaupten gesonnen war."

(1064) "Wir haben alle empfunden, stärker als wir es je für möglich gehalten haben, tiefer, als wir überhaupt wußten, daß diese Erlebnisse reichen können -den Wert der Nation, des Staates für unser Einzelleben."

(1066) "'Aber für die Grundlagen unsres Daseins als Frauen in dem kommenden Deutschland, die Grundlagen dafür, daß wir unsre Pflichten und Verantwortungen diesem Deutschland gegenüber mit Freude und Stolz und Ehre erfüllen können, ist es entscheidend, daß wir unser Geschlecht nicht lediglich als Werkzeug fühlen, als Mittel und Objekt, sondern daß wir in den Gestalten verantwortlicher Führerinnen den Willen zu restlosem Einsatz der uns innewohnenden wesenseigenen Kräfte gewährleistet sehen."

(1067) " Ihre größere Gebundenheit an die natürlichen Bedingungen und Tatsachen des Lebens bringt es mit sich, daß Frauen unter sich eine weit einheitlichere, will heißen weit undifferenziertere Masse darstellen als die Männer. Sie sind mehr Volk und sie bleiben mehr Volk, auch wenn sie nicht Masse im dumpfen Sinne sind."

(1069) "Es untersteht daher keinem Zweifel, daß ein wirklicher Wiederaufbau der Familie auszugehen hat von einer völlig neuen, nach innen wie nach außen gestärkten und veränderten Stellung der Frau nachdem die Manneskultur diese Familie ganz oder doch nahezu zerstörte (im Extrem des Bolschewismus ganz, und zwar prinzipiell). "

(1070) "Wir haben alle empfunden, stärker las wir es je für möglich gehalten haben, tiefer, als wir überhaupt wußten, daß diese Erlebnisse reichen können - den Wert der Nation, des Staates für unser Einzelleben. Was uns sonst teuer war, was unser Leben reich und wertvoll gemacht hat - wir haben erlebt, daß es alles nicht so kostbar ist wie dieses eine, wie das einzige, wofür heute der Preis des Lebens gegeben wird, das Fortbestehen, der Zusammenhalt unseres Staates. Und so sind wir innerlich vorbereitet darauf, daß in der Pädagogik für die kommende Generation, für Knaben und Mädchen, über alle individualistischen Ziele hinaus, über alle subtilen Fragen der Verfeinerung der Einzelseelen hinaus, an die oberste Stelle unseres Bildungsideals das Wort rückt: die Nation, der Staat, die lebendige Gemeinschaft der Kultur, der Arbeit, der Lebensformen deren Bedeutung für unser aller Leben bis in seine letzen Zweige wir gefühlt haben."

(1071) "Wir danken jede echte Richtung, die in früherer zeit getan würde, weil das den Sinn des Nationalsozialismus entspricht."

(1073) "'Als deutscher Mensch wurde ich zuerst geistig entwickelt durch die Schöpfergeister meiner eignen Nation. (...) Als deutscher Mensch habe ich ein besonderes "geschichtliches Bewußtsein", d. h. ich weiß mich erbe der besonderen Vergangenheit meines Volkes, und ich weiß mich zugleich mitverantwortlich für die Gestaltung seiner Gegenwart und Zukunft. Meine Volkszugehörigkeit ist blutwarme Wirklichkeit, mein Volk ist mein eigener erweiterter Leib - wenn es leidet, so leide ich mit, auch ohne unmittelbares Betroffensein. Wenn die Führer meines Volkes Fehler mache, fühle ich mich mitverantwortlich." 
(1074) "Wir freuen uns an der Hingegebenheit an hohe überpersönliche Ziele, Glaube und Hoffnung auf neue Große unseres Vaterlandes. Wir billigen nicht fanatischen $\mathrm{Haß}$ gegen andersgeartete Volksgenossen, nicht-verstehen-wollen andersartiger Überzeugungen, Ungerechtigkeit, wilde Roheit. Der Wertmaßstab für alle diese Kritiken ist Menschlichkeit und Toleranz, denn Humanität ist der höchste unabdingbare Anspruch des Einzelmenschen. Die Ausbreitung dieser Humanität sollte auch das höchste Ziel einer Kollektivmacht sein."

(1077) "Es gibt heute viele Frauen, die in der nationalsozialistischen Weltanschauung eine große Möglichkeit für die Überwindung bisheriger Unstimmigkeiten in den Beziehungen Frau und Volk, Frau und Staat sehen."

(1078) "Es scheint wirklich notwendig, nicht nur in bezug auf die Frauenangelegenheiten, neben das rassischen Deutschland nachdrücklich das geistige Deutschland zu stellen. Und man darf vielleicht endlich einmal darauf hinweisen, daß "rassisch" ja nicht nur ein Artbegriff: ostich, fälisch, nordisch usw., sonder auch ein Qualitätsbegriff ist (...)"

(1079) "Wo nämlich die Demokratie wie in Frankreich und wie genau so in der Schweiz, durch die soziologische Schichtung des Volkes dem Kleinbürgertum und der ländlichen Bevölkerung das politische Schwergewicht zuschiebt, wird sie, wie die Schweizer Volksabstimmungen ganz klar zeigen, zu einem schwer zu besiegenden Hemmnis für den Austieg der Frau zur politischen Mitverantwortung."

(1081) "Sozialismus und Kapitalismus standen auf gleichem Boden. Die Geltung der materialistischen Gesichtsauffassung wurde durch den Nationalsozialismus entscheidend erschüttert. Sie war längst viel weniger ein Glaube als eine Theorie: Die Menschheit wird maßgeblich durch materielle Umstände und Interessen bewegt. Der Nationalsozialismus wollte den Sozialismus in Rahmen der Nation verwirklichen. Was er unter Sozialismus verstand, erscheint neben den scharfen und klaren Formulierung des Marxismus."

(1083) "Man ist manchmal versucht zu sagen, daß der konsequente Marxismus kein Sozialismus ist, sondern eine merkwürdige Verbindung von Kollektivismus und Individualismus."

(1087) "Der Sozialismus, von dem wir sprechen, ist nicht der heute so oft genannte Sozialismus. Er ist kein System, keine Lehre, keine Maxime und kein aus sozialen Maximen quellendes Tun. Er kommt nicht "von oben" und stammt nicht aus Einsicht oder Interesse. Der Sozialismus, von dem hier gehandelt wird, ist ein älterer primitiverer Sozialismus, zeitlos, ewig und unveränderlich als solcher, wenn auch variable in seiner Form und Struktur. Er ist eine Grundtatsache des menschlichen Lebens (...). In dieser Ausgestaltung ist der Sozialismus der weiblichen Natur aufs engste mit dem jeweiligen Zeitgeist verbunden; im Inhalt selbst aber ist er zeitlos, ja a-historisch."

(1094) "Es ist mehr als einmal deutsches Schicksal gewesen, selbst den Bau seines Reiches in solchem Feuer zusammenbrechen zu sehen,- im Mittelalter im Kampf des deutschen Kaiserreichs mit dem Papsttum, dann in der Reformation, im dreißigiährigen Krieg- während die Nachbarn bald in den warmen Luftwellen, die dies Feuer aussandte, umhegt vom Frieden der Zivilisation, edle Blüten abendländischer Kultur reifen lassen konnten. Wir wissen auch heute von diesem Feuer, das immer in der deutschen Erde schwelt oder brennt, daß Gott es entzündet hat. Wenn wir dies nicht wüßten, so würden wir ja glauben, daß Gott tot ist." 
(1097) "Religiöses Leben und seine Gestaltung zu gemeinschaftsbildenden Formen wird wohl fraglos (...) weitgehend mit in "Blut und Boden" begründet sein. (...) Blut und Boden formen den Menschen im sonnendürchglühten Süden anders als im ernsten, grauen Norden. Darin liegt Andersartigkeit, aber keine Minderwertigkeit wie der konfessionell Denkende oftmals meinte. Es scheint sicher, daß Abstammung und Heimaterde auf alles auf ihnen Erwachsende tiefen Einfluß ausübt. Ein Ringen nach tieferer Schau, nach wahrhaftiger Erkenntnis, ein Ernst- und Schwernehmenden aller Glaubensfragen hängt doch wohl mit der Art mehr nordischer Völker zusammen. Auch daß wir in Nordlanden mehr Protestantismus finden als im Süden, scheint mir wesensbedigt."

(1099) "Und man wird die Deutsche Glaubensbewegung als das begreifen, was sie ist: den einzig möglichen Weg zur Vollendung der Selbstbesinnung und einheitlichen Selbstfindung eines Volkes. Denn ohne Wurzel keine lebendige Blüte und keine wirkliche Erneuerung."

(1101) "In den "Bekenntnisgottesdiensten" hat es hier und da schon den Anschein, als sollte wirklich "Kirche" neu erstehen. Eins freilich muß betont werden: Politische Opposition, so wenig sie irgend ein Staatswesen auf die Dauer ohne schaden entbehren kann, muß sich eigene Wege suchen und darf sich unter gar keinen Umständen in die kirchlichen Auseinandersetzungen hinein flüchten. Grade weil wir es so fruchtbar empfunden haben, daß von anderer Seite Politik in die Kirche hineingetragen wurde, wollen wir nun die seelische Sachlichkeit so rein wahren wie nur menschenmöglich. "

(1103) "Das Christentum als die Weltreligion, die von allen im tiefsten Sinne Religion ist, kann, seinem Wesen nach, sich nicht erschöpfen in der Aufgabe, einem Volk oder einem Staat den weltanschaulichen Hintergrund für seine völkischen und staatlichen Ziele zu geben. Es ist keine Lebenslehre -nicht in diesem unmittelbaren Sinn- für diese Selbsbehauptung in der Sphäre der Macht. Es ist kein System staats oder volksbürgerlicher Werte und Tugenden."

(1104) "Kirche darf nur von denen gesäubert werden und erneuert werden, die wirklich die Kirche suchen. An der Religion bauen kann man nur von der Religion her. Und möchte doch über allem Leiden und Tun die Liebe wachsen!."

(1108) In dem lebhaften Streit über Wert und Wirkung des Christentums auf Wesen und Entwicklung der germanischen Stämme wird heute vielfach die Behauptung aufgestellt, daß die Stellung der germanischen Frau durch dad Christentum gedrückt worden sei. Diese Behauptung hat von vornherein eine gewisse Unwahrscheinlichkeit gegen sich. Wo immer die Frau nicht als ebenbürtig angesehen wird, sind die biologischen Eigenschaften und Bindungen in dem Sinne maßgebend gewesen, daß man ihre Art und Bestimmung, an Wesen und Tun des Mannes gemessen, als minderwärtig ansah."

(1112) "Wissend schaut die Priesterin das Leben und den Tod, die Tat und den Traum, den dunklen Rausch und die Klarheit, die Passion und die Erlösung."

(111) "Immer noch menschlich gesehen, erscheint hier die Frau als Trägerin der heilenden Kräfte -als Mittlerin für das Dasein der Gegenmacht, die den Tod überwindet."

(1114) "Hier ist aber auch der Grund, weshalb auch eine Frau in der Gemeinde nicht zu schweigen braucht, ja nicht eimal schweigen darf, wenn sie Gott mehr gehorchen will als den Menschen in dem, was sie zu sagen hat." 
(1115) "Ist es möglich, von Volksreligion zu sprechen, in dem Sinne, daß sie ein ganzes Volk zur erfüllen und zu umfassen vermag? Ja und Nein. Volk sind wir alle; gemessen an den letzten Wahrheiten bleibt der Unterschied der Bildung so gering, daß wir ausnahmslos als Suchende Blickende, der das dunkle Wort zurückwirft."

(1119) "(...) wir haben heute so und so viele Millionen Erbkranker, die unter das Gesetz fallen; sie kosten jährlich so und so viele Millionen Reichsmark; dank der Sterilisierung werden sie binnen 30 bis 40 Jahren nachkommenlos aus der Bevölkerung verschwunden sein, und damit werden all diese Millionen für andere Zwecke frei."

(1134) "Zudem sind es oft gerade die besten und leistungsfähigsten Menschen, die auf dem Weg über den "Doppelverdienst" versuchen, durch erhöhte Anstrengungen sich einen erhöhten Lebenstandard (...). Manche Familien können überhaupt erst dadurch gegründet werden, daß Mann und Frau weiterhin einen Beruf ausfüllen. (...)Der Kampf gegen das Doppelverdienertum ist deshalb unsozial, insoweit er den erhöhten Leistungswillen eines Menschen oder einer Familie bestraft, während der Doppelverdienst, der mit Kapitaleinlagen verbunden ist, unberücksichtigt bleibt und aus Gründen der Kapitalbildung unberücksichtigt bleiben muß."

(1135) "Wir können sagen: auch da und überhaupt überall da, wo ein Mensch lernt, sich zusammenzuraffen, eine Arbeit gleichmäßig und stetig zu leisten, und im Umgang mit Menschen weder kriecherisch noch anmaßend- sondern eben angemessen zu sein. Das lernt sich im Berufsleben- und darin liegt der Wert des Berufslebens gerade auch für die Frau und die künftige Mutter."

(1137) "Die Forderung, daß Arbeit nicht ausschließlich dem gegeben werden soll, der sie wirtschaftlich am nötigsten hat, sondern vor allem doch auch dem, der sie am besten leisten kann, ist nicht "individualistisch". Auch die Blüte der Volkswirtschaft, die die Gesamtheit eines Volkes trägt, beruht auf der Qualität insbesondere der führenden Kräfte, aller geistig Produktiven, aller derer, deren gestaltende kraft im Wettbewerb der Völker schließlich ausschlaggebend ist. Es ist nicht gleichgültig, ob die gesamte Arbeitsleistung eines Volkes von mehr oder weniger geeigneten Kräften getragen wird."

(1138) "Es ist unverkennbar, daß der Anteil der Frauen an der Schulleitung erheblich zurückgegangen ist, und daß dies nicht nur durch die Beseitigung politisch belasteter Frauen, sondern auch weit darüber hinaus im Sinne einer Ablehnung der weiblichen Schulleitung geschehen ist. Von der Schulverwaltung gar nicht zu reden, in der Neueinstellungen von Frauen in etatmäßige Stellen mit Aufrückungsmöglichkeiten, so weit das übersehen werden kann, nicht erfolgt sind."

(1139) "Wir brauchen im komplizierten Sozialkörper der Gegenwart eine weibliche Führerschicht, die an diesen Fragen "mitdenken" kann auf Grund der fachlichen Ausbildung, die zu ihrer Beherrschung notwendig ist, und die dem lebendigen Mitdenken und Mitfühlen aller anderen dann die Wege der Verwirklichung zeigen kann."

(1143)" Sie muß so sein, daß sie alles, was von ihr gefordert wird, gern tut. Sie muß, ich fasse es in einem Wort zusammen, politisch denken können, nicht politisch im Sinne eines Kampfes mit anderen Nationen, sondern politisch so, daß sie mitfühlt mitdenkt, mitopfern mit dem ganzen Volk in einer selbstsicheren, stolzen Haltung." 
(1144) "Von Nationalsozialismus aus gesehen ist die entscheidende Frage die biologische: ist das Frauenstudium der Erhaltung und Förderung des Erbgutes unseres Volkes abträglich oder nicht?. Die Behauptung, daß die einzelne Frau durch das Studium für die Fortpflanzung "verdorben" würde, entbehrt der sachlichen Grundlage."

(1146) "Die gibt es erst, seitdem die Frauen angefangen haben, sich nicht mehr allein nach dem Wunschbild männlichen Geistes zu richten, seit dem sie ihren eigenen Gesetzen nachspüren und ihrer eingeborenen Persönlichkeit nicht mehr Gewalt antun- nicht eimal mehr um den geliebten Preis der Liebe!."

(1147) "Aber die Frau ist ja nicht nur Frau, nicht nur Naturwesen, nicht nur bedingungslose Dienerin des Lebens. Sie ist auch Mensch."

(1149) "Frau Arends ist eine Ausnahme, das muß deutlich erkannt werde. Wohl trägt sie ein proletarisches Schicksal in ihrer äußeren Lebensgestaltung. Aber ihre Widerstandskraft gegen das Untergehen bezieht sie offenbar nicht nur aus vitalen, sondern auch aus religiösen Kräften (sie ist Mitglied einer Gemeinschaft), die sie sehr stark bestimmen."

(1152) "Die Forderung, daß Arbeit nicht ausschließlich dem gegeben werden soll, der sie wirtschaftlich am nötigsten hat, sondern vor allem doch auch dem, der sie am besten leiten kann, ist nicht "individualistisch"."

(1154) "Die gesundesten Formen der Arbeit und des Erwerbs sind diejenigen, die familienhaft betrieben werden können. Niemand wird die Mitarbeit der Frau in der Landwirdschaft oder in Handwerk und Handel im Familienbetrieb als Doppelverdienertum stigmatisieren (...)."

(1156) "Denn es gibt tatsächlich manche Arbeit, die der Mann gar nicht machen kann oder aber nicht so gut und so schnell wie eine Frau. Falsch ist es auch, anzunehmen, daß die Frau durch ihre Arbeit im Betrieb Schaden an ihrer Gesundheit nehme."

(1158) "Duch die Arbeit im Hause sollen die Gefühle der gegeseitigen Hilfsbereitschaft, die Erkenntnis von der Selbstverantwortlichkeit des Einzelnen für Alle, des Segens der natürlichen Gemeinschaftsbeziehungen, des Zusammenstehens Aller für Eine stärken. Nicht nur de wirtschaftliche Lage der Familie, auch die geistig-seelischen Familienbände sollen durch Zusammenarbeit im Haus gekräftig werden."

(1161) "Der Arbeit der deutschen Frau kommt eine kriegsentscheidende Bedeutung zu. Tausende von Frauen arbeiten heute angestrengt in unseren Fabriken, schaffen mit unserer Wehrmacht Munition und Waffen im notwendigen Ausmaß zu liefern, pflegen und erziehen in ihrer Freizeit ihrer Kinder zu tragen die stumme Sorge in sich um den Mann, der draußen vor dem Feinde steht. Ihr Haltung ist vorbildlich und manchmal ohne Beispiel. "

(1171) "Sie ermöglicht uns eine innere Aufrichtung, die Hinwendung vom Tode zum Leben, von der Zerstörung zum Aufbau, vom machtlosen Zuschauen und Leiden zum heilenden Schaffen."

(1181) "Ihre Tendenz zur Innerlichkeit erneuert einen Typus der Lebenshaltung, den die abendländlische Geistesgeschichte ausgeprägt und aufbewahrt hat. Die Wiederentdeckung der Innerlichkeit durch die Innere Emigration hat ihre Basis in der christlichen Ideewelt." 
(1184) "Indem dieser Strom abgestaut wurde, verfiel unser Volk einer seelischen Entartung, die Zug seine höhere Menschlichkeit zersetze. Es ergab sich immer willenloser einer Dämonie, die nicht nur seine Willen betäubte, sondern seine sittliche Urteilskraft mehr und mehr umdunkelte."

(1185) "Der nationalsozialistischer Staat war grundsätzlich ein Männerstaat: aufgebaut auf jenem Prinzip der "Härte", (...). Der Ausschluß der Frauen von Verwaltungsaufgaben, in denen ihnen etwa Männer in irgendeiner Form unterstellt gewesen wären, wurde genau durchgeführt. (...) In der Tat haben die führenden Frauen der Partei praktisch auf die nationalsozialistische Politik nicht den geringsten Einfluß gehabt, (...)." 


\section{Bibliografia}

Acker-Wulff, Marie: "Frau und Maschine", DIE FRAU, Febrero 1935 (nº5),

pp.271-276

Arnold, Sybille: "Der Weg der Mutter", DIE FRAU, Noviembre 1933 (nº2),

pp. $452-456$

Anz, Theodore: "Stimmung", Evangelische FraUenZEITUnG, Enero 1942 (año 43), pp.31-32

Auburtin, Angele: "Katholische Friedensidee und Frau", DIE CHRISTLICHE FRAU, Diciembre 1932, n²12, pp. 396-400

Baum, Marie: "Das Opfer der Mutter", DIE FrAU, Enero 1934 (nº), pp.41-43

Bäumer, Gertrud: Die Fran in der Krisis der Kultur, Berlin, Herbig, 1927

- Die Frau im neuen Lebensraum, Berlin, Herbig, 1931

- "Was nun? Erneuerung der politischen Fundamente", KÖNIGSBERGER HART. ZEITUNG, (n³66), v. 6, Agosto 1932

- "Unsere nationalsoziale Bewegung und der Nationalsozialismus", DIE HiLfE, Marzo $1933, n^{\circ} 6,161-164$

- $\quad$ "Um die Kirche", DIE FraU, Julio 1933 (nº10), pp.578-581

- "Das Ende des allgemeinen deutschen Frauenvereins", DIE FRAU, Noviembre 1933 $\left(n^{\circ} 2\right)$, pp.119-120

- $\quad$ "Panik über den Frauenberufen", DIE FRAU, Noviembre 1933 (nº2), pp. 81-88

- "Mann und Frau in der politischen Aufgabe", DIE FraU, Noviembre 1933 (n²), pp.476-478

- $\quad$ "Frauenbewegung und Mutterschaft", DIE FrAU, Diciembre 1933 (n³), pp.171-181

- $\quad$ "Spießbürgertum in der Frauenfrage", DIE FrAU, Marzo 1934 (nº), pp.321-325

- "Zum Schicksal des Christentums", DIE FRAU, Abril 1934 (nº7), pp.386-390

- $\quad$ "Der Einfluß des Christentums auf die Stellung der germanischen Frau", DIE FRAU, Octubre 1934 (n¹), pp.8-16

- "Die Welt und das Christentum", DIE FrAU, Diciembre 1934 (n³), pp.133-137

- "Gertrud von Le Fort zur Frauenfrage", DIE FRAU, Enero 1935 (nº4), pp.168171

- "Bilanz 1934", DiE FraU, Enero 1935 (n4), pp.193-202

- "Der Sinn der Wohlfahrtspflege und die Frauenarbeit", DIE FRAU, Marzo 1935 (n6), pp.321-330

- $\quad$ "Wie entwickelt sich die Rechtsstellung der deutschen Frau?", DIE FRAU, Junio 1935 $\left(\mathrm{n}^{\circ} 9\right)$, pp.565-566 
- "Frauenbewegung und Mutterschaft", DiE FraU, Agosto 1935 (nº5),

pp.171-181

- $\quad$ "Der Feind", DiE FraU, Octubre 1936 (n¹), pp.3-7

- "Die Priesterin", Die FraU, Agosto 1937 (n¹1), pp.605-607

- "Zum Status der deutschen Frau", Die FrAu, Septiembre 1937 (n¹2),

pp.641-649

- "Frauenschaften 1938 und ihre Zukunft", DIE FRAU, Enero 1938 (nº4), pp.169173

- $\quad$ "Der hohe Dienst", DIE FraU, Marzo 1938 (nº), pp.286-293

- $\quad$ "Einsatz der Frau in der Nationalwirtschaft", DIE FRAU, Febrero 1939 (nº5), pp.225-228

- "Die Menschenrechte und die Frauen. A propos d' un Anniversaire", DIE FRAU, Julio 1939 (n'10), pp.505-509

- $\quad$ "Die wahre Frau", DiE Frau, Octubre-Noviembre 1939 (nº1/2),

- $\quad$ "Demokratie und Klassenherrschaft in England", DIE FrAU, Abril 1940 (nº7), pp.193197

- $\quad$ "Arbeitsdienstpflicht im Rahmen der deutschen Frauenerziehung", DIE FraU, Octubre 1940 (nº), pp.3-8

- "Fraueneinsatz in der Kriegswirtschaft 1940", DIE FRAU, Diciembre 1940 (n³), pp.107112

- $\quad$ "Frauenreserven", DIE FraU, Abril 1941 (nº7), pp.194-197

- $\quad$ "Die falsche Emanzipation. Zur Stellung der Frau in der Sowjet-Union", Die FraU, Octubre-Noviembre 1941 (n¹/2), pp.1-5

- "Fünfzig Jahre DiE FraU", DiE FraU, Diciembre 1943 (n³), p.1

Baumgart, Gertrud: "Vom Bildungsziel der Frau im Lichte des Nationalsozialismus und der Frauenbewegung", DIE FrAU, Noviembre 1933 (n²), pp.98-106

Beckmann, Emmy: "Die Auflösung des Allgemeinen Deutschen Lehrerinnen-Vereins", DIE FRAU, Junio 1933 (nº), pp.546-550

Beyer, Hans: Die Frau in der politischen Entscheidung, Stuttgart, Ferdinand Enke Verlag, 1933

Bergmann, Ernst: Erkenntnisgeist und Muttergeist, Breslau, Ferdinand Hirt Verlag, 1933

Biesig, A.: "Verborgene Frauenbewegung", EvAngELISCHE FrAUENZEITUNG, Enero 1933 (año 34), pp.56-58

Blochmann, Elisabeth: "Die Studentin und das akademische Leben", DIE FRAU, Diciembre 1934 (n³), pp.230-235

Bluhm, Agnes: "Das Gesetz zur Verhütung erbkranken Nachwuchses. Eine kritische Würdigung", DIE FRAU, Junio 1934 (nº9), pp.529-538

Boedeker, Elisabeth: "Die werktätige Frau im vierten Kriegsjahr", DIE FRAU, Febrero-Marzo 1943 (n ${ }^{\circ}$ /6), pp.76-82

Borghaus, Herta: "Hauswirtschaft, ein gelernter Beruf?", DIE FRAU, Enero 1935 (n4), pp.239-242

Brumann, L.: "Es bleibt uns nichts erspart. Zum 5. März", BAYRISCHES FrAUENLAND, Marzo 
1933 (año 15), pp.18-19

Busch, Eberhard: Karl Barths Lebenslauf. Nach seinen Briefen und autobiographischen Texten, München, Kaiser Verlag, $3^{\circ}$ Ed., 1

Cremer, Marlise: "Der Arbeitsdienst für die weibliche Jugend. Sein Werden, Wesen und seine Bedeutung", NATIONALSOZIALISTISCHE MONATSHEFTE, Abril 1938 (nº97), pp.311-325

Cosack, Elisabeth: "25 Jahre Frauenland", Frauenland, Enero 1933, n¹, p. 25 pp.23-26

- 25 Jabre Katholischer Deutscher Frauenbund, Köln, Katholischer Frauenbund, 1938

Dieck, I.: "Das Christentum und die deutsche Glaubensbewegung", DiE ChrisTLICHE FrAU, Febrero 1936, n², pp.39-42

Diehl, Guida: Die dentsche Frau und der Nationalsozialismus, Gotha, Leopold Klotz Verlag, 1928

Dobroschke-Taeschner, Maria: "Mutterkirche", DIE FrAU, Octubre 1933 (nº1), p.10

Doherr, Annemarie: "Ersatz von Frauenarbeit in der Industrie", DIE FrAU, Marzo 1935 (nº)

Dönhoff, Martha: "Von der parlamentarischen Mitarbeit der Frau", DIE FRAU, Septiembre 1933 (n¹2), pp.730-731

Drechsler, Albin: "Die evangelische Kirche im Sudetenland und ihre Liebeswerke", DIE CHRISTLICHE FRAU, Febrero 1939, nº 2, p. 73

Dürck, Johanna: "Allein durch den Glauben", DIE FrAU, Julio 1933 (n¹0), pp.582-589

Ehrle, Gertrud: "Frauenberufe und Frauenberuf", DiE CHRISTLICHE FrAU, Diciembre 1932, (año 30), pp. 381-387

Erdmann, Franz: "Von der bürgerlichen Verbesserung der Weiber", DIE FrAU, Septiembre 1938 (n¹2), pp.253-258

Ernst, Johanna: "Berufsberatung der Mädchen unter nationalsozialistischer Zielsetzung", DIE FraU, Agosto 1935 (n¹1), pp.349-353

Esch, Margarete: "Lage und Aussichten in den höheren Frauenberufen", DIE FRAU, Marzo $1941\left(n^{\circ} 6\right)$, pp.168-173

Eyl, Meta: "Zum Kampf um das Alte Testament", Evangelische Frauenzeitung, Mayo 1932, (año 33), 119-122

- "Der innermissionarische Auftrag der evangelischen Frau", Aufgaben und ZIELE, Diciembre 1934, n 12 , p.190

- "Das Gebot der Stunde", Evangelische Frauenzeitung, Abril 1934 (año 35), pp.98-102

- $\quad$ "Der Auftrag der evangelischen Frau im Volke", AufGABEN UND ZIELE, Junio 1935, nº 6, p. 84 
- "Was ist der Deutsch-Evangelische Frauenbund?", EvangELISCHE FrauENZEITUNG, Octubre 1935 (año 37), pp.1-4

- $\quad$ "Die Bibel in der kirchlichen und geistigen Lage Deutschlands", EvangELISCHE FRAUENZEITUNG, Diciembre 1937 (año 39), pp.35-38

- $\quad$ "Das Reich als Eidgenossenschaft?, AUfGABEN und ZIELE, Mayo 1940, n 5, p. 60-63

- "Zwischen Kirche und Reich. Ein Nachtrag", Evangelische FrauenZeITUNG, Febrero 1941 (año 42), pp.37-38

- "Zeiten der Bewährung", Evangelische Frauenzeitung, Abril 1941 (año 42), pp.57-62

Eyl, M., Bismarck, D., Nopitsch, A., Brandmeier, P.: "Neujahrgruß der Evangelischen Frauenarbeit für Kirche und Gemeinde", EvANGELISCHE FrAUENZEITUNG, Febrero 1941, $\mathrm{n}^{\circ} 2$, pp. 38-39

Fröhlich, A.: "Eröffnung der Aussprache am 20. Juni", EvANGELISCHE FrAuENZEITUNG, Julio-Agosto 1934 (año 35), pp.147-148

- "Männer machen die Geschichte?", EVANGELISCHE FrAUENZEITUNG, Enero 1936 (año 37), pp.103-108

Gaebel, Käthe: "Die Frau in der Statistik der Arbeitslosen", DIE FraU, Agosto 1935 (n¹1), pp.362-364

Gemtges, M.: "Die Frau als Gattin", Die Christliche FraU, Diciembre 1932, (año 30), pp.387-391

Gierke, Anna: "Der 'Nationale Frauendienst' im Weltkriege", DIE FrAU, Enero 1944 (nº4), pp.676-682

Gillet, Grete: "Die Frau nach christlichem Glauben", EvangELISCHE FrAUENZEITUNG, Junio 1934 (año 35), pp.124-134

Gillet, Meta: "Das biblische Wort über die Frau", Evangelische FrauEnZEITUnG, Octubre 1936 (año 38), p.5

- $\quad$ "Von Beruf und Berufung der Frau", Evangelische Frauenzeitung, Mayo 1938 (año 39), pp.98-99

Glaue, Helene: "Aus dem Suchen der Zeit", DIE FrAU, Abril 1934 (nº7), pp.391-394

Graefe, Johanna: "Liebe zum Lebendigen. Vom Sozialismus der Frau", DIE FraU, Agosto 1935 (n¹1), pp.686-689

von der Gröben, Selma: "Zeitwende und Frauenbewegung. Gedanken zu unserem Verbandsthema", EvangeLISCHE FrAUENZEITUNG, Julio-Agosto 1932 (año 33), pp.150-154

- "Ein Neues?", Evangelische Frauenzeitung, Mayo 1933, (año 34), (pp.113-115)

Gross, Walter: "Unsere Arbeit gilt den deutschen Familien", NATIONALSOZIALISTISCHE MoNATSHEFTE, Febrero 1939 (nº107), pp.99-106

Pater Grösser: "Religion und Volkstum", Die ChristiliChe Frau, Agosto 1932, nº 8, pp.239- 
Haas, Sibylle: "Das Wochenende der Hausfrau", DIE FRAU, Febrero 1941 (nº5), pp.139141

Harmaen, Elisabeth: "Das Muttergefühl der unehelichen Mutter", DIE FRAU, Diciembre 1933 (n³), pp.156-162

Hasse, Else: "Die Geschlecterfrage als Grundproblem der Weltgeschichte", DiE CHRISTLICHE FRAU, Junio 1932, pp.177-181

Häußler, G.: "Deutsches Muttersein", EvAnGELISCHE FrauEnZEITUNG, Mayo 1934 (año 35), pp.114-115

Heinrichs, Charlotte: "Besoldung der Mutterschaftsleistung", DIE FRAU, Enero 1941 (n4), pp.343-347

Heinsius, Maria: "Die Macht der Frau", EvangelisChe FrauEnZEITUnG, Noviembre 1939 (año 41), pp.9-11

Heuss-Knapp, Elly: "Rheinüberwärts", DIE FRAU, 1940/1941 (nº48), pp. 45-47

- "Vom Werben und vom Waschen", DiE FrAU, 1940/1941 (n48), pp. 148-149

Hoffmann-Linke, Eva: "Frau, Volk, Nation", DIE FrAU, Septiembre 1933 (nº12), pp.712-717

Hopmann, Antonie: "Mitarbeit der katholischen Frauen am Notwerk für die deutsche Jugend", NACHRICHTENBLATT DES KATHOLISCHEN DEUTSCHEN FrAUENBUNDES, Febrero $1933\left(\mathrm{n}^{\circ} 2\right)$, p. 1

- $\quad$ "Fragen der Zeit an die berufstätige Frau", DiE CHRISTLICHE FRAU, Enero 1934 (año 32), pp.10-16

Huber, Engelbert: Das ist Nationalsozialismus, Stuttgart, 1933

Huch, A.: "Berufstätige und Hausfrauen in gemeinsamer Arbeit", NACHRICHTENBLATT FÜR DIE ZWEIGVEREINE DES KATHOLISCHEN DEUTSCHEN FRAUENBUNDES, Enero $1932, n^{\circ} 1$, p. 4.

Hueck-Dehio, Else: "Die Frau und die geistige Schöpferkraft", DIE FRAU, Febrero 1934 (no5), pp.266-271

- $\quad$ "Erziehung und Selbsterziehung der Frau zur Mutterschaft", EvANGELISCHE FRAUENZEITUNG, Mayo 1937 (año 38), pp.127-131

Jarausch, R.: "Evangelischer Religionsunterricht heute", AUFGABEN UND ZIELE, Septiembre $1935, n^{\circ} 9$, p. $129-136$

Jellinek, Camilla: "Zum Gesetz über die Anwendung deutschen Rechtes bei der Ehescheidung vom 24. Januar 1935", DIE FrAU, Mayo 1935 (nº), pp.489-492

Kaufmann, Günter: "Wir Feldgrauen und die Mutter des Volkes", WILLE UND MACHT, 1940 
(cuaderno $\left.\mathrm{n}^{\circ} 10\right)$, pp.5-9

Klamroth, K.: "Die Neugestaltung der evangelischen Kirche Deutschlands", EvANGELISCHE FRAUENZEITUNG, Junio 1933 (año 34), pp.133-135

Klingg, Thomas: "Die Frau in der letzten Berufszählung", Die FraU, Marzo 1935 (nº), pp.331-337

Koehl, Else: Die Stellung der Fran im volkswirtschaftlichen Verteilungsprozeß, Ochsenfurt am Main, Fritz und Rappert, 1937

Köhler-Irrgang, Ruth: "Frau im Gefüge des Volkes", NATIONALSOZIALISTISCHE MONATSHEFTE, Mayo 1939 ( $\left.\mathrm{n}^{\circ} 110\right)$, pp.465-467

- Die Sendung der Frau in der dentschen Geschichte, Leipzig, Hase und Koehler, 1940

Krabbel, Gerta: "Katholische Frauen zur Abrüstung", DiE ChristLiCHE FrAU, Enero 1932, (ao 1932), p. 2 pp. 1-4

- $\quad$ "Um Deutschlands Schicksal", Die Christliche FraU, Julio 1932, nº 7, pp.203-205

- "Der KDF in der Zeit", NACHRICHTENBLATT FÜR DIE ZWEIGVREINE DES KATHOLISCHEN DEUTSCHEN FRAUENBUNDES, Mayo 1933, n5, p. 1

- $\quad$ "Ringen der Zeit", Die Christliche FraU, Septiembre 1933 (año 31), pp.225-229

- "Wir katholische Frauen im Bund", FrauenLand, November 1933, nº 11, pp. 281-282

- "Mütterschulung", NACHRICHTENBlatT FÜR DIE ZWIEGVEREINE DES KATHOLISCHEN DEUTSCHEN FRAUENBUnDES, Diciembre 1933, nº12, p.44

Krukenberg-Conze, Elsbeth: "Ich glaube an das Licht, das in mir leuchtet", DIE FRAU, Abril $1935\left(\mathrm{n}^{\circ} 7\right)$, pp.399-403

Kühn, Leonore: "Frau, Familie und Staat", DIE FraU, Septiembre 1933 (n¹2), pp.669-683

- "Frauen an die Völkerfronten!", Die FraU, Diciembre 1934 (n³), pp.138-145

- $\quad$ "Das Bild der Frau", Die FraU, Enero 1935 (nº4), pp.288-290

- "Die Deutsche Glaubensbewegung", DIE FraU, Abril 1935 (nº7), pp.405-410

Lange, Helene; Bäumer, Gertrud; (eds.): Handbuch der Frauenbewegung. Die Geschichte der Frauenbewegung in de Kulturländern, Berlín, W. Moeser Buchhandlung 1901

von Le Fort, Gertrud: "Die Frau in der Zeit", Die ChristLICHe FraU, Abril 1934, (año 32), pp. 97-102

Lenz, Fritz: "Über Fortpflanzung und Ehehäufigkeit in Berlin", VOLK UND RASSE, Septiembre $1940\left(\mathrm{n}^{\circ} 9\right)$, pp.125-128

Lenz-Borries, Klara: "Frauenstudium und Auslese", DIE FraU, Enero 1934 (nº4), pp.202-204 - "Zum Sterilisierungsgesetz", DIE FrAU, Marzo 1939 (nº), pp.354-357

Lippert, Elisabeth: "Die Lage in den spezifischen Frauenberufen", DIE FrAU, Octubre 1940 $\left(\mathrm{n}^{\circ} 1\right)$, pp.197-205 
- "Die Autorität der Mutter in der Familienerziehung", DIE FraU, Enero 1941 (nº4), pp.15-19

Lion, Hilde: Zur Soziologie der Franenbewegung. Die sozialistische und die katholische Franenbewegung, Berlín, Schriftenreihe der Akademie für soziale und pädagogische Frauenarbeit in Berlin, Herbig 1926

Lucas, Gerda: "Kameradin", AufGaBEN UND ZIELEN, Enero-Marzo 1936 n 1-3, pp. 10-16

Ludwig, Renate: "Darf die Frau predigen?", DIE FrAU, Agosto 1939 (n¹1), pp.598-601

Magnus-von Hausen, Frances: "Zum Bruch mit dem Völkerbund", DIE FraU, Noviembre $1933\left(\mathrm{n}^{\circ} 2\right)$, pp.65-66

- "Zur Krisis des Frauenstudiums", Die FraU, Enero 1934 (nº4), pp.193-196

- "Hatten wir eine Kirche?", DIE FraU, Abril 1934 (nº7), pp.128-132

- "Zwangsweise Christianisierung", DIE FrAU, Enero 1938 (nº4), pp.171-176

Mahrenbach, Maria: "Über das weibliche Pflichtjahr", Evangelische FrauenZeItunG, Junio 1938 (año 39), pp.137-140

Malsburg, Fides: "Die Landfrau im Weltkriege", DIE FrAU, Noviembre 1934 (n²), pp.104109

Maresch, M.: "Beruf und Mutterschaft", Die ChristLiCHE FrAU, Marzo 1933, n³, pp. 77-79

Meyn-von Westenholz, Elisabeth: "Flammen Gottes", DIE FraU, Diciembre 1934 (n³), pp.129-132

- $\quad$ "Die Weltangst vor dem Kriege", Die Frau, Mayo 1935 (nº8), pp.461-463

- "Nation als Bildungsidee der Frau", Die FraU, Enero 1936 (número especial)

Müller-Ortfried, Paula: "Reichspräsidentenwahl", EvangELISCHE FrauENZEITUNG, Marzo 1932 (año 33), p.85

- "Rückblick und Ausblick", Evangelische FrauenZeitung, Enero 1933 (año 34), pp.49-50

- $\quad$ "Die Fragen der geschlechtlichen Sittlichkeit, insbesondere das Eheproblem in der evangelischen Kirche", EVANGELISCHE FRAUENZEITUNG, Febrero 1933 (año 34), pp.70-75

- "Deutschlands Entscheidung", Evangelische Frauenzeitung, Marzo 1933 (año 34), p.81

- $\quad$ "Nationale Erhebung", Evangelische FrauenZeitung, Abril 1933 (año 34), pp.9798

- "Abschied", Evangelische FrauenZeitung, Enero 1935 (año 36), pp.49-50

Montgelas, P.: "Das Ergebnis der Abrüstungskonferenz", DiE ChrisTLICHE FRAU, Octubre 1932, nº 10 , pp. 308-313

Muckermann, H.: "Zur Frage der Verhütung erbkranken Nachwuches", DiE CHRISTLICHE FRAU, Junio 1934, nº 6, pp.176-181 
Neumeister, Heddy: "Die Berufslage der geschiedenen Frau", DIE FrAU, Julio 1940 (nº10), pp.305-307

Obermaier-Schoch, Hilde: "Zur Frage der Auslese für das akademische Studium", DIE FRAU, Enero $1934\left(\mathrm{n}^{\circ} 4\right)$, pp.205-207

Paulsen, Anna: "Glaube und Sein", Die FraU, Abril 1935 (nº7), pp.385-390

- "Geboren von der Jungfrau Maria", EvANGELISCHE FrAUENZEITUNG, Diciembre 1938 (año 40), pp.38-41

Philipp, Beda: "Zwiefältig Gewirk des nördlichen Geistes", EvANGELISCHE FrAUENZEITUNG, Mayo 1940 (año 41), pp.58-59

Quentin, Emil: "Familienerziehung", VOLK UND RASSE, Diciembre 1940 (nº12), pp.181-184

Reich, E.: "Über das Frauenwahlrecht", Evangelische Frauenzeitung, Mayo 1933 (año 34), pp.118-121

Reichenau, Irmgard: Deutsche Frauen an Adolf Hitler, Leipzig, Adolf Klein, 1934

Reicke, Ilse: "Wandlung der Mutter durch das Kind", DIE FraU, Diciembre 1933 (n³), pp.152-154

- $\quad$ "Probleme der Müttererholung", DIE FraU, Julio 1935 (nº10), pp.615-618

- "Arbeitseinsatz von Müttern", Die FraU, Diciembre-Enero 1941/1942 (nº3/4), pp.8285

- "Die Frau als Künstlerin", DIE FrAU, Junio-Julio 1942 (nº/10), pp.151-160

Rilke, Alice: "Die soziale Betreuung der Frauen durch die Deutsche Arbeitsfront", DIE FRAU, Diciembre $1933\left(\mathrm{n}^{\circ} 3\right)$, pp.67-70

- $\quad$ "Frauenarbeit und Meldepflicht", DIE FrAU, Abril-Mayo-Junio 1943 (nº7/8/9), pp.98103

Rosenberg, Alfred: Der Mythus des 20. Jabrbunderts. Eine Wertung der seelisch-geistigen Gestaltenkämpfe unserer Zeit, München, Hoheneichen Verlag, 1933

Rötger, A.: "Gedanken über Frauenarbeit", EVANGELISCHE FrAUENZEITUnG, Febrero 1933 (año 34), pp.67-69

Rüdel, M.: "Der Christ zu dem Problem der Eugenik", Evangelische Frauenzeitung, Septiembre 1934 (año 35), pp.181-183

Schaeffer, S.: "Aus der evangelischen Frauenarbeit", EvANGELISCHE FrAUENZEITUNG, 1938 (año 39), p.106

Scherer, Elsbeth: "Die Frau als Trägerin des Volkstums", Die Christliche FraU, Septiembre 1933 (año 31), pp.229-235

- $\quad$ "Vom Zeitlosen Wesen der Frau", Die ChristLiche Frau, Febrero 1934, (año 32), pp. 33-36

- "Bildung zur Ehe", Die ChristLiChe Frau, Junio 1932, (año 30), pp. 169-176 
- $\quad$ "Ein christliches Geschichtsbild", Die ChristLiche FraU, Febrero 1937, año 35, p. 43

Schlüter-Hermkes, M.: "Katholische Gedanken zu Nationalismus und Krieg", DIE CHRISTLICHE FRAU, Julio 1932, año 30, pp.205-210

Schmidt-Meyer, H.: "Entgegnung auf Grundlagen zur Mitarbeit der Frau am Staat", NACHRiCHTENBlatT Des Bundes Deutscher FrauenVEREINE, Marzo 1933, nº 3, p. 28

Schroeder, A.: "Erbe deutscher Frauen", Die Christliche FrAU, Octubre 1933 (año 31), pp. $272-277$

Schubart-Fikentscher, Gertrud: "Zum Problem der weiblichen Homosexualität", DIE FRAU, Abril $1939\left(\mathrm{n}^{\circ} 7\right)$, pp.366-375

Schumacher, Minna: "Wende in der Frauenbewegung", Die ChristliChe FraU, Enero 1933 (año 31), pp.11-16

Schwarz, M.: "Unsere Tagung in Hamburg", Evangelische FraUenZeitung, Julio-Agosto 1933 (año 34), pp.145-147

Schwarzhaupt, E.: "Die Stellung des Nationalsozialismus zur Frau", EvANGELISCHE FRAUENZEITUNG, Mayo 1932 (año 33), pp.122-123

Seggel, Sophie: "Vom F.A.D., dem Weiblichen Arbeitsdienst", DIE FraU, Enero 1936 (nº4), pp.216-218

Sellmair, J.: "Die Frau in der christlich-humanen Ordnung", Die ChristLICHE FraU, Enero 1936, n 1 , p. 4 pp. $2-5$

Staewen-Ordemann, Gertrud: "Proletarische Mütter. Bilder ihrer Lebenslast und Leistung", DIE FrAU, Enero 1934 (nº4), pp.140-145

Stahl-Meding, Hildegard: "Frauenumschulung im Kriege", DIE FRAU, Junio-Agosto 1941 $\left(\mathrm{n}^{\circ} 9 / 10\right)$, pp. $291-295$

Syrup, Friedrich: "Der Arbeitseinsatz der Frauen", DIE FrAU, Abril 1939 (nº), pp.69-74

Teußner, Irmgard: "Schule und Erziehung", AUfGABEN UnD ZIELE, Diciembre 1934, nº 12, pp.194-197

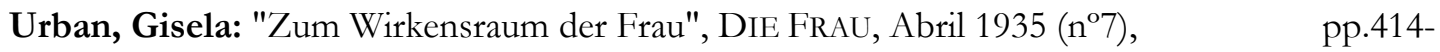
416

- $\quad$ "Die Vierzigstundenwoche und die Frau", Die FraU, Abril 1935 (nº7), pp.358-363

Ulich-Beil, Else: "Naiv oder sentimentalisch", DIE FRAU, Enero 1935 (nº4), $\quad$ pp.218-226

- "Die Zerstörung Europas durch Versailles", DIE FraU, Octubre 1936 (nº1), pp.35-37

von Velsen, Dorothee: "Frauen, Volk und Staat", Die FraU, Marzo 1933 (nº), pp.334-341

- $\quad$ "Zur Frage einer Volksreligion", DIE FraU, Agosto 1933 (n¹1), p.663 
Voigt, E.: "Der evangelische Christ zur Frage der Erziehung und Pflege von Anormalen", EVANGELISCHE FRAUENZEITUNG, Febrero 1935 (año 36), pp.72-76

Wagner, Elisabeth: "Sinngehalt der Ehe in evangelischer Auffassung", DIE FRAU, Junio 1933 $\left(\mathrm{n}^{\circ} 9\right)$, pp.556-560

Weber, Helene: "Frauenberufsarbeit und Frauenpersönlichkeit", DIE ChrISTLICHE FRAU, Abril 1932, (año 30), pp. 97-102

- "Eine Entscheidung über die Rechtsstellung der weiblichen Beamten", DiE CHRISTLICHE FRAU, Junio 1932, (año 30), pp.181-187

- $\quad$ "Volk und Staat. Eine Zeitgeschichtliche Betrachtung zur Frauenfrage", DIE CHRISTLICHE FraU, Octubre 1932, n¹0, pp.298-300

- $\quad$ "Die betende Frauengemeinschaft", Die ChristLiche FraU, Agosto/Septiembre 1934, n8/9, pp. 231-233

- "Der Katholische Deutsche Frauenbund. Sein Gesicht im Wandel der Zeit", Die CHRISTLICHE FRAU, Enero 1939, n¹, pp.2-6

Weber, Marianne: Frauenfragen und Frauengedanken. Gesammelte Aufsätz̨e, Tübingen, Paul Siebeck, 1919

- "Wahlmutterschaft", DiE FraU, Febrero 1935 (nº5), pp.260-269

- "Die Ehe als Daseinserfüllung", Die FrAU, Julio 1935 (nº10), pp.589-594

- $\quad$ "Die Frauen und die Liebe", DIE FraU, Noviembre 1935 (n²), pp.65-68

- "Zur Ethik des Geschlechtslebens", Die FraU, Diciembre 1936 (n³),

- "Zur Krisis des Frauenstudiums", Die FraU, Enero 1937 (nº), pp.218-224

- "Drei zeitgeborene Fragen über Christentum und Welt", DIE FraU, Junio 1940 (nº9), pp.169-172

Werfer, Fanny: "Christliche Ehe in katholischer Auffassung", DIE FRAU, Mayo 1933 (nº), pp.490-494

Widerholz, M.: "Volk", Evangelische Frauenzeitung, Octubre 1934 (año 36), pp.1-29

Willmer, Hermann: "Der Arbeitseinsatz der verheirateten Frau und seine Wirkung auf die Ehe", DIE FRAU, Octubre 1940 (nº1), pp.115-117

Winnecke, Hedwig: "Das unbekannte Heer", Evangelische FraEunZeitung, Febrero 1936 (año 37), pp.81-83

- "Ein Dokument", Evangelische FrauenZeitung, Enero 1937, pp. 62-63

Witte, H.: "Die Verantwortung der evangelischen Frau für die heutige Volkspflege", EvaNGELISCHE FRAUENZEITUNG, Marzo 1936 (año 37), pp.97-101

Witting, Gabriele: "Der Ausländerinnen-Einsatz in Deutschland", DIE FRAU, Mayo-JunioJulio $1944\left(\mathrm{n}^{\circ} 7 / 8 / 9\right)$, pp.84-86

Wolff, Emmy: "Die Frau im deutschen Volk", DIE FraU, Abril 1933 (nº7),

pp.421437 
Wünsche, Ilse: "Mutterschaft und Frauenarbeit im Tabakgewerbe", DIE FrAU, Febrero 1939 $\left(\mathrm{n}^{\circ} 5\right)$, pp.534-539

von Zahn-Harnack, Agnes: Die Frauenbewegung, Berlin, 1928

- "Schlußbericht über die Arbeit des Bundes Deutscher Frauenvereine", DIE FraU, Junio 1933 (nº), pp.551-555

- "Mütterschulung", Die FraU, Diciembre 1933 (n³), pp.146-149

- "Fünfundzwanzig Hausfrauen", DIE FraU, Julio 1939 (nº10), pp.510-517

Zarncke, Lily: "Der geistliche Sinn der Ehe bei Luther", DIE FRAU, Junio 1935 (nº9), pp.89-97 
Adorno, Theodor: Crítica cultural y sociedad, Madrid, Sarpe, 1984

Aguado, A; Capel, R.; Calbet, T.; Martinez López, C.; Nash, M.; Nielfa, G.; Ortega, M.; Pastor, R.; Ramos, D.; Rodriguez Galdo, M.; Tavera S.; Ugalde, M.: Textos para la bistoria de las mujeres en España, Madrid, Cátedra, 1994

Aicher-Scholl, Inge: Die weiße Rose, Frankfurt am Main, Fischer, 1983 (9ª d.)

Allen Taylor, Ann: "Mothers of the New Generation: Adele Schreiber, Helene Stöcker and the Evolution of a German Ideal of Motherhood", SIGNS, 1985 (año 20), pp.56-89

- Feminism and Motherhood in Germany 1800-1914, New Brunswick N.J., 1991

Anders, Marga; Reicke Ilse (ed.): Zabn-Harnack, Agnes. Scbriften und Reden 1914-1950, Tübingen, Hopfer Verlag, 1964

Andrae, Friedrich (ed.): Deutsche Demokratie von Bebel bis Heuss. Geschichte in Lebensbildern, Hamburg, Baken, 1964

Arendt, Hanna: The Origins of Totalitarism, New York, Harcourt Brace, 1951

Arendt, Hans Jürgen: "Die Gleichschaltung der bürgerlichen Frauenorganisationen in Deutschland 1933-1934", ZEITSCHRIFT FÜR GESCHICHTSWISSENSCHAFT, 1979 (año 27), pp.615-627

- "Die bürgerlichen Frauenorganisationen in der Weimarer Republik. Ein Überblick", JH. GESCHICHTE, 1989 (año 38), pp.167-200

Aurand, Daran; Stoehr, Irene: "Opfer oder Täter?", COURAGE, n¹1, 1982

Ayaß, Wolfgang: Das Arbeitshaus Breitenau. Bettler, Landstreicher, Prostituierte, Zubälter und Fürsorgeempfänger in der Korrektions- und Landarmenanstalt Breitenau 1874-1949, Kassel, Gesamthochschule Kassel, 1992

Bach, Marie Luise: Gertrud Bäumer. Biographische Daten und Texte zu einem Persönlichkeitsbild, Weinheim, Deutscher Studien Verlag, 1989

Bajohr, Stefan: "Weiblicher Arbeitsdienst im Dritten Reich. Ein Konflikt zwischen Ideologie und Ökonomie", VIERTELJAHRESSCHRIFT FÜR SOZIAL- UND WIRTSCHAFTSGESCHICHTE, 1980 (año 28), pp.331-357

- Die Hälfte der Fabrik. Geschichte der Franenarbeit in Deutschland

1914-1945, Marburg, Verlag Arbeiterbewegung und Gesellschaftswissenschaft, 1979

Barthes, Roland: Fragmente einer Sprache der Liebe, Frankfurt am Main, Suhrkamp, 1988

Bauer, Gerhard: Sprache und Sprachlosigkeit im "Dritten Reich", Köln, Bund Verlag, 1988 
Baum, Marie: Rückblick auf mein Leben, Heidelberg, Kerle Verlag 1950

- Anna von Gierke. Ein Lebensbild, Weinheim, Berlin, Julius Beltz, 1954

Baum, Gerhart: Der Lebensweg Gertrud Bäumers, Hohenlimburg 1973

Baumann, Ursula: Protestantismus und moderne Gesellschaft. "Frauenfrage" und Frauenbewegung in der evangelischen Kirche Deutschlands 1850-1920, Berlin, Dissertation, 1990

- "Religion und Emanzipation. Konfessionelle Frauenbewegung in Deutschland 19001933", Tel AVIVER JahrbuCH FÜr DEUTSCHE GeSCHICHTE, 1992 (año 21), pp.171206

Bäumer, Gertrud: Der nene Weg der deutschen Frau, Stuttgart, Deutsche Verlags-Anstalt, 1946

- Gestalt und Wandel. Frauenbildnisse, Berlin, Herbig, 1950

- Im Licht der Erinnerung, Tübingen, Wunderlich Verlag, 1953

Beckmann, Emmy (ed.): Gertrud Bäumer. Des Lebens wie der Liebe Band, Tübingen, Wunderlich Verlag, 1950

- $\quad$ "Sonderheft Gertrud Bäumer", MÄDCHENBILDUNG UND FrAuENSCHAFTEN, September 1953, año 3 .

- Was ich bier geliebt. Briefe von Helene Lange, Tübingen, Wunderlich Verlag, 1957

Beckmann, Emmy; Kardel, Elisabeth: Quellen zur Geschichte der Frauenbewegung, Frankfurt am Main-Berlin-Bonn, Moritz Diesterweg, 1955

Bender, Oskar: Der gerade Weg und der Nationalsozialismus: Ein Beitrag zur katholischen Widerstandspresse vor 1933, München, Tesis Doctoral, 1959

Bennholt-Thomsen, Veronika: "Zivilisation, moderner Staat und Gewalt. Eine feministische Kritik an Norbert Elias' Zivilisationstheorie", BEITRÄGE ZUR FEMINISTISCHEN THEORIE UND PRAXIS, 1985 (n¹3), pp.123-131

Benz, Ute (ed.): Frauen im Nationalsozialismus. Dokumente und Zeugnisse, München, Beck, 1993

- "Deutsche Frau und deutsche Mutter- die langen Wirkungen der Ideologisierung im Nationalsozialismus", en Niethammer, O.: Frauen und Nationalsorialismus. Historische und Kulturgeschichtliche Position, Osnabrück, Rasch, 1996

Bernecker, Walter: "La historiografía alemana reciente", HiSTORIA CONTEMPORÁNEA, 1992 $\left(\mathrm{n}^{\circ} 7\right)$, pp.31-49

Berning, Cornelia: Vom Abstammungsnachweis zum Zuchtwart. Vokabular des Nationalsozialismus, Berlin, Walter de Gruyter, 1964

Beuys, Barbara: Familienleben in Deutschland. Neue Bilder aus der deutschen Vergangenheit, Reinbek, Rowohlt, 1980

Bessel, Richard; Feuchtwanger, E.J. (eds.): Social Change and Political Development in Weimar Germany, London, Croom Helm, 1981 
Bleuel, Hans-Peter: Das saubere Reich. Theorie und Praxis des sittlichen Lebens im Dritten Reich. Ein bisher ungeschriebenes Kapitel deutscher Vergangenheit, Bern-München-Wien, Scherz, 1972

Blühm, Elger; Gebhardt, Hartwig: Presse und Geschichte II. Neue Beiträge zur historischen Kommunikationsforschung, München - London - New York - Oxford - Paris, K.G. Saur, 1987 pp. 349-363

Boak, Helen: "Women in Weimar Germany. The 'Frauenfrage' and the Female Vote", en: Bessel, Richard (ed.): Social Change and Political Development in Weimar Germany, London, Croom Helm, 1981, pp.155-173

- "Our Last Hope. Women’s Votes for Hitler. A Reappraisal", GERMAN STUdiEs REVIEW, 1989 (año 12), pp.289-310

- "Women in Weimar Politics", European History QuARTERLy, 1990 (año 20), pp.369-399

Boedeker, Elisabeth: Marksteine der deutschen Frauenbewegung von ibren Anfängen im 19. J.H. bis zum Neuanfang 1945 Boedeker, Hannover, Selbstverlag, 1968

Bock, Gisela: "Frauen und ihre Arbeit im Nationalsozialismus", en: Kuhn, A. / Schneider, A. (eds.): Frauen in der Geschichte, Düsseldorf, Schwann, 1979, pp.113-149

- "Zum Wohle des Volkskörpers. Abtreibung und Sterilisation im Nationalsozialismus", JOURNAL FÜR GESCHICHTE, 1980 (año 26), pp.58-65

- Maternity and Gender Politics. Women and the Rise of European Welfare States 1880s-1950s, London, 1981

- $\quad$ "Racism and Sexism in Nazi Germany. Motherhood, Compulsory Sterilization and the State", en: Bridenthal, Renate; Grossmann, Atina; Kaplan, Marion (eds.): When Biology Became Destiny, New York, 1984, pp.271-296

- Zwangssterilisation im Nationalsozialismus. Studien zur Rassenpolitik und Frauenpolitik, Opladen, Westdeutscher Verlag, 1986

- "Geschichte, Frauengeschichte, Geschlechtergeschichte", GESCHICHTE UND GESELLSCHAFT, 1988 (año 14), pp.364-391

- "Literaturbericht: 'Die Frauen und der Nationalsozialismus'. Bemerkungen zu einem Buch von Claudia Koonz", GESCHICHTE UND GESELLSCHAFT, 1989 (año 15), pp.563579

- $\quad$ "Políticas sexuales nacionalsocialistas e historia de las mujeres", en: Thebáud, Françoise: Historia de las mujeres. El siglo XX, Madrid, Taurus, 1993, pp.171-201

Boedeker, Elisabeth (ed.): Die Frau. Gesamtverzeichnis der Aufsätz̨, Hannover, 1968

Bohleber, Werner; Drews, Jörg: "Gift, das du unbewußt eintrinkst...". Sprache im Nationalsozialismus. Versuch einer historischen Argumentationsanalyse, Opladen, Westdeutscher Verlag, 1984

Bonhoeffer, Dietrich: Ethik, München, Christian Kaiser Verlag, 1988 (12ª ed., 1ªed. 1949)

Boyens, A.: "Widerstand der Evangelischen Kirche im Dritten Reich", en: Bracher, K.D.; Funke, M.; Jacobsen, H.A. (eds.): Nationalsozialistische Diktatur 1933-1945. Eine Bilanz, Bonn, Bundeszentrale für politische Bildung, 1986 
Bracher, K.D.; Funke, M.; Jacobsen, H.A. (eds.): Nationalsozialistische Diktatur 1933-1945. Eine Bilan₹, Bonn, Bundeszentrale für politische Bildung, 1986

Bracher, K.D.; Schulz, Gerhard; Sauer, Wolfgang: Die nationalsozialistische Machtergreifung. Studien zur Errichtung des totalitären Herrschaftssystems in Deutschland 1933/34, Bonn, Bundeszentrale für politische Bildung, 1974

Brezinsky, Friederich: Totalitarism, Dictatorship and Autocracy, New York, Frederik Praeger Publishers, 1968

Bridenthal, Renate: "Beyond Kinder, Kirche, Küche. Weimar Women at Work", CENTRAL EUROPEAN HISTORY, 1973 (nº), pp.148-166

Bridenthal, Renate; Grossmann, Atina; Kaplan, Marion (eds.): When Biology Became Destiny. Women in Weimar and Nazi Germany, New York, Schwann, 1984

Bridenthal, Renate; Koonz, Claudia: "Las Mujeres de Weimar en la Política", en: Amelang, James; Nash, Mary (eds.): Historia y Género. Las Mujeres en la Europa Moderna y Contemporánea, Valencia, Institució Valenciana d'Estudis i Investigació, Ed. Alfons El Magnánim, 1990

Broszat, Martin; Schwabe, Klaus, (eds.): Die deutschen Eliten und der Weg in den zweiten Weltkrieg, München, Beck'sche Reihe, 1989

Burggraf, Jutta: "Maria als Vorbild für die Frau", en: Bossle, Lothar; Pottier Joël (eds.): Christliche Literatur im Aufbruch. Im Zeichen Gertrud von Le Forts, Würzburg, Creator, 1988

Burghardt, Christina: Die deutsche Frau: Küchenmagd, Zuchtsau, Leibeigene im III. Reich. Geschichte oder Gegenwart?, Münster, Verlag Frauenpolitik, 1978

Buttler, Judith: Das Unbehagen der Geschlechter, Frankfurt am Main, Fischer, 1991

Carreras, Juan José (ed.): "El estado alemán 1870-1992", REVISTA AYER, 1992 (n5), pp.1125

Czarnowski, Gabriele: "Frauen - Staat - Medizin. Aspekte der Körperpolitik im Nationalsozialismus", BEITRÄGE ZUR FEMINISTISCHEN THEORIE UND PRAXIS, 1985 (nº14), pp.79-99

- "Familienpolitik als Geschlechterpolitik", en: Otto, Hans-Uwe; Sünker, Heinz (eds.): Soziale Arbeit und Faschismus, Frankfurt am Main, Suhrkamp, 1989, pp.130-156

Cosack, E.: 25 Jahre Katholischer Deutscher Frauenbund, Köln, s.a.

Corbin, Alain; Farge, Arlette; Perrot, Michelle: Geschlecht und Geschichte. Ist eine weibliche Geschichtsschreibung möglich?, Frankfurt am Main, Fischer, 1989, (Une histoire des femmes es-elle possible?, Paris, 1984)

Dammer, Susanne: Mütterlichkeit und Frauendienstpflicht. Versuche der Vergesellschaftung "weiblicher Fähigkeiten" durch eine Dienstverpflichtung. Deutschland 1890-1918, Weilheim, 1988 
- "Nationalsozialistische Frauenpolitik und soziale Arbeit", en: Otto, Hans-Uwe / Sünker, Heinz (eds.): Soziale Arbeit und Faschismus, Frankfurt am Main, Suhrkamp, 1989, pp.156175

Dahrendorf, Ralf: El conflicto social moderno. Ensayos sobre la política de la libertad, Madrid, Mondadori, 1988

von der Decken, Godele: Emanæipation auf Abwegen. Frauenkultur und Frauenliteratur im Umkreis des Nationalsozialismus, Frankfurt am Main, Athenäum, 1988

Denzler, Georg: Widerstand oder Anpassung? Katholische Kirche und Drittes Reich, München -Zürich, Piper, 1984

Denzler, Georg; Fabricius, Volker (eds.): Die Kirchen im Dritten Reich. Christen und Naz̨is Hand in Hand, Frankfurt am Main, Fischer, 1984

Delvendahl, Ilse; Marek, Moris: Deutscher Akademikerinnenbund. Die Frauenfrage in Deutschland. Bibliographie, München, K.G. Saur, 1979

Domarus, H. (ed.): Hitler - Reden und Proklamationen 1932-1945 (Vol.1), Würzburg, 1962

Dönhoff, Marion Gräfin: "Vorurteil statt Fakten", SÜDDEUTSCHE ZEITUNG, n 178, 5.08.1997, p. 9

Dovirat, E.: "Die Presse der Weimarer Zeit", Zeitungsverlag Und Zeitschriften VeRLAG, 1982, año $60, \mathrm{n}^{\circ} 13$

Duden, Barbara: "Die Frau ohne Unterleib", Feministische Studien, 1993, Cuardeno n 2, pp. 2433.

Dukes, Jack R. / Remak, J. (eds.): Another Germany. A Reconsideration of the Imperial Era, London, Boulder, 1988

Dürkop, Marlis: "Erscheinungsformen des Antisemitismus im Bund Deutscher Frauenvereine", Feministische Studien, n 1, 1985, pp. 140-149

Ebbinghaus, Angelika (ed.): Opfer und Täterinnen. Frauenbiograpbien des Nationalsozialismus, Nördlingen, Delphi, 1987

Eco, Umberto: "Urfaschismus", DIE ZEIT, 7.7 .1995 (nº28), p.48

Ehlich, Konrad: Sprache im Faschismus, Frankfurt am Main, Suhrkamp, 1989

Ehrle, Gertrud: Licht über dem Abgrund. Aufzeichnungen und Erlebnisse christlicher Frauen 1933-1945, Freiburg, Herder, 1951

- Jahrbundertwende, Jahrhundertmitte. De Katholsiche deutsche Frauenbund auf dem Wege. 1903-1953, Köln, Zentrale des Katholischen Deutschen Frauenbundes, 1953 
Eifert, Christiane; Epple, Angelika (eds.): Was sind Frauen? Was sind Männer? Geschlecbterkonstruktionen im bistorischen Wandel, Frankfurt, Suhrkamp, 1996

Elias, Norbert: Studien über die Deutschen. Macbtkä̈mpfe und Habitusentwicklung im 19. und 20. Jabrbundert, Frankfurt am Main, Suhrkamp, 1992

Evans, Richard J.: The Feminist Movement in Germany 1893-1933, London, 1976

- "German Women and the Triumph of Hitler, Journal of Modern History, Marzo 1976

- "Ascenso y triunfo del nazismo en Alemania", en: Cabrera, M.; Juliá, S.; Martín Aceña, P. (eds.): Europa en Crisis 1919-1939, Madrid, Editorial Pablo Iglesias, 1991

- "Modernization Theory and Women's History. Literaturbericht", ARCHIV FÜR SOZIALGESCHICHTE, 1980 (año 20), pp.492-514

Fels, Orla Maria: Die deutsche bürgerliche Frauenbewegung als juristisches Phänomen dargestellt an der Erscheinung Gertrud Bäumers, Dissertation, 1960

Fest, Joachim C.: Das Gesicht des Dritten Reiches. Profile einer totalitären Herrschaft, MünchenZürich, Piper, 1963

- Eine Biographie, Frankfurt am Main, Propyläen, 1973

Festinger, Leon: A Theory of Cognitive Dissonance, Evanstown, 1957

Fieg1, Verena: "Über den Zusammenhang von Staat - Militär - Prostitution", BEITRÄGE ZUR FEMINISTISCHEN THEORIE UND PRAXIS, 1985 (nº13), pp.123-145

Fischer, Fritz: "Zum Problem der Kontinuität in der deutschen Geschichte von Bismarck zu Hitler" en: Bracher, K.D.; Funke, M.; Jacobsen, H.A. (Ed.): Nationalistische Diktatur 19331945. Eine Bilan₹, Bonn, Schritenrihe der Bundeszentrale für politische Bildung, Band 192, 1986

Flemming, Jens; Saul, Klaus; Witt, Peter-Christian (eds.): Familienleben im Schatten der Krise. Dokumente und Analysen zur Sozialgeschichte der Weimarer Republik, Düsseldorf, Droste, 1988

Frandsen, Dorothea: Helene Lange, Hannover, Niedersächsiche Landeszentrale für Politische Bildung, 1974

Frauengruppe Faschismusforschung (ed.): Mutterkereuz und Arbeitsbuch. Zur Geschicbte der Frauen in der Weimarer Republik. und im Nationalsozialismus, Frankfurt am Main, Fischer, 1985

Frauen gegen Antisemitismus: Deri Nationalsozialismus als Extremform des Patriarchats. Zur Lengnung der Täterschaft von Frauen und zur Tabuisierung des Antisemitismus in der Auseinandersetzung mit dem NS, BEITRÄGE ZUR FEMINISTISCHEN THEORIE UND PRAXIS 35, 1883, pp. 77-89

Frevert, Ute: Franen-Geschichte. Zwischen bürgerlicher Verbesserung und neuer Weiblichkeit, Frankfurt am Main, Suhrkamp, 1986

- "Bewegung und Disziplin in der Frauengeschichte. Ein Forschungsbericht", GESCHICHTE UND GESELLSCHAFT, 1988 (año 14), pp.240-262 
- "Frauen an der 'Heimatfront", en : Kleßmann, Christoph (ed.): Nicht nur Hitlers Krieg. Der Zweite Weltkrieg und die Deutschen, Düsseldorf, Droste, 1989, pp.51-69

- Mann und Weib, und Weib und Mann. Gescblechter-Differenzen in der Moderne, München, Beck, 1995

Frei, Norbert; Schmitz, Johannes: Journalismus im Dritten Reich, München, Beck, 1989

Frey, Christofer: Die Theologie Karl Barths. Eine Einführung, Frankfurt, Athenäum, 1988

Fricke, Dieter: "Zur Erforschung konservativer Politik und Ideologie", ZEITSCHRIFT FÜR GESCHICHTE, 1979 (año 27), pp.1139-1155

- "Zur Geschichte der politischen Organisation der bürgerlichen Gesellschaft. Methodologische Probleme", ZEITSCHRIFT FÜr GESCHICHTE, 1985 (año 33), pp.683-688

Friedlander, Judith; Wiesen-Cook, Blanche; Kessler-Harris, Alice; Smith-Rosenberg, Carroll (eds.): Women in Culture and Politics. A Century of Change, Bloomington, Indiana University Press, 1986

Frind, Sigrid: Die Sprache als Propagandainstrument in der Publizistike des Dritten Reiches, untersucht an Hitlers "Mein Kampf" und den Kriegsjabrgängen des "Völkischen Beobacbter", Berlin, Ernst Reuter Gesellschaft, 1964

Foucault, Michel: Historia de la sexualidad. La voluntad de saber, Madrid, Siglo XXI, 1989 (17ª ed., $1^{a}$ ed. en francés 1976)

Galling, Kurt (Ed.): Die Religion in Geschicbte und Gegenwart. Handwörterbuch für Theologie und Religionswissenschaft, Tübingen, J.C.B. Mohr, 1958, $3^{\text {a }}$ ed.

García del Pozo, Rosario: Michel Foucault. Un arqueólogo del humanismo, estructuralismo, genealogía y apuesta estética, Sevilla, Universidad de Sevilla, 1988

Gellot, Laura; Phayer, Michael: "Dissenting Voices. Catholic Women in Opposition to Fascism", JOURNAL OF CONTEMPORARY HISTORY, 1987 (año 22), pp.91-114

Gerhard, Ute: "Über die Angänge der deutschen Frauenbewegung um 1848. Frauenpresse, Frauenpolitik und Frauenvereine", en: Hausen, K (ed.): Franen suchen ibre Geschichte. Historische Studien zum 19. Und 20 Jabrbundert, München, Beck, 1987

- Unerbört. Die Geschichte der deutschen Franenbewegung, Hamburg, Rowohlt, 1990

Geyer, Anna: "Die Bedeutung der Erwerbsarbeit verheirateter Frauen für die wirtschaftliche Lage und den Zusammenhalt der Familie", en: Flemming, Jens; Saul, Klaus; Witt, PeterChristian (eds.): Familienleben im Schatten der Krise. Dokumente und Analysen zur Sozialgeschichte der Weimarer Republike, Düsseldorf, Droste, 1988, pp.138-141

Giner, Salvador: Sociología, Barcelona, Nexos, 1987 ( $3^{\mathrm{a}} \mathrm{ed}$.)

Goldhagen, Daniel: Hitlers willige Vollstrecker. Gan₹ gewöhnliche Deutsche und der Holocaust, Berlin, Siedler, 1996 
Gollwitzer, Heinz: Vorüberlegungen zu einer Geschichte des politischen Protestantismus nach dem konfessionellen Zeitalter, Düsseldorf, Rheinisch-Westfälische Akademie der Wissenschaften, 1981

Gotto, Klaus; Hockerts, Günter; Repgen, Konrad: "Nationalsozialistische Herausforderung und kirchliche Antwort. Eine Bilanz", en: Bracher, K. D.; Funke, M.; Jacobsen, H.A. (eds.): Nationalsozialistische Diktatur 1933-1945. Eine Bilanz, Bonn, Bundeszentrale für politische Bildung, 1986, pp. 655-668

Götz von Olenhusen, Irmtraud (ed.): Wunderbare Erscheinungen. Frauen und Katholische Frömmigkeit im 19. Und 20. Jahrbundert, Paderborn-München-Wien-Zürich, Ferdinad Schöningh, 1995

Gravenhorst, Lerke; Tatschmurat, Carmen (eds.): Töchter-Fragen zur NS-Frauen-Geschichte, Freiburg, Kore, 1990

Greven-Aschoff, Barbara: Die bürgerliche Frauenbewegung in Deutschland 1894-1933, Göttingen, Vandenhoeck und Ruprecht, 1981

Griffin, Susan: Frau und Natur, Frankfurt am Main, Suhrkamp, 1978

Grossmann, Atina: "The New Woman and the Rationalization of Sexuality in Weimar Germany", en: Snitow, Ann; Stangel, Christine; Thompson, Sharon (eds.): Powers of Desire. The Politics of Sexuality, New York, Monthly Review Press, 1983, pp.153-171

- "Girlkultur or Thoroughly Rationalized Female. A New Woman in Weimar Germany?", en: Friedlander, Judith; Wiesen-Cook, Blanche; Kessler-Harris, Alice; Smith-Rosenberg, Carroll (eds.): Women Culture and Politics. A Century of Change, Bloomington, Indiana University Press, 1986, pp.62-80

Groth, Silvia: "Nationalsozialistische Körperpolitik", CLIO, 1985 (año 23), pp.8-10

Günsche, Karl-Ludwig: Phasen der Gleichschaltung. Stichtagsanalysen deutscher Zeitungen 1933-1938, Osnabrück, Dialogos, 1979

Hagemann, Karen: Frauenalltag und Männerpolitik. Alltagsleben und gesellschaftliches Handeln von Arbeiterfrauen in der Weimarer Republik, Bonn, Dietz, 1990

Haffner, Sebastian: Anmerkungen zu Hitler, Frankfurt am Main, Fischer, 1981

Hansen-Blancke, Dora: "Als Schülerinnen Gertruds Bäumers", Mädchenbildung und Frauenschaffen, Septiembre 1953

Haß, Ulrike: "Zum Verhältnis von Konservatismus, Mütterlichkeit und dem Modell der Neuen Frau", en: Schaeffer-Hegel, Barbara (ed.): Frauen und Macht. Der alltägliche Beitrag der Frauen zur Politik des Patriarchats, Pfaffenweiler, Centaurus, 1988

Haug, W. F.: Die Faschierung des bürgerlichen Subjekts. Die Ideologie der gesunden Normalität und die Ausrottungspolitiken im deutschen Faschismus, Berlin, Argument, 1985

Haupt, H.G.: "Mittelstand und Kleinbürgertum in der Weimarer Republik", ARCHIV FÜR SOZIALGESCHICHTE, 1986 (año 26), pp.217-238 
Hausen, Karin: "Die Polarisierung der 'Geschlechtscharaktere'. Eine Spiegelung der Dissoziation von Erwerbs- und Familienleben", en: Conze, Werner (ed.): Sozialgescbicbte der Familie in der Neuzeit Europas, Stuttgart, 1976, pp.363-393

- Frauen suchen ibre Geschicbte. Historische Studien zum 19. und 20. Jabrbundert, München, Beck, 1987

Hauser, H.: Geschichte des Films im Dritten Reich, München, Carl Hanser Verlag, 1975

Hausmann, Christian: Leitbilder in der katholischen Frauenbewegung der Bundesrepublik, Freiburg, Diss, 1973

Hennig, Eike: Bürgerliche Gesellschaft und Faschismus in Deutschland. Ein Forschungsbericht, Frankfurt am Main, Suhrkamp, 1977

Hermand, Jost: "All Power to the Women. Nazi Concepts of Matriarchy", JOURNAL OF CONTEMPORARY HISTORY, 1984 (año 19), pp.345-369

Heuss, Theodor: Politiker und Publirist. Aufsätze und Reden, Tübingen, Rainer Wunderlich Verlag, 1984

Heuss-Knapp, Elly: Ausblick vom Münsterturm. Erinnerungen, Tübingen, Wunderlich Verlag, 1954 $\left(4^{\mathrm{a}}\right.$ ed $)$

- Bürgern zweier Welten. Ein Leben in Briefen und Aufzeichnungen, Tübingen, Marg-Vater,1961

Hilpert, Christiania: Die Gescbicbte des Deutsch-Evangelischen Frauenbundes 1899-1914, Magisterarbeit, Ruhr-Universität Bochum, 1982

Hof, Renate: "Die Entwicklung der Gender Studies", en: Bußmann, H.; Hof, R.: Genus. Zur Geschlechterdifferen₹ in den Kulturwissenschaften, Stuttgart, Alfred Kröner Verlag, 1995

Hofer, Walther (ed.): Der Nationalsozialismus. Dokumente 1933-1945, Frankfurt am Main, Fischer, 1977

Holm, Helene: "Geschichte der Frauenfrage und Frauenbewegung. Bericht und Bibliographie", JAHRESBIBLIOTHEK DER ZEITGESCHICHTE, 1980 (año 51), pp.401-446

Huber, W.: Gertrud Bäumer, Augsburg, 1970

Hüttenberg, Peter (ed.): "Vorüberlegungen zum "Widerstandsbegriff" en: Kocha, Jürgen: Theorien in der Praxis des Historikers, Geschichte und Gesellschaft. Zeitschrift für Historische Sozialwissenschaft, Sonderheft 3, Göttingen1977, pp.117-139

- Bibliographie zum Nationalsozialismus, Göttingen, 1980

- "Policracía nacionalsocialista", REVISTA AYER, 1992 (nº5), pp.159-190

Jacobi, Juliane: "Töchter-Fragen zur NS-Frauen-Geschichte", FEMINISTISCHE STUDIEN, 1992 $\left(n^{\circ} 1\right)$, pp.131-141 
Jacobsen, Hans-Adolf; Jochmann, Werner (eds.): Ausgewählte Dokumente zur Gescbichte des Nationalsozialismus (Loseblatt-Sammlung), Bielefeld, Universität Bielefeld, 1961

Jaschke, Hans-Gerd: "Zur politischen Orientierung von Frauen und Frauenverbänden in der Weimarer Republik", en: Lehnert, Detlef; Mergele, Klaus (eds.): Teillkulturen zwischen Integration und Polarisierung, Frankfurt am Main, Westdeutscher Verlag, 1990, pp.143-160

Jurczyk, Karin: Frauenarbeit und Frauenrolle. Zum Zusammenhang von Familienpolitik und Frauenerwerbsarbeit 1918-1945, Frankfurt am Main, Campus, 1978

Kaiser, Jochen-Christoph: "Kirchliche Frauenarbeit in Westfalen. Ein Beitrag zur Geschichte des Provinzialverbandes der Westfälischen Frauenhilfe 1906-1945", en: Jahrbuch für westfälische Kirchengeschichte 74, 1981, p. 159-190

- "Das Frauenwerk der deutschen evangelischen Kirche. Zum Problem des Verbandsprotestantismus im Dritten Reich, in: Dollinger, Heinz (ed): Weltpolitik -Europagedanke- Regionalismus, Festschrift für Heinz Gollwitzer, Münster 1982

- Frauen in der Kirche. Evangelische Franenverbände im Spannungsfeld von Kirche und Gesellschaft 1890-1945, Quellen und Materialien, Düsseldorf, Schwann, 1985

- "Das Frauenwerk der Deutschen Evangelischen Kirche. Zum Problem des Verbandsprotestantismus im Dritten Reich", en: Götz von Olenhusen, I.: Frauen unter dem Patriarchat der Kirchen. Katholikinnen und Protestantinnen im 19. Und 20. Jahrbundert, Stuttgart, Berlin, Köln, Kohlhammer, 1995

Kall, Alfred: Katholische Franenbewegung in Deutschland. Eine Untersuchung zur Gründung katholischer Frauenvereine im 19. Jabrbundert, Paderborn, 1983

Kater, Michael: "Frauen in der NS-Bewegung", VIERTELJAHRESHEFTE FÜR ZEITGESCHICHTE, 1983 (año 13), pp.202-239

Katholischer Deutscher Frauenbund: Elisabeth Gnauck-Kübne. Wegbereiterin katholischer Franenbewegung, Hildesheim, 1992

Kaplan, Marion: "Schwesterlichkeit auf dem Prüfstand. Feminismus und Antisemitismus in Deutschland, 1904-1938", FEMINISTISCHE STUDIEN n 3, 1984, pp. 128-139

Kaufmann, Doris: "Vom Vaterland zum Mutterland. Frauen im katholischen Milieu der Weimarer Republik", en: Hausen, Karin (ed.): Frauen suchen ibre Geschichte. Historische Studien zum 19. und 20. Jabrbundert, München, Beck, 1983, pp.250-275

- "Die Begründung und Politik einer evangelischen Frauenbewegung in der Weimarer Republik", en: Dalhoff, Jutta; Frey, Uschi; Schöll, Ingrid (eds.): Frauenmacht in der Geschichte. Beiträge des Historikerinnentreffens 1985 zur Frauengeschichtsforschung, Düsseldorf, Schwann, 1986, pp.380-389

- Frauen zwischen Aufbruch und Reaktion. Protestantische Frauenbewegung in der ersten Hälfte des 20. Jahrbunderts, München; Zürich, Piper, 1988

- Religion und Emanzipation: Konfessionelle Frauenbewegung in Deutschland 1900-1936", en: Götz von Olenhusen, I.: Frauen unter dem Patriarchat der Kirchen. Katholikinnen und Protestantinnen im 19. Und 20. Jabrbundert, Stuttgart-Berlin-Köln, Kohlhammer, 1995 
Kaufmann, Friedrich: Rat und Tat. Elly Heuss-Knapp. Nachklang eines Lebens, Tübingen, Rainer Wunderlich Verlag, 1964

Keifer, Ellen: "Frauendiskriminierung im Nationalsozialismus", ZEITSCHRIFT FÜR GESELLSCHAFTSPOLITIK, 1978 (año 32), pp.91-98

Kellner, Hanna: Die Evangelische Frauenzeitung 1930-1941, Arbeit zum Ersten Staatsexamen, Göttingen, 1993

Kempowski, Walter: Haben Sie Hitler gesehen? Deutsche Antworten, München, Goldmann, 1979

Kershaw, Ian: Der Hitler-Mythos. Volksmeinung und Propaganda im Dritten Reich, Stuttgart, Deutsche Verlags-Anstalt, 1980

- Hitlers Macbt. Das Profil der NS-Herrschaft, München, Deutscher Taschenbuch-Verlag, 1992

Klausener, Erich: Frauen in Fesseln. Hoffnung in der Finsternis. Von Mut und Opfer katholischer Frauen im Dritten Reich, Berlin, Morus, 1982;

Kleinwächter, Johannes: Frauen und Männer des christlichen Widerstands. 13 Profile, Regensburg, Friedrich Pustet, 1990.

Klemperer, Victor: LTI. Lingua Tertii Imperii. Die Sprache des Dritten Reichs, Frankfurt am Main, Röderber, 1982

- Ich will Zeugnis ablegen bis zum letžten, Berlin, Aufbau-Verlag, 1995

Klimmer, Dagmar: The Social Position of Women in Weimar and Nazi Germany. Retention of the Status quo?, Adelaide, Thesis presented at the University of Adelaide, 1989

Klinsiek, Dorothee: Die Fran im NS-Staat, Stuttgart, Deutsche Verlags-Anstalt, 1982

Kokula, Ilse: "Zur Situation lesbischer Frauen während der NS-Zeit", BEITRÄGE ZUR FEMINISTISCHEN THEORIE UND PRAXIS, 1989 (nº25-26), pp.67-85

Kolb, Eberhard: Die Weimarer Republik, München, Oldenburg Verlag, 1993, $3^{\circ} \mathrm{ed}$

Königs, Cosima: Die Frau im Recht des Nationalsozialismus. Eine Analyse ibrer familien-, erb- und arbeitsrechtlichen Stellung, Frankfurt am Main, Peter Lang, 1988

Koonz, Claudia: "Nazi Women before 1933. Rebels against Emancipation", SOCIAL SCIENCE QUARTERLY, 1976, pp.553-563

- "Das 'zweite’ Geschlecht im Dritten Reich", Feministische Studien, 1986 (n²), pp.1433

- "Reaktionen katholischer und protestantischer Frauen in Deutschland auf die nationalsozialistische Sterilisationspolitik 1933-1937", en: Siegele-Wenschkewitz, Leonore; Stuchlik, Gerda (eds.): Franen und Faschismus in Europa, Freiburg, Centaurus, 1988

- Mütter im Vaterland. Frauen im Dritten Reich, Freiburg, Kore, 1991

Koselleck, Reinhart; Gadamer, Hans-Georg: Hermeneutik und Historik, Sitzungsberichte der Heidelberger Akademie der Wissenschaften, Heidelberg, Carl Winter, 1987 
Koselleck, Reinhart: "Sozialgeschichte und Begriffsgeschichte, en: Schieder, Wolfgang; Sellin, Volker (eds.): Sozialgeschichte in Deutschland, Göttingen, Vandehoeck \& Ruprecht, 1986

- Bildungsbürgertum im 19. Jabrbundert, Stuttgart, Klett-Cotta, 1990

Kottye Raymund; Moeller, Bernd: Ökumenische Kirchengescbicbte 3, München, Christian Kaiser Verlag, 1989

Krabbel, Gerta: Selig sind des Friedens Wächter. Katholische Deutsche Frauen aus den letzten bundert Jahren, Münster, Regensberg, 1949

- Aus der Arbeit des Katholischen Deutschen Frauenbundes, Köln, Katholische Deutsche Frauenbund, 1959

Kraft, Sybille (Cood.): Frauenleben in Bayern: Vor der Jabrbundertwende bis zur Trümmerzeit, München, Bayerische Landeszentrale für politische Bildungsarbeit, 1993

Kramer, H.: "Veränderung der Frauenrolle in der Weimarer Republik", BEITRÄGE ZUR FEMINISTISCHEN THEORIE UND PRAXIS, 1981 (nº5), pp.23-45

Krumwiede, Hans-Walter: Evangelische Kirche und Theologie in der Weimarer Republik, NeukirchenVluyn, Neukirchener Verlag, 1990

Kuhn, Annette; Rothe, Valentine (eds.): Frauen im deutschen Faschismus. Eine Quellensammlung mit fachwissenschaftlichen und fachdidaktischen Kommentaren (Band 1: Frauenpolitik im NS-Staat, Band 2: Frauenarbeit und Frauenwiderstand), Düsseldorf, Schwann, 1982-83

Kuhn, Annette; Schneider, G. (eds.): Frawen in der Geschichte, Düsseldorf, Schwann, 1979

Kühnl, Reinhard: Liberalismo y fascismo. Dos formas de dominio burgués, Barcelona, Editorial Fontanella, 1982

La Chevallerie, Elonore von: Gertrud von Le Fort. Wirken und Wirkung, Heidelberg, Heidelberger Bibliotheksschriften, 1983

Landweer, Hilge: "Kritik und Verteidigung der Kategorie Geschlecht", FEMINISTISCHE STUDIEN, 1993, Cuardeno n 2, pp. 34-43

Laqueur, Walter (ed.): Fascism. A Reader's Guide. Analyses, Interpretations, Bibliography, Los Angeles, Berkley, 1976

Lemker, Marianne: Frauen im Nationalsozialismus, Frankfurt am Main, Materialis Verlag, 1984

Lethmair, Thea: Die Franenbeilage der "Frankfurter Zeitung". Ibre Struktur - ibre geistigen Grundlagen, München (Dissertation), 1957

Lindt, Andreas: Das Zeitalter des Totalitarismus. Politische Heilslebre und ökumenischer Auffruch, Stuttgart, 1981 
Lindemann, Gesa: "Wider Verdrängung des Leibes aus der Geschlechtskonstruktion, ", FEMINISTISCHE STUDIEN, 1993, Cuardeno no 2, p. 44-54

Lion, Hilde: Zur Soziologie der Franenbewegung. Die sozialistische und die katholische Frauenbewegung, Berlin, F.A. Herbig, s.a.

Lixl-Purcell, Andreas (ed.): Erinnerungen deutsch-jüdischer Frauen 1900-1990, Leipzig, Reclam, 1992

Lott, Silvia: Die Frauenzeitscbriften von Hans Hultzly und John Jabr. Zur Gescbichte der deutschen Frauenzeitschriften zwischen 1933 und 1970, Berlin, Volker Spieß, 1985

Löwenthal, Richard: "Deutsche Opposition gegen das NS-Regime", en: Bracher, K.D.; Funke, M.; Jacobsen, H.A. (eds.): Nationalsozialistische Diktatur 1933-1945. Eine Bilanz, Bonn, Schriftenreihe der Bundeszentrale für politische Bildung, 1986, pp.618-632

Lozano, Jorge: El discurso historico, Madrid, Alianza Universidad, 1987

Lück, Margret: Die Frau im Männerstaat. Die gesellschaftliche Stellung der Fran im Nationalsozialismus, Frankfurt am Main, Peter Lang, 1979

Lüders, Marie-Elisabeth: Fürchte dich nicht. Persönliches und Politisches aus mehr als 80 Jahren, KölnOpladen, Westdeutscher Verlag, 1963

Maser, Werner (ed.): Hitlers Briefe und Notizen. Sein Weltbild in handschriftlichen Dokumenten, Düsseldorf-Wien, 1973

Mason, Timothy: "Zur Frage der Frauen in Deutschland 1930-1940", BEITRÄGE ZUR MARXSCHEN THEORIE, 1976 (año 6), pp.118-193

- "Women in Germany 1925-1940. Family, Welfare and Work" (part I and II), HISTORY WORKSHOP. A JOURNAL OF SOCIALIST HISTORIANS, part I: 1976 (primavera), pp.74-113 / part II: 1976 (otoño), pp.5-32

- Sozialpolitik im Dritten Reich: Arbeiterklasse, Volksgemeinschaft, Opladen, Westdeutscher Verlag, 1977

Mass, Utz: "Als der Geist der Gemeinschaft eine Sprache fand". Sprache im Nationalsozialismus. Versuch einer historischen Argumentationsanalyse, Opladen, Westdeutscher Verlag, 1984

Meding, Dorothee: Mit dem Mut des Herzens. Die Frauen des 20. Juli, Berlin, Siedler, 1992

Mehnert, Gottfried: Evangelische Presse. Geschichte und Erscheinungsbild von der Reformation bis zur Gegenwart, Bielefeld, Luther-Verlag, 1983

Meyerhofer, Nicolas J.: Gertrud von Le Fort, Berlin, Morgenbuch Verlag, 1993;

Moltmann-Wendel, Elisabeth: Frau und Religion. Gotteserfabrungen im Patriarchat, Frankfurt am Main, Fischer, 1983

Mosse, George: Der nationalsozialistische Alltag, Frankfurt am Main, Athenäum, 1993 
Mybes, Fritz: Geschichte der Evangelischen Frauenhilfe in Quellen, Gladbeck, SchriftenmissionsVerlag, 1975

- Agnes von Grone und das Frauenwerk der Deutschen Evangelischen Kirche, Düsseldorf, Presseverband der Evangelischen Kirche im Rheinland, 1981

- "Widerstand wider Willen. Das Verfahren gegen Agnes von Grone vor den Gerichten der NSDAP", MONATSHEFTE FÜR EVANGELISCHE KIRCHENGESCHICHTE DES RHEINLANDES, 1986 (año 35), pp.221-250

Nave-Herz, Rosemarie: Die Geschichte der Frauenbewegung in Deutschland, Bonn, Bundeszentrale für politische Bildung,1993

Niethammer, Otrun: "Holocaust und Gedächtnis: Autobiographien von nationalsozialistischen Autorinnen" en : Niethammer, O.: Frauen und Nationalsorialismus. Historische und kulturgeschichtliche Positionen, Osnabrück, Universitätsverlag Rasch, 1996

Nipperdey, Thomas; Doering-Manteuffel, Anselm; Thamer, Hans-Ulrich: Weltbürgerkerieg der Ideologien. Antworten an Ernst Nolte, Frankfurt am Main, Propyläen, 1993

van Norden, Günther: "Politischer Protestantismus in Deutschland", NEUE POLITISCHE LITERATUR, 1978 (año 23), pp.34-45

van Norden, Günther; Mybes, Fritz (eds.): Evangelische Franen im Dritten Reich, Düsseldorf, Presseverband der Evangelischen Kirche im Rheinland, 1979

Nowak, Kurt: "Coercive Sterilization in Nazi Germany", Simon Wiesenthal Center ANNUAL, 1987 (n4), pp.371-381

- "Sterilisation und 'Euthanasie' im Dritten Reich. Tatsachen und Deutungen", GESCHICHTE IN WISSENSCHAFT UND UNTERRICHT, 1988 (año 39), pp.327-341

Nowak, Kurt; Raulet, Gérard (ed.): Protestantismus und Antisemitismus in der Weimarer Republik, Frankfurt-New York, Campus, 1994

Nummer-Winkler, Gertrud (Ed): Weibliche Moral. Die Kontroverse um eine geschlechtsperifische Ethik, München, DTV, 1995

Oberman, Heiko A.: Lutero. Un hombre entre Dios y el diablo, Madrid, Alianza Editorial, 1992 ( $1^{\mathrm{a} e d}$. en alemán 1982)

Otto, Hans-Uwe; Sünker, Heinz (eds.): Soziale Arbeit und Faschismus. Volkspflege und Pädagogik im Nationalsozialismus, Frankfurt am Main, Suhrkamp, 1989

Pankoke-Schenk, Monika: "Katholizismus und Frauenfrage", en: Rauscher, Anton (ed.): Der soziale und politische Katholizismus. Entwicklunslinien in Deutschland 1803-1963, München-Wien, Günter Olzog Verlag, 1982

Pauls, Maria: Die deutschen Frauenorganisationen. Eine Übersicht über den Bestand, die Ursprünge und die kulturellen Aufgaben, Diss, Aachen, 1966 
Paulsen, Anna: Elly Heuss-Knapp. Zeugnisse ihres Wirkens, Stuttgart, Calwer Verlag, 1959

Petzina, Dietmar: "Die Mobilisierung deutscher Arbeitskräfte vor und während des 2. Weltkrieges", VIERTELJAHRESHEFTE FÜR ZEITGESCHICHTE, 1970, Heft 4

Peukert, Detlev: Die Weimarer Republik, Frankfurt am Main, Suhrkamp, 1987

Phayer, Michael: "Protestant and Catholic Women Confront Social Change", en: Dukes, J. R.; Remak, J.: Another Germany. A Reconsideration of the Imperial Era, London, Boulder, 1988

- Protestant and Catholic Women in Nazi Germany, Detroit, Wayne State University Press, 1990

Pini, Udo: Leibeskult und Liebeskitsch. Erotik im Dritten Reich, München, Klinkhardt und Biermann, 1992

Pithan, Annebelle (ed.): Religionspädagoginnen des 20. Jahrhunderts, Göttingen-Zürich, Vandenhoeck \& Ruprecht, 1997

Pregardier, Elisabeth; Mohr, Anne: Politik als Aufgabe christlicher Franen in der Weimarer Republik, Anweiler- Essen, Plöger, 1990

- Helene Weber (1881-1962), Ernte eines Lebens. Weg einer Politikerin, Essen, Plöger, 1991

- Der Beitrag der christlichen Frauenbewegung zur politischen Kultur in Deutschland, Schriften des KDFB, n², 1994

Prinz, M.: Vom neuen Mittelstand zum Volksgenossen, München, 1986

Prokop, Ulrike: "Die Sehnsucht nach der Volkseinheit. Zum Konservatismus der bürgerlichen Frauenbewegung vor 1933", en: Dietze, Gabriele (ed.): Die Überwindung der Sprachlosigkeit. Texte aus der neuen Frauenbewegung, Darmstadt, Luchterhand, 1981, pp.186-202

Puleo, Alicia H.: Dialéctica de la sexualidad. Género y sexo en la filosofía contemporánea, Madrid, Cátedra, 1992

Pusch, Luise (Ed.): Feminismus. Inspektion der Herrenkultur. Ein Handbuch, Frankfurt am Main, Surhkamp, 1983

de Ras, Marion: Körper, Eros und weibliche Kultur. Mädchen im Wandervogel und in der Bündischen Jugend 1900-1933, Pfaffenweiler, 1988

Rauscher, Anton (ed.): Geschichte und Staat. Der soziale und politische Katholizismus. Entwicklungslinien in Deutschland 1803-1963, München, Günter Ulzog, 1982

Reagin, Nancy, R.: Class and Gender in Hanover, 1880-1933, Chapel Hill \& London, University of North Carolina Press, 1995

Reese-Nübel, Dagmar: "Kontinuitäten und Brüche in den Weiblichkeitskonstruktionen im Übergang von der Weimarer Republik zum Nationalsozialismus", en: Otto, Hans; Sünker, Heinz (eds.): Soziale Arbeit und Faschismus, Frankfurt am Main, Suhrkamp, 1989, pp.109-129 
Reicke, Ilse: Die großen Frauen der Weimarer Republik. Erlebnisse im "Berliner Frübling", Frankfurt am Main, Suhrkamp, 1989

Romero, José Luis: Estudio de la mentalidad burguesa, Madrid, Alianza Editorial, 1987

Rohr, Barbara: Die allmähliche Schärfung des weiblichen Blicks. Eine Bildungsgeschichte zwischen Faschismus und Frauenbewegung, Berlin, Argument, 1992

Van Roon, Ger: Widerstand im Dritten Reich. Ein Überblick, München, Beck Verlag, 1987, p. 82, $\left(1^{\mathrm{a}}\right.$ ed.1979)

Rauh-Kühne, Cornelia: „Katholikinnen zwischen Vereinnahmung und Resistenz“, en: Wickert, Christl: Frauen gegen die Diktatur. Widerstand und Verfolgung im nationalsozialistischen Deutschland, Berlin, Hentrich, 1995

Rosenberg, Arthur: Geschichte der Weimarer Republik, Hamburg, Europäische Verlagsanstalt, 1991 (1ª ed. 1946)

Rupp, Leila J.: "Klassenzugehörigkeit und Arbeitseinsatz der Frauen im Dritten Reich", SOZIALE WELT. ZEITSCHRIFT FÜR SOZIALWISSENSCHAFTLICHE FORSCHUNG UND PRAXIS, 1980 (n²), pp.191-205

Sack, Brigitte: "Katholische Frauenbewegung, Katholische Jugendbewegung und Politik in der Weimarer Republik: Standorte, Handlungspielräume und Grenzen im Kontext des Generationskonflikts", en: Götz von Olenhusen, I.: Frauen unter dem Patriarchat der Kirchen. Katholikinnen und Protestantinnen im 19. Und 20. Jahrhundert, Stuttgart-Berlin-Köln, Kohlhammer, 1995

Sáez Arance, Antonio: "El honor de burgués. A propósito de la historia social del duelo en Alemania", Historia CONTEMPORÁNEA, 1991 (nº), pp.255-264

Sagarra, Eda: "Recent Feminist Scholarship in the Field of German Studies. A Review Essay", INTERNATIONALE SOZIALGESCHICHTE, 1993 (n³), pp.113-158

Schaub, Roland: Die Geschichte der Katholischen Frauenbewegung in Deutschland bis 1914, Freiburg, Zulassungsarbeit, 1970

Scheich, Elvira (ed.): Vermittelte Weiblichkeit. Feministische Wissenschafts- und Gesellschaftstheorie, Hamburg, Edition, 1996

Schmidt-Harzbach, Ingrid: "Eine Woche im April. Berlin 1945. Vergewaltigung als Massenschicksal", FEMINISTISCHE STUDIEN, 1984 (n³), pp.51-65

Schmidt-Waldherr, Hiltraud: Emanzipation durch Professionalisierung? Politische Strategien und Konflikte innerhalb der bürgerlichen Frauenbewegung während der Weimarer Republik und die Reaktion des bürgerlichen Antifeminismus und des Nationalsozialismus, Frankfurt am Main, Falta Verlag, 1987

- "Pervertierte Emanzipation und die Organisation von weiblicher Öffentlichkeit im Nationalsozialismus", en: Schaeffer-Hegel, Barbara (ed.): Frauen und Macht. Der alltägliche Beitrag der Frauen zur Politik des Patriarchats, Pfaffenweiler, Centaurus, 1988, pp.10-35 
Schneider-Lüdorff, Guy en: Religionspädagoginnen des 20. Jahrbunderts, Göttingen-Zürich, Vandehoeck \& Ruprecht, 1997

Schiffler, L.: Dei Antwort der Frau in der sich ändernden Welt, Münster, Regensberg, 1969

Scholder, Klaus: Die Kirchen und das Dritte Reich (Band 1: Vorgeschichte und Zeit der Illusionen 19181934), Frankfurt am Main / Berlin / Wien, 1977

- Die Kirchen zwischen Republik und Gewaltherrschaft, Frankfurt am Main, Siedler, 1983

Scholtz-Klink, Gertrud: Die Frau im Dritten Reich. Eine Dokumentation, Tübingen, Grabert Verlag, 1978

Schomburg, Petra: "Frauen im Nationalsozialismus. Ein Überblick über die historische Frauenforschung und die feministische Diskussion um Verantwortung und Beteiligung von Frauen am Nationalsozialismus", en: Niethammer, O. (ed.): Frauen und Nationalsozialismus. Historische und Kulturgeschichtliche Positionen, Osnabrück, Universitäts Verlag, Rasch, 1996

Schoenbaum, David: Die Braune Revolution. Eine Sozialgeschichte des Dritten Reiches, Köln, Kiepenheuer \& Witsch, 1980

Schroeder, Louise: Ein Frauenleben unser Zeit, Berlin, Arami, 1956

Schubert, Helga: Judasfrauen. Zehn Fallgeschichten weiblicher Denunziation im Dritten Reich, Freiburg, Kore, 1990

Schulin, E.: "El desarrollo de la historia social en la historiografía alemana posterior a 1945", La historia social de España. Actualidad y perspectivas. Actas del I Congreso de la Asociación de Historia Social, Zaragoza, septiembre, 1990, Madrid, Siglo XXI, 1991, pp. 27-46

See, Wolfgang; Weckerling, Rudolf: Frauen im Kirchenkampf. Beispiele aus der Bekennenden Kirche Berlin-Brandenburg 1933 bis 1945, Berlin, Wichern-Verlag, 1984

Seeger, Jutta: Das Wesen der deutschen allgemeinen Frauenzeitschrift unter besonderer Berücksichtigung von DIE FRAU (1893-1944), München, Dissertation, 1953

Seiterich, Bernhard: Demokratische Publizistik gegen den deutschen Faschismus: Die DEUTSCHE REPUBLIK, eine politische Wochenschrift der späten Weimarer Republik. Ein Beitrag zur Geschichte der demokratischen Presse, Frankfurt am Main, Peter Lang, 1988

Siegele-Wenschkewitz, Leonore; Stuchlik, Gerda (eds.): Franen und Faschismus in Europa, Pfaffenweiler, Centaurus, 1990

- "Die Rezeption und Diskussion der Genus-Kategorie in der theologischen Wissenschaft", en: Bußmann, H.; Hof, R.: Genus. Zur Geschlechterdifferenz in den Kulturwissenschaften, Stuttgart, Alfred Kröner Verlag, 1995

Smelzer, Neil; Warner, Stephen: Teoría sociológica. Análisis histórico y formal, Madrid, EspasaCalpe, 1982

Smid, Marikje: Deutscher Protestantismus und Judentum 1922-1933, München, 1990 
Smith, Arthur: Die Hexe von Buchenwald. Der Fall Ilse Koch, Köln- Wien, 1983

Snitow, Ann; Stansel, Christine; Thompson, Sharon (eds.): Powers of Desire. The Politics of Sexuality, New York, Monthly Review Press, 1983

von Soden, Kristina: Die Sexualberatungsstellen der Weimarer Republik. 1919-1933, Berlin, Hentrich, 1988

Sorge, Elga: Religion und Frau. Weibliche Spiritualität im Christentum, Stuttgart-Berlin-Köln-Mainz, Kohlhammer, 1985

Stephan, Werner: Aufstieg und Verfall des Linksliberalismus 1918-1933. Geschichte der Deutschen Demokratischen Partei, Göttingen, Vandenhoeck \& Ruprecht, 1973

- Joseph Goebbels. Dämon einer Diktatur, Stuttgart, Union Deutsche Verlagsgesellschaft, 1949,

Stephenson, Jill: Women in Naz̨i Society, London, Croom Helm, 1975

- "Nationalsozialistischer Dienstgedanke. Bürgerliche Frauenorganisationen im Dritten Reich", GESCHICHTE UND GESELLSCHAFT, 1981 (año 7), pp.555-571

- The Nazi Organisation of Women, London, Croom Helm, 1981

Sternheim-Peters, Eva: Die Zeit der großen Täuschungen. Mädchenleben im Faschismus, Bielefeld, AJZ Verlag, 1987

Stoehr, Irene: "Macht ergriffen?. Deutsche Frauenbewegung 1933", COURAGE, 8, 1983, pp. $24-$ 32

- Emanzipation zum Staat? Der Allgemeine Deutsche Franenverein - Deutscher Staatsbürgerinnenverband 1893-1933, Pfaffenweiler, Centaurus, 1990

Strobl, Ingrid: "Mütter im Vaterland", KONKRET, Februar 1992, pp.49-51

Stroech, Jürgen: Die Illegale Presse. Eine Waffe im Kampf gegen den deutschen Faschismus. Ein Beitrag zur Geschichte und Bibliographie der illegalen antifaschistischen Presse 1933-1939, Frankfurt am Main, Röderberg-Verlag, 1979

Strothmann D.: Nationalsozialistische Literaturpolitik. Ein Beitrag zur Publizistik im Dritten Reich, Bonn, Bouvier Verlag, 1985

Studer, Brigitte: "Das Geschlechterverhältnis in der Geschichtsschreibung und in der Geschichte des 19. und 20. Jahrhunderts", FeministisCHE STUDIEN, 1989 (n¹)

Stumpfe, Gertrud: "Lebensbilder deutscher Politikerinnen", POLITISCHE STUDIEN, 1959 (año 10), pp.670-684

Sveistrup, Hans; von Zahn-Harnack, Agnes: Die Frauenfrage in Deutschland. Strömungen und Gegenströmungen 1790-1930, Tübingen, Hopfer, 1961

Szepansky, Gerda: "Blitzmädel", "Heldenmutter", "Kriegerwitwe". Frauenleben im Zweiten Weltkrieg, Frankfurt am Main, Fischer, 1986 
Teusch, Christine: Im Dienst der Stunde. Aus Lebensweg und Lebenswerk von Elly Heuss-Knapp, Nürnberg, Deutsches Mütter-Genesungswerk,1953

Thalmann, Rita: Frausein im Dritten Reich, München, Carl Hanser Verlag, 1984

Thebáud, Françoise: Historia de las mujeres. El siglo XX, Madrid, Taurus, 1993

Theweleit, Klaus: Männerphantasien, Frankfurt am Main, Fischer, 1987

Thornton, M.J.: El nazismo 1918-1945, Barcelona, Tau, 1967

Thürmer-Rohr, Christine: Vagabundinnen. Feministischen Essays, Berlin, Orlanda Frauenverlag, $1987,3^{\mathrm{a}}$ ed.

Tid1, Georg: Die Fran im Nationalsozialismus, Wien, 1984

Losseff-Tillmann, G.: Frauenemanzipation und Gewerkschaften (1800-1975), Diss., Bochum 1975

Todorow, Almut: "Frauen im Journalismus der Weimarer Republik", INTERNATIONALE SOZIALGESCHICHTE, 1991 (n¹6), pp.84-103

Tröger, Annemarie: Die Dolchstoßlegende der Linken: "Frauen haben Hitler an die Macht gebracht". Thesen zur Geschichte der Frauen am Vorabend des Dritten Reichs, en: Frauen und Wissenschaft. Beiträge zur Berliner Sommeruniversität für Frauen, Berlin, 1977

- "The Creation of a Female Assembly-Line Proletariat", en: Bridenthal, Renate; Grossmann, Atina; Kaplan, Marion (eds.): When Biology Became Destiny. Women in Weimar and Nazi Germany, New York, Schwann, 1984, pp.237-270

Ulich-Beil, Else: Ich ging meinen Weg. Lebenserinnerungen, Berlin, Herbig Verlag, 1961

- "Aus persönlichen Erinnerungen", Mädchenbildung und Frauenschaffen, Septiembre 1953

Unger, Eva-Maria: Illustrierte als Mittel zur Kriegsvorbereitung 1933 bis 1939, Köln, Pahl-Rugestein Verlag, 1984

Usborne, Cornelie: The Politics of the Body in Weimar Germany. Women's Reproductive Rights and Duties, London, Houndmills Machmillan, 1992

von Velsen, Dorothee: Im Alter die Fülle. Erinnerungen, Tübingen, Rainer Wunderlich Verlag, 1956

- "Gertrud Bäumer in der Frauenbewegung", MÄDCHENBILDUNG UND FRAUENSCHAFFEN, Septiembre 1953, nº 9, año 3

Weber, Marianne: Lebenserinnerungen, Bremen, Johannes Storm Verlag, 1948

- Ein Lebensbild, München-Zürich, Piper, 1989 (1ª ed. 1926)

Weigel, Sigrid: "Judasfrauen. Sexualbilder im Opfer-Täter-Diskurs über den Nationalsozialismus", FEMINISTISCHE STUDIEN, 1992 (n¹), pp.113-121 
Werner, Huber: Gertrud Bäumer. Eine politische Geographie, Inaugural-Dissertation, Augsburg 1970

West, Candace; Zimmermann, Don H.: "Doing Gender", Gender AND SOCIETY, 1987, año 1, pp. 125-151

Weyrather, Irmgard: Muttertag und Mutterkeren: Der Kult um die "deutsche Mutter" im Nationalsozialismus, Frankfurt am Main, Fischer, 1993

Wiggershaus, Renate: Frauen unterm Nationalsozialismus, Wuppertal, Peter Hammer Verlag, 1984

Wilhelms, Kerstin: "Frauenzeitschriften und der Weimarer Republik", en: Hart und Zart, Frauenleben 1920-1970, Berlin, Elefanten Press 1990, pp. 53-60

Wimschneider, Anna: Herbstmilch. Lebenserinnerungen einer Bäuerin, München-Zürich-Piper, 1987

Winckler, Lutz: Studie zur gesellschaftlichen Funktion faschistischer Sprache, Frankfurt am Main, Suhrkamp, 1971

Windaus-Walser, Karin: "Gnade der weiblichen Geburt? Zum Umgang der Frauenforschung mit Nationalsozialismus und Antisemitismus", Feministische STUDIEN 6, n¹, 1988, pp. $102-115$

Winkler, H.A.: Mittelstand, Demokratie und Nationalsożalismus, Köln, 1972

Wischermann, Ulla: Die Presse der deutschen Frauenbewegung 1848-1918. Anregungen zur Erforschung einer fast vergessenen Öffentlichkeit, Presse und Geschichte II, München 1987

- Die Presse der radikalen Frauenbewegung, s.a.

Wittrock, Christine: Das Frauenbild in faschistischen Texten und seine Vorläufer in der bürgerlichen Frauenbewegung der zwanziger Jabre, Frankfurt am Main (Dissertation), 1981

Wolf, Ernst: Kirche zwischen Versuchung und Gnade, München, Christian Kaiser, 1984, $3^{\mathrm{a}} \mathrm{ed}$.

Woolf, Virginia: A Room of One's Own, London, Grafton Books, 1988

Yorck von Wartenburg, Bertha Davida Gräfin: Gertrud Bäumer. Eine Bibliographie, Tübingen 1957

Zimmermann-Buhr, Bernhard: Die katholische Kirche und der Nationalsozialismus in den Jabren 1930-1933, Frankfurt am Main-New York, Campus, 1982

Zottmann, Birgit: Zum Helfen, Pflegen, und Lehren verurteilt?. Der Beitrag Gertrud Bäumers zum Berufsbild der Frau in der sozialen Arbeit, Frankfurt, Dissertation, 1986 


\section{Fuentes}

\section{Bischöfliches Ordinariat Augsburg}

Allg. Kath. Frauenbund. Fen-57

Frauenseelsorge. Fen-148

Frauenbund. Fen-146

Akt-Nr, Db-814

\section{Bundesarchiv Koblenz}

Informe Gertrud Bäumer. NL 076

Informe Camilla Jellinek. NL 137

Informe Marie Elisabeth Lüders. NL 151

Informe Theodor Heuss. NL 221

Informes anuales del Bund Deutscher Frauen, 1928, 1931

Pequeño informe, Gertrud Bäumer. Kl. Erw, n²67, nº258

Pequeño informe, Helene Lange. Kl. Erw, n ${ }^{\circ} 268$

Pequeño informe, Gertrud Bäumer a Dorothee von Velsen. Kl. Erw, n²96

\section{Bundesarchiv Potsdam}

Auswärtiges Amt, 69468

Dienststellen Rosenberg, 62 Di 1, 62 Di. FC 2379

Reichsministerium des Innern, R. 18, $\mathrm{n}^{\circ} 476$

Reichsministerium für kirchliche Angelegenheiten, R 58, 3577 ,R 58, 2469

\section{Bundesarchiv Zehlendorf, antiguo Berlin Document Center}

Getrud Bäumer. RKK/2101

Ilse Hülsen. RKK/ 2100

Oberparteigerichtskammer. $\mathrm{n}^{\circ} 1, \mathrm{n}^{\circ} 2$

Katholische Kirche I. 243 I

Katholische Kirche II. 243 II

Kirche Allgemeimein. 244

Kirche und Partei. 215

\section{Deutsch-evangelischer Frauenbund}

A 2b: Protocolos del consejo ejecutivo

A 6 n.o.: Reunión general en Naumburg 1933, antes A 6 o 
A 6p: Reunión en Eisenach 1935

A 7 1b: Correspondencia entre las secretarias de viaje

T 1b: Escritos de Meta Eyl

B 7 III: Curriculum de Paula Müller-Ortfried

\section{Evangelisches Zentralarchiv}

Evangelische Ober-Kirchenrath 7/ 3989

$$
\text { 7/ } 3990
$$

Frauenvereine u. Verbände. 1/ C3 183

1/ C3 184

1/ C3 185

$1 /$ C3 186

$50 / 222$

$611 \mathrm{n}^{\circ} 16,2-12$

\section{Bayerisches Hauptstaatsarchiv München}

Sammlung Rehse

Marie Baum P 1054

Gertrud Bäumer P 562

Helene Lange P 328

Theodor Heuss P 3486

Friedrich Naumann P 3458

Marianne Weber P 3065

Ilse Reicke P 0870

Katholische Frauenbund, no 1366

\section{Helene Lange Archiv}

ADLV. L.000403

ADLV. L.000405

ADLV. L.000406

BDF 22-97/1

Magistrar von Groß Berlin Finanzen, Rep. 105, no 4459

NL. Helene Lange Stiftung

NL. Anna Gierke

NL. Dorothee von Velsen

\section{Institut für Zeitgeschichte München}


Biografía manuscrita de Alice-Erika Bieber, MS 540

Catálogo de la exposición, "Frau und Mutter. Lebensquell des Volkes", celebrada en Berlín en 1934. DB 04.24

Colección Marianne Zeller, E D 322

Correspondencia privada de Adele Köhler. E D 512

Diario de Ruth Studtmann. E D 517

Documentos sobre el Partido Demócrata Alemán. MA 741

\section{Landeskirchlichesarchiv, Hannover}

N 127: Nachlaß Magdalene v. Tiling $\mathrm{n}^{\circ} 3,6,11,16,33,35,44$

N 10 : Nachlaß Agnes v. Grone $\mathrm{N}^{\circ} 2,8,7,12,13,15,6$,

\section{Landeskirchlichesarchiv, Nürnberg}

Evangelisches Frauenwerk 1933-1936. LKR V 963 a (2986b)

Frauenwerk der deutschen evagelischen Kirche 1926-1959. LKR. V 963a

Frauenwerk und Volksmission in Bayern, Mai 1935-39, Frauenwerk der deutschen evangelischen Kirche in Bayern. LKR V 963a (2986a)

Frauenwerk u. Gemeindehilfen. 1933. LKR Z V 9632896 d

Frauenvereine. Bahnhofmission. LKR V 963a (2986c)

Evangelische Frauenzeitung. Za 369

Mutter und Volk. Za 781

\section{Staatsarchiv, München}

\section{- Inventario del centro de la Gestapo en München:}

Einsatz von Männern und Frauen bei Aufgabe der Reichsverteidigung. 1943-1944. Nationalsozialistischer Erziehungsanstalten Adolf Hitler-Schulen; Neuburg, u. a. 1943.

Zeitungenausschnitte (Zeitungarchiv Teil VI) über Tagungen, Propaganda, Kultur.

Unfruchtbarmachung, Verhütung erbkranken Nachwuchses, Ehevermittlung für

Sterilisierte.(Rasse politisches Amt). 1938-1943.

Reichsbund DeutscheFamilie (RDF): Schriftwechseldes rassenpolitischen Amtes. 1944-1945.

Reichsbund Deutsche Familie; Ehevermittlung (Anfragen weiblich, A-Z), 1944-1945.

Schriftwechsel mit und über NS-Frauenschaft. (1934-1943).

Schriftwechselung Rundschreiben über NS-Frauenschaft, Mütterehrenkreuz v. a. 1933-1941.

Schriftwechsel mit der NS-Frauenschaft,Verzeichnisder Amtswalterinnen.

Verleihung von Mutterkreuzen. 1939-1940.

Mutterkreuze; Heeresdienst von Politischen Leitern. Arbeitsbeschaffung. 1933- 1945.

Kirchlichen Angelegenheiten; Verhältnis zu den Kirchen; Privatunterricht durch Klosterfrauen; Sammlungen u. a. 1937-1942.

Rundscreiben der BPP und der Gestapo Leitstelle. München. Verbotene Zeitschriften, Broschüren und Zeitungen 1935-1941. 
Massnahmen der politische Polizei gegen Kirchen religiöse Gemeinschaften.

Allgemeine Anordnungen. 1934-1931.

Schriftwechsel, vor allem mit dem Verlag Teubrer über die Gestaltung der Zeitschrift

"NS-

Mädchen-erziehung".

- Actas del Tribunal Extraordinario: Procedimientos judiciales contra mujeres miembros de organizaciones religiosas:

Strafverfahren gegen Jeanette Ried, 1933.

Strafverfahren gegen Kate Schumann, Betätigung für die JBV,1936, $\quad \mathrm{n}^{\circ} 16$.

Strafverfahren gegen Philomena, Pfäffinger, 1936.

Strafverfahren gegen Franziska Lampertsteder wegen Zundererhandlung gegen die Bekantmachung des Staatsministeriums des Innern vom 1936.

Strafverfahren gegen Amalie Kahl, 193

\section{Stadtarchiv Heidelberg}

Presseauschnitte zur Hitler Jugend und Bundesdeutscher Mädel. 1786

Veranstaltungen und Führerinnenschulungskurse des Bundes deutscher Mädel. 1788

Rechtsschutzstelle für Frauen und Mächen. 1890

Unterbringung von weibliche Minderjährigen im Jugendschutzlager

Uckermark. 1921

\section{Revistas y periódicos.}

Aufgaben und Ziele

Deutsches Frauenschaften. Jabrbuch der Reichsfrauenfübrung

Evangelische Frauenzeitung

Die Christliche Fran

Die Fran

Frauenland

Mutter und Volk

Nationalsozialistische Monatshefte

Volk und Rasse

Wille und Macht

\section{Bibliotecas consultadas:}

Biblioteca de la Universidad de Bayreuth

Biblioteca de la Universidad de Bielefeld

Biblioteca de la Universidad de München

Biblioteca de la Universidad de Heidelberg

Staatsbibliotek, München 


\title{
Abreviaturas
}

\author{
ADEF: Archiv des Deutsch-Evangelischen Frauenbundes Hannover \\ BAK: Bundesarchiv Koblenz \\ BAP: Bundesarchiv Potsdam \\ BAZ: Bundesarchiv Zehlendorf \\ BDF: $\quad$ Bund deutsche Frauenvereine \\ BdM: $\quad$ Bund deutscher Mädels \\ BHA: Bayerisches Hauptstaatsarchiv \\ BK: $\quad$ Bekennende Kirche \\ BOA: Bischöfliches Ordinariat Augsburg \\ DC: Deutsche Christen \\ DEF: Deutsch-Evangelischer Frauenbund \\ DDP: Deutsche Demokratische Partei \\ DFW: Deutsches Frauenwerk \\ DNVP: Deutsche Nationale Volkspartei \\ EFZ: Evangelische Frauenzeitung \\ EvFW: Frauenwerk der Deutschen Evangelischen Kirche \\ EZA. Evangelisches Zentralarchiv \\ HLA: Helene-Lange-Archiv \\ KDF: Katholischer Deutscher Frauenbund \\ KFB: Katholischer Frauenbund München \\ LKAH: Landeskirchliches Archiv Hannover \\ LKAN: Landeskirchliches Archiv Nürnberg \\ NSF: Nationalsozialistische Frauenschaft \\ RFH: Reichsfrauenhilfe \\ VEFD: Vereiningung evangelischer Frauenverbände Deutschlands
}

